


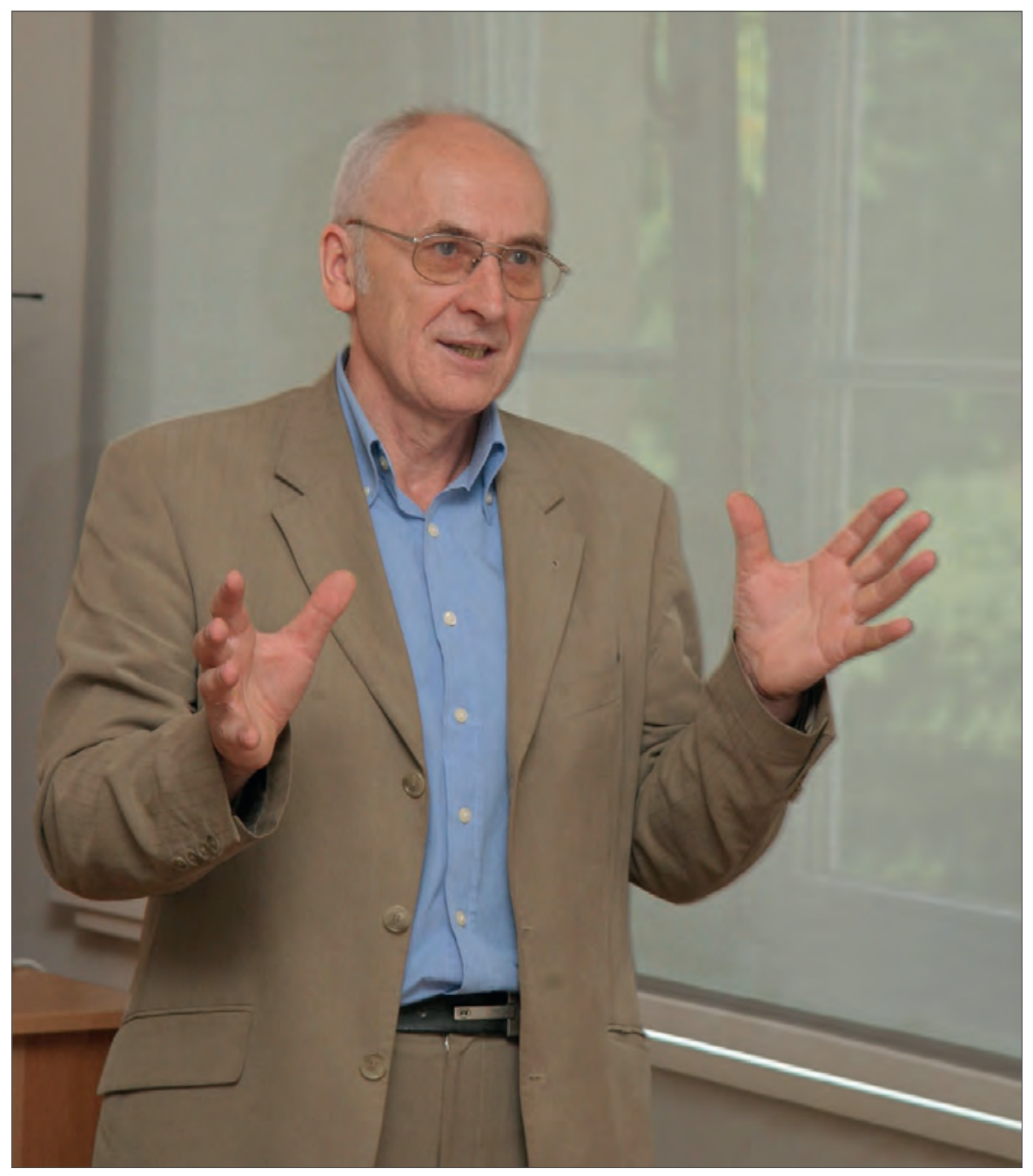




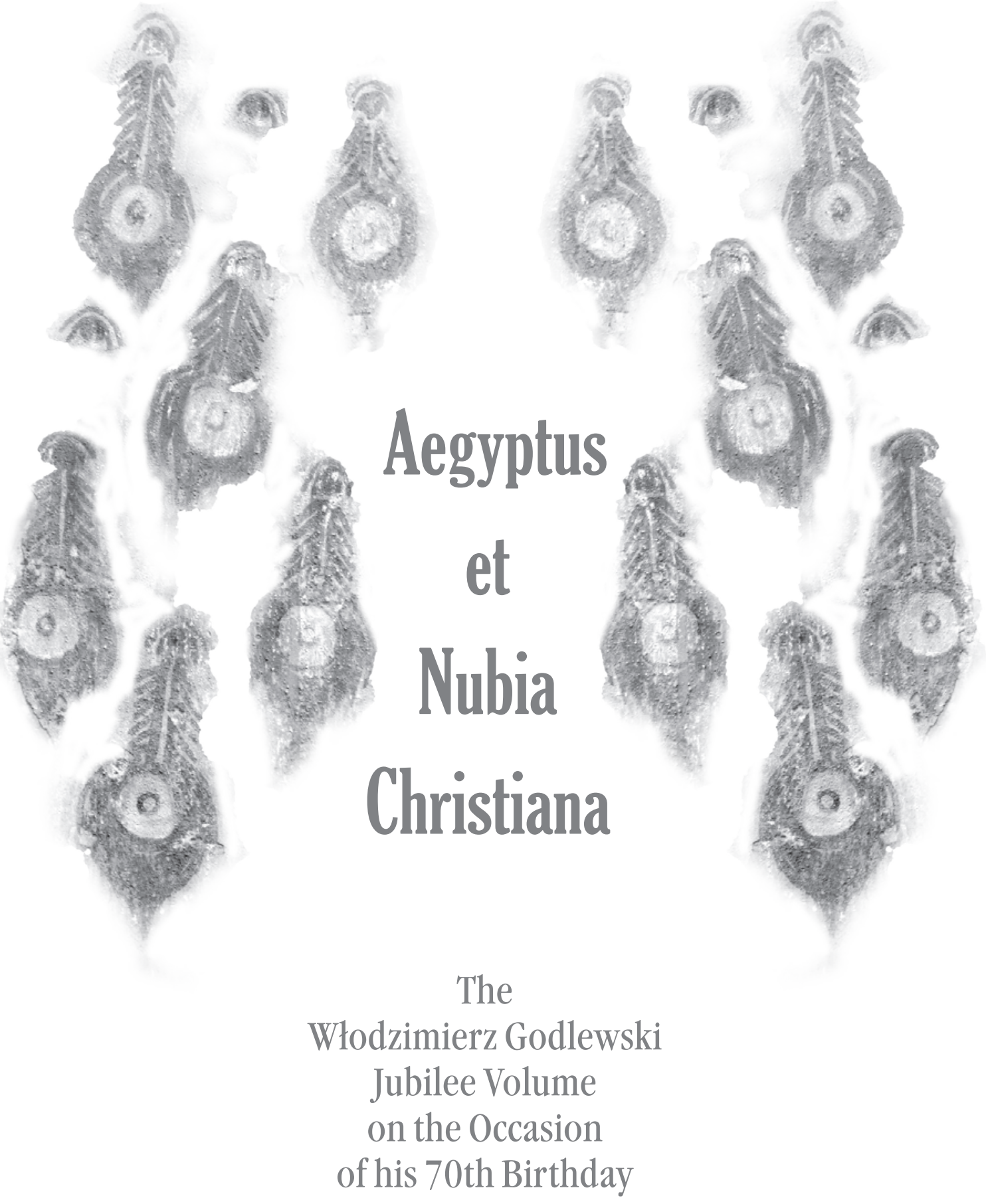

Editors

Adam Łajtar,

Artur Obłuski and Iwona Zych 


\section{Polish Centre of Mediterranean Archaeology University of Warsaw}

EDITORIAL BOARD

Piotr Bieliński, Krzysztof M. Ciałowicz, Wiktor Andrzej Daszewski, Michał Gawlikowski, Włodzimierz Godlewski, Karol Myśliwiec, Tomasz Waliszewski INTERNATIONAL ADVISORY BOARD Jean Charles Balty, Charles Bonnet, Giorgio Bucellatti, Stan Hendrickx, Johanna Holaubek

PCMA PUBLICATIONS CHIEF EDITOR Iwona Zych

Peer-Reviewed.

Volume editors: Adam Łajtar, Artur Obłuski, Iwona Zych LANGUAGe CONSUltation ANd proofreading: Katarzyna Bartkiewicz (French), Andrzej Reiche (German), Iwona Zych (English) PeEr-Review process: Urszula Wicenciak Bibliographic EDiTOR: Aleksandra Zych Image processing: Ewa Czyżewska-Zalewska, Konrad Krajewski DTP: Konrad Krajewski

Cover \& Title Page design: Dobrochna Zielińska Photo on frontispiece: Anna Południkiewicz (2015)

Cover: Motif from the wings of a figure of the Archangel Raphael, painted in the naos of the royal church B.V on the citadel of Old Dongola

Ifao-Grec Unicode font for ancient Greek courtesy Ifao, Cairo (www.ifao.egnet.net).

Coptic and Nubian font Antinouu.

Published with generous support from

The Kazimierz Michaeowski Foundation.

ISBN 978-83-235-4726-6 (pdf online)

(C) Polish Centre of Mediterranean Archaeology, University of Warsaw, Warszawa 2016

(C) Copyright by Wydawnictwa Uniwersytetu Warszawskiego, Warszawa 2020

(C) The Authors

All rights reserved. No part of this publication may be reproduced or transmitted in any form or by any means, electronic or mechanical, including photocopying, recording, or any information storage or retrieval system, without permission in writing from the copyright holders.

CIP - Biblioteka Narodowa

Aegyptus et Nubia christiana : the Włodzimierz Godlewski jubilee volume on the occasion of his 70th birthday / eds. Adam Łajtar, Artur Obłuski and Iwona Zych. - Warszawa : Polish Centre of Mediterranean Archaeology. University of Warsaw, cop. 2016

Polish Centre of Mediterranean Archaeology, University of Warsaw ul. Prosta 69, 00-838 Warsaw, Poland, www.pcma.uw.edu.pl 


\section{CONTENTS}

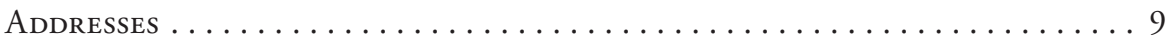

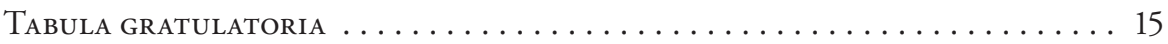

Adam Łajtar, Artur ObŁuski and Iwona Zych

Włodek on the Nile . . . . . . . . . . . . . . . . . . . . . 19

WŁodzimierz GodLewski: List of publications. . . . . . . . . . . . . . . . . 29

\section{Aegyptus Christiana}

\section{Anne Boud'hors and Esther Garel}

Que reste-t-il de la bibliothèque du monastère de Saint-Phoibammon

à Deir el-Bahari? . . . . . . . . . . . . . . . . . . . . . . . . . . 47

Alain Delattre and Naïm Vanthieghem

Les trois « colophons " de l'Évangile de Jean découvert à Naqlūn . . . . . . . . . . 61

Tomasz Derda and Joanna Wegner

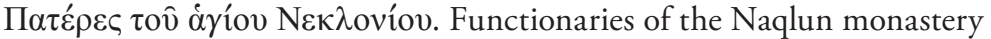

in the first two centuries of its existence $\ldots \ldots \ldots \ldots \ldots \ldots \ldots \ldots \ldots$

Dorota Dzierzbicka

Wine consumption and usage in Egypt's monastic communities

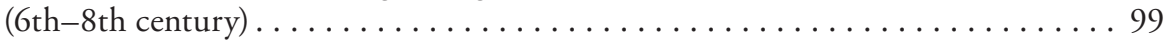

\section{ToMasz Górecki}

Phasing out LRA 7 amphorae in favor of new wine containers:

Preliminary remarks based on finds from excavations in Naqlun . . . . . . . . 113

Peter Grossmann

Spätantike und mittelalterliche Vierstützenkirchen in Ägypten . . . . . . . . . . . 139

SzYMon Maślak

The burning of a monastery? Story blazed on the walls of monastic buildings at Nekloni (Naqlun) . . . . . . . . . . . . . . . . . . . . . . . . . . 149

Maria Mossakowska-Gaubert

Verres décorés d'époque arabe médiévale (VIII $-\mathrm{XIII}{ }^{\mathrm{e}}$ siècles) : quelques exemples provenant de Naqlun . . . . . . . . . . . . . . . . . . 187

Marguerite Rassart-Debergh

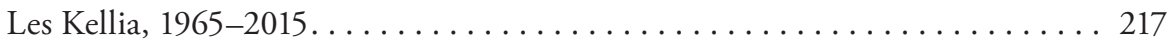


Tonio Sebastian Richter

Eine koptische und eine arabische Bauinschrift zwischen Assuan und Kom Ombo

\section{Jacques VAN DER Vliet}

"Alone in Naqlun": A fresh look at the Bohairic letter P. Lond. Copt. I, 590 (2) (British Library Or. 4720 [31], vo) . . . . . . . . . . . . . . . . . . . . 247

Gertrud J.M. van Loon

“...that the mountain of the holy wilderness may be inhabited...": Saint John the Baptist in the Infancy scenes in the narthex of the Quarry Church of Dayr Abū Hinnis . . . . . . . . . . . . . . . . . . . . . . . . . . . . . 257

Ewa Wipszycka

Saint Claude à Pohe : un exemple de fonctionnement d'un sanctuaire de pèlerinage dans l'Égypte de l'Antiquité tardive. . . . . . . . . . . . 281 IwONA ZYCH A monastic library at Nekloni? 307

\section{Nubia Christiana}

\section{William Y. Adams}

Evolution and revolution in Nubian pottery . . . . . . . . . . . . . . . 315

Julie Renee Anderson and Anna Harrison

Some unique medieval Nubian textiles in the British Museum collections. . . . . 329

Katarzyna Danys and Adam Łajtar

Egyptian amphorae LR 5/6 with Greek dipinti found in Dongola . . . . . . . . . 347

\section{David N. EDWARds}

Among the rocks: A first look at medieval Duweishat, from the archive. . . . . . . 359

Krzysztof GrzyMsKi

Beyond Old Dongola: The multicomponent site of Hag Magid (Letti Basin) . . 381

Henriette Hafsaas-Tsakos and Alexandros Tsakos

Nubian cathedrals with granite columns: A view from Sai Island. . . . . . . . . . . 389

Karel C. InNemée

Monks and bishops in Old Dongola, and what their costumes can tell us . . . . . 411

Adam Łajtar and Dobrochna Zielińska

The northern pastophorium of Nubian churches: ideology and function (on the basis of inscriptions and paintings) .

Magdalena Łaptaś

Archangel Raphael as protector, demon tamer, guide and healer. Some aspects of the Archangel's activities in Nubian painting. 
Artur Obeuski

Nobadian and Makurian church architecture. Qasr el-Wizz, a case study . . . . . 481

Grzegorz OchaŁa

When epigraphy meets art history: On St Phoibammon from Abdallah-n Irqi 513

Marta Osypińska

The pig — a mystery of medieval Makuria

\section{Giovanni R. Ruffini}

Dotawo's later dynasties: a speculative history

\section{Robin SEIgnobos}

La liste des conquêtes nubiennes de Baybars selon Ibn Šaddād (1217-1285) . . . . 553

\section{JoAnna Then-ObzusKa}

The 'bead-side' story of medieval and post-medieval Nubia:

Tentative approach to the bead collection of the Museum of Archaeology

University of Stavanger, Norway . . . . . . . . . . . . . . . . . . . . . 579

Derek A. Welsby

Observations on the graves of the medieval period in the SARS concession

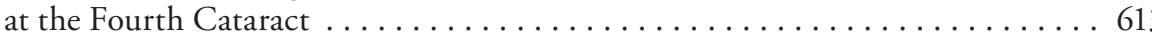

\section{Magdalena M. Woźniak}

The chronology of the eastern chapels in the Upper Church at Banganarti: Some observations on the genesis of "apse portraits" in Nubian royal iconography . . . 629 BogdAN ŻUrawsKI

Banganarti Nativity: Enkolpion with scene of the Birth of Jesus from House

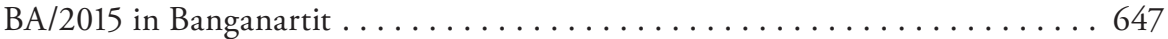

\section{Miscellanea}

\section{Nettie K. Adams}

The lions of Qasr Ibrim

\section{MirosŁaw BarwiK}

A record of offerings from the Temple of Hatshepsut in Deir el-Bahari: ostrakon DeB Inv. No. $85 / 75$ reconsidered . . . . . . . . . . . . . . . . . . . 665

\section{BARBARA LICHOCKA}

A stray late Roman coin from the Temple of Hatshepsut at Deir el-Bahari. . . . . 679

Adam Łukaszewicz

Cleopatra and kandake. 



\section{Addresses}

"Godlewski the Scholar, Godlewski the Academic, Godlewski the Organizer - and yet there is also Godlewski the Man" - hardly a better prospective outline for a Jubilee Volume dedicated to a man as active as Professor Włodzimierz Godlewski and as fulfilled as he is in so many fields. If a man be measured by the influence he has had on others, then the names of the scholars who have penned contributions for this volume and who have forwarded their greetings in the Tabula Gratulatoria on this memorable anniversary are the best proof of how his activities have affected those around him and the respect that they have engendered him over the years.

Between Egypt and Nubia, always on the Nile. A thoughtful advisor, attentive and ironical, generously supportive, especially when assured of his partners' good intentions in facing common challenges and generous concern for the well-being of people and places. A good spirit of the Polish Centre of Mediterranean Archaeology of the University of Warsaw, which he helped to shape in its current form, the branch in Cairo as much as the head office in Warsaw. His often repeated "you are right, but I totally disagree with you" can be irritating, but only to those unwilling to take up what is on one hand an intellectual challenge and on the other, a quest for standards, in the scholarly life, as much as in interpersonal relations.

It is a pleasure to be able to look back with satisfaction on past achievements, but I will not be far off the mark when I say that this will hardly keep Godlewski with his indefatigable energy and curiosity of the world from making new discoveries in the coming years, and stimulating research of the next generation of archaeologists, in Poland as well as abroad. We are proud at the Polish Centre to have produced this Jubilee Volume, underscoring Professor Godlewski's close ties with the Centre. The Editors, who belong among the Professor's students and associates, are to be commended for preparing this handsome and informative volume and congratulated for working so closely with him. I wish the Professor pleasant reading, wondering only how many interesting things about oneself and others one can learn on the occasion of such a full anniversary.

Tomasz Waliszewski

Director of the Polish Centre of Mediterranean Archaeology

Universiy of Warsaw 
An indefatigable energy and concern for Polish Mediterranean archaeology led to Professor Włodzimierz Godlewski's decision to be one of the founders of the Kazimierz Michałowski Foundation. He has served on the Board of the Foundation and continues to support it with his well-informed counsel based on an extensive institutional experience. It is thanks to his help among others that the Foundation has been successful in fulfilling its objectives for more than 20 years. Today, it proudly contributes to the production of this Jubilee Volume in gratitude for everything that he has done for the Foundation. Members of the present as well as past Boards offer their best wishes for a continued and satisfying life of research and publication in the privacy of his Legionowo home, as well as on the Nile.

Tomasz Scholl, Dorota Dzierzbicka, Ewa Chrzanowska and Artur Obłuski

The Kazimierz Michałowski Foundation Board Members

$* * *$

Archaeology today is a science of many disciplines, as distant from one another as Lower Paleolithic prehistory can be from modern urban archaeology. In effect, figures of scientific authority are seldom recognized, the achievements of an eminent specialist in one field of archaeology being unknown, perhaps even not quite understood by archaeologists of other specialties. We are fortunate though still to have exceptions to this rule: scholars whose achievements are widely recognized by the scholarly community and Włodzimierz Godlewski is one of them. It is a necessity, one might say, because his chosen discipline, which he has helped to shape over the years, the archaeology of Egypt and Nubia, demands exceptionally broad involvement. One factor is the extensive chronological range, reaching deep into Classical antiquity and extending through medieval Islamic times. Another is the broad spectrum of diverse auxiliary study specialties involved, from epigraphy to art history, to architecture, to the histories of the different groups of African Christianity. A polymath approach is unavoidable in this case, but one will agree that creative use of an instrument of such class requires masterly skill.

Godlewski is just such a paradigm of excellence - suffice it to look at his long list of publications that cover and even exceed the thematic and chronological ranges described above. One should note that these texts often present research that has already entered the mainstream of science and are 
recognized by people outside the professional community of archaeologists and dedicated specialists: studies of the Coptic monastery at Naqlun in Egypt or Old Dongola, capital of the almost fairytale Nubian kingdom of Makuria, in Sudan. These presentations have truly filtered through to the common man, popularizing a unique part of our cultural heritage.

Godlewski's willingness and ability to reach different audiences is another important aspect of his personality. It is a successful combination of his wide experience, as a museum curator preparing displays and exhibition catalogues for an audience interested in Classical antiquity and as an academic lecturer initiating undergraduate and graduate students to increasingly higher levels of scholarly research.

Then there is his uninterrupted activity, which is so commendable in times when habilitation degrees, not to mention professorial positions, are often considered in Polish science as fulfillment, if not crowning of a scientific career, to be followed by nothing but self-promotion. Włodzimierz Godlewski shows an enthusiasm for work that is fairly incompatible with his status of a sedate university professor, a zeal characterizing the youngest of scholars embarking on a lifelong adventure with archaeology. It is this youthful enthusiasm next to his excellent method and extensive knowledge that engender respect and admiration... and just a touch of envy!

Wojciech Nowakowski Director of the Institute of Archaeology Universiy of Warsaw

\section{$* * *$}

On behalf of my friends, colleagues and associates from the National Corporation for Antiquities and Museums of Sudan, I am honored to express our thanks and appreciation to a man whose life as a scholar has been devoted to uncovering an important part of our Sudanese national heritage. Over the years and throughout my time with the Sudanese antiquities service, as well as my academic career with the Institute of Archaeology and now the Polish Centre of Mediterranean Archaeology, I have had the opportunity to work with Włodek, to benefit from his knowledge of Ancient Nubia, and most importantly, to shape my own views on the issues involved in often heated debate, but always seeking that level of scientific truth that is a mark of scholarly excellence.

Mahmoud El-Tayeb 
$\mathrm{O}_{\mathrm{n}}$ behalf of the organizers and participants of the National Conference of Nubian Studies I congratulate you on the occasion of this wonderful anniversary.

I take this opportunity to thank you warmly for participating in our meetings from the very beginning.

For the past 23 years we have enjoyed your presence, benefited from your knowledge and experience - made even more valuable by the fact that you are one of the pioneers of Nubiology, both in Poland and abroad - and learned by example the art of academic debate as well as the art of diplomacy and uncomprising when it comes to scientific principles.

Your participation in our conferences raised their merit, attracting at the same time many young archaeologists for whom you were, and are, an acknowledged role model. We are also grateful for your initiating of the "Poles on the Nile" conference, where we can present the most recent results of our research, expand our knowledge, improve our professional qualifications and skills, enjoy the opportunity to exchange scientific opinions, learn from the best.

We thank you for all of this and for your patronage of the conferences organized in Gdańsk, and we wish you many more years of fruitful professional work in good health and all the best in your professional and personal life.

Henryk Paner

Gdańsk Archaeological Museum

$* * *$

Thank you for the past thirty years. If I am where I am today, it is because you were there to inspire, to discuss and to "push", whenever I wavered. I am proud to have worked together on so many different initiatives, during the years at the National Museum in Warsaw, as part of the Naqlun excavation project and as a co-organizer of the 11th Conference of Nubian Studies. Thank you for the challenges that I have risen to and the ones that we may yet achieve working together.

Iwona Zych 
Congratulations for your wonderful career and for the result we expect.

Charles Bonnet

Don't forget: Beyond 60 you are ageless.

Sylvia Schoske and Dietrich Wildung

When it comes to the Christian history of the Nile Valley, everyone knows how much Egypt, Sudan and the entire scientific community owe to the remarkable contribution of Polish archaeology in the region. Among the many talented colleagues I've had the pleasure to meet while working in Sudan, Professor Włodzimierz Godlewski has been a leading figure of this tradition of excellence. Francophile, always welcoming you with a smile, it is a privilege to add my greetings to such a distinguished scholar and scientist.

Vincent Francigny

***

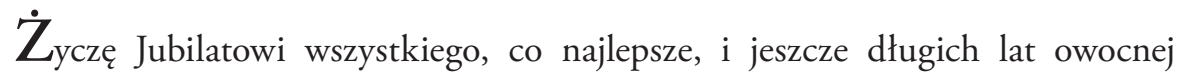
działalności!

Piotr Dyczek

$* * *$

Thank you Prof. Godlewski for your remarkable career and accomplishments in Nubian Studies. They have added so much to our knowledge of Ancient Nubia.

Janice Yellin 
$* * *$

Gratulacje za pracę i dorobek Profesora Włodzimierza Godlewskiego w roku jego siedemdziesiątych urodzin.

Marek Tycjan Olszewski

$* * *$

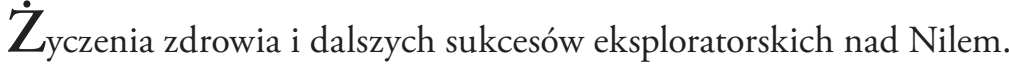

Ewa Parandowska

$* * *$

Dużo zdrowia i wielu kolejnych lat owocnej i satysfakcjonującej pracy naukowej.

Robert Ryndziewicz 


\section{TABULA GRATULATORIA}

Krzysztof Babraj

Roger S. Bagnall

Brenda J. Baker

Marek Barański

Grażyna Bąkowska-Czerner

Thomas Beckh

Heike Behlmer

Dominique Bénazeth

Catherine Berger-El Naggar

Piotr Bieliński

Przemysław Bobrowski

Benedetto Bravo

Darlene L. Brooks Hedstrom

Aleksandra Brzozowska

Andrzej Buko

Mariusz Burdajewicz

Aleksander Bursche

Paola Buzi

Cristobal Calaforra-Rzepka

Florence Calament

Aneta Cedro

Marek Chłodnicki

Gabriela Chmiel

Wojciech Chmiel

Ewa Chrzanowska

Patryk Chudzik

Krzysztof Ciałowicz

Emanuele Marcello Ciampini

Joanna Ciesielska

Renata Ciołek

Barbara Czaja

Rafał Czerner

Ewa Czyżewska-Zalewska

Elżbieta and Andrzej Daszewski

Stephen J. Davis

Agata Deptuła

Agnieszka and Jarosław Dobrowolski

Monika Dolińska

Ewa Domańska
Olga Drewnowska

Mariusz Drzewiecki

Teresa Dziedzic

Grzegorz Dziemidowicz

Eugenio Fantusati

Cäcilia Fluck

Gawdat Gabra

Christian Gaubert

Krystyna and Michał Gawlikowski

Daniel Gazda

Tadeusz Gołgowski

Julia Górecka

Sabina Grzegrzółka

Witold Gumiński

Randi Haaland

Gisela Helmecke

Tomasz Herbich

Mateusz Iskra

Jadwiga Iwaszczuk

Urszula Iwaszczuk

Bożena Iwaszkiewicz-Wronikowska

Marcus Jaeger

Stefan Jakobielski

Łukasz Jarmużek

Piotr Jaworski

Wanda and Waldemar Jerke

Friederike Jesse

Mariusz Jucha

Jacek Kabaciński

Maria Kaczmarek

Barbara Kaim

Joanna Kalaga

Henrietta, Jerzy and Darek Kania

Radosław Karasiewicz-Szczypiorski

Małgorzata Karkowska

Janusz Karkowski

Michał Kobusiewicz

Joanna Kociankowska-Bożek

Rafał Koliński 
Teresa and Wojciech Kołątaj

Piotr Kołodziejczyk

Elżbieta Kołosowska

Bartosz Kontny

Małgorzata Korzeniowska

Jacek Kościuk

Hanna Kozińska-Sowa

Janusz K. Kozłowski

Martin Krause

Maria Krogulska

Ewa Krygier

Renata Kucharczyk

Kamil Kuraszkiewicz

Ewa Laskowska-Kusztal

Andrzej Leligdowicz

Szymon Lenarczyk

Kazimierz Lewartowski

Angelika Lohwasser

Anetta Łyżwa-Piber

Beata Madaj

Robert Mahler

Marc Maillot

Jacek Maj

Grzegorz Majcherek

Aleksandra Majewska

Piotr Makowski

Piotr Maliński

Wiesław Małkowski

Małgorzata Martens-Czarnecka

Agnieszka Mączyńska

Izabela Medeksza

Henryk Meyza

Bożena Mierzejewska

Marta Mierzejewska

Jolanta Młynarczyk

Iwona Modrzewska-Pianetti

Marta Momot

Jean-Michel Mouton

Monika Muszyńska

Karol Myśliwiec

Andrzej Niwiński

Tomasz Nowakiewicz
Wojciech Nowakowski

Piotr Osypiński

Marzena Ożarek-Szilke

Laure Pantalacci

Barbara and Franciszek Pawlicki

Karol Piasecki

Cornelius von Pilgrim

Rosario Pintaudi

Tomasz Płóciennik

Anna Południkiewicz

Joanna Popielska-Grzybowska

Marek Puszkarski

Gillian Pyke

Małgorzata Radomska

Dominic Rathbone

Małgorzata Redlak

Andrzej Reiche

Monika Rekowska

Jerzy Rekucki

Siegfried Richter

Alessandro Roccati

Marzanna Romaniuk

Vincent Rondot

Pamela Rose

Elżbieta Roszyk

Agnieszka Ryś

Sławomir Rzepka

Teodozja Rzeuska

Tadeusz Sarnowski

Tomasz Scholl

Sylvia Schoske

Steven E. Sidebotham

Zbigniew Solarewicz

Arkadiusz Sołtysiak

Jay Spaulding

Franciszek M. Stępniowski

Aleksandra Sulikowska

Katarzyna and Zbigniew E. Szafrański

Joanna Katarzyna Szczepkowska

Barbara and Tomasz Szmagier

Zofia Sztetyłło

Romuald Tarczewski 
Thelma K. Thomas

Agnieszka Tomas

Alfed Twardecki

Agata Ulanowska

Tomasz Waliszewski

Władysław Weker

Steffen Wenig

Janina Wiercińska

Marcin Wiewióra

Wiesław Więckowski

John P. Wild

Bruce Williams

Anna Wodzińska
Pawel Wolf

Dariusz Wolski

Grzegorz Wyrzykowski

Michael Zach

Szymon Zdziebłowski

Karola Zibelius-Chen

Łukasz Zieliński

Leszek Zinkow

Adam Ziółkowski

Aleksandra Zych

Jerzy Żelazowski

Magdalena Żurek 


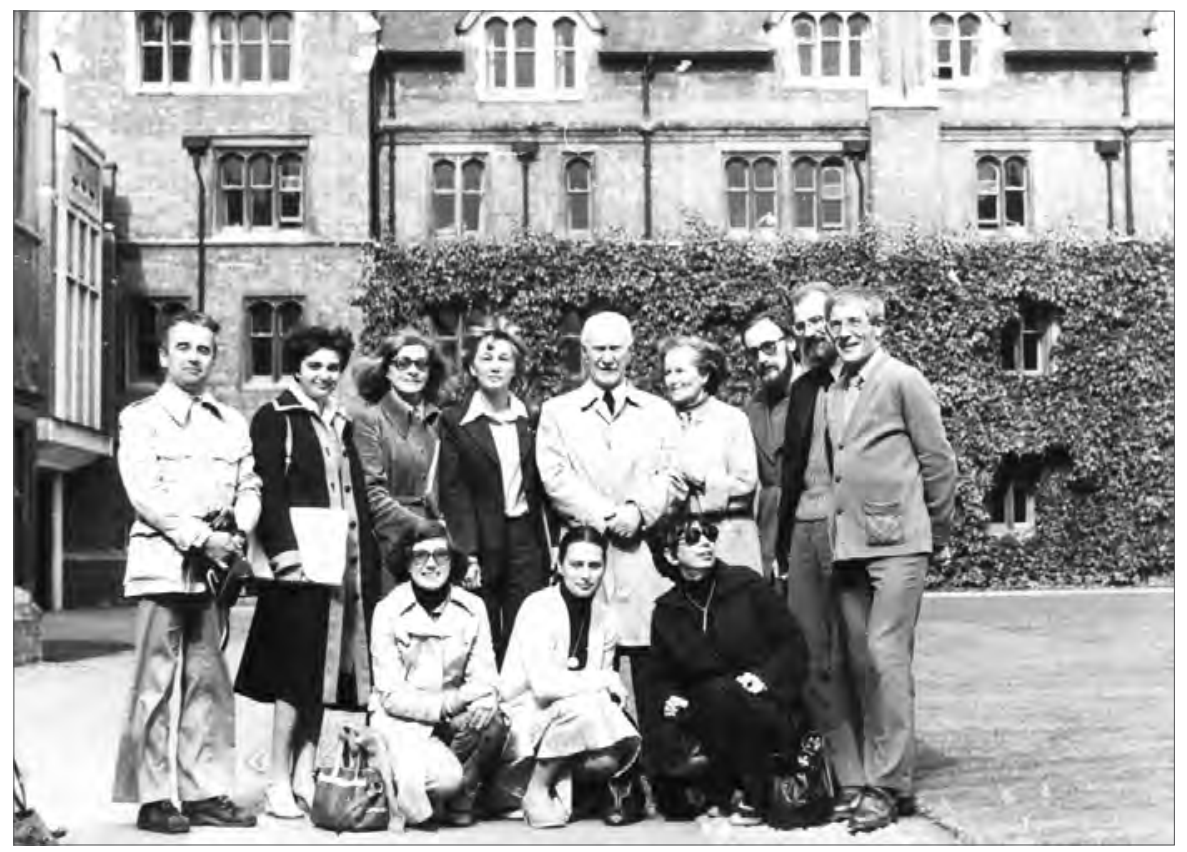

Fig. 1. Wtodzimierz Godlewski with Professor Kazimierz Michatowski and a group of colleagues at the Symposium for Nubian Studies, Selwyn College, Cambridge, 1978; standing from right, Przemystaw Gartkiewicz, Stefan Jakobielski, Wodzimierz Godlewski, Mrs. Krystyna Michatowska, Prof. Kazimierz Michatowski, Elżbieta Promińska, Bożena Rostkowska, NN, Lech Krzyżaniak; lower row, from right, Jadwiga Lipińska, Matgorzata Martens, Krystyna Polaczek (Photo courtesy PCMA Archives) 


\title{
WŁODEK ON THE NILE
}

\author{
Adam Łajtar \\ Department of Papyrology, Institute of Archaeology \\ University of Warsaw \\ Artur Obłuski \\ Research Centre in Cairo, Polish Centre of Mediterranean Archaeology \\ University of Warsaw \\ Iwona Zych \\ Polish Centre of Mediterranean Archaeology \\ University of Warsaw
}

A jubilee presentation is fraught with the danger of becoming a panegyric and Włodzimierz Godlewski is more likely to welcome stinging remarks than such a panegyrical tone. In these few words that we wish to offer to him on the occasion of his Jubilee, we shall hopefully steer a middle course between these two extremities.

Włodzimierz Godlewski studied Mediterranean archaeology at the University of Warsaw in 1964-1971, adding in due course Egyptology with a specialization in Coptology. In his time, Mediterranean archaeology as an academic course in Poland was still of very fresh date, having been founded as a chair at the university barely a few years earlier by a nestor of Polish Classical archaeology, Professor Kazimierz Michałowski. With his developed scholarly interests and prewar experience in field excavations in Egypt, Professor Michałowski wished to establish a joint approach to studies of Greek and Roman antiquity on one hand and the ancient cultures of the Near East on the other, the latter encompassing Egyptian, Syro-Palestinian, Mesopotamian and Anatolian. In the 1960s, following the fall of Stalinism in Poland and the new opening to the world that the country was experiencing, under Michałowski's energetic direction, but also thanks to Near Eastern geopolitics, Polish Mediterranean archaeology was developing rapidly. The world situation after the Six-Day War opened the way to the founding of a Polish Centre of Mediterranan Archaeology in Cairo as a permanent base for conducting excavations at flagship sites in Egypt (Alexandria and Deir el-Bahari), Syria (Palmyra), Sudan (Faras and Dongola) and Cyprus (Nea Paphos). Of all these 
Godlewski the student was most captivated by the excavations in Faras. He devoted his Master's thesis in Mediterranean archaeology to Faras, discussing the topographical history of the settlement, and developed his interests in his Master's in Egyptology, writing on the organization of the Christian church in Makuria.

In 1968, still a student, Godlewski joined the staff of the National Museum in Warsaw on commission, assisting in the conservation of wall paintings from the cathedral in Faras which had just reached the Polish capital. This brief episode was to have a lasting effect. Having completed his studies, Godlewski got a position with the National Museum and remained part of that institution for a quarter of a century, forming the core staff of the Ancient Art Gallery, which included in the years 1972-1991 also the Faras collection. He rose in the ranks from assistant to curator (from 1979) and director of the Museum (19901994). For two years after that, until 1996, he headed the Faras Gallery, which had been made into a separate museum department. A quarter of a century in one institution leaves an indelible mark. Despite 20 years at the university, Godlewski is still a museum man at heart. Many a time his associates have heard him grumble about the convolutions of university life as opposed to museum ways.

In 1997 Godlewski accepted a professorial position in the Institute of Archaeology of the University of Warsaw, which he has kept for the past 20 years. For most of this time he has served as head of the Department of the Archaeology of Egypt and Sudan. In the past few years he has also headed the Scientific Council of the Institute. His academic career has abounded in didactic achievements, attested by a large group of students and associates involved in studies of the Christian civilization developing in the Nile Valley. Several of these are represented in this Jubilee volume. Apart from the Warsaw Institute, Godlewski has also lectured at the École Pratique des Hautes Études in Paris (semester in 1991) and in the Institut für Ägyptologie und Sudanarchäologie of the Humboldt University in Berlin (semester in 2001).

Leaving the Museum and the Institute aside, there is yet another institution that has been at the core of Godlewski's activities for a major part of his life, namely, the Centre of Mediterranean Archaeology of the University of Warsaw in Cairo. Twice, in 1976-1979 and in 1984-1985, he served as the institution's Scientific Secretary in Cairo. He was a member and subsequently head of archaeological expeditions working under the Centre's auspices. For many years up to the present he has sat on the Centre's Scientific Council and is currently also on the Editorial Board of the Centre's publications. His identification with the Centre is almost as strong as with the National Museum. Its development 
has always been close to his heart, in which he has undoubtedly emulated his Master, the Centre's founder, Kazimierz Michałowski, always keeping in fond memory the happy years spent in Cairo as the Centre's Secretary.

His scholarly career has followed an unbending path, developing from his early interests into a fully fledged study of Christian culture in the Nile Valley in its two variants, Nubian and Egyptian. The three milestones in his scientific writing were connected with it. First was his doctoral dissertation devoted to an analysis of Nubian baptisteries, submitted at the University of Warsaw in 1976. Second was a monograph of the monastery of Saint Phoibammon in Deir el-Bahari, prepared as a habilitation in 1986 at the Faculty of History of the University of Warsaw. Third in this crown was a monograph, published in 2006, presenting a diachronic approach to the architectural development of the cathedral complex excavated at Faras in the 1960s. One should note also an archaeological guide to Dongola, the ancient capital of the Christian Nubian kingdom of Makuria. Do not be mislead by the term "guide", which does not reflect the nature of this book. It is an exhaustive presentation of this site in the many diverse aspects of its functioning. Apart from these books, Godlewski has published close to 200 articles of different character: starting with excavation reports, overview articles, publications of objects or groups of objects, as well as broader studies on various issues connected with the history and culture, both material and spiritual, of Christian Nubia and Christian Egypt.

Archaeological fieldwork is integral to Godlewski's scholarly achievement. His name is linked inseparably with two archaeological sites excavated under the auspices of the Polish Centre of Mediterranean Archaeology University of Warsaw, namely, Dongola and Naqlun. Dongola was his first training ground, where he started in 1972, the ninth season after Michałowski initiated work at the site. He has returned there practically every year since then, as a team member, then, in 1990-2006, as a principal investigator in his own research project and since 2007 as head of the whole excavation project. And Dongola will surely remain - we believe — Godlewski's academic love. The capital of Makuria owes him research in the Throne Hall-turned-mosque, the excavation of the Cruciform Church, the discovery of the royal complex on the citadel, several domestic buildings on the citadel and in the suburbs of the city, excavation of an extensive stretch of the monumental town defenses, studies on the architecture and material culture of post-Makurian date and last but not least, the discovery and investigation of the royal complex on the citadel with the king's palace, commemorative building and church of the Archangel Raphael. It is also characteristic that Godlewski bends to the needs of the nonacademic world, making an effort always to preserve the excavated ancient 
Fig. 2. Provisionalphoto documentation atelier at the monastery in Naqlun, 2008 (Photo I. Zych)

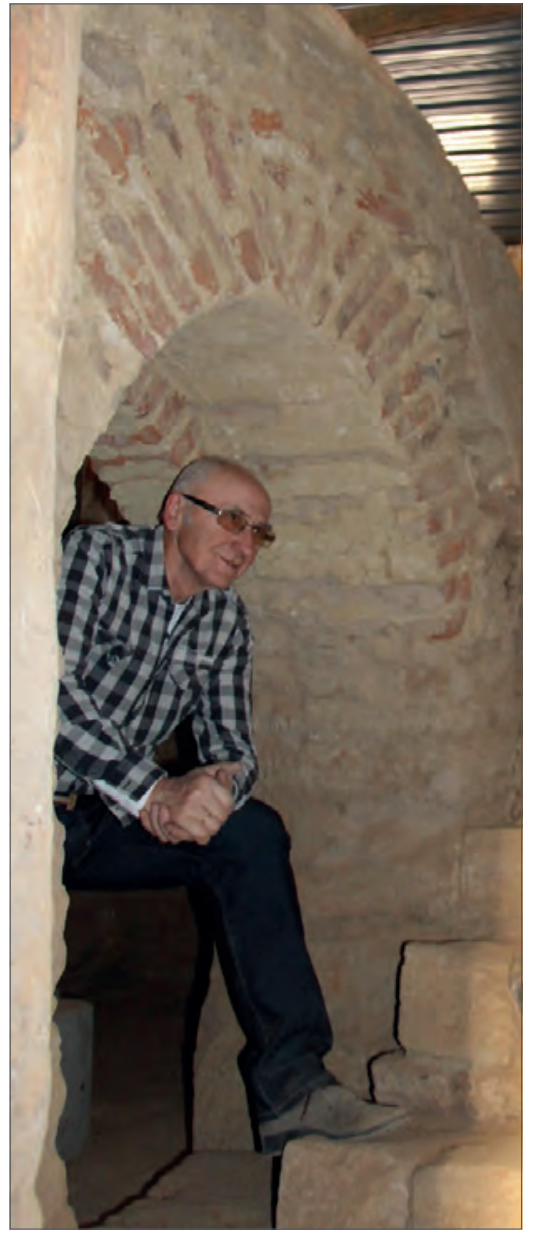

Fig. 3. Wtodzimierz Godlewski, Dongola 2016 (Photo T. Derda)
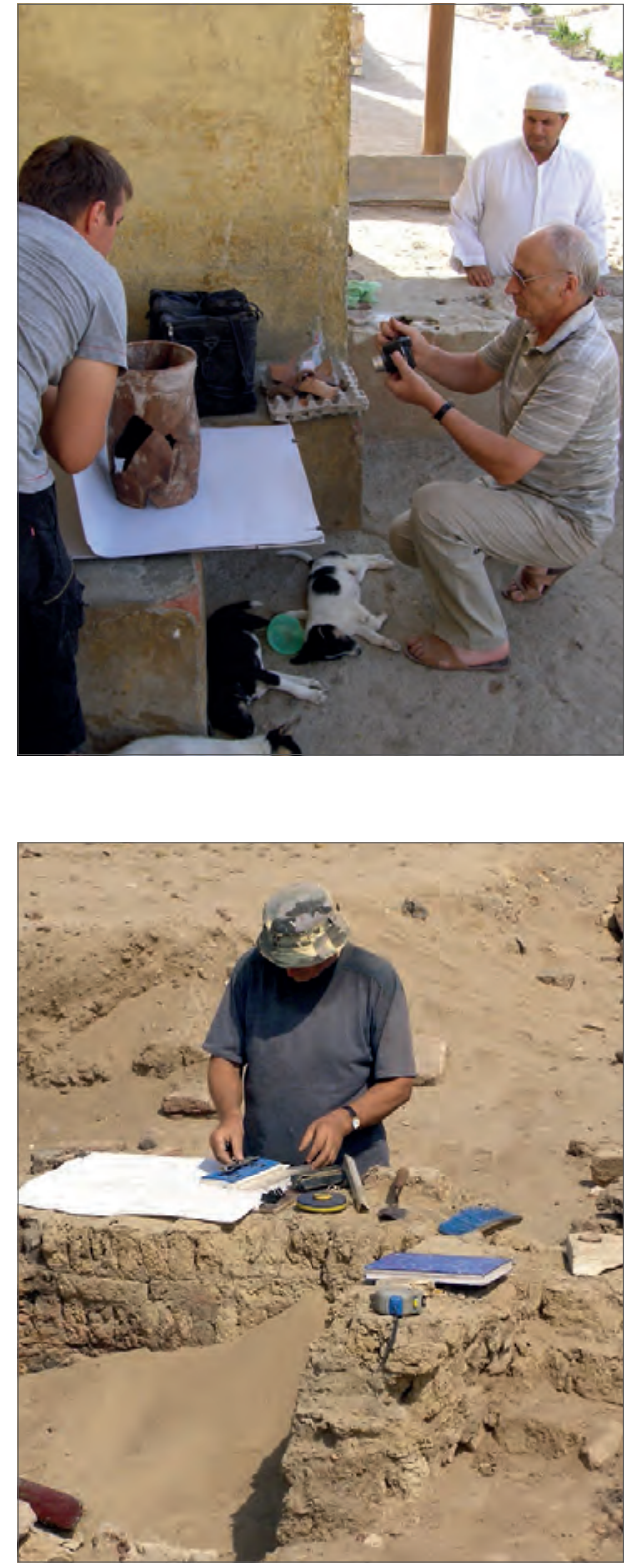

Fig. 4. Documenting mud-brick architecture in the field, Naqlun 2008

(Photo I. Zych) 
substance and to foster projects for site management and display in line with the objectives of the tourist industry in Sudan.

Dongola was Godlewski's training ground, but the Naqlun excavation project is entirely his brainchild. He chose the site and has directed all of the 30 excavation seasons that have been carried out to date, between 1986 and 2015. The richness and diversity of the discoveries by Godlewski's team in Naqlun have turned a site that was practically lost in oblivion into one of the most important post-Pharaonic sites currently being investigated in Egypt. Domestic and religious architecture, documentary texts in Greek, Coptic and Arabic, coins, pottery, glass, textiles and many others - taken together this evidence attests, on one hand, to the functioning of an important coenobitic monastery and anchoritic laura, and on the other, to the social landscape of the Fayum Oasis and more generally Egypt during an important period of political and religious transformation in the second half of the 1st millennium and at the beginning of the 2 nd millennium in our history.

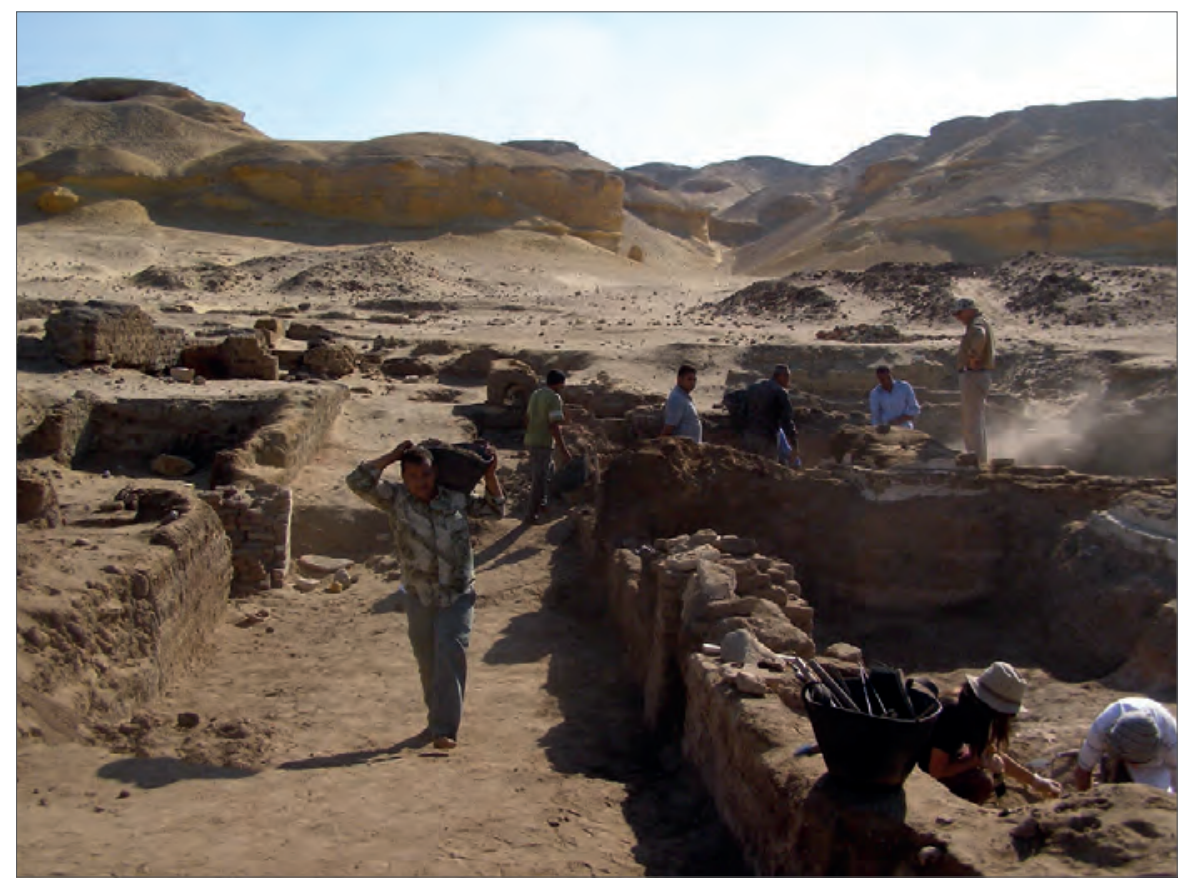

Fig. 5. Supervising excavations on the upper plateau at Naqlun, 2008 (Photo I. Zych) 
Beside Dongola and Naqlun Godlewski also participated in the Polish Centre's excavations on Kom el-Dikka in Alexandria (1972), in the restoration project of the Polish Centre in the Mamluk Mausoleum of Amir Qurqumas in the City of the Dead in Cairo (1975-1976), and in Deir el-Bahari, where he documented the remains of the monastery of St Phoibammon for his habilitation thesis (1978). In 2004, in response to an appeal from the National Corporation of Antiquities and Museums of the Republic of Sudan, he sent his team to carry out salvage excavations in the Fourth Cataract region to be inundated as a result of yet another dam-construction project. This involved investigations of principally post-Meroitic remains on Uli island and constituted foreplay to a new program, developed together with Mahmoud El-Tayeb and focusing on the formative period in the history of the kingdom of Makuria. He headed the MtoM (Meroe to Makuria) program in 2005-2007, excavating post-Meroitic cemeteries at Merowe Sheriq, Tanqasi and Ghaddar. The project is now fully fledged under the direction of Mahmoud El-Tayeb who is exploring the tumuli field in El-Zuma. Investigations within the frame of the MtoM project have made a key contribution to an understanding of the territorial, political and cultural development of Makuria before the emplacement of its capital in

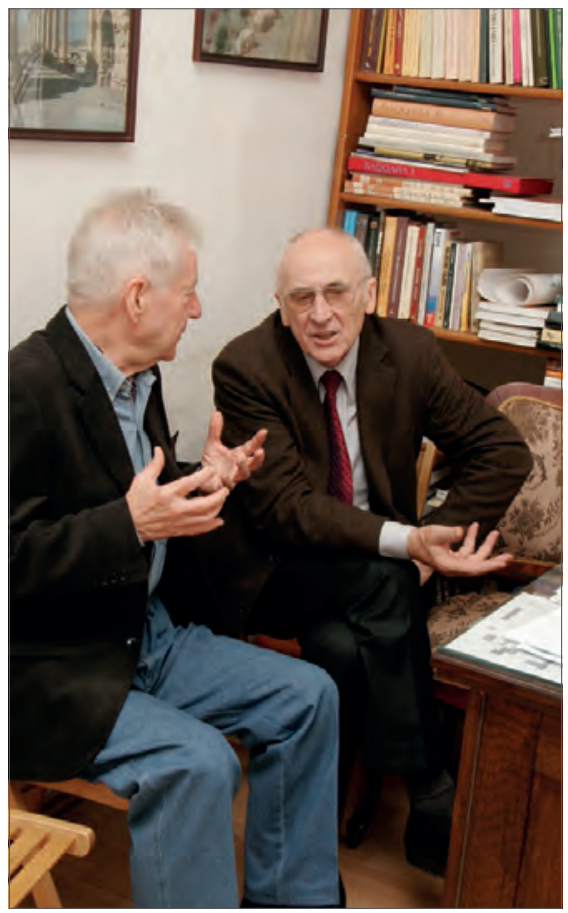

Fig. 6. Wtodzimierz Godlewski in discussion with Professor Romuald Schild at the Warsaw office of the Polish Centre of Mediterranean Archaeology (Photo courtesy PCMA) 
Dongola. In 1994-1996, Godlewski had his share in a project of the École biblique et archéologique française in Jerusalem, carried out in association with the National Museum in Warsaw, uncovering within the frame of this project the remains of a pagan temple in Gaza-Blakhiyah, the ancient Anthedon, destroyed presumably in the course of the conflict between the Christian and traditional religions.

Godlewski the scholar is indefatigable in the field. He has an iron constitution and the industriousness of the proverbial monk. Members of his teams are witness to this: whether at Dongola or Naqlun, Godlewski is up well before sunrise (taking time to listen to the news on radio with his morning coffee) and operates without break all day long, looking to the minutest aspects of the functioning of his expedition, both scholarly and material. In the excavation trenches he does not let anything pass, from exploration through documentation, to proper safety measures when required. He expects such universality from his team and here, we must confess as his long-term associates, it is seldom that most of us can manage. His approach to the archaeological sources is exceptionally critical. This is well illustrated by a remark to one of the Dongola team members, following a discussion of some scientific idea, when Godlewski quipped: "Yes, yes, you are entirely right, but I do not agree". Godlewski will question every, even the most obvious truths, because he believes this to be the only sure way to reach original conclusions. These conclusions may sometimes be controversial to say the least, but they are intellectually stimulating, leading to an advancement in science, which is after all what our work is all about. Last but not last, Godlewski has an inkling for holistic approaches and is adroit at formulating them. Naturally, he has his preferences in the field of material studies, his favorites being architecture, which he knows well and understands (also in practice, having rebuilt his own house practically with his own hands), but also wall painting, pottery and textiles. Yet it is never a formal or stylistic, or even iconographic analysis that he engages in. Artifacts are of interest to him as far as they can substantiate the development of more general ideas concerning the society that produced them and used them in their everyday life. In his academic studies Godlewski is as much an archaeologist, as a historian, student of the political sciences, economic analyst and explorer of Christian religion and culture.

It would be an overlooking not to mention Godlewski the organizer. During his lifetime he has organized two major international conferences: of Coptic studies in 1984 and Nubian Studies in 2006, both in Warsaw. The circumstances, in which the first of these two meetings was organized, shortly after the lifting of martial law in Poland, were an exceptional challenge, which 
Godlewski met with his usual practical and enterprising approach. He has also organized three smaller international symposia at the Nieborów Palace near Warsaw, the first, in 1988, on Coptic and Nubian pottery, the second a year later on Nubian wall painting and the third, in 1990, on Ethiopian art. Starting from 2005, he has organized with his associates from the Archaeology of Egypt and Nubia Department at the Institute of Archaeology University of Warsaw, in cooperation with the Polish Centre of Mediterranean Archaeology, an annual conference "Poles on the Nile", dedicated to a presentation of current Polish research in Egypt and Sudan. From 2015, a day devoted entirely to Makuria has become a staple of the conference program. Thus, largely thanks to Godlewski's efforts, Makuria is being raised from oblivion back into the mainstream of public discussion on mankind's historical and cultural heritage.

Godlewski the Scholar, Godlewski the Academic, Godlewski the Organizer - and yet there is also Godlewski the Man. Those who have benefited know best what they owe to him, but that helping hand, offered with no strings attached, has tided a few over some rough times. His generosity and kindness is not advertised, but it is extended without asking whenever the need arises, including a "retirement" for an old worker at Dongola who had spent his life

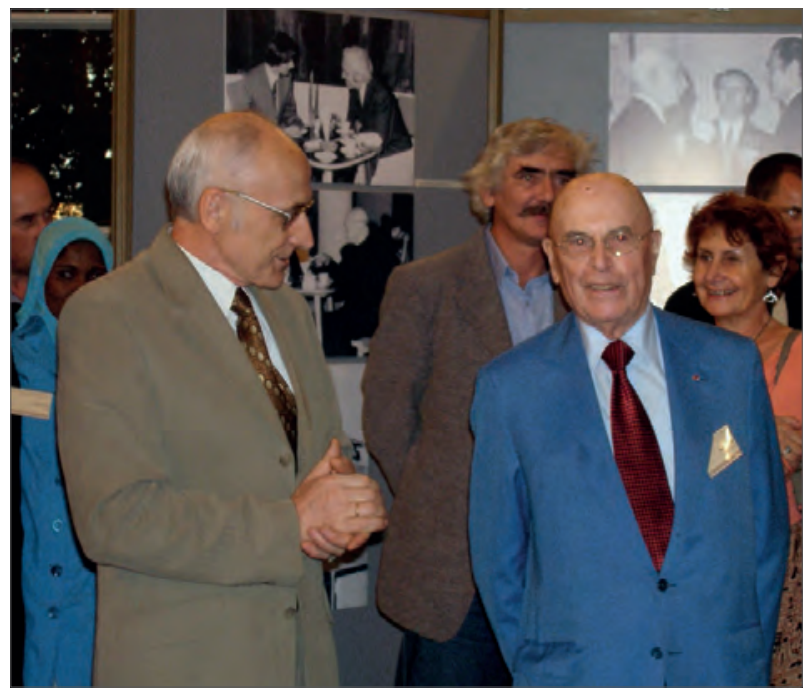

Fig. 7. Wtodzimierz Godlewski and Jean Leclant at the opening of an exhibition accompanying the 11th Conference of Nubian Studies in Warsaw in 2006 (Photo courtesy PCMA) 
on the excavations. Animals figure strongly in Godlewski's life. In his home at Legionowo (a suburb of Warsaw) there is Albin, an adorable white mongrel already advanced in age, and Walus sthe cat, offspring of the late lamented Lutka, a stray who arrived one winter February ('luty' in Polish) and stayed. Godlewski's love of animals is evident also at excavations. The story of his "affair" with a cat from the monastery in Naqlun is common lore. She arrives within hours of the team's arrival and is a regular visitor at the table for the duration of the season, then by some unfathomed instinct disappears just before the mission is packed to leave. One year she even brought her litter of newborn kittens for Godlewski to "manage". At Dongola, the evening ritual involves Godlewski setting aside part of his dinner for his pet animals, who wait in a set hierarchy for the repast. Half the village cats are there and in a recent season a mongoose also considered himself as invited. There is also Godlewski the political animal who has to be abreast of the political situation in the world, listening to the $\mathrm{BBC}$ evening or morning news on his old, crackling radio and commenting on events at the dining table (he is as often right as he is wrong in his political prognoses). Let us not forget Godlewski the Musical Man with a strong preference for traditional American jazz. And Godlewski the Host, offering his guests a shot of whiskey, his favorite, to Ella Fitzgerald's songs and treating them to an excellent dinner prepared by Lilka, his wife and companion for close to half a century. 



\section{Włodzimierz Godlewski: List of publications}

\section{Books}

- Les baptistères nubiens [=Faras 6], Warsaw: PWN - Éditions scientifiques de Pologne, 1979.

- Le monastère de St Phoibammon [=Deir el-Bahari 5], Warsaw: PWN - Éditions Scientifiques de Pologne, 1986.

- Wystawa Sztuka Koptyjska: Warszawa 1984 [Exhibition of Coptic art: Warsaw 1984], Kraków: Oficyna Wydawnicza “GT Urania”, 1988 (editor).

- Coptic and Nubian pottery: International workshop, Nieborów, August 29-31, 1988, Warsaw: National Museum in Warsaw, 1990 (editor).

- Coptic studies: Acts of the Third International Congress of Coptic Studies, Warsaw, 20-25 August, 1984, Warsaw: PWN, 1990 (editor).

- Galeria Faras: przewodnik / The Faras Gallery: Guide, Warsaw: Muzeum Narodowe w Warszawie, 1993.

- Dongola: City of kings and bishops, Warsaw: PCMA UW, 2006.

- Pachoras: The cathedrals of Aetios, Paulos and Petros. The architecture [=PAM Supplement Series 1], Warsaw: Warsaw University Press, 2006.

- Between the cataracts: Proceedings of the 11th Conference for Nubian Studies, Warsaw University, 27 August-2 September 2006, I. Main papers [=PAM Supplement Series 2.1], Warsaw: Warsaw University Press, 2008 (editor with A. Łajtar).

- Between the cataracts: Proceedings of the 11th Conference for Nubian Studies, Warsaw University, 27 August-2 September 2006, II. Session papers [=PAM Supplement Series 2.2], Warsaw: Warsaw University Press, 2010 (editor with A. Łajtar).

- Dongola: Ancient Tungul. Archaeological guide, Warsaw: PCMA UW, 2013.

- Dongola 2012-2014. Report on work in the Mosque Building, Citadel and Monastery on Kom H [=PCMA Excavation Series 3]. Warsaw: PCMA UW, 2015 (editor with D. Dzierzbicka). 


\section{Book chapters}

- Some problems connected with Nubian baptisteries. In Etudes nubiennes: colloque de Chantilly, 2-6 juillet 1975 [=Bibliothèque d'étude 77] (pp. 107-117), Cairo: Institut français d'archéologie orientale, 1978.

- Some comments on the wall painting of Christ from Old Dongola. In J.M. Plumley (ed.), Nubian studies: Proceedings of the Symposium for Nubian Studies, Selwyn College, Cambridge, 1978 (pp. 95-99), Warminster: Aris \& Phillips, 1982.

- The mosque building in Old Dongola. In P. van Moorsel (ed.), New discoveries in Nubia: Proceedings of the Colloquium on Nubian Studies, the Hague, 1979 (pp. 21-28), Leiden: Nederlands Instituut voor het Nabije Oosten, 1982.

- The Late Roman necropolis in Deir el Bahari. In P. Nagel (ed.), GraecoCoptica: Griechen und Kopten im byzantinischen Ägypten (pp. 111119), Halle: Martin-Luther-Universität, 1984.

- Remarks on the art of Nobadia (V-VIII century). In M. Krause (ed.), Nubische Studien: Tagungsakten der 5. Internationalen Konferenz der International Society for Nubian Studies, Heidelberg, 22.-25. September 1982 (pp. 269-280), Mainz am Rhein: Philipp von Zabern, 1986.

- The Nubian Seraphim. In P.O. Scholz and R. Stempel (eds), Nubia et Oriens Christianus: Festschrift für C. Detlef G. Müller zum 60. Geburtstag (pp. 367-371), Cologne: J. Dinter, 1987.

- Coptic pottery from Deir el-Naqlun (Fayum). In W. Godlewski (ed.), Coptic and Nubian pottery: International workshop, Nieborów August 29-31, 1988 [=National Museum in Warsaw Occasional Paper 1] (pp. 49-62), Warsaw: National Museum in Warsaw, 1990.

- The Cruciform Church at Old Dongola (Sudan). Some comments. In W. Godlewski (ed.), Coptic studies: Acts of the Third International Congress of Coptic Studies, Warsaw, 20-25 August, 1984 (pp. 127137), Warsaw: PWN, 1990.

- The birth of Nubian art: Some remarks. In W.V. Davies (ed.), Egypt and Africa: Nubia from prehistory to Islam (pp. 253-256), London: British Museum Press, 1991.

- Architectural elements of churches: Baptistery. In A.S. Atiya (ed.), The Coptic encyclopedia I (pp. 197-200), New York: Macmillan, 1991. 
- Dayr Apa Phoibammon: Buildings. In A.S. Atiya (ed.), The Coptic encyclopedia III (pp. 780-781), New York: Macmillan, 1991.

- Deir el-Naqlun. Quelques observations historiques. In M. Rassart-Debergh and J. Ries (eds), Actes du IVe congrès copte: Louvain-la-Neuve, 5-10 septembre 1988, I [=Publications de l'Institut orientaliste de Louvain 40] (pp. 177-186), Louvain-la-Neuve: Institut orientaliste, 1992.

- La frise l'abside de la première Cathédrale de Pachoras (Faras). In P.O. Scholz (ed.), Orbis Aethiopicus: Studia in honorem Stanislaus Chojnacki natali septuagesimo quinto dicata, septuagesimo septimo oblata (pp. 327-356), Albstadt: K. Schuler, 1992.

- The early period of Nubian art. Middle of 6th - beginning of 9th centuries. In C. Bonnet (ed.), Etudes nubiennes: conférence de Genève. Actes du VII Congrès international d'études nubiennes, 3-8 septembre 1990, I. Communications principales (pp. 277-305), Geneva: C. Bonnet, 1992.

- Das Nationalmuseum in Warschau - historisches Konzept, moderne Entwicklung und aktuelles Programm. In M.-L. von Plessen (ed.), Die Nation und ihre Museen (pp. 160-168), Frankfurt am MainNew York: Campus Verlag, 1992.

- Naqlun 1989-1992. In D.W. Johnson (ed.), Acts of the Fifth International Congress of Coptic Studies: Washington, 12-15 August 1992, II.1 (pp. 183-195), Rome: CIM, 1993.

- A new approach to the Christianization of Makuria: An archaeological note. In C. Berger, G. Clerc, and N. Grimal (eds), Hommages à Jean Leclant II. Nubie, Soudan, Ethiopie [=Bibliothèque d'étude 106/2] (pp. 169176), Cairo: Institut français d'archéologie orientale, 1994.

- The Bishopric of Pachoras in the 13th and 14th centuries. In C. Fluck, L. Langener, S.G. Richter, S. Schaten, and G. Wurst (eds), Divitiae Aegypti: koptologische und verwandte Studien zu Ehren von Martin Krause (pp. 113-118), Wiesbaden: L. Reichert, 1995.

- The late period in Nubian art - from the middle of 13th to the end of 14th centuries. In R. Gundlach, M. Kropp, and A. Leibundgut (eds), Der Sudan in Vergangenheit und Gegenwart / Sudan past and present (pp. 37-63), Frankfurt am Main: P. Lang, 1995.

- The Paulos Cathedral in Faras (Pachoras) and the question of Byzantine influence. In C.F. Moss and K. Kiefer (eds), Byzantine East, Latin West: Art-historical studies in honor of Kurt Weitzmann (pp. 235-243), Princeton, NJ: Department of Art and Archaeology, Princeton University, 1995. 
- Deir el Naqlun. Topography and tentative history. In C. Basile (ed.), Archeologia e papiri nel Fayyum: storia della ricerca, problemi e prospettive. Atti del Convegno internazionale, Siracusa, 24-25 maggio 1996 [=Quaderni del Museo del Papiro, Siracusa 8] (pp. 123-145), Siracusa: Istituto internazionale del papiro, 1997.

- Old Dongola: The early fortifications. In Actes de la VIII Conférence Internationale des Etudes Nubiennes: Lille 11-17 septembre 1994, II. Découvertes archéologiques [= Cahiers de recherches de l'Institut de papyrologie et d'égyptologie de Lille 17/2] (pp. 175-179), Villeneuved'Ascq: Université Charles de Gaulle - Lille III, 1997.

- The role of Dongolese milieu in the Nubian church architecture. In M. Krause and S. Schaten (eds), Themelia: spätantike und koptologische Studien. Peter Grossmann zum 65. Geburtstag (pp. 127-142), Wiesbaden: Reichert Verlag, 1998.

- Christian Nubia: Recent studies (1990-1996). In S. Emmel, M. Krause, S.G. Richter, and S. Schaten (eds), Ägypten und Nubien in spätantiker und christlicher Zeit: Akten des 6. Internationalen Koptologenkongresses, Münster, 20.-26. Juli 1996, I. Materielle Kultur, Kunst und religiöses Leben [=Sprachen und Kulturen des christlichen Orients 6] (pp. 51-64), Wiesbaden: Reichert, 1999.

- Naqlun 1993-1996. In S. Emmel, M. Krause, S.G. Richter, and S. Schaten (eds), Ägypten und Nubien in spätantiker und christlicher Zeit: Akten des 6. Internationalen Koptologenkongresses, Münster, 20.-26. Juli 1996, I. Materielle Kultur, Kunst und religiöses Leben $[=$ Sprachen und Kulturen des christlichen Orients 6] (pp. 157-162), Wiesbaden: Reichert, 1999.

- The earliest evidence of the settlement at Old Dongola. In S. Wenig (ed.), Studien zum antiken Sudan: Akten der 7. Internationalen Tagung für meroitistische Forschungen von 14. bis 19. September 1992 in Gosen/bei Berlin (pp. 554-559), Wiesbaden: Harrassowitz, 1999.

- Naqlun. The hermitage of Phibamo. In K.M. Ciałowicz and J.A. Ostrowski (eds), Les civilisations du bassin Méditerranéen: hommages à Joachim Śliwa (pp. 91-98), Kraków: Instytut Archeologii Uniwersytetu Jagiellońskiego, 2000.

- Nubia, Egypt, and Byzantium. In O.Z. Pevny (ed.), Perceptions of Byzantium and its neighbors (843-1261): The Metropolitan Museum of Art symposia (pp. 168-182), New York: Metropolitan Museum of Art, 2000.

- The monastery Nekloni in the Egyptian Fayoum. In S. McNally (ed.), Shaping community. The art and archaeology of monasticism (pp. 3940), Oxford: Archaeopress, 2001. 
- Abu Mena na styku antyczności i średniowiecza orientalnego [Abu Mena between Antiquity and the Medieval Orient]. In B. IwaszkiewiczWronikowska and D. Próchniak (eds), Sympozja Kazimierskie poświęcone kulturze świata późnego antyku i wczesnego chrześsijaństwa II. Topografia świata wczesnochrześcijańskiego. Między starożytnością a średniowieczem (pp. 241-258), Lublin: Towarzystwo Naukowe KUL, 2001.

- Les textiles issus des fouilles récentes de Naqlun. In M. Durand and F. Saragoza (eds), Égypte, la trame de l'histoire: textiles pharaoniques, coptes et islamiques (pp. 100-104), Paris: Somogy, 2002.

- Christian Nubia, studies 1996-2000. In M. Immerzeel and J. van der Vliet (eds), Coptic studies on the threshold of a new millennium: Proceedings of the Seventh International Congress of Coptic Studies, Leiden, August 27-September 2, 2000, II [=Orientalia Lovaniensia Analecta 133] (pp. 1037-1051), Leuven: Peeters. 2004.

- Old Dongola. In D.A. Welsby and J.R. Anderson (eds), Sudan: Ancient treasures. An exhibition of recent discoveries from the Sudan National Museum (pp. 209-213), London: British Museum Press, 2004.

- The rise of Makuria (late 5th-8th cent.). In T. Kendall (ed.), Nubian studies, 1998: Proceedings of the Ninth Conference of the International Society of Nubian Studies, August 21-26, 1998, Boston, Massachusetts (pp. 52-73), Boston: Department of African-American Studies, Northeastern University, 2004.

- Faras i Naqlun - dwa odkrycia i dwa odmienne zadania konserwatorskie oraz ich odbiór społeczny [Faras and Naqlun - two discoveries and two separate conservation tasks and their social reception]. In D. Królak-Merska and K.J. Kwiecińska (eds), Spotkania w willi Struvego 2001-2003. Wyktady o dziedzictwie kultury (pp. 177-183), Warsaw: Towarzystwo Opieki nad Zabytkami, 2004.

- Excavating the ancient monastery at Naqlun. In G. Gabra (ed.), Christianity and monasticism in the Fayoum oasis: Essays from the 2004 International symposium of the Saint Mark Foundation and the Saint Shenouda the Archimandrite Coptic Society in honor of Martin Krause (pp. 155-171), Cairo: American University in Cairo Press, 2005.

- The medieval Coptic cemetery at Naqlun. In G. Gabra (ed.), Christianity and monasticism in the Fayoum oasis: Essays from the 2004 international symposium of the Saint Mark Foundation and the Saint Shenouda the Archimandrite Coptic Society in honor of Martin Krause (pp. 173183), Cairo: American University in Cairo Press, 2005. 
- Al-Naqlun: Links between archaeology and textiles. In S. Schrenk (ed.), Textiles in situ: Their find spots in Egypt and neighbouring countries in the first millenium CE (pp. 33-42), Riggisberg: Abegg-Stiftung, 2006.

- Nubian studies 2000-2004. In A. Boud'hors and D. Vaillancourt (eds), Huitième Congrès international d'études coptes, Paris 2004, I. Bilans et perspectives 2000-2004 (pp. 217-230), Paris: De Boccard, 2006.

- The churches of Dongola, their origin and importance in the general line of development of church architecture in Makuria. In I. Caneva and A. Roccati (eds), Acta Nubica: Proceedings of the X International Conference of Nubian studies, Rome, 9-14 September 2002 (pp. 263-286), Rome: Istituto Poligrafico e Zecca dello Stato, Libreria dello Stato, 2006.

- King Qalidurut's Dongola: Arabic sources and archaeology. In B. Gratien (ed.), Mélanges offerts à Francis Geus [=Cahiers de recherches de l'Institut de papyrologie et d'égyptologie de Lille 26] (pp. 131-140), Villeneuve-d'Ascq: Université Charles-de-Gaulle - Lille 3, 2007.

- Naqlun. In E. Laskowska-Kusztal (ed.), Seventy years of Polish archaeology in Egypt (pp. 171-182), Warsaw: PCMA UW, 2007.

- Naqlun. Catalogue nos 79-93. In A. Majewska (ed.), Seventy years of Polish archaeology in Egypt: Egyptian Museum in Cairo, 21 October21 November 2007 (pp. 183-203), Warsaw: PCMA UW, 2007.

- Bishops and kings. The official program of the Pachoras (Faras) Cathedrals. In W. Godlewski and A. Łajtar (eds), Between the cataracts: Proceedings of the 11th Conference for Nubian studies, Warsaw University, 27 August-2 September 2006, I. Main papers [=PAM Supplement Series 2.1] (pp. 263-282), Warsaw: Warsaw University Press, 2008.

- Naqlun. Monastery never to be forgotten. In H. Froschauer and C. Römer (eds), Spätantike Bibliotheken: Leben und Lesen in den frühen Klöstern Ägyptens (pp. 71-79), Vienna: Phoibos-Verlag, 2008.

- Naqlun (Nekloni). The hermitages, cemetery and the keep in the early 6th century. In S.L. Lippert and M. Schentuleit (eds), Graeco-Roman Fayum: Texts and archaeology. Proceedings of the third International Fayum Symposion, Freudenstadt, May 29-June 1, 2007 (pp. 101112), Wiesbaden: Harrassowitz, 2008.

- Mosaic floor from the sanctuary of the EC.II cathedral in Dongola. In H. Meyza and I. Zych (eds), Classica orientalia: Essays presented to Wiktor Andrzej Daszewski on his 75th birthday (pp. 193-198), Warsaw: PCMA UW; Wydawnictwo DiG, 2011. 
- Naqlun cemetries. In G.A. Belova and S.V. Ivanov (eds), Achievements and problems of modern Egyptology: Proceedings of the international conference held in Moscow on September 29-October 2, 2009 (pp. 139-152), Moscow: Russian Academy of Sciences, 2012.

- Naqlun: The earliest hermitages. In R.S. Bagnall, P. Davoli, and C.A. Hope (eds), The Oasis Papers 6: Proceedings of the Sixth International Conference of the Dakhleh Oasis Project (pp. 475-489), Oxford: Oxbow Books, 2012.

- A short essay on the history of Nobadia from Roman to Mamluk times. In J. van der Vliet and J.L. Hagen (eds), Qasr Ibrim, between Egypt and Africa: Studies in cultural exchange (Nino Symposium, Leiden, 1112 December 2009) [=Egyptologische Uitgaven 26] (pp. 123-133), Leiden: Nederlands Instituut voor het Nabije Oosten, 2013.

- Monastic life in Makuria. In G. Gabra and H.N. Takla (eds), Christianity and monasticism in Aswan and Nubia (pp. 157-174), Cairo: American University in Cairo Press, 2013.

- The kingdom of Makuria in the 7th century. The struggle for power and survival. In C.J. Robin and J. Schiettecatte (eds), Les préludes de l'Islam: ruptures et continuités dans les civilisations du Proche-Orient, de l'Afrique orientale, de l'Arabie et de l'Inde à la veille de l'Islam (pp. 85-104), Paris: De Boccard, 2013.

- Dongola. In Voices from the Nile Valley: Polish archaeology between Alexandria and Dongola, Warsaw: Warsaw University Press, 2013 (with A. Łajtar).

- Faras. In Voices from the Nile Valley: Polish archaeology between Alexandria and Dongola, Warsaw: Warsaw University Press, 2013 (with A. Łajtar).

- Naqlun. In Voices from the Nile Valley: Polish archaeology between Alexandria and Dongola, Warsaw: Warsaw University Press, 2013 (with T. Derda).

- The kingdom of Makuria. In J.R. Anderson and D.A. Welsby (eds), The Fourth Cataract and beyond: Proceedings of the 12th International Conference for Nubian Studies [=British Museum Publications on Egypt and Sudan 1] (pp. 155-169), Leuven: Peeters, 2014.

- Site et decouverte du lot d'archives. In C. Gaubert and J.-M. Mouton, Hommes et villages du Fayyoum dans la documentation papyrologique arabe ( $X^{e}-X I^{e}$ siècles) (pp. 300-306), Geneva: Droz, 2014.

- Monastic architecture and its adaptation to local land features (Egypt). In O. Delouis and M. Mossakowska-Gaubert (eds), La vie quotidienne des moines en Orient et en Occident (IV $V^{e} X^{e}$ siècle), I. L'état des sources (pp. 3-22), Cairo: Institut français d'archéologie orientale, 2015. 
- Monastic life in Makuria. In O. Delouis and M. Mossakowska-Gaubert (eds.), La vie quotidienne des moines en Orient et en Occident (IVe $X^{e}$ siècle), I. L'état des sources (pp. 81-98), Cairo: Institut français d'archéologie orientale, 2015.

- Naqlun - Das Kloster des Erzengels Gabriel. In C. Fluck, G. Helmecke, and E.R. O'Connell (eds), Ein Gott: Abrahams Erben am Nil. Juden, Christen und Muslime in Ägypten von der Antike bis zum Mittelalter (pp. 130-133), Berlin: Staatliche Museen zu Berlin, Preussischer Kulturbesitz, 2015.

- Monastery of the Archangel Gabriel, Naqlun. In C. Fluck, G. Helmecke, and E.R. O'Connell (eds.), Egypt: Faith after the Pharaohs (pp. 128-131), London: The British Museum, 2015.

- The architecture of the Central Hall. In W. Godlewski and D. Dzierzbicka (eds), Dongola 2012-2014. Report on work in the Mosque Building, Citadel and Monastery on Kom $H[=P C M A$ Excavation Series 3] (pp. 15-24), Warsaw: PCMA UW, 2015.

- Building SWN.B.V: The Church of Raphael. In W. Godlewski and D. Dzierzbicka (eds), Dongola 2012-2014. Report on work in the Mosque Building, Citadel and Monastery on Kom $H[=P C M A$ Excavation Series 3] (pp. 53-64), Warsaw: PCMA UW, 2015.

- Palatial Building SWN.B.I and earlier relics of Buildings SWN.B.IV and SWN.B.X. In W. Godlewski and D. Dzierzbicka (eds), Dongola 2012-2014. Report on work in the Mosque Building, Citadel and Monastery on Kom H [=PCMA Excavation Series 3] (pp. 65-84), Warsaw: PCMA UW, 2015 (with contributions by M. Osypińska and K. Danys-Lasek).

- The fortifications of Dongola and houses to the north of the Citadel. In W. Godlewski and D. Dzierzbicka (eds), Dongola 2012-2014. Report on work in the Mosque Building, Citadel and Monastery on Kom H $[=P C M A$ Excavation Series 3] (pp. 183-214), Warsaw: PCMA UW, 2015.

- SWN.B.I.E: Residential quarter of the Funj period (17th century). In W. Godlewski and D. Dzierzbicka (eds), Dongola 2012-2014. Report on work in the Mosque Building, Citadel and Monastery on Kom H $[=P C M A$ Excavation Series 3] (pp. 223-232), Warsaw: PCMA UW, 2015.

- The southwestern part of Kom H in Dongola: Research on the monastic gates and protection work in the cemeteries. In W. Godlewski and D. Dzierzbicka (eds), Dongola 2012-2014. Report on work in the Mosque Building, Citadel and Monastery on Kom H $[=P C M A$ Excavation Series 3] (pp. 273-284), Warsaw: PCMA UW, 2015. 


\section{Journal articles}

- Koptyjska legenda o świętym Onufrym [Coptic legend of Saint Onnophrios], Euhemer 3 (1971), 23-25 (with A. Szczudłowska).

- Faras à l'époque méroïtique, Études et Travaux 6 (1972), 185-193.

- Le baptistère de la Vieille Eglise à Dongola, Études et Travaux 10 (1978), 363-374.

- Le baptistère de l'église au dallage de pierre à Dongola, Études et Travaux 11 (1979), 139-150.

- Throne Hall at Old Dongola (the Sudan), Africana Bulletin 30 (1981), 39-51.

- Od Faras do Dongoli [From Faras to Dongola], Meander 36/6 (1981), 351355 (with S. Jakobielski).

- Le baptistère de l'église dans le temple de Mandulis à Kalabsha, Nubia Christiana 1 (1982), 134-140.

- The Throne Hall in Old Dongola (Sudan), Jahrbuch der österreichischen Byzantinistik 32 (1982), 569-574.

- Monastère nord ou monastère de St Phoibammon, Études et Travaux 13 (1983), 93-98.

- Polish excavations at Old Dongola (1980-1983), Nyame Akuma 23 (1983), 27-28.

- Polskie badania archeologiczne w Starej Dongoli (Sudan) w latach 19811982 [Polish archaeological research in Old Dongola (Sudan) in 1981-1982], Rocznik Muzeum Narodowego w Warszawie 28 (1984), 465-484.

- The Church of Stone Pavement in Old Dongola, Nubian Letters 2 (1984), 11-16.

- Egipskie stele nagrobne z okresu rzymskiego w zbiorach Muzeum Narodowego w Warszawie [Egyptian funerary stelae of the Roman period in the collections of the National Museum in Warsaw], Rocznik Muzeum Narodowego w Warszawie 29 (1985), 235-252.

- Some remarks on the Cruciform Church in Old Dongola (Sudan), Nubian Letters 4 (1985), 20-22.

- The Church of Stone Pavement in Old Dongola. Part II, Nubian Letters 8 (1987), 2-6.

- The so-called Mosque Building in Old Dongola (Sudan). A structural analysis, Archéologie du Nil Moyen 2 (1987), 185-205 (with S. Medeksza).

- Polskie odkrycia w Naqlun (Fajum) w 1986 roku [Polish discoveries at Naqlun (Fayum) in 1986], Rocznik Muzeum Narodowego w Warszawie 32 (1988), 489-499. 
- Badania archeologiczne w Starej Dongoli (Sudan) w latach 1985-1987 [Archaeological research in Old Dongola (Sudan) in 1985-1987], Rocznik Muzeum Narodowego w Warszawie 33-34 (1989), 625-638.

- Badania wykopaliskowe w Deir el-Naqlun (Fajum): sezon drugi [Excavations in Deir el-Naqlun (Fayum): Second season], Rocznik Muzeum Narodowego w Warszawie 33-34 (1989), 639-652.

- Maski grobowe z okresu rzymskiego w zbiorach Muzeum Narodowego w Warszawie [Mummy masks of the Roman period in the collections of the National Museum in Warsaw], Rocznik Muzeum Narodowego $w$ Warszawie 33-34 (1989), 91-100.

- Old Dongola 1988-1989. The House PCH.1, Polish Archaeology in the Mediterranean 1 (1990), 14-16.

- Polish excavations at Naqlun (1988-1989), Polish Archaeology in the Mediterranean 1 (1990), 29-34.

- Deir el Naqlun (Nekloni) 1986-87: First preliminary report with Appendix from 1988 by Jarosław Dobrowolski, Nubica 1-2 (1990), 171-207 (with T. Herbich and E. Wipszycka).

- The Cruciform Church site in Old Dongola. Sequence of buildings from the 6th to the 18th century, Nubica 1-2 (1990), 511-534.

- The Northern Church in Old Dongola, Archéologie du Nil Moyen 4 (1990), 37-62.

- Dongola 1978-1980, Études et Travaux 14 (1990), 393-408 (with S. Jakobielski).

- Deir el-Naqlun, 1990, Polish Archaeology in the Mediterranean 2 (1991), 48-53.

- The Old Dongola fortifications, Polish Archaeology in the Mediterranean 2 (1991), 74-77.

- Old Dongola 1988-1989. The House PCH.1, Archéologie du Nil Moyen 5 (1991), 79-101.

- The fortifications of Old Dongola. Report on the 1990 season, Archéologie du Nil Moyen 5 (1991), 103-128.

- Archaeological research in Naqlun in 1991, Polish Archaeology in the Mediterranean 3 (1992), 49-56.

- Some remarks on the Faras Cathedral and its painting, Journal of Coptic Studies 2 (1992), 99-116.

- Wczesne malowidła ścienne z terenów Nobadii [Early wall paintings from Nobadia], Rocznik Muzeum Narodowego w Warszawie 36 (1992), 23-39. - Deir el-Naqlun, 1992, Polish Archaeology in the Mediterranean 4 (1993), 43-48. - Dongola, capitale de la Nubie chrétienne, Dossiers d'archéologie 196 (1994), 72-77. 
- Naqlun 1993, Polish Archaeology in the Mediterranean 5 (1994), 55-62 (with E. Parandowska).

-Old Dongola town fortifications, 1993, Polish Archaeology in the Mediterranean 5 (1994), 129-132.

- Deir el Naqlun (Nekloni), 1988-1989. Second preliminary report, Nubica 3/1 (1994), 201-263 (with T. Derda and T. Górecki).

- Old Dongola. The fortifications, 1994, Polish Archaeology in the Mediterranean 6 (1995), 93-97.

- Naqlun: Excavations 1995, Polish Archaeology in the Mediterranean 7 (1996), $82-88$.

- Old Dongola. Kom A, 1995, Polish Archaeology in the Mediterranean 7 (1996), $115-120$.

- Naqlun: Excavations 1996, Polish Archaeology in the Mediterranean 8 (1997), 88-97 (with E. Parandowska).

- Old Dongola, Kom A (1996), Polish Archaeology in the Mediterranean 8 (1997), 179-187.

- Old Dongola, excavations 1997 - Kom A, Polish Archaeology in the Mediterranean 9 (1998), 171-179.

- Wielkość Dongoli [The greatness of Dongola], Światowit, 41/A (1998), 243249.

- Naqlun: Excavations 1998. Polish Archaeology in the Mediterranean 10 (1999), 113-117.

- Les peintures de l'église de l'Archange Gabriel à Naqlun, Bulletin de la Société d'archéologie copte 39 (2000), 89-101.

- Naqlun: Excavations, 1999, Polish Archaeology in the Mediterranean 11 (2000), $125-132$.

- Old Dongola. Kom A, 1999, Polish Archaeology in the Mediterranean 11 (2000), 197-206.

- Początki biskupstwa w Pachoras: katedra Aetiosa [The beginnings of the bishopric of Pachoras. The cathedral of Aetios], Swiatowit 2(43)/A (2000), 43-48.

- Naqlun: Recent studies, Bulletin de la Société d'archéologie copte 39 (2000), 69-87 (with B. Czaja-Szewczak).

- Naqlun: Excavations, 2000, Polish Archaeology in the Mediterranean 12 (2001), 149-161.

- Introduction to the Golden Age of Makuria (9th-11th century), Africana Bulletin 50 (2002), 75-98.

- Naqlun: Excavations, 2001, Polish Archaeology in the Mediterranean 13 (2002), 159-170. 
- Old Dongola. Kom A, 2001, Polish Archaeology in the Mediterranean 13 (2002), 203-216.

- Naqlun: Excavations, 2002, Polish Archaeology in the Mediterranean 14 (2003), 163-171.

- Naqlun (Nekloni): Season 2003, Polish Archaeology in the Mediterranean 15 (2004), 141-151.

- Old Dongola. Kom A (Acropolis), 2003, Polish Archaeology in the Mediterranean 15 (2004), 193-215.

- Naqlun (Nekloni): Season 2004, Polish Archaeology in the Mediterranean 16 (2005), 181-190.

- Uli Island. Preliminary report, Polish Archaeology in the Mediterranean 16 (2005), 339-350 (with A. Obłuski and D. Zielińska).

- MtoM. Early Makuria Research Project, Polish Archaeology in the Mediterranean 16 (2005), 385-388.

- Grave stelae from Deir el-Naqlun, Journal of Juristic Papyrology 36 (2006), 43-62 (with A. Łajtar).

- Naqlun (Nekloni): Preliminary report, 2005, Polish Archaeology in the Mediterranean 17 (2007), 195-205.

- Old Dongola. Kom A (Acropolis), 2005, Polish Archaeology in the Mediterranean 17 (2007), 287-299.

- Naqlun (Nekloni): Season 2006, Polish Archaeology in the Mediterranean 18 (2008), 195-206.

- Cemetery C.1 in Naqlun: Tomb C.T.5 and its cartonnages, Polish Archaeology in the Mediterranean 18 (2008), 247-260 (with B. Czaja-Szewczak).

- MtoM. Early Makuria Research Project, season 2006, Polish Archaeology in the Mediterranean 18 (2008), 463-476.

- Dongola after the 2008-2010 seasons: Royalty, saints and blessed bishops, Sudan \& Nubia 14 (2010), 75-82.

- Naqlun 2007: Preliminary report, Polish Archaeology in the Mediterranean 19 (2010), 229-244.

- Old Dongola. Kom A (Citadel), 2007, Polish Archaeology in the Mediterranean 19 (2010), 313-326.

- Early Makuria Research Project. Season 2007, Polish Archaeology in the Mediterranean 19 (2010), 494-499 (with J. Kociankowska-Bożek).

- In the shade of the Nekloni monastery (Deir Malak Gubrail, Fayum), Polish Archaeology in the Mediterranean 20 (2011), 467-482.

- Naqlun (Nekloni) excavations in 2008-2009, Polish Archaeology in the Mediterranean 21 (2012), 193-211. 
- Dongola 2008-2009, Polish Archaeology in the Mediterranean 21 (2012), 289-314.

- Crypts 1 and 2 in the Northwest Annex of the Monastery on Kom H in Dongola: Report on the exploration in 2009, Polish Archaeology in the Mediterranean 21 (2012), 338-360 (with R. Mahler and B. CzajaSzewczak).

- Washtub from the Palace of Ioannes in Dongola, Etudes et Travaux 25 (2012), $119-125$.

- The Mosque Building in Old Dongola. Conservation and revitalization project, Polish Archaeology in the Mediterranean 22 (2013), 248272 (with A. Obłuski, W. Kołątaj, S. Medeksza and C. CalaforraRzepka).

- Archbishop Georgios of Dongola. Socio-political change in the kingdom of Makuria in the second half of the 11th century, Polish Archaeology in the Mediterranean 22 (2013), 663-677.

- Dongola, Sudan. Excavations in 2012, Światowit 10(51)/A (2013), 185-192.

- Naqlun, Egypt. Excavations in 2012, Swiatowit 10(51)/A (2013), 193-201.

- Dongola, Sudan. Excavations in 2012/2013, Światowit 11(52)/A (2014), 233-240.

- Naqlun (Nekloni). Excavations in 2010-2011, Polish Archaeology in the Mediterranean 23/1 (2014), 173-191.

- Dongola 2010-2011, Polish Archaeology in the Mediterranean 23/1 (2014), 265-284.

- Dongola. Seasons in 2012-2013, Polish Archaeology in the Mediterranean 24/1 (2015), 325-339.

- Crypt 3 and the commemorative burial complex in the Northwest Annex of the Monastery on Kom H in Dongola: Report on the exploration in 2012, Polish Archaeology in the Mediterranean 24/1 (2015), 352-367 (with R. Mahler, B. Czaja and K. Danys-Lasek).

- Dongola, Sudan. Season 2013-2014, Światowit 12(53)/A (2015), 239-246.

- Naqlun, Egypt. Excavations in 2014, Światowit 12(53)/A (2015), 247-254.

\section{Popular articles}

- Dongola - stolica chrześcijańskiej Nubii [Dongola - the capital of Christian Nubia], Z otchtani wieków 39/4 (1973), 296-303.

- Dongola: stolica królestwa Makurii [Dongola: the capital of the kingdom of Makuria]. Archeologia Żywa 8/3 (2003), 8-11. 
- Skarb mnichów z Naqlun [Treasure of the monks from Naqlun], Archeologia Żywa 15/2 (2010), 20-22.

- W koptyjskim klasztorze [In a Coptic monastery], Archeologia Żywa 16/1 (2011), 12.

\section{Reports from conferences}

- II Międzynarodowy Kongres Studiów Koptologicznych, Rzym, 22-26 września 1980 r. [Second International Congress of Coptic Studies, Rome, 22 26 September 1980], Collectanea Theologica 52/2 (1982), 176-180.

- V Międzynarodowy Kongres Studiów Nubiologicznych w Heidelbergu, 20-25 września 1982 r. [Fifth International Conference of Nubian Studies, Heidelberg, 20-25 September 1982], Collectanea Theologica 54/1 (1984), 133-136.

\section{Book reviews}

- Trzy państwa - jedna cywilizacja [Three states - one civilization], review of: F. Daumas, Od Narmera do Kleopatry. Cywilizacja starożytnego Egiptu, Warszawa: Państwowe Wydawnictwo Naukowe, 1973, Nowe Książki 15 (1973), 26-27.

- Review of: F. Daumas, Od Narmera do Kleopatry. Cywilizacja starożytnego Egiptu, Warszawa: Państwowe Wydawnictwo Naukowe, 1973, Z otchtani wieków 39/4 (1973), 326.

- O archeologii [About archaeology], review of: W. Hensel, Archeologia żywa, Warszawa: Wydawnictwa Artystyczne i Filmowe, 1973, Nowe Książi 10 (1974), 51-52.

- Ocalone malowidła [Rescued paintings], review of: K. Michałowski, Faras, malowidta ścienne $w$ zbiorach Muzeum Narodowego, Warszawa: Wydawnictwo Artystyczno-Graficzne, 1974, Nowe Książki 18 (1974), $10-11$.

- Review of: R. Kasser et al., Le site monastique des Kellia (Basse-Egypte). Recherches des annees 1981-1983 (Mission suisse d'archéologie copte de l'Université de Genève), Louvain: Peeters, 1984, Bibliotheca Orientalis 45 (1988), 150-151. 
- Review of: G. Ruffini, Medieval Nubia. A social and economic history, Oxford: Oxford: Oxford University Press, 2012, The Medieval Review (2013). Retrieved from: https://scholarworks.iu.edu/journals/index.php/tmr/ article/view/17848/23966.

\section{Miscellanea}

- Kazimierz Michałowski 1901-1981, Muzealnictwo 25 (1982), 123-126.

- P. du Bourguet, Sztuka Koptów [The art of the Copts], Warsaw: WAiF, 1991 (author of the afterword).

- Przemówienia wygłoszone podczas uroczystego wieczoru poświęconego pamięci profesora Stanisława Lorentza (Muzeum Narodowe w Warszawie, 8 maja 1991) [Speech given during an official reception dedicated to the memory of Professor Stanisław Lorentz (National Museum in Warsaw)], Biuletyn Historii Sztuki 55/2-3 (1993), 308312 (with A. Rottermund, T.S. Jaroszewski and A. Gieysztor).

- C. Gaubert and J.-M. Mouton, Hommes et villages du Fayyoum dans la documentation papyrologique arabe ( $X^{e}-X I^{e}$ siècles). Geneva: Droz, 2014 (author of the introduction).

Compiled by Aleksandra Zych 



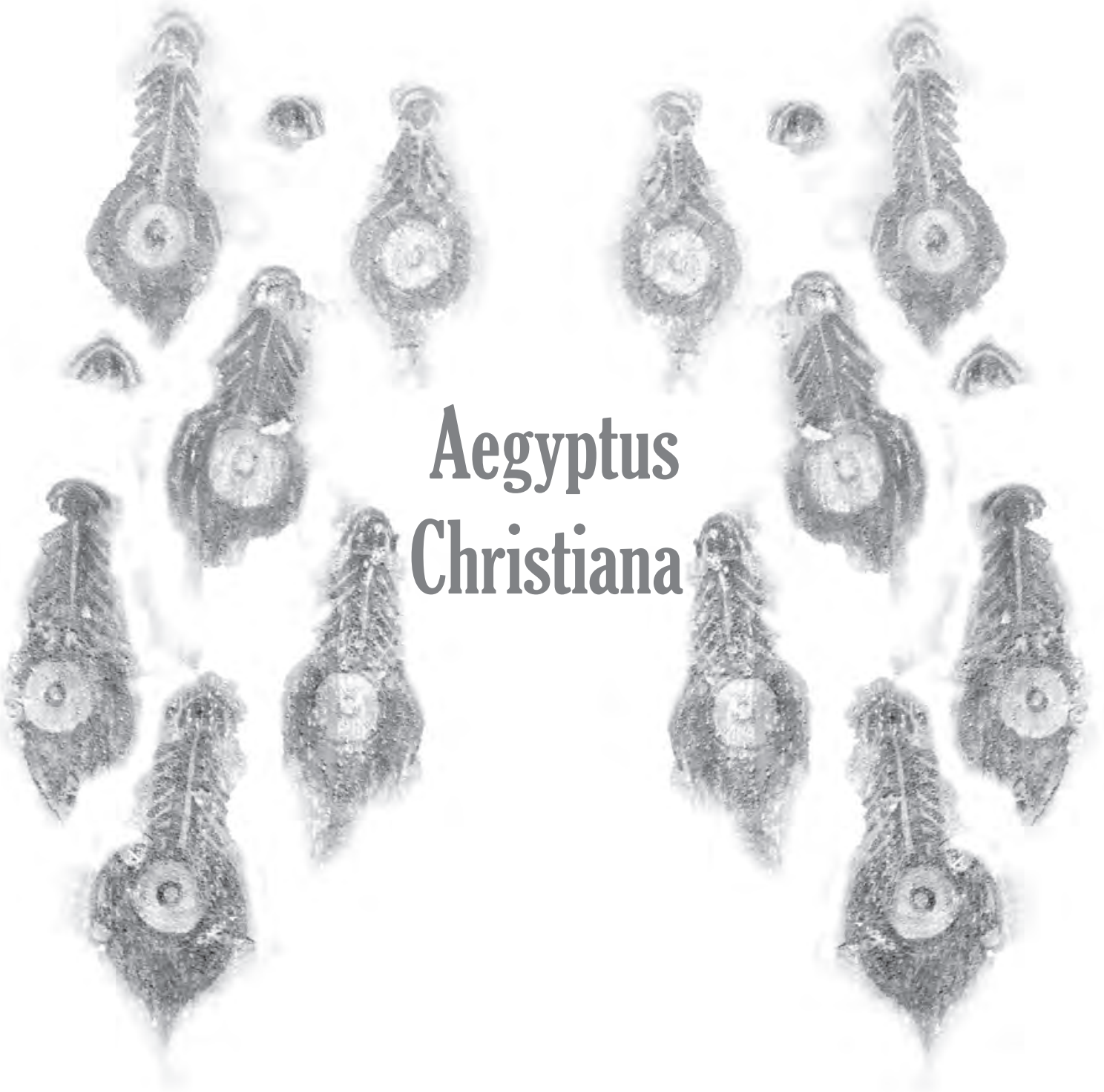





\title{
Que reste-t-il de la bibliothèque du monastère de Saint-Phoibammon à Deir el-Bahari ?
}

\author{
Anne Boud'hors \\ CNRS / IRHT, section Grecque \\ anne.boudhors@irht.cnrs.fr \\ Esther Garel \\ Österreichische Akademie der Wissenschaften \\ esthergarel@gmail.com
}

KeYwords

Coptic Bible, Coptic manuscripts, monasticism, libraries

\begin{abstract}
Some scraps of Coptic literary texts (parchment and papyrus) have been excavated at Deir el-Bahari in 2008/2009. Identified as biblical passages, they are published here and offer the opportunity to return to the question of the existence and contents of the library of the monastery of Saint-Phoibammon: firstly, to what extent can these fragments be considered as remains of such a library? Then, since the publication of Włodzimierz Godlewski’s monograph on this monastery, are there other clues that make new hypotheses possible?
\end{abstract}

Lors de la saison 2008-2009 à Deir-el-Bahari, l'équipe du docteur Zbigniew E. Szafrański a exhumé quelques petits fragments de manuscrits littéraires en copte sahidique. Pour réduits qu'ils soient, ces fragments ne sont pas sans intérêt sur le plan textuel : l'un fournit quelques phrases du livre de Jérémie non encore attestées en copte sahidique, un autre quelques mots de l'Évangile de Marc qui permettent d'identifier son type de texte. Comme ce sont d'autre part les premiers fragments littéraires retrouvés sur le site du monastère de Phoibammon, ils amènent à reposer et à compléter la question plusieurs fois soulevée : existait-il dans ce monastère une bibliothèque et peut-on considérer que ces débris en sont les rescapés ? Nous présenterons ici, après l'édition des fragments, quelques réflexions sur ce point, en hommage aux travaux de Włodzimierz Godlewski à Deir el-Bahari (Godlewski 1986), qui constituent une étape décisive dans la recherche sur la région thébaine à l'époque chrétienne. 


\section{I. Édition des fragments}

Ils ont été trouvés dans le remplissage secondaire - résultat de pillage - d'une tombe de la Troisième Période Intermédiaire (tombe X), soit le secteur S.7C/82. Cette tombe est située dans la partie ouest de la chapelle d'Hatchepsout, qui avait été reconvertie en église, sous la fausse porte en granit réutilisée comme abside dans le mur ouest de l'église. Le matériel de remplissage était mélangé et il n’y pas de contexte stratigraphique pour les fragments coptes.

\section{Fragments de JÉRÉMIE (INV. 822)}

Fragment d'un codex de parchemin $(2.2 \mathrm{~cm}[\mathrm{H}] \times 11.5 \mathrm{~cm}$ [L]). Partie inférieure d'un feuillet écrit sur deux colonnes, avec les restes de 3-4 lignes pour chaque colonne. La hauteur moyenne d'une lettre est de $3 \mathrm{~mm}$. On notera particulièrement la variation de la forme du $\mathrm{M}$. Une trace de pli oblique traverse le fragment dans toute sa largeur. Le côté chair est taché et moins lisible.

Ce fragment provient d'un codex aux dimensions assez réduites (la largeur devait être d'environ $13 \mathrm{~cm}$ ), ce qui, en considération de l'écriture - une petite majuscule biblique - plaide pour une date assez haute $: 5^{\mathrm{e}}$ siècle ?

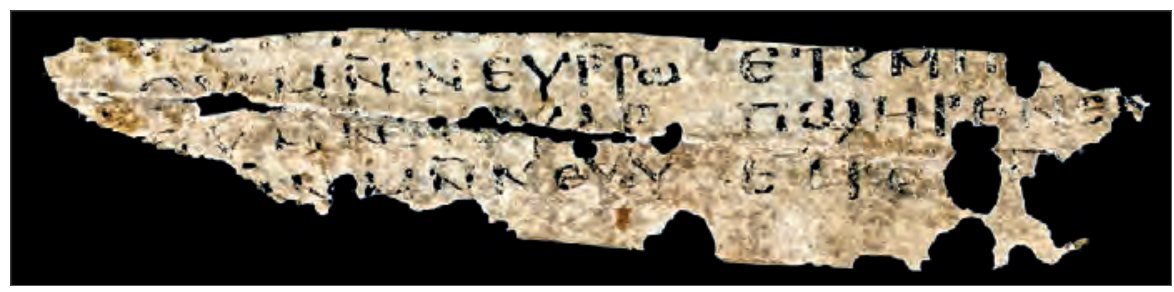

Fig. 1. Fragment de parchemin copte; Jér 39, 32.35

(Photo avec l'aimable autorisation du PCMA/M. Jawornicki)

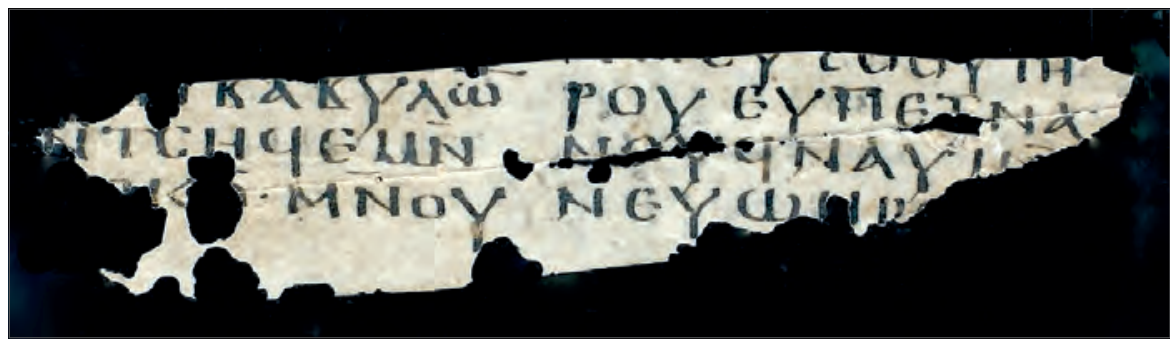

Fig. 2. Fragment de parchemin copte ; Jér 39, 36.39

(Photo avec l'aimable autorisation du PCMA/M. Jawornicki) 
Ce texte n'est pas encore attesté en sahidique. Par ailleurs, la date probable du fragment en fait l'un des plus anciens témoins de Jérémie ${ }^{1}$.

Recto (côté chair ?) [Fig. 1]

39,32

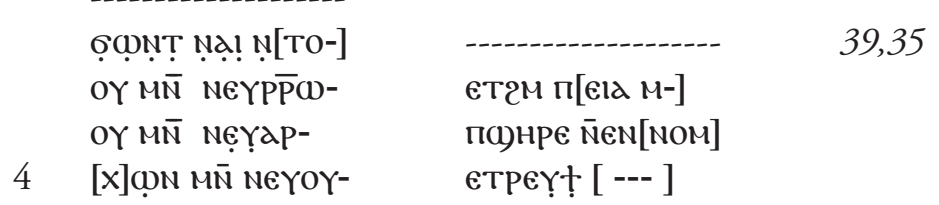

$32:[\ldots]$ me provoquer, eux et leurs rois et leurs princes et leurs prêtres [...]

(1. 4 : le mot coupé à la fin de la colonne 1 est or(нHв)).

$35:$ :...] qui sont dans la vallée du fils d'Ennom, pour offrir [...]

Verso (côté poil ?) [Fig. 2]

39,36

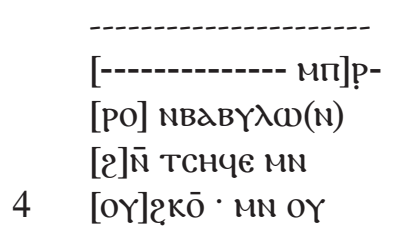

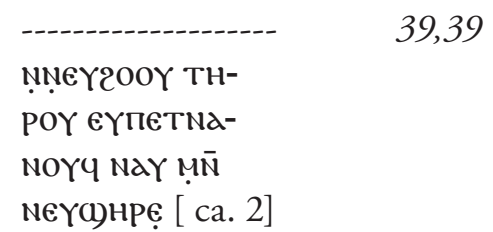

36 : [... du roi] de Babylone, par l'épée, la famine ou [...]

$39:[\ldots]$ pendant tous leurs jours pour leur bien et celui de leurs fils [...]

\section{Fragments D'évangiles (Inv. 826)}

Sept fragments de papyrus, dont deux se raccordent. Ils mesurent de $1.3 \mathrm{x}$ $2.4 \mathrm{~cm}$ à $5.3 \times 5.8 \mathrm{~cm}$. Des passages des évangiles de Marc, Luc et Jean ont pu être identifiés [Figs 3-6]. Seuls les deux plus petits restent pour le moment non identifiés [Fig. 7]. Il est probable que tous ces fragments proviennent du même codex, ou du moins sont dus à la même main. L'écriture est une majuscule alexandrine très régulière (Irigoin 1959 ; Cavallo et Maehler 1987: Pl. 51 et 52a pour des exemples proches en grec), dans laquelle on peut relever la forme ample du $\kappa$, et la surligne inhabituelle sur les deux syllabes $\bar{N} a \gamma$ (fragment 1 recto 1.1 ) et $\bar{N} a Y$ (fragment 2 verso 1. 5). Elle n'est certainement pas antérieure au $8^{\mathrm{e}}$ siècle, et plus probablement attribuable au $9^{\mathrm{e}}$ siècle, ce

Voir Feder 2002. Le plus ancien est le $P$. Bodmer XXII, copié en pleine page. Les manuscrits 802 et 804 , dont on ignore la provenance, semblent les plus proches de notre fragment, bien que non exactement semblables (le texte de 802 semble copié en pleine page). Nous remercions Frank Feder de nous avoir donné son avis sur ce fragment. 


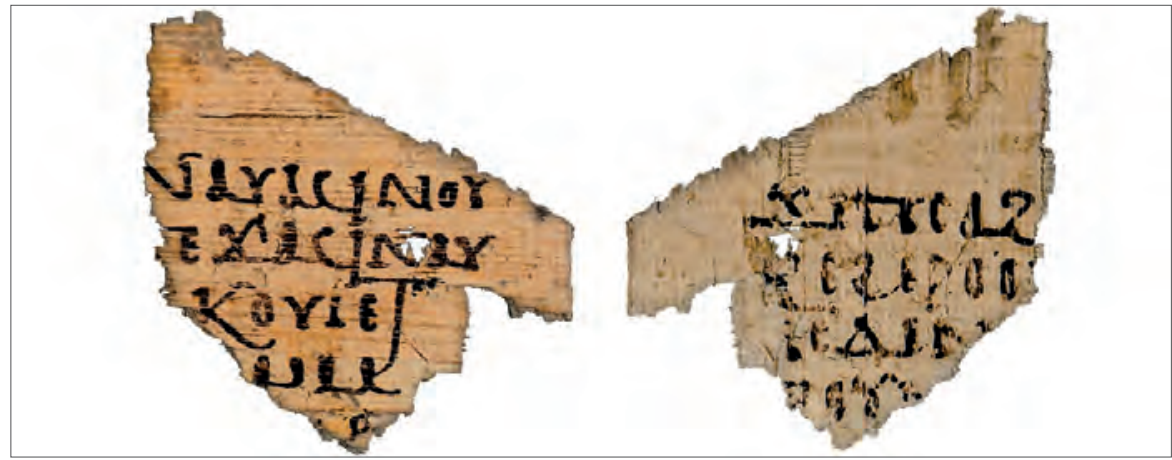

Fig. 3. Fragment de papyrus copte : évangile de Marc 10, 14. 20-21
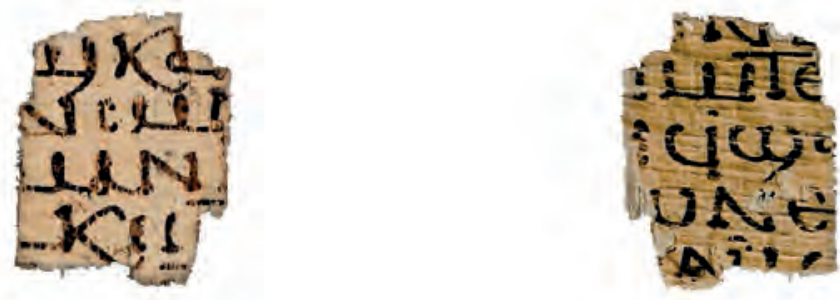

Fig. 4. Fragment de papyrus copte : évangile de Luc 4, 33-34, 40-41
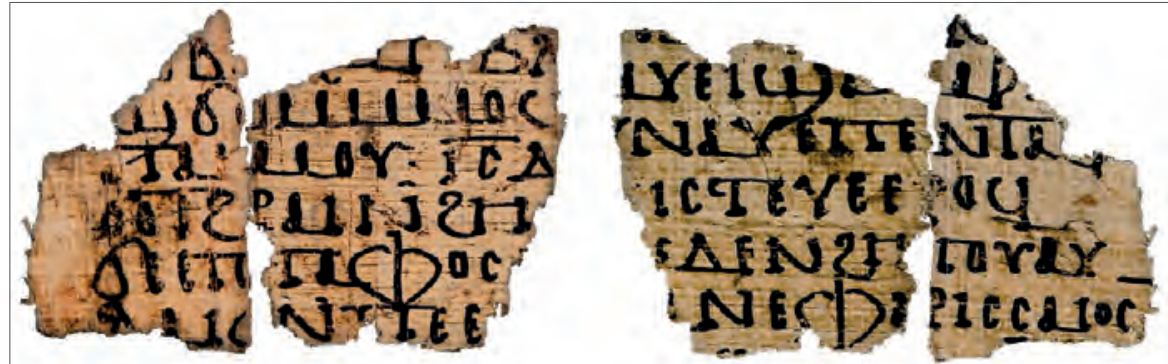

Fig. 5. Fragments de papyrus copte : évangile de Jean 11, 37-38. 45-46)
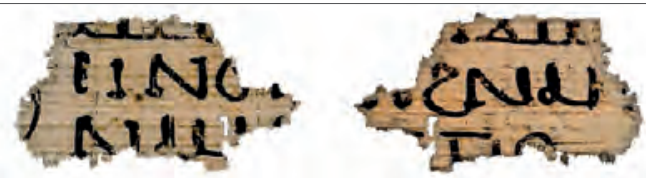

Fig. 6. Fragment de papyrus copte : évangile de Jean 20, 24-25. 30-31

(Photos avec l'aimable autorisation du PCMA/M. Jawornicki; retravaillée par C. Askeland) 
qui serait plus cohérent avec les dimensions telles qu'on peut tenter de les reconstruire à partir du texte manquant entre le recto et le verso du fragment 1 : une colonne devait contenir une trentaine de lignes, et la hauteur originale d'une page ne peut guère avoir été inférieure à $30 \mathrm{~cm}$. Comme les codex de papyrus sont en général très fragmentaires et dispersés, il est difficile de faire des comparaisons (voir cependant les remarques de la deuxième partie).

\section{Marc 10, 14. 20-21 [Fig. 3]}

Coin supérieur externe d'un feuillet de papyrus, avec les restes de 4 et 5 lignes. Les marges supérieure et externe sont conservées.

Le texte de l'évangile de Marc est plus variant que celui des autres évangiles. On peut grossièrement y distinguer une traduction ancienne (sal) et une traduction révisée (saII), les deux ayant continué à circuler dans des conditions qui restent à élucider ${ }^{2}$. La variante du verset 14 (recto l. 1-2), permet de rattacher le texte de ce fragment à la tradition saII, c'est-à-dire la traduction révisée, ce qui correspond aux observations faites jusqu'ici : la version ancienne aurait circulé surtout au Fayoum et dans le nord de la Moyenne-Égypte (mais aussi au monastère Blanc où on en a quelques témoins), tandis que la version révisée était plus commune dans le sud de l'Égypte.

\begin{tabular}{|c|c|}
\hline cto & \\
\hline 10,14 & 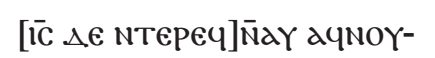 \\
\hline & 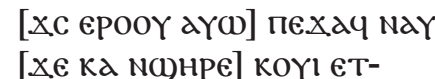 \\
\hline 4 & 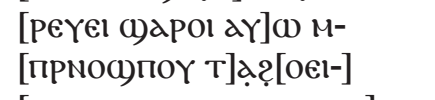 \\
\hline & [Ne гגp -----------------] \\
\hline
\end{tabular}

1-2. ауNoүхс epooY saII : ay6nat sa1 sa9 ;

4. c)apol sa9 saII : Nal sa1.

Verso $\downarrow$

Xe nCal [nal ThpoY alga-]

PE2 EPOOY [XIN TAMNTKOYI]

$10,21 \quad$ ic $\Delta \in \mathrm{N}[\mathrm{Tepeq \sigma o \omega ) \textrm {T }} \mathrm{e}-]$

4 гоүм [еграч ----------- ]

2 Voir Boud'hors 1993 et Boud'hors à paraître a. Les sigles des manuscrits de la version sahidique sont formés de «sa » suivis d'un numéro, selon le système de Schmitz et Mink 1986; 1989; 1991 ; sa II représente un texte qui s’appuie sur différents manuscrits, selon les passages conservés. 


\section{2. $L u c$ 4, 33-34. 40-413 [Fig. 4]}

Fragment de la colonne externe (restes de 5 lignes). Au verso, les $€$ plus grands des lignes 2 et 4 sont caractéristiques de la fin des lignes. Il est donc probable que les fins de lignes sont préservées au verso, et les débuts au recto.

$$
\begin{aligned}
& \text { Recto } \downarrow \\
& \text { 4,34 Nсмн [Хе агрок мM-] }
\end{aligned}
$$

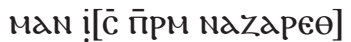

$$
\begin{aligned}
& 4 \text { aKel eT[aKON +COOYN] } \\
& \text { [Хe] NT![K NIM NTK --- ] } \\
& \text { Verso } \rightarrow \\
& \text { 4,40 [ --- ерє прн } \Delta] \epsilon \text { Na- } \\
& \text { [гळтп OYON N]IM ETE }
\end{aligned}
$$

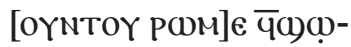

$$
\begin{aligned}
& 4 \text { [Ne 2N 2EN()] } \\
& \text { [ЕҮ()оBє аYNTO]Y } \bar{N} \alpha Y
\end{aligned}
$$

5. Cette ligne semble un peu trop longue.

\section{Jean 11, 37-38. 45-46 [Fig. 5]}

Deux fragments jointifs qui constituent une partie de la colonne externe. Le texte est étonnamment variant par rapport au texte standard attesté par une grande quantité de témoins de tous âges et de toutes provenances, même si ces variantes sont mineures ${ }^{4}$.

$$
\begin{aligned}
& \text { Recto } \downarrow
\end{aligned}
$$

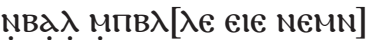

$$
\begin{aligned}
& \text { а) бом мMоч [ON пе етмтPе-] } \\
& 11,38 \quad \text { паl мOY. ic } \Delta[\epsilon \text { ON (N)eq-] }
\end{aligned}
$$

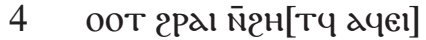

$$
\begin{aligned}
& \text { бе ептафос [Nеүспн-] }
\end{aligned}
$$

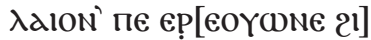

$$
\begin{aligned}
& \text { [рOч ------------------------] }
\end{aligned}
$$

2. ()6ом est une leçon propre à ce fragment et à sa 187 (un manuscrit provenant du Fayoum), tous les autres témoins ont 60M ;

3 Lidentification de ce passage est due à Christian Askeland, nous l'en remercions vivement.

4 Nous remercions Christian Askeland pour ses remarques sur le texte de ce fragment. 
3. $\Delta \mathrm{e}: \mathrm{Ge}$ ceteri;

5. 6૯: addition propre à ce manuscrit ;

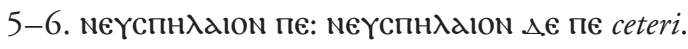

Verso $\rightarrow$

11,45

[ ----------------- оүмн-]

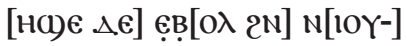

[Adl ENT]aYel a)a MaP![a]

[NTEPO]YYNAY EחENTAY-

4 [адч aү]п़стеҮе ероч

$11,46 \quad$ [20єIN] $\Delta \epsilon$ ल

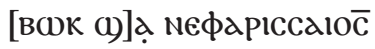

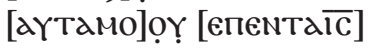

[ady ------------------]

3. [aүo d] ỴNaY, variante bien attestée, est également possible ;

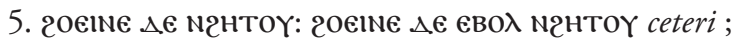

6. фapıccaıoc: la graphie avec un seul sigma se rencontre aussi, les témoins sont divisés sur ce point; noter la surligne en fin de ligne.

\section{Jean 20, 24-25. 30-315 [Fig. 6]}

Petit fragment de la colonne externe d'un feuillet (restes de 3 lignes). L'espace entre les colonnes est visible au recto, avec une trace qui peut provenir de la colonne interne ou être le reste d'un début de verset placé en retrait.

Recto $\downarrow$

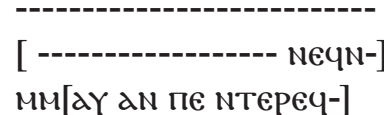

20,25 el nG! [NеүХल мMOC] NaY Ṇ[G1 NKемаөнтнс]

Verso $\rightarrow$

[ENCECH 2 an ene]!XX)-

20,31 [Wme nTaY]ce? nal 4 [e]

[Хекас eтетNте] пIC-

[теүє $x \in$-------------- ]

$5 \quad$ Identification due à Christian Askeland. 

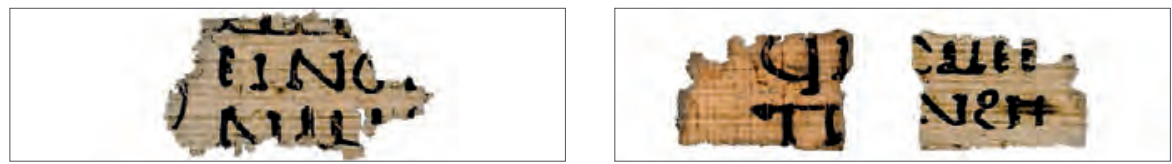

Fig. 7. Fragments d'évangile non identifiés

(Photos avec l'aimable autorisation du PCMA/M. Jawornicki; retravaillée par C. Askeland)

\section{II. À propos de la bibliothèque du monastère de Saint-Phoibammon}

L'existence d'une bibliothèque dans un établissement aussi important que le monastère de Phoibammon semble hors de doute. Pourtant, aucune trace directe n'en a été retrouvée ${ }^{6}$. Une $\beta \imath \beta \lambda$ ro $\theta \hat{n} \kappa \eta$ est bien mentionnée dans plusieurs documents, mais elle est surtout reliée à l'existence des archives juridiques qui y étaient déposées ${ }^{7}$. Les testaments des supérieurs du monastère au $7^{\mathrm{e}}$ siècle mentionnent, parmi les biens à transmettre, des $\gamma \rho \alpha \mu \mu \alpha \tau \varepsilon i \hat{\imath}$, c'est-à-dire des documents administratifs (contrats de prêts, créances ou ventes à terme), et l'un d'entre eux y ajoute des хюळme, un terme copte un peu équivoque, qui peut renvoyer aussi à des documents, mais peut également désigner des livres au contenu littéraire ${ }^{8}$. Par ailleurs, la copie et la circulation des livres dans la région thébaine sont bien attestées, que ce soit par des fragments de manuscrits, des lettres, des inventaires, parmi lesquels le plus célèbre, celui du topos de Saint-Élie du Rocher, fait état de quatre-vingts livres?. Face à ce riche catalogue d'un établissement dont la localisation est

6 Godlewski 1986: 58 et note 90, renvoyant à $P$. Lond. I: 231, où il est indiqué, à propos du testament d'Abraham d'Hermonthis : "It was found with a number of other documents among the ruins of the monastery about 1856, and was brought along with them to England by the Rev. H. Stobart. The other documents included a fragment of the Sahidic version of the New Testament, and a number of deeds and grants relating to the monastery ». Qu'est-il advenu de ce fragment copte? Nous y reviendrons brièvement plus loin.

7 Témoins tous les papyrus documentaires concernant le monastère, dont une partie au moins a pu être retrouvée sur place (cf. Godlewski 1986: chap. 3).

8 Voir Godlewski 1986: 79-80. Le mot хо⿴囗十е est attesté à la ligne 54 de $P$. KRU 65, testament du supérieur Jacob, attribuable à la fin du $7^{\mathrm{e}}$ siècle. Son absence dans les trois testaments précédents pourrait refléter le fait que la bibliothèque n'était pas encore constituée. L'ensemble de ce dossier testamentaire a fait l'objet de la thèse de doctorat d'Esther Garel, en cours de publication.

9 Édition Coquin 1975. Pour les livres thébains, voir Winlock et Crum 1926: 186-208 ; Boud'hors 2008. 
inconnue, les fragments d'inventaire qui pourraient concerner la bibliothèque de Saint-Phoibammon font certes pâle figure ${ }^{10}$. L'inventaire de Saint-Élie peut néanmoins servir de référence. Il nous apprend notamment que cet établissement possédait des livres de parchemin et des livres de papyrus, " anciens " et "neufs ». D’autre part, le prêtre Biktôr, qui fut le deuxième supérieur du monastère de Phoibammon, semble avoir pris une part active dans la circulation des manuscrits. Parmi les lettres de son dossier, un groupe se distingue en effet nettement : dans $O$. Crum 248, il est question de la vente d'un psautier ; O. Crum Ad.33 accompagne l'envoi à Biktôr d'un livre qu'il avait réclamé ; dans $P$. Pintaudi 67, Biktôr demande qu'on lui envoie un livre de Grégoire de Nysse ; O.MMA 1152174 et 180 attestent l'échange de livres avec apa Iezekiêl et apa Djôr, notamment des œuvres attribuées à Chénouté ; deux lettres sont adressés par Biktôr à Moïse, copiste de manuscrits, pour demander qu'il lui envoie un livre (O. Frange 771 et O. Louvre inv. N688; voir Garel à paraitre). Peut-être avons-nous là l'indice que Biktôr était en train de constituer la bibliothèque du monastère.

Par ailleurs, quelques exemplaires de manuscrits produits dans la région thébaine ont été conservés. L'ensemble le plus important en nombre est le lot de Londres, BL Or 7561, soit les restes de vingt-deux codex de papyrus à l'allure bien caractéristique : textes le plus souvent écrits en pleine page, en majuscule biblique, etc. ${ }^{11}$. Il s'en dégage une sorte de "standard thébain ", qui peut être identifié dans d'autres fragments trouvés sur place ou conservés dans diverses collections ${ }^{12}$. Un autre exemple de manuscrits sûrement thébains est le groupe de trois manuscrits découverts dans l'ermitage MMA 1152 par Tomasz Górecki, deux de papyrus, et un de parchemin ${ }^{13}$. Etant donné que l'activité monastique dans cette région semble s'être manifestée aux $7^{\mathrm{e}}-8^{\mathrm{e}}$ siècles, on peut plus ou moins dater tous ces manuscrits de cette période, encore qu'il reste un doute à propos du manuscrit de parchemin (livre d'Isä̈e) trouvé à MMA 1152, dont l'écriture paraît devoir être attribuée à une date un peu plus tardive.

10 Godlewski 1986: 58-59 cite trois ostraca (O. Crum 250, 402, 458) parmi lesquels il y aurait "des fragments d'inventaire de la bibliothèque ". Seul O. Crum 458 semble être en effet un petit fragment de liste qui contenait au moins l'Évangile de Marc et celui de Jean.

11 Layton 1987: XVI-XVII, LXXII-LXXIII (introduction), et les diverses notices du catalogue concernant ces fragments.

12 Sur ces manuscrits, voir Boud'hors à paraître b. Voir aussi la remarque de Crum à $P$. Mon. Epiph. 2: "A considerable number of small papyrus fragments (uncials) were found at this site [= unnumbered tomb], but are not here published ».

13 Voir Górecki 2005 ; 2007. Ces manuscrits sont toujours inédits. 
C'est le moment de revenir sur le fragment du Nouveau Testament sahidique qui aurait été retrouvé avec le testament d'Abraham (voir ci-dessus note 6). À moins que ce fragment n'ait été définitivement perdu ou confié à quelqu'un, il aurait dû aboutir, comme tous les autres, au British Museum. Seul le papyrus XIII (= P. Lond. Copt. I 115), qui est un feuillet de papyrus de l'Évangile de Jean aux caractéristiques nettement thébaines, pourrait correspondre ${ }^{14}$. Pourtant cette hypothèse est peu plausible, car ce papyrus avait été acheté par Wilkinson, et il a dû arriver à Londres avant la découverte des papyrus au monastère de Phoibammon. Un autre candidat est le papyrus LXXXIX (= P. Lond. Copt. I 280), le seul papyrus copte littéraire qui vient de Stobart ${ }^{15}$. Mais son contenu n'est pas biblique, en-dehors d'une citation d'Isaïe et d'une autre de l'Évangile de Jean.

Quoi qu'il en soit, il apparaît clairement que les fragments trouvés à Deir elBahari et publiés ici ne correspondent pas aux livres produits sur place. Le petit morceau de codex de Jérémie est trop ancien pour cela et provient probablement d'ailleurs. Il est en revanche comparable avec quelques fragments de manuscrits du même genre découverts lors des fouilles de la tombe thébaine 29, notamment un petit rectangle qui contient quelques mots de la Première épître aux Corinthiens et dont l'écriture est très similaire $[\mathbf{F i g} .8]^{16}$. Ce rectangle a été nettement découpé et son usage est facile à identifier, puisqu'il se trouvait avec un ensemble de fragments

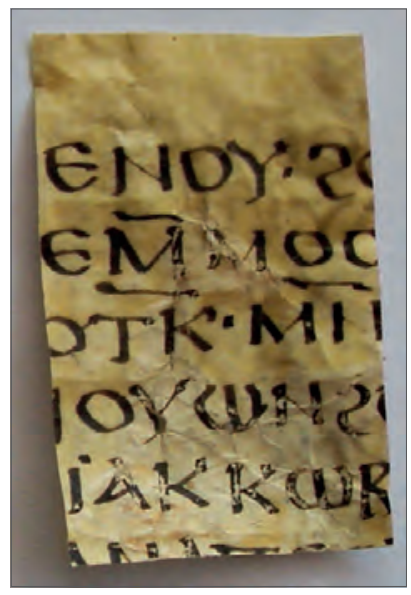

Fig. 8. Fragment de parchemin copte ; 1 Co 15, 6-7 (Photo MANT)

14 Reproduction dans Horner 1911: Pl. I (avec une datation au $4^{\mathrm{e}}$ siècle, beaucoup trop haute).

15 Cette hypothèse se trouve déjà dans Godlewski 1986: 58, note 90. Il s'agit d'un fragment d'homélie ou de lettre.

16 Les dimensions manquent dans la documentation de la fouille, mais le fragment ne mesure pas beaucoup plus de $2 \mathrm{~cm} \times 4 \mathrm{~cm}$, et le module de l'écriture est d'environ $3 \mathrm{~mm}$ aussi. Nous remercions Laurent Bavay, directeur de la Mission archéologique dans la nécropole thébaine (MANT), de nous avoir autorisées à reproduire ce fragment ici. 
de papyrus taillés dans des documents pour servir de remplissage aux couvertures de livres que confectionnait le moine Frangé, dans le $2^{\mathrm{e}}$ quart du $8^{\mathrm{e}}$ siècle ${ }^{17}$. Le P. Mon. Epiph. 2, petit fragment de la Genèse sur parchemin, est probablement du même ordre, comme le notait déjà Crum ${ }^{18}$. Dans le cas du fragment de Jérémie, la pliure oblique qui traverse la bande de parchemin, et qui n'est pas une marque de réglure, pourrait être l'indice que ce fragment a servi à consolider un cahier ou un bifolio d'un autre manuscrit, comme cela se faisait couramment ${ }^{19}$. D'où venaient ces manuscrits déclassés que les copistes utilisaient pour réparer les livres ou pour fabriquer leurs couvertures? C'est pour le moment bien difficile à dire, car si de nombreux petits fragments du même genre sont conservés dans diverses collection $s^{20}$, on ne connaît que très exceptionnellement leur provenance.

Quant aux fragments de codex de papyrus, la question est moins facile à trancher. Leur type d'écriture, la majuscule alexandrine, se trouve bien dans certains fragments de manuscrits thébains, par exemple BL Or 7561, $\mathrm{n}^{\text {os }} 107,116$, 135, 146. Mais elle est nettement moins exercée, et surtout les manuscrits sont de taille plus réduite. Encore une fois une production thébaine est peu vraisemblable pour ces fragments, qui devaient eux aussi être du matériel de relieur. Des comparaisons sont néanmoins possibles avec divers manuscrits du même genre (mais jamais exactement semblables) dont la provenance est plus ou moins bien connue : P. Sorbonne Inv. 2554, fragment de l'Évangile de Matthieu, qui provient d'un achat de Jouguet à Louxor en 1920 (Pezin 1993: 42-43, Pl. I), attribué au $8^{\mathrm{e}}-9^{\mathrm{e}}$ s.; P. Vindob. Inv. K 7535 (Orlandi 1974: 47-48, Pl. 6), feuillet de l'Évangile de Marc attribué au $8^{\mathrm{e}}$ siècle, et pour lequel l'éditeur propose le monastère Blanc comme provenance ; Pierpont Morgan Library C 32 (Depuydt 1993: 462-463, Pls 416-417, $\mathrm{n}^{\circ} 268$ ), provenant du Fayoum. Ce type de codex de papyrus semble en fin de compte avoir été bien répandu dans toutes les régions de l'Égypte ${ }^{21}$.

Si l'on considère les petits fragments de papyrus documentaires utilisés par Frangé, on constate qu'ils étaient eux-mêmes thébains et qu'ils ne venaient pas de très loin. On aurait tendance à penser que le matériel utilisé pour les couvertures de livres devait lui aussi provenir d'une région proche. Il faut cependant rester prudent: les livres, comme les gens, voyageaient. À titre d'exemple, le P. CLT 3 concerne une autorisation pour des moines qui veulent se rendre au Fayoum. Pourquoi n'auraientils pas éventuellement rapporté avec eux quelques vieux manuscrits?

\footnotetext{
17 Voir Boud'hors et Heurtel 2010: 19. Le matériel de remplissage, qui comprend à son tour d'intéressants documents, est en cours de publication par Anne Boud'hors et Alain Delattre.

18 "Fragments of the back of book bindings".

19 Nous devons cette observation à Alin Suciu.

20 Voir par exemple ceux de la Sorbonne publiés par Pezin 1993.

21 Mais on manque d'études systématiques sur les codex de papyrus coptes.
} 
Si les fragments publiés ci-dessus sont susceptibles d'être des traces de la bibliothèque du monastère de Phoibammon, c'est donc d'une manière secondaire, en tant que matériel remployé dans les couvertures. Il reste cependant encore une piste à explorer, que nous nous bornons à mentionner ici, faute d'en avoir encore étudié tous les aspects. Parmi les fragments de manuscrits thébains du lot BL Or 7561 mentionnés plus haut (voir note 12), se trouvent deux fragments qui n'ont pas été inclus dans le catalogue de Bentley Layton (Layton 1987). Lun (n 57) est un fragment de document juridique, publié par Crum comme O. Crum ST 59. Le document est appelé au verso $\triangle$ Oplactikon (grec $\delta \omega \rho \varepsilon \alpha \sigma \tau$ ikóv), terme quasiment exclusif, dans les documents coptes, des donations faites au monastère de SaintPhoibammon et, dans une moindre mesure, de Saint-Paul (voir P. KRU 78-111). Au recto, seules les quatre premières lignes du texte sont conservées, ainsi que le protocole arabe, attribuable à la mi- $8^{\mathrm{e}}$ siècle ${ }^{22}$. Lautre fragment $\left(\mathrm{n}^{0} 54\right)$ contient au recto quelques mots en majuscule biblique qui permettent d'identifier une doxologie, marquant probablement la fin d'un texte littéraire, tandis que le verso est inscrit dans une écriture penchée non littéraire qui fait penser à un colophon : on y lit le mot « livre » ( $\chi \omega \omega m \epsilon)$, un nom de personne $\left(\operatorname{Kyriakos}^{23}\right)$, ainsi que le nom d' $[\lambda]$ па фоїва[мळN], qui montre que ce livre était, d'une manière ou d'une autre, lié au monastère. Le lot BL Or 7561 a été acheté à Thèbes par le collectionneur Anthony Charles Harris en 1846, quelques années avant la découverte des documents du monastère de Phoibammon. Il n'est pas impossible que cet ensemble représente les restes de la partie littéraire de la bibliothèque. L’enquête doit se poursuivre...

\section{REMERCIEMENTS}

Nous remercions le docteur Zbigniew E. Szafrański de nous avoir confié la publication de ces fragments et de nous avoir fourni les informations concernant leur contexte de découverte.

\section{Références bibliographiques}

Les papyrus sont cités conformément aux sigles de J.F. Oates et al., Checklist of Greek, Latin, Demotic and Coptic papyri, ostraca and tablets, disponible sur Internet : http:// scriptorium.lib.duke.edu/papyrus/texts/clist.html.

22 Information aimablement fournie par Naïm Vanthieghem (Bruxelles), que nous remercions. Le texte a été édité dans les addenda de CPR III, p. 293, par Adolf Grohmann, qui n’en proposait aucune datation.

23 Deux supérieurs du monastère portent ce nom : l'un est attesté en 733 , l'autre dans le $3^{\mathrm{e}}$ quart du $8^{\mathrm{e}}$ siècle (voir Godlewski 1986: 73-74). 
Boud'hors, A. (1993). L'Évangile de Marc en copte-sahidique : essai de clarification. Dans D.W. Johnson (éd.), Acts of the Fifth International Congress of Coptic Studies: Washington, 12-15 August 1992, II.1 (pp. 53-65). Rome : CIM

Boud'hors, A. (2008). Copie et circulation des livres dans la région thébaine (VII ${ }^{\mathrm{e}}$ VIII siècles). Dans A. Delattre et P. Heilporn (éds), Et maintenant ce ne sont plus que des villages: Thèbes et sa région aux époques hellénistique, romaine et byzantine. Actes du colloque tenu à Bruxelles les 2 et 3 décembre 2005 [=Papyrologica Bruxellensia 34] (pp. 149-161). Bruxelles : Association égyptologique Reine Elisabeth

Boud'hors, A. (à paraitre a). The Gospel of Mark in Sahidic Coptic: New insights. Dans P. Buzi et A. Camplani (eds), Acts of the Tenth International Congress of Coptic Studies. Louvain : Peeters

Boud'hors, A. (à paraître b). À la recherche des manuscrits coptes de la région thébaine. In Scripta Coptice. Louvain : Peeters

Boud'hors, A. et Heurtel, C. (2010). Les ostraca coptes de la TT 29 : autour du moine Frangé I-II [=Études d'archéologie thébaine 3/1-2]. Bruxelles : CReA-Patrimoine

Cavallo, G. et Maehler, H. (1987). Greek bookhands of the early Byzantine period, A.D. 300-800 [=University of London, Institute of Classical Studies Bulletin Supplement 47]. Londres : University of London, Institute of Classical Studies

Coquin, R.-G. (1975). Le catalogue de la bibliothèque du couvent de Saint-Élie « du rocher " (ostracon IFAO 13315). Bulletin de l'Institut français d'archéologie orientale, $75,207-239$

Depuydt, L. (1993). Catalogue of Coptic manuscripts in the Pierpont Morgan Library I-II $[=$ Corpus of Illuminated Manuscripts 4-5]. Louvain : Peeters

Feder, F. (2002). Biblia Sahidica Ieremias, Lamentationes (Threni), Epistula Ieremiae et Baruch [=Texte und Untersuchungen zur Geschichte der altchristlichen Literatur 147]. Berlin : de Gruyter

Garel, E. (à paraitre). The ostraca of Victor the priest found in the hermitage MMA 1152. Dans T. Derda et J. Urbanik (éds), Proceedings of the 27th International Congress of Papyrology (Warsaw, 29 July-3 August 2013)

Godlewski, W. (1986). Le monastère de St Phoibammon [=Deir el-Bahari 5]. (Z. Kiss, trad.). Varsovie : PWN - Éditions Scientifiques de Pologne

Górecki, T. (2005). Manuskrypty z Qurna [Manuscrits de Qurna]. Uniwersytet Warszawski, 2(23), 16-17 [en polonais]

Górecki, T. (2007). Sheikh Abd el-Gurna (hermitage in Tomb 1152). Preliminary report, 2005. Polish Archaeology in the Mediterranean, 17, 263-274

Horner, G.W. (1911). The Coptic version of the New Testament in the southern dialect otherwise called Sabidic and Thebaic III. The Gospel of S. John. Oxford : Clarendon Press

Irigoin, J. (1959). L'onciale grecque de type copte. Jahrbuch der österreichischen byzantinischen Gesellschaft, 8, 29-51

Layton, B. (1987). Catalogue of Coptic literary manuscripts in the British Library acquired since the year 1906. Londres : British Library 
Orlandi, T. (éd.). (1974). Papiri copti di contenuto teologico [=Mitteilungen aus der Papyrussammlung der Österreichischen Nationalbibliothek. Neue Serie 9]. Vienne : Hollinek

Pezin, M. (1993). Coptica Sorbonica II. Langues Orientales Anciennes Philologie et Linguistique, 4, 41-55

Schmitz, F.-J. et Mink, G. (1986). Liste der koptischen Handschriften des Neuen Testaments I.1. Die Sahidischen Handschriften der Evangelien [=Arbeiten zur neutestamentlichen Textforschung 8]. Berlin : de Gruyter

Schmitz, F.-J. et Mink, G. (1989). Liste der koptischen Handschriften des Neuen Testaments I.2. Die Sahidischen Handschriften der Evangelien [=Arbeiten zur neutestamentlichen Textforschung 13]. Berlin : de Gruyter

Schmitz, F.-J. et Mink, G. (1991). Liste der koptischen Handschriften des Neuen Testaments I.2.2. Die Sabidischen Handschriften der Evangelien [=Arbeiten zur neutestamentlichen Textforschung 15]. Berlin : de Gruyter

Winlock, H.E. et Crum, W.E. (1926). The Monastery of Epiphanius at Thebes I. New York : Metropolitan Museum of Art 


\title{
Les trois « colophons » de l'Évangile de Jean découvert à Naqlūn
}

\author{
Alain Delattre \\ Université libre de Bruxelles \\ Alain.Delattre@ulb.ac.be \\ Naïm Vanthieghem \\ Université libre de Bruxelles \\ Naim.Vanthieghem@ulb.ac.be
}

\section{KeYwords}

Gospel of John, Fatimid period, 11th-12th century, Naqlūn, burial practices, bilingualism

\section{Abstract}

Edition of two Coptic colophons and an Arabic note written at the end of the 11th-12th manuscript of the Gospel of John found in a grave at Naqlūn in 2002. We argue the Gospel was the property of the deacon Shenoute, son of John, who was probably buried there.

En 2002 l'équipe dirigée par W. Godlewski ${ }^{1}$ dégagea la partie est du cimetière situé sur la section centrale du site de Naqlūn ${ }^{2}$. Les archéologues y mirent au jour près d'une centaine de tombes datant des XI-XIII ${ }^{\mathrm{e}}$ siècles, voire du XIV siècle pour les plus récentes. Dans le coin sud-est de l'église $A$, ils dégagèrent un mausolée familial qui comprenait trois tombes (T 322-T 324). À l'intérieur de la dernière sépulture gisait le corps d'un homme enveloppé dans un linceul couvert d'inscriptions arabes ${ }^{3}$. Un riche matériel (Godlewski 2002: 168-170) avait été disposé autour du défunt : deux bouteilles en verre, un plumier avec deux calames ${ }^{4}$; un livre avait même été placé à droite de la tête du cadavre 5 . Une telle découverte est exceptionnelle, mais pas sans parallèle : on mentionnera ici

1 Sur les fouilles menées depuis vingt ans sur le site, voir Godlewski 2005a.

2 Godlewski 2003 ; sur le cimetière en général, voir Godlewski 2005b.

3 Sur les turuz et autres inscriptions arabes trouvées dans les tombes de Naqlūn, voir Helmecke 2005.

4 Semblable matériel a été aussi mis au jour dans la tombe 358; cf. Godlewski 2005c: 182.

5 Pour une description de l'objet, voir Godlewski 2003: 168-170 ; van der Vliet 2003: 172-174. 
en particulier le psautier d'al-Mudil, qui était placé sous la tête de la momie d'une jeune fille ${ }^{6}$, ou le codex contenant des écrits chrétiens découvert à Achmîm à la fin du XIX ${ }^{\mathrm{e}}$ siècle ${ }^{7}$. D'autres exemples de cette pratique sont attestés à l'époque gréco-romaine ${ }^{8}$.

Le manuscrit se compose de 72 feuillets, dont certains sont sobrement décorés au moyen d'entrelacs polychromes. Il était protégé par une belle reliure à rabat en cuir ouvragé. Jacques van der Vliet, qui a réalisé une description codicologique préliminaire du manuscrit, a mis en évidence l'intérêt de cette copie pour l'histoire de la tradition sahidique de cet évangile'. Le codex conserve en effet l'exemplaire complet le plus récent de la version copte sahidique de l'Évangile de Jean. Le texte, resté inédit à ce jour ${ }^{10}$, est désormais enregistré sous le sigle « sa 600 » dans le répertoire des textes bibliques de Karlheinz Schüssler ${ }^{11}$.

Grâce à un colophon (fo 71 v.), la copie peut être précisément datée de 1099-1100. Après celui-ci, au fo 72 , on trouve deux autres textes, brièvement décrits par Jacques van der Vliet (2003). Depuis lors, les colophons de ce manuscrit n'ont fait l'objet d'aucune étude. Nous en proposons ici une édition qui permettra, nous l'espérons, de remettre en contexte cette découverte exceptionnelle.

\section{Le premier colophon : prière pour le commanditaire}

Le colophon occupe la moitié inférieure de la page ; il est encadré de deux bandeaux à guillochis. Le papier est de couleur beige foncé. Le texte est écrit de la même main que le reste de l'évangile, dans une onciale de type copte ${ }^{12}$. Les

6 Ce manuscrit fut mis au jour en octobre 1984 dans une nécropole des environs du village d'al-Mudil (dans la région d'Oxyrhynchus) ; cf. Gabra 1995; Emmenegger 2007.

7 Cf. Bouriant 1892: 93-94 ; van Minnen 2007. Sur les livres chrétiens découverts dans des tombes, voir Luijendijk 2010: 238-239 ; 2011: 404-405.

8 On songera par exemple au rouleau contenant les deux premiers livres de l'́lliade découvert à Hawara (P. Bodl. Ms. Gr. class. a. 1 [= M.-P. ${ }^{3}$ 616; LDAB 1695]) ou encore au Partheneion d'Alcman trouvé entre les jambes d'une momie à Saqqara (P. Louvre Inv. 3320 [= M.-P. ${ }^{3}$ 78; LDAB 179]). Ces exemples rappellent les Livres des morts de la religion égyptienne, qui accompagnaient les défunts dans la tombe, mais la pratique est attestée aussi dans la Grèce classique, comme le montrent les célèbres papyrus de Derveni ou les fragments de poésie découverts dans une tombe à Daphni, à côté d'instruments de musique (cf. Pöhlmann et West 2012).

9 Van der Vliet 2003; voir aussi les remarques de Askeland 2012: 93-94.

10 Le texte sera étudié par Chr. Askeland.

11 Schüssler 2007: 70-71, qui fournit une description exhaustive du manuscrit.

12 Cf. Boud'hors 1997: 118-120 (onciale grecque " de type copte»). 
coupes de mot sont conformes à la pratique ; l'orthographe est généralement bonne, même si elle présente quelques curiosités (cf. l. 6). Le colophon est daté de l'an 493 de l'hégire, ce qui permet d'en situer la rédaction entre le 17 novembre 1099 et le 5 novembre 1100 .

Le texte est une prière au bénéfice du commanditaire de l'œuvre; il emprunte un formulaire bien connu des colophons (van Lantschoot 1929: $\mathrm{n}^{\text {os }} 37-38$ ) et des prières aux donateurs, connues également par l'épigraphie (Delattre et Vanthieghem 2014: n. 14). Le caractère général et anonyme de la prière suggère qu'il ne s'agit pas d'une commande à proprement parler : le copiste a noté des formules usuelles, qui peuvent convenir à tout acheteur. On y demande que le Christ bénisse le commanditaire de l'évangile et l'on y précise que le texte a été copié pour le bien de son âme afin que son nom figure dans le livre de la vie, dans la Jérusalem céleste.

Inv. Nd.02.239

Naqlūn, 17 novembre 1099-5 novembre 1100

$19.2 \times 12.8 \mathrm{~cm}[$ Fig. 1]

(Bandeau à guillochis)

пхоеıс ı(нсоү)с пех(Рісто)с ечесмоү епмаї-

NOYTE NCON N̄TaYYI проOY() $\bar{M}-$

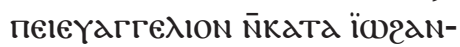

4 NH. ачседісч етреч(0) $\overline{\mathrm{N}}_{2 H T} \bar{\varphi}$

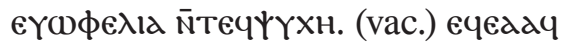

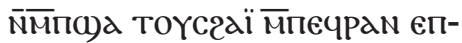

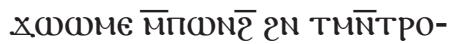

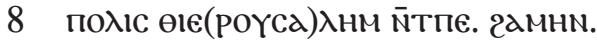

(Bandeau à guillochis)

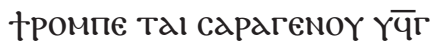

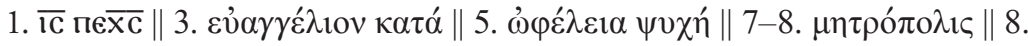

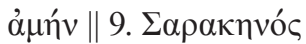

Puisse le Seigneur Jésus-Christ bénir le pieux frère qui a commandé cet évangile selon Jean. Il l'a écrit pour le lire, pour le bien de son âme. Puisset-il le rendre digne que son nom soit écrit dans le livre de la vie, dans la métropole de la Jérusalem céleste. Amen. L'an des Sarrasins 493.

2. м̄таччı прооү(): Cf. par exemple van Lantschoot 1929: № 5, 1-4

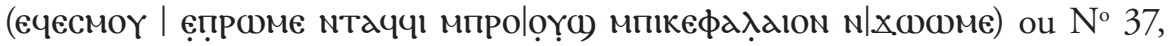

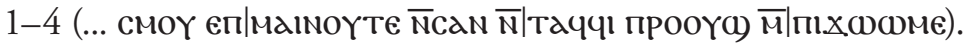




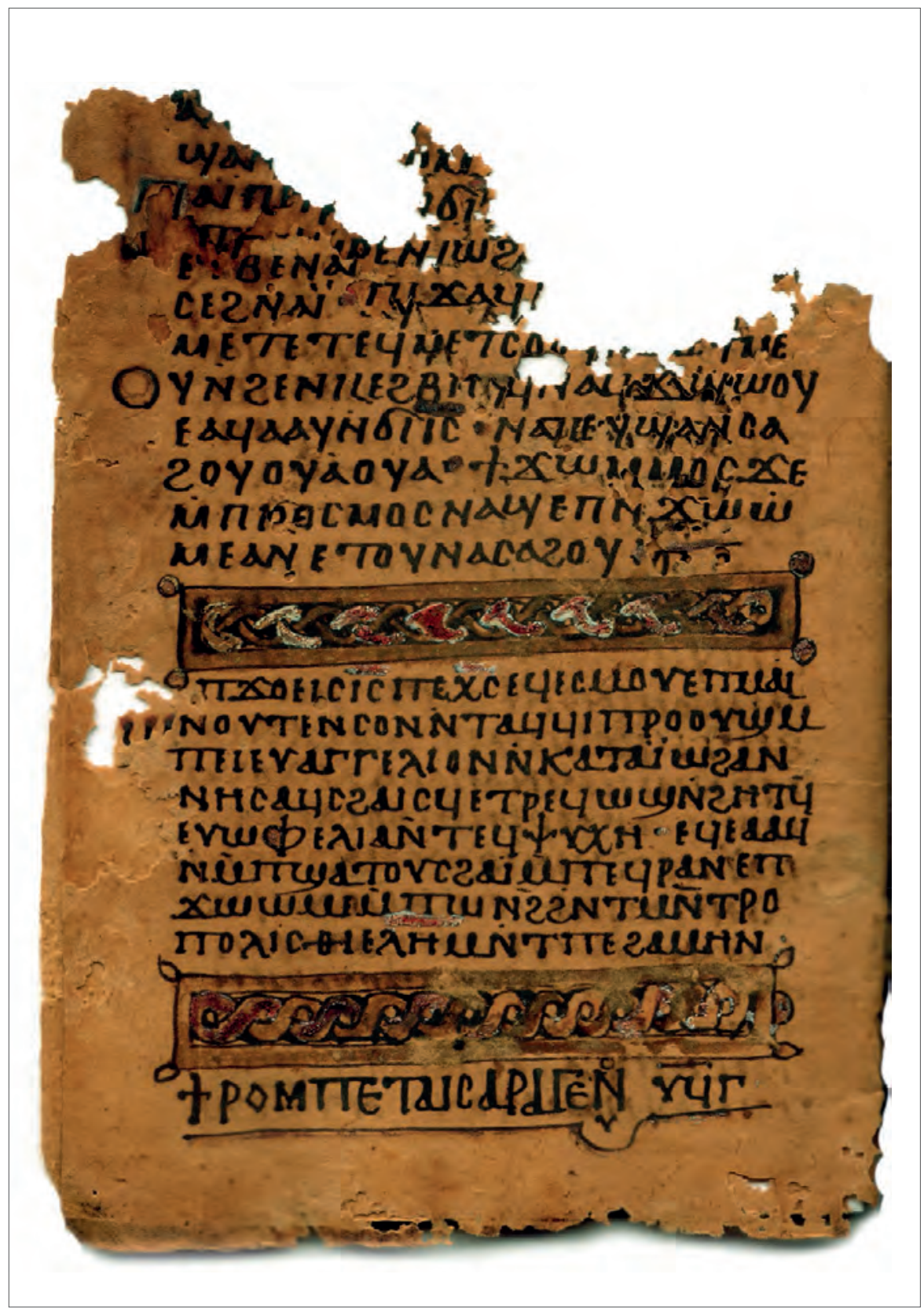

Fig. 1. $\quad F^{\circ} 71$ verso de l'Évangile de Jean de Naqlün

(Image scannée par C. Gaubert; publiée avec l'aimable autorisation du PCMA) 
4-5. ачсгаıсч етреч(0): Il faut comprendre « il l'a fait copier pour le lire ».

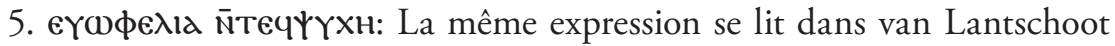
1929: No 101, 28-29.

6. Toүc2aï: Il s'agit d'une forme de conjonctif (comprendre ncec2al).

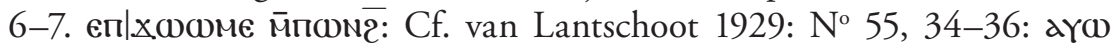

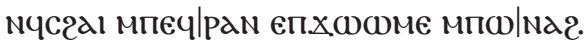

7-8. тмйтро|по入ıc: Le scribe semble avoir voulu écrire le mot grec

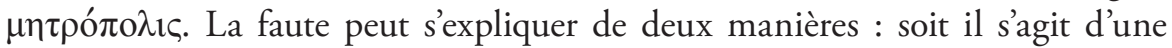

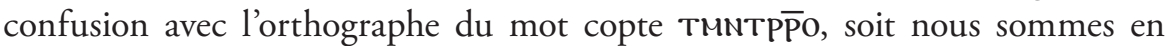
présence d'une simple confusion phonétique (le préfixe MNT s'orthographie M€T ou MHT en fayoumique).

\section{Le deuxième colophon : prière pour le diacre Chenoute}

Une bonne moitié de la surface de la page a disparu. Le papier est de couleur beige clair. Le texte occupe la partie supérieure du coupon. L'écriture, tracée à l'encre noire dans un module fort différent de celle du reste du manuscrit, est de type documentaire, comparable à celle des papiers de Techlôt (XI ${ }^{\mathrm{e}}$ siècle). Le nom de l'auteur du texte est mentionné 1.9 : Chenoute. Comme le notait J. van der Vliet, les formules utilisées semblent le désigner comme le copiste du livre, mais cette interprétation du rôle de Chenoute pose de nombreux problèmes. Outre les coupes de mots aberrantes, les normes or thographiques sont très différentes de celles du premier colophon : le scribe écrit ainsi iodnne $(2,10)$ au lieu de ïmran/nhc $(1,3-4)$ ou dmhn $(2,14)$ au lieu de zaмнn $(\mathbf{1}, 8)$. On relève en outre quelques formes fayoumiques, comme neqlat (11), le conjonctif te- (13) ou la graphie $\overline{\overline{0}} \mathbf{c}$ (13). Par ailleurs, il ne note aucune surligne et utilise deux types de ponctuation (le point médian et le dicôlon), contrairement à celui du premier texte. Enfin, le second texte est daté de l'an 500 de l'hégire, soit sept ans plus tard que le premier. Ces éléments invitent à penser que le second texte copte a été écrit par une autre personne.

Le contenu du colophon, fort mutilé, n'est pas clair. Il s'agit sans doute d'une prière commençant par les mots apl ח[Mє€ү€], que l'on rencontre fréquemment dans les colophons. Suivent des protestations d'humilité et le nom du scripteur : Chenoute, fils d'al.../Jean. Le texte se conclut par une date et une demande de prière. 
Nd.02.239: $19.2 \times 12.8 \mathrm{~cm}$

Naqlūn, 25 juillet-21 août 1107

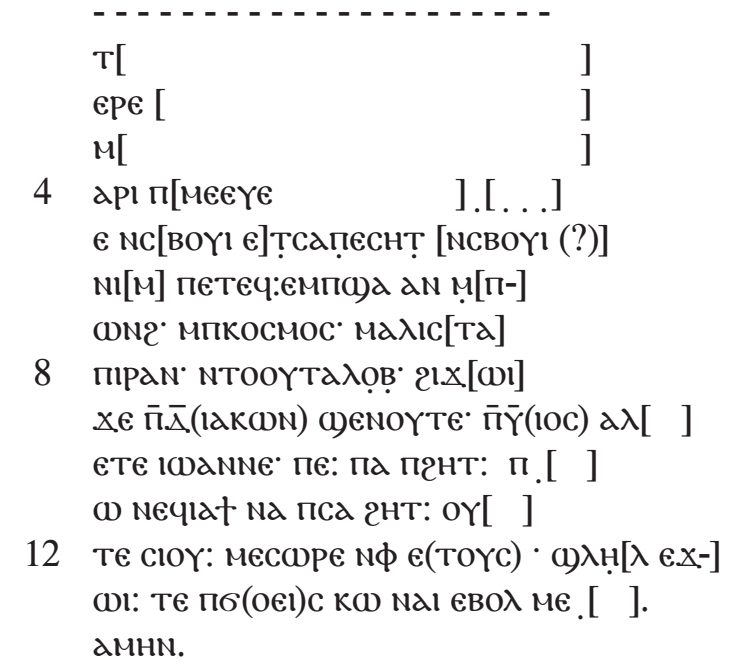

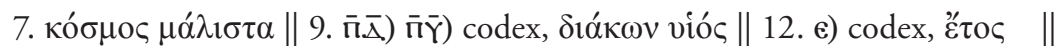
13. $\pi \overline{\mathrm{o}} \mathrm{c}$ codex

... Souviens-toi ... du disciple ..., le plus insignifiant de tous, qui n'est pas digne de vivre dans ce monde et encore moins du nom qu'on lui a donné, à savoir le diacre Chenoute, le fils d'al..., c'est-à-dire Jean, celui du nord ... ses pères, ceux du côté nord... Mesorê de l'an 500. Prie pour moi; que le Seigneur me pardonne ... Amen.

4-5. apı п[меєүє].[. . .]|є: On peut penser à restituer anок пірєчрмов|є.

5. enc[воү є] тсапеснт: Pour la restitution, comparer avec van Lantschoot 1929: $\mathrm{n}^{\text {os }}$ 51, 19-20 (anon пе nae[1оте ето]|оүадв' меісвоүl етсапеснт

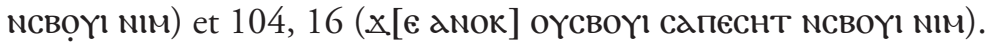

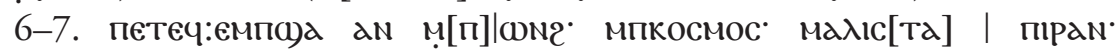

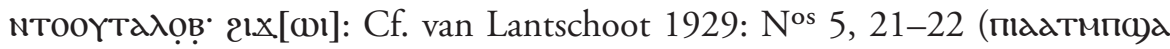

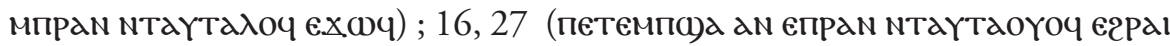

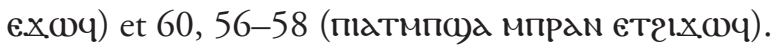

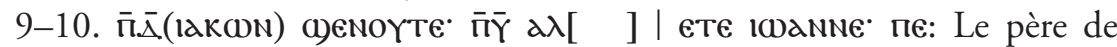
Chenoute portait manifestement deux noms (sur les noms doubles, cf. infra). L'un est clairement identifiable, car précisé par l'explicative єтє ı)anne пе, " c'est-à-dire Jean ". De l'autre, on ne conserve plus que les deux premières lettres, $\mathrm{d} \lambda[$ ], qui suggèrent qu'il s'agit de la transcription d'un nom arabe. 
11-12. oY[ ]|Te cloY: On pourrait songer à interpréter la séquence cloY comme la forme fayoumique coүeel, qui signifie le "premier jour", mais on voit mal comment articuler le passage avec ce qui précède (le T€ pourrait être la fin de €те, mais que faire du mot, court, qui commence par or[? ?).

12. mecope $\mathrm{N \phi} \in$ (ToY): Le mois de Mesorê commence le 25 juillet et se termine le 23 août. Pour l'an 500 ( 2 septembre 1106-21 août 1107), les 22 et 23 août sont exclus car l'année 501 commence le 22 août 1107.

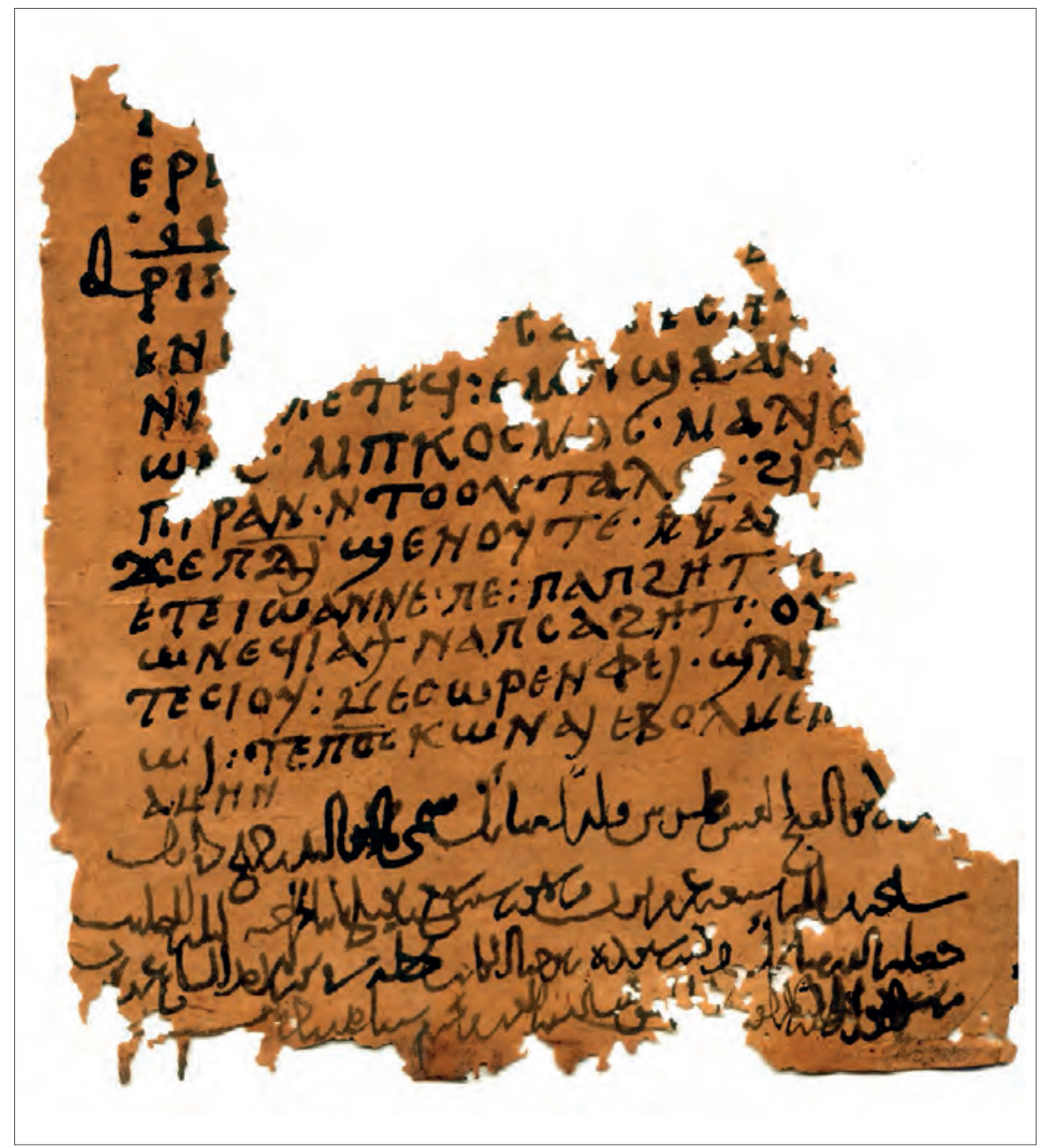

Fig. 2. $\quad F^{\circ} 72$ recto de l'Évangile de Jean de Naqlūn

(Image scannée par C. Gaubert; publiée avec l'aimable autorisation du PCMA) 


\section{Troisième colophon : une note en arabe}

Au bas de la page sur laquelle est écrit le deuxième colophon copte, figure une note écrite en arabe. Le texte, bien conservé, est réparti sur quatre lignes. L'écriture, tracée à l'encre noire, est cursive et professionnelle. Elle peut être rapprochée des écritures de l'époque fatimide telles qu'on les rencontre par exemple dans les documents CPR XXI 87-89. Par endroits, on peut voir des traces de surcharges (ll. 1-4) ; les lettres ne sont pas pourvues de points diacritiques (mais on rencontre trois tanwīn, 11.1 et 3). Ce troisième texte est précisément daté du 26 muharram 501, soit du 16 septembre 1107. L'identité de la personne qui a rédigé cette note est révélée par la 1.3 : il s’agit d’un certain Šanūda, fils de Yụ annā, c'est-à-dire le Chenoute fils de Jean cité dans le texte précédent.

Il n'est pas aisé de définir à quelles fins ce texte a été écrit à la fin de l'évangéliaire. Il ne s'agit pas d'un colophon sensu stricto, car rien dans le vocabulaire ou le formulaire ne rappelle ce type de textes (cf. Gacek 2009: 71-76), ni, comme le suggérait J. van der Vliet, d'une marque de propriété ou de la note d'un lecteur (van der Vliet 2003: 175). Le texte commémore l'entrée dans la communauté monastique, la nuit de la célébration de la Sainte Croix, d'un nouveau moine nommé al-Walīd fils de Ğurayğ.

Nd.02.239

$19.2 \times 12.8 \mathrm{~cm}$ [voir Fig. 2]

Naqlūn, 16 septembre 1107

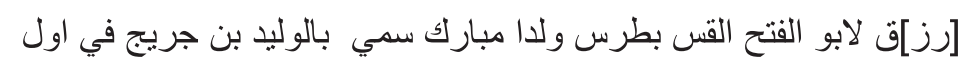

ساعة من ليلة سبعة عشر من توت من شهور سنة سبع عشر وثمانماية الخر اجية ليلة الصليب

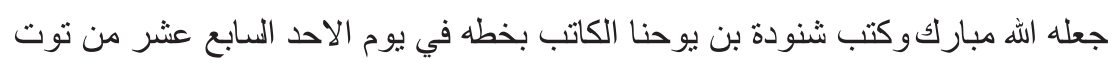
من شهور السنة المذكور [ة] الموافق للسادس و العشرين من محرم سنة احدى وخمس ماية

Abù al-Fath, le prêtre Pierre s'est vu accorder un fils béni du nom d'alWalìd, fils de Ğurayğ, à la première heure de la nuit du 17 Tüt des mois de l'année de l'imposition 817, la nuit de la Croix - Dieu la bénisse! Šanüda fils de Yuhannā, le scribe, a écrit (cette note) de sa main le lundi 17 Tüt des mois de la même année, ce qui correspond au 26 muharram de l'année 501. 
1. Abū al-Fatḥ al-qiss Butrus: La kunya Abū al-Fatḥ, à première vue typiquement musulmane, pouvait s'appliquer aussi à des chrétiens puisque la vie 66 de l'Histoire des Patriarches rapporte que le patriarche d'Alexandrie Christodoulos (1047-1077) avait cette kunya dans son nom. Pour un autre exemple de Copte portant un nom double chrétien et musulman, cf. P. Vindob. Inv. A.Ch. 9, 3 un contrat qui concerne un individu nommé Muhammad Ğāme (=KגMH) (Youssef-Grob 2015). Il faut sans doute y voir un signe d'acculturation par l'onomastique plutôt qu'une conversion ou une apostasie.

2. sab'a 'ašar min tūt min šuhūr sana saba'a 'ašara wa-țamānmi'a al-b̧äriğiyya: Dans les documents, l'adjectif al-hāriğiyy qualifie régulièrement des années pour signifier qu'il s'agit de l'année fiscale musulmane — c'est-àdire une année solaire - que l'on opposera à l'année religieuse musulmane, qui est lunaire (cf. par ex. CPR XXI 61, 9; P. Naqlun Arab. 30, 4;31, 6; 32, 5 et 33, 6 ; cf. aussi Rabie 1972: 133-134). Dans la note du manuscrit de Naqlūn, l'adjectif est utilisé pour désigner une année de l'ère des Martyrs par opposition à l'année musulmane; c'est là un usage inédit à notre connaissance. Chenoute a commis une erreur de conversion : le 17 Tüt de l'an 817 de l'ère des Martyrs ne correspond pas au 26 muharram 501, mais au 8 dù al-qa'da 493 (4 septembre 1100). L’année correcte devrait être 824.

laylat al-șalìb: Deux fêtes de la Sainte Croix sont fêtées chez les Coptes. L'une, qui avait lieu le 17 Tūt (14 septembre), commémorait l'invention de la Croix par l'impératrice Hélène (cf. Basset 1904-1923: 61-65) ; l'autre, qui prenait place le 10 Baramhāt (5 avril), célébrait la restauration de la Croix à Jérusalem après la victoire d'Héraclius sur les Perses en 628 (cf. Basset 19041923: 855-859).

al-muwäfiq li-l-sādis wa-l- 'išriñ min muharram sanat 'iḥdā wa-hamsami'a: Le participe muwäfiq, qui permet d'établir des équivalences entre différents computs, est peu courant dans les documents ; cf. par ex. P. Kaufurkunde, 17 et le commentaire p. 40. On notera que la conversion donnée par le scribe est à nouveau fausse : le 17 Tūt ne tombait en effet pas un 26 muharram en 501 de l'hégire, mais un 25 muharram. C'est pourtant bien la date du 26 muharram, qui est un lundi, qu'il faut retenir.

\section{Conclusion}

Grâce au premier colophon, Jacques van der Vliet a mis en évidence que le manuscrit a été copié en 1099/1100. En raison de l'absence de notes de lecture ou de corrections dans l'évangéliaire, il estimait fort vraisemblable que le manuscrit 
n'avait circulé que peu de temps avant d'être placé dans le cercueil (van der Vliet 2003: 174-175). Nous pouvons à présent préciser la chronologie du codex grâce aux autres "colophons". Le manuscrit a été copié par un scribe inconnu, puis acquis par un diacre du nom de Chenoute fils de Jean, qui y a ajouté une demande de prière en copte en juillet-août 1107, puis, quelques semaines plus tard une note commémorant en arabe l'entrée d'un nouveau moine dans la communauté monastique. La suite de l'histoire de ce manuscrit ne peut être déterminée avec certitude, mais nous serions tentés de croire qu'il a suivi Chenoute dans la tombe : dans le cercueil du défunt de la T 324, on a en effet retrouvé un étui contenant des calames et l'on apprend justement par la note arabe que Chenoute était scribe.

Les colophons jettent également une lumière intéressante sur l'identité des moines qui occupaient encore le monastère à l'époque. Comme Chenoute, dont le père portait un nom arabe (al-...) et un nom copte (Jean), comme alWalīd, dont le père s'appelait " petit George » (Ǧurayğ), et comme le prêtre Pierre, dont la kunya était Abū al-Fatḥ, il paraît probable qu'en cette fin de l'époque fatimide les moines qui continuaient d'occuper le site de Naqlūn avaient une double culture. Ils étaient à la fois chrétiens et utilisaient le copte comme langue liturgique, rédigeant à ce titre leurs prières dans cet idiome, mais ils étaient aussi complètement arabisés et recouraient à l'arabe, de préférence au copte, dans leur vie quotidienne ${ }^{13}$.

\section{REMERCIEMENTS}

Le Prof. Włodzimierz Godlewski, directeur de la fouille conduite sur le site du monastère de Naqlūn, nous a aimablement autorisé à publier ces trois textes et nous a fourni de nombreuses informations sur leur contexte de découverte. Qu'il trouve ici l'expression de notre gratitude. Nous remercions aussi Anne Boud'hors d'avoir voulu relire et critiquer une version préliminaire de cette contribution.

\section{Références bibliographiques}

Les papyrus sont cités conformément aux sigles de J.F. Oates et al., Checklist of Greek, Latin, Demotic and Coptic papyri, ostraca and tablets, disponible sur Internet : http://scriptorium.lib.duke.edu/papyrus/texts/clist.html.

13 Le même genre de phénomène est observable dans un linceul bilingue copte-arabe, datable d'après la langue des XII $-\mathrm{XIV}^{\mathrm{e}}$ siècles. Tout comme dans nos textes, la prière funéraire est écrite en copte alors que l'information factuelle, le nom du défunt, l'est en arabe. Cf. Delattre et Vanthieghem 2015. 


\section{SOURCES PRIMAIRES}

Sawirus ibn al-Mukaffa, History of the patriarchs of the Egyptian Church, known as the history of the Holy Church II.3. Christodoulus-Michael, A.D. 1046-1102, trad. par A.S. Atiya, Y. Abd al-Masih, et O.H.E. Burmester, Le Caire : Institut français d'archéologie orientale, 1959

\section{SOURCES SECONDAIRES}

Askeland, C. (2012). John's Gospel: The Coptic translations of its Greek text [=Arbeiten zur neutestamentlichen Textforschung 44]. Berlin : de Gruyter

Basset, R. (1904-1923). Le synaxaire arabe jacobite (rédaction copte) I-V. Paris : FirminDidot

Boud'hors, A. (1997). L'onciale penchée en copte et sa survie jusqu'au XVe siècle en Haute-Égypte. In F. Déroche et F. Richard (éds), Scribes et manuscrits du MoyenOrient (pp. 117-133). Paris : Bibliothèque nationale de France

Bouriant, U. (1892). Fragments grecs du livre d'Énoch. Mémoires publiés par les Membres de la Mission Archéologique Française au Caire, 9(1), 91-147

Delattre, A. et Vanthieghem, N. (2014). Une inscription disparue du Dayr al-Fahūrī. Bulletin de l'Institut français d'archéologie orientale, 114, 149-154

Delattre, A. et Vanthieghem, N. (2015). Un linceul copte-arabe inscrit de l'ancienne collection Michaelidès. Chronique d'Égypte, 90, 195-198

Emmenegger, G. (2007). Der Text des koptischen Psalters aus al-Mudil ein Beitrag zur Textgeschichte der Septuaginta und zur Textkritik koptischer Bibelhandschriften, mit der kritischen Neuausgabe des Papyrus 37 der British Library London (U) und des Papyrus 39 der Leipziger Universitätsbibliothek (2013). Berlin : de Gruyter

Gabra, G. (éd.). (1995). Der Psalter im oxyrhynchitischen (mesokemischen/mittelägyptischen) Dialekt. Heidelberg : Heidelberger Orientverlag

Gacek, A. (2009). Arabic manuscripts: A vademecum for readers [=Handbuch der Orientalistik 98]. Leyde : Brill

Godlewski, W. (2003). Naqlun: Excavations, 2002. Polish Archaeology in the Mediterranean, 14, 163-171

Godlewski, W. (2005a). Excavating the ancient monastery at Naqlun. Dans G. Gabra (éd.), Christianity and monasticism in the Fayoum oasis: Essays from the 2004 international symposium of the Saint Mark Foundation and the Saint Shenouda the Archimandrite Coptic Society in honor of Martin Krause (pp. 155-171). Le Caire : American University in Cairo Press

Godlewski, W. (2005b). The medieval Coptic cemetery at Naqlun. Dans G. Gabra (éd.), Christianity and monasticism in the Fayoum oasis: Essays from the 2004 international symposium of the Saint Mark Foundation and the Saint Shenouda the Archimandrite Coptic Society in honor of Martin Krause (pp. 173-183). Le Caire : American University in Cairo Press

Godlewski, W. (2005c). Naqlun (Nekloni): Season 2004. Polish Archaeology in the Mediterranean, 16, 181-190 
Helmecke, G. (2005). Textiles with Arabic inscriptions excavated in Naqlun 1999-2003. Polish Archaeology in the Mediterranean, 16, 195-202

Luijendijk, A. (2010). Sacred scriptures as trash: Biblical papyri from Oxyrhynchus. Vigiliae Christianae, 64, 217-254

Luijendijk, A. (2011). "Jesus says: 'There is nothing buried that will not be raised'." A Late-Antique shroud with Gospel of Thomas Logion 5 in context. Zeitschrift für Antikes Christentum, 15, 389-410

Pöhlmann, E. et West, M.L. (2012). The oldest Greek papyrus and writing tablets: Fifth-century documents from the "Tomb of the Musician" in Attica. Zeitschrift für Papyrologie und Epigraphik, 180, 1-16

Rabie, H.M. (1972). The financial system of Egypt A.H. 564-741/A.D. 1169-1341. Londres : Oxford University Press

Schüssler, K. (2007). Biblia coptica IV.1. Das sabidische Alte und Neue Testament: Vollständiges Verzeichnis mit Standorten (sa 586-620). Wiesbaden : Harrassowitz

van der Vliet, J. (2003). The Naqlun John: A preliminary report. Polish Archaeology in the Mediterranean, 14, 172-176

van Lantschoot, A. (1929). Recueil des colophons des manuscrits chrétiens d'Égypte [=Bibliothèque du Muséon 1]. Louvain : J.-B. Istas

van Minnen, P. (2007). The Akhmîm Gospel of Peter. Dans T.J. Kraus and T. Nicklas (éds), Das Evangelium nach Petrus: Text, Kontexte, Intertexte (pp. 53-60). Berlin : de Gruyter

Youssef-Grob, E.M. (2015). The earliest paper documents in the Vienna Collection revisited. Chronique d'Égypte, 90(180), 431-443 


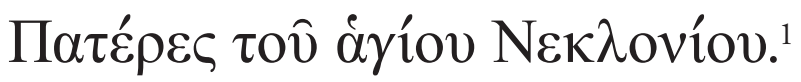 Functionaries of the Naqlun monastery in the first two centuries of its existence}

Tomasz Derda

Department of Papyrology, Institute of Archaeology, University of Warsaw t.derda@uw.edu.pl

Joanna Wegner

Department of Papyrology, Institute of Archaeology, University of Warsaw j.wegner@student.uw.edu.pl

\section{KeYwORDS}

Naqlun, laura, prosopography, bishop Nikolaos, monastic administration

\section{Abstract}

The present contribution explores the organisation of the monastic community at Naqlun in the 6th and 7th centuries. It starts with an overview of the sources and proceeds to a prosopography of various figures from the Naqlun community attested in the evidence. The concluding section is devoted to a brief synthesis of our current knowledge of the community structure and its development before the Arab conquest.

Close to 30 years of excavations carried out since 1986 under the direction of Włodzimierz Godlewski have not revealed yet all of the secrets of the monastic site at Deir el-Naqlun. ${ }^{2}$ Much can be said about the architectural history of the complex (see, e.g., Maślak 2016, in this volume) and conditions of life

1 The title of the present contribution is a paraphrase of the titles of address used by the writers of P. Naqlun 39, a letter from the inhabitants of the village of Tebetny to the monastic community of Naqlun: 'the beloved and fathers' of the 'holy Neklonion'. This letter is a document of major importance for our present argument.

2 On the excavation campaigns carried out to date at Naqlun, see Godlewski, Herbich, and Wipszycka 1990; Godlewski, Derda, and Górecki 1994. Since 1989 reports have been published in the journal Polish Archaeology in the Mediterranean (PAM). See also Godlewski 1997; 2005; for general remarks on the topography of the site, see Dobrowolski 1992. See also Wipszycka 2009a: 128-138. 
in the monastery in Antiquity and the Middle Ages, but many details still need clarification. The present paper addresses the question of organisation and structure of the Naqlun monastic community in the initial phase of its existence. At the time Greek was the predominant language in the community's relations with the outer world, as attested by documents discovered to date. A preliminary conclusion presented in some of the publications, namely that a laura of anchorites resident in the Naqlun gebel in the 6th and 7th century functioned simultaneously with a koinobion on the upper plateau, ${ }^{3}$ has already been challenged and consequently modified. ${ }^{4}$ However, the image of the Naqlun community needs to be further nuanced in the light of information gathered over years of research. What follows does not pretend to be an exhaustive or final discussion; the very nature of the sources prevents conclusive statements. The authors' aim has been to collect the available evidence, sketching a tentative picture of ancient reality that may be useful in precising questions for future research.

\section{Sources}

The architectural features of ancient monastic settlement, as well as papyrus texts reflecting the activities of its inhabitants, convey information about the functioning of the Naqlun community. The organisational structures are reflected both in the spatial disposition of the buildings and the titles of address used in documents and letters. Excavation carried out from the onset with special attention to textual finds has yielded archaeological material permitting an investigation of various types of sources in close association with one

3 The term 'upper plateau' is used for the area at the foot of Gebel el-Naqlun, between the hills and the modern monastic complex around the Church of Archangel Gabriel; 'lower plateau' designates the space stretching between the Bahr el-Gharaq canal and the modern monastery. Consequently, the upper plateau includes the area that was called 'kom' in earlier writing.

$4 \quad$ P. Naqlun I, pp. 28-33; see also Derda 1994. The koinobion was supposed to be of a later date than the semi-anchoritic laura; this opinion was challenged by Włodzimierz Godlewski (1997: 126-127); see also Godlewski 1992: 183, where the author states only that 'l'ensemble monastique de Naqlun se composait d'un certain nombre d'ermitages rupestres et d'une église avec les constructions auxiliaires sur le plateau. Les deux éléments du complexe existaient dès la seconde moitié du IV ${ }^{\mathrm{e}}$ siècle et étaient certainement contemporains'. See the opinion expressed already in P. Naqlun II, p. 94: 'Already in the first centuries of the monastery's existence this area [upper plateau] must have functioned as a hub of industrial activity and certainly also a religious centre, although it surely was not a Pachomian-style cenobium'. 
another. ${ }^{5}$ Literary sources, luckily available, help to sketch an overall picture of the community. The present section aims to describe these sources and assess their value.

Vestiges dating from the earliest period were discovered in three areas of the site $^{6}$ and comprise the following structures:

- buildings A, AA 20, first phase of buildings $\mathrm{E}$ and $\mathrm{J}$, as well as the earliest layers of the rubbish dump in Sector B on the upper plateau (end of 5th and 6th century);

- Hermitages 85 and 87 on the western site by the Bahr el-Gharaq canal (both dated to the second half of the 5th century), hewn in soft sedimentary rock;

- Hermitages 1, 2, 25, 44, 89, and 6, hewn in Gebel el-Naqlun east of the upper plateau; the earliest phase of occupation of Hermitages 44 and 89 is dated to the end of the 5th century; the remaining ones date from the first half of the 6th century.

The structures on the upper plateau, which underwent reconstruction in the Arab period, are difficult to interpret. The most imposing of these is Building A ( $18.5 \mathrm{~m}$ by $13.0 \mathrm{~m}$; walls $1.50 \mathrm{~m}$ thick), built in the early 6th century. It is interpreted as a keep; ${ }^{7}$ at some point in the later history of the monastery, Church a was built on the site. ${ }^{8}$ A complex of contemporary structures was

5 A short characteristic of Naqlun finds together with an assessment of their value for the reconstruction of the history of late antique monasticism is to be found in Wipszycka 2009a: 134.

6 The site at Deir el-Naqlun is vast, comprising: a) the modern monastery of Archangel Gabriel, nowadays a thriving religious centre, surrounding an eponymous church (11th century; wall paintings in the interior from the beginning of the 11th century; on their documentation and conservation, see Godlewski 2000b); b) the upper plateau east of the modern monastery with several clusters of buildings dated from the 6th to the 11 th century; site disturbed by burials belonging to the medieval so-called Cemetery A; c) the eastern group of hermitages located in Gebel el-Naqlun, a small range of desert hills east of the upper plateau; approximately 90 hermitages were hewn in soft sedimentary rock here, the oldest of which date from the end of the 5th century; some of the caves must have remained in use well into the medieval period, as attested by Coptic and Arabic documents excavated therein (see Urbaniak-Walczak 1994); d) the western cluster of hermitages, west of the modern monastery and road; these dwellings, located in the proximity of the canal which was the main watercourse in the area, were the earliest at Naqlun (second half of the 5th century). Between this site and the modern road was a burial ground (so-called Cemetery $\mathrm{C}$ dated to the 6th-7th century). Funerary stelae with Greek inscriptions discovered reused in medieval structures on the upper plateau are likely to have been brought from this necropolis (on the stelae, see Godlewski and Łajtar 2006).

7 See, however, the interpretation put forward by Peter Grossmann (2002: 513), who sees in this building a church that underwent several alterations.

8 On Building A and Church A, see Godlewski, Herbich, and Wipszycka 1990: 181-188; see also Godlewski 2000a: 128-129. 
discovered west of Building A; it was provided with a staircase and probably had an upper storey (see Godlewski 2001: 151-154; 2002: 160-166). The deposits in the rubbish dump in Sector B, located in the south part of the upper plateau, were accumulated by basketloads, as indicated by small clusters of finds discernible in the layers. The hermitages consist of rooms surrounding a courtyard. Hermitages of the west group were well-executed living quarters provided with kitchen facilities; Hermitage 85 had a small single-aisled church with apse, adjacent to the north side of the inner courtyard of the complex (see Godlewski 2008a: 198-206). Rock-hewn hermitages in the gebel were less amply furnished; kitchen and storage facilities therein were of a basic nature (each of the excavated hermitages, however, was provided with deep storage pits; it was in such a pit in Hermitage 89 that one of the most important dossiers of documentary papyri from Naqlun was discovered). They were designed to host one or two anchorites.

The hermitages and the rubbish dump on the upper plateau yielded most of the Greek documents excavated to date at Naqlun. . As said already, the proportion of Greek to Coptic documents in the layers dated archaeologically to the 6th and 7th centuries indicates the predominance of Greek in the monastery. The papyri excavated on the site are an invaluable source for the reconstruction of the functioning of the monastery; however, they also pose several problems which need to be addressed. First of all, by no means do they form a closed dossier. The rubbish dump has not been excavated in its entirety and only a very small percentage of hermitages were excavated (six of the more or less 90 identified in the gebel and two of nine in the area close to Bahr el-Gharaq). Therefore, possible future discoveries of new texts may bring about significant changes in the image of the Naqlun monastery as sketched in documentary papyri. ${ }^{10}$ Second, the task of reading and interpreting the texts is made extremely difficult by their state of preservation: out of hundreds of excavated Greek documents only about 20 are preserved well enough to be of any use (some of them are usable only thanks to their established archaeological context; had they been chance finds of no indicated provenance, they would

9 Greek papyri from Deir el-Naqlun were published by Tomasz Derda in two volumes: P. Naqlun I (1995), and II (2008); four texts from season 2011 (P. Naqlun 35-38) were published by Tomasz Derda and Joanna Wegner (Derda and Wegner 2014); an extremely interesting letter written to monks by the villagers of Tebetny (P. Naqlun 39) awaits publication by the same authors in a collection of contributions in honour of Jean Gascou (Derda and Wegner forthcoming).

10 Moreover, we must note that Coptic material pertaining to the period of interest remains unpublished; how much information we are thus bereft of is difficult to estimate. 
have no value whatsoever ${ }^{11}$ ). Third, of the published papyri only a few provide us with dates based on more than palaeographical grounds.

Last but not least, the very nature of the documents does not make the task any easier: only three papyri (P. Naqlun II 21, 22, and 23) are legal texts, in which the engaged parties are described with greater precision regarding their standing; moreover, none of the Greek documents published to date were produced by an administrative unit. This may create the impression that no such structures existed at Naqlun in the said period; other indications, however, prevent too hasty a judgment (see especially P. Naqlun 39, addressed to the whole community in a way suggesting the existence of internal organisation and hierarchy: 'To our beloved and fathers, Agathes the presbyter, and apa Paulos, and apa Neilammon, and apa Aanios the deacons, and to all the monks of the holy Neklonion'). These reservations appear to justify a pessimistic approach, but the truth of the matter is that there is enough to give an idea of how the monastic community at Naqlun functioned in Antiquity. The documents have preserved the names and titles of some of its members, permitting a microprosopography of the monastery which we shall treat as a point of departure for further research.

Finally, let us have a look at two literary sources connected with Naqlun. The first is the so-called Rule of Naqlun, wrongly attributed to St Anthony the Great. ${ }^{12}$ This text, preserved in Arabic and in a 17th-century translation into Latin, is not an actual rule, but a set of very general precepts concerning monastic life; its interest lies in the fact that it was designed for a group of monks living in a laura-type community. Close to nothing can be inferred from it regarding organisational structures: the only trace of some kind of recognised leadership appears in $\$ 32$ (rendered by Michel Breydy as 'N'entreprends aucun travail sans avoir consulté le père du couvent'). The overall picture transpiring from this source is that of a loosely-structured community, with monks living in separate dwellings connected by internal roads (see $\$ 26$, forbidding the monks to sit 'dans les sentiers du couvent'), paying visits to one another, attending mass in the monastery's church, and organising their ascetic life according to the master-disciple model (see $\$ 4$, speaking of taking 'enfants spirituels' by elder monks). The other source is an account concerning Naqlun included by Isaac the Presbyter in the Life of Samuel of Kalamun. Samuel was a 7th-century monk

11 See P. Naqlun 37 and 38, two fragmentarily preserved openings of what could have been business letters, which contribute to our knowledge only because they can be juxtaposed with another, this time well preserved document found in the immediate proximity (P. Naqlun 39). On the so-called Rule, see Wipszycka 1990; Breydy 1996; Mokbel 1966; Wipszycka 2009a: 66-67. Godlewski (1997: 126-127) expresses his justified criticism concerning this text. 
who dwelled at Naqlun in the first half of the 7th century, thus in a period not chronologically remote from the dates of the papyrus documents discussed here. Although the account of his life was written down about a century later, the text is considered to be highly credible. ${ }^{13}$ The author had a good orientation in the topographical situation of Naqlun: he was well aware of the closeness of the monastery to a canal, and when narrating Samuel's desire to separate himself from the crowds of visitors attracted by his holiness, he sent his hero to 'a cave on the east side of the monastery'. This reflects the actual situation of the biggest cluster of Naqlun hermitages. The description of the monastery suggests a community centred around a unit with a church, where Samuel attended masses on Saturdays and Sundays, and provided with a gate where the visitors gathered to meet the famous monk. ${ }^{14}$

\section{Prosopography}

Let us now focus on particular pieces of information which can be drawn from these sources. We shall begin with a concise prosopography of the monastic centre, in order to identify individuals fulfilling various functions in the community. For the sake of clarity, we shall present them in points.

13 See the opinion of Ewa Wipszycka (2009a: 432).

14 No building of this kind has been excavated at Naqlun. The role of the monastery gate is underscored in the Canons of Shenoute (which describe a well-organised, centralised community with legible structures and division of responsibilities, by no means analogous to what we have at Naqlun), and in Pachomian writings (it is the place of admission and preliminary instruction of novices). At the gate the monastic world meets the secular one; it is a liminal spot whose administration, on one hand, needs to be entrusted to reliable people, but which, on the other hand, can be treated as a place of punishment (see Layton 2014: 5354, with references to all canons of Shenoute's federation pertaining to the gatehouse). Such a function of the gate in a community similar to Naqlun in the earliest period of its existence is rather unthinkable. Ewa Wipszycka has rightly remarked that the information may refer not to the time when Samuel resided at Naqlun, but to the period when Isaac the Presbyter wrote down the holy man's life. Under Arab rule, Egyptian monasteries were subject to brutal interventions prompted by the authorities who pursued fugitives there. Some people, unable to meet their fiscal obligations, fled to monasteries in order to evade taxes; they were not members of monastic communities and the Arab administration took pains to force them to return to their place of residence. Monks tried to protect themselves from acts of violence which took place on such occasions and surrounded their monasteries with gated walls. In Isaac's time, such solutions must have become common and it is possible that he projected the practice into the past. 


\section{Phibamo (end of 5 th century)}

Attestations: the name of Phibamo was inscribed on a bowl found in Hermitage $44, i^{15}$ the inscription probably referred to the owner of the bowl and maybe, as may be inferred from the context of the find, of the whole hermitage in the first phase of its functioning. The complex yielded interesting finds: Coptic magical texts, ${ }^{16} \mathrm{a}$ bronze spoon, mortars and grinders. This may point to the occupation of the hermit, who could have been a physician. Phibamo could have received visitors from the 'world outside': Hermitage 44 had a spacious room accessed both from the internal courtyard and an outer vestibule, and provided with benches along the walls. The closeness of the connection of Phibamo's hermitage with the main Naqlun complex remains moot; it was the northernmost of the caves, located $1.20 \mathrm{~km}$ away from the upper plateau. It ceased to be occupied early in the 6th century following a natural disaster.

\section{Bishop Nikolaos (6th-7th century) ${ }^{17}$}

Certainly connected: P. Naqlun I 12 (a letter from the bishop and his secretary to komes Basileios signed $\uparrow$ Nikód $\alpha$ oc $\uparrow ;$ P. Naqlun II 32, 33, 34 (small fragments

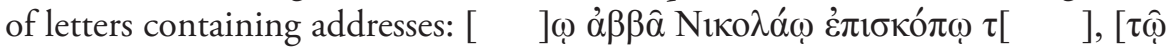

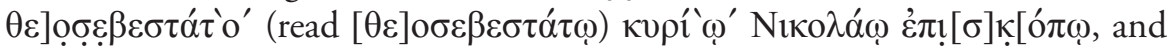

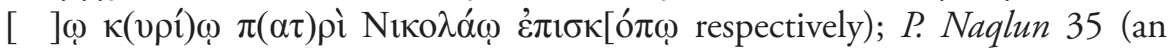
address tag, probably attached to goods delivered to the bishop: $\dagger \delta \varepsilon \sigma \pi$ ó $\tau$ ॄุ $\dot{\varepsilon} \mu \widehat{\varphi}$

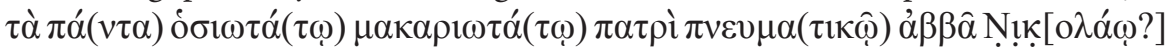

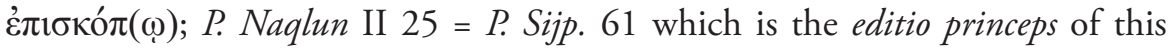
document with a more exhaustive commentary (a letter reporting social unrest

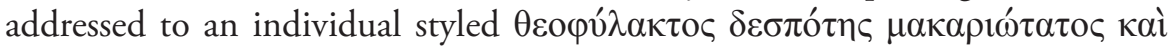

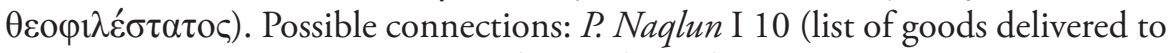

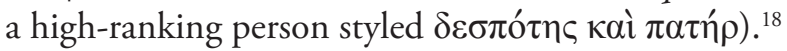

15 On Hermitage 44, see, among others, Godlewski 1996: 82-85; 2000c; Wipszycka 2009a: 137.

16 One of these texts has been published by Jacques van der Vliet (2000).

17 All the documents which pertain, whether certainly or only possibly, to Nikolaos are dated only on palaeographical grounds; see the editio princeps and van Minnen 2009: especially 223. In the editio princeps it was assumed that the list was connected with an abbot. The titles despotes kai pater are used in monastic context in P. Fouad 86, where they refer to the abbot of the Metanoia monastery, and in $S B$ I 4323, an undated (4th-7th century) letter from

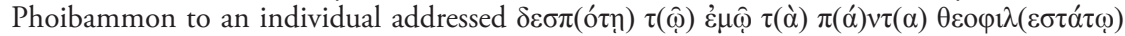

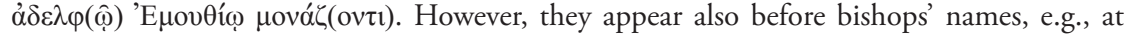

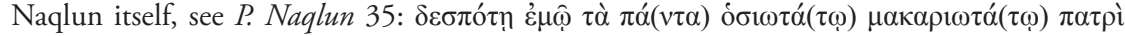

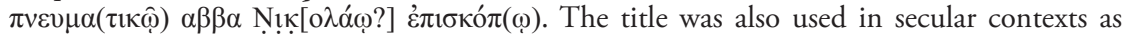
a mark of respect (e.g., komes and pagarch Papas from the 7th-century letters P. Apoll. 49

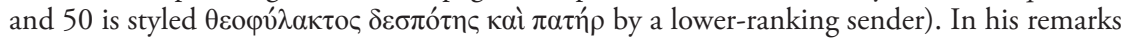


Bishops' residence in monasteries is attested in Egypt, the most prominent examples being Abraham of Hermonthis and Pisentios of Koptos; they had their living quarters in monastic establishments of the Theban region. The episcopal see of our Nikolaos remains unknown; two possibilities, namely Arsinoiton Polis and Herakleopolis, ${ }^{19}$ can be taken into consideration (Arsinoiton Polis, given the geographical proximity, seems more logical, but no solid proof has been provided to date). The preserved documents permit nothing certain to be inferred concerning Nikolaos' role within the monastic community (see below). If the meagre number of documents connected with the bishop can be treated as any indication, it seems that Nikolaos was more engaged in the affairs of the 'external world': P. Naqlun I 12, written in the name of Nikolaos to komes Basileios, touches upon matters in which lay individuals: kyrios Timotheos, kyra Ioannia, and kyrios Philoxenos, are involved; more specifically, in the case of Timotheos, it is probably a dispute over land that is concealed behind the

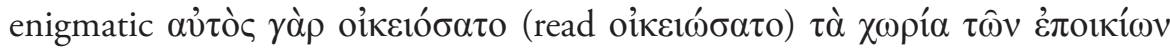
(1l. 2-3). ${ }^{20}$ More striking is the letter P. Sijp. $61=$ P. Naqlun II 25, reporting on some turbulent events (including the burning down of a praetorium) and the ensuing death penalties for the perpetrators. ${ }^{21}$ The document, interestingly,

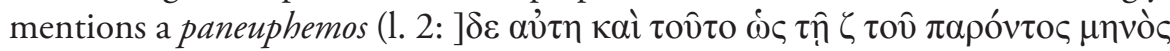
ó $\pi \alpha v \varepsilon v ́ \varphi[\eta \mu \circ)$; a question arises whether this high-ranking individual can

concerning P. Naqlun II 29, Dieter Hagedorn (2010: 132) has suggested that on the verso of this letter, certainly addressed to a prominent member of the Naqlun community, the traces

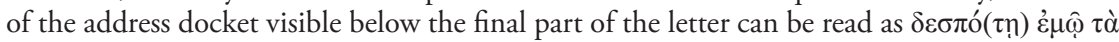
$\pi \alpha ́(v \tau \alpha) \ldots$. This may suggest that also this document was connected with a bishop residing at Naqlun (Nikolaos?); however, an examination of the text confirms only $\dot{\varepsilon} \mu \hat{\omega}$ (additionally, there is also the formula oìv $\Theta(\varepsilon \hat{\varphi})$ written above the docket, and traces of one more line above it). Therefore, nothing certain can be said about the addressee. For the same letter,

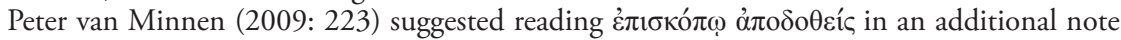
at the end of line 8 , but this reading is impossible. a new suggestion can be offered following

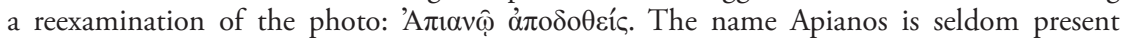
in documents from the 5th century (SB XVI 12838-12840, see also Apiane daughter of Dioskourides in P. Sorb. II 69, 39 G 1, of AD 633-634, or 618-619). In P. Naqlun II 29, something (but not the letter, note the masculine of the participle) was handed to a certain Apianos, an individual unknown so far.

19 The monastic complex at Naqlun lies between the Nile valley and the Fayum, approximately $1 \mathrm{~km}$ away from the fields in the oasis and no more than $3 \mathrm{~km}$ away from the ancient Herakleopolites. Contacts between the monastery at Naqlun and the Herakleopolite nome are attested explicitly in two documents, P. Naqlun II 24 (a tax register dated to the 7th-8th century, found on Site D on the upper plateau), and II 28 (a letter sent from Herakleopolis, found in Sector B; 6th century).

20 On the bishops' involvement in settling disputes of laity in their dioceses, see Schmelz 2002: 278-283.

21 For more information, see commentary to P. Sijp. 61, pp. 383-384. 
be identified with the well-known Flavius Strategios paneuphemos, the pagarch of the Arsinoites and Theodosiopolites in the first decade of the 7th century. ${ }^{22}$ As stated by Jairus Banaji, '[Strategios] retained control of this crucial position in the terrible conflicts that devastated Egypt towards the end of that decade [i.e., the 610s]'. This identification is absolutely tentative, but it might be an argument in support of van Minnen's inference that there may be a connection between the content of the letter and the 'eventful time' in the first half of the 7th century (van Minnen 2009: 222). P. Naqlun II 25 was most probably dispatched from a chancellery of an official of rank, as indicated by the manner in which the address on the verso was written; this, and the mention of a paneuphemos in the text, suggests that the bishop maintained relations with representatives of an administrative elite, a rare situation in the episcopal correspondence of Abraham and Pisentios who dealt mostly with local petty affairs. Nikolaos's dealings with the external world resulted from his episcopal rank and had nothing to do with the fact of his residence in the monastery. Besides the mere fact that Nikolaos lived at Naqlun, we are at a loss for what were the details of his links with this centre; was he a monk of the laura in the period preceding his ordination? Let us note that his name is extremely rare in Egypt: this typically Greek name is attested in Egypt from the Ptolemaic period until the 2nd century $\mathrm{AD}$, only to reappear once after a long break in late antique/Byzantine material of a provenance other than Naqlun. ${ }^{23}$ Observing the linguistic proportions of the Naqlun material from the period preceding the Arab conquest, we are tempted to see this community as an essentially Greek one; a monk, then bishop, bearing a name with strong connotations with the Byzantine cultural 'mainstream' would not be out of place in such a milieu.

\section{Apa Neilos (end of 6th century)}

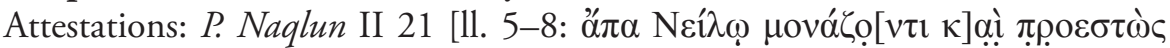

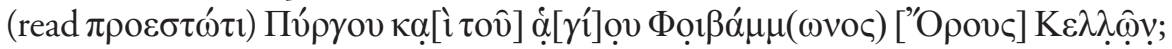

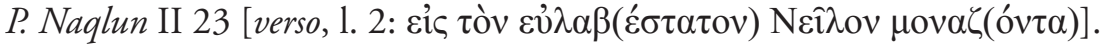

Both documents are contracts found in Hermitage 89, with P. Naqlun II 22 (see below). P. Naqlun II 21 is a loan of an unknown sum of money, while P. Naqlun II 23 is a loan of an unknown amount of nomismatia to be repaid in kind with 200 kouri of wine. Apa Neilos acts in them as the creditor.

22 He appears with the title paneuphemos already at the end of the 6th century (see Banaji 2001: 143, also 233-234, Appendix 1, Table 10).

23 A Christian letter of commendation written in an extraordinarily neat, 'Coptic' hand, described in P. Oxy. XXXI 2603 (edited in Journal of Egyptian Archaeology 48 [1962]),

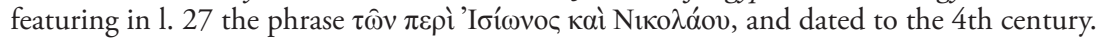


The meaning of Pyrgos and hagios Phoibammon in the document is a major issue. The identification of Pyrgos with Hermitage 89, supposedly equipped with a storage tower (analogous to the one excavated by Tomasz Górecki at Sheikh Abd el-Gurna ${ }^{24}$ ) that had disappeared presumably in a landslide, put forward in the editio princeps, has been challenged. In view of the archaeological data presented by Włodzimierz Godlewski, structure A-AA on the upper plateau, ${ }^{25}$ consisting of a large tower and three rooms to the west, and dated to the first phase in the existence of the monastery, was proposed as a better candidate for our Pyrgos. The question of hagios Phoibammon remains, as well as the one concerning Neilos's position in the monastic community as a whole; these problems shall be addressed in detail further on.

\section{Abba Apanakios (end of 6th-beginning of 7 th century $^{26}$ )}

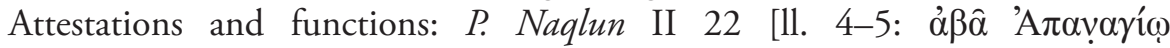

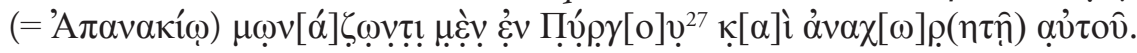

24 On these excavations of a Pharaonic tomb in the Theban region reused as hermitage at the beginning of the 8th century, see reports in Polish Archaeology in the Mediterranean, and Wipszycka 2009a: 190-196. The hermitage had a tower (approximately $5 \mathrm{~m}$ by $5 \mathrm{~m}$ ), located in the courtyard in front of the entrance and used as a storehouse.

25 Tower a was investigated in 1986 (plan established in trial pits; see Godlewski, Herbich, and Wipszycka 1990), and in 1999 (cleaning of the structure, see Godlewski 2000a: 130). For the reports on the excavations of the complex AA west of the Tower, see above, note 8 .

26 On controversies concerning the date of the three documents from Hermitage 89, see Gonis 2008; Gonis suggests dating this document to 8 August 623. However, the dates of P. Naqlun II 21 and 23 proposed by the editor, moved by Gonis also to the beginning of the 7 th century (see Gonis 2008: 229, n. 6: ' '.. there is no compelling reason to place P. Naqlun 21 and 23 in the 590s'), need not be changed. P. Naqlun II 21 lacks the religious formula, introduced by Mauricius and appearing consistently in documents from 17 September 591 onwards (see Bagnall and Worp 2004: 102 and 99: '...the invocation becomes virtually universal within a short time, and legal acts without it become extinct after 594/5'). In his criticism of the date proposed in the editio princeps, Nikolaos Gonis puts forward the opinion that the omission of the regnal year in the dating formula points to a date under Persian occupation. However, P. Naqlun I 21, which can be securely dated to the period before the introduction of the religious invocation under the reign of Mauricius, also lacks a regnal date. Apart from the validity issue of these texts, we can conclude that the absence of regnal years in this ensemble cannot be considered as decisive, and thus the date proposed in the editio princeps cannot be rejected too easily.

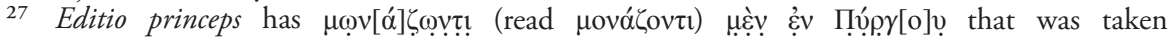

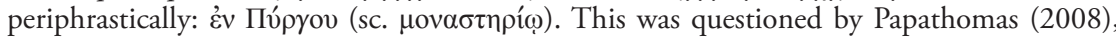

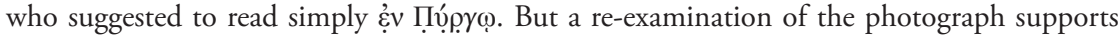
the editio princeps: traces at the bottom point to a letter that is sharply shaped (like the upsilon in this document as a rule) and not rounded as an omega should be. Ink traces can be seen above and to the right, suggesting a continuation of the trace at the bottom. This resembles

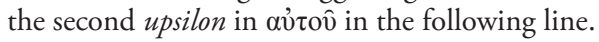


The document is a loan contract, in which abba Apanakios may have acted as a representative of the borrower (van Minnen 2009: 222), his son Aurelius Georgios, who entrusted his father with a copy of the document.

The suggestion in the editio princeps is that abba Apanakios was the immediate successor of Neilos as the resident of the 'monastery of the Tower', that is, Hermitage $89 .{ }^{28}$ The involvement in the loan recorded in P. Naqlun II 23 would therefore be one of the first activities of abba Apanakios in his new place of residence. The difficulties in establishing the dates of the three papyri from Hermitage 89 prevent us from expressing such a certainty. It ought to be underscored, however, that in contrast to his predecessor, Apanakios does not

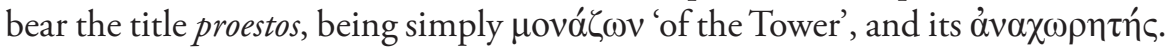
We shall address this question further on.

\section{Abba Menas (end of 6th-beginning of 7 th century)}

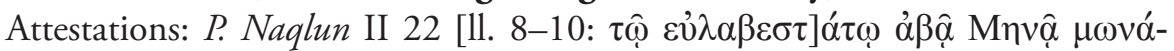

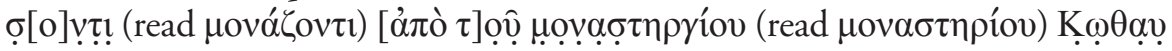

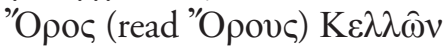

Abba Menas is a creditor in a loan transaction concluded with the son of the monk, abba Apanakios (4).

Abba Menas is styled only as a 'monk from the monastery Kothau of the Mountain of Cells' and bears no honorary titles. The reading of 'Kothau' is uncertain; it seems, however, that we are dealing with a unit of a similar status within the monastic community as Pyrgos and hagios Phoibammon from P. Naqlun I 21.

\section{Abba Menas (beginning of 7 th century)}

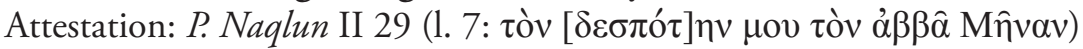

The honorary designation $\mathrm{abba}^{29}$ points to the prestigious position of the individual mentioned in this letter written by an unknown person. ${ }^{30}$ Was Menas the addressee of the letter? In the preserved ending of the greeting formula

28 This hermitage is said to have been designed for one person only (thus Derda in P. Naqlun II, p. 9, following the opinion of Godlewski expressed in several publications).

29 On the use of monastic and ecclesiastical honorary titles, see Derda and Wipszycka 1994.

30 The reading Klodios of the name of the sender, proposed in the editio princeps, was contested first by Peter van Minnen (2009: 223), then by Nikolaos Gonis (2009). They proposed to read either a name ending in $\kappa 1 \omega$ and abbreviated $\delta 1(\alpha)$ afterwards (van Minnen), or the date $\kappa \kappa^{\prime}{ }^{i} v \delta\left(1 \kappa \tau \tau^{\prime} \omega v o \varsigma\right) \delta^{\prime}+($ Gonis). But the most convincing reading was suggested by Hagedorn 2010: 132: 'E $\pi] \varepsilon[i] \varphi \kappa i v \delta(1 \kappa \tau i ́(\omega v) \varsigma) \delta+$. All these propositions leave us with no clue as to the identity of the sender. 


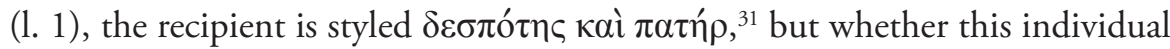
and Menas (in whose case the title despotes is largely reconstructed) are the same person is doubtful. Other people, probably also recipients of the writer's

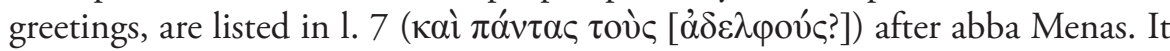
is possible that this fragment reflects a loose monastic organisation with many members and a few more prominent figures (as is the case with the famous Nepheros).

Abba Menas (6) is probably different from the other abba Menas (5).

\section{Agathes (6th or 7th century)}

Attestations: P. Naqlun 39 (1l. 3-4: A $\gamma \alpha \theta \varepsilon \varsigma, \pi \rho \varepsilon \sigma \beta v \tau \varepsilon \rho o v$, read 'A $\gamma \alpha$ ón $\pi \rho \varepsilon \sigma \beta v \tau \varepsilon \dot{\varepsilon} \omega)$

Agathes is mentioned here with his ecclesiastical title, ${ }^{32}$ but no monastic designations. The character of the letter and Agathes's place at the beginning of the address ${ }^{33}$ can point to his position at the head of the community (this opinion was expressed in the editio princeps of this document; for details, see below). Surprisingly, in contrast to the three deacons addressed in the letter, Agathes does not bear the honorary title of apa.

\section{Apa Paulos (6th or 7 th century)}

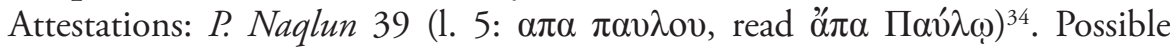

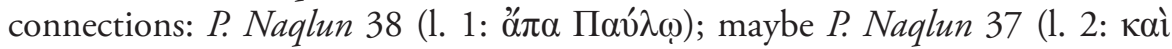

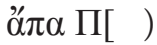

All three documents were excavated in the rubbish heap in Sector B on the upper plateau (see Derda and Dzierzbicka 2012), in immediate physical proximity to one another. Due to the commonness of the name of the individual in question we cannot be certain of the identification. The deacon

31 On Hagedorn's efforts to read a similar formula in the badly preserved address docket of the letter, see above, note 18 .

32 This results from the fact that the writers of the letter, a presbyter and a deacon from the village of Tebetny, addressed Agathes and his colleagues-deacons more as brothers in priesthood than monastic officials. We do not know, however, what kind of reality was reflected in this designation: Was Agathes an anchorite living in a cell provided with a church (like Hermitage 85), or a laura dweller who happened to be a presbyter and officiated in a church common to the whole community? The second option seems to us more probable.

33 The address reads (in the diplomatic transcription of this document written in extremely

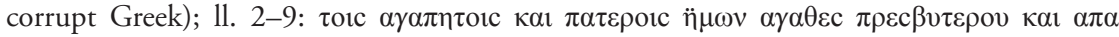

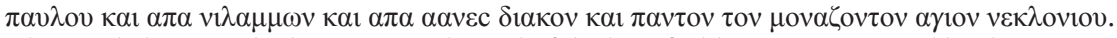

34 The word 'deacon' which appears at the end of the list of addressees mentioned by their names refers most probably to the three individuals following the presbyter Agathes (see Derda and Wegner forthcoming). 
Paulos of P. Naqlun 39 seems to have belonged to a group of people with certain administrative offices; the person(s) in the latter two texts are addressees of private business(?) letters.

\section{Apa Neilammon (6th or 7 th century)}

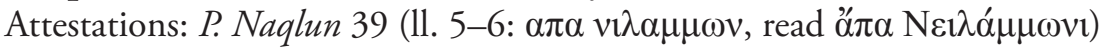

\section{Apa Aanis/Aanios (6th or 7th century)}

Attestations: P. Naqlun 39 (ll. 6-7: $\alpha \pi \alpha \alpha \alpha v \varepsilon \varsigma$, read ö $\alpha \alpha$ 'Aóvi = 'A $\alpha v i ́ \omega$ )

Both (9) and (10) were deacons, and belonged to the same group of people, probably concerned with administrative affairs, as Paulos and Agathes.

\section{Ioannes presbyter}

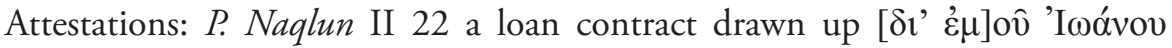

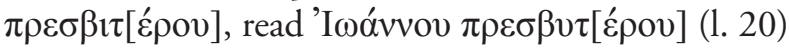

No certain connection between this man and the monastery can be proved, but the context indicates that he could have been a member of the community, since the document is very closely connected with it: the debtor is a son of a respected monk, and the creditor another monk of the community.

\section{Samuel of Kalamun ${ }^{35}$}

His sojourn at Naqlun in the first half of the 7 th century ${ }^{36}$ is mentioned in Chapters 9-11 of his Life penned by Isaac the Presbyter. Samuel's monastic career began at Scetis, whence he was driven out on account of his opposition against the patriarch Cyrus who sought to impose Chalcedonian doctrine on the monks. Having taken with him four disciples, Samuel came to Naqlun; there he lived first at the monasterion, in a place accessible to visitors who streamed there in great numbers to meet the holy man. Samuel decided to establish himself in a cave east of the centre and visited the monasterion only on Saturdays and Sundays to attend Mass. In a situation of crisis caused by another

35 For a brief bibliographical note on Samuel, see Alcock 1991.

36 The date of Samuel's three-year stay at the monastery is established based on the key role of the Chalcedonian patriarch of Alexandria Cyrus in the narrative; it is thus assumed that Samuel lived at Naqlun in the 630s. However, the date of Cyrus's patriarchate is in itself problematic (see Booth 2014; Wipszycka 2015, Annexe 'Alexandrian patriarchs from the patriarchate of Demetrius to the end of the seventh century'): in 631-633 Cyrus was only the topoteretes of the Alexandrian episcopal throne and was raised by Heraclius to the See of Alexandria perhaps in 633. Isaac states that in the period when the events at Scetis took place, Cyrus 'sat on the throne and he was given civil authority' (апхаүкїанос qмоос qïхмпеөропоб

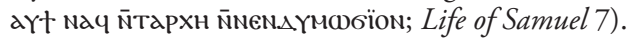


attempt to impose the acknowledgement of the Tome of Leo, ${ }^{37}$ he persuaded his fellow monks to hide in the mountains (his persuasiveness was clearly a result of personal charisma and authority). A wroth Cyrus caused Samuel's expulsion also from the Naqlun monastery. After a period of wandering and misfortunes (he was captured twice by Berbers), Samuel managed to establish a community at Kalamun, which was joined by some monks from Naqlun.

\section{3-16. Jacob, Joseph, Solomon, Selbane (Silvanus)}

Four disciples of Samuel of Kalamun mentioned in Chapter 8 of the Life, who left Scetis with their master. Nothing can be said either concerning their place of residence at Naqlun or their position in the community.

\section{Oikonomos of the monasterion at Naqlun, anonymous}

Attested in Chapter 10 of the Life of Samuel (once as mєT_ïaroneï, 'the one who serves', once as поїкомомос, 'steward'). He was the only member of the Naqlun community encountered by soldiers and officials upon their arrival at the monastery with the Tome. He seems to have been a person charged with taking care of the material goods of the community stored at the monasterion.

Two other men, whose designations in the documents convey no details of their standing in the community, can be found in the Naqlun documentation, namely:

\section{Apa Phoibammon (uncertain)}

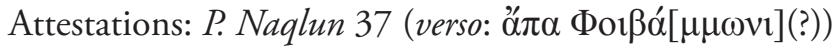

One of the addresses of a business(?) letter (together with apa Paulos?), mentioned in the address on the verso.

\section{Apa Hor}

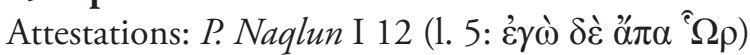

It follows from the context that this individual was a secretary to bishop Nikolaos (he adds his own postscript in an unsent letter written on behalf of Nikolaos to komes Basileios).

37 The document in question, which is called 'Tome of Leo' in the Life of Samuel, referred in fact to the Monothelete doctrine, formulated with the hope of reconciling Chalcedonians and Monophysites. The actual Tome of Leo (Tomus ad Flavianum) was a doctrinal letter of pope Leo I, sent in 449 to Flavian, the bishop of Constantinople. It contained an exposition of the doctrine of the two natures of Christ and was acknowledged by the Council of Chalcedon in 451; see Studer 1983. 


\section{Preliminary conclusions}

The material is not easy to use for the task set; hardly any titles are mentioned explicitly, and if they are, they are difficult to interpret in the context of the Naqlun community. However, before we proceed to such details as we can discuss, let us focus for a moment on the general impression given by our material, including pieces of information gathered from archaeological and literary sources. The Life of Samuel describes a community whose members were free to choose the model of their ascetic practice and lived separately, but were united by participation in the Eucharist in a church: '.. he [Samuel] made for

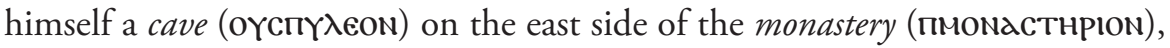
about a mile away, and nobody knew of it. The holy Apa Samuel would shut himself up in it for the whole week working on nets, which are called baskets. When he reached Saturday and Sunday, he would go to the monastery to

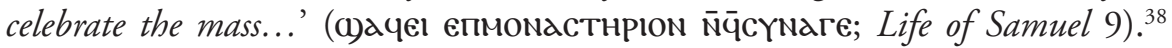
Further on, the author mentions Samuel who, concerned about the approach of Cyrus intending to force the monks to sign the Tome of Leo, 'assembled

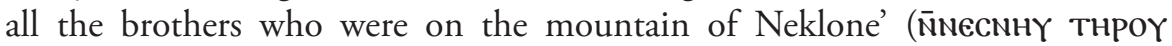

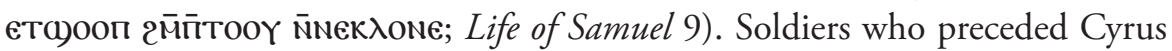
'came to the monastery (ёпмоластнріon) to prepare the place,' to find there no one but 'the one who serves' (пєт $\triangle$ ïakoneï), several lines later called 'the steward' (поїкомомос; Life of Samuel 10). What transpires from Isaac's account is an image of an establishment with a centre, both religious (the church) and economical (the oikonomos encountered by the soldiers must have been a monk charged with management of goods which were probably stored in this unit; the technical term used to describe this individual leaves no doubt about it). The

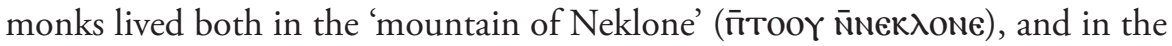
monasterion (this was the first place where Samuel was accommodated after his arrival at Naqlun). Even if some details of the account may not reflect reality (for example, the issue of the gate addressed in note 14), and other information which might have been considered useful is simply absent (Isaac's purpose was not to dwell on monastic organisation but to describe the life and deeds of his hero), we can easily note the overall resemblance of what is described to what can actually be seen on the spot and inferred from the documents. a large tower, which due to its size (it occupied a surface of approximately $240 \mathrm{~m}^{2}$ and almost certainly had more that one storey) could have been multi-functional

$\overline{38}$ Words of Greek origin used in the Coptic text italicised by Alcock. 
and served the whole community, stands on the upper plateau, along with an adjoining complex of buildings (the function of which cannot be determined persuasively owing to alterations introduced later). The upper plateau seems to be the most probable location of the monastery church ${ }^{39}$ the monks must have possessed their own place of worship, since attending masses at village churches was considered reprehensible in the monastic milieu. ${ }^{40}$ Except for Hermitage 85 , none of the monastic dwellings we know had a church ${ }^{41}$ (the church of Hermitage 85 was far too small to serve a community which may have numbered up to 120 monks; ${ }^{42}$ anyway, the hermitage was abandoned in the end of the 6th century due to natural collapse). Godlewski noted (2005: 159) that the hill hermitages were not self-sufficient in terms of provisioning, having no breadbaking facilities and storage spaces for water and wine. This must have rendered the inhabitants dependent on a central unit, which could have been located on the upper plateau. Moreover, the upper plateau was an important meeting point between the monastery and the outer world: all documents which can be connected with bishop Nikolaos (an individual who maintained lively relations with laypeople), as well as the letter from the Tebetny community of villagers addressed to the Naqlun community of monks, were found in the rubbish heap on the upper plateau, where they ended up discarded most probably from structures located nearby.

A close archaeological analogy is provided by the laura at Deir el-Qarabin located on the right bank of the Nile, close to Oxyrhynchus. ${ }^{43}$ The monastery, located about a kilometre from the fields, consisted of 20 hermitages in reused Pharaonic tombs hewn in the hills, and a religious and economic centre, which comprised, among others, a small church and domestic spaces with bread ovens, a big tower-refuge, grain silos, and water-collecting cistern. The domestic quarter yielded also numerous finds of pottery and wine amphorae. Just like at Naqlun, no wall surrounding the central unit was discovered. Deir el-Qarabin

39 During the excavations, a considerable number of architectural elements have been discovered; some were scattered on the plateau while others were reused in the church of Archangel Gabriel (see, e.g., Godlewski 1997: 127; 2005: 161; 2008b: 104). Originally they must have adorned a church building, most probably incorporated in complex A-AA, whose precise location has not been identified to-date.

40 Cf. point 28 of the so-called Rule of Naqlun, which reflects well the attitude towards attending village churches: 'Ne te rends pas à une église où se réunissent les gens.

41 They were provided with oratoria with niches destined for individual prayer.

42 According to the Life of Samuel 9, the community of Naqlun numbered 120 monks and 200 kosmikoi (by the latter term we understand lay people serving at the monastery); the figure is considered probable by Wipszycka 2009a: 432.

43 On this centre, see Huber 2004, and Wipszycka 2009a: 138-143. 
seems even more similar to Naqlun in terms of situation and spatial distribution than the establishments at Esna invoked in P. Naqlun II (pp. 94-95).

How can we place the aforementioned bearers of monastic and ecclesiastical titles in this setting? Who could have wielded authority over the monastery in the early period of its existence? What kind of authority was it? First, we need to consider the exceptional situation of Nikolaos' residence in the monastery. His role in the community itself is unclear, yet it is hardly imaginable that a bishop would make no effort whatsoever to control the institution in which he resided. Based on the general content of P. Naqlun I 12 (a letter from Nikolaos and apa Hor to komes Basileios which probably never left the monastery), we may guess that Nikolaos at least intended to exert some influence on the community: his 'secretary', apa Hor, chided the komes for not informing the bishop about a gift of wine granted probably to some of the monks. Nothing in this otherwise unclear text points to any administrative powers of the hierarch and the whole affair seems to be rather a matter of propriety. Nikolaos most probably resided on the upper plateau, in the immediate vicinity of the church and the main storage facilities; his presence must have boosted the dynamics of contacts between the community and the 'world outside': we can imagine messengers of the local officials coming and going, and deliverers carrying goods for the bishop (see $P$. Naqlun 35, an address tag probably attached to a parcel delivered to the monastery and destined for the bishop, ${ }^{44}$ maybe also P. Naqlun I 10

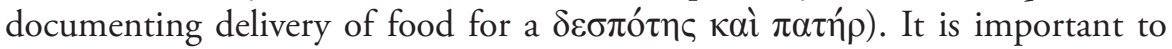
note individuals of high rank among the mentioned officials, who felt obliged to inform the bishop about the grave consequences of turmoil in the region (see P. Sijp. 61 = P. Naqlun II 25).

At the time when the letter from Tebetny (P. Naqlun 39) was dispatched, ${ }^{45}$ a kind of 'administrative board', composed of community members of ecclesiastical rank, existed at Naqlun. It comprised four men addressed by their names and titles: the presbyter Agathes, and the deacons Paulos, Neilammon, and Aanis. ${ }^{46}$ These men, headed by Agathes (who seems to have been the main

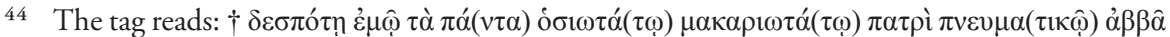

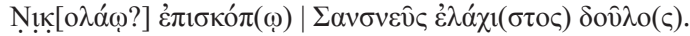

45 The date of this text was established on palaeographical grounds to the 6th-7th century. We are almost certain that there was no bishop in the monastery when the letter reached the community at Naqlun. It is improbable that the senders would have ignored the bishop and addressed only the presbyter, the deacons, and 'all the monks of the holy Neklonion'.

46 The fact that these individuals were clerics must have enhanced their position in the community and made them appear more trustworthy, therefore more suitable for exercising responsible functions. On the significance of ecclesiastics in monasteries, see Wipszycka 1996. 
addressee), were responsible for decision-making in the sphere of management: it was harvest time and Agathes was asked to dispatch a group of monks to take part in fieldwork. ${ }^{47}$ In the very same letter, Agathes was urged to visit the Fayumic village of Oxyrhyncha, most probably as a mediator in some kind of dispute between the Tebetny and Oxyrhyncha communities. We do not know why Agathes had to be involved in matters of the 'world outside' in this way: Was it only his authority as a priest and monastic leader, or had he practical reasons to intervene? We will probably never learn this, but we observe a certain mobility expected from the monastery's management, as well as the conviction that Agathes and his peers would be able to find a way out of the trouble in which the people of Tebetny, Oxyrhyncha, and hagia Eirene found themselves at a crucial time of the year. ${ }^{48}$ This 'managerial board' of the Naqlun monastery was apparently recognisable in the region. ${ }^{49}$

If our presbyter, helped by the deacons, was supposed to appoint tasks to

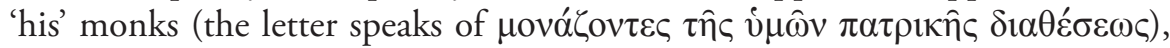
we may also assume that running other day-to-day affairs of the community was the duty of the same people. They operated most probably from the upper plateau (P. Naqlun 39 was unearthed from the rubbish heap in Sector B). It is natural that the community developed some forms of management and work organisation the responsibility for which lay with trustworthy individuals of high standing (clerics); yet still we know very little about forms of leadership within the monastery. From the documents and literary sources we learn the name

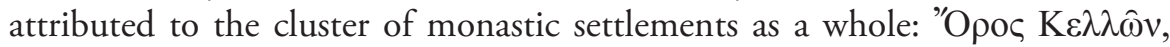

47 Let us note that one of the very few precepts of the so-called Rule of Naqlun saying anything about the organisation of the community, namely $₫ 32$, concerns the role of the 'father of the monastery', who is supposed to be consulted before undertaking any labour ('N'enterprends aucun travail sans avoir consulté le père du couvent'). This, however, fits the frame of spiritual guidance (in monastic writings labour is considered a kind of ascetic practice) rather than work organisation; the 'father' in the so-called Rule is an advisor who expresses his opinion on the monks' initiatives and their possible profit for spiritual advancement, not a steward who appoints tasks (let us also note that the very figure of 'the father' is quite vague; it is difficult to imagine a laura-type community having a single prior). On the contrary, Agathes and his colleagues, dispatching their fellow monks to the harvest at what was probably a local epoikion, performed a purely administrative task with economical implications for the monastery (the monks received wages for their work).

48 For the proposition how to identify hagia Eirene, see Derda and Wegner forthcoming. It could have been part of an estate (epoikion?) belonging to the episcopal church of the Arsinoites dedicated to St Eirene (see P. Köln III 152).

49 Interestingly, the management of the Naqlun community appears here to have been the hub of a local network of relations; it is a pity that the letter fails to give any clues as to whether this position was a 'by-product' of the monks' high reputation, or resulted from some more tangible interests. 


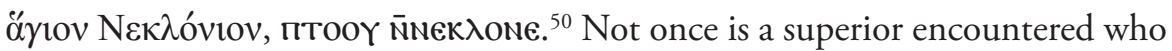
would be connected with these names. The only term referring to monastic hierarchy (as we know it from documents and literary sources) which we find in the Naqlun material is proestos (from the Greek $\pi \rho o$ í $\tau \tau \eta \mu 1$, 'to be at the head of', 'to be chief or leader') ${ }^{51}$ attested in one document, P. Naqlun II 21, in which

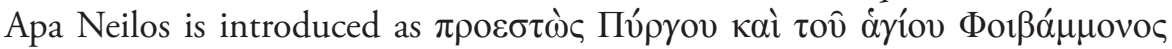
"Opovৎ K K $\varepsilon \lambda \hat{\omega} v$. It is clear that Oros Kellon should be understood as the Naqlun community as a whole, but where should we search for Pyrgos and hagios Phoibammon? We have already mentioned the two interpretations of the word Pyrgos (see above, Neilos [3]). The intuitive identification of the tower from the document with a tower which is still a prominent feature of the site on the upper plateau is tempting indeed; doubts remain however. First, we are inclined to see the complex on the upper plateau as a central unit, filling religious and economic functions. Building A — the supposed 'Tower' of our papyri — would have been a crucial element of this unit, important on the scale of the whole monastery. Our documentary record mentions three units treated autonomously (or simply distinguished) within the larger 'super-structure' (Oros Kellon), namely Pyrgos, hagios Phoibammon, ${ }^{52}$ and the mysterious monasterion Kothau. Of these, Pyrgos and hagios Phoibammon certainly had their own proestos (or proestotes; stability

50 Concerning the relation between the Greek and Coptic name of the monastery, Tomasz Derda has hypothesised (see P. Naqlun I, pp. 23-27, P. Naqlun II, pp. 93-94, and most recently the edition of $P$. Naqlun 39 in Derda and Wegner forthcoming) that the Coptic name

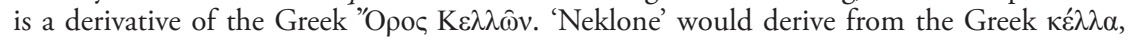
'cells', preceded by the Coptic plural article N. Although this hypothesis has raised some controversies (see the discussion cited in P. Naqlun I, pp. 26-27, note 31), there is no better explanation for the time being of how the Coptic name came into existence. Let us note that this Coptic form found its way also into Greek usage: the addressees of P. Naqlun 39 are the

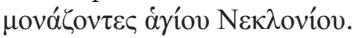

51 For general information about the use of the term in various communities from the 4 th to the 9th century, see Wipszycka 1991.

52 This name is a source of confusion; Phoibammon is a typically Theban saint, popular mostly in Upper Egypt; his cult is unattested in the Fayum (see Papaconstantinou 2001: 283-285). It is assumed that the existence of a monastic unit named after the popular Theban saint could be a result of activity of an Upper Egyptian monk at Naqlun (an individual named Phoibammon is probably attested in the address docket of a letter unearthed on the upper plateau, see prosopography [18], P. Naqlun 37; Hermitage 44, one of the oldest at the laura [second half of the 5th century] was probably inhabited by a certain Phibamo, whose name was written on a bowl discovered therein); unfortunately, we know too little about the history of the community and the practices of naming of its parts to be able to prove this or to propose another explanation. See the three contracts from Labla, P. Dubl. 32, 33, and 34, where particular monasteria, i.e., singular dwellings composed of $\kappa \varepsilon \lambda \lambda i$ i (rooms), are clearly named after their contemporary or former inhabitants; unfortunately, the Naqlun material does not provide us with such clear indications in this respect. 
of hierarchies is seldom achieved in communities of this kind and any 'personal unions' are not bound to last long). In the documents at our disposal there is no differentiation between these units, among which Pyrgos would have certainly been the most prominent, were its identification with Building A correct. Out of the three, only Kothan is explicitly called monasterion. It is also possible that

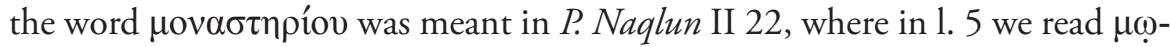

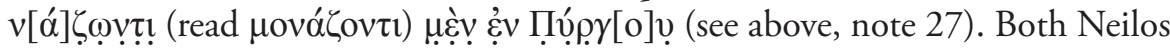
and Apanakios (numbers 3 and 4 in the 'Prosopography' section) are called 'monks of the Tower', which indicates that also this unit can be treated as a part of monastic settlement. Of course, being ignorant of the character of hagios Phoibammon and Kothau, we cannot treat this argument as more than another hypothesis concerning the structures at Naqlun. What we do want to say is that no conclusive determinations can be put forward at the moment; the preference for the identification of Pyrgos with Building A, not with a hypothetical tower of Hermitage 89 destroyed in a landslide, results from a fairly natural tendency to seek tangible points of reference.

An interesting question concerns the sequence of the inhabitants of Hermitage 89 who created the little dossier discovered therein. As noted already, Apanakios was Neilos' successor (doubts concerning the exact dates of the document prevent us from saying whether immediate or not). In P. Naqlun

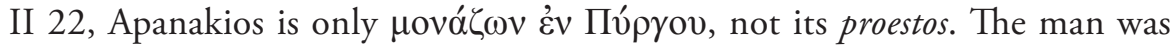
certainly a respected individual, as indicated by his title anachoretes. ${ }^{53}$ If Pyrgos is Hermitage 89, and Godlewski is right to claim that the hermitage had only one inhabitant, we are faced with the question of the changing title of its residents. This cannot be explained convincingly except by saying merely that laura-type communities were characterised by changeable hierarchies in which much depended on individual charisma and authority of particular members. But the identification of Pyrgos with Building A on the plateau poses other unsolvable questions (e.g., the relation between the central, 'eponymous' Tower and the hermitage(s) connected with it, and the organisation of this 'sub-structure' of Oros Kellon). The only certainty issuing from an analysis of the three documents forming the little dossier from Hermitage 89 is that the dwellers of the Oros Kellon had a kind of 'double affiliation': they belonged to the Naqlun community in the broad sense, but in official documents they also identified

53 The title in the documentary record applies usually to particularly holy monks and is an honorary title used to stress the sanctity of a person; on the evolution of meaning of the title anachoretes, see Wipszycka 2009a: 294-303. 
themselves in reference to smaller units. ${ }^{54}$ The latter apparently could have some structure of their own, comprising both proestotes and ordinary monazontes.

Based on our modest documentary record we cannot speak of the history of the Naqlun community through the prism of the papyri; what we have are rather some scattered leaves of a history. In these leaves we see mostly individuals: not only bishop Nikolaos, who is a case apart, but also others, bearing titles or not. Neilos, Apanakios, and Menas (5) are involved in contractual transactions (laura-dwellers were free to have private funds at their disposal and to engage in financial operations $\left.{ }^{55}\right)$. Apart from them are Paulos, Phoibammon(?), and Menas (6), recognisable individuals who lived and pursued their activities most probably on the plateau and who were correspondents of unidentifiable addressees who probably belonged to 'the world outside.' No clearly established spiritual hierarchy can be discerned in the available documentation; ${ }^{56}$ the only structure we are able to glimpse is the

54 Compare this situation with the one known from the aforementioned 6th-century dossier of three legal deeds from Labla (P. Dubl. 32, 33, 34). The subject of these deeds are monastic dwellings (see Wipszycka 2009b), located within a larger structure, Labla. The dwellings are consistently called $\mu$ ov $\alpha \sigma \tau$ ń $\rho \alpha$ and named after their inhabitants (see above); as for the whole community, the situation is more complex. In P. Dubl. 32 and 34, monasteria are placed $\dot{\varepsilon} v \tau \hat{\varphi}$

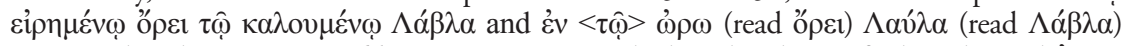
respectively, whereas in $P$. Dubl. 33 a monasterion, which is the object of sale, is located $\dot{\varepsilon} v \tau \hat{\varphi}$

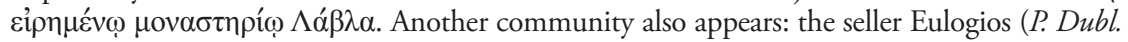

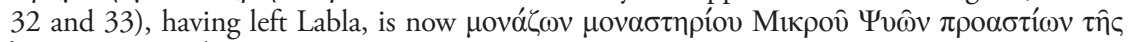

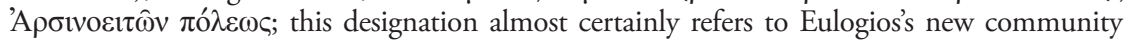
as a whole. Although the scribes are inconsistent in their designations of Labla (which shows that the words monasterion in the broad sense, and oros could be interchangeable), the usage of calling the single habitations monasteria seems quite well established.

On possession of goods among the monks, see, e.g., Bagnall 2001; on the participation of monks in financial transactions involving credit, see Markiewicz 2009.

56 The account of Samuel's effective entreaty to hide from the oppressive church officials addressed to his fellow monks in a situation when, according to Samuel's belief, the monks' salvation was at stake, shows that a charismatic individual could persuade the community to act in one way or another even without having formalised status. Of course, the whole history serves to emphasise Samuel's holiness and ability to act efficiently in a difficult situation in order to save both the immortal souls and the earthly lives of the brethren. It was not intended to inform about the manner of settling problematic matters in a laura where the hero happened to live. Yet further on (Life of Samuel 11), our protagonist faced Cyrus, who perceived Samuel's behavior as insolent and asked him who had made him a superior over the brothers ('Who appointed you hegumen over this monastery?', мїм пектачкаөїста мтмок

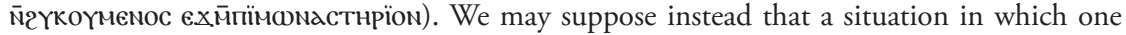
person gave directives to a whole community of monks living individually in the manner of a superior was considered contradictory to tradition and reprehensible (regardless of the obvious hostility of the bishop towards Samuel on account of the latter's theological stance). On the problem of 'père du couvent' from $\$ 32$ of the so-called Rule, see above, note 47. 
'administrative panel' composed of Agathes, Aanis, Paulos, and Neilammon (let us note that the only individual performing a concrete function in the account of the Life of Samuel is also an administrative functionary, an oikonomos). As observed already, the hermitages at Naqlun must have depended on a kind of central establishment which was charged with satisfying both the bodily and the spiritual needs of the monks, providing them with bread and wine, and giving them the opportunity to participate in the Eucharist every Sunday. A Sunday gathering of the brethren would have ended probably in a common meal $;{ }^{57}$ the community as a whole must have had resources to provide for all these basic needs. Their accumulation could have boosted the development of administrative structures (loose and momentary as they might have been), but the model of life - highly personalised, with a considerable margin of individual freedom - could have remained unchanged for some time. The laura consisted of people leading their own distinctive lives. Structures were created according to particular needs and did not assume any formalised shape; they were the result of internal negotiations of power and prestige, but also of circumstances (see the case of Samuel). Monks were treated as a collective body probably only exceptionally: it is the case of P. Naqlun 39, a letter from one community to another (presumably the villagers of Tebetny, headed by their clerics, perceived the Naqlun community as a structure which, at least in social terms, was somehow analogous to their own).

Time and future discoveries will probably verify this picture of the Naqlun community in the first centuries of its existence. For the time being, however, in view of the available data, we believe that the reconstruction proposed here is the most plausible one.

\section{References}

The abbreviated references to documentary sources follow J.F. Oates et al., Checklist of Greek, Latin, Demotic and Coptic papyri, ostraca and tablets, available online at http://scriptorium.lib.duke.edu/papyrus/texts/clist.html.

57 See a big room $\left(31 \mathrm{~m}^{2}\right)$ in Hermitage 85 , interpreted by Godlewski (2008b: 103) as an assembly room. It could have served the monks for common meals after celebrating mass in the church adjoining the hermitage. 


\section{Primary SOURCES}

Isaac the Presbyter, The life of Samuel of Kalamun, transl. by A. Alcock, Warminster: Aris \& Phillips, 1983

\section{SECONDARY SOURCES}

Alcock, A. (1991). Samūîl of Qalamūn, Saint. In A.S. Atiya (ed.), The Coptic Encyclopedia VII (pp. 2092-2093). New York: Macmillan

Bagnall, R.S. (2011). Monks and property: Rhetoric, law, and patronage in the Apophthegmata Patrum and the papyri. Greek, Roman, and Byzantine Studies, 42(1), 7-24

Bagnall, R.S. and Worp, K.A. (2004). Chronological systems of Byzantine Egypt (2nd ed.). Leiden: Brill

Banaji, J. (2001). Agrarian change in late antiquity: Gold, labour, and aristocratic dominance. Oxford: Oxford University Press

Booth, P. (2014). Crisis of empire: Doctrine and dissent at the end of Late Antiquity [=Transformation of the Classical Heritage 52]. Berkeley: University of California Press

Breydy, M. (1996). La version des Règles et préceptes de St. Antoine vérifiée sur les manuscrits arabes. In E. Wipszycka, Études sur le christianisme dans l'Égypte de l'antiquité tardive (pp. 395-403). Rome: Institutum Patristicum "Augustinianum"

Derda, T. (1994). Polish excavations at Deir el-Naqlun 1986-1991: Interdependence of archaeology and papyrology. In A. Bülow-Jacobsen (ed.), Proceedings of the 20th International Congress of Papyrologists, Copenhagen, 23-29 August, 1992 (pp. 124130). Copenhagen: Museum Tusculanum Press

Derda, T. and Dzierzbicka, D. (2012). Refuse dump in sector B in Naqlun: Excavation report 2008-2009. Polish Archaeology in the Mediterranean, 21, 212-221

Derda, T. and Wegner, J. (2014). New documentary papyri from the Polish excavations at Deir el-Naqlun (P. Naqlun 35-38). Journal of Juristic Papyrology, 44, 117-131

Derda, T. and Wegner, J. (forthcoming). Letter from Tebetny to the monks of Naqlun concerning fieldwork. In Festschrift P. Gascou

Derda, T. and Wipszycka, E. (1994). L'emploi des titres abba, apa et papas dans l'Égypte byzantine. Journal of Juristic Papyrology, 24, 23-56

Dobrowolski, J. (1992). The monastic complex of Naqlun - topography of the site. In P.O. Scholz (ed.), Orbis Aethiopicus: Studia in honorem Stanislaus Chojnacki natali septuagesimo quinto dicata, septuagesimo septimo oblata [=Bibliotheca Nubica 3] (pp. 309-325). Albstadt: K. Schuler

Godlewski, W. (1992). Deir el-Naqlun. Quelques observations historiques. In M. Rassart-Debergh and J. Ries (eds), Actes du IVe congrès copte: Louvain-la-Neuve, 5-10 septembre 1988, I [=Publications de l'Institut orientaliste de Louvain 40] (pp. 177-186). Louvain-la-Neuve: Institut orientaliste

Godlewski, W. (1996). Naqlun: Excavations 1995. Polish Archaeology in the Mediterranean, 7, 82-88 
Godlewski, W. (1997). Deir el Naqlun. Topography and tentative history. In C. Basile (ed.), Archeologia e papiri nel Fayyum: storia della ricerca, problemi e prospettive. Atti del Convegno internazionale, Siracusa, 24-25 maggio 1996 [=Quaderni del Museo del Papiro, Siracusa 8] (pp. 123-145). Syracuse: Istituto internazionale del papiro

Godlewski, W. (2000a). Naqlun: Excavations, 1999. Polish Archaeology in the Mediterranean, 11, 125-132

Godlewski, W. (2000b). Les peintures de l'église de l'Archange Gabriel à Naqlun. Bulletin de la Société d'archéologie copte, 39, 89-101

Godlewski, W. (2000c). Naqlun. The hermitage of Phibamo. In K.M. Ciałowicz and J.A. Ostrowski (eds), Les civilisations du bassin Méditerranéen: hommages à Joachim Śliwa (pp. 91-98). Kraków: Instytut Archeologii Uniwersytetu Jagiellońskiego

Godlewski, W. (2001). Naqlun: Excavations, 2000. Polish Archaeology in the Mediterranean, 12, 149-161

Godlewski, W. (2002). Naqlun: Excavations, 2001. Polish Archaeology in the Mediterranean, 13, 159-170

Godlewski, W. (2005). Excavating the ancient monastery at Naqlun. In G. Gabra (ed.), Christianity and monasticism in the Fayoum oasis: Essays from the 2004 international symposium of the Saint Mark Foundation and the Saint Shenouda the Archimandrite Coptic Society in honor of Martin Krause (pp. 155-171). Cairo: American University in Cairo Press

Godlewski, W. (2008a). Naqlun (Nekloni): Season 2006. Polish Archaeology in the Mediterranean, 18, 195-206

Godlewski, W. (2008b). Naqlun (Nekloni). The hermitages, cemetery and the keep in the early 6th century. In S.L. Lippert and M. Schentuleit (eds), Graeco-Roman Fayum: Texts and archaeology. Proceedings of the third International Fayum Symposion, Freudenstadt, May 29-June 1, 2007 (pp. 101-112). Wiesbaden: Harrassowitz

Godlewski, W., Derda, T., and Górecki, T. (1994). Deir el Naqlun (Nekloni), 19881989. Second preliminary report. Nubica, 3(1), 201-263

Godlewski, W., Herbich, T., and Wipszycka, E. (1990). Deir el Naqlun (Nekloni) 1986-87: First preliminary report. Nubica, 1-2, 171-207

Godlewski, W. and Łajtar, A. (2006). Grave stelae from Deir el-Naqlun. Journal of Juristic Papyrology, 36, 43-62

Gonis, N. (2008). Korr. Tyche 588-597. Tyche, 23, 227-229

Grossmann, P. (2002). Christliche Architektur in Ägypten [=Handbuch der Orientalistik 62]. Leiden: Brill

Hagedorn, D. (2010). Ein Kyrill-Zitat in P. Naqlun II 19. Zeitschrift für Papyrologie und Epigraphik, 173, 131-132

Huber, B. (2004). Die Klosteranlage bei el-Kom el-Ahmar / Šaruna (Mittelägypten). Bulletin de la Société d'archéologie copte, 43, 45-61

Layton, B. (2014). The canons of our fathers: Monastic rules of Shenoute. Oxford: Oxford University Press 
Markiewicz, T. (2009). The Church, clerics, monks, and credit in the papyri. In A. Boud'hors, J. Clackson, C. Louis, and P. Sijpesteijn (eds), Monastic estates in late antique and early Islamic Egypt: Ostraca, papyri, and essays in memory of Sarah Clackson [=American Studies in Papyrology 46] (pp. 178-202). Cincinnati, OH: American Society of Papyrologists

Maślak, S. (2016). The burning of a monastery? Story blazed on the walls of monastic buildings at Nekloni (Naqlun). In A. Łajtar, A. Obłuski, and I. Zych (eds), Aegyptus et Nubia Christiana. The Wtodzimierz Godlewski Jubilee Volume on the occasion of his 70th birthday (pp. 149-186). Warsaw: PCMA UW

Mokbel, A. (1966). La règle de Saint Antoine le Grand. Parole de l'Orient, 2(2), 207-227

Papaconstantinou, A. (2001). Le culte des saints en Égypte des Byzantines aux Abbasides: l'apport des inscriptions et des papyrus grecs et coptes. Paris: CNRS Editions

Papathomas, A. (2008). Korr. Tyche 600-610. Tyche, 23, 233-236

Schmelz, G. (2002). Kirchliche Amtsträger im spätantiken Ägypten: nach den Aussagen der griechischen und koptischen Papyri und Ostraka [=Archiv für Papyrusforschung und verwandte Gebiete, Beiheft 13]. Munich: K.G. Saur

Studer, B. (1983). Tomus ad Flavianum. In A. Di Berardino (ed.), Dizionario patristico e di antichità cristiane II (col. 3480). Casale Monferrato: Marietti

Urbaniak-Walczak, K. (1994). P. Naqlun inv 12/89: ein Fragment eines Syllabars aus Naqlun (Faijum). Journal of Juristic Papyrology, 24, 145-148

van der Vliet, J. (2000). Les anges du Soleil. À propos d'un texte magique copte récemment découvert à Deir en-Naqloun (N. 45/95). In N. Bosson (ed.), Études Coptes VII: Neuvième journée d'études, Montpellier 3-4 juin 1999 [=Cahiers de la Bibliothèque copte 12] (pp. 319-338). Paris-Leuven: Peeters

van Minnen, P. (2009). [Review of] Tomasz Derda, Deir el-Naqlun: The Greek Papyri, Volume Two. Bulletin of the American Society of Papyrologists, 46, 219-223

Wipszycka, E. (1990). Une nouvelle Règle monastique égyptienne. In W. Godlewski (ed.), Coptic studies: Acts of the Third International Congress of Coptic Studies, Warsaw, 20-25 August, 1984 (pp. 499-503). Warsaw: PWN

Wipszycka, E. (1991). Proestos. In A.S. Atiya (ed.), The Coptic Encyclopedia VI (p. 2021). New York: Macmillan

Wipszycka, E. (1996). Les clercs dans les communautés monastiques d'Égypte. Journal of Juristic Papyrology, 26, 135-166

Wipszycka, E. (2009a). Moines et communautés monastiques en Égypte (IVe-VIII siècles) [=Journal of Juristic Papyrology Supplement 11]. Warsaw: Raphael Taubenschlag Foundation

Wipszycka, E. (2009b). Monks and monastic dwellings. P. Dubl. 32-34, P. KRU 105 and BL Ms.Or. 6201-6206 revisited. In A. Boud'hors, J. Clackson, C. Louis, and P. Sijpesteijn (eds), Monastic estates in late antique and early Islamic Egypt: Ostraca, papyri, and essays in memory of Sarah Clackson [=American Studies in Papyrology 46] (pp. 236243). Cincinnati, OH: American Society of Papyrologists

Wipszycka, E. (2015). The Alexandrian Church: People and institutions [=Journal of Juristic Papyrology Supplement 25]. Warsaw: Raphael Taubenschlag Foundation 



\title{
Wine consumption and usage in Egypt's monastic communities (6th-8th century)
}

Dorota Dzierzbicka

Institute of Archaeology, University of Warsaw d.dzierzbicka@uw.edu.pl

\begin{abstract}
KeYwords
wine, monasteries, monks, health, payment, liturgy, prosphora, amphorae, stoppers
\end{abstract}

\begin{abstract}
Wine was crucial for the monastic economy, religion, health and lifestyle. The paper begins with a brief overview of the evidence for monastic vineyard ownership and considers other options available to monks seeking to procure wine for their needs. Further on, the contribution discusses the various uses of wine in coenobitic monasteries and lavras. It explores the issue of the monastic communities' need for wine for liturgical purposes and payments in kind, as well as the evidence for its consumption among monks in medical, social and everyday contexts. Lastly, relying on textual and archaeological evidence the paper addresses the question of the volume of wine consumed by monks.
\end{abstract}

Wine, a staple product ubiquitous in Late Antique Egypt, was an important feature in the life of monastic communities. ${ }^{1}$ It therefore seemed fit to contribute a paper on this subject to the volume in honor of Włodzimierz Godlewski, who has devoted nearly three decades to uncovering the material remains of the monastery at Deir el-Naqlun in the Fayum Oasis. The following contribution aims to discuss the uses of wine in coenobitic monasteries and lavras, and to explore the issue of its consumption among monks.

1 I am deeply indebted to Ewa Wipszycka-Bravo and Tomasz Górecki for their invaluable comments on a draft version of this text. The research was conducted with financial support from the National Science Centre of Poland (Research Grant No. 2013/11/D/HS3/02461) and the Foundation for Polish Science (START 2013 scholarship). 
Before focusing on the uses and consumption of wine, however, it is necessary to first briefly address the question of supply. Alongside grain, wine was one of the most frequently attested commodities arriving to monasteries from different villages, as illustrated by invoices from Bawit, Wadi Sarga and Edfu. ${ }^{2}$ The 6th7th century documentary evidence from the monastery of Apa Thomas at Wadi Sarga near Assiut mentions camels bringing must from vineyards to the monastic complex. The monastery received 2937 large and 1690 small jars of wine in the month of Thoth alone and a total of 25,665 liters of wine in the course of a single year. At Bawit, 6142 liters of wine were received in one day (Bacot 1998).

A number of monasteries had vineyards on their estates. Although documents referring to the transport of wine or freshly pressed must to monasteries are not direct proof of vine land ownership (Wipszycka 2011:207-208), in some cases other compelling evidence is available. Papyri explicitly mention vineyards belonging to monasteries (P. Mich. XIII 667, P. Cairo Masp. II 67151). In the absence of such documentary sources some indirect clues can be considered. For instance, a likely

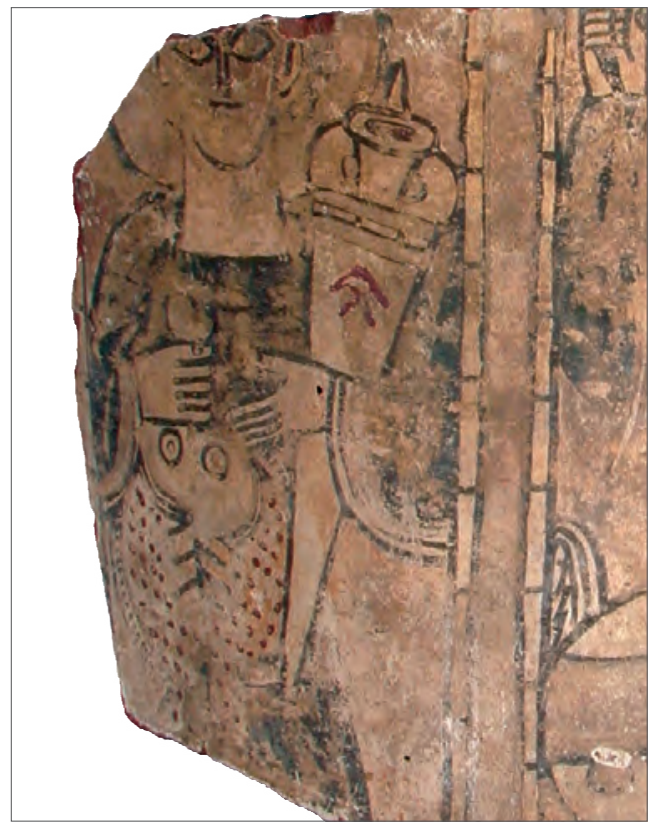

Fig. 1. Representation of a holy monk holding a wine jar and fish, on a potsherd (Xanthopoulou 2010: 4042), London, Petrie Museum of Egyptian Antiquities (Inv. No. UC19480)

(Photo courtesy of The Petrie Museum of Egyptian Archaeology, UCL)

2 For editions of texts from Bawit, see P. Brux. Bawit, P. Bawit Clackson and P. Mon. Apollo; for ostraka from Edfu, see O. Edfou IFAO; for documents from Wadi Sarga, see P. Sarga. Camels carrying wine to the monastery are attested in P. Sarga 121-124, 208-381; wine delivery documents from Wadi Sarga: P. Sarga 233, 234, 259, 289, 290, 318, 319, and 371. 
vineyard owner was the monastery of Apa Thomas at Wadi Sarga, as otherwise it would have had little motivation to organize the transport of wine from distant vineyards in the Fayum and the Herakleopolite nome (Cromwell 2013).

Monastic communities not only owned vineyards, but also produced wine on their own estates, as was the case of the communities at Bawit, Wadi Sarga and Saqqara (Bacot 1998: 272-273; Wipszycka 2011: 207-208). Wine-making facilities have been found in the monastery of St Simeon near Aswan (Ballet et al. 1991: 141). References to monks with expertise in wine production show that work at a monastic winery need not have required employing specialists from the outside world. Two funerary stelae from Wadi Sarga (P. Sarga 55 and 56) commemorate three monastic wine pressers (Рміом) and an inscription on a wall at Bawit mentions "brothers of the cell of the wine pressers" (Maspero 1931: No. 60).

Monasteries with no vineyards of their own, as well as individual monks, could acquire wine for their needs through purchases or gifts. Contracts for work in a vineyard seem to be exceptional among monastics, but they are nonetheless attested in the documentary record. In one early-6th-century lease document from Aphrodito, P. Flor. III 279, a monk is indicated as the tenant who agrees to work in a vineyard and water a reed bed belonging to an Aphroditan landlord for four years in exchange for a share of the yield.

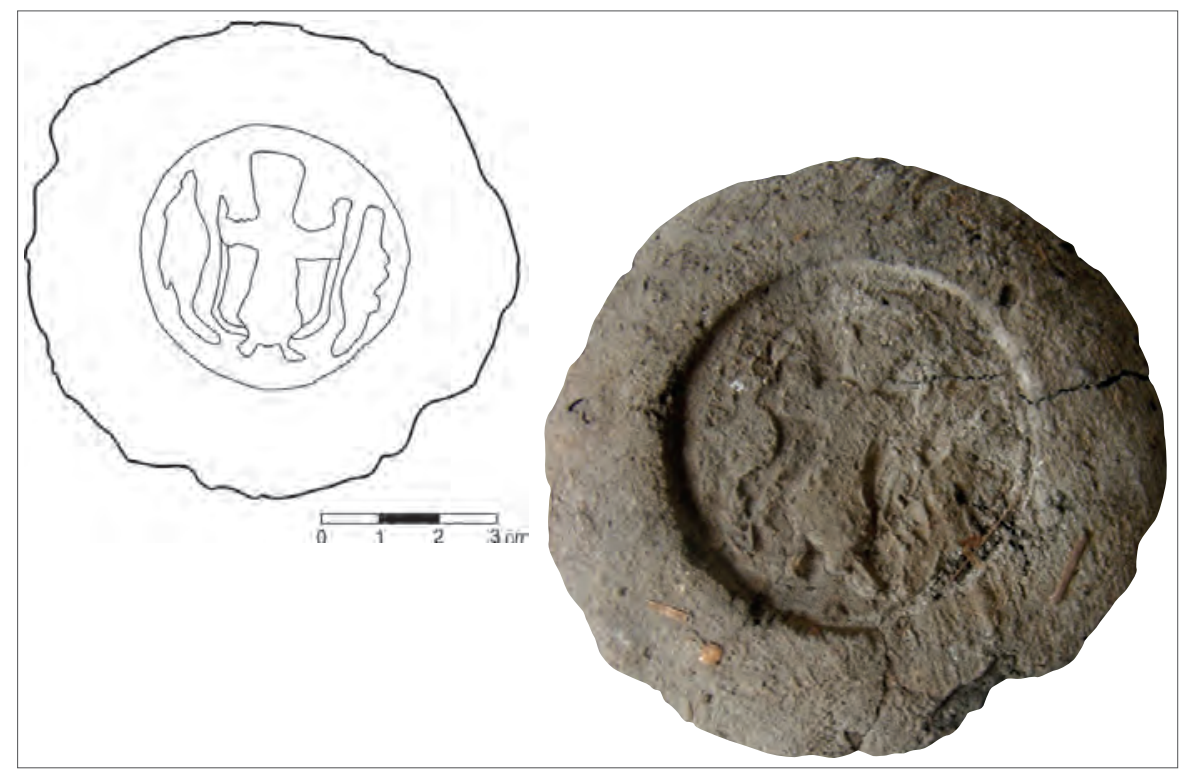

Fig. 2. Amphora stopper from Naqlun (Nd.08.290) with a stamp impression showing Saint Menas (Photo D. Dzierzbicka, PCMA archives) 
Let us now turn to the main topic of this paper. Wine had several uses, all of which were crucial for the monastic economy, religion, health and lifestyle. A large part of the wine collected by monastic estates was issued to workers and specialists hired by the monastery as payments in kind complementary to cash wages. For instance, at the monastery of Apa Thomas at Wadi Sarga the salaries of a carpenter (P. Sarga $161)$ and a salt merchant (P. Sarga 164) were partly paid in wine. It also constituted payment for fodder given to camels transporting a shipment of wine (P. Sarga 139).

Wine was required for liturgy and pious offerings. 122 jars are listed in an inscription carved in a wall at the monastery of Apa Jeremias at Saqqara (Quibell 1912: 69-70, No. 226). The wine was to be used for offerings on designated days of the liturgical year: 52 Sundays and 31 feasts. Also anchorites needed wine for liturgical purposes. Like all the faithful partaking in the Eucharist, monks were required to contribute to the donation of foodstuffs (bread, wine, olive oil, etc.) intended for a common meal in the church complex, as well as for the clergy (Wipszycka 1972: 64-92). A request for wine needed for such a donation is found in a letter of Theban priest and anchorite Moise (7th century, O. TT 29752.16-17):

"...be so kind as to send me wine so that I can make prosphora [a pious offering $]^{3}$ for the feast of [?]..."

It is without a doubt that monks - anchorites and members of coenobitic communities alike - consumed wine at least on occasion. It is a recurring subject in literary and normative sources concerning the monastic alimentary regime, but while for instance meat is strictly forbidden to all healthy monastics, there is no explicit ban on wine consumption (Mossakowska-Gaubert and Wipszycka forthcoming). There are frequent mentions of the danger wine poses to the soul, and overindulgence is condemned; however, references to abstinence are usually found either in normative texts or in accounts of exceptional piety and asceticism.

Wine drinking in coenobitic communities is discussed at length in the Canons of Shenoute and in the Pachomian dossier, according to which wine consumption was formally reserved for monks who were sick. Studying these sources, however, one should keep in mind that the Pachomian alimentary regime was relatively strict and the diet that Shenoute imposed on his monks was particularly severe. The same rules need not have applied to other communities (Mossakowska-Gaubert and Wipszycka forthcoming).

3 For the meaning of the term prosphora, see P. Oxy. LXVII 4620, 2-3 and references. 
The issue of wine consumption in the anchoretic milieu is addressed in the Apophthegmata Patrum, which encouraged abstinence and preached that "wine is alien to monks who live according to God" (Apophth. Pat., Xoius 1). However, the aim of this source was to showcase idealized role models rather than real people, therefore we should not conclude on this basis that anchorites typically shunned wine. Naturally, to give up drinking wine was admired as a sign of extraordinary virtue (e.g., Apophth. Pat., Abraham 1), but moderate wine drinking was not condemned, since the rules concerning wine were not as strict as those concerning meat. Both drinking and abstaining were considered admissible and a choice in this matter depended on the monks' individual decisions (Mossakowska-Gaubert and Wipszycka forthcoming).

Wine was not only permitted but in fact recommended for the ill and the weak. According to Clement, even though young monastics should avoid wine "for hence wild impulses and burning lusts and fiery habits are kindled; and young men inflamed from within become prone to the indulgence of vicious propensities", there is no harm in older brothers having a cup for the sake of their health, "to warm by the harmless medicine of the vine the chill of age, which the decay of time has produced" (Clem., Paed. II:2). It was, therefore, not considered sinful for older ascetics to drink wine in moderate quantities. ${ }^{4}$ The reasoning presented in Paedagogus alludes to the Hippocratic theory of humors, according to which wine was credited with increasing the heat and moisture of the body (Jouanna 2012: 181); wine stimulated sexual desire and impulsive behavior, and was therefore a threat to young men, but its warming and invigorating properties were beneficial to the elderly, whose blood had cooled.

In keeping with long-standing medical traditions, wine was an ingredient of medication prescribed at monastic infirmaries (Crislip 2005: 31-36). A collection of prescriptions requiring the use of wine was found on a wall at the monastery of Apa Thomas in Wadi Sarga (P. Sarga 21). Fragments of a medical handbook found at the coenobium of Apa Jeremias in Saqqara contained a recipe for a healing poultice made from marjoram and Egyptian incense (kuphi) mixed with wine (Erichsen 1963: 23-45). Possible wine cellars were found close to the monastic infirmary (Quibell 1909: 15, 18, 28).

Beside use as an ingredient of medication, wine itself was served in monastic infirmaries as a comfort food to strengthen the ill and to lift their spirits (Crislip 2005: 33-34, 74-75). It was not offered freely, however, but

4 Our ignorance as to the average age of members of the monastic milieu impedes a better understanding of the patterns of wine consumption in this group. Apophthegmata, which mention numerous young ascetics, cannot be considered a reliable source in this matter. 
issued to the ill at their request to avoid unnecessary use. Shenoute confirms that moderate amounts of wine should be given to the sick, but only if they request it:

"And if an emergency occurs and someone asks for a little wine in his time of sickness ... they shall give it to them if they are truly sick and they need it, though taking care also for them not to deceive them so they drink too much ... In any case no house leader or any other person whosoever, male or female, shall say cajolingly to any person in his languishing, Would you like a little wine to drink?" (Shen., Can. 5:189-191)

Doubts about the use of wine are expressed in the Pachomian rule:

"In fact, knowing the great amount of harm caused by wine, our fathers abstained from it. They drank only very little of it and only in case of illness ... But what shall I say to the man who is bubbling over with vice and in the prime of youth, weighed down under the impurities of passions? I am afraid to tell him not to drink at all, for fear that some one, mindless of his salvation, might murmur against me." (Pach., Inst. 1.46)

It is impossible to determine how dogma and theory compared to practice and if indeed in coenobitic communities only sick monks consumed wine. However, it is reasonable to suppose that the ban on wine among healthy monastics functioned in the sphere of ideals rather than facts. Persons visiting the sick could also be treated to some wine (Apophth. Pat., Rho 1). Controlled issues to the sick were intended to prevent abuse, but their effectiveness must have been limited. Some monks feigned sickness in order to receive privileges accorded to the ill, including better food (Crislip 2005: 91-92). Shenoute condemns such practices in the following words: "Despised in the eyes of Jesus be all among us, whether male or female, who ask for any dish deceitfully as though they were sick, when they are not." (Shen., Can. 5:156).

Theban ostraka from the monastery of Epiphanius and from the hermitage in Theban Tomb No. 29 often contain requests for foodstuffs and other products, for instance, for oil, as gifts or in exchange for prayers for various intentions. Sometimes, though rarely, monks ask for wine. Frange, an 8th-century monk

5 See also Hors., Reg. 49. 
who inhabited the Theban Tomb No. 29 and is known well thanks to his correspondence, asks his addressees to send him wine. The texts are worth quoting as much for the content as for the style. O. TT 2998 reads as follows:

“... when my brother Thomas comes ... for the love of God, the salvation of your soul and the health of your cattle give him good wine to bring to me; I need it because I am ill”.

A similar justification is found in $O . T T 2999$, in which Frange requests wine from an anonymous addressee:

"Have mercy on this poor brother who is ill and send some wine".

P. Naqlun I 9, a 6th-century account from Deir el-Naqlun, mentions

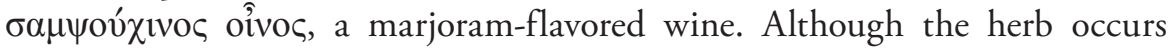
in medical papyri, ${ }^{6}$ it is found mostly in recipes for externally applied medicaments (Plin., NH XXI 163). Marjoram wine, in turn, is attested only in the Naqlun text. It seems to belong to a category of herbal concoctions that became fashionable in Egypt in Late Antiquity. In order to prepare them, wine was mixed with honey and various aromatic ingredients (spices and herbs) that were to ensure important health benefits. Other herbal wines attested in Egypt were flavored with, among others, myrtle, styrax resin, wormwood, cloves, and citron (Dzierzbicka 2011: 166-178). The attestation of marjoram-flavored wine at Naqlun can serve as additional evidence for medically motivated wine consumption in monastic communities.

Beyond medical needs, wine was also consumed by healthy monastics on various occasions. Among anchorites it was imbibed on festive days or in the company of visitors. ${ }^{7}$ Some documentary texts referring to coenobitic monasteries of the 6th-8th centuries mention issues of wine to monks for the celebration of feasts. An account from Deir el-Bala'izah (P. Bal. II 312.8, 10) dating from the late 7th-mid 8th century mentions the issue of wine for the "table of the superior" and for "our table", but the occasion is not given. A series of documents from the monastery of Apa Thomas at Wadi Sarga refer to issues of wine to individual monks and nuns, either for personal use or for

$6 \quad$ SB VIII 9860 (3rd century BC); P. Coll. Youtie I 4 (3rd century AD); P. Coll. Youtie II 87 (6th

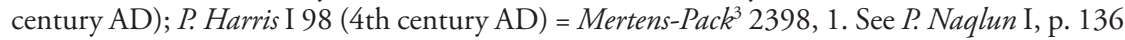
for commentaries on these texts and references.

7 Cass., Col. XVII, 24; Apophth. Pat., Macarius the Great 10, Poemen 4, Sisoes 2 and 8, anon. 60 and 148 . 
the use of their communities. ${ }^{8}$ Guidelines regarding the consumption of wine among female ascetics are found in the Discourse on Salvation to a Virgin by Pseudo-Athanasius. ' The women were allowed to have some wine, if they were weak and even those who abstained from wine were encouraged not to refuse a cup when having a meal in the company of other female wine-drinkers in the community.

Textual evidence for wine consumption among monks is corroborated by archaeological finds. Containers used for the storage and transport of wine are ubiquitous on monastic sites and also hermitages have yielded an abundance of amphorae originally used for this commodity. Anchorites likely collected empty wine jars from surrounding villages and brought them to their cells after filling with water (Wipszycka 2011: 242), but it cannot be excluded that at least some of them reached the hermitages with their original content. At Naqlun, the 6th-7th century dump layers consisting mostly of kitchen refuse included numerous fragments of wine amphorae (Danys-Lasek 2014). In the oldest phase dated to the 6th century, the dominant wine jar is the Late Roman 7 amphora produced in the Nile Valley. There are also isolated fragments of Aswan amphorae and their imitations in Nile clay. Also represented are Late Roman 1 amphorae used to transport wine or oil from Cilicia and Cyprus, as well as Late Roman 4 amphorae, which carried Gaza wine. In the middle phase dated to the early 7 th century, Late Roman 4 wine amphorae were replaced by the Levantine Late Roman 5/6. In the second half of the 7th century, in turn, one can see a greater variety of Egyptian wine jars. Although local LR 7 vessels dominate, we also encounter Lower-Egyptian LR 5/6, in both alluvial and marl clay, as well as Egyptian imitations of LR 1, the content of which is unknown.

In the case of Naqlun, the amphorae themselves are not direct evidence for wine consumption at the monastery; they could have served as containers for other foodstuffs or they may have been reused for carrying water. Equally ambiguous is the testimony of stemmed glass goblets found among monastic rubbish (e.g., Mossakowska-Gaubert 2004). Although the interpretation of these finds as wine glasses is generally accepted and indeed likely, there is no evidence that would permit to link them exclusively to the consumption of wine.

Regardless of these caveats, direct evidence for wine consumption at Naqlun is offered by amphora stoppers found amid refuse from the monastic kitchens. The rubbish dump on kom B at Naqlun contains a large variety of plugs used to

Examples are $P$. Sarga 92.5, 8-9; 168.4; 169.8; 170.5; 186. 6, 10 (6th-early 8th century).

9 De virginitate $12(P G 28,263 \mathrm{D}$ and $264 \mathrm{~A})$ and $22(P G 28,278 \mathrm{D}$ and $280 \mathrm{~A})$. For an English translation, see Shaw 2000: 91 and 96. 
seal wine containers at their place of origin. Imprints of rims preserved on some of these objects correspond to several amphora types found in the dump, providing evidence of consumption of several varieties of wine. ${ }^{10}$ Mud stoppers were also found on numerous other monastic sites, for instance the monastery of Apa Jeremias at Saqqara (Quibell 1912: 4, 24, 27-30), the monastery of Epiphanius at Thebes (Winlock and Crum 1926: 79-81), Wadi Sarga (O'Connell 2014: 128), as well as at Kellia (Egloff 1977: 33-35) and Bawit (Lyon-Caen 2008).

The need for wine in larger, coenobitic communities can be explained by economic factors, liturgical practices and the presence of infirmaries and therefore evades being linked to consumption habits of individual monks in a direct fashion. Stoppers found in hermitages, however, leave little doubt that it was the monks themselves who drank the wine. In the 7th-century hermitage inside Theban tomb No. MMA 1152 at Sheikh Abd el-Gurna, over 20 mud stoppers were found in a storage chamber (Górecki 2007a: 266) and several more fragmentary ones were recovered from deposits of monastic rubbish (Górecki 2010: 301). Also at Naqlun stoppers matching amphora rims of various sizes were found during the excavation of Hermitages 44 , as well as 25 and 89. ${ }^{11}$

Based on the available data it is impossible to determine just how much wine monks consumed or how regularly; this certainly varied widely depending on the health of the individual, personal preferences and approach to ascetic practice. However, in the Apophthegmata a recurring quantity of wine consumed by monks is three cups:
"There was a liturgy on the mountain of Abba Anthony and they had a small bottle of wine there. One of the old men took a jug and a cup and offered some to Abba Sisoes. He drank some. A second time, he also accepted some. But when he was offered some a third time, he did not accept it, saying, 'Stop, brother, don't you know that it is of Satan?' " (Apophth. Pat., Sisoes 8, transl. B. Ward)

In another place, an elder condemns overindulgence saying: "Let no monk who drinks more than three cups of wine pray for me" (Apophth. Pat., anon. 465, transl. J. Wortley). The didactic nature of the texts and the symbolic value of

10 This picture is supplemented by evidence for the presence of other comfort foods recovered from the monastic kitchen refuse. Remains of imported fruits and nuts, such as plums, walnuts, hazelnuts and almonds, show that the diet of at least some monks at Naqlun was fairly varied. The author is currently preparing a study of the palaeobotanical assemblage together with archaeobotanist Jarosław Zieliński.

11 Unpublished material, personal observation; for reports on excavations in the hermitages see Godlewski 1992; 1996. 
both wine and the number three make it risky to treat this statement literally. It is tempting, nonetheless, to tentatively consider three cups as an acceptable winedrinking limit for monks. ${ }^{12}$ The size of cups that the monks used for drinking wine certainly varied. However, over 50 small cups measuring approximately $0.10-0.12$ liters in capacity have been found at the hermitage at Sheikh Abd elGurna and their use for drinking wine is a likely possibility (T. Górecki, personal communication). Three such cups would add up to $0.30-0.36$ liters of wine. ${ }^{13}$

Relying on the evidence of mud stoppers we could speculate about the order of magnitude of the wine supply to the hermitage at Sheikh Abd elGurna mentioned above. An LR 7 wine amphora had an average capacity of approximately 5.5 liters. ${ }^{14}$ Twenty stoppers testify to the consumption of the contents of 20 jars, which add up to about 110 liters of wine. Given that the hermitage seems to have been inhabited by two monks (Górecki 2007b: 186), the amount of wine per monk would have been 55 liters. Having arrived at this figure, we could risk an estimate of the rate at which this supply was consumed. It would seem reasonable to assume that the stoppers found in the storage compartment were deposited there over a period of no more than a year (although the question how long garbage could lie around in a dwelling space in antiquity has not, to my knowledge, received a satisfactory answer to date). Thus, if our assumption as to the size of the cups is correct and there were eight to ten cups to a liter, then with a supply of 55 liters one monk could drink an average of one cup of wine a day for a period of over 14 months to a year and a half, respectively. Taking three cups as the hypothetical acceptable wine-drinking limit for monks, the assemblage of amphora stoppers found at the hermitage in Theban tomb No. MMA 1152 would testify to a supply of wine for five to six months, assuming the wine was consumed on a daily basis.

12 Mossakowska-Gaubert and Wipszycka (in the article of the former and in the paper written by the two researchers together, both forthcoming) consider this likely on the basis of Apophth. Pat., Sisoes 2 and 8.

13 By comparison, in the Benedictine rule (BR 40.2-3) healthy monks are allowed one hemina (about $0.27-0.29$ l) of wine a day, but the ration was increased in case of illness, particular "endurance of abstinence" or other circumstances, such as hot weather. Meanwhile, the standard wine ration for Roman soldiers attested in some 6th-century documents amounted to about 1 liter of wine a day (P. Oxy. XII 1920; P. Oxy. XVI 2046).

14 According to calculations made by Tomasz Górecki on the basis of dimensions of 6th-7thcentury LR 7 amphorae from Naqlun, Abu Fano, Shenhur, Sheikh Abd el-Gurna, and Edfu (National Museum in Warsaw collection), the capacities of these vessels spanned from 3.70 to $8.20 \mathrm{l}$; however, amphorae measuring from 4 to $5.8 \mathrm{l}$ constituted $70 \%$ of the assemblage, 6.0-6.9 1 or $20 \%$, and $7-81$ or $10 \%$. The average of 5.51 is calculated on the basis of the latter data, which Tomasz Górecki kindly shared with me. 
Whether for individual consumption, liturgical purposes or economic reasons, monastics used wine. The existence of material evidence for wine consumption on monastic sites should not surprise and the recurring mentions of wine in literary texts are clear indications of its omnipresence. This seems like a fairly banal conclusion from the viewpoint of research on monasticism, but it is of some significance for economic studies. The evidence presented above demonstrates that monastic communities were a noteworthy group of wine consumers in Egypt and that the demand they generated likely had an influence on the market. Research on monastic wine-drinking habits brings us a step closer to understanding changes in the supply of wine in Late Antiquity, as well as trends in Egypt's wine economy in general.

\section{References}

The abbreviated references to documentary sources follow J.F. Oates et al., Checklist of Greek, Latin, Demotic and Coptic papyri, ostraca and tablets, available online at http://scriptorium.lib.duke.edu/papyrus/texts/clist.html.

\section{Primary sources}

Apophthegmata Patrum. Edition of the alphabetical collection: J.B. Cotelerius, Ecclesia Graeca Monumenta, Paris: Muguet, 1677, reprint in PG LXV (71-440); English translation: The sayings of the Desert Fathers: The alphabetical collection (rev. ed.), transl. by B. Ward, Kalamazoo, MI: Cistercian Publications, 1984. Select edition and English translation of the anonymous collection: The "Anonymous" sayings of the Desert Fathers: A select edition and complete English translation, ed. and transl. by J. Wortley, Cambridge: Cambridge University Press, 2013

Clement of Alexandria, Paedagogus. Text: Clementis Alexandrini Paedagogus [=Supplements to Vigiliae Christianae 61], ed. by M. Marcovich, Leiden: Brill, 2002; English translation: The Ante-Nicene fathers II. Fathers of the second century: Hermas, Tatian, Athenagoras, Theophilus, and Clement of Alexandria, ed. by S. Roberts, J. Donaldson, and A.C. Coxe, New York: Cosimo Classics, 2007 (reprint of the 1885 edition)

Horsiese, Rules. Text: Oeuvres de S. Pachôme et de ses disciples [=Corpus Scriptorum Christianorum Orientalium 150; Scriptores Coptici 23], ed. by L.T. Lefort, Leuven: L. Durbecq, 1956

John Cassian, Iohannis Cassiani Collationes XXIIII, ed. by M. Petschenig, Vienna: Geroldi, 1886 
Pachomius, Instructions. Text: Oeuvres de S. Pachôme et deses disciples [=Corpus Scriptorum Christianorum Orientalium 150; Scriptores Coptici 23], ed. by L.T. Lefort, Leuven: L. Durbecq, 1956; translation: Pachomian koinonia III. Instructions, letters, and other writings of Saint Pachomius and his disciples [=Cistercian Studies Series 47], transl. by A. Veilleux, Kalamazoo, MI: Cistercian Publications, 1982

Pliny the Elder, C. Plini Secundi Naturalis Historiae libri XXXVII, ed. by K. Mayhoff (post L. von Jan), 6 vols, Leipzig: Teubner, 1875-1906

Shenoute of Atripe, Canons. Edition and translation: B. Layton, The canons of our fathers: Monastic rules of Shenoute, Oxford: Oxford University Press, 2014

\section{Secondary sources}

Bacot, S. (1998). La circulation du vin dans les monastères d'Égypte à l'époque copte. In N. Grimal and B. Menu (eds), Le commerce en Égypte ancienne [=Bibliothèque d'étude 121] (pp. 269-288). Cairo: Institut français d'archéologie orientale

Ballet, P., Mahmoud, F., Vichy, M., and Picon, M. (1991). Artisanat de la céramique dans l'Égypte romaine tardive et Byzantine. Prospections d'ateliers de potiers de Minia à Assouan. Cahiers de la céramique égyptienne, 2, 129-143

Crislip, A.T. (2005). From monastery to hospital: Christian monasticism and the transformation of health care in Late Antiquity. Ann Arbor, MI: University of Michigan Press

Cromwell, J. (2013). Delivering monastic wine, by boat and by camel. Unpubl. paper presented at the "Researches and reflections". The Tenth Biennial ASTENE Conference, Aston University Birmingham, 12-15 July 2013

Danys-Lasek, K. (2014). Pottery from Deir el-Naqlun (6th-12th century). Preliminary report from Polish excavations in 2010 and 2011. Polish Archaeology in the Mediterranean, 23/1, 543-642

Dzierzbicka, D. (2011). Wine in Graeco-Roman Egypt (unpubl. Ph.D. diss.). University of Warsaw

Egloff, M. (1977). Kellia, la poterie copte: quatre siècles d'artisanat et d'échanges en BasseEgypte I-II [=Recherches suisses d'archéologie copte 3]. Geneva: Georg

Erichsen, W. (1963). Aus einem koptischen Arzneibuch. Acta Orientalia, 27, 23-45

Godlewski, W. (1992). Archaeological research in Naqlun in 1991. Polish Archaeology in the Mediterranean, 3, 49-56

Godlewski, W. (1996). Naqlun: Excavations 1995. Polish Archaeology in the Mediterranean, 7, 82-88

Górecki, T. (2007a). Sheikh Abd el-Gurna (hermitage in Tomb 1152). Preliminary report, 2005. Polish Archaeology in the Mediterranean, 17, 263-274

Górecki, T. (2007b). Sheikh Abd el-Gurna. In E. Laskowska-Kusztal (ed.), Seventy years of Polish archaeology in Egypt (pp. 183-190). Warsaw: PCMA UW

Górecki, T. (2010). Sheikh Abd el-Gurna. Hermitage in Tomb 1152 and chapel in Tomb 1151. Polish Archaeology in the Mediterranean, 19, 297-303

Jouanna, J. (2012). Greek medicine from Hippocrates to Galen: Selected papers. Leiden: Brill 
Lyon-Caen, C. (2008). Bouchons d'amphore et bouchons de jarre du site de Baouit : problématique et premier récolement. In A. Boud'hors and C. Louis (eds), Études coptes X: douzième journée d'études (Lyon, 19-21 mai 2005) [=Cahiers de la Bibliothèque copte 16] (pp. 63-75). Paris: De Boccard

Maspero, J. (1931). Fouilles exécutées à Baouît [=Mémoires publiés par les membres de l'Institut français d'archéologie orientale 59]. Cairo: Institut français d'archéologie orientale

Mossakowska-Gaubert, M. (2004). La verrerie utilisée par les anachorètes: l'ermitage No 44 à Naqlun (Fayyoum). In M. Immerzeel and J. van der Vliet (eds), Coptic studies on the threshold of a new millennium: Proceedings of the Seventh International Congress of Coptic Studies, Leiden, August 27-September 2, 2000, II [=Orientalia Lovaniensia Analecta 133] (pp. 1443-1470). Leuven: Peeters

Mossakowska-Gaubert, M. and Wipszycka, E. (forthcoming). Les moines égyptiens de l'Antiquité tardive et les interdits alimentaires

O'Connell, E. (2014). R. Campbell Thompson's 1913/14 excavation of Wadi Sarga and other sites. British Museum Studies in Ancient Egypt and Sudan, 21, 121-192

Quibell, J.E. (1909). Excavations at Saqqara, 1907-1908. Cairo: Institut français d'archéologie orientale

Quibell, J.E. (1912). Excavations at Saqqara IV. 1908-10. The monastery of Apa Jeremias. Cairo: Institut français d'archéologie orientale

Shaw, T.M. (2000). Pseudo-Athanasius. Discourse on Salvation to a Virgin. In R. Valantasis (ed.), Religions of Late Antiquity in practice (pp. 82-99). Princeton, NJ: Princeton University Press

Winlock, H.E. and Crum, W.E. (1926). The Monastery of Epiphanius at Thebes. New York: Metropolitan Museum of Art

Wipszycka, E. (1972). Les ressources et les activités économiques des églises en Égypte du IVe au VIII siècle [=Papyrologica Bruxellensia 10]. Brussels: Fondation égyptologique reine Élisabeth

Wipszycka, E. (2011). Resources and economic activities of the Egyptian monastic communities (4th-8th century). Journal of Juristic Papyrology, 41, 159-263

Xanthopoulou, M. (2010). Martyrs, monks, and musicians: Two enigmatic Coptic vases in the Benaki Museum and their parallels. Mouseio Mpenaki, 10, 19-51 



\title{
Phasing out LRA 7 amphorae in favor of new wine containers: Preliminary remarks based on finds from excavations in Naqlun
}

\author{
Tomasz Górecki \\ National Museum in Warsaw \\ tgorecki@mnw.art.pl
}

\begin{abstract}
KeYwORDS
wine production / distribution / transport / consumption, monastic archaeology, transport containers, pottery production
\end{abstract}

\begin{abstract}
Clay pots were in antiquity the most popular kind of transport container for liquid goods (wine, olive oil etc.). In Egypt, the commonly used traditional amphoras were supplemented in the Islamic period by mostly unhandled bag-shaped bottles, which until recently did not seem to have been particularly frequent in the archaeological record. Meanwhile, excavations in Fustat and Naqlun produced quite a sizable assemblage of this kind of vessels. The paper presents a tentative typology of these containers and a provisional determination of the liquid goods transported in them. The author hypothesizes on the reasons behind the spectacular career of the bottle apparently inspired by vessels of the LRA 5/6 type, which totally replaced the traditional LRA 7 amphora within just a hundred or two hundred years. The most important factor in this process of change may have involved practical considerations (including economical ones).
\end{abstract}

Late Roman Amphora 7 is rightly considered as the principal and dominant amphora type used in the Egyptian late antique wine economy. Its origins in the 5th(?) century $\mathrm{AD}$ is of lesser importance for the present considerations, which are concentrated rather on the latest variants of this form from the terminal period of its occurrence in Egypt. They were produced most likely until the 9th century, 
perhaps even in the 10th-11th centuries. ${ }^{1}$ However, their presence in the latter contexts could be the effect of their prolonged use as secondary containers and even as building material in makeshift structures or as terracotta coffins, water pipes etc. ${ }^{2}$

The latest LRA 7 variants are sufficiently different morphologically from the earlier models from the 5th through 8th centuries to make them easily distinguishable. They are furnished with a short strong neck with thickened rim [Fig. 1A:2-6]. A pair of handles is stuck to the neck below the rim and to the lowest part of the shoulders. The vessel surface is well profiled in two places, on the shoulders [Fig. 1A:2-6,7,12] (with low shoulders prevailing) and the lowest body just above the spike [Fig. 1B:15-19], where the ribbing is broad, semicircular in section, approximately $0.7-0.8 \mathrm{~cm}$ deep. ${ }^{3}$ Tooling traces are evident on the vessel surface, especially in the upper parts. None of these are marks of the potter's fingers during turning. The end result is almost "mannerist" in effect, that is, an exaggerated, decorative underlining with a tool of the natural ribbing on the

$1 \quad$ It is not always clear whether the dating given in publications is based on the actual stratigraphic context of the finds or whether the excavators took into account the possibility of reuse, hence the secondary nature of the context should be an integral part of amphora studies. The broad dating range for these vessels could well derive from this situation. The phasing out of LRA 7 amphorae was discussed by Władysław B. Kubiak, who gave the latest occurrence of LRA 7 at about 1075 (Kubiak 1986: page 18 of an unpublished typescript containing 235 pages, accompanied by 50 figures and 35 plates). Other datings: through the end of the 9th century AD (Vogt 1977: 258), mid 9th century (Vogt et al. 2002: 66), mid 9th-10th century (Marangou and Marchand 2007: Figs 164-165), more probably the 10th century (Rousset and Marchand 1999: 241, No. 136), mid 9th and 10th century (Rousset, Marchand, and Foy 2001: Figs 22 and 28, mid 9th century, and Fig. 42 o, 10th century), 9th century (Scanlon 1974: 85 and Pl. XIXa), 8th-9th century (Bailey 1998: Pls 83/V84, 84/V92 and 134-135), as late as the 11th century (Lecuyot 2007: 200 and Figs 2.1, 2.6, 2.7, Photo 2), 8th century? (Tomber and Williams 2000: Fig. 4.4). In the opinion of the present author, the latest LRA 7 amphorae can be dated to the 9th century, possibly even the 10th century. Most of the 10th-century finds and the 11th century ones represent vessels reused in secondary contexts.

2 Gayraud 2007: 721-725; Bahgat and Gabriel 1921: 94 and Fig. 39, sketch of the lower halves of amphorae(?) placed vertically under the floor, a form of insulation perhaps, see Kubiak 1986: 16: "the layer of empty vessels between the floor and underlying bed-rock provided the floor above with a sort of insulation against humidity and cold". On a different form of reuse, see Kubiak 1986: 17: "It was used to construct circular open air fireplaces"; the identification illustrated in Kubiak and Scanlon 1989: 21 and Figs 16, 31, 33; Godlewski 1999: Fig. 1 (as part of the structure of benches built against the east wall of tower I DB and the north wall of tower II DB); Scanlon 1974: Pl. XIXa (the manner in which the vessels were broken off points to their use as a kind of pipe); Gallazzi and Hadji-Minaglou 2012: 395 and Figs 1-4 (LRA 7 as coffins for child burials, 9th century); similarly Tomber and Williams 2000: 50, burial containers(?).

3 See illustrations mentioned in note 1, especially Rousset, Marchand, and Foy 2001: Figs 22, 28; Tomber and Williams 2000: Fig. 4.4; Lecuyot 2007: 200 and Figs 2.1, 2.6, 2.7, Photo 2; Bailey 1998: Pls 83/V84, 84/V92 and 106; also Marchand and Dixneuf 2007: 323, Figs 44-46 (44: H. 62, Diam. maximum 20; 45: H. 66, Diam. maximum 19.5; 46: H. 64, Diam. maximum 21), first half of the 7th century; Wulff 1909: 289 (No. 1526). 
shoulders and in the lowest parts of the body at the junction with the spike. The junction of the body and shoulders is also emphasized with a modeled ridge, either rectangular [Fig. 1A:2-4,11], semicircular [Fig. 1A:5,7,10,12] or almost triangular in section [Fig. 1A:8-9]. The surface of the body below this ridge is tooled to form a quasi ribbing, often simply by lightly grooving the smooth clay surface [Fig. 1A:3,4,8,10,11]. The body is almost cylindrical in the top, densely ribbed part [Fig. 1A:2-4], sometimes slightly bulging, so that the biggest diameter may be even below the ridge at the edge of the shoulders [Fig. 1A:5,7-10]. The later vessels were taller than the earlier ones, between $65 \mathrm{~cm}$ and 73-75(?) $\mathrm{cm}$, with often thicker walls (up to $1.2 \mathrm{~cm}$ in thickness, hence heavier), some with a capacity to hold more wine than the vessels from the 5 th-7th centuries. ${ }^{4}$ Interestingly, their maximum diameter was less than the average maximum diameter of amphorae from the earlier period. ${ }^{5}$

LRA 7 amphorae are clearly missing from the latest archaeologically dated contexts in the Naqlun monastery (10th-12th century). They are found in earlier layers, dated to the 8th-9th centuries (such as E.9, which was a passage between Building E and Church A; Godlewski 2007: Plan in Fig. 1). A test dug in this unit yielded 77 fragments of LRA 7 and 14 fragments of, also Egyptian, LRA 5/6 (all 14 with loop handles). ${ }^{6}$ A rigorous consideration of solely diagnostic sherds ensures the credibility of the proportionate share of the two types. The same situation occurred in the rubbish dump in Sector $\mathrm{B}$, where the latest layers are dated by pottery reaching into the 10th century. The assemblage contains a handful of significant LRA 7 and late Egyptian LRA $5 / 6$ fragments, but absolutely none representing bag-shaped unhandled bottles

4 See below, Appendix 2. For volume capacity, see Vogt et al. 2002: 68 (a single amphora held 7-8 liters). Kubiak in his unpublished typescript (1986) did not estimate capacity. The amphora from Shenhur (No. 149.8, unpublished; Fig. 1B:13) contained 10.64 liters, itself weighing approximately $6.94 \mathrm{~kg}$. It was not the rule, however. Based on an amphora from Naqlun (Nd.99.008, Fig. 1B:14) it was calculated that the vessel could hold about $5.75 \mathrm{l}$ of a liquid while weighing about $5.49 \mathrm{~kg}$. Amphora V 84 had a similar capacity (5.7 l) (see Bailey 1998: 134).

5 Forms from the 5th-7th century: the narrowest vessels are 18-19 cm in diameter, the biggest $25-26 \mathrm{~cm}$, but the most common size was $21-23 \mathrm{~cm}$. The latest forms had a maximum diameter of $16-18 \mathrm{~cm}$ at the narrowest and (seldom) $21-22 \mathrm{~cm}$ at the widest; the most frequent maximum diameter of these vessels was $18-20 \mathrm{~cm}$.

6 Górecki 2001: Fig. 3. The acronym LRA 5/6 is used here for the sake of convenience, although the author is perfectly aware of how with time and advances in research this term has ceased to be universal. New discoveries have broadened the range of shapes and variants (there is no morphological standard), especially in view of the broad chronological timeframe from the 6th to the 12th century. LRA 5/6 may be referred to as an Egyptian bag-shaped amphora or oval-shaped amphora, or some new symbol with morphological variants and divisions by clay type (e.g., A,B,C, etc.). 

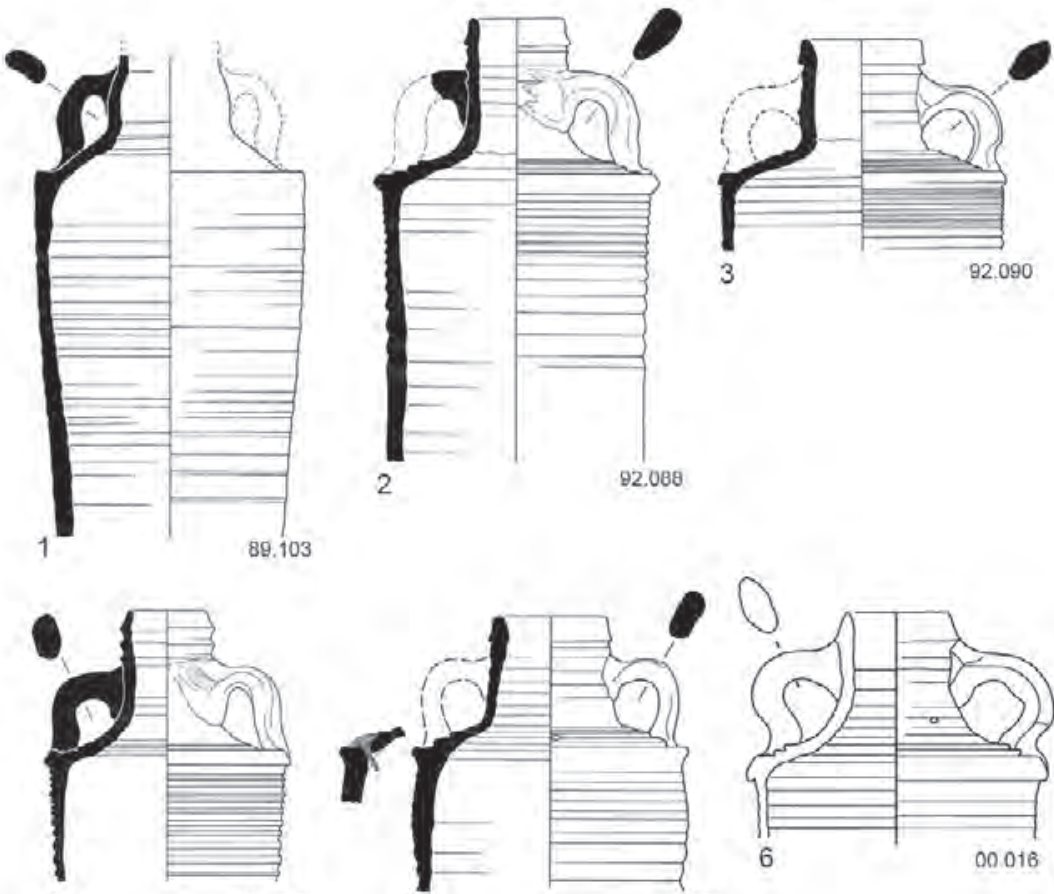

4

92.089

5

88.380

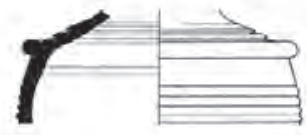

7

92092

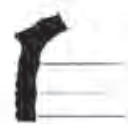

8

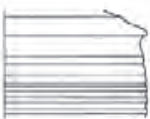

88.381

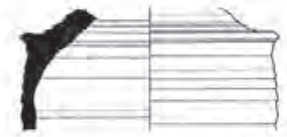

9

88.382

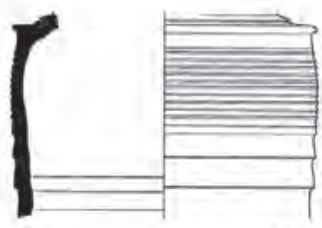

10

92.012
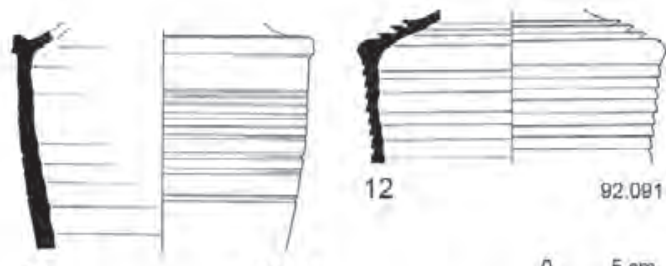

11

89.364

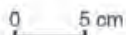

Fig. 1A. LRA 7 amphorae from Naqlun, selected examples (1-12)

(Drawing T. Górecki, M. Zurek [No. 6]; digitizingJ. Górecka;

plate processing E. Czyżewska-Zalewska) 


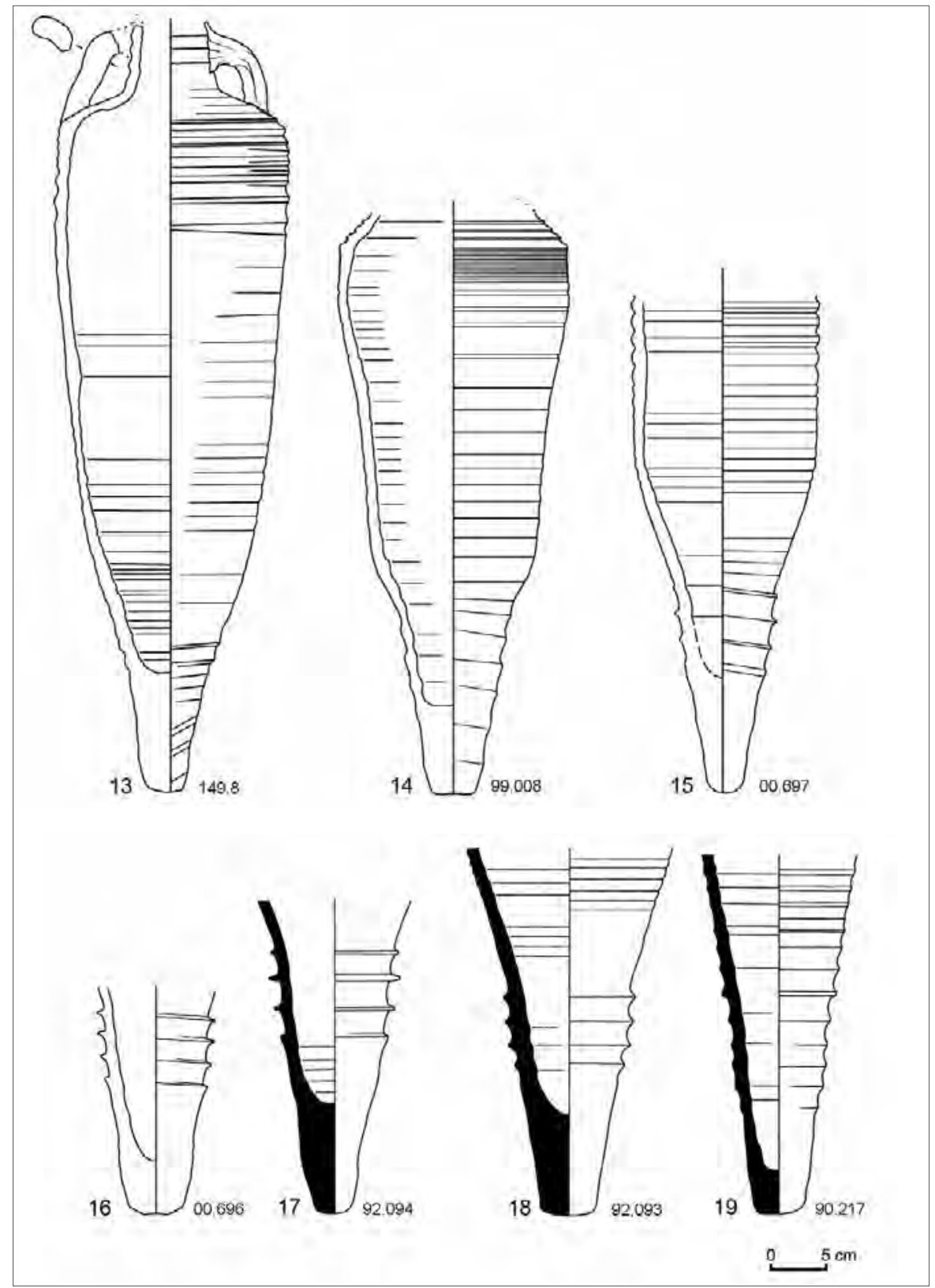

Fig. 1B. LRA 7 amphorae from Naqlun, selected examples (13-19)

(Drawing T. Górecki, M. Zurek [Nos 15, 16]; digitizing J. Górecka; plate processing E. Czyżewska-Zalewska) 
(Godlewski, Derda, and Górecki 1994: 223-226, section on "The pottery 1988-1989"; Górecki 1993: 61, and Figs 5b, 5c). One explanation for this evident drop in quantity is that wine deliveries to the monastery had fallen to such minuscule levels that the remains of wine containers simply escaped the attention of the archeologists. The deliveries could have ceased entirely, but that does not seem possible. Perhaps wine essential for liturgical purposes, if not for other uses, was delivered in different containers?

Having said this, let us take a closer look at a unique set of extremely characteristic bag-shaped unhandled bottles, forming a well defined formal and typological group, found in Naqlun during excavations from 1988 to 2012. The assemblage comprised about 30 well preserved vessels and roughly 50 diagnostic fragments, and in the light of currently available ceramological data, it is the only collection of this size from the Fayum Oasis and perhaps also from all of Egypt. ${ }^{7}$ Its presence in Fayum may be explained by some local phenomenon, such as local workshop traditions limited to carrying out deliveries only within the borders of the oasis. It is naturally difficult to picture a Fayum potter producing transport containers for a local clientele alone. The few finds from other sites point to a wider distribution of these containers. And it is possible to distinguish a few variants of these bottles based on visual examination of the clay matrix, the hardness of the fired clay and firing technique (often in a reduction atmosphere), ornamentation and minor morphological differences of the shape (rim, base, bulging of the body). This could suggest a number of different pottery workshops involved in the production of these vessels, although at this stage of the research their locations cannot be identified. ${ }^{8}$

7 This view is formed from a perusal of excavation reports from sites dated to the late period. Kubiak wrote of "... hundreds of thousands. For instance one sanitation pit alone (XXI-7) yielded several hundred fragmentary water bottles" (1986: 24) and dated unhandled jars/ bottles to the 10th-11th century. For the present author's remarks on ovoid-shaped bottles, see Górecki 1994: 63-65, Figs 1A (Nd.93.123), 1B (Nd.93.119). Most recently in a report on pottery from Bawit the unhandled bottles from the 9th-10th century were referred to as a type "as yet unknown" (Południkiewicz and Konstantinidou 2012: 94 and Fig. 19). A few examples were published recently from Naqlun (Danys-Lasek 2014: 607 and Fig. 22C [Nd.11.157], 627 and Fig. 24 [Nd.11.228] and 603 and Fig. 20 [Nd.10.034]); these bottles were lined with bitumen on the inside and dated to the 9th-11th century based on the present author's earlier determinations regarding the dating, that is, AD 850-1050, see Górecki 1994: 75 and 78. Currently, however, the author would see a 9th century date as being too early for the bottles and would suggest a shift in the dating from 950 to no later than 1150 .

8 The present remarks are concerned foremost with presenting a certain type of vessel, its basic morphological characteristics and function. Questions of clay (marl clay or Nile silt), workshop (Nile Delta or Middle Egypt) and firing (normal or reduction) are not of primary significance at this stage. On one of the places of production of LRA 5/6 containers, see Ballet 1994 and 2007. 
Most of the Naqlun finds came from sector D, a few in sectors AA and J. At first glance, the characteristic bag-shaped body would have them attributed to the broad LRA 5/6 group. The maximum diameter is at one-third but more often at one-fourth of the height and even lower (marked here with the letter Y) counting from the vessel bottom. It means that point $\mathrm{Y}$ is either $7.6 \mathrm{~cm}$ or $12 \mathrm{~cm}$ from the base, assuming vessel height is respectively $33.6 \mathrm{~cm}$ [Fig. 2B:11] and $36 \mathrm{~cm}$ [Fig. 2B:12]. In seven fully preserved examples, point $Y$ is calculated precisely, whereas in a few dozen other vessels the proportion of point $Y$ to the reconstructed height of the vessel can be determined with little margin for error, the result being similar. The height of most vessels (based on fully preserved examples) falls within the range of $31.3 \mathrm{~cm}$ to $36.0 \mathrm{~cm}$; the maximum diameter in this case is respectively from 19.6 to $20.6 \mathrm{~cm}$. Just two unhandled bottles [Figs 2A:1, 2C:13] are clearly of a larger size. The preserved heights were respectively $37.7+\mathrm{cm}$ (with a maximum diameter of $24.3 \mathrm{~cm}$ ) and $32.0+\mathrm{cm}$ (with a maximum diameter of $23.0 \mathrm{~cm}$ ), hence the reconstructed size, compared to surviving whole examples, must have been respectively about $42 \mathrm{~cm}$ and $36 \mathrm{~cm}$.

The body of the bottle is roughly globular in the lower part and much less bulging above point $Y$, sometimes practically conical [Fig. 2B:9]. The shoulders narrow toward the top of the body and are convex. The neck with concave sides is narrow (4.3-7.4 cm in diameter), not well separated and terminating in a thickened rim with straight edge outside [Figs 2B:8, 2C:17] or with a semicircular undercutting [Figs 2B:10-12; 2C:13,14]. In a rare few cases, the edge was not distinctive and the neck terminated in a straight rim with rounded top [Figs 2A:5, 2B:7].

The bottles are without handles as a rule. ${ }^{9}$ In one case, the vessel has a pair of small handles that could not have been used for lifting the vessels, clearly decorative and not functional [Fig. 2B:7]. In another case, the container has typical loop handles, like on LRA 5/6 vessels (Nd.01.013, Fig. 2C:17), although this could be due to the earlier dating of this vessel or its size $(\mathrm{H} .+37.2 \mathrm{~cm}$, maximum diameter $26 \mathrm{~cm}$, weight $4.09 \mathrm{~kg}$, capacity 11.450 liters), justifying the application of handles, which make handling of such large vessels easier to an extent. It could also be a feature typifying a different workshop than that engaged in producing unhandled containers.

9 Similarly as a smaller group of unhandled bottles (not discussed here in detail) [Table 1 and Fig. 2D:18-20] with slightly different proportions than discussed here. The bottles have a characteristic sharp collar on the neck and a rim with modeled spout. They had a capacity of approximately 161 (see Górecki 1994: 69-72 and Figs 8A, 8B). For the same kind of containers found on the caravan trails, see Eichhorn et al. 2005: Figs 4-7, 9. 
A vessel with the center of gravity set so low can stand alone without a support of some kind, regardless of whether it is full or empty. It can have rounded bottoms without a distinct base [Figs $2 A: 4,5 ; 2 B: 8,12]$ or a small base, very low, the underside slightly concave, diameters from 3.4 to $5.5 \mathrm{~cm}$

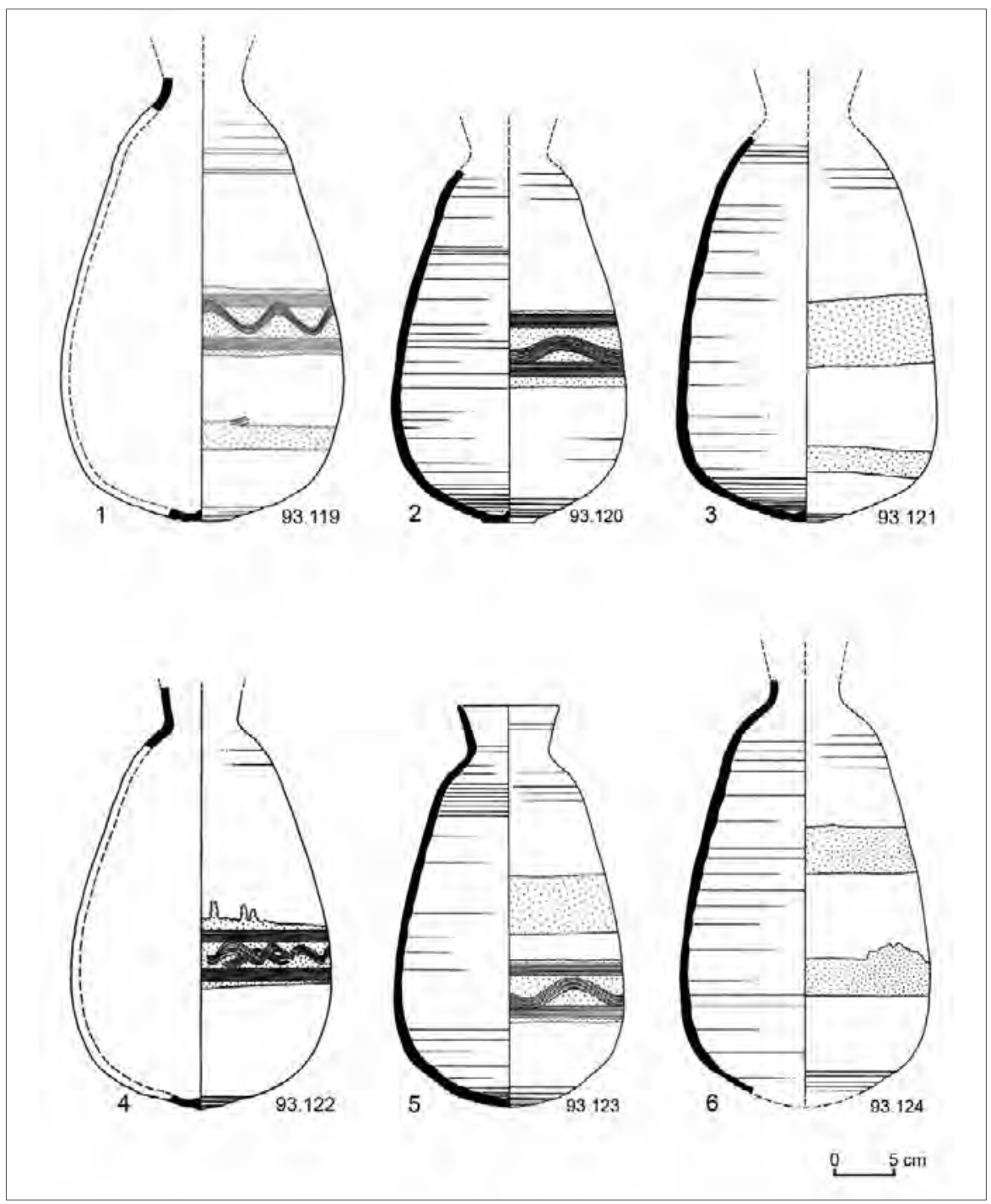

Fig. 2A. Bag-shaped unhandled bottles from Naqlun, selected examples (1-6)

(Drawing T. Górecki; plate processing E. Czyżewska-Zalewska) 
[Figs 2A:1,3; 2B:7,10,11; 2C:15]. The Nile silt used to make these vessels has practically the same color and texture as other Egyptian containers for liquids, especially containers of the LRA 7 type. The difference in the specific gravity of the clay $\left(\mathrm{g} / \mathrm{cm}^{3}\right)$ used to make ovoid bottles and LRA 7 amphorae is very small:

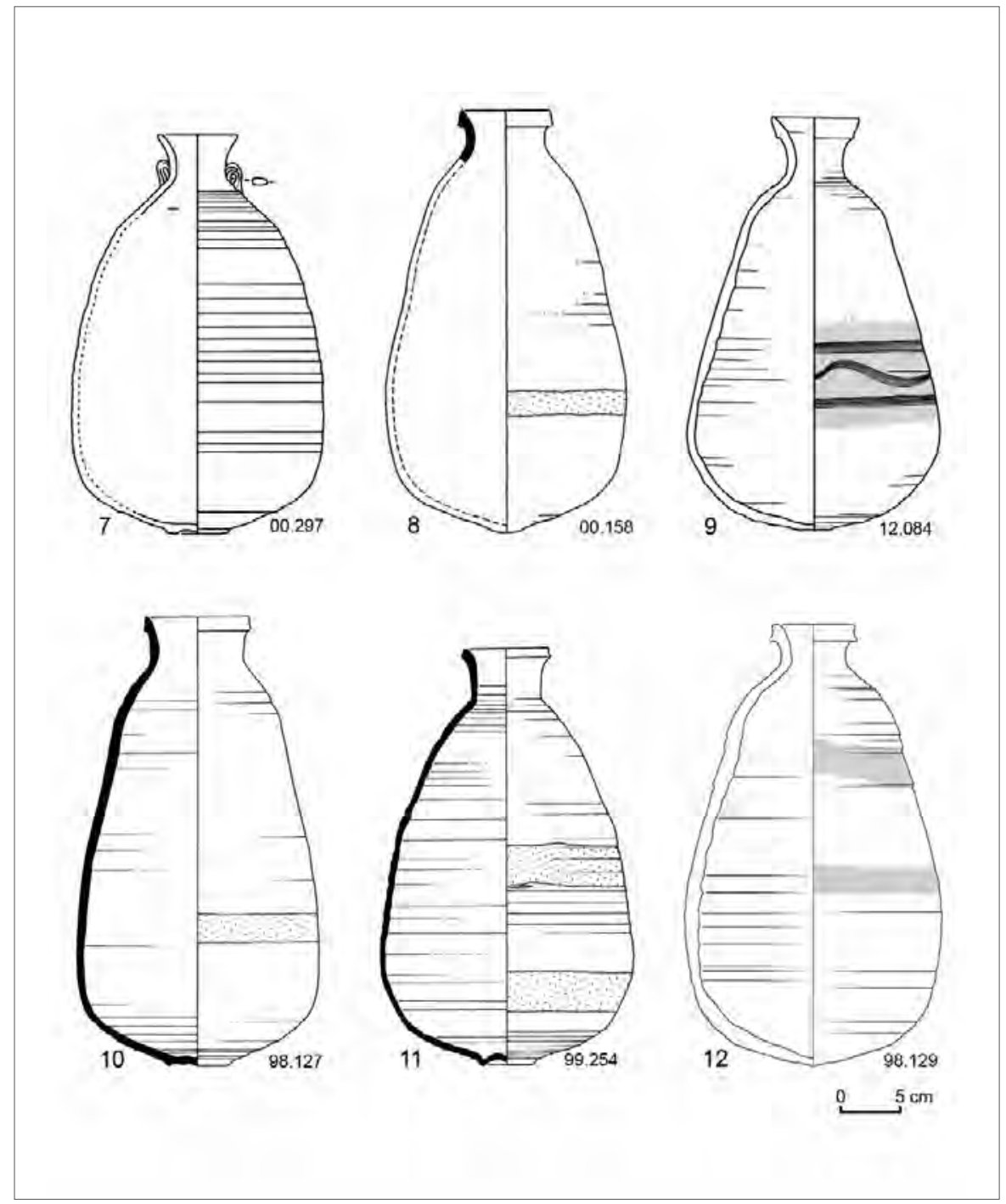

Fig. 2B. Bag-shaped unhandled bottles from Naqlun, selected examples (7-12)

(Drawing T. Górecki, K. Danys [No. 9], M. Zurek [Nos 7, 12]; digitizing K. Danys, J. Górecka; plate processing E. Czyżewska-Zalewska) 

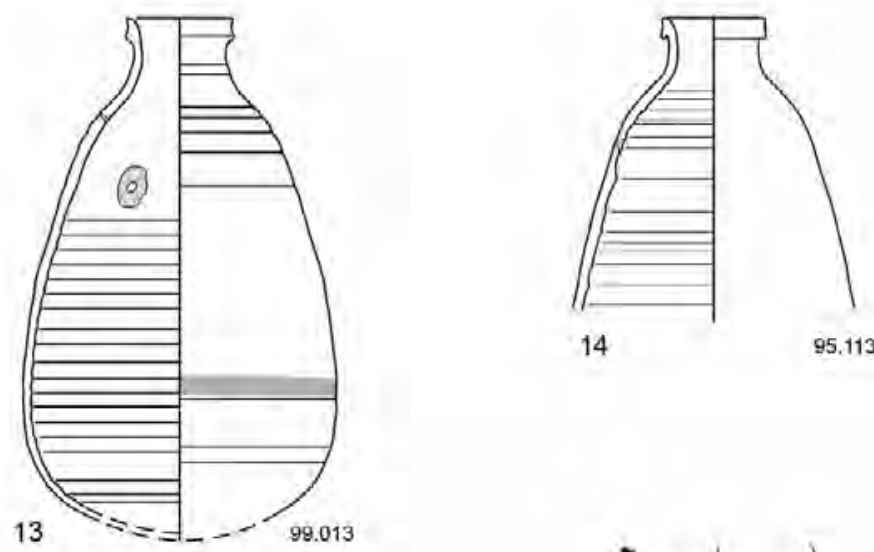

14

95.113
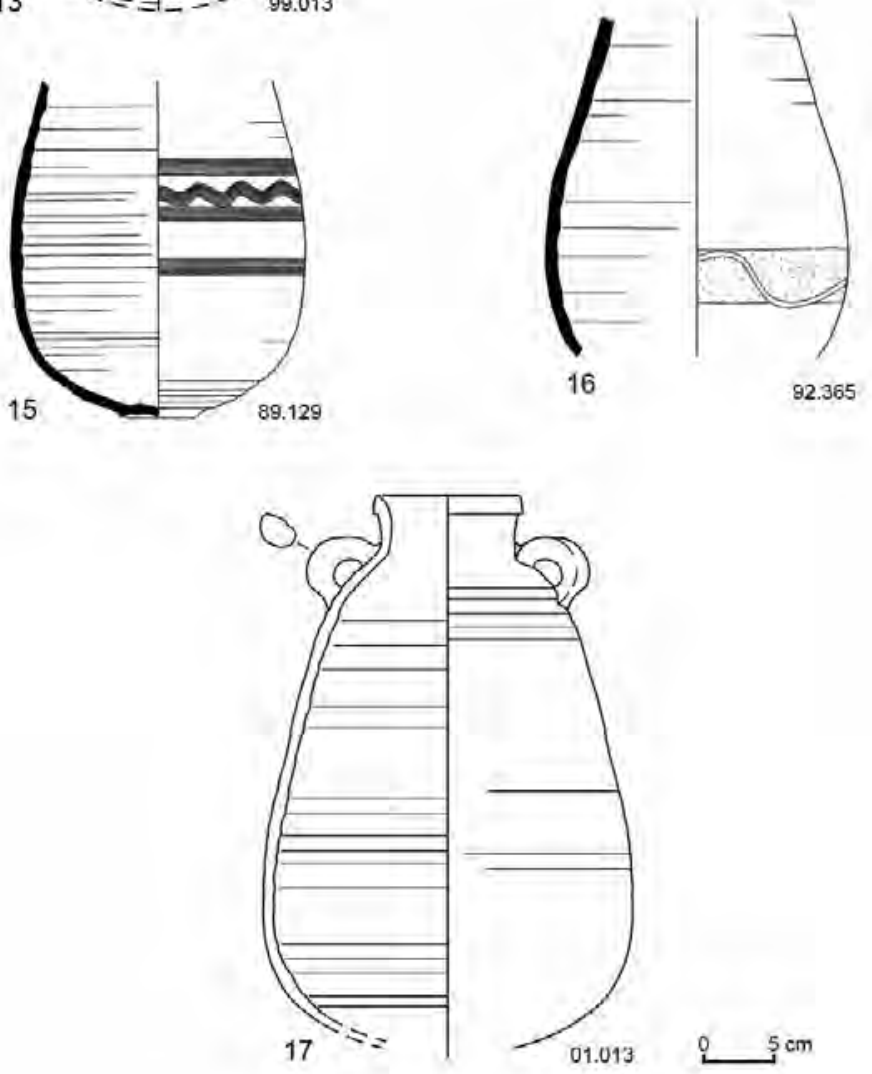

Fig. 2C. Bag-shaped unhandled bottles from Naqlun, selected examples (13-17) (Drawing T. Górecki, M. Żurek [No. 17]; digitizing J. Górecka; plate processing E. Czyżewska-Zalewska) 
$1.92 \mathrm{~g}$ per $\mathrm{cm}^{3}$ for the ovoid bottles as compared to $1.88 \mathrm{~g}$ per $\mathrm{cm}^{3}$ for the amphorae. ${ }^{10}$ Furthermore, compared to LRA 7 or the so-called Pseudo-Aswan containers (Bavay 2007: 395-397), the Naqlun bottles were fired much better, occasionally in a reduction atmosphere, the clay being harder and denser, and the walls thinner.

The outer surface of the vessels was covered with a fairly consistent redbrown slip, which is identical in color with LRA 7 and with many other ordinary domestic pots. Decoration on the body (although a few vessels were not decorated)
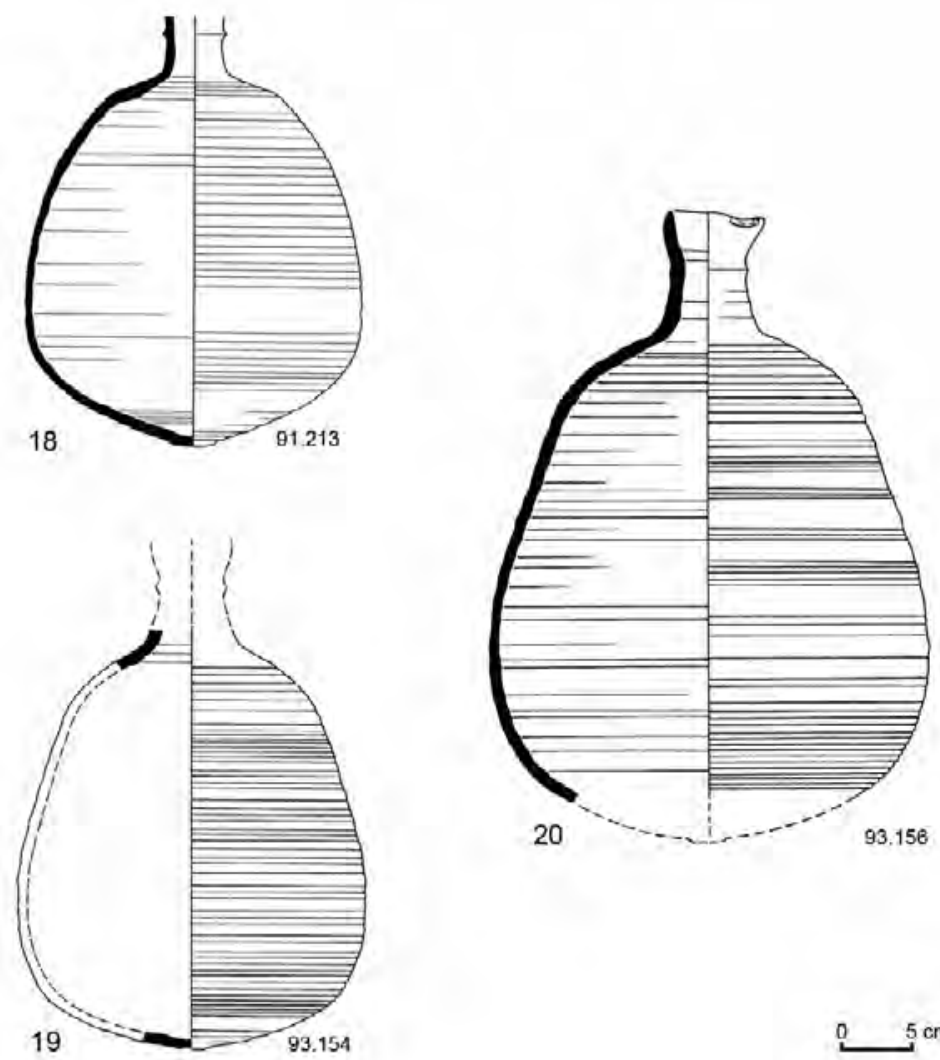

93.156

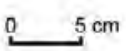

Fig. 2D. Bag-shaped unhandled bottles (type with spout) from Naqlun, selected examples (18-20) (Drawing T. Górecki; plate processing E. Czyżewska-Zalewska)

$\overline{10}$ The process of calculating specific gravity is described in Appendix 1. 
comprised either painted or combed bands, or a combination of the two. ${ }^{11}$ The decoration appeared on the middle and bottom parts of the vessels, never on the rim, neck and shoulders. A horizontal band of decoration, if there was only one, occurred most often just above the maximum diameter, in the middle part of the body. If there were two bands, then one was placed usually just above and the other just below the maximum diameter. The repertoire of ornaments was limited and rather monotonous. Five different ornamental patterns could be distinguished:

A. Single painted band (white/cream/beige) [Figs 2B:8,10; 2C:13];

B. Two painted bands [Figs 2A:3,6; 2B:11,12];

C. Band comprising three combed motifs: a wavy line between two horizontal ones [Fig. 2C:15];

D. Pattern C applied to a painted light-colored band, the combed lines cutting through the painted layer and taking on in effect the red-brown color of the clay [Figs 2A:1,2,4,5; 2B:9];

E. Single wavy line engraved on a painted band [Fig. 2C:16].

Vessels were decorated either standing up or set upside down on the neck during the painting; stains of light-colored slip directed upward on the vessels attest to the latter position [Figs 2A:4,6;2B:9]. Both painting and combing were easier to perform in the upside down position of the vessel as it must have been more stable than when standing on the rounded bottom.

Another observation important for the present discussion is the presence of an intentionally pierced or knocked small opening in the upper part of the body on some of the vessels [Fig. 2C:13,14]; of these, Nd.99.013 has exceptionally two openings. ${ }^{12}$ Similar openings can be observed also an about $10 \%$ of LRA 7 amphorae, which were mass-produced during the wine harvest with the purpose of collecting wine, storing it during the fermentation process and then transporting the ready product to a mainly Egyptian clientele, but also farther out, from Nubia to Britain, for example. The holes were pierced from the outside and, if necessary, closed and sealed with clay (the percentage share of this procedure in the production being difficult to estimate)..$^{13}$

11 The present author's observation is that LRA 5/6 amphorae from earlier stratigraphic contexts had combed rather than painted decoration, either horizontal, wavy or a combination of the two, appearing almost exclusively on the upper parts of vessels.

12 These holes were believed to play a role as escape for gasses at a certain stage of the fermentation process. A more probable interpretation is that the holes were used to test the quality of the wine (Vogt et al. 2002: 68-69).

13 The present author knows of cases of an acacia thorn (as in the illustrated fragment of LRA 7 amphora, see Fig. 1A:5), a twig or an ordinary piece of wood being used to close the opening in a wine container. 
Despite limited coverage in the literature, ${ }^{14}$ bottles have enough characteristic elements to facilitate an identification of their purpose. They were made of the same kind of Nile silt as LRA 7 amphorae, although the composition of the matrix may have differed somewhat from batch to batch. ${ }^{15} \mathrm{~A}$ bitumen deposit can be seen on the inside surface of slightly more than half of the vessels. In comparison with the most common LRA 7 amphorae from the 5th-8th century, the practice of resinating bottles seems to have been less common. Capacity [see Table 1], which is dependent on size, is comparable as a rule with the capacity of LRA 7 amphorae. The narrow cylindrical neck (which could have from 4.3 to $7.4 \mathrm{~cm}$ in diameter) and rim (from 6.3 to $8.6 \mathrm{~cm}$ in diameter) that permitted the content to be poured out slowly leaves no doubt that the bottles were used for beverages. Summing up, it seems that the bottles in question could not have been used for anything else but the storage and transport of wine (for consumption and for liturgical purposes). ${ }^{16}$

Ovoid bottles occur mainly in late contexts with few LRA 7 fragments. On the other hand, wherever LRA 7 appears in abundance, LRA 5/6 is rare and the unhandled ovoid bottles discussed here are missing altogether. ${ }^{17}$ There is much to indicate that sometime in the 10th century, in the course of perhaps fifty, perhaps a hundred years, ovoid forms pushed out LRA 7 amphorae. ${ }^{18}$

14 For the few parallels for Naqlun bottles, see above, note 7 .

15 Macroscopic examination is not enough to establish this and it was not possible to analyze the raw material.

16 It is not surprising in the context of containers being found in the monastery. On the other hand, wine seems to have been traded in Egypt also in the medieval period and was consumed by Christians, Jews and also elite Muslims (Vogt et al. 2002: 77, based on other sources). Delphine Dixneuf (2011: 207) expressed a similar opinion based on sources dating through the 14th century, partly the same as those considered by Christine Vogt. See also Goitein 1999: 215; Mikhail 2000: 111-112. For the most recent and fullest discussion of the issue of wine consumption in medieval Cairo, see Lewicka 2011: 493-513 (see also chapter VI on alcohol and its consumption in medieval Cairo, 483-550). On the whole, most of the unhandled ovoid bottles were intended for wine deliveries. For other kinds of content, see Taxel and Fantalkin 2011: 82.

17 A provisional chronology for the bottles based on the present author's observations is the second half of the 10th-11th century, perhaps even the 12th century. A thorough and time-consuming analysis of many stratigraphic contexts, taking into consideration deposits of whole pots as well as fragmentary sherds from leveling layers, is essential for a more precise dating. There are no parallels from other sites. Were one to consider an ovoid amphora (now in the Coptic Museum in Cairo) apparently well dated by an inscription from AD 1156 preserved on it (see Crum 1902: No. 8104, Pl. I), a dating of ovoid forms into the 12th century would be unquestionable. It should be noted, however, that the vessel was sealed with a stopper already after having lost one handle, which suggests secondary use (especially as incense was the content) of a vessel made earlier and damaged. With this in mind, the dating suggested by the inscription should be treated with reserve.

18 Generally on the gradual increase in the use of LRA 5/6 amphorae and then other ovoid variants of the form at the cost of LRA 7 amphorae from the 7th century, see Dixneuf 2011: 246, in the context of the progressing "Arabization" of Egypt. 


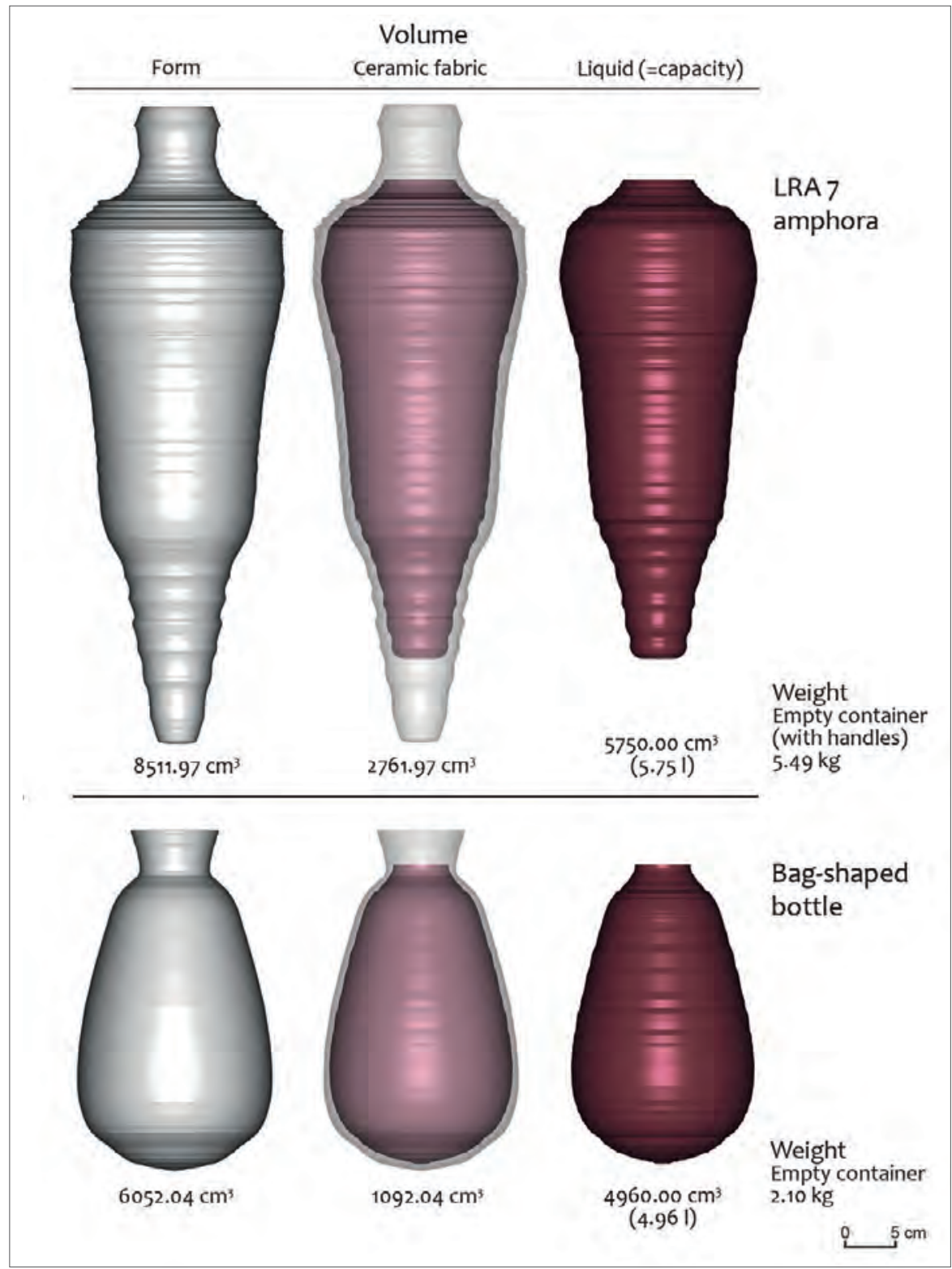

Fig. 3. Computer-based method for determining liquid capacity and weight of clay containers (the section profile is turned around the axis to "draw" the shape; top, container of the LRA 7 type from Naqlun (Nd.99.008, see Fig. 1B:14), upper part reconstructed based on other examples of the type from Naqlun; bottom, bag-shaped unhandled bottlelcontainer from Naqlun (Nd.93.123, see Fig. 2A:5) (Method and computer rendering M. Caban) 
An interesting question in this context is why was the production of LRA 7 amphorae stopped despite a veritable "monopoly" on the market of wine containers in Egypt for so long (almost 500 years). Imitations in Nile silt of imported LRA 1 and LRA 2 amphorae, occurring concurrently with LRA 7, had an almost imperceptible share of the local market and they never threatened the "hegemony" of LRA 7 containers. All kinds of amphorae, including imported examples, were reused in Egypt for transporting wine. They were presumably salvaged for secondary use because of their quality (for instance, resistance to damage) or handling convenience. Several factors can be hypothesized as having bearing on the introduction of ovoid bottles in Egypt (even locally, in Fayum): 1) socio-economic factors; 2) practical issues; 3) the weight of the vessels.

Socio-economic factors. The change may have been caused by a progressing (perhaps even from the beginning of the 7th century) replacement of the traditional Late Roman form by a Levantine bag-shaped one. The change could have been conditioned culturally, but the Arab/Muslim population influx in Egypt was not sufficient to justify a change in the form of containers. Shifting political and consequently also commercial ties created a new economic situation and a partial transformation of existing markets or the emergence of new ones. ${ }^{19}$ A question one could ask in this context was whether bag-shaped amphorae pushed out LRA 7 containers or whether they filled a void on the market left by the disappearing LRA 7.

Practical issues. Issues to be considered in this regard include the following:

a) Greater durability of ovoid containers due to their shape. Spherical or ovoid vessels are generally more resistant to lateral breakage. Cylindrical and conical (e.g., LRA 7) containers are less resistant to lateral pressure despite the fact that the relief ribbing on the body increases the durability of the walls. Those with a spike/toe are definitely more resistant to vertical pressure. ${ }^{20}$

19 Taxel and Fantalkin 2011: 77-90. Palestine was also a traditional market; the authors discuss finds of Egyptian red-brown ovoid amphorae from the 8th-10th century in Palestine, explaining the case in socio-economic terms as reflecting normal trade relations. The clientele there presumably preferred their traditional packaging in the form of bag-shaped containers. They do not mention, however, the category of unhandled bottles among the finds from Palestine.

Radić Rossi 2005-2006: 161-163, 168. The author cites several opinions that containers with flat or rounded base were more practical for stationary storage, whereas those with a toe were better suited to moving, standing up on an uneven surface and foremost for fardistance travel. 
Table 1. Capacity and weight data for bag-shaped bottles (1-18) and bag-shaped bottles (type with spout) (19-21) acquired by different measuring and computing techniques, plus relevant measurements for individual vessels

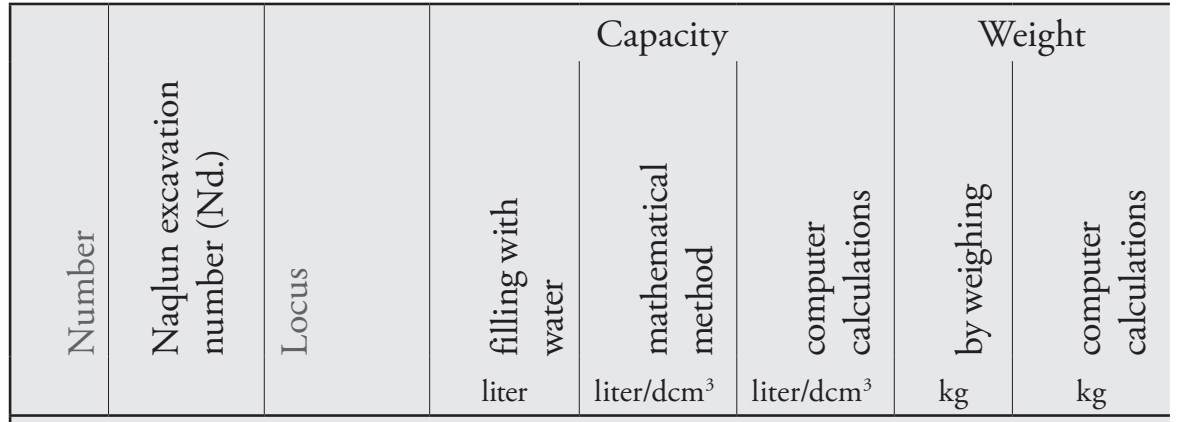

BAG-SHAPED BOTTLES

\begin{tabular}{|c|c|c|c|c|c|c|c|}
\hline 1. & 89.129 & D.3 & - & - & - & - & - \\
\hline 2. & 92.365 & D.15 & - & - & - & - & - \\
\hline 3. & 93.119 & D.21 & 9.25 & 9.70 & 9.42 & 3.75 & 3.41 \\
\hline 4. & 93.120 & D. 21 & 5.32 & 5.84 & 5.41 & 2.75 & 2.44 \\
\hline 5. & 93.121 & D.21 & 7.10 & 6.92 & 7.07 & - & 2.97 \\
\hline 6. & 93.122 & D.21 & 6.10 & 6.17 & 6.28 & 2.30 & 2.50 \\
\hline 7. & 93.123 & D.21 & 4.70 & 4.62 & 4.96 & 2.10 & 2.10 \\
\hline 8. & 93.124 & D.21 & 7.03 & 7.15 & 7.00 & - & 2.76 \\
\hline 9. & 98.120 & D. 40 & - & 6.28 & - & - & - \\
\hline 10. & 98.127 & D. 40 & - & 5.51 & 5.52 & - & 2.33 \\
\hline 11. & 98.129 & D. 40 & - & 5.10 & 5.42 & - & 3.54 \\
\hline 12. & 99.013 & D.D.32 & - & - & 8.02 & - & 2.54 \\
\hline 13. & 99.254 & D.30 & - & 5.60 & 5.67 & - & 1.60 \\
\hline 14. & 99.271 & D. 40 & - & 4.28 & - & - & - \\
\hline 15. & 00.158 & A.AA 30.1 & 5.90 & - & 5.56 & 1.63 & 2.20 \\
\hline 16. & 00.297 & A.AA 40.2 & - & - & 5.50 & - & 1.72 \\
\hline 17. & 01.013 & A.AA 20.2 & - & - & 11.45 & - & 4.09 \\
\hline 18. & 12.084 & 6.2012 & - & - & 5.15 & - & 2.42 \\
\hline \multicolumn{8}{|c|}{ BAG-SHAPED BOTTLES (TYPE WITH SPOUT) } \\
\hline 19. & 91.213 & D.9 & - & - & 6.93 & - & 2.23 \\
\hline 20. & 93.154 & D.15 & - & 16.50 & 16.34 & - & 5.29 \\
\hline 21. & 93.156 & D.15 & 7.80 & 7.35 & 7.88 & - & 2.88 \\
\hline
\end{tabular}


Table 1 (continued from opposite page)

\begin{tabular}{|c|c|c|c|c|c|c|}
\hline \multicolumn{6}{|c|}{ Dimensions } & \multirow[b]{2}{*}{ 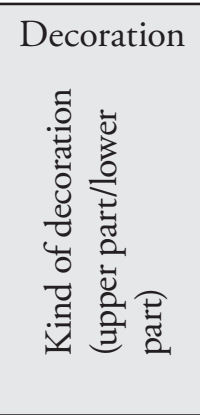 } \\
\hline 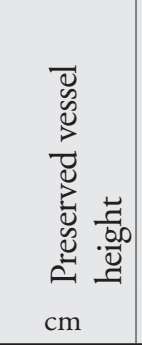 & 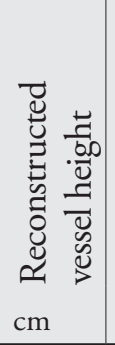 & 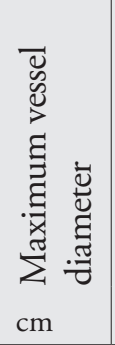 & 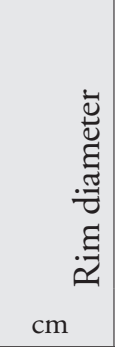 & 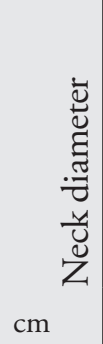 & 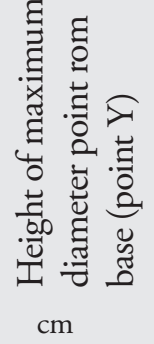 & \\
\hline \multicolumn{7}{|c|}{$\begin{array}{l}\text { + incomplete dimension: preceding - missing upper part, following - missing base; on both } \\
\text { ends - preserved middle part }\end{array}$} \\
\hline $24.1+$ & - & 21.1 & - & - & 11.3 & $\mathrm{C}$ \\
\hline$+23.5+$ & - & 20.8 & - & - & - & E \\
\hline $37.7+$ & 42 & 24.3 & - & 6.8 & 12.4 & $\mathrm{D} / \mathrm{A}$ \\
\hline $30.2+$ & 34 & 20.2 & - & - & 9.9 & $\mathrm{D}$ \\
\hline $31.6+$ & 36 & 21.6 & - & - & 7.6 & B \\
\hline $34.5+$ & 38 & 21.5 & - & 6.0 & 10.0 & $\mathrm{D}$ \\
\hline 33.5 & - & 19.3 & 8.5 & 6.8 & 8.6 & $\mathrm{~A} / \mathrm{D}$ \\
\hline$+34.8+$ & 41 & 21.4 & - & 5.8 & - & B \\
\hline $35.6+$ & 40 & 21.2 & - & 5.5 & 11.3 & A \\
\hline 35.9 & - & 19.6 & 8.6 & 7.6 & 8.7 & A \\
\hline 36.0 & - & 20.6 & 6.9 & 5.2 & 12.0 & B \\
\hline+32.0 & 36 & 23.0 & 7.3 & 6.3 & - & A \\
\hline 33.6 & - & 20.6 & 7.2 & 5.6 & 7.6 & B \\
\hline $30.6+$ & 34 & 19.2 & - & 6.0 & 10.2 & No decoration \\
\hline 34.6 & - & 19.8 & 7.7 & 6.4 & 10.2 & A \\
\hline 31.3 & - & 19.6 & 6.3 & 4.3 & 8.8 & No decoration \\
\hline+37.2 & 39 & 26.0 & 10.6 & 9.4 & - & No decoration \\
\hline 34.0 & - & 21.0 & 7.2 & 4.5 & 7.6 & $\mathrm{D}$ \\
\hline $30.8+$ & 34 & 24.1 & - & 4.0 & 9.0 & No decoration \\
\hline+42.0 & 45 & 31.8 & $6.4-7.2$ & 5.4 & - & No decoration \\
\hline $29.5+$ & 37 & 24.5 & - & $\approx 4.5$ & 10.0 & No decoration \\
\hline
\end{tabular}


b) The bag-shaped form of vessels with a low center of gravity, allowing the containers to stand on their own without any stand, ${ }^{21}$ versus having to lean against something or be placed in a stand, as was the case with spiked amphorae of the LRA 7 type. One should also keep in mind that vessels of the discussed bag-shaped form were better suited to the Oriental way of carrying bag-shaped pots on the head, unlike LRA 7 containers. Even today, bag-shaped vessels of the ballas type continue to be carried on the head in this fashion, ${ }^{22}$ something that never occurred for the LRA 7 in the past. ${ }^{23}$

c) Lighter and larger bag-shaped amphorae (as indicated by the data in the Appendix 2) as compared to diverse examples of LRA 7. For each kilogram of baked ceramic mass in the case of the LRA 7 amphorae there is from 1.1 to 1.6 liters of wine. The same relation for ovoid bottles is almost 2.5 liters of wine per one kilogram of ceramic mass. A ship with space for $1000 \mathrm{am}-$ phorae under deck (assuming suitable tonnage) in the 9th century could carry 1600 liters of wine compared to 2500 liters in the 10 th-12th centuries. It is difficult to know what difference did this actually make to sailors and merchants. We are not always capable of reconstructing and understanding economic processes taking place in culturally and chronologically distant times.

Vessel weight. Another potential reason for change was amphora weight. Being lighter than LRA 7 containers (which meant, however, that they were more susceptible to being crushed), the LRA $5 / 6$ bag-shaped vessel required less clay to be made and less fuel to be baked. Lesser weight translated into lesser transport costs for the empty containers being delivered to the vineyards and lesser transport costs for the wine-filled containers being sent to urban and monastic customer.

21 Wulff 1909: relief depicting a carrot-shaped amphora on a stand (No. 65, Figure on page 31) and metal model(?) of an amphora on a stand (No. 1034, Pl. 51); von Falck and Lichtwark 1996: No. 22, page 88 (=Wulff 1909: No. 65), No. 221, page 214: small vessel and stand of bronze.

22 Krol and Kuznecova 2014: 235, Photo 1025 shows village women drawing water from a canal in vessels of the ballas type; empty vessels, unlike full ones, could also be carried on their side.

23 Scenes of moving carrot-shaped amphorae (narrower in their lower part) are known from Roman iconography; morphologically, these vessels are somewhat like LRA 7 in these images. They were either carried on the shoulder (Friedman 2005-2006: Figs 17-18) or held by the neck and toe (Bounegru 2005-2006: Fig. 4); they could also be carried in front, vertically neck up and leaning against the shoulder, held in place by one hand (Bröker 1967: Fig. 14). Comparing the manner in which amphorae were carried as described in the note above with the one cited here, one should keep in mind that carrying loads on the head is typical of women, whereas carrying loads on the shoulder or held in the hands is characteristic of men. 
The sole element in favor of the LRA 7 vessels was the said center of gravity located close to the neck and not near the bottom as in the case of the ovoid vessels. This translated into practical benefits, it being much easier to pour the content from the amphora. It sufficed to tip the vessel holding the body with one hand and the narrow neck with the other. Amphorae were also carried in this manner. ${ }^{24}$

The present preliminary analysis of the morphology and functional purpose of unhandled ovoid bottles based on examples of containers from the excavations in the monastery in Naqlun justifies the following provisional conclusions. Namely, all the bottles were of Lower Egyptian manufacture; they were all locally distributed, albeit the range of this distribution remains unknown, and they were used generally for the transport of wine. Dating based on the preliminary results of excavations carried out in Naqlun places these containers between the second half of the 10th century and the second half of the 12th century. More precise dating will follow from a thorough consideration of the stratigraphy of parts of the monastic compound in Naqlun, even as new data is produced from a comparative study of pottery from chronologically convergent archaeological sites. The information will be useful in determining pottery workshops and the distribution range for their products.

\section{Appendix 1}

\section{Calculation of specific gravity of LRA containers}

Specific gravity (of the baked clay) of LRA 7 containers and ovoid bottles was calculated in two ways (sample of 18 sherds). The first method calculated the surface area of each sampled sherd and its thickness. Multiplying these two values gave the mass of the vessel in cubic centimeters. Each sherd was then weighed and the specific gravity of the ceramic body in $\mathrm{g} / \mathrm{cm}^{3}$ was calculated.

The second method called for each sherd to be dipped in water to see how much water it displaced. Knowing this number $\left(1 \mathrm{ml}=1 \mathrm{~cm}^{3}\right)$ and sherd weight permitted the specific gravity of the pot to be calculated.

Comparison of results of the two methods demonstrated the purely geometric superiority of the method of dipping the sherd in water. The results were practically identical, but only in those cases when volume was calculated

24 Radić Rossi 2005-2006: 160, citing Virginia Grace: "the knob serves as a third handle, below the weight, needed when one inverts a heavy vessel to pour from it". 
for a sherd with uniform thickness of the vessel wall. More significant differences were noted when the thickness of a sherd varied by as much as $2-3 \mathrm{~mm}$.

The experiment demonstrated the superiority of a method first calculating volume and then specific gravity (of baked clay) by dipping of the sherd in water.

Specific gravity of the ceramic mass of LRA 7 amphorae turned out to be $1.88 \mathrm{~g} / \mathrm{cm}^{3}$ (calculations done for six fragments) and for unhandled ovoid bottles $1.92 \mathrm{~g} / \mathrm{cm}^{3}$ (based on 12 fragments). The results are so close as to be almost identical. It means that Nile silt used in the production of both types of containers was the same in terms of its weight (clay+temper). By no means does this suggest the same composition of the ceramic mass of the two groups of containers, as that could be determined only in a series of laboratory analyses.

Knowing the specific gravity of the wine containers by means of the above described calculations was necessary to calculate the weight of vessels that had failed to be weighed in the field. The calculations for these vessels were made based on 3D models generated using Microstation V8i software by Bentley [Fig. 3]. The calculations were carried out by Mariusz Caban from the Wrocław University of Technology. He applied to his calculations a software program that uses typical precise documentation drawings to calculate with a high degree of accuracy the volume of individual vessels and their weight. ${ }^{25}$

The first step in the experiment was to calculate the volume of the shape of the whole vessel (following the external outline of the pot) and then volume (=capacity) of the inside containing the liquid goods. The difference between the two values gave the mass of the clay in the pot in $\mathrm{cm}^{3}$ and this served to calculate the weight of a given pot. When calculating capacity, the real, meaning maximum used space inside the vessel, was taken into consideration, that is, capacity up to the base of the neck. ${ }^{26}$ This assumption drew from the fact that the necks of vessels were often stopped with bunches of grass/straw/grapevine leaves and sealed with clay (so-called mud-stoppers) which, having dried, tightly closed the container. There are other arguments for not filling wine containers with wine right up to the top, but there is no need to go into them here.

25 Vessel Nd.93.123 was weighed $(2.10 \mathrm{~kg})$ and the volume measured with water $(4.70 \mathrm{l})$. But using a detailed drawing of the container, Mariusz Caban calculated the weight and capacity as respectively $2.10 \mathrm{~kg}$ and 4.96 liters. He demonstrated that the result changed with the of the line in the drawing: a line $1 \mathrm{~mm}$ thicker gave the results $2.52 \mathrm{~kg}$ and $4.82 \mathrm{l}$, a line $1 \mathrm{~mm}$ thinner $1.90 \mathrm{~kg}$ and $5.11 \mathrm{l}$. Hence, reliable calculations of measurements with the computer method depend on accurate pottery drawings and any error may lead to deviations up to $12-15 \%$.

26 Other researchers have a similar approach to the question of measuring volume, see Greene and Lawall 2005-2006: 18-19; they measure the capacity to the neck-shoulder joint, referring to this as the "short" measure. 
Capacity calculations were also calculated by a laborious method applied by Wolfgang Hautumm (1981: 168-169), referred to as the geometric (mathematical) method in Table 1. It calls for inscribing the most geometric figures possible (cylinders, truncated cones, cones) into the vessel outline, then calculating the volume of each and totaling the results. Table 1 shows beyond all doubt that calculations by practical experimentation (filling whole vessels with water) and by the computer method developed by Mariusz Caban give results that are fairly close, while Hautumm's mathematical method is less precise, although still useful.

\section{Appendix 2}

The most and the least "economic" examples of LRA 7 amphorae from five archaeological sites (6th-7th century)

The sample studied was about 150 vessels from the sites listed below. The weight $(\mathrm{kg})$ to volume (liter) ratio is presented in the last column on the right.

1. The most "economic" LRA 7 containers from the following sites:

\begin{tabular}{l|l|l|l|}
\hline Site & Weight $(\mathbf{k g})$ & Volume (liter) & $\begin{array}{l}\text { Weight to volume } \\
\text { ratio }(\mathbf{k g}: \text { liter })\end{array}$ \\
\hline Abu Fano & 2.40 & 3.60 & $1: 1.50$ \\
\hline Naqlun & 4.30 & 5.10 & $1: 1.19$ \\
\hline Edfu & 3.60 & 5.68 & $1: 1.58$ \\
\hline $\begin{array}{l}\text { Qurna } \\
\text { (hermitage MMA 1152) }\end{array}$ & 3.10 & 6.90 & $1: 2.22$ \\
\hline Shenhur & 4.30 & 6.90 & $1: 1.60$ \\
\hline
\end{tabular}

2. The least "economic" LRA 7 containers from the following sites

\begin{tabular}{l|l|l|l|}
\hline Site & Weight $(\mathbf{k g})$ & Volume (liter) & $\begin{array}{l}\text { Weight to volume } \\
\text { ratio }(\mathbf{k g}: \text { liter })\end{array}$ \\
\hline Abu Fano & 3.90 & 3.80 & $1: 0.97$ \\
\hline Naqlun & 4.40 & 4.37 & $1: 0.99$ \\
\hline Edfu & 6.50 & 6.83 & $1: 1.05$ \\
\hline $\begin{array}{l}\text { Qurna } \\
\text { (hermitage MMA 1152) }\end{array}$ & 4.00 & 5.00 & $1: 1.25$ \\
\hline Shenhur & 3.74 & 4.90 & $1: 1.31$ \\
\hline
\end{tabular}


3. Mean weight of wine per $1 \mathrm{~kg}$ of empty container of the LRA 7 type (6th-7th century): from1.09 (Naqlun) to 1.74 (Qurna) liters of wine:

$\begin{array}{ll}\text { Abu Fano } & 1: 1.24 \\ \text { Naqlun } & 1: 1.09 \\ \text { Edfu } & 1: 1.32 \\ \text { Qurna (hermitage MMA 1152) } & 1: 1.74 \\ \text { Shenhur } & 1: 1.46\end{array}$

4. Mean weight of wine per $1 \mathrm{~kg}$ of empty container of the LRA 7 type (8th century): from 1.05 (Naqlun) to 1.53 (Shenhur) liters of wine:

Naqlun [Nd.99.008, see Fig. 1B:14] $1: 1.05$

Shenhur [No. 149.8, see Fig. 1B:13] $1: 1.53$

5. Comparing the results given in Appendix 2 and the calculations of the ratio of liquid (in liters) to the weight (in kilograms) of the container [Table 1], one observes immediately the greater economy of ovoid containers as compared to LRA 7: from 1.531 (item 11) to 3.541 (item 13) per $1 \mathrm{~kg}$ of container. The mean based on calculations made on 14 best preserved ovoid vessels is 2.571 of liquid content per $1 \mathrm{~kg}$ of container mass. With regard to the less representative group of three bottles [Fig. 2D:18-20], the proportions are slightly different: almost 31 of liquid content per $1 \mathrm{~kg}$ of container.

\section{References}

Bahgat, A. and Gabriel, A. (1921). Fouilles d'al Foustât, publiées les auspices du Comité de conservation des monuments de l'art arabe. Paris: E. de Boccard

Bailey, D.M. (1998). Excavations at el-Ashmunein V. Pottery, lamps and glass of the late Roman and early Arab periods. London: British Museum Press

Ballet, P. (1994). Un atelier d'amphores Late Roman Amphora 5/6 à Kôm Abou Billou (Égypte). Chronique d'Égypte, 69(138), 353-365

Ballet, P. (2007). Un atelier d'amphores LRA 5/6 à pâte alluviale dans le Delta occidental (Kôm Abou Billou / Térénouthis). In S. Marchand and A. Marangou (eds), Amphores d'Égypte de la Basse Époque à l'époque arabe I [=Cahiers de la céramique égyptienne 8/1] (pp. 157-160). Cairo: Institut français d'archéologie orientale

Bavay, L. (2007). Les amphores d'un anachorète copte de la montagne thébaine.

In S. Marchand and A. Marangou (eds), Amphores d'Égypte de la Basse Époque à l'époque arabe I [=Cahiers de la céramique égyptienne 8/1] (pp. 389-399). Cairo: Institut français d'archéologie orientale 
Bounegru, O. (2005-2006). Naves actuariae - Seeschiffe für den Amphorentransport in römischer Zeit? Eine ikonographische und historische Untersuchung. Skyllis. Zeitschrift für Unterwasserarchäologie, 7(1-2), 136-139

Bröker, G. (1967). Koptische Stoffe. Leipzig: Insel-Verlag

Crum, W.E. (1902). Catalogue général des antiquités égyptiennes du Musée du Caire. Nos. 8001-8741, Coptic monuments. Cairo: Institut français d'archéologie orientale

Danys-Lasek, K. (2014). Pottery from Deir el-Naqlun (6th-12th century). Preliminary report from Polish excavations in 2010 and 2011. Polish Archaeology in the Mediterranean, 23/1, 543-642

Dixneuf, D. (2011). Amphores égyptiennes: production, typologie, contenu et diffusion, III ${ }^{e}$ siècle avant J.-C-IX siècle après J.-C [=Études Alexandrines 22]. Alexandria: Centre d'études alexandrines

Eichhorn, B., Hendrickx, S., Riemer, H., and Stern, B. (2005). Desert roads and transport vessels from late Roman-Coptic times in the Eastern Sahara. Journal of African Archaeology, 3(2), 213-229

Friedman, Z. (2005-2006). Sea trade as reflected in mosaics. Skyllis. Zeitschrift für Unterwasserarchäologie, 7(1-2), 126-134

Gallazzi, C. and Hadji-Minaglou, G. (2012). Sépultures de nouveaux-nés et d'enfants dans une nécropole de la fin du VIII et du IX ${ }^{\mathrm{e}}$ s. apr. J.-C. à Umm-el-Breigât, Tebtynis. In M.-D. Nenna (ed.), L'enfantet la mort dans l'Antiquité. Actes de la table ronde internationale organisée à Alexandrie, Centre d'études alexandrines, 12-14 novembre 2009, II [=Études Alexandrines 26] (pp. 389-406). Alexandria: Centre d'études alexandrines

Gayraud, R.-P. (2007). Quand l'amphore fait le mur... In S. Marchand and A. Marangou (eds), Amphores d'Égypte de la Basse Époque à l'époque arabe II [=Cahiers de la céramique égyptienne 8/2] (pp. 721-725). Cairo: Institut français d'archéologie orientale

Godlewski, W. (1999). Naqlun: Excavations 1998. Polish Archaeology in the Mediterranean, 10, 113-117

Godlewski, W. (2007). Naqlun (Nekloni): Preliminary report, 2005. Polish Archaeology in the Mediterranean, 17, 195-205

Godlewski, W., Derda, T., and Górecki, T. (1994). Deir el Naqlun (Nekloni), 19881989. Second preliminary report. Nubica, 3(1), 201-263

Goitein, S.D. (1999). A Mediterranean society: An abridgment in one volume. (J. Lassner, ed.). Berkeley: University of California Press

Górecki, T. (1993). Deir el-Naqlun 1992: The pottery. Polish Archaeology in the Mediterranean, 4, 53-64.

Górecki, T. (1994). The pottery from Naqlun, 1993. Polish Archaeology in the Mediterranean, 5, 63-78

Górecki, T. (2001). Naqlun: The pottery. Polish Archaeology in the Mediterranean, 12, 162-167

Greene, E.S. and Lawall, M. (2005-2006). Amphora capacities in early monetary Asia Minor. The Pabuç Burnu shipwreck. Skyllis. Zeitschrift für Unterwasserarchäologie, $7(1-2), 17-23$ 
Hautumm, W. (1981). Studien zu Amphoren der spätrömischen und frühbyzantinischen Zeit. Fulda: W. Hautumm

Krol, A.A. and Kuznecova, A. (2014). Fotografičeskầ pamât'. Fotoarhiv U.M.F. Pitri iz Nacional'novo muzeâ Sudana [Photographic memory. Archive of photos by U.M.F. Petrie from the National Museum of Sudan]. Moscow: Rossijskaâ Akademiâ Nauk, Centr egiptoločeskih issledovanij [in Russian]

Kubiak, W. (1986). Unglazed domestic wares from Fustat. Unpubl. typescript in the author's possession

Kubiak, W.B. and Scanlon, G.T. (1989). Fust.āt. expedition final report II. Fust.āt.-C [=American Research Center in Egypt Reports 11]. Winona Lake, IN: Eisenbrauns

Lecuyot, G. (2007). Amphores de la Basse Époque à l'époque copte provenant de Saqqâra, secteur du mastaba d'Akhethetep. In S. Marchand and A. Marangou (eds), Amphores d'Égypte de la Basse Époque à l'époque arabe I [=Cahiers de la céramique égyptienne 8/1] (pp. 199-206). Cairo: Institut français d'archéologie orientale

Lewicka, P.B. (2011). Food and foodways of medieval Cairenes: Aspects of life in an Islamic metropolis of the eastern Mediterranean [=Islamic History and Civilization 88]. Leiden: Brill

Marangou, A. and Marchand, S. (2007). Conteneurs importés et égyptiens de Tebtynis (Fayoum) de la deuxième moitié du IV ${ }^{\mathrm{e}}$ siècle av. J.-C au $\mathrm{X}^{\mathrm{e}}$ siècle apr. J.-C. (1994-2002). In S. Marchand and A. Marangou (eds), Amphores d'Égypte de la Basse Époque à l'époque arabe I [=Cahiers de la céramique égyptienne 8/1] (pp. 239-294). Cairo: Institut français d'archéologie orientale

Marchand, S. and Dixneuf, D. (2007). Amphores et conteneurs égyptiens et importés du VII e siècle apr. J.-C. Sondages récents de Baouît (2003-2004). In S. Marchand and A. Marangou (eds), Amphores d'Égypte de la Basse Époque à l'époque arabe I [=Cahiers de la céramique égyptienne 8/1] (pp. 309-343). Cairo: Institut français d'archéologie orientale

Mikhail, M.S.A. (2000). Some observations concerning edibles in late antique and early Islamic Egypt. Byzantion, 70(1), 105-121

Południkiewicz, A. and Konstantinidou, A. (2012). Bawit - Church “D”. Bulletin de liaison de la céramique égyptienne, 23, 91-99

Radić Rossi, I. (2005-2006). The amphora's toe: Its origin and function. Skyllis. Zeitschrift für Unterwasserarchäologie, 7(1-2), 160-170

Rousset, M.-O. and Marchand, S. (1999). Tebtynis 1998, travaux dans le secteur nord. Annales Islamologiques, 33, 185-262

Rousset, M.-O., Marchand, S., and Foy, D. (2001). Secteur nord de Tebtynis (Fayyoum). Mission de 2000. Annales Islamologiques, 35, 409-489

Scanlon, G.T. (1974). Fustāt expedition: Preliminary report 1968. Part I. Journal of the American Research Center in Egypt, 11, 81-91

Taxel, I. and Fantalkin, A. (2011). Egyptian coarse ware in early Islamic Palestine: between commerce and migration. Al-Masāq. Journal of the Medieval Mediterranean, 23(2), 77-97 
Tomber, R. and Williams, D. (2000). Egyptian amphorae in Britain and the Western Provinces. Britannia, 31, 41-54

Vogt, C. (1997). Les céramiques ommeyyades et abbassides d'Istabl'antar - Fostat: Traditions méditerranéennes et influences orientales. In G. Démians d'Archimbaud (ed.), La céramique médiévale en Méditerranée. Actes du VIe Congrès de l'AIECM2, Aix-en-Provence (13-18 novembre 1995) (pp. 243-260). Aix-en-Provence: Narration

Vogt, C., Bourgeois, G., Schvoerer, M., Gouin, P., Girard, M., and Thiébault, S. (2002). Notes on some of the Abbasid amphorae of Istabl Antar-Fustat (Egypt). Bulletin of the American Schools of Oriental Research, 326, 65-80

von Falck, M. and Lichtwark, F. (eds). (1996). Ägypten: Schätze aus dem Wüstensand: Kunst und Kultur der Christen am Nil [exhibition catalog]. Wiesbaden: Reichert

Wulff, O. (1909). Altchristliche und mittelalterliche byzantinische und italienische Bildwerke I. Altchristliche Bildwerke. Berlin: Reimer 



\title{
Spätantike und mittelalterliche Vierstützenkirchen in Ägypten
}

\author{
Peter Grossmann \\ emeritus Professor \\ Gro.Ath-Cai@t-online.de
}

\begin{abstract}
KeYwords
Christian Egypt, Christian Nubia, church architecture, spatial organization of churches
\end{abstract}

\begin{abstract}
The article offers an architectural analysis of a late antique and medieval type of church characterized by a naos with four pillars or columns supporting the roof. Variants that can be distinguished include one with a passage around the supports and another in which the supports form a cross-in-square. The analyzed type is poorly represented in the church architecture of Egypt, but is well attested in Lower Nubia. Nubian examples of the type give an idea of what the lost Egyptian prototypes may have looked like.
\end{abstract}

Unter den kirchlichen Denkmälern der frühmittelalterlichen Baukunst in Ägypten konnten bisher nur sehr wenige Vierstützenbauten, Kirchen deren Naosbereich durch vier Stützen, Pfeiler oder Säulen, gekennzeichnet ist, nachgewiesen werden. Das ist um so erstaunlicher, als dieser Typus in der byzantinischen Architektur für Jahrhunderte zum vorherrschenden Bautypus gehörte und auch in Nubien ${ }^{1}$, dem südlichen Nachbarland Ägyptens, durch

$1 \quad$ Zur Vereinfachung der Literaturverweise haben wir bei jedem hier zitierten Bau die Nr. des von William Y. Adams (1965: 126-131), beigefügt. Sie sind auch in dem neuen Werk von W.Y. Adams (2009/I: 4-5) enthalten. Die hier angegebene Literatur betrifft nur die nach diesem Katalog erschienenen Veröffentlichungen. 
eine beträchtliche Anzahl von Beispielen vertreten ist ${ }^{2}$. Da andererseits aber davon auszugehen ist, daß die christliche Baukunst in Nubien in mancherlei Hinsicht unter dem allerdings wechselnden Einfluß Ägyptens stand, sollte es auch in Ägypten im Gegensatz zu dem tatsächlich erhaltenen bzw. archäologisch nachweisbaren Bestand eine nicht geringe Zahl von Repräsentanten dieses Bautypus gegeben haben. Im Gegensatz dazu sind aber Denkmäler dieser Art in Ägypten kaum vorhanden, und auch die nachgewiesenen Beispiele nur gering an Zahl. Es führt daher wohl kein Weg daran vorbei, daß die entsprechenden Beispiele in Ägypten aus irgendeinem Grunde frühzeitig verloren gegangen sind $^{3}$.

Unter den auf uns gekommenen Beispielen der Vierstützenbauten im byzantinischen Raum und auch in Nubien, das hier wegen der Verbindung mit Ägypten ebenfalls erwähnt sei, sind verschiedene Varianten zu unterscheiden. Jeweils handelt es sich um verhältnismäßig kleine, mit einem räumlich betonten Zentrum ausgebildete Zentralbauten ${ }^{4}$, deren inneres Raumgefüge durch die Anordnung und formale Ausbildung der die Decke tragenden Stützen (Pfeiler oder Säulen) gegliedert ist. Eine bestimmende Bedeutung kommt dabei auch der Art der Deckengestaltung dieser Bauten (zumeist aus Gewölbeformationen bestehend) zu. Von diesen Varianten haben die von uns als „Umgangsvierstützenbauten“ bezeichneten Kirchen als die älteste Gruppe zu gelten. Das auf ägyptischem Boden am besten, wenngleich nur in Ruinen auf uns gekommene Beispiel dieser Gruppe ist die in das 6./7. Jahrhundert datierbare Kirche der kleinen spätantiken Siedlung im Hof des Chnumtempels von Elephantine (Grossmann 1980a: 75-86, Abb. 12-13) [Fig. 1:A]. Sie besitzt vier Winkelpfeiler, die einen quadratischen, wohl einst überkuppelten Zentralraum umschließen. Die übrigen Beispiele dieses Typus aus Ägypten sind mehrheitlich nur äußerst fragmentarisch erhalten, bzw. durch spätere

2 S. die Beispiele in: Grossmann 1990. $\mathrm{Zu}$ nennen sind ferner die Gruppe der Umgangsvierstützenbauten, die in: Grossmann 1980a: 86-111, Abb. 14-27, aufgeführt sind.

3 Ein ähnliches Bild zeigt der Typus des Achtstützenbaus, der auffälligerweise nur im Raum von Aswan in mehreren Beispielen belegt ist, während im übrigen Ägypten bisher nur ein einziges Beispiel nachgewiesen werden konnte. Gemeint ist die nach Abū l-Makārim um 1130 von Abū 'l-Barakāt Yūhannā wieder aufgebaute Kirche des Arseniosklosters bei Turā (südlich von Cairo), nachdem das Kloster in 1010 unter dem Khalifen al-Hakim (996-1021) zerstört worden war; vgl. Yahya Ibn Sa'îd al Antaki, Continuation de Sa’ìd ibn Bitriq, Hrg. I. Kratchkovsky und A. Vasiliev in: Patrologia Orientalis XXIII,3, 495; s. auch Grossmann 2002: 511-512, Abb. 130.

4 Die Beispiele sind streng von den ebenfalls mit vier Stützen ausgestatteten Längsbauten, bei denen es sich nur um den Basiliken näher stehende verkürzte Longitudinalbauten handelt, zusammengestellt in: Grossmann 1990: 152, Abb. 1, unter dem Oberbegriff: „Verkürzte Longitudinalbauten". 
Umbauten stark, teilweise bis zur Unkenntlichkeit verändert. Hingegen standen die einst (bis zum Bau des Aswan-Staudamms) wesentlich zahlreicher auf uns gekommenen Beispiele aus Nubien stellenweise bis in die Gewölbezone hinein aufrecht.

Eine vereinfachende Lösung bietet eine Gruppe von nubischen Kirchen mit quadratischen Pfeilerquerschnitten, die in entsprechender Weise ein räumlich betontes Zentralkompartiment umstellten, bei denen allerdings der Umgangscharakter wegen der auf ganzer Länge durchgezogenen seitlichen Tonnenwölbungen weniger deutlich ausgeprägt war ${ }^{5}$.

Neu hinzugekommen ist die jetzt wohl endgültig geklärte Nordkirche [Fig. 1:B] der Klosteranlage von Bawit, die im Naosbereich den Typus des Umgangsvierstützenbaus in der Ausbildung mit Säulen repräsentiert ${ }^{6}$. Sie entspricht damit der kleinen ebenfalls mit Säulenstützen ausgestatteten Kapelle am sogenannten Refektorium des Jeremiasklosters bei Saqqara (Grossmann 1980b: 197f., Abb. 3) [Fig. 3:A]. Bedauerlicherweise sind jedoch von den Stützen in der Nordkirche von Bawìt nur die attischen Basen inklusive der bei der ersten Freilegung teilweise noch aufrecht stehenden Schäfte auf uns gekommen, die aber keine Hinweise auf die Art der Deckengestaltung bieten. Die Wandgliederung mit den alternierenden Nischen könnte analog dem Saalbau von Ober-Ansinā in Mittelägypten ${ }^{7}$ [Fig. 3:B] einen Hinweis auf eine Zugehörigkeit zu dem cross-in-square-Typus bieten, doch passt die Anordnung der Säulen nicht zu der vorliegenden Gliederung der Seitenwände, so dass dieser Gedanke aufgegeben werden muss. Der Sanktuariumsbereich ist in Bawit vom Naos durch einen auf Säulen ruhenden Triumphbogen (tribelon) getrennt, auf den ein schon damals üblich gewordener und mit einem eigenen nördlichen Außeneingang versehener Khurus folgt. Das Ostende der Kirche ist dreigeteilt. Ob daraus auch auf die Existenz von drei Altären geschlossen werden muss, wie das später der Fall war, ist allerdings zweifelhaft. Insgesamt hat damit die Nordkirche von Bawit mit dem auf allen vier Seiten vollständig enthaltenen Umgang und dem eingeschobenen Khurus als der in räumlicher Hinsicht am reichsten ausgestattete Vertreter des Umgangsvierstützenbaus in Ägypten zu gelten.

5 Die Beispiele dieser Variante haben wir in: Grossmann 1990: 156ff., Abb. 4 zusammengestellt; besonders charakteristisch ist die zweite Bauphase der weit im Süden gelegenen Kirche von Nuri, s. Grossmann 1990: 89-91, Abb. 15 B.

6 Bénazeth 2013, wo der Bau von den Grabungsarchitekten (ebenda 5f.) allerdings als dreischiffige Basilika mißverstanden wurde; s. auch Bénazeth 2010.

7 Grossmann 1982: 176-178, Abb. 63, doch ist hier die Beziehung der Säulen zu der Nischengliederung der Wände wesentlich überzeugender. 

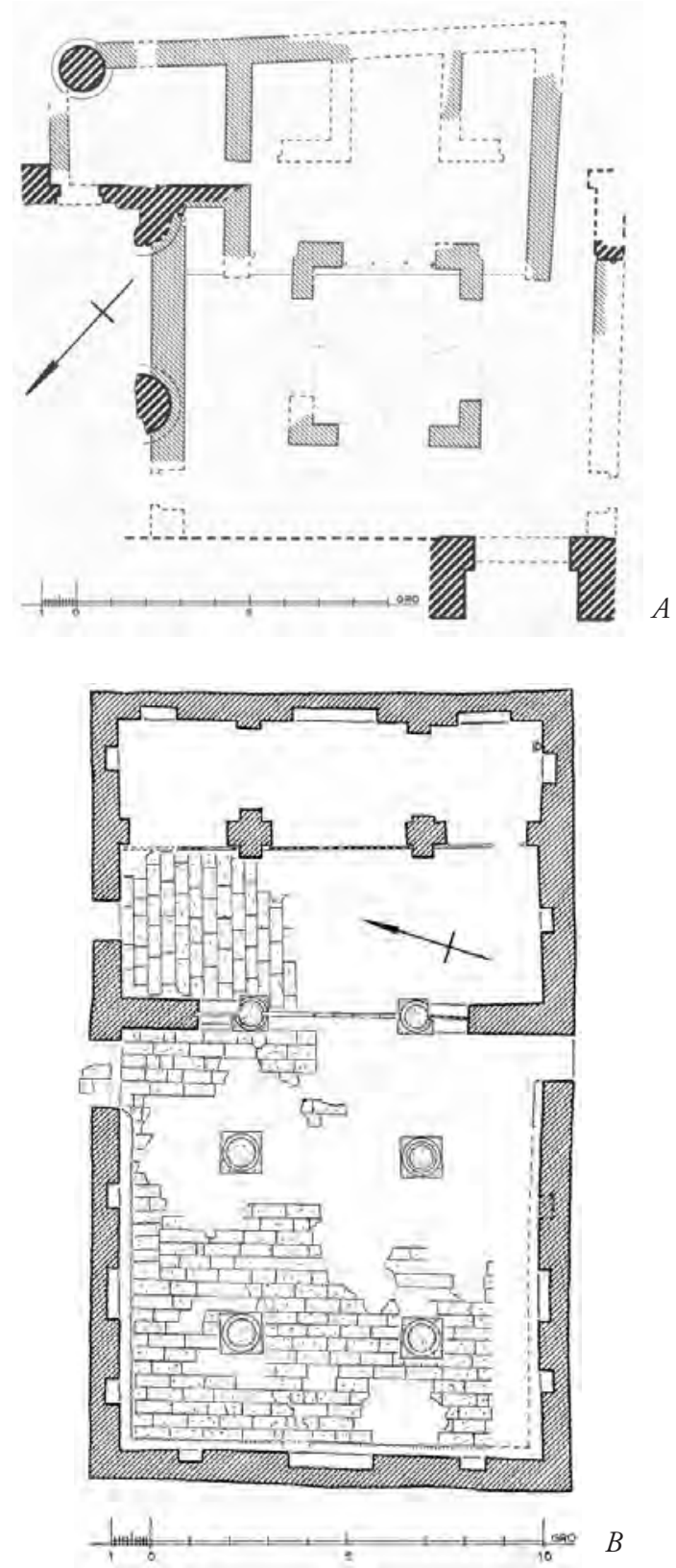

Fig. 1. A - Umgangsvierstützenkirche im Hof des Chnumtempels von Elephantine mit Winkelpfeilern; B - Grundriß der Nordkirche von Bawit (Alle Zeichnungen vom Autor) 
Spätantike und mittelalterliche Vierstützenkirchen in Ägypten

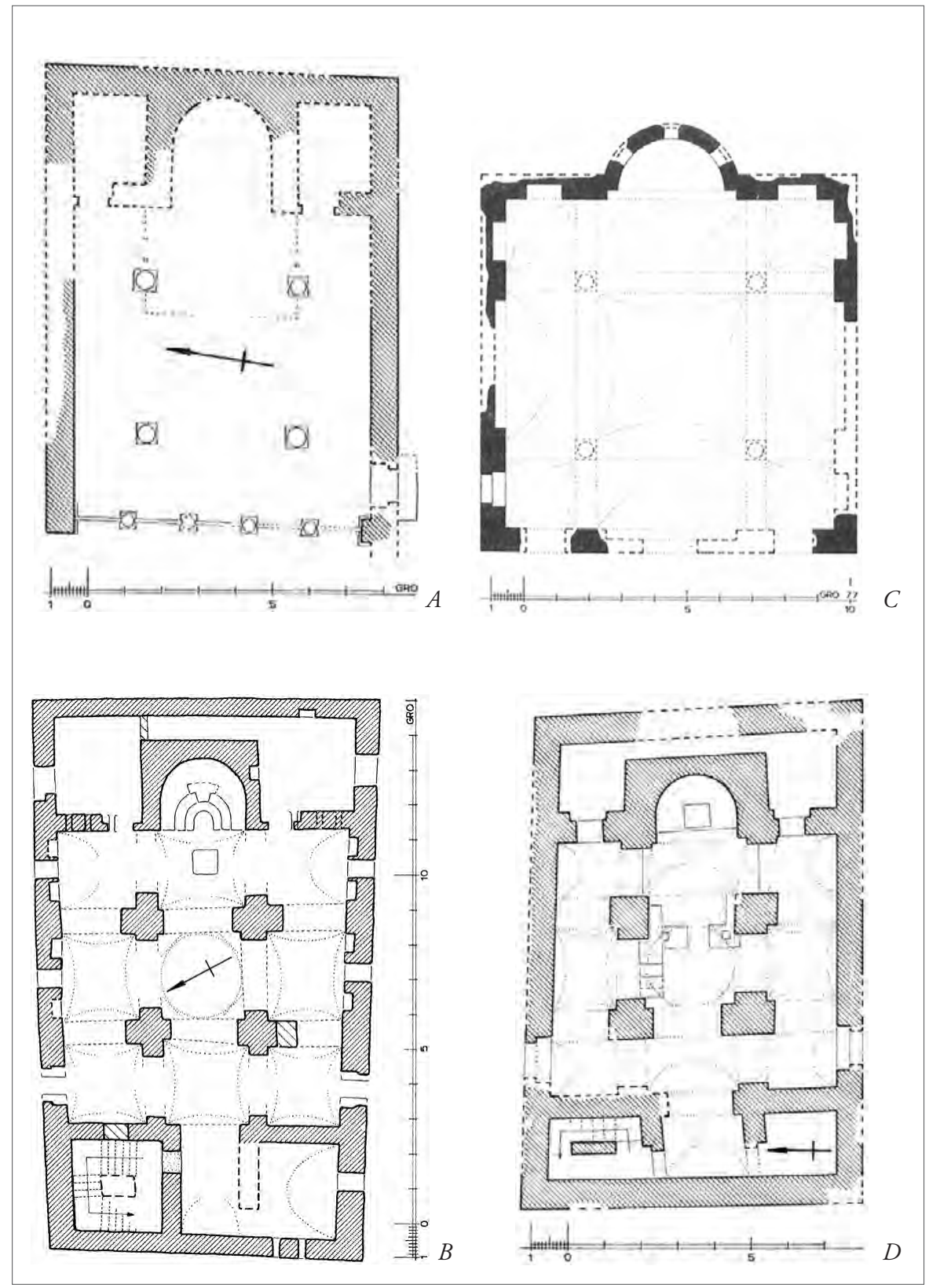

Fig. 2. A-Kapelle am sogenannten Refektorium des Jeremiasklosters bei Saqqara; B - Saalbau aus Ober-Ansinā (Mittelägypten); C - Raphaelskirche von Tamit (Nubien); D - Mit T- und winkelförmigen Pfeilern ausgebildete Nordkirche von Abdallah Nirqi 
An zweiter Stelle seien hier die Kirchen genannt, die dem byzantinischen sog. cross-in-square-Typus nahestehen. Auch unter diesem Typus gab es mit Winkelpfeilern ausgestattete Beispiele. Doch von diesen wurde durch die Ausrichtung der Pfeilerschenkel nicht ein inneres, etwa quadratisches Zentrum umschlossen, sondern die ausgreifenden inneren Schenkel dieser Pfeiler wiesen umgekehrt jeweils in die Gegenrichtung nach außen, womit sie einen eventuell zunächst vorstellbaren Umgang um ein auch hier vorhandenes zentrales Raumquadrat in den Raumachsen unterbrachen und statt dessen eine gewissermaßen kreuzförmige Raumgestalt aus einem größeren Gesamtraum herausschnitten. Charakteristische Beispiele, die auf diese Weise ein eindeutiges Bild über ihre Raumgestaltung vermitteln, sind aus Nubien die einst von einem Shaykh-Grab überbaute Raphaelskirche (Adams Nr. 48) von Tamit (Bresciani 1967: 34f.; Grossmann, in: Deichmann und Grossmann 1988: 38-42, Abb. 19) [Fig. 3:C] und die kleine Nordkirche (auch „Ostkirche“ genannt) von Abdallah Nirqi (Hajnóczi 1974: 360f. Abb. 8; sowie Barkóczi und Salomon 1974: 314, Abb. 49; s. auch Grossmann 1982: 188f., Abb. 70) [Fig. 3:D] (Adams Nr. 52). Mit gewissen Einschränkungen kann ihnen noch ein Bau mit kreuzförmigen Pfeilern, die Kirche von Madīq (Monneret de Villard 1935: 56, Abb. 47) bei Garf Hussayn (Adams Nr. 22), zugewiesen werden. Die große Mehrheit der Beispiele dieses Typus ist jedoch mit indifferenten, quadratischen Pfeilern ausgestattet, bei denen ohne eindeutige Reste der von den Pfeilern aufgenommenen Gewölbe oder wenigstes auf die Pfeiler Bezug nehmenden Wandvorlagen an den Seitenwänden nicht zu erkennen ist, welchem Typus, ob Umgang oder cross-in-square, sie nun angehören.

Leider hat sich von diesem cross-in-square-Typus in Ägypten abgesehen von dem Saalbau in Ober-Ansinā [Fig. 4] mit bisher unbekannter Stützenstellung - auch in Rudimenten kein einziges eindeutiges Beispiel erhalten. Die grundsätzliche Raumgestaltung kann daher nur auf der Grundlage der nubischen Bauten erfolgen. Am klarsten sind die Verhältnisse in der von einer italienischen Mission unter S. Donadoni freigelegten Raphaelskirche [Fig. 5] von Tamit. Sie war ebenfalls mit kreuzförmigen Pfeilern ausgestattet, von denen allerdings die dem Innern zugewendeten Pfeilerschenkel bedeutend kürzer als die äußeren Schenkel ausgebildet waren und sich damit als untergeordnet erwiesen. Der quadratische Zentralraum trug eine über Ecktrompen konstruierte höher hinaufragende Vollkreiskuppel, während die das Kreuz bildenden, die Zusammengehörigkeit mit dem Zentralraum durch höher hinaufragende Bogen demonstrierenden, seitlichen sowie vorderen und hinteren Kompartimente einfache Hängekuppeln trugen. Die hinteren (östlichen) Eckkompartimente waren schließlich als die unterste Kategorie mit 
quer geführten Tonnenwölbungen, die vorderen (westlichen) wiederum mit flachen Hängekuppeln überdeckt. Die trennenden Bogen der letzteren gegen die jeweiligen Nachbarkompartimente waren tiefer gezogen also die übrigen Bogen, wodurch die untergeordnete Bedeutung dieser Raumkompartimente zusätzlich verdeutlicht wurde. Alles übrige dieser Kirche glich der üblichen Bauweise der Zeit in Nubien.

Sehr klar läßt sich die Gewölbegestaltung aus dem Befund der bereits oben genannten, etwas kleineren Nordkirche von Abdallah Nirqi [Fig. 3:D] erschließen, die von einer ungarischen Mission freigelegt und publiziert wurde ${ }^{8}$, und von der sich leider nur die Grundmauern erhalten haben (Hajnóczi 1974: Taf. 43, 1). In der Mitte befand sich aller Wahrscheinlichkeit nach wiederum eine das Zentrum betonende Vollkreiskuppel, während es sich bei den tragenden Stützen um im Querschnitt T-förmige Pfeiler handelte. Die Gewölbe über den Kreuzarmen könnten mit Hängekuppeln oder Tonnenwölbungen überdeckt gewesen sein, während alle vier Eckkompartimente wegen derer äußerst schmalen zur Verfügung stehenden Ausdehnung wohl sämtlich mit schmalen Tonnengewölben überdeckt gewesen waren. Typologisch könnte schließlich auch die mit kreuzförmigen Pfeilern ausgestattete Kirche von Madīq (s. Grossmann 1990: Abb. 3, Nr. 22; sowie Monneret de Villard 1935: 56, Abb. 47) (Adams Nr. 22) diesem Typus zugewiesen werden, von der sich freilich nur das hintere (westliche) Pfeilerpaar erhalten hatte.

Die übrigen Beispiele dieses Typus (Grossmann 1990: Abb. 3), die noch Reste von auf die Innenpfeiler Bezug nehmenden Wandpfeilern aufweisen und damit mehrheitlich mit kreuzförmigen Innenpfeilern zu ergänzen sind, bzw. sogar noch Reste der einstigen Gewölbe bewahrt haben, zeichnen sich durch eine strenge Uniformierung aller Raumkompartimente aus, wodurch ihnen die räumliche Spannung und Differenzierung der einzelnen Raumkompartimente weitgehend abhanden kam. Typologisch gleichen sie bereits sehr den vermutlich aus letzteren hervorgegangenen neuzeitlichen Neunkompartimente-Kirchen und wurden damit von uns als „Hallenkirchen“ klassifiziert. Allenfalls mag noch das Zentrum durch eine höher hinaufragenden Kuppel betont worden sein. In neuerer Zeit wurden dann auch alle Kompartimente mit Vollkreiskuppeln überdeckt, womit der letzte Rest an räumlicher, nach baukünstlerischen Gesichtspunkten gestalteter Gliederung verloren ging. Bauten dieser Art kennt auch die islamische Baukunst (Grossmann 1982: 219-222, Abb. 85). Es ist daher nicht unwahrscheinlich, daß diese Entwicklung durch Einflussnahme aus der islamischen Architektur ihren Anfang genommen hat.

8 S.o. Anm. 7. 
Auch wenn die nubischen Vierstützenbauten durch den großen Stausee südlich von Aswan fast alle verloren gegangen sind, so wurde doch durch die Ergebnisse der von der UNESCO angeregten archäologischen Erforschung dieser Bauten ein nicht überschätzbarer wissenschaftlicher Schatz gewonnen, der noch keineswegs vollständig ausgewertet ist. Darüber hinaus bilden diese nubischen Vierstützenbauten einen Ersatz für das, was es einst auch in Ägypten gegeben hat, aber in der Vergangenheit durch Unachtsamkeit oder mutwillige Zerstörung verloren gegangen ist und zerstört wurde.

\section{Bibliographie}

Adams, W.Y. (1965). Architectural evolution of the Nubian Church, 500-1400 A.D. Journal of the American Research Center in Egypt, 4, 87-139

Adams, W.Y. (2009). The churches of Nobadia [=Sudan Archaeological Research Society Publications 17; British Archaeological Reports International Series 2000]. Oxford: Archaeopress

Barkóczi, L. und Salomon, A. (1974). Abdallah Nirqi 1964. Archaeological investigation of the settlement town "A." Acta Archaeologica Academiae Scientiarum Hungaricae, 26, 289-338

Bénazeth, D. (2010). Nouvelles campagnes de fouilles à Baouit $(2005,2006)$. In A. Boud'hors und C. Louis (Hrg.), Études coptes XI: treizième journée d'études (Marseille 7-9 juin 2007) (pp. 17-24). Paris: De Boccard

Bénazeth, D. (2013). L'église de l'archange Michel à Baouit. Journal of Coptic Studies, $15,3-20$

Bresciani, E. (1967). Le chiese. In Tamit (1964). Missione archeologica in Egitto dell'Università di Roma (pp. 27-37). Rom: Istituto di Studi del Vicino Oriente

Deichmann, F.W. und Grossmann, P. (1988). Nubische Forschungen [=Archäologische Forschungen 17]. Berlin: Gebr. Mann

Grossmann, P. (1980a). Elephantine II. Kirche und spätantike Hausanlagen im Chnumtempelhof. Beschreibung und typologische Untersuchung [=Archäologische Veröffentlichungen 25]. Mainz am Rhein: Philipp von Zabern

Grossmann, P. (1980b). Reinigungsarbeiten im Jeremiaskloster bei Saqqara: Dritter vorläufiger Bericht. Mitteilungen des Deutschen Archäologischen Instituts Abteilung Kairo, 36, 193-202

Grossmann, P. (1982). Mittelalterliche Langhauskuppelkirchen und verwandte Typen in Oberägypten: eine Studie zum mittelalterlichen Kirchenbau in Ägypten [=Abhandlungen des Deutschen Archäologischen Instituts Kairo, Koptische Reihe 3]. Glückstadt: J.J. Augustin 
Grossmann, P. (1990). Typologische Probleme der nubischen Vierstützenbauten. In W. Godlewski (ed.), Coptic studies: Acts of the Third International Congress of Coptic Studies, Warsaw, 20-25 August, 1984 (pp. 151-160). Warschau: PWN

Grossmann, P. (2002). Christliche Architektur in Ägypten [=Handbuch der Orientalistik 62]. Leiden: Brill

Hajnóczi, G. (1974). Abdallah Nirqi 1964. Architectural characteristics of the settlement and buildings. Acta Archaeologica Academiae Scientiarum Hungaricae, 26, 339-368

Monneret de Villard, U. (1935). La Nubia medioevale I. Kairo: Institut français d'archéologie orientale 



\title{
The burning of a monastery? Story blazed on the walls of monastic buildings at Nekloni (Naqlun)
}

\author{
Szymon Maślak \\ Polish Centre of Mediterranean Archaeology, University of Warsaw \\ szymonmaslak@uw.edu.pl
}

\section{KeYwords}

Nekloni (Naqlun), monastery, fire, burnt walls, medieval, conflagration

\section{Abstract}

The walls of a late antique-medieval monastic complex at Nekloni (Naqlun) spreading on a plateau at the foot of Gebel al-Naqlun in the southeastern Fayum Oasis bear evidence of damage or destruction by fire. The extent of this conflagration is one issue to be considered: evident clusters of burnt walls are concentrated around the landmark Building A with more dispersed traces of burning to the south and north of it. Another issue is the date of this event, which the present author places closer to the end of the 10th or in the first decades of the 11 th century. The monastery burned down at the very heyday of its existence, this prosperity attested by a collection of gold coins as well as pieces of decorated codices recovered from the ruins, giving a date prior to the 11th century. Whatever the reason for this conflagration, it did not put an end to the existence of the monastic community in this area. Soon after that some of the monastery buildings were rebuilt, and others, like the main church, were refurbished and repainted.

The medieval monastery at Nekloni (Naqlun) burned down at the heyday of its existence. There can be no doubt about it. The walls of the main complex bear evidence of burning of varying intensity and this evidence has been analyzed in this article in a broader archaeological context to bring out its significance for a general understanding of the history of this monastic complex. 
Medieval Nekloni (Naqlun), known in modern Arabic as Dayr al-Malāk Ghubriyāl, lies approximately $16 \mathrm{~km}$ southeast of Medinet el-Fayum, $3 \mathrm{~km}$ by road and about $1.4 \mathrm{~km}$ as the bird flies from the Bahr el-Gharaq canal. This canal separates the cultivated fields of Fayum Oasis from the desert and the low hills called Gebel el-Naqlun. Both the hills and an extensive plateau sloping down westward to the canal were inhabited by anchorites from about the mid-5th century. ${ }^{1}$

The monastic settlement, which is the main topic of this paper, was spread on the upper plateau from north to south, along the hills to the east. The complex included the church of the Archangel Gabriel and surrounding buildings, located directly to the west of this plateau [Fig. 1]. This area started to be occupied at the turn of the 5th or at the beginning of the 6th century (Godlewski 1990: 33; 1993b: 183; 2005b: 157, 160; 2008b: 71, 74; 2008c: 101; 2010: 230; 2012b: 138; 2012c: 475). The architecture on the upper plateau developed gradually, from a hermitage consisting of Buildings $\mathrm{A}, \mathrm{AA}$, and $\mathrm{J},{ }^{2}$ into a vast and elaborate monastic settlement (Godlewski 2014a: 173). Successive phases of development cannot be distinguished with certainty. However, traces of burning are clearly discernible throughout the upper plateau. Evidence of this burning is present with varying intensity on many walls. A fire consumed different parts of the settlement, and temporally interrupted architectural development. There is no doubt that this happened at the heyday of the medieval monastery's existence.

The author has been recording these burnt traces meticulously ever since joining the Polish Centre's excavation project directed by Włodzimierz Godlewski in 2000. The present article is the outcome of many long and often heated discussions on this and related subjects, and owes much to the Professor's suggestions concerning both published and unpublished material. It is offered in gratitude for the years of working together, for his continuous support and for shaping me as a researcher independent in my thinking even if not free of error.

1 For an updated topography of the site, see Godlewski 2010: 230, Fig. 1; 2012b: 138; 2012c: 475. For information on the hermitages on the lower plateau and in the hills, see Godlewski 1993b: 184-188; 1999b: 157-158; 2000c; 2005b: 157-160, 169; 2007b: 173-174; 2008a: 198-205; 2008b: 71-75; 2008c: 102-106, Figs 3-4; 2010: 232-240; 2012b: 138; 2015: 130-131; Godlewski and Czaja-Szewczak 2000: 69-77, Figs 1-6; and especially Godlewski 2012c, all with further references.

2 For the identification of this hermitage, see Godlewski 2014a: 173; 2015: 131. 


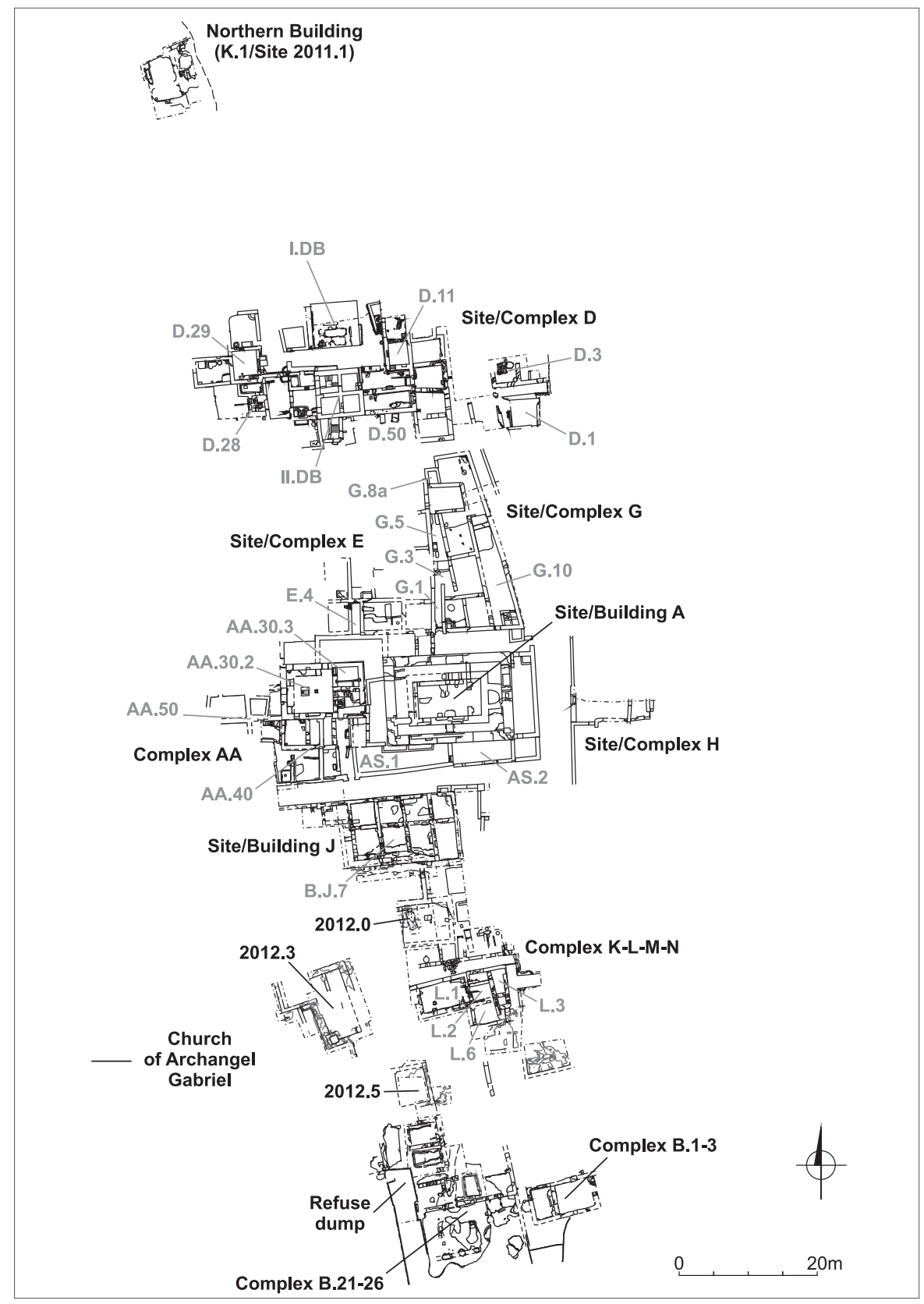

Fig. 1. Plan of the monastic architecture on the upper platean

(Drawing J. Dobrowolski, W. Godlewski, D. Zieliniska, S. Maślak (C PCMA) 


\section{Review of burning traces in the monastic buildings}

Smoked or heavily burned walls were discovered all over the upper plateau, scattered in different areas as well as clustered together, the severely burned parts often in close proximity to wall faces untouched by the fire. There is no doubt that the central part of the monastery was devastated by a conflagration of considerable proportions. The fire spread to the southern part of Building A as well as to Building(-s?) E further to the northwest, complex AA to the west and Buildings I and J to the south (Godlewski 2000b: 78). But were all these burnt buildings and single walls in other parts of the monastic settlement destroyed in the same cataclysm and at the same time?

\section{Northern Building (K.I/Site 20I I.I)}

The surviving architecture is reduced to a large section of floor burned in its central and southern parts (Godlewski 2014a: 183, Fig. 12; see also Godlewski 2011b) [Fig. 2]. Traces of burning and a layer of ash (Danys-Lasek 2014: 589)

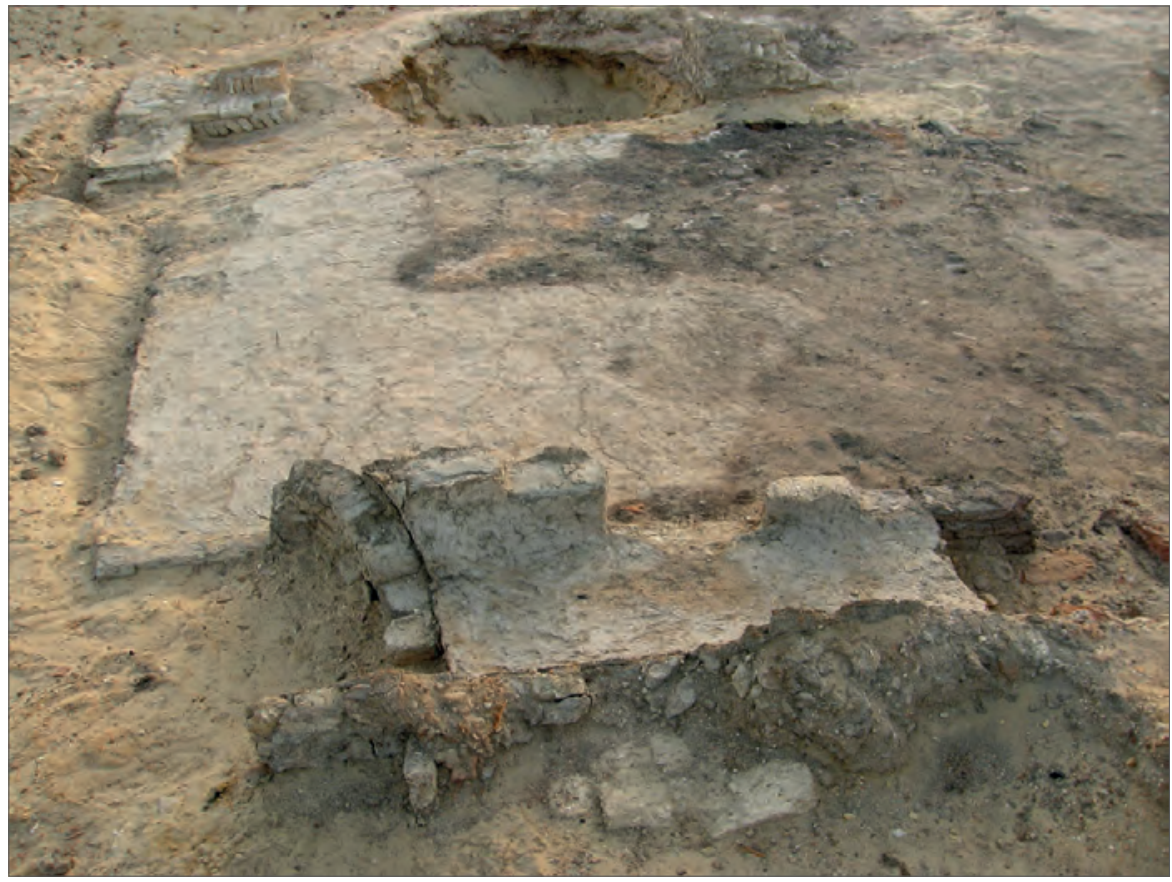

Fig. 2. Floor remains in the Northern Building (Site K.1) with burnt surface to the right, view looking southeast (Photo W. Godlewski (C) PCMA) 
extended in three directions at least (probably not to the north), reaching beyond the vestiges of walls and their "ghost foundations" into adjacent, still unexcavated areas. The peculiar vessel assemblage found directly on the floor contained LR NAQLUN 11 amphorae and huge basins with a white residue on the inner walls (Danys-Lasek 2014: 589-593). It may well be proof of lime and/ or gypsum production on the spot (Danys-Lasek 2014: 589-593, especially 593). The workshop evidently ceased operations owing to the fire. The pottery from Sector K.1 can be dated to the mid-9th century or even later, to the middle of the next century (Danys-Lasek 2014: 593, 638). Other finds from the site confirm a 10th century time horizon (Godlewski 2014a: 187).

\section{Site/Complex D, eastern part (Rooms D.I-D.4)}

Destruction by fire is also evident in the easternmost excavated sections of Site D (Rooms D.1-D.4) (Godlewski, Herbich, and Wipszycka 1990: 189; Godlewski, Derda, and Górecki 1994: 212). ${ }^{3}$ The walls here were burnt severely and the rooms were filled with a thick rubble deposit comprising sun-dried bricks along with large amounts of ash, burnt straw included (Godlewski, Derda, and Górecki 1994: 212).

The pottery from these rooms fails to set a precise date for the period of their final occupation and hence destruction. Vessels from the occupation level ${ }^{4}$ in Room D. 1 have been dated rather broadly, from the mid-8th to the mid-12th century (Godlewski, Derda, and Górecki 1994: 226-227, 228). Circular depressions with lining in neighboring room D.3 yielded material of greater use. ${ }^{5}$ Several potsherds (including glazed ware) pressed into this lining have suggested a time from the 9th to the end of the 11th century for their original use (Godlewski, Derda, and Górecki 1994: 228-231). Their discovery just below a thin top layer of windblown soil (Godlewski, Derda, and Górecki 1994: 228) suggested not only that they must have belonged to the last occupation phase in this area, but that they could be considered most certainly as proof of reoccupation after the fire. Vessels from another group (mostly amphorae?), found in the easternmost

3 Some ceramics and glasses found in the fill overlying this part of Site D have suggested that the conflagration of surrounding walls occurred in the Mamluk period (see Godlewski, Herbich, and Wipszycka 1990: 189). It is more likely, however, that these artifacts were deposited in the already abandoned and partly ruined structures, rather than in contexts preceding or contemporaneous with the conflagration (see Godlewski, Derda, and Górecki 1994: 226, 228).

4 In fact, there were two recognized occupation phases in Room D.1 (Godlewski, Derda, and Górecki 1994: 212, 214). The second one corresponds to the cessation of all activities due to a violent fire (see Godlewski, Derda, and Górecki 1994: 212).

5 For information on these depressions and their function, see Godlewski 1990: 33; Godlewski, Derda, and Górecki 1994: 214, 228. 
part of Site D, were produced presumably in the 11th-12th century (Godlewski 1990: 33). An ostrakon with a Coptic letter, discovered in Room D.1, confirms an earlier date (9th-11th century) for the latest activity in these units (Godlewski, Derda, and Górecki 1994: 215-216, 228).

Site/Complex D, central part (Rooms D.5-D.i 8, D.20, D.40, D.42-D.43, AND D.50, INCluding Towers I. AND II.DB)

Traces of fire in the central rooms of Complex D were more dispersed. The bottom sections of walls in rooms D.5 and D.8 were severely burnt [Figs 3-4]. Spots of fire were revealed also on the sandy floor levels in the form of patches of black ash, overfired sand, and a few pieces of charred palm wood. The finds from the rubble filling room D.8 included a few pieces of charred jarids and rush.

The pottery from rooms D.5-D.7 and the area between them and Rooms D.1-D.3, from the 8th to 12th century, is likely to be entirely secondary (Godlewski, Derda, and Górecki 1994: 231), although it is hard to believe that nothing remained in place from the last occupation. The ceramics from the fill of Room D.9, including a few glazed wares, originated from the 11th and 12th centuries (Godlewski 1992: 51). A piece of Coptic ostrakon from the fill of Room D.1, dated to the 9th-11th century, was found here as well (Godlewski, Derda, and Górecki 1994: 215-216, 228). Fragments of painted plaster from the same rubble, doubtless part of the decoration from the upper story rooms, may be attributed on stylistic grounds to the 11th or 12th centuries (Godlewski 1990: 33; 1993b: 189; 2007b: 175; 2008b: 76; Godlewski, Derda, and Górecki 1994: 215-216).

The extant faces of walls in Room D.50 seem not to have been affected by the fire (see Godlewski 2014b). However, there is some evidence of burning in the rubble fill overlying the floor. Many sun-dried and baked bricks in this deposit were damaged by smoke and/or had been burnt. There were also numerous irregular limestone tiles, certainly from the floors of the upper level(s), their upper surfaces bearing a thin greasy black coating [Fig. 5]. Accompanying this were brown-orange stains on the same surfaces, on the edges and sometimes even on the bottom sides. These were most certainly traces of a liquid organic substance, which had penetrated between the tiles while warmed to a high temperature and then solidified after cooling. Other finds from the rubble, such as gypsum window grilles, had soot inside the ventilation holes and sometimes around them on the outer surfaces of the grilles [Fig. 6].

Rooms further to the west displayed few traces of burning. Smoke damage to the wall faces was recorded in the interior of Room D.43 [Fig. 7], east of staircase D.42, and in the northeastern corner of Tower II.DB (Room D.14), 
The burning of a monastery?...

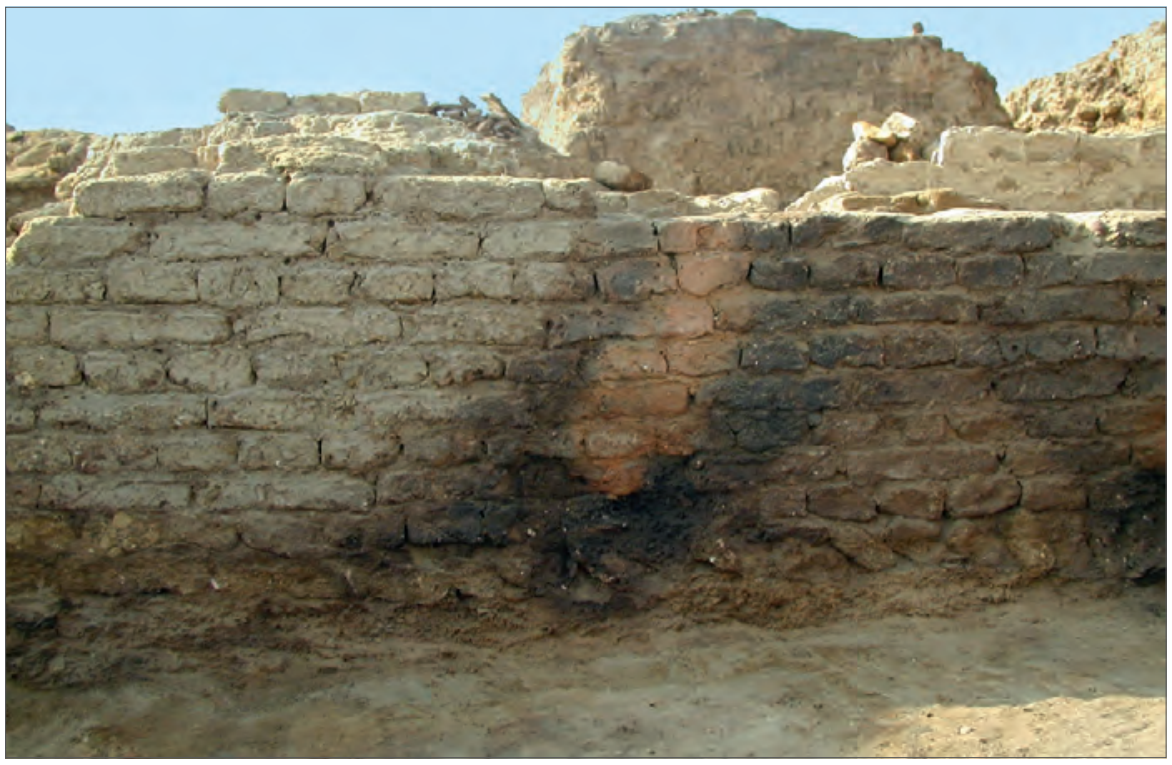

Fig. 3. Burnt patch on the northern face of the south wall of Room D.8, view looking southwest (Photo W. Godlewski (C PCMA)

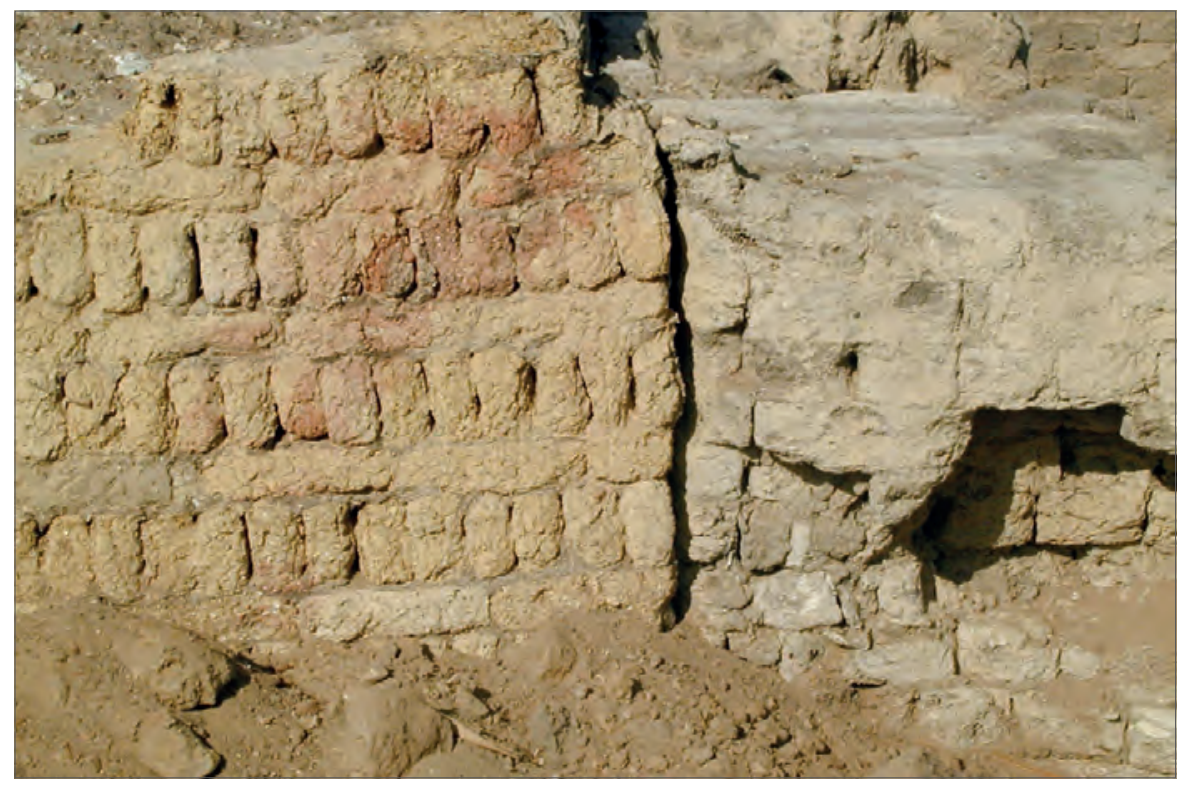

Fig. 4. Traces of burning on the eastern face of the west wall of Room D.8, looking west (Photo W. Godlewski (C PCMA) 


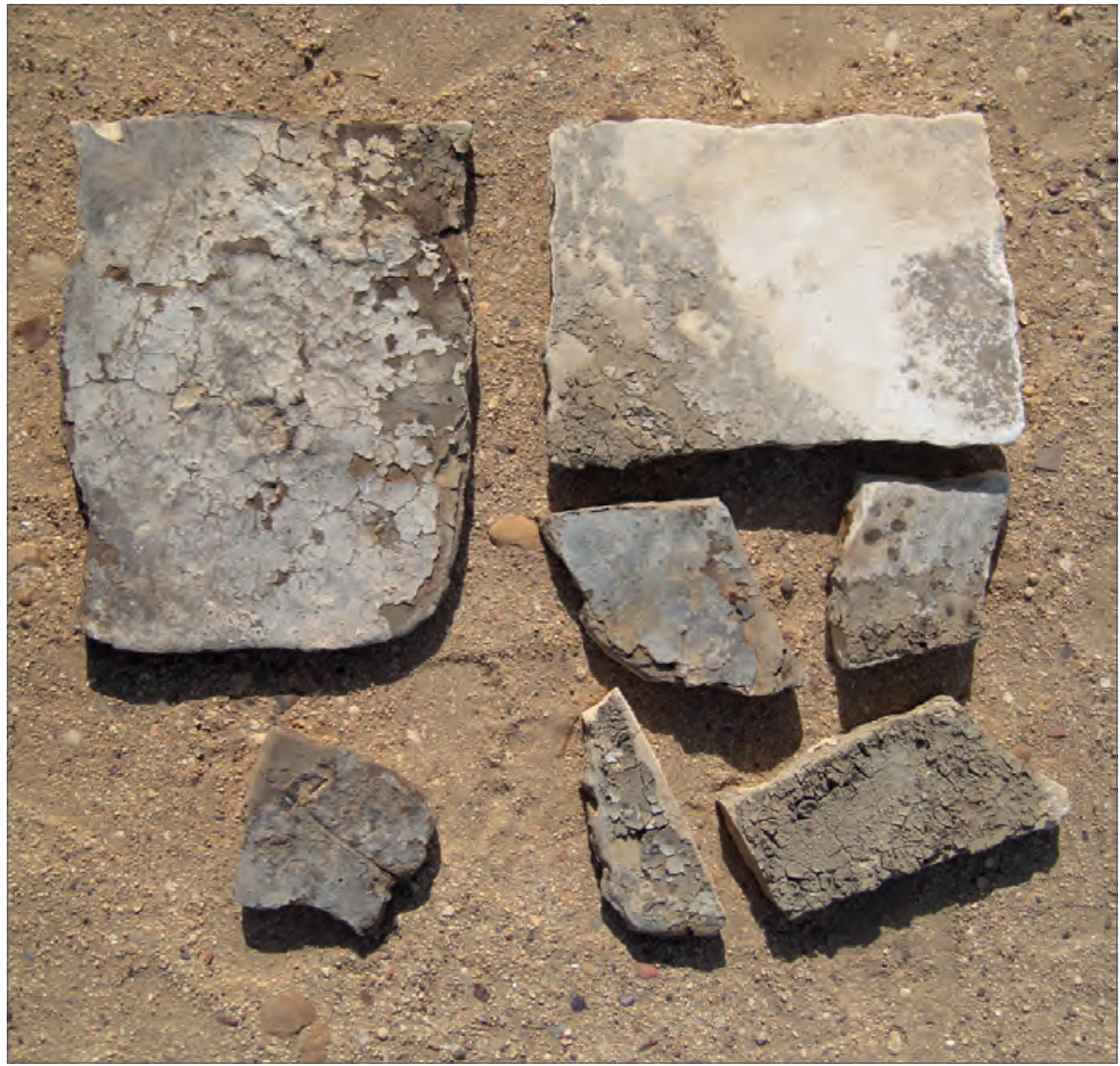

Fig. 5. Traces of a burnt substance on tiles retrieved from the fill of Room D.50 (Photo S. Maślak (C) PCMA)
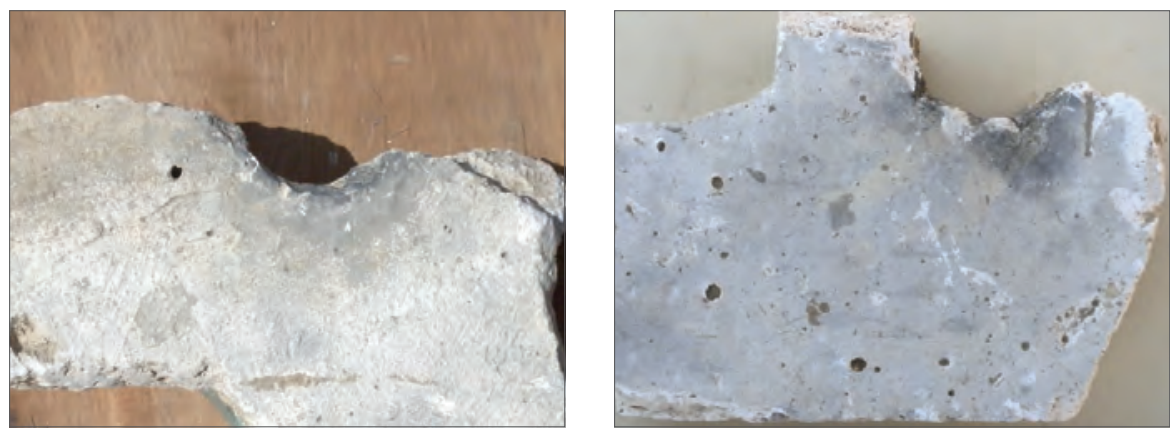

Fig. 6. Smoked ventilation holes in window grills retrieved form the fill of Room D.50 (Photos W. Godlewski (C) PCMA) 
as well as on the northwestern wall of Room D.10. Save for Room D.14, and a small burnt patch on the outer face of the west wall of Room D.18, none of the walls in Tower II.DB had been damaged by fire. Nothing certain can be said about when and why these structures were deserted. The burning of the tower (D.14) was placed by the excavator tentatively in the early Mamluk period (see Godlewski 1999b: 159). The pottery found in the rubble fill of Rooms D.11-D.15 was likely a secondary deposit (Górecki 1993: 61) (although some of it could represent the last phase of occupation), the date ranging from the 9th to the 12th century (Górecki 1993: 61-64, especially 64). Most of the pottery from the fill in the compartments of Towers I.DB and II.DB should be dated to the 9th-11th century (Górecki 1994: 75). The fill of Room D.9 contained ceramic material from the 11th and the 12th centuries (Godlewski 1992: 51). One of the numismatic finds was a gold dinar (Nd.92.185) minted under one of the Abbasid caliphs (Morisot 2000: 329, Fig. 3), found in Room D.11 outside of a clear burning context. ${ }^{6}$

Site/Complex D, Western PART (Rooms D.i 9, D.2 I-D.33, D.4I, D.44-D.47) The inner faces of the west and north walls of Room D.22 preserved some traces of burning discernible immediately above the floor level, either on the plaster coating or the brick bonding in those places where the plaster is missing. Remarkably, such burning traces are hardly evident on the wall faces in adjacent rooms D.19 and D.21 (east) and D.28 (west), an exception being a burnt patch on the outer face of Room D.18 (Tower II.DB), that is, on the east wall of room D.19. In room D.28 was another gold dinar ( $\mathrm{Nd}$.98.012) lying directly on the floor (Morisot 2000: 329, Fig. 2); it was dated to the reign of the Abbasid caliph al-Mutamid (870-892) (G. Helmecke, personal communication to W. Godlewski).

By contrast, each wall face in rooms D.29 and D.24 (courtyard?), with only a few exceptions, was severely consumed by fire [Figs 8-9]. The fill of Room D.29 contained quantities of over-fired brick rubble and ash (Godlewski 1999a: 116). Traces of burning were also recorded on the inner wall faces of rooms D.41 and D.44, located in the southwestern part of Site D.

The pottery from rooms D.22 and D.24 dates from the 10th to the 12th centuries (Godlewski 1996: 86). Another key category of finds, helpful in providing a date for the destruction of the buildings in Site $\mathrm{D}$, is a group of

6 Attribution Gisele Helmecke from the Staatliche Museen zu Berlin, Museum für Islamische Kunst (W. Godlewski, personal communication); initially, the coin was identified tentatively as being an Ayyubid issue (see Godlewski 1993a: 46). 
texts discovered in the rubble. Several dozen parchment codex leaves written in Coptic, fully or partly preserved, were discovered in Rooms D.19 and D.22 (Godlewski and Parandowska 1994: 58). A time horizon for some of these literary texts was the 9th-10th century (Godlewski and Parandowska 1994: 59). The parchment leaves found in Rooms D.22 and D.24 were written almost exclusively in Coptic (with one bilingual Greek and Coptic leaf) and can be dated to the 9th-10th centuries in general (Godlewski 1996: 86; 1999b: 159). Again, new texts found in Rooms D.21 and D.22 were written in Coptic and included fragments of at least 12 parchment codices (Urbaniak-Walczak 1997: 98). The oldest codices among these may be dated, on paleographic grounds, to the 5th and 6th/7th century (Urbaniak-Walczak 1997: 98-99). Other codices were of a much later date, mostly from the 9th/10th and the 10th, but also from the 11th centuries (Urbaniak-Walczak 1997: 99-102; Godlewski 1999b: 160). Among the texts from other rooms were some codex leaves in Coptic dated precisely by colophons to AD 963-964 and AD 876-877 (van der Vliet 2000: 143).

Documents (including letters), both in Arabic and in Coptic, were also discovered at this location. (Godlewski and Parandowska 1994: 58) One of them, a Coptic letter from the monastery klerikos to Apa Khael, gives a precise date of AD 992 (Godlewski and Parandowska 1994: 59; Godlewski 1999b: 160).

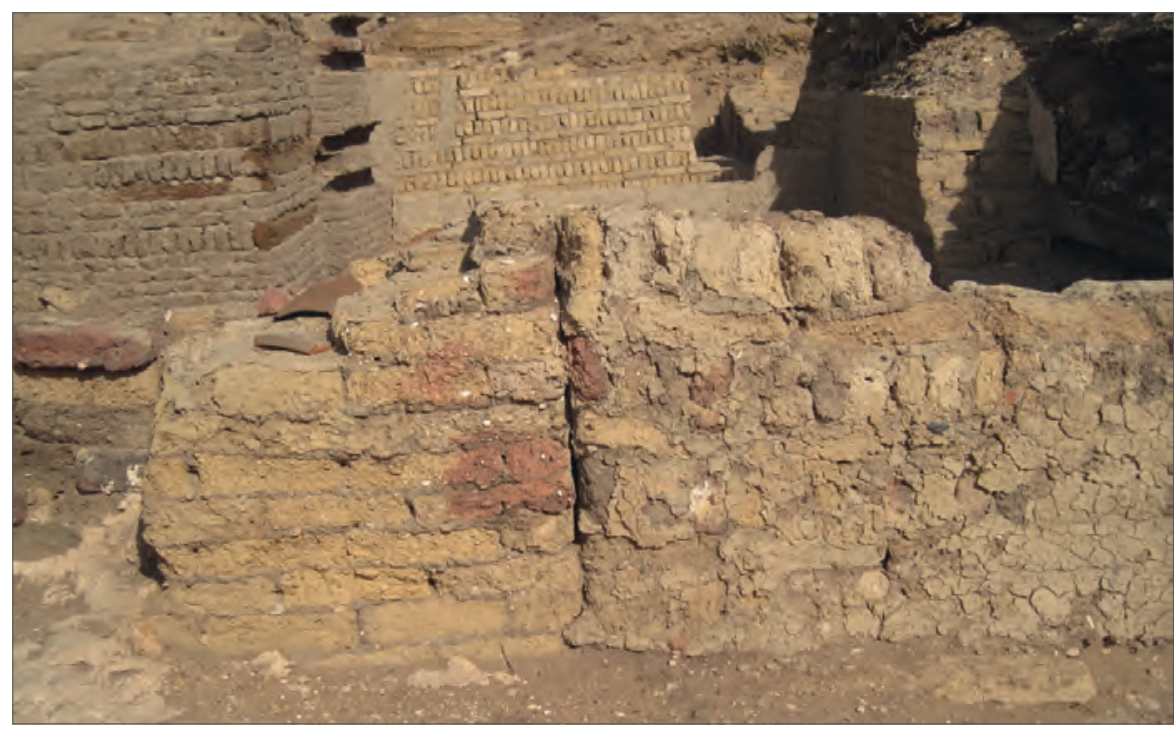

Fig. 7. Western face of wall(s) separating Room D.43 from Room D.50, view looking east (Photo S. Maślak (C) PCMA) 
The burning of a monastery?...

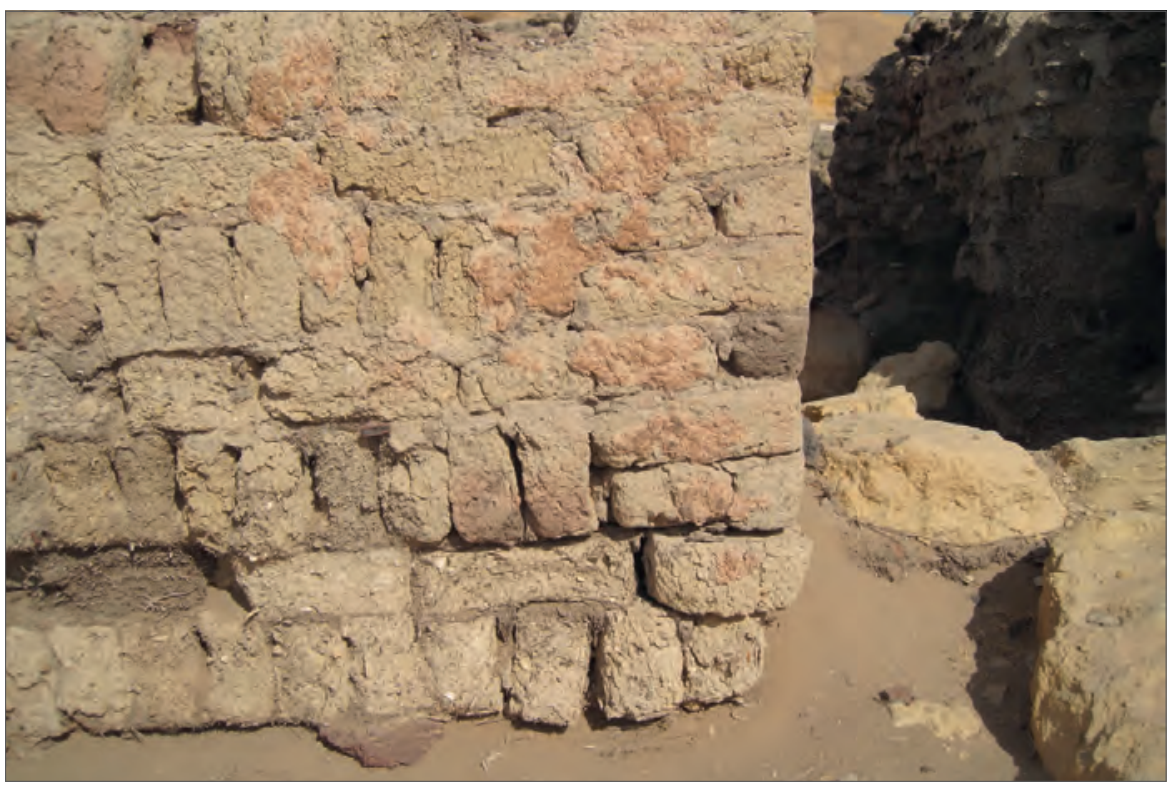

Fig. 8. Traces of burning on the jamb of the eastern entrance to room D.29, view looking southeast (Photo S. Maślak (C) PCMA)

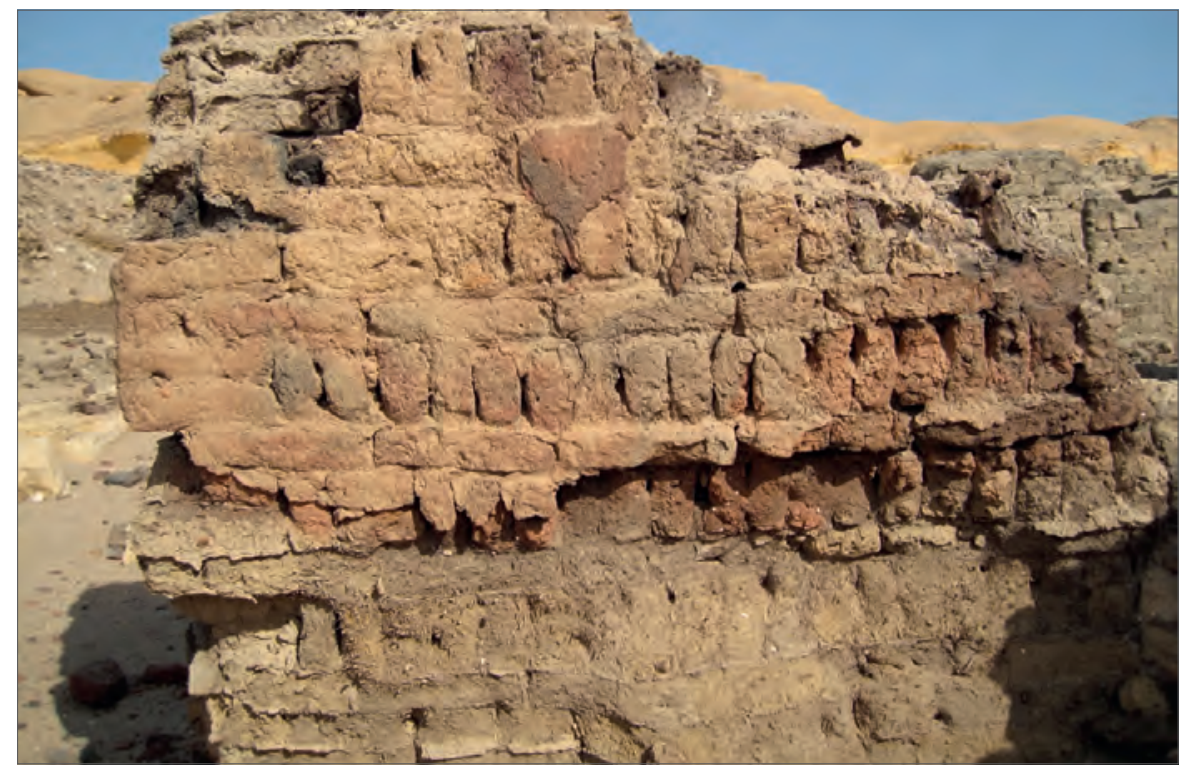

Fig. 9. Burnt western face of the eastern Room (Courtyard?) D.24, view looking east (Photo S. Maślak () PCMA) 
The same date appears on another document, a receipt, from the same spot (van der Vliet 2000: 143; 2015: 164-165). Paleographic analyses, too, suggest "a statistic peak" for the whole group of texts from Site D in and around the 10th century (van der Vliet 2000: 143).

\section{Complex/Site E}

All structures from the original building(s?) on Site $\mathrm{E}$ were destroyed in a violent fire (Godlewski 1998: 83; 1999a: 117; 2001: 153; 2005b: 168; Godlewski and Czaja-Szewczak 2000: 82). Most sun-dried brick (and few baked-brick) walls in this area were burnt right through their thickness. Consequently, a thick layer of ash and burnt rubble covered these wall remains and filled the spaces between them (Godlewski 1999a: 117; 2001: 153; Godlewski and Czaja-Szewczak 2000: 78). A gold dinar (Nd.98.091), discovered in the ashes below the later room E.4, was issued under the caliphate of al-Mutamid (869-892) by a Tulunid governor of Egypt, Khumārawayh ibn Ahmed (884-896) in the year 891/892 (Godlewski 1999a: 117; 2001: 153; Morisot 2000: 328-329, Fig. 1). ${ }^{7}$ It has provided a terminus post quem for the conflagration in the building(s?) on Site E.

\section{Complex/Site G}

As with the building complex on Site D, Building G was extended by gradually adding new walls to already existing structures (cf. Godlewski 1992: 50). Certainly its final layout was established after the huge conflagration on the neighboring Site E. Along with new buildings on Site E and Church A to the south, it functioned as a single combined architectural complex (Godlewski 2000a: 128, 130; 2001: 161; 2003: 165; 2004: 147; 2005b: 166, 168, 169; 2005c: 173; 2012b: 140; Godlewski and Czaja-Szewczak 2000: 82, 83; Żurek 2000: 134). ${ }^{8}$ Nevertheless, it is fairly certain that at least some parts of Building $G$ must have been raised apparently before the original walls on neighboring Site $E$ were consumed by fire.

Few traces of burning have been documented in Building G. There are two minor burnt patches in the southwestern corner of the building. One is discernible at the southern end of the original wall that confined corridor G.1 on the east. Another patch was discovered on the street side of the south wall of the building [Fig. 10]. As is evidenced by the structural rearrangements of these two walls, they obviously preceded all the nearby parts of Building G.

7 Initially dated to the 10th century AD (Godlewski 2000a: 130; Godlewski and CzajaSzewczak 2000: 78).

8 The new Building E was probably erected in the 11th century (Godlewski 1999a: 117; 2001: 150); likewise Church A (Godlewski 2005b: 169). Building G being contemporary to these structures, it should share their dating as well. 
More problematic is a fairly long section of the west wall of the building [Fig. 11]. In fact, from a structural point of view, this wall is the east wall of a building, called Structure 100, which once occupied the northern part of Site E (Maślak 2007: 218) and which has yet to be excavated. A fragment of this wall in room G.3 and the southern part of room G.5 was burned down completely. As is evidenced by its remains, the fire moved from the west, that is, from Site E, and caused no or little damage to the other structures inside Building G (Maślak 2007: 218). The date of this burning is obscure. Apparently, it was the same fire that destroyed the original structures on Site E. On the other hand, it is hard to imagine how a corridor consisting of Rooms G.1, G.3, and G.5 could function afterwards when an extensive part of the building's west wall was in ruins.

The ruins of Building $G$ provided a bulk of texts, both in Coptic and in Arabic (Godlewski 2004: 149, Fig. 9; 2005a: 187, 189, Fig. 9; 2007a: 199, 203, Fig. 7; 2008b: 76; van der Vliet 2005a; 2015). Room G.10 in the eastern part of the building was remarkably rich in this sort of finds (Godlewski 2005a: 187, 189, Fig. 9; 2007a: 199, 203). Regrettably, none of these artifacts was found in a context, which had any relation to the destruction of the original structures on Site E and/or could explain the changes in the layout of Building G. The whole dossier dates generally to the 10th-11th centuries (Godlewski 2004: 149; 2005a: 187; 2007a: 199, 203; van der Vliet 2005a: 191; 2015: 157-166, Pl. 7.1). A few Arabic documents were complete, and have been precisely dated to AD 1013 through 1059 (Godlewski 2007a: 203). They seem to confirm that Building G, or a part of the building, was still in use in the second half of the 11th century and served some sort of administrative functions (Godlewski 2005a: 189; 2007a: 199; 2008b: 75-76; van der Vliet 2015: 157).

Apparently, not all of Building G was occupied at the same time. Small Room G.8a at the northwestern corner of Building G, which probably served as the cesspool of a latrine(?) (Zurek 2007: 219), contained ceramic material confirming its use in the 9th and 10th centuries, but probably not beyond that period (Zurek 2007: 224). More light on the date of the abandonment of this part of Building $\mathrm{G}$ was shed by a hoard of gold dinars (Nd.05.091) found beside room G.8a (Godlewski 2007a: 199, Fig. 3). Whereas the bulk of the coins were minted under the Fatimid caliph al-Muizz (AD 952-976), the issues dating all through his reign from 955 to 976 (Godlewski 2007a: 199), ${ }^{9}$ two were issues of caliph al-Aziz (976-996), struck in the 970s(?) and 980s (Godlewski 2007a: 199). By contrast with the other hoards of gold coins from the Nekloni monastery, these were not found in a burning context.

9 Mistakenly described as Abbasid in Godlewski 2007b: 176; 2008b: 77. 


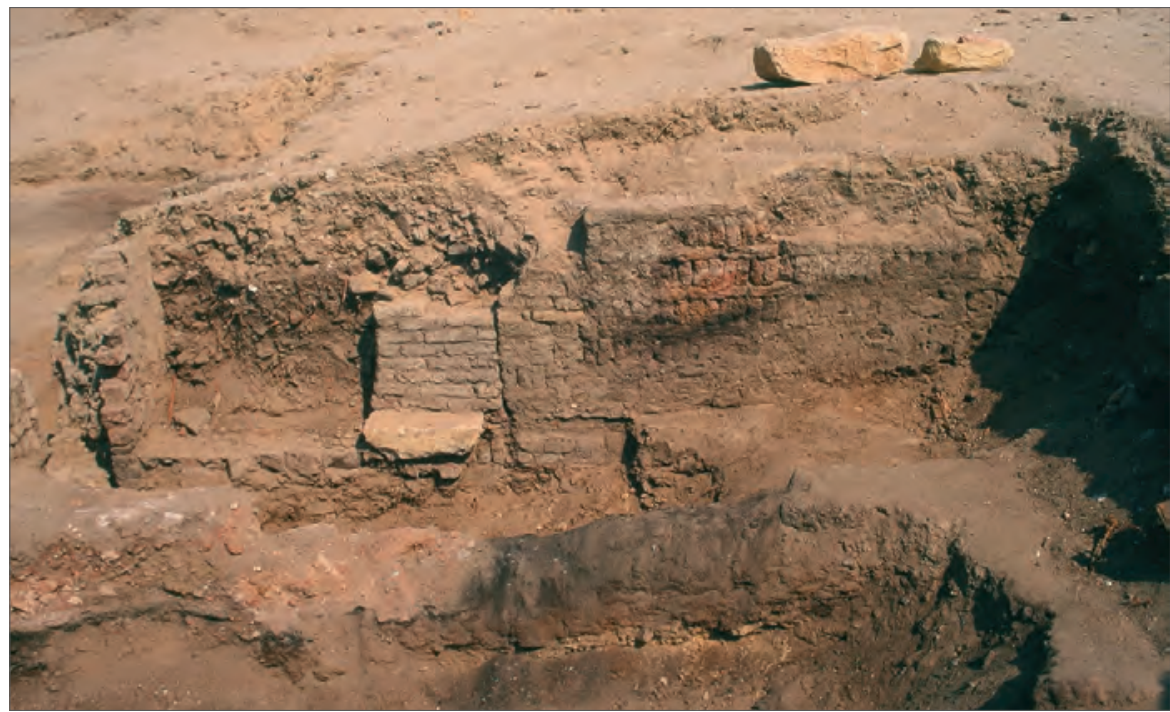

Fig. 10. Southern elevation of Building $G$ with traces of burning and deposits of over-fired rubble on the street in front of it, view looking north

(Photo W. Godlewski (C PCMA)

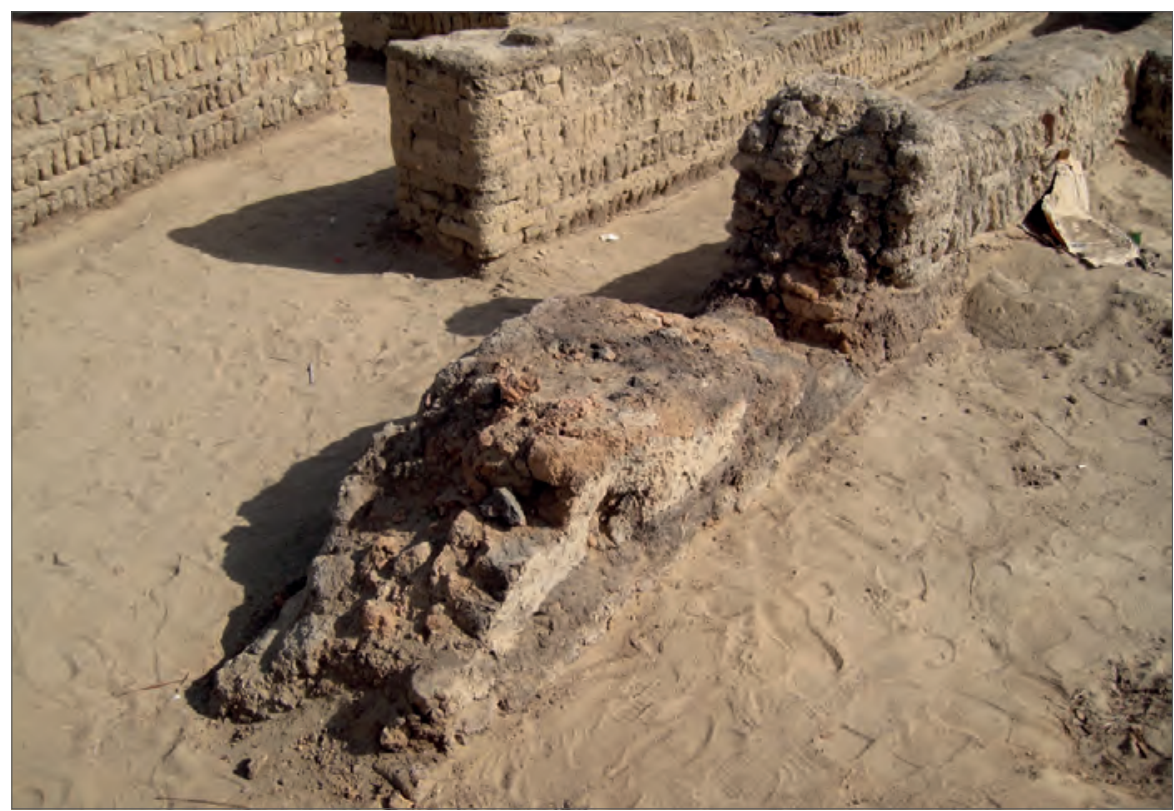

Fig. 11. East wall of Building E (Structure 100)/west wall of Building G, view looking southeast (Photo S. Maślak (C PCMA) 


\section{Site/Building A And Complex AA}

The state of preservation of the walls in Building $\mathrm{A}$ indicated that a major conflagration scorched its south wall (Godlewski 2001: 153; 2005b: 162) and extended to the walls of adjacent rooms AS.1 and AS.2 [Fig. 12]. In 2014, it was found that the walls of room AS.2 were already standing when the fire consumed the building (personal observation by the author). ${ }^{10}$ Immediately to the south of the building, a layer of ash came to light (Godlewski 2001: 153). Surprisingly, the remains of the other outer walls of Building A do not bear considerable traces of burning. Slightly fire-reddened bricks were found only in some of the inner walls in the eastern part of the building.

The walls of Complex AA to the west preserved much more extensive evidence of fire destruction (Godlewski 2001: 153; 2014a: 177). Each wall face inside room AA.30.2 was devastated by the fire (Godlewski 2001: 153; 2002: 164; 2004: 150) [Figs 13-16]. Thick deposits of over-fired and charred brick rubble mixed with ash from burnt reeds were also found in this room (Godlewski 2001: 153; 2002: 164) [Fig. 17]. Surprisingly, the conflagration spared the adjacent room AA.30.3, where no trace of burning was found (Godlewski 2002: 166).

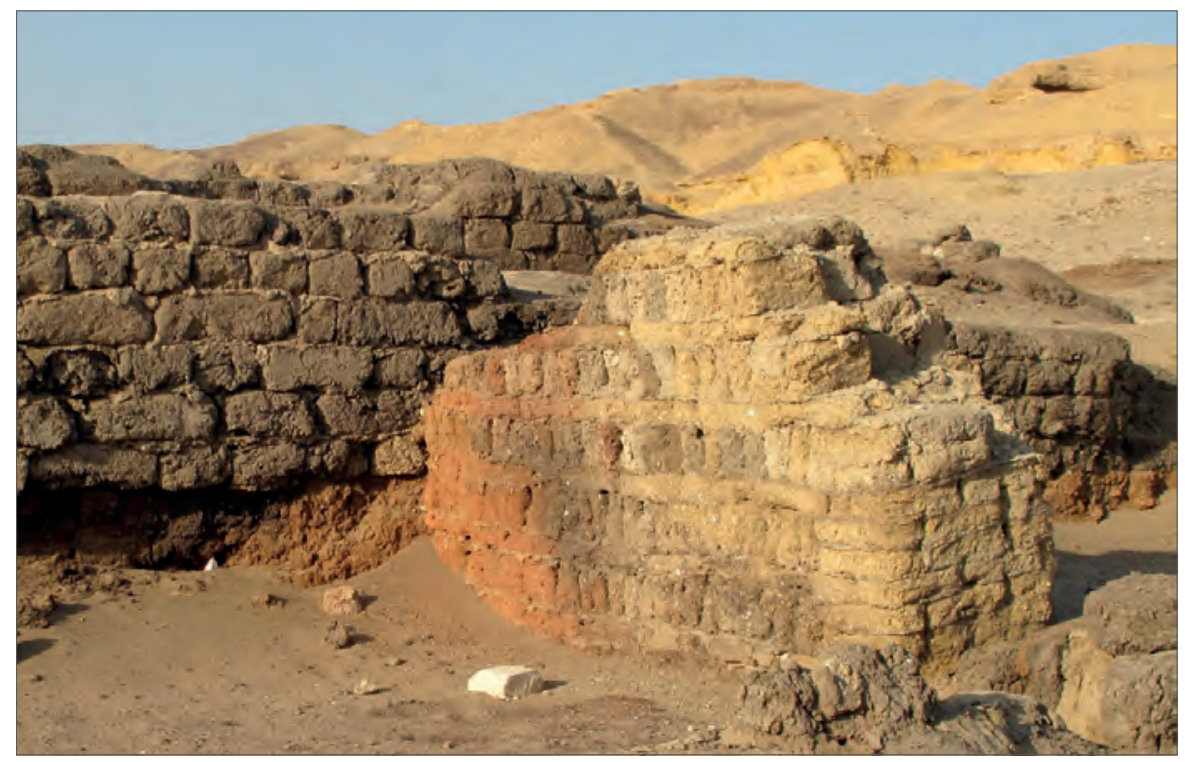

Fig. 12. Eastern wall of Room AS.1 with entirely burnt vestiges of Building A overbuilt by later walls of Church $A$ in the background, looking northeast

(Photo S. Maślak (C) PCMA)

$\overline{10}$ For the previous interpretation, see Godlewski 2003: 165; 2005a: 189. 


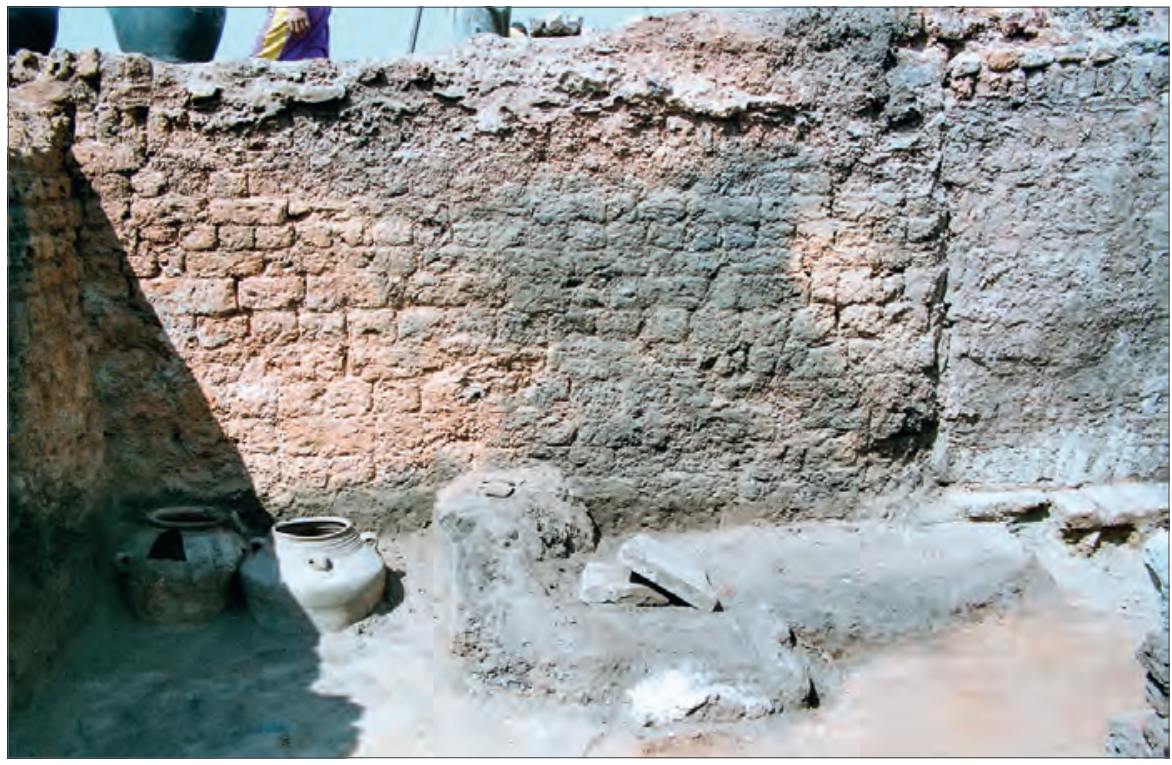

Fig. 13. Southern section of the eastern face of the west wall of Building AA.30, view looking west (Photo W. Godlewski (C) PCMA)

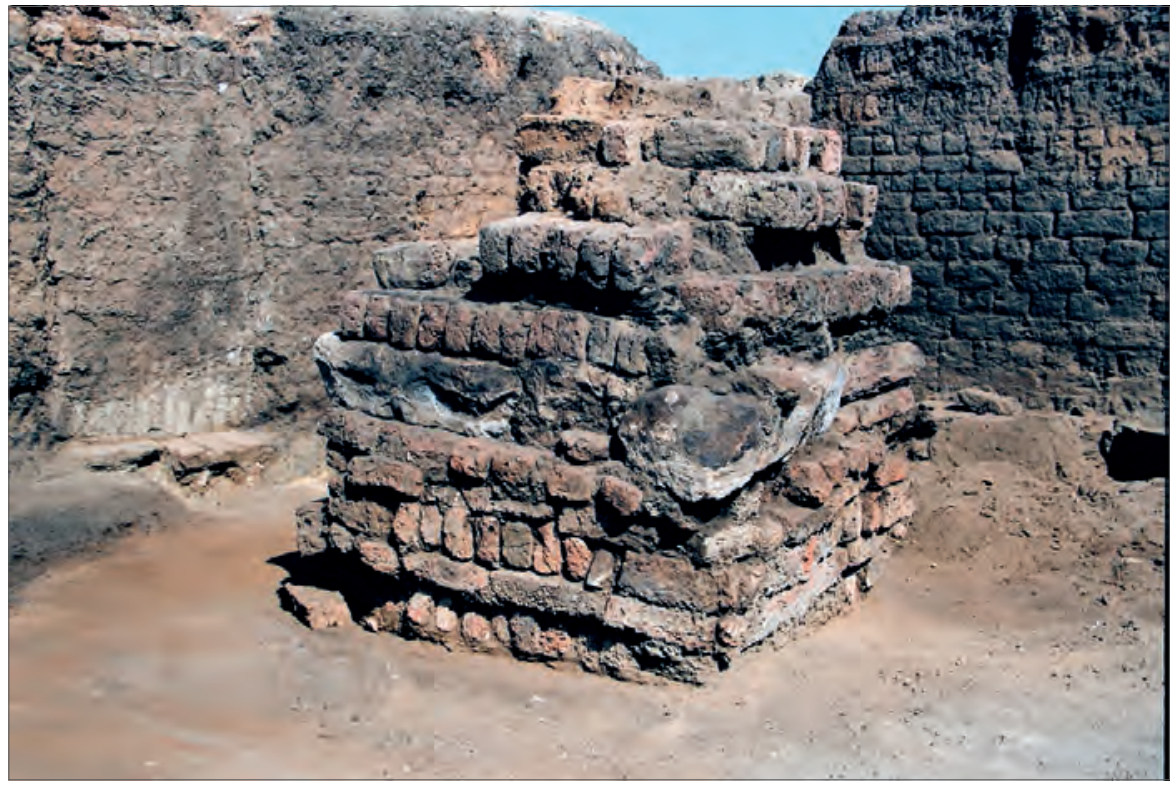

Fig. 14. Pillar structure in the western part of room AA.30.2, view looking northwest (Photo W. Godlewski (C PCMA) 


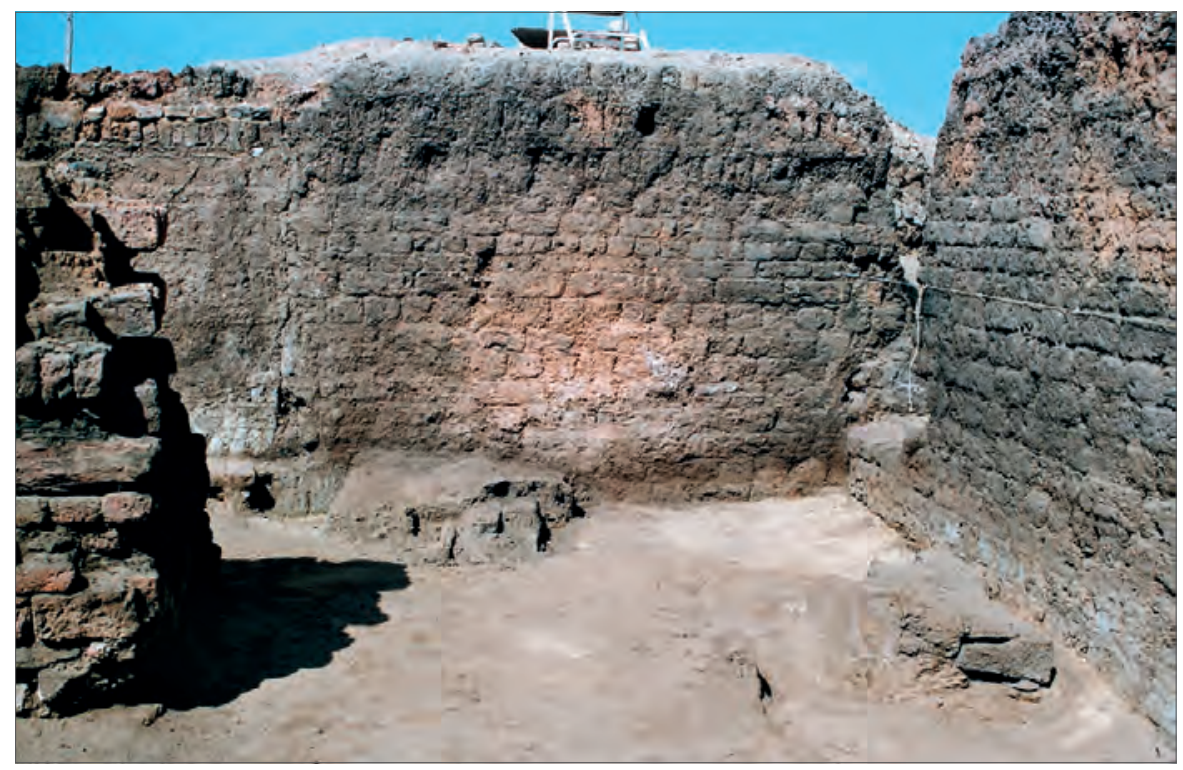

Fig. 15. Northern section of the eastern face of the west wall of Building AA.30, view looking west (Photo W. Godlewski (C) PCMA)

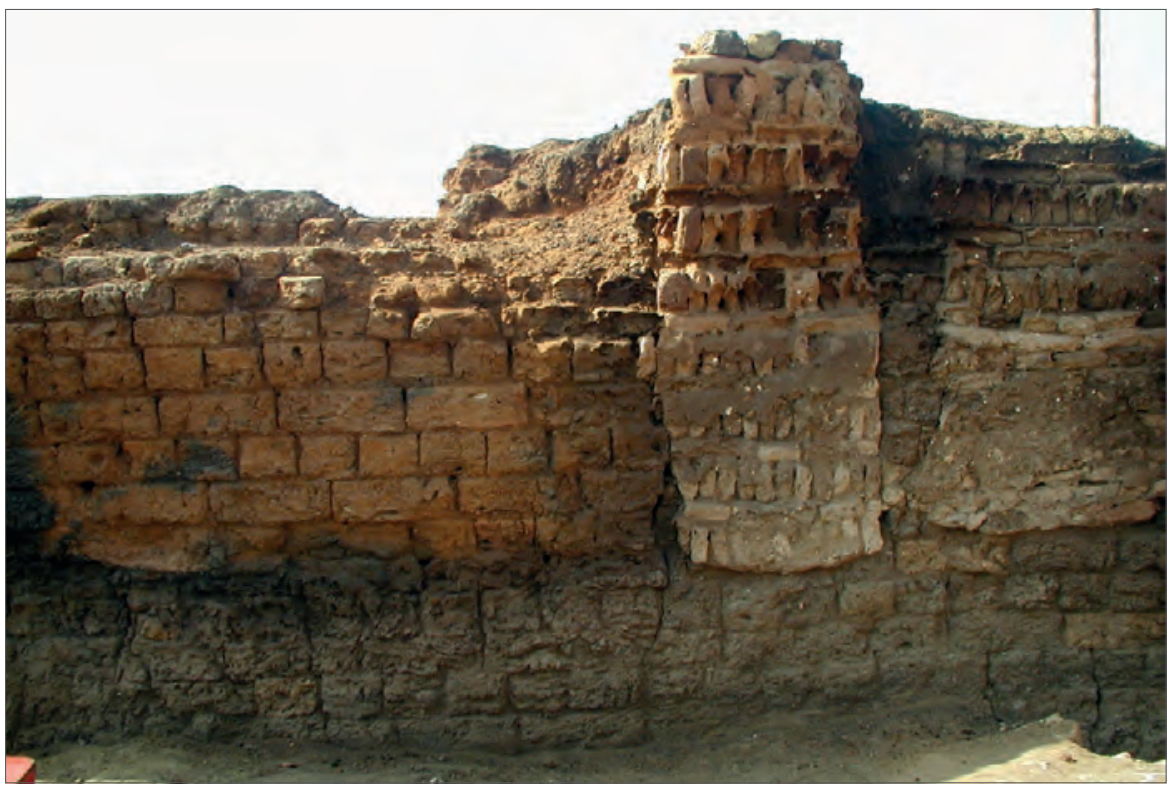

Fig. 16. Middle part of the northern face of the south wall of Room AA.30.2, view looking south (Photo W. Godlewski (C) PCMA) 


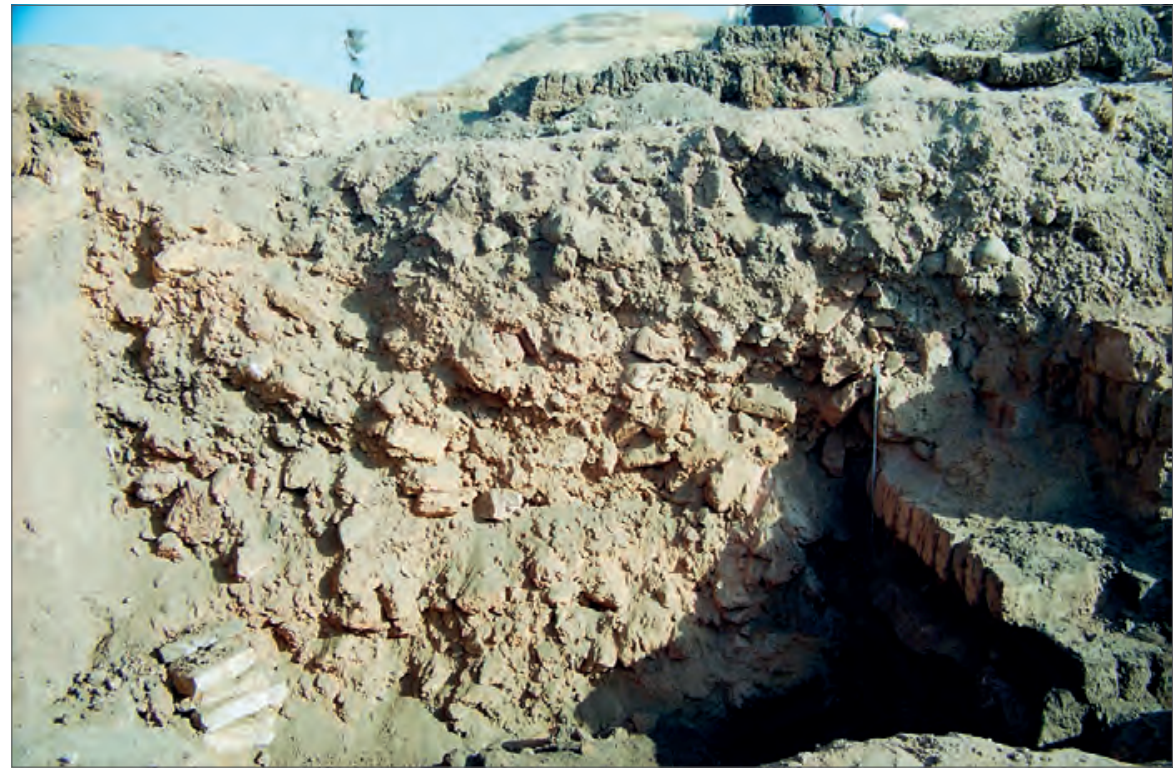

Fig. 17. Over-fired rubble fill inside room AA.30.2, view looking north (Photo W. Godlewski (C) PCMA)

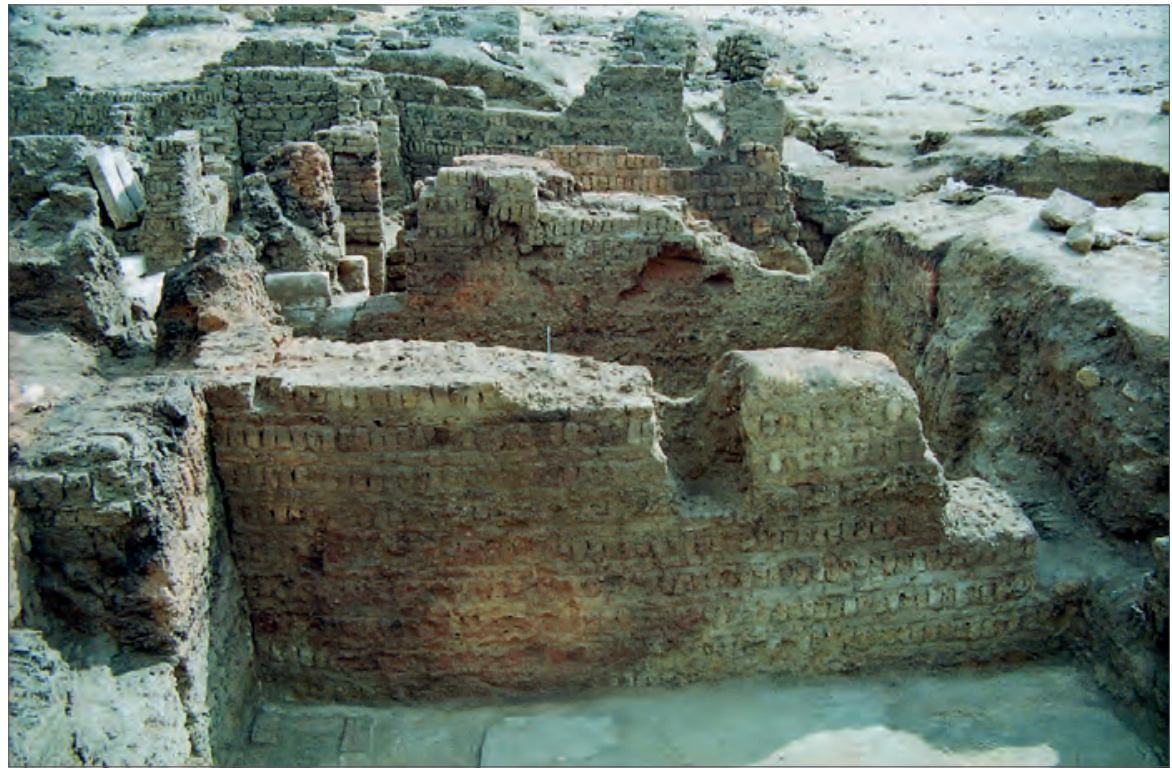

Fig. 18. View of the burnt walls of Building AA.40, view looking east (Photo W. Godlewski (C PCMA) 


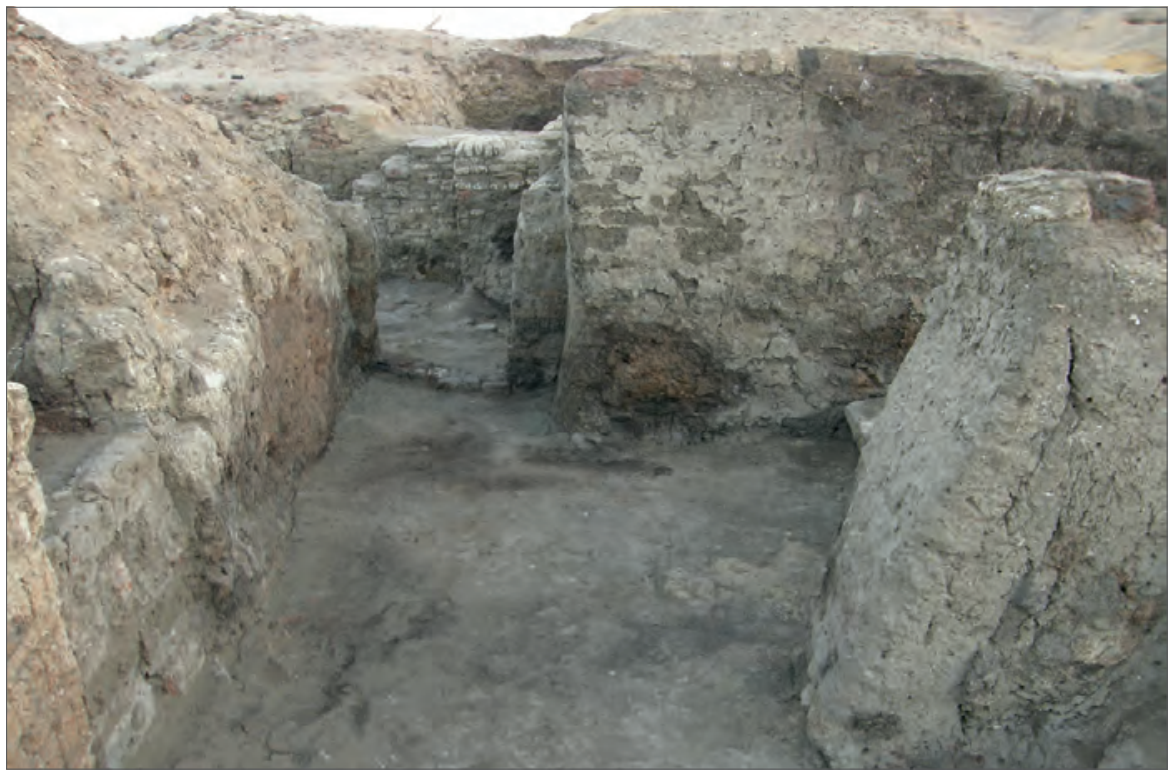

Fig. 19. Traces of burning on the walls in the western part of room AA.40.6, view looking north (Photo W. Godlewski (C) PCMA)

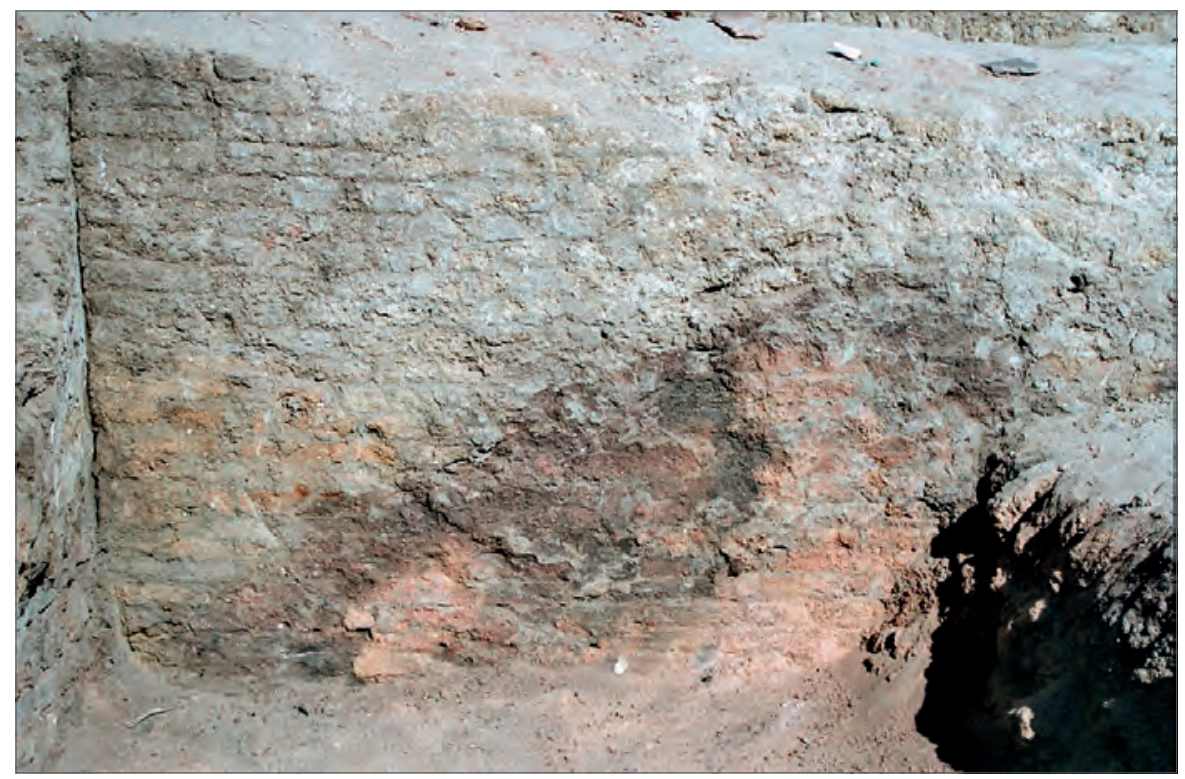

Fig. 20. Burnt patch on the western face of the east wall of Room AA.50.4, view looking east (Photo W. Godlewski (C) PCMA) 
In general, the relatively thick walls of Building AA.30 were burnt mainly on their faces. The thinner walls of the southerly Complex AA.40 (Godlewski 2004: 144) were penetrated deeply by the fire, sometimes through their thickness [Figs 18-19]. Not infrequently, parts of the wall were turned by the fire into shapeless crust. The rooms of Complex AA.50, occupying an area to the west of Buildings AA.30 and AA.40, were also consumed by fire to some extent (Godlewski 2002: 168) [Fig. 20]. Not surprisingly, traces of burning were discovered on the enclosure walls of the tower complex, namely in Area AA.20.1, and ash deposits were revealed along these walls as well (Godlewski 2000a: 130; Godlewski and Czaja-Szewczak 2000: 78).

There is no doubt that the destruction of Building $A$ and Complex AA was caused by the same intensive and spreading conflagration, which destroyed the building(s?) on Site E (Godlewski 2001: 153). It is clear then that the gold dinar (Nd.98.091), found in a layer of burning debris under room E.4, and dated to AD 891/892 (see above), could conceivably provide a terminus post quem for

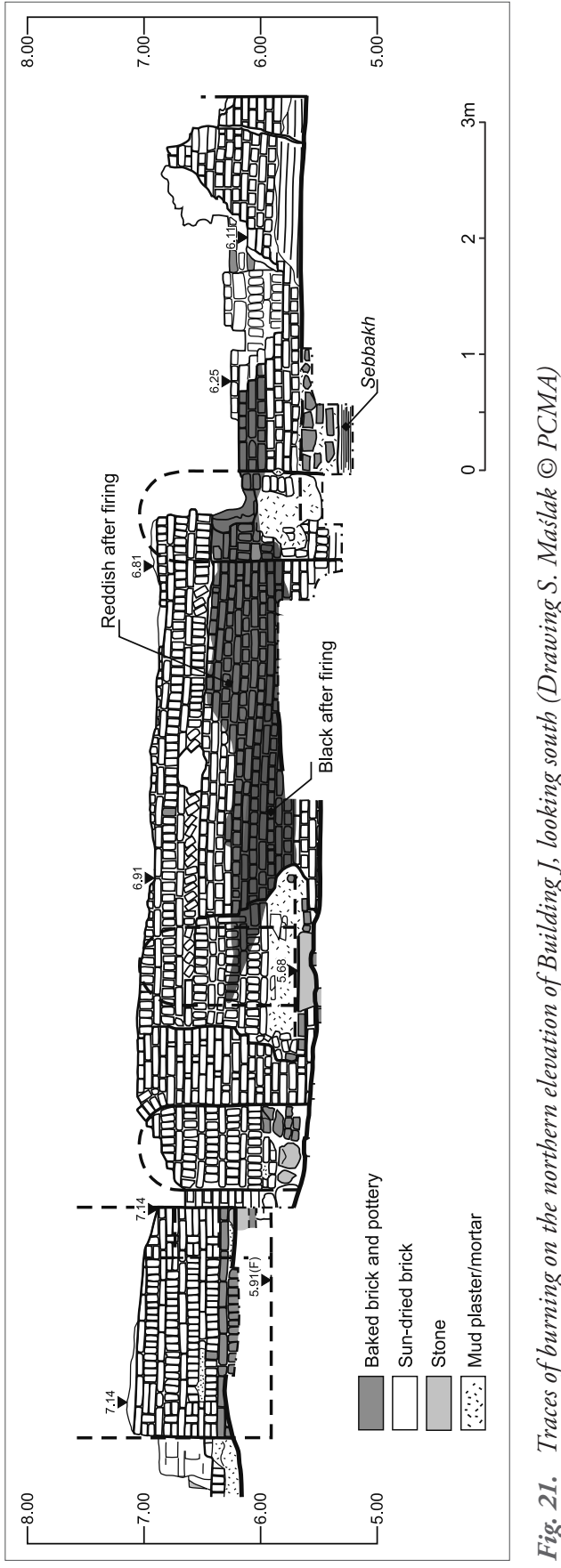


the conflagration that destroyed these buildings (Godlewski 2001: 153). The only numismatic find which came directly from a burned context in Buildings A and AA was a bronze coin attributed to the caliph al-Hakim (996-1021), found in the fill of room AA.40.3 (Godlewski 2001: 153).

Pottery deposits from Complex AA suggested a later date than AD $891 / 892$ for the conflagration. Deposits from the area of Mausoleum I, abutting the ruins of AA.30 by its northeastern corner, provided pottery dated from the 10th to the early 11 th century (Żurek 2007: 219). The last occupational layer in Building AA.30 contained vessels from the 10th/11th century (Żurek 2004: 165). Pottery found on the floor of room AA.40.2 gave a time horizon from the 8 th/9th century through the middle of the 10th century (Zurek 2004: 172), making the second half of the 10th century the most likely time for the deposition of rubble inside the structure (Godlewski 2001: 153). Some vessels from staircase AA.30.1 supported the 10th century attribution of the pottery deposits there (Godlewski 2001: 153). Similarly, a deposit of tableware from room AA.40.7 dated from the 9th-10th century

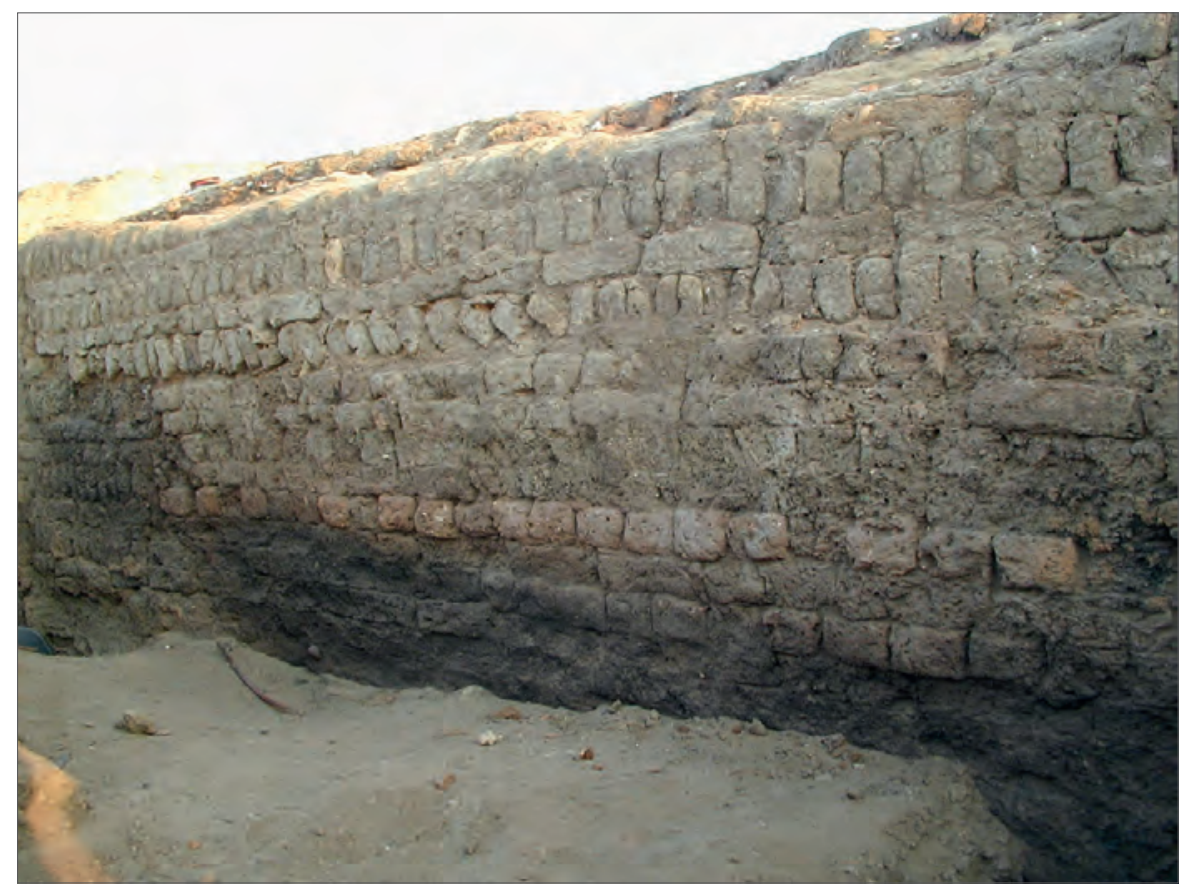

Fig. 22. Traces of burning on the northern elevation of Building J, looking southeast (Photo W. Godlewski (C) PCMA) 
(Godlewski 2014a: 177; Danys-Lasek 2014: 606-607, 609, 626), although some glazed pieces could belong to vessel types that existed for a longer period of time (Danys-Lasek 2014: 608-609). Different vessel repertoires from neighboring rooms AA.40.6 and AA.50.3 confirmed the same time horizon (Danys-Lasek 2014: 606-607, 609, 626-627, 630).

\section{Site J/Building J}

Similar to Complex AA, Building J, which extends immediately across the street (AS.4) in a southerly and southeasterly direction, demonstrated extensive evidence of a violent conflagration (Godlewski 2005a: 189; 2007a: 199; 2012a: 201-205; 2014a: 179) [Figs 21 and 22]. Some of its walls were not only charred on both faces, but were also burnt through their thickness. In the western part of the building (Rooms J.9-J.10), the heat must have been sufficient to melt bricks, transforming some wall sections into shapeless crust. As the evidence of burning demonstrates, fire spots were located along the northern facade of the building, as well as in individual rooms. However, traces of burning in the rooms were not evenly distributed. While most of the western (J.8, J.9, and J.10) and central (J.5, J.6, and J.7) rooms were severely damaged, those in the eastern part of the building were hardly affected by the fire [Figs 23-25].

Amphorae and various storage containers dominated the repertoire of vessel forms from layers associated with the conflagration in Building J (Danys-Lasek 2014: 631). These layers also contained some tablewares of a south Egyptian provenance with analogies among those from Fustat dated from the 10th to the second half of the 11th centuries (Danys-Lasek 2014: 631). Imitations of Chinese celadon and multicolored Fayyumi ware were present here as well (Danys-Lasek 2014: 631). The whole assemblage demonstrated a chronological horizon from the mid-9th up to the middle of the 10th century (Danys-Lasek 2014: 638).

The clearly burned context in Room B.J.7 yielded an impressive hoard of coins, containing altogether 80 fully preserved specimens and fragments (Godlewski 2012a: 203, Fig. 12; 2013: 199-200; 2014a: 174). Eleven coins were minted by the Tulunid governors of Egypt, Khumārawayh ibn Ahmed (884-896) and his son and successor Harun (896-904) in the name of the Abbasid caliphs (Godlewski 2013: 199). Another very large amount of dinars and fragments of dinars was found in a hoard dated from the time of the caliph al-Muqtadir bi-Ilah (908-932) (Godlewski 2012a: 203; 2013: 199). The latest identifiable Abbasid coins in the hoard were minted under the caliph al-Radi bi-Illah (934-940) in the year 936/937 (Godlewski 2013: 199). A small group of seven items in this hoard were issued by the Aghlabids; the only fully preserved coin in this group 
The burning of a monastery?...

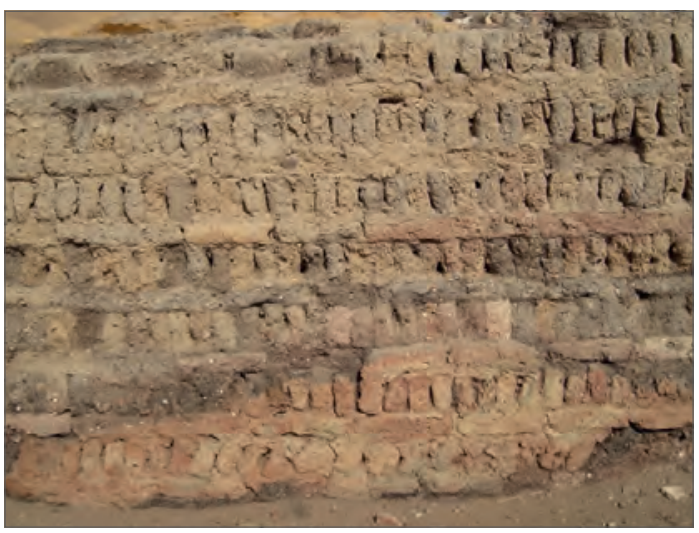

Fig. 23. Traces of burning on the western face of the east wall of Room J.3, view looking east (Photo S. Maślak (C) PCMA)

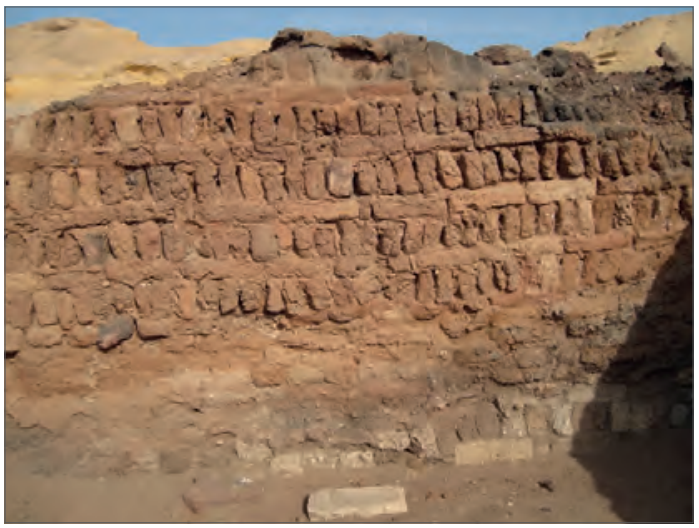

Fig. 24. Western face of the east wall of Room J.9, view looking east

(Photo S. Maślak

(C) PCMA)

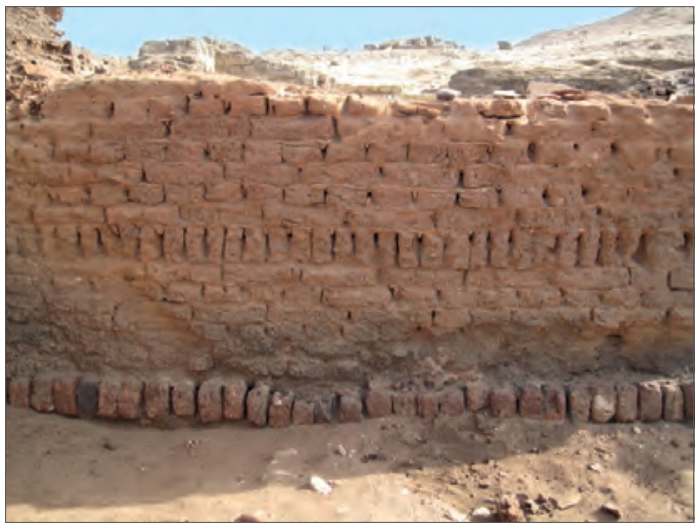

Fig. 25. Northern face of the south wall of Room J.9, view looking south (Photo S. Maślak (C) PCMA) 
was a small dirham minted in $\mathrm{AD}$ 886/887 during the reign of Emir Ibrahim II al-Aghlab (874-902) (Godlewski 2013: 199). In summary, the hoard proved that Building J could not have burned down before AD 937.

\section{Complex K-L}

The architectural remains of Complex $\mathrm{K}$ were too meager to show any large traces of burning on its wall faces; however, the surviving lowermost brick courses were evidently charred (Godlewski 2012a: 196). A relatively thin layer of burnt and crushed sun-dried brick mixed with black ash covered the area, and may also be proof of fire destruction in Building $\mathrm{K}$.

Most of the eastern part of Complex L (Rooms L.2, L.3, and L.6) was destroyed by fire [Figs 26 and 27]. The wall faces were burnt up to their extant heights (approximately $0.75 \mathrm{~m}$ ), and fire penetrated into the wall structures as well. Sometimes the walls were heavily burnt at the bottom, but their upper parts, while surviving, were predominantly smoke damaged. Traces of burning on the walls were accompanied by a layer of black ash mixed with burnt

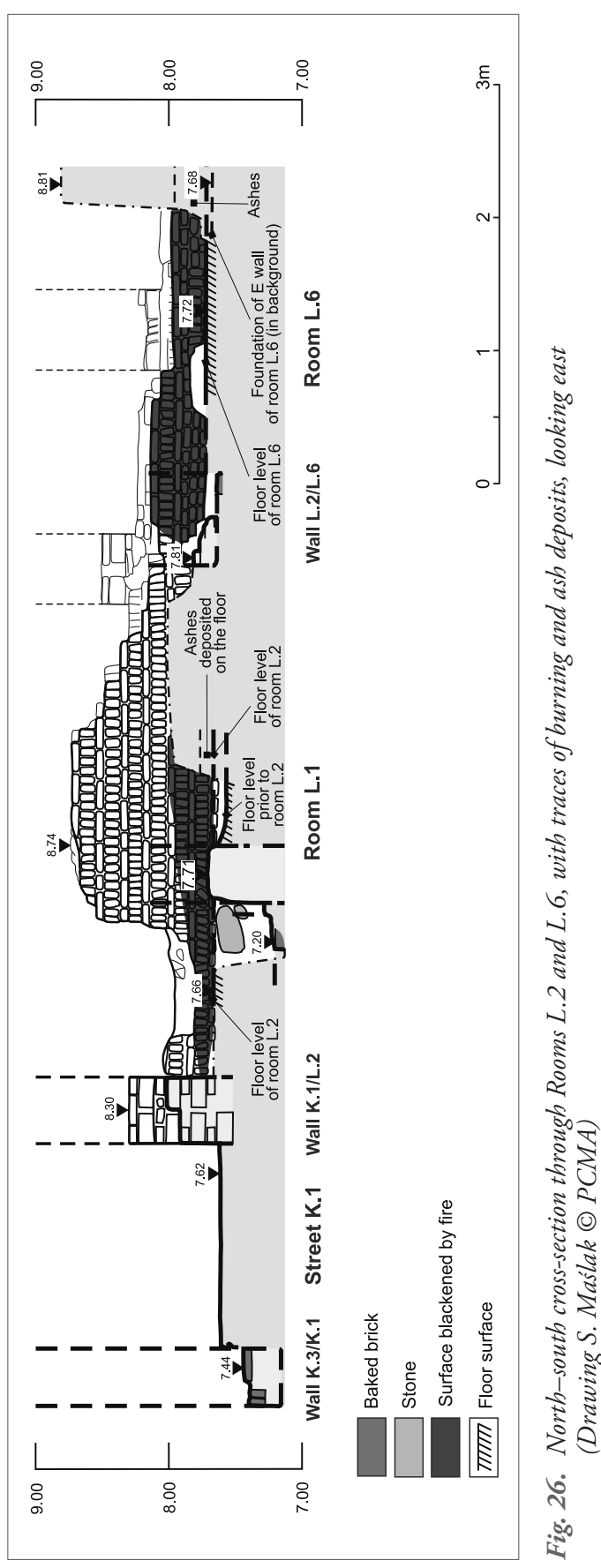


sun-dried brick rubble and other building materials scattered on the floor level. The fire scarcely damaged the inner wall faces in some rooms (L.1 and L.5). In Room L.1, burnt patches were concentrated mainly at the southeastern corner, although separate traces of burning were discernible on the other walls as well.

As the traces of burning on the wall faces demonstrated, at least some parts of Complexes $\mathrm{K}$ and $\mathrm{L}$ burned down at the same time in all likelihood, in one huge conflagration that had engulfed both structures. Ash and burnt rubble inside these buildings supported this idea, although nothing in the archaeological record could provide a date for this event. Coptic texts from this area were quite fragmentary and appeared to date from the 10th-11th centuries (Godlewski 2007a: 203; 2012a: 200). Two coin dies (Nd.05.312-313), obverse and reverse, found in Room L.2 (previously labeled Sector S.3) were used for striking dinars of Abbasid rulers, and probably date from the 9th-10th (or 11th?) centuries (Godlewski 2007a: 199, Fig. 6; 2007b: 175, 176; 2008b: 76, 77; 2012a: 200, Fig. 7). A stamped glass weight (Nd.06.810) dated to the beginning of the 11th

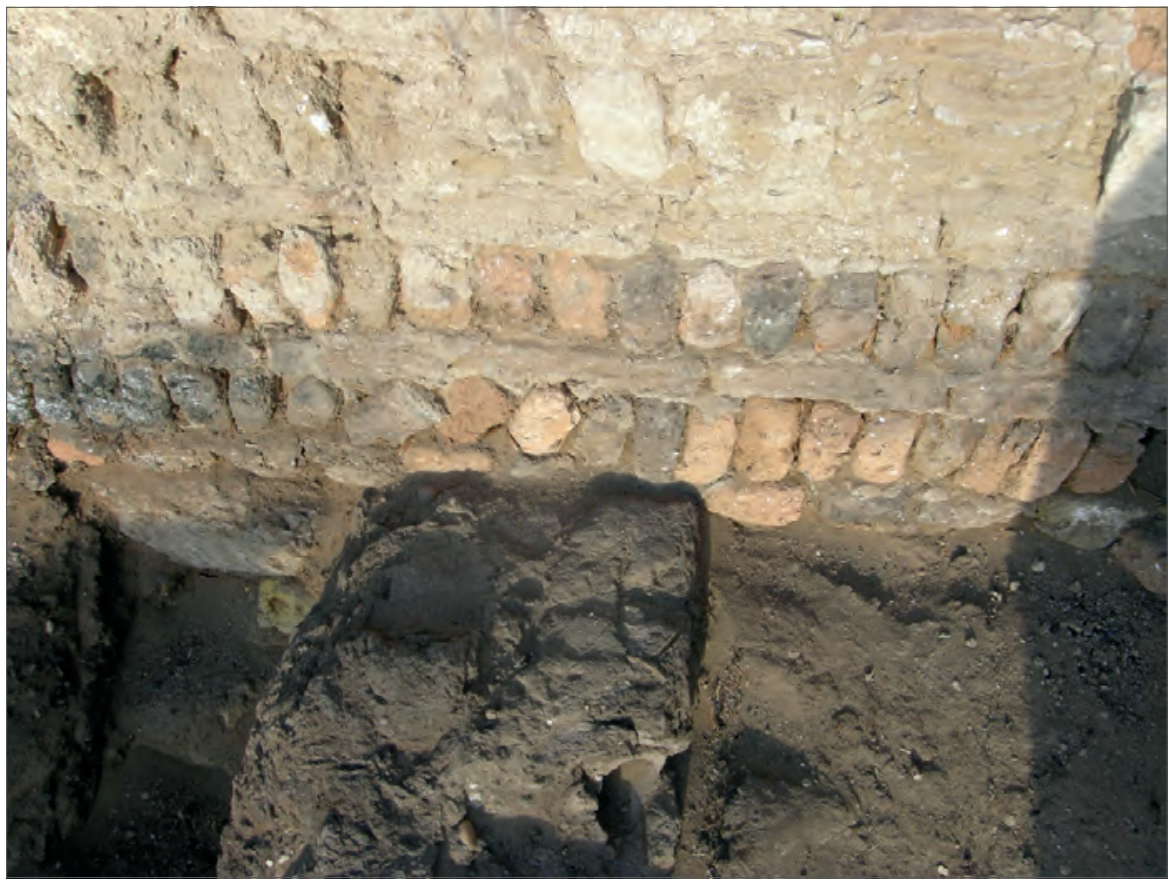

Fig. 27. Bottom section of the east wall of Room L.2 with traces of burning and older wall structure beneath (Photo W. Godlewski (C) PCMA) 
century was found in Room L.1 (previously labeled Sector S) (Godlewski 2008a: 196, Fig. 3). The most puzzling artifact was a fragment of an Arabic funerary stela (Nd.06.808), also from Room L.1 (Godlewski 2008a: 196, Fig. 4) ${ }^{11}$ It may have been used in the construction as early as the late 10th or 11 th century but it could have been transferred here at a much later date as well. There is some evidence, however, to suggest that parts of the burned Building $L$ were resettled (for example, the wall faces in Room L.3 were replastered after being burnt). Buildings $\mathrm{K}$ and $\mathrm{L}$ or their ruins were most probably abandoned in the late 12th century (Godlewski 2007a: 199).

\section{Area between Sector I-J and B (Excluding Complexes K-L-M-N)}

The north-south oriented wall on the western border of Trench 2012.0 bore traces of fire damage but little else. A few isolated concentrations of burning were recorded on the walls in Trench 2012.3, especially on the stones reinforcing a joining of walls in the southern part of the trench. The wooden elements inside this structure were also charred or burnt. Another wall at the northwestern end of the trench appeared to have been destroyed by fire down to the floor level. This floor was also badly burnt. The pottery assemblage from this area was dated to the 9th-10th century (Godlewski 2013: 193).

The most evident burning traces appeared in Trench 2012.5. A northsouth oriented wall in the central part of the trench had burned down and subsequently was dismantled down to one-two brick courses above floor level. The floor extending west of this had a partly charred surface, and was covered by burnt rubble.

\section{SITE B}

There were some deposits of ash on Site B [Fig. 28]. The easternmost deposit extended along the east, as well as south walls of Room B.2 (Maślak 2012: 668). Further to the west, a thick deposit of ash directly underlay at least some parts of the area of Complex B.21-B.26 (Maślak 2012: 659, 663, 664, 665, 668). Apart from the different kinds of ash, these deposits contained some sand and a huge amount of potsherds (Godlewski, Derda, and Górecki 1994: 210; Górecki 1993: 53; Derda and Dzierzbicka 2012: 213, Fig. 1 layers 5, 10, 11 and 12; Dzierzbicka 2014: 194, Fig. 1 especially layers 3-5). The uppermost ashy layers of this section of refuse dump abounded in pottery, which was dated to the

11 It was tentatively dated to the 11th century at the moment of discovery (see Godlewski 2008a: 196, Fig. 4). The fragment actually bears a precise date to the year 922 (Naïm Vanthieghem, handout to a paper read at the Institute of Archaeology, University of Warsaw, on June 16, 2015). 
7th, possibly beginning of the 8th century (Danys-Lasek 2012: 222-225; 2014: 588). This precluded deposition of the ash layers at a time after the conflagration (Maślak 2012: 668). Although these ashy deposits were impressive, they were likely kitchen waste (Dzierzbicka 2014: 194). There were some fragmented sun-dried bricks, baked bricks and stone rubble in the uppermost layers of the rubbish dumps (Dzierzbicka 2014: 194), but they should be treated as random rubble and not resulting from the dismantling of burnt structures. Finally, no walls in either of the complexes B.1-B.3 and B.21-B.26 bore clear traces of burning.

The discovery of al-Hakim's dinars in the fill of Complex B.1-B.3 (Godlewski 2012a: 209) suggests that the building may have been abandoned as early as his reign. The fact that gold coins were left in the rubble leads to the assumption that the building was abandoned under violent circumstances. However, the destruction of Complex B.1-B.3 does not necessarily mean the destruction and abandonment of adjacent Complex B.21-B.26, since the two need not have been contemporary (Maślak 2012: 669-670). As for the coins, taking into

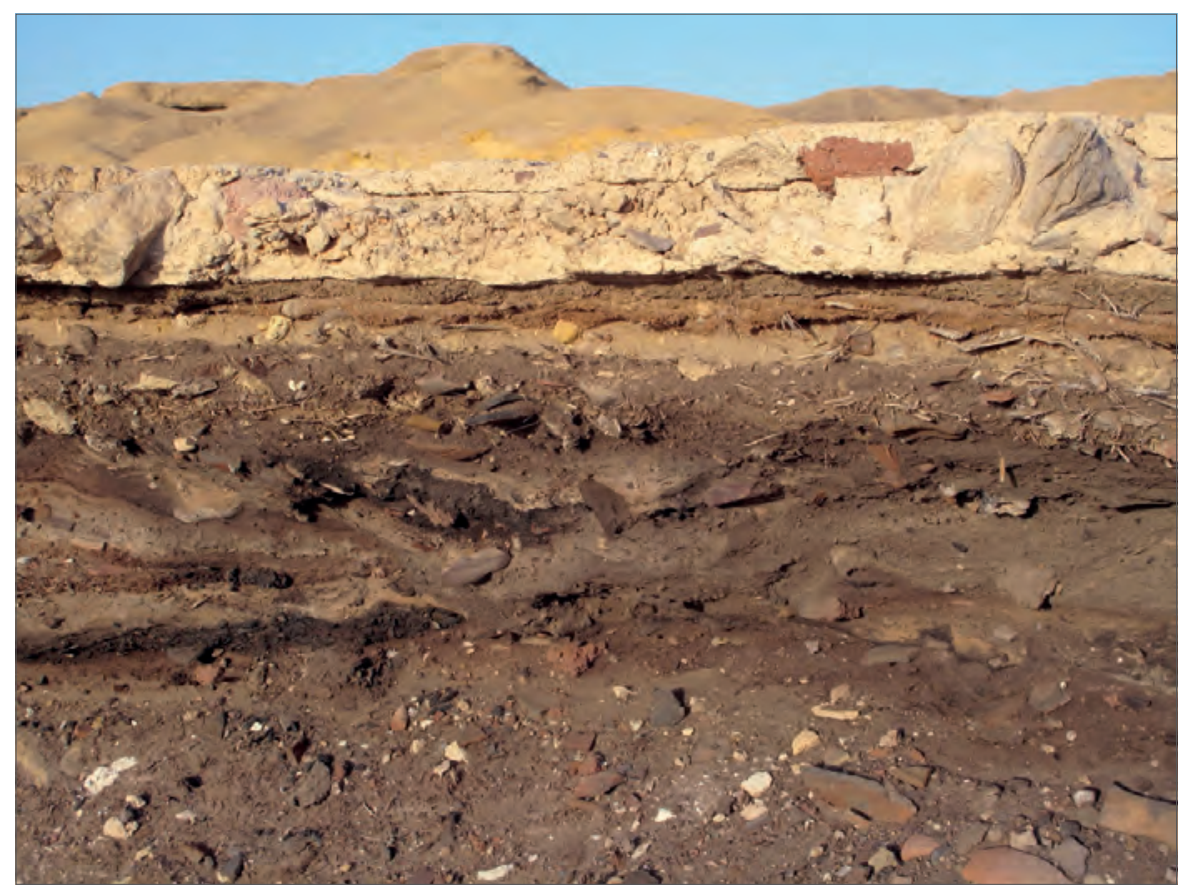

Fig. 28. Rubbish dump on Site B. Ash deposits under the pavement of Unit B.22, looking east (Photo S. Maślak (C) PCMA) 
account their circulation, they cannot provide a date either for the construction of the two complexes or their final destruction. These buildings could have been raised a long time after the era of al-Hakim (10th/11th century) and abandoned even later.

\section{Church of the Archangel Gabriel}

Written sources mention a church dedicated to the Archangel Gabriel under that name at least from the $12 \mathrm{th} / 13$ th century AD. ${ }^{12}$ Nevertheless, the building is certainly much earlier. ${ }^{13}$ Apparently, after the mysterious disappearance of the caliph al-Hakim (February 1021), but before the death of archbishop Zacharias (1032), whose name is preserved in the founding inscription in the apse (Godlewski 1996: 87-88; 1999b: 161; 2000b: 92-93, 99; 2005b: 163164; 2008b: 75; 2012c: 475; Godlewski and Parandowska 1997: 95; van der Vliet 2005a: 191; 2005b: 84; n.d.: 3, 11-14), the sanctuary of the church was provided with a rich set of wall paintings. ${ }^{14}$ Another inscription (in Coptic), left on the already painted wall by Jacob, the Bishop of Aphroditopolis (Atfih), during his visit to the church in 1033, provides a terminus ante quem for the decoration in the apse (Godlewski 1996: 88; 1999b: 161; 2000b: 95, Fig. 3; 2005b: 164; 2007b: 174; 2008b: 75; van der Vliet 2005b: 85; n.d.: 4, 16-18). Paintings in other parts of the church may have been introduced at a slightly later date. ${ }^{15}$

The church was not only furnished with new paintings, but its interior was also rebuilt (Godlewski 1999b: 160; 2000b: 90-91; 2005b: 163-164; van der Vliet 2005b: 83-84). This must have been an expensive and time-consuming

12 The first relatively well-dated written source in which the church dedication appeared is Abu al-Makārim, The churches and monasteries of Egypt, fol. 71a, see also Dobrowolski 1990: 161; Godlewski 1993b: 189. However, earlier documents, which very likely date to the first half of the 11th century (see van der Vliet 2015: 162), speak explicitly of a celebration of "the Feast of Gabriel" at Nekloni (van der Vliet 2005a: 194; 2015: 165). This could be an indication of who was the patron of the Nekloni church at that time.

13 A precise date for the construction of the church cannot be established due to poor evidence. The 8th century appears a most likely date in the light of the most recent examination (Godlewski 2012c: 475; 2015: 132).

14 For representations inside the church, see Godlewski 1992: 52, Figs 1-2; 1993a: 47-48; 1996: 87-88; 1998: Fig. 3; 2008b: 75; 2015: 132; Godlewski and Parandowska 1994: 60, and especially Godlewski 1993b: 189-194; 2000b: 91-99, Figs 1-2, 4; 2005b: 163-166, Figs 14.6-7; Godlewski and Parandowska 1997: 93-97, Fig. 4; Parandowska 2005: 280-282, Figs 24.1-4.

15 For example inscription N.5 placed one of the paintings from the north wall of the nave evidently later in time (AD 1035/36) than counterparts from the apse (van der Vliet n.d.: 38-39). See van der Vliet 2015: 159. 
venture. The donors appear to be "mostly well-to-do monks, priests and deacons, from the 'mountain of Naqlun'" (Godlewski 2000b: 92-93; van der Vliet 2005b: 84-85; van der Vliet n.d.: 2, especially 27). In other words, the monks and other inhabitants of the Nekloni monastery(?) as well as probably some clerics from the outside, for the most part, if not for the whole, sponsored the renovation of the church (Godlewski 2015: 132; van der Vliet n.d.). No name of an evidently lay person has been found thus far among the foundation inscriptions on the church walls.

Except for the apse, ${ }^{16}$ there were no traces of earlier paintings inside the church (Godlewski 2000b: 90; 2005b: 163; Parandowska 2005: 279)..$^{17}$ Surprisingly, all of these new representations were painted on the first layer of plaster (Godlewski 1992: 54; Parandowska 2005: 284). It cannot be proven whether this coating was really original, or if it replaced an earlier one that had been removed thoroughly before the refurbishment of the church in the third decade of the 11th century (the walls are thought to have been re-plastered; see Godlewski 2000b: 91). The size of this venture, which probably involved each wall inside the church, may suggest that the building had been neglected, if not simply abandoned at that time. Remarkably, there was no evidence of destruction inside the building (especially by fire, see Dobrowolski 1990) preceding its refurbishment. However, the dating of the wall redecoration, immediately after the time of the caliph al-Hakim, may suggest that there was some regression in the monastery during his reign and a sudden revival after his disappearance (cf. Godlewski 2000b: 99).

\section{Summing up}

Dating of the pottery does not determine explicitly whether the traces of burning scattered all over the upper plateau belong to the same, precisely dated conflagration. However, there are many parallels among the pottery deposits from the different parts of the site that had been consumed by fire (see Danys-Lasek 2014). Fill inside the rooms of Complex D contained largely secondarily deposited material (Godlewski, Derda, and Górecki 1994: 231; Górecki 1993: 61), consisting of a repertoire of

16 For the original composition in the apse, see Godlewski 1998: 86; 2002: 169-170, Fig. 3; 2007b: 175; 2008b: 75; Calaforra-Rzepka 2002: 174, Fig. 3; 2003: 185-186.

17 Some fragmentarily preserved paintings from the south wall of the naos are considered as belonging to the same phase as the remodeling of the original mural in the apse; see Godlewski 2005b: 163 . 
vessel types, which existed for a relatively long time. Therefore, in general, this pottery ranges from the 8th to the 12th century (Godlewski 1992: 51; 1996: 86; Godlewski, Derda, and Górecki 1994: 226-227, 228, 231; Górecki 1993: 61-64). Rarely the date of the ceramic material can be limited to the 9th-11th century, as is the case of Room D.3 and the fill from Buildings I.DB-II.DB (Godlewski, Derda, and Górecki 1994: 228-231; Górecki 1994: 75). A more precise dating was provided by Complex AA, where all the pottery from the layers immediately preceding the conflagration came from the 10th to early 11th century (Godlewski 2001: 153; 2014: 177; Danys-Lasek 2014: 606-609, 626-627, 630; Żurek 2004: 165, 168-172; 2007: 219). Moreover, ceramic deposits from the reservoir of the possible latrine G.8a in Building G, dated to the 9th-10th century, were sealed before or at the beginning of the 11th century (Zurek 2007). Pottery finds from the northernmost Site K.1, as well as from Building J, were dated roughly from the 9th to the mid-10th century (Danys-Lasek 2014: 593, 631, 638).

Coins from contexts containing burnt brick rubble and ash provided more precise data on the time of the conflagration. However, only a few of the numismatics were found actually in explicitly burnt layers. These included the gold hoard from Room J.7, which leaves no doubt that the building could not have been destroyed before AD 937 (Godlewski 2012a: 203, Fig. 12; 2013: 199-200; 2014a: 174). A single coin minted in 891/892 and retrieved from the ash in Site E, supports this date (Godlewski 1999a: 117; 2001: 153; Morisot 2000: 328-329, Fig. 1).

Coins and some numismatics from other parts of the monastic settlement, fairly distant from the most heavily burned buildings located around Building A in the central part of the upper plateau, raise controversy. Two coins from rooms D.11 and D.28 (Complex D), found outside of a clearly burnt context, appear to have been minted in the name(s) of the Abbasid caliph(s) (only one has been fully deciphered), giving a date of issue for one of them in the last quarter of the 9th century (see Morisot 2000: 329, Figs 2-3 and above). The same imprecise dating is shared by dies from Room L.2, which were used for production of coins with the name of one of the Abbasid caliphs, probably dating from the 9th-10th (11th?) century (Godlewski 2007a: 199, Fig. 6; 2007b: 175, 176; 2008b: 76, 77; 2012a: 200, Fig. 7). The most remarkable finds outside of fire contexts were made beside Room G.8. By contrast with the coins mentioned above, a whole hoard here consisted of coins minted exclusively by the early Fatimids, giving a date for their abandonment after the 980s (Godlewski 2007a: 199, Fig. 3).

Even if these coins vary, as far as their find context is concerned, they have some features in common that may support the idea of their being lost during the same catastrophic event. For some reason, the individuals who had collected these coins and kept them while residing in the monastic buildings, did not 
manage to protect them when evidently fleeing the place. Moreover, they never returned to seek for the gold dinars in the rubble which had nicely sealed everything; perhaps they could not. They had likely abandoned the monastery in extraordinary circumstances that left them no chance to collect their valuables. Whether they were simply prevented from coming back by external conditions or had died during or soon after the catastrophe is pure speculation.

Paradoxically, the most valuable numismatic object for establishing the date of the conflagration was a bronze coin found in the ashes of room AA.40.3. It was very likely minted under the caliph al-Hakim (Godlewski 2001: 153). This evidence testifies that the conflagration could not have occurred before his reign.

The ruins of the monastic buildings from the upper plateau did not provide us with any codex leaves, letters or other documents later than the 11th century. The only exceptions were some Ayyubid-Mamluk texts (AD 1181 and later) discovered in Room D.9 in a Sicilian casket, which was deposited there at an unknown point in time, but definitely after the conflagration (Godlewski 1992: 51-52; 1993b: 189; 2005b: 171; 2007b: 176; 2008b: 76-77; Ragheb 1992). The other exceptions were inscribed objects found in funeral contexts (inscribed textiles, a codex with the Gospel of John, inscribed vessels etc. $)^{18}$ coming from the Cemetery A, which was installed in the middle of the upper plateau in or above the partly ruined monastic buildings sometime in the mid-11th century. ${ }^{19}$

Texts providing proof of revival or reoccupation of monastic buildings on the upper plateau come from the turn of the 10th and the 11th centuries. The Arabic documents of Girga Ben Bifam dated to AD 992-1029 should be ascribed to the first group (Godlewski 1998: 85, Fig. 2; 1999a: 117; 2000a: 131; 2005b: 168-169; 2007b: 175-176; 2008b: 76; 2011a: 477-478; Godlewski and Czaja-Szewczak 2000: 82; Gaubert 1998: 87-89; Gaubert and Mouton 2014). They do not deal with monastic affairs and all were written outside of Nekloni (some of them certainly in the notary office at Lahun) and transferred to the site sometime after the conflagration (Godlewski 1998: 85; 2008b: 76). Other texts, this time from Room G.10, which was very likely part of the

18 For inscribed textiles, see Godlewski 2003: 166, 168, Fig. 3b; 2004: 143, Figs 1-2; 2005a: 190; 2007a: 204-205; 2011a: 478, 479; Godlewski and Czaja-Szewczak 2000: 84-86; Helmecke 2005; van der Vliet 2005b: 86. For a codex with the Gospel of John, see Godlewski 2003: 168-170, Fig. 6; van der Vliet 2003. For an inscribed bronze bowl, see Godlewski 2005a: 183, Fig. 3; 2011a: 475-476, Fig. 6 (colorful photo after restoration). For inscriptions on other objects, see Łajtar 1994: 265-269.

19 For the date of the beginnings of this cemetery (Cemetery A), see Godlewski 2003: 168, 171; 2005b: 169; 2005c; 2007b: 173; 2008b: 71, 78; 2010: 230; 2011a: 468, 478; 2012b: 138, 140, 143; 2012c: 475 . 
administrative building, came from the first half and the middle of the 11th century (Godlewski 2004: 149; 2005a: 187, 189; 2007a: 199, 203; van der Vliet 2005a; 2015: 157-166, Pl. 7.1).

In the context of textual evidence from the Nekloni monastery, one should take up the issue of the library (and likely archive of sorts) which was housed, probably on the upper floor, in the buildings clustered on Site D (Godlewski 1996: 86; 1998: 83; 1999b: 159-160; 2000a: 131-132; 2005b: 167; 2007b: 175; 2008b: 76; 2015: 132; van der Vliet 2000: 143). Various texts retrieved from the fill on the spot confirm this. The most recent document discovered on Site D so far, a letter to Apa Khael, is dated AD 992 (Godlewski 1999b: 160; Godlewski and Parandowska 1994: 59). Another document (a receipt) comes from the same year (van der Vliet 2000: 143; 2015: 164-165). Most of the fragments from the scattered codices are of 10th-century date (van der Vliet 2000: 143). The most recent colophon of a codex dates from AD 963/964 (van der Vliet 2000: 143). However, the paleography of some of the texts reaches into the 11th century (Urbaniak-Walczak 1997: 99-102).

A considerable number of texts dated to the 10th century suggests that the library was at its zenith at that time. Fragments of codices and documents found in the rubble on Site D appear to be the only surviving remains of it. Texts deciphered so far indicate that its destruction could not have happened before AD 992. It took place in all likelihood sometime in the 11th century, at the very beginning being as probable as later dates.

\section{Conclusions}

The walls and the buildings scattered on the upper plateau may be divided into two groups, as far as their destruction by fire is concerned. The structures most damaged by fire clustered in the central part of the monastic settlement and included Buildings E, AA and J, which surrounded the centrally situated Building A to the northwest, west, southwest and south. Building A appears to have been heavily destroyed, but only in its southern part. Surprisingly, other sections of the building yielded little evidence of burning.

A dense distribution of burnt patches on wall surfaces characterized the burning evidence from the other buildings in this area. Whereas the thicker walls were only smoke-damaged or superficially/partly burnt (Building AA.30), thinner walls were usually penetrated by fire through their thickness and sometimes even melted into a hard crust (Buildings AA.40, E and J). This could be explained by the presence 
of considerable amounts of flammable materials which fueled the flames. Flat roofs with wooden elements covered by layers of bound rush would be sufficient to maintain the fire for a longer time and to cause destruction of this kind.

Traces of burning are more dispersed and generally not as severe for other parts of the monastery as in the buildings on the central part of the plateau. This was the case on Site D. A number of peripheral rooms burned down here, but the centrally located towers (I.DB and II.DB) were barely touched by fire. This could again be explained by the fact of there being probably less flammable material in these buildings.

Nevertheless, there is no doubt that fire consumed different parts of the monastic settlement on the upper plateau, as far north as the Northern Building (K.1) and also reached Complexes $\mathrm{K}$ and $\mathrm{L}$ and the surrounding walls to the south, but probably not the southernmost Site B. ${ }^{20}$ Buildings appeared to have been destroyed methodologically with the fire breaking out in different parts of the settlement. However, the epicenter of the conflagration was in and around Building $\mathrm{A}$ in the central part of the upper plateau. The conflagration was certainly a sudden catastrophe for which the inhabitants of the monastery were not prepared. At least some of them, especially those in charge of the gold coins, did not or could not return afterwards to the rebuilt monastic buildings.

After the conflagration the upper plateau remained deserted not for long, suggesting that it played an important role for the local Christian community. ${ }^{21}$ The community and its clergy/monks were sufficiently affluent to rebuild some monastic buildings at least in part ${ }^{22}$ and refurbish others (i.e., the church) (see Godlewski 2015: 132).

20 In earlier publications, the destruction by fire of the whole monastery was discussed (see Godlewski 2005b: 162; 2014a: 174). However, the term "whole monastery" appears to refer mostly to buildings in the central part of the upper plateau (see Godlewski 2015: 132). Especially Maqrizi, Account of the monasteries..., p. 314, and after him Timm 1985: 765-766. See also Godlewski, Herbich, and Wipszycka 1990: 174; Wipszycka 1996: 374-375; van der Vliet 2015: 165.

22 New buildings, partly reusing earlier extant walls, were built in the central part of the upper plateau (Church A, Buildings E and G). Some structures to the south (Building L?) may have been resettled as well (see above). Others, such as complexes B.1-B.3 and B.21-B.26, could have been raised from the bottom up some time after the conflagration (see Maślak 2012). As indicated by Mamluk objects from one of the rubbish dumps on Site D (see Godlewski, Herbich and Wipszycka 1990: 189; Godlewski, Derda, and Górecki 1994: 226, 228), this area remained occupied. Cemetery A apparently coexisted for a while with a few buildings clustered around Church A (Godlewski 2000a: 128; 2005b: 169; Godlewski and CzajaSzewczak 2000: 83); however, when all of these buildings fell into disuse, graves started to be installed in their ruins (Godlewski 2004: 148, 150; 2005a: 187; 2005c: 173-175; Maślak 2007: 218). 
There is some evidence giving reasonable grounds for placing the conflagration in the mid-10th century (Godlewski 2012a: 201, 205; 2013: 193; 2014a: 173174; 2015: 132). However, artifacts such as ceramics, numismatics (both coins and dies), and different types of texts analyzed altogether demonstrate that the event occurred slightly later. Certain finds suggest that the date should be moved even into the 11th century. If one takes into consideration the resettlement of the central part of the plateau around a newly built Church A sometime in the first half of the 11th century, and the beginnings of the cemetery in the surrounding area in the second half of the 11th century, the only safe dates for the conflagration are the very end of the 10th or the first decades of the 11th century.

\section{References}

\section{Primary SOURCES}

Abū al-Makārim, The churches and monasteries of Egypt and some neighbouring countries,

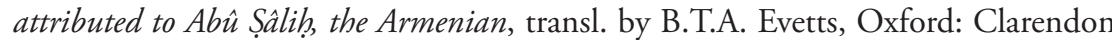
Press, 1895

Maqrizi, Account of the monasteries and churches of the Christians of Egypt. In Abū al-Makārim, The churches and monasteries of Egypt and some neighbouring countries, attributed to Ab̂̀ Șalihh, the Armenian (pp. 305-346), transl. by B.T.A. Evetts, Oxford: Clarendon Press, 1895

\section{SECONDARY SOURCES}

Calaforra-Rzepka, C. (2002). Naqlun 2001: Wall-painting transfer and conservation. Polish Archaeology in the Mediterranean, 13, 171-177

Calaforra-Rzepka, C. (2003). Wall-painting transfer and conservation at Naqlun. Part 2. Polish Archaeology in the Mediterranean, 14, 185-187

Danys-Lasek, K. (2012). Pottery from the refuse dump under unit B.26 in Naqlun. Polish Archaeology in the Mediterranean, 21, 222-232

Danys-Lasek, K. (2014). Pottery from Deir el-Naqlun (6th-12th century). Preliminary report from Polish excavations in 2010 and 2011. Polish Archaeology in the Mediterranean, 23/1, 543-642

Derda, T. and Dzierzbicka, D. (2012). Refuse dump in sector B in Naqlun: Excavation report 2008-2009. Polish Archaeology in the Mediterranean, 21, 212-221

Dobrowolski, J. (1990). Naqlun - Deir al-Malak Ghubräil: The existing monastic complex. Nubica, 1-2, 161-170

Dzierzbicka, D. (2014). Refuse dump in sector B in Naqlun: Excavation report 2011. Polish Archaeology in the Mediterranean, 23/1, 192-203 
Gaubert, C. (1998). Naqlun. Remarques préliminaires sur les archives d'époque fatimide d'une famille copte. Polish Archaeology in the Mediterranean, 9, 87-89

Gaubert, C. and Mouton, J.-M. (2014). Hommes et villages du Fayyoum dans la documentation papyrologique arabe ( $X^{e}-X I^{e}$ siècles) [=Hautes études orientales 52]. Geneva: Droz

Godlewski, W. (1990). Polish excavations at Naqlun (1988-1989). Polish Archaeology in the Mediterranean, 1, 29-34

Godlewski, W. (1992). Archaeological research in Naqlun in 1991. Polish Archaeology in the Mediterranean, 3, 49-56

Godlewski, W. (1993a). Deir el-Naqlun, 1992. Polish Archaeology in the Mediterranean, 4, 43-48

Godlewski, W. (1993b). Naqlun 1989-1992. In D.W. Johnson (ed.), Acts of the Fifth International Congress of Coptic Studies: Washington, 12-15 August 1992, II.1 (pp. 183-195). Rome: CIM

Godlewski, W. (1996). Naqlun: Excavations 1995. Polish Archaeology in the Mediterranean, 7, 82-88

Godlewski, W. (1998). Naqlun: Excavations 1997. Polish Archaeology in the Mediterranean, 9, 77-86

Godlewski, W. (1999a). Naqlun: Excavations 1998. Polish Archaeology in the Mediterranean, 10, 113-117

Godlewski, W. (1999b). Naqlun 1993-1996. In S. Emmel, M. Krause, S.G. Richter, and S. Schaten (eds), Ägypten und Nubien in spätantiker und christlicher Zeit: Akten des 6. Internationalen Koptologenkongresses, Münster, 20.-26. Juli 1996, I. Materielle Kultur, Kunst und religiöses Leben [=Sprachen und Kulturen des christlichen Orients 6] (pp. 157-162). Wiesbaden: L. Reichert

Godlewski, W. (2000a). Naqlun: Excavations, 1999. Polish Archaeology in the Mediterranean, 11, 125-132

Godlewski, W. (2000b). Les peintures de l'église de l'Archange Gabriel à Naqlun. Bulletin de la Société d'archéologie copte, 39, 89-101

Godlewski, W. (2000c). Naqlun. The hermitage of Phibamo. In K.M. Ciałowicz and J.A. Ostrowski (eds), Les civilisations du bassin Méditerranéen: hommages à Joachim Śliwa (pp. 91-98). Cracow: Instytut Archeologii Uniwersytetu Jagiellońskiego

Godlewski, W. (2001). Naqlun: Excavations, 2000. Polish Archaeology in the Mediterranean, 12, 149-161

Godlewski, W. (2002). Naqlun: Excavations, 2001. Polish Archaeology in the Mediterranean, 13, 159-170

Godlewski, W. (2003). Naqlun: Excavations, 2002. Polish Archaeology in the Mediterranean, 14, 163-171

Godlewski, W. (2004). Naqlun (Nekloni): Season 2003. Polish Archaeology in the Mediterranean, 15, 141-151

Godlewski, W. (2005a). Naqlun (Nekloni): Season 2004. Polish Archaeology in the Mediterranean, 16, 181-190 
Godlewski, W. (2005b). Excavating the ancient monastery at Naqlun. In G. Gabra (ed.), Christianity and monasticism in the Fayoum oasis: Essays from the 2004 international symposium of the Saint Mark Foundation and the Saint Shenouda the Archimandrite Coptic Society in honor of Martin Krause (pp. 155-171). Cairo: American University in Cairo Press

Godlewski, W. (2005c). The medieval Coptic cemetery at Naqlun. In G. Gabra (ed.), Christianity and monasticism in the Fayoum oasis: Essays from the 2004 international symposium of the Saint Mark Foundation and the Saint Shenouda the Archimandrite Coptic Society in honor of Martin Krause (pp. 173-183). Cairo: American University in Cairo Press

Godlewski, W. (2007a). Naqlun (Nekloni): Season 2005. Polish Archaeology in the Mediterranean, 17, 195-205

Godlewski, W. (2007b). Naqlun. In E. Laskowska-Kusztal (ed.), Seventy years of Polish archaeology in Egypt (pp. 171-182). Warsaw: PCMA UW

Godlewski, W. (2008a). Naqlun (Nekloni): Season 2006. Polish Archaeology in the Mediterranean, 18, 195-206

Godlewski, W. (2008b). Naqlun. Monastery never to be forgotten. In H. Froschauer and C. Römer (eds), Spätantike Bibliotheken: Leben und Lesen in den frühen Klöstern Ägyptens [=Nilus 14] (pp. 71-79). Vienna: Phoibos-Verlag

Godlewski, W. (2008c). Naqlun (Nekloni). The hermitages, cemetery and the keep in the early 6th century. In S.L. Lippert and M. Schentuleit (eds), Graeco-Roman Fayum: Texts and archaeology. Proceedings of the third International Fayum Symposion, Freudenstadt, May 29-June 1, 2007 (pp. 101-112). Wiesbaden: Harrassowitz

Godlewski, W. (2010). Naqlun 2007: Preliminary report. Polish Archaeology in the Mediterranean, 19, 229-244

Godlewski, W. (2011a). In the shade of the Nekloni monastery (Deir Malak Gubrail, Fayum). Polish Archaeology in the Mediterranean, 20, 467-482

Godlewski, W. (2011b). The monastery of Nekloni, excavations in 2011. PCMA Newsletter. Retrieved from http:/www.pcma.uw.edu.pl/pl/newsletter-pcma/2011/ late-roman-byzantine-and-medieval/naqlun-egypt/ [accessed: November 2015]

Godlewski, W. (2012a). Naqlun (Nekloni) excavations in 2008-2009. Polish Archaeology in the Mediterranean, 21, 193-211

Godlewski, W. (2012b). Naqlun cemetries. In G.A. Belova and S.V. Ivanov (eds), Achievements and problems of modern Egyptology: Proceedings of the international conference held in Moscow on September 29-October 2, 2009 (pp. 138-149). Moscow: Russian Academy of Sciences

Godlewski, W. (2012c). Naqlun: The earliest hermitages. In R.S. Bagnall, P. Davoli, and C.A. Hope (eds), The Oasis papers 6: Proceedings of the Sixth International Conference of the Dakhleh Oasis Project [=Dakhleh Oasis Project Monograph 15] (pp. 475-489). Oxford: Oxbow Books

Godlewski, W. (2013). Naqlun, Egypt. Excavations in 2012. Światowit, 10 (51) Fasc. A, 193-201 
Godlewski, W. (2014a). Naqlun (Nekloni). Excavations in 2010-2011. Polish Archaeology in the Mediterranean, 23/1, 173-191

Godlewski, W. (2014b). Excavations in Complex D: Reexamination and new research (Naqlun 2014). PCMA Newsletter. Retrieved from http://www.pcma.uw.edu. $\mathrm{pl} /$ ?id=1275\&L=0 [accessed: November 2015]

Godlewski, W. (2015). Naqlun - Das Kloster des Erzengels Gabriel. In C. Fluck, G. Helmecke, and E.R. O'Connell (eds), Ein Gott: Abrahams Erben am Nil. Juden, Christen und Muslime in Ägypten von der Antike bis zum Mittelalter (pp. 130-133). Berlin: Staatliche Museen zu Berlin, Preussischer Kulturbesitz

Godlewski, W. and Czaja-Szewczak, B. (2000). Naqlun: Recent studies. Bulletin de la Société d'archéologie copte, 39, 69-87

Godlewski, W., Derda, T., and Górecki, T. (1994). Deir el Naqlun (Nekloni), 19881989. Second preliminary report. Nubica, 3(1), 201-263

Godlewski, W., Herbich, T., and Wipszycka, E. (1990). Deir el Naqlun (Nekloni) 1986-87: First preliminary report. Nubica, 1-2, 171-207

Godlewski, W. and Parandowska, E. (1994). Naqlun 1993. Polish Archaeology in the Mediterranean, 5, 55-62

Godlewski, W. and Parandowska, E. (1997). Naqlun: Excavations 1996. Polish Archaeology in the Mediterranean, 8, 88-97

Górecki, T. (1993). Deir el-Naqlun 1992: The pottery. Polish Archaeology in the Mediterranean, 4, 53-64

Górecki, T. (1994). The pottery from Naqlun, 1993. Polish Archaeology in the Mediterranean, 5, 63-78

Helmecke, G. (2005). Textiles with Arabic inscriptions excavated in Naqlun 19992003. Polish Archaeology in the Mediterranean, 16, 195-202

Łajtar, A. (1994). Two Greek inscriptions from Deir el-Naqlun. Nubica, 3(1), $265-274$

Maślak, S. (2007). Building G in Naqlun: Material, construction, furnishing. Polish Archaeology in the Mediterranean, 17, 206-218

Maślak, S. (2012). Buildings on Site B at Naqlun (Nekloni). Polish Archaeology in the Mediterranean, 21, 653-676

Morisot, C. (2000). Quelques monnaies découvertes à Deir al-Malak. Annales Islamologiques, 34, 327-333

Parandowska,E. (2005). Preservation of thewall paintings in the Church of the Archangel Gabriel at Naqlun. In G. Gabra (ed.), Christianity and monasticism in the Fayoum oasis: Essays from the 2004 international symposium of the Saint Mark Foundation and the Saint Shenouda the Archimandrite Coptic Society in honor of Martin Krause (pp. 279-287). Cairo: American University in Cairo Press

Ragheb, Y. (1992). L'inventaire des documents exhumes à Naqlun, 1991. Polish Archaeology in the Mediterranean, 3, 57-58

Timm, S. (1985). Dēr Naqlūn. In S. Timm, Das christlich-koptische Ägypten in arabischer Zeit II (pp. 762-767). Wiesbaden: Reichert 
Urbaniak-Walczak, K. (1997). Naqlun. The literary texts from seasons 1993 and 1995. Polish Archaeology in the Mediterranean, 8, 98-102

van der Vliet, J. (2000). Preliminary remarks on the Coptic texts from seasons 1998 and 1999. Polish Archaeology in the Mediterranean, 11, 143-144

van der Vliet, J. (2003). The Naqlun John: A preliminary report. Polish Archaeology in the Mediterranean, 14, 172-176

van der Vliet, J. (2005a). Preliminary observations on the Coptic texts found during seasons 2003 and 2004. Polish Archaeology in the Mediterranean, 16, 191-194

van der Vliet, J. (2005b). Reconstructing the landscape: Epigraphic sources for the Christian Fayum. In G. Gabra (ed.), Christianity and monasticism in the Fayoum oasis: Essays from the 2004 international symposium of the Saint Mark Foundation and the Saint Shenouda the Archimandrite Coptic Society in honor of Martin Krause (pp. 7989). Cairo: American University in Cairo Press

van der Vliet, J. (2015). Nekloni (al-Naqlūn) and the Coptic account book British Library Or. 13885. In A. Kaplony, D. Potthast, and C. Römer (eds), From Bawit to Marw: Documents from the medieval Muslim world [=Islamic History and Civilization 112] (pp. 155-169). Leiden-Boston: Brill

van der Vliet, J. (n.d.). Wall inscriptions from the Church of the Archangel Gabriel. Unpubl. manuscript

Wipszycka, E. (1996). Les rapports entre les monastères et les laures à la lumière des fouilles de Naqlun (Fayoum). In E. Wipszycka, Études sur le christianisme dans l'Égypte de l'antiquité tardive [=Studia ephemeridis Augustinianum 52] (pp. 373-393). Rome: Institutum Patristicum "Augustinianum"

Żurek, M. (2000). The modern cemetery on Site A/E at Deir an-Naqlun. Polish Archaeology in the Mediterranean, 11, 133-134

Żurek, M. (2004). Two pottery deposits from Building AA in Naqlun. Polish Archaeology in the Mediterranean, 15, 165-172

Żurek, M. (2007). Naqlun 2005. Pottery deposit from room G.8A. Polish Archaeology in the Mediterranean, 17, 219-224 


\title{
Verres décorés d'époque arabe médiévale (VIII - XIII ${ }^{\mathrm{e}}$ siècles) : quelques exemples provenant de Naqlun ${ }^{1}$
}

\author{
Maria Mossakowska-Gaubert \\ Institut français d'archéologie orientale, Cairo \\ mmossakowska@ifao.egnet.net
}

\begin{abstract}
KeYwords
Islamic glass, decorative techniques, Egypt, monastic complex, Naqlun
\end{abstract}

\begin{abstract}
The article presents the chronological and typological variety of decorated glasses found in the central part of the site at Naqlun, in the monastic buildings and tombs of the civil cemetery situated in the complex. Artifacts were dated between the 8th and the beginning of the 13th century. The decorated motifs on these glasses were executed with diverse techniques: tool marks, applied, pinched, impressed with tongs, impressed, mould-blown, engraved, cut, incised, scratchengraved, stained, marvered trails. Many similarities are to be observed with material from Fustat. However, the Naqlun assemblage as a whole is more modest, which is not surprising considering the context: provincial, rural and monastic at the same time.
\end{abstract}

Les fouilles menées depuis 1986 par une mission du Centre Polonais d'Archéologie Méditerranéenne (Université de Varsovie) à Naqlun, dirigées par Włodzimierz Godlewski, ont mis au jour une importante quantité d'objets en verre dans les différents secteurs du site ${ }^{1}$. Plusieurs études ont déjà été publiées sur les objets en verre trouvés dans les ermitages, ceux notamment de l'ermitage $\mathrm{N}^{\circ} 44$ (Mossakowska-Gaubert $2000 ; 2004 ; 2012$ ), le plus riche en matériel de ce type, mais aussi des ermitages $N^{\text {os }} 85$ et 87 (Mossakowska-Gaubert 2008 ; 2012) fouillés relativement récemment. En ce qui concerne les objets provenant du kôm, seule

1 Je souhaite remercier chaleureusement Włodzimierz Godlewski de m’avoir confié en 1996 l'étude de ce matériel : c'est le premier ensemble d'objets en verre qu'il m’a été donné d'étudier. 


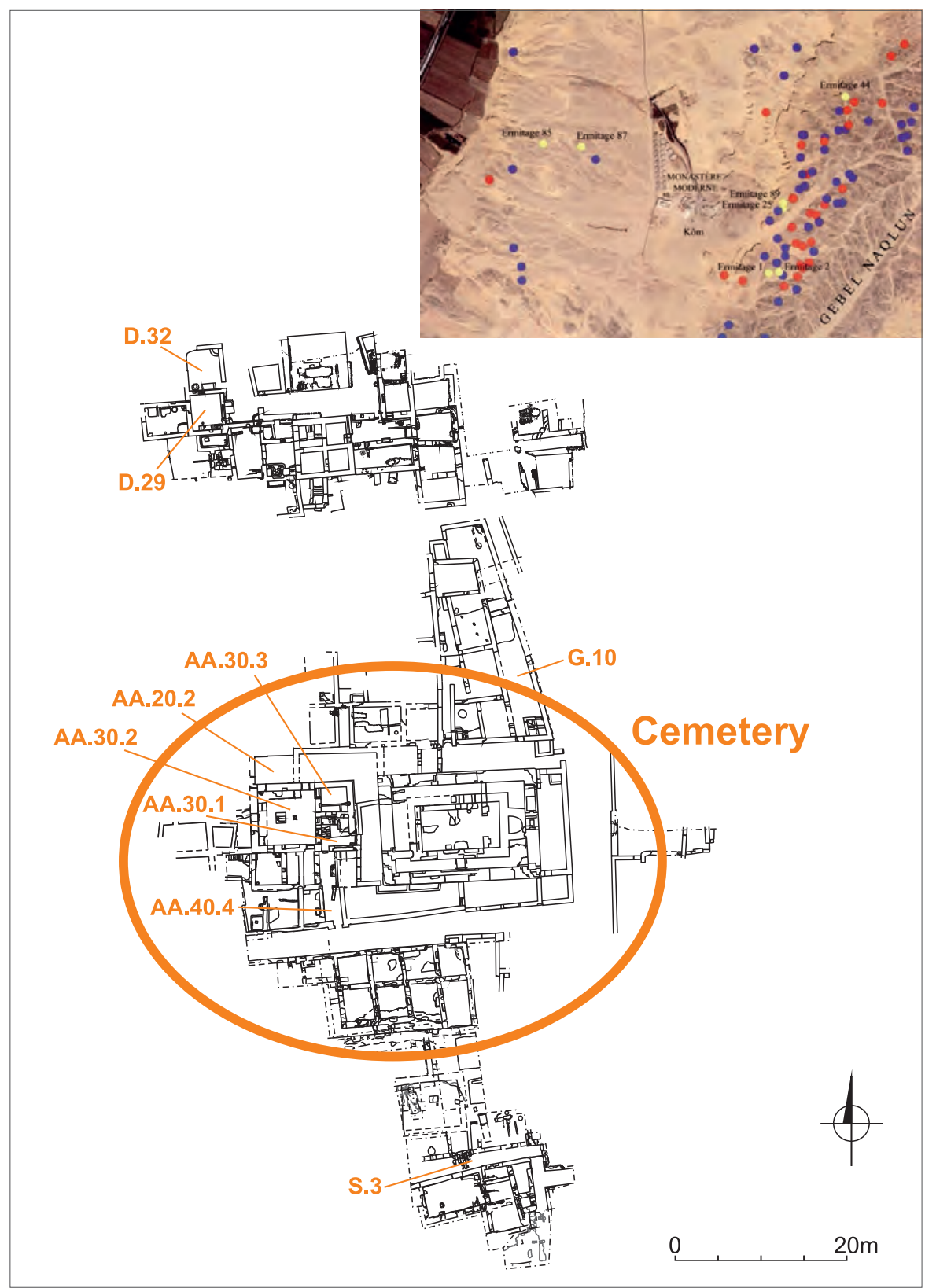

Fig. 1. Dessin : plan général de la partie centrale du complexe monastique de Naqlun. Photo satellite : site de Naqlun dans son ensemble

(Dessin S. Maślak; map d'après Google Map W. Matkowski (C) PCMA) 
une partie des verres trouvés sur le cimetière $\mathrm{A}$ a déjà fait l'objet d'une présentation (Mossakowska-Gaubert 2001 ; 2003 ; 2014 ; Godlewski 2007 : 194-197).

Cet article enrichit et actualise l'image des verres trouvés sur le kôm [Fig. 1]. Son but est de montrer la diversité des types et des techniques de décoration des objets en verre trouvés dans ce secteur et datés entre le VIII ${ }^{e}$ et le début du XIII ${ }^{\mathrm{e}}$ siècle. Néanmoins, la présente étude est loin d'épuiser la richesse de la totalité du matériel en verre provenant de ce secteur, qui sera intégralement traité dans une publication finale consacrée aux travaux de la mission sur le kôm de Naqlun.

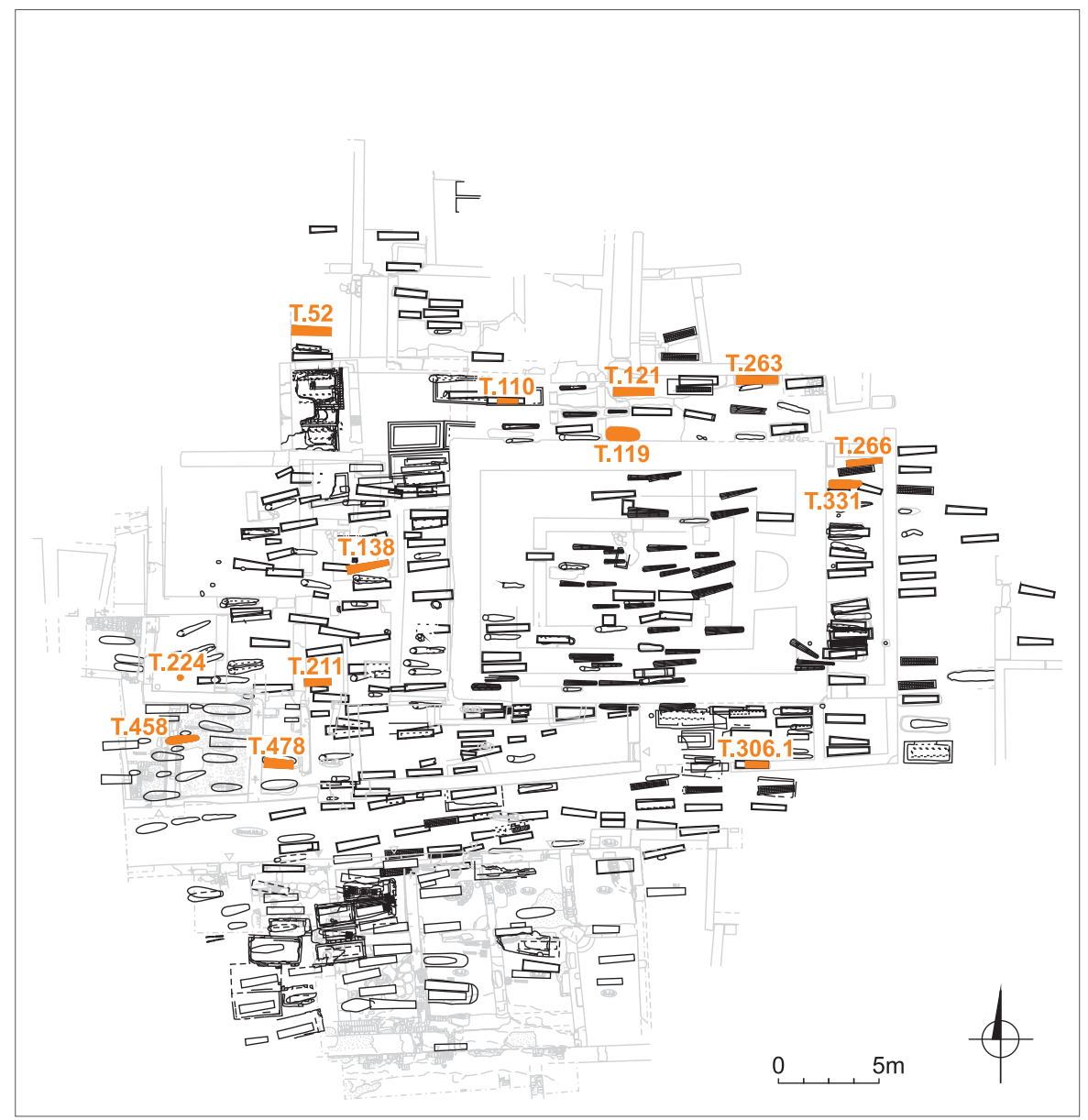

Fig. 2. Plan du cimetière A avec localisation des tombes qui ont fourni des objets en verre (Dessin D. Zieliniska, S. Maślak (C) PCMA) 


\section{Provenance}

Les objets trouvés dans le bâtiment AA.20 proviennent du contexte du VIII siècle. Certains verres, qui peuvent être datés du début du IXe siècle ou même plus tôt, ont été trouvés avec d'autres objets, plus tardifs, dans les dernières phases d'occupation du bâtiment AA.30 et AA.40, datables de la première moitié du $\mathrm{X}^{\mathrm{e}}$ siècle. Le complexe AA et ses pièces annexes servaient probablement d'entrepôt. Cette structure est située dans la plus ancienne partie du complexe monastique de Naqlun occupée du $\mathrm{VI}^{e}$ siècle jusqu'à l'incendie qui eut probablement lieu vers le milieu du $\mathrm{X}^{\mathrm{e}}$ siècle.

Les objets postérieurs proviennent dans la grande majorité du cimetière $\mathrm{A}$ [Fig. 2], des tombes datées des périodes fatimide et ayyoubide où ils ont été placés soit près de la tête soit près des jambes du défunt. En général, on disposait dans la fosse un récipient, plus rarement deux ou même trois.

Un objet a été trouvé dans une pièce datée du $\mathrm{XI}^{\mathrm{e}}$ siècle, construite comme annexe d'un bâtiment servant de dépendance (GG 10). Une coupe du Xe-début $\mathrm{du} \mathrm{XI}^{\mathrm{e}}$ siècle provient des bâtiments découverts au sud de la tour (tranche $S 3$ ) et enfin, deux fragments (un probablement résiduel du $\mathrm{X}^{\mathrm{e}}$ siècle) ont été trouvés dans des pièces abandonnées à la fin du XII ${ }^{\mathrm{e}}$-début du XIII ${ }^{\mathrm{e}}$ siècle appartenant à un complexe d'ateliers dans le secteur D (D 29, D 32), probablement un atelier de reliure de codex.

L'étude de ces secteurs et du matériel qui y a été trouvé est en cours et certaines constatations exposées ici concernant notamment une chronologie relative restent à vérifier.

L'ordre retenu pour classer les objets a pour critère la technique du décor.

\section{Décor de traces d'outils}

Un simple décor de traces d'outils, connu dans la Méditerranée orientale, attesté en Égypte à partir du $\mathrm{IV}^{\mathrm{e}}$ siècle, répandu aux $\mathrm{V}^{\mathrm{e}}-\mathrm{VI}^{\mathrm{e}}$ siècles, a été pratiqué sur les pieds de verres à boire encore au VIII e siècle (Harden 1936 : Nos 479, 482, 484, Karanis : Ve-VIe siècles [?] ; Foy 2000 : 152-154, Fig. 1, Nos 4-8, Fusțāṭ : deuxième moitié du VII ${ }^{\mathrm{e}}-\mathrm{VIII}{ }^{\mathrm{e}}$ siècle ; Nenna $2000: \mathrm{N}^{\circ} 10$, Koptos : IV $\mathrm{e}_{-}$ milieu du VIe siècle [?] ; Foy 2001 : $\mathrm{N}^{\text {os }} 35$, 37-45, Tebtynis : VII - -milieu VIII siècle; Mossakowska-Gaubert 2004 : Cat. I,3, Naqlun : deuxième moitié $V^{\mathrm{e}}$-début du VI ${ }^{\mathrm{e}}$ siècle; Nenna 2010 : Cat. 56-57, Bagawat: IVe siècle), et sur 
les pieds annulaires des assiettes/bols jusqu'au IX ${ }^{\mathrm{e}}$ siècle (Harden $1936: \mathrm{N}^{\text {os }} 1$, 15, 17, 21, 83, 89, 90, 101, 107, 108, 116, 228, 235, Karanis : $\mathrm{V}^{\mathrm{e}}-\mathrm{VI}^{\mathrm{e}}$ siècles [?] ; Foy 2000 : 154-155, Fig. 2, Nos 6-8, Fusțāt : IX siècle ; MossakowskaGaubert 2004 : Cat. II,3 , III,1-3, Naqlun : deuxième moitié Ve-début du VI siècle).

Les deux fragments de Naqlun présentés ici - un pied d'un verre à tige lisse et pleine ( $\left.\mathrm{N}^{\circ} 1\right)$ et un pied annulaire d'un bol ou d'une assiette $\left(\mathrm{N}^{\circ} 2\right)$ ont été trouvés dans un contexte du VIII siècle (pièce annexe AA 20.2).

No 1. (Nd. 01.106) pied d'un verre à tige, décor de traces d'outil, diam. 3.5$4.0 \mathrm{~cm}, \mathrm{H}+2.6 \mathrm{~cm}$; verdâtre bleuâtre

$\mathrm{N}^{\circ}$ 2. (Nd. 01.067) pied annulaire d'un bol ou d'une assiette, décor de traces d'outil, diam. $5.4 \mathrm{~cm}, \mathrm{H}+1.5 \mathrm{~cm}$; vert

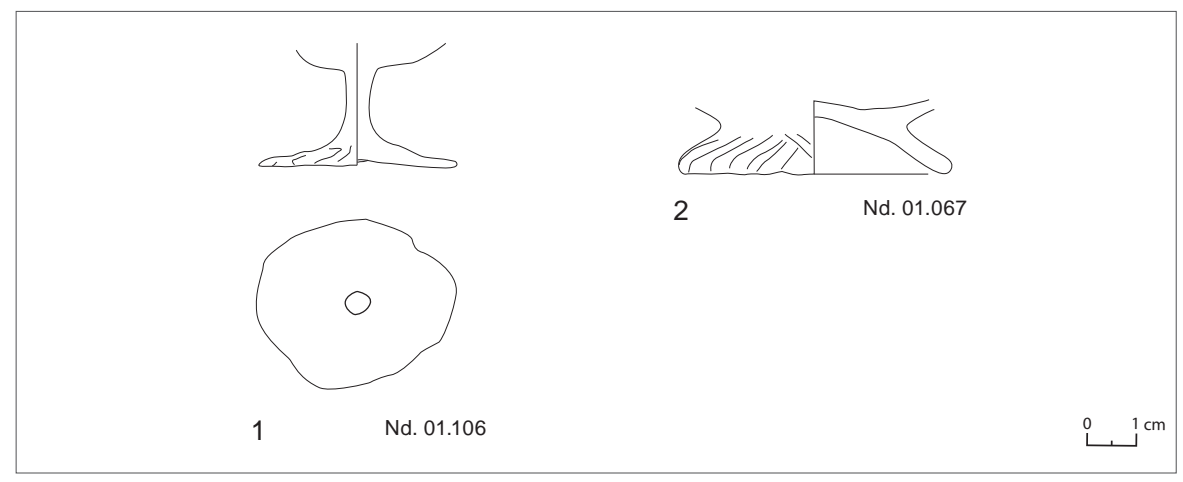

Fig. 3. Verres à décor de traces d'outils (Nos $1-2)$

(Dessins et vectorisation M. Mossakowska-Gaubert)

\section{Décor appliqué}

Les éléments qui étaient appliqués à chaud sur des objets en verre avaient, le plus souvent, une forme de fils de verre disposés en spirale ou en motif plus complexe, par exemple une "cage" entourant un récipient, un ruban ou un large volant, des pastilles, des médaillons, des anses plus ou moins élaborées ou encore des formes fantaisistes, surtout dans le décor de récipients zoomorphiques. Cette technique, pratiquée largement déjà dans l'Antiquité, s'est répandue aussi sur les verres à l'époque arabe médiévale (voir, par exemple, Carboni 2001 : 
162-195). Toutes sortes de récipients pouvaient porter un décor de ce type, notamment des flacons, des bouteilles, des cruches, des gobelets, des coupes et des lampes.

De nombreux objets en verre à décor appliqué ont été trouvés sur le site de Naqlun. Un rebord de gobelet (?) ou de lampe (?) avec une double lèvre appliquée ( $\mathrm{N}^{\circ}$ 3) a été découvert dans un bâtiment abandonné avant le milieu du $\mathrm{X}^{\mathrm{e}}$ siècle (AA 30, pièce AA30.2). Ce type de lèvre "doublée" est aussi présent sur deux autres objets : il s'agit d'un flacon à col large et à panse tronconique, avec un repli horizontal interne fermé ( $\mathrm{N}^{\circ}$ 5) (Mossakowska-Gaubert 2014 : $\mathrm{N}^{\circ} 7$, tombe $\mathrm{T}$ 458), et d'un autre, exécuté en verre opaque, trouvé également dans le contexte funéraire (voir plus loin, № 27).

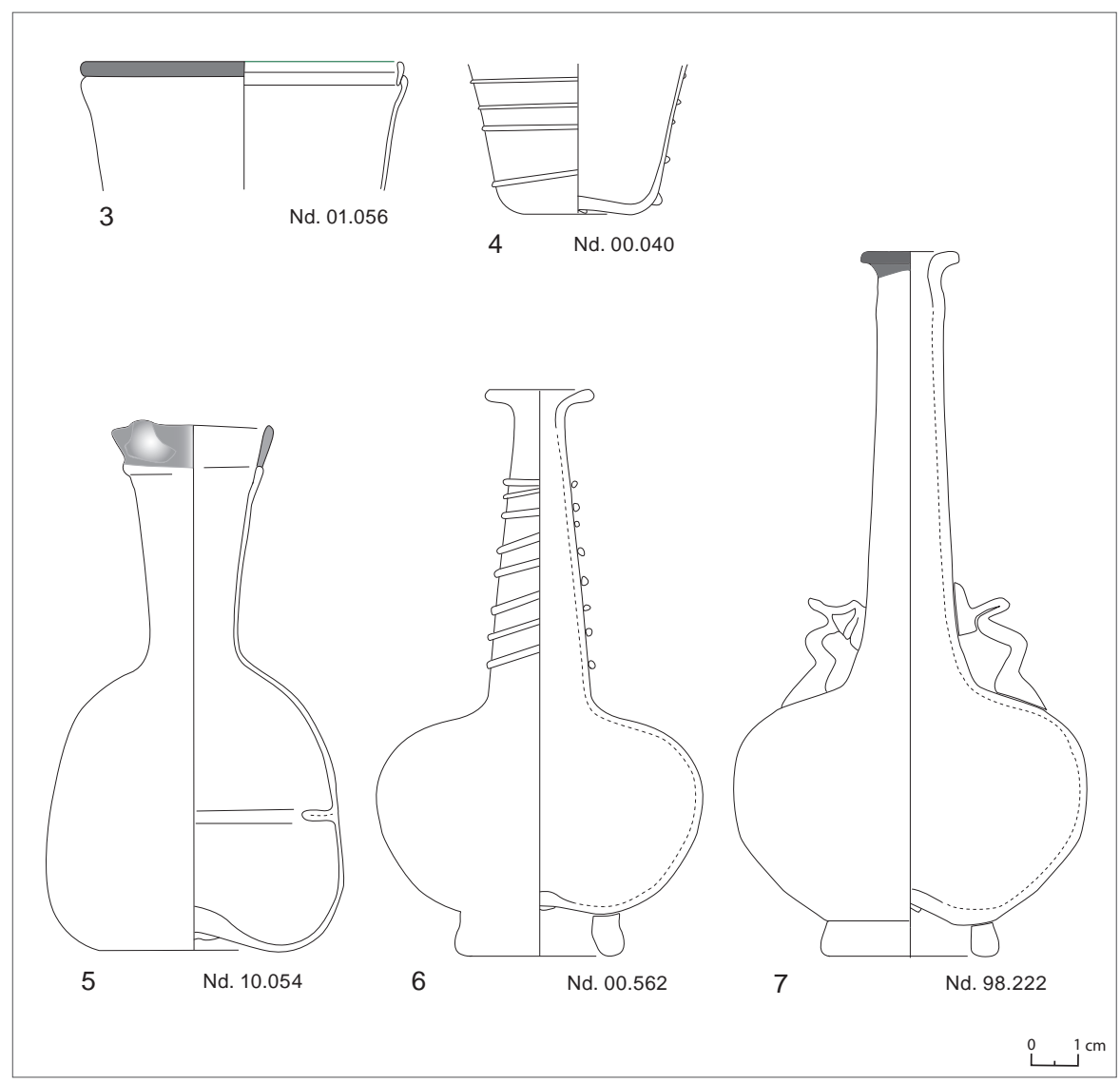

Fig. 4. Verres à décor appliqué (Nos 3-7)

(Dessins et vectorisation M. Mossakowska-Gaubert) 
Dans le matériel de Naqlun on trouve aussi des exemples de verres décorés avec des fils de verre rapportés, comme c'est le cas de la partie inférieure d'un flacon (?), provenant de la pièce $\mathrm{AA} 30.2$ du bâtiment $\mathrm{AA} 30$ ( $\mathrm{N}^{\circ}$ 4), ou d'un flacon à col long, conique, avec une panse sphérique et un pied annulaire collé, décoré de fils appliqués en spirale sur le col. Ce dernier date de l'époque fatimide et il a été trouvé dans le tombeau T 138 (№ 6) (Mossakowska-Gaubert 2001 : type 6).

Enfin, un autre flacon, appartenant au même type de récipient que celui № 6, trouvé dans le tombeau T 52, porte deux anses décoratives appliquées (№ 7) (Mossakowska-Gaubert 2003 : type 6a).

No 3. (Nd. 01.056) rebord d'un gobelet, diam. $6.8 \mathrm{~cm}, \mathrm{H}+2.8 \mathrm{~cm}$; verdâtre, lèvre appliquée : bleu

$\mathrm{N}^{\circ}$ 4. (Nd. 00.562) partie inférieure d'un flacon, diam. $2.6 \mathrm{~cm}, \mathrm{H}+3.2 \mathrm{~cm}$; verdâtre jaunâtre, fils appliqués : même couleur que le récipient

No 5. (Nd. 10.054) flacon conservé partiellement, diam. du rebord : $3.6 \mathrm{~cm}$, H $11.1 \mathrm{~cm}$; verdâtre, fortement irisé, lèvre appliquée : bleu foncé

No 6. (Nd. 00.040) flacon intact, diam. du rebord : $2.2 \mathrm{~cm}, \mathrm{H} 12.1 \mathrm{~cm}$; vert clair, fils appliqués : même couleur que le récipient

$\mathrm{N}^{\circ}$ 7. (Nd. 98.222) flacon intact, diam. du rebord : $1.9 \mathrm{~cm} ; \mathrm{H} 15.0 \mathrm{~cm}$; verdâtre, lèvre : bleu foncé, anses appliquées : même couleur que le récipient

\section{Picotement et retirement de la matière}

Le décor qui consiste à pincer et retirer la matière chaude sur la surface d'un récipient, apparu à l'époque byzantine, est pratiqué largement au Proche-Orient dans les premiers siècles de l'époque arabe, notamment à la période omeyyade, mais aussi plus tard, au début de la période abbasside (cf. Harden 1936 : Nos 681-682, Karanis : Ve_VI ${ }^{\mathrm{e}}$ siècles [?] ; Shindo 1992 : 579, Nos 1-3, Fusțāț ; Silvano 1999 : № 26, Medinet Madi : Ve siècle ; Foy 2000 : 161-162, Fig. 13, Nos 3-8, Fusțāț : VIII -début du IXe siècle ; 2001 : No 103, Tebtynis : antérieur à l'époque fatimide; Scanlon et Pinder-Wilson 2001 : Nos 33a-b, Fusțāṭ : avant l'an 1000 ; Ballet 2003 : No 5, Kellia : VIII ${ }^{e}$ siècle). Les petits picotements sur la panse ou sur le fond d'un récipient pouvaient être disposés en motifs simples, comme des petits pieds rayonnant ou comme une frise sur la panse.

Plusieurs fragments de verres ainsi décorés ont été trouvés lors des fouilles sur le site de Naqlun. Nous avons choisi ici pour exemple un fond en verre décoré de picotements ( $\left.N^{\circ} 8\right)$, trouvé dans la pièce AA.30.1. Cette pièce ayant 
été abandonnée vraisemblablement vers le milieu du $\mathrm{X}^{\mathrm{e}}$ siècle, il est donc possible que l'objet était résiduel dans ce contexte.

No 8. (Nd. 00.161) fragment d'un fond décoré d'une frise de picots; $\mathrm{H}+1.2 \mathrm{~cm}$; vert bleu

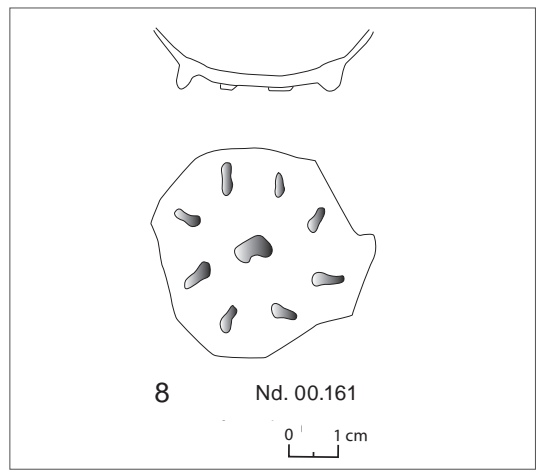

Fig. 5. Verres décorés par picotement et retirement de la matière ( $\left.N^{\circ} 8\right)$ (Dessins et vectorisation M. Mossakowska-Gaubert)

\section{Décor imprimé à la pince}

L'impression de motifs décoratifs à l'aide d'une pince sur un récipient encore chaud a été très répandue en Égypte de la fin du VIII ${ }^{\mathrm{e}}$ siècle jusqu'au $\mathrm{X}^{\mathrm{e}}$ siècle (cf. Harden 1940 : No 23, Armant : VIII ${ }^{\mathrm{e}}-\mathrm{X}^{\mathrm{e}}$ siècles ; Shindo 1992 : 577, $\mathrm{N}^{\text {os }} 17$ et 22, Fusțāt ; Bailey 1998 : $\mathrm{N}^{\text {os }} \mathrm{Y} 28-30$, Ashmounein : VIII $-\mathrm{X}^{\mathrm{e}}$ siècles ; Foy 2001 : Nos 84-101, Tebtynis : fin du VIII -début du IX siècles ; Scanlon et Pinder-Wilson 2001 : Nos 38a, f, g, h, i, j, Fusțāț : IX $-X^{\mathrm{e}}$ siècles ; Foy, Picon, et Vichy 2003 : No 16, Fusțāt : abbasside ; Shindo 2003 : Fig. 3, 1-2, Rāya : IX ${ }^{\mathrm{e}}$ siècle ; 2009 : Fig. 2-d, Rāya : IX ${ }^{\mathrm{e}}$ siècle). L'apogée de l'utilisation de cette technique se situe pendant la première moitié du IX ${ }^{\mathrm{e}}$ siècle (cf. Carboni 2001 : 261-271 ; Foy, Picon, et Vichy 2003 : 140 ; Shindo 2015). Par ailleurs, des verres ainsi décorés ont aussi été trouvés dans d'autres pays du Proche-Orient, mais leur origine demeure discutable (Carboni 2001 : 269). Ce type de décor est fréquent sur la vaisselle à forme ouverte. Dans la majorité des cas, il s'agit de motifs géométriques, parfois des palmettes, des arabesques, très rarement des représentations d'animaux ou des inscriptions. 
Parmi les nombreux exemples d'utilisation de cette technique dans le matériel de Naqlun, nous mentionnerons les fragments de deux gobelets provenant du bâtiment AA 30. Le premier fragment ( $\left.\mathrm{N}^{\circ} 9\right)$, trouvé dans la pièce AA 30.3, est un rebord décoré de losanges imprimés. De la pièce AA 30.2.4 proviennent 11 fragments d'un gobelet qui portait un décor de losanges et de doubles "grillades" formées par des guillochis ( $\left.\mathrm{N}^{\circ} 10\right)$.

No 9. (Nd. 01.003) fragment d'un rebord à décor imprimé à la pince ; diam. $6.6 \mathrm{~cm}, \mathrm{H}+2.5 \mathrm{~cm}$; vert

$\mathrm{N}^{\circ}$ 10. (Nd. 01.184) 11 fragments d'un gobelet à décor imprimé à la pince ; diam. $7.4 \mathrm{~cm}, \mathrm{H}+7.2 \mathrm{~cm}$; vert

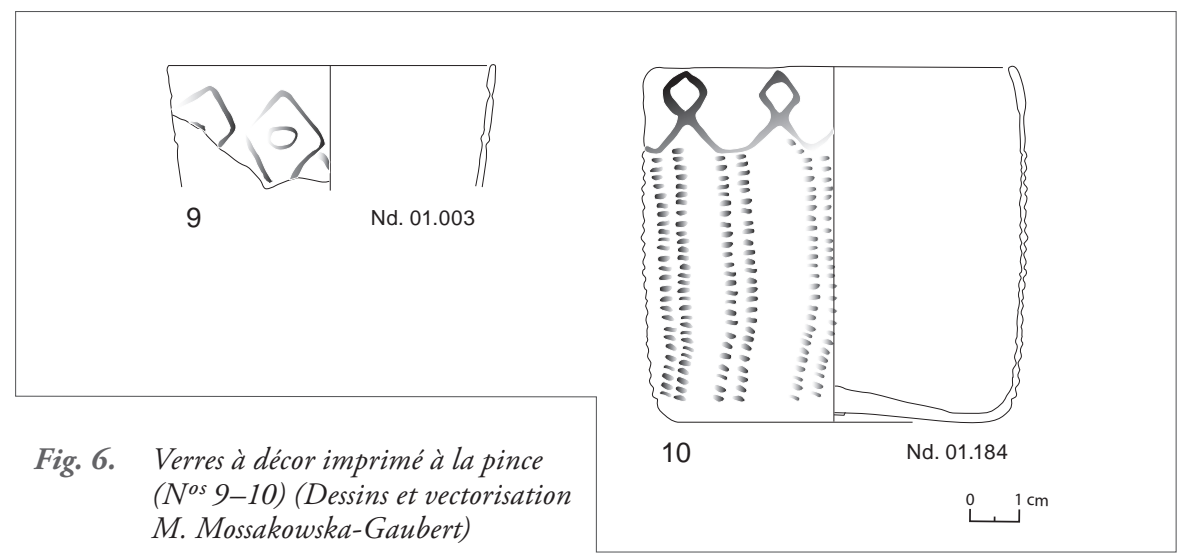

\section{Décor estampé}

Le décor estampé est une variante du décor imprimé. Il était exécuté directement sur la surface et/ou sur des pastilles rapportées. Cette technique semble se développer surtout aux $\mathrm{IX}^{\mathrm{e}}-\mathrm{X}^{\mathrm{e}}$ siècles (cf. un commentaire de Foy 2001 : 476 ; les exemples trouvés en Égypte, cf. Shindo 1992 : 577, Nos 1-5, Fusțāț ; Scanlon et Pinder-Wilson 2001 : Nos 37 c, d, e, Fusțāț : IX ${ }^{\mathrm{e}}-\mathrm{X}^{\mathrm{e}}$ siècles ; Foy 2001 : No 102, Tebtynis : vers le milieu du IX siècle ; Foy, Picon, et Vichy 2003 : No 27, Fusțāta : la seconde moitié du IX $\mathrm{X}^{\mathrm{e}}$-première moitié du $\mathrm{X}^{\mathrm{e}}$ siècle ; Shindo 2003 : Fig. 3, 9, Rāya : IX ${ }^{\mathrm{e}}-\mathrm{X}^{\mathrm{e}}$ siècles).

Les objets en verre ainsi décorés sont moins fréquents dans le matériel de Naqlun que ceux à décor imprimé. Un fragment, qui appartenait probablement à un col de bouteille, trouvé dans la pièce annexe AA 40.4, peut illustrer 
l'utilisation de cette technique. Il est décoré d'une frise composée d'un motif ovale au centre duquel se trouve un globule en haut-relief (motif dit "d'omphalos"). Le motif "d'omphalos", qui semble être d'origine iranienne, repris dans d'autres pays islamiques (Carboni 2001 : 74 et 267), a été exécuté sur les verres soit en technique sculptée (p. ex. : Kröger 1995 : Nos 174-183, Iran : IX ${ }^{\mathrm{e}}-\mathrm{X}^{\mathrm{e}}$ siècles ; Carboni 2001 : Cat. 16c et d, Kuwait National Museum — région d'Iran : VIII - IX $^{\mathrm{e}}$ siècles), soit soufflé dans un moule (cf. $\mathrm{N}^{\circ} 16$ ), ou encore estampé (Carboni 2001 : Cat. 3, 55 a-f, Kuwait National Museum probablement la région de la Mésopotamie ou d'Iran : $\mathrm{IX}^{\mathrm{e}}-\mathrm{X}^{\mathrm{e}}$ siècles).

№ 11. (Nd. 01.285) fragment d'un rebord à décor estampé ; diam. $5.4 \mathrm{~cm}$, $\mathrm{H}+5.9 \mathrm{~cm}$; jaunâtre

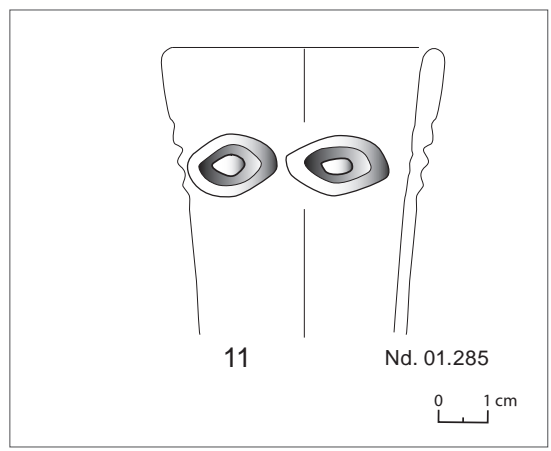

Fig. 7. Verre à décor estampé ( $\left.N^{o} 11\right)$

(Dessin et vectorisation

M. Mossakowska-Gaubert)

\section{Verres soufflés dans un moule}

Le soufflage de verre dans un moule, inventé à l'époque romaine, a été largement pratiqué à l'époque arabe médiévale (Clairmont 1977 : 59-60 ; von Folsach et Whitehouse 1993 ; Carboni 2001 : 197-199 ; Lledó et Matthews 2009). Cette technique connaît sa période la plus florissante aux $\mathrm{XI}^{\mathrm{e}}-\mathrm{XII}{ }^{\mathrm{e}}$ siècles. Les moules, aux formes et aux décors variés, étaient fabriqués en bronze ou dans un autre matériau, plus périssable, comme la terre cuite. Les moules utilisés à cette époque étaient simples ou doubles. Un moule simple pouvait servir à décorer des récipients aux formes variés, comme des bols et des assiettes, la forme finale étant en fait élaborée après la sortie du récipient du moule.

Les verres soufflés dans un moule sont nombreux dans le matériel de Naqlun. Nous avons choisi comme exemples huit objets, tous datés de l'époque fatimide. 
Les six premiers récipients ont été trouvés dans des tombes du cimetière A.

Le flacon octogonal $\left(\mathrm{N}^{\circ} 12\right)$ fut découvert dans la tombe $\mathrm{T}$ 263. Son col est large et les lèvres évasées. Il a été trouvé avec un cordon attaché sur la partie supérieure du col. Un autre flacon ( No 13) (Mossakowska-Gaubert 2014 : № 6), provenant du tombeau $\mathrm{T} 478$, possède un col à deux replis et ses lèvres sont arrondies. La panse a une forme "prismatique ", composée de six panneaux. Enfin, un troisième flacon ( $\mathrm{N}^{\circ} 14$, tombe $\mathrm{T}$ 266) porte sur sa panse un motif côtelé. Les lèvres arrondies, comme dans le cas du récipent $\mathrm{N}^{\circ} 13$, sont précédées d'un repli sur le col. La panse est globulaire. Ce type de repli, attesté sur les deux derniers flacons, est bien connu sur des cols de bouteilles et de flacons datés du IX $^{\mathrm{e}}$ au XIII ${ }^{\mathrm{e}}$ siècle (Davidson 1952 : 118-119, № 780, Corinth : XI ${ }^{\mathrm{e}}-$ milieu du XII siècle ; Meyer 1992 : 76-77, Pl. XV, Nos 374-378, Quseir al-Qadim : fin du XII -début du XIV e siècles ; Carboni 2001 : Cat. 65 et 66, région d'Iran : XII ${ }^{\mathrm{e}}$-première moitié du XIII ${ }^{\mathrm{e}}$ siècle ; Mossakowska-Gaubert 2001 ; 2003 : type 4, Naqlun : XIe-XIII ${ }^{\mathrm{e}}$ siècles ; Puche Acién, Matthews, et Bass 2009 : plusieurs exemples, Serçe Limanı : 1025 apr. J.-C.).

Le flacon ( $\mathrm{N}^{\circ}$ 17, tombe T 224) (Mossakowska-Gaubert 2001 ; 2003 : type 5) à col large, droit, rétréci dans la partie supérieure, lèvres évasées porte un décor "gaufré" disposé en quatre registres sur la panse. Le décor est visible aussi sur le fond. Ce motif, qui ressemble aux "nids d'abeille" connus déjà dans les premiers siècles de l'art islamique, était très répandu à l'époque fatimide et ses origines directes remontent vraisemblablement à l'art sassanide où il était taillé à facettes (Pinder-Wilson et Scanlon 1987 : 64 ; Pinder-Wilson 1991 : 116 ; Beech 1992 : 72-74 ; Carboni 1999 : 175). D'autre part, le motif de "nids d'abeille" soufflé dans un moule est connu aussi sur les verres de l'époque romaine, mais il ne semble pas qu'il existe de passage direct entre ce décor et celui pratiqué sur des verres islamiques (Clairmont 1977 : 60).

Le récipient suivant ( $\mathrm{N}^{\circ} 18$, tombe $\left.\mathrm{T} 331\right)$ est une bouteille en forme de grande ampoule à col large, avec un repli dans la partie inférieure du col d'où partent deux petites anses. Sa panse est ovoïdale, aplatie, le fond arrondi. Le verre, de couleur pourpre pâle, a été produit grâce à l'addition de manganèse. Le décor de motifs végétaux stylisés, en forme d'un " $S$ ", est situé au centre et sur la partie inférieure de la panse. Ces motifs et leur composition ressemblent aux motifs représentés sur quelques bouteilles du Musée national de Koweït, provenant probablement d'Iran (Carboni 2001 : Cat. 64c et d, XII ${ }^{\mathrm{e}}$-première moitié du XIII siècles). Par ailleurs, la couleur "pourpre manganèse" a été utilisée de manière réduite aux $\mathrm{XII}^{\mathrm{e}}$ et $\mathrm{XIII}^{\mathrm{e}}$ siècles dans les ateliers iraniens (cf. Carboni 2001 : 231, Cat. 63, Kuweit National Museum, région d'Iran : XII ${ }^{\mathrm{e}}$ siècle, et Cat. 65, Kuweit National Museum, région d'Iran : XII ${ }^{\mathrm{e}}$-première 
moitié du XIII siècle). Il est difficile de trouver, parmi les verres de l'époque arabe médiévale, une forme analogue de ce récipient.

Le flacon ( $\mathrm{N}^{\circ} 19$, tombe $\mathrm{T}$ 306.1), à panse cylindrique et col large, lèvres évasées, rebord à bourrelets, porte un motif ondulé sur la panse, tandis que le fond est décoré d'une étoile à six bras. Le même motif (gravé ?) est visible aussi sur un fond en verre trouvé à Fusțāt (cf. Shindo 1992 : 583, No 18, Fusțāṭ). Une étoile à six bras, appelée aussi un "sceau de Salomon", est connue

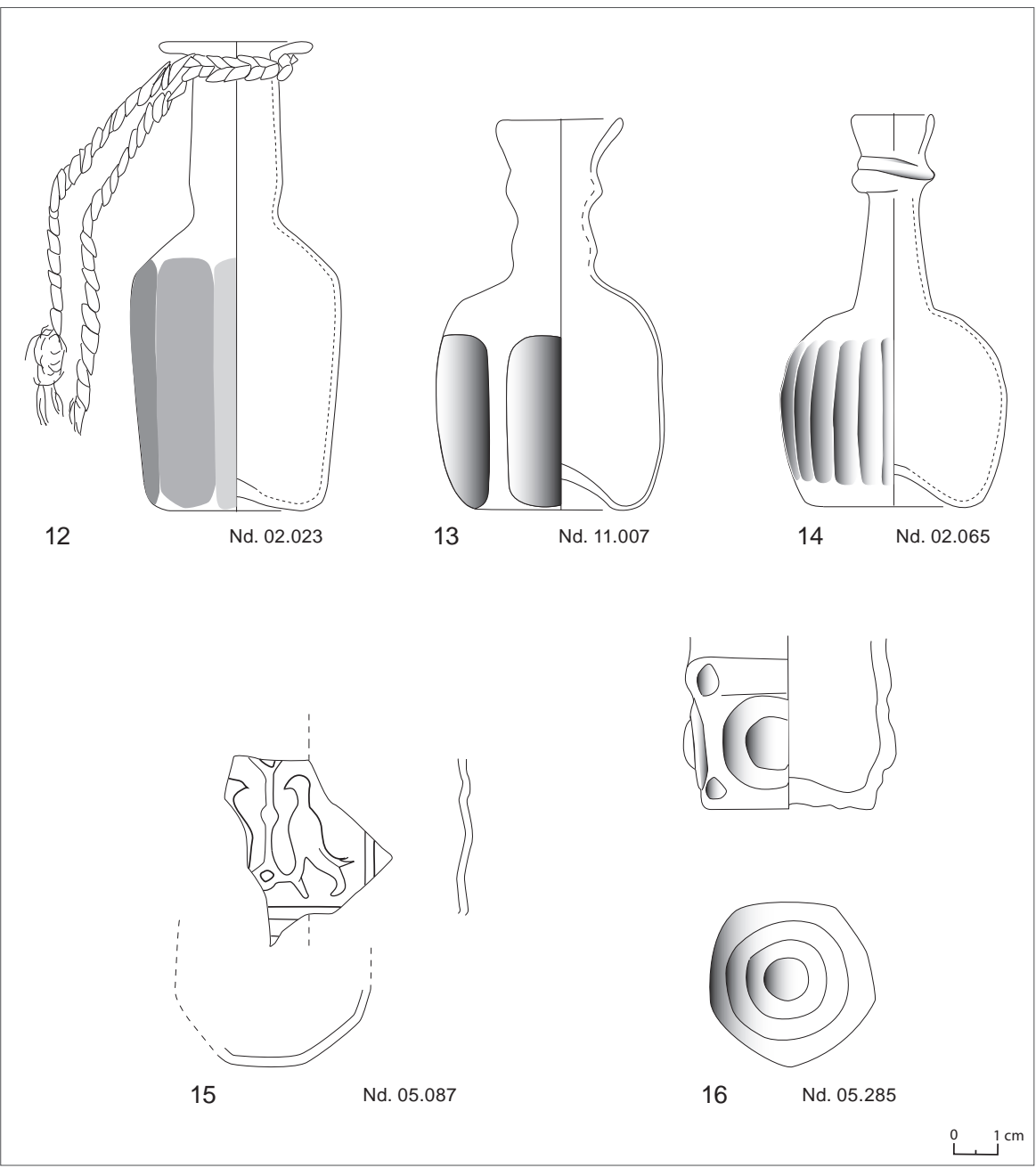

Fig. 8. Verres soufflés dans un moule (Nos $12-16)$

(Dessins et vectorisation M. Mossakowska-Gaubert) 
dans l'iconographie islamique déjà à l'époque ummayyade. On la trouve aussi représentée sur les monnaies omeyyades et ayyoubides (cf. Guilhot 2010 : 72-73).

D'une pièce de service datée du XIe siècle (GG 10) provient le fragment d'un récipient (bouteille, flacon ?) octogonal ( $\left.\mathrm{N}^{\circ} 15\right)$. Ce récipient portait un motif décoratif répété quatre fois : à chaque fois le motif occupait deux panneaux. On peut identifier ici une figuration de deux oiseaux affrontés de chaque côté

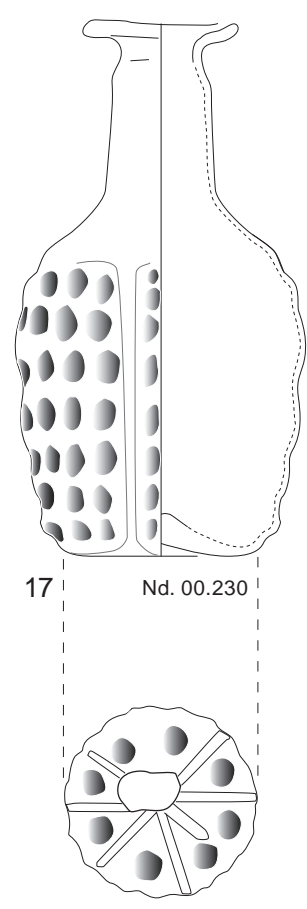

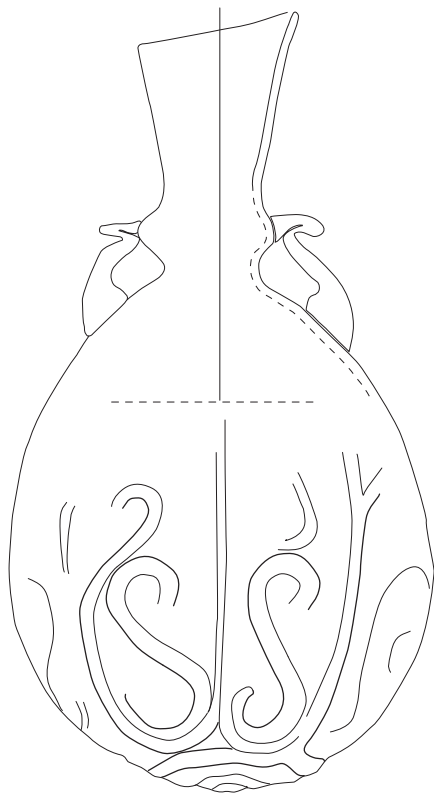

18

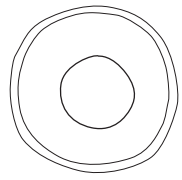

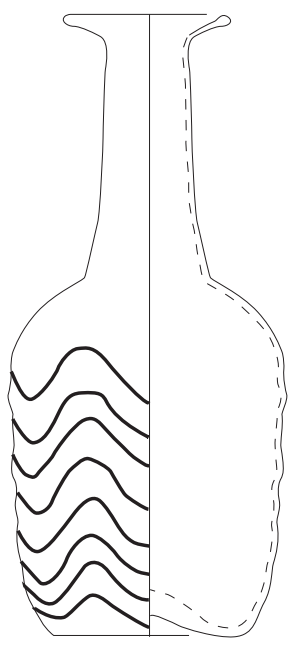

19

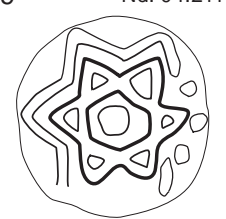

Fig. 9. Verres soufflés dans un moule (Nos 17-19)

(Dessins et vectorisation M. Mossakowska-Gaubert; dessin $N^{o} 18$ D. Dzierzbicka) 
de l'arbre de vie stylisé (ou peut-être d'une colonne). Il s'agit probablement de faucons. Les décors animaliers sont typiques de l'art fatimide (Contadini 1998 : 81). Les représentations de deux oiseaux affrontés, séparés par l'arbre de vie ou un autre motif, sont connues dans l'iconographie copte. On peut voir ce type de représentations p.ex. sur des tissus (Martiniani-Reber 1986: № 73 Achmim ?: VII ou VIII siècle ; Cornu, Martiniani-Reber, et Fiette 2008 : No 1 Égypte : fin du IX ${ }^{\mathrm{e}}$-début du $\mathrm{X}^{\mathrm{e}}$ siècle, cf. aussi le commentaire).

Le dernier exemple enfin est la partie inférieure d'une petite bouteille ou flacon (?) ( $\left.\mathrm{N}^{\circ} 16\right)$ à panse pentagonale, trouvée dans un contexte du $\mathrm{X}^{\mathrm{e}}$-début $\mathrm{du} \mathrm{XI}^{\mathrm{e}}$ siècle (tranche S 3). Un motif de deux cercles, un petit cercle inscrit dans un autre plus grand ("motif d'omphalos", cf. supra), est répété dans cinq registres (cf. Carboni 2001 : Cat. 3.37a et 3.38 Kuwait National Museum, région $\mathrm{d}^{\prime} I r a n: \mathrm{X}^{\mathrm{e}}-\mathrm{XI}^{\mathrm{e}}$ siècles). Deux petits boutons, à section triangulaire, marquent chaque fois les limites des registres.

$\mathrm{N}^{\circ}$ 12. (Nd. 02.023) flacon intact, soufflé dans un moule; diam. de rebord: $3.2 \mathrm{~cm}, \mathrm{H} 10.7 \mathrm{~cm}$; vert olive

$\mathrm{N}^{\circ}$ 13. (Nd. 11.007) flacon conservé parteillement, soufflé dans un moule ; diam. du rebord $2.9 \mathrm{~cm}, \mathrm{H} 9.0 \mathrm{~cm}$; couleur verdâtre-bleuâtre.

№ 14. (Nd. 02.065) flacon intact, soufflé dans un moule; diam. de rebord : $1.8 \mathrm{~cm}, \mathrm{H} 8.9 \mathrm{~cm}$; vert

$\mathrm{N}^{\circ}$ 15. (Nd. 05.087) fragment de parois d'un flacon (?) soufflé dans un moule : $\mathrm{H}+4.3 \mathrm{~cm}$; légèrement jaunâtre

№ 16. (Nd. 05.285) fragment d'un fond et des parois d'un flacon (?) souffé dans un moule : diam. $3.8 \mathrm{~cm}, \mathrm{H}+4.0 \mathrm{~cm}$; vert - nuance bleu

No 17. (Nd. 00.230) flacon intact, soufflé dans un moule; diam. de rebord: $3.1 \mathrm{~cm}, \mathrm{H} 10.8 \mathrm{~cm}$; vert foncé

$\mathrm{N}^{\circ}$ 18. (Nd. 09.331) ampoule intacte, soufflée dans un moule : diam. de rebord : 3.3-3.5 cm, H $15.9 \mathrm{~cm}$; pourpre manganèse

$\mathrm{N}^{\circ}$ 19. (Nd. 04.211) flacon intact, soufflé dans un moule; diam. de rebord: $3.4 \mathrm{~cm} ; \mathrm{H} 12.6 \mathrm{~cm}$; vert

\section{Verres gravés}

Le décor gravé à l'aide de techniques variées (sculpté, taillé, rainures, abrasé, incisé, facettes...) a été pratiqué sur des objets en verre depuis l'Antiquité. Les IX ${ }^{\mathrm{e}}-\mathrm{X}^{\mathrm{e}}$ siècles constituent la grande époque des verres gravés dans l'art islamique. 
Cependant, la question des centres de production de ces verres reste toujours ouverte, celle surtout de(s) lieu(x) de production de verre sculpté. Certaines pièces trouvées en Égypte, comme la fameuse cruche de Fusțāt (Scanlon et Pinder-Wilson 2001 : No 43f.) datée de la fin du IX ${ }^{\mathrm{e}}$ siècle, ont été produites selon toute vraisemblance en Iran. Il est fort possible néanmoins qu'il existât aussi une production locale égyptienne de verre sculpté, peut-être initiée par des artisans venus d'Iran ou d'Irak (Carboni 1999 : 176-177).

Parmi les quelques verres gravés trouvés sur le site de Naqlun, nous avons choisi quatre objets susceptibles d'illustrer la variété des techniques et des motifs décoratifs.

\section{DÉCOR DE RAINURES}

Plusieurs fragments en verre trouvés à Naqlun dans la pièce AA 30.2 appartiennent à une cruche à la panse en forme de poire ( $\left.\mathrm{N}^{\circ} 22\right)$. La partie supérieure de ce récipient porte un décor de motifs floraux et géométriques constitués par des rainures profondes. La forme des cruches en verre qui ressemblent à une poire est dérivée des objets en métal produits en Iran à l'époque sassanide. Cependant, il est difficiel de déterminer, à l'époque arabe médiévale, les centres de production des cruches en verre qui gardaient cette forme, en Iran ou en Égypte (Carboni 2001 : 219 ; Kenesson 2009 : 293. Exemples des cruches de forme analogue: Whitehouse 1993 : Figs 1-5, décor camée, The Corning Museum of Glass, Iran ou Égypte : fin du X $\mathrm{X}^{\mathrm{e}}$-milieu du XI ${ }^{\mathrm{e}}$ siècles ; Scanlon et Pinder-Wilson 2001 : No 43f., décor sculpté, trouvé à Fusțāt, production probablement iranienne : fin du IX ${ }^{\mathrm{e}}$ siècle ; Carboni 2001 : Cat. 56, souflé dans un moule, Kuwait National Museum, probablement la région d'Iran : $\mathrm{X}^{\mathrm{e}}-\mathrm{XI}$ siècles).

Par sa forme, par la technique décorative et la disposition des motifs, la partie préservée du récipient de Naqlun n'est pas sans rappeler certaines cruches en verre trouvées dans l'épave à Serçe Limanı (Kenesson 2009 : notamment EW 40, 42 et 43, 1025 apr. J.-C.). Eu égard à la qualité plutôt médiocre de l'exécution du décor, l'objet de Naqlun devait être une production locale.

\section{DÉCOR TAILLÉ}

Des simples motifs linéaires ou géométriques ont été souvent taillés sur de petits flacons et bouteilles destinés à contenir des parfums ou des essences (cf. Carboni 2001 : 98-109). Ces containers à formes variés (p. ex. flacons "molaires", petites bouteilles cylindriques, en forme de poire à la section carrée ou parfois polygonale ou en forme de poisson) étaient très répandus 


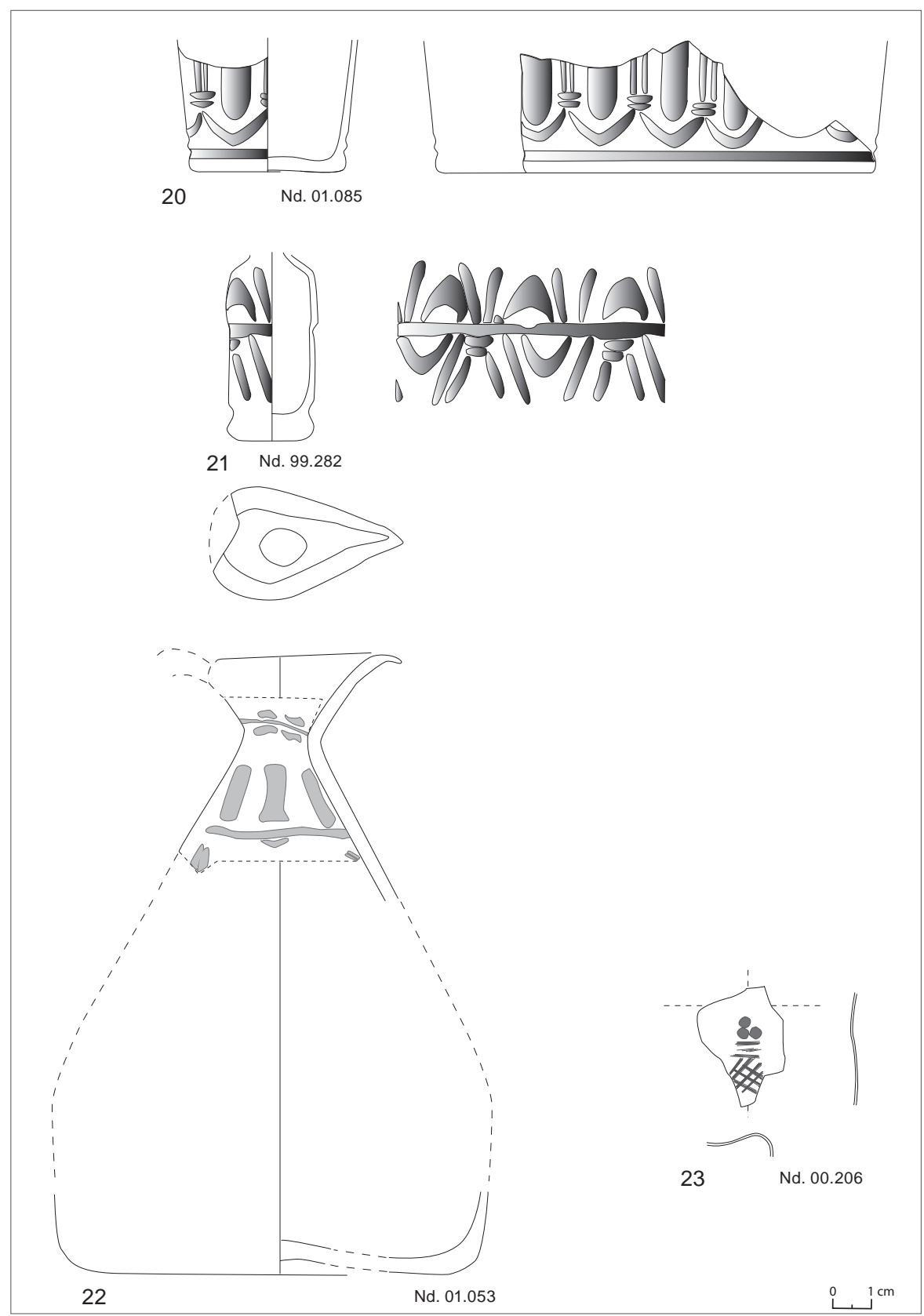

Fig. 10. Verres gravés (Nos 20-23)

(Dessins et vectorisation M. Mossakowska-Gaubert) 
dans le monde islamique. Leur présence sur plusieurs sites reflète l'ampleur du commerce de parfumerie et leurs lieux de production correspondaient aux centres de production de parfums. Certains types de ces containers, notamment les flacons molaires, sont associés à la production égyptienne. L'apogée de leur diffusion correspond aux $\mathrm{IX}^{\mathrm{e}}-\mathrm{X}^{\mathrm{e}}$ siècles.

Comme exemples de verres taillés de Naqlun, nous retenons ci-après deux petits flacons cylindriques partiellement préservés (pour les trouvailles de petits flacons taillés sur d'autres sites en Égypte cf. surtout Shindo 1992: 583, $\mathrm{N}^{\text {os }}$ 12-13, 16-17, p. 585, Nos 5-11, Fusțāt ; Scanlon et Pinder-Wilson 2001 : 91-99, Nos 42a-ziii, Fusțāṭ : IX $-X^{\mathrm{e}}$ siècles ; Shindo 2003 : 182, Fig. 3,8, Rāya : $\mathrm{IX}^{\mathrm{e}}-\mathrm{X}^{\mathrm{e}}$ siècles) Shindo 2009 : 309, Fig. 2, e-f, Rāya : $\mathrm{X}^{\mathrm{e}}$ siècle). Le premier ( $\mathrm{N}^{\circ}$ 20), trouvé dans un contexte d'avant le milieu du $\mathrm{X}^{\mathrm{e}}$ siècle (structure AA 30.3), est décoré de motifs ressemblant à des colonnes (vraisemblablement huit) reliés entre eux, dans la partie inférieure, par une "guirlande". Nous pouvons seulement supposer qu'une autre "guirlande" faisait le lien entre les sommets des colonnes. Chaque "arcade" (cf. Kröger 1995 : 155-157) ainsi formée est remplie par un motif arrondi, difficile à identifier en raison du mauvais état de préservation de l'objet.

Le deuxième flacon ( $\mathrm{N}^{\circ} 21$ ), qui provient du contexte antérieur au XIII e siècle (D 32), date probablement du $\mathrm{X}^{\mathrm{e}}$ siècle. Sa décoration de trois "bicornes" alternés de deux lignes est disposée en faux "miroir" sur deux registres. La panse du récipient est entièrement préservée, mais le col manque. D'après des pièces analogues, devait avoir la forme d'un entonnoir (Carboni 2001 : Cat. 2.20 b, Kuwait National Museum - probablement Égypte : IX ${ }^{\mathrm{e}}$ $\mathrm{X}^{\mathrm{e}}$ siècles ; Scanlon et Pinder-Wilson 2001 : No 42u, Fusțāt : IX ${ }^{\mathrm{e}}$ siècle).

\section{DÉCOR INCISÉ À LA POINTE FINE}

La technique consistant à inciser un décor sur les verres à l'aide d'un outil à pointe fine (cf. Carboni 2001 : 76-81; Whitehouse 2001 : 156, 162-167), probablement fabriqué en diamant, apparaît avant le milieu du VIII e siècle, mais était surtout répandue au IX ${ }^{\mathrm{e}}$ siècle. Cette technique permettait d'obtenir des lignes nettes et très fines qui composaient tant des motifs linéaires, géométriques, végétaux, animaliers que des inscriptions. Ce type de décor était exécuté le plus souvent, mais pas exclusivement, sur des verres à couleur prononcée (bleu foncé, pourpre, jaune ambré). Les centres principaux de production de verres incisés à la pointe fine se trouvaient vraisemblablement en Syrie et/ou en Mésopotamie. Il semble cependant que certains de ces verres ont été exécutés en Égypte. 
Un petit fragment ( $\left.\mathrm{N}^{\circ} 23\right)$ trouvé à Naqlun à l'entrée de la pièce A 30.2 (contexte d'avant le milieu du $\mathrm{X}^{\mathrm{e}}$ siècle, résiduel ?) appartenait à un récipient dont la forme est difficile à reconstituer. Le décor se compose de lignes et de cercles incisés. Les trouvailles de verres à décor incisé à la pointe fine sont peu nombreuses sur le site de Naqlun (pour d'autres sites en Égypte, cf. Shindo 1992 : 583, Nos 21-23, Fusțāt ; Foy 2001 : № 130, Tebtunis : $\mathrm{X}^{\mathrm{e}}-\mathrm{XI}{ }^{\mathrm{e}}$ siècles [?] ; Scanlon et Pinder-Wilson 2001 : Nos $39 \mathrm{a}$-b, Fusțāț : VIIIe_ IX ${ }^{\mathrm{e}}$ siècles ; Foy, Picon, et Vichy 2003 : No 20, Fusțāt : IX ${ }^{\mathrm{e}}$ siècle ; Shindo 2003 : 183, Fig. 5, Rāya : IX ${ }^{\mathrm{e}}-\mathrm{X}^{\mathrm{e}}$ siècles).

№ 20. (Nd. 01.085) partie inférieure d'un petit flacon, décor taillé : diam. $3.6 \mathrm{~cm} ; \mathrm{H}+3.4 \mathrm{~cm}$; jaunâtre

№ 21. (Nd. 99.282) panse d'un petit flacon, décor taillé : diam. $1.6 \mathrm{~cm}$; $\mathrm{H}+4.9 \mathrm{~cm}$; verdâtre

$\mathrm{N}^{\circ}$ 22. (Nd. 01.053) 4 grands fragments et plusieurs petits du fond et de la partie supérieure d'une cruche à décor de rainures : L. de rebord : $3.0 \mathrm{~cm}$, H $16.0 \mathrm{~cm}$; jaunâtre

$\mathrm{N}^{\circ} 23$. (Nd. 00.206) fragment d'une panse (?) à décor incisé à la pointe fine : L+2.9 cm ; sans couleur, fortement corrodé

\section{Décor lustré}

Les verres lustrés (cf. Carboni 2001 : 50-69) étaient peints avec des pigments à base d'oxydes de cuivre ou d'argent, selon une technique vraisemblablement inventée en Égypte, dans la deuxième moitié du VIIIe siècle. Un verre de ce type et portant une date précise — l'an 779 — appartenant probablement à la première génération d'objets en verre à décor lustré, a été découvert à Fusț àț. Ce type de décor exécuté sur les verres, très en vogue aux $\mathrm{X}^{\mathrm{e}}-\mathrm{XI}^{\mathrm{e}}$ siècles, a été utilisé jusqu'au XIIe siècle. Les verres ainsi décorés ont été produits uniquement en Égypte et en Syrie. Les motifs peints à l'aide de cette technique sont de couleurs diverses, jouant le plus souvent des nuances de la palette du jaune, orange, brun et blanc, mais aussi rouge, pourpre, vert, bleu et bleu gris. La peinture pouvait être appliquée sur la surface externe ou interne du récipient, parfois sur les deux. Le répertoire iconographique était vaste : motifs abstraits, géométriques, végétaux, animaliers, figurations de personnages, inscriptions. Les motifs abstraits et végétaux sans forme distincte sont caractéristiques de la fin de la période fatimide et de la période ayyoubide, soit la dernière phase d'emploi de cette technique. 
Du site de Naqlun proviennent un flacon complet et quelques fragments en verre décorés de motifs lustrés (exemples trouvés sur d'autres sites en Égypte : Harden 1940 : № 33, Armant : XIe-XII siècles ; Scanlon et PinderWilson 2001 : 110-114, Nos 45a-h, Fusțāt : VIII -XIe siècles ; Foy, Picon, et Vichy 2003 : Nos 29-30, Fusțāț : VIII ${ }^{\mathrm{e}}-\mathrm{IX}^{\mathrm{e}}$ siècles ; Shindo 2003 : 181-182, Fig. 2.10 et 3.3-6, Rāya : IX $-\mathrm{X}^{\mathrm{e}}$ siècles ; Shindo 2005, Rāya : IX ${ }^{\mathrm{e}}-\mathrm{X}^{\mathrm{e}}$ siècles). Trois parmi ces verres sont présentés ici. Eu égard à leurs formes et leurs décors, il semble que tous les trois datent du XII e siècle.

Le flacon à panse globulaire, portant le dessin d'une branche représentée d'une manière schématique et quelques motifs abstraits peints en blanc et crème ( $\left.\mathrm{N}^{\circ} 24\right)$, provient de la tombe $\mathrm{T} 121$.

Quelques fragments d'un autre flacon, avec une panse en forme ovoïdale décorée d'un motif ondulé délimité dans la partie inférieure par des lignes horizontales ( $\left.\mathrm{N}^{\circ} 25\right)$, ont également été trouvés dans une tombe (T 110). Des traces de lignes horizontales peintes sont aussi visibles sur le col. Le décor est exécuté en couleur crème.

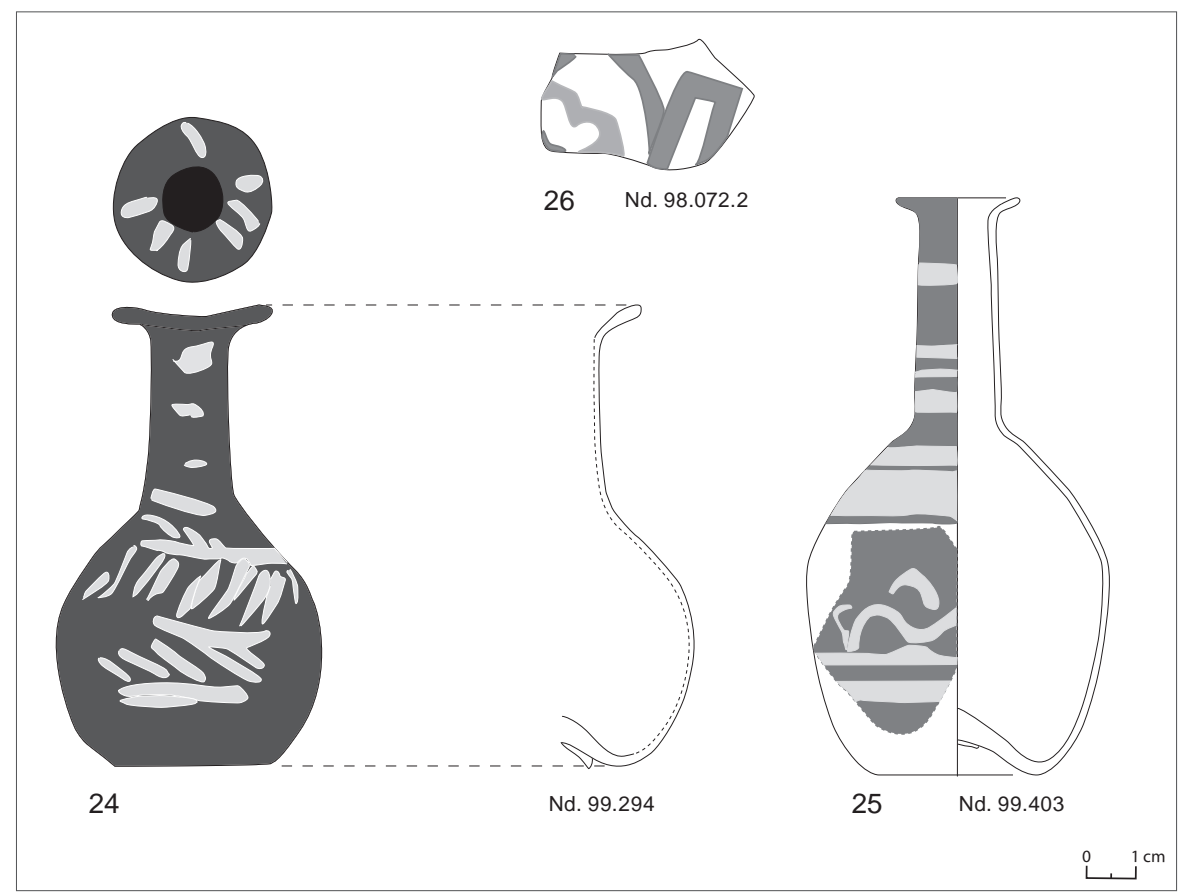

Fig. 11. Verres lustrés (Nos 24-26)

(Dessins et vectorisation M. Mossakowska-Gaubert) 
Le dernier fragment ( $\left.\mathrm{N}^{\circ} 26\right)$, trouvé dans une pièce des ateliers dans le secteur D (D.D. 29), appartenait à la panse d'un récipient non défini, avec un décor de couleur rouge et vert difficile à déterminer en raison de son état de conservation; il peut s'agir de motifs abstraits ou de fragments d'une inscription. Le décor est peint sur la face interne du récipient.

№ 24. (Nd. 99.294) flacon complet à décor lustré ; diam. de rebord : $3.2 \mathrm{~cm}$, $\mathrm{H} 9.4 \mathrm{~cm}$; récipient : brun foncé, décor : blanc et crème

№ 25. (Nd. 99.403) fragments d'un flacon à décor lustré ; diam. de rebord : $2.6 \mathrm{~cm}, \mathrm{H} 11.8 \mathrm{~cm}$; récipient : vert, décor : crème

No 26. (Nd. 98.072.2) fragment d'une panse à décor lustré ; L+ $3.8 \mathrm{~cm}$; récipient : sans couleur, décor : rouge et vert.

\section{Effet décoratif obtenu par l'utilisation du verre opaque}

Un flacon turquoise à col large, à panse sphérique et muni de deux petites anses repliées a été trouvé dans la tombe T 211 sur le site de Naqlun ( $\mathrm{N}^{\circ} 27$ ) (Mossakowska-Gaubert $2001 ; 2003$ : type 7). Le rebord de ce récipient est formé d'une bande appliquée de couleur blanche. Un fragment de col à deux anses provenant de Fusțāt pourrait constituer une parallèle du flacon de Naqlun (Shindo 1992 : 593, № 3).

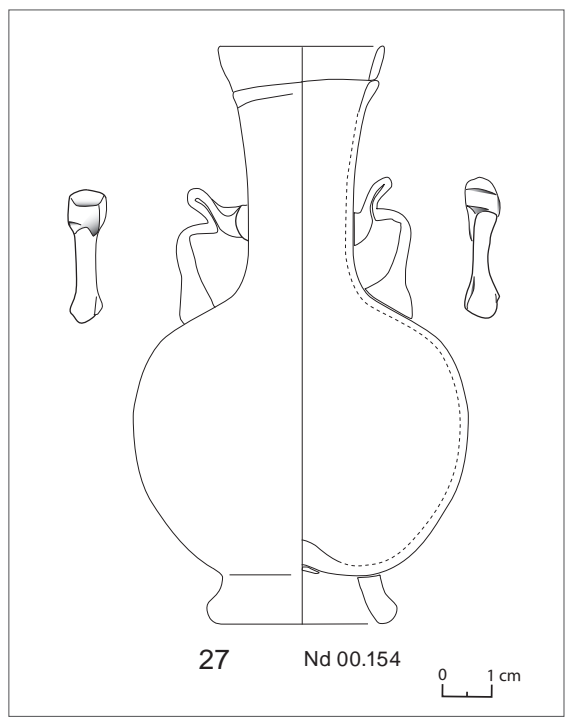

Fig. 12. Flacon à verre opaque (No 27)

(Dessin et vectorisation M. Mossakowska-Gaubert) 
Les verres opaques sont très rares à l'époque arabe. Des exemples de verres turquoises sont connus déjà aux IX ${ }^{\mathrm{e}}-\mathrm{XI}^{\mathrm{e}}$ siècles (Jenkins $1986: 23$, No 21 , The Metropolitan Museum of Art, probablement Égypte : $\mathrm{X}^{\mathrm{e}}$ siècle ; Whitehouse 2001 : Cat. 83, Tresaure de San Marco, Venise, probablement Iran : IX ${ }_{-}$ $\mathrm{X}^{\mathrm{e}}$ siècles, Cat. 75, The Corning Museum of Glass, probablement Iran : $\mathrm{XI}$ siècle), mais l'emploi du verre turquoise et/ou blanc opaque était surtout répandu au XII e siècle ainsi que pendant les premières décennies du XIII ${ }^{\mathrm{e}}$ siècle (cf. le commentaire de Kolbas 1983 : 96 et 100 ; voir aussi Riis et Poulsen 1957 : 47-48, Fig. 112-117, Hama : XIe-XIIe siècles ; Pinder-Wilson 1991 : 128-129, № 160, British Museum, probablement Syrie, XII ${ }^{\mathrm{e}}-\mathrm{XIII}{ }^{\mathrm{e}}$ siècles).

No 27. (Nd 00.154) flacon intact : diam. de rebord : $3.4 \mathrm{~cm} ; \mathrm{H} 11.7 \mathrm{~cm}$; récipient : bleu turquoise, rebord blanc

\section{Décor marbré}

La technique de décor marbré, inventée au cours du Nouvel Empire, fut pratiquée jusqu'à l'époque hellénistique sur les verres formés sur un noyau. Ce type de décor apparaît ensuite à l'époque romaine, cette fois sur les verres soufflés. On peut observer un retour des verres marbrés à l'époque arabe (cf. Carboni 2001 : 290-321). Le décor marbré, pratiqué en Égypte et en Syrie de la période abbasside jusqu'à l'époque mamelouk ${ }^{2}$, a été surtout en vogue du $\mathrm{XII}^{\mathrm{e}}$ au XIII ${ }^{\mathrm{e}}$ siècle. Cette technique consiste à appliquer des fils de verre opaque sur un objet en formant des motifs simples, le plus souvent des zigzags ou des linges ondulés. Puis l'objet était roulé pour polir la surface sur une plaque lisse en marbre ou en fer. Les objets ainsi décorés semblent souvent être noir opaque, mais sont en réalité transparents, pourpre foncé, bleu, vert ou brun dans la plupart des cas. Le décor est blanc, parfois aussi rouge, vert, jaune et bleu.

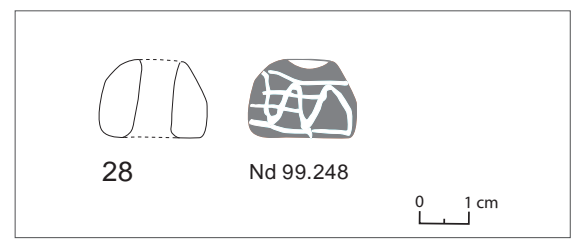

Fig. 13. Perle à décor marbré ( $\left.N^{o} 28\right)$

(Dessin et vectorisation

M. Mossakowska-Gaubert)

2 Les dates de la production des verres marbrés dans le monde arabe sont controversées : cf. la discussion chez Carboni 2001 : 290-293 ; voir aussi O’Hea 2003 : 135-136. 
Les objets marbrés sont peu nombreux dans le matériel de Naqlun (exemples sur d'autres sites en Égypte : Harden 1940 : $N^{\text {os }} 27-31$, Armant : VII $-\mathrm{XI}^{\mathrm{e}}$ siècles ; Meyer 1992 : 89-90, Pl. 19, Nos 542-553, Quseir Al-Qadim : fin du XIIe-début du XIVe siècle ; Shindo 1992 : 581, Nos 1-32, Fusțāt ; Scanlon et Pinder-Wilson 2001 : Nos 44 a-h, Fusțāt : IX ${ }^{\mathrm{e}}-\mathrm{XII}$ siècles ; Shindo 2003 : 183, Fig. 4, 2, Rāya : IX ${ }^{\mathrm{e}}$ $\mathrm{X}^{\mathrm{e}}$ siècles [?]). À titre d'exemple, nous mentionnerons une grosse perle ( $\left.\mathrm{N}^{\circ} 28\right)$ provenant d'une fosse de la tombe T 119 (trouvée dans un contexte perturbé). En outre, d'autres exemples de perles de forme et de décor variés ainsi que des fragments de bracelets en verre sont assez fréquents parmi les bijoux trouvés dans les tombes à Naqlun.

No 28. (Nd 99.248) perle complète : diam. max. : $2.2 \mathrm{~cm} ; \mathrm{H}+1.6 \mathrm{~cm}$; perle : rouge brique ; décor : blanc opaque

\section{Verres de Naqlun et d'autres sites égyptiens}

Tous les types de décor ainsi que la plupart des formes de verres que nous avons présentés provenant de Naqlun ont des parallèles dans le matériel en verre de Fusțāț, mais les analogies sont nombreuses également avec les verres trouvés dans le fort et dans l'habitat de la ville portuaire de Rāya (Sud-Sinaï). Les verres antérieurs au $\mathrm{X}^{\mathrm{e}}$ siècle, à décor de traces d'outils, appliqué, pincé, imprimé à la pince, estampé et incisé à la pointe fine trouvent aussi des parallèles dans le matériel de la zone d'habitat du village fayoumite de Tebtynis. Quelques pièces comparables aux verres à décor de traces d'outils, appliqué et à picotements proviennent également de Karanis, de Kellia et de Bagawat, et il existe aussi des exemples de verres imprimés à la pince ou à décor marbré à Armant, à Ashmunein et à Quseir al-Qadim.

\section{Lieu de production}

Nous n'avons aucune indication concernant le lieu de production de ces objets. Il semble que les verres trouvés à Naqlun ont été manufacturés en Égypte. Toutefois, il n'est pas complètement exclu que certains de ces verres aient été importés de Syrie — une région grande productrice de verres jusqu’au 
début du $\mathrm{XV}^{\mathrm{e}}$ siècle. On peut observer aussi dans quelques cas une influence de l'art iranien, visible par exemple dans la forme de la cruche gravée (№ 22), dans la couleur pourpre manganèse et dans la forme des motifs décoratifs de l'ampoule soufflée dans un moule ( $\left.\mathrm{N}^{\circ} 18\right)$, ou peut-être encore dans le décor de la petite bouteille soufflée dans un moule à cinq registres ( $\left.\mathrm{N}^{\circ} 16\right)$. Il est même possible que ces deux derniers récipients, notamment l'ampoule, aient été importés d'Iran.

Pour cette période, nos informations sur les ateliers égyptiens sont très limitées ; nous pouvons mentionner les ateliers secondaires de Marea près d'Alexandrie en fonction vers la fin du VII e et au VIII ${ }^{e}$ siècle (Foy, Picon, et Vichy 2003) ainsi que celui d'Ashmunein, actif du V $\mathrm{V}^{\mathrm{e}}$ au VII ${ }^{\mathrm{e}}$ siècle et peutêtre plus tard (Bimson et Freestone 1987). On suppose que, pour la période plus tardive, il y avait aussi des ateliers à Fusțāṭ. On ne peut pas exclure qu’à l'époque médiévale, il y eût également un atelier au Fayoum, mais, en raison du manque de preuves archéologiques et de mentions dans les sources écrites, cela reste une hypothèse.

En ce qui concerne l'identification des ateliers primaires, les analyses chimiques de verres trouvés sur la prospection des ateliers secondaires de Marea et lors des fouilles d'habitats de Tebtynis, de Fusțāț et de Rāya apportent certaines informations.

Une étude comparative du matériel daté du milieu du VII ${ }^{e}$ jusquau $\mathrm{IX}^{\mathrm{e}}$ siècle a été menée sur un échantillonnage de verres provenant des sites de Marea, de Tebtynis et de Fusțāt (Foy, Picon, et Vichy 2003). Tous ces verres étaient fabriqués à base de natron. Les analyses ont porté sur huit constituants ( $\mathrm{Ca}, \mathrm{Fe}, \mathrm{Ti}, \mathrm{K}, \mathrm{Si}, \mathrm{Al}, \mathrm{Mg}, \mathrm{Na}$ ). Quatre groupes de compositions chimiques ont ainsi été observés, et tout prête à penser que la plupart des verres utilisés en Égypte du milieu du VII ${ }^{\mathrm{e}}$ jusqu'au IX ${ }^{\mathrm{e}}$ siècle, étaient fabriqués avec des matières premières locales. Les gisements de sable utilisés en Égypte pour produire les verres aux époques omeyyade et abbasside sont différents de ceux utilisés dans l'Antiquité. Cependant, la localisation des ateliers primaires et secondaires (à l'exception de ceux de Marea et d'Ashmunein) demeure inconnue.

Les études des verres de Rāya apportent quelques nouveaux éléments concernantl'origine de matières premières utilisées pour fabriquer les récipients en verre utilisés en Égypte. Dans le matériel de Rāya (VIII -XII ${ }^{\mathrm{e}}$ siècle) on peut distinguer trois types de compositions chimiques (Kato, Nakai, et Shindo 2009). Le premier, N1-type, auquel appartiennent les verres à base de natron, avec une composante d'oxydes de magnésium, de potassium et de strontium, suggère comme lieu de provenance un atelier syro-palestinien, probablement celui de 
Bet Eli'ezer ${ }^{3}$. Ces verres sont datés du VIII ${ }^{\mathrm{e}}$ siècle. Le second groupe de verres, N2-type, également à base de natron, mais comprenant les oxydes susmentionnés dans des proportions différentes, est typique de la production égyptienne $e^{4}$ Les verres de cette composition trouvés à Rāya sont datés des VIII $^{\mathrm{e}}-\mathrm{IX}^{\mathrm{e}}$ siècles. Enfin, le troisième groupe, PA-type, contient des verres postérieurs au $\mathrm{IX}^{\mathrm{e}}$ siècle, fabriqués à base de cendres végétales dans des ateliers non identifiés.

\section{Conclusion}

Les objets que nous avons présentés montrent une variété typologique et chronologique de verres décorés trouvés dans le complexe monastique de Naqlun et dans les tombes du cimetière civil fondé à l'intérieur de ce complexe. Il semble que les besoins esthétiques des habitants du monastère et/ou de gens qui fréquentaient le lieu pouvaient être parfois assez élevés, la qualité des objets reflétant un certain niveau économique de leurs utilisateurs.

Le répertoire de formes et de décors des verres de Naqlun est comparable à celui des objets en verre de Fusțāț. Il faut noter cependant le nombre réduit de verres lustrés et marbrés ainsi que la quantité limitée de verres gravés provenant de Naqlun par rapport au matériel trouvé dans la capitale. En revanche, les verres imprimés à la pince et ceux soufflés dans un moule sont bien représentés à Naqlun, avec des qualités tout à fait comparables à celles des objets à décor analogue provenant de Fusțāṭ. Enfin, le flacon en verre opaque turquoise trouvé dans une des tombes à Naqlun peut être considéré comme une pièce de luxe, unique en son genre. Eu égard à son état de conservation, il est comparable aux rares récipients en verre opaque turquoise conservés dans quelques grandes collections mondiales. La bouteille en forme d'ampoule semble également être un objet rare et précieux.

Une question se pose alors, à savoir la raison de ces différences et disproportions observées entre le matériel en verre provenant de Naqlun et celui de Fusțātt. Plusieurs facteurs sont susceptibles d'apporter un élément de réponse.

3 Ce groupe correspond au type 'Levantine II' chez Freestone, Greenwood, et Gorin-Rosen 2002 .

4 Le type N2-a2 est similaire au groupe 'Egypt I' chez Freestone, Greenwood, et Gorin-Rosen 2002 et au " Groupe 8 et 9 » chez Foy, Picon, et Vichy 2003. Le type N2-b correspond au 'Egypt II' chez Freestone, Greenwood, et Gorin-Rosen 2002 et au “Group 7” chez Foy, Picon, et Vichy 2003. 
Le facteur économique semble être le plus évident. On peut en effet supposer que le niveau de vie dans la capitale était plus élevé que dans une communauté mixte, composée de moines et de laïcs issus de toutes les couches sociales du milieu rural de l'oasis de Fayoum, habitant ou fréquentant le monastère de Naqlun et enterrés en ce lieu ${ }^{5}$. L'abondance à Naqlun de verres soufflés dans un moule, considérés souvent comme un substitut, moins cher et plus facile à produire, des verres gravés, notamment à décor sculpté (cf. le commentaire de Carboni 2001 : 187), semble corroborer cette explication. Par ailleurs, jusqu’à présent, aucun verre sculpté n’a été découvert sur le site.

En ce qui concerne d'autres types de verres gravés, notamment les petits flacons taillés à parfum ("molaires" ou autres), peu représentés dans le matériel de Naqlun, il se peut qu'ils ne trouvaient pas beaucoup d'utilisateurs parmi les moines ou les hommes travaillant pour le monastère. Ce type de récipients était sans doute surtout prisé par les femmes, qui devaient rarement les prendre avec elles quand elles venaient en visite au monastère. En outre, dans les tombes du cimetière $\mathrm{A}$ aménagé sur le site, ont été trouvés, déposés près du défunt — homme, femme ou enfant — des flacons assez grands, des bouteilles ou des jarres à décor appliqué, soufflé dans un moule, lustré ou sans décor, contenant probablement des parfums ou des huiles.

Il est plus difficile d'expliquer l'absence quasi totale à Naqlun d'objets à décor marbré, certes dotés d'une certaine valeur, mais ne pouvant pour autant être considérés comme des produits de luxe, inaccessibles pour des gens de condition ordinaire. On remarque de même l'absence à Naqlun, avant le XII ${ }^{e}$ siècle, de verres lustrés, si du moins les datations proposées ici sont correctes. S'agit-il d'une mode locale reflétant le goût du marché fayoumite, ou, peut-être, y avait-il à proximité des ateliers spécialisés dans la production de verres portant d'autres types de décor, plus facilement accessibles?

Il faut enfin rappeler que le dépôt dans les tombes à Naqlun de récipients en verre ou en céramique, voire d'autres objets de la vie quotidienne, auprès du défunt constitue la seule attestation connue à ce jour d'une telle coutume funéraire pratiquée par la population chrétienne aux époques fatimide et ayyoubide en Égypte ${ }^{6}$.

5 Ces constatations sont fondées surtout sur les différences constatées dans l'équipement des tombes du cimetière A (époque fatimide-ayyoubide) ainsi que sur les sources écrites, notamment une archive de 51 documents découverte à Naqlun, concernant les affaires d'une riche famille copte de Girga ben Bifâm du village Damûya al-Lâchûn. Cette archive est datée entre 992 et 1029. Sur cette archive cf. Gaubert et Mouton 2014.

6 Pour une étude plus développée, voir Mossakowska-Gaubert 2003 : 187-188. 


\section{Références bibliographiques}

Bailey, D.M. (1998). Excavations at el-Ashmunein V. Pottery, lamps and glass of the late Roman and early Arab periods. Londres : British Museum Press

Ballet, P. (2003). Le verre. Dans P. Ballet, N. Bosson, et M. Rassart-Debergh, Kellia II.2. L'ermitage copte $Q R$ 195. La céramique, les inscriptions, les décors [=Fouilles de l'Institut français d'archéologie orientale 49] (pp. 199-204). Le Caire : Institut français d'archéologie orientale

Beech, G.T. (1992). The Eleanor of Aquitaine vase: Its origins and history to the early twelfth century. Ars Orientalis, 22, 69-79

Bimson, M. et Freestone, I.C. (1987). The discovery of an Islamic glass-making site in Middle Egypt. Dans Annales du $10^{e}$ congrès de l'Association internationale pour l'histoire du verre: Madrid-Segovie, 23-28 septembre 1985 (pp. 237-243). Amsterdam : AIHV

Carboni, S. (1999). Glass production in the Fatimid lands and beyond. Dans M. Barrucand (éd.), L'Egypte fatimide: son art et son histoire. Actes du colloque organisé à Paris les 28, 29 et 30 mai 1998 (pp. 169-177). Paris : Presses de l'Université de Paris-Sorbonne

Carboni, S. (2001). Glass from Islamic lands. New York : Thames \& Hudson

Clairmont, C.W. (1977). Catalogue of ancient and Islamic glass. Athènes : Benaki Museum

Contadini, A. (1998). Des arts décoratifs florissants. Dans Trésors fatimides du Caire: exposition présentée à l'Institut du monde arabe du 28 avril au 30 août 1998 (pp. 74 84). Paris : Institut du monde arabe

Cornu, G., Martiniani-Reber, M., et Fiette, A. (2008). Tissus islamiques: collections $d u$ Musée d'art et d'histoire de Genève. Neuchâtel : Chaman Edition

Davidson, G.R. (1952). Corinth: Results of excavations conducted by the American School of Classical Studies at Athens XII. The minor objects. Princeton, NJ : American School of Classical Studies at Athens

Foy, D. (2000). L'héritage antique et byzantin dans la verrerie islamique : exemples d'Istabl 'Antar-Fostat. Annales Islamologiques, 34, 151-178

Foy, D. (2001). Secteur nord de Tebtynis (Fayyoum) : le verre byzantin et islamique. Annales Islamoloqiques, 35, 465-489

Foy, D., Picon, M., et Vichy, M. (2003). Verres omeyyades et abbassides d'origine égyptienne : les témoignages de l'archéologie et de l'archéométrie. Dans Annales du $15^{e}$ congrès de l'Association internationale pour l'histoire du verre : New York-Corning 2001 (pp. 138-143). Nottingham : Association internationale pour l'histoire du verre

Freestone, I.C., Greenwood, R., et Gorin-Rosen, Y. (2002). Byzantine and Early Islamic glassmaking in the Eastern Mediterranean: Production and distribution of primary glass. Dans G. Kordas (éd.), Hyalos = Vitrum = Glass: History, technology and conservation of glass and vitreous materials in the Hellenic world (pp. 167-174). Athènes : Glasnet Publications 
Gaubert, C. et Mouton, J.-M. (2014). Hommes et villages du Fayyoum dans la documentation papyrologique arabe ( $X^{e}-X I^{e}$ siècles). Genève : Droz

Godlewski, W. (2007). Naqlun. Catalogue Nos 79-93. Dans A. Majewska (éd.), Seventy years of Polish archaeology in Egypt: Egyptian Museum in Cairo, 21 October-21 November 2007 (pp. 183-203). Varsovie : PCMA UW

Guilhot, J.-O. (2010). Le système de fortification. Dans J.-M. Mouton (éd.), Sadr, une forteresse de Saladin au Sinaï: histoire et archéologie I [=Mémoires de l'Académie des inscriptions et belles-lettres 43] (pp. 65-78). Paris : Académie des inscriptions et belles-lettres

Harden, D.B. (1936). Roman glass from Karanis found by the University of Michigan Archaeological Expedition in Egypt, 1924-29. Ann Arbor, MI : University of Michigan Press

Harden, D.B. (1940). The glass. Dans R. Mond et O. H. Myers, Temples of Armant: A preliminary survey (pp. 117-127). Londres : Egypt Exploration Society

Jenkins, M. (1986). Islamic glass: A brief history. The Metropolitan Museum of Art Bulletin, 44(2), 1-56

Kato, N., Nakai, I., et Shindo, Y. (2009). Chemical composition of early Islamic glass excavated in Rāya, Egypt. Dans K. Janssens, P. Degryse, P. Cosyns, J. Caen, et L. Van't dack (éds), Annales du $17^{e}$ Congrès de l'Association internationale pour l'histoire du verre (pp. 274-280). Anvers : AIHV

Kenesson, S. (2009). Ewers. Dans G.F. Bass, B. Lledó, S. Matthews, et R.H. Brill, Serçe Limanı II. The glass of an eleventh-century shipwreck [=Nautical Archaeology Series 4] (pp. 293-302). College Station, TX : Texas A\&M University Press

Kolbas, J.G. (1983). A color chronology of Islamic glass. Journal of Glass Studies, 25, 95-100

Kröger, J. (1995). Nishapur: Glass of the early Islamic period. New York : Metropolitan Museum of Art

Lledó, B. et Matthews, S. (2009). The molds. Dans G.F. Bass, B. Lledó, S. Matthews, et R.H. Brill, Serçe Limanı II. The glass of an eleventh-century shipwreck (pp. 2737). College Station, TX : Texas A\&M University Press

Martiniani-Reber, M. (1986). Lyon, Musée historique des tissus: soieries sassanides, coptes et byzantines: $V^{e}-X I^{e}$ siècles [=Inventaire des collections publiques françaises 30]. Paris : Editions de la Réunion des musées nationaux

Meyer, C. (1992). Glass from Quseir al-Qadim and the Indian Ocean trade [=Studies in Ancient Oriental Civilization 53]. Chicago : Oriental Institute of the University of Chicago

Mossakowska-Gaubert, M. (2000). Question d'éclairage : l'ermitage No 44 à Naqlun (Fayyoum). Annales Islamologiques, 34, 335-357

Mossakowska-Gaubert, M. (2001). Remarques préliminaires (saison 2000). Récipients en verre provenant des tombeaux datés du XI ${ }^{e}$ au XIII ${ }^{\mathrm{e}}$ siècle. Polish Archaeology in the Mediterranean, 12, 168-172 
Mossakowska-Gaubert, M. (2003). Les objets en verre trouvés dans les tombeaux des époques fatimide et ayyoubide (Deir el Naqlun - Égypte). Dans Annales du $15^{e}$ congrès de l'Association internationale pour l'histoire du verre: New YorkCorning 2001 (pp. 185-189). Nottingham : AIHV

Mossakowska-Gaubert, M. (2004). La verrerie utilisée par les anachorètes : l'ermitage No 44 à Naqlun (Fayyoum). Dans M. Immerzeel et J. van der Vliet (éds), Coptic studies on the threshold of a new millennium: Proceedings of the Seventh International Congress of Coptic Studies, Leiden, August 27-September 2, 2000, II [=Orientalia Lovaniensia Analecta 133] (pp. 1443-1470). Louvain : Peeters

Mossakowska-Gaubert, M. (2008). La verrerie de l'ermitage 85 à Naqlun - rapport préliminaire. Polish Archaeology in the Mediterranean, 18, 213-219

Mossakowska-Gaubert, M. (2012). Verres del'époque byzantine-début del'époque arabe ( $\mathrm{V}^{\mathrm{e}-\mathrm{VIII}}{ }^{\mathrm{e}}$ siècle) : objets provenant des ermitages en Égypte. Dans D. Ignatiadou et A. Antonaras (éds), Annales du $18^{e}$ Congrès de l'Association Internationale pour l'Histoire du Verre: Thessaloniki 2009 (pp. 357-366). Thessalonique : AIHV

Mossakowska-Gaubert, M. (2014). Les objets en verre provenant de tombes fatimides et ayyoubides à Naqlun (saison 2010-2011). Polish Archaeology in the Mediterranean, 23/1, 204-210

Nenna, M.-D. (2000). Ateliers de production et sites de consommation en Égypte ( ${ }^{\mathrm{e}}$ siècle av. J-C-VII e s. ap. J-C.). Premier bilan. Dans Annales du $14^{e}$ congrès de l'Association internationale pour l'histoire du verre: Italia/Venezia-Milano 1998 (pp. 20-24). Lochem : AIHV

Nenna, M.-D. (2010). The glass vessel decor of a funerary chapel in the Bagawat necropolis, Kharga Oasis, Egypt. Dans J. Drauschke et D. Keller (éds), Glass in Byzantium - production, usage, analyses: International workshop organised by the Byzantine Archaeology Mainz, 17th-18th of January 2008, Römisch-Germanisches Zentralmuseum (pp. 199-214). Mayence : Verlag des Römisch-Germanischen Zentralmuseums

O'Hea, M. (2003). Some problems in early Islamic glassware. Dans Annales du $15^{\circ}$ congrès de l'Association internationale pour l'histoire du verre: New York-Corning 2001 (pp. 133-137). Nottingham : AIHV

Pinder-Wilson, R.H. (1991). The Islamic lands and China. Dans H. Tait (éd.), Five thousand years of glass (pp. 112-143). Londres : British Museum Press

Pinder-Wilson, R.H. et Scanlon, G.T. (1987). Glass finds from Fustat: 1972-1980. Journal of Glass Studies, 29, 60-71

Puche Acién, C., Matthews, S., et Bass, G. F. (2009). Bubble-neck bottles. Dans G.F. Bass, B. Lledó, S. Matthews, et R.H. Brill, Serçe Limanı II. The glass of an eleventh-century shipwreck (pp. 223-235). College Station, TX : Texas A\&M University Press

Riis, P.J. et Poulsen, V. (1957). Hama : fouilles et recherches de la Fondation Carlsberg (1931-1938) IV.2. Les verreries et poteries médiévales [=Nationalmuseets skrifter. Større beretninger 3]. Copenhague : Nationalmuseet 
Scanlon, G.T. et Pinder-Wilson, R.H. (2001). Fustat glass of the early Islamic period: Finds excavated by the American Research Center in Egypt, 1964-1980. Londres : Altajir World of Islam Trust

Shindo, Y. (1992). Glass. Dans K. Sakurai et M. Kawatoko (éds), Egyptian Islamic city: Al-Fustat. Excavations report, 1978-1985 (pp. 304-335). Tokyo : Waseda Daigaku Shuppanbu [in Japanese]

Shindo, Y. (2003). Islamic glass finds from Raya, Southern Sinai. Dans Annales du $15^{e}$ congrès de l'Association internationale pour l'histoire du verre: New YorkCorning 2001 (pp. 174-177). Nottingham : AIHV

Shindo, Y. (2005). Islamic lustre-stained glass from Raya between the ninth and tenth centuries. Dans Annales du $16^{e}$ Congrès de l'Association internationale pour l'histoire du verre, London, 7-13 September, 2003 (pp. 174-177). Nottingham : AIHV

Shindo, Y. (2009). Islamic glass excavated in Egypt: Fustāt, Rāya, and al-Tūr al-Kīlānī. Dans K. Janssens, P. Degryse, P. Cosyns, J. Caen, et L. Van't dack (éds), Annales du $17^{e}$ Congrès de l'Association internationale pour l'histoire du verre (pp. 308-313). Anvers : University Press Antwerp

Shindo, Y. (2015). Islamic glass with impressed decoration: The problems of dating and production. Dans I. Lazar (éd.), Annales du $19^{\circ}$ Congrès de l'Association Internationale pour l'Histoire du Verre: Piran 2012 (pp. 455-461). Koper : AIHV

Silvano, F. (1999). Vetri bizantini dall'Egitto: Medinet Madi, 1988. Pise : ETS

von Folsach, K. et Whitehouse, D. (1993). Three Islamic molds. Journal of Glass Studies, 35, 149-153

Whitehouse, D. (1993). The Corning ewer: A masterpiece of Islamic cameo glass. Journal of Glass Studies, 35, 48-56

Whitehouse, D. (2001). Cut and engraved glass. Dans S. Carboni et D. Whitehouse, Glass of the sultans (pp. 155-197). New York : Metropolitan Museum of Art 



\title{
Les Kellia, 1965-2015
}

\author{
Marguerite Rassart-Debergh \\ Professeur émérite \\ jacques.debergh@skynet.be
}

\section{MOTS-CLEFS}

Égypte tardo-antique, Kellia, monachisme, peinture Copte

\begin{abstract}
RéSUMÉ
Découvert et partiellement excavé pour la première fois en 1904, le site des Kellia, les Cellules, un des plus vastes ensembles monastiques d'Egypte, ne fut réellement identifié définitivement qu'en 1960 ; fouillées à partir de 1965, les Cellules n'existent plus ; les publications et les objets conservés au Musée Copte du Vieux-Caire témoignent de leur richesse passée. On trouvera ici un bref rappel chronologique des fouilles (égytiennes, françaises et suisses) et des principales découvertes ; sont illustrées une des premières peintures et une mosaïque dont les meilleurs parallèles furent découverts à Faras par les équipes polonaises; c'est du moins une hypothèse qui mériterait, je pense, des recherches ultérieures.
\end{abstract}

Deux célébrations ont lieu cette année 2015 : celle du savant auquel sera offert ce volume - notre ami depuis plus de 40 ans - mais aussi les 50 ans des premières fouilles aux Kellia, après la redécouverte du site par une mission de l'IFAO. Celles-ci sont définitivement terminées et, comme constaté, en 2009, le site a maintenant disparu sous les cultures. Espérée (et tentée) la conservation 'in situ' s'est rapidement avérée utopique et irréalisable. Une des raisons est l'étendue du site, sans doute le plus vaste jamais découvert et fouillé sur le sol égyptien. Certes du matériel a été prélevé, restauré et conservé au Musée Copte du Vieux-Caire (Mohamed 2011 ; Rassart-Debergh 2011 ; Rutschowscaya 1992) mais, de l'ensemble des monastères, il ne reste désormais que leurs 
publications ; les fouilles sont toutes publiées ; un dernier volume a vu le jour il y a peu (Weidmann 2013); il est consacré à un ensemble, Qouçoûr 'Isâ 1, qui avait retenu l'attention dès la première campagne, comme Denis Weidmann l'a rappelé lors du colloque sur les Ermitages d'Egypte au premier millénaire (Weidmann à venir).

Il m’a semblé approprié de rappeler très rapidement les grandes étapes de ces fouilles et d'attirer, une fois encore, l'attention sur les représentations, nombreuses et variées, de croix dont une peinture particulièrement a ses meilleurs parallèles dans les croix de Nubie chrétienne, les " théophanies nubiennes".

\section{Historique des fouilles}

Les Apophtegmes des Pères, l' Historia Monachorum in Aegypto, l'Histoire Lausiaque de Pallade et les Consolationes de Cassien mentionnent, en Basse-Égypte, trois centres de monachisme aux $4^{\mathrm{e}}-5^{\mathrm{e}}$ siècles : le Désert de Nitrie, celui de Scété et celui des Cellules ou Kellia. Il restait à les identifier in situ : plus d'un demi-siècle fut nécessaire pour placer, avec précision, ces trois sites sur une carte.

Dans les années 1960, Antoine Guillaumont, étudiant alors Évagre le Pontique, qui vécut et mourut aux Kellia, est amené à reprendre les sources anciennes et toutes les identifications, parfois contradictoires, de ses prédécesseurs et à resituer précisément " les Cellules ". Un survey a lieu dès mars 1964. Constatant à quel point les lieux ont changé depuis la description de Antoine de Cosson - des constructions modernes remplaçant les ruines anciennes - il signale la chose au directeur de l'IFAO, François Daumas, et au Service des Antiquités. Un premier projet de fouilles voit rapidement le jour ; Rodolphe Kasser, qui se trouvait alors à l'IFAO pour ses recherches personnelles, propose d'y joindre les efforts de l'Université de Genève où il enseigne (Daumas 1965). Une première mission, conjointe a donc lieu dès l'hiver (Guillaumont 1965). C'était, il y a 50 ans et, comme on le verra, elle va immédiatement mettre au jour des informations de toute première importance.

Mais l'intérêt du site avait été signalé bien avant. En effet, dès 1904, Evaristo Breccia avait fait des sondages dans la région maréotique dont les fouilles ultérieures, notamment celles menées par les missions polonaises, ont confirmé le grand intérêt. Breccia signalait un endroit qui, lui semblait-il, recélait « [...] d'intéressants documents de l'âge chrétien. Cet endroit se trouve en plein désert, en face du Canal Nubarieh entre le Km. 36-37, à deux km. environ au sud du dit Canal. Il s'agit d'un groupe de petites élévations sablonneuses [...]. 
Ces élévations se rattachent à la série de monticules qui, aux environs du $\mathrm{km}$. 40 du canal Nubarieh, se dirigent vers le nord-ouest et qui sont connues sous la dénomination de Kosur Roubayat. Les noms Isa et Roubayat semblent révéler une persistance de la tradition en ce qui concerne le caractère chrétien de la localité. Avec l'aide de quelques bédouins de la contrée, j'ai pu identifier la chambre qui a fait l'objet d'une lettre de la Direction du Service des Antiquités d'après un signalement d'un ingénieur du Survey Department. On voyait la partie supérieure d'une construction en briques [...]. L'Ingénieur du Survey Department ayant omis de faire remblayer les parties qu'il avait fait déblayer les agents atmosphériques ont fait disparaitre toute trace des peintures et des inscriptions qu'il a signalées dans le croquis annexé à sa lettre. D'ailleurs l'enduit se détache et tombe avec une extrême facilité. J'ai fait déblayer jusqu'à un mètre de profondeur la paroi ouest, ce qui nous a permis de constater que celle-ci aussi était recouverte, en partie au moins de peintures [...]. Après un examen rapide, $j$ 'ai fait remblayer et couvrir tout à fait les peintures avec du sable. En parcourant le monticule où se trouve la chambre en question, ainsi que les monticules environnants nous avons pu constater les traces d'autres constructions du même type. Évidemment nous avons ici les restes d'un ou de plusieurs monastères ou coenobia dont, d'après la tradition, la région désertique à l'ouest d'Alexandrie, de Mariout à Wadi Natroun, a été peuplée à partir du III siècle. [...] » (Breccia 1970). Même si le souhait de Breccia de mener des fouilles sur le site n'est point entendu, la région continue à susciter l'intérêt : Evelyn-White identifie les quatre couvents du Wadi Natroun comme étant les survivants de ceux, plus nombreux, qui occupaient autrefois le désert de Scété et propose de placer le désert de Nitrie près de l'actuel village de Barnougi, dans le Delta, au sud-ouest de Damanhour (Evelyn-White 1926-1933). Comme Breccia, Anthony De Cosson prospecte, lui aussi, la région (De Cosson 1935) et, dans deux articles, il met en rapport les élévations sur le sol d'El Mouna avec les Cellules (De Cosson 1936) ; il y mentionne les ruines de "Qusûr el Rubaiyat, Qasr Waheida, Qusûr el Izeila, Qusûr el Abd and Qusûr Isa » et la centaine de kôms couvrant des constructions ; il donne même une description et un plan de l'une d'elles. Mais, à la même époque, le prince Omar Toussoun croit avoir trouvé l'emplacement précis des Cellules et sa publication (Toussoun 1935) va, pour longtemps, éloigner les chercheurs de l'emplacement véritable des Kellia.

Une vingtaine d'années plus tard, Charles Bachatly tente de dresser sur une carte les édifices chrétiens tant les contemporains que ceux qui ont disparu (Bachatly 1954) ; ce travail restera malheureusement trop peu connu ; il tient pourtant compte des propositions d'E. Breccia et d'A. de Cosson et place, en effet, les couvents de Nitrie légèrement au nord-ouest de l'évêché d'El Barnougi et les "Cellia" au-dessous, au sud-ouest. La situation des trois ensembles de Nitrie, 
des Kellia, du Ouadi Natroun est donc exacte mais sans doute pas assez précise. L'oubli vient alors pour une dizaine d'années, jusqu'aux recherches d'Antoine Guillaumont et la redécouverte, en 1964, de l'emplacement des Kellia.

Le printemps 1964 est marqué par une prospection du site. L’hiver et le début de 1965 voient la première fouille ; cette campagne unit les efforts de l'université de Genève et ceux de l'IFAO sur un bâtiment des Qouçoûr el-Roubaiyât, l'ermitage 219 ; le rapport complet de cette campagne est rapidement divulgué (Daumas et Guillaumont 1969). Mais cette investigation a dévoilé combien le terrain à explorer était vaste et, surtout, elle a clairement montré les dangers qu'il courait ; le site est donc alors partagé entre les deux missions. Désormais, les Français continueront les recherches aux Qouçoûr el-Roubaiyât (plus de six cents

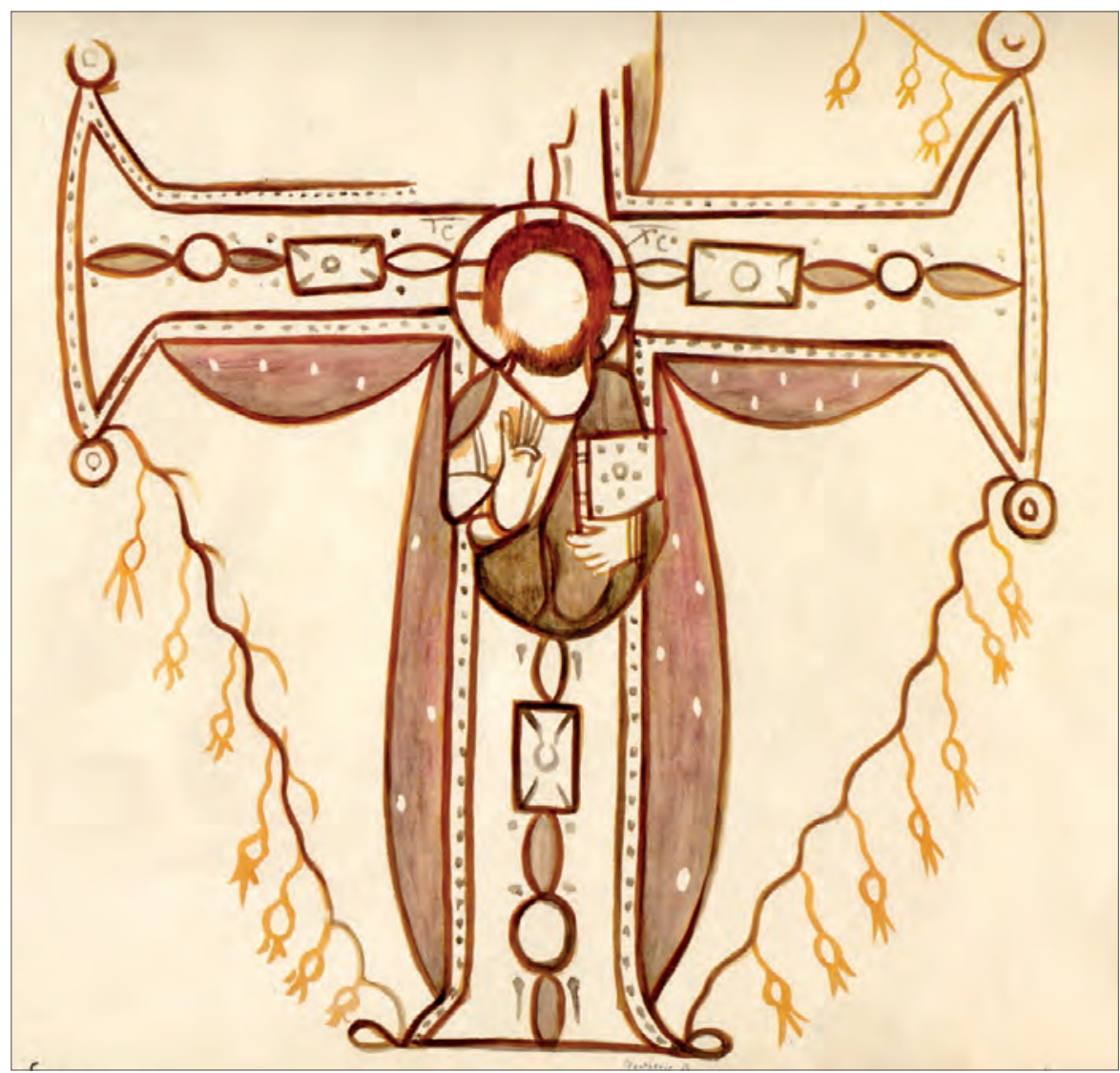

Fig. 1. Croix, salle XII du bâtiment 219 des Qouçoûr el-Roubaiyât (Musée Copte du VieuxCaire, inv. 11530) (d'après Daumas et Guillaumont 1969: Pl. XXXIX) 
kôms) et à Qasr el-Waheida ; dès novembre-décembre 1965, ils poursuivent le dégagement de l'ermitage 219 et entreprennent le relevé topographique de la zone des Qouçoûr el-Roubaiyât. De leur côté, les Suisses se chargeront des Qouçoûr el-'Izeila, de Qouçour el-'Abîd et de Qouçoûr 'Isâ (environ deux cents kôms). La mission commence alors les premières mensurations de la zone dont les résultats sont rapidement publiés dans un volume où figurent également les premiers sondages d'un bâtiment de Qouçour 'Isâ qui allait, par la suite, se révéler appartenir à un vaste complexe contenant trois églises (Kasser 1967). De leur côté, les Français procèdent, entre 1966 et 1969, aux dégagements successifs de kôms, ainsi que l'annonce régulièrement François Daumas, dans ses rapports (Daumas 1966 ; $1967 ; 1968$; 1969). L'IFAO dégage d'abord le kôm 6, dont deux peintures, des panneaux géométriques, rejoignent les salles du Louvre (section copte, inv. E 26824 et E 26825). L'Institut fouille ensuite les kôms 1 à 4, menacés de destruction car à la lisière des cultures; il fait également une incursion à Qasr el-Waheida, où une vaste enceinte avec deux tours de défense regroupe, outre des cellules, deux églises, une hôtellerie et trois puits. Mais à partir de 1969, si les chercheurs des missions française et suisse ainsi que le Service poursuivent leurs travaux en bibliothèques et dans les laboratoires, fouilles et sondages sur le terrain sont interrompus pour des raisons militaires : aucune campagne de fouilles aux Kellia n’a été autorisée entre 1969 et 1972.

En 1976-1977, la mission suisse achève la fouille intégrale de Qouçour 'Isâ 1 dont on avait déjà fait connaître, en 1969, les premiers résultats. L'année suivante, les inspecteurs du Service des Antiquités pratiquent des sondages sporadiques dans la zone des Roubaiyât. Ainsi, par exemple, en 1978 MM. Abbas al-Shennawi, Abd al Ma'bud et Saber Selim Muhammad ont-ils dégagé plusieurs pièces de l'ermitage 490 ; œuvrant dans des lieux particulièrement menacés, le Service demande à la mission suisse de faire une étude rapide des ermitages qu'il vient de fouiller ; ces couvents seront publiés ultérieurement avec ceux mis au jour en 1982 et 1983 par la MSAC. Dès 1979, la reprise des fouilles de l'IFAO a lieu sous la direction de René-Georges Coquin ; la sixième campagne (1979-1980) commence par des vérifications et des sondages dans les églises de Qasr el-Waheida (QR 34); les résultats sont rapidement annoncés par le directeur de l'IFAO, Jean Vercoutter, au sein des travaux de l'Institut et immédiatement publiés (Vercoutter 1980 ; Andreu, Castel, et Coquin 1980).

Toutefois, en 1980, durant leurs fouilles, les deux missions constatent, tout comme le Service des Antiquité, que $60 \%$ de la zone suisse et $40 \%$ de la française ont disparu depuis l'exploration des lieux en 1964-1965; cette destruction est liée à la construction d'une voie de chemin de fer entre Alexandrie et Le Caire, à l'établissement de nouveaux villages et à la 
sédentarisation massive de Bédouins. C’est pourquoi un appel officiel est lancé en septembre, à Rome, lors du Congrès de l'International Association for Coptic Studies, demandant une aide internationale ; R.-G. Coquin s'engage à poursuivre les recherches dans la zone française ; du côté suisse, on crée alors la MSAC (Mission Suisse d'Archéologie Copte de l'Université de Genève) et le projet EK 8184 Projet international de sauvetage scientifique des Kellia; bien que "suisse", la MSAC me confia alors l'étude des peintures; devant l'intérêt manifesté par K. Michałowski, elle y intègre également des chercheurs polonais. À l'automne 1981, la MSAC entreprend donc, durant plusieurs mois, un survey global dans la zone des Qouçoûr el-'Izeila (Kasser 1983), et se livre à un sondage en surface ou "analyse horizontale" de 132 kôms ; leur étude et la fouille d'autres ermitages de la zone se poursuivront ultérieurement. En janvier de la même année, dans le cadre du colloque célébrant le centenaire de l'IFAO, les problèmes que connaissent les Kellia sont abordés dans "Prospection et Sauvegarde des antiquités de l'Égypte ". Cette discussion est publiée dans les Actes de la Table Ronde (Grimal 1981: 195-203, 229, 234). Durant les années suivantes, les fouilles de l'IFAO se poursuivent régulièrement toujours sous la direction de R.-G. Coquin. Les résultats de la septième campagne (avril 1981), de la huitième (avril 1982) et de la neuvième (avril 1983) sont rapidement évoqués par la direction de l'IFAO dans le résumé des travaux de l'Institut (Andreu and Coquin 1981; Coquin 1982 ; 1985). De plus, en 1982-1983, devant le danger imminent d'importantes destructions que représentent l'extension des cultures et la construction du chemin de fer, l'IFAO demande l'aide de la MSAC pour un survey des Qouçoûr el-Roubaiyât. La mission suisse l'accomplit à l'automne 1983 et procède, en outre, au dégagement partiel des ermitages QR 227, 233 et 306 ; l'ensemble de ces recherches ainsi que les résultats des dégagements antérieurs du Service des Antiquités sont rassemblés par la mission suisse (Bridel 1994). L'année suivante, un colloque réunit, à Genève, les membres des missions française, suisse et égyptienne pour confronter leurs résultats et leurs hypothèses avec des spécialistes du monde paléochrétien ; un premier bilan est alors dressé et publié par les soins de Ph. Bridel (1986). Ensuite, les problèmes de santé que connaît R.-G. Coquin mettent momentanément fin aux fouilles françaises sur le terrain, mais pas aux recherches comme l'indique le directeur de l'époque, Madame Paule Posener-Kriéger, dans son rapport sur les travaux de l'Institut. En effet, dès 1986, l'IFAO commence la fouille de QR 195 ; à la même époque, les Égyptiens, sous la direction de l'inspecteur Abd El-Mahboud, continuent à dégager des ermitages dans la zone des Rouba'iyât comme le montre le rapport de l'IFAO pour l'année 1986-1987. 
Les campagnes suisses de 1984, 1985, 1986, 1989 et de 1990 se focalisent à nouveau sur les Qouçoûr el-'Izeilâ (Bridel 1999), alors que celles de 1987, 1988 et en partie celle de 1989 se penchent sur les zones des Qouçoûr Hégeila et des Qouçoûr 'Ereima (Bridel 2003). En octobre 1989, le musée d'art et d'histoire de Genève présente une exposition de matériel provenant du site ; son catalogue (Mottier et Bosson 1989) est une sorte de premier bilan des travaux menés par les équipes suisses depuis 1965. De son côté, de 1986 à 1990, l'IFAO concentre ses efforts sur l'ermitage 195 des Qouçoûr el-Roubaiyât ; l'ensemble est publié ensuite sous forme d'une vaste monographie en deux volumes (Henein et Wuttmann 2000 ; Ballet, Bosson, et Rassart-Debergh 2003). QR 195 fait partie des monastères "tardifs" du site; fondé vers le milieu du $7^{\mathrm{e}}$ siècle, il fut occupé durant près de deux siècles. Létude de Michel Wuttmann et de Nessim Heinen offre un bilan de ce qu'était devenue l'architecture kelliote ; tout y est examiné et analysé avec soin : "voûtes kelliotes", arc quadruple, récolte de l'eau de pluie, fonctionnement des bassins, des cuisines, de l'aération, ... Tableaux et explications en retracent l'évolution. Les céramiques, les textes et les décors constituent le second volet. Le tout donne une vision fort complète d'un monastère dont la fin semble par ailleurs correspondre au déclin définitif du site.

\section{Conservation et restauration}

On l'a dit déjà, la conservation in situ de monastères s'était avérée utopique et irréalisable. Par contre, celle de certaines peintures et inscriptions était du domaine du possible tout comme celle des céramiques et du petit matériel ; souvent les plus intéressants de ces derniers avaient été consolidés sur place, alors que des exemplaires d'inscriptions et de peintures rares ou jugés importants avaient été transportés au Musée Copte mais y étaient souvent demeurés fragiles.

Les constatations faites au cours du survey de 1981 m'avaient amenée à m'interroger sur les techniques et les matériaux employés autrefois par les moines. Aussi, après la fin des fouilles, avec l'accord et sous la surveillance des inspecteurs du Service, des fragments au sol, destinés à une totale destruction immédiate, furent ramassés puis étudiés selon des méthodes alors les plus modernes. On a ainsi obtenu les premières informations techniques sur les supports, les pigments et les liants utilisés pour les peintures; dès lors, dans chaque rapport, j'ai joint à l'étude des peintures des remarques techniques : présence d'un dessin préparatoire ou motif réalisé à main levée, emploi de compas 
ou de pochoir, utilisation de divers types de pinceaux et de spatules, mélange de couleurs ou superposition de couches pour créer de nouvelles teintes ... Ces constatations énumérées avec soin dans chaque publication ont ensuite été analysées et comparées par des spécialistes et des essais de restauration ont été tentés avec succès. Les dernières missions de l'IFAO voient donc se constituer, sous la direction de Michel Wuttmann, une équipe de restaurateurs ; après avoir appris les rudiments sur le chantier, des ouvriers particulièrement doués reçurent une formation en France, où certains furent même envoyés pour suivre des cours de spécialisation ; l'équipe ainsi formée n'a pas reculé devant la difficulté et des pièces entières de grandes dimensions (comme des piliers ou des arcs) ont été prélevées, restaurées et reconstituées : les principales œuvres de QR 195 ont ainsi été sauvées. Dans le même souci, la MSAC organisa en juin et juillet 1991 une campagne de restauration ; la mission (réduite à Giorgio Nogara, à Georges Descoeudres et à Marguerite Rassart-Debergh) travailla en collaboration avec Michel Wuttmann et son équipe à la conservation de peintures prélevées dans la zone suisse et consolidées sur place par Giorgio Nogara et Sébastien Favre durant le projet EK 8184. Les œuvres restaurées furent ensuite transportées au Musée Copte du Vieux Caire et déposées dans les réserves ; quelques-unes ont été exposées. Avec les publications, ces objets porteront témoignage de ce que furent les Cellules.

\section{Découvertes de 1965}

La première campagne franco-suisse sur le bâtiment 219 des Qouçoûr elRoubaiyât s'est révélée d'un intérêt tout particulier tant par la découverte d'un vaste ensemble monastique que par celle des peintures. En effet, à côté de croix, de panneaux géométriques, de bateaux et de poissons, on découvrit un saint Ménas (maintenant au Louvre, section copte, inv. E 26822) et une croix avec, en son centre, le buste de Christ ; cette peinture demeure à ce jour un unicum (Musée Copte du Vieux-Caire, inv. 11530). Elle fut décrite comme " [...] le chef-d'oeuvre de l'iconographie chrétienne [...] ; dans la chambre XII (Pl. XXXIX), au fond d'une niche [...], on avait peint une croix latine gemmée, aux extrémités élargies, reliées par une chaînette où pendent des grenades stylisées. Une sorte de draperie rouge brique, piquée de points blancs pend sous les bras de la croix et entoure la partie inférieure. Au centre on voit le buste du Christ portant le nimbe crucifère. De la main gauche il tient le livre et de la droite, pouce et annulaire rapprochés, il bénit. Cette figuration 
est certainement très rare [...]» (Daumas et Guillaumont 1969 : 24-25). Cette croix fut maintes fois reproduite et commentée, et, comme indiqué plusieurs fois déjà, je crois qu'il n'en existe aucune de réellement identique dans le monde paléochrétien; en outre cette peinture me semble constituer le chaînon entre la croix et le Christ en gloire - si fréquents dans l'iconographie de l'Égypte chrétienne - et les représentations, plus tardives, des théophanies nubiennes (Rassart-Debergh 1986 ; 1987 ; 1994). La croix demeure le thème kelliote par excellence. Certes elle apparaît en d'autres lieux mais jamais en tel nombre et avec une telle variété ; ses nombreux exemplaires correspondent parfaitement à ceux décrits dans l'hymne à la croix (de Fenoyl 1960). Elle figure aux Kellia comme signe du salut, mais aussi comme arbre de vie et comme chandelier ; elle repose sur une estrade ou un coussin ; souvent croix de bénédiction, elle se présente aussi comme une croix de procession, munie de clochettes ou de guirlandes. Enfin, il faut compléter ce rapide inventaire par la description que fit Breccia d'une peinture disparue « [...] Au centre de la paroi, au-dessus d'une proéminence conique flanquée de deux gros bouquets de fleurs couleur marron, se dresse une surface rectangulaire, à fond jaunâtre et à contour bleu, décorée vers le milieu par deux rangées de petits cercles couleur orange (serait-ce une porte ?). À droite et à gauche d'un bois formé surtout par des arbres qui rappellent les cyprès, deux gazelles sont en train de brouter les feuilles des arbres" (Breccia 1970: 55-56). On peut aisément reconstituer une croix entre deux cervidés, thème fréquemment illustré dans l'art paléochrétien. On a découvert par la suite aux Kellia plusieurs exemples de croix entre des perdrix ou des perroquets, et même entre des canards mais on n'a plus trouvé d'exemple semblable à celui découvert par Breccia ; là, la base de la croix reposait sur un monticule ce qui correspond, dans le reste du monde chrétien, au tertre d'où jaillissent les quatre fleuves. Cette représentation comme celle de la croix encadrée par Pierre et Paul sous forme de béliers dans la pièce 2 du bâtiment 39/40 de Qouçoûr Hegeila s'intègrent parfaitement dans l'iconographie paléochrétienne classique. Si les croix kelliotes sont nombreuses et variées, celle de QR 219, découverte en 1965, demeure par contre un intéressant exemplaire.

Toujours en 1965, les sondages du bâtiment 1 de Qouçour 'Isâ par la mission suisse puis leur poursuite vont conduire à une meilleure connaissance de l'occupation kelliote. Comme l'a résumé, en 2009, Denis Weidmann, cet ermitage fouillé intégralement entre 1965 et 1977 a livré les plus anciens témoignages de l'occupation du lieu dès la fin du $4^{\mathrm{e}}$ siècle jusqu'à environ 625. On y a déterminé neuf états successifs dont on a pu identifier les habitats. Les premières cellules ont été creusées dans le sol comme à Esna ; leur plan 
présente une certaine analogie avec les ermitages de Naqloun. On considère qu'elles furent construites à partir de 350 , et que n'existait alors aucune salle de réunion pour la prière commune. Mais rapidement, la petite communauté, qui s'y installe vers 380 , se dote d'une église. On se trouve donc devant les toutes premières constructions sur le site des Kellia. Dans troisième quart du $5^{\mathrm{e}}$ siècle, le monastère connaît un important agrandissement avec l'érection, après 450, d'une seconde église au sud. Semi-excavé, cet imposant édifice de plan basilical est complété par une pièce contenant un bassin-baptistère, accolée au nord du chœur. Une troisième église et ses annexes seront érigées à la fin du $6^{\mathrm{e}}$ siècle. L'abandon progressif des parties habitées se fera dans la première moitié du $7^{\mathrm{e}}$ siècle; peu à peu les tombes s'installent à l'est des deux grandes basiliques; le cimetière perdurera sans doute jusqu'à la fin du même $7^{\mathrm{e}}$ siècle. Puis les modes de réunion changent ; d'autres lieux des Kellia (ainsi les Qouçoûr Izeila et les Roubaiyât) se peuplent. Denis Weidmann comptait reprendre et illustrer cette évolution de l'occupation du site dans la publication des actes du colloque sur les Ermitages d'Egypte au premier millénaire. Il convient, pour en terminer avec les découvertes de 1965, de signaler le bel opus sectile qui ornait la paroi orientale du chœur de l'église sud de Qouçoûr 'Isâ 1. Sa description technique a fait l'objet de minutieuses recherches de Denis Weidmann et je me suis

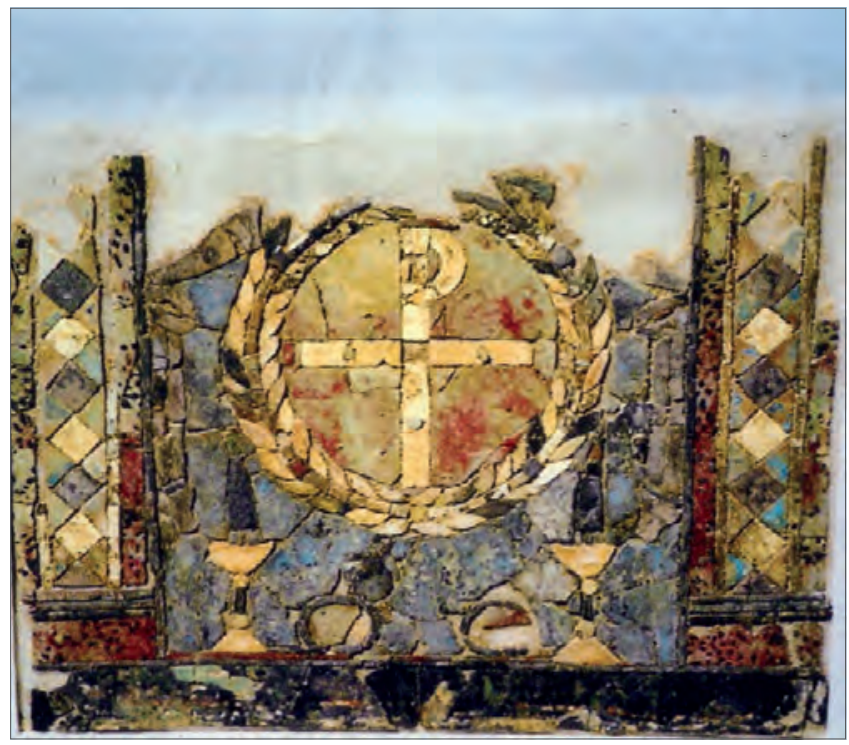

Fig. 2. Opus sectile de l'église sud de Qouçoûr 'Isâ 1 (Courtoisie de la Mission Suisse) 
penchée sur son iconographie (Weidmann et Rassart-Debergh 2013). On y voit une croix monogrammatique, de couleur or, trônant au centre d'une triple couronne de feuillages jaune-or rehaussés de camées rouges et verts ; les trois éléments constituant la couronne pourraient symboliser la trinité. Le haut de l'opus manque mais sont bien visibles, encadrant la couronne, deux piliers auxquels sont attachées des tentures. Trois exemplaires égyptiens lui ressemblent : deux ornaient la petite basilique à Abou Menas; le troisième est attribué au Fayoum. Mais la particularité de l'opus kelliote réside dans les objets peu communs - et à l'identification incertaine - qui se trouvent sous le chrisme gemmé : deux anneaux sombres, qu'encadrent deux cônes inversés, unis par une tige jaune-or. Surmonte chacun de ces derniers une forme allongée, verdâtre, dont l'une, à notre droite, se termine par une touche de rouge. Aux propositions d'analyses et de comparaisons que j'ai faites (chandeliers ? calices ?...), je voudrais, pour les éléments ronds, ajouter, et soumettre à réflexion, une peinture de Faras, elle aussi exceptionnelle; datée du début du $8^{\mathrm{e}}$ siècle, elle ornait la première cathédrale ; le panneau conservé (Varsovie, Musée National, Inv. 234060) montre une couronne contenant le calice avec l'eucharistie, corps du Christ que symbolise également le chrisme kelliote. Deux représentations rares dont l'explication se trouvera peut-être dans une nouvelle étude liturgique.

Sans doute serait-il utile également de comparer la description du site faite par les fouilleurs, il y a cinquante ans, avec la végétation luxuriante et les animaux qui peuplent les parois des vestibules. Deux citations, anciennes déjà, justifieraient une telle recherche. Dans sa description des lieux, François Daumas insistait sur le fait que les indications données « n'ont d'autre but que de situer, par l'observation actuelle, un certain nombre de passages de la littérature monastique où plantes et animaux ont une place parfois importante. Ils ont joué, en tout cas, les uns et les autres, le rôle de décor de cette vie érémitique primitive, et il faudra sans doute, un jour, revenir sur ces notices un peu sommaires " (Daumas et Guillaumont 1969 : XI). Une première constatation y répondait. Après un de ses séjours dans la mission, Ewa Wipszycka écrivait : " [...] Ce qui m’a frappée le plus aux Kellia, ce ne sont pas les peintures figuratives, mais la décoration géométrique ou florale, dépourvue de signification religieuse [...]. Elle témoigne de l'existence d'exigences esthétiques très poussées. [...] L'étude de l'architecture, de la décoration et du mobilier des ermitages nous oblige d'admettre non seulement que les ascètes des $\mathrm{VI}^{\mathrm{e}}-\mathrm{VIII} \mathrm{e}^{\mathrm{e}}$ siècles se servaient des biens qu'ils possédaient dans le monde, mais aussi — fait encore plus significatif — qu'ils n'éprouvaient pas de gêne à faire étalage de leur richesse [...] " (Wipszycka 1995). Par ailleurs, la végétation spontanée née durant les 
années qui ont suivi la fouille a permis de constater combien riche devait être la flore à l'époque des moines : dans le sol des jardins dégagés, autour des anciens puits, les plantes ont jailli et se sont développées rapidement, transformant les lieux en de véritables petites oasis.

Cinquante années après les premiers sondages, les décors kelliotes réclament d'autres recherches : une étude, par des spécialistes, de la faune et de la flore figurées sur les parois serait la bienvenue et sa comparaison avec l'environnement mentionné dans les textes s'avérerait bien utile et précieuse.

\section{Références bibliographiques}

Andreu, G., Castel, G., et Coquin, R.-G. (1980). Sixième campagne de fouilles aux Kellia (1979-1980). Rapport préliminaire. Bulletin de l'Institut français d'archéologie orientale, $80,347-368$

Andreu, G. et Coquin, R.-G. (1981). Septième campagne de fouilles aux Kellia (avril 1981). Rapport préliminaire. Bulletin de l'Institut français d'archéologie orientale, 81, 159-188

Bachatly, C. (1954). Cartes de l'Égypte chrétienne : évêchés et couvents. Le Caire : Societé d'archéologie copte

Ballet, P., Bosson, N., et Rassart-Debergh, M. (2003). Kellia II.2. L'ermitage copte QR 195. La céramique, les inscriptions, les décors [=Fouilles de l'Institut français d'archéologie orientale 49]. Le Caire : Institut français d'archéologie orientale

Breccia, E. (1970). Le Musée gréco-romain d'Alexandrie, 1925-1931 (Reprint de 1932 éd.). Rome : Bretschneider

Bridel, P. (éd.). (1986). Le site monastique copte des Kellia: sources historiques et explorations archéologiques. Actes du Colloque de Genève 13 au 15 août 1984. Genève : Mission suisse d'archéologie copte de l'Université de Genève

Bridel, P. (éd.). (1994). Explorations aux Qouçoûr er-Roubâầyât : rapport des campagnes 1982 et 1983, I-II. Louvain : Peeters

Bridel, P. (éd.). (1999). Explorations aux Qouçoûr el-Izeila : lors des campagnes 1981, 1982, 1984, 1985, 1986, 1989 et 1990. Louvain : Peeters

Bridel, P. (éd.). (2003). Explorations aux Qouçoûr Hégeila et Ereima lors des campagnes 1987, 1988 et 1989. Louvain : Peeters

Coquin, R.-G. (1982). Huitième campagne de fouilles aux Kellia (avril 1982). Rapport préliminaire. Bulletin de l'Institut français d'archéologie orientale, 82, 363-377

Coquin, R.-G. (1985). Neuvième campagne de fouilles aux Kellia (avril 1983). Rapport préliminaire. Annales du Service des antiquités de l'Égypte, 70, 107-124

Daumas, F. (1965). Rapport sur les travaux scientifiques de l'I.F.A.O. durant l'année 1964-1965. Comptes rendus de l'Académie des inscriptions et belles-lettres, 109(2), 383-390 
Daumas, F. (1966). Les activités de l'Institut français d'archéologie orientale en 19651966. Comptes rendus de l'Académie des inscriptions et belles-lettres, 110(2), 298-309

Daumas, F. (1967). Les travaux de l'Institut français d'archéologie orientale pendant l'année 1966-1967. Comptes rendus de l'Académie des inscriptions et belles-lettres, 111(3), 436-452

Daumas, F. (1968). Fouilles et travaux de l'Institut français d'archéologie orientale durant l'année 1967-1968. Comptes rendus de l'Académie des inscriptions et belleslettres, 112(3), 395-408

Daumas, F. (1969). Rapport sur l'activité de l'Institut français d'archéologie orientale du Caire au cours des années 1968-1969. Comptes rendus de l'Académie des inscriptions et belles-lettres, 113(3), 496-507

Daumas, F. et Guillaumont, A. (1969). Kellia I. Kom 219: Fouilles exécutées en 1964 et 1965 [=Fouilles de l'Institut français d'archéologie orientale 28]. Le Caire : Institut français d'archéologie orientale

De Cosson, A. (1935). Mareotis, being a short account of the history and ancient monuments of the north-western desert of Egypt and of Lake Mareotis. Londres: Country Life Ltd

De Cosson, A. (1936). El Barnugi. Bulletin de la Société archéologique d'Alexandrie, 30(9/1), 113-116

de Fenoyl, M. (1960). Le sanctoral copte. Beirut : Imprimerie catholique

Evelyn-White, H.G. (1926-1933). The monasteries of the Wadi 'n Natrûn I-III. New York: Arno Press

Grimal, N.-C. (éd.). (1981). Prospection et sauvegarde des antiquités de l'Égypte : actes de la table ronde organisée à l'occasion du centenaire de l'IFAO, 8-12 janvier 1981 [=Bibliothèque d'étude 88]. Le Caire : Institut français d'archéologie orientale

Guillaumont, A. (1965). Premières fouilles au site des Kellia (Basse-Égypte). Comptes rendus de l'Académie des inscriptions et belles-lettres, 109(1), 218-225

Henein, N.H. et Wuttmann, M. (2000). Kellia II.1. L'ermitage copte QR 195. Archéologie et architecture [=Fouilles de l'Institut français d'archéologie orientale 41]. Le Caire : Institut français d'archéologie orientale

Kasser, R. (éd.). (1967). Kellia 1965. Topographie génerale, mensurations et fouilles aux Qouçoûr "Îsâ et aux Qouçoûr el-"Abîd, mensurations aux Qouçoûr el-'Izeila. Première expédition archéologique de l'Université de Genève au site copte appelé Kellia, en BasseÉgyte occidentale [=Recherches suisses d'archéologie copte 1]. Genève : Georg

Kasser, R. (éd.). (1983). Survey archéologique des Kellia (Basse-Egypte) : rapport de la campagne 1981, I-II. Louvain : Peeters

Mohamed, F.M. (2011). Catalogue général du Musée Copte (section des céramiques). Dans M. Eaton-Krauss, C. Fluck, et G.J.M. van Loon (éds), Egypt 1350 BC-AD 1800: Art historical and archaeological studies for Gawdat Gabra [=Sprachen und Kulturen des christlichen Orients 20] (pp. 109-112). Wiesbaden : Reichert

Mottier, Y. et Bosson, N. (éds). (1989). Les Kellia : ermitages coptes en Basse-Egypte. Musée d'art et d'histoire, Genève, 12 octobre 1989-7 janvier 1990 [catalogue d'exposition]. Genève : Éditions du Tricorne 
Rassart-Debergh, M. (1986). Le thème de la croix sur les peintures murales des Kellia, entre l'Égypte et la Nubie chrétiennes. Dans M. Krause (éd.), Nubische Studien: Tagungsakten der 5. Internationalen Konferenz der International Society for Nubian Studies, Heidelberg, 22.-25. September 1982 (pp. 363-366). Mayence : Philipp von Zabern

Rassart-Debergh, M. (1987). Quelques croix kelliotes. Dans P.O. Scholz et R. Stempel (éds), Nubia et Oriens Christianus: Festschrift für C. Detlef G. Müller zum 60. Geburtstag [=Bibliotheca Nubica 1] (pp. 373-385). Cologne : J. Dinter

Rassart-Debergh, M. (1994). Le Christ et la croix dans l'art copte. Dans S. Giversen, M. Krause, et P. Nagel (éds), Coptology: Past, present, and future. Studies in honour of Rodolphe Kasser [=Orientalia Lovaniensia Analecta 61] (pp. 45-69). Louvain : Peeters

Rassart-Debergh, M. (2011). Au sujet du Catalogue général du Musée Copte. Les peintures Kelliotes. Dans M. Eaton-Krauss, C. Fluck, et G.J.M. van Loon (éds), Egypt 1350 BC-AD 1800: Art historical and archaeological studies for Gawdat Gabra [=Sprachen und Kulturen des christlichen Orients 20] (pp. 113-118). Wiesbaden : Reichert

Rutschowscaya, M.-H. (1992). La peinture copte. Paris : Réunion des musées nationaux Toussoun, O.A. (1935). Notes sur le Désert Libyque. «Cellia » et ses couvents. Mémoires de la Société royale d'archéologie d'Alexandrie, 7(1), 1-35

Vercoutter, J. (1980). Les travaux de l'Institut français d'archéologie orientale en 1979_ 1980. Bulletin de l'Institut français d'archéologie orientale, 80, 369-392

Weidmann, D. (2013). Kellia : Kôm Qouçoûr 'Îsâ 1. Fouilles de 1965 à 1978 [=Recherches suisses d'archéologie copte 4]. Louvain : Peeters

Weidmann, D. (à venir). Kellia,Qouçour Isâ 1. Évolution d'un centre de réunion monastique, de 350 à $650 \mathrm{AD}$. Dans Ermitages d'Égypte au premier millénaire. Colloque international, IFAO, Le Caire, 24-26 janvier 2009

Weidmann, D. et Rassart-Debergh, M. (2013). Les décors. Dans D. Weidmann, Kellia: Kôm Qouçồr 'I $\hat{s} \hat{a} 1$. Fouilles de 1965 à 1978 [=Recherches suisses d'archéologie copte 4] (pp. 365-420). Louvain : Peeters

Wipszycka, E. (1995). Apports de l'archéologie à l'histoire du monachisme égyptien. Dans M. Starowieyski (éd.), The spirituality of ancient monasticism: Acts of the International Colloquium, held in Cracow-Tyniec, 16-19th November 1994. Specialized contributions (pp. 63-78). Tyniec: Wydawnictwo Benedyktynów 


\title{
Eine koptische und eine arabische Bauinschrift zwischen Assuan und Kom Ombo
}

\author{
Tonio Sebastian Richter \\ Freie Universität Berlin \\ sebastian.richter@fu-berlin.de
}

KeYwORDS

Coptic / Arabic epigraphy, Fatimid Egypt, road network

\begin{abstract}
The present article suggests a hypothetical localization and provides a reconstructed text of a Coptic inscription which was seen by Urbain Bouriant on the road along the east bank of the Nile, halfway between Assuan and Kom Ombo. Bouriant edited this inscription twice in the 1890s, presenting it, together with an Arabic inscription that lay underneath, as a bilingual report on roadwork, and dated it to year 409 of Diocletian, resp. 7[3] Higrri, i.e., AD 693. This article argues that, on the contrary, the two inscriptions are of different and much later date, and commemorate two distinct (albeit similar) events.
\end{abstract}

Die koptische und die arabische Inschrift, von denen im folgenden die Rede sein wird, existieren aller Wahrscheinlichkeit nach nicht mehr. Sie sind von Urbain Bouriant in den frühen 1890er Jahren gesehen und zweimal in kurzer Folge publiziert worden (Bouriant 1893; de Morgan et al. 1894: 206-228). Dabei gab Bouriant die arabische Inschrift nach einem Abrieb oder Abklatsch wieder, so dass die Lesung und die Paläographie des Texts heute noch kontrolliert werden können, während er die koptische Inschrift nur transkribierte $[A b b .1]{ }^{1}$

Bouriant hielt die beiden Inschriften für zwei Versionen desselben Texts („Inscription historique bilingue, copte et arabe“), da in beiden straßenbauliche Maßnahmen kommemoriert werden. Deshalb identifizierte er den Namen des Bauherrn anoүגace, den er in Z. 4 des koptischen Texts las, mit dem in

$1 \quad$ In Bouriant 1893: 177 ist die Inschrift in koptische Drucktype ediert, in de Morgan et al. 1894: 206 ist anscheinend eine Handkopie abgebildet. Sollte diese Abschrift etwas von der Anmutung des Originals vermitteln, so wäre die koptische Inschrift oberhalb der arabischen Inschrift in einem links und rechts durch Streifen gerahmten, fast quadratischen Feld eingeschrieben gewesen. 
der arabischen Inschrift genannten Namen, den er „Abou Lezz [ابولز] Yakmer El-Nadri» transkribierte. Da Bouriant die Buchstabenfolge $\gamma \Theta$ am Ende von Z. 14 der koptischen Inschrift - als Zahlbuchstaben gelesen 409 - auf ano $\Delta \mathrm{lo}[\mathrm{\kappa}]$ (Ära Diokletians) am Ende von Z. 13 bezog, datierte er beide Inschriften ins Jahr 693 n.Chr. Die Datierung der arabischen Inschrift, die er „l'an $70+$ ?..." las, ergänzte er dementsprechend zu Jahr 7[3] (Hĭgri). ${ }^{2}$

Wie Andreas Kaplony uns freundlicherweise mitteilte, ist die arabische Inschrift inzwischen auf der Basis von Bouriants Abbildung mit signifikant veränderter Lesung des Namens und der Datierung reediert worden. ${ }^{3}$ Es kann kein Zweifel daran bestehen, dass als Bauherr der Straßenarbeiten Boktomor al-Badri genannt ist, eine bekannte Persönlichkeit des ägyptischen Mamlukensultanats unter alNasir. ${ }^{4}$ Die Lesung des Hiğri-Jahres ist 737 (AD 1336/7). ${ }^{5}$

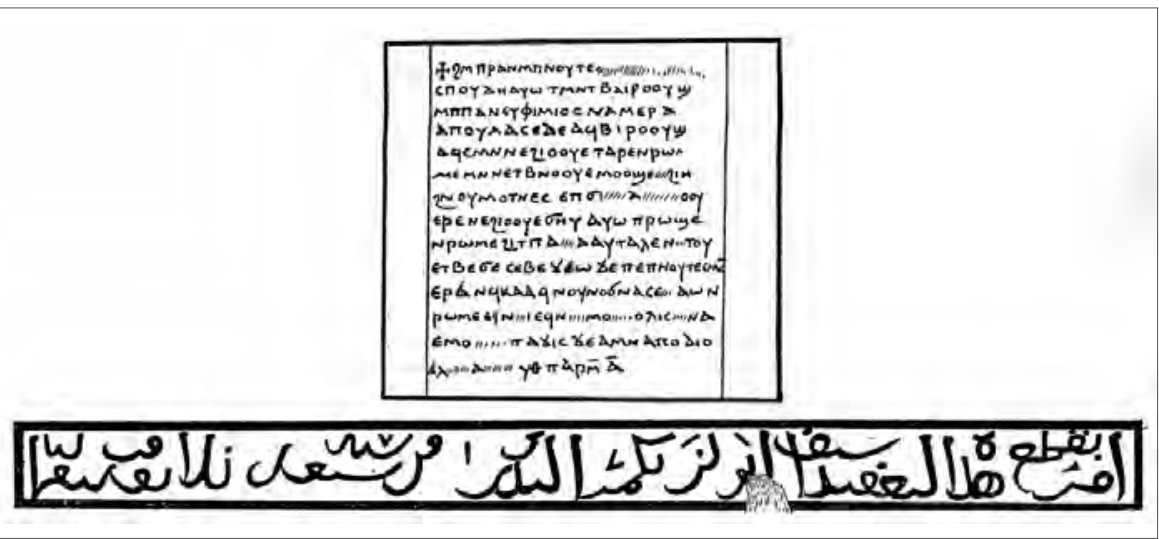

Abb. 1. Bouriants Abbildung der koptischen und arabischen „Bilingue“ (de Morgan et al. 1894: 206)

2 Bouriant 1893: 177: „La ponctuation qui manque dans l'arabe en rend la lecture incommode. Voici ce que j’y vois...: «Ordre (a été donné) de couper cette barrière par Seïf Abou Lezz Yakmer El-Nadri dans l'an 70+?..."."

3 Combe, Sauvaget, und Wiet 1931-1964/XV: n 5705; vgl. Kevran, Ory, und Schneider 1975 und Thésaurus d'épigraphie arabe <http://www.epigraphie-islamique.org>, Numéro de fichier: 7367. Wir danken Andreas Kaplony für den bibliographischen Nachweis der Inschrift.

4 Andreas Kaplony teilt uns dazu mit: „Baktamur, in der E[ncyclopedia of] I[slam] als Baktamur al-Mu azzamī (d.h. er war in der Faktion von al-Mu 'azzam) al-Badrī (und in der Faktion eines Badr ad-dīn) as-Sāqī (der Mundschenk), war enger Vertrauter des Mamlukensultans an-Nāșir Muhammad b. Kalāwūn (684-741/1285-1341), hat ein schönes Grab im al-Qarāfa Friedhof, und heute ist eine Straße bzw. ein Quartier (Boktomor) in Kairo nach ihm bekannt."

5 Auf die Datierung der arabischen Inschrift in die Mamlukenzeit hatte uns bereits Lennart Sundelin während der DAI-Konferenz Epigraphy Through Five Millennia - the Area of Aswan im März 2013 hingewiesen. 
Im folgenden werden wir versuchen, die Lokalisierung der beiden Inschriften und den Text der koptischen Inschrift zu rekonstruieren. Dabei wird sich zeigen, dass auch die koptische Inschrift höchstwahrscheinlich nicht aus der Umajjadenzeit stammt, sondern viel später, eventuell fatimidenzeitlich, datiert.

\section{Die Lokalisierung der Inschriften}

Bouriant hat uns zwei Beschreibungen des Anbringungsortes der Inschriften hinterlassen, die heute, da die Inschriften sich nicht mehr in situ befinden und wahrscheinlich gar nicht mehr existieren, zu primären Dokumenten geworden sind.

In de Morgans Catalogue des Monuments et Inscriptions schreibt Bouriant (206-208), „206 Au nord de Khattarah commence la montagne appelée Gebel El-Hamam (جبل الحمام montagne des pigeons) ... La route, longeant le pied de la montagne, est le plus souvent taillée dans la rocher même, et parfois traverse la plaine quand les montagnes s'éloignent par trop des cultures; les graffiti sont [208] rares et la récolte est maigre de long de la route; le plus intéressant est celui qui se trouve au bord de la route elle-même et qui fut gravé en l'honneur de l'émir Abou Lazz (ابولز) qui fit tracer ce chemin ... . L'inscription est bilingue, copte et arabe, et fut rédigée le $1^{\text {er }}$ Pharmouthi de l'an 409 de Dioclétien (693 de notre ère) d'après l'inscription copte. Cette inscription est gravée à peu près à mi-chemin, entre Aqaba el-Kebir et Melisah. De là jusquà Deraou on ne rencontre plus que les carrières d'El-Hadadeïn, carrières considérables à ciel ouvert où quelques marques d'ouvriers accompagnent deux inscription latines et une inscription gréco-copte."

In Recueil de Travaux 15 (1893) beschrieb Bouriant die nähere Umgebung des Anbringungsortes der Inschriften noch etwas genauer: „Elles sont gravées l'une au-dessus de l'autre au bord du sentier qui conduit, en longeant le Nil, d'Asouan à Kom Ombo (rive droite). Dans cette partie de la route, le rocher qui barrait le passage a été coupé et paré, c'est sur le parement que sont gravés les deux textes. Le rocher est visible du Nil, il est situé au bord du chemin, un peu au sud (1 kilomètre environ) de Khannaqah, à peu près à mi-chemin entre El-Aqaba, El-Kébira [sic, lies El-Aqaba el-Kébira] et El-Haddadéin; ce dernier village est lui-même à 6 ou 7 kilomètres au sud de Déraou."

Während wir die Ortslagen von Khannaqah — „... un peu au sud (1 kilomètre environ) de Khannaqah...“ - und Melisah — „...entre Aqaba el-Kebir et Melisah..." - nicht lokalisieren können und uns die Identität des von Bouriant 


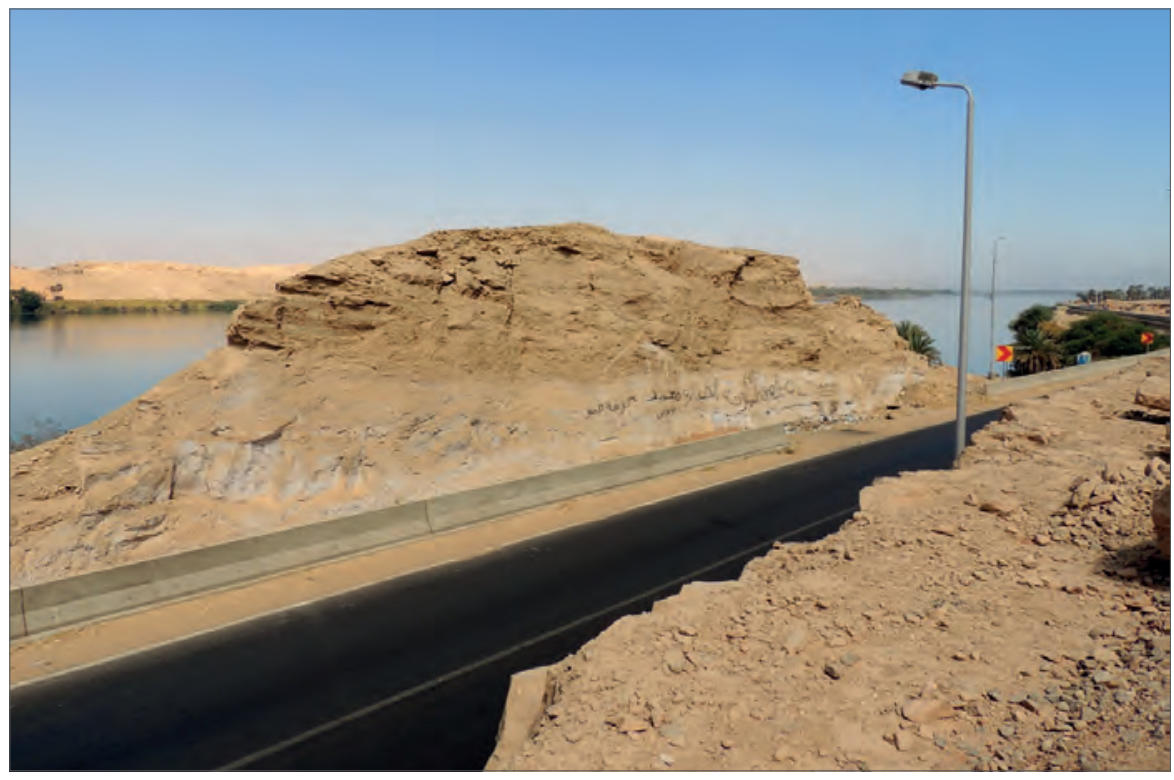

Abb. 2. Felsen nilseitig der Straße von Assuan nach Kom Ombo, 24ำ18,419' nördlicher Breite, 3254,616' östlicher Länge (Foto T.S. Richter)

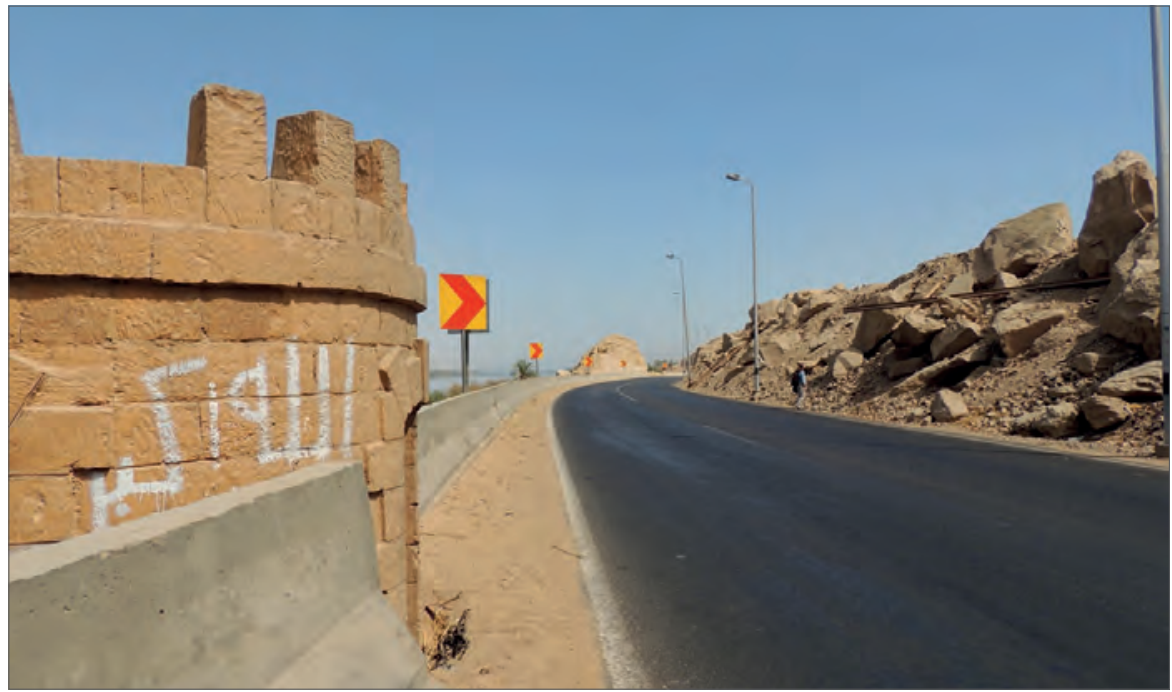

Abb.3. Wachturm unweit des Felsens (Foto T.S. Richter) 
genannten El-Haddadéin nicht restlos sicher erscheint, ${ }^{6}$ ist doch so viel klar, dass die Inschriften sich direkt an der Straße nördlich von Al-'Aqaba al-Kabïra befanden, diesem Ort wesentlich näher gelegen als dem nächsten größeren Ort Darāw. Nach dem alten wie dem neuen Straßenverlauf gibt es tatsächlich ein Wegstück, das so nahe am Ufer verläuft („le plus souvent taillée dans la rocher même"), dass ein vom Ufergebirge auslaufender Felsen den Straßenverkehr stören musste. Im Frühjahr 2013 sind wir dieses Wegstück abgelaufen. An einer Stelle nördlich von Al- 'Aqaba al-Kabīra und einige hundert Meter südlich von Al-Ga fara $^{7}$ steht noch heute ein Felsen flußseitig am Straßenrand an [Abb. 2], der auch vom Nil aus zu sehen ist („le rocher est visible du Nil“). Ein jüngerer Wachtturm in kurzer Distanz [Abb.3] zeigt, dass hier noch in späterer Zeit die hohle Gasse war, durch die jedermann kommen musste. Wir sind uns daher so sicher, wie es den Umständen nach möglich ist, dass unsere Inschriften sich genau hier befunden haben müssen. ${ }^{8}$

Die der Straße zugewandte Seite des Felsens zeigt Spuren von Abarbeitung, wie schon Bouriant sie beschrieb (,...le rocher qui barrait le passage a été coupé..."). Natürlich rühren die heute sichtbaren Abarbeitungsspuren [Abb.4] von weiteren, späteren Verbreiterungen der Passage her, die nötig waren, um Raum für die moderne Fahrstraße und das Eisenbahngleis zu gewinnen. Sie sind folglich die Chiffrenschrift, die vom irreversiblen Verlust unserer Inschriften kündet, zumal diese ja in eine Wandverkleidung, also wohl in eine Putzschicht, eingraviert waren („...sur le parement ... gravés...").

Abb. 4. Rezente Abarbeitungsspuren am Felsen (Foto T.S. Richter)

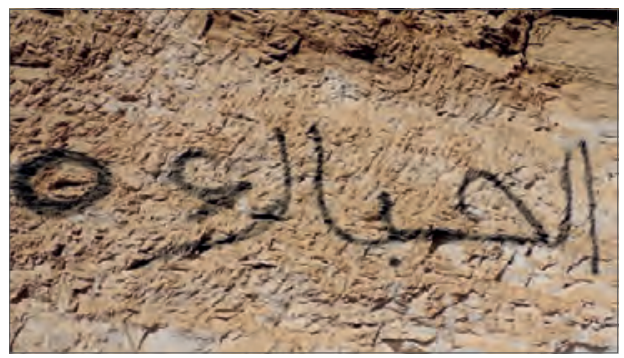

6 Khannaqah ist, wie Cornelius von Pilgrim uns freundlicherweise mitteilte, einer der Ortsnamen, der für Nag' el-Hagar gebraucht wurde. Bouriants El-Haddadéin könnte dem Namen nach das Dorf Nag' el-Haddâdîn sein, das in den älteren Plänen jedoch unmittelbar am Ostrand von Al-'Aqaba al-Kabīra eingetragen ist, so das eher Nag' Hadidūn kurz vor $\mathrm{Al}-\mathrm{Ga}$ ' fara in Betracht käme.

7 Die erste Ortschaft nördlich des Engpasses heißt heute laut Ortschild der Bahnstation Al-Ga fara. In Google Maps wird sie allerdings als „Naqaa ash-Sheikh al-Jarad“ bezeichnet.

8 Die GPS-Daten sind 24 18,419` nördlicher Breite, 3254,616` östlicher Länge. 


\section{Mallons text}

1912 veröffentlichte Alexis Mallon unter dem Bouriant-Zitat „Inscription historique" eine durch Rekonstruktionen im koptischen Text und Neulesungen im arabischen Texts verbesserte Reedition der beiden Bauinschriften zwischen Assuan und Kom Ombo (Mallon 1912). Mallons Rekonstruktionen basieren leider nicht auf einer Kollation der Inschrift, sondern allein auf Bouriants Text in De Morgans Catalogue de monuments et inscriptions von 1894 und seiner Kenntnis des Formulars koptischer Stifterinschriften. So konnte Mallon den Anfang der Inschrift (Z. 1) und die Formel „Gott möge ihn segnen und ihn eine lange Lebenszeit lang erhalten etc." (Z. 10-13) sinngemäß rekonstruieren. Auch las Mallon in der arabischen Inschrift richtig den Namen Boktomor und korrigierte Bouriants Lesung des Datums richtig in A.H. 737. Bouriants Lesung des Namens Abu Lazz (statt al-dīn) in der arabischen Inschrift korrigierte Mallon nicht. Deshalb fasste auch er die koptische und die arabische Inschrift als Versionen einer Bilingue zum Gedenken ein- und desselben Ereignisses auf und datierte die koptische Inschrift, unter Hinweis auf die Unsicherheit der Lesung des Diokletiansjahres 409, ${ }^{9}$ ins 14. Jahrhundert: „Elle a été composée par un copte qui savait encore assez bien la langue. Le XIVe siècle marque ainsi, semble-t-il, l'extrème limite de la littérature et de l'épigraphie copte". Auf Mallons Reedition basiert eine weitere Textwiedergabe, die sich in den Lesestücken zu Wolfgang Kosacks koptischer Grammatik findet. ${ }^{10}$ Dieser Text weist allerdings willkürliche Veränderungen und grammatisch unmögliche Ergänzungen auf und ist für uns wertlos. So rekonstruierte Kosack, der von Mallon vorgeschlagenen Datierung der koptischen Inschrift in die Zeit Boktomors folgend, gegen den von Bouriant gelesenen Text ein Diokletiansjahr aNe „1055“ (= A.D. 1338/9). Vor wenigen Jahren wurde die koptische Bauinschrift zwischen Assuan und Kom Ombo von Jacques van der Vliet wieder in die Diskussion gebracht; ${ }^{11}$ zuletzt wurde sie von Jelle Bruning in seiner Dissertation eingehend philologisch und inhaltlich kommentiert (Bruning 2014). Van der Vliet und Bruning kehrten zur Datierung der koptischen Inschrift ins Diokletiansjahr 409 (A.D. 693) zurück.

9 „De Morgan a lu « l'an 409 de Dioclétien » en se basant sur le copte, mais celui-ci est trop incertain à cause de la lacune" (Mallon 1912: 134).

10 Kosack 1974: 398, Nr. 191: „Gedenkinschrift über eine Straßenanlage”.

11 „A somewhat forgotten Coptic inscription, dated to 25 February of the year 693, explicitly attests to activity connected with the improvement of infrastructure around Aswan. It formally thanks " the wholly praiseworthy Amir Abu'l-Azz " for improving the road between Aswan and Kom Ombo, "so that men and animals travel on the road comfortably " (Mallon 1911-12:132*-34*).“ (van der Vliet 2013: 72). 


\section{Der Inhalt der Inschriften}

Beide Inschriften berichten von anscheinend ähnlich gearteten Baumaßnahmen zur Verbreiterung der vom Felsen des Ufergebirges beengten Straße. Der arabische Text sagt lapidar: „Es hat befohlen, dieses Hindernis wegzuschlagen, Sayf al-dīn Boktomor al-Badrī im Jahre 737“ (Übersetzung: Andreas Kaplony).

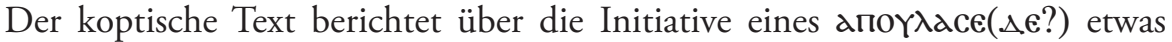
ausführlicher: „Er trug Sorge und befestigte die Wege, damit Menschen und Vieh in Ruhe (ihres) Weges gehen könnten ... da die Wege (zu) eng waren“. Bouriant hatte diesen Inhalt als „Inscription historique“ klassifiziert, nicht ohne auf die Seltenheit historischer Texte in koptischer Sprache hinzuweisen. ${ }^{12}$ Tatsächlich kann jedoch unser koptischer Text nicht als Beleg einer koptischen „historischen“ Inschrift gelten. ${ }^{13}$ Vielmehr folgt er dem Formular koptischer Stifterinschriften, das in stehenden Ausdrücken und Phrasen (s.u.) die Leistung des Bauherrn oder Stifters eines Gebäudes oder Bauteils würdigt und mit guten Wünschen für ihn und der Aufforderung, für ihn zu beten, schließt. ${ }^{14}$ Dasselbe Formular kennen wir in wesentlichen Stücken auch aus den Kolophonen koptischer literarischer Manuskripte des 9. bis 11. Jahrhunderts, wo diese Wünsche von den Stiftern und Schreibern der Bücher vorgetragen werden (vgl. van Lantschoot 1929).

12 „On connait peut de textes historiques Coptes. J'en ai, il y a plusieures années, publié un qui était tracé sur les parois d'une tombe d'Assouan". Bei dieser lange Zeit einzigen bekannten historischen Inschrift in koptischer Sprache handelt es sich um den Graffito Qubbet el Hawa $34 \mathrm{f}$ (Nordwand) aus dem Jahr MÄ 889 = AD 1173 über die Eroberung von Qasr Ibrim durch die Schams ad-Dawla, vgl. Bouriant 1886; de Morgan et al. 1894: 162 ( ${ }^{\circ} 1$.); Mallon 1914: 2879; Griffith und Crowfoot 1934: 5-8; Kosack 1974: 335, no 119; SBKopt. II, no 1060; T.S. Richter in Edel 2008: 514-519 (dort auch die einzige publizierte Fotografie und Edels Faksimile). Die rote Tinteninschrift ist heute so weitgehend von modernen, tief in den Putz geritzten Besucherinschriften gestört, dass Edels Dokumentation in Zukunft das Original ersetzen muss.

13 Eine zweite „historische“ Inschrift in koptischer Sprache befindet sich unweit des Klosters an der Qubbet el-Hawa im Deir Anba Hadra; sie wurde während des koptischen epigraphischen Surveys des DAI im März 2013 als K_78_a aufgenommen. Es handelt sich um einen 19-zeiligen roten Dipinto, aufgebracht auf der Südwand des Südschiffs in vierliniger Kursive, wie sie in der Epigraphie der Region noch bis in die zweite Hälfte des 10. Jahrhundert in Gebrauch war. Ebenso wie die historische Inschrift aus QH $34 \mathrm{f}$ beginnt sie mit den Worten 2Pal 2N- einer Datierungsformel, wodurch sich ein immerhin existierendes Formular der „historischen Inschrift“ in koptischer Sprache abzuzeichnen beginnt.

14 Zum Formular koptischer Bau- und Stifterinschriften vgl. Schaten 1999. 


\section{Rekonstruktion des koptischen Texts}

Nachdem wir nicht damit rechnen können, das Original der Inschrift jemals wiederzusehen, werden wir im folgenden versuchen, so viel wie möglich davon aus Bouriants zwei Publikationen zu rekonstruieren und dabei auch auf Mallons Rekonstruktionsvorschläge eingehen.
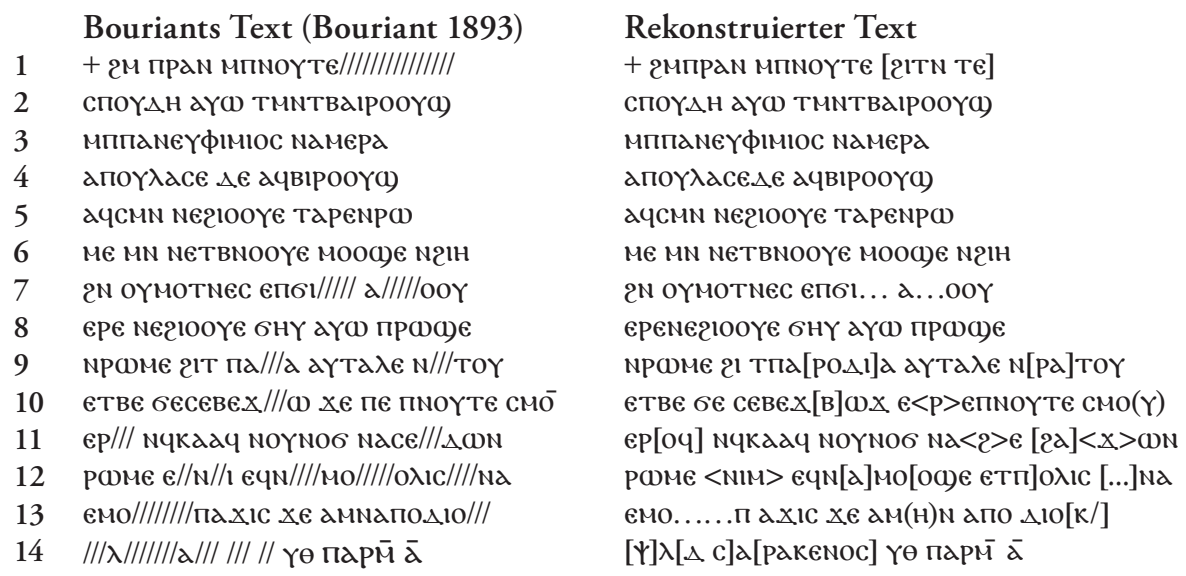

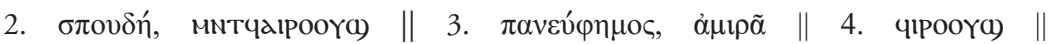

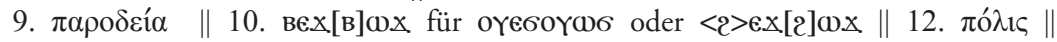

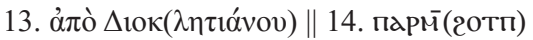

1-2. гмпрам мпноүте [2ІтN те]споүАн аүш тмптваірооү(): Mallon 1912 ergänzte [Mм тє] споү $\Delta$ H. Jedoch ist die in Bouriants Text bezeichnete Lücke relativ groß, die Invokation „im Namen Gottes“ sonst nicht mit der Stifterformel verbunden und 2ITN die am häufigsten belegte Präposition in dieser Formel. споү $\Delta \mathrm{H}$ „Eifer“ und чıрооү() „Sorge tragen“ "bzw. мnтчаıрооү() „Fürsorge“ gehören zum festen Vokabular der koptischen Bau- und StifterInschriften, vgl. für die Stifterinschriften der Kolophone van Lantschoot 1929: 129 [s.v. споү $\Delta \mathrm{H}$ ] und 148 [s.v. чl]). Zur Stifterformel 2ІтN теспоүАн мN тмNтчалрооү() „Durch den Eifer und die Fürsorge“ vgl. in den koptischen Kolophonen van Lantschoot 1929: $n^{\circ}$ xcviii, 3-4 (A.H. 423 = A.D. 1032); cviii,1 (A.M. 697 = A.D. 981); cx, 2.,1 (A.H. 698 = A.D. 981); cxi,1 (A.M. 70[3] / A.H. 376 = A.D. 987); cxii, 1 (A.M. 703 / A.D. 987); cxiii, 1.,1 (A.M. 703 / A.D. 987); cxviii, 1.,vo 1 (A.M. 719 / A.H. 393 / A.D. 1003) u.ö. Im Raum Assuan finden wir die Formel etwa in der koptischen Stifterinschrift in 
der Westkirche von Philae (Jahr Diokletians 469 = A.D. 752, ed. Wreszinski 1902: 62-65; reed. Mallon 1905: 107-111 und Richter 2002: 128-135), Z.

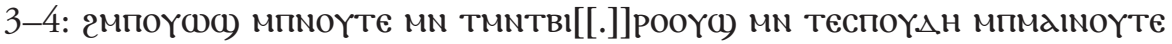
nCON KYPOC „Durch den Willen Gottes und die Fürsorge und den Eifer des gottliebenden Bruders Kyros“. Die Inschrift anlässlich der Stiftung eines Anteils vom Ernteertrag zugunsten der Armen CG 8322 in Deir Anba Hadra (de Morgan 1894: 139, Fn. 1; Crum 1902: 77, no 8322; Mallon 1914: Sp. 2879; Moneret de Villard 1927: 146; Neuedition durch Lena Krastel in Vorbereitung) rühmt тбом єтоүав м[те ...] мй тммтчалрооүу) „die heilige Kraft v[on ...] und die Fürsorge" des Stifters (vgl. auch Dekker 2006: 44-45; van der Vliet

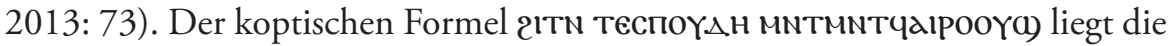

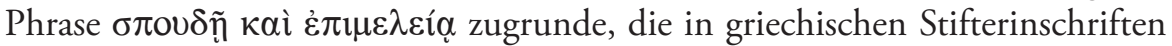
bereits im 5.-7. Jh.s zu finden ist, wie etwa in der Mosaikinschrift des Jahres A.D. 587 in der Kirche des Bischofs Sergios in Umm al-Rassas in Jordanien (Metzger 2012: Tafel 32). Adam Łajtar weist uns auf Feissel 2006 hin, wo in

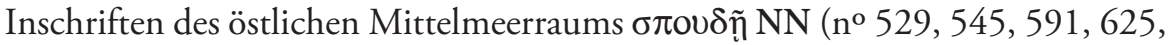

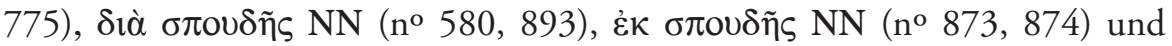

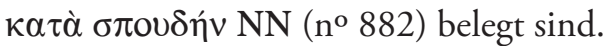

3. ппамеүфіміос мамера: Das anscheinend frühestens im byzantinischen Griechisch bezeugte Attribut $\pi \alpha v \varepsilon v ́ \varphi \eta \mu o s$ ist in koptischen Texten aus vorarabischer Zeit für einen $\Delta$ oYz $(O$. Crum 356,6) und einen патрıкıос (P. Lond. V 1709, um 570 n.Chr.) belegt. In koptischen und griechischen Texten des 7. und 8. Jh.s wird es dem Statthalter Ägyptens (сүмвоү入oc) beigelegt (z.B. SBKopt. I 242, 649 n.Chr. und P. Lond. IV passim). Für spätere Verwendungen des Wortes fehlen griechische und koptische Quellen aus Ägypten. Im volkssprachigen Mittelgriechisch ist es weiter belegt (Kriara 1997: 275f.). Die koptische Transkription des Ehrentitels 'amīr ,Befehlshaber' für hohe Beamten bis hinauf zum Kalifen ist eines der am frühesten belegten arabischen Wörter im Koptischen. Die auf -d auslautende Form, über die Mallon 1912: 133, sich wunderte („Je m'explique difficilement l'a qui vient après дмєе ... le plus étonnant c'est que l'arabe donne aussi deux alifs pour Aboulazz.") ist in der Tat die im Koptischen am häufigsten vorkommende Schreibung des Titels, der

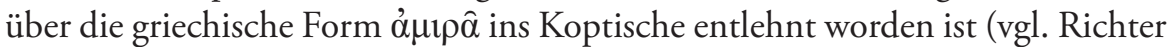
2001: 75-89), ist vom 7./8. Jh. (z.B. CPR IV 51,8; P. Bal. 122,5; 183,3; 184,1; 187,11; 242,4; P. Lond IV 1603; P. KRU passim, O. Medin. Habu Copt. 281,5; O. Vindob. Copt. 384,8), reichen bis ins 9./10. Jh. (z.B. P. Ryl. Copt. 373; 374). Die direkt aus dem Arabischen entlehnte Form aגamip kommt nur in wenigen spätkoptischen Texten (P. Lond. Copt. I 487,8; P. Lond. Copt. I 659,6-7) vor. In Anbetracht der vermuteten Datierung der Inschrift ins 11. Jh. (s.u.) und 
in Ermangelung zeitgenössischer Belege ist fraglich, welchen Würdenträger ппамеүфіміос мамера hier bezeichnen könnte.

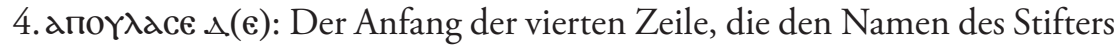

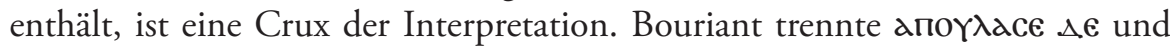

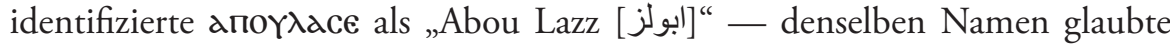
er in der arabischen Inschrift zu lesen. In diesen Prämissen folgte ihm Mallon. Der Personenname (Abū) Lazz ist indessen nicht belegt, und Mallons Hinweis auf eine Bezeichnung des Elias (Mallon 1912: 133: „Quant à ce dernier nom, sa seconde partie pourrait bien être l'équivalent turc de Elias. Actuellement encore les Ottomans appellent St Elie للز خضر et (Hezrr Ellazz)" hilft uns nicht aus dieser Verlegenheit. Wahrscheinlicher wäre noch die Transkription Abū l-'Āṣ [ابو العاص] bzw. Abū l- 'Âṣī, die Andreas Kaplony uns vorgeschlagen hat und die auch Bruning 2014: 104, ansetzt. Schließlich wäre hier noch die Kunya Abū 'l-A'azz zu erwägen, wie sie z.B. für Dubays b. 'Alī Abū 'l-A'azz Nūr al-Dawla (EI VI, 965b) belegt ist. Der Gedanke, unseren ппдмєүфıмıос nגмера mit diesem Mazyadiden zu identifizieren, dem der Titel Amir in der Tat zustünde und der nach unserem Datierungsvorschlag für die koptische Bauinschrift in Jahr A.H. 409 ein Zeitgenosse wäre (er gelangte A.H. 408/A.D. 1017 zur Herrschaft), ist wohl abwegig, zumal alle diese Namensformen mit einem grundsätzlichen Problem behaftet sind: Bouriant hat nach anoүגace die Zeichen $\Delta \epsilon$ gelesen. Diese wurden in der bisherigen Forschung seit Bouriant (außer von Mallon) fraglos als griechische Partikel verstanden, aber nicht ernstgenommen. Stünde wirklich diese Partikel hier, d.h. an zweiter Stelle, so würde sie die Person des Wohltäters anоүגace von der Person eines namentlich ungenannten памеүфіміос мамера trennen: „Durch den Eifer und die Fürsorge des allgepriesenen Emirs; Apoulase aber...". Dies erscheint im Rahmen des Konzepts und des Formulars der Stifterinschriften, die ja gerade den Eifer und die Sorgfalt der namentlich genannten Stifter feiern, schlechthin undenkbar. Offenbar hat auch Mallon die Unmöglichkeit dieser Konstruktion empfunden, denn er emendierte Bouriants $\Delta € \mathrm{zu} \times €$. Ein $\chi €$ wäre zwar vielleicht grammatisch nicht unmöglich, aber es spricht dagegen, dass in den vielen Belegen (s.o. zu Z. 1-2) des koptischen Stifterformulars zwischen der Formel 2ITN теспоү $\Delta H$ aү(0 тмnтваıрооү) $\mathrm{N}$-Titel-Name und der Nennung der Stifterleistung aч-... „er tat..." kein einziges Mal ein solches $\chi €$ belegt ist. Deshalb ist wohl ernsthaft zu erwägen, die Zeichen $\Delta €$ zum Namen selbst zu ziehen. Dieser müsste dann ungefähr einem Abū 'l-'Assād, 'l-Asad, 'l-Asadī, 'l-Azdī o.ä. entsprechen, ohne dass wir eine solche Person prosopographisch identifizieren könnten.

4-5. чірооү() „Sorge tragen“ und cmine „aufrichten, befestigen“ sind zentrale Ausdrücke der koptischen Stifter-Terminologie, vgl. van Lantschoot 
1929: passim, und unseren Kommentar zu Z. 1-2 zu мnт4aıpooy(a). In Verbindung miteinander vgl. van Lantschoot 1929: $\mathrm{n}^{\circ} \mathrm{x}, 4-5$; xxvii, 14-17 u.ö.

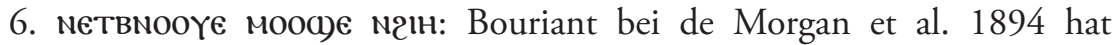
мєтвnooye ///2lн. Mallon 1912, der nur auf Bouriant bei de Morgan et al. 1894 basierte, füllte die dort angegebene Lücke mit [21 T€], und das ist im Sinne der koptischen Idiomatik zweifellos die beste Ergänzung. Wir nehmen daher an, dass die Textwiedergabe der Handkopie in Bouriant bei de Morgan et al. 1894 der in Bouriant 1893 gedruckten Version dieser Zeile vorzuziehen ist.

7. епбI/////a/////ooץ: Die Ergänzung dieser Lücken ist unklar; der Syntax nach und in Anbetracht von $\mathrm{e}-\Pi$ - dürfte eine zweite Adverbialphrase folgen. Ob das maskuline Nomen $6 \mathbf{l}$, $\mathrm{GlH}$ „Grenze, Grenzbezirk, Grenzwache“ (Crum 1939: 803a; Westendorf 1965: 445) anzusetzen ist?

9. гттпа[Pо_l]d: Vgl. Förster 2002: 625, dort dieselbe Phrase in einem zweiten koptischen Beleg, P. Mon. Epiph. 283,3: dlaпаnта єрок әІтпараגı[а], von Crum als $\pi \alpha \rho \rho \delta \varepsilon i ́ \alpha$ identifiziert, also „Ich traf Dich unterwegs“; zu $\pi \alpha \rho o \delta \varepsilon i ́ \alpha$ vgl. LSJ 1341b: „passing by“, die Schreibung $\pi \alpha \rho o \delta i ́ \alpha$ auch direkt als „by-road“;

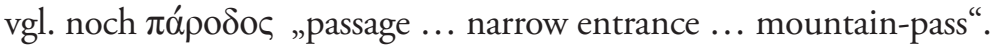

9. аүтаגе $\mathrm{N}[\mathrm{Pd}]$ ToY: Nach Bouriants Transkription ist die zu füllende Lücke sehr klein. Man möchte sich vorstellen, dass hier die Beschwerlichkeit des Vorankommens zum Ausdruck gebracht wird. Zur Form Ta $\lambda \epsilon$ im Status absolutus vgl. Crum 1939: 408a. Alternativ könnte man [(є)la]Tơ „ihre Augen" ergänzen: Vielleicht ging der Sinn der Stelle dahin, dass die Passanten aufblickten. Das Zeilenende rekonstruierte Kosack 1974: 398, folgendermaßen: аүталє ктоо „sie bestiegen die Berge“. Diese Ergänzung erscheint dem Sinne nach plausibel, sie erfordert jedoch ein zweites Omikron, wo Bouriants Text keine Lücke vorsieht.

10. єтвє бє севєх[в] Bouriant bei de Morgan et al. 1894 las anscheinend ceвexẹx. Es scheint hier eine Stativform eines reduplizierenden zweiradikaligen Verbs vom Typ

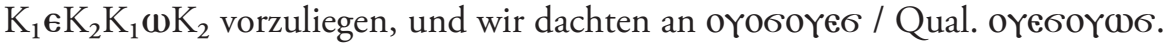
Ein anonymer Referee dieses Artikels schlug die Lesung/Emendation $<2>\varepsilon \times$ [2] $\omega x$ „(sie sind) bedrängt/beengt" vor. Das scheint uns ein guter Vorschlag, zumal die Orthographie вохвєх / Qual. вехвшх (B) für das Verb oүобоүє6 / Qual. oүєбоүшб $(S)$ in einer oberägyptischen, sonst rein sahidischen Inschrift durchaus auffällig wäre. Es erscheint nicht undenkbar, dass Bouriant zwei schlecht erhaltene Hori einmal als Beta und einmal als Epsilon verlesen haben könnte.

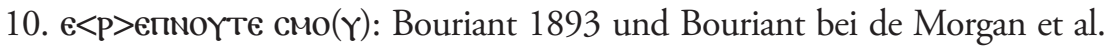
1894 bieten jeweils $х є$ пє пмоүтє смо̄. Mallon 1912 rekonstruierte und übersetzte: 


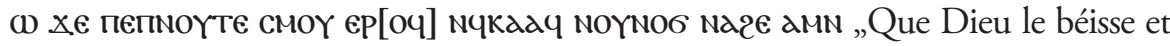
lui donne longue vie! Amen!“. Besser noch wird man hier, wie auch in anderen Bauinschriften (vgl. Wreszinski 1902: 64-65, No II; Mallon 1905; Schaten 1999: No 3; Teil davon Kamel CG 8650, Pl. 50, No 214), in Kolophonen (vgl. die Belege in van Lantschoot 1929: 140 s.v. cmoY) und auch in spätkoptischen Briefen, ein energetisches Futur emendieren. смо̄: Die Handkopie in Bouriant bei de Morgan et al. 1894 lässt erkennen, dass das Wort den Rahmen des Inschriftfeldes touchierte, daher vielleicht hier eine abgekürzte Schreibung смо ( $\gamma$ ) oder auch смо ' $\gamma$ '.

11. єр[oq]: Bouriant 1893 liest $\mathrm{ep///,} \mathrm{Bouriant} \mathrm{bei} \mathrm{de} \mathrm{Morgan} \mathrm{et} \mathrm{al.} 1894$ hat anscheinend epạ, lies aber sicherlich ep[oq], wie schon Mallon 1912.

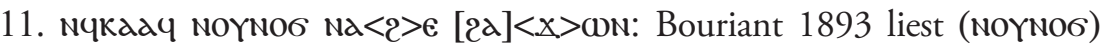

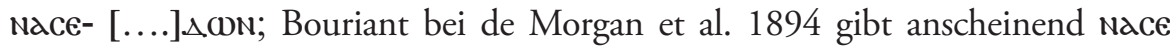
[....]dWN. Mallon 1912 erkannte bereits richtig die Wunschformel für no6 Ną€ „lange Lebenszeit“. Diese Formel findet sich z.B. in van Lantschoot 1929: $\mathrm{n}^{\circ}$ xvi,23; xlii, 8.13; lxxxii, 8; lxxxviii, 14; cxx 2.8. Mallon wollte am Zeilenende ]

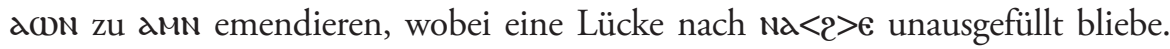
Stattdessen ist vermutlich [2a] XWN zu lesen. Zur gesamten Formel in Z. 10-11 vgl.

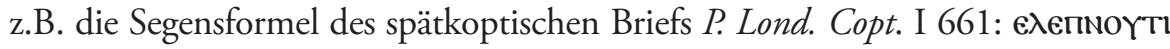

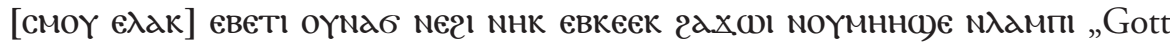
[segne Dich] und gebe Dir eine lange Lebenszeit und erhalte Dich viele Jahre für mich". Diese Formel und ihre Komponenten sind typisch für spätkoptische Texte (Briefe, Kolophone) des 10. und 11. Jh.s. Der Gebrauch von $\kappa \omega$ im Sinne von "erhalten“ (in der Formel Nчкdak, NчKday etc.) scheint eine lexikalische Innovation spätkoptischer Texte zu sein, wie schon Crum 1939: 95, s.v. kw notierte: „preserve in greetings in letters (late)“, vgl. Richter 2008: bes. $752 \mathrm{f}$.

12. рбме Є[.]м[.]l: lies evtl. рФме <мIM>, wie bereits Mallon 1912. Hier beginnt wohl ein Anruf an die Vorbeikommenden, für den Stifter zu beten, wie auch sonst in derartigen koptischen Formularen.

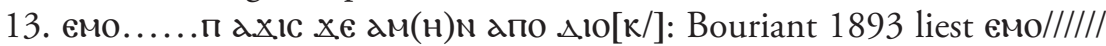
пахıс хе дммапо Аılo///; Bouriant bei de Morgan et al. 1894 zeigt die Fehlstelle hinter $\Delta l 0$ nicht an. Zur Aufforderung an die Passanten: "Sprecht "Amen", die schon Mallon 1912 vorgeschlagen hat, vgl. д Хос хє дмнм єчє()ळп in $I$. Kellia, passim (7. Jh.), z.B. Andreu und Coquin 1981: 178.

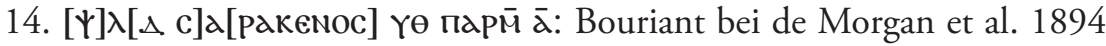

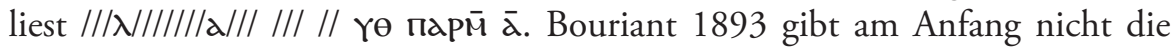
Fehlstelle vor $\lambda$ und am Ende keinen Strich über $\bar{\lambda}$ an. Falls $\gamma \Theta$ wirklich eine Jahreszahl darstellt, was nicht unwahrscheinlich ist, dann nach der Größe der Lücken und der durchschnittlichen Zeichenzahl pro Zeile zu urteilen wohl nicht nach der Ära Diokletians, sondern, wie hier rekonstruiert, nach dem Jahr der 
Hiğra, so dass 409 dem Jahr AD 1018 entspräche. Zum korrelierenden Jahr 734/5 der Ära Diokletians würde die Lesung eines Lambda an zweiter Stelle der Zeile bei Bouriant bei de Morgan et al. 1894 passen, daher die Rekonstruktion $[\gamma] \lambda[\Lambda]$. Zu Doppeldatierungen nach Hiğra- und Diokletiansjahr (wobei das Hiğra-Jahr fast immer dem Jahr nach Diokletian folgt) vgl. Bagnall und Worp 2004: 68-86; van Lantschoot 1929: 114-115; Ochała 2009: 133-160; 2011: 137-164. Der Strich über My in парм̄ könnte ein Indiz dafür sein, das hier Parmhotep (1. des Monats $=25$. Februar), nicht Parmouthe (1. des Monats = 27. März) gemeint ist.

\section{ÜBERSETZUNG}

"Im Namen Gottes! [Durch den] Eifer und die Fürsorge des weithin berühmten Emirs Abū Abū 'l-Asad, er trug Sorge und befestigte die Wege, damit Mensch und Vieh in Ruhe ihres Weges gehen könnten ... da die Wege (zu) eng waren, und die vielen Menschen auf der Durchreise hoben ihre Füße (? - oder: „Augen“), weil sie bedrängt waren. <Möge> Gott ihn segnen und ihn eine große Lebenszeit lang für uns bewahren. $<$ Jeder $>$ man, der zur $[S] \operatorname{tadt}$ [...] ge[hen] wird, [...], spreche: Amen! Seit Diokletian (Jahr) [7]3[4], [(Ära der) S]a[razenen] 409, (Monat) Parm(hotep), (Tag) 1.”

\section{ZuSAMMENFASSUNG}

Die beiden von Bouriant als koptisch-arabische Bilingue publizierten Texte [Vgl. Abb. 1], die an einem Engpass der Uferstraße nördlich von Al-'Aqaba alKabìra angebracht waren, können hypothetisch an einem noch immer uferseitig anstehenden Felsen einige hundert Meter vor dem Ortseingang von Al-Ga fara [Vgl. $A \boldsymbol{b} b .2]$ historisch lokalisiert werden, sie sind aber aller Wahrscheinlichkeit nach für immer verloren. Wie sich zeigt, sind die Texte nicht zwei Teile einer zweisprachigen epigraphischen Referenz auf ein- und dasselbe Ereignis, sondern zwei epigraphische Referenzen auf zwei zeitlich gestaffelte Ereignisse ähnlicher Art - jeweils straßenbauliche Maßnahmen zu Erleichterung der Passage.

Die koptische Inschrift, sicherlich die ältere der beiden, kommemoriert im Formular koptischer Stifterinschriften die Straßenbau-Initiative eines Abū Lazz / Abū 'l- 'Ạṣ / Abū 'l- 'Assād. Ihm werden Gottes Segen und ein langes Leben gewünscht, und die Passanten, im Moment ihrer Passage die unmittelbaren Nutznießer der Bauarbeiten, sind aufgefordert, dazu ihr Amen zu sprechen. Nach Maßgabe des Textformulars und der Phraseologie ist die Inschrift nicht in die Umajjadenzeit, wie Bouriant vermutete, sondern wesentlich später, wahrscheinlich ins 10 . oder 11. Jh., zu datieren. Nach der vorgeschlagenen Rekonstruktion der textinternen Datierung stammt sie vielleicht aus der Regierungszeit des Fatimidenkalifen Al-Hākim. Die 
epigraphische Verwendung der koptischen (sahidischen) Sprache durch eine arabische Autorität im 7. Jh. wäre ein geradezu unerhörtes Szenario (vgl. Richter 2013). Im 11. Jahrhundert, als in der Region von Assuan die sahidische Epigraphik in voller Blüte stand (vgl. Dekker 2006; van der Vliet 2013), ist sie wesentlich plausibler, gleichwohl aber bemerkenswert genug und nach unserem Wissen ohne Parallele.

Die arabische Inschrift kommemoriert in knappen Worten eine StraßenbauMaßnahme ähnlicher Art, die der mamlukische Hofbeamte Boktomor alNadri einige Jahrhunderte später anordnete. Durch den Anbringungsort unter der koptischen Inschrift (,...gravées l'une au-dessus de l'autre...”) ${ }^{15}$ wird diese Maßnahme in eine lokale Tradition von arabischem Beamten-Euergetismus gestellt.

\section{DANKSAgungen}

Wir, der Autor und seine Mitarbeiterin Lena Krastel, danken Ralph Bodenstein, Jitse Dijkstra, Andreas Kaplony, Adam Łajtar, Dietrich Raue, Stephan Seidlmayer, Lennart Sundelin, Naïm Vanthiegem, Cornelius von Pilgrim und zwei anonymen Referees dieses Artikels für wertvolle Hinweise.

\section{Literaturverzeichnis}

Abkürzungen für die Editionen der Papyri nach J.F. Oates et al., Checklist of Greek, Latin, Demotic and Coptic papyri, ostraca and tablets, online verfügbar: http://scriptorium.lib.duke.edu/papyrus/texts/clist.html.

\section{AbKürzungen}

EI

LSJ

The Encyclopaedia of Islam, 2nd ed., Leiden: Brill, 1954-2005

Greek-English Lexicon, zusammengestellt von H. Liddell und R. Scott, überarbeitet und erweitert von H.S. Jones, 9th ed., Oxford: Clarendon, 1925

Andreu, G. und Coquin, R.-G. (1981). Septième campagne de fouilles aux Kellia (avril 1981). Rapport préliminaire. Bulletin de l'Institut français d'archéologie orientale, $81,159-188$

15 Vgl. in Abb. 1 die Darstellung der Inschriften bei Bouriant in de Morgan et al. 1894: 206, die vielleicht einen Eindruck von der Anordnung der beiden zueinander gibt. 
Bagnall, R.S. und Worp, K.A. (2004). Chronological systems of Byzantine Egypt (2. Ed.). Leiden: Brill

Bouriant, U. (1886). Petite inscription historique en dialecte thébain: copiée à Assouan. Recueil de travaux relatifs à la philologie et à l'archéologie égyptiennes et assyriennes pour servir de bullletin à la Mission Française du Caire, 7, 218

Bouriant, U. (1893). Notes de voyage, $\$$ 17: Inscription historique bilingue, copte et arabe. Recueil de travaux relatifs à la philologie et à l'archéologie égyptiennes et assyriennes pour servir de bullletin à la Mission Française du Caire, 15, 176-177

Bruning, J. (2014). The rise of a capital: On the development of al-Fustatt's relationship with its hinterland, 18/639-132/750 (Ph.D. diss.). Leiden University. Abgerufen von https://openaccess.leidenuniv.nl/handle/1887/25008 [accessed: June 2016]

Combe, E., Sauvaget, J., und Wiet, G. (Hrg.). (1931-1964). Répertoire chronologique d'épigraphie arabe I-XVI. Kairo: Institut français d'archéologie orientale

Crum, W.E. (1902). Catalogue général des antiquités égyptiennes du Musée du Caire. Nos. 8001-8741, Coptic monuments. Cairo: Institut français d'archéologie orientale

Crum, W.E. (1939). A Coptic dictionary. Oxford: Clarendon Press

Dekker, R. (2006). Monasticism in the First Cataract Region (unveröffentlichte Magisterarbeit). Universität Leiden

de Morgan, J.J.M., Barsanti, A., Bouriant, U., Jéquier, G., und Legrain, G.A. (1894). Catalogue des monuments et inscriptions de l'Égypte antique. Série 1, Haute Égypte I. De la frontière de la Nubie à Kom Ombos. Wien: Holzhausen

Edel, E. (2008). Die Felsgräbernekropole der Qubbet el-Hawa bei Assuan: I. Abteilung. (K.-J. Seyfried und G. Vieler, Hrg.). Parderborn: F. Schöningh

Feissel, D. (2006). Chroniques d'épigraphie byzantine: 1987-2004. Paris: Association des amis du Centre d'histoire et civilisation de Byzance

Förster, H. (2002). Wörterbuch der griechischen Wörter in den koptischen dokumentarischen Texten [=Texte und Untersuchungen zur Geschichte der altchristlichen Literatur 148]. Berlin-New York: W. De Gruyter

Griffith, F.L. und Crowfoot, G.M. (1934). On the early use of cotton in the Nile Valley. Journal of Egyptian Archaeology, 20(1/2), 5-12

Kamel, I. (1987). Catalogue général des antiquités du Musée copte, nos. 1-253: Coptic funerary stelae. Kairo: Organisation égyptienne générale du livre

Kervran, M., Ory, S., und Schneider, M. (1975). Index géographique du Répertoire chronologique d'épigraphie arabe (tomes I à XVI) [=Bibliothèque d'étude 68]. Kairo: Institut français d'archéologie orientale du Caire

Kosack, W. (1974). Lehrbuch des Koptischen. Graz: Akademische Druck- und Verlagsanstalt

Kriara, E. (1997). Lexiko tēs mesaiōnikès Hellēnikès dèmōdus grammateias, 1100-1669, XIV. Thessaloniki: Royal Hellenic Research Foundation

Mallon, A. (1905). Nouvelle inscription copte de Philae. Annales du Service des antiquités de l'Égypte, 6, 107-111 
Mallon, A. (1912). Coptica III. Inscription historique. Mélanges de la Faculté orientale, 5(2), $132-134$

Mallon, A. (1914). Copte (épigraphie). In F. Cabrol und H. Leclercq, Dictionnaire d'archeologie chrétienne et de liturgie III.2 (cols 2819-2886). Paris: Letouzey et Ané

Metzger, C. (2012). La mosaïque de Qabr Hiram [=Collection Solo 52]. Paris: Somogy; Louvre

Monneret de Villard, U. (1927). Il monastero di S. Simeone presso Aswân I. Descrizione archeologica. Milan: Tipografia e libreria pontificia arcivescovile S. Giuseppe

Ochała, G. (2009). The era of the Saracens in non-Arabic texts from Nubia. Journal of Juristic Papyrology, 39, 133-160

Ochała, G. (2011). Chronological systems of Christian Nubia [=Journal of Juristic Papyrology Supplement 16]. Warschau: Raphael Taubenschlag Foundation

Richter, S.G. (2002). Studien zur Christianisierung Nubiens [=Sprachen und Kulturen des christlichen Orients 11]. Wiesbaden: Reichert

Richter, T.S. (2001). Arabische Lehnworte und Formeln in koptischen Rechtsurkunden. Journal of Juristic Papyrology, 31, 75-89

Richter, T.S. (2008). Coptic letters. In E.M. Grob und A. Kaplony (Hrg.), Documentary letters from the Middle East: The evidence in Greek, Coptic, South Arabian, Pehlevi, and Arabic (1st-15th c. CE) [=Asiatische Studien 62/3] (S. 739-770). Bern-New York: Peter Lang

Richter, T.S. (2013). "An unseren Herrn, den allberühmten Korra, den herrlichsten Gouverneur, durch Dich, glorreichster Herr Basilios, Pagarch von Djkow mit seinen Gehöften». Verwaltung und Verwaltungssprachen Ägyptens im 8. Jh. nach den QurraPapyri. In F. Feder (Hrg.), Ägypten und sein Umfeld in der Umfeld in der Spätantike: vom Regierungsantritt Diokletians 284/285 bis zur arabischen Eroberung des Vorderen Orients um 635-646. Akten der Tagung vom 7.-9.7.2011 in Münster [=Philippika 61] (S. 121138). Wiesbaden: Harrassowitz

Schaten, S. (1999). Griechische und koptische Bauinschriften. In S. Emmel, M. Krause, S.G. Richter, und S. Schaten (Hrg.), Ägypten und Nubien in spätantiker und christlicher Zeit: Akten des 6. Internationalen Koptologenkongresses, Münster, 20.-26. Juli 1996, I. Materielle Kultur, Kunst und religiöses Leben [=Sprachen und Kulturen des christlichen Orients 6] (S. 305-314). Wiesbaden: Reichert Verlag

van der Vliet, J. (2013). Contested frontiers: Southern Egypt and Northern Nubia, AD 300 1500. The evidence of the inscriptions. In G. Gabra und H.N. Takla (Hrg.), Christianity and monasticism in Aswan and Nubia (S. 63-78). Kairo: American University in Cairo Press

van Lantschoot, A. (1929). Recueil des colophons des manuscrits chrétiens d'Égypte [=Bibliothèque du Muséon 1]. Leuven: J.-B. Istas

Westendorf, W. (1965). Koptisches Handwörterbuch. Heidelberg: C. Winter Universitätsverlag Wreszinski, W. (1902). Zwei koptische Bauurkunden. Zeitschrift für Ägyptische Sprache und Altertumskunde, 40(1), 62-65 


\title{
"Alone in Naqlun": A fresh look at the Bohairic letter P. Lond. Copt. I 590 (2) (British Library Or. 4720 [31], vo)
}

\author{
Jacques van der Vliet \\ Leiden University \\ j.van.der.Vliet@hum.leidenuniv.nl
}

KeYwords

Bohairic, Coptic monasticism, Naqlun, Kellia

\section{Abstract}

A re-edition of the Bohairic Coptic letter British Library Or. 4720 [31], vo (=P. Lond. Copt. I 590 (2), 11th century) with particular attention to its interest for contemporaneous Coptic monasticism in Naqlun and Kellia. The addressee of the letter is a certain deacon Makari from Nekloni, who is asked to join a party of people engaged in building activity in Talmouna in the north, bringing with him blankets and wine.

The document presented here as a tribute to the indefatigable leader of the Polish archaeological mission in Naqlun is neither brought to light by that mission nor totally new and unknown. In fact, it has been known for over a hundred years and is invariably quoted whenever the history of monasticism at Naqlun is discussed. It was Włodek Godlewski himself who challenged me many years ago, during a postprandial discussion in Naqlun, to have a new look at the document, which was only partly published by Walter E. Crum in 1905. The task, however, proved more daunting than foreseen. Many of the problems left unsolved by Crum I have likewise been unable to solve. It is with considerable misgivings, therefore, that I present here my far from final reedition of the text as a token of great respect and infinite gratitude to Włodek, to whom I owe much more than this meager tribute can express. 
British Library Or. 4720 (31) is a fragmentary sheet of paper framed under one glass together with eight other Coptic documents on paper or papyrus, all bearing the number 4720 [Fig. 1]. All of these documents were acquired in the late 19th century from the famous collector and dealer Theodor Graf (1840-1903). Considerable parts of the latter's papyrus collections hail from the

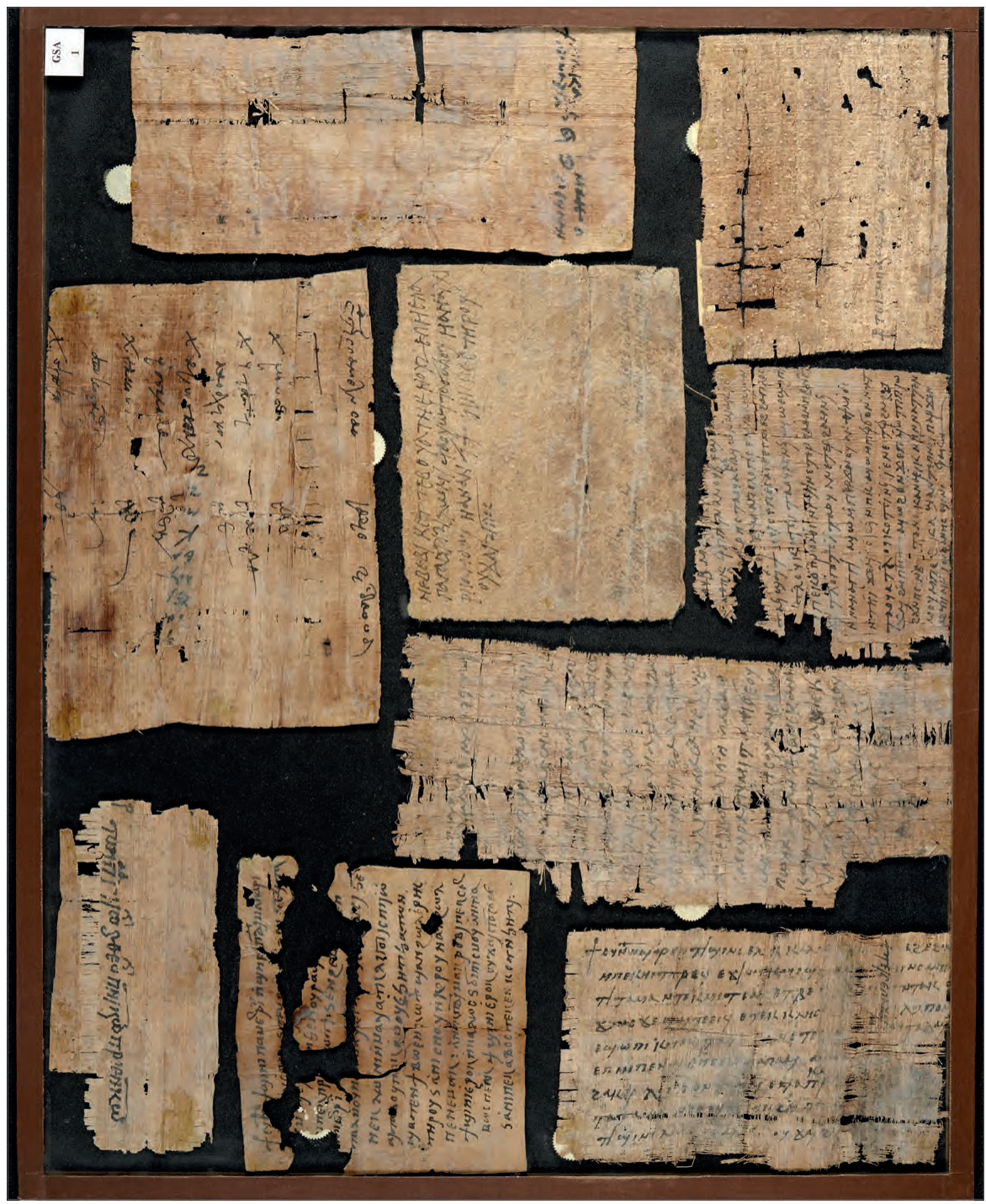

Fig. 1. British Library Or. 4720 (31), verso (@ British Library Board) 
Fayum. Internal criteria, for which see below, suggest that Or. 4720 (31) was discovered specifically at Naqlun.

In its present disjointed condition, Or. 4720 (31) appears to measure $12 \mathrm{~cm}$ by $13 \mathrm{~cm}$. It consists of four fragments (not three, pace Crum). The top fragment, preserving the upper margin of the letter on Crum's side 2, connects with the two smaller fragments below in 1.2 of the text. Both smaller fragments should be moved a bit to the right and plausibly connect with 1.5 of the fourth and largest fragment on the basis of their contents. In this view, all fragments join and the sheet is more or less complete, with a reconstructed height of roughly $11 \mathrm{~cm}$. Note that the line numbers below differ by one from the numbering in Crum's editio princeps, which renders only the largest fragment.

The sheet is inscribed on each side with the remains of a different Coptic text. Both texts are letters. Crum's side 2 is the later of the two letters, written on the verso of a trimmed earlier letter (Crum's side 1). The letter on side 2 is written in Bohairic, the one on side 1 in Fayumi-Sahidic. The hand of side 2 is neat and practiced, writing a sloping uncial of a late type without ligatures; the hand of side 1 is also a late sloping uncial, but much bigger, badly ruled and extremely rough and clumsy. Both hands are clearly contemporaneous and suggest a date in the 11th century. Here only the more or less complete letter of side 2 is reedited after photos provided by the British Library; a satisfactory edition of the earlier letter of Crum's side 1 would demand autoptic study and — quite likely - restoration of the original document.

Side 2 of the letter bears the remains of 13 lines of Bohairic text, of which lines 2-5 are very lacunose. The purport of the letter is further obscured by several lexical problems, which are discussed below. The scribe writes a fairly standard Bohairic. He occasionally uses colons to separate clauses, as well as various conventional abbreviations; the abbreviations in the end of lines 5, 10 and 12 and for the $n y$ in menpIT (1. 1 and 4) are made by an upward swirl, while a slip in 1.12 is corrected in the same manner. Instead of the clause linker oro?, "and", an ampersand ( $\varsigma$ ) is used consistently (1. 2, 4, 9, 11 and 13). Syllabic vowels and consonants are marked by superlinear dots in a fairly regular way. In the last word of 1. 6, the diaeresis over the second iota was shifted to the following omega. The sheet was folded once in its length and several times across its width.

Editio princeps: Crum in P. Lond. Copt. I 590 (2), who offers a partial edition, of 1.4 end-13 only (his $11.3-12$ ). The secondary literature is entirely dependent on Crum's edition and will be mentioned, as far as relevant, in the commentary below. 
British Library Or. 4720 (31), verso

Kellia, 11 th century

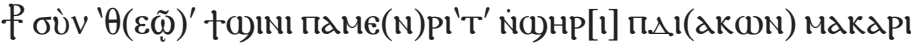

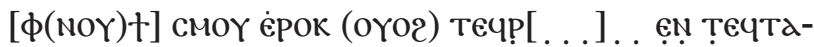

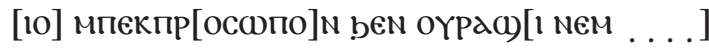

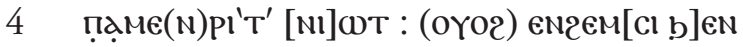

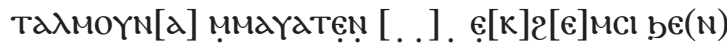

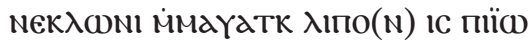

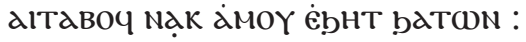

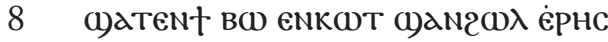

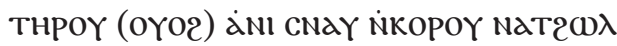

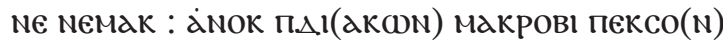

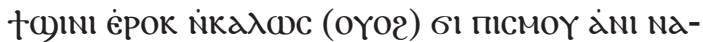

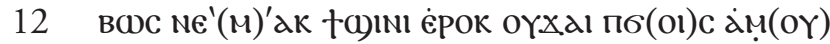

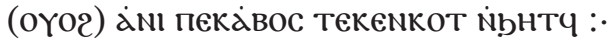

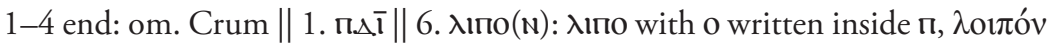
|| 7. alтавоч: read alтаүоч | bатоn: for bаbтеn? Crum; read bатотем ||

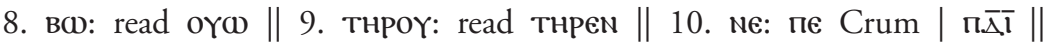

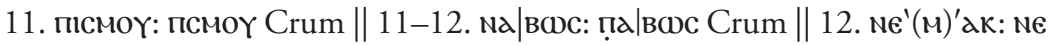

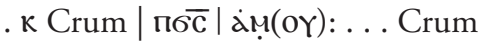

+ With God. I greet my beloved son, the deacon Makari. May God bless you and may he [...] us (?) and may he adorn your countenance with joy together with [N.N.], my beloved father. Furthermore, while we are sitting alone in Talmouna [...] you are sitting alone in Nekloni. Well then, look, I sent you the donkey. Come to the north to join us until we finish building (and) shall all return to the south. Moreover, bring two korou that are without fault(?) with you. I, the deacon Makrobi, your brother, greet you warmly. And please, bring the abos (plur.) with you! I greet you. Farewell (in) the Lord. Come and bring your abos (sing.), that you sleep in it.

1. The same playful writing of MenpiT, with a swirl to render the $\mathrm{N}$ and a raised $T$, appears in 1.4 .

2. Part of the stroke over the abbreviation $\overline{\phi \dagger}$ is still visible.

3. проссипо seems a bit too long for the lacuna and the reconstruction of the entire phrase is tentative only. The same holds for the second part of the line, where I postulate a proper name (presumably that of the superior of the correspondents) in the lacuna, to which the partly reconstructed noun phrase 
пุame(N)Pi'T' [NI] WT (in 1.4) would be in apposition. For similar wishes, echoing biblical language, in a contemporaneous letter found at Naqlun, see P. Worp 64.

4. After [NI] WT no iota is to be read; instead, we have a $\mathrm{T}$ with a strong dropping bar plus a colon.

4-6. The essential structure of the two balancing clauses is clear, even though a short word (a conjunction?) that perhaps linked them is lost in the lacuna.

5. The reconstruction of the beginning of the line is next to certain: MMaYaT = can only agree with the first person plural of 1.4 ; assuming that it is spelt correctly with a double $m y$ as in 1. 6, it leaves space for one letter only in the preceding lacuna and this must be an alpha owing to the gender of the Copticized Arabic word beginning in Taג-.

7. bגт0N for bגтотеN can perhaps be explained by analogy with bax心= (or similar).

8. The sentence illustrates the "sequeling" role of the habitual (c)an2 $0 \lambda$ ), which has a future interpretation here; see Shisha-Halevy 2007: 211-214, and already Stern 1880: 218.

9. A короY is a measure for wine, presumably a late spelling of кой

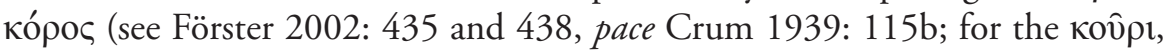
see Kruit and Worp 1999: 110-111); it is found as kapoY in a contemporaneous letter from Naqlun; see Urbaniak-Walczak 1999: 123-124 (on No. 8, 1. 9, with further references). The negative adjective aт20 $\lambda$ must qualify either the measure or, more likely, the wine containing it, but defies interpretation; Crum (1939: $666 \mathrm{~b})$, mentions our passage, with due hesitation, under $2 \omega \lambda$, "to be hoarse, to hawk", which is only used with reference to the voice or the throat, however. In his earlier edition, Crum (incorrectly) read $a \mathrm{~T} 2 \omega \lambda \mid \pi \epsilon$, which would be even more problematic. The translation proposed here is one possible suggestion.

11. For the expression 61 пісмоү, see Crum 1939: 336a-b (quoting the present letter).

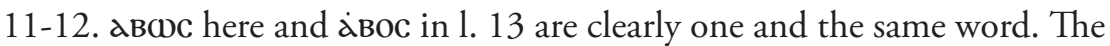
analogy of both passages and the spelling in 1.13 (with $\dot{\alpha}-$ ) formally exclude a reading кавос in 1.13 (pace Crum; Förster 2002: 1, s.v.). The origin of the word is unknown, as is its meaning; the context suggests a kind of blanket. A Bohairic spelling for 2BWC / 2BOc, "covering, garment", although perhaps

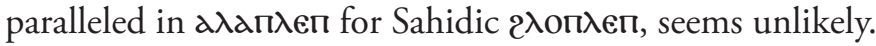

12. The $m y$ in $\mathrm{NE}^{\prime}(\mathrm{M})^{\prime} \mathrm{\lambda} \mathrm{\alpha}$ was forgotten and filled in later by a swirl; the alpha is blotted. At the end of the line, the group $\dot{\alpha} \mathbf{M}(\mathrm{o \gamma})$ is barely visible beyond the alpha; yet it does not seem to have been deliberately erased (pace Crum).

The general purport of this letter to a deacon Makari is straightforward enough. Makari is asked to join a party of people who are engaged in building 
activity in the north, in Talmouna, and return together with them to the south, once their job is finished. A donkey is sent for his journey and he is asked to take blankets(?) and two jars of wine(?) with him when coming north. He is apparently staying in Naqlun (Nekloni) and that is - as may be assumed where the party will return after having accomplished their mission. The letter must have accompanied the donkey and its driver from Talmouna in the north, where the author of the letter and his company are staying, to Nekloni in the south. The writer of the letter is most likely the deacon Makrobi, who identifies himself only in 1. 10, however. ${ }^{1}$ The language of fatherhood (1l. 3-4), sonship (1. 1) and brotherhood (1. 10) makes it sufficiently clear that the correspondents are monks. Both Makrobi and Makari are deacons, which is by far the most common clerical title found in contemporaneous documents concerning the monastery of Naqlun. ${ }^{2}$

The document offers a relatively rare example of a letter in Bohairic, suggesting that the place "in the north" where it was written, undoubtedly by a local scribe, pertained to a region where Bohairic was the predominant form of written Coptic. ${ }^{3}$ This is confirmed by the toponym in 1. 5, Talmouna, which is the Arabic name al-Muna, Copticized by the addition of the Coptic feminine article. Al-Muna, which in turn hides the Greek word, "monastery", is the medieval name for the region that was known in late antiquity as Kellia ("The cells", in Coptic Nipl). ${ }^{4}$ In recent decades, Swiss and French excavations in the region discovered huge amounts of Bohairic inscriptions and also ostraca, showing that Bohairic was indeed its main written language (in addition to Greek). ${ }^{5}$ In spite of more pessimistic estimates, it is clear - both from the

$1 \quad$ For this reason Crum suggested that Makrobi was perhaps only adding a postscript to a letter authored by a third person, which cannot be formally ruled out. Yet no other sender is mentioned and the letter bears no formal address, identifying this first author. Of course, the latter, anonymous in the written text, could have been named orally by the carrier. In support of his suggestion, Crum notes that the ego addresses Makari as "my son" in 1. 1, assuming a paternal role, whereas Makrobi in 1.10 calls himself Makari's "brother". None of these arguments are conclusive.

2 See, e.g., Urbaniak-Walczak 1999: 103. The same in the 11th-century inscriptions from the church and the Naqlun account book in the British Library (for which see van der Vliet 2015).

3 This was already assumed by Abbott 1937: 47, who supposed on the basis of Crum's incomplete editio that the letter could have been written from Nitria (meaning Sketis).

4 For al-Muna / Kellia, see Evelyn-White 1932: 25-27; De Cosson 1937; Coquin 1975: 54, 98-99; Timm 1988: 1691-1712. The Naqlun account book British Library Or. 13885 (see above, note 2) thrice mentions a toponym (?) талмоүмid (f. 20ro, 1. 10; f. 23ro, 1. 8; f. 28vo, 1. 6); given the very local scope of the account book, there is no reason to assume that the same place is meant.

5 For the latest publication in a long series, see Weidmann 2013. Nathalie Bosson, Geneva, is preparing a comprehensive edition of the Kellia inscriptions. 
geographical handbook of the Muslim author al-Bakri (died 1094) and the present letter - that monastic life continued there till well in the 11 th century. ${ }^{6}$

The London letter interestingly shows that at the time lively contacts were maintained between both monastic centers, Kellia, in the north, and Naqlun, far to its south. Beyond epistolary contacts, groups of monks were moving around to take part in building activities. The earlier letter on the reverse of Makrobi's letter, actually the recto of the sheet (Crum's side 1), fits in with this picture. It is written not in Bohairic, but in Fayumi-Sahidic, the standard idiom of 10th11th-century Coptic documents from Naqlun. It mentions several deacons and a "father", again suggesting a monastic context. Although its mutilated state forbids us to be categorical, it can be surmised - on the basis of its language and onomastics ${ }^{7}$ - that, first, the letter of side 1 was sent from the Fayum, plausibly Naqlun itself, to the north (Kellia); then, in reply, the letter of side 2 was sent from Kellia to Naqlun, re-using the same sheet of paper, trimmed to size for the purpose. One of the monks mentioned in the earlier letter is a "Lord (KHPı, Kúpıоc) deacon Makari" (1. 4). Even though Makari was a very common name, one wonders whether this could not be the same Makari who was the addressee of the later letter on the verso, a monk living at Naqlun. If this hypothesis is correct, not only the letter of side 2, but both letters can be added to the ever growing dossier of late Coptic documents emanating from Naqlun. ${ }^{8}$

By the same token, it can be categorically ruled out that the phrase "you (i.e., Makari) are sitting alone in Nekloni" (1l. 5-6) should be taken to mean that Makari was the only monk surviving at the time in Naqlun. He was a member of a group of monks, perhaps the inhabitants of a single house or hermitage or more likely, a team specializing in building operations, missed by his comrades who by the present letter invited him to come and join them and travel back together to rejoin their community, in all likelihood, in Naqlun. ${ }^{9}$ Even if details in this picture may be unverifiable, the letter cannot be taken as an indication that the monastery in Naqlun had been deserted by the 11th century, as stated

6 For al-Bakri on al-Muna / Kellia, see in particular De Cosson 1937, whose findings were confirmed by the later French and Swiss excavations.

7 The name Pantoules or Pantoulesnios (thus Crum) in 1.3 was particularly common in the Fayum; see Boud'hors and Calament 2004: 457.

$8 \quad$ This can be assumed a priori for the letter on side 2: whether or not Makari went to join his brethren in the north, he most likely left the letter at Naqlun. As I argued earlier, this makes it likely that more material acquired by Theodor Graf from Fayum sources actually comes from Naqlun; see van der Vliet 2000: 239-240; 2013: 205.

9 This possibility is already envisaged by Godlewski, Herbich, and Wipszycka 1990: 173, followed by T. Derda, in P. Naqlun I, p. 22. 
in secondary literature. ${ }^{10}$ To the contrary, the combined evidence of both letters of the London paper sheet suggests a vigorous community that extended its activity far to the north. Also local discoveries, such as the beautifully rebuilt church of the same period with its many wall paintings and inscriptions, create a picture of wealth and vigorous development.

The letter presented above has been used in part of the scholarly literature for far-reaching conclusions about the state of Naqlun circa the 11th century, conclusions that are unwarranted by a closer study of the document. Instead, the letter confirms the picture of growth and development that arises from the findings of the mission led by the dedicatee of these lines, to whose vision and energy the study of Egyptian monasticism owes so much.

\section{References}

The abbreviated references to documentary sources follow J.F. Oates et al., Checklist of Greek, Latin, Demotic and Coptic papyri, ostraca and tablets, available online at http://scriptorium.lib.duke.edu/papyrus/texts/clist.html.

Abbott, N. (1937). The monasteries of the Fayyum [=Studies in Ancient Oriental Civilization 16]. Chicago: University of Chicago Press

Boud'hors, A. and Calament, F. (2004). Un ensemble de stèles fayoumiques inédites : à propos de la stèle funéraire de Pantoleos de Toutôn. In M. Immerzeel and J. van der Vliet (eds), Coptic studies on the threshold of a new millennium: Proceedings of the Seventh International Congress of Coptic Studies, Leiden, August 27-September 2, 2000, I [=Orientalia Lovaniensia Analecta 133] (pp. 447-476). Leuven: Peeters

Coquin, R.G. (ed.). (1975). Livre de la consécration du sanctuaire de Benjamin [=Bibliothèque d'études coptes 3]. Cairo: Institut français d'archéologie orientale

Crum, W.E. (1939). A Coptic dictionary. Oxford: Clarendon Press

De Cosson, A. (1937). The desert city of El Mûna. Bulletin de la Société archéologique d'Alexandrie, 31(9/2), 247-253

Evelyn-White, H.G. (1932). The monasteries of the Wadi 'n Natrûn II. New York: Arno Press

Förster, H. (2002). Wörterbuch der griechischen Wörter in den koptischen dokumentarischen Texten [=Texte und Untersuchungen zur Geschichte der altchristlichen Literatur 148]. Berlin-New York: W. De Gruyter

10 Thus Abbott 1937: 47: "The place is deserted except for Macrobius (sic, Makari must be meant)". Otto Meinardus (1991) turned this into the confident statement that "in the middle of the tenth century only one monk inhabited the Monastery of Saint Gabriel”. 
Godlewski, W., Herbich, T., and Wipszycka, E. (1990). Deir el Naqlun (Nekloni) 198687: First preliminary report with Appendix from 1988 by Jarosław Dobrowolski. Nubica, 1-2, 171-207

Kruit, N. and Worp, K.A. (1999). Metrological notes on measures and containers of liquids in Graeco-Roman and Byzantine Egypt. Archiv für Papyrusforschung und Verwandte Gebiete, 45(1), 96-127

Meinardus, O. (1991). Dayr Al-Naqlun. In A.S. Atiya (ed.), The Coptic encyclopedia III (pp. 845-847). New York: Macmillan

Shisha-Halevy, A. (2007). Topics in Coptic syntax: Structural studies in the Bohairic dialect [=Orientalia Lovaniensia Analecta 160]. Dudley, MA: Peeters

Stern, L.C. (1880). Koptische Grammatik. Leipzig: Weigel

Timm, S. (1988). Das christlich-koptische Ägypten in arabischer Zeit IV [=Tübinger Atlas des Vorderen Orients 41/4]. Wiesbaden: Reichert

Urbaniak-Walczak, K. (1999). Deir el-Naqlun: die koptischen Texte aus der Ermitage Nr. 25. Journal of Juristic Papyrology, 29, 93-136

van der Vliet, J. (2000). A Naqlûn monk brought home: On the provenance of Louvre inv. E 26798-26799. Bulletin de la Société d'archéologie copte, 39, 239-244

van der Vliet, J. (2013). Coptic documentary papyri after the Arab conquest. Journal of Juristic Papyrology, 43, 187-208

van der Vliet, J. (2015). Nekloni (al-Naqlūn) and the Coptic account book British Library Or. 13885. In A. Kaplony, D. Potthast, and C. Römer (eds), From Bāwìt to Marw: Documents from the medieval Muslim world [=Islamic History and Civilization 112] (pp. 155-169). Leiden-Boston: Brill

Weidmann, D. (2013). Kellia: Kôm Qouçoûr 'T̂sâ 1. Fouilles de 1965 à 1978 [=Recherches suisses d'archéologie copte 4]. Leuven: Peeters 



\title{
"...that the mountain of the holy wilderness may be inhabited...": Saint John the Baptist in Infancy scenes in the narthex of the Quarry Church of Dayr Abū Hinnis
}

\author{
Gertrud J.M. van Loon \\ KU Leuven, Near Eastern Studies \\ Gertrud.vanLoon@arts.kuleuven.be
}

\section{KeYwords}

Dayr Abū Hinnis, John the Baptist, wall painting, Infancy scenes, monasticism

\section{Abstract}

The iconographical program of wall paintings in the Quarry Church of Saint John the Baptist in Dayr Abū Hinnis focuses on its patron saint. A frieze of Infancy scenes in the narthex of the church, seemingly centering on the early life of Christ, was thought to be an exception. In this paper, I argue that the unusual beginning of the frieze (Massacre of the Innocents) shows that the guiding element of this series of paintings is the Infancy of Saint John the Baptist. Thus, this frieze, in which generally known images were combined in an original and creative way, fits perfectly in the carefully designed overall iconographical program honoring the titular saint of the church, the model par excellence of monastic life.

To the east of the village of Dayr Abū Hinnis (4-5 kilometers south of Antinoupolis, a city founded by the Emperor Hadrian around AD 130-132²), the hills harbor a large group of pharaonic limestone quarries mainly from the

$\overline{1}$ Citation from the Vita of St. John, attributed to Serapion of Tmuis (Mingana 1927: 241). A study on Saint John the Baptist, the inspirational model of monastic life seems to me a fitting tribute to Włodek Godlewski’s lifelong research on monastic settlements. When I first began research on the wall paintings and the iconographical program in the Quarry Church of Dayr Abū Hinnis, I had the chance to discuss this interesting ensemble with Włodek. His insightful remarks and questions showed me new angles of research and have helped me to shape my ideas.

2 http://antinoupolis.net/bibliography/ (accessed: 7.06.2016). 
New Kingdom [Fig. 1]. From the 4th century these quarries were reused by monks and hermits. They transformed the deserted quarry area into laurae: semi-organized communities, which settled around a core of structures with a communal function (Delattre 2013; van Loon in van Loon and Delattre 2014; van Loon and De Laet 2014). The southwestern part of one of the largest quarries in this region (DAH 012) was used as a church with a baptistery [Fig. 2]. It was extensively decorated with wall paintings, and the inscriptions and dipinti show that it was dedicated to Saint John the Baptist. ${ }^{3}$

As the titular saint of the church, John the Baptist plays an important role in the iconographical program. Scenes from the first chapter of the Gospel of Luke are depicted in the baptistery, on the eastern rock face: the annunciation of John's birth to his father the High Priest Zacharias, Zacharias coming out of the temple and robbed of speech, the meeting between Zacharias and his wife Elisabeth, followed by the annunciation to the Virgin. There is space for one more scene but this has entirely disappeared [Fig. 2:B.1]. To the left of the baptismal

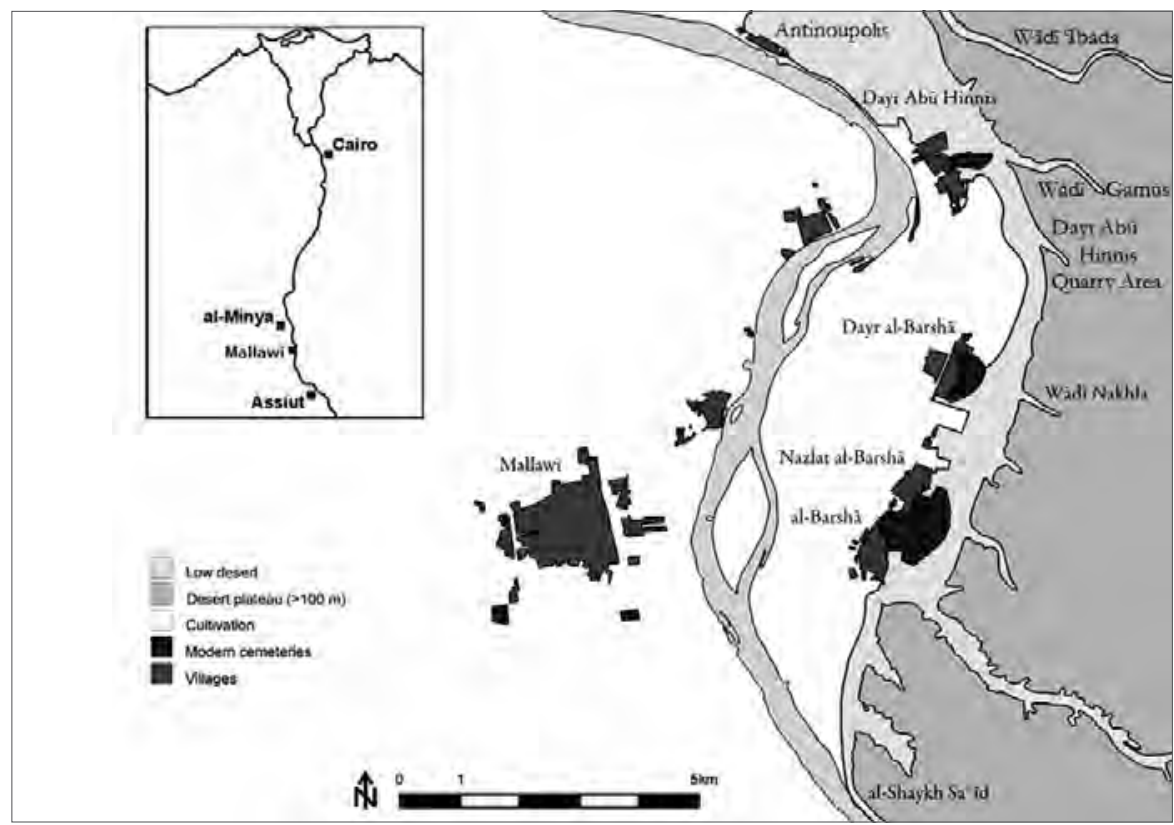

Fig. 1. Middle Egypt, Dayr Abü Hinnis in the Greater Dayr al-Barshä Region (Dayr al-Barshä Project KULeuven, courtesy C. Peeters [with adaptations])

3 Alain Delattre (Université Libre, Brussels) is studying the inscriptions. 
"...that the mountain of the holy wilderness may be inhabited..."

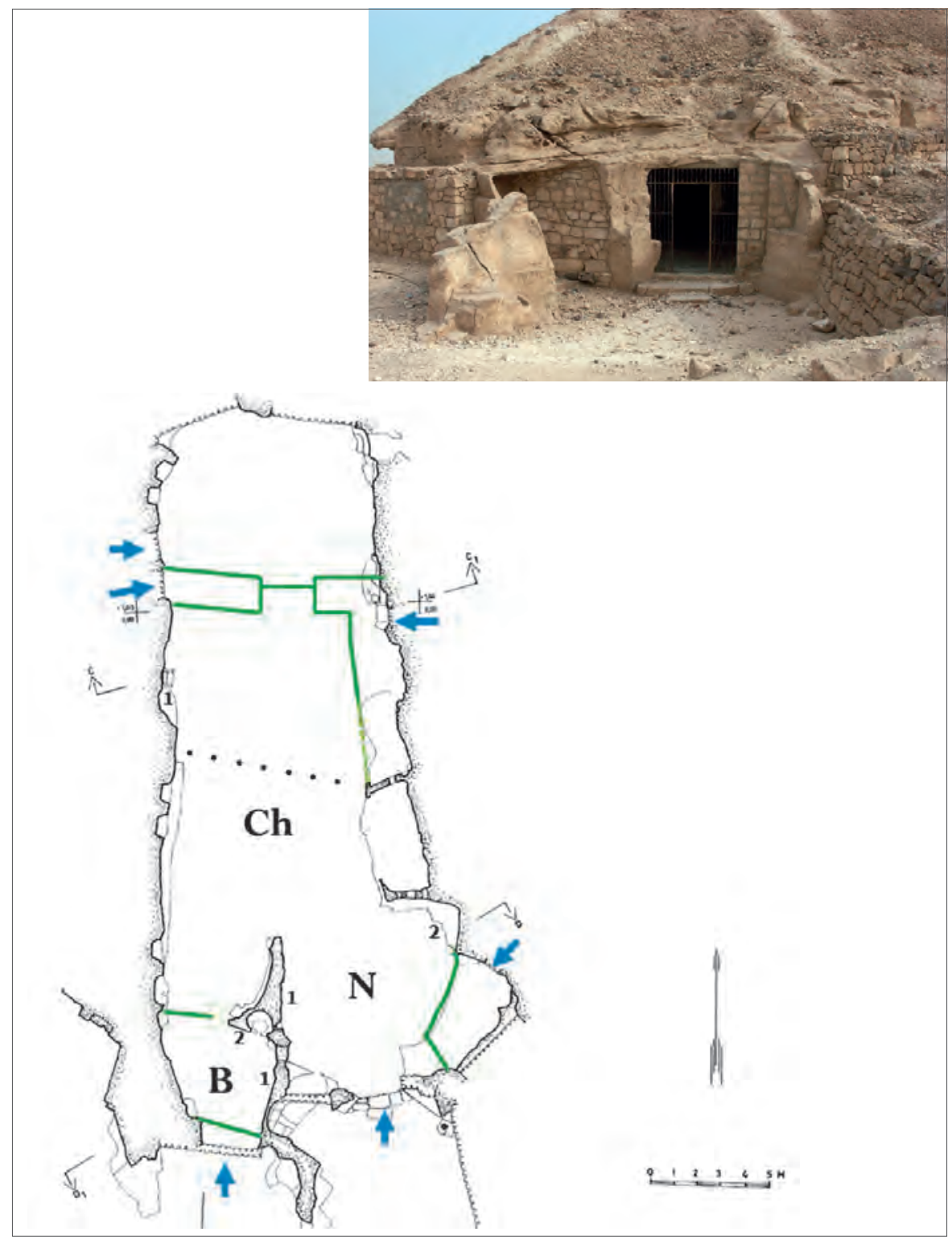

Fig. 2. Plan of the church area in Quarry DAH 012. Blue arrows point to original entrances; green lines indicate wall traces on the ceiling. Small holes in the ceiling of the church (Ch), following the black dotted line, indicate the installation of a wooden screen. $N=$ narthex, $B=$ baptistery; inset, the southern entrance of the quarry church; at the far left, the walled up entrance to the baptistery. All built walls are modern (Plan S. Darmark, the Finnish Egyptological Society; photo G.J.M. van Loon, 2004) 
font is a medallion with John as a small child accompanied by Elisabeth, his mother [Fig. 2:B.2]. In the church, on the western rock face, John, dressed in the traditional garb of a hermit, a belted tunic and a hairy cloak, is holding a scroll with the text "Behold the Lamb of God..." (John 1:29). He is standing on Christ's right, while Zacharias is depicted on Christ's left side [Fig. 2:Ch.1].

The western rock face of the narthex shows the hermit John, in orans position, in the center of a row of saints. The cortège is composed of monks, Desert Fathers and medical saints [Fig. 2:N.1]. The northern and eastern rock faces of the narthex are decorated with a narrative frieze depicting what are known as Infancy scenes: The Massacre of the Innocents, the Flight of Elisabeth, the Murder of Zacharias, the Second Dream of Joseph, and the Flight into Egypt. There was space for probably four more scenes but the wall, which once was an extension of the rock face, has completely disappeared [Fig. 2:N.2].

The paintings were all executed using an al-secco technique on a layer of lime plaster which covers all rock faces and the ceiling of the entire church, baptistery, and narthex. The murals represent the last phase of decoration and cover two earlier layers bearing inscriptions and paint fragments. They have been dated to the 6th-8th centuries. Our recent research tends towards the first half of this period (Zibawi 2003: 58-66; van Loon and Delattre 2004; 2005; 2006; 2014; forthcoming; van Loon 2011). ${ }^{4}$

Whereas John clearly played a central role in the paintings in the church, in the baptistery and in the cortège of saints in the narthex, the narrative frieze of Infancy scenes in the narthex gives the impression of focusing on the Infancy of Christ. If this is indeed the case, it seems to be out of order in the iconographical program. Moreover, the first scene, the Massacre of the Innocents, is an unusual beginning of an Infancy of Christ. In this paper, I shall explore the meaning of the cycle and its place in the overall iconographical program, taking the function of the space into account.

\section{The narthex in the church complex}

The church occupies the southwestern corner of Quarry DAH 012 [Fig. 2]. Because of the physical limits of its situation, it is oriented to the north. In total,

4 Some authors (for example, Thierry 1998: 15) prefer a later date for the cycle of Saint John the Baptist in the baptistery, owing to the static rendering of the figures in contrast to the much livelier Infancy cycle in the narthex. No justification for this later date has been found so far. 
the present church area is approximately $28.50 \mathrm{~m}$ long and $9-13 \mathrm{~m}$ wide. The southern part is divided into two rooms, separated by a rock wall. Each of these two rooms once had its own entrance from the south. The western room housed a baptistery (B). The eastern room, whose east wall has partly disappeared, served as a narthex $(\mathrm{N})$. It has a continuous low bench along the east wall and partly along the north wall. The nave, with two large niches or compartments in the eastern rock face, and the sanctuary occupied the northern part $(\mathrm{Ch})$. Plaster layers and traces of (former) walls on the ceiling show that the church did not take up the complete depth of the area which is now partitioned off. ${ }^{5}$ Most probably, it ran as far as the double entrance in the western rock face. This idea is supported by the inscriptions, dipinti and graffiti written and scratched onto the rock faces: these are few and far between to the north of the double entrance, while more than one hundred texts have been recorded in the church, the narthex, and the baptistery (Delattre 2003; Delattre in van Loon and Delattre 2006; Delattre in van Loon and Delattre 2014; Delattre in van Loon and Delattre forthcoming). The wall paintings are also restricted to these particular spaces.

The narthex is about $7.70 \mathrm{~m}$ by $7 \mathrm{~m}$. The northern rock face is approximately $3 \mathrm{~m}$ long; the eastern rock face has a length of about $2 \mathrm{~m}$, prolonged to the south by a built wall about $4 \mathrm{~m}$ long. Traces of this wall are visible on the ceiling [Figs 3, 9]. Three windows in the northern rock face, a square one (with a ledge for a wooden window frame) between two small round ones, communicate with the southern compartment in the eastern rock face of the church [Figs 3, 7]. The two compartments, which are connected, probably served as the cell of a recluse, as is indicated by a painted inscription mentioning a monk Mena who lodged there for a certain time (van Loon and Delattre 2014: 251 and 258, Figs 5 and 10). The southern entrance of the narthex is divided into two parts by a large rock pillar. The western part of this entrance is now closed by a modern wall, while an iron gate about $2.15 \mathrm{~m}$ wide was set in the eastern part [Fig. 2 inset]. This was probably the original entrance: on the outside, the rock face has cut-outs for a door frame.

The space referred to as a narthex is hardly a classical form in the architectural sense: it is not an anteroom or entrance hall spanning the entire width of the church. In fact, a narthex is not a compulsory element in Egyptian church

5 Around 1950, all entrances to the southwestern part of the quarry were walled up (leaving space for a gate in the narthex) in order to protect the paintings. Inspector Ashraf Rashad Youssif Daker obtained this information in the archives of the SCA office in Mallawi (2008). Newly built walls can be seen in the photographs of Jean Doresse (1951) (Doresse 2000/II.2: Figs 63', 63" and 89. Fig. 63 ["entrée de l'église"] does not show the entrance to the church but one of the western entrances of Quarry DAH 014). 
architecture and it is seldom seen in monastic churches (Grossmann 2002: 101105; see De Blaauw 2008: 359-364). At Dayr Abū Hinnis, it was a narthex from a functional point of view: located at the "western end" (literally the southern end) of the church, it connected different rooms and could be used for gatherings as well as for visitors to the recluse residing in the two niches inside. To the north of the church, the quarry runs on for almost a hundred meters. Inside the western part as well as in front of the numerous western entrances are the remains of rooms and built structures. To the east of the church are more quarry rooms, with communicating doorways to the church and narthex [Fig. 2]. Outside, to the south and to the west of the church, are the remains of floors, walls, doorways, and staircases. In conclusion: the liturgical center was incorporated into an extensive complex of rooms and spaces with as yet unknown functions.

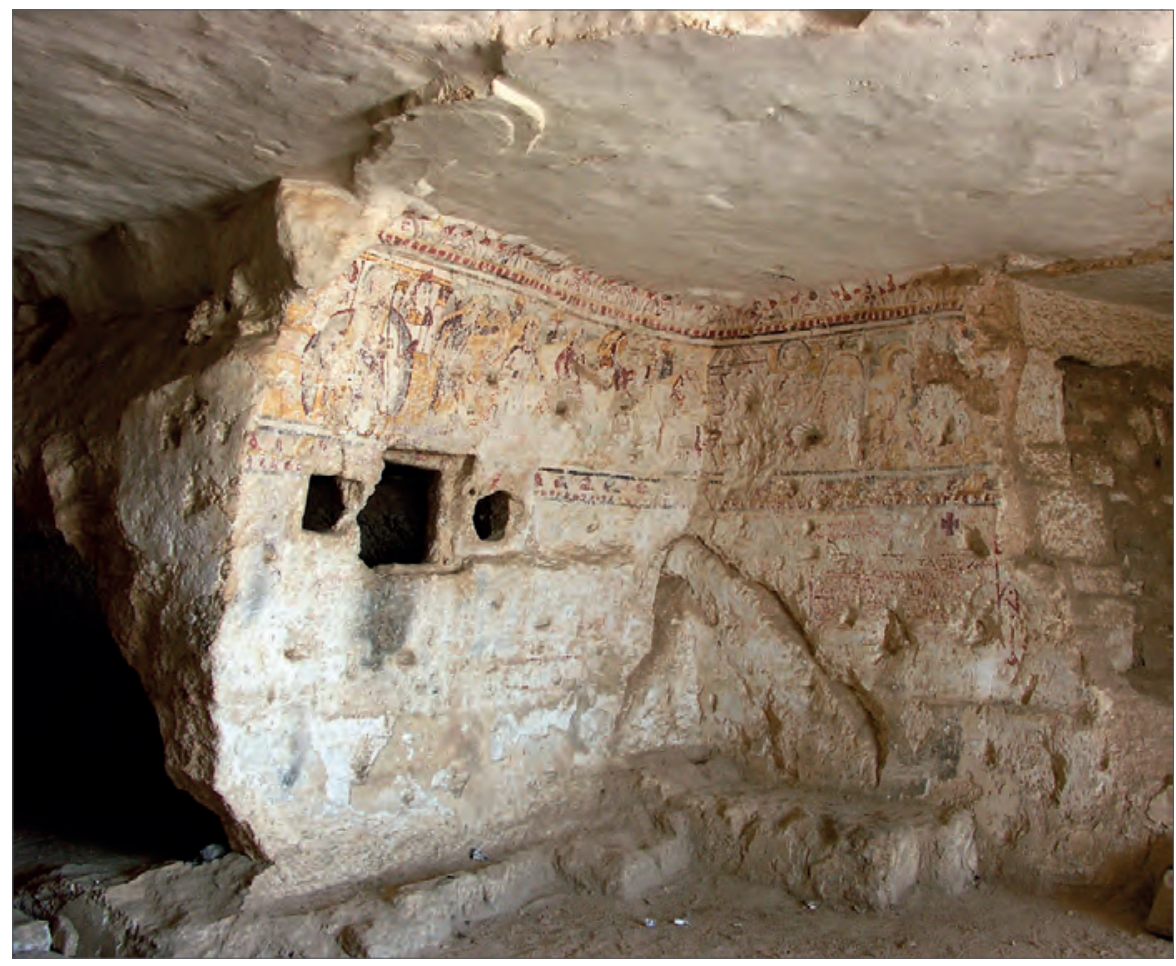

Fig. 3. The northeastern corner of the narthex with the frieze of Infancy scenes. A small part of the wall trace on the ceiling is visible in the upper right hand corner. The windows belong to the compartment to the north, which probably once served as the cell of a recluse (Photo G.J.M. van Loon, 2006) 


\section{The wall paintings in the narthex}

The narthex used to be decorated completely with wall paintings. On the irregular western rock face (about $6.50 \mathrm{~m}$ long), a row of standing saints was grouped around Saint John the Baptist shown in the center [Figs 2:N.1, 4-6. Images of six figures (three monastic saints and three healing saints), surviving in fragmentary condition, can be counted to the right and seven (three monastic saints, a brother and three unidentified individuals) to the left. Saint John and three saints on either side are preserved from head to shoulder- or knee-level (although all the faces have disappeared). Only tiny fragments of the other saints survive. John is standing in orans position. He has long black hair falling over his shoulders and a short, pointed, dark beard. His orange-yellow tunic girdled around his hips probably reached his ankles. A large round fibula fastens his yellow ochre hairy cloak at the chest.

Tall, slender trees separate the figures. All the saints have nimbi and their names were written above their haloes. Still legible today are the names of Apa Makarios the Great from Sketis and Apa Arsenios, standing on John's right side, and further down, Brother Patermoute. The healing saints Cosmas, Damian, and Dometios were depicted on the far right (van Loon and Delattre 2004; 2005).

Just below, and partly on the ceiling, is a foliage pattern. Traces of this border can be distinguished on the ceiling along the modern south wall (continuing for about $2.60 \mathrm{~m}$ ) showing that, originally, there also used to be a built wall on this spot. The row of saints most probably extended onto this wall.

The narrative frieze on the northern and eastern rock faces is painted just below the ceiling and is framed above and below by a decorative border (Clédat 1902: 49-51 and Pls I-II; Rosenstiehl 1991: 54; van Loon and Delattre 2006) [Figs 2:N.2, 3 and 7-9]. The lower border covers the upper ledge of the center window in the northern rock face, which belonged to the hermit's abode. Therefore, we do not know if there was still a recluse living there when the spaces were used as a church. By the time of the last phase of decoration, the wooden window frame, which would have been inserted here, had obviously disappeared. Part of the upper border of flowers and fruit is painted on the ceiling. In total, the register is about $1.35-1.40 \mathrm{~m}$ high and about $5 \mathrm{~m}$ long. This frieze was cut off by the destruction of the wall, which was built to continue the eastern rock face. Traces of this wall are visible on the ceiling along the upper foliage pattern. The original frieze would probably have been about $9 \mathrm{~m}$ long and might have contained four more scenes. 


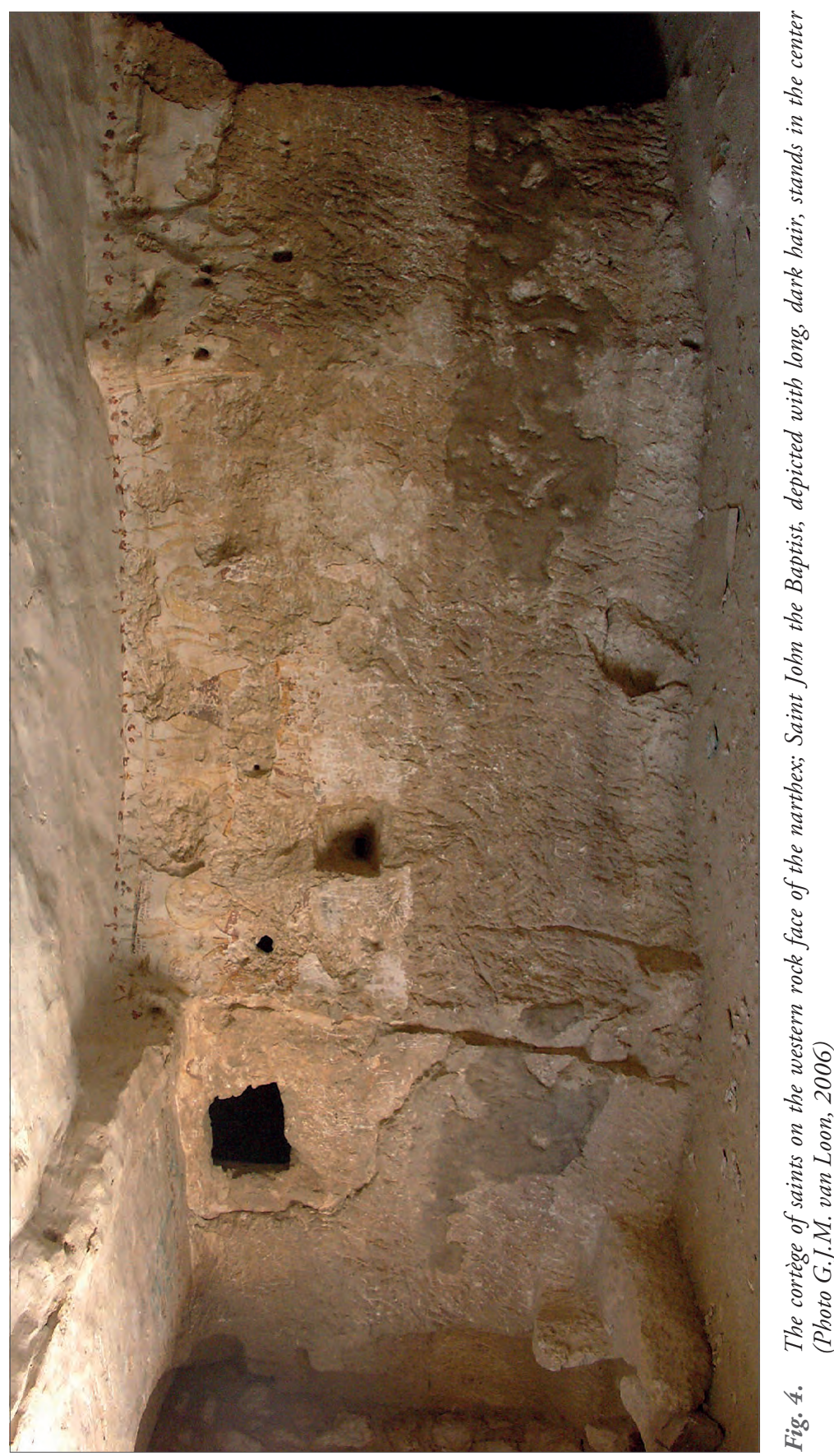


"...that the mountain of the holy wilderness may be inhabited..."

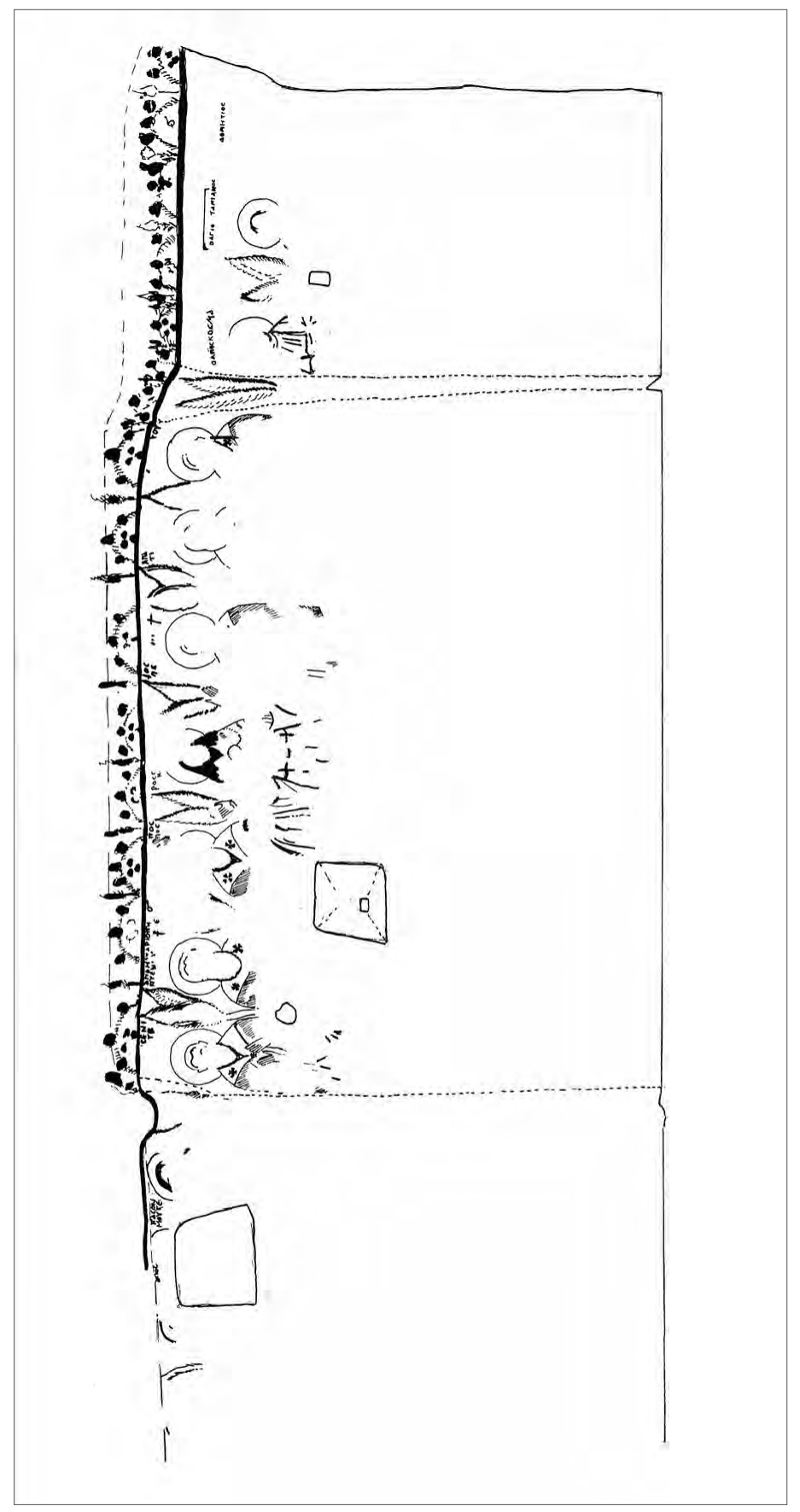

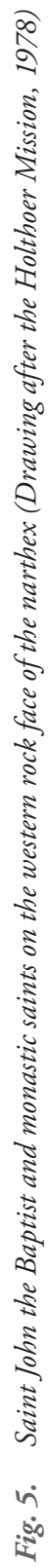


The sequence of scenes commences on the northern rock face. The painter made a choice from events related in the Gospel of Matthew and the apocryphal Protevangelium of James, which was most probably written in Egypt (2nd century AD). This immensely popular text begins with Mary's birth and childhood and ends with the murder of Zacharias (Geerard 1992: 50; De Strycker 1961: 412-423; Zervos 2004: 81-91).

The sequence preserved from left to right is:

- Massacre of the Innocents [Fig. 7]: King Herod ordering the slaughter of all male infants and toddlers in Bethlehem (Matthew 2:16; Protev. James XXII, 1; De Strycker 1961: 174-175; Elliott 1993: 65-66);

- Flight of Elisabeth [Fig. 7]: Elisabeth escaped from the massacre with her son to the mountains where a mountain closed around them (Protev. James XXII,3; De Strycker 1961: 174-177; Elliott 1993: 66);

- murder of Zacharias [Fig. 8]: her husband Zacharias was killed in the temple, before the altar (Protev. James XXIII-XXIV,3; De Strycker 1961: 176-187; Elliott 1993: 66);

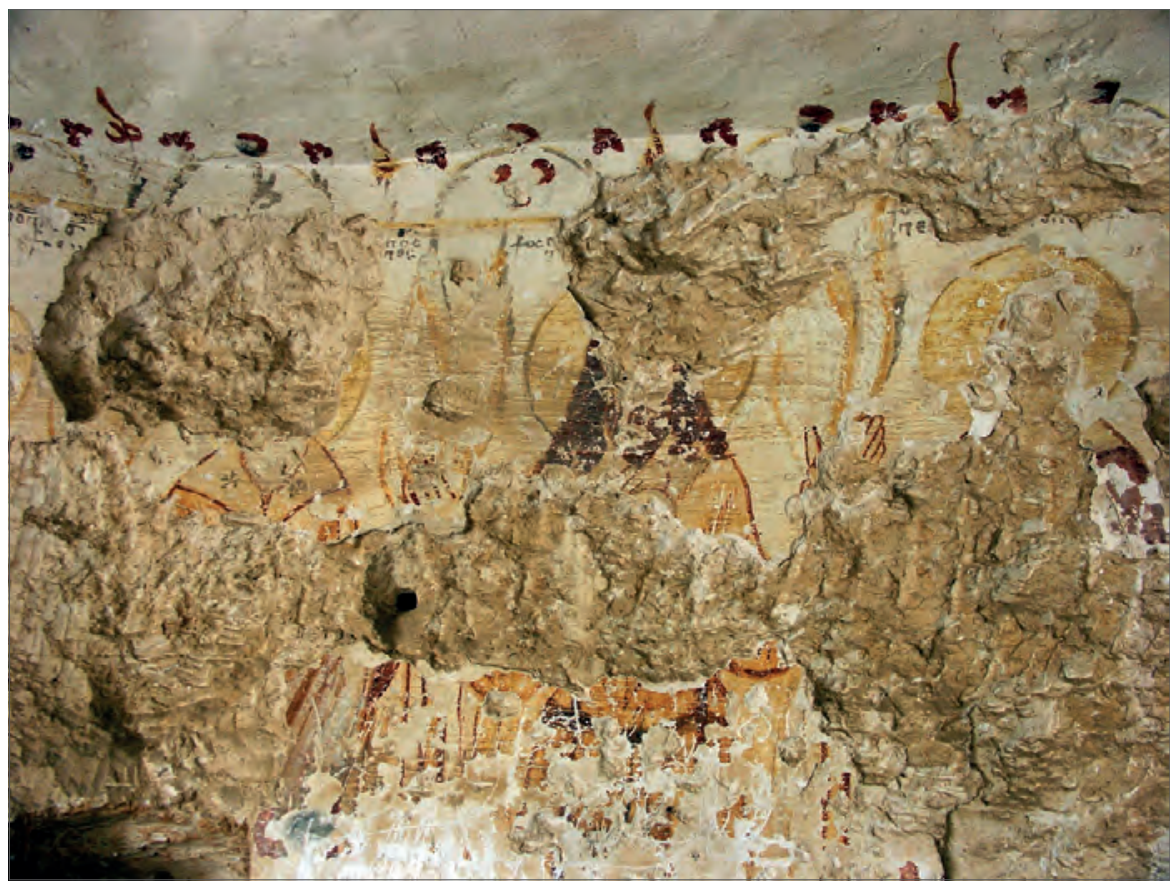

Fig. 6. Saint John the Baptist and monastic saints, western rock face of the narthex (Photo G.J.M. van Loon, 2006) 
- Second Dream of Joseph [Fig. 9]: in a dream Joseph is warned by an angel to take Mary and the Child and go to Egypt (Matthew 2:13);

- Flight into Egypt [Fig. 9]: Mary and Joseph escaping to Egypt with their son (Matthew 2:14).

The story runs from left to right. All the compositions are directed to the right and the protagonists are identified by inscriptions. Therefore, although the paintings are damaged, the identification of most scenes has posed hardly any problems throughout the centuries. One exception is the scene in the corner, with a standing figure on the northern rock face and a kneeling figure in front of a building on the eastern rock face [Fig. 8]. Although alternative interpretations exist (e.g., Clédat 1902: 50; Rosenstiehl 1991: 54; Doresse 2000/II.1: 468; De Grüneisen 1922: 96, note 5; Jastrzębowska 1992: 202), most scholars studying this series have seen this scene as "The Murder of Zacharias" (e.g., Morey 1953: 86-87; Wessel 1978a: 634; Badawy 1978: 248; Thierry 1998: 10; Brubaker 1999: 67-68). According to the Protevangelium of James, a servant of King Herod interrogated Zacharias to discover the hiding place of Elisabeth and

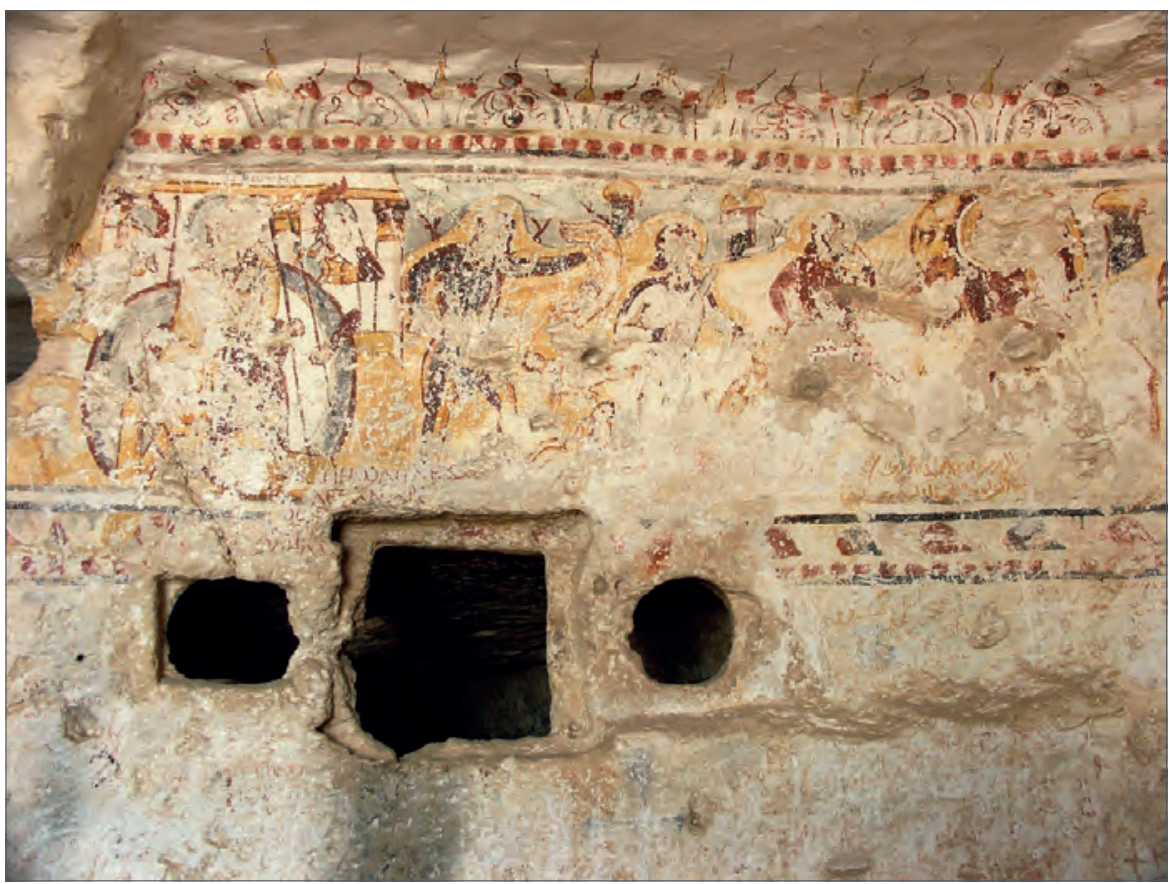

Fig. 7. Massacre of the Innocents and Flight of Elisabeth, northern rock face of the narthex (Photo G.J.M. van Loon, 2006) 
John. When Zacharias denied any knowledge of his wife's whereabouts, King Herod flew into a rage and ordered he be executed. Zacharias was killed in the temple, in front of the altar.

I agreed that, as part of the series, the Murder of Zacharias was the most logical subject (van Loon in van Loon and Delattre 2006: 124-126, Figs 5-6). This conclusion was based on the photographic documentation of the Finnish mission to Dayr Abū Hinnis led by Rostislav Holthoer in 1978 and was written before our first fieldwork campaign of 2004. Meticulous research on site revealed that the standing person on the northern rock face was indeed a soldier: tiny fragments of a yellow ochre cuirass are still visible. Moreover,

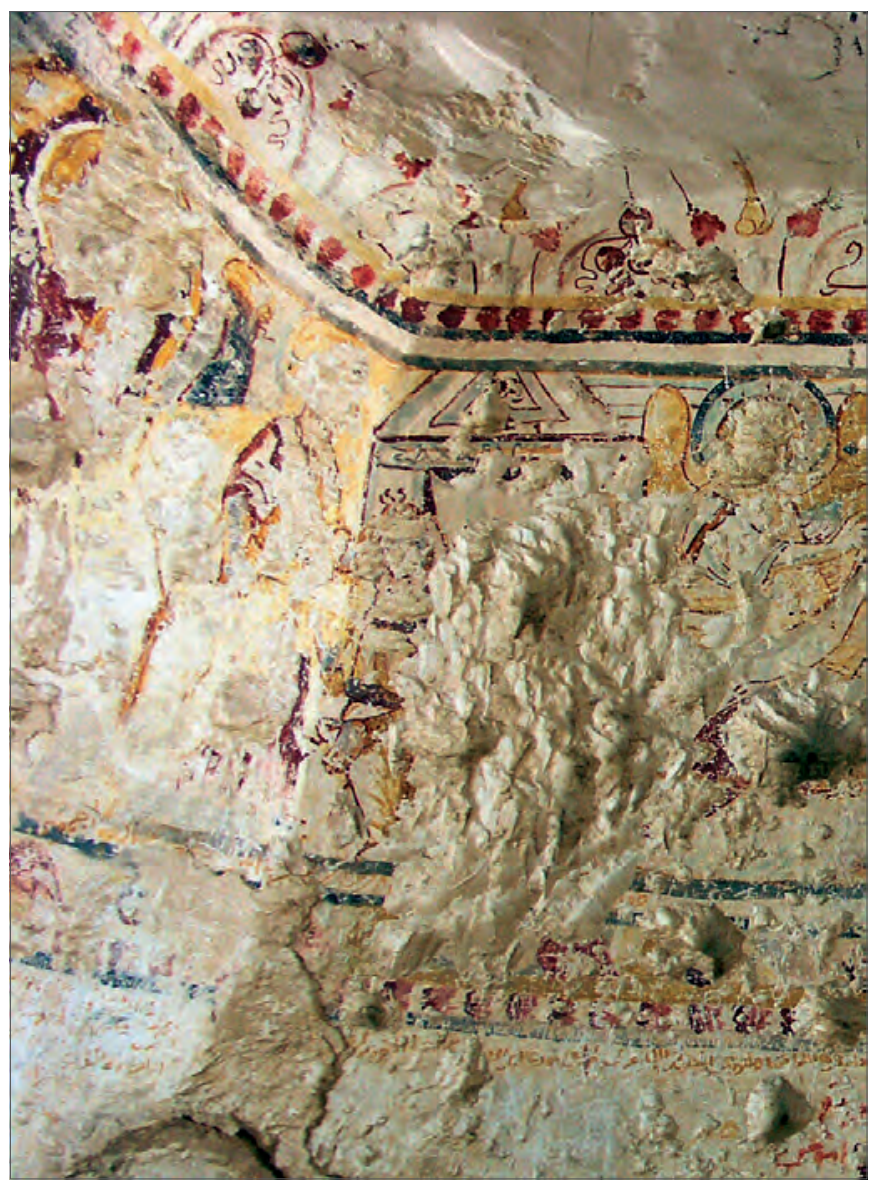

Fig. 8. Murder of Zacharias, northeastern corner of the narthex (Photo G.J.M. van Loon, 2006) 
a study of the photographs taken by the American art historian Arthur Kingsley Porter $(\dagger 1933)$ acquired afterwards (Harvard, Fine Arts Library, Collection A.K. Porter 370 C D 33 M 2, Neg. Nos. 428 and 2216, undated), permitted the fragments of the set of clothes of the kneeling figure to be pieced into garments worn by a high priest, albeit with some original details (van Loon 2011: 91 and 100). The identification as the Murder of Zacharias can therefore be confirmed.

\section{Narrative series of Infancy scenes}

A comparison with cycles with Infancy scenes in other Egyptian churches and monastic buildings might shed more light on the problems. Apart from Dayr Abū Hinnis, these cycles have, up to now, been found in the Church of Karm alAhbarīya, southwest of Alexandria (second half of 6th century, only fragments survive) and in several rooms in the Monastery of Apa Apollo in Bawit, Middle

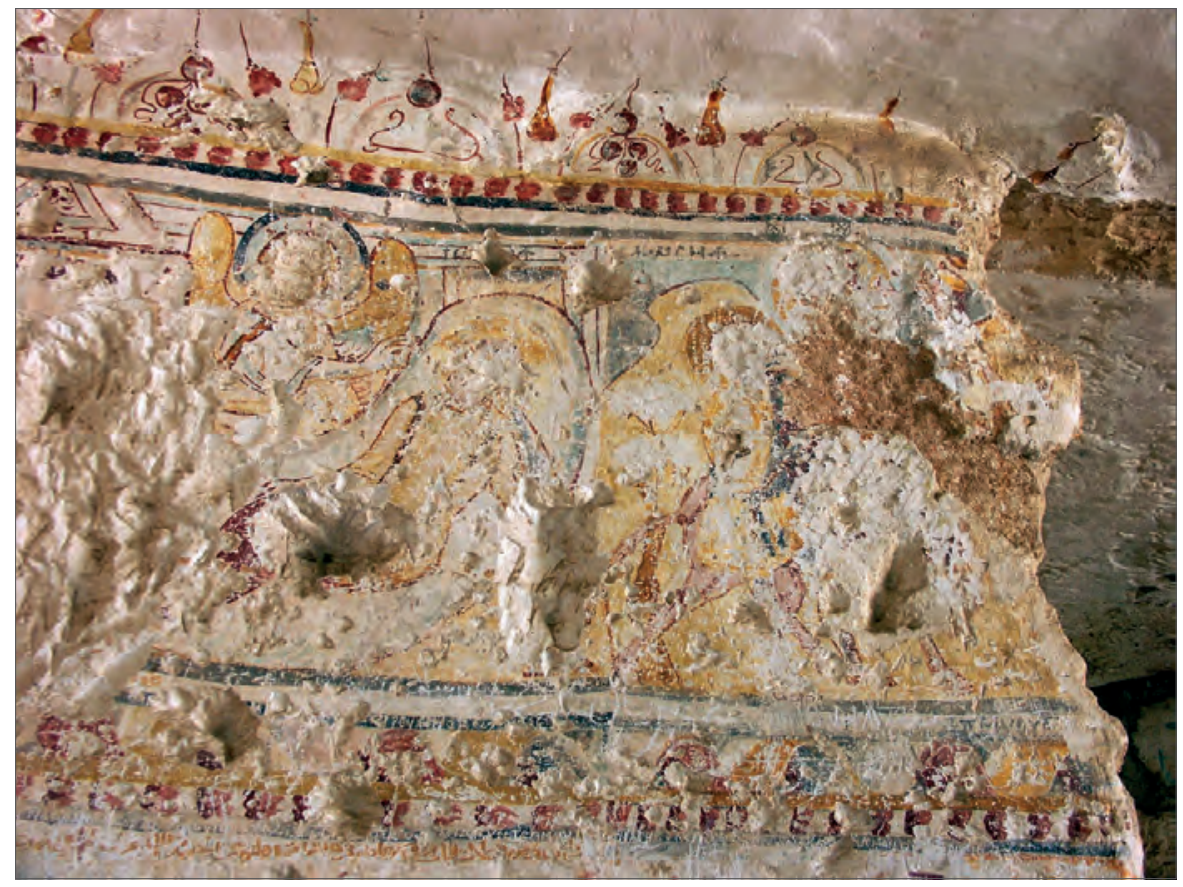

Fig. 9. Second Dream of Joseph and Flight into Egypt, eastern rock face of the narthex (Photo G.J.M. van Loon, 2006) 
Egypt (Chapel XXX, Chapel LI, and Room 18 (6th-7th centuries? now all lost) and Building 1/Room 7 (7th century, largely preserved). Except for the paintings in Chapel LI, the cycles were fragmentarily preserved at the time of their discovery and individual scenes were often difficult to identify.

In early Christian art, cycles of the Life of Mary or the Infancy of Christ show no consistent choice of scenes. They draw inspiration from several sources, for example Gospel books and apocryphal stories. Local narratives, legends or encomia containing childhood stories of the central characters might also have played a role (Schiller 1966: 36-37). ${ }^{6}$

Childhood and girlhood scenes of Mary are inspired by apocryphal stories, primarily the Protevangelium of James. Annunciation to the Virgin, Visitation, First Dream of Joseph, Journey to Bethlehem, Nativity, Adoration of the Magi, Circumcision, Presentation in the Temple, Second Dream of Joseph, Flight into Egypt, Murder of the Innocents, Return from Egypt, and the youthful Jesus in the Temple are the most extensive choice of scenes offered by the Gospels of Matthew and Luke (Wessel 1978b: 677); besides these, the First Dream of Joseph, Ordeal of the Bitter Water, Flight of Elisabeth, and Murder of Zacharias are potential scenes from the Protevangelium. Details taken from the latter book can also be found in more established scenes, such as the episode of the midwife Salomé in the Nativity (see van Loon 2006: 89-95). Moreover, the choice made from these three main sources, the Gospels of Matthew and Luke, and the Protevangelium of James, does not always follow the sequence of the episodes in that particular narrative.

It is often difficult to establish the central themes of these series. The Life of the Virgin Mary and the Infancy of Christ is, of course, a continuing story and numerous events, for example, the Annunciation, the Visitation, the Journey to Bethlehem, or the Nativity, can be found in both cycles. Therefore, the arrangement of scenes and the overall iconographical program are factors which determine the principal subject or character of the frieze. Moreover, it is essential to realize that the meaning of such a series is not hidden in the separate images: its strength and impact lie in the cycle as a whole.

In the Church of Karm al-Ahbariya, the Annunciation, Visitation (or Ordeal of the Bitter Water?), Adoration of the Magi, Massacre of the Innocents, and Flight into Egypt could be identified on the south wall of the nave, as part of a more extensive cycle of the Life of Christ (Witte-Orr 2010). A cycle of the Life of Mary containing the Annunciation, Visitation, Journey to Bethlehem, and

6 Wessel (1978b: 677) excludes the apocryphal stories from the source material, a view that does not make sense. 
the Virgin Mary and midwife Salomé was found on the north wall of Chapel LI (Clédat 1904: 523-525; 1999: 109-132; van Loon 2006). Chapel XXX presented on the north wall the Massacre of the Innocents, unidentified figures, a woman carrying a child, and the Baptism of Christ, followed on the east wall by a banqueting scene. Clédat expected the series to start on the west wall (which had already disappeared at that time) (Clédat, Carnet Baouit 1903: 24-43 [Louvre, Département des antiquités égyptiennes, section copte]; Clédat 1904/I: 519-520; 1916: 1-9 and Pls I-IV; 1999: Photos 15-18; Bénazeth 2005: 5-7). The few fragments in Room 18 are insufficient for identification. Maspero and Drioton have argued that the fragment of a donkey points to the Journey to Bethlehem or the Nativity. The Flight into Egypt is a third possibility. Another fragment shows Elisabeth and John (Maspero 1931-1943/I: 10, 3031 and Pls XXIX-XXX). The series on the north wall of Room 7 of Building 1 misses the first two scenes, for which Marie-Hélène Rutschowscaya (2010: 46) proposes the Annunciation and the Nativity. The First Dream of Joseph, Journey to Bethlehem, Nativity, Presentation in the Temple and Adoration of the Magi have been preserved there (Bénazeth 2010: 21-23 and Fig. 4; Rutschowscaya 2010; Evans and Ratliff 2012: 82 and Fig. 34 (D. Bénazeth) 7.

The Infancy section of the cycle in Karm al-Ahbariya, which was definitely part of a cycle of the Life of Christ, seems to have been based on the Gospels of Luke and Matthew. ${ }^{8}$ The cycle of the Life of Mary in Chapel LI was based on both Gospel and apocryphal sources. The Gospels of Luke and Matthew and the Protevangelium of James play a role in the narratives in the narthex of Dayr Abū Hinnis and in Room 18, Chapel XXX, and Room 7 of Building 1 in Bawit. ${ }^{9}$ The principal subject of the latter cycles is under investigation.

The narrative frieze in these monuments is part of a more extensive decorative program. In all cases, standing (monastic) saints are part of the

7 http://www.louvre.fr/fouilles-de-baouit-egypte-saison-2010;

http://www.ifao.egnet.net/archeologie/baouit/ (accessed: 7.06.2016).

8 The Ordeal of the Bitter Water would have been based on the Protevangelium of James.

9 According to Rutschowscaya 2010: 50, the Gospel of Pseudo-Matthew (or Infancy Gospel of Matthew) probably influenced the sequences of scenes in Building 1, Room 7, where the Presentation in the Temple precedes the Adoration of the Magi (see above). As Jan Gijsel points out, in the Gospel of Matthew the magi arrive a few days after the birth of Christ, while in Pseudo-Matthew, they arrive two years later. However, Pseudo-Matthew is a Western compilation, based largely on the Protevangelium of James. It probably originated at the end of the 6th-beginning of 7th century (Gijsel 1997: 107-115; Gijsel in Gijsel and Beyers 1997/I: 67). The late visit of the magi as described in Pseudo-Matthew was well known in the East and West, and can already be found in the 3rd-4th century, in writings of, for example, Origen, Eusebius and Epiphanius (Gijsel 1997: 111; Gijsel in Gijsel and Beyers 1997/I: 56-57). The latter authors are a more likely source in 7 th-century Egypt. 
decoration. Whether the saints and narrative cycles in Chapels XXX and LI and in Room 18 were related and consequently made up a general theme is difficult to determine. In Room 7, prophets carrying scrolls with texts of their prophesies are painted on the south wall. They prefigure the New Testament scenes on the opposite wall, while the monastic saints among the prophets can be counted among the champions of faith (Rutschowscaya 2010: 49-50 and Pl. 4-A). There was, however, probably no relation between the prophets with scrolls depicted above the cycle of the Infancy in the nave of the Church of Karm al-Ahbariya and the narrative scenes (Witte-Orr 2010: 76-77).

So far, the cycle of Infancy scenes in Karm al-Ahbariya is the only example of such a cycle in the nave of a church. Seen in the corpus of preserved contemporary church decoration, this decorative system is atypical of Egypt; it belongs to a tradition found in Early Christian churches around the Mediterranean (Böck 1995). Karm al-Ahbarīya was located near Abu Mina and Alexandria, which might account for the choices made.

In Bawit, Room 7 was almost certainly part of a hostel complex (Bénazeth 2010: 21-23; Rutschowscaya 2010). Chapel LI might have been a community oratory, a reception room or both (van Loon 2006: 100-101). No specific function has been assigned yet to Chapel XXX and Room 18. In Dayr Abū Hinnis, the narthex of the quarry church was a room for gathering. It might also have been a visitor's room, if there was still a recluse living next to it.

In conclusion, almost all of these narrative cycles were based on several sources. They were found in rooms with a non-liturgical function to which visitors were also admitted (fellow monks, clerics or ordinary lay people), as attested by the graffiti (Clédat 1904-1906: 8-9; 1999: 161-121; Maspero 1931-1943/II: 126-127; van Loon 2006: 101; Delattre in van Loon and Delattre forthcoming). All the cycles have their own characteristics, from an iconographical point of view as well as in the place they occupy in the decoration of the respective spaces. As remarked above, the individual scenes have no direct message; the strength lies in the ensemble. Although refectories, community oratories, and reception or waiting rooms have a practical function, they also qualify as places for contemplation and meditation. The decorative programs of church buildings found in this area so far have a strong symbolic meaning, closely tied to their liturgical function (van Loon 2014: 195-204).

In the case of the rooms discussed here, the function is less compelling. It would have allowed more freedom in the choice of decoration and offered the possibility "to tell stories", which are edifying and visually attractive and would have reached monks and lay visitors alike. 
Following my predecessors and taking into account the content of the cycles listed above, I have long considered the series in the narthex of Dayr Abū Hinnis as a Cycle of the Infancy of Christ (van Loon in van Loon and Delattre 2006; van Loon 2011). Nonetheless, the first scene, the Massacre of the Innocents, continued to puzzle me. Why would a cycle dedicated to the Infancy of Christ begin with the Massacre of the Innocents? Usually, this gruesome story follows a Nativity or some other scenes. It is obvious that the sequence of the pictures runs from left to right. Therefore, there is no other wall space available which could have been used for a more conventional beginning. The question continued to trouble me until I realized that the beginning and development of this series of narrative scenes make sense only if the Infancy of Saint John the Baptist, and not the Infancy of Christ, is taken as the guiding element.

The Massacre of the Innocents was a crucial episode in the life of John. $\mathrm{He}$ was, after Christ, an intended victim, especially sought by Herod's henchmen. Through divine intervention, his mother was able to bring him to safety and this was how his life in the desert began. His father refused to betray him and was murdered. Later in life, following his father's example of prophecy and faith, John, too, would be murdered (Matthew 14:1-12) (van Loon 2011: 102-103). Christ also escaped the massacre: Joseph was warned in a dream to take mother and child and flee to Egypt. Christ's public life and death require no further explanation.

John is Christ's forerunner, his kinsman and friend. In this unusual, creative, and innovative iconographical program in Dayr Abū Hinnis, John's life and vocation are entwined with Christ's life and mission on earth. The series in the narthex might even be seen as a continuation of the series of narrative paintings in the baptistery, where the story of John — and the story of Christ - begins with the annunciation of their respective births by the Archangel Gabriel.

\section{Saint John the Baptist}

Saint John the Baptist is a most appropriate choice as titular saint of the church of a monastic settlement. He is held in high esteem in the Egyptian Church. His cult has been attested since the end of the 5th century and is very probably much older. Apart from the Vitae, the corpus dedicated to John is composed of homilies, doxologies, hymns, magical texts, descriptions of miracles and so forth (Till 1958; Aranda Pérez 1991; Papaconstantinou 
2001: 112-115). ${ }^{10}$ The major events of his life are commemorated in the Arabic Synaxarium: the announcement of his birth (26 Tüt/23 September), his birth (30 Ba'ūnah/24 June), the Baptism of Christ (11 Tübah/6 January), and his death by beheading ( 2 Tüt/30 August). Furthermore, the discovery of his relics is celebrated on 30 Amshīr/24 February (the discovery of his head) and $2 \mathrm{Ba}$ 'ūnah/27 May (the discovery of his body) (see the relevant dates in Basset 1907-1929; Forget 1905-1926; Meinardus 1963-1964; Atiya 1991). The earliest mention of these feast days dates to the 9th or 10th century (Papaconstantinou 2001: 114).

Apart from his qualities outlined above, his asceticism and his sojourn in the desert (Matthew 3:1-4; Luke 1:80; 3:2) are examples for monks. Alongside the prophets Elijah and Elisha, he is the model par excellence of monastic life: "Elijah and Elisha and John the Baptist made their abode first in the desert, until our fathers followed them" (On Apa Anthony. An acrostic hymn from New York, PML, M 574, AD 897-898; Depuydt 1993/I: 113-121, No. 59; Kuhn and Tait 1996: 135). ${ }^{11}$ Two encomia in John's honor attributed to Theodosius of Alexandria and John Chrysostom even speak of his time in the desert as dating from the moment his mother fled in order to save him, until the day he appeared at the River Jordan. Locusts and wild honey (see Matthew 3:4; Mark 1:6) are mentioned as his food (Geerard 1992: 185; New York, PML, M 853; Depuydt 1993/I: 325-332, no. 164; Kuhn 1966/I: 37-38 [text]; II: 32-33 [transl.]). ${ }^{12}$ Theodosius does not refer to the mountain (according to his encomium, they dwelled in the desert), but in the text attributed to John Chrysostom the mountain which opened for them was like "a quiet monastery (MONdCTHPION)" (Geerard 1992: 184; London, BL, Ms. Or. 7024, AD 987; Layton 1987: 188-190, no. 159; Budge 1913: 136-137 [text], 343 [transl.]; Till 1958: 313-314 [No. 20], 326; Boud'hors 1997: 1570).

The latter idea is also found in a Vita of Saint John, attributed to Serapion of Thmuis (end of the 4th century) which is known from a 16th and 18th century Garshūni manuscript (Arabic written in Syriac characters). The origin

10 Additions: Magical text (Rutschowscaya and Bénazeth 2000: 120, No. 91); Hymn to Saint John the Baptist, ostrakon from Antinoupolis, 5th-6th century (Delattre 2008: 149-151 and Pl. VIII-8). An 8th-century inventory list of the library of the Monastery of Saint Elijahon-the-Rock (end of 7th-beginning of 8th century) contains several texts on Saint John the Baptist (Coquin 1975: 212, 218, 232, and 235).

11 This manuscript contains a compilation of old hymns or is a later copy (Kuhn and Tait 1996: 13).

12 The manuscript is dated AD 848, but according to Kuhn (1966/I: v and x), a version of this text must have been known in the 7 th century. 
of this text might be Egyptian (Manchester, John Rylands Library, Mingana Syr. 22 and Syr. 183; Geerard 1992: 183; Boud'hors 1997: 1570; Mingana 1927: 234-260 [transl.]; 261-287 [text]). The text relates how the Archangel Gabriel brought the raiment of Elijah and the girdle of Elisha from heaven to Zacharias, who was to give them to John when he bid his wife and son goodbye (Mingana 1927: 239-240). Later, Elisabeth says: "I went and put on my son a raiment of camel's hair and a leathern girdle in order that the mountain of the holy wilderness may (in future) be inhabited, and in order that monasteries and congregations of monks may increase in it and that sacrifice may be offered in it in the name of the Lord Jesus Christ" (Mingana 1927: 241).

\section{Conclusion}

All the decoration in the quarry church of Dayr Abū Hinnis highlights the patron saint, Saint John the Baptist. In the cycle of paintings on the northern and eastern rock faces of the narthex, John, and not Christ, is the central character. The frieze demonstrates that his life and message were intrinsically bound up with the life and mission of Christ. Furthermore, in this monastic context and close to (the memory of) an abode of a recluse, John's eminence as a desert ascetic was highly valued. On the western rock face he is surrounded by at least two famous Desert Fathers and four other saintly monks, as well as a brother (Patermoute). The arrangement of the scenes in the narrative frieze also underlines this aspect of his life: it begins with the Massacre of the Innocents in Bethlehem, which caused his mother to hide him in the desert where he grew up in solitude and meditation. "The mountain of the holy wilderness" did become inhabited, even filled to capacity with monastic communities.

\section{ACKNOWLedgments}

Dayr Abū Hinnis is the northern part of the archaeological concession of the Dayr al-Barshā Project (KU Leuven, Research Group Egyptology) directed by Harco Willems, which also includes al-Shaykh Saîd in the south (http://www.dayralbarsha.com, funded by research grants of FWO Vlaanderen and the Bijzonder Onderzoeksfonds of KU Leuven). Fieldwork was carried out from 2004 to 2008 and we would like to thank Prof. Willems and his team 
very warmly for their hospitality and assistance over the years. My research on the wall paintings has been funded by NWO (Netherlands Organization for Scientific Research) and the Byvanck Fund (Leiden University). Special thanks go to Mrs. Rosemary Robson-McKillop.

\section{References}

Aranda Pérez, G. (1991). John the Baptist, Saint. In A.S. Atiya (ed.), The Coptic encyclopedia V (pp. 1354-1357). New York: Macmillan

Atiya, A.S. (1991). Synaxarion, Copto-Arabic. In A.S. Atiya (ed.), The Coptic encyclopedia VII (pp. 2171-2190). New York: Macmillan

Badawy, A. (1978). Coptic art and archaeology: The art of the Christian Egyptians from the late antique to the Middle Ages. Cambridge, MA: MIT Press

Basset, R. (ed.). (1907-1929). Le Synaxaire arabe jacobite (redaction copte) I-VI [=Patrologia Orientalis 1, 3, 11, 16, 17, 20]. Paris: Firmin-Didot

Bénazeth, D. (2005). Calques de Baouit archivés à l'Ifao. Bulletin de l'Institut français d'archéologie orientale, 105, 1-12

Bénazeth, D. (2010). Nouvelles campagnes de fouilles à Baouit (2005, 2006). In A. Boud'hors and C. Louis (eds), Etudes coptes XI: treizième journée d'études (Marseille 7-9 juin 2007) [=Cahiers de la Bibliothèque copte 17] (pp. 17-24). Paris: De Boccard

Böck, A. (1995). Langhauszyklen. In M. Restle (ed.), Reallexikon zur byzantinischen Kunst V (pp. 621-651). Stuttgart: Hiersemann

Boud'hors, A. (1997). Éloge de Jean-Baptiste. In F. Bovon and P. Geoltrain (eds), Écrits apocryphes chrétiens I [=Bibliothèque de la Pléiade 442] (pp. 1553-1578). Paris: Gallimard

Brubaker, L. (1999). Vision and meaning in ninth-century Byzantium: Image as exegesis in the homilies of Gregory of Nazianzus [=Cambridge Studies in Palaeography and Codicology 6]. Cambridge: Cambridge University Press

Budge, E.A.W. (1913). Coptic apocrypha in the dialect of upper Egypt. London: British Museum

Clédat, J. (1902). Notes archéologiques et philologiques. Bulletin de l'Institut français d'archéologie orientale, 2, 41-70

Clédat, J. (1904). Nouvelles recherches à Baouît (Haute-Égypte). Campagnes 19031904. Comptes rendus de l'Académie des inscriptions et belles-lettres, 48(5), 517-526

Clédat, J. (1904-1906). Le monastère et la nécropole de Baouît I.1-2 [=Mémoires publiés par les membres de l'Institut français d'archéologie orientale 12]. Cairo: Institut français d'archéologie orientale

Clédat, J. (1916). Le monastère et la nécropole de Baouît II.1 [=Mémoires publiés par les membres de l'Institut français d'archéologie orientale 39]. Cairo: Institut français d'archéologie orientale 
Clédat, J. (1999). Le monastère et la nécropole de Baouit [=Mémoires publiés par les membres de l'Institut français d'archéologie orientale 114]. (D. Bénazeth and M.-H. Rutschowscaya, eds). Cairo: Institut français d'archéologie orientale

Coquin, R.-G. (1975). Le catalogue de la bibliothèque du couvent de Saint-Élie "du rocher" (ostracon IFAO 13315). Bulletin de l'Institut français d'archéologie orientale, 75, 207-239

De Blaauw, S. (2008). Kultgebäude (Kirchenbau). In Reallexikon für Antike und Christentum XXII (pp. 227-393). Stuttgart: Hiersemann

de Grüneisen, W. (1922). Les charactéristiques de l'art copte. Florence: Fratelli Alinari

Delattre, A. (2003). L'apophtegme de Grégoire de Nysse au Deir Abou Hennis. Aegyptus, 83(1/2), 223-227

Delattre, A. (2008). Textes coptes et grecs d'Antinoé. In R. Pintaudi (ed.), Antinoupolis I [=Scavi e materiali 1] (pp. 131-162). Florence: Istituto Papirologico "G. Vitelli"

Delattre, A. (2013). Les rapports entre la ville d'Antinoé et le monastère du Deir Abou Hennis en Moyenne-Égypte. In B. Astrua (ed.), Itinerari mediterranei fra IV e IX secolo: città-capitale e deserto-monastico. Atti del convegno (pp. 39-54). Turin: Accademia University Press

Depuydt, L. (1993). Catalogue of Coptic manuscripts in the Pierpont Morgan Library I-II [=Corpus of Illuminated Manuscripts 4-5]. Leuven: Peeters

de Strycker, É. (1961). La forme la plus ancienne du Protévangile de Jacques [=Subsidia hagiographica 33]. Brussels: Société des Bollandistes

Doresse, J. (2000). Les anciens monastères coptes de Moyenne-Egypte (du Gebel-et-Teir à Kôm-Ishgaou) d'après l'archéologie et l'hagiographie I-III [=Neges Ebrix 3-5]. Yverdon-les-Bains: Institut d'archéologie yverdonnoise

Elliott, J.K. (1993). The Apocryphal New Testament: A collection of apocryphal Christian literature in an English translation. Oxford: Oxford University Press

Evans, H.C. and Ratliff, B. (eds). (2012). Byzantium and Islam: Age of transition, 7th-9th century. New York: Metropolitan Museum of Art

Forget, J. (ed.). (1905-1926). Synaxarium Alexandrinum [=Corpus scriptorum Christianorum Orientalium 47-49, 67, 78, 90]. Beirut: E Typographeo catholico

Geerard, M. (ed.). (1992). Clavis apocryphorum Novi Testamenti. Turnhout: Brepols Gijsel, J. (1997). Évangile de l'enfance du Pseudo-Matthieu. In F. Bovon and P. Geoltrain (eds), Écrits apocryphes chrétiens I [=Bibliothèque de la Pléiade 442] (pp. 105-140). Paris: Gallimard

Gijsel, J. and Beyers, R. (eds). (1997). Libri de nativitate Mariae I-II [=Corpus Christianorum Series Apocryphorum 9-10]. Turnhout: Brepols

Grossmann, P. (2002). Christliche Architektur in Ägypten [=Handbuch der Orientalistik 62]. Leiden: Brill

Jastrzębowska, E. (1992). Bild und Wort: das Marienleben und die Kindheit Jesu in der christlichen Kunst vom 4. bis 8. Jh. und ihre apokryphen Quellen. Warsaw: Uniwersytet Warszawski, Instytut Archeologii 
Kuhn, K.H. (ed.). (1966). A Panegyric on John the Baptist attributed to Theodosius Archbishop of Alexandria [=Corpus scriptorum Christianorum Orientalium 268269]. Leuven: Secrétariat du Corpus SCO

Kuhn, K.H. and Tait, W.J. (eds). (1996). Thirteen Coptic acrostic hymns: From manuscript M574 of the Pierpont Morgan Library. Oxford: Griffith Institute

Layton, B. (1987). Catalogue of Coptic literary manuscripts in the British Library acquired since the year 1906. London: British Library

Maspero, J. (1931-1943). Fouilles exécutées à Baouît I-II [=Mémoires publiés par les membres de l'Institut français d'archéologie orientale 59]. (É. Drioton, ed.). Cairo: Institut français d'archéologie orientale

Meinardus, O.F.A. (1963-1964). A comparative study on the sources of the Synaxarium of the Coptic Church. Bulletin de la Société d'archéologie copte, 17, $111-156$

Mingana, A. (1927). A new life of John the Baptist. In A. Mingana (ed.), Woodbrooke studies: Christian documents in Syriac, Arabic, and Garshüni I (pp. 234-287). Cambridge: W. Heffer \& Sons

Morey, C.R. (1953). Early Christian art: An outline of the evolution of style and iconography in sculpture and painting from antiquity to the eighth century (2nd ed.). Princeton, NJ: Princeton University Press

Papaconstantinou, A. (2001). Le culte des saints en Égypte des Byzantines aux Abbasides: l'apport des inscriptions et des papyrus grecs et coptes. Paris: CNRS éditions

Rosenstiehl, J.-M. (ed.). (1991). L'Égypte en Périgord: dans les pas de Jean Clédat. Catalogue raisonné de l'exposition, Musée du Périgord, 16 mai-15 septembre 1991. Paris: Peeters

Rutschowscaya, M.-H. (2010). Nouvelles peintures découvertes dans le monastère de Baouit. In A. Boud'hors and C. Louis (eds), Études coptes XI: treizième journée d'études (Marseille 7-9 juin 2007) [=Cahiers de la Bibliothèque copte 17] (pp. 4551). Paris: De Boccard

Rutschowscaya, M.-H. and Bénazeth, D. (eds). (2000). L'art copte en Égypte: 2000 ans de christianisme. Exposition présentée à l'Institut du monde arabe, Paris du 15 mai au 3 septembre 2000 et au musée de l'Éphèbe au Cap d'Agde du 30 septembre 2000 au 7 janvier 2001. Paris: Gallimard

Schiller, G. (1966). Ikonographie der christlichen Kunst I. Inkarnation, Kindheit, Taufe, Versuchung, Verklärung, Wirken und Wunder Christi. Gütersloh: Mohn

Thierry, N. (1998). Les peintures de Deir Abou Hennis près d'Antinoé. In M. RassartDebergh, Palette égyptienne de la peinture romaine au décor des monastères coptes II [=Solidarité Orient 207] (pp. 5-16). Brussels: Solidarité-Orient

Till, W.C. (1958). Johannes der Täufer in der koptischen Literatur. Mitteilungen des Deutschen Archäologischen Instituts Abteilung Kairo, 16, 310-332

van Loon, G.J.M. (2006). The Virgin Mary and the midwife Salomé. A so-called Nativity Scene in "Chapel" LI in the Monastery of Apollo in Bawit. Eastern Christian Art, 3, 81-102 
van Loon, G.J.M. (2011). Priest and father, prophet and martyr: Zacharias, parent of Saint John the Baptist. In M. Eaton-Krauss, C. Fluck, and G.J.M. van Loon (eds), Egypt 1350 BC-AD 1800: Art historical and archaeological studies for Gawdat Gabra [=Sprachen und Kulturen des christlichen Orients 20] (pp. 87-108). Wiesbaden: Reichert

van Loon, G.J.M. (2014). Decoration of Coptic churches. In G. Gabra (ed.), Coptic civilization: Two thousand years of Christianity in Egypt (pp. 195-216). Cairo: American University in Cairo Press

van Loon, G.J.M. and De Laet, V. (2014). Monastic settlements in Dayr Abu Hinnis (Middle Egypt): The spatial perspective. In E.R. O'Connell (ed.), Egypt in the first millennium AD: Perspectives from new fieldwork [=British Museum Publications on Egypt and Sudan 2] (pp. 157-175). Leuven: Peeters

van Loon, G.J.M. and Delattre, A. (2004). La frise des saints de l'église rupestre de Deir Abou Hennis. Eastern Christian Art, 1, 89-112

van Loon, G.J.M. and Delattre, A. (2005). La frise des saints de l'église rupestre de Deir abou Hennis. Correction et addition. Eastern Christian Art, 2, 167-167

van Loon, G.J.M. and Delattre, A. (2006). Le cycle de l'enfance du Christ dans l'église rupestre de Saint-Jean Baptiste au Deir Abou Hennis. In A. Boud'hors, J. Gascou, and D. Vaillancourt (eds), Études coptes IX: Onzième journée d'études, Strasbourg 12-14 juin 2003 [=Cahiers de la Bibliothèque copte 14] (pp. 119-134). Paris: De Boccard

van Loon, G.J.M. and Delattre, A. (2014). Patterns of monastic habitation on the east bank of the Nile in Middle Egypt: Dayr al-Dik, Dayr Abu Hinnis and al-Shaykh Sa'id: With an appendix on inscriptions. Journal of Coptic Studies, 16, 235-278

van Loon, G.J.M. and Delattre, A. (forthcoming). Dayr Abü Hinnis. The hermitages in the quarries I-II

Wessel, K. (1978a). Johannes Baptistes (Prodromos). In K. Wessel and M. Restle (eds), Reallexikon zur byzantinischen Kunst III (pp. 616-647). Stuttgart: Hiersemann

Wessel, K. (1978b). Jugend Jesu. In K. Wessel and M. Restle (eds), Reallexikon zur byzantinischen Kunst III (pp. 676-687). Stuttgart: Hiersemann

Witte-Orr, J. (2010). Kirche und Wandmalereien am Karm al-ALbbarìya [=Jabrbuch für Antike und Christentum 36]. Münster: Aschendorff

Zervos, G.T. (2004). Caught in the act: Mary and the adulteress. Apocrypha, 15, 57-114 Zibawi, M. (2003). Images de l'Egypte chrétienne: iconologie copte. Paris: Picard 



\title{
Saint Claude à Pohe : un exemple de fonctionnement d'un sanctuaire de pèlerinage dans l'Égypte de l'Antiquité tardive
}

\author{
Ewa Wipszycka \\ Department of Papyrology, Institute of Archaeology, University of Warsaw \\ e.wipszycka@uw.edu.pl
}

\section{KeYwords}

Constantine from Lycopolis, Coptic hagiography, Great Persecution, pilgrimage sanctuary, cult paraphernalia, consensual slavery, Melitian schism

\begin{abstract}
Texts on the martyrdom of St Claudius and on his cult center at Pohe in the Lycopolitan nome were published in 1970 but were never studied exhaustively. This interesting Coptic hagiographic dossier, preserved in its entirety in a codex from the early 9th century (also in smaller fragments from the same period), was put together specifically for the purpose of the cult. Two panegyrics written by Constantine, Bishop of Lycopolis, ordained by the patriarch Damianos (578-607) and his curate in Upper Egypt, are of particular interest as a literary product and at the same time testimony of a pilgrimage center in operation. Two other anonymous texts from the same codex (Pierpont Morgan 587, 9th century), which are both much later, supply historians with useful data on Christian beliefs during the Great Persecution.
\end{abstract}

Parmi les textes de provenance égyptienne qui peuvent nous donner une idée sur le fonctionement des sanctuaires de pèlerinage, il y a un dossier qui, bien qu'il ait été publié il y a longtemps (en 1970), n’a pas encore attiré l'attention des chercheurs qui s'intéressent aux pèlerinages: c'est un groupe de quatre ouvrages écrits en l'honneur de saint Claude, un martyr dont le sanctuaire se trouvait dans la petite localité de Pohe, dans le nome de Lykopolis (Assiout). Ce dossier 
contient plusieurs informations intéressantes, qu'il vaut la peine d'utiliser pour l'histoire du christianisme dans l'Égypte de l'Antiquité tardive.

Ni le sanctuaire de saint Claude, ni le culte de ce saint n'est attesté par des inscriptions ou des papyrus documentaires, c'est pourquoi saint Claude ne figure pas dans le catalogue dressé par Arietta Papaconstantinou (2001). Il est impossible de savoir à quoi est dû le silence des documents épigraphiques et papyrologiques. Les papyrologues ne prétendent pas que toutes les églises importantes d'Égypte aient laissé des traces dans des papyrus.

\section{Saint Claude et son dossier}

Saint Claude, qui aurait subi le martyre sous Dioclétien, est sans aucun doute un personnage fictif. Une tradition copte tardive lui a donné une place parmi les membres de la famille de Basilidès d'Antioche, qui faisaient l'objet d'un cycle de récits épiques ${ }^{1}$. Ces récits sont caractérisés par une grande liberté d'invention. En particulier, les scènes de torture et d'exécution sont très développées, avec un abondant emploi de moyens rhétoriques: les héros soumis à la torture restent vivants contre toute vraisemblance, jusqu'au moment où Dieu juge bon de les laisser mourir. Le plus souvent ils ne souffrent pas, constituant ainsi la preuve de la puissance du vrai Dieu.

Saint Claude est présenté comme un membre du cercle restreint d'hommes qui gouvernaient l'empire, proches de l'empereur. Il aurait été un vaillant chef militaire, il aurait défendu avec succès le souverain sur le champ de bataille. Ses mérites, cependant, n'auraient pas suffi à le protéger quand Dioclétien ordonna à tous ses sujets d'offrir un sacrifice aux dieux païns. Déporté en Égypte, en Thébaïde, il aurait été exécuté à Pohe, localité proche d'Assiout. Son corps aurait été enterré sous le mur d'un temple d'un dieu païen.

Le toponyme Pohe (погє, “enclos") est bien attesté dans des textes documentaires. M. Drew-Bear et S. Timm identifient ce village avec l'actuel Kom Bouh. À proximité

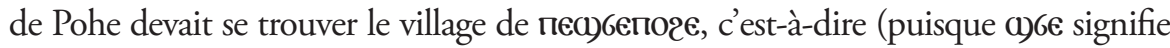
en copte "la colline") Haute Pohe. C'est près de Pohe Basse que Saint Claude aurait été exécuté et enterré (Timm 1984: 422-423, s.v. Būhā; Drew-Bear 1979 : 220). Bien des années plus tard, les restes de son corps auraient été découverts et placés dans un sanctuaire construit exprès pour ce but. Il n'a pas laissé de traces sur le terrain.

1 Theofrid Baumeister (1972) appelait l'ensemble de ces récits le "koptischer Konsens"; voir Orlandi 1986: 78-80 ; 1991a ; 1991b ; 1995 ; Papaconstantinou 2011: 329-332. 
Le dossier concernant saint Claude consiste en un recueil de quatre textes, contenu dans un codex qui fut produit aux environs de l'an 900 et fut trouvé, à peu près complet, sur le site du monastère de saint Michel à Tutun (Fayoum). À présent, ce manuscrit fait partie de la collection Pierpont Morgan ( No $^{\circ} 587$ ). Des passages de trois de ces textes sont conservés également par des fragments de manuscrits produits dans le scriptorium du Monastère Blanc. Il est probable que les copistes qui ont produit ces derniers manuscrits avaient déjà affaire au même recueil qui est contenu dans le manuscrit Pierpont Morgan 587. L'ensemble a été publié par Gérard Godron $(1970)^{2}$. Il existe une traduction arabe (inédite) du recueil tout entier et une traduction éthiopienne d'un seul des quatre textes.

Le texte qui, dans le codex Pierpont Morgan 587, occupe la première place est présenté comme le martyre du saint. À la fin, on lit :

“Moi, Anastase, le serviteur d'Apa Claude, qui ai accompagné mon maître, témoin de tous les prodiges, des souffrances et des grâces que Dieu lui a données depuis Antioche jusqu'au jour où Dieu lui a accordé la couronne du martyre, je les écris, l'un après l'autre.

Le Dieu vivant m’est témoin que je n’ai ni retranché ni ajouté, mais, Dieu m'ayant placé pour l'accompagner, que je les écris de mes mains, afin que l'on se souvienne de moi aussi par la grâce de Dieu, le Christ Jésus.

Celui à qui convient toute gloire, ainsi qu'à son Père plein de bonté et à l'Esprit Saint, jusqu’à l'Éternité des Éternités. Amen. ” (Godron 1970)

Tout ce qui se trouve dans ce colophon a un caractère conventionnel. La déclaration que rien n'a été ni ajouté, ni retranché, est typique des textes hagiographiques coptes, et plus précisément de ceux qui s'éloignent le plus de la réalité. La figure du fidèle serviteur qui accompagne son maitre jusqu’à la mort de celui-ci appartient, elle aussi, aux éléments traditionnels de l'hagiographie copte.

Le texte raconte d'abord comment les persécutions ont commencé. Dioclétien réside à Antioche, il est chrétien (motif banal de l'hagiographie copte), mais il abandonne la foi après avoir vu le comportement malhonnête de l'archevêque d'Antioche. Celui-ci, ayant reçu en cachette des dons importants,

2 Cette édition doit être utilisée avec le livre Godron 1976, où sont publiés de nombreux addenda et corrigenda ainsi que de nouveaux témoins des textes. Malheureusement ce livre ne traite pas de problèmes qui ne sont pas de nature strictement éditoriale; il n'essaie pas de donner une évaluation littéraire de ces textes, ni d'établir les rapports entre eux. 


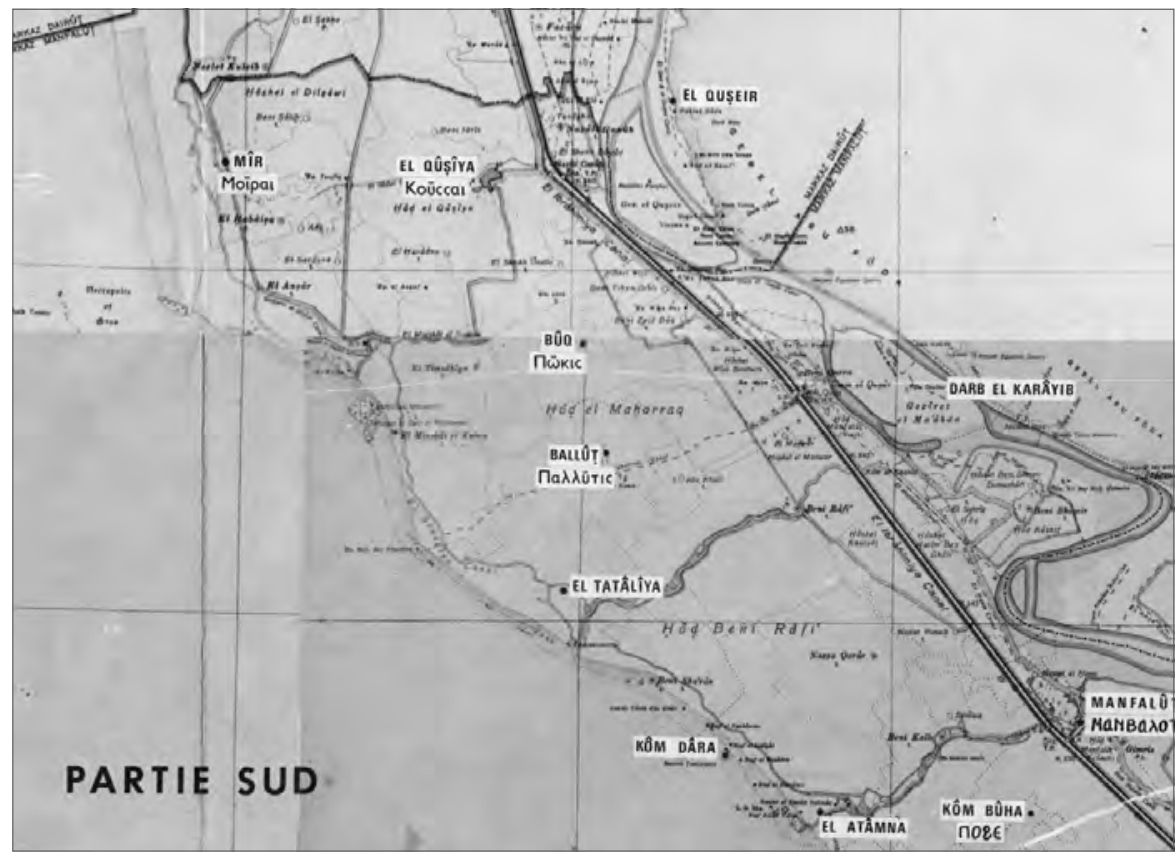

Fig. 1. Carte des alentours du nome d'Hermoupolis (d'après Drew-Bear 1979: Carte 2)

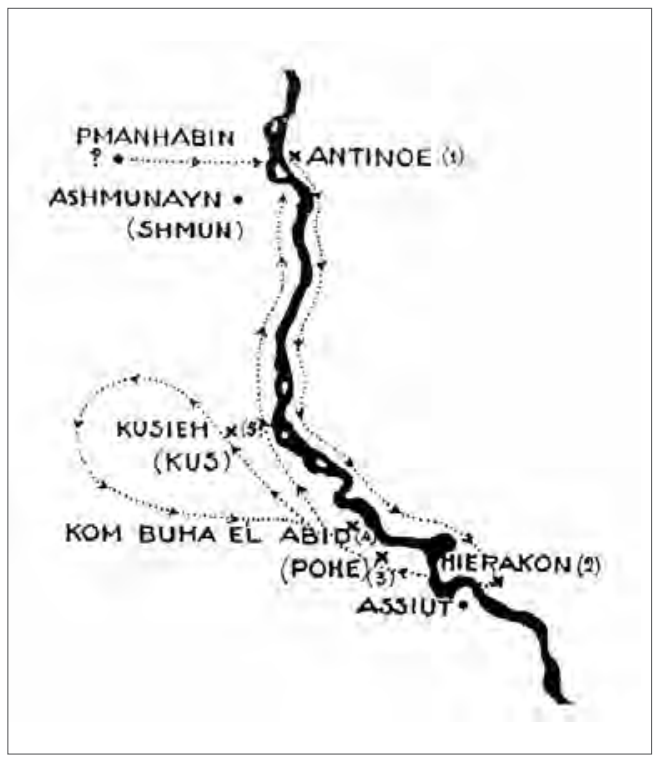

Fig. 2. Chemin que les voleurs auraient parcouru (d'après Drescher 1942: 85) 
avait remis au roi perse son fils qui avait été fait prisonnier au cours d'une guerre contre Dioclétien. L'archevêque avait déclaré à l'empereur que le garçon était mort (cette histoire fantaisiste a l'air d'être une invention originale de l'auteur du texte). Indigné, Dioclétien fait faire soixante-dix statues de divinités païennes en or et en argent, et ordonne que tous ses sujets fassent un sacrifice.

"Il y avait un grand chef, rhéteur, qui craignait Dieu depuis son enfance, suivant la loi de Dieu et ses commandements. Son nom était Claude. C'était de lui que le roi prenait conseil pour les affaires du royaume et les honneurs dans le palais.

Il advint que lorsque le roi eut adoré ses dieux, il appela aussi ses trois stratélates pour qu'ils vinssent aussi adorer [on pourrait penser que ce sont les trois autres tétrarques, mais ils portent des noms différents. $E W]$.

Lorsqu'ils eurent adoré, le roi se tourna vers Apa Claude, le grand rhéteur, et lui dit : "Avance-toi et adore mes dieux, car tu sais, toi aussi, que ce sont eux qui ont marché avec nous le jour du combat. Il nous faut donc les adorer aussi »." (Godron 1970)

Claude refuse d'obéir à cet ordre. Un long dialogue s'ensuit, et finalement :

"Le roi lui dit : "Je te ménage, Claude, parce que tu as combattu pour moi un jour à la guerre, lorsque mes ennemis m’ont entouré, que tu as risqué ta vie et sauvé la mienne de la mort. C'est pourquoi je ne désire pas te tuer. Car je ne te tuerai pas, méchant que tu es! »" (Godron 1970)

Cependant le "roi " (Dioclétien) envoie Claude à Alexandrie. De cette ville, le saint est transporté à Antinoè, et de là il marche sous escorte pour aller se présenter devant Arianus, gouverneur de la Thébaïde, qui voyage dans la province (ce personnage apparaît souvent dans les Actes des martyrs en tant que persécuteur). Les discours et le comportement de Claude devant le gouverneur ont pour conséquence qu'après lui, beaucoup se déclarent chrétiens; le récit des tortures qui leur sont infligées et de leurs discours remplit une bonne partie de l'ouvrage, le complique et l'enrichit. Le martyre de Claude s'accomplit lorsque le saint arrive à птоо мподє ("la montagne de Pohe "), lieu destiné par Dieu pour cela. Il est décapité à la porte d'un temple païen et enterré en ce lieu.

Les lecteurs et les auditeurs du texte d'Anastase pouvaient ainsi apprendre — outre des histoires passionnantes de persécutions — la raison pour laquelle le sanctuaire et les reliques d'un grand martyr d'Antioche se trouvaient dans le village de Pohe. 
La question de savoir pourquoi saint Claude était vénéré justement dans ce village est également au centre du texte qui, dans le recueil du codex Pierpont Morgan 587, se trouve à la deuxième place. Ce texte, selon le colophon qui l'accompagne, serait un encomion que Sévère, patriarche monophysite d'Antioche, aurait prononcé dans un sanctuaire qui avait été bati pour lui et qui " est dans le grand palais d'Antioche ". C'est un texte très bref, conservé exclusivement dans ce codex. Il contient principalement un récit de la découverte du corps de saint Claude. Sévère affirme que le saint lui était apparu en rêve, lui avait indiqué l'endroit où son corps était enseveli et lui avait ordonné de construire un martyrion à cet endroit. Il affirme en outre avoir été aidé, dans l'exécution de la volonté du saint, par Apa Stéphanos, moine et presbytre du lieu, qui, d'une façon miraculeuse, aurait eu connaissance de la vision de Sévère. Le habitants de Pohe auraient travaillé avec enthousiasme à la construction du martyrion : " toute la population se rassembla avec des bêtes et des outils pour creuser et nous détruisîmes le temple. Nous le purifiâmes, chacun apporta autant d'or qu'il put et le donna au prêtre Apa Stéphanos et l'on commença la construction du sanctuaire. "Suit le récit de la translation du corps dans le sanctuaire et de la consécration de celui-ci.

James Drescher, le premier éditeur de cet Éloge, a remarqué qu'il n’avait pu être écrit par Sévère ${ }^{3}$. Le narrateur, qui se présente sous le nom de Sévère, évêque d'Antioche, prétend être revenu à Antioche après des années d'exil, alors que nous savons que Sévère ne put revenir à la capitale de son patriarcat et qu'il est mort en Égypte. Il est étonnant, en outre, que le narrateur situe le sarcophage contenant le corps de saint Claude à deux endroits : à Antioche et à Pohe. L'auteur, manifestement, ne s'est pas soucié de cette incohérence. C'est sans doute pour augmenter le prestige du sanctuaire de Pohe que la découverte des reliques du saint a été attribuée à Sévère d'Antioche.

Les deux autres textes du recueil sont des Panégyriques qui, dans les colophons du manuscrit, sont attribués à un auteur copte qui est bien connu de nous, Constantin, qui fut évêque d'Assiout à la fin du VI et dans les premières décennies du VII ${ }^{e}$ siècle (Garitte 1950 ; Orlandi 1974: V-XIX, introduction ; Coquin 1981 ; Coquin et Samir 1991). Il est l'un des évêques célèbres consacrés par le patriarche Damien (578-607) et fut vicaire (diadochos) de celui-ci pour la Haute-Égypte. Certains de ses ouvrages se sont conservés.

L'attribution de ces Panégyriques à l'évêque Constantin suscite bien des problèmes. Garitte, le premier chercheur qui a consacré une étude sérieuse à ce

3 Drescher 1944. Voir aussi De Lacy O’ Leary 1952 (malheureusement, ce chercheur ne connaissait pas l'article de Drescher). 
personnage, exprima des doutes au sujet de cette attribution à cause d'un détail du récit d'un des miracles qui, selon le narrateur, auraient eu lieu en sa présence (Garitte 1950: 298-300). Le héros négatif de ce récit est présenté comme étant l'un des fonctionnaires (magistrianos) qui auraient été envoyés par l'empereur Anastase pour lever un impôt extraordinaire frappant tous les habitants de l'Égypte (un sou d'or par tête, riche ou pauvre) : ce fonctionnaire et les soldats de sa suite se seraient comportés d'une manière brutale au cours de la fête dans le sanctuaire; saint Claude, le patron du sanctuaire, serait alors apparu à la foule sous les traits d'un chef militaire de haut rang (d'un stratelates), sur un cheval blanc, "vêtu d'un manteau royal, sanglé d'un ceinturon de garde du corps, une épée dégainée à la main et accompagné d'une troupe de soldats ", et aurait tué le magistrianos. Or, Anastase a régné de 491 à 518, une centaine d'années avant que Constantin ne devînt évêque d'Assiout. Cela prouverait, selon Garitte, que le Panégyrique contenant ce récit n'a pas été écrit par Constantin. (Garitte ne s'est pas étonné d'autres détails étranges contenus dans ces textes. Notons, à l'occasion, que l'impôt extraordinaire, égal pour tous, que, d'après le récit, l'empereur aurait ordonné de lever en Égypte, est tout à fait invraisemblable, contraire à la pratique fiscale - que ce soit celle du VI ${ }^{\mathrm{e}}$ ou de la première moitié du VII siècle.)

Le raisonnement de Garitte n'a pas convaincu Orlandi. Selon ce savant, il serait possible que le nom de l'empereur, Anastase, soit un lapsus d'un copiste; il serait tout aussi possible que l'auteur se soit servi, pour nommer l'empereur, du premier nom qui lui était venu à l'esprit, sans se soucier de l'exactitude historique : dans un récit de miracles, un comportement pareil ne serait pas étonnant ${ }^{4}$.

Cependant, il existe d'autres raisons pour douter que les Panégyriques en l'honneur de saint Claude aient été écrits en entier par Constantin. Si on les compare avec les Panégyriques en l'honneur d'Athanase, dont l'attribution à Constantin est sûre, on constate une grande différence de niveau littéraire. Les premiers n'ont pas un construction claire, ils ce sont des ensembles d'épisodes mal cousus entre eux; les derniers sont de bons produits rhétoriques, écrits dans un style solennel et développant une ligne de pensée clairement reconnaissable 5 .

4 Orlandi 1974: V-VI : " per un publico disposto ad accettare (anzi a pretendere) narrazioni come quella di cui si parla, non si sarà certo preoccupato di scegliere il nome di un imperatore cronologicamente plausible".

5 Sheridan 2011: "Obviously we are in a different and later cultural world than that of the real Constantine of Assiut. These are stories that circulated in the shrines of the martyrs Claude and Victor ... The author's contact with the classical rhetoric tradition has been minimal. It is simple impossible that the same writer capable of producing the encomia of Athanasius could also have produced these of Claude ". 
Le Panégyrique I raconte diffusément les actions héroïques que Claude aurait accomplies pour assurer l'incolumité de Dioclétien pendant la guerre contre les Arméniens et les Thraces, ainsi que les persécutions ordonnées par cet empereur et le martyre de Claude. Toutes ces informations, Constantin les aurait trouvées "dans la première histoire écrite par le philosophe Aristotèlos, d'après Anastase, le serviteur d'Apa Claude, lorsque ce dernier revint d'Égypte après la mort de son maître. On la déposa dans la bibliothèque de la grande ville de Cappadoce. Il fit connaître son martyre aux Égyptiens " (pp. 576-577). Dans le Panégyrique II aussi, il est dit qu'Anastase transmit ses souvenirs de son maître à "Aristotèlos " (pp. 596-597). En dépit de ces déclarations, les épisodes présents dans le texte d'Anastase ne se retrouvent pas dans les Panégyriques attribués à Constantin. Il existe aussi des différences importantes : selon Constantin (mais non selon Anastase), Dioclétien, à un certain moment, aurait décidé de rappeler Claude de l'exil, mais cet ordre serait arrivé trop tard, et l'empereur, fâché, aurait fait mettre Arianos en prison (pp. 600-603).

Entre le premier et le second Panégyrique, on constate quelques différences concernant les détails : dans le premier, les guerres menées par Claude ont pour adversaires d'abord les Mansiketes ou Mansaketes (pp. 514-515), ensuite les Arméniens et les Thraces (pp. 518-519) ${ }^{6}$; dans le second, Claude combat contre les Perses, comme dans l'ouvrage d'Anastase.

Des histoires fantaisistes comme celle-ci, il y en a beaucoup dans ces Panégyriques.

Malgré tout cela, il n’est pas du tout évident qu'il faille nier la paternité de Constantin pour la totalité des deux Panégyriques. Les informations contenues dans les deux colophons (je vais les examiner plus loin) s'accordent avec ce que nous savons de l'époque où Constantin, évêque d'Assiout, vécut; et il est difficile d'imaginer qu'elles aient pu être écrites par quelqu'un qui aurait vécu beaucoup plus tard. Les miracles racontés par Constantin ont un caractère tout à fait différent de celui des miracles qu'on lit chez Anastase ou dans les parties de nos deux Panégyriques qui ont pu être empruntées à Anastase : ils sont très détaillés et solidement encadrés dans les réalités géographiques et historiques (à une seule exception près : épisode indiqué par Garitte $)^{7}$. Orlandi a trouvé des analogies étroites entre ce que Constantin dit de l'éducation de Claude (pp. 514-517) et ce qui, dans l'Histoire ecclésiastique sur Eusèbe (VII 30, 22), est dit de la position qu’Anatolios, évêque de Laodicée de

6 Godron y voit les Mazikes. La traduction arabe donne à cet endroit Béjas, c'est-à-dire les Blemmyes.

7 Dans le Panégyrique I, ces miracles se trouvent aux pp. 578-591; dans le Panégyrique II, aux pp. 616-669. 
Syrie, occupait dans le monde de la culture alexandrine. Constantin n'a pas copié ce passage d'Eusèbe; il l'a utilisé, d'une façon originale, comme modèle. C'est là, selon Orlandi, une opération dont un auteur plus tardif n'aurait pas été capable. Orlandi soutient que les Panégyriques écrits par Constantin sont à l'origine du cycle hagiographique de la famille des Basilidès d'Antioche, qui a été très populaire dans la littérature copte, devenant de plus en plus riche et compliqué au cours des siècles.

Dans le Panégyrique II, à la fin du récit du martyre de Claude (récit dont il est dit qu'il provient du texte d'Anastase) et quelques lignes avant le premier récit de miracle (récit qui, à mon avis, doit être attribué à Constantin), il y a un passage qui peut susciter des problèmes : "Voilà ce que j'ai trouvé dans la bibliothèque de Cappadoce au temps où je faisais la route avec mon frère Apa Rufus, ermite (apotaktikos) comme moi, étant donné que nous nous rendions, cette année-là à la ville sainte de Jérusalem, pour vénérer la croix, avant de venir ici " (pp. 614-615; “ ici ”, cela veut dire " à Lykopolis ”). Il ne faut pas trop s'étonner que dans un texte hagiographique copte tardif, le chemin de l'Égypte à Jérusalem passe par la Cappadoce. Il faut plutôt se demander d'où le rédacteur de ce corpus savait que Constantin avait été un ami d'Apa Rufus. Celui-ci est un personnage historique, évêque de Shotep, ayant été ordonné - de même que Constantin - par Damien ; les deux évêques se connaissaient certainement, puisqu'ils provenaient d'un même milieu (Rufus de Shotep, Homélies). Je me demande : y avait-il peut-être des informations à ce sujet dans le Panégyrique original? Ou bien le rédacteur n'était-il pas si ignorant que je le pense? Peut-être connaissait-il les écrits de Rufus assez bien pour savoir que celui-ci avait été un contemporain de Constantin; en ce cas, la mention de Rufus pourrait n'être qu'un expédient littéraire, destiné à rehausser la valeur du texte.

Je suppose que ce que le codex Pierpont Morgan 587 nous a transmis est l'œuvre d'un rédacteur tardif qui aurait fait une opération compliquée, consistant à créer un grand corpus de textes sur saint Claude à partir des écrits attribués à Anastase et des Panégyriques de Constantin. Je n'exclurais pas qu'il ait écrit lui-même le Panégyrique en l'honneur de Sévère. J'ai raison de penser que c'est lui qui a introduit dans les textes de Constantin des mentions d'Anastase et de Sévère. L'opération aurait privé les Panégyriques écrits par Constantin de leur logique interne. Des sutures sont nettement visibles, qui témoignent d'un travail de compilation. Certaines informations saugrenues concernant le passé s'expliquent : vivant dans une Égypte isolée du reste du monde chrétien, le rédacteur ne savait plus rien des guerres faites par l'empereur, ni du pouvoir impérial ou des coutumes de la cour de Constantinople. Ce qui lui importait, c'était de lier le corpus des récits concernant saint Claude aux récits concernant d'autres héros du cycle des martyres d'Antioche : c'est ce qui explique les 
nombreuses mentions d'Apa Victor ${ }^{8}$, un célèbre martyr qui aurait été un ami de saint Claude et dont le sanctuaire se trouvait sur la rive est du Nil, à peu près à la hauteur de Pohe (les textes de ses Passions étaient très populaires).

Ayant ainsi récupéré au moins une partie de l'œuvre de Constantin, je peux passer à ce qui fait proprement l'objet de cet article, c'est-à-dire à l'étude des récits de ce qui se passait dans le sanctuaire de saint Claude.

Naturellement, le fait que l'auteur soit un évêque connu de nous et qui a prononcé ces Panégyriques devant des foules participant à une fête dans le même sanctuaire, ne nous garantit pas que ces récits correspondent à des événements réels. Comme tant d'autres prédicateurs et hagiographes, Constantin a pu inventer des exempla. Cependant, la question de savoir si les personnages de ces récits sont réels ou fictifs n'a pas d'importance pour moi, car ce qui m'intéresse, ce ne sont pas les événements individuels. Le cadre dans lequel Constantin plaçait ses récits devait sembler normal et crédible au public présent dans le sanctuaire, même si les événements racontés étaient fictifs.

\section{Les colophons des Panégyriques par Constantin}

Voici, l'un après l'autre, le colophon du premier et celui du deuxième Panégyrique :

“Panégyrique prononcé par notre saint père, vénéré en tout point et porteur de toutes les vertus de l'Esprit Saint, Apa Constantin, évêque de la ville d'Assiout; (panégyrique) prononcé au sujet du bienheureux vaillant, vrai porte-couronne du Christ, du commandant de camp vainqueur et athlète bon combattant, de l'écuyer du grand roi, du martyr vénéré, Saint Apa Claude. Il le prononça en son saint oratoire, alors qu’il célébrait la fête avec tout le peuple des trois villes, une grande foule s'étant jointe aux philopones (et) en présence du préfet, du commandant des forces armées et d'un agent impérial que le roi avait envoyé avec des lettres de paix et qui était arrivé pour la fête du saint martyr, au jour de sa sainte commémoraison, c'est-à-dire le onze du mois de paôné; dans la paix de Dieu. Amen ". (Godron 1970)

“Second panégyrique prononcé par Apa Constantin, évêque de la ville d'Assiout. Il le prononça au sujet du valeureux athlète et porte-

8 Des pp. 524-525 aux pp. 570-571, Victor constamment présent auprès de Claude. 
couronne du Christ, le saint Apa Claude, le vénéré commandant des forces armées, vierge et martyr. Il le prononça dans son saint oratoire, alors qu'il célébrait sa fête avec le peuple tout entier, hommes et femmes, et une foule de la ville de Chmoun, qui étaient venus pour la fête, désireux d'entendre son enseignement suave. Était présent le vicaire du patriarche, qui était venu au sud, en Égypte, et était arrivé pour la fête du martyr; et, voyant les miracles qui se produisaient dans son sanctuaire, il les mit par écrit et les porta au patriarche Apa Andronicos, qui s'en réjouit beaucoup et les lut au peuple tout entier de la ville d'Alexandrie; dans la paix de Dieu. Amen ". (Godron 1970)

Dans le colophon du premier Panégyrique, d'après le codex Pierpont Morgan 587, il est dit que les fidèles qui participèrent à la cérémonie pendant laquelle Constantin prononça l'éloge du saint, étaient venus de trois villes. Dans un manuscrit de la Biblioteca Laurenziana, le Medic. 125 (daté de 1508), le colophon précise que les fidèles étaient venus de Lykopolis, d'Hermoupolis et de Panopolis?. On peut se demander pourquoi Antinoé - qui était proche de ces villes — n'a pas été incluse dans la liste, mais il se peut que celui qui a écrit ce colophon n'ait indiqué des noms de villes qu'exempli gratia.

La mention de la présence des philoponoi - membres de confréries lä̈ques - n'est pas surprenante. Nous savons par ailleurs que dans les fêtes réunissant des foules de fidèles, les philoponoi formaient un groupe à part, chantant des psaumes et d'autres chants religieux et aidant le clergé à maintenir l'ordre (Wipszycka 1996). Ils apparaissent dans différents textes littéraires, le plus souvent justement dans des colophons, ce qui m'inquiète un peu : on peut en effet se demander si mentionner les philoponoi dans un colophon n'était pas une convention (voir Wipszycka 1996: 262-263).

À la fête dans le sanctuaire de saint Claude participent des hôtes prestigieux. Le premier Panégyrique mentionne deux hauts dignitaires, un eparchos et un stratelates. Compte tenu de l'époque où le Panégyrique fut prononcé, il faut sans doute entendre le terme eparchos comme un équivalent de hegemon = praeses; il s'agit donc du gouverneur de la province de Thébaïde Inférieure, dont les compétences étaient du domaine civil et qui résidait à Antinoé.

Il n'est pas aussi facile de décider comment il faut entendre stratelates, terme qui pouvait désigner divers chefs militaires de haut rang. Étant donné que la fête eut lieu dans le sanctuaire de saint Claude, il est naturel de supposer que le stratelates mentionné dans notre texte était le gouverneur de la Thébaïde

9 Cela a été vu par P. Peeters cité dans Garitte 1950: 292. 
Supérieure. Ayant un rang plus élevé par rapport à celui de la Thébaïde Inférieure, le gouverneur de la Thébaïde Supérieure portait le titre de dux et augustalis et avait des compétences à la fois civiles et militaires (car à la frontière méridionale de cette province stationnait une importante garnison). Nous ne pouvons cependant pas exclure totalement que le stratelates mentionné ait été un autre haut fonctionnaire portant le même titre : le gouverneur de la province Aegyptus I, résidant à Alexandrie, ou celui de la province Augustamnica I, résidant à Arsinoé. Que l'un ou l'autre de ces deux gouverneurs ait participéà une cérémonie près d'Assiout, n'est pas impossible, bien que ce ne soit pas probable. Une autre possibilité qu'il faut envisager, est celle de supposer que stratelates, dans le texte en question, désigne un chef militaire de rang inférieur par rapport au dux et augustalis, car nous savons que ce terme pouvait être employé de cette manière ${ }^{10}$. Certes, notre connaissance des lieux de stationnement des unités militaires vers la fin $\mathrm{du} \mathrm{VI}{ }^{\mathrm{e}}$ et au début du VII ${ }^{\mathrm{e}}$ siècle (en dehors du limes) est modeste, mais puisque nous savons quau temps de Justinien, des soldats stationnaient à Pbau (centrale des monastères pachômiens) et à Antaiopolis, il est permis de supposer que dans la Thébaïde Inférieure, il y avait des unités militaires et que leurs chefs pouvaient être appelés stratelatai.

Encore un autre personnage important, selon l'auteur du colophon, aurait été présent à la cérémonie pendant laquelle Constantin aurait fait l'éloge du saint : un magistrianos, qui serait arrivé là en portant des "lettres de paix " de la part de l'empereur. Les magistrianoi, dits aussi agentes in rebus, nous les connaissons par ailleurs : c'était des membres d'un corps spécial de courriers, qui portaient souvent les ordres de l'empereur; ils servaient également à espionner les fonctionnaires dans les provinces pour le compte de leurs supérieurs.

La mention, dans ce colophon, des "lettres de paix " impériales (2€NC2dI NIPHNIKON) est énigmatique. Le terme est connu de nous, mais il n'est attesté qu'en tant que terme désignant des lettres échangées entre évêques comme signes de communion. Si le stratelates du Panégyrique I était le dux et augustalis de la Thébaïde Supérieure, on peut supposer que ce haut fonctionnaire fit un voyage vers le nord pour rencontrer le magistrianos et recevoir de lui une dépêche urgente de l'empereur. Si la fête en l'honneur de saint Claude avait lieu non loin de l'endroit $\mathrm{du}$ lieu de rencontre de ces deux fonctionnaires, ceux-ci ont pu y participer.

La présence de ces dignitaires à Pohe dans une fête réunissant une foule de fidèles est un fait d'autant plus remarquable qu'en tant que fonctionnaires de haut rang, ils appartenaient certainement à l'Église chalcédonienne, alors que

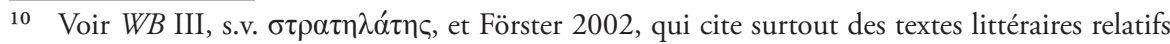
aux célèbres martyrs Théodore et Phoibammon. 
l'orateur, Constantin, était un monophysite, vicaire du patriarche monophysite Damien. Cette situation contraste avec l'idée qu'on se fait de ce qu'ont pu être les rapports entre chalcédoniens et anti-chalcédoniens au temps de l'empereur Héraclius qui persécutait énergiquement les monophysites. Le Panégyrique I s'ajoute ainsi aux témoignages qui nous obligent à corriger l'opinion courante au sujet des rapports entre les deux Églises (voir Wipszycka 2015: 418-438).

Le colophon du Panégyrique II dit que ce discours fut prononcé devant " le peuple tout entier, hommes et femmes, et une foule de la ville de Chmoun, qui étaient venus pour la fête du martyr ". Il ne mentionne pas d'autres villes. Il est cependant vraisemblable qu'il y avait, dans la foule, également des gens venus d'autres villes, du moins de la ville d'Assiout, très proche de Pohe. Le copiste a pu abréger la liste qu'il avait devant les yeux.

La mention de la présence du vicaire (diadochos) du patriarche est très importante. Le colophon ne donne pas son nom, ni le nom de la ville dont il était évêque. Il donne en revanche le nom du patriarche qu'il représentait : Andronikos. Nous savons que celui-ci fut patriarche dans les années entre 619 et 626. Cela nous permet d'établir la date précise du Panégyrique II : le 5 juin (fête de saint Claude) de l'an 619. En effet, Andronikos était déjà évêque d'Alexandrie, et l'invasion perse n'avait pas encore commencé (elle commença vers le mois de juillet de 619). Il est invraisemblable qu'une grande fête ait eu lieu en Haute Égypte et qu'un vicaire du patriarche ait pu se rendre à Pohe à l'époque de l'Invasion perse.

\section{Informations sur le sanctuaire de saint Claude}

Dans les colophons des deux Panégyriques en question, le sanctuaire de saint Claude est appelé eukterion, tandis que dans le texte même de ces deux ouvrages, c'est presque toujours le terme topos qui est employé pour le désigner, ekklesia apparaît une seule fois, une fois apparaît aussi eukterion (pp. 508-509, dans le préambule : il se peut que le copiste l'ait pris du colophon). Je ne crois pas qu'il faille se préoccuper de cette incohérence terminologique. Certes, on a l'habitude de traduire eukterion par "oratoire" (voir par exemple le dictionnaire de Lampe : house of prayer, oratory") et de penser que le terme désigne un lieu de culte de rang inférieur par rapport à une église; mais dès le VI ${ }^{\mathrm{e}}$ siècle, la terminologie concernant les lieux de culte cessa d'être précise (on ne distinguait plus, par exemple, ekklesia de martyrion). Les exemples cités dans le dictionnaire de Förster n'aident pas à comprendre le sens exact de eukterion. 
Les fidèles qui entraient dans l'église d'un sanctuaire comme celui de saint Claude voyaient " le sanctuaire illuminé d'une multitude de lampes et d'étoffes de prix " (p. 627). Le fort éclairage et le jeu des couleurs des tapisseries produisaient chez eux un choc, les transportaient dans une réalité presque paradisiaque. L'effet était intensifié par les parfums, car à l'huile des lampes on ajoutait des substances aromatiques qui s'évaporaient.

Une partie des lampes étaient suspendues à des chaînes, d'autres étaient fixées à des candélabres, d'autres enfin se trouvaient dans des niches. Certaines brûlaient sans cesse, jour et nuit. L'entretien des lampes faisait partie des devoirs du clergé. Plus le sanctuaire était grand et plus la fête était importante, plus nombreuses étaient les lampes qui brûlaient (T. Górecki dans : Wipszycka 2015: 343-348, Appendix B : Lighting of the churches). Les tapisseries étaient attachées aux murs ou suspendues entre les colonnes. Nous pouvons imaginer quel était leur aspect non seulement grâce à des descriptions, mais aussi grâce à des fragments conservés (Clarysse et Geens 2009).

Quelques informations sur ce qui se trouvait dans l'église du sanctuaire de saint Claude nous sont fournies par un récit du Panégyrique II de Constantin d'Assiout (épisode 3) : c'est l'histoire d'un vol accompli par des malfaiteurs qui, ayant fait croire à l'économe qu'ils voulaient passer la nuit en priant, seraient restés à l'intérieur de l'église après que celle-ci avait été fermée. Parmi les objets volés, est mentionnée une lampe d'argent " qui brillait près de l'autel " (pp. 616-617). Il vaut la peine d'observer un détail : la lampe n'était pas “ sur ”, mais " près de " l'autel; la sainteté de l'autel excluait qu'on pût y placer un objet aussi banal qu'une lampe, fût-elle d'argent. Voici les autres objets que les voleurs auraient emportés : " des ornements de soie sur le corps du Juste, une croix d'argent suspendue à une chaîne d'argent, des calices en argent, des plateaux (trapeza) en argent, un plateau en argent au centre duquel se trouvait une croix d'or " (p. 643). Pour sortir de l'église fermée, les voleurs, des païens, auraient eu recours à la magie ${ }^{11}$.

Ce récit a besoin d'un commentaire. Dans la réalité, les calices et les plateaux en argent, on ne les laissait évidemment pas traîner n'importe où dans l'église, on les gardait dans un endroit sûr, bien fermé; parfois, l'économe les emportait chez lui (Wipszycka 2015: 368-369). Les Canons d'Athanase un texte normatif de la fin du $\mathrm{IV}^{\mathrm{e}}$ ou du début du $\mathrm{V}^{\mathrm{e}}$ siècle — rappellent avec force le devoir de protéger les objets de ce genre (Can. Athan. 61-62). Dans les églises d'importance secondaire, le clergé était tenu de montrer ces objets

11 Cet épisode a été publié à part, avec un bon commentaire, dans Drescher 1942. 
à l'économe de l'évêque au moins une fois par an ${ }^{12}$. Le vol des patènes et des calices, qui entraient en contact avec le pain et le vin eucharistiques, était considéré non seulement comme une perte matérielle, mais aussi comme un sacrilège dangereux pour toute la communauté.

Comme dans cet ouvrage de Constantin d'Assiout, dans d'autres textes aussi il est question d'un vol d'objets précieux dans une église et de la punition miraculeuse qui aurait frappé le voleur : c'était là un motif littéraire attrayant ${ }^{13}$.

Le Panégyrique II de Constantin mentionne une agape qui eut lieu pendant la fête en l'honneur de saint Claude (pp. 581-585) : c'était un banquet pour tous ceux qui participaient à la fête ${ }^{14}$. Des agapai sont mentionnées également dans les miracula de saint Ménas ${ }^{15}$ ainsi que dans des papyrus : SBX 10269 et P. Oxy. LXVI 3864 (voir Papaconstantinou 1992).

12 Certains papyrus nous permettent de voir ce qui pouvait se trouver dans des églises nonépiscopales. Voir par exemple P. Grenf. II 111 ( $\mathrm{V}^{\mathrm{e}} / \mathrm{VI}^{\mathrm{e}}$ siècle), contenant une liste des objets de l'église d'Apa Psoios dans le petit village d'Ibion — une église qui, érigée par un certain Apa Psoios, n'était même pas l'église paroissiale de cette localité. La liste fut dressée par l'archidiacre Élie et remise à Jean, presbytre et économe. Cette petite église possédait: trois calices en argent, un broc en argent, deux tapisseries pour l'autel, un autel de marbre, un trépied de bronze, vingt-trois nappes de lin pour l'autel, cinq nappes de laine pour la table, six tapisseries pour les portes, quatre lampes de bronze, huit lampes d'un autre type, deux lampes de fer, un autel de bronze, deux bassins de bronze, un vase pour ablutions, un broc, un couteau, un cercueil et un autre cercueil de bois, deux coussins de cuir, trois chaises avec dossier, deux chaises d'un autre genre, et vingt et un codex en parchemin. Une liste des documents (grecs et coptes) témoignant des objet précieux appartenent aux églises se trouve dans Schmelz 2002: 93-125.

13 Voici un épisode raconté comme exemplum dans un texte normatif, Can. Athan. 90: "I know of a marvel which befell in my days, when I was a youth, in the church. A thief entered the church and stole from among the vessels. And he could not flee, because the divine providence hindered him; and they drove him forth from the holy place. But instead of fleeing, he, as they tell, continued fighting with the priests, since the guardian had not laid hold upon him. And still went he not forth but rather remained, smiting and being smitten, if perchance he might be able to take the vessels. And while he was embroiled with them, the officers came upon him and laid hold of him and delivered him unto the authority, because he had ventured and entered in unto the holy vessels. But we, O my brethren, let us keep ourselves from all such wickedness".

14 Il est intéressant d'observer que dans ce banquet, le vin n'était pas prévu. Cela ressort de ce qui est raconté au sujet du mauvais comportement de magistrianos et son groupe de soldats: la nourriture était prête sur les tables, mais le vin, c'est le magistrianos qui le fit apporter (pp. 584-585).

15 Dans Drescher 1946: 157-159, le héros (négatif) du miracle est un homme riche, qui donnait tous les ans, pour la fête dans le sanctuaire, 25 cochons et 25 veaux. Ces chiffres sont fictifs, mais la pratique de dons pour l'agape ne l'est pas. 


\section{Les visiteurs du sanctuaire}

Constantin d'Assiout met en relief la présence d'une foule de gens pendant la fête. Parmi ceux qu'il choisit comme héros de ses histoires de miracles, il y a même des païens, un mélitien et une personne qui pratique la magie. Cette manière de procéder est normale chez les auteurs de récits de miracula : par exemple, dans le recueil de récits concernant des miracles qui auraient eu lieu dans le sanctuaire de saint Ménas, nous rencontrons des païens, des Juifs, un samaritain, un zoroastrien. Manifestement, les miracles que les saints auraient faits pour des gens vivant hors de la vraie foi véritable étaient plus intéressants, servaient à montrer la générosité des saints.

Le sanctuaire de saint Claude à Pohe était visité également en dehors des jours de fête, mais alors par des individus isolés ou de petits groupes. Dans le Panégyrique I nous lisons (pp. 579-581):

“Il y eut dans ce sanctuaire un prêtre qui en était l'économe. Il était charitable et hospitalier, sa table était ouverte à quiconque marchait sur les routes, sa renommée s'était étendue très loin. À sa mort il fut remplacé par un autre, extrêmement cruel, qui haïssait les pauvres. Il advint, un jour, que quatre hommes égarés arrivèrent à la tombée de la nuit. Ils allèrent au sanctuaire d'Apa Claude pour y dormir jusqu'au matin. C'étaient des hommes de Psoï, venus là en se rendant à Antinoé pour se plaindre au duc d'avoir été maltraités par les magistrats. S'étant attardés et couchant dehors malgré leur désir d'entrer, ils furent rabroués par cet économe, qui ne leur donna ni pain ni nattes, mais les laissa auprès du portique du sanctuaire, rejetés misérablement. Lorsque la nuit fut arrivée, voici que le saint Apa Claude vint au seuil de la porte du sanctuaire sous les traits d'un respectable magistrat. Il dit aux hommes : "Vous couchez ici, vous, avec les bêtes? - Nous sommes, répondirent-ils, des étrangers, habitants de Psoï ». Il ordonna à son serviteur d'appeler l'économe, qui vint ouvrir la porte, une chandelle à la main. Il vit le magistrat et se prosterna devant lui en disant : " D'où est venu le magistrat à cette heure? — Je suis, dit-il, du sud, de la province d'Esna; je suis venu pour recevoir la bénédiction dans ce sanctuaire et lui faire une petite offrande. - Tu es le bienvenu, vénérable magistrat, lui dit l'économe; entre, homme vertueux ». Il dit au portier d'étendre des nattes et des couvertures et il tua un mouton ...”. (Godron 1970) 
Il ressort de ce récit que des visiteurs pouvaient dormir dans l'église du sanctuaire, si l'économe le leur permettait. Cela ne plaisait pas à tout le monde, comme en témoigne le Codex Theodosianus IX 45, 6 (de l'an 431), où Théodose II interdit ce genre de comportement, mais la pratique pouvait s'écarter des normes. Certes, dans les grands sanctuaires, on construisait des portiques ou des exèdres pour les malades et les visiteurs, cependant, dans d'autres sanctuaires, moins importants, on tolérait que des lä̈cs passent une nuit dans l'église.

J'ai déjà mentionné un récit de Constantin d'Assiout (p. 643), d'après lequel des malfaiteurs auraient le fait croire à l'économe qu'ils voulaient passer la nuit dans l'église pour prier.

\section{Le mélitiens à Lykopolis}

Dans le Panégyrique II, Constantin mentionne le groupe schismatique des mélitiens, dont des sectateurs, comme nous l'apprenons par son témoignage, étaient présents à Assiout. Voici ce qu'il dit à ce sujet (p. 627) :

“J'ai beaucoup souffert des plantes que Mélèce a plantées. Je n’ai pas pu les déraciner de cette ville, car il avait détaché bien des gens de la foi au Fils de Dieu en tenant des propos blasphématoires contre la Trinité. Il n'enseignait pas la pratique des Écritures, mais il disait: «le Père, le Fils, l'Esprit Saint » en les séparant les uns des autres. Cette foi a subsisté dans la ville d'Assiout jusqu'à aujourd'hui ". (Godron 1970)

Cette rapide caractérisation de la foi des mélitiens semble, à première vue, correspondre plutôt aux ariens qu'aux mélitiens. Ces derniers, du moins dans la première moitié du IV ${ }^{\mathrm{e}}$ siècle, ne se distinguaient pas, au point de vue dogmatique, des catholiques. C'est à cause de leurs alliances tactiques avec les ariens, au cours de la lutte contre Athanase, qu'ils ont pu être considérés comme étant proches des ariens ${ }^{16}$. Cependant, l'opinion exprimée par Constantin et le fait qu'il affirme que la foi des mélitiens est encore présente à Assiout en dépit de ses efforts visant à la déraciner, doivent être pris au sérieux. Je ne vois pas pourquoi l'évêque de cette ville aurait introduit les

16 Au sujet de Mélitios et des raisons pour lesquelles il refusa de se soumettre à l'évêque d'Alexandrie, Pierre (300 ou 303-311), voir Wipszycka 2015: 81-91 et Camplani 2011. 
mélitiens dans son récit, si ce groupe religieux avait cessé d'exister longtemps auparavant ${ }^{17}$. Constantin était un homme cultivé; il a pu savoir beaucoup au sujet de ses adversaires. Il se peut qu'au début du VII ${ }^{\mathrm{e}}$ siècle, la position dogmatique des mélitiens au sujet de la Trinité fût été très différente de celle qui était généralement acceptée à cette époque par les fidèles égyptiens.

Dans le même Panégyrique, Constantin rapporte — selon ce qu'il déclare - un récit concernant Mélitios et qui se trouverait dans un ouvrage d'Anastase (mais ce récit manque dans le texte attribué à Anastase que nous possédons). Mélitios, évêque d'Assiout, se serait rendu à Pohe avec une charrette dans le but d'emporter le corps de saint Claude, il aurait donné des pièces d'or aux prêtres du temple païen afin qu'ils lui remissent le corps du saint, et les prêtres se seraient laissés convaincre par lui. Mais le saint serait apparu à Anastase :

"Au milieu de la nuit, mon maître vint à moi et me dit : "Anastase, ne vois-tu pas la charrette qu'on a amenée pour transporter mon corps vers le sud? - Que ferai-je, Monseigneur, dis-je? - Il ne pourra pas le transporter, Anastase, me dit-il, et je ne permettrai en aucune façon qu'il pénètre dans le lieu où est mon corps, parce qu'il est corrompu comme [lacune dans le manuscrit]. Il n'est pas digne du pain dont se rassasient les chiens, car il a blasphémé contre le Christ en le divisant et en s'opposant au Christ et à son saint patriarche Apa Pierre à Alexandrie en disant: ' Je placerai toute l'Égypte sous ma domination et je chasserai Pierre d'Alexandrie'. Mais Dieu ne fera pas cela pour lui. Bien au contraire, il le réduira à l'impuissance, car c'est un corrompu qui mange les mets offerts aux idoles que sont les porcs qu'égorgent pour lui les prêtres corrompus, ainsi que les chameaux, les corbeaux, les panthères et tous les autres animaux corrompus que l'on égorge pour lui, et qui, en plus, enseigne ces pratiques aux hommes. C'est pourquoi je ne permettrai pas qu'il touche à mon corps, et mon corps ne quittera pas ce lieu de longtemps, jusqu'à ce qu'on bâtisse mon martyrion ". À l'instant même, le lieu où se trouvait cet impie trembla avec un grand vacarme et des éclairs qui s'abattirent sur son visage. Le démon qui habitait cette idole cria aux

17 Voir Camplani 1990, qui a accordé beaucoup d'attention à l'histoire des mélitiens postérieure à l'époque d'Athanase. Camplani a réussi à donner un sens aux témoignages tardifs (assez nombreux) mentionnant les mélitiens. À la lumière de cette étude, il faut dire que Peter van Minnen (2006: 76-77) n’a pas eu raison d'affirmer que Constantin, dans son Panégyrique II, a construit sa représentation des mélitiens avec des éléments tirés des œuvres d'Athanase. 
prêtres : "Chassez vite cet évêque, car le Dieu de Claude va détruire tout ce village à cause de lui ". Et à l'instant ils se rendirent là où il était avec des fouets, le frappant, lui et ses hommes, en disant: " Voleurs! C'est pour cela que le Dieu des Chrétiens vous hait, toi et tes gens " ". (Godron 1970)

L'expression " diviser le Christ " vient de la polémique des monophysites avec les chalcédoniens: dans ce texte qui prétend décrire des événements du début du IV $\mathrm{V}^{\mathrm{e}}$ siècle, elle est anachronique. Quant à l'histoire fictive d'après laquelle Mélitios aurait essayé de voler le corps de saint Claude, on pourrait être tenté de penser qu'elle témoigne que le culte des reliques des martyrs était particulièrement développé chez les mélitiens. Cependant, les mélitiens n'étaient pas les seuls, en Égypte, qui cherchaient à se procurer ces restes précieux : des groupes de fidèles rivalisaient parfois âprement pour assurer des reliques à leurs églises ou chapelles (voir Martin 1996: 702-703).

Un mélitien est le héros d'un des miracles racontés par Constantin (p. 629) :

“ Il y avait [à Assiout] un prêtre, adepte secret de cette croyance. Il advint une fois que, pour la fête du juste Apa Claude, il se leva et alla vers le nord en direction du sanctuaire avec ceux qui se rendaient à la fête. Mon humble personne n'y assistait pas. On s'adressa à lui pour célébrer l'anaphore en ce saint sanctuaire. " Au moment où il allait accomplir le sacrifice eucharistique, le presbytre mélitien “vit une puissance sur l'autel, une épée à la main, qui le menaçait". Il s'enfuit de l'église, il s'évanouit, et quand il eut repris connaissance, il se présenta spontanément à l'episkopeion, abjura sa foi erronée, déclara qu'il voulait devenir un moine et alla dans le désert, où, ayant été tenté par le diable, il fut au centre d'un autre épisode miraculeux. (Godron 1970)

Ce récit est surprenant à deux points de vue. Il est étrange qu'un presbytre ait pût être clandestinement un mélitien, sans que personne ne s'en ait aperçu. Il est étrange aussi qu'un presbytre qui n'appartenait pas au clergé du sanctuaire ait pût célébrer une messe dans ce lieu prestigieux. La permission aurait dû être donnée par l'évêque. Il est significatif que Constantin déclare ne pas avoir été présent : il fait comprendre ainsi qu'il n'est aucunement responsable de la présence d'un crypto-mélitien auprès de l'autel. 


\section{Des monnaies cousues dans un pli du vêtement}

Un épisode du Panégyrique II de Constantin est l'histoire d'une vieille mendiante aveugle, qui vit des aumônes des visiteurs du sanctuaire. Une fois, un homme qui pratiquait la magie la vit au moment où, ayant reçu d'un visiteur un sou d'or, elle était en train de le cacher dans un pli de son vêtement. Dans cette cachette elle avait d'autres sous d'or au nombre de seize, " qu'on lui avait donnés durant toute sa vie ". Profitant du fait qu'un incendie avait éclaté dans une maison voisine et que tous ceux qui étaient dans le sanctuaire en étaient sortis pour voir l'incendie, le magicien " se précipita vers la femme aveugle et déroba le vêtement où les pièces d'or étaient attachées. ... Elle poussa un cri en le saisissant. Il la frappa à la tête et s'éloigna d'elle, courut et continua à courir jusqu'à la montagne occidentale ". Mais saint Claude, ayant pris l'apparence du gouverneur, monta sur un cheval blanc "et accompagné du saint Apa Victor, qui chevauchait avec lui, ainsi que de soldats", il poursuivit et saisit le malfaiteur.

Bien sûr, l'idée qu'une mendiante eût pu accumuler un trésor de seize sous d'or, n'est pas du tout réaliste; mais le fait de garder l'argent cousu dans un pli du vêtement est certainement conforme à une pratique réelle.

\section{Le sanctuaire tirant profit de la conversion des pécheurs}

Un voleur surpris en train de voler un chandelier d'argent dans le sanctuaire obtient du saint miséricordieux le pardon. Constantin écrit (pp. 625-627) :

"Je baptisai l'homme, lui donnai la communion dans ce sanctuaire le jour même et il passa sept jours dans le sanctuaire pour être instruit. Ensuite il se rendit chez lui, en ramena tout son bien et entra dans ce sanctuaire avec sa servante. Quant à l'idole, il la brisa et la donna pour le service des pauvres. Et lui et sa servante demeurèrent dans le sanctuaire à servir jusqu'au jour de leur mort ”. (Godron 1970)

Le mélitien converti dont il est question dans un récit mentionné ci-dessus, ne réussit pas à devenir moine, mais finalement Constantin lui dit (p. 629) :

“ "Obéis-moi: je t'envoie au sanctuaire du Saint où tu serviras jusqu’au jour de ta mort ». Il obéit". (Godron 1970) 
L'histoire de deux voleurs amenés devant le gouverneur de la Thébaïde se termine ainsi (p. 655) :

"Le duc ordonna de hisser les voleurs sur le chevalet. Apa Claude l'en empêcha et leur demanda : "Qui êtes-vous? — Nous sommes, dirent-ils, des païens, habitants du village appelé Manhabin, dans la province de Chmoun, et adorateurs d'une idole à l'image d'un dragon. - Si je me porte garant de vous, leur dit Apa Claude, deviendrez-vous chrétiens? Oui, vraiment, Notre Seigneur, répondirent-ils ». Il fit appeler par le duc un prêtre pieux, auquel il les confia. Celui-ci les instruisit et les baptisa. Ils devinrent croyants. Ils se consacrèrent à leur travail manuel, faisant la charité et restant au service du sanctuaire de saint Apa Colluthus et venant chaque année au vénéré sanctuaire où nous sommes pour lui faire leurs offrandes". (Godron 1970)

L'histoire de l'homme qui pratiquait la magie et qui avait enlevé à une mendiante les pièces d'or qu'elle gardait dans son vêtement, se termine ainsi (p. 663) : saint Claude ordonne au voleur de rendre l'argent volé, de brûler ses livres de magie et d'aller au sanctuaire avec sa femme et ses enfants. "L'homme alla chez lui, brûla ses livres, prit sa femme et ses enfants sur des montures, entra dans le sanctuaire et commença à le servir ".

Nous connaissons d'autres textes de miracula, où l'on voit des pécheurs convertis à la suite d'un miracle, qui demeurent dans le sanctuaire où le miracle s'est produit $^{18}$. Certes, il s'agit là d'un motif conventionnel, topique; mais son existence est un reflet de ce qui se passait dans la réalité. En témoignent plusieurs documents du VIII ${ }^{\mathrm{e}}$ siècle provenant du monastère de saint Phoibammon à Deir el-Bahari : un acte d'auto-réduction en esclavage ( $P$. KRU 104) et 26 actes où des enfants sont offerts au monastère par leurs parents (P. KRU 78-103).

\section{Une église à visites}

Nous ne prêtons pas foi au récit attribué à Sévère, il nous faut supposer qu’à Pohe ou dans les alentours, il y eut un homme riche, dévôt de saint Claude et qui, pour quelque raison, décida de faire une donation pour la construction d'un

18 Panégyrique de saint Victor Stratèlatès dans Budge 1914: 308 ; von Lemm 1911 ; Amélineau 1888: 720-723 ; martyre de saint Georges dans Till 1936: 91 (105). 
sanctuaire. J'ai raison de croire que ce riche inconnu fit aussi écrire le dossier littéraire indispensable pour le culte (peut-être le fit-il écrire dans le Monastère Blanc tout proche, dont les manuscrits proviennent).

Dans le titre du présent article, par commodité, j'ai classé le sanctuaire de saint Claude parmi les sanctuaires de pèlerinage. C'est un terme couramment employé et facilement compréhensible. Cependant, il faut préciser. Tous ceux qui ont eu affaire aux dossiers littéraires des grands sanctuaires de pèlerinage, comme celui d'Abu Mena, ou celui des saints Cyr et Jean près d'Alexandrie, ou celui de saint Kollouthos à Antinoè (dans lequel on a découvert les restes d'une église avec 90 places pour l'incubation), se seront rendu compte immédiatement qu'à Pohe, il s'agit d'un lieu de culte d'un rang décidément inférieur. Parmi les miracles racontés dans ce dossier, il n'y a pas une seule guérison ${ }^{19}$. Dans le sanctuaire, on ne célèbre qu'une seule grande fête, celle de l'anniversaire du martyre de saint Claude, et ceux qui y participent ne proviennent que des nomes voisins. Une fête de ce genre, on l'appelle aujourd'hui, en Égypte, mulid (au pluriel mawalid) (voir Meinardus 1970: 214-219). En dehors du jour ou des jours du mulid (car cette fête peut durer plus d'un jour), l'église est visitée par quelques personnes qui sont de passage dans les alentours pour d'autres buts. Ces visiteurs sont accueillis avec attention — surtout s'ils sont riches — par le clergé permanent, peu nombreux, de l'église. Christian Décobert a appelé les églises de ce genre "églises à visites" (Boutros et Décobert 2001: 82).

\section{Références bibliographiques}

Les papyrus sont cités conformément aux sigles de J.F. Oates et al., Checklist of Greek, Latin, Demotic and Coptic papyri, ostraca and tablets, disponible sur Internet : http://scriptorium.lib.duke.edu/papyrus/texts/clist.html.

\section{SOURCES PRIMAIRES}

Athanasius, The Canons of Athanasius of Alexandria: The Arabic and Coptic versions, éd. et trad. par W. Riedel et W.E. Crum, Londres : Williams and Norgate, 1904

Codex Theodosianus: Theodosiani libri 16 cum constitutionibus Sirmondianis, éd. par T. Mommsen et P.M. Meyer, Berlin : Weidmann, 1905

19 Notons cependant que selon l'histoire des voleurs qui se seraient faits enfermer dans l'église pour la nuit, ceux-ci auraient dit qu'ils avaient l'intention de prier pour la guérison de l'un d'eux. À un autre endroit, il est dit que le saint pouvait guérir une femme de sa stérilité. 
Eusèbe de Césarée, Eusebii Pamphili. Caesareae Palestinae episcopi, opera omnia quae exstant II. Historia ecclesiastica, éd. par J.-P. Migne, Paris : J.-P. Migne, 1857

Rufus de Shotep, Rufus of Shotep: Homilies on the Gospels of Matthew and Luke, éd. et trad. par J.M. Sheridan, Rome : CIM, 1998

\section{SOURCES SECONDAIRES}

Amélineau, E. (1888). Monuments pour servir à l'histoire de l'Égypte chrétienne aux $I V^{e}, V^{e}, V I^{e}$ et VII $I^{e}$ siècles I [=Mémoires publiés par les membres de la Mission archéologique française au Caire 4/1]. Paris : Leroux

Baumeister, T. (1972). Martyr invictus: Der Martyrer als Sinnbild der Erlösung in der Legende und im Kult der frühen koptischen Kirche [=Forschungen zur Volkskunde 46]. Münster : Regensberg

Boutros, R. et Décobert, C. (2000). Les installations chrétiennes entre Ballas et Armant : implantations et survivances. Dans N. Bosson (éd.), Études coptes VII : neuvième journée d'études, Montpellier, 3-4 juin 1999 [=Cahiers de la Bibliothèque copte 12] (pp. 77-108). Paris-Louvain : Peeters

Budge, E.A.W. (1914). Coptic martyrdoms etc. in the dialect of Upper Egypt. Londres : British Museum

Camplani, A. (1990). In margine alla storia dei Meliziani. Augustinianum, 30(2), 313-351

Camplani, A. (2011). Melitianer. Dans G. Schöllgen et al. (éds), Reallexikon für Antike und Christentum XXIV (cols 629-638). Stuttgart : Hiersemann

Clarysse, W. et Geens, K. (2009). Textiles and architecture in Graeco-Roman and Byzantine Egypt. Dans A. De Moor et C. Fluck (éds), Clothing the house: Furnishing textiles of the 1st millennium AD from Egypt and neighbouring countries. Proceedings of the 5th conference of the research group "Textiles from the Nile Valley" Antwerp, 6-7 October 2007 (pp. 38-47). Tielt : Lannoo Publishers

Coquin, R.-G. (1981). Saint Constantin, évêque d'Asyut. Studia Orientalia Christiana. Collectanea, 16, 151-170

Coquin, R.-G. et Samir, K. (1991). Constantine. Dans A.S. Atiya (éd.), The Coptic encyclopedia II (pp. 590-593). New York : Macmillan

De Lacy O'Leary, E. (1952). Severus of Antioch in Egypt. Aegyptus, 32(2), 425-436

Drescher, J. (1942). Apa Claudius and the thieves. Bulletin de la Société d'archéologie copte, 8, 63-86

Drescher, J. (1944). An encomium attributed to Severus of Antioch. Bulletin de la Société d'archéologie copte, 10, 43-68

Drescher, J. (éd.). (1946). Apa Mena: A selection of Coptic texts relating to St. Menas [=Publications de la Société d'archéologie copte. Textes et documents 6]. Le Caire : Institut français d'archéologie orientale

Drew-Bear, M. (1979). Le nome Hermopolite: toponymes et sites [=American Studies in Papyrology 21]. Missoula, MT : Scholars Press 
Förster, H. (2002). Wörterbuch der griechischen Wörter in den koptischen dokumentarischen Texten [=Texte und Untersuchungen zur Geschichte der altchristlichen Literatur 148]. Berlin-New York : De Gruyter

Garitte, G. (1950). Constantin, évêque d'Assiout. Dans Coptic studies in honor of Walter Ewing Crum [=Byzantine Institute of America Bulletin 2] (pp. 287-304). Boston : Byzantine Institute

Godron, G. (1970). Textes coptes relatifs à saint Claude d'Antioche [=Patrologia Orientalis 35/4]. Turnhout: Brepols

Godron, G. (1976). Recherches sur les Textes coptes relatifs à saint Claude d'Antioche [=Études d'égyptologie et de coptologie 1]. Louvain : Peeters

Martin, A. (1996). Athanase d'Alexandrie et l'église d'Egypte au IVe siècle (328-373) [=Collection de l'École française de Rome 216]. Rome : École française de Rome

Meinardus, O.F.A. (1970). Christian Egypt: Faith and life. Le Caire : American University in Cairo Press

Orlandi, T. (éd.) (1974). Constantini episcopi urbis Siout Encomia in Athanasium duo I-II [=Corpus scriptorum Christianorum Orientalium 349-350; Scriptores Coptici 37-38]. Louvain : Peeters, 1974

Orlandi, T. (1986). Coptic literature. Dans B.A. Pearson et J.E. Goehring (éds), The roots of Egyptian Christianity (pp. 51-81). Philadelphie : Fortress Press

Orlandi, T. (1991a). Cycle. Dans A.S. Atiya (éd.), The Coptic Encyclopedia III (pp. 666-668). New York : Macmillan

Orlandi, T. (1991b). Hagiography, Coptic. Dans A.S. Atiya (éd.), The Coptic Encyclopedia IV (pp. 1191-1197). New York : Macmillan

Orlandi, T. (1995). Claudio martire e Anatolio di Laodicea. Un problema letterario fra III e VI secolo. Dans C. Fluck, L. Langener, S.G. Richter, S. Schaten, et G. Wurst (éds), Divitiae Aegypti: koptologische und verwandte Studien zu Ehren von Martin Krause (pp. 237-245). Wiesbaden : L. Reichert

Papaconstantinou, A. (1992). L'agapè des martyrs : P.Oxy. LVI 3864. Zeitschrift für Papyrologie und Epigraphik, 92, 241-242

Papaconstantinou, A. (2001). Le culte des saints en Égypte des Byzantines aux Abbasides: l'apport des inscriptions et des papyrus grecs et coptes. Paris : CNRS éditions

Papaconstantinou, A. (2011). Hagiography in Coptic. Dans S. Efthymiadis (éd.), The Ashgate research companion to Byzantine hagiography I. Periods and places (pp. 323-343). Farnham : Ashgate

Schmelz, G. (2002). Kirchliche Amtsträger im spätantiken Ägypten: nach den Aussagen der griechischen und koptischen Papyri und Ostraka [=Archiv für Papyrusforschung und verwandte Gebiete 13]. Munich : K.G. Saur

Sheridan, J.M. (2011). The encomium in Coptic sermons of the late sixth century. Dans P. Buzi et A. Camplani (éds), Christianity in Egypt: Literary production and intellectual trends. Studies in honor of Tito Orlandi [=Studia ephemeridis "Augustinianum" 125] (pp. 443-464). Rome : Institutum Patristicum Augustinianum 
Till, W.C. (éd.). (1936). Koptische Heiligen-und Martyrerlegenden: Texte, Übersetzungen und Indices II [=Orientalia Christiana analecta 108]. Rome : Pontificium Institutum Orientalium Studiorum

Timm, S. (1984). Das christlich-koptische Ägypten in arabischer Zeit I [= Tübinger Atlas des Vorderen Orients 41/1]. Wiesbaden : L. Reichert

van Minnen, P. (2006). Saving history? Egyptian hagiography in its space and time. Dans J.H.F. Dijkstra et M. van Dijk (éds), The encroaching desert. Egyptian hagiography and the Medieval West (pp. 57-91). Leyde-Boston : Brill

von Lemm, O. (1911). Zu einem Enkomium auf den hl. Viktor. Zeitschrift für Ägyptische Sprache und Altertumskunde, 48, 81-86

Wipszycka, E. (1996). Les confréries dans la vie religieuse de l'Égypte chrétienne. Dans E. Wipszycka, Études sur le christianisme dans l'Égypte de l'antiquité tardive [=Studia ephemeridis "Augustinianum" 52] (pp. 257-278). Rome : Institutum Patristicum Augustinianum

Wipszycka, E. (2015). The Alexandrian Church: People and institutions [=Journal of Juristic Papyrology Supplement 25]. Varsovie : Raphael Taubenschlag Foundation 



\title{
A monastic library in Nekloni?
}

\author{
Iwona Zych \\ Polish Centre of Mediterranean Archaeology, University of Warsaw \\ i.zych@uw.edu.pl
}

\section{KeYwords}

Naqlun, monastic architecture, library, wood artifacts, lock, key, furniture

\section{Abstract}

The presence of a monastic library, possibly connected with a scriptorium, in the complex labeled as D on the upper plateau in the monastery at Nekloni (Naqlun), has been suggested in research, based on finds of texts, as well as other categories of artifacts presented in excavation reports. The paper discusses the collection of wooden artifacts from the complex, emphasizing objects that could have been part of the upper-floor reception rooms envisioned as the place where one would expect to find the monastery library.

The importance of the building or buildings, referred to as Kom D, on the upper plateau in Naqlun has already been presented in reports on the excavation of this structure, carried on and off for the past 30 years and most recently in 2014 (Godlewski 2014). Evidence has accrued over the years to bolster a picture of a building complex rising on a rocky height at the far northern end of a plateau that extends at the foot of the Nekloni hills with their numerous hermitages cut into the rock.

The complex consisted of a tower keep that stood separate in the center of a compound of dwellings and domestic units built probably in the 7th century and still in use at least through the end of the 12th century (Godlewski 1993: 45-46; 1996: 86) [Fig. 1]. Opposite it to the south rose another tower of more or less the same size. A staircase was located here. Extant Coptic monasteries from Egypt indicate that the first tower was accessed via an upper-floor bridge or passage, leading from a landing of the staircase in the second tower, which also opened onto the second story of a building. The assumption, based on archaeological 
evidence, is that this upper level may have comprised the reception rooms, including a library and possibly a scriptorium.

The evidence marshaled in favor of this assumption encompasses different find categories. Elements of architectural interior furnishings, such as limestone pavers and ceramic tiles, as well as gypsum window grilles with remains of windowpanes (see Godlewski 2014: Fig. 4) are proof of relatively higher building standards in this part of the building. As Szymon Maślak has shown (2016: 178 and 180, in this volume), the ramshackle building must have collapsed in on itself, letting these elements fall to the ground floor, overlying the accumulated occupational fill found there. The building was deserted apparently sometime in the early 11th century after its partial destruction by burning (for the fire and an analysis of the destruction and its dating, see Maślak 2016: 181, in this volume; see also Godlewski, Derda, and Górecki 1994: 228-231; Górecki 1994: 75).

The windows filled by these glass windowpanes lighted up rooms on the upper floor, commanding a view of the oasis to the south and southwest. The walls were decorated with wall paintings on plaster, encompassing a variety of figural and geometric motifs, including a finely rendered representation of a quadruped against a red background (see Godlewski 2014: Fig. 3; 1990: 33). Further proof of a certain opulence lies in finds like a metal suspension element from a hanging lamp or censer, as well as wooden beams and ceiling planks excavated most recently on the southern fringes of the complex, in units D.50 and D.41 (see Godlewski 2014: Fig. 5). Were a library to have existed anywhere in this complex, it would be in these upper-floor rooms.

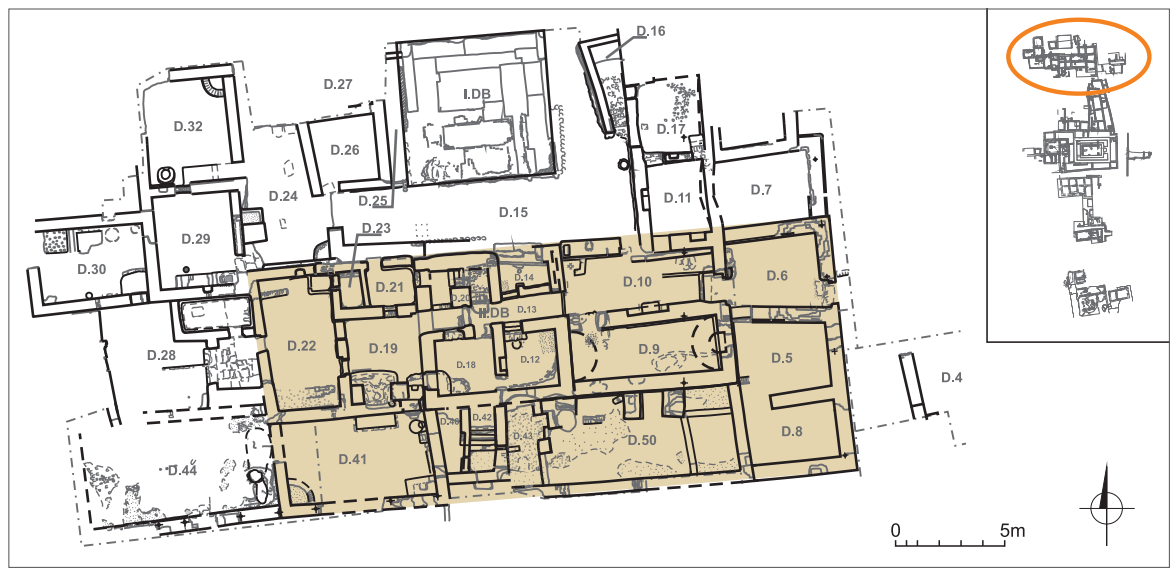

Fig. 1. Plan of the monastery complex D in Naqlun; the presumed library may have occupied the upper-floor rooms in the southern wing, on either side of unit I.DB (Drawing W. Godlewski, S. Maślak, (C) PCMA) 
More important for the existence of a library is the extensive collection of fragmentary texts, whole cards and stamped-leather book covers coming from the fill throughout the complex, but especially from units D.21, D.22, D.24 and D.50, as well as D.6 (see, for example, Godlewski 2014: Fig. 6). These documents, on parchment, papyrus and paper, dated mostly to the 9th, 10th and 11th century, identified as Biblical texts, but also as homilitical and magic pieces, as well as more or less private letters, demonstrate a considerable variety both thematically and chronologically. Many are specifically dated in the colophons. As Jacques van der Vliet wrote in a handy summary of these documents (van der Vliet 1999; see also Urbaniak-Walczak 1997 with further references, also to excavation reports), "at best, they represent the much disturbed debris of the monastery library and archives. Indeed, much of the material seems to have been recycled, perhaps — as has been suggested [by the excavator] — in the process of book production" (van der Vliet 1999: 143). The latter idea is supported by the presence of texts dated on paleographic grounds to an earlier period, the 5th and 6th centuries AD, with evidence of reuse in the form of texts written on the clean backs of cards (Urbaniak-Walczak 1997: 98-99). A fine example of the kind of books that could have been found in the monastery library is the so-called Naqlun Codex of St John (for a fine illustration of pages from the Codex, see van der Vliet 2002: Fig. 1).

The excavation of complex $\mathrm{D}$ also left no doubt as to the presence of open courtyards and work areas, which would have occupied the ground-floor units (Godlewski 1993: 45). A wooden plough fragment from unit D.41 identifies this area as a place for safekeeping of the monastery's agricultural implements, which the monks would have used in whatever activities were carried out on monastery land in the oasis. A rat trap is a singular find from courtyard D.15 (see Zieliński and Zych 2012: 249; previously described as a press in Zych 2000: 147), indicating that rodents infested the compound.

Other fairly mundane artifacts were present throughout the excavation: diverse tools and tool handles, a bucket frame, bottle plugs, pegs and wedges. Fragments of door and window frames were common, as were grooved rectangular elements and flat panels which were slotted together to form decorative wings of doors. Planks and boards were recorded, including a wooden roof in D.10 and fragments identified as parts of stairs (e.g., Godlewski 1992: 51; Godlewski and Parandowska 1994: 58).

Three pieces [Fig. 2 bottom row] belong to the wooden architectural decoration that must have constituted the fine interior finishing of the upper floor. The relief decoration on these fragments is compromised by the softness of the wood in which they were carved, but the composition of the friezes and 
choice of floral and geometric motifs is clearly in the mainstream of carved art in the period. The fragments are too small to reconstruct the interiors that they decorated, but the remains of a plaster ground and pigment, especially white, yellow and red, as well as a hint of blue on one of the friezes, suggests a colorful and vibrant look of the finished decoration.

The arched fragments with carved geometric (two) and floral (one) friezes, and one plain fragment [Fig. 2 top] were part of the furniture, which could have been in use in the rooms on the upper floor. Similar elements of furniture were discovered in the monastery of St Phoibammon at Deir el-Bahari (Godlewski 1986: Nos 16 and 17, Figs 83-86).

Security concerns were evident throughout the complex, taking on the form of a door blocked with a beam from inside in the entrance to the tower II.DB,

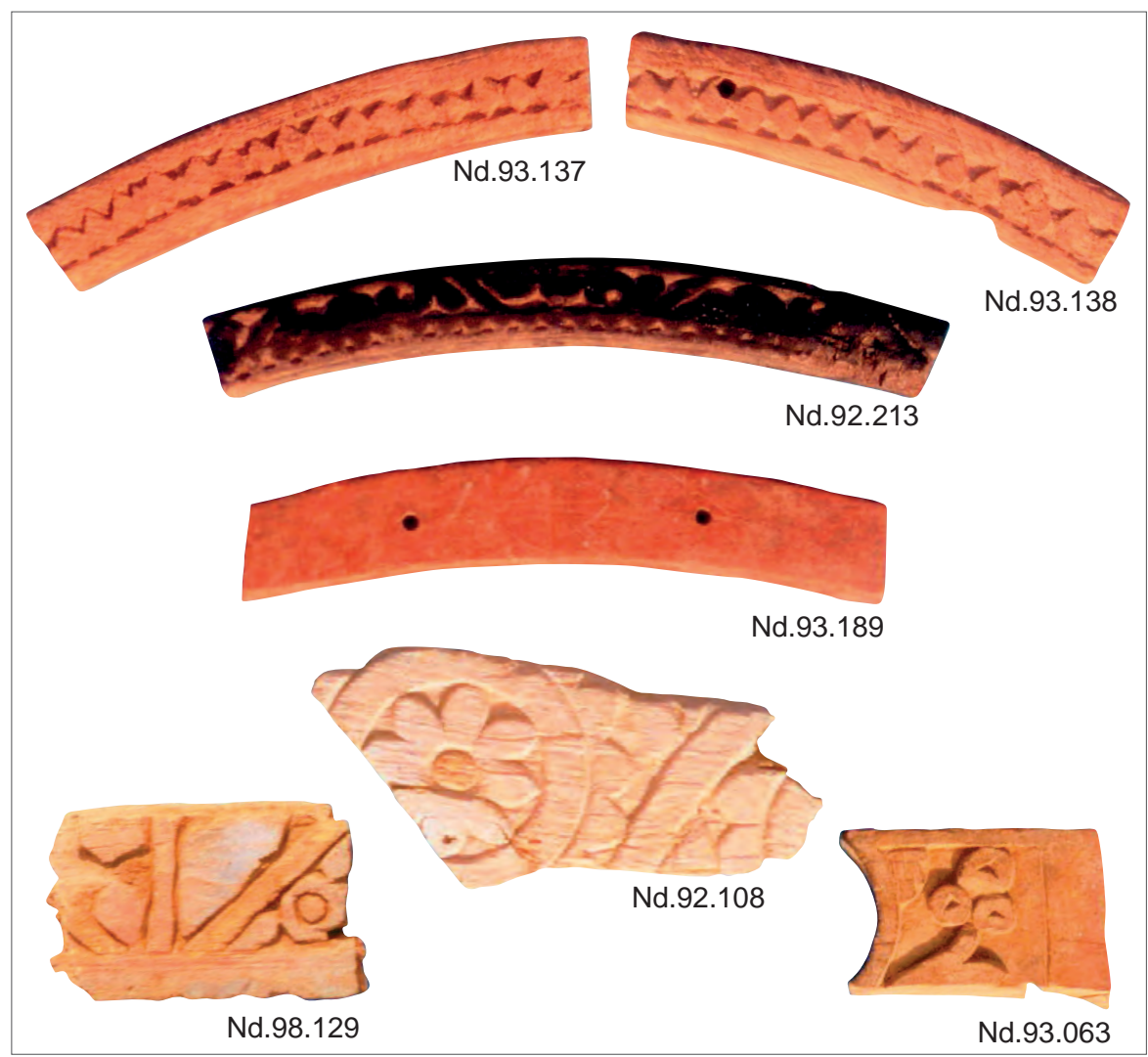

Fig. 2. Wooden furniture pieces (above) and elements of architectural decoration from complex D (Photos I. Zych (C) PCMA) 
which gave access to the rest of the complex (Godlewski 1993: 45), as well as a surprising number of locking devices: locks, bolts, keys and bolt casings in different shapes, sizes and wood material (Zych 2000: 146-147; Zieliński and Zych 2012) [Fig. 3]. The devices closed either regular doors or possibly shelf cabinets or smaller cupboards.

Considering the still sizable collection of more exquisite and valuable artifacts of wood, like the pyxis lid found in D.22 for example (Zych 2005), as well as crosses, stands, bread(?) stamps, oil lamps, not to mention the gold coins lost all over the site during the conflagration that consumed the monastery in the early 11th century (see Maślak 2016, in this volume, for a compendium of information on hoards lost at the site), the presence of so many locking devices becomes more natural. Especially, if the lock was meant to protect a library on the upper floor, protecting the valuable codices that may have been kept there in number.

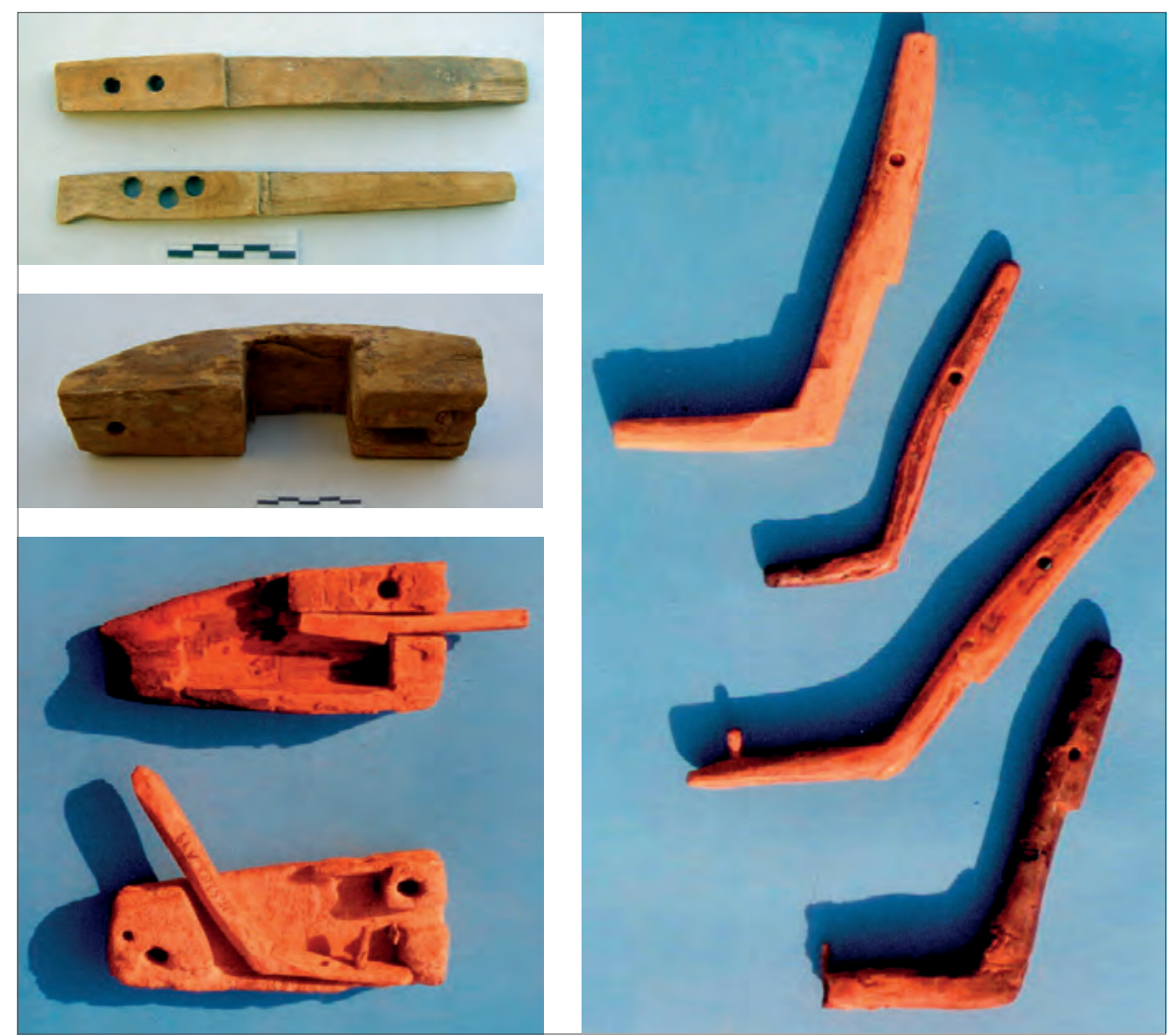

Fig. 3. Locking devices from complex D: bolts, bolt casing, outer lock casings with matching bolt and sliding key, and different sliding keys (Photos I. Zych (C) PCMA) 


\section{References}

Godlewski, W. (1986). Le monastère de St Phoibammon [=Deir el-Bahari 5]. Warsaw: PWN - Éditions scientifiques de Pologne

Godlewski, W. (1990). Polish excavations at Naqlun (1988-1989). Polish Archaeology in the Mediterranean, 1, 29-34

Godlewski, W. (1992). Archaeological research in Naqlun in 1991. Polish Archaeology in the Mediterranean, 3, 49-56

Godlewski, W. (1993). Deir el-Naqlun, 1992. Polish Archaeology in the Mediterranean, 4, 43-48

Godlewski, W. (1996). Naqlun 1995. Polish Archaeology in the Mediterranean, 7, 82-88

Godlewski, W. (2014). Excavations in Complex D: reexamination and new research (Naqlun 2014). PCMA Newsletter. Retrieved from: http://www.pcma.uw.edu. $\mathrm{pl} /$ ?id $=1275 \& \mathrm{~L}=0$ [accessed: 10.06 .2016 ]

Godlewski, W., Derda, T., and Górecki, T. (1994). Deir el Naqlun (Nekloni), 19881989. Second preliminary report. Nubica, 3(1), 201-263

Godlewski, W. and Parandowska, E. (1997). Naqlun: Excavations 1996. Polish Archaeology in the Mediterranean, 8, 88-97

Górecki, T. (1994). The pottery from Naqlun, 1993. Polish Archaeology in the Mediterranean, 5, 63-78

Maślak, S. (2016). The burning of a monastery? Story blazed on the walls of monastic buildings at Nekloni (Naqlun). In A. Łajtar, A. Obłuski, and I. Zych (eds), Aegyptus et Nubia Christiana. The Wtodzimierz Godlewski Jubilee Volume on the occasion of his 70th birthday (pp. 149-186). Warsaw: PCMA UW

Urbaniak-Walczak, K. (1997). The literary texts from seasons 1993 and 1995. Polish Archaeology in the Mediterranean, 8, 98-102

van der Vliet, J. (1999). Preliminary remarks on the Coptic texts from seasons 1998 and 1999. Polish Archaeology in the Mediterranean, 11, 143-144

van der Vliet, J. (2002). The Naqlun John: a preliminary report. Polish Archaeology in the Mediterranean, 4, 172-176

Zieliński, J. and Zych, I. (2012). On the collection of wooden finds from Naqlun again. Polish Archaeology in the Mediterranean, 21, 244-250

Zych, I. (2000). Note on the collection of wooden finds from Naqlun. Polish Archaeology in the Mediterranean, 11, 145-149

Zych, I. (2005). A wooden pyxis lid from far away? Études et Travaux, 20, 315-318 


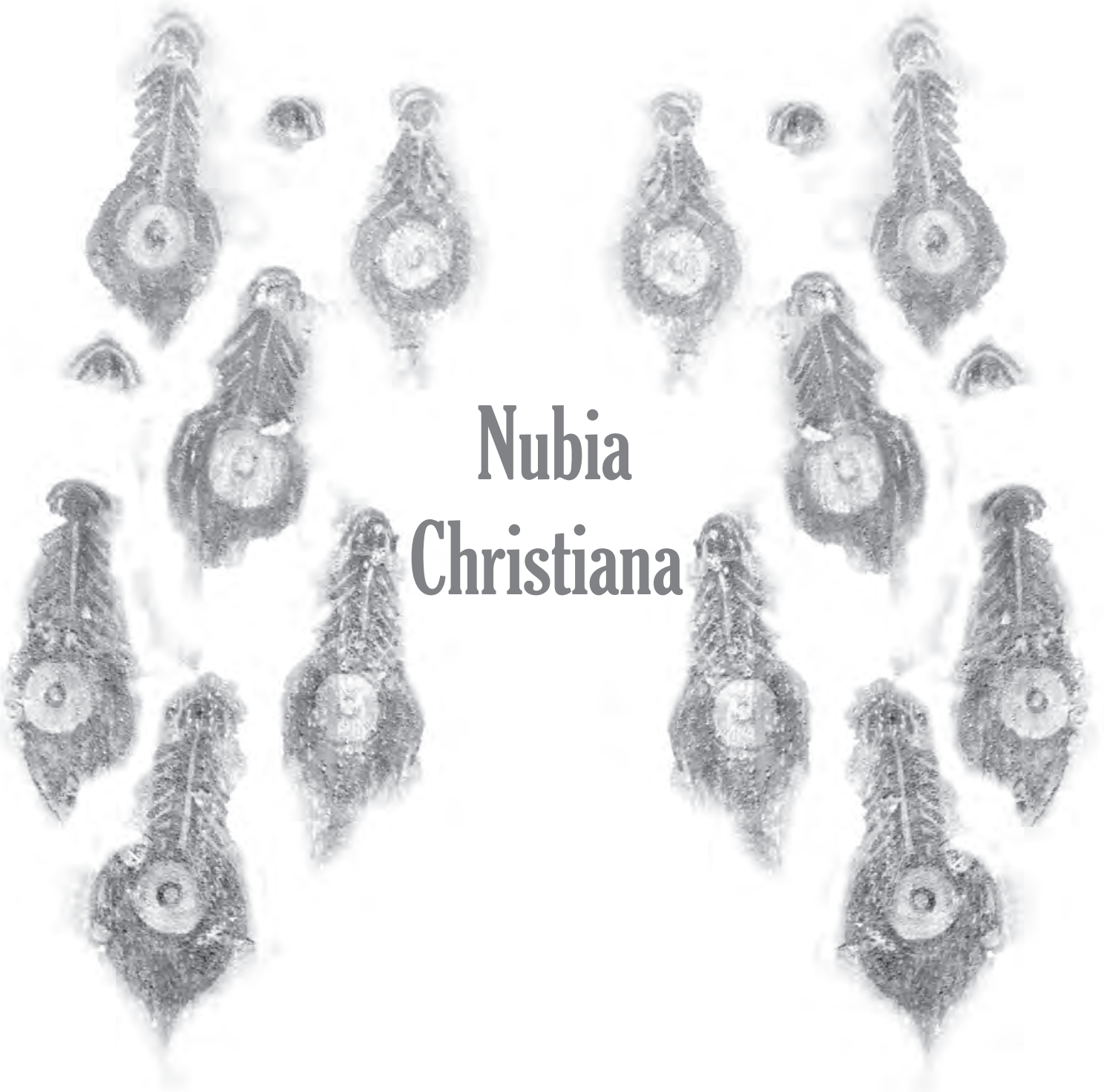





\title{
Evolution and revolution in Nubian pottery
}

\author{
William Y. Adams \\ Emeritus professor of anthropology, University of Kentucky \\ drwyadams@aol.com
}

\section{KeYwORDS}

Meroitic Nubia, post-Meroitic Nubia, Christian Nubia, pottery

\begin{abstract}
The author traces the evolution of Nubian decorated pottery from the middle Meroitic (1st century BC/1st century AD) through the terminal Christian (about AD 1500), arguing in favor of four different revolutions, technological and stylistic, which shaped the ruling paradigm. These revolutions are assigned to the Meroitic, post-Meroitic, Classical Christian and Terminal Christian periods.
\end{abstract}

It is both a pleasure and a privilege for me to join in honoring a longtime friend and colleague, who also happens to share my special interest in the underappreciated civilization of medieval Nubia. Włodzimierz Godlewski has surely distinguished himself as the heir to Kazimierz Michałowski, and the leading figure in the field of Christian Nubian studies.

One of the outstanding products of Christian Nubian civilization, as indeed of its predecessors, was decorated pottery — the one creative domain in which the artistry of the Nubians consistently surpassed that of their Egyptian neighbors. Nubian pottery, made by hand since the stone age and on the wheel since New Kingdom times, underwent an extraordinarily complex and interesting history, reflecting a multitude of influences. Like much of human culture, it underwent both evolutionary and revolutionary changes. I here use the term evolution not in its narrow Darwinian sense, but more broadly to designate any orderly and more or less predictable process of change, such as is going on all the time in all cultures. By revolution I refer to abrupt, unpredictable changes that often involve a deliberate rejection of whatever went before. 
Fig. 1. Chronology of Nubian ceramic styles and paradigms

\begin{tabular}{|c|c|c|}
\hline Year (AD) & Style & Paradigm \\
\hline 1500 & \multirow[t]{2}{*}{ N.VII } & Terminal Christian paradigm \\
\hline 1400 & & Terminal Christian revolution \\
\hline 1300 & N.VI & \multirow{4}{*}{$\begin{array}{c}\text { Classic to late Christian } \\
\text { paradigm }\end{array}$} \\
\hline 1200 & & \\
\hline 1100 & N.V & \\
\hline 1000 & \multirow[t]{2}{*}{ N.IVA } & \\
\hline & & Classic Christian revolution \\
\hline $\begin{array}{l}800 \\
700\end{array}$ & N.III & \multirow{3}{*}{$\begin{array}{c}\text { Ballaña to early Christian } \\
\text { paradigm }\end{array}$} \\
\hline 600 & \multirow{3}{*}{ N.II } & \\
\hline $\begin{array}{l}500 \\
400\end{array}$ & & \\
\hline & & Ballaña revolution \\
\hline 300 & \multirow{3}{*}{ N.I } & \multirow[b]{2}{*}{ Meroitic paradigm } \\
\hline $\begin{array}{l}200 \\
100\end{array}$ & & \\
\hline $\mathrm{BC} / \mathrm{AD}$ & & Meroitic revolution \\
\hline
\end{tabular}


In the field of Nubian pottery, each revolution ushered in what I think may appropriately be called a new paradigm, involving at a stroke a new constellation of vessel forms, preferred colors, and decorative traditions, and differing in all these respects from predecessors and successors alike. Once introduced, each paradigm underwent several centuries of gradual, evolutionary change, until overthrown by the next ceramic revolution (charted in Fig. 1). The underlying, determining factors involved in those two processes will be considered at the end of my paper.

I have to confine myself here to the last two thousand years of Nubian potterymaking, for my analysis is based in considerable part on quantitative data not available for earlier periods. Archaeologists in earlier times did not bother to count potsherds - the one reliable way of measuring stylistic popularity - and more recent digs have not yet been published. For the same reason my conclusions can be stated with confidence only for Lower Nubia and the Batn el-Haggar - the only regions in which comprehensive excavations and survey have so far been carried out, and published.

My analysis is confined also to the Nubian wheel-made wares that were widely traded from a limited number of factories, some of which have been identified. Though always the most numerous, they were never the totality of pottery used in Nubia. At all times there were also handmade wares, produced in all probability by Nubian women, and there were imported wares from a variety of sources, but above all from Aswan. At least one revolution of a sort can be observed in each of these latter industries, but the Nubian wheel-made wares underwent no fewer than four of them. Far more than other wares they exhibit the reality, and to some extent the enigma, of revolutionary change.

\section{The Meroitic revolution}

The Meroitic paradigm made its appearance seemingly full-blown in the latter half of the Meroitic period, around the beginning of our Christian era. Excavations in earlier Meroitic sites have so far discovered few if any antecedents. Its abrupt appearance was coincident with the wholesale reoccupation of Lower Nubia around two thousand years ago, and it is perhaps attributable to the cultural stimulation as well as the prosperity arising from renewed, close contact with Hellenized Egypt.

Put in the simplest terms, the Meroitic paradigm involved a very wide range of vessel forms that were often of Greek inspiration; a strong preference for lightslipped over red-slipped wares; and an enormously complex decorative tradition 
combining representational, geometric, and purely abstract motifs from a variety of sources (Adams 1986: 435-440) [Fig. 2]. The tradition reached its climax in the marvelously thin-walled Meroitic fine wares (Family M), though these were never more than a small minority of the Meroitic products.

Without any doubt, the Meroitic painted wares represent the highest achievement of the Nubian potter, and for sheer artistry they exceed any

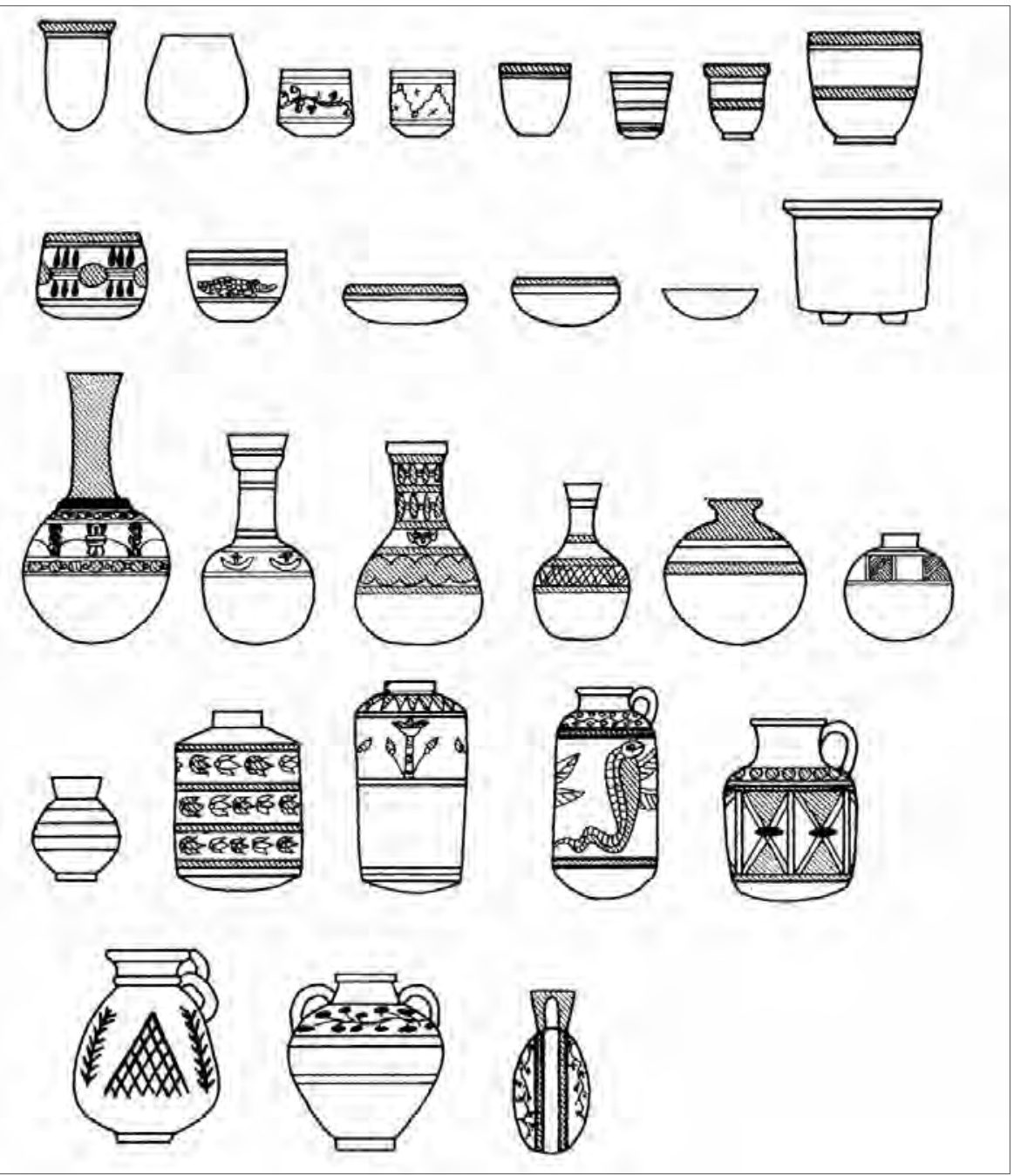

Fig. 2. Typical Meroitic vessel forms and decoration All drawings by the author, after Adams 1986. 
ceramics produced even in Egypt. Their individual decorative motifs are largely of foreign origin: a wide variety of Greek floral designs together with ankhs, wadjet eyes, lotus flowers, and other elements from pharaonic art. Combining with these, however, are such purely indigenous figures as gazelles, frogs, crocodiles, snakes, and caricatured human faces. These elements are woven together in a uniquely Nubian way never found anywhere else; they serve to illustrate the catholicism that has always been characteristic of Nubian art. The predominance of vessels is decorated in red and black on a white to cream background (Style N.IA); a smaller and somewhat distinct group is decorated in black and, very occasionally, white, on a red background (Style N.IC). In the former case, especially, the designs are noteworthy for the careful precision with which they have been executed. These vessels, though turned on the wheel, were clearly not mass-produced. Abundance and wide distribution suggests that they were made at quite a few places, though none have actually been identified.

But a separate undercurrent of purely Roman influence is also perceptible. Highly polished red vessels — particularly those from North Africa — were very much the vogue in the early Roman Empire (see especially Hayes 1972). Egyptian potters at Aswan, among many others, began to imitate them, and they in turn were copied on a small scale by the Nubian potters. As a result there appears, in late Meroitic sites, a range of simple, undecorated red vessels, sometimes but not always with a white interior (Ware R32). The finds are very largely cups and food bowls. They have been found in considerable abundance in habitation sites but very rarely in graves, which suggests that they did not enjoy high prestige. At the same time, they seem to foreshadow the coming importance of all things Roman and Byzantine in the succeeding Ballaña paradigm.

During its persistence of more than three centuries, the Meroitic paradigm undoubtedly underwent evolutionary change. However, the overwhelming majority of decorated Meroitic vessels have thus far been found in graves, which cannot be very precisely dated. Hence it has not been possible, up to now, to recognize a clear developmental sequence in forms or style.

\section{The Ballaña revolution}

With the fall of the Kushite Empire, the Meroitic paradigm disappeared as rapidly and completely as it had begun. The ensuing paradigm, especially in the Ballaña period, represents the absolute triumph of Roman influence in Nubian art. It involves a whole new range of vessel forms, largely of Roman inspiration; an overwhelming 


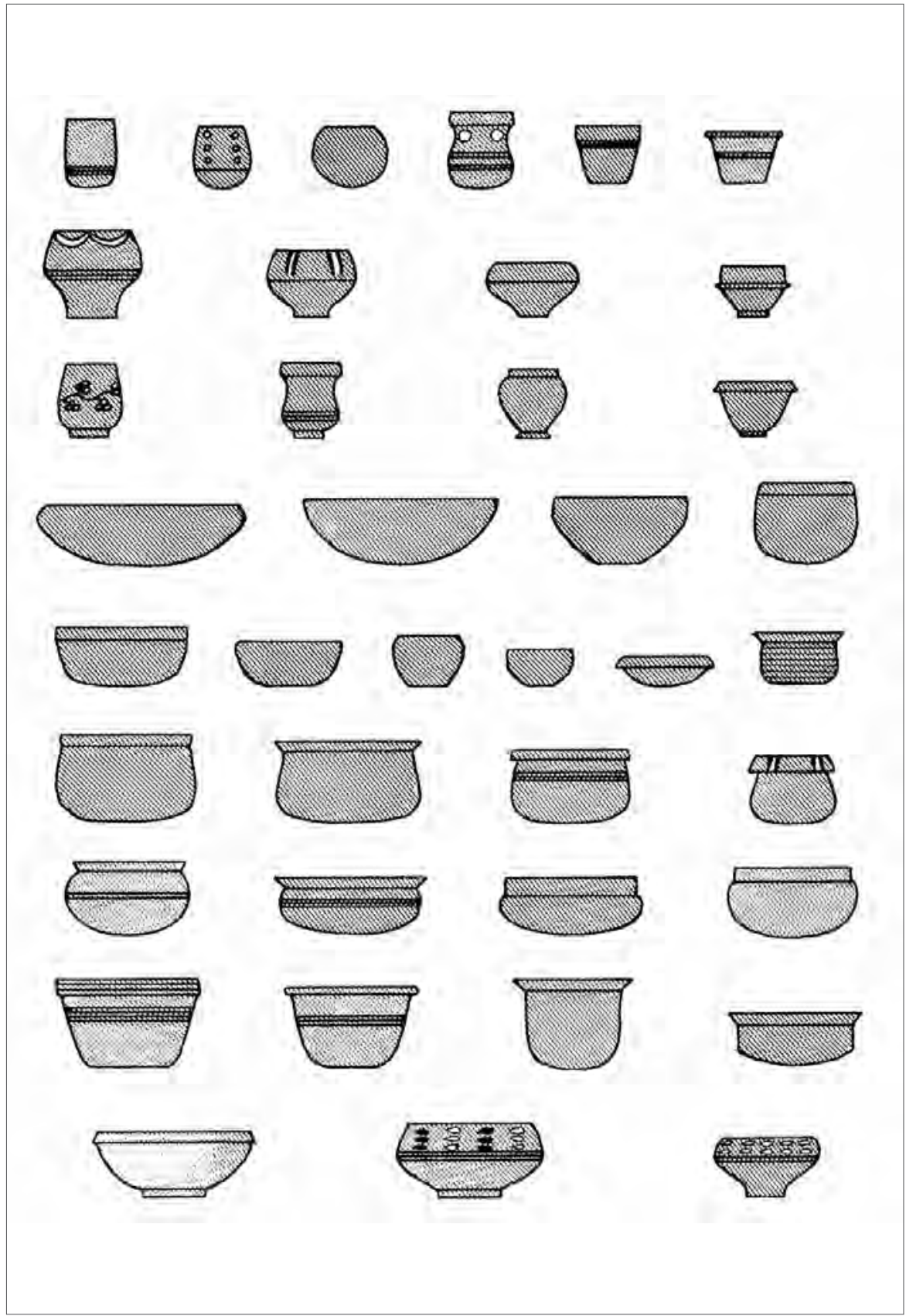

Fig. 3. Typical Ballaña vessel forms and decoration 
preference for red over white slipped vessels; and the sparest of decoration which in most vessels is lacking altogether [Fig. 3]. Decoration when present consists mostly of irregular clusters of disconnected spots, slashes, or vertical stripes, almost entirely in white (Style N.IIA). These are noteworthy for the carelessness of their application, indicative of rapid mass-production. Among vessel forms, difference from the Meroitic tradition is exhibited also in the abundance of goblets and footed bowls.

Following the "Ballaña revolution", Nubian pottery decoration evolved in a gradual and orderly fashion over the next four centuries. Decoration became very gradually more abundant and more formal, as the disconnected splash and stripe designs of Ballaña times evolved into simple linear friezes in the Early Christian period (Style N.III). Representational designs, so abundant in Meroitic art, still remained absent. White-slipped wares, virtually absent in the Ballaña period, made a modest reappearance in Early Christian times, though still heavily outnumbered by red vessels of Roman inspiration. Many vessel forms persisted into the Christian period, but the super-abundant goblets of Ballaña times gave way to cups and a variety of new bowl forms. The abundance and wide distribution of both Ballaña and Early Christian wares suggests once again that they were made at many places, though kiln sites have actually been identified only at Gezira Dabarosa and Debeira (Adams 1962: 65-70), for the Ballaña wares, and at Serra West and Faras for the Early Christian wares (Adams 1961: 40; 1962: 70-71).

The ceramic paradigm shift of Ballaña times was so abrupt, and seemingly so total, that Reisner and several contemporaries, exponents of migration theory, took it as evidence for the coming of a new people (see Adams 1977: 4-5). We know now that this thesis is untenable; the Lower Nubians of Ballaña times, now known as the Nobadae, were the same as the Lower Nubians of Meroitic times, although a few Blemmye invaders had seized territory in the north. How, then, shall we account for the extreme pottery change? Without peering into the minds of the early Nubians, we can only suppose that they were succumbing to the appeal of all things Roman, as did other peoples on the fringes of the empire. Power always begets imitation, and there was no more absolute manifestation of power in the ancient world than the Roman Empire. Note that in this same period the Nobadian rulers adopted Greek (the language of the eastern Roman Empire), rather than Meroitic, for their few written documents, and, at least according to some sources, their officials bore Byzantine titles (Thompson and Ferguson 1969: 50). In a somewhat chaotic and changing world, perhaps we could say that the Nubians saw things Roman as the way of the future, and things Kushite as the way of the past

The coming of Christianity, around the beginning of the 7th century, wrought a major transformation in many aspects of Nubian life (see Adams 1977: 435-438), 
but it was long ignored by the potters. Motifs of religious origin, such as the ankhs and sacred animals abundant in Meroitic art, were absent in both the Ballaña and the Early Christian wares. The only exceptions were very occasional cross designs, impressed in the bottoms of red bowls. It was not until the middle of the 9th century that Nubian pottery was, so to speak, "Christianized".

\section{The Classic Christian revolution}

Around the middle of the 9th century there occurred, out of nowhere, another ceramic revolution, every bit as rapid as the Ballaña revolution and even more unexplained. The Classic Christian paradigm as it first arrived (Style

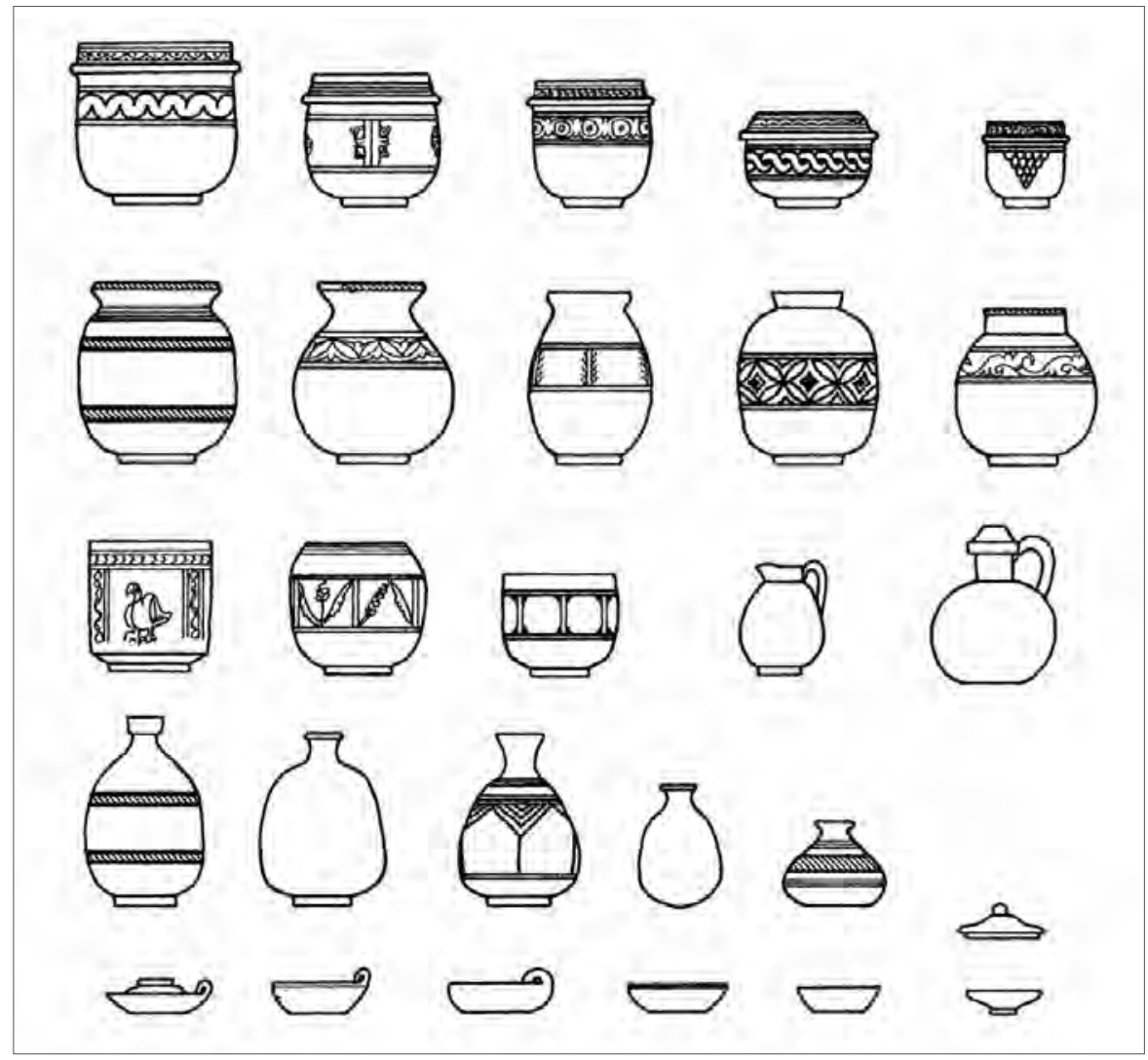

Fig. 4. Typical Classic Christian vessel forms and decoration 
N.IVA) once again involved new forms, this time apparently of purely Nubian origin; an overwhelming preference for white or cream over red slips; and the reappearance of very complex decoration combining representational, geometric, and abstract motifs in prodigious variety (Style N.IVA; Fig. 4 ). The Classic and Meroitic paradigms have, superficially, far more resemblance to each other than either has to the intervening Ballaña paradigm, notwithstanding the interval of four to five centuries between them. This does not hold true however in the case of vessel forms; the cups and goblets so abundant in both Meroitic and Ballaña pottery have nearly disappeared, while for the first time there is a range of vase forms that are virtually the signatures of the Classic Christian period.

The rapidity of stylistic transition is concretely demonstrated by stratigraphy at the Faras Potteries, the one ceramic factory with a long and well-investigated history (Adams 1961; 2005: 71-89). The place was in the beginning some kind of monastic establishment where, late in the Early Christian period, pottery of Early Christian type (Style N.III) began to be produced on a small scale, probably for local use.

Some time in the 9th century a flood wrought major damage, and evidently caused the monks to move away. Parts of the complex were however restored to use, and thenceforth were devoted exclusively to pottery production. Various kinds of pottery-making apparatus as well as unfinished vessels were found scattered all through the restored rooms. In time the Potteries grew into a major factory with six large kilns and several smaller ones. In the earlier part of the Classic Christian period it appears to have been the major source for fine decorated wares that were traded all through Lower Nubia. From the moment of restoration, however, the wares produced at Faras were exclusively of Classic Christian type, which may well have originated here.

The ceramic revolution of Ballaña times had occurred concurrently with the demise of the Kushite Empire and its replacement by the Ballaña splinter-state, and the two developments were quite probably connected. On the other hand the revolution of Classic Christian times was concurrent with nothing except the destruction and restoration of the Potteries, and it remains unexplained. Christianity with its profound cognitive changes had arrived in Nubia three centuries earlier; the formerly independent kingdoms of Nobadia and Makuria had been united at least a century earlier; and Christian Nubia basked in peace and prosperity under the umbrella of the baqt treaty with Egypt (Adams 1977: 451-456). I have cited this evidence more than once to demonstrate that major ceramic changes cannot always be linked to other cultural or social changes, as archaeologists so commonly suppose (Adams 1979; 1988). 
The most conspicuous feature of the Classic Christian decorative style as it first appears is its use of the guilloche, rinceau, and other friezes inspired by medieval manuscript illumination. Christian influence is even more clearly expressed in the frequent use of the cross as a decorative motif (see especially Adams 1981). In the Late Christian period we also begin to find actual holy names, or combinations of letters having religious significance (e.g., XC for Christos) painted in the bottoms of bowls (see especially Adams 1977: 348). Also new to the style is a wide variety of bird figures which may have holy significance, and occasional fish.

The Faras factory was abandoned, for unexplained reasons, late in the Classic Christian period, and with it disappeared some of the most distinctive features of Christian Nubian decoration. The paradigm nevertheless persisted for more than five centuries, until near the end of the Christian Nubian period. During so long a time there was fairly consistent evolutionary change, though more rapid at some times than at others. It involved especially color preferences and decoration, while vessel forms remained largely unchanged. In the PostClassic period (Style N.V) orange slips appeared for the first time, and in Late Christian times they became heavily predominant, largely supplanting the white or cream slips of Classic times. In the Late period red slips also once again became common. In the field of decoration, representational elements, except for the cross, largely disappeared, while decorative friezes became more and more geometric and "busy", with increasing preference for rectilinear over curvilinear elements (Style N.VI). Radial designs in the interior of bowls became especially elaborated.

\section{The Terminal Christian revolution}

A final ceramic revolution, of a sort, occurred not much more than a century before the end of the Christian Nubian era. In this instance it was especially marked in the case of vessel forms, which had changed relatively little during the previous five centuries. But the Terminal Christian paradigm included a new line of notably large vessels with massively thick walls, the use of which can only be guessed at [Fig. 5]. Many of the vessels, including the huge vases which are the Terminal Christian hallmarks, lack a footed base, and could only have stood upright in a bed of sand. It is impossible to guess what some of these vessels might have been used for. Designs, though clearly derived from those of the Late Christian style, are notably simplified, with the bundled lines so 
conspicuous in Style N.VI often replaced by single, bold lines (Style N.VII). The outstanding characteristics of the paradigm, in both vessel forms and decoration, are boldness and simplification. Unlike its predecessors however the Terminal Christian paradigm did not immediately or entirely supplant its predecessor; vessels of both types continued to be made until the end of the Christian period.

The Terminal Christian paradigm appeared at a time when the shrinking world of Christian Nubia was under siege. Dynastic quarrels at the capital as well as repeated Mamluk invasions from Egypt created a state of continuing instability, to be followed by the gradual nibbling away of the southern Christian territories by Arab invaders. By the 15th century nothing remained of the once widespread and flourishing Christian Nubian civilization except the remnant kingdom of Dotawo in the far north, surrounded and beset on all sides by hostile Muslim regimes. Might we guess, then, that the bold style adopted by the Terminal Christian potters represents a final, rather pathetic waving of the fist, as if to say "We're still tough; we can endure"?

But Christian Nubian civilization of course did not endure. Around the end of the 16th century it simply disappeared, unnoticed by history. The last

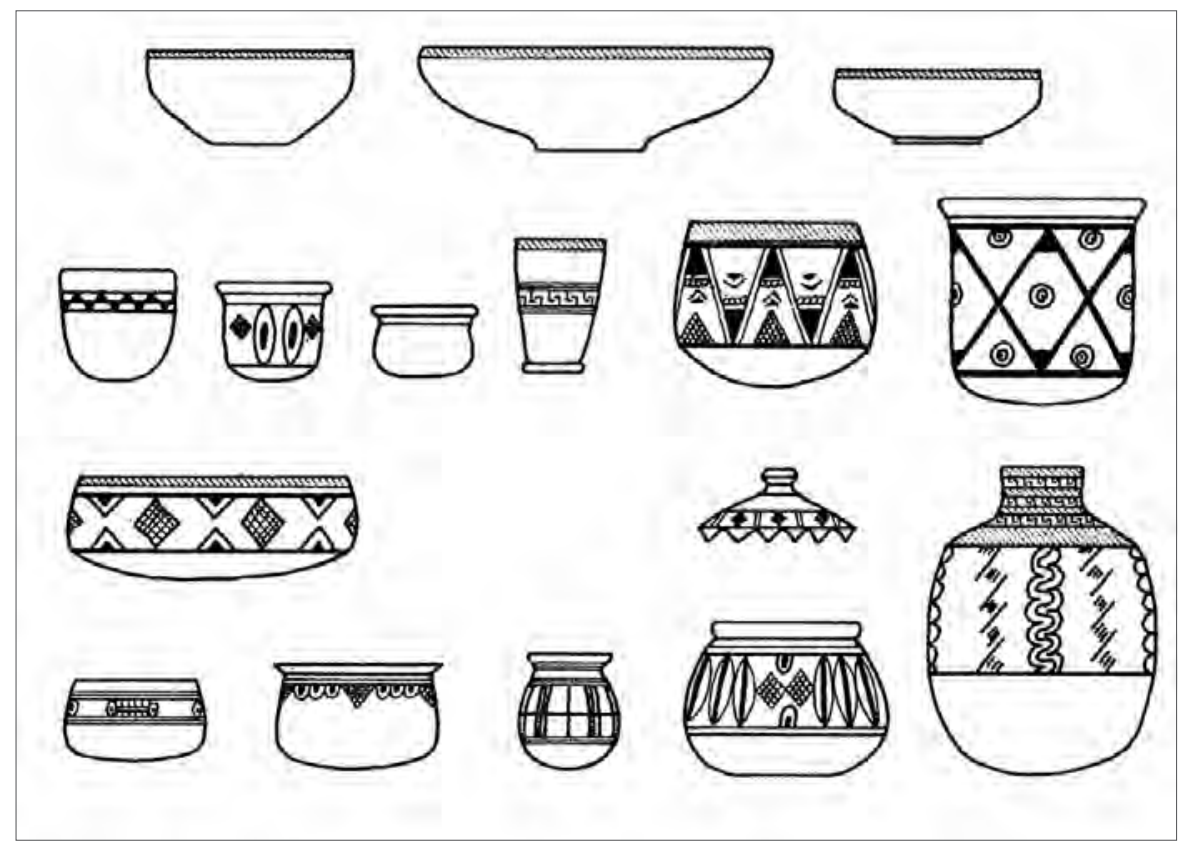

Fig. 5. Typical Terminal Christian vessel forms and decoration 
known inscription of a Christian king is dated AD 1482. Ottoman Turks took possession of Egypt in 1520, and of northern Nubia a generation later, but by that time the Kingdom of Dotawo and the Bishopric of Qasr Ibrim were already gone with hardly a trace. With them passed the entire decorated pottery tradition that had been one of the glories of Nubian art since Meroitic times.

The impoverishment and cultural retrogress of Ottoman Nubia can hardly be understated. Not only the whole medieval artistic tradition but even literacy disappeared. Pottery was now made almost entirely by hand, as it had been in Neolithic times. J.L. Burckhardt, the first foreign visitor to enter the region in several centuries, described the Nubians of the early 19th century as illiterate, miserably poor, and nearly naked (Burckhardt 1819: 139-141). Many causal factors for this impoverishment have been suggested, but the most determining of them was surely the opening of maritime trade to the west African coasts, by European powers. Nubia's prosperity had always depended not on its own resources but on its position astride the world's richest trade route - for centuries the only secure corridor through which the highly coveted products of tropical Africa could reach the Mediterranean Basin. That monopoly was somewhat undermined by the development of trans-Saharan caravan trade in the Middle Ages, but it was forever destroyed when sea-lanes were opened (Adams 2013: 41).

\section{Some afterthoughts}

The Nubian ceramic data suggest some general thoughts about the nature and the dynamics of style. It is, of course, something present to a degree in nearly every human action and every human product. There are usually several equally suitable ways of doing or making a thing, and it is style that makes the choice for us. Apart from providing aesthetic satisfaction, it saves us from having to think. Yet the content of style, unlike other aspects of culture, is wholly unpredictable; it is susceptible to no deterministic explanation. "There's no accounting for taste", as the old English saying has it, or de gustibus non disputandum, as the Romans put it.

The fact of stylistic change, over time, is as predictable as is the existence of style itself, if for no other reason than that we humans get tired of everything. But the direction of change is once again entirely unpredictable. Change in all other aspects of culture is change toward some desired goal, but stylistic change is change away from whatever is currently prevailing. It can go in any direction, 
and it can reverse direction at any time, going back to something earlier. This happened several times in the case of Nubian pottery decoration, as for example when the Classic Christians revived so many Meroitic decorative practices, or when color preference alternated over time between red and white slips.

But while the direction of change is unpredictable, the rate of change can to some extent be explained. In the case of Nubian pottery, we can observe that stylistic change in the wheel-made wares was very much more rapid than in the case of the handmade wares. Here, market factors were at work. The handmade wares were simple, basic necessities, mainly connected with food consumption; as such they had a guaranteed market that did not change as long as people had to eat. But the wheel-made wares were to some extent luxury goods, as is demonstrated by the fact that the Nubians got along well enough without them, after the disappearance of the wheel-made industry in postChristian times. Indeed some of the wheel-made products seem to have been showpieces, without any practical function. It is difficult to see what function could have been served by the numerous vase forms of Classic Christian times, and indeed the vessels rarely show any recognizable signs of wear. The thinwalled Meroitic fine wares were too fragile for any kind of everyday use, and it is possible that they were destined primarily for mortuary use. Practically all of the fineware cups, in particular, have been found in graves. The existence of these showpieces calls to mind the Victorian and Edwardian eras in out own recent past, when there was a great demand for "art pottery" among the elite.

Luxury goods may be prized, but they have no guaranteed market. It has to be created, and then maintained, by the makers. Thus the Nubian wheel-made wares, unlike the handmade wares, were commercial goods, which moved in a competitive market. The potters were full-time specialists, who relied on the sale of their pots for their livelihood. There was probably competition at times between factories; there was competition at all times with the Aswan wares. Hence, like the makers of luxury goods everywhere, the Nubian potters had to have an eye on their markets. Change would predictably be introduced whenever sales were flagging, or when possible new customers were identified, and it would likely be most rapid in times of uncertain demand. This seems to have been the case in the later Classic and post-Classic Christian periods, when cheap Aswan wares had seized a good share of the Nubian market.

Revolutions are another and more problematical matter, marking unexplained outbursts of creativity. They represent, I think, moments in history when the potters, for whatever reason, rose from the level of mere craftsmen to that of true artists. As such, like artists in all times, they were seeking to make a statement about their society and their time: "this is who 
we are". But what it was that triggered such outbursts remains elusive. I have suggested certain historical factors that might have triggered the Meroitic, Ballaña, and Terminal Christian revolutions, but that of Classic Christian times remains a mystery. As the great anthropologist A.L. Kroeber long ago showed, in Configurations of Culture Growth, human creativity marches to no drummer but its own (Kroeber 1944).

\section{References}

Adams, W.Y. (1961). The Christian potteries at Faras. Kush, 9, 30-43

Adams, W.Y. (1962). Pottery kiln excavations. Kush, 10, 62-75

Adams, W.Y. (1977). Nubia: Corridor to Africa. Princeton, NJ: Princeton University Press Adams, W.Y. (1979). On the argument from ceramics to history: A challenge based on evidence from medieval Nubia. Current Anthropology, 20(4), 727-744

Adams, W.Y. (1981). Medieval Nubian design elements. In W.K. Simpson and W.M. Davis (eds), Studies in Ancient Egypt, the Aegean, and the Sudan: Essays in honor of Dows Dunham on the occasion of his 90th birthday, June 1, 1980 (pp. 1-10). Boston: Department of Egyptian and Ancient Near Eastern Art, Museum of Fine Arts

Adams, W.Y. (1986). Ceramic industries of Medieval Nubia I-II [=Memoirs of the UNESCO Archaeological Survey of Sudanese Nubia 1]. Lexington, KY: University Press of Kentucky

Adams, W.Y. (1988). Puzzle of the Nubian pots. Archaeology, 41(2), 46-53

Adams, W.Y. (2005). The West Bank survey from Faras to Gemai III. Sites of Christian age [=British Archaeological Reports International Series 1421]. Oxford: Archaeopress

Adams, W.Y. (2013). Nubian history in global perspective. In J. van der Vliet and J.L. Hagen (eds), Qasr Ibrim, between Egypt and Africa: Studies in cultural exchange (Nino Symposium, Leiden, 11-12 December 2009) [=Egyptologische uitgaven 26] (pp. 23-44). Leiden: Nederlands Instituut voor het Nabije Oosten

Burckhardt, J.L. (1819). Travels in Nubia. London: John Murray

Hayes, J.W. (1972). Late Roman pottery. London: British School at Rome

Kroeber, A.L. (1944). Configurations of culture growth. Berkeley, CA: University of California Press

Thompson, L.A. and Ferguson, J. (eds). (1969). Africa in Classical Antiquity. Ibadan: Ibadan University Press 


\title{
Some unique medieval Nubian textiles in the British Museum collections
}

\author{
Julie Renee Anderson \\ The British Museum \\ janderson@thebritishmuseum.ac.uk
}

Anna Harrison

The British Museum

aharrison@thebritishmuseum.ac.uk

\section{KeYwords}

Kulubnarti, medieval, textile, economy, conservation, hair, Nubian

\begin{abstract}
An ongoing British Museum-Glasgow University conservation project has focused on medieval textiles excavated from Kulubnarti, Sudan. Textile manufacture was an important industry on the site and this is reflected in the artefacts found there. Methods used to conserve the textiles are discussed and the fibres used, notably human hair, identified. The reasons for the use of various fibres and weaving techniques are considered.
\end{abstract}

The Kulubnarti Textile Research and Conservation Project recently launched by the British Museum in partnership with the Centre for Textile Conservation and Technical Art History, University of Glasgow has provided an opportunity to examine more closely and reflect upon some unique, little known, medieval

1 This ongoing conservation project is under the supervision of Sarah Foskett, Conservation Tutor, Glasgow University, Anna Harrison, Senior Organic Artifacts Conservator, British Museum and Julie Anderson, Assistant Keeper, Ancient Egypt and Sudan, British Museum. 
Nubian artifacts in the British Museum's collection and to bring them to the attention of the wider academic community. ${ }^{2}$ Initiated in 2013, the purpose of the project is twofold: first, to conserve the Kulubnarti textiles, making them accessible for study while providing suitable storage and second, to enable Glasgow conservation students to develop practical conservation, observation and documentation skills by working with these archaeological textiles.

Kulubnarti, located in northern Sudan approximately $400 \mathrm{~km}$ upstream of Aswan, Egypt, was excavated by the University of Kentucky in 1969 and 1979, under the direction of William Y. Adams (Adams 2011; Adams and Adams 1998; Adams et al. 1999). ${ }^{3}$ Environmental conditions on the site were favourable and many organic objects that would normally decompose, including wood, leather, basketry and textiles, were preserved creating a remarkable corpus of Nubian material comparable with that of medieval Qasr Ibrim, Egypt excavated by the Egypt Exploration Society (W.Y. Adams 1996; 2010). The Kulubnarti excavations focused on the settlements, housing and cemeteries of common people and as such have provided exceptional insight into daily life in the kingdoms of Nobadia and Makuria (and later); kingdoms about which Włodzimierz Godlewski, to whom this volume is dedicated, has written extensively, publishing numerous seminal works, and in which he has conducted years of archaeological excavation, notably in the Makurian capital of Dongola.

Excavations in the northern suburb of Dongola (Kom P) uncovered marvellous spacious villas, notably House PCH.1, which in its earliest phase of construction, dated to the latter half of the 8th century, was found to contain among other things, inscribed stele fragments bearing the name of Petros, Eparch of Nobadia (AD 798). The suburb itself is believed to date to the Early Christian period (7th-9th centuries AD) (Godlewski 1991: 79, 87) and it was suggested that these buildings housed the elite (Godlewski 1990: 15; 1991: 8485; see also Jakobielski 1982 for Houses A and B). Despite the small number of buildings excavated, this conclusion is not unreasonable as it could be expected that the Makurian court and government bureaucrats would have resided in

2 Registration numbers of British Museum objects discussed herein are prefaced by the designation EA followed by a number. Records for objects may be seen in the British Museum Collections Online Catalogue at: http://www.britishmuseum.org/research/collection_online/ search.aspx.

3 Some artifacts excavated from Kulubnarti form part of a recent donation to the British Museum by the W.S. Webb Museum of Anthropology, University of Kentucky, which received the artefacts from the Sudanese Antiquities Service in accordance with the Sudanese Antiquities law. 
the vicinity of the capital city. Although the exact socio-economic status of the occupants remains uncertain, it is clear that the houses were occupied by persons of means and that their location within the fertile Letti Basin may have enabled a portion of the population to become disproportionately wealthy when compared to the inhabitants of poorer regions of Nubia.

In comparison with Dongola, Kulubnarti was one such impoverished region. It was not the capital situated in the heartland of the kingdom with the benefit of a fertile basin, but rather was on the periphery in the hinterlands as embodied by the rough terrain of the Batn el-Hajar. It is the lack of resources and limited amount of available agricultural land that shaped the fabric of Kulubnarti society and the lives of its 'more ordinary' inhabitants.

Textile manufacturing was one of Kulubnarti's most important industries throughout the medieval period (and beyond) and is attested to by numerous artifacts connected with weaving, sewing and spinning. For example, British Museum EA77429 from the Terminal Christian period found in the fill of settlement 21-S-2, House C1, room 1, is a complete palm spindle and gourd whorl with attached cotton yarn [Fig. 2 right]. A whittled, lozenge-shaped loom shuttle of acacia wood (EA77597) [Fig. 2 above], also from settlement 21-S-2 but later in date, is another such example.

The majority of textiles found were excavated from two cemeteries, 21R-2, located near Kulbincoing on the east bank of the river, and 21-S-46 on

Fig. 1. Map of the Kulubnarti area with cemetery sites 21-R-2 and 21-S-46 (Drawing C. Thorne (C) The British Museum, after Adams et al. 1999: 4)

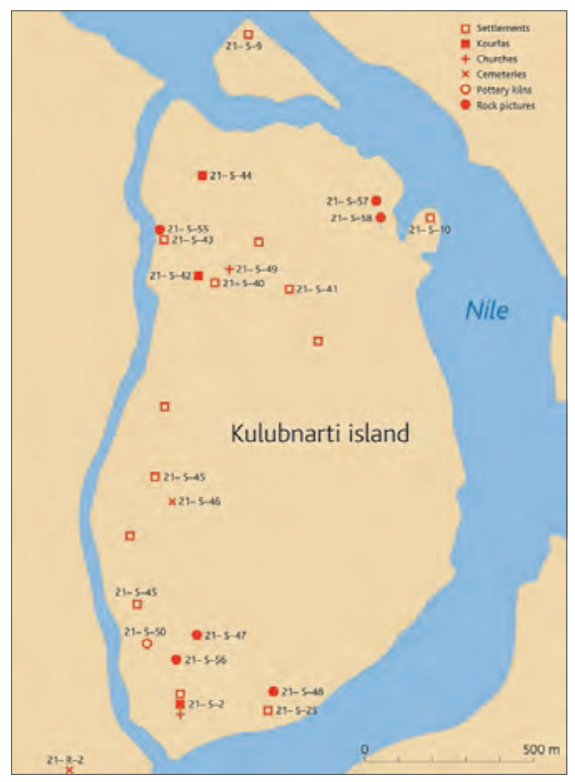




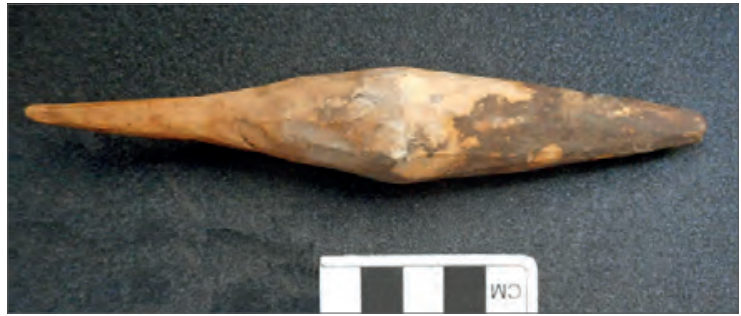

Fig. 2. Artifacts connected with weaving: above, acacia wood shuttle (British Museum EA77597); right, drop-spindle with palm spindle and gourd whorl and attached cotton yarn (British Museum EA77429) (Photos (C) The British Museum)

Fig. 3. Loin-cloth and close-up of part of the fringe (British Museum EA77321) (Photos (C) The British Museum)

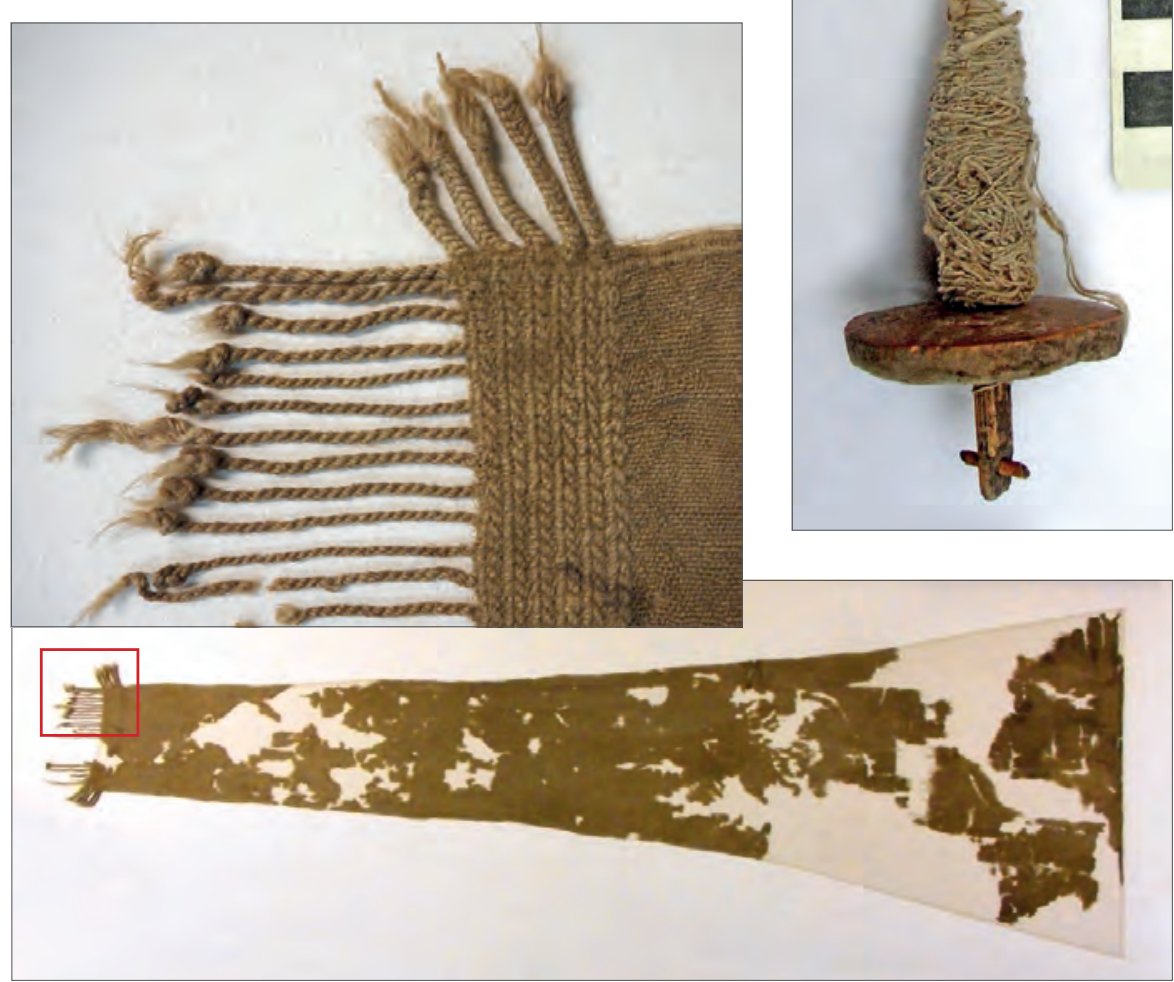


Kulubnarti [Fig. 1]. In both cemeteries most graves were dated to the Early Christian period with some caveats (7th-9th century AD) (Adams et al. 1999: 7, 26). Unfortunately, no Early Christian settlements were found associated with these cemeteries.

Textiles recovered from cemeteries 21-R-2 and 21-S-46 largely consisted of fragments whose original form or function remains unrecognizable and it seems that rags or garments no longer deemed serviceable for the living were reused to wrap the deceased. Within the late Nubian textile assemblage of the Scandinavian Joint Expedition "the fact that the shrouds were often made of several pieces of cloth which were sewn together to produce a sufficient length and width to envelop the body seems to indicate that the cloths were not specially woven for funerary purposes" (Bergman 1975: 10). Within the Kulubnarti assemblage, there are however, a few exceptions where the presence of seams, hems, cords and braids provides clues that aid in identifying the garment. These garments include mantles (i.e., EA84342), loin-cloths (i.e., EA77321), tunics (i.e., EA78941), and more rarely skirts (i.e., EA78936) and trousers (i.e., EA 78841). Wool loin-cloth EA77321, for example [Fig. 3], retained much of its trapezoidal shape, a two cord selvedge, decorative fringe and part of the twoelement, s-twist cord, sewn on one end, which had been used to tie the garment around an individual's waist. The textiles found at Qasr Ibrim were discovered in a similar state of reuse.

After the original garment or household furnishing was worn out it was torn into pieces, and used a second time in a variety of ways. Consequently, in most cases the original function of the fabric cannot be determined, although sometimes the remains of seams and hems provide useful clues (N.K. Adams 2010: 156). Across the Nile Valley, garment life was extended by darning, altering adult clothing for children, creating new garments from recycled cloth and basically using garments for as long as possible (Pritchard 2006: 37).

Among the collection of Kulubnarti cemetery textiles are three that are worthy of special comment due to their unusual nature; they were woven out of human hair and are largely complete unlike the majority of textiles recovered from the cemeteries [Figs 4, 5]. The general characteristics of these artifacts are provided in Table 1. They are roughly of the same size, made of various shades of dark brown hair, woven in plain weave with S-spun threads, and have raised, fibrous faces. There are minor differences in the finishing and construction of the selvedges and edges with one being finished with a cord while the other two with fringing [details in Figs 4, 5]. 
Table 1. General characteristics of the human hair mats (see Adams 1999: 61, 64)

\begin{tabular}{|c|c|c|c|c|}
\hline $\begin{array}{l}\text { British } \\
\text { Museum } \\
\text { Number }\end{array}$ & $\begin{array}{l}\text { Kulubarti } \\
\text { Excavation } \\
\text { Number }\end{array}$ & $\begin{array}{l}\text { Dimensions } \\
\text { (m) }\end{array}$ & Weave & Structure \\
\hline \multirow{3}{*}{ EA77320 } & 93.1 .190 & $\begin{array}{l}\text { Wp: } 0.86 \\
\text { (incomplete) }\end{array}$ & \multirow{3}{*}{ Plain, open } & \multirow{3}{*}{ Wf-predominan } \\
\hline & $\mathrm{Cl}-190$ & Wf: 1.26 & & \\
\hline & & Th: $2 \mathrm{~mm}$ & & \\
\hline \multirow{3}{*}{ EA78247 } & 93.2 .1 & Wp: 1.06 & \multirow{3}{*}{ Plain, open } & \multirow{3}{*}{ Balanced } \\
\hline & $\mathrm{Cl}-1$ & Wf: 0.69 & & \\
\hline & & Th: $2 \mathrm{~mm}$ & & \\
\hline \multirow{3}{*}{ EA78248 } & $93.1 .225 \mathrm{c}$ & Wp: 1.35 & \multirow{3}{*}{$\begin{array}{l}\text { Half-basket, } \\
\text { open }\end{array}$} & \multirow{3}{*}{ Balanced } \\
\hline & $\mathrm{Cl}-225 \mathrm{c}$ & Wf: 0.77 & & \\
\hline & & Th: $2 \mathrm{~mm}$ & & \\
\hline
\end{tabular}

Abbreviations: $\mathrm{Wp}=$ warp, $\mathrm{Wf}=$ weft, $\mathrm{Th}=$ mat thickness

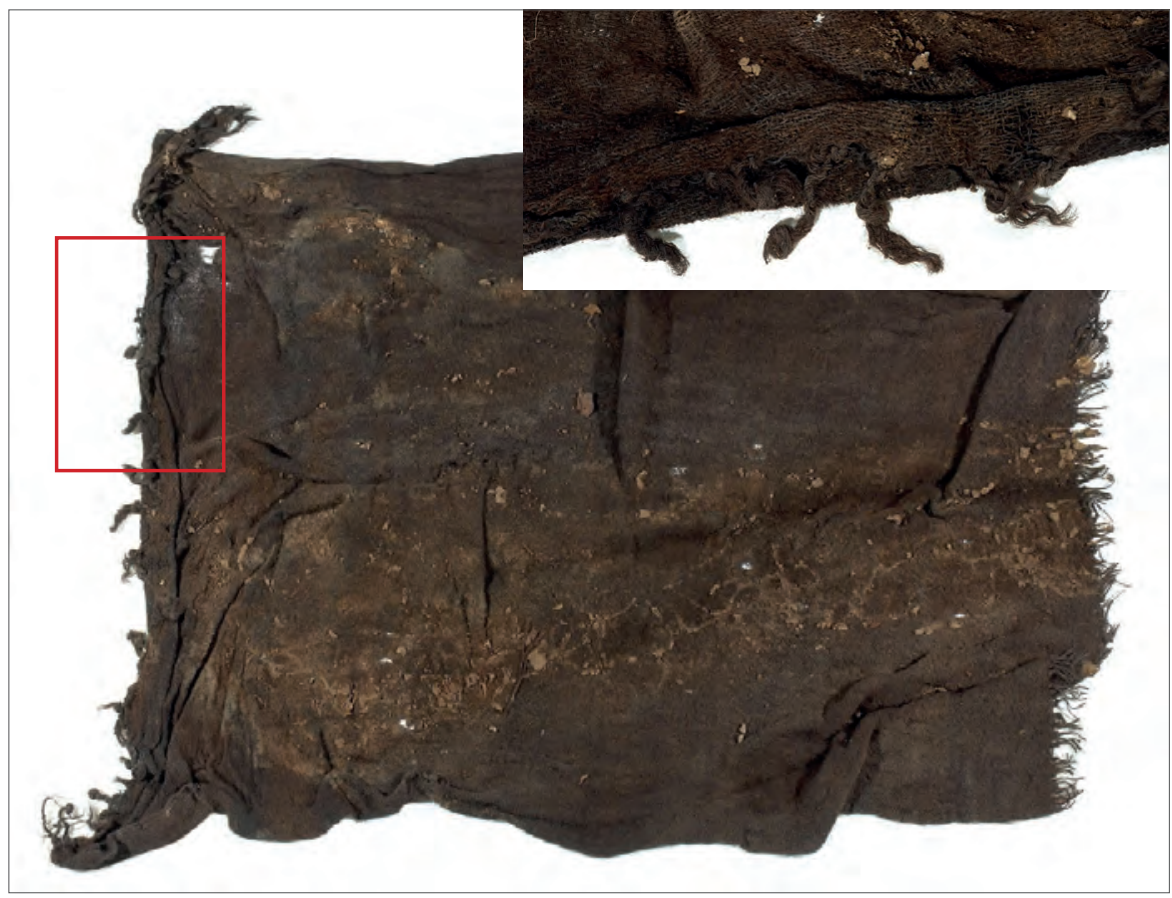

Fig. 4. Human hair textile from grave 172, Cemetery 21-S-46 (British Museum EA78247); detail of knotted fringe finish (Photo (C) The British Museum) 
Table 1 (continued from opposite page)

\begin{tabular}{|c|c|c|c|c|c|}
\hline $\begin{array}{l}\mathrm{Wp} / \\
10 \mathrm{~mm}\end{array}$ & $\begin{array}{l}\text { Wp } \\
\text { Spin }\end{array}$ & $\begin{array}{l}\text { Wf/ } \\
10 \mathrm{~mm}\end{array}$ & $\begin{array}{l}\text { Wf } \\
\text { Spin }\end{array}$ & Selvedge & Edge \\
\hline \multirow[b]{2}{*}{4} & \multirow[b]{2}{*}{$S$} & \multirow[b]{2}{*}{10} & \multirow[b]{2}{*}{$S$} & 1. Plain, with 2 paired warps & \multirow{2}{*}{$\begin{array}{l}\text { Knotted } \\
\text { fringe }\end{array}$} \\
\hline & & & & 2. Reinforced with 2 paired warps & \\
\hline 6 & $S$ & 7 & $S$ & Reinforced & $\begin{array}{l}\text { Knotted } \\
\text { fringe, } \\
\text { loops }\end{array}$ \\
\hline 4 & S & $\begin{array}{l}5 \\
\text { (paired) }\end{array}$ & $S$ & Plain, with 2 paired warps & $\begin{array}{l}\text { S-twisted } \\
\text { cords }\end{array}$ \\
\hline
\end{tabular}

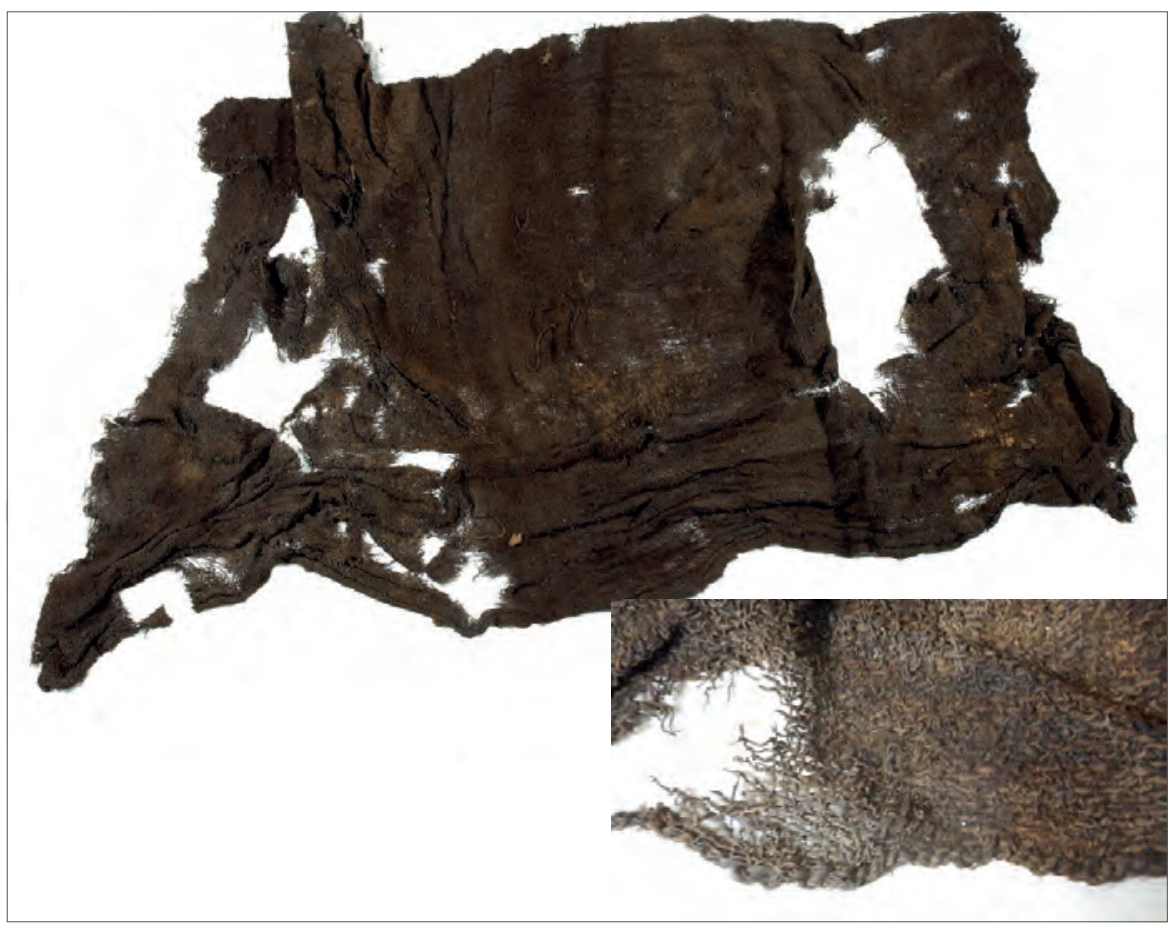

Fig. 5. Human hair textile from grave 70, Cemetery 21-R-2 (British Museum EA78248); detail of cord finish (Photos (C) The British Museum) 
Table 2. Description of hair textile provenance. Age designations adapted from Buikstra and Uberlaker 1994 by D. Antoine (Adams and Van Gerven 1969-1979; Adams et al. 1999: 14, 21, 34, 40, 42)

\begin{tabular}{|c|c|c|c|}
\hline $\begin{array}{l}\text { British } \\
\text { Museum } \\
\text { Number }\end{array}$ & $\begin{array}{l}\text { Kulubnarti } \\
\text { number }\end{array}$ & Provenance & Grave structure (m) \\
\hline \multirow{2}{*}{ EA77320 } & 93.1 .190 & $21-\mathrm{R}-2$ & $\begin{array}{l}1 \text { course of small scattered stones } \\
\text { roughly diamond-shaped }\end{array}$ \\
\hline & $\mathrm{Cl}-190$ & Grave 168 & Slot grave L: 1.77; W: 0.47; D: 0.92 \\
\hline \multirow{2}{*}{ EA78247 } & 93.2 .1 & $21-S-46$ & $\begin{array}{l}2 \text { courses of rowlock brick sepa- } \\
\text { rated by a single course of rowlock } \\
\text { stretchers L: } 1.82 \text {; W: } 0.84 ; \mathrm{H}: 0.05\end{array}$ \\
\hline & $\mathrm{Cl}-1$ & Grave 172 & Slot grave L: 1.80; W: 0.60; D: 1.02 \\
\hline \multirow[b]{2}{*}{ EA78248 } & $93.1 .225 \mathrm{c}$ & $21-\mathrm{R}-2$ & No superstructure found \\
\hline & $\mathrm{Cl}-225 \mathrm{c}$ & Grave 70 & $\begin{array}{l}\text { Slot grave with rounded ends } \\
\text { L: } 2.02 \text {; W: } 0.41 ; \mathrm{D}: 1.14\end{array}$ \\
\hline
\end{tabular}

Abbreviations: $\mathrm{Wp}=$ warp, $\mathrm{Wf}=$ weft, $\mathrm{Th}=$ mat thickness

Their provenance and a brief description of the graves in which they were found and of their associated individuals may be found in Table 2. Neither the graves nor their occupants seem to share many characteristics or similarities which might be used to distinguish the graves that contained the hair textiles from those that did not, although with a sample size of three, this is by no means statistically significant. The graves were found in two different cemeteries (21-R-2; 21-S-46) and the burials were of similar form. The individuals ranged in age, were oriented in the same manner with faces covered, and hair textiles were associated with both sexes and variably positioned when wrapped around the body.

When the textiles arrived in the Museum, they were deeply creased, folded, contained small insect holes, and earth from the graves' fill, as well as human remains adhered to their surfaces. They had not previously undergone conservation. The condition and physical qualities of the artifacts, and ethical 
Table 2 (continued from opposite page)

\begin{tabular}{|c|c|c|}
\hline $\begin{array}{l}\text { Sex and age } \\
\text { of individual }\end{array}$ & Orientation of body & $\begin{array}{l}\text { Position of } \\
\text { human hair textile }\end{array}$ \\
\hline Male? & \multirow{3}{*}{$\begin{array}{l}\text { Extended on left side, facing } \\
\text { north, brick fragments over face }\end{array}$} & \multirow{3}{*}{$\begin{array}{l}\text { Wrapped around body to the } \\
\text { knees; legs wrapped in leather }\end{array}$} \\
\hline Adolescent & & \\
\hline$(16-19)$ & & \\
\hline Female & \multirow{3}{*}{$\begin{array}{l}\text { Extended on left side, facing } \\
\text { north, } 3 \text { stone slabs cover face }\end{array}$} & \multirow{3}{*}{$\begin{array}{l}\text { Folded around legs; binding } \\
\text { cords of human hair(?) }\end{array}$} \\
\hline Middle Adult & & \\
\hline$(36-44)$ & & \\
\hline Female & \multirow{2}{*}{$\begin{array}{l}\text { Extended on left side, facing } \\
\text { north, } 3 \text { stone slabs cover face }\end{array}$} & \multirow{2}{*}{$\begin{array}{l}\text { Wrapped around body; } \\
2 \text { additional reused wool } \\
\text { textile fragments }\end{array}$} \\
\hline Old Adult (50+) & & \\
\hline
\end{tabular}

considerations guided treatment decisions. ${ }^{4}$ Minimal cleaning was carried out removing insect remains, soiling and earth. Deposits were particularly notable on EA78247. They were then humidified over a series of days at levels of $90 \%$ to relax the creasing and to facilitate the opening out of the textiles as gently as possible. During this process, fine pins were placed in openings in the weave to hold the textiles open and to avoid flattening, breaking or otherwise damaging the hair fibres. The fibres are friable and disposed towards breakage, so conservation was carried out with the aim of limiting fibre loss and with minimal intervention. Where traces of human remains, skin and deposits, folds and creases provided evidence of burial practices, manufacture and use, these were left in situ.

4 As the textiles are closely associated with human remains, research and conservation work is conducted in accordance with the British Museum Policy for Human Remains (http:// www.britishmuseum.org/about_us/management/human_remains/policy.aspx) and follows the Department for Culture, Media and Sport Code of Practice. Conservation of these hair textiles was carried out by Anna Harrison. 
Identification of the textile material as human hair was initially made by fibre analyses conducted by McCrone Research Institute, Chicago and also by Wool Industries Research Association, Leeds UK (Adams 1999: 55, notes 17,18$)$. The excavators made additional identifications of human hair items visually and these included a number of funerary tapes and bindings. Recently, many of these identifications have been further confirmed. As part of the Kulubnarti Textile Research and Conservation Project a number of hair textiles, particularly tapes, cords and bindings (such as EA77166, several fragments of binding consisting of nine elements of hair grouped together and connected by knots [Fig. 6]), were conserved and fibres from these objects were examined macroscopically to investigate scale structures, thickness and medulla. It was not possible to identify the scale structures as human (an imbricated scale pattern) due to the degradation of the fibres; however, the discontinuous medulla and diameter of the strands (70 microns) was found to be consistent with that of human hair. ${ }^{5}$ This may be contrasted, for example, with fibre diameter measurements of various types of fleeces as documented and discussed by M. Ryder (2011). This recent work has also suggested that usage of human hair elements in the Kulubnarti bindings was perhaps more widespread than previously thought.

At the time of discovery these textiles were unique in the Nile valley (Adams 1999: 69; 2004: 16). This appears to have remained the case even with subsequent excavations at several medieval Nubian and Sudanese sites and with additional textile analyses. See for example, the compilations of De Moor, Fluck, and Linscheid (2013) and De Moor and Fluck (2009); the analysis of Meroitic, X-Group and Medieval Nubian fabrics by Mayer Thurman and Williams (1979); the textile studies of Vogelsang-Eastwood (1991; 1998) at Soba East and similarly Crowfoot (2011) and Nettie K. Adams $(1996 ; 2010)$ at Qasr Ibrim; and the work of Bergman on the Nubian textiles of the Scandinavian Joint Expedition (Bergman 1975: 9-14). In these studies, several types of fabrics were identified including wool, cotton, silk and flax, but none of human hair. At Gabati, the textiles were largely of wool (Taylor 1998), though a hair cord used for stringing a bead found in a post-Meroitic tomb (T.83) was macroscopically examined and identified as horsehair. A few finer fibres were also observed with the cord and were postulated as being wool-fibre or perhaps human hair. The diameter of the hairs did not match that of human hair and these fibres, likely contaminants,

5 For a discussion concerning the composition, growth and structure of human hair, see Thompson, Wilson, and Ehleringer 2014: 371; and Ogle and Fox 1999. 
were not investigated further (Ryder 1998: 252). More recently, skeleton 353 from site el-Tereif (site 3-J-23) in the Fourth Cataract, excavated during the Merowe Dam Archaeological Salvage Campaign (see further Carpio and Guillen 2005) was found wrapped in a wool shroud tied with cords possibly made of human hair (A. Harrison and R. Webster, personal communication). Further examination to confirm this hypothesis is required and upon visual examination, it is more likely that they were woven from goat hair.

The main instigators of human hair decomposition are zoophilic and geophilic keratinolytic fungi. These are inhibited when access to oxygen or water is restricted in extreme environments (Thompson, Wilson, and Ehleringer 2014: 373), such as the dry, desiccating environments found in Sudan and Egypt. It is possible that the absence of human hair textiles from other sites in the Nile valley may result from differential preservation; however, the conditions of organic preservation, the nature and type of artifacts recovered from Qasr Ibrim, for example, are extremely similar to those found at Kulubnarti, yet human hair textiles were not recovered from the former, whereas they were from the latter. It is also worth noting that wigs of human hair and mummified remains with preserved hair have been recovered from many areas within the Nile valley and its hinterland, which again might suggest that differential preservation is not the primary factor here.

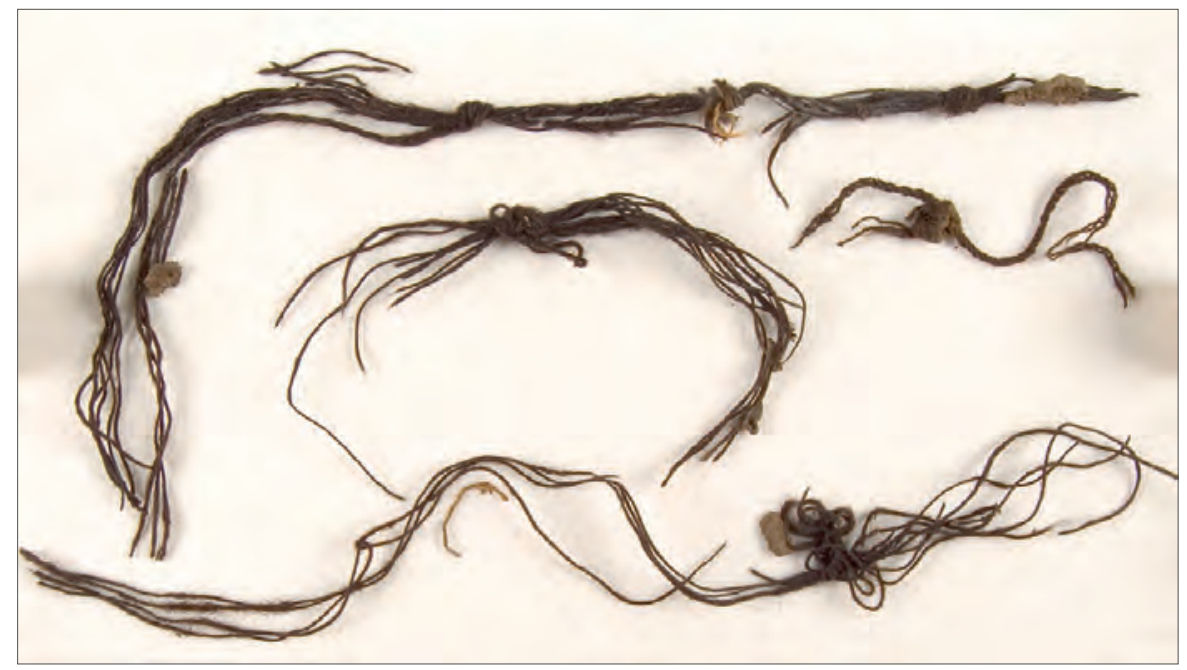

Fig. 6. Funerary binding with human hair elements and knotting (British Museum EA77166) (Photo (C) The British Museum) 
These three textiles form a remarkable group of artifacts, but questions remain as to why human hair was utilized and what function the mats served originally. In modern society, human hair often is a waste product and apart from wigs, hair extensions or other beauty accessories, artifacts made of it often induce a visceral response. "Some functions are intrinsic to the fabric" (N.K. Adams 2010: 156). Were these textiles specifically woven for funerary use? This seems highly unlikely for several reasons. A hole (about $130 \mathrm{~mm}$ by $100 \mathrm{~mm}$ ) in textile EA78248 was repaired. It was coarsely darned with a mixture of lighter and darker, S-spun thread of goat and human hair fibres [Fig. 7] and in some sections the textile is worn and threadbare. This indicates lengthy usage of the artefact prior to its inclusion in the burial. In one corner, textile EA77320 was pierced by a tapered wooden toggle pin [Fig. 8] which may also suggest usage before its burial. Wrappings used in the Kulubnarti graves were often secured with knotted cords, bindings, ribbons or tapes (Adams 1999: 57-58, 60-61) but not with wooden toggle pins.

Provided hair was available, it could be spun quite quickly into yarn, in much the same way as wool is spun, using a drop spindle such as those found at Kulubnarti [see Fig. 2] and many other medieval Nubian sites. Jose Gonzalez (2014) has produced a visual demonstration illustrating the ease with which human hair may be spun using a drop spindle. As such, cords, bindings and tapes made of hair for funerary use could have been created quite quickly with little effort and N.K. Adams has suggested they may have been produced as an act of mourning (Adams 1999: 67). This may have been true in some cases. The diversity of the materials incorporated into many of the funerary bindings from Kulubnarti, wherein some combine various elements of flax, wool, cotton and hair (i.e., EA 78893, EA78894, EA78883), would suggest that in many cases they were created simply using the materials that were readily to hand. This is further reinforced by the usage of rags and garment fragments as body wrappings, rather than purposewoven shrouds of which few were recovered. More complicated flat tapes or ribbons, incorporating woven decoration (i.e., EA78870 from Kulubnarti and from burial QI.84T/965 from Qasr Ibrim; see further Crowfoot 2011: 21; South and Muhlestein 2013: 68, Fig. 9), would have necessitated more time, effort and availability of appropriate materials for their manufacture. Some materials may not have been locally or readily available at Kulubnarti and indeed ribbons of this type may have been brought from elsewhere as they appear purpose-made for burial.

The larger hair textiles would have taken time and effort to manufacture. Although they are primarily dark brown in colour, light brown or reddish 
Some unique medieval Nubian textiles in the British Museum collections

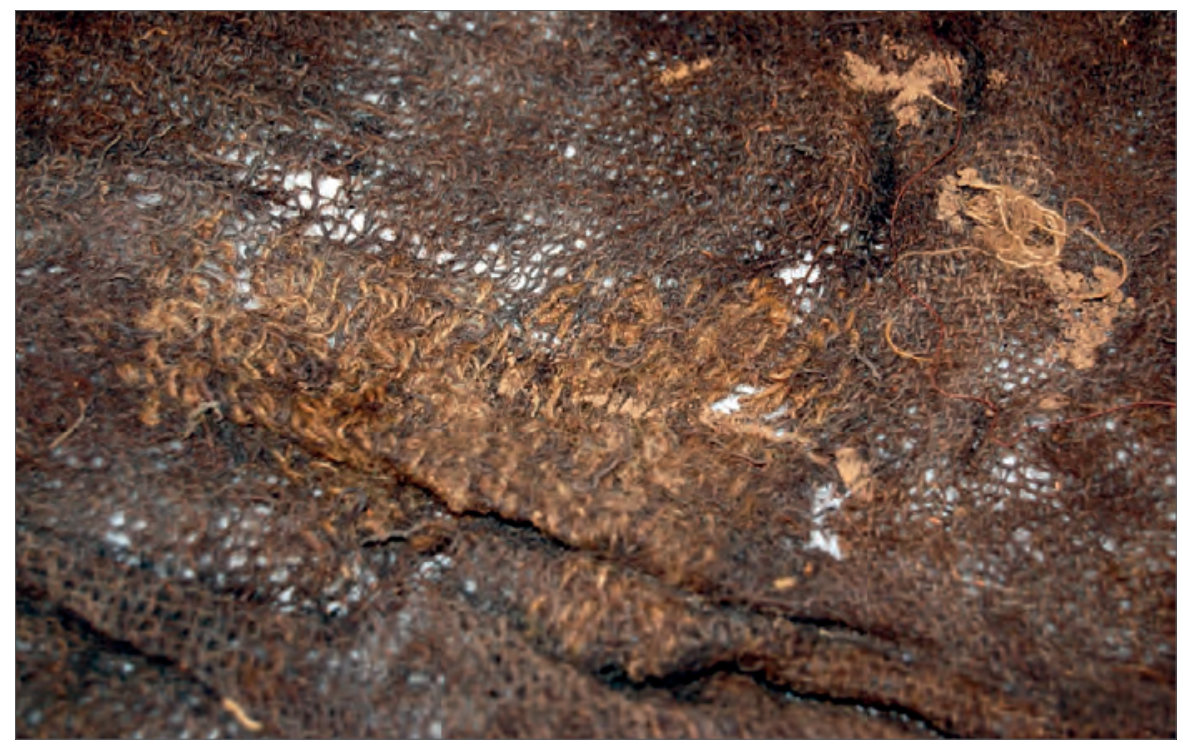

Fig. 7. Darned repair in EA78248

(Photo (C) The British Museum)

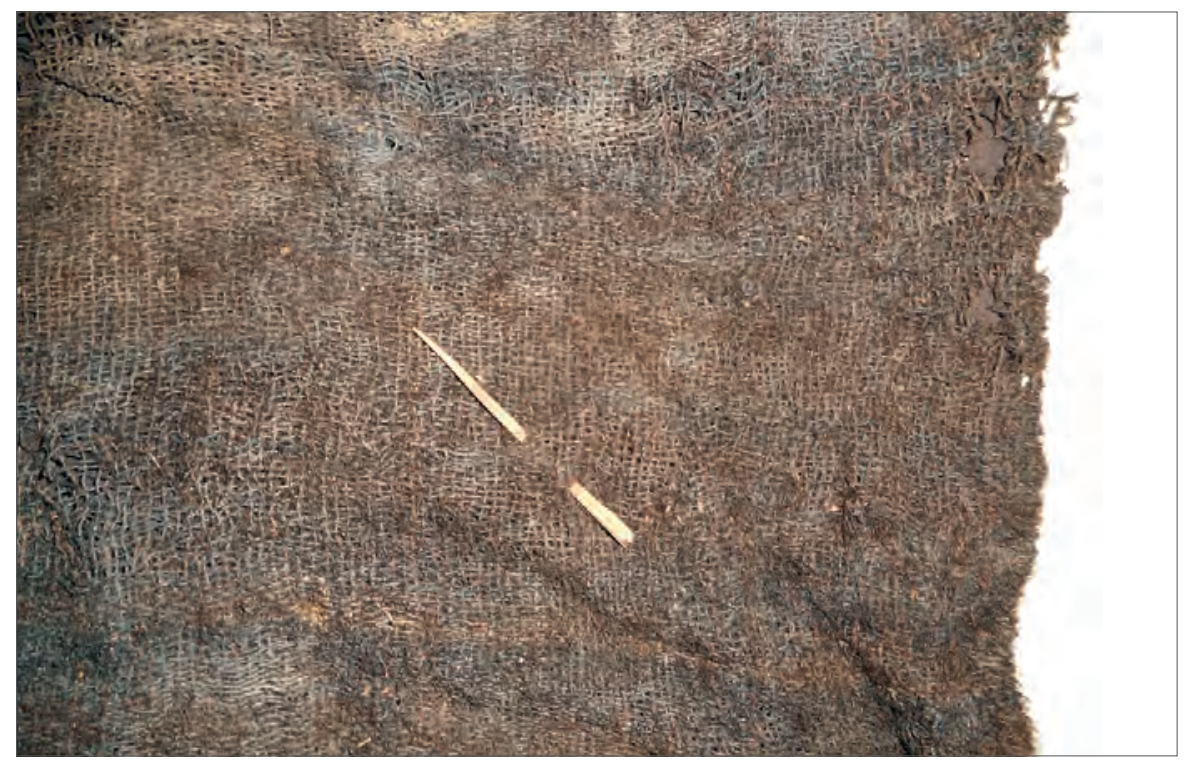

Fig. 8. Wooden toggle pin in EA77320

(Photo (C) The British Museum) 
bands are visible, particularly on EA77320, indicating that the hair used came from more than one individual and perhaps a decorative effect was intended. In addition to the collection of hair, they "could not have been quickly made. The hair had to be twisted into yarn, some of that yarn used for a warp which was set up on a loom, then the weaving of the mat and the knotting of the fringe..." (Adams 1999: 67). Prior to reuse as burial wrappings, it seems clear that these items had a different function. They are complete, of simple design with little decoration, and taking into account their limited distribution, very likely locally made. Their shape and size would suggest a primary usage as garments or house-hold furnishings. Although due to their simplicity they could have had multiple functions, they seem a bit small to function as bedcovers, lack evidence for filling as required for a pillow, are not particularly decorative as might be expected for a wall-hanging, and lack additional seams and selvedges as would be found in a fitted garment. "It is, indeed, often difficult to distinguish wool mantles from furnishing fabrics such as mattress covers" (Pritchard 2006: 123). The toggle-pin and darned repair might suggest usage as a scarf, shawl or a rather short mantle. Mantles and shawls are rectangular and can be simply wrapped around the body. One of the diagnostic features of wool mantles is the open, balanced plain weave that "would have helped to trap the air and keep the body warm" (Pritchard 2006: 123). The Kulubnarti hair textiles share this characteristic and in any case they could be wrapped around an individual or sat upon and either or both functions could account for the wear observed. Fragments of several wool mantles were found in the cemeteries (Adams 1999: 55). Similarly, a number of large undecorated textiles found reused as burial wrappings among the late Nubian textiles collected by the Scandinavian Joint Expedition were thought to have originally been mantles (Bergman 1975: 10).

The last question to be addressed is why was human hair used? Is this simply the practical use of an available resource or is it a reflection of the lack of access to other resources on the part of either some or many individuals within society and therefore a material utilized out of necessity or is it something else? Obłuski (2014: 178-183) has recently evaluated the social structure and the emergence of elites in Lower Nubia and growth of the state during the Nobadian period, the phase to which these textiles date, and this discussion will not be repeated here. It is possible that the manufacture of these textiles reflects a class distinction within Kulubnarti society, but it should be reiterated that apart from the presence of the larger textiles themselves, there is little to connect the individuals or to differentiate them from other inhumations in the cemeteries. The use of human hair in 
binding cordage was slightly more widespread, thus this usage of hair may be more of a general indicator of the relative poverty and inaccessibility of the region. As noted by the excavator, Kulubnarti is situated in an area of rocky inhospitable terrain that lacks a continuous floodplain and has little arable land (Adams et al. 1999: 1; Adams 2011: 1). Flax, silk and most likely cotton are commodities that would have had to be brought to Kulubnarti through the difficult environment of the Batn el-Hajar presumably in exchange for something, and the inhabitants may have had little to offer. Unlike other medieval sites in Lower Nubia, imported luxury items found at Kulubnarti were scarce in every period of its occupation (Adams and Adams 1998: 99). Perhaps confirmation of continuing hardship at Kulubnarti and of survival on the periphery may be found in a fragment of an Ottoman letter (EA77436) from the mid 1800s, written in Arabic in ink on light brown paper [Fig. 9]. A postscript scrawled along the bottom, perhaps desperately, reads: "Send us a portion of oil [or butter]. We are short of food" (Adams and Adams 1998: 88, Pl. 11.1C).

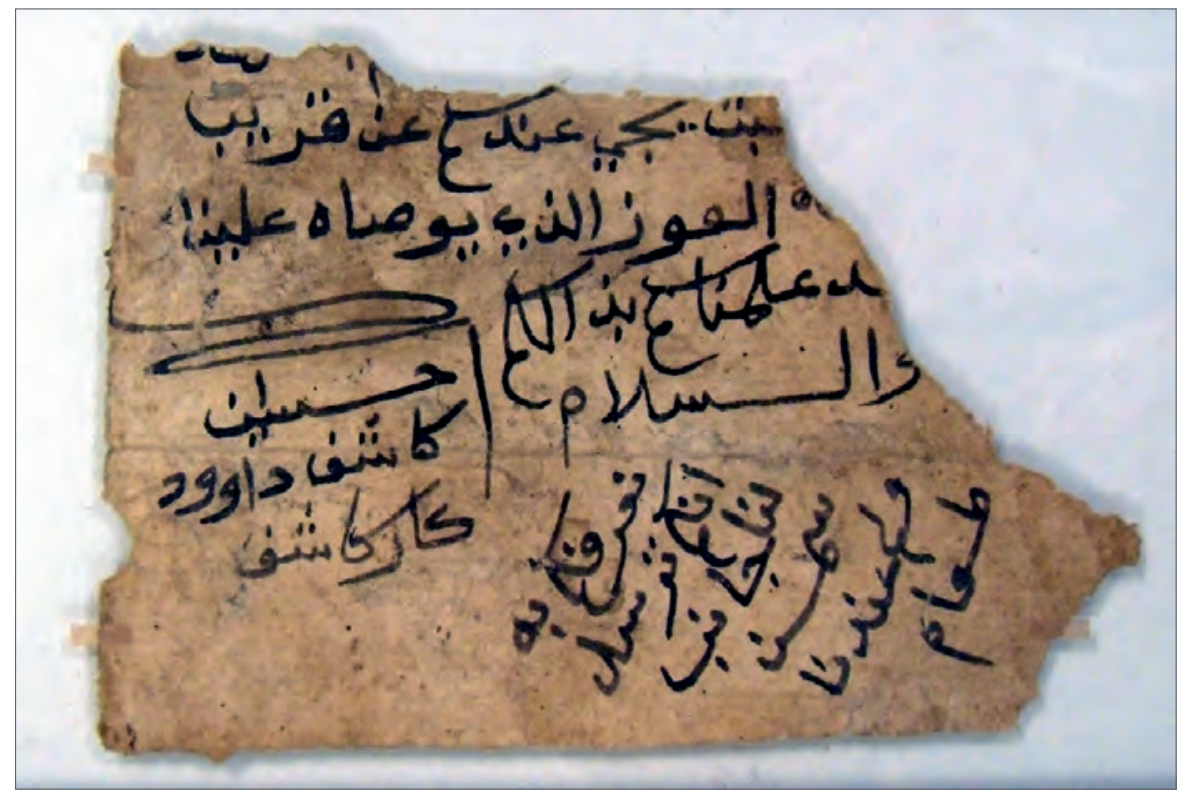

Fig. 9. Ottoman letter fragment (British Museum EA77436)

(Photo (C) The British Museum) 


\section{References}

Adams, N.K. (1996). Textile materials and weaves. In W.Y. Adams, Qașr Ibrîm: The late medieval period [=Excavation Memoir 59] (pp. 160-170). London: Egypt Exploration Society

Adams, N.K. (1999). The grave goods. In W.Y. Adams, N.K. Adams, D.P. Van Gerven, and D.L. Greene, Kulubnarti III. The cemeteries [=Sudan Archaeological Research Society Publications 4; British Archaeological Reports International Series 814] (pp. 51-71). Oxford: Archaeopress

Adams, N.K. (2004). Bindings and three mats made of human hair. Archaeological Textiles Newsletter, 38, 16-20

Adams, N.K. (2010). Textile materials and fabrics. In W.Y. Adams, Qasr Ibrim: The earlier medieval period [=Excavation Memoir 89] (pp. 156-164). London: Egypt Exploration Society

Adams, W.Y. (1996). Qașr Ibrîm: The late medieval period [=Excavation Memoir 59]. London: Egypt Exploration Society

Adams, W.Y. (2010). Qasr Ibrim: The earlier medieval period [=Excavation Memoir 89]. London: Egypt Exploration Society

Adams, W.Y. (2011). Kulubnarti I. The architectural remains [=Sudan Archaeological Research Society Publications 18; British Archaeological Reports International Series 2241]. Lexington, KY: Program for Cultural Resource Assessment, University of Kentucky

Adams, W.Y. and Adams, N.K. (1998). Kulubnarti II. The artifactual remains [=Sudan Archaeological Research Society Publications 2]. London: SARS

Adams, W.Y., Adams, N.K., Van Gerven, D.P., and Greene, D.L. (1999). Kulubnarti III. The cemeteries [=Sudan Archaeological Research Society Publications 4; British Archaeological Reports International Series 814]. Oxford: Archaeopress

Adams, W.Y. and Van Gerven, D.P. (1969-1979). Excavation notes from Kulubnarti cemeteries 21-S-46 and 21-R-2. Unpubl. manuscript

Bergman, I. (1975). Late Nubian textiles [=Scandinavian Joint Expedition to Sudanese Nubia 8]. Stockholm: Esselte studium

Carpio, G. and Guillen, S. (2005). Excavations at site 3-J-23, et-Tereif, Sudan. Sudan \& Nubia, 9, 14-15

Crowfoot, E. (2011). Qasr Ibrim: The textiles from the cathedral cemetery [=Excavation Memoir 96]. London: Egypt Exploration Society

De Moor, A. and Fluck, C. (eds). (2009). Clothing the house: Furnishing textiles of the 1 st millennium AD from Egypt and neighbouring countries. Proceedings of the 5th conference of the research group "Textiles from the Nile Valley" Antwerp, 6-7 October 2007. Tielt: Lannoo Publishers

De Moor, A., Fluck, C., and Linscheid, P. (eds). (2013). Drawing the threads together: Textiles and footwear of the 1st millennium AD from Egypt. Proceedings of the 7 th 
conference of the research from the Nile Valley, Antwerp, 7-9 October 2011. Tielt: Lannoo Publishers

Godlewski, W. (1990). Old Dongola 1988-1989. The House PCH.1. Polish Archaeology in the Mediterranean, 1, 14-16

Godlewski, W. (1991). Old Dongola 1988-1989. The House PCH.1. Archéologie du Nil moyen, 5, 79-101

Gonzalez, J. (2014). Spinning human hair into yarn... Retrieved from https://www. youtube.com/watch?v=WQkqdbqBEmU [accessed: April 2015]

Jakobielski, S. (1982). Polish excavations at Old Dongola in 1976 and 1978. In J.M. Plumley (ed.), Nubian studies: Proceedings of the Symposium for Nubian Studies, Selwyn College, Cambridge, 1978 (pp. 116-126). Warminster: Aris \& Phillips

Mayer Thurman, C.C. and Williams, B. (1979). Ancient textiles from Nubia: Meroitic, X-group, and Christian fabrics from Ballana and Qustul. Chicago: Art Institute of Chicago

Obłuski, A. (2014). The rise of Nobadia: Social changes in Northern Nubia in late Antiquity [=Journal of Juristic Papyrology Supplement 20]. (I. Zych, trans.). Warsaw: Raphael Taubenschlag Foundation

Ogle, R.R. and Fox, M.J. (1999). Atlas of human hair microscopic characteristics. Boca Raton, FL: CRC Press

Pritchard, F. (2006). Clothing culture: Dress in Egypt in the first millennium AD. Clothing from Egypt in the collection of the Whitworth Art Gallery, the University of Manchester. Manchester: Whitworth Art Gallery

Ryder, M.L. (1998). Appendix 11. Animal hair from Gabati. In D.N. Edwards, Gabati: A Meroitic, post-Meroitic and medieval cemetery in central Sudan I [=Sudan Archaeological Research Society Publications 3; British Archaeological Reports International Series 740] (p. 252). Oxford: Archaeopress

Ryder, M.L. (2011). The kinds of wool in the textiles from Qasr Ibrim. In E. Crowfoot, Qasr Ibrim: The textiles from the cathedral cemetery [=Excavation Memoir 96]. London: Egypt Exploration Society

South, K.H. and Muhlestein, K.M. (2013). Regarding ribbons: The spread and use of narrow purpose-woven bands in Late Roman Egyptian burials. In A. De Moor, C. Fluck, and P. Linscheid (eds), Drawing the threads together: Textiles and footwear of the 1st millennium AD from Egypt. Proceedings of the 7 th conference of the research from the Nile Valley, Antwerp, 7-9 October 2011 (pp. 56-73). Tielt: Lannoo Publishers

Taylor, S. (1998). Appendix 8. The textiles - sample description. In D.N. Edwards, Gabati: A Meroitic, post-Meroitic and medieval cemetery in central Sudan I [=Sudan Archaeological Research Society Publications 3; British Archaeological Reports International Series 740] (pp. 236-240). Oxford: Archaeopress

Thompson, A.H., Wilson, A.S., and Ehleringer, J.R. (2014). Hair as a geochemical recorder: Ancient to modern. In T.E. Cerling (ed.), Treatise on geochemistry XIV. 
Archaeology and anthropology (2nd ed., pp. 371-393). Amsterdam: Elsevier Vogelsang-Eastwood, G. (1991). The textiles. In D.A. Welsby and C. Daniels (eds), Soba: Archaeological research at a medieval capital on the Blue Nile [=British Institute in Eastern Africa Memoir 12] (pp. 300-309). London: British Institute in Eastern Africa Vogelsang-Eastwood, G. (1998). The textiles. In D.A. Welsby, Soba II. Renewed excavations within the metropolis of the Kingdom of Alwa in Central Sudan [=British Institute in Eastern Africa Memoir 15] (pp. 177-180). London: British Museum Press 


\title{
Egyptian amphorae LR 5/6 with Greek dipinti found in Dongola
}

\author{
Katarzyna Danys \\ Polish Centre of Mediterranean Archeology University of Warsaw \\ katarzyna_danys@o2.pl \\ Adam Łajtar \\ Department of Papyrology, Institute of Archaeology, University of Warsaw \\ a.f.lajtar@uw.edu.pl
}

\section{KeYwords}

Makuria, Dongola, amphorae, wine trade

\section{Abstract}

Seven LR 5/6 amphora sherds from Polish excavations in the building B.I on the citadel of Dongola published in the present article are thought to represent pottery production from the northwestern part of the Nile Delta. Their principal content was wine in all probability and they all came from 7 th century contexts. These particular seven pieces all carried dipinti in black reading: "To the Four + a number", which apparently indicates that the Church of Four Living Creatures was the recipient of the wine contained in these vessels. Assuming the interpretation is correct, the finds cast light on the organization of Egyptian wine exports to Makuria in the 7 th century.

Archaeological excavations conducted by a team from the Polish Centre of Mediterranean Archaeology University of Warsaw on the site of Dongola, capital of the Nubian Christian kingdom of Makuria, have had as one of its main objectives in recent years the unearthing of the "royal" quarter situated in the southwestern part of the citadel. The quarter included a small cruciform building of commemorative character, later turned into a church (B.III) located in the center, a church (B.V) to the south of it, and a spacious building of palatial character (B.I) in the northern part of the complex (Godlewski 2013: 25-29). 
The palace [Fig. 1], which is the focus here, was constructed in the 6th century and used, with some modifications, until the 14th/15th century. Adjoining the west wall of the palace was a series of units (rooms): 15, 36, 37, 40, 41, 42, that, in Włodzimierz Godlewski's interpretation, could have been storage rooms initially, later turned into the depositories of palace latrines located on the upper floor, and finally a place to dump refuse (Godlewski 2013: 30). The units yielded rich deposits of pottery manufactured mainly in the local, Dongolese workshops, both tableware and amphorae (Bagińska 2005; Danys-Lasek 2012). Also registered were transport containers produced in Egyptian centers, from the north and middle of the land, but mainly from the south (Bagińska 2005; Danys-Lasek 2012: 322). This ceramic material can be dated in its entirety to the 7 th century.

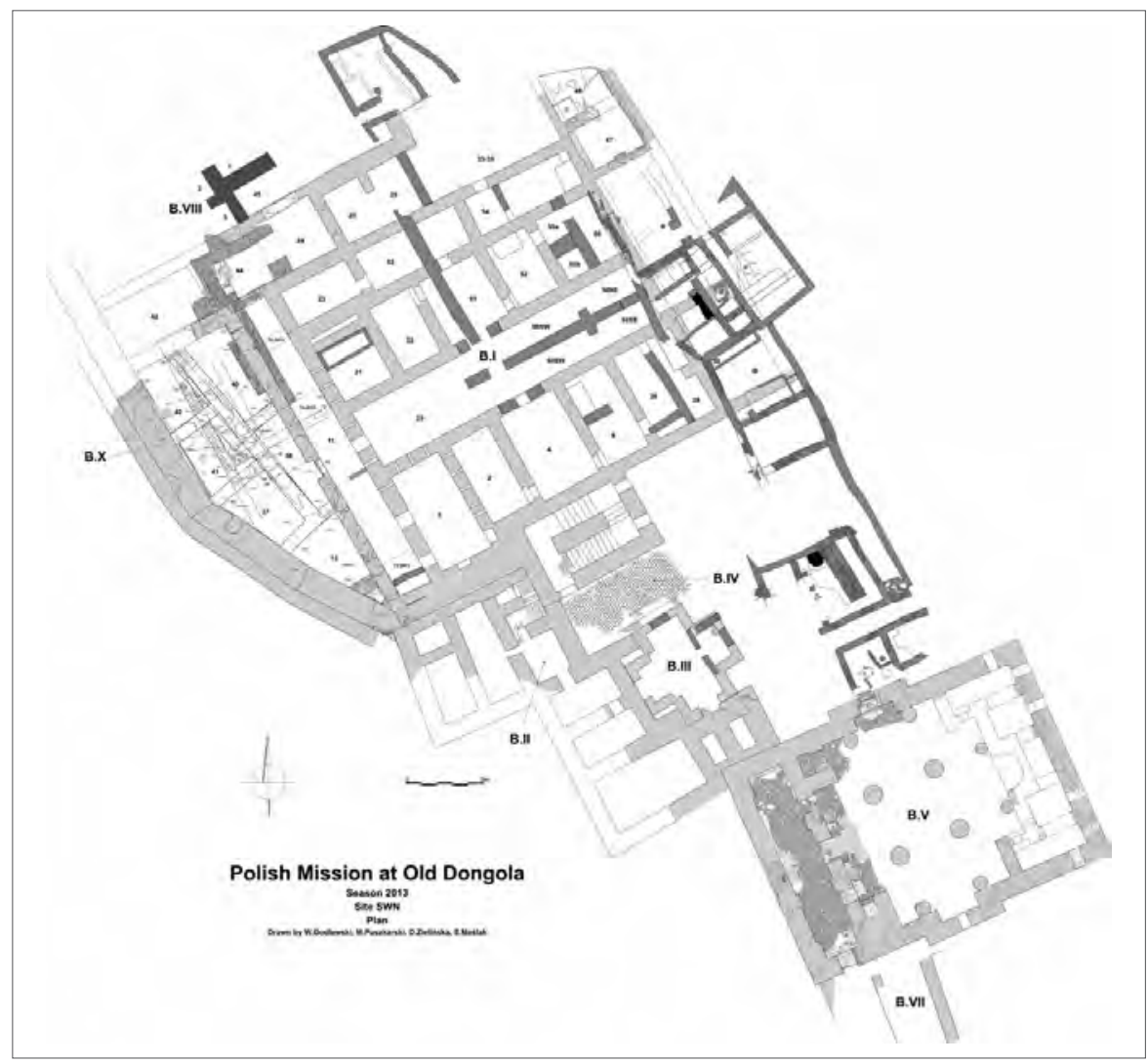

Fig. 1. Plan of Building B.I on the citadel of Dongola

(Drawing S. Maślak; courtesy PCMA UW) 
Included in this pottery assemblage is a group of bag-shaped amphorae made of brown, alluvial fabric recognizable as Egyptian LR 5/6. They represented variant $\mathrm{A}$, referred to as 2.1 in Delphine Dixneuf's typology (2011: 34, 149, Fig. 135), produced of fabric A12 and A13, which corresponds in Dongola to AIF4/A and AIF4/B respectively (see below). Specimens of the same containers found in Lower Nubia in the 1960s were classified by William Y. Adams as form Z23 (Ware U12, Sub-Family LB: the so-called Ballas Drab Utility Ware) (1986: 578, Fig. 317:23); the state of knowledge at the time allowed him to identify these vessels as an Egyptian product from Ballas workshops and he dated them to a period after AD 1100. In Kellia, analogous bag-shaped forms made of alluvial fabrics were classified as E187-190 by Michel Egloff (1977: Pl. 61:4), and on Elephantine they constituted type K768 according to Robert D. Gempeler (1992: Fig. 129/5).

The amphorae in question [Fig. 2] are bag-shaped, characterized by rounded and outcurved rim and loop handles attached to the upper part of shoulders. The surface is brown in color and the interior is resinated. The shoulders and the belly on occasion bear wide bands of combed decoration or ribbing. The fabric, AIF4, of alluvial origin, comes in two variants distinguished by the color of the break and the graining of inclusion. Variant $\mathrm{A}$ is light brown and brown, sometimes with a reddish tint, mediumdensity, hard with an admixture of white particles and sporadic grey bits $(0.25-0.1 \mathrm{~mm})$, mica, burnt chaff and crushed shells. Variant B is brown, sometimes with a reddish tint and a grey/dark grey core, medium-density, hard with a substantial admixture of white particles in two grain sizes $(0.7-0.3 \mathrm{~mm}$ and $0.25-0.1 \mathrm{~mm})$, sporadic grey ones $(0.25-0.1 \mathrm{~mm})$, with more burnt chaff than in variant $A$, and fewer crushed shells.

LR 5/6 amphorae of Nile fabric have been discovered throughout the Nile Valley, including Alexandria (Majcherek 2004: Fig. 7:6), Marea (Majcherek 2008: Cat. 82), Abu Mena (Engemann 1992: 157, Fig. 11:a, b), Kom Abou Billou with a workshop for these containers (Ballet and Dixneuf 2004: 70), Kellia (Egloff 1977: Pl. 61:4; Ballet, Bosson, and Rassart-Debergh 2003: Fig. 20, No. 124), Fustat and Old Cairo (Gayraud and Tréglia 2014: Fig. 2:2; Gascoigne 2007: Figs 16, 17), Tod (Lecuyot and Pierrat-Bonnefois 2004: Pl. 9, Fig. Td131), and Elephantine (Gempeler 1992: Abb. 129: 5). They were also recorded in Lower Nubia (Adams 1986: 575), and Dongola (Godlewski 2002: Fig. 5; Bagińska 2005: Figs 222, 223, 228; Danys-Lasek 2012: Fig. 4). Judging by the resination of internal surfaces, the principal content of the amphorae must have been wine. Examples from Kellia and Kom Abou Billou were divested of black impregnate, thus they may have served as containers for other commodities, like grain or 


\section{Catalogue}

The catalogue follows the order: catalogue number; site inventory number; findspot; state of preservation; fabric; inscription; remarks

No. 1. ADd.01.161

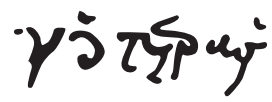

No. 2. ADd.03.075

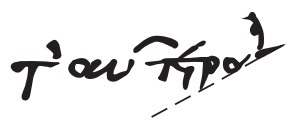

No. 3. ADd.09.154

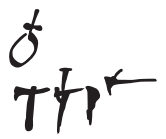

No. 4. ADd.09.365

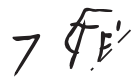

No. 5. ADd.12.208

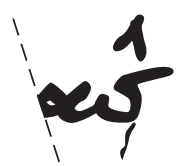

No. 6. ADd.12.239

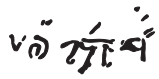

No. 7. ADd.12.259

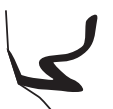

Building B.I, unit 15

Almost complete amphora

AIF4A

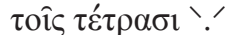

"To the Four, a numeral"

Building B.I, unit 15

Shoulder fragment with partly preserved handle AIF4B

$\tau(\mathrm{o} \hat{\varsigma} \varsigma) \alpha \hat{v}(\tau 0 \hat{\imath} \varsigma) \tau \varepsilon^{\prime} \tau \rho \alpha \sigma[\mathrm{l}]{ }^{\prime} \delta^{\prime}$

"To the same Four, 4"

Building B.I, unit 37

Upper part of amphora with rim and handles

AIF4A

$\tau \iota^{\prime} \tau \rho \alpha(\sigma \mathrm{l})$

"To the Four"

Oval surmounted by a cross to the left of the inscription and slightly above it. Meaning of the sign unknown.

Building B.I, unit 37

Upper part of amphora with one handle

AIF4A

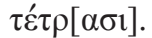

"To the Four"

Building B.I, unit 37

Upper part of amphora with one handle AIF4B

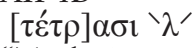

"To the Four, 30"

Building B.I, unit 41

Upper part of amphora with one handle

AIF4A

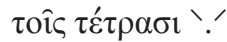

"To the Four, numeral"

Building I, unit 41

Upper part of amphora with one handle AIF4B

Illegible due to fragmentary state of preservation 


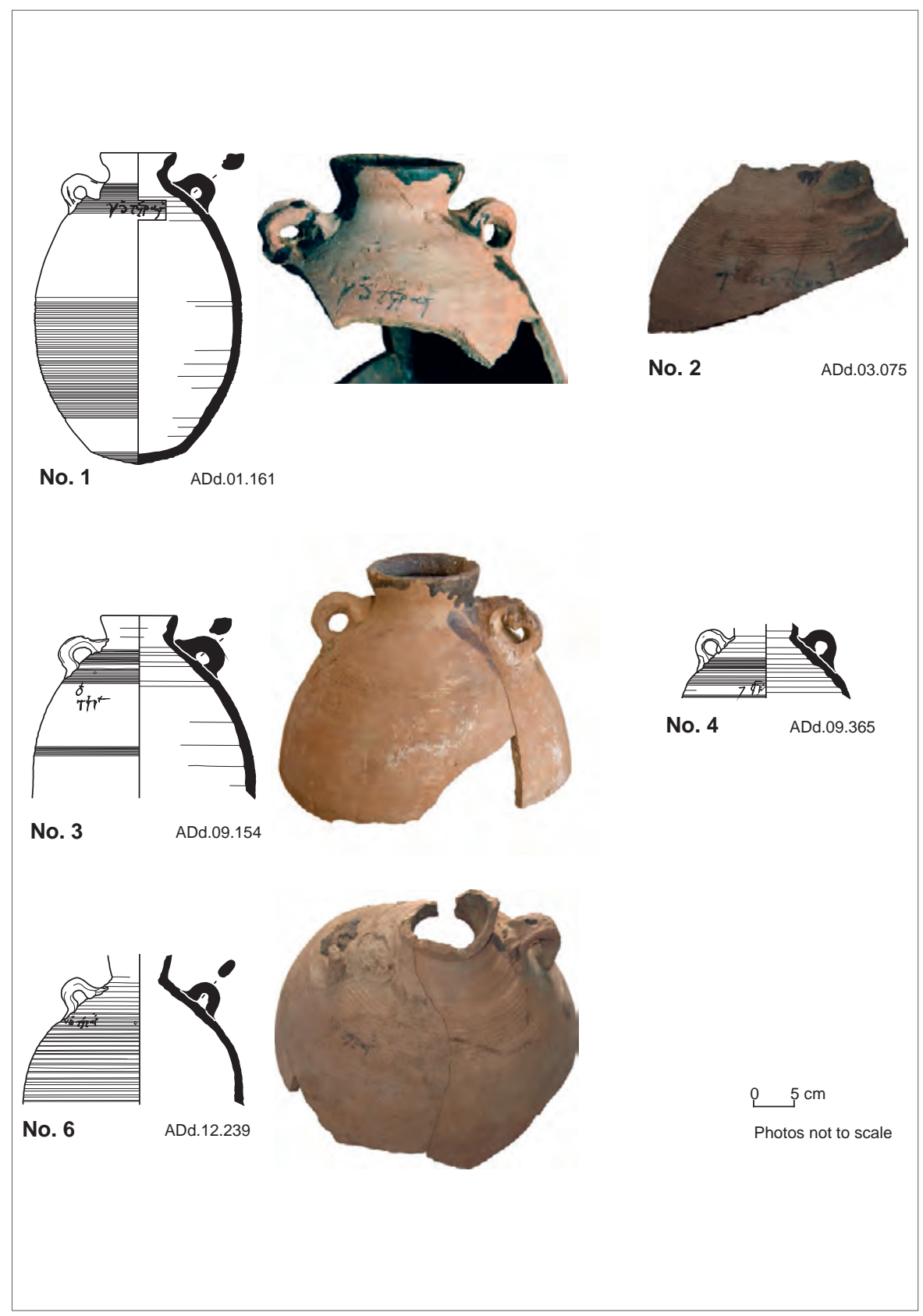

Fig. 2. Selection of LR 5/6 amphorae found in B.I; numbers refer to the catalogue on the opposite page (Drawing K. Danys; photos W. Godlewski) 
natron (Ballet and Dixneuf 2004: 70; Ballet 1994: 364). Textual sources testify to a large active wine industry in the Mareotis region in late antiquity (Dzierzbicka 2010: 128-129), which could have extended over the neighboring areas located on west bank of Delta's Canopic branch. It is in this region of Egypt where LR 5/6 amphorae (including the objects found in Dongola) undoubtedly were produced.

Several of the LR 5/6 sherds found in Building B.I carried inscriptions painted in black ink on the shoulders [Fig. 3]. Among them was one almost complete vessel (ADd.01.161), reconstructed from fragments (Godlewski 2002: Fig. 5; Bagińska 2005: Figs 222, 223). The complete height of the amphora amounted to $38.5 \mathrm{~cm}$, the rim was $10 \mathrm{~cm}$ in diameter (Bagińska 2005: 297). Other examples preserved only the upper part of a vessel (ADd.09.154, ADd.09.365, ADd.12.239) or existed as small body sherds (ADd.03.075, ADd.12.208, ADd.12.294). Both distinguished fabric variants were represented among these finds: variant A: specimens ADd.01.161, ADd.09.154, ADd.09.365, ADd.12.239 [Fig. 3: Cat. Nos 1, 3, 4 and 6 respectively]; variant B: specimens ADd.03.075, ADd.12.208, ADd.12.259 [Fig. 3: Cat. Nos 2, 5 and 7 respectively]. A complete dipinto was registered on ADd.01.161, ADd.09.154, and ADd.12.239 [Fig. 3: Cat. Nos 1, 3 and 6 respectively]; other examples were preserved in fragmentary form.

Tituli picti were observed on various types of amphorae manufactured at different sites of the Mediterranean in antiquity. As far as Late Roman containers (5th-7th century) are concerned, inscriptions painted in red on LR 1 amphorae are the most common. The production centers of these amphorae were located in Cyprus, southern Turkey, Crete and northern Syria (Williams 2005: Fig. 4), and their distribution encompassed the entire Mediterranean, from the Nile Valley to the Black Sea region and to southwestern Britain (Peacock and Williams 1986: 186). In Egypt, LR 1 amphorae with tituli picti are represented abundantly among finds from Antinooupolis (Fournet and Pieri 2008). Painted inscriptions were registered on amphorae manufactured in Lebanon (Pieri 2007: Fig. 3:2), and on Italian containers of the Keay LII type discovered, among others, in Marseille (Bonifay and Pieri 1995: Fig. 12:78, 79). Amphorae LR 1, LR 2, and spatheia found in Egypt (Alexandria, Naqlun, Oxyrynchos), Romania, Bulgaria and Italy also bore inscriptions (Derda 1992: 141-152), as did LR 4 amphorae found in the Nile Valley (Pieri 2005: 108). The list given here is by no means exhaustive and should be considered only as an outline of a much broader custom of inscribing on ceramic containers.

As far as Egyptian amphorae are concerned, Greek and/or Coptic dipinti, painted in black, seldom in red, occurred sporadically on LR 7 vessels, produced mainly in Middle Egypt. Examples of such amphorae are known from Kellia 
(Egloff 1977: 114), Deir el-Naqlun (Danys-Lasek 2014: Fig. 11G), Antinooupolis (Fournet and Pieri 2008: 176), and Tell el-Amarna (Pyke 2005: Fig. 4.8: KN11). Judging from inscriptions, their principal content was probably wine. Inscriptions on LR 5/6 made of Nile clay are extremely rare. One specimen, found in Bawit, had two letters painted in black (Marchand and Dixneuf 2007: 338, Fig. 39). Two other examples, one from Fustat (Gayraud and Tréglia 2014: Fig. 2:2), another from Tod (Lecuyot and Pierrat-Bonnefois 2004: Pl. 9, Fig. 131) bore Arabic dipinti dated to the 8th century. A similar situation was observed by Dominique Pieri (2005: 123-124) with relation to bag-shaped specimens found in Gaul, both the marl products of Palestinian provenance and the alluvial ones originating from Egypt. He noted that tituli picti painted in red occurred, together with white painted decoration, on Palestinian examples from the Roman Imperial period, while containers dated to the end of the 7th-9th century, including LR 5/6 of Nile clay, bore Arabic inscriptions.

Three out of seven dipinti on LR 5/6 amphorae found in Dongola (Cat. Nos 1, 5 and 6) seem to have been the work of one hand, a nice and well-trained cursive with occasional minuscule traits (see especially sigma). Three further inscriptions (Cat. Nos 2, 3 and 4) were written each probably by a different hand, although the one responsible for the dipinto Cat. No. 2 resembles that previously described, but is more formal (see especially tau). The seventh dipinto (Cat. No. 7) is too fragmentary for anything certain to be said about the hand.

All the dipinti seem to have the same or a very similar text reading: $\tau \dot{\varepsilon} \tau \rho \alpha \sigma \mathrm{l} /$

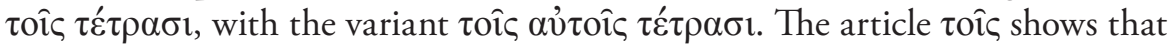

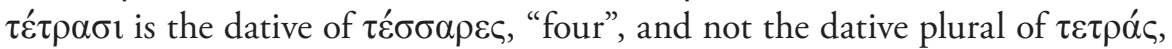
"the number four". $\tau \dot{\varepsilon} \tau \rho \alpha \sigma 1$ as a dative of $\tau \dot{\varepsilon} \sigma \sigma \alpha \rho \varepsilon \varsigma$ was originally used only in poetry (as a counterpart of $\left.\tau \dot{\varepsilon} \sigma \sigma \alpha \rho \sigma 1 / \tau \varepsilon^{\prime} \tau \tau \alpha \rho \sigma \imath\right)$, but later became common in prose, too, and is found also in the papyri from Egypt (Gignac 1981: 192).

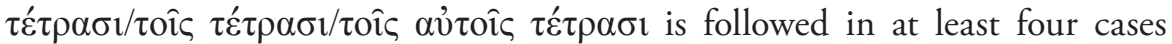
(Cat. Nos $1,2,5,6)$ by a sign written over the last two letters of $\tau \dot{\varepsilon} \tau \rho \alpha \sigma 1$. In Cat. No. 2, this shifted letter can be identified as a delta and in Cat. No. 5 as a lambda. These are likely the numerals 4 and 30 respectively. Providing the above remarks are correct, the inscriptions should be translated: "to the (same) four + a numeral".

The dative suggests that the inscriptions should be considered as addresses. The numbers occurring in the addresses may refer to the number of a vessel within the freight. The question arises who were "the four" mentioned as the receivers of the wine sent in the amphorae. No obvious answer is available to this question. Quite tentatively, we suggest that "the four" may be the Four Living Creatures of the Apocalypse, Greek $\tau \dot{\varepsilon} \sigma \sigma \alpha \rho \alpha \zeta \hat{\varphi} \alpha$, here used, 
through brachylogy, as the name of a church. It is known that the Four Living Creatures, like all angelic beings, enjoyed a vivid cult in Christian Nubia. They were represented in paint in Nubian sacral spaces (see, e.g., MartensCzarnecka 2011: 181-184) and are known as patrons of churches. A church of the Four Living Creatures is mentioned in the epitaph of Marianou, a bishop of Faras, who died and was buried in Qasr Ibrim in AD 1036 (Łajtar and van der Vliet 2010: No. 22, 11. 11-12), in a wall inscription from the cathedral at Faras (unpublished; preliminarily see Łajtar and van der Vliet 1998: 46-47), in a Coptic epitaph of priest Marianou from Faras, dated AD 955 (van der Vliet 1999: 141-142), in a wall inscription from the church at Sonqi Tino (unpublished, preliminarily see Donadoni 1975: 35), and in a wall inscription in the upper church at Banganarti (unpublished; Adam Łajtar's reading from the original). Assuming "the four" from the dipinti here discussed are the Four Living Creatures of the Apocalypse, the existence of a church of the Four Living Creatures should be hypothesized also for Dongola. The church in question should have been located somewhere in the close neighborhood of the palace B.I, considering that the empty amphorae were thrown into the depositories of the palace latrines.

An alternative interpretation of the inscriptions was suggested to us by Dorota Dzierzbicka. According to her, $\tau \dot{\varepsilon} \tau \rho \alpha \sigma \mathrm{l}$ may denote a feast, for which the wine sent in the amphorae was destined. However attractive, this interpretation seems less probable to us, as no feast of this name is known.

The above reasoning, providing it is correct, has consequences for determining the actual source of the inscriptions on the pottery and indirectly for the organization of wine commerce between Egypt and Dongola in the 7th century. It is difficult to imagine that those who dispatched wine from Mareotis to Dongola had knowledge of a Church of the Four Living Creatures in this remote place and indicated it as the addressee of freight or at least a part of it. More probably, the amphorae came to Dongola without the painted addresses, which were added on the spot as part of the distribution process taking place already in Dongola and assigning individual amphorae with the goods to the ultimate recipients. It would mean that the inscriptions were executed most probably in the port or dock warehouses of Dongola, directly below the place where the inscribed amphorae were found.

\section{ACKNOWLEDGMENTS}

The ceramological part of the paper was prepared by Katarzyna Danys, the epigraphic part by Adam Łajtar. The authors wish to thank Constantinos Balamoshev, Tomasz Derda, and Dorota Dzierzbicka for information and discussion. 


\section{References}

Adams, W.Y. (1986). Ceramic industries of medieval Nubia I-II [=Memoirs of the UNESCO Archaeological Survey of Sudanese Nubia 1]. Lexington, KY: University Press of Kentucky

Bagińska, D. (2005). Amfory z terenów Nubii od II w. p.n.e. do XIV w. n.e. Studium nad typologia naczyń $i$ kontaktami handlowymi Nubii ze światem śródziemnomorskim [Amphorae from the territory of Nubia from the 2nd century BC through the 14th century AD. Study of vessel typology and Nubia's commercial contacts with the Mediterranean] (unpubl. Ph.D. diss.). University of Warsaw [in Polish]

Ballet, P. (1994). Un atelier d'amphores Late Roman Amphora 5/6 à Kôm Abou Billou (Égypte). Chronique d'Égypte, 69(138), 353-365

Ballet, P., Bosson, N., and Rassart-Debergh, M. (2003). Kellia II.2. L'ermitage copte $Q R$ 195. La céramique, les inscriptions, les décors [=Fouilles de l'Institut français d'archéologie orientale 49]. Cairo: Institut français d'archéologie orientale

Ballet, P. and Dixneuf, D. (2004). Ateliers d'amphores de la chora egyptienne aux époques romaine et byzantine. In J. Eiring and J. Lund (eds), Transport amphorae and trade in the Eastern Mediterranean: Acts of the international colloquium at the Danish Institute at Athens, September 26-29, 2002 [=Monographs of the Danish Institute at Athens 5] (pp. 67-72). Aarhus: Aarhus University Press

Danys-Lasek, K. (2012). Dongola 2009: Pottery from Building I (Kom A). Polish Archaeology in the Mediterranean, 19, 315-329

Danys-Lasek, K. (2014). Pottery from Deir el-Naqlun (6th-12th century). Preliminary report from Polish excavations in 2010 and 2011. Polish Archaeology in the Mediterranean, 23/1, 543-642

Derda, T. (1992). Inscriptions with the formula 'theou haris kerdos' on Late Roman amphorae. Zeitschrift für Papyrologie und Epigraphik, 94, 135-152

Dixneuf, D. (2011). Amphores égyptiennes: production, typologie, contenu et diffusion, III siècle avant J. $-C-I X^{e}$ siècle après J.-C. [=Etudes Alexandrines 22]. Alexandria: Centre d'études alexandrines

Donadoni, S. (1975). Les graffiti de l'église de Sonqi Tino. In K. Michałowski (ed.), Nubia: récentes recherches. Actes du Colloque nubiologique international au Musée national de Varsovie 19-22 Juin 1972 (pp. 31-39). Warsaw: National Museum in Warsaw

Dzierzbicka, D. (2010). Wineries of the Mareotic Region. In L. Blue and E. Khalil (eds), Lake Mareotis: Reconstructing the past. Proceedings of the International Conference on the Archaeology of the Mareotic Region held at Alexandria University, Egypt, 5th-6th April 2008 [=British Archaeological Reports International Series 2113] (pp. 127-134). Oxford: Archaeopress

Egloff, M. (1977). Kellia, la poterie copte: quatre siècles d'artisanat et d'échanges en BasseEgypte I-II [=Recherches suisses d'archéologie copte 3]. Geneva: Georg 
Engemann, J. (1992). À propos des amphores d'Abou Mina. Cahiers de la céramique égyptienne, 3, 153-159

Fournet, J.-L. and Pieri, D. (2008). Les dipinti amphoriques d'Antinoopolis. In R. Pintaudi (ed.), Antinoupolis I [=Scavi e materiali 1] (pp. 175-216). Florence: Istituto Papirologico "G. Vitelli"

Gascoigne, A.L. (2007). Amphorae from Old Cairo: A preliminary note. In S. Marchand and A. Marangou (eds), Amphores d'Égypte de la Basse Époque à l'époque arabe I [=Cahiers de la céramique égyptienne 8/1] (pp. 161-174). Cairo: Institut français d'archéologie orientale

Gayraud, R.-P. and Tréglia, J.-C. (2014). Amphores céramiques culinaires et céramiques communes Omeyyades d'un niveau d'incendie à Fustat - Istabl'antar (le Caire, Égypte): The containers. In N. Poulou-Papadimitriou, E. Nodarou, and V. Kilikoglou (eds), LRCW 4: Late Roman coarse wares, cooking wares and amphorae in the Mediterranean. Archaeology and archaeometry. The Mediterranean: A market without frontiers I [=British Archaeological Reports International Series 2616/1] (pp. 265-375). Oxford: Archaeopress

Gempeler, R.D. (1992). Elephantine X. Die Keramik römischer bis früharabischer Zeit [=Archäologische Veröffentlichungen 43]. Mainz am Rhein: Philipp von Zabern

Gignac, F.T. (1981). A grammar of the Greek papyri of the Roman and Byzantine periods

II. Morphology [=Testi e documenti per lo studio dell'antichità 55/2]. Milan: Istituto editoriale cisalpino

Godlewski, W. (2002). Old Dongola. Kom A, 2001. Polish Archaeology in the Mediterranean, 13, 203-216

Godlewski, W. (2013). Dongola: Ancient Tungul. Archaeological guide [=PCMA Archaeological Guides 1]. Warsaw: PCMA UW

Lecuyot, G. and Pierrat-Bonnefois, G. (2004). Corpus de la céramique de Tôd. Fouilles 1980-1983 et 1990. Cahiers de la céramique égyptienne, 7, 145-209

Łajtar, A. and van der Vliet, J. (1998). Rich ladies of Meinarti and their churches. With an appended list of sources from Christian Nubia containing the expression "having the Church of so-and-so". Journal of Juristic Papyrology, 28, 35-53

Łajtar, A. and van der Vliet, J. (2010). Qasr Ibrim: The Greek and Coptic inscriptions [=Journal of Juristic Papyrology Supplement 13]. Warsaw: Raphael Taubenschlag Foundation

Majcherek, G. (2004). Alexandria's long-distance trade in Late Antiquity - the amphora evidence. In J. Eiring and J. Lund (eds), Transport amphorae and trade in the Eastern Mediterranean: Acts of the international colloquium at the Danish Institute at Athens, September 26-29, 2002 [=Monographs of the Danish Institute at Athens 5] (pp. 229238). Aarhus: Aarhus University Press

Majcherek, G. (2008). The pottery assemblage from the baths and sāqiyah. In H. Szymańska and K. Babraj (eds), Marea I. Byzantine Marea: Excavations in 2000-2003 and 2006 [=Biblioteka Muzeum Archeologicznego w Krakowie 4] (pp. 105-127). Kraków: Muzeum Archeologiczne w Krakowie 
Marchand, S. and Dixneuf, D. (2007). Amphores et conteneurs égyptiens et importés du VII siècle apr. J.-C. Sondages récents de Baouît (2003-2004). In S. Marchand and A. Marangou (eds), Amphores d'Égypte de la Basse Époque à l'époque arabe I [=Cahiers de la céramique égyptienne 8/1] (pp. 309-343). Cairo: Institut français d'archéologie orientale

Martens-Czarnecka, M. (2011). The wall paintings from the Monastery on Kom $\mathrm{H}$ in Dongola [=Nubia 3; Dongola 3; PAM Monograph Series 3]. (B.M. Gostyńska, trans.). Warsaw: Warsaw University Press

Peacock, D.P.S. and Williams, D.F. (1986). Amphorae and the Roman economy: An introductory guide. London: Longman

Pieri, D. (2005). Le commerce du vin oriental à l'époque byzantine, Ve-VIIe siècles : le témoignage des amphores en Gaule [=Bibliothèque archéologique et historique 174]. Beirut: Institut français du Proche-Orient

Pieri, D. (2007). Les centres de production d'amphores en Méditerranée orientale durant l'Antiquité tardive: quelques remarques. In M. Bonifay and J.-C. Tréglia (eds), LRCW 2. Late Roman coarse wares, cooking wares and amphorae in the Mediterranean. Archaeology and archaeometry [=British Archaeological Reports International Series 1662] (pp. 611-625). Oxford: Archaeopress

Pieri, D. and Bonifay, M. (1995). Amphores du Ve au VII es. à Marseille : nouvelles données sur la typologie et le contenu. Journal of Roman Archaeology, 8, 94-120

Pyke, G. (2005). Late Roman Egyptian amphorae from squares U and V at Kom elNana. In J. Faiers, Late Roman pottery at Amarna and related studies [=EES Excavation Memoirs 72] (pp. 213-244). London: Egypt Exploration Society

van der Vliet, J. (1999). Churches in Lower Nubia, old and "new". Bulletin de la Société d'archéologie copte, 38, 135-142

Williams, D.F. (2005). An integrated archaeometric approach to ceramic fabric recognition: A study case on late Roman amphora 1 from the eastern Mediterranean. In J.M. Gurt i Esparraguera, J. Buxeda i Garrigós, and M.A. Cau Ontiveros (eds), LRCW 1. Late Roman coarse wares, cooking wares and amphorae in the Mediterranean: Archaeology and archaeometry [=British Archaeological Reports International Series 1340] (pp. 613-624). Oxford: Archaeopress 



\title{
Among the rocks: \\ A first look at medieval Duweishat, from the archive
}

\author{
David N. Edwards \\ University of Leicester \\ dne1@leicester.ac.uk
}

\section{KeYwords}

Medieval Nubia, Duweishat, Nobadia, landscape, settlement, social archaeology, churches

\section{Abstract}

During the 1960s, the Archaeological Survey of Sudanese Nubia (ASSN) created a systematic record of the archaeology of a whole landscape, now lost, providing a body of data of exceptional value. Drawing on still unpublished data this paper explores the medieval settlement archaeology of the Duweishat region of the central Batn al-Hajar. Evidence is examined for a gradual agricultural colonisation during the first millennium $\mathrm{AD}$ as well as the penetration of Christianity into this isolated rural area. How social landscapes may have been organised around churches and cemeteries is also discussed, as well as how such regions may have interacted with (episcopal) centres such as Sai and Faras.

The Duweishat area of the southern Batn al-Hajar seems likely to represent a not atypical rural settlement landscape of this notoriously rugged and inhospitable region, and one almost equidistant (approximately $110 \mathrm{~km}$ ) from the two major medieval centres of Sai and Faras. If the wider region is more popularly glossed as the "Belly of Stones", as suggested by Herman Bell, its Nubian/Nobiin form of Kidin Tuu may better be represented as 'among the 
rocks'. Its core was the area between Saras and Kidin Kony ('the upstream end of the rocks') in Sonki (Bell 1970: 44-46), with Duweishat very much in its belly. Such a name does not misrepresent this area, far, in many ways from Old Dongola, the site of so much of Włodek Godlewski's varied research at the heart of medieval Makuria.

One of the more inhospitable parts of an inhospitable region, the home of small groups of herders in the 3rd and 2nd millennia BC, Duweishat and its eastern hinterland also saw significant Egyptian gold-mining operations in the later 2nd millennium BC (Edwards and Mills 2013) but latterly remained very thinly populated until the mid-1st millennium AD. With very little agricultural land or other resources the population remained limited in more recent centuries. Notwithstanding general population

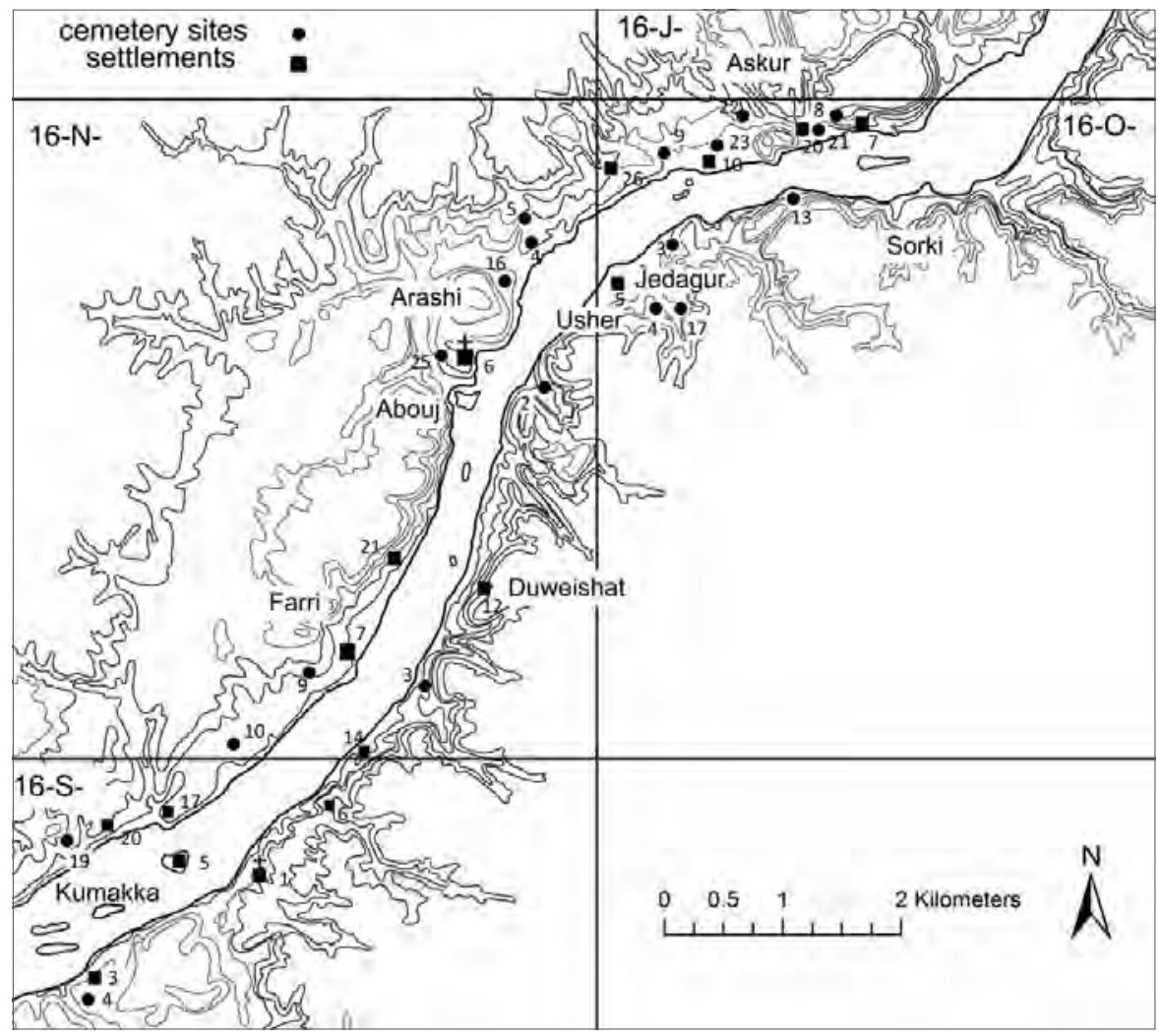

Fig. 1. Map of Duweishat with known medieval sites. Site numbers relate to grid squares (based on ASSN survey maps prepared by W.Y. Adams) 
growth through the 20th century, the survey of 1960 recorded a resident population of only 638. Unlike many other parts of Nubia, this was apparently not significantly affected by outmigration, as unusually low levels of absentees were recorded (Dafalla 1975: 90, 337). This population was divided between nine hamlets.

Little was known of the archaeology of this area prior to the 1960s, although a brief horseback reconnaissance by Chittick in 1955 drew attention to the existence of often well-preserved medieval sites in the southern Batn al-Hajar (Chittick 1957). This was confirmed by the early fieldwork of the Archaeological Survey of Sudanese Nubia $=$ ASSN (Mills 1992). Its initial reconnaissance survey in 1963-1964 reached this area in early March 1964 and registered 22 sites in Duweishat (Mills 1965: 7); these were mainly medieval ('Christian') and 'Pharaonic', with some evidence for an 'X-Group' presence in the form of tumulus burials.

Fieldwork resumed in this area at the end of January 1967 on the east bank of Duweishat around the modern hamlets of Jedagur (Jaddi-gur) and Usher $\left(U_{\text {ssheri }}\right)^{1}$ and on the west bank in November 1967, being completed in early 1968. This later fieldwork identified a number of additional sites and provided an opportunity for more extensive testing of known sites, both cemeteries and settlements. In the former, surface clearances commonly confirmed that most cemeteries were significantly larger than originally estimated on the basis of surface observations. While few medieval graves were excavated, surface clearances provided valuable information on both the character and size of these sites.

In this brief paper, a descriptive outline of the medieval settlement archaeology uncovered by the ASSN will be presented [Fig. 1], to provide both an introduction to some of the material in this still unpublished archive, as well as raise a few questions concerning the nature of some of these sites and their significance. One concern is to begin a process of exploring such sites as part of a settlement landscape, with its own historical trajectory, both part of as well as apart from more general historical processes, more commonly viewed through the lens of the urban and elite centres of medieval Nubia. There is good reason to believe that one of the great achievements of the ASSN fieldwork of the 1960 s will prove to be the systematic recording of a whole landscape, prior to its destruction, providing a body of data of exceptional value for future landscape research.

1 Toponym forms collected by Herman Bell are also included here, as recorded in his published study (Bell 1970). 
Approaching the Attiri bend on the west bank, two clusters of medieval settlement sites [16-O-26, 16-O-10, 16-O-21, 16-O-7] were identified in the vicinity of the modern hamlet of Askur (see Fig. 1). Associated with them were at least five cemeteries [16-O-9, 16-O-23, 16-O-22, 16-O-20, 16-O-8]. Among the eastern/downstream sites [16-O-20 and 16-O-21] possible indications of a Meroitic presence were found, although potentially some centuries earlier, and with no clear evidence for more long established settlement. Amongst the larger cemeteries [16-O-9] and [16-O-23] an early foundation was indicated by likely 'X-Group' burials, in the latter case including two covered by substantial tumuli. There, surface clearance also confirmed a much longer history of cemetery use, with a well-defined shift to Islamic burial forms, extending to the modern cemetery. Overall, notwithstanding some equivocal indications of a Meroitic presence, it seems likely that a number of small settlements were established here in the early medieval period, each perhaps with their own burial ground. Opposite Askur on the east/right bank, a settlement of about 20 stone huts [16-O-13] was also tentatively assigned a late medieval date. Some medieval crosses were added to rock drawings on a hillside to their east [16-O-31].

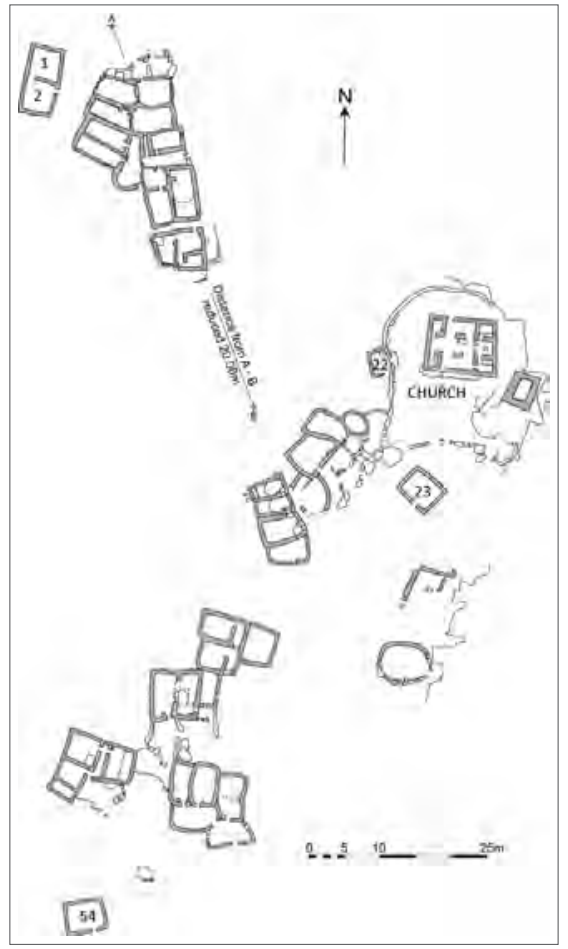

Fig. 2. Plan of settlement and church [16-N-6] in Duweishat West (ASSN archive, surveyed 1967; digital drawing M. Finch) 
A further cluster of sites lay around the hamlets of Arashi/Araasha and Abouj/Abooj, the latter a seasonal island. Here, a relatively well-preserved medieval settlement [16-N-6] was sited on a rocky outcrop overlooking a point in the river where it narrows to approximately $120 \mathrm{~m}$, with a sheltered bay and landing point below it (see Fig. 2). This site was briefly examined in early 1964 and reported in the reconnaissance report (Mills 1965: 7, Pl. I.a). Further excavations were carried out in the last days of December 1967 going into early January 1968, with architectural recording completed by Jim Knudstad in March 1968. A brief note on the church was included by W.Y. Adams in his overview of Nobadian churches (Adams 2009: 334, Fig. 4.32) based on a sketch plan made in 1964. The records of the fuller investigations of 1967-1968 in the ASSN archive provide additional records both of the church and the associated settlement. $^{2}$

Knudstad's plan of the church [Fig. 3 left] makes clear that it has a more typical plan of Adams' type 4d. Closer study confirmed the presence of the square drum of a small dome, represented in Knudstad's reconstructed section drawing [Fig. 3 right]. His field notes also draw attention to the generous provision of wall niches in the sacristies, side aisles and northwestern corner room. The only surviving decoration was within the haikal. As described by Knudstad, this included on its east wall: "a large winged (and seated?) figure with the haloed faces of two smaller figures in front of its lower left below the shoulder. The south wall bears the face and robing of five haloed figures (standing?) apparently bearded and shoulder to shoulder with right hands upraised. There remains a gap on the eroded wall sufficient for a sixth figure to their left, suggesting that each side bore half of the Twelve Apostles. Only small bits of paint remain on the north wall. All the figures appear delineated in red over a yellow filling or skin shading upon a general background of white on the plaster. Eyes and brows were accentuated in black. No inscriptions or graffiti, painted or incised, were found". ${ }^{3}$

The church is also notable for having its own enclosure wall creating an open yard to the south and west. The poorly preserved heavy stone foundations of what may have been a watchtower lay on the east side of the wall overlooking the river. The larger settlement adjoining the church (see Fig. 2) comprised three distinct groups of structures with perhaps six houses in the northern group, two

2 Core records for the site include ASSN field notebooks AJM III: 92-93; JEK I: 1-18; WYA XII: 2-4. Most of this site still remains above current river levels and can be located on satellite imagery at $30^{\circ} 56^{\prime} 33.79^{\prime \prime} \mathrm{E} / 21^{\circ} 22^{\prime} 53.23^{\prime \prime} \mathrm{N}$.

3 ASSN field notes JEK I: 16. 


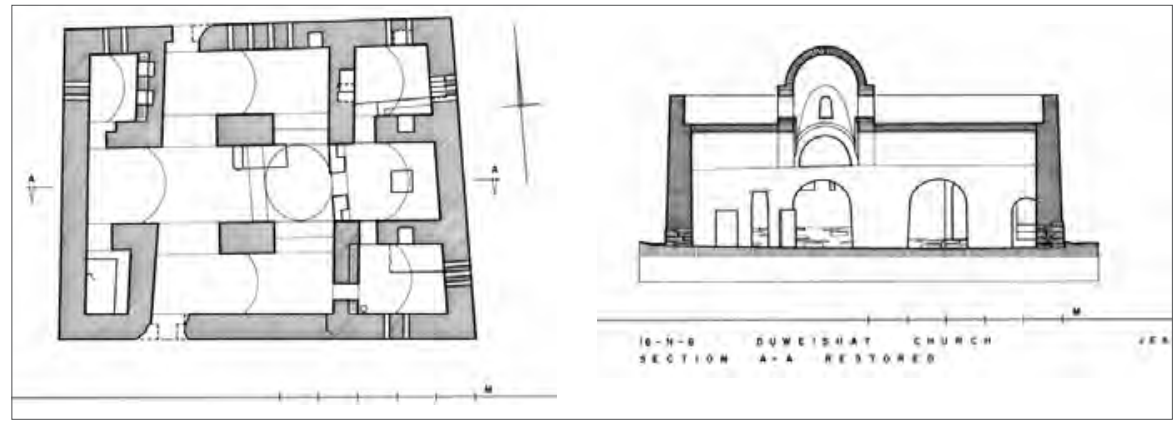

Fig. 3. Church 16-N-6: left, plan; right, reconstructed section (ASSN archive, surveyed 1967; drawing J.E. Knudstad)

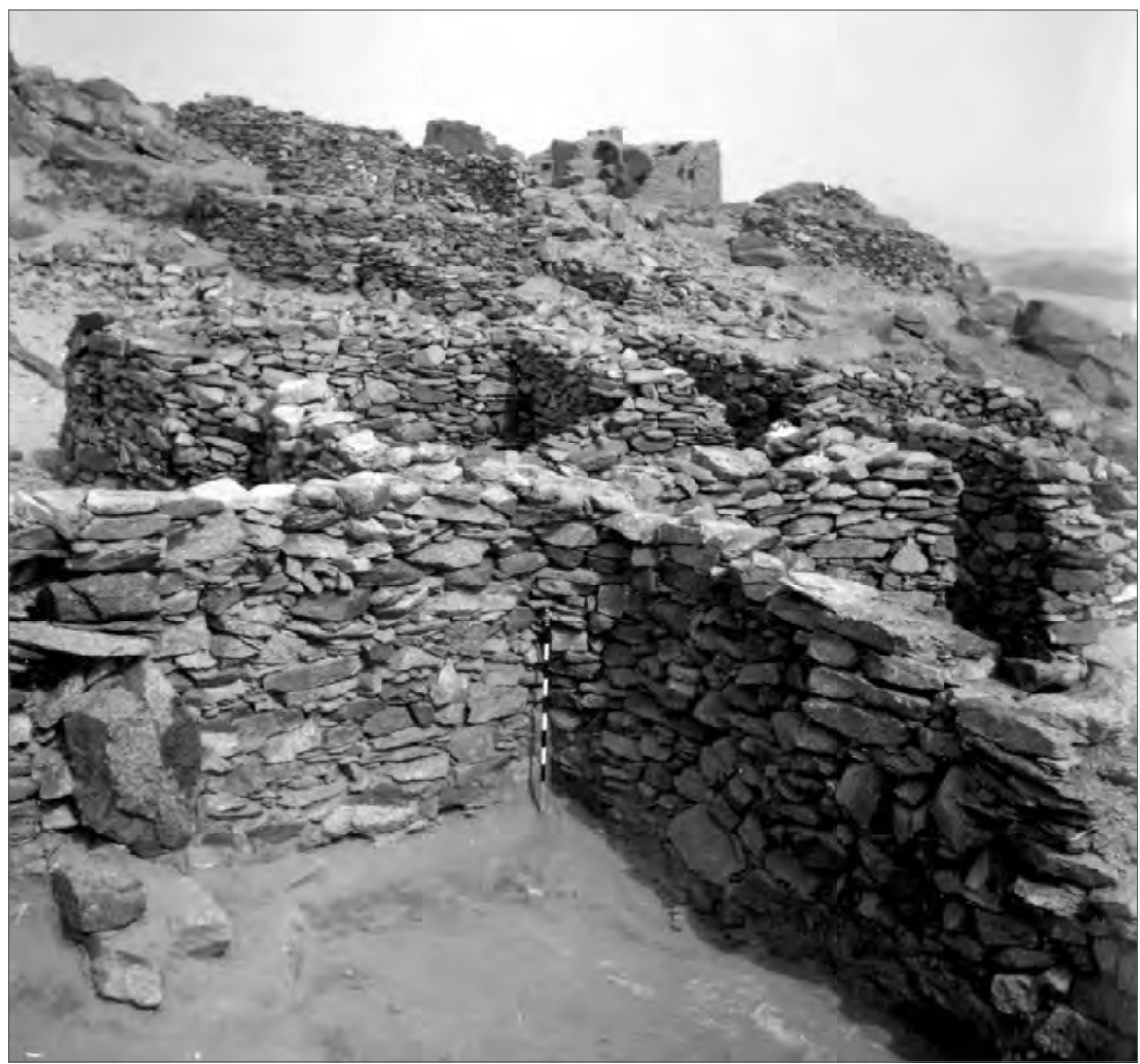

Fig. 4. Stone-built structures to the southwest of the church (visible in the background) in settlement [16-N-6] (Photo ASSN F418/3) 
or three close to the church and five houses in the southern group. Surviving walls were largely of mud-mortared stone rubble construction [Fig. 4]. The more regular rectangular structures in several cases preserved elements of mudbrick vaulted roofs. Possible comparisons may be found in narrow vaulted rooms adjoining the church at Sonki West (21-D-5) some $30 \mathrm{~km}$ upriver (Fanfoni 1967: 14-16). The other more irregular/larger rooms will have supported flat roofs, if covered. Four 'rooms' $(1,2,23,54)$ which were freestanding with wellpreserved drystone walls were thought likely to be of more recent date.

In most cases, groups of rooms appear to have developed around a singleroom core structure, creating three and four room 'houses'. Where excavated, very little accumulated occupation debris was encountered in most houses, with single mud floor surfaces. Room 22, a room added to the west wall of the church enclosure, was unusual in holding an accumulation of about $30-40 \mathrm{~cm}$ of ashy debris around an oven, presumably a communal facility. Little sherd material was recovered from the church but datable finewares identified in field notes included sherds of 'Late Christian' Wares W15 and W16; from the surface of settlement both 'Late Christian' (R11) and 'Terminal Christian' wares (Adams Wares W14, W18, R26, R28) were recorded. ${ }^{4}$

Several further cemeteries were found in this area. To the north of Araasha were two cemeteries [16-N-4] and [16-N-5], the latter with both Christian and Islamic burials. These may perhaps have been associated with another (late?) medieval settlement in the area of what was identified as a 'Turkish fort' known as Diff. This trapezoidal walled site was located close to the river bank. Assumed to be of relatively recent date, the site was not registered or further examined by the ASSN team. To the north of the [16-N-6] settlement was a second larger cemetery [16-N-16], partly overbuilt by the modern hamlet of Araasha and estimated as holding a minimum of 100 medieval graves, as well as some possibly earlier 'X-Group' tombs. Traces of mud-brick superstructures survived on some graves. This suggests the possibility of an earlier, if unlocated, settlement in this area, predating the 'Late Christian' site [16-N-6] on the hilltop. This may have been masked by blown sand, which was causing problems in the modern settlement in the mid-20th century. To the west of the settlement a further cemetery [16-N-25] of 68 graves was tested. At least 28 graves had rectangular mud-brick superstructures and a further 11 had stone superstructures bonded with mud mortar. A single grave beneath a stone superstructure was excavated. A lampbox at its west end held a fragmentary ('Classic Christian') W5 bowl used as a lamp.

4 All pottery identifications follow ware designations in field records, in turn based on Adams (1986). 


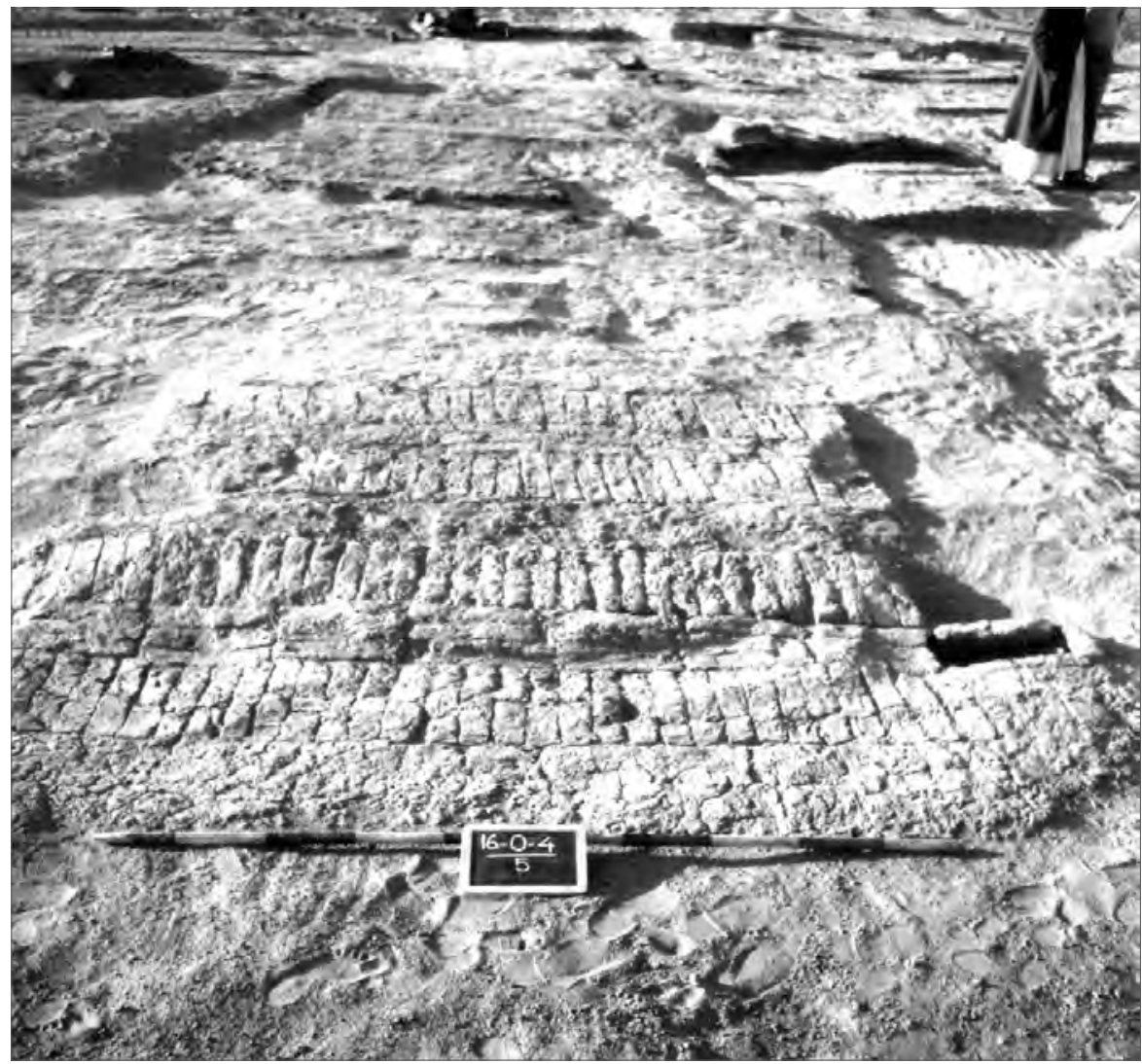

Fig. 5. Mud-brick superstructure over grave 5 in cemetery [16-O-4] (Photo ASSN F357/7)

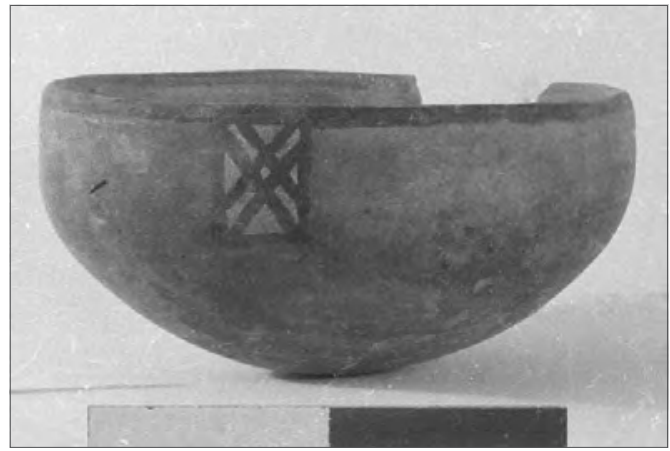

Fig. 6. Ware R5 bowl (16-O-4/5/1; SNM 19778) from cemetery [16-O-4] (Photo ASSN C093/9) 
Mere traces of denuded stone structures [16-O-5] survived of the medieval settlements on the east bank around the two small hamlets of Jedagur and Usher. However, a number of groups of burials were located and registered as three distinct sites: to the north a group of about 10 graves [16-O-3], while to the east a medieval cemetery [16-O-4] with about 85 graves, mostly with rectangular mud-brick superstructures [Fig. 5], but also a few post-Meroitic/'X-Group' burials. Lamps and fineware bowls (wares R5 and W2?), some containing charcoal fragments, were found in 'lampboxes' at the end of the brick superstructures in some of the early medieval Christian graves [Fig. 6 . To the east separated by a wadi from the other burials a second small cemetery [16-O-17] appeared to include mainly post-Meroitic/'X-Group' burial types. A little to the south, around a headland, a further small cemetery of about 15 graves [16-N-2], some with stone superstructures, was sited opposite the church and settlement of [16-N-6].

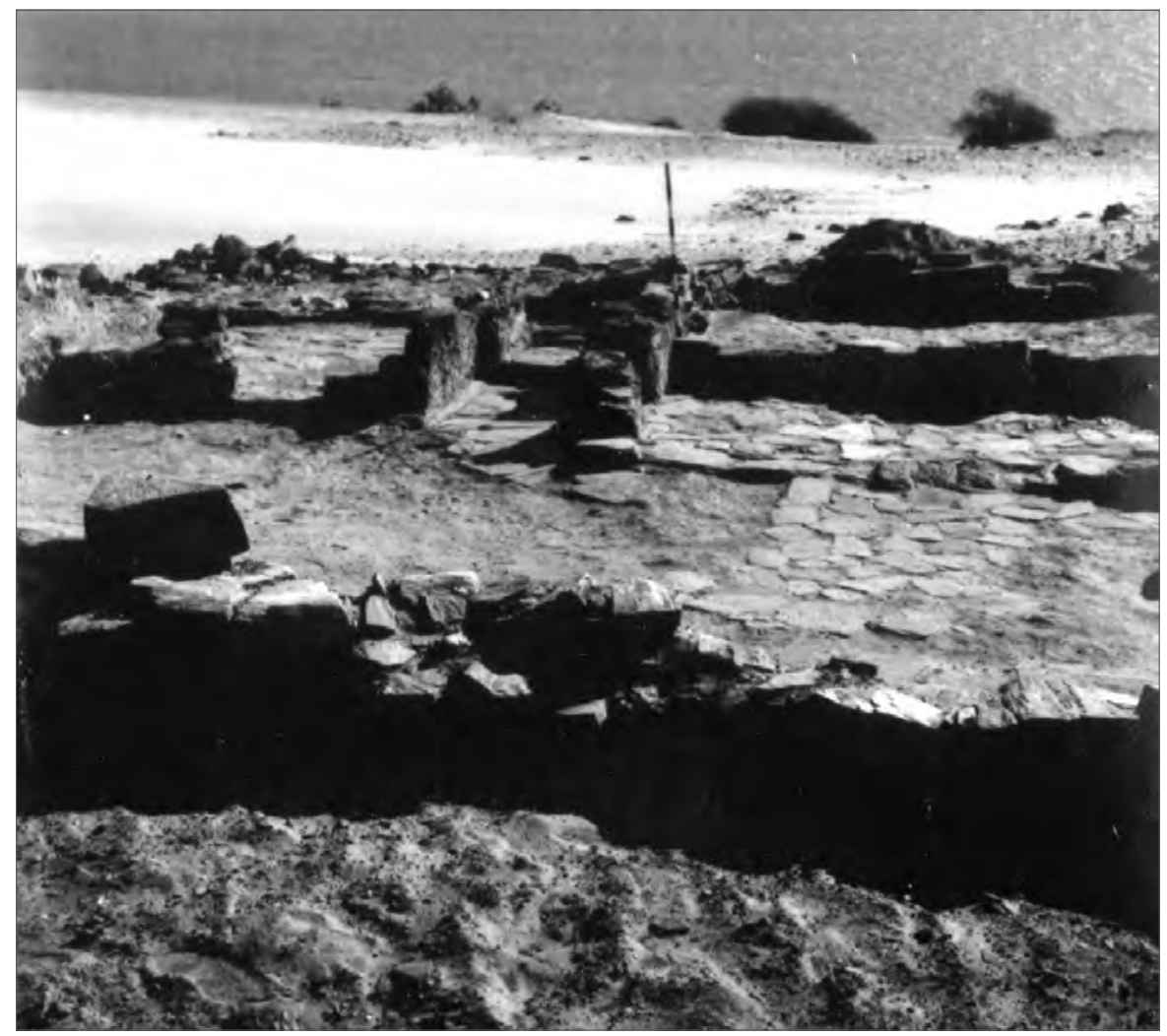

Fig. 7. Stone-floored medieval structure [16-N-21] (Photo ASSN F374/10) 


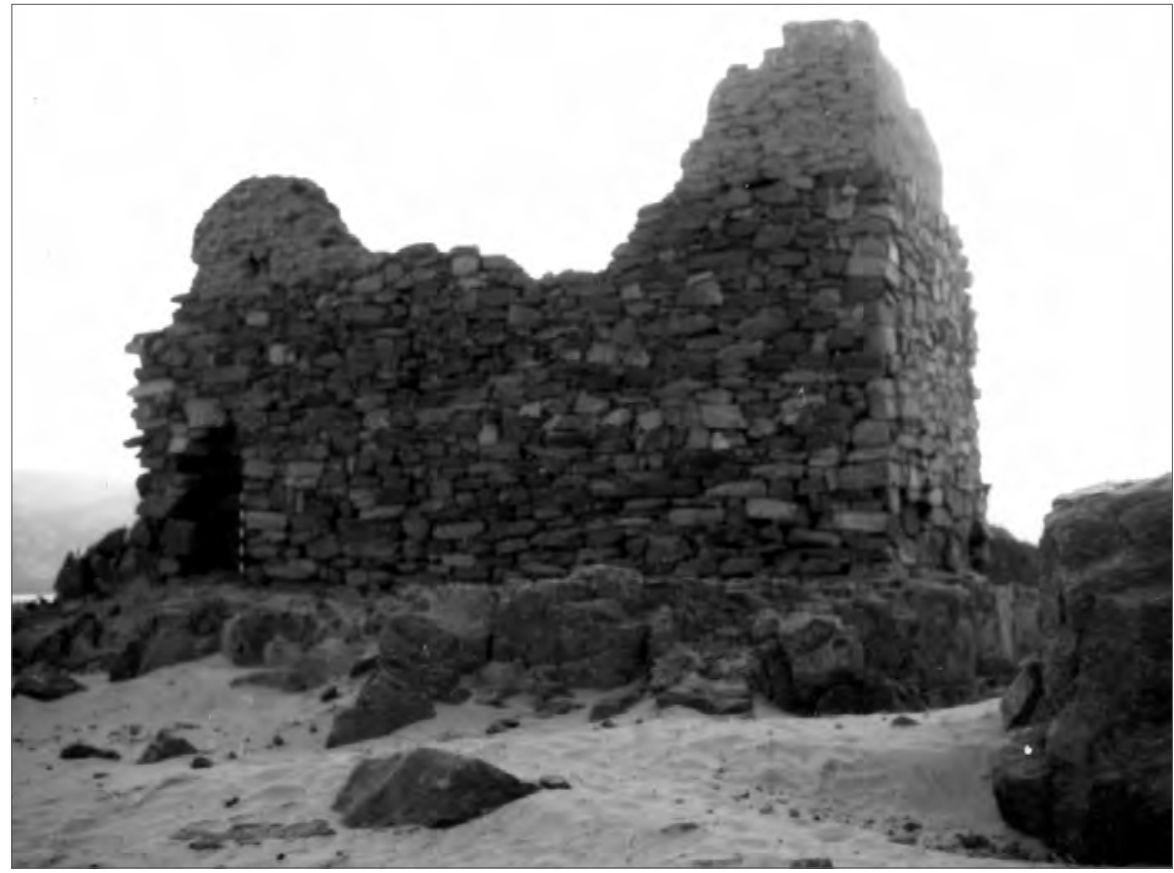

Fig. 8. Late Christian tower-house within settlement [16-N-7] (Photo ASSN F376/4)

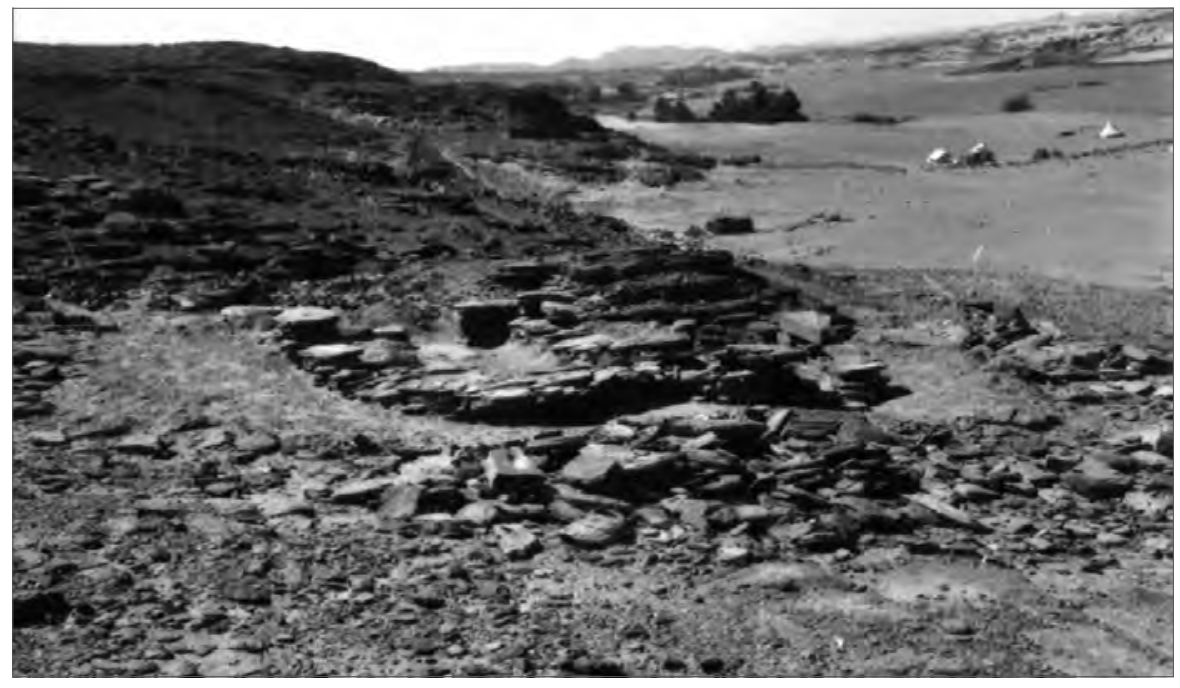

Fig. 9. Poorly preserved stone structure at site [16-N-12] in the barren landscape of Duweishat East, looking south (Photo ASSN F360/4) 
Further upstream, almost all the available agricultural land is located on the west bank, in and around the hamlet of Farri/Farre. The toponym identifies this as an area of 'fields', and more specifically, farreen kissee, 'the church of the field', was the name given to the upstanding medieval ruins (Bell 1970: 99). Aerial photographs suggest that the modern hamlet may have sustained three or four saqiyas along this part of the west bank. One isolated structure [16-N-21] at its north end was notable for the stone flagged floors and the use of some mudbrick for internal walls [Fig. 7]. Limited pottery finds indicate a 'Late Christian' date, although some possible 'X-Group' burials were found close by [16-N-22].

The main settlement [16-N-7] comprised up to 15 structures spread over approximately $300 \mathrm{~m}$ by $200 \mathrm{~m}$, mainly stone-built with limited use of mudbrick. The most prominent and best-preserved was a tower-house (Mills 1965: 7) with heavy stone foundations [Fig. 8], enclosing ground-floor storerooms, very similar to examples widely encountered further south in Middle Nubia and the Third Cataract region (Adams 1994; Salih and Edwards 2011: 157-159). Two other houses were excavated, suggesting quite lengthy histories of occupation and remodeling of the buildings. With little depth to the stratigraphy, ceramic finds were also not abundant, but as well as coarsewares (e.g., U5, U6 and H4) included examples of some 'Classic Christian' (wares W6, R7), 'Late Christian' (R17, W16), and 'Terminal Christian' wares (W14). Its cemetery [16-N-9] held about 93 burials; at least three examples had mud-brick superstructures.

On the rocky and much more inhospitable east bank, another cemetery [16-N-3] was sited, immediately opposite [16-N-7]. Amongst some 94 'Christian' burials there were also a small number of 'X-Group' burials, indicators of the early origin of this cemetery; two of these were excavated. The nearest settlement on the east bank was a (very eroded) site [Fig. 9] approximately $1.5 \mathrm{~km}$ downstream, close to the modern hamlet of Duweishat [16-N-12].

The almost total absence of alluvial land beneath the rocky hillsides of this section of the east bank provided minimal opportunities for agriculture. Some possible reuse of a New Kingdom stone hut [16-N-14] and another isolated building [16-S-6] was recorded, 'Early Christian' pottery being found in both.

A southern focus of settlement was around a group of small islands which marked the boundary between Duweishat and Ambikol. The two largest were Kumukka/Kumaki and Meenarti, the first being the site of a small medieval settlement [16-S-5] consisting of a cluster of small stone structures built around a substantial two-storey mud-brick building [Fig. 10]. Located on the highest point of the east side of the island, it commands good views up and down the river. Dateable pottery recorded there was of 'Late' and 'Terminal Christian' wares (R11, R17, R26, W14, U5, U13, GII, H5). 
On the east bank, overlooking Kumukka island, a single isolated structure [16-S-1] proved on excavation to be a small church. This has also been described by Adams, his church 111 (Adams 1998: 332-333, Fig. 4.31). Its outer walls were constructed on stone foundations, while all internal walls and features were of mud brick [Fig. 12]. Little of its mud-brick superstructure has survived. An unusual feature was the placement of its doors at the west ends of the north and south walls, lacking the more usual western rooms. In this and others features it bears some similarity to the (unexcavated) church at Masiida (MAS021) on the Third Cataract (Edwards and Osman 2011: 325). One striking find within this church was a ceramic chalice [Fig. 11], found with a large ceramic bowl inside a pit within the sacristy. Little other pottery was recovered from the site, all datable material being late medieval 'Terminal Christian' wares (R26, R27, U5, GIV).

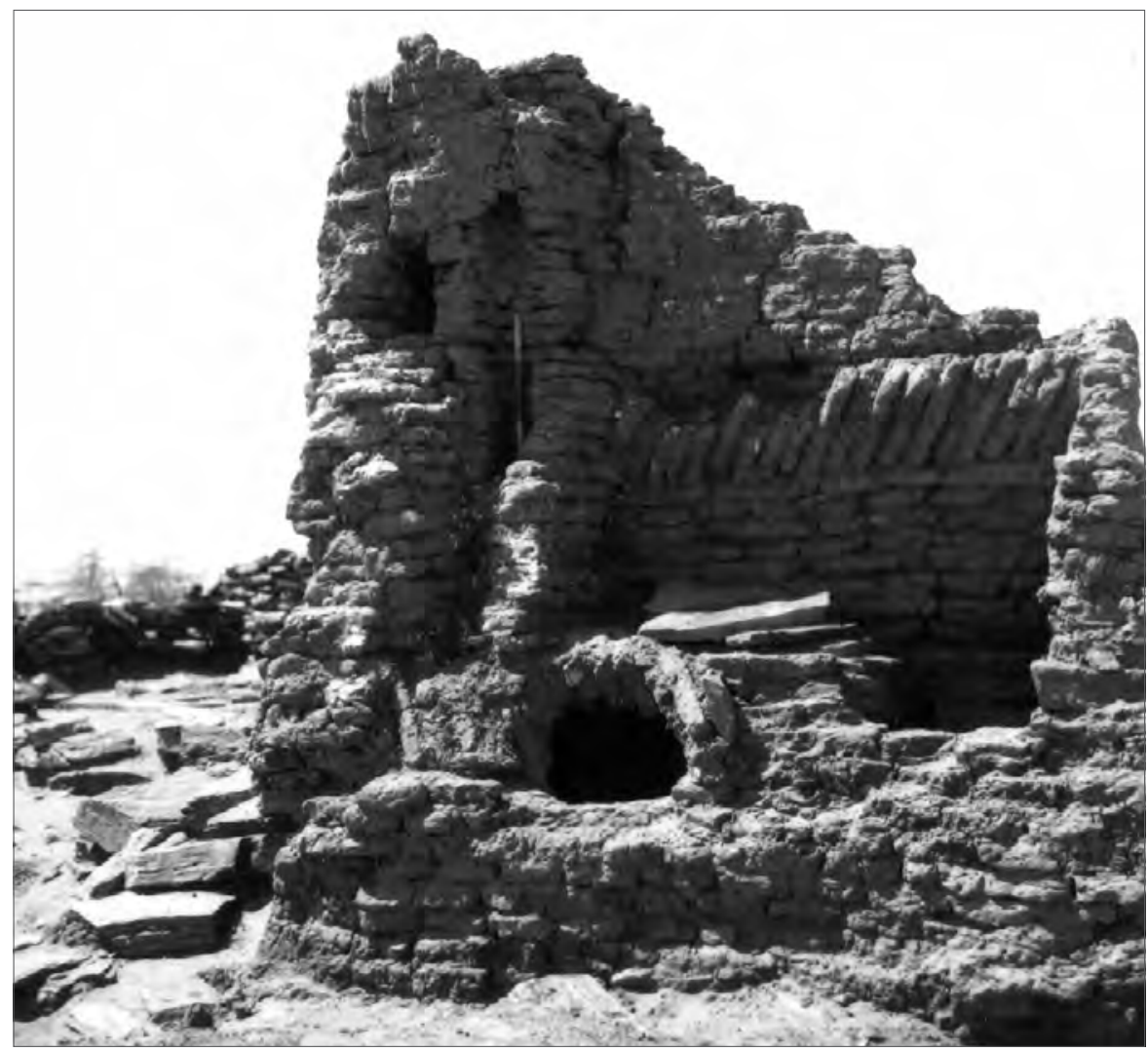

Fig. 10. Kumukka island. Core two-storey mud-brick building in settlement [16-S-5] (Photo ASSN F365/5) 
Among the rocks: A first look at medieval Duweishat, from the archive

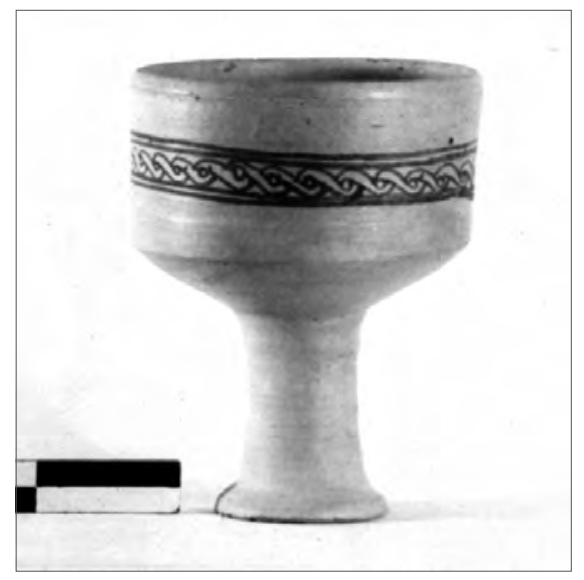

Fig. 11. Pottery cuplchalice (16-S-1/1; SNM. 20047) recovered from a pit in the Duweishat East church [16-S-1] sacristy. Polished orange ware, probably Ware R21 (Photo ASSN C110/1)

Fig. 12. Church at Duweishat East [16-S-1]. View east towards the altar. Note reused New Kingdom grindstone in the floor in the foreground (Photo ASSN F363/4)

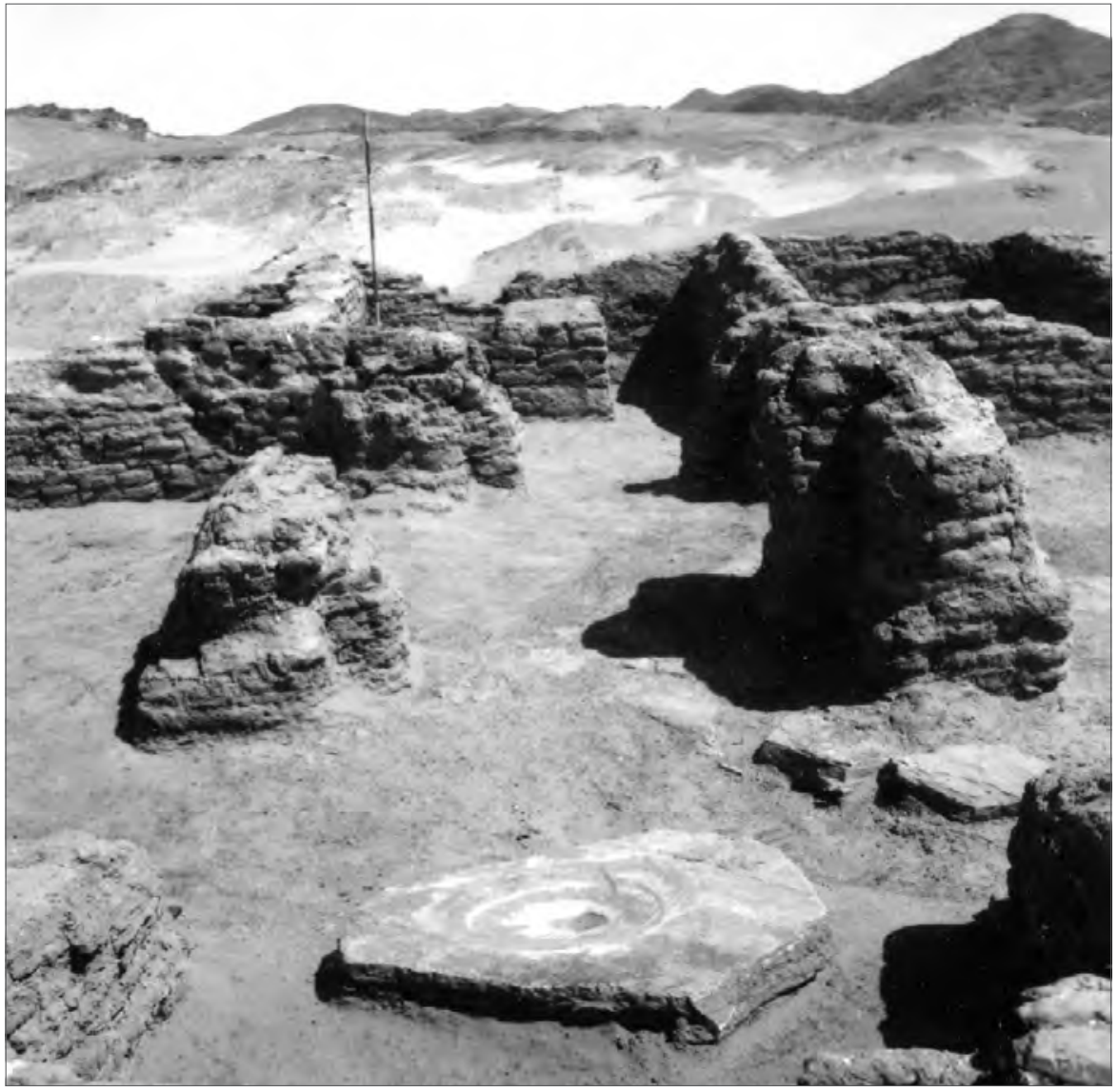


Early medieval settlement in the area seems to be confirmed again by a small east bank settlement [16-S-3] and associated cemetery [16-S-4], with a minimum of about 25 graves, just upstream of the islands on the east bank (falling within the modern administrative unit of Ambikol East). Pottery from the settlement was predominantly of early medieval date, including 'Transitional' and 'Early Christian' wares (R2, R5, W1, H3). A similar early medieval presence is indicated on the west bank, in two small cemeteries, [16-S-19] with seven graves, one perhaps of 'X-Group' form and [16-N-10] with two tumuli, although covering east-west aligned burials. Evidence for associated settlements was limited to a very eroded spread of occupation debris [16-S-20] and a single two-roomed mud-brick house [16-S-17] [Fig. 13]; surface pottery at both indicated a later medieval ('Late Christian') occupation.

No evidence was found for medieval reuse of the extensive New Kingdom gold workings and workshops widely encountered on the hillsides of east-bank Duweishat and its hinterland (Edwards and Mills 2013). The foundations of the Kumukka church [16-S-1] included several reused grindstone settings, almost certainly removed from a nearby New Kingdom workshop site [16-S-2].

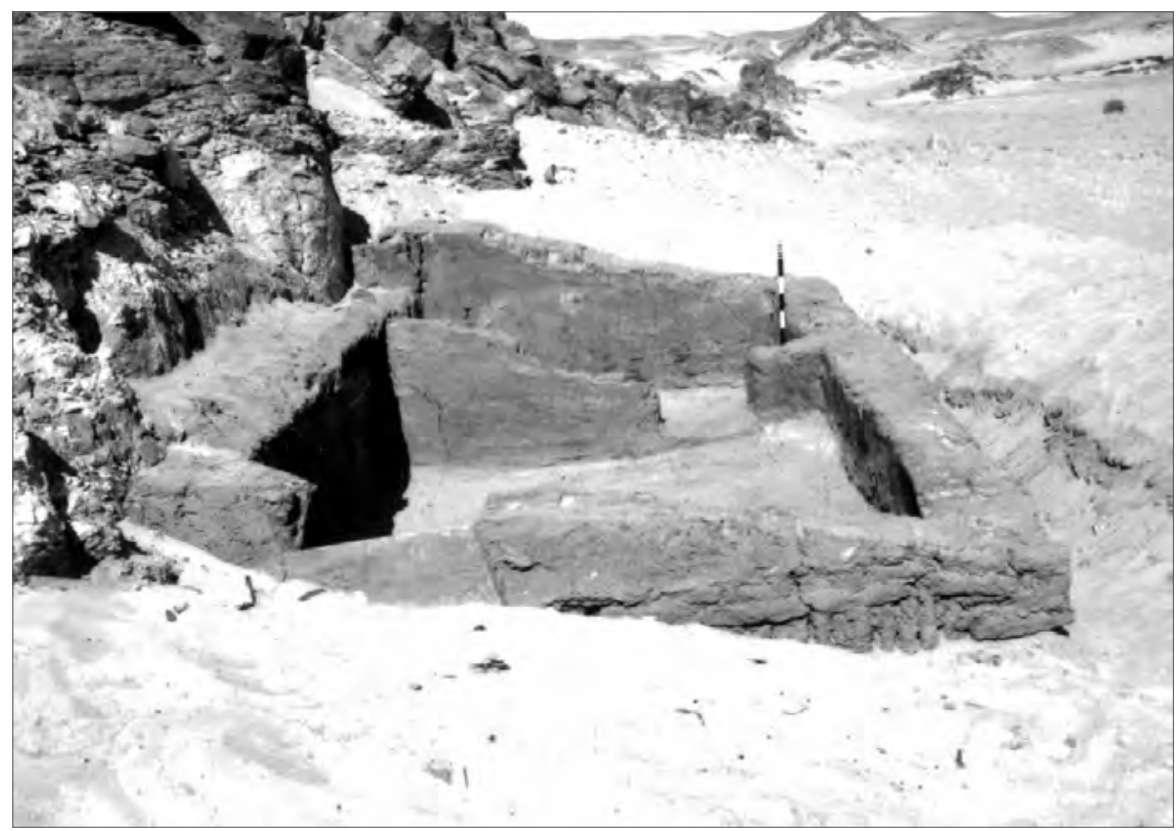

Fig. 13. Mud-brick two-roomed 'Late Christian' building [16-S-17] overlooking Kumukka island (Photo ASSN F379/5) 
On the basis of this brief overview, can we draw a few observations about the character of medieval settlement in this area, and its development? As noted above, as late as the early 1960s, the population of Duweishat remained quite small, above all constrained by the very limited agricultural potential of this barren rocky landscape. Notwithstanding considerable disruption to the region during the Mahdiyya, ${ }^{5}$ the 1960 s population levels seem unlikely to have been surpassed in any earlier periods. However, most areas settled in the 20th century show evidence of medieval occupation, the southern end of Duweishat being exceptional, lacking modern counterparts. In that area, the west bank may have been rather more exposed to the encroachment of drifting sands, which may have discouraged more recent occupation. Similar factors seem likely to have affected settlement in other parts of the Batn al-Hajar; a medieval settlement at Sonki West [21-D-5] lay in another such area threatened by moving sand, and was finally abandoned in recent centuries.

That the foundations of this pattern of settlement seem to have been established in the post-Meroitic centuries also seems clear. The origins of the early settlers of the several small early medieval communities established within the Duweishat area remain uncertain. Very little trace was found of any Meroitic presence in the locality, with none on the east bank and some rather equivocal evidence for a presence downstream of Askur (sites [16-O-20] and [16-O-21]). The main Meroitic sites in this part of the Batn al-Hajar seem to have been established on islands: Ambikol to the south and Tila to the north, sites some $20 \mathrm{~km}$ apart. As I have suggested elsewhere (Edwards 2007), the primary purpose of these more substantial Meroitic centres (and indeed other Meroitic outposts) was to manage river communications passing through this region, rather than representing agricultural communities. However, it remains distinctly possible that the communities at these outposts survived into the 4th and 5th centuries to provide a nucleus for later dispersal and colonisation of the wider landscape, albeit also probably drawing in settlers from a wider region.

That these settlements were being established before the 6th century seems likely on the basis of more 'classic' forms of post-Meroitic ('X-Group') pottery recovered from a number of these sites. The presence of small numbers of tumuluscovered burials closely associated with more typical 'Christian' burial forms also repeats a more widely encountered pattern of continued cemetery use through a period of transition which saw the gradual abandonment of traditional forms

5 During the Mahdiyya almost all the date palms of the region south of Saras were destroyed, removing a key subsistence resource for many communities. Their replacements took some years to become productive. 
of tumulus grave markers. Here, as at a number of other sites of this transitional period (e.g., Sesibi, Jebel Ghaddar), some at least of the tumulus-covered burials had adopted an east-west orientation (e.g., El-Tayeb 2012: 75-76). At Askur, their close proximity to early medieval Christian burials (site 16-O-4) with brick superstructures and lampboxes also recalls such close associations of late 'X-Group' tumuli and early 'Christian' burials. As elsewhere, these are commonly associated with pottery from the first of the distinctive 'Early Christian' pottery workshops, operating both at Dongola as well as in the Faras area, and perhaps at other, as yet unidentified locations. At sites such as this, R5 and W2 bowls were deposited in the lampboxes of Christian burials. Elsewhere in the region they were incorporated into tumuli of 'transitional' graves, for example at Murshid [11-D-4] (Donner 1998: 240-243, Pl. 189). The absence of imported mould-made 'Early Christian' lamps, not uncommon in the very early cemeteries north of the Second Cataract (e.g., Griffith 1927: Pl. LVIII; Säve-Söderbergh 1981: Pl. 15), should also be noted.

This brief overview of the medieval settlement landscape, relating to small populations, almost certainly to be numbered in hundreds rather than thousands, invites reflection on how such sites may have interrelated. How, for example, do these cemeteries relate to settlements? To what extent may we expect their locations to be determined by the proximity of single settlements, or might they relate to wider corporate groups, of the kind documented by the Kronenbergs in the 1960s, and still extant in other parts of Middle Nubia today. In the 20th century, the inhabitants of Duweishat participated in mourning parties between Semna and Melik en Nasir (Kronenberg and Kronenberg 1965: 212). Where these landscapes are conceived of as social landscapes, cemetery location may potentially have been determined by wider social networks, potentially serving multiple settlements, or perhaps lineages spread between a number of different settlements? Within such linear landscapes, it may also be considered that these are very likely to include related communities on different banks of the river, not least where cross-river traffic can pose quite significant practical challenges in certain seasons and adverse weather conditions.

The quite numerous medieval cemeteries identified in Duweishat certainly suggest that no simple correlations may be assumed between individual settlements and cemeteries. Social as much as spatial factors seem likely to have played significant roles on occasion in determining the location of cemeteries. In such terms, the location of at least one of the east bank cemeteries [16-N-3] is of interest. It lies directly opposite the west bank settlement of Farre, but at least $1.5 \mathrm{~km}$ from any known east-bank settlement. Potentially used by the few (dispersed) inhabitants of the east bank south of Jedagur, its location would however also be well-placed 
to allow easy access from the more populous west bank. 'Off-island' burial also may be suggested for the inhabitants of small islands/seasonal islands. From such a perspective, it is perhaps to be regretted that more attention could not be paid to the medieval cemeteries during the work of the ASSN. There is certainly much scope to further explore the extent to which medieval burial practices in the Batn al-Hajar followed patterns observed elsewhere in Nubia (Adams 1998). That they may, in fact, have provided valuable indirect evidence for some key social/ corporate groupings within these small rural communities may be suggested, even in the absence of bioarchaeological studies. ${ }^{6}$ Even with the incomplete records of medieval cemeteries in Duweishat region, there is clearly some basis for tracing the chronological development of burial sites from their origins in the 5th-6th century, through to the appearance of Islamic burial practices; some cemeteries remaining in use until the abandonment of settlements in the 20th century. Data concerning a significant number of medieval cemeteries in this area, as well as other parts of the Batn al-Hajar is likely to provide useful information adding to the material collated by Adams (1998: 32-33), not least where it may be possible to identify more late medieval cemeteries, as well as many more 'transitional' cemeteries, albeit relating to changes in burial practice occurring rather later than in some other parts of Nubia.

On the basis of this local study, attention may again be drawn to other interesting questions which may be raised about the distribution of churches in the landscape. Both the churches in this area have been dated to the 'Late Christian' period, probably in the 13th century, and these may well be the first churches built in this area, as seems likely to have been the case in many parts of the Batn al-Hajar (Adams 2009: 441). In earlier centuries, the nearest churches may have been at Semna and Sonki, although in the 'Early Christian' period there may well have been very few churches in the region. The two examples found in Duweishat represent two different types of foundation, the first [16-N-6] closely associated with a settlement and the latter [16-S-1] apparently standing in isolation. In the former case, the unusual character of some of the core vaulted buildings also suggests the possibility of a special function of some kind, although with no more obvious indications of, for example, a monastic presence. ${ }^{7}$

6 The lack of a specialist physical anthropological component in the work of the ASSN is clearly to be much regretted, as very little anthropological data was recovered from the many cemeteries, of many periods, in the region. Some samples are recorded to have been taken from cemetery [16-O-4] for study by John Huizanga.

7 It may be noted that no examples of inscribed sherds were found; these are often common finds in monastic contexts, including some Batn al-Hajar sites, such as the enclosed settlement at Kulb (Dinkler 1970). 
The upstream site [16-S-1] could relate to the small medieval settlement located on Kumukka island. The construction of a substantial mud-brick building on the island could perhaps relate to the construction of the church, and would represent a project of similar scale. While a direct association with the island settlement remains a possibility, it is perhaps of interest that an 'offisland' location was chosen for the church. One result of this choice would be to make the site more accessible to a wider population, potentially including several settlements. The potential social isolation of island settlements should be borne in mind here, as has been highlighted in work elsewhere in Middle Nubia (Salih and Edwards 2011: 30). Such issues may well have been relevant to the siting of such important communal resources as churches. On the east/ right bank, the closest medieval occupation was a small settlement [16-S-6] about $0.5 \mathrm{~km}$ downstream, or approximately $2 \mathrm{~km}$ upstream [sites 16-S-3, 16-S-4]. Its site also lies above a small bay, which affords the most obvious landing spot for boats in the vicinity of these islands. Interestingly, in Bell's records the area below the church may perhaps be identified with the toponym sheemt-el-jemaa, ${ }^{8}$ glossed by him as 'the bay of the congregation' (Bell 1970: 60). Might we though suggest that this name could indicate the presence of something perceived as a religious congregation (mosque?)?

In general, 'mainland' locations would make churches more accessible as important points within the landscape, perhaps performing roles other than as congregational spaces. That they may mark land and community territory outside settlements might be considered. In the case of [16-S-1], its elevated position would have made it a fairly prominent landscape feature in the immediate area. Similar occurrences of churches away from settlements (may we call them exokklisia?) are not uncommon and may raise more questions about their construction, ownership (Eajtar and van der Vliet 1998) and practical support in such deep rural locations. Unusual concentrations of churches in other locales (e.g., Semna) may also be noted and also invite further investigation, sensitive to their possible roles both within the social as well as spatial landscapes.

As has been noted in other areas, medieval rock art, particularly crosses, may well serve to mark and protect more liminal areas away from the settlements (Salih and Edwards 2011: 167-170). Such carved crosses were recorded in this area at [16-O-31], which is just such a liminal location on the barren hills between the hamlets of Usher/Jedagur and Sorki, opposite Askur. Interesting parallels may be drawn with some of the patterns identified in studies of the

8 In the absence of a detailed mapping of Bell's data, the toponym may relate to a location a little to the north, although this seems the most prominent bay on the riverbank in this area. 
social construction of other sacred landscapes in the medieval world (e.g., Nixon 2006). In this respect, where we do encounter rare island churches, specific circumstances may have demanded their presence, as for example on the 'special' island site of Meinarti, at the foot of the Second Cataract (Adams 2014).

Relatively few medieval sites were sufficiently well preserved to merit extensive excavation during the ASSN fieldwork and fewer still contained much depth of stratigraphy or indeed abundant artifacts. At a general level, spotdating of the decorated medieval finewares provide some dating evidence, while also confirming that these small rural communities had access to the products of the main medieval workshop centres. A range of 'Early Christian' wares (mainly small bowl forms) were found, mainly associated with early medieval cemeteries. Examples of 'Classic Christian' wares are much less in evidence however; it will be of interest to see whether this is a local anomaly (or problem with the data), or a more general feature of assemblages within the Batn al-Hajar. More prominent in the collections are examples of 'Late Christian' wares (Adams Ware Group N.VI), identified at several sites and suggested by Adams as being the products of a single production centre (1986: 504). There is increasing reason to believe that this may in fact have been at Old Dongola (Edwards 2014), being distributed northwards from there into the Batn al-Hajar and beyond. While the ceramic data in the ASSN archive is generally limited, it may also be noted that occasional Egyptian imports, both glazed finewares as well as more functional utility vessels, were also reaching these small communities. While, at this time, no studies of the medieval pottery supply to the Batn al-Hajar region have been undertaken, the ASSN records have the potential to provide new and interesting insights into the penetration of Makurian material culture into these northern regions, long after its political ascendancy had been established (Godlewski 2004).

The very sparse collections of registered finds from the Duweishat sites may provide some indication of the more general character of medieval occupation. Notwithstanding occasional sherds of imported Egyptian pottery, metalwork and glass appears very rare, and no inscribed sherds/ostraca were encountered, suggestive of a limited impact of habits of literacy in this area. Most of the medieval settlement remains suggest a predominance of stone architecture, with generally limited use of mud brick (with notable exceptions, not least in new forms of 'Christian' grave markers). In such an area of abundant stone and where alluvial land is rare and a valued resource, this limited use of mud brick is perhaps not surprising.

It does however return our focus to the two known Duweishat churches and a few more impressive brick-built buildings. With their reliance on specific 
architectural practices and skills working in the medium of mud brick, as Adams has suggested, it may well be that the necessary architectural expertise was not to be found locally (2009: 382-386). In this region we must presumably expect to look to the nearest episcopal centres, Sai to the south and Faras to the north, for such expertise. Future studies of these and other 'Late Christian' churches of the Batn al-Hajar may yet provide new insights into the architectural and artistic skills and practices which created and decorated them, as well as the possibly quite varied imperatives for their construction. There is certainly reason to believe that closer examination of some of Adams' 'types', and their distribution, may allow some to be linked, the distribution of type $4 \mathrm{~d}$ churches, being a case in point, with a cluster of quite similar constructions built at Serra East and the Second Cataract, and another in the southern Batn al-Hajar (Adams 2009: $312 \mathrm{ff}$ ). That some may have been constructed as part of larger projects seems not unlikely.

Far from the metropoles which have been the focus of so much of Włodek Godlewski's work in Nubia, the archaeology of areas such as Duweishat, largely destroyed 50 years ago, may yet provide insights into the character of their rural medieval communities, as well as some measure of the penetration of the Church and its institutional reach into these unwelcoming landscapes.

\section{ACKNOWLEDGMENTS}

A full acknowledgment is due here to all those who undertook the fieldwork in Duweishat in the 1960s, both the expatriate staff working with Anthony J. Mills, especially James E. Knudstad, Bengt Schönbäck and Lars Gezelius, as well as their Sudanese and Egyptian workers. It is, as ever, a pleasure to be revisiting their fieldwork and the excellent records they created. Thanks also to Margaret Finch for preparation of digital versions of field drawings and Nick Hannon and Chantal Bielmann for assistance with digitization and GIS-based mapping.

\section{References}

Adams, W.Y. (1986). Ceramic industries of medieval Nubia I-II [=Memoirs of the UNESCO Archaeological Survey of Sudanese Nubia 1]. Lexington, KY: University Press of Kentucky

Adams, W.Y. (1994). Castle-houses of late medieval Nubia. Archéologie du Nil moyen, $6,11-46$

Adams, W.Y. (1998). Towards a comparative study of Christian Nubian burial practices. Archéologie du Nil moyen, 8, 13-41 
Adams, W.Y. (2009). The churches of Nobadia [=Sudan Archaeological Research Society Publications 17; British Archaeological Reports International Series 2000]. Oxford: Archaeopress

Adams, W.Y. (2014). The Eparch at Meinarti. In J.R. Anderson and D.A. Welsby (eds), The Fourth Cataract and beyond: Proceedings of the 12th International Conference for Nubian Studies [=British Museum Publications on Egypt and Sudan 1] (pp. 875-885). Leuven: Peeters

Bell, H. (1970). Place names in the Belly of Stones [=Linguistic Monograph Series 5]. Khartoum: Sudan Research Unit, Faculty of Arts, University of Khartoum

Chittick, H.N. (1957). Antiquities of the Batn el Hajjar. Kush, 5, 42-48

Dafalla, H. (1975). The Nubian Exodus. London: Hurst \& Co.

Dinkler, E. (1970). Die Deutschen ausgrabungen auf den inseln Sunnarti, Tangur und in Kulb 1968-69. In E. Dinkler (ed.), Kunst und Geschichte Nubiens in christlicher Zeit: Ergebnisse und Probleme auf Grund der jüngsten Ausgrabungen (pp. 259-272). Recklinghausen: A. Bongers

Donner, G. (1998). The Finnish Nubia expedition to Sudanese Nubia 1964-65: The excavation reports. Helsinki

Edwards, D.N. (2007). Meroitic settlement landscapes in Middle Nubia. Cahiers de recherches de l'Institut de papyrologie et d'égyptologie de Lille, 26, 59-70

Edwards, D.N. (2014). Medieval Nobadia. In J.R. Anderson and D.A. Welsby (eds), The Fourth Cataract and beyond: Proceedings of the 12th International Conference for Nubian Studies [=British Museum Publications on Egypt and Sudan 1] (pp. 171-182). Leuven: Peeters

Edwards, D.N. and Mills, A.J. (2013). Pharaonic' sites in the Batn al-Hajar - the "Archaeological Survey of Sudanese Nubia” revisited. Sudan \& Nubia, 17, 8-17

El-Tayeb, M. (2012). Funerary traditions in Nubian early Makuria [=Gdańsk Archaeological Museum African Reports Monograph Series 1]. Gdańsk: Muzeum Archeologiczne w Gdańsku

Godlewski, W. (2004). The rise of Makuria (late 5th-8th cent.). In T. Kendall (ed.), Nubian studies, 1998: Proceedings of the ninth conference of the International Society of Nubian Studies, August 21-26, 1998, Boston, Massachusetts (pp. 52-73). Boston: Department of African-American Studies, Northeastern University

Griffith, F.L. (1927). Oxford excavations in Nubia. Liverpool Annals of Archaeology and Anthropology, 14, 57-116

Kronenberg, A. and Kronenberg, W. (1965). Preliminary report on the anthropological field work in Sudanese Nubia, 1964. Kush, 13, 205-212

Łajtar, A. and van der Vliet, J. (1998). Rich ladies of Meinarti and their churches. With an appended list of sources from Christian Nubia containing the expression "having the Church of so-and-so". Journal of Juristic Papyrology, 28, 35-53

Mills, A.J. (1965). The reconnaissance survey from Gemai to Dal: A preliminary report for 1963-64. Kush, 13, 1-12 
Mills, A.J. (1992). The archaeological survey from Gemai to Dal. In C. Bonnet (ed.), Études nubiennes: conférence de Genève. Actes du VII Congrès international d'etudes nubiennes, 3-8 septembre 1990, I. Communications principales (pp. 29-31). Geneva: C. Bonnet

Nixon, L. (2006). Making a landscape sacred: Outlying churches and icon stands in Sphakia, southwestern Crete. Oxford: Oxbow Books

Salih, A.O.M. and Edwards, D.N. (2012). The archaeology of a Nubian frontier: Survey on the Nile third cataract, Sudan. Leicester: Mauhaus

Säve-Söderbergh, T. (1981). Late Nubian cemeteries [=Scandinavian Joint Expedition to Sudanese Nubia 6]. Copenhagen: Scandinavian University Books 


\title{
Beyond Old Dongola: The multicomponent site of Hag Magid (Letti Basin)
}

\author{
Krzysztof Grzymski \\ Royal Ontario Museum, Toronto \\ krzysg@rom.on.ca
}

KeYwords

Letti Basin, Neolithic, Christian and post-Christian Nubia

Abstract

A brief presentation of the Hag Magid archaeological site located on the east side of the Letti Basin, several kilometers to the north of the ruins of Dongola. Material from the Neolithic, Christian and postChristian periods were recorded from the site during three visits in the 1980s and 1990s.

Professor Włodzimierz Godlewski is widely recognized as a distinguished scholar in the field of Coptic and Christian Nubian studies, but interestingly his first major academic publication dealt with neither of these two research areas and instead was concerned with the analysis of the Meroitic remains at Faras (Godlewski 1972). My own archaeological career took exactly the opposite course. While my scholarly interests were in the field of Meroitic studies, culminating in the last fifteen years in the co-directorship of the University of Khartoum-Royal Ontario Museum excavations at Meroe, my early activities in the Sudan involved medieval Christian sites in the neighborhood of Old Dongola. The Christian-period material was discovered during the survey carried out in 1984-1986 by the Royal Ontario Museum expedition directed by this author. This survey in the Dongola Reach was then followed by excavations at the medieval site of Hambukol, some $7 \mathrm{~km}$ north 
of Old Dongola (Grzymski and Anderson 2001). The latter site, the capital of the medieval kingdom of Makuria, has for many years now been explored with great success by Godlewski himself.

Old Dongola is located at the southern tip of an elongated, island-like region known as the Letti Basin, made up of two wide belts of cultivated land separated by a flat, sandy interior. The west belt extends along the main channel of the Nile, while the east side, known as Khor Letti, undoubtedly represents an extinct Nile channel. The two branches of the Nile (i.e., modern and extinct) separate on the north side of Old Dongola and rejoin in the area of Amentogo and Nawa, some $20 \mathrm{~km}$ further north. The site of Hag Magid (also

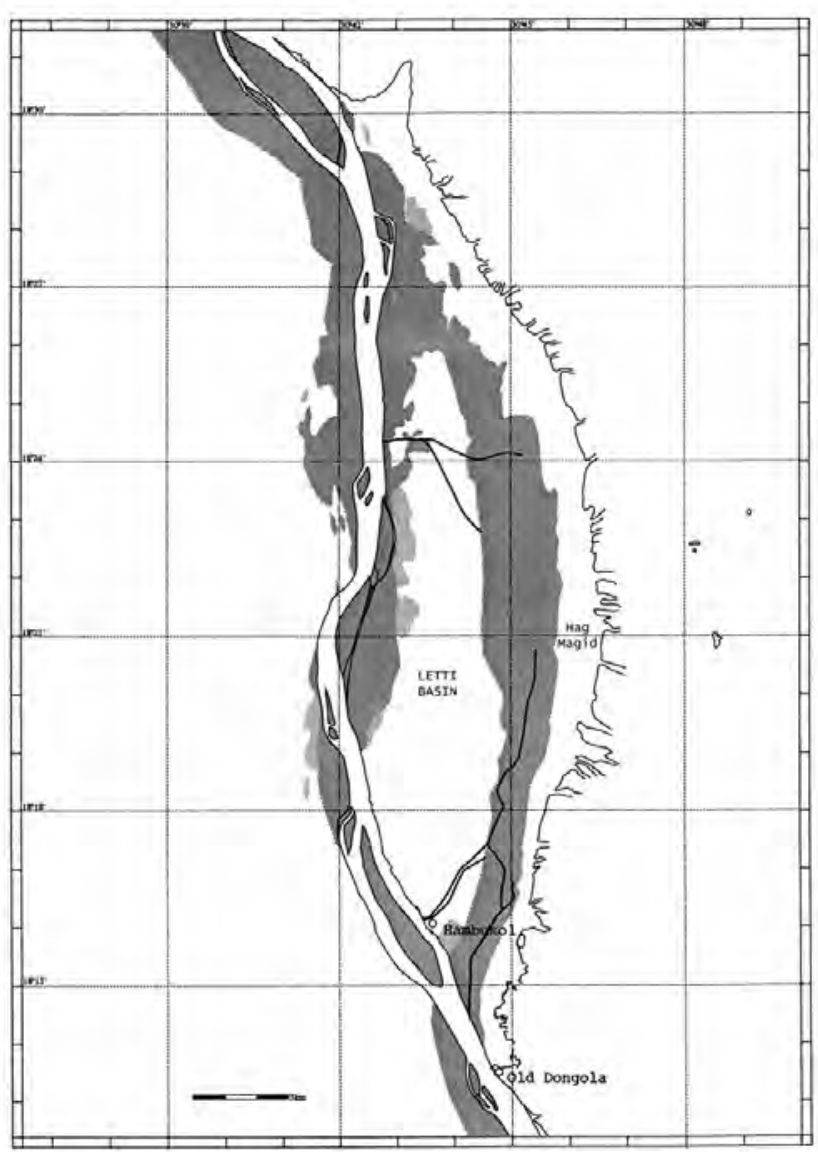

Fig. 1. Map of the Letti Basin, circle indicates the location of Hag Magid (Drawing I. Grzymska) 
spelled Haj Majid or Hajj Majid) is located on the east side of Khor Letti, about halfway between Old Dongola and Amentogo [Fig. 1]. In this very modest contribution to the book honoring Professor Godlewski I would like to provide additional information and observations regarding this site thus expanding on the description provided in my early report (Grzymski 1987: 19-20).

Until the construction of a modern road in the last decade the site of Hag Magid was very difficult to access having been separated from the fields of Khor Letti (section/gism 3, basin/hod 2) by high sand dunes. Between the sand dunes to the west and the terraces and gebels to the east extends a gravelly plain with a large undulating, sand-covered mound rising about $7 \mathrm{~m}$ above the surrounding area. The most visible remains are two red-brick gubbas (graves) of Hag Magid and Hag Mohammed and several stone columns (site ROM 49; Grzymski 1987: 19-20) [Figs 2, 4]. Nearby one can also see the ruins of a third gubba constructed, like the other two, from reused red bricks.

Another interesting feature was a brick-lined well reminiscent of the one found a few years ago at Selib (Żurawski 2014: 895-896). The site was marked,

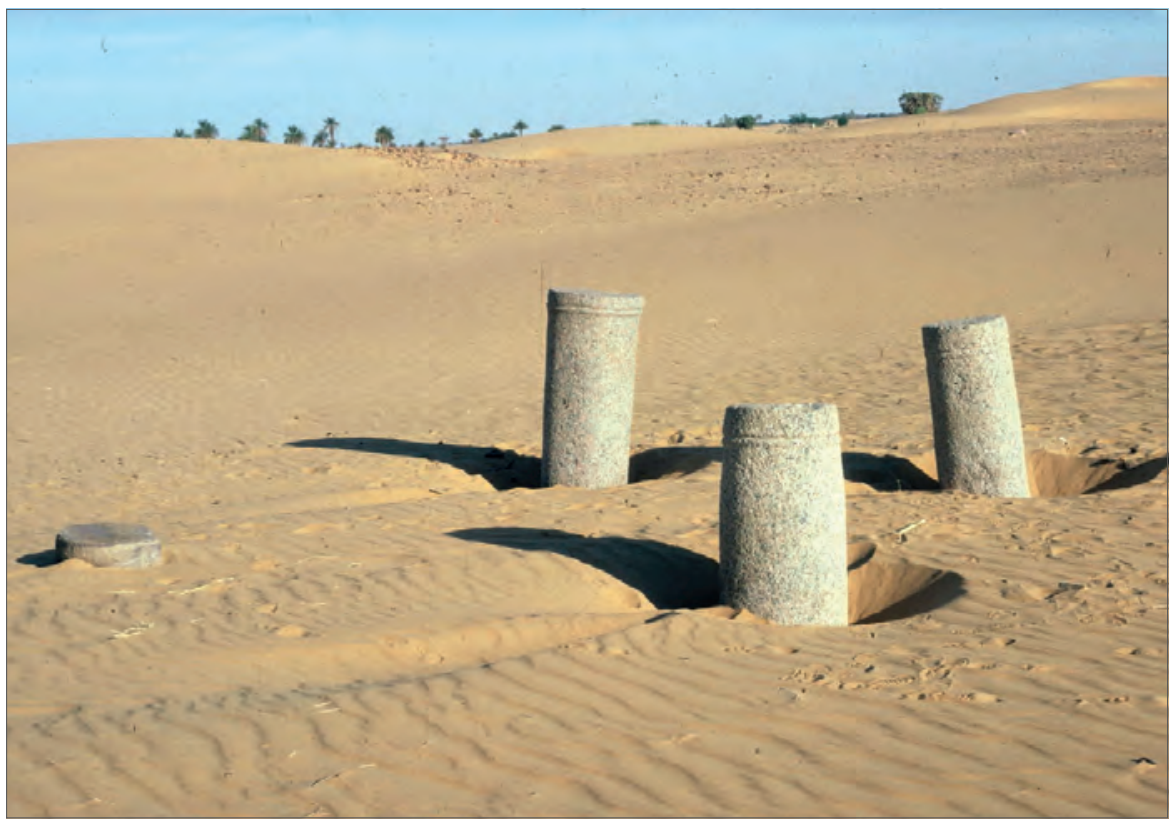

Fig. 2. Granite columns of a church (Photo K. Grzymski) 


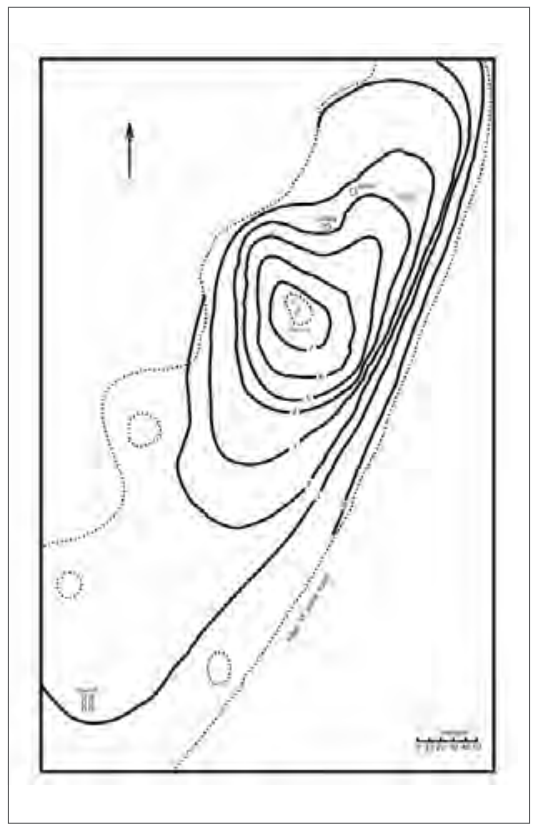

Fig. 3. Sketch plan of the main mound of Hag Magid (Drawing M. Mallinson)

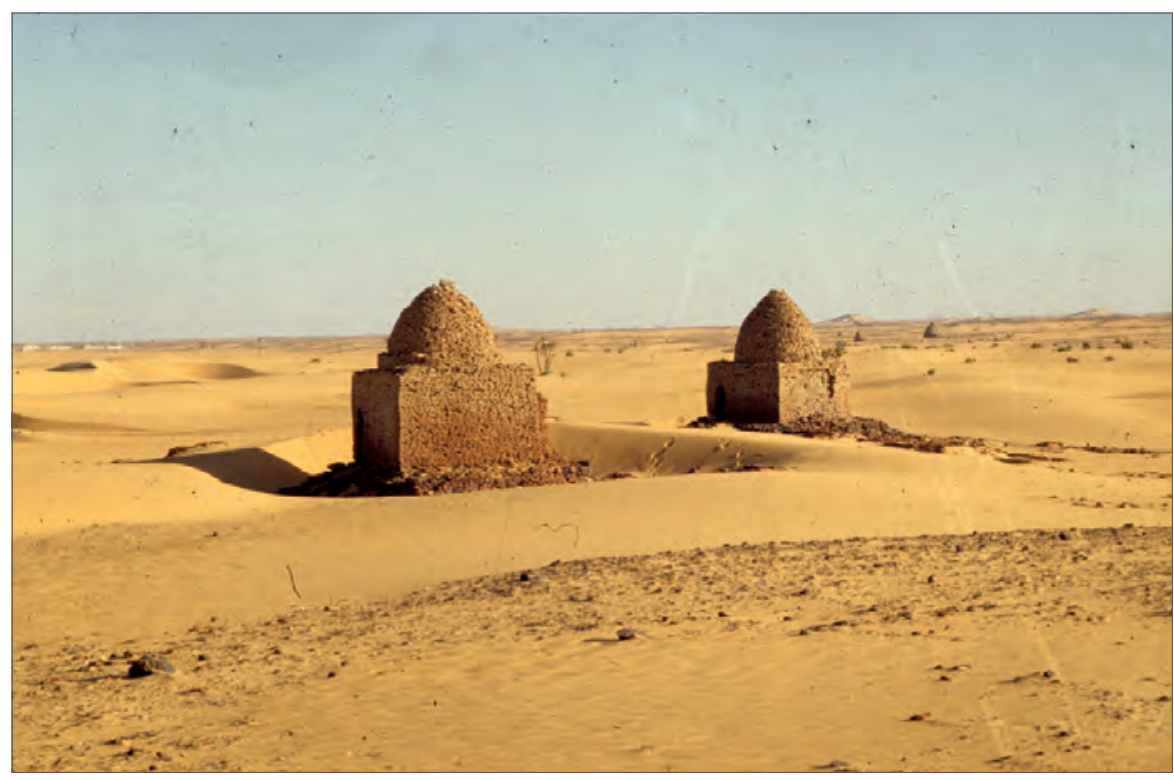

Fig. 4. Two Islamic gubbas of Hag Magid and Hag Mohammed (Photo K. Grzymski) 
albeit incorrectly, on the 1:250,000 map of Sudan. During my survey of the Letti Basin I visited the site in November 1985. I returned to Hag Magid in the fall of 1988, this time accompanied by Michael Mallinson, who drew a preliminary plan of the main mound [Fig. 3] with its Christian period and Islamic monuments. My third visit to the site took place in 1993 when an opportunity arose to show the area to a group of prehistorians, namely Marek Chłodnicki, Jacek Kabaciński and Donatella Usai. They immediately noticed Neolithic remains in the flat, gravelly plain between the sand dunes west of the main mound. During that visit we also found an apparently Napatan grave on a low terrace to the west of the mound. It became obvious that the main mound with its three gubbas, two standing and one ruined, was just one part of a large, multicomponent site. In addition to the abovementioned Islamic, Christian, Neolithic and Napatan remains the site also contains several post-Meroitic

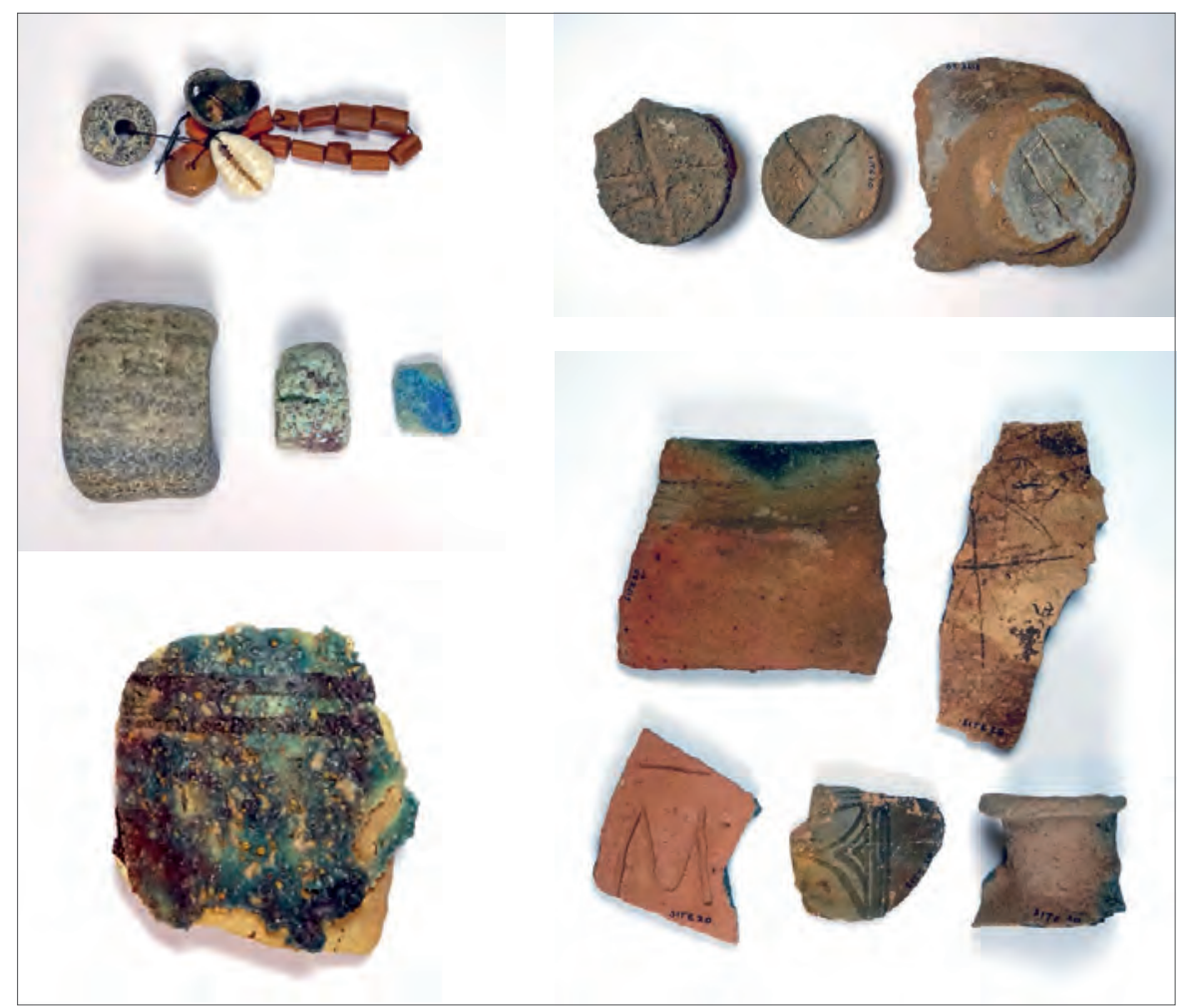

Fig. 5. Selected finds: top left, an archer's ring, beads and faience fragments; top right, qadus knobs; bottom right, Christian-age sherds; bottom left, green-glazed Islamic sherd (Photos K. Grzymski) 
cemeteries (sites ROM 84, ROM 105), possibly Terminal Christian or Early Funj habitation remains (ROM 83). The material collected on the surface near one of the cemeteries also included a fragment of a Meroitic or post-Meroitic archer's ring, carnelian, cowry-shell beads and small pieces of faience [Fig. 5 top left]. Near the main site (ROM 49) we also found qadus knobs [Fig. 5 top right], clear evidence of the presence of a saqiya water wheel and thus confirming the existence of a Nile branch well into the Middle Ages. Most of the potsherds came from larger utility wares, amphorae, jars, bowls and pilgrim flasks of the Christian Period [Fig. 5 bottom right], but an Islamic glazed sherd with underglaze paint decoration was also noticed [Fig. 5 bottom left]. In 2008, the site was visited by Professor Godlewski's former student, Dr. Dobiesława Bagińska of the Poznań Archaeological Museum, who identified the pottery found on the surface of the main mound as dating to the Classic Christian and post-Classic Christian periods, that is, AD 850-1200. In her opinion the decoration and forms of ceramics from Hag Magid indicated that this pottery was probably produced in Old Dongola. It is hoped that as a result of an agreement between the Royal Ontario Museum and the Poznań Archaeological Museum a more detailed investigation of the site will be undertaken in the near future.

Although numerous Christian period sites have been located to the north and south of Old Dongola, the most impressive ones, such as the large mounds of Hambukol, Jogob Sheikh Mohammed, Megauda and Kadakol are all found along the banks of the Nile. The site of Hag Magid, on the other hand, has the distinction of lying on the very eastern edge of cultivable land bordering the rocky hills of the Nubian Desert. Any future investigation of Hag Magid has the potential to contribute not only to the cultural history of Nubia, but also to a better understanding of the cultural and natural landscape of the area and the relationship between man and the environment on the outskirts of Old Dongola.

\section{References}

Godlewski, W. (1972). Faras à l'époque méroïtique. Études et Travaux, 6, 185-193

Grzymski, K.A. (1987). Archaeological reconnaissance in Upper Nubia [=Society for the Study of Egyptian Antiquities Publication 14]. Toronto: Benben Publications Grzymski, K.A. and Anderson, J.R. (2001). Hambukol excavations, 1986-1989 [=Society for the Study of Egyptian Antiquities Publication 16]. Mississauga: Benben Publications 
Żurawski, B. (2014). Meroitic to medieval occupation upriver from Dongola. Excavations at Banganarti and Selib in 2010. In J.R. Anderson and D.A. Welsby (eds), The Fourth Cataract and beyond: Proceedings of the 12th International Conference for Nubian Studies [=British Museum Publications on Egypt and Sudan 1] (pp. 887-900). Leuven: Peeters 



\title{
Nubian cathedrals with granite columns: A view from Sai Island
}

\author{
Henriette Hafsaas-Tsakos \\ Volda University College, Norway \\ henriette.hafsads.tsakos@hivolda.no
}

Alexandros Tsakos

University of Bergen, Norway atsakos@gmail.com

\section{KeYwORDS}

Nubian cathedral, church, Sai, granite columns

\begin{abstract}
With the purpose of providing insights into the position of the church on Sai Island among the bishoprics of Christian Nubia, the paper contextualizes archaeologically well-known Nubian cathedrals with monolithic granite columns as roof supports (Old Dongola, Faras and Qasr Ibrim), presenting them against the background of historically known bishoprics from medieval Nubia and archaeologically attested episcopal churches. Four granite columns at the locality 8-B-500 on Sai Island, identified with the site of a medieval cathedral, are compared with like roof supports from other Makurian buildings of the kind to show that the church was constructed at the beginning of the 8th century AD and modeled on the Church of Granite Columns from Old Dongola.
\end{abstract}

For more than a decade Professor Włodzimierz Godlewski has headed Polish archaeological expeditions to Old Dongola, the capital of Makuria. Makuria was the intermediate polity of the three medieval kingdoms in Nubia, until the Makurian rulers seized the northern kingdom of Nobadia in the 7th century AD (Godlewski 2004: 58-61). The southern kingdom was Alwa (for a general description of the Christian kingdoms of medieval Nubia, see Adams 1977: 433546; Welsby 2002; Edwards 2004: 212-255) [Fig. 1]. Godlewski's vast knowledge of Christian Nubia and his excavations at Old Dongola have empowered him 


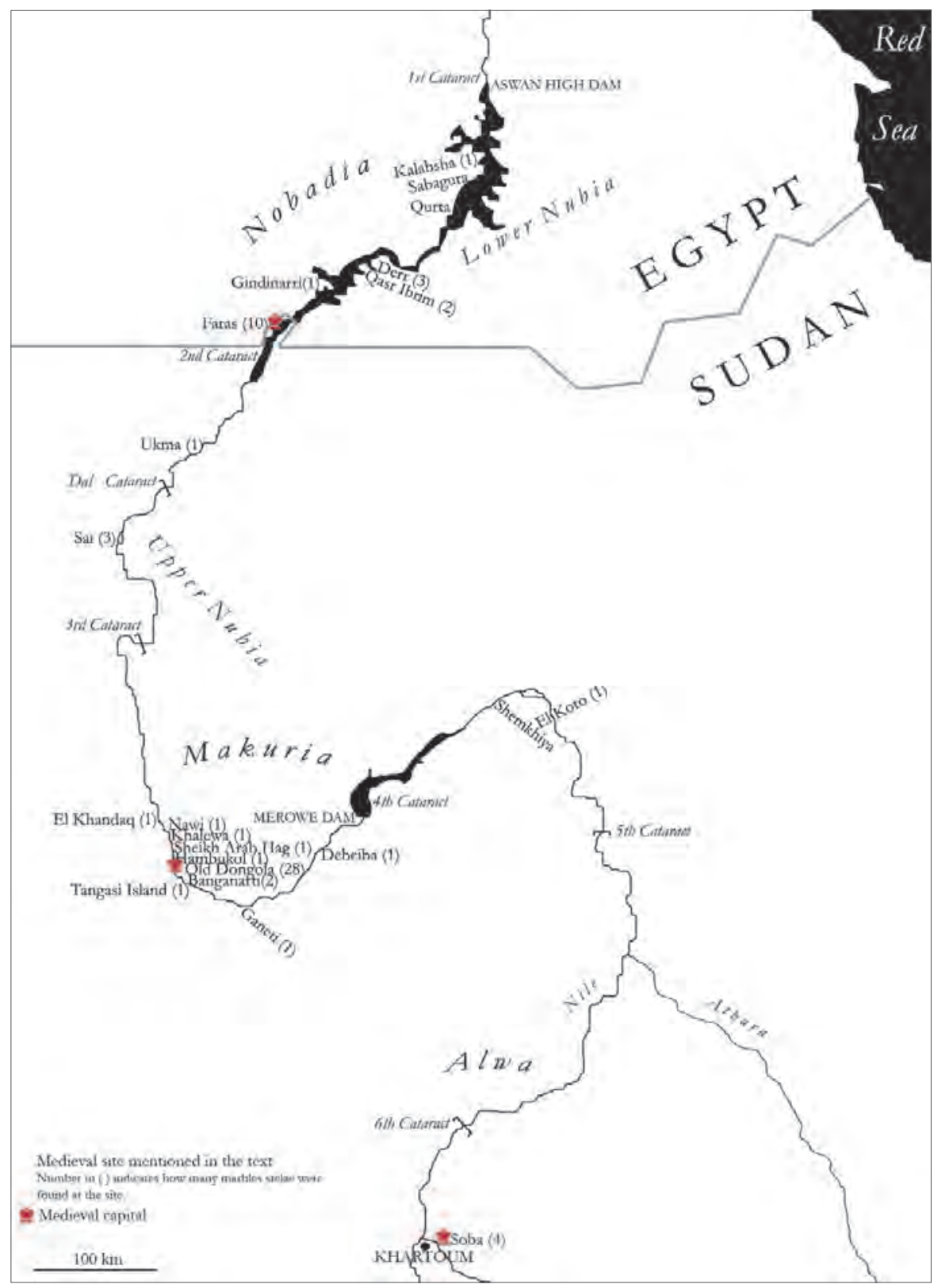

Fig. 1. Map of Nubia with medieval sites mentioned in the text (Drawing H. Hafsaas-Tsakos) 
with a privileged overview of historical, political, religious, technological, literary and artistic achievements of the Nubians during the medieval era. Several of his numerous publications have become definite references for students of the medieval past in Nubia. Not least among those are his analyses of the current state of knowledge regarding the bishoprics and the cathedrals of the Christians in Nobadia and Makuria (e.g., Godlewski 2006).

It is within the framework of research on the Nubian cathedrals that we wish to make a contribution to the academic celebration of Godlewski's 70th birthday, having undertaken the first archaeological investigation of the ruins of the proposed cathedral on Sai Island (Hafsaas-Tsakos and Tsakos 2009; 2012). This article is inspired by Godlewski's observation concerning the cathedrals in Nubia after the 7th century AD: "The partial isolation of Makuria from the Mediterranean world favored a display of local talent. So it is hardly surprising that the Church of the Granite Columns became a model for the rebuilding of the Paulos Cathedral in Faras, as well as for the cathedral raised on the island of Sai" (Godlewski 1998: 131).

\section{Bishoprics of medieval Nubia}

The ecclesiastic hierarchy in Christian Nubia is best known from the tenth chapter of the first book of the History of the Church of Alexandria by the German savant Johann Michael Wansleben (1635-1679), written during his stay in Egypt in 1672 and 1673. Wansleben listed seven bishoprics in Makuria, including the former independent kingdom of Nobadia, moving apparently from north to south: Korta, Ibrim, Bucoràs, Dunkala/Dungala, Sai, Termus and Scienkur. The identification of Korta with Qurta, Ibrim with Qasr Ibrim, Bucoràs with Faras, Dunkala/Dungala with Old Dongola, and Sai with Sai Island is secured by the similarity of the medieval and modern place names, references in written sources and, for all except Qurta, monuments uncovered in archaeological excavations (Adams 1977: 472). Termus may be placed in Makuria proper, perhaps between Old Dongola and the Fourth Cataract (Seignobos 2015: 213). The suggestion that Scienkur is similar to Shenqir and that is should be identified as the region of Shemkhiya at the upstream end of the Fourth Cataract is based on written sources, similarities in the place names and a high density of Christian archaeological remains in the area (Crawford 1951: 26; Zurawski 2007: 180; Seignobos 2015: 196). 
Robin Seignobos (2015) published recently the original Copto-Arabic source of Wansleben's list along with two other lists, one in Coptic and the other in Arabic. These lists confirm the importance of Ibrim, Faras, Dongola and Korta, adding at the same time at least four new names to the list of Makurian bishoprics, ${ }^{1}$ namely Onadour/B.r.nus, Terpekkil, Silme Thiopi and Sigklotta. The first might be a variant for Termus (Seignobos 2015: 211). Although the exact location of Terpekkil cannot be established, Seignobos (2015: 191) makes a tentative identification with Sabagura. There is furthermore a phonetic resemblance of the first toponym in Silme Thiopi with the Nubian name of Ibrim, namely Silmi (Seignobos 2015: 191), and Silme Thiopi could thus be a particular district of Ibrim (Seignobos 2015: 192). The importance of the fourth name, Sigklotta, is twofold: First, it can probably be identified both geographically and etymologically with the area of Sikkoot/Sukkoot, which centers on Sai Island (Werner 2013: 262, note 137). Second, it shows that a bishopric could be identified with its territory and not only with its episcopal see. Sai Island or its region may thus have been granted a reference in two out of three lists (see Seignobos 2015: 193-195).

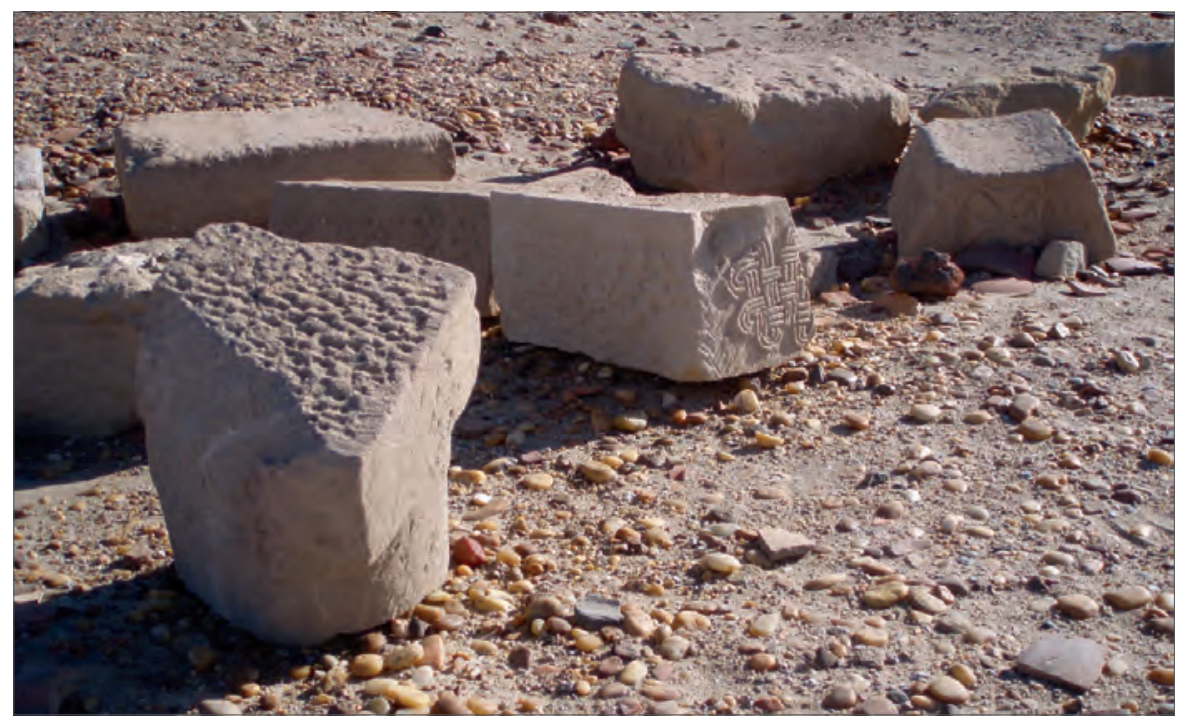

Fig. 2. Sandstone spolia from a church, found in the fortress of Sai Island (Photo A. Tsakos)

1 Philae is also present in one of these lists, but as a Nubian and not Egyptian bishopric, the only medieval text to present Philae in such light. 
In any case, none of the Nubian bishoprics recently identified in the written sources has been linked with churches known from archaeological investigations, although this might be a promising field to explore further. The recently discovered and excavated church at Ganati with its eight granite columns is a case in point (Bakhiet 2015: 149-151).

The architectural remains of the attested bishopric on Sai Island are best compared with the securely identified and sufficiently investigated monumental cathedrals preserved at Old Dongola and Qasr Ibrim, the cathedral in Faras that is now flooded by the reservoir behind the Aswan High Dam, as well as the newly excavated church with granite columns at Ganati. These four churches will be reviewed here in brief.

\section{Medieval cathedrals with granite columns in Nubia}

In the 6th century $\mathrm{AD}$, several basilican churches were constructed in Nubia, using locally available sandstone at Qasr Ibrim and Faras and red bricks at Old Dongola and Soba (Godlewski 2006: 41). William Y. Adams (2009: 44) argued that these five-aisle buildings were the earliest churches in Nubia to be commissioned by either church or civil authorities. Their ground plans and architecture were inspired by Egyptian churches of the same period.

On Sai, architectural spolia are in abundance, with a concentration in the fortress [Fig. 2]. Numerous decorated sandstone blocks of medieval date were moved to archaeological storerooms on the island, probably during the excavations at the fortress. These finds indicate that there was an important church on Sai Island, presumably in the fortress, already during the 6th century AD.

This article, however, deals with architectural roof supports consisting of a particular type of monolithic granite columns. Their introduction in church architecture, mainly cathedrals, should be linked with a second phase of church construction in Nubia. Following Przemysław M. Gartkiewicz (1990), Godlewski $(1995 ; 2006)$ suggested that the architecture of this building phase depended on Nubian creativity initiated with the building of the Church of Granite Columns at Old Dongola. This church is probably the earliest of the Nubian churches with granite columns, and it became a model for the architectural renovation of the other cathedrals in Makuria. 


\section{Old Dongola}

Makuria was probably Christianized by missionaries coming from Constantinople, and a bishopric seems to have been established in the capital Old Dongola around AD 570 (Godlewski 2004: 210). The town cathedral was rebuilt three times, but it is the phase with new granite columns, 16 in all, from just before the end of the 7th century AD that is of concern here (Godlewski 2004: 210, Fig. 153). This church had the characteristic features of a basilica with a nave, double side aisles and a narthex, but it also had some distinctive features, first and foremost two aisles with apses added crossing the nave in the center (Gartkiewicz 1990: 218; Godlewski 2004: 211). Godlewski argued that the latter was a typical feature of church building in Old Dongola and that this architectural plan was later adopted by bishop Paulos in the reconstructed cathedral at Faras shortly after the turn of the 8th century AD (see below), although it seems not to have been implemented in the Cathedral of Qasr Ibrim (see Aldsworth 2010: Fig. 19).

The present summary of the Church of Granite Columns is based on a thorough examination by Przemysław M. Gartkiewicz. The roof supports of the church consisted of bases, shafts and capitals, carved of coarse-grained grey granite (Gartkiewicz 1990: 120). The execution of various elements varied significantly (Gartkiewicz 1990: 134), and this lack of uniformity seems to be characteristic of the columns in all the Nubian churches with granite roof

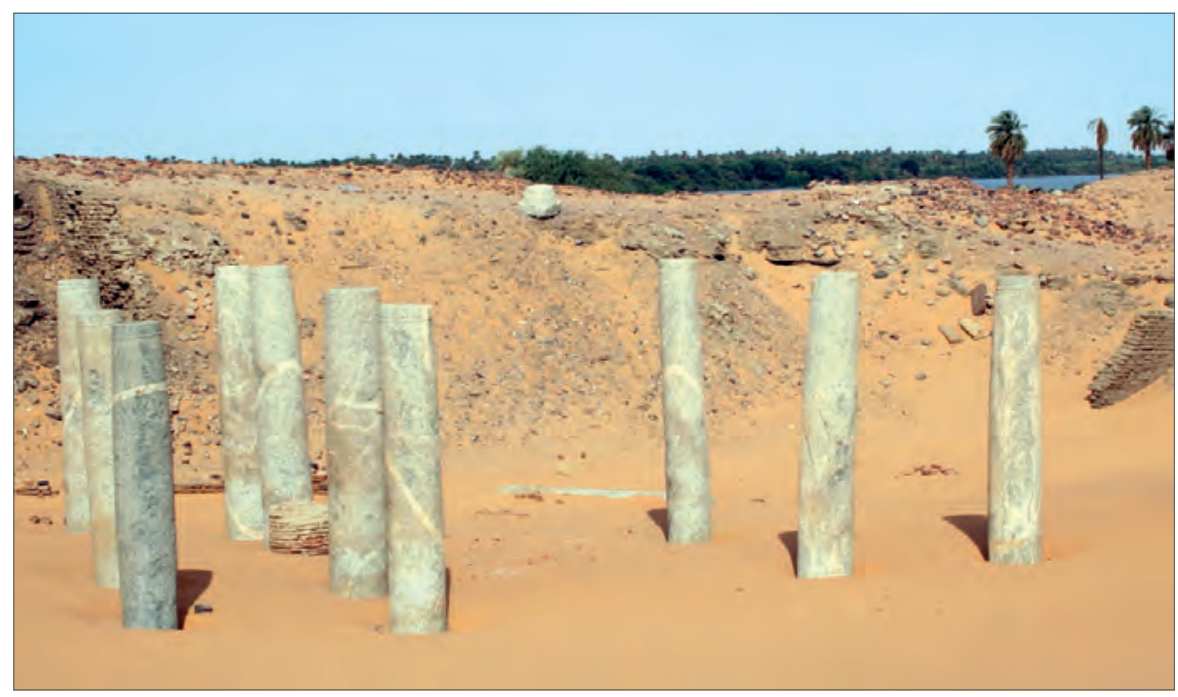

Fig. 3. Twelve column shafts standing in situ in the Church of Granite Columns at Old Dongola (Photo A. Tsakos) 
supports (Ryl-Preibisz 2001: 375). The abacus of the capitals and the plinths of the bases were supposed to have the same square outline and to be of similar sizes, but this was never adhered to at Old Dongola (Gartkiewicz 1990: 135).

Of the 16 columns in the church, 12 had bases still in situ and one of these was a reused capital (Gartkiewicz 1990: Fig. 62). The plinths of the bases were square, and the carcases had conical (without the pointed top), domed or cylindrical shapes, corresponding to three types of bases called I, II and III (Gartkiewicz 1990: 186187, Fig. 100). The height of the bases in the Church of Granite Columns varied significantly and ranged between $0.46 \mathrm{~m}$ and $1.05 \mathrm{~m}$ (Gartkiewicz 1990: 136).

Twelve shafts still stood in position on top of the undisturbed bases (Gartkiewicz 1990: 309) [Fig. 3], four shafts had fallen and were left close to their original positions (Gartkiewicz 1990: Fig. 188). The shaft lengths were between $3.95 \mathrm{~m}$ and $4.28 \mathrm{~m}$ (Gartkiewicz 1990: 137). The shafts had decorative bands or moldings at both the upper and lower ends (Gartkiewicz 1990: 185).

All of the capitals were toppled, presumably in an earthquake, together with the four fallen shafts (Gartkiewicz 1990: 315). All of the capitals were of a new type that was massive and structurally compact, furnished with a square, undecorated abacus panel and simplified volutes. The central motif on the sides of these capitals generally consisted of a cross. More than 20 variants of the motif were recorded and they were often dissimilar on different faces of the same capital (Ryl-Preibisz 1986: 381-382).

At the beginning of the 11th century $\mathrm{AD}$, the church was renovated again. During this stage 22 brick pillars were constructed inside the building, giving this phase its name: Church of the Brick Pillars (Gartkiewicz 1990: 264, 299). The Cathedral of Old Dongola was probably abandoned as a religious structure at the time of the Muslim conquest of Old Dongola in the latter half of the 13th century AD (Gartkiewicz 1990: 306).

\section{FARAS}

Faras, or Pachoras as it was called in medieval times, was the capital of the kingdom of Nobadia and subsequently the seat of the eparch of Nobadia. The most thorough presentation of the architecture of the various phases of the Cathedral of Faras is that by Godlewski (2006). He also made an interesting historical contextualization of the various building phases, which will be summarized here.

The violent expansion of the Sassanids into Egypt and their seizure of power there in AD 618 also affected Nobadia on Egypt's southern frontier (Godlewski 2004: 58; 2006: 33). Sassanid raids into Nobadia probably contributed to the weakening of the kingdom, allowing Makuria to incorporate it into its territory 
and to take control over its population and resources (Godlewski 2006: 33). Godlewski (2006: 30, 33) furthermore proposed that a bishopric see at Faras was established when Nobadia was incorporated into a uniform church system under the metropolitan of Old Dongola. According to a list of bishops of Pachoras recorded in the apse of the baptismal chapel of the cathedral (Jakobielski 1972: 190-195), the first bishop of Pachoras was probably a man by the name of Aetios. It has thus been suggested that he was the initial builder of the cathedral of Faras, which was raised on the ruins of a mud church from the middle of the 6th century AD, located on the central elevation of the fortified settlement at Faras (Grossmann 1971: 331-335; Török 1988: 69-73; Godlewski 2006: 31). This so-called Cathedral of Aetios seems to have been destroyed in the Sassanid raids before $\mathrm{AD} 620$, and the demolition necessitated the building of a new cathedral (Godlewski 2006: 33).

The reconstruction of the cathedral is of interest for the argument at hand. This building phase, which is conventionally dated to the beginning of the 8th century $\mathrm{AD}$, is associated with the fifth bishop of Pachoras, Paulos, on the grounds of two dedicatory inscriptions, one in Greek and one in Coptic, that are dated to AD 707 (Godlewski 2006: 71). Jacques van der Vliet has remarked that these inscriptions were located on a different building than the cathedral itself, although inside the enclosure of the holy precinct of the cathedral (van der Vliet 1999: 85). Moreover, he observed no reference in these inscriptions to actual building activities in the cathedral (van der Vliet 1999: 89). Van der Vliet has thus argued that these texts should not be taken as proof that the renovation of the Cathedral at Faras took place in AD 707 (van der Vliet 1999: 97). However, the granite capitals found in the Cathedral at Faras were dated independently to approximately the same period, i.e., the end of the 7 th and beginning of the 8 th century $\mathrm{AD}$, on the grounds of developments in architectural decoration (RylPreibisz 1986: 382). This indicates that substantial architectural changes were taking place in the cathedral as well, and the transversal nave of the new layout of the so-called Cathedral of Paulos was most probably introduced at this time (Godlewski 2006: 58).

The new central plan with longitudinal and vertical axes, as well as the granite columns, is construed as evidence that the inspiration for these changes derived from a new architectural model introduced by Nubian craftsmen in the building of the Church of Granite Columns at Old Dongola (e.g., Gartkiewicz 1980: 139; Ryl-Preibisz 1986: 382; Godlewski 1995: 236, 239; 2006: 45, 72). The granite columns from the Cathedral of Paulos consisted of 16 granite bases of which eight were still found in their original position inside the church and the other eight remained inside the church, but ex situ (Godlewski 2006: 153). 
Godlewski thus argued that the nave of the Cathedral of Paulos had 16 columns, similar to the Church of Granite Columns at Old Dongola (Godlewski 2006: 60, contra Gartkiewicz 1980: Fig. 7/a/3 who suggested only eight columns). Three shafts remained in place and two complete shafts were found lying on the pavement. Several dozen shaft fragments were also discovered (Godlewski 2006: 153). At least 12 large granite capitals were excavated inside the late cathedral (Godlewski 2006: 155-165), probably from these columns (Godlewski 2006: 153). The total reconstructed height of the columns was approximately $5 \mathrm{~m}$ (Godlewski 2006: 60). Like the columns at Old Dongola, elements of granite columns at Faras were not of homogenous shape and size (see the listed architectural elements in Godlewski 2006: 155-165).

Although the shapes and dimensions of several bases were left unrecorded in the haste of the salvage excavations, overall they appear to be of type I in Gartkiewicz's typology of bases, being furnished with a square plinth and conical carcase. Base height varied by at least $0.30 \mathrm{~m}$ (see the list in Godlewski 2006: 155-165). The complete shafts seem to have had moldings on both the upper and lower ends, like the shafts in the Church of Granite Columns (see above). The new granite capitals at Faras were clearly modeled on the capitals in the Church of Granite Columns in Old Dongola (Ryl-Preibisz 1971: 234; 1986: 382).

The Cathedral of Paulos was renovated and restructured in the latter half of the 10th century (Godlewski 2006: 116). The eight columns constituting the side aisles in Godlewski's reconstruction of the ground plan were removed, although their elements were preserved inside the building. The eight columns along the nave were incorporated into the brick pillars. The new internal arrangements were made to facilitate the construction of barrel vaults as roofing (Godlewski 2006: 93).

The cathedral was blocked with masonry and abandoned in the late 14th century (Godlewski 2006: 19-20).

\section{QASR IBRIM}

Qasr Ibrim had the most impressive location of the fortresses along the Nile, perched as it was on top of a sandstone hill about $80 \mathrm{~m}$ above the Nile (Adams 2009: 49). It now survives as an island in the reservoir behind the Aswan High Dam - the only preserved monumental site in Lower Nubia. In similarity to the foundation at Faras, the cathedral in Qasr Ibrim was built on the highest elevation of bedrock inside the fortifications (Adams 2009: 49). The building phase in question is the second one, dated to the beginning of the 8th century AD (see Aldsworth 2010: 136).

This building phase of the church originally had 12 pink granite columns with six columns on either side of the nave. Only the bases and a single standing shaft were 
uncovered in situ during excavations by the Egypt Exploration Society. The rows of bases formed a rectangular ground plan (Aldsworth 2010: 57, Fig. 19), emphasizing by this arrangement the axiality of traditional early Christian church building. The ground plan of the Cathedral at Qasr Ibrim thus diverged from the new church structure on a cruciform plan developed at Old Dongola, but the granite columns were carved in the same Makurian style as the Church of Granite Columns at Old Dongola and the Cathedral of Paulos at Faras.

The bases seem to have been of type I with a square plinth and conical carcase (see Aldsworth 2010: 70, 98). The shafts were about $4 \mathrm{~m}$ high (Aldsworth 2010: 95) and were decorated with a cross motif about a meter below the top (Aldsworth 2010: 96). This decorative element did not appear on the shafts of columns from the cathedrals at Old Dongola and Faras. The discovery of 12 shaft fragments with top moldings and 12 fragments with end moldings suggests that 12 similarly decorated shafts were placed on the bases of the nave (Aldsworth 2010: 96). However, there were only three granite capitals inside the cathedral. One of them was of the massive type with volutes and central cross motif that was characteristic of Old Dongola and Faras (Aldsworth 2010: 92, Pls 162-163); the other two capitals were of a type with interlaced decoration that is not found in churches further to the south.

The Cathedral at Qasr Ibrim was later modified, but this did not constitute a single remodeling of the church like at Old Dongola and Faras (Aldsworth 2010: 142). It was probably abandoned in the 1480s (Aldsworth 2010: 145).

\section{GanATI}

At the modern village of Ganati, ${ }^{2}$ about $65 \mathrm{~km}$ south of Old Dongola, a collapsed church with granite columns was partly excavated and the columns re-erected by Sudanese archaeologists in 2014 and 2015 (Bashir 2014: 158, 160; Bakhiet 2015: 150). The site has been known since the early 20th century (Crowfoot 1905: 315; Budge 1907: 301), and Somers Clarke (1912) made the first detailed description of the ruin after a visit in 1910. Clarke must have cleared the surface of the site, because he published a plan of seven bases in position (Clarke, 1912: Pl. 4/2). Recent clearance of the site revealed an eighth base, producing a plan with two parallel east-west oriented rows of three columns each, and two more columns placed at equal distance from both sides of the central pair of columns (Bakhiet 2015: Fig. 2) [Fig. 4]. ${ }^{3}$

The columns at Ganati were made of grey granite, similarly as those at Old Dongola and Faras. The eight bases seem to be in situ. All appear to

2 Alternative writings of the name: Gimeti (Crowfoot 1905; Budge 1907), Ginetti (Clarke 1912) and Ganetti (Sudan National Museum archive).

3 As far as the authors could establish, no other church in Nubia appears to have a similar distribution of the columns as the one at Ganati. 
be of type I with a square plinth and conical carcase (Bakhiet 2015: Pl. 7). Seven shafts were found fallen from the bases (Bakhiet 2015: Table 1). They had both top and end moldings and were between $2.30 \mathrm{~m}$ and $2.60 \mathrm{~m}$ high (Bakhiet 2015: Pl. 7 and Table 1), making them significantly shorter than the shafts of the cathedrals described above. In contrast, the diameters of the shafts were greater than at the other sites, that is, between $0.50 \mathrm{~m}$ and $0.90 \mathrm{~m}$ (Bakhiet 2015: 149). The columns at Ganati thus appear shorter and stouter than the columns of the cathedrals described above.

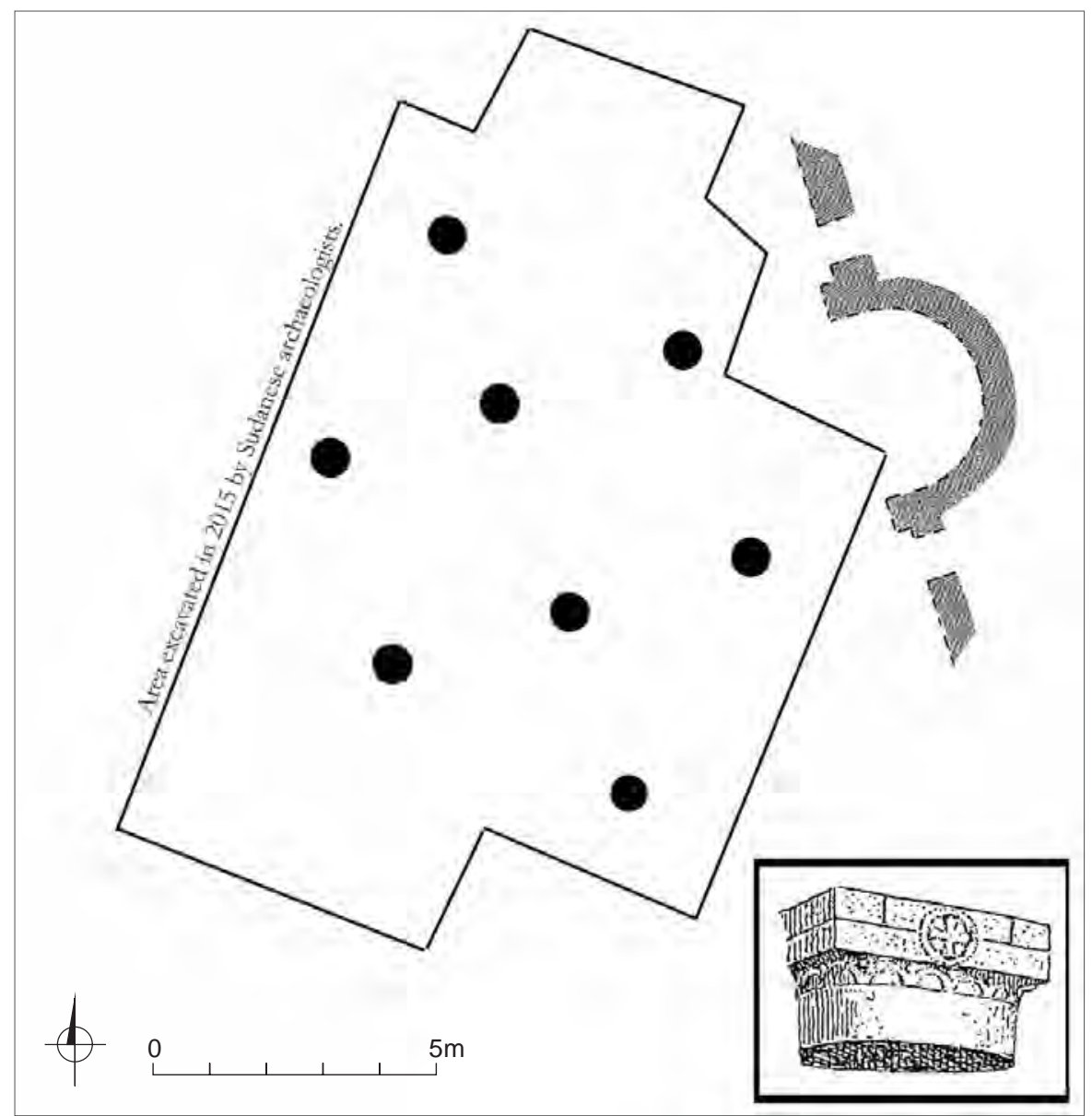

Fig. 4. Plan of the layout of the column bases at Ganati: the southern base excavated in 2015, the apse and east wall conjectural; lower right corner, one of the capitals from Ganati (Modified plan after Clarke 1912: Pl. 4/2 and Bakhiet 2015: Fig. 2; drawing of capital after Clarke 1912: Fig. 8) 
The six capitals uncovered at Ganati were of a more simplified style than the capitals at the cathedrals. The square abacus was exceptionally thick with a central cross motif in the middle of each face (Clarke 1912: 42-43). The cylindrical parts of the capitals were without volutes, rather short and with a curved decoration just below the abacus (see the drawing of a capital in Fig. 4). One of the capitals was reduced to a square panel with a central-cross motif (Bakhiet 2015: Pls 2 and 8). It is unique, being carved as one with the shaft (Clarke 1912: 42). It was still standing when Clarke visited Ganati in 1912, but has been toppled since, like the other shafts and capitals.

Ganati yielded also two epigraphic finds: a fragment of terracotta funerary stela in Greek and a fragment of marble stela (Tsakos 2009: 205 and 208). The stela in Greek places Ganati among the sites that followed this language tradition for terracotta funerary stelae, a practice found exclusively in Makuria (Tsakos 2010: 690-692). The marble stela is a rare find: only 68 inscriptions carved on marble objects have been found in Nubia so far (although four are of unknown provenance) and all but eight of them are funerary in character [Table 1].

Nine of the funerary stelae commemorated bishops, while another eleven were made for individuals holding both secular and ecclesiastic offices. ${ }^{4}$ The marble stelae come from 19 different sites in Nubia, and more than half of these come from the Dongola Reach between the Third and the Fourth Cataracts [highlighted with grey in Table 1]. The use of marble as a writing surface for an inscription seems to place Ganati among the centers of authority for both the Makurian church and state.

The granite columns of the church at Ganati were of smaller scale and the capitals were less elaborate than the columns of the cathedrals mentioned above, but the building would still have been distinct from the ordinary mudbrick churches in other villages of medieval Nubia. Current research makes it reasonable to assume that the church at Ganati was built in the same tradition as the cathedrals with granite columns, which appear to have been state-run construction projects and, apart from the neighborhood of Old Dongola, were apparently located in episcopal sees (for possible granite column elements at other sites in the upper Dongola Reach, see Żurawski 2002). Some of the sites recorded in the written sources as bishoprics of medieval Nubia

4 It is perhaps worth noting that four of the stelae were written in Arabic: three funerary stelae from Derr were made for people with Arabic names and genealogies dating to the 11th and 12 th centuries, while the fourth marble stela with an Arabic inscription is the so-called conversion stela from the Throne Hall at Old Dongola, dating to AD 1317. 
remain unidentified. Following a revisiting of the list of Nubian bishoprics by Seignobos (2015), Ganati is now suggested a candidate for one of these bishoprics.

Table 1. Marble stelae found in Nubia from north to south; those from the Dongola Reach marked in grey (Source: online Database of Medieval Nubian Texts created by Grzegorz Ochata)

\begin{tabular}{|c|c|c|c|c|}
\hline $\begin{array}{l}\text { Location } \\
\text { from } N \text { to } S\end{array}$ & $\begin{array}{l}\text { Total } \\
\text { number of } \\
\text { marble stelae }\end{array}$ & $\begin{array}{l}\text { Funerary } \\
\text { stelae }\end{array}$ & $\begin{array}{l}\text { For } \\
\text { bishops }\end{array}$ & $\begin{array}{l}\text { For other secular } \\
\text { and ecclesiastic } \\
\text { offices }\end{array}$ \\
\hline Kalabsha & 1 & 1 & & 1 \\
\hline Derr (see note 4) & 3 & 3 & & \\
\hline Qasr Ibrim & 2 & 2 & & \\
\hline Gindinarri & 1 & 1 & & \\
\hline Faras & 10 & 8 & 6 & \\
\hline Ukma & 1 & & & \\
\hline Sai Island & 3 & 2 & 2 & \\
\hline El Khandaq & 1 & 1 & & \\
\hline Nawi & 1 & 1 & & \\
\hline Khalewa & 1 & 1 & & \\
\hline Sheikh Arab Hag & 1 & 1 & & 1 \\
\hline Hambukol & 1 & 1 & & \\
\hline Old Dongola & 28 & 26 & 1 & 6 \\
\hline Banganarti & 2 & 2 & & 1 \\
\hline Tangasi Island & 1 & 1 & & \\
\hline Ganati & 1 & 1 & & \\
\hline Debeiba & 1 & 1 & & \\
\hline El Koro & 1 & 1 & & 1 \\
\hline Soba & 4 & 2 & & 1 \\
\hline Unprovenanced & 4 & 4 & & \\
\hline Total & 68 & 60 & 9 & 11 \\
\hline
\end{tabular}




\section{The Medieval Sai Project}

Sai is one of the largest islands on the Nile, and it is located midway between the Second and Third Cataracts. The Sai Island Archaeological Mission of the University Charles-de-Gaulle-Lille 3 in France has held an archaeological concession for the island since 1969. Forty years later, the Medieval Sai Project was established as the first systematic investigation of the remains from the medieval period on the island.

A site in an old river channel in the northern part of the island has been proposed as the location of the cathedral of Sai. This identification was based on the existence of four granite shafts and their capitals located about $1250 \mathrm{~m}$ northwest of Qalat Sai, the island's fortress since the Bronze Age (Vercoutter 1970: 159). Several external written sources from the Middle Ages mention a bishopric on Sai Island (Monneret de Villard 1938: 162; see also Seignobos 2015: 226-227). Furthermore, nine inscribed funerary epitaphs in stone referring to bishops, five of them named, have been uncovered on the island, six of these were found in the fortress (Tsakos 2012: Table 1). There are also several other texts from Nubia testifying to the presence of an episcopal see on Sai (Łajtar 2006), but little attention was focused on the purported architectural remains until the two field seasons, in the winters of 2009 and 2010, of the Medieval Sai Project carried out by the authors. ${ }^{5}$

The site has been code-named 8-B-500 (Hafsaas-Tsakos and Tsakos 2009: 79), taking advantage of the archaeological map of Sudan (Hinkel 1979).

\section{Site 8-B-500 with granite columns on Sai Island}

The site considered to be the cathedral of Sai consists of four grey granite shafts with capitals standing to a height of more than $3 \mathrm{~m}$ above the present surface of a low mound.

Three of the column shafts still stand straight with capitals in place, the fourth is tilted and the capital lies some meters away [Fig. 5]. Based on parallels

5 Field excavation reports have been presented in Beiträge zur Sudanforschung (Hafsaas-Tsakos and Tsakos 2009; 2012) and a short note in the proceedings of the 12th International Conference of Nubian Studies (Tsakos and Hafsaas-Tsakos 2014). The medieval funerary inscriptions from Sai Island have been edited and published (Tsakos 2012). The authors have also made several public presentations of their project, and they have been writing a blog entitled Medieval Sai Project since 2009 (http://medievalSaiproject.wordpress.com). 
with Faras and Qasr Ibrim, the total height of the shafts can be set between $3.40 \mathrm{~m}$ and $4 \mathrm{~m}$ (see Godlewski 2006: 60 and Aldsworth 2010: 95 respectively), and they are certainly taller than those at Ganati. The fact that three of the shafts are still standing, and even the tilted one is imbedded, indicates that the

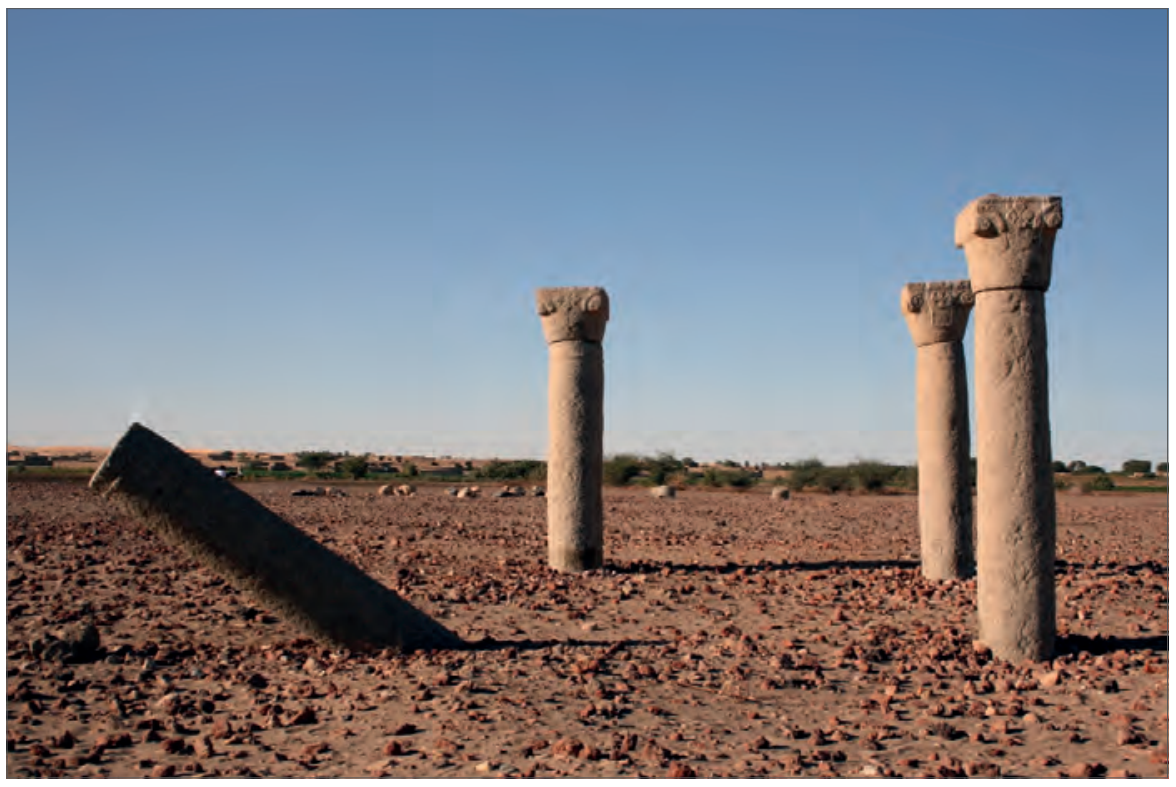

Fig. 5. Granite columns standing on site 8-B-500 (Photo H. Hafsaas-Tsakos)

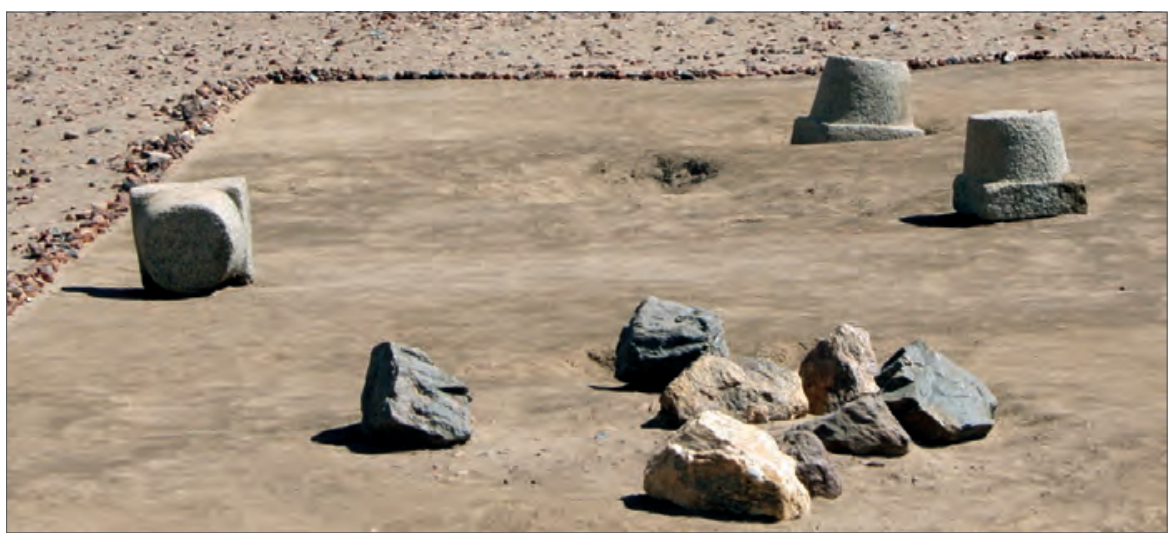

Fig. 6. Granite bases on site 8-B-500 after excavations in 2010 (Photo H. Hafsaas-Tsakos) 
shafts are inserted deep into the ground. These observations may support the suggestion of a total length of a column exceeding $4 \mathrm{~m}$. Just below the top of the shafts is a molding consisting of a simple band; similar moldings on the shafts are known from Old Dongola (Gartkiewicz 1990: 185), Faras (see Godlewski 2006: Fig. 148), Qasr Ibrim (Aldsworth 2010: 96) and Ganati (Bakhiet 2015: observed in Pls 4, 5 and 7).

The surface around the columns is littered with fragments of red bricks, sandstone, plaster and potsherds. The concentration of red bricks is densest in the area surrounding the columns. A survey of the surface also revealed fragments of terracotta window grilles and sepulchral crosses. Jean Vercoutter also collected a fragment of a terracotta funerary stela from the vicinity of the columns (Tsakos 2012: 309).

Three column bases lay $50 \mathrm{~m}$ to the north, on the surface, in the northern part of the central mound of site 8-B-500. Excavations in 2010 showed the bases to be out of context and not part of any building at this location [Fig. 6]. The bases are of the same kind of granite as the columns and their respective diameters match. A similar base was located inside the fortress of Sai. All four bases are of type I in Gartkiewicz's classification, characterized by a rectangular plinth with conical carcase (Gartkiewicz 1990: 186-187).

The capitals preserved in place on the top of the column shafts, a singular case in Nubia (Gartkiewicz 1990: 142), conform to the "massive structurally compact" type in Ida Ryl-Preibisz's typology of capitals from Old Dongola (Ryl-Preibisz 2001: 368, Fig. 1/c/1-2). The type is characterized by an undecorated square abacus panel. The decoration of the overhanging corners
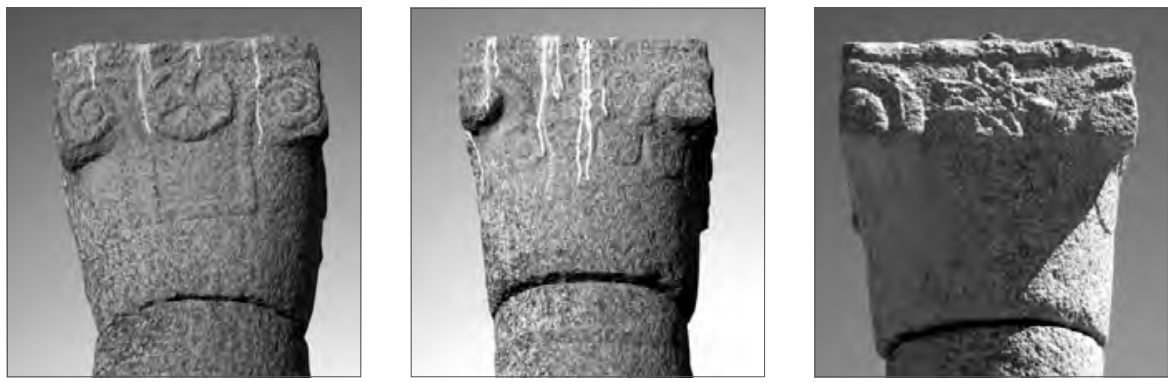

Fig. 7. Granite capitals from site 8-B-500: left, capital from the northeastern column, eastern face, style typical of that in the Church of Granite Columns at Old Dongola; center, capital from the southeastern column, eastern face with characteristic wreath of half-circles pending from the square upper part; right, capital from the southeastern column, western face, showing the unique equal-armed cross with v-shaped indentation of the arms (Photos H. Hafsaas-Tsakos) 
usually consists of rather flat volutes adapted to the shape of the block. The central elements consist of various cross motifs (Ryl-Preibisz 2001: 374-375, Fig. 8). Capitals of this kind first appeared in the Church of Granite Columns in Old Dongola (Gartkiewicz 1990: 197; Ryl-Preibisz 2001: 374), and they date from the late 7 th and early 8th century AD (Ryl-Preibisz 2001: 375). At Sai, the northeastern capital and the fallen southwestern capital were decorated in this style. On both of these capitals, the volutes were connected by a ribbon forming a rectangular frame around the central motif. A cross with flaring arms was carved in raised relief inside a circle on all four sides [Fig. 7 left]. Similar granite capitals have been found in the Church of Granite Columns at Old Dongola (e.g., Ryl-Preibisz 1971: Pls 1-4), in the Paulos cathedral at Faras (e.g., Godlewski 2006: Fig. 151), as well as a single specimen in the Cathedral of Qasr Ibrim (Aldsworth 2010: 92, Figs 162-163).

The northwestern and southeastern capitals at Sai are of a less typical style. They are of the massive type, but the decoration of the overhanging corners consists of broad concentric half-circles (see Gartkiewicz 1990: 195), which most

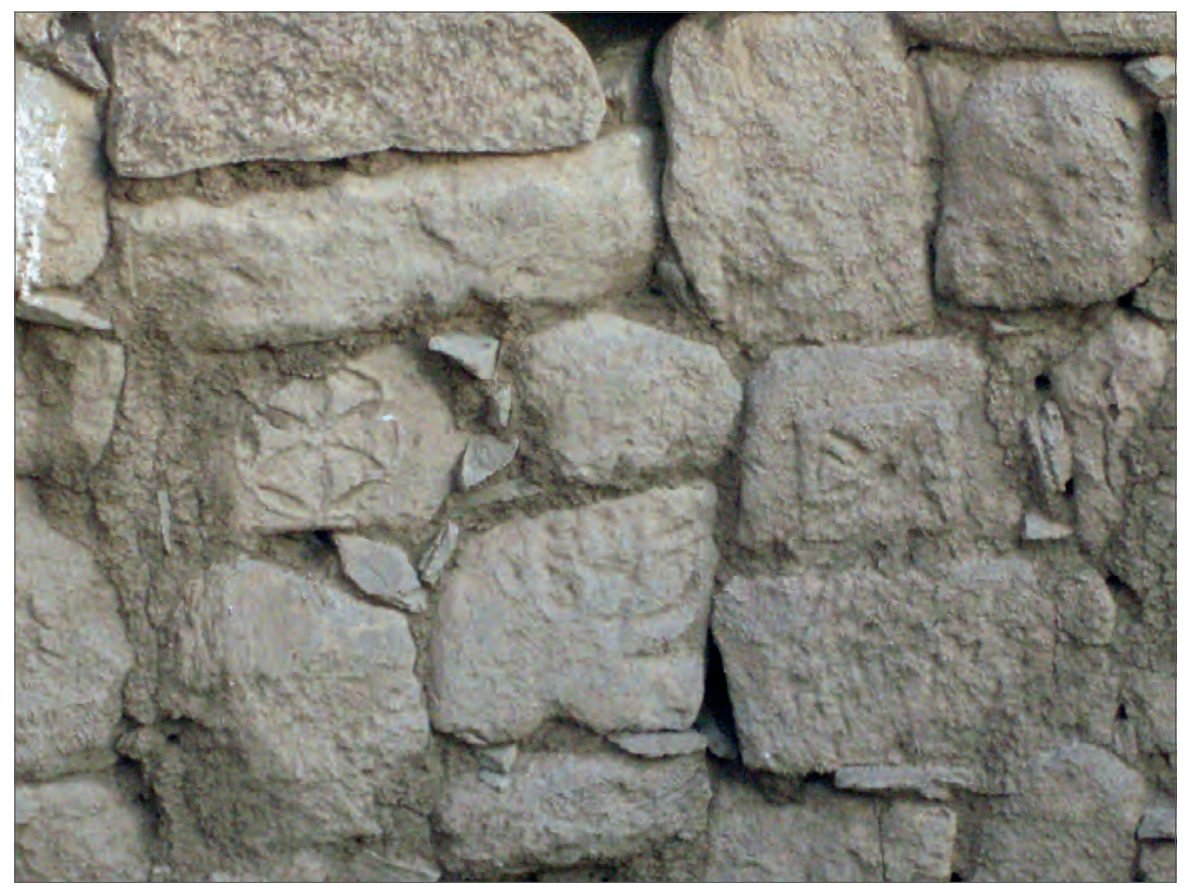

Fig. 8. Sandstone blocks with Christian decoration probably from a church and reused in the walls of a saqiyah well at site 8-B-500

(Photo H. Hafsaas-Tsakos) 
likely represented highly stylized volutes. Similar corner decorations also occurred on a few capitals from Old Dongola and Faras (see Gartkiewicz 1990: Figs 106 and 109). On the cylindrical part of these capitals from Sai, there is an apparently unique wreath of half-circles pending from the square upper part [Fig. 7 center].

The central motif is different on three of four faces of the northwestern capital. The western face has an intriguing equal-armed cross with v-shaped indentation of the arms, and this symbol is also known under the term eightpointed star or rose [Fig. 7 right]. This cross-shape appears only on one capital from Faras (see Ryl-Preibisz 1971: Pl. XI/18b) and a voussoir stone from Qasr Ibrim (see Aldsworth 2010: Pl. 188, Fig. 40). ${ }^{6}$ The southeastern capital has the eight-pointed cross on two faces. The other faces of these capitals have more typical crosses as central motifs.

The variations in the decoration of the capitals are hardly unique as it was common in medieval Nubia for the massive structurally compact capitals to have different central motifs on the four faces, just as it was common for the capitals of one set to be slightly different from one another (Ryl-Preibisz 2001: 375).

South of the columns is a post-medieval saqiyah well, which is at least $6 \mathrm{~m}$ deep. The walls of the well are lined with sandstone blocks that in all probability originated from the cathedral. Several of the blocks exhibit decorative carvings such as crosses and rosettes [Fig. 8].

To the east of the column bases there is a medieval Christian cemetery. Three graves were discovered there by local farmers during the decade preceding the present project. The grave pits were oriented E-W and lined with mud brick. One of them had been opened enough to reveal a vaulted chamber (Hafsaas-Tsakos and Tsakos 2009: 79). A fourth grave was plundered in 2012. It revealed a barrel-vaulted mud-brick substructure. The bones thrown out of the grave belonged to at least two individuals. The skin was well-preserved and suggested a date late in the medieval era. Textile fragments decorated with colored thread were found in the debris (HafsaasTsakos and Tsakos 2012: 89-90).

Stray finds of terracotta funerary stelae, a total of 39 fragments to date, testify to more Christian graves being present on the island (Tsakos 2012; Hafsaas-Tsakos and Tsakos 2012: 90). An Islamic grave discovered in 2010 while excavating around the bases (Hafsaas-Tsakos and Tsakos 2012: 80-81) is proof of continued religious practices on the site even after the religious shift from Christianity to Islam.

6 This cross-shape also appears on surfaces other than architectural elements. A separate study is under preparation by the authors. 


\section{Concluding remarks}

The presentation of the granite column elements from medieval Sai and comparison with similar finds from the other cathedrals of Christian Nubia have verified Godlewski's theory that the Cathedral of Sai, as identified archaeologically by the four granite shafts with capitals and the four ex situ granite bases, was constructed after the model of the Church of Granite Columns at Old Dongola, just as the cathedrals of Faras, Qasr Ibrim, and, albeit on a smaller and simpler scale, the possible cathedral at Ganati.

Consequently, it becomes legitimate to speculate that the cathedral on Sai went through a number of building phases, just like the cathedrals at Old Dongola, Faras and Qasr Ibrim (see also Gartkiewicz 1980: 139). We have already proposed the fortress of Sai as the original location of the Cathedral of Sai (see above), and we will briefly elaborate on this working hypothesis here. The most important church on Sai appears to have started as an early cathedral with architectural elements in sandstone probably located in the fortress [see Fig. 2]. A Makurian-style cathedral with four to eight columns was subsequently located in the early 8th century AD either in the fortress or at site 8-B-500. Finally, a late cathedral was constructed at site 8-B-500, where four granite columns were reused in a church with a central cross-shaped plan, covered by a central dome and barrel vaults over the crossing aisles [see Fig. 3]. Only further excavations will be able to test this working hypothesis based on an examination of the granite columns.

The analysis of elements of granite columns from Sai Island presented here can be used to investigate further the relations of size and ranking within the frame of the hierarchy of the bishoprics of Christian Nubia. Assuming the Sai foundation of the early 8th century had only the four columns and four bases discovered at site 8-B-500, it would have been probably one of the smallest cathedrals of Christian Nubia. This sounds unlikely given the prominence of Sai in the medieval period, so the possibility of more granite column members being preserved underground on Sai will not be excluded. The standing shafts on site 8-B-500 may well be balancing on bases that are still buried in the sand. Together with the four ex situ granite bases, it could raise the number of granite columns in the original Sai cathedral of this phase to a total of eight. It would still make the cathedral on Sai the smallest of the securely identified Makurian cathedrals with granite columns. At the same time, Sai would place fourth in size among the cathedrals in Makuria and thus emphasize the importance of further investigations on site 8-B-500 and Sai Island. 


\section{References}

\section{ONLINE RESOURCES}

Database of Medieval Nubian Texts: http://www.dbmnt.uw.edu.pl/ (C) Grzegorz Ochała

Medieval Sai blog: https://medievalSaiproject.wordpress.com

Adams, W.Y. (1977). Nubia: Corridor to Africa. Princeton, NJ: Princeton University Press

Adams, W.Y. (2009). The churches of Nobadia [=Sudan Archaeological Research Society Publications 17; British Archaeological Reports International Series 2000]. Oxford: Archaeopress

Aldsworth, F. (2010). Qasr Ibrim: The Cathedral Church [=Excavation Memoir 97]. London: Egypt Exploration Society

Bakhiet, F.H. (2015). QSAP Dam-Debba Archaeological Survey Project (DDASP). Preliminary results of the second season. Sudan \& Nubia, 19, 149-160

Bashir, M.S. (2014). QSAP Dam-Debba Archaeological Survey Project (DDASP). Preliminary report on the NCAM mission's first season, 2013-2014. Sudan \& Nubia, 18, 156-164

Budge, E.A.W. (1907). The Egyptian Sûdân: Its history and monuments. London: K. Paul, Trench, Trübner \& Co.

Clarke, S. (1912). Christian antiquities in the Nile Valley. A contribution towards the study of the ancient churches. Oxford: Clarendon Press

Crawford, O.G.S. (1951). The Fung kingdom of Sennar, with a geographical account of the Middle Nile region. Gloucester: J. Bellows

Crowfoot, J.W. (1927). Five Greek inscriptions from Nubia, Journal of Egyptian Archaeology, $13 / 3-4,226-231$.

Edwards, D.N. (2004). The Nubian past: An archaeology of the Sudan. London: Routledge

Gartkiewicz, P.M. (1980). New outline of the history of Nubian church architecture. Bulletin Antieke Beschaving, 55(1), 137-160

Gartkiewicz, P.M. (1990). The Cathedral in Old Dongola and its antecedents [=Nubia 1; Dongola 2]. Warsaw: Państwowe Wydawnictwo Naukowe

Godlewski, W. (1995). The Paulos Cathedral in Faras (Pachoras) and the question of Byzantine influence. In C.F. Moss and K. Kiefer (eds), Byzantine East, Latin West: Arthistorical studies in honor of Kurt Weitzmann (pp. 235-243). Princeton, NJ: Department of Art and Archaeology, Princeton University

Godlewski, W. (1998). The role of Dongolese milieu in the Nubian church architecture. In M. Krause and S. Schaten (eds), Themelia: spätantike und koptologische Studien. Peter Grossmann zum 65. Geburtstag [=Sprachen und Kulturen des christlichen Orients 3] (pp. 127-142). Wiesbaden: Reichert Verlag

Godlewski, W. (2004). The rise of Makuria (late 5th-8th cent.). In T. Kendall (ed.), Nubian studies, 1998: Proceedings of the ninth conference of the International Society of Nubian Studies, August 21-26, 1998, Boston, Massachusetts (pp. 52-73). Boston: Department of African-American Studies, Northeastern University 
Godlewski, W. (2006). Pachoras: The cathedrals of Aetios, Paulos and Petros. The architecture [=PAM Supplement Series 1]. Warsaw: Warsaw University Press

Grossmann, P. (1971). Zur Datierung der frühen Kirchenanlagen aus Faras. Byzantinische Zeitschrift, 64(2), 330-350

Hafsaas-Tsakos, H. and Tsakos, A. (2009). First glimpses into the medieval period on Sai Island. Beiträge zur Sudanforschung, 10, 77-85

Hafsaas-Tsakos, H. and Tsakos, A. (2012). A second look into the medieval period on Sai Island. Beiträge zur Sudanforschung, 11, 75-92

Hinkel, F.W. (1979). The archaeological map of the Sudan. Berlin: Akademie Verlag

Jakobielski, S. (1972). A history of the Bishopric of Pachoras on the basis of Coptic inscriptions [=Faras 3]. Warsaw: Éditions scientifiques de Pologne

Łajtar, A. (2006). Christian Saï in written records (inscriptions and manuscripts). Journal of Juristic Papyrology, 36, 91-104

Monneret de Villard, U. (1938). Storia della Nubia cristiana [=Orientalia Christiana analecta 118]. Rome: Pontificium Institutum Orientalium Studiorum

Ryl-Preibisz, I. (1971). Chapiteaux en granit de Nubie. Études et Travaux, 5, 209241

Ryl-Preibisz, I. (1986). On the type of capitals in Christian Nubia. In M. Krause (ed.), Nubische Studien: Tagungsakten der 5. Internationalen Konferenz der International Society for Nubian Studies, Heidelberg, 22.-25. September 1982 (pp. 379-384). Mainz am Rhein: Philipp von Zabern

Ryl-Preibisz, I. (2001). Elements of architectural decoration from Old Dongola. In S. Jakobielski and P.O. Scholz (eds), Dongola-Studien: 35 Jahre polnischer Forschungen im Zentrum des makuritischen Reiches [=Bibliotheca Nubica et Aethiopica 7] (pp. 367-387). Warsaw: ZAŚ PAN

Seignobos, R. (2015). Les évêchés nubiens: nouveaux témoignages. La source de la liste de Vansleb et deux autres textes méconnus. In A. Łajtar, G. Ochała, and J. van der Vliet (eds), Nubian voices II. New texts and studies on Christian Nubian culture [=Journal of Juristic Papyrology Supplement 27] (pp. 151-230). Warsaw: Raphael Taubenschlag Foundation

Török, L. (1988). Late antique Nubia: History and archaeology of the southern neighbor of Egypt in the 4th-6th c. A.D. [=Antaeus 16]. Budapest: Archaeological Institute of the Hungarian Academy of Sciences

Tsakos, A. (2010). Terracotta funerary stelae from Christian Nubia. In W. Godlewski and A. Łajtar (eds), Between the cataracts: Proceedings of the 11th Conference for Nubian studies, Warsaw University, 27 August-2 September 2006, II.2. Session papers [=PAM Supplement Series 2.2/2] (pp. 683-694). Warsaw: Warsaw University Press

Tsakos, A. (2012). Medieval funerary inscriptions from Saï Island. In F. Doyen and D. Devauchelle (eds), Fouilles sur l'île de Sä̈, Soudan: 2005-2010 (pp. 297-330). Lille: Université Charles de Gaulle-Lille 3 
Tsakos, A. and Hafsaas-Tsakos, H. (2014). A note on the medieval period of Sai Island, Sudan. In J.R. Anderson and D.A. Welsby (eds), The Fourth Cataract and beyond: Proceedings of the 12th International Conference for Nubian Studies [=British Museum Publications on Egypt and Sudan 1] (pp. 985-987). Leuven: Peeters

van der Vliet, J. (1999). The Church of the Twelve Apostles: The earliest cathedral of Faras? Orientalia, 68(1), 84-97

Vercoutter, J. (1970). Les trouvailles chrétiennes françaises à Aksha, Mirgissa et Saï. In E. Dinkler (ed.), Kunst und Geschichte Nubiens in christlicher Zeit: Ergebnisse und Probleme auf Grund der jüngsten Ausgrabungen (pp. 155-162). Recklinghausen: A. Bongers

Welsby, D.A. (2002). The medieval kingdoms of Nubia: Pagans, Christians and Muslims along the Middle Nile. London: British Museum Press

Werner, R. (2013). Das Christentum in Nubien: Geschichte und Gestalt einer afrikanischen Kirche [=Studien zur orientalischen Kirchengeschichte 48]. Berlin: Lit

Żurawski, B. (2002). Survey and excavations between Old Dongola and Ez-Zuma. Sudan \& Nubia, 6, 73-85

Żurawski, B. (2007). Where the water is crying. Survey and excavations in Shemkhiya, Dar el-Arab (Suegi el-Gharb) and Saffi Island carried out by the Polish Joint Expedition to the 4th Cataract in the winter of 2004/2005. Preliminary report. In C. Näser and M. Lange (eds), Proceedings of the Second International Conference on the Archaeology of the Fourth Nile Cataract, Berlin, August 4th-6th, 2005 [=Meroitica 23] (pp. 179-205). Wiesbaden: Harrassowitz 


\title{
Monks and bishops in Old Dongola, and what their costumes can tell us
}

\author{
Karel C. Innemée \\ Leiden University \\ k.c.innemee@arch.leidenuniv.nl
}

\author{
Keywords \\ religious costume, mural painting, Dongola
}

\begin{abstract}
In past years numerous wall-paintings have come to light in annexes of the monastery of Dongola and in other buildings in and around the citadel. Some of these paintings represent ecclesiastical dignitaries and the costumes in which they are depicted can give us information about their status, the development of religious dress in Makuria, but also about the intertwinement of the episcopal and monastic hierarchies.
\end{abstract}

A person, wherever and whenever, appears in clothes, a costume or a uniform that tells something about his or her place in society. Nubia was no exception to this. a considerable number of paintings from Nubian churches represent saints or church dignitaries in ecclesiastical costumes. The cathedral at Faras, so far the most important source when it comes to our knowledge of Christian painting in Makuria, has yielded the largest number of such representations. Here, an important series of portraits ${ }^{1}$ of bishops was found, painted during the lifetime (Jakobielski 1982: 125). Apart from that we find representations of saints in liturgical dress, not only in Faras, but in churches all over Makuria. In the past 20 years, a great number of paintings have come to light during the Polish excavations in Old Dongola and also here a number of personages in liturgical dress occur.

1 The term 'portrait' is used here to distinguish between representations of church dignitaries, donors and other living or possibly just deceased individuals on one hand and representations of saints on the other hand. No implication concerning the realism of the paintings is meant. 
We have a general idea of the liturgical costumes that were worn in the Makurian Church and of the way that saints in priestly or episcopal dress were depicted (Innemée 1992), but many questions remain to be answered. Concerning Nubian monastic dress, for instance, very little is known so far. The discoveries of paintings in Dongola can help us fit small pieces into the puzzle and the aim of this article is to take a closer look at these paintings in order to see what they can tell us about the development of liturgical and monastic costumes in Makuria and the people who wore them.

\section{The monastery complex on Kom $\mathrm{H}$}

Excavation since 1990 has uncovered a monastery complex on Kom H, just outside the town. On the western side of this monastery two structures were added that are known as the Northwest Annex and the Southwest Annex. The original function of these additions seems difficult to establish and especially the architectural development of the Northwest Annex is a gradual process of additions and modifications. The original basic elements according to Godlewski are a keep (Building I) to the north and Building II/III to the south (Godlewski 2013: 85). The latter would have been a church in its final shape (Zielińska 2010), founded by Georgios, who became bishop of Dongola in AD 1063 (Jakobielski 1997: 163166; Łajtar 2002: 191). In the dedicatory inscription in room 29 he is still called archpriest and archistylites, ${ }^{2}$ which would date the church to the period before 1062 (Łajtar 2002: 184-185). In the course of time Buildings I and II/III were connected by a chapel dedicated to the Archangel Michael in between, while to the west of Building I a memorial chapel was established for bishop Georgios. $\mathrm{He}$ was buried in a crypt under this chapel in 1113 (Jakobielski 1994: 109-114; 2001: 164-166), where apparently an earlier burial had already taken place (Godlewski 2013: 87). The Northwest Annex gradually became a commemorative building for other people as well, comprising two chapels. Although the exact identity of these other persons is unknown, they must have been people of prominent position, most likely bishops of Dongola (Godlewski 2013: 87).

In the 10th or 11th century, a building was added to the outside of the southern part of the western perimeter wall, the so-called Southwest Annex. Also this building was elaborately decorated with mural paintings, but little can be said so far about the function of the building.

2 An archistylites was a person responsible for the spiritual life of the monks (Łajtar 2002: 176). 


\section{i.i. Paintings in the Northwest Annex}

The paintings in the Northwest Annex are as diverse in style and iconography as the composite architecture in which they appeared. ${ }^{3}$ Some paintings must have been executed specifically to underline the liturgical function of certain parts of the building, such as the Nativity on the east wall of room $22 .{ }^{4}$ In other cases paintings may have been executed as commissions by private individuals with a commemorative purpose in mind in the first place. ${ }^{5}$ The Northwest Annex is not a building that fits in a particular type of architecture and since it was conceived and modified as an extension of the monastery, it looks as if it was not freely accessible to the general public; the tombs and commemorative paintings must have been connected with the religious elite.

\subsubsection{Representations of Archbishop Georgios}

One bishop of Dongola whose life is relatively well known is Georgios. ${ }^{6}$ From his tombstone we know something of his impressive career, namely that he was archistylites of the monastery of the Holy Trinity, archimandrite of the monastery of St Anthony, and archipresbyteros, before becoming bishop and (possibly later, as a personal title of honour) archbishop of Dongola.

His funerary chapel takes a central place in the Northwest Annex, and here (room 5) he was represented under the protection of the Holy Trinity. Unfortunately little has been preserved of his representation, merely fragments of the face and a part of what seems to be a decorated vestment [Fig. 1]. Małgorzata MartensCzarnecka, in her catalogue of wall paintings from the monastery, interprets this fragment as a sleeve with a cuff and a hand that holds a book (Martens-Czarnecka 2011: 267, Cat. 21, MMC-021-02).7 This detail needs renewed analysis, since the yellow-red pattern of lozenges with inscribed crosses is typical not of book covers, but rather of luxurious fabrics. The scapular of the bishop (St Epiphanios?) in the Southwest Annex (Martens-Czarnecka 2011: Cat. 101) bears a similar pattern. Furthermore, judging from the position of the thumb, it must be the right hand of the bishop and books were always held in the left hand.

On the function of different rooms in the monastery, see Martens-Czarnecka 1998.

4 Martens-Czarnecka 2011: 135-137, for the Nativity in a liturgical context, see Innemée 1995: 280; Zielińska 2010: 643-651.

5 A number of protection scenes, such as Cat. 18, 21, 53, 54 can be considered as personal, commemorative commissions.

6 For biographical data concerning Georgios, see Łajtar 2002; Ruffini 2011.

7 The publication of the paintings (Martens-Czarnecka 2011) contains a CD-ROM with photographs and descriptions of the paintings. Reference will be made to the numbers of the paintings in this catalogue and the numbering of the photographs as given here. 


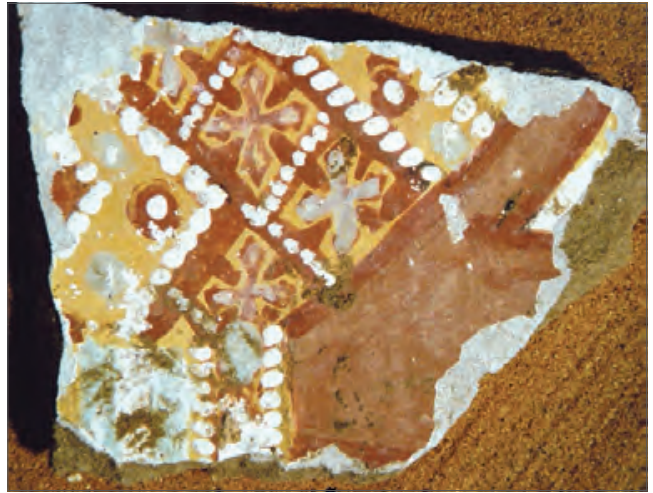

Fig. 1. Fragment of a painting of Georgios with hand and decorated textile, Northwest Annex, room 5 (After Martens-Czarnecka 2011: Cat. 21, MMC-021-02)

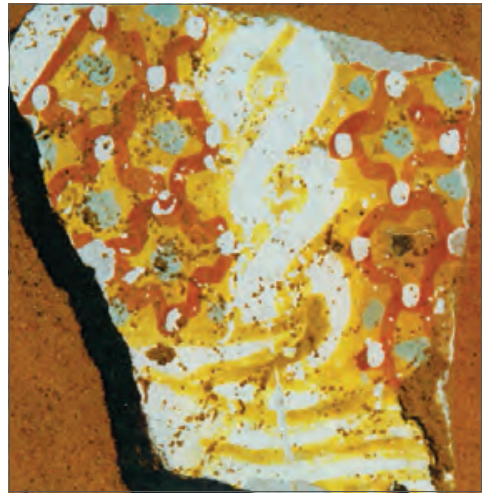

Fig. 2. Fragment of a painting with hand and decorative textile, provenance unknown (After Martens-Czarnecka 2011: 217)

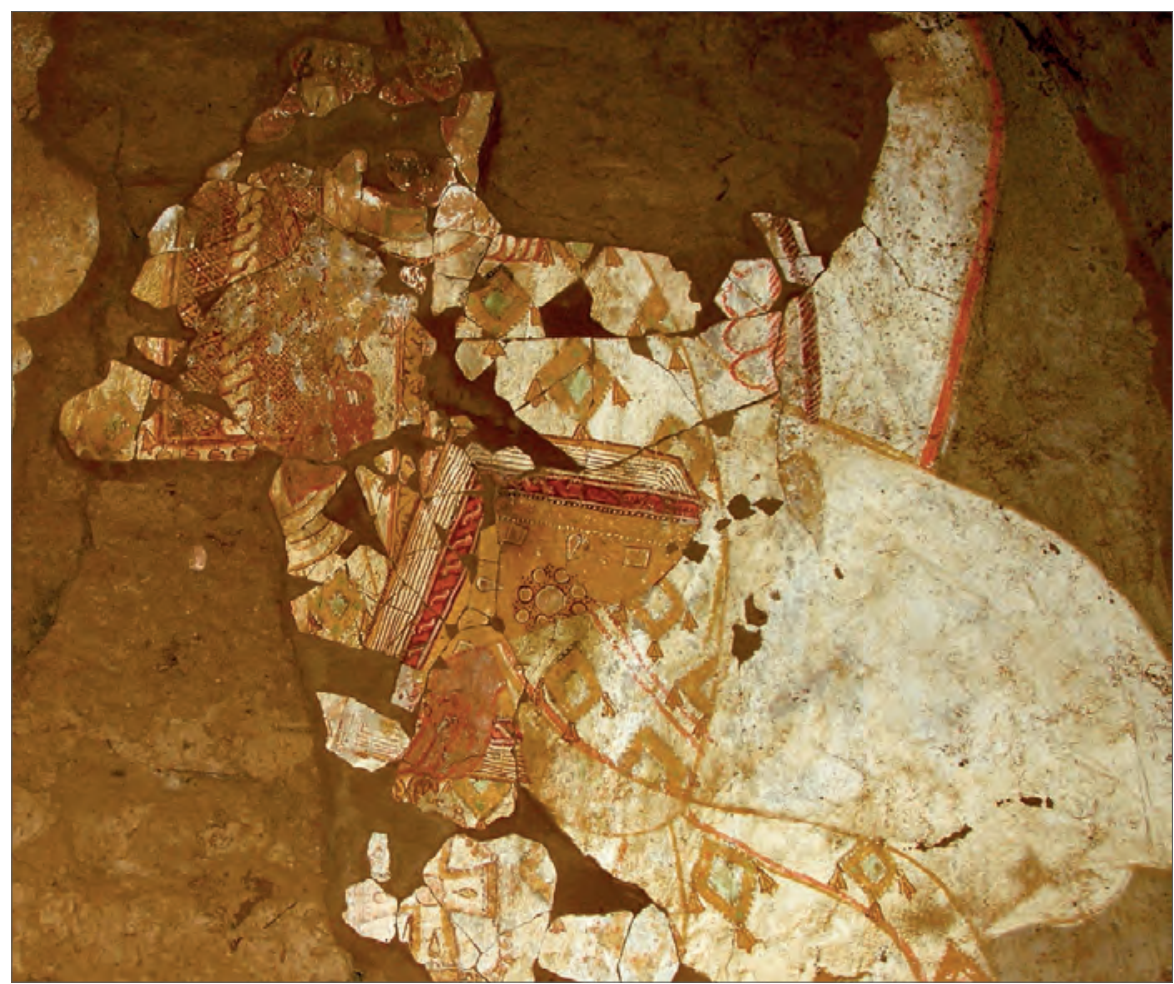

Fig. 3. Painting of Georgios, Northwest Annex, room 31 (After Martens-Czarnecka 2011: Cat. 53) 
Another painting where a similar pattern is used is a bishop's representation, most probably Georgios as well, found in room 31 of the Northwest Annex, the part that was furnished as a church by Georgios (Martens-Czarnecka 1998: 9091; 2011: 217, Cat. 53) [Fig. 3]. It is entirely possible that the person depicted on the east wall of room 31 is Georgios, although it is seriously doubted that he was represented here as a bishop. The dedication inscription in the adjacent room mentioned him only as an archpriest and archistylites. The least that can be said is that the elaborately decorated costume shows his high rank. The upper garment is creamy white in colour, decorated with a remarkable pattern of lozenge-shaped ornaments, green with a wide yellow (gold?) border, with small bells suspended from three of the corners of each lozenge. Martens-Czarnecka calls this a phelonion, but a remarkable difference with the phelonia known from bishops' portraits in Faras is the decorative strip with a stylised pattern in yellow and red that runs down vertically from the collar in this painting. This could mean that the person depicted is not wearing a phelonion of the usual shape, round or oval with an opening for the head in the middle, but a cape with a seam in front. a comparison with a bishop's portrait from the same period (second half of the 11th century), namely that of Bishop Georgios of Faras, now in the National Museum in Khartoum [Fig. 4], reveals a number of similarities, such as the flared shape of the upper garment (phelonion in the case of Georgios of Faras) which seems to have replaced the more vertical contours of earlier phelonia. The decorative border of this phelonion with its grid of lozenges with inscribed crosses is similar to the pattern on the fragment from room 5 (Martens-Czarnecka 2011: Cat. 21) and also in the painting from room 31 the same pattern is used on a garment hanging from the right shoulder. But there is no reason to identify the person in room 31 as a bishop. The main reason for this is that there is no omophorion visible. Martens-Czarnecka (2011: Cat. 53) identifies the collar with round and rectangular ornaments as such, but apart from this decoration there is no similarity with the omophoria as we know them from Makurian bishops' portraits from the 10th and 11th centuries. In this period the omophorion was worn in a wide loop around the neck, hanging in a V-shape on the chest; no such vestment can be seen in this painting. There are other details in this particular costume that deserve attention. Worn over the right shoulder is a garment that looks like a rectangular piece of fabric with the pattern of lozenges with crosses as mentioned above. Pellet-bells hang from the lower border. In the middle of this rectangle there is what seems to be a plaited or twisted strip of fabric. This strip shows a similarity with the garment worn by the anchorite Amone in a painting from Faras (Innemée 1992: 204, Pl. 25), a garment which is also depicted on the so-called tombstone of Shenoute 


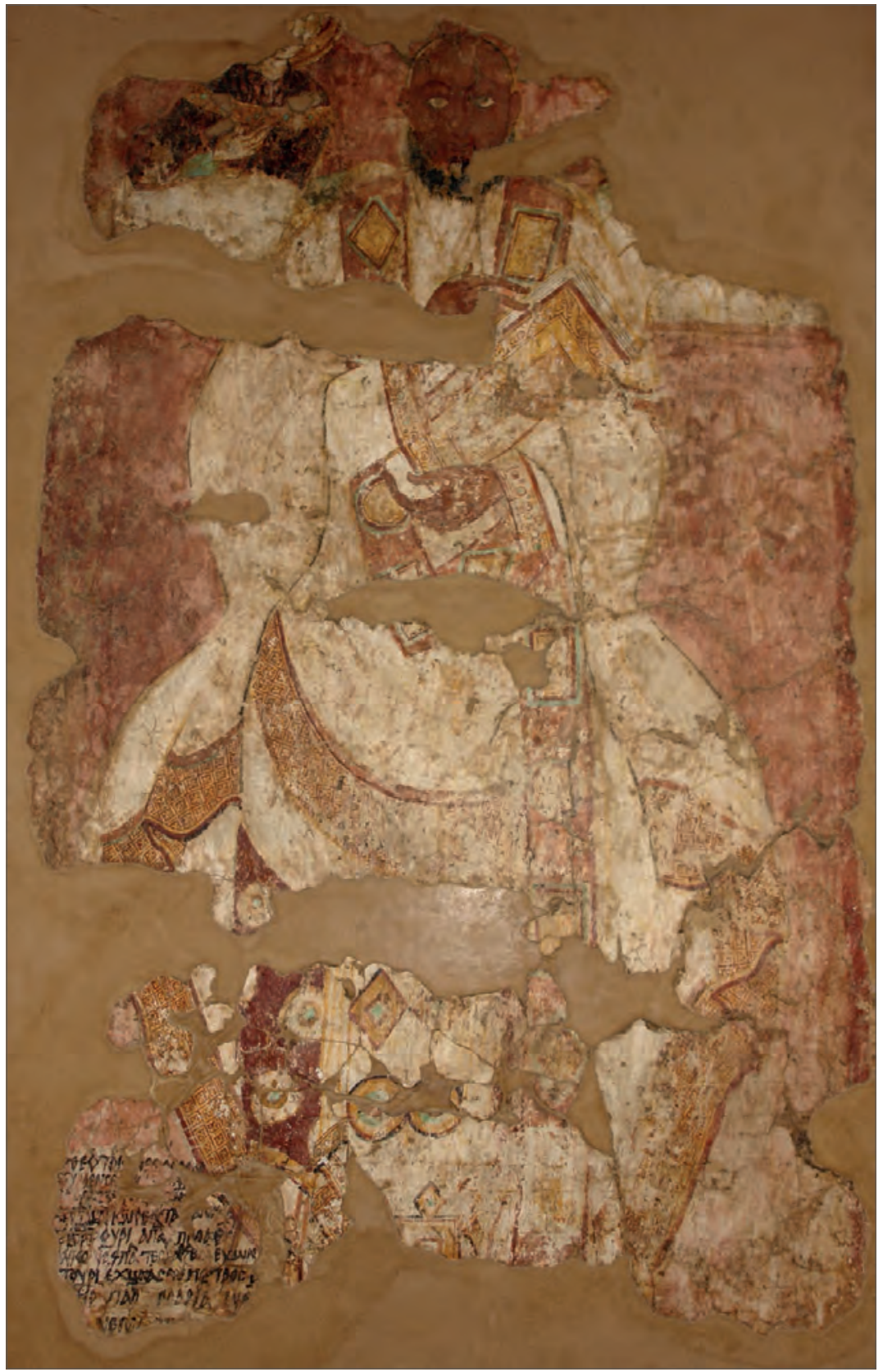

Fig. 4. Bishop Georgios of Faras, Sudan National Museum, Khartoum (Courtesy of the National Museum in Khartoum) 
(Effenberger and Severin 1992: 156). Martens-Czarnecka interprets this part of the costume as an analabos and a sign of the monastic status of the wearer. a fragment from Dongola of unknown provenance shows a seemingly similar garment (Martens-Czarnecka 2011: 217) [Fig. 2]. a comparison of the position of the hand and the textile pattern suggests a similar vestment in the fragment of Cat. 21. The similarity with the monastic analabos cannot be denied, but at the same time it concerns here a part of a costume that is extremely rich in its decoration and can only belong to someone high up in the ecclesiastical hierarchy.

Another element that deserves attention is the cross that is visible below the left hand that holds the gospel book. According to Martens-Czarnecka, the cross hangs from the arm of the dignitary, but since it is positioned in the middle against the abdomen, as in the painting of a bishop in the Southwest Annex (Martens-Czarnecka 2011: Cat. 110, MMC-110-02; see below, Fig. 12], it is more likely that it is a pectoral cross or encolpion. In the bishops' portraits from Faras, crosses of this kind do not occur and neither are they present in depictions of priests and other dignitaries from Dongola. We can presume, therefore, that it was not a sign of episcopal rank, but possibly connected with the bearer's place in the monastic hierarchy.

Coming to a preliminary conclusion, it may be said that the person represented in room 31 of the Northwest Annex is likely to be Georgios, but still in his position of archipresbyteros and archistylites. His outfit shows that he was of important rank, and although only a fragment of the painting has been preserved, the dress is much more likely to be monastic than liturgical. The garment hanging over his right shoulder is difficult to interpret and identifying it as an analabos seems premature, given the fact that there is so little information about it. It is a lavish dress that was meant to show status.

\subsubsection{Other church dignitaries}

A number of other portraits have survived in the Northwest Annex and one of them is a painting of two individuals in the protection of the archangel Michael. It is located on the south wall of room 31 and was applied in the second painting phase, after 1113 (Martens-Czarnecka 2011: Cat. 54, MMC-054-01, MMC054-03) [Fig. 5].

There can be no doubt that a portrait of a bishop was intended in the case of one of these figures. He wears a creamy white phelonion decorated with ornaments looking like drop-shaped flower buds in yellow and red. ${ }^{8}$ His omophorion has

8 Two fragments woven in linen and wool with a similar pattern and in the same colours are kept in the Coptic Museum in Cairo, Inv. No. 12742/12743 (Nauerth 2009: 104). 
one rectangular red ornament and a red collar. In his right hand the bishop holds a staff terminating in a cross, in his left a book. The headdress on his head looks like a scarf hanging down to the neck. It is white with yellow lines or folds. The ornament on the forehead looks like a cross of interlacing yellow lines. There is a great deal of similarity between this image and a painting of an anonymous bishop from the Rivergate Church at Faras (Griffith 1926: Fig. LV) [Fig. 6] $]^{9}$. The phelonion in the latter case is decorated with similar flower-like ornaments and the headdresses of both bishops are similar. In the drawing published by Monneret de Villard the ornament on the headdress looks like a flower, but Griffith's photograph of 1926 shows hardly any details of the worn

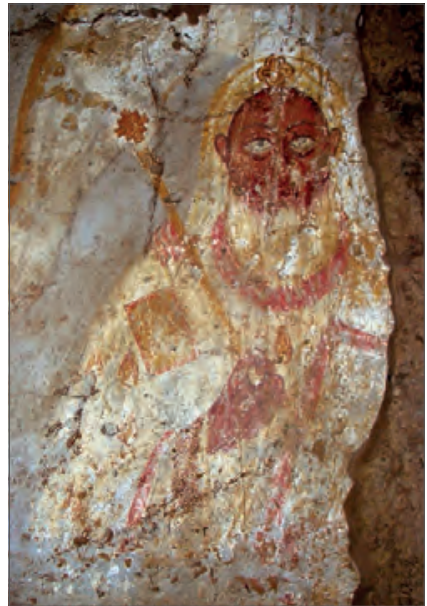

Fig. 5. Portrait of an unknown bishop, Northwest Annex, room 31 (After MartensCzarnecka 2011: Cat. 54, MMC-054-01, MMC-054-03)

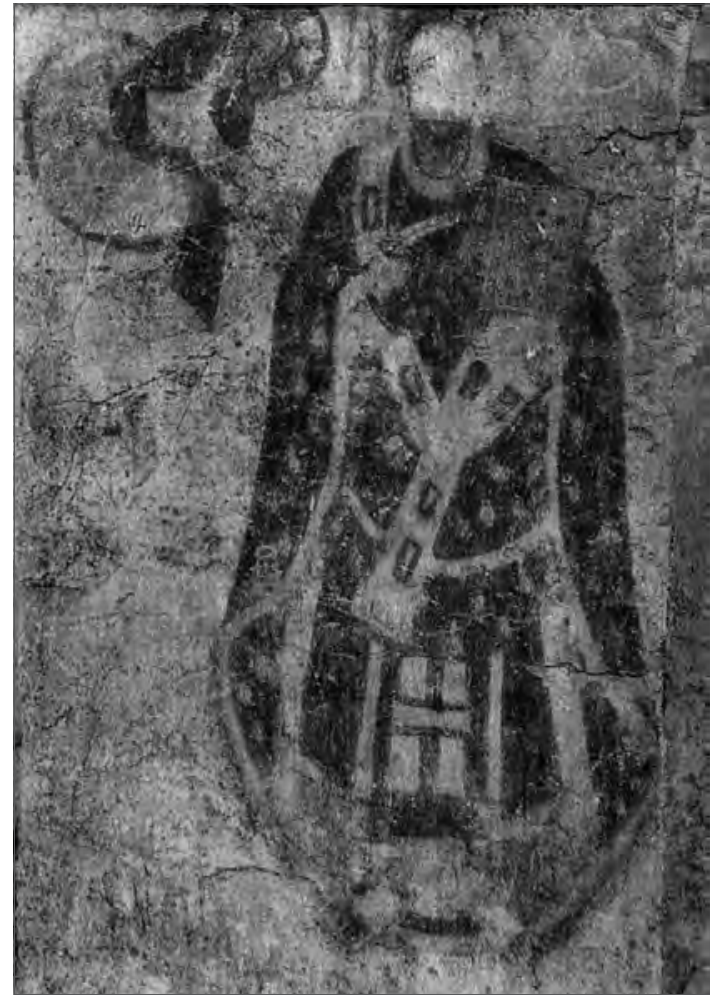

Fig. 6. Portrait of an anonymous bishop, Faras, Rivergate Church (After Griffith 1926)

9 Most of this painting is lost, with the exception of the head, which was painted on a piece of stone and which is now preserved in the National Museum of Khartoum, Inv. No. KH 3825. 
painting, so the image of a cross is highly possible here as well (Monneret de Villard 1957: Pls CXLV, CXLVI). The portrait of the bishop from the Rivergate Church was the only image with a headdress that had a cross depicted on it until the paintings in the Northwest Annex and the Cruciform Building (see below) were discovered. The painting from the Rivergate Church is possibly from the late 11th/early 12th century, and the painting from the Northwest Annex from the 12th century, so this may be taken as an indication that this type of head cover was introduced in Makuria around AD 1100.

The main difference between the two representations is the staff that the Dongolese bishop holds in his hand and which is absent from the image from Faras. The staff is not a fixed part of the Makurian episcopal outfit, if the bishops' portraits from Faras are anything to go by, but it does occur occasionally in representations of monastic saints and holy monk-bishops in Egypt from the 6th century onwards. Thus, we find it on the so-called tombstone of Shenoute in Berlin (Effenberger and Severin 1992: 156), a book illustration showing Christ and Shenoute (New York, MS Pierpont Morgan Libr. 604; Leroy 1974: 32), and in several of the representations of monks and monk-bishops in the monastery of St Anthony on the Red Sea: Shenoute and Pisentios, amongst others, hold staffs in their right hands (van Moorsel 1997: Pls 66, 88). The staff (bacillum or $\rho \alpha ́ \beta \delta o c)$ is mentioned as part of the Pachomian costume (Innemée 1992: 99). In his portrait in room 31, Georgios holds a staff and from this we can conclude that it symbolised monastic status of a kind rather than episcopal dignity.

The archipresbyteros Marianos commissioned a painting of the archangel Michael on the west wall in room 22 and had himself depicted in priestly liturgical dress on the right side of the angel (Martens-Czarnecka 2011: Cat. 39; MMC-030-01) [Fig. 7]. He wears a white sticharion and over this a scapular that is decorated with a red-yellow pattern. Over this he wears a white epitrachelion with rectangular and round decoration in light blue, red and yellow. His phelonion is of a remarkable turquoise colour, with a red border. He holds a book in his left hand and a censer in his right. Marianos's dress looks modest compared to the portrait of Georgios, who was also an archpresbyter. The only part of his dress that shows his monastic status is the scapular, well-known from the bishops' portraits from Faras (Innemée 1992: 149-150). It could mean that an archpresbyter was not necessarily dressed in a sumptuous way and that the portrait of Georgios in room 31 shows him as an archistylites and hegoumenos.

On the north wall of room 13 there is a representation of the Holy Trinity with a portrait of the donor at their right-hand side (Martens-Czarnecka 2011: Cat. 71; MMC-071-05, MMC-071-06) [Fig. 8]. His dress is comparable to that 
of Marianos, although there are some significant differences in the details. $\mathrm{He}$ wears a white sticharion and a turquoise scapular, on top of which there is a white epitrachelion with round and rectangular ornaments in yellow, red and turquoise. The phelonion is blue. Apart from the colours these vestments are the same as Marianos's. The donor holds a book in his left hand and a staff instead of a censer in his right hand. Hanging from his left shoulder is a strip of fabric with the hem appearing from under the book held in the hand. Its decoration consists of a pattern of diagonally crossing lines with green dots in between. This cannot be an omophorion, since the characteristic V-shaped loop on the chest is absent, but it seems equally problematic to interpret it as an analabos, as Martens-Czarnecka does, since it bears no resemblance to the monastic scarves as they occur on other paintings. The staff instead of a censer may be the result of random choice, but it could also indicate a difference in position. Representations are known of priests, monastic or parish, holding censers: Marianos (Martens-Czarnecka 2011:

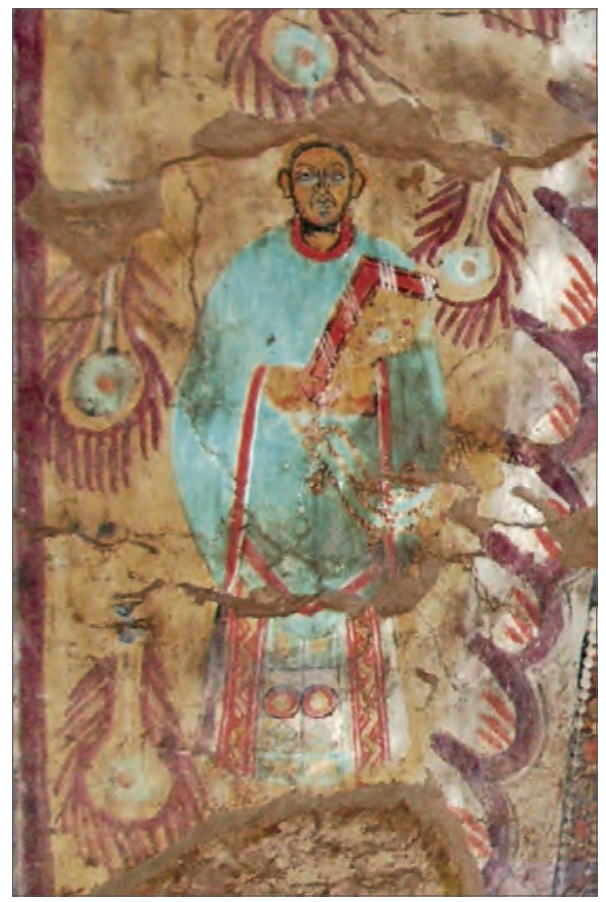

Fig. 7. Portrait of archpresbyter Marianos, Northwest Annex, room 22 (After Martens-Czarnecka 2011: Cat. 39; MMC-030-01) 
Cat. 39), Church of St Rafael in Tamit, an anonymous priest (Innemée 1992: 213-214) and a recently discovered painting of a priest holding a censer in the King's Church or Royal Church (B.V) in Dongola (D. Zielińska, publication in preparation) and these have no other signs of distinction than their epitrachelion and phelonion. Even Marianos, an archipresbyteros, is not represented with a staff. Therefore, it seems to be an attribute that went together with a higher (monastic) rank and other signs of distinction, such as the so far unidentified shouldergarment. One possibility is that the staff is an attribute of the archimandrites, but more paintings showing this attribute will have to come to light to prove it.

On the south wall of room $1 \mathrm{~b}$ of the Annex there is a painting that may have represented a standing saint with a donor on the right (Martens-Czarnecka 2011: Cat. 2; MMC-002-01) [Fig. 9]. No inscriptions remain to identify the figures, making it impossible even to be sure beyond doubt that the smaller of the two persons, standing with raised hands in a gesture of prayer, was indeed a donor. Nevertheless his costume deserves attention. The painting shows a man in a white tunic with short sleeves, decorated with red clavi or potamoi and decorative bands on the shoulders and the lower edge. The tunic was girded, and around his shoulders and over the chest there was a yellow scarf of which the ends were shown hanging in front. Martens-Czarnecka interpreted this scarf as an orarion and identified the figure as a deacon (Martens-Czarnecka 2011: 221). There is, however, a more plausible identification. The liturgical sticharion usually has long sleeves and the model in this painting should be identified as a lebiton or kolobion, a vestment often worn by Upper-Egyptian monks (Innemée 1992: 101-102; Mossakowska-Gaubert 2004). The scarf is part of Pachomian costume, a balteolus or sabanum, occuring a number of times in both texts and representations (Innemée 1992: 99, 105-106, Pls 50-53). It can be worn as a kind of plait over one shoulder, but also in the way depicted here. Both Pachomius and Shenoute are depicted with a scarf worn in this way in the 13th century paintings from the monastery of St Anthony on the Red Sea (van Moorsel 1997: Pls 65, 66). The person depicted here, therefore, seems to be a monk from the monastery shown in his everyday dress.

\subsubsection{Saints in ecclesiastical vestments}

In room 13 on the north wall there is a painting of a saint dressed in the costume of a bishop (Martens-Czarnecka 2011: Cat. 38, MMC-038-01) [Fig. 10]. He wears a red phelonion, which has a green decorative strip decorated with white dots at shoulder-level. This particular detail seems to occur only in representations of saints and not in portraits of Makurian bishops, judging from the paintings found in Faras. Here we see that St John 
Chrysostom, St Kaau and St Psate wear similar decorative bands (Innemée 1992: Pls 19, 22, 26). The omophorion, as far as it is visible, is worn in an archaic way, rather tight around the neck, with both ends hanging in front. In many of the paintings from Faras holy bishops are represented with such an omophorion, probably with the intention of showing a bishop 'from the past' in contrast to contemporary bishops, who were depicted with a more modern variant of the same garment (Innemée 1992: 151).

Another painting of a saint in liturgical costume was found on a corner pier of the south wall in room 11 (Martens-Czarnecka 2011: Cat. 17, MMC017-01) [Fig. 11]. Only the lower part has survived and this shows a sticharion with the unusually large feet, dressed in decorated shoes, appearing from under it. An epitrachelion was worn over the sticharion; it was decorated with rectangular and round ornaments painted in mostly yellow and red and the lower edge with little bells. The phelonion, worn on top of this, is yellow with a red border. No further vestments can be seen, so that the least that can be said is that it concerns a representation of a priest. Under his feet there is a crocodile-like creature, apparently an image of evil overcome by this person, which makes it unlikely that a contemporary person was portrayed

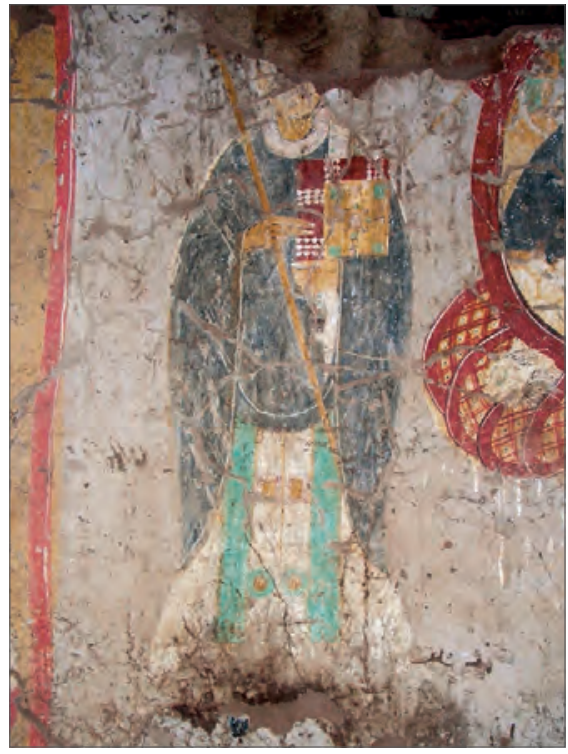

Fig. 8. Portrait of an anonymous donor, Northwest Annex, room 13 (After Martens-Czarnecka 2011: Cat. 71; MMC-071-05, MMC-071-06)

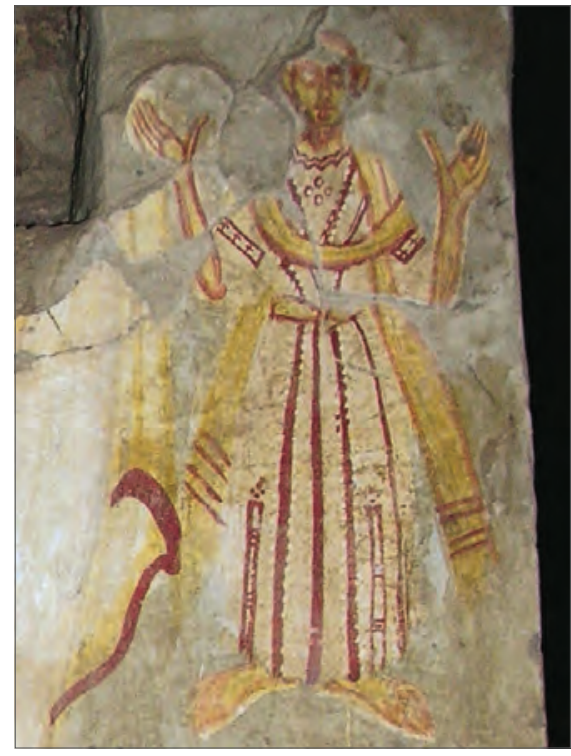

Fig. 9. Portrait of anonymous donor, Northwest Annex, room $1 b$ (After Martens-Czarnecka 2011: Cat. 2; MMC-002-01) 
here. Creatures such as dragons and other monsters are usually depicted under the feet of warrior saints and not of clerics. Furthermore, there is no trace of a spear or other weapon by which the animal was attacked or killed. Crocodiles are rare in hagiography and iconography, but there is at least one clue. In the First Greek Life of Pachomius there is a passage where it is said that he (Pachomius) "... manifested such perfect faith as to tread underfoot serpents and scorpions openly, and to stand on crocodiles in the water..." (Veilleux 1980: 310). ${ }^{10}$ The position of standing on a crocodile is of course a sign of domination, but it could also refer to legends about using the animal as a ferry across the Nile. ${ }^{11}$ This would have been an indication to identify the

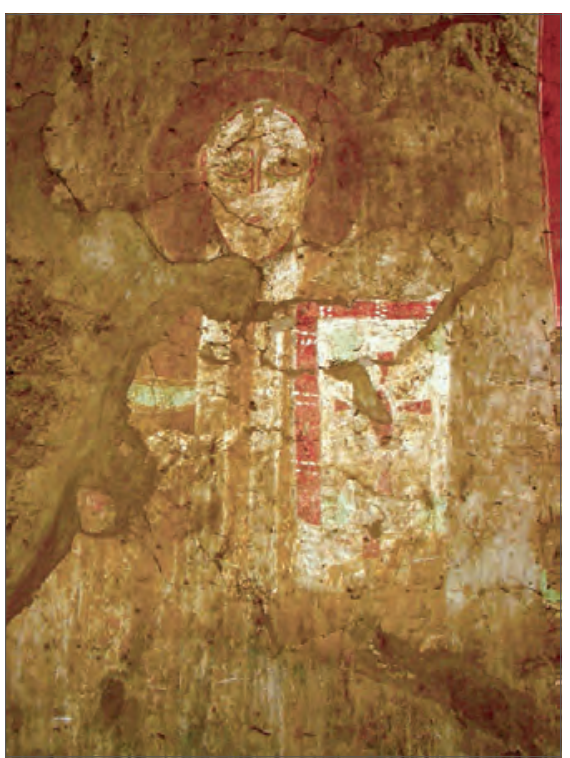

Fig. 10. Unknown holy bishop, Northwest Annex, room 13

(After Martens-Czarnecka 2011: Cat. 38, MMC-038-01)

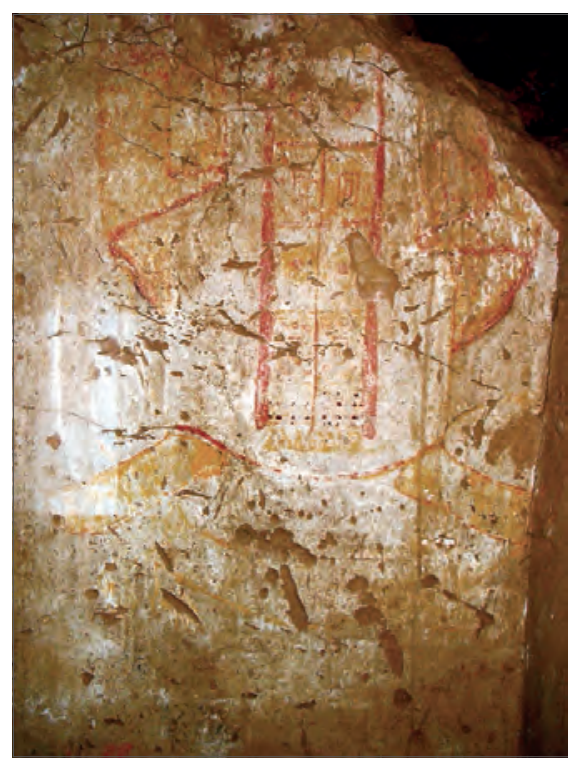

Fig. 11. Saint in liturgical costume, Northwest Annex, room 11 (After Martens-Czarnecka 2011: Cat. 17, MMC-017-01)

10 In the Bohairic Life of Pachomius there is another, slightly different passage about how Pachomius chased away a crocodile (Veilleux 1980: 43).

11 In the Vitae Patrum, a collection of hagiographies of desert fathers, based on a 13th century text with the same title, edited by Heribert Rosweyde and published in 1615, the crocodile is mentioned as a means of transport for Pachomius: "...necnon crocodili, siquando necessitas fluvium transire compelleret, eum cum summa subjectione portabat, exponents eum ad locum quocunque preacepisset" (PL 73, col. 241, 120). It is not clear on what earlier source(s) this passage is based. The crocodile as a means of crossing the river is also mentioned in a passage concerning Apa Helle in the Historia Monachorum XII, 7-10 (Festugière 1961: 94-95). 
person depicted as Pachomius were it not that he is usually depicted as a monk in his own characteristic costume and not as a priest. The identity of the saint therefore remains uncertain.

\section{i.2. Paintings in the Southwest Annex}

\subsubsection{Ecclesiastical dignitaries}

On the north wall of room 5 there is a painting that represents a bishop under the protection of the Archangel Michael (Martens-Czarnecka 2011: Cat. 110, MMC-110-01, MMC-110-02) [Fig. 12]. The painting is in poor condition, but in spite of this the red phelonion with an omophorion hanging from the left shoulder can still be discerned. The figure holds a book in the left hand and raises the right one in a closed fist, as if holding something that cannot be identified. a cross is visible below the hand, apparently a pectoral cross of the same kind as seen in the portrait of Georgios (Martens-Czarnecka 2011: Cat. 53) [see above, Fig. 3]. Georgios has his right hand in a similar position, holding a staff, so it is possible that the person in this painting was equipped

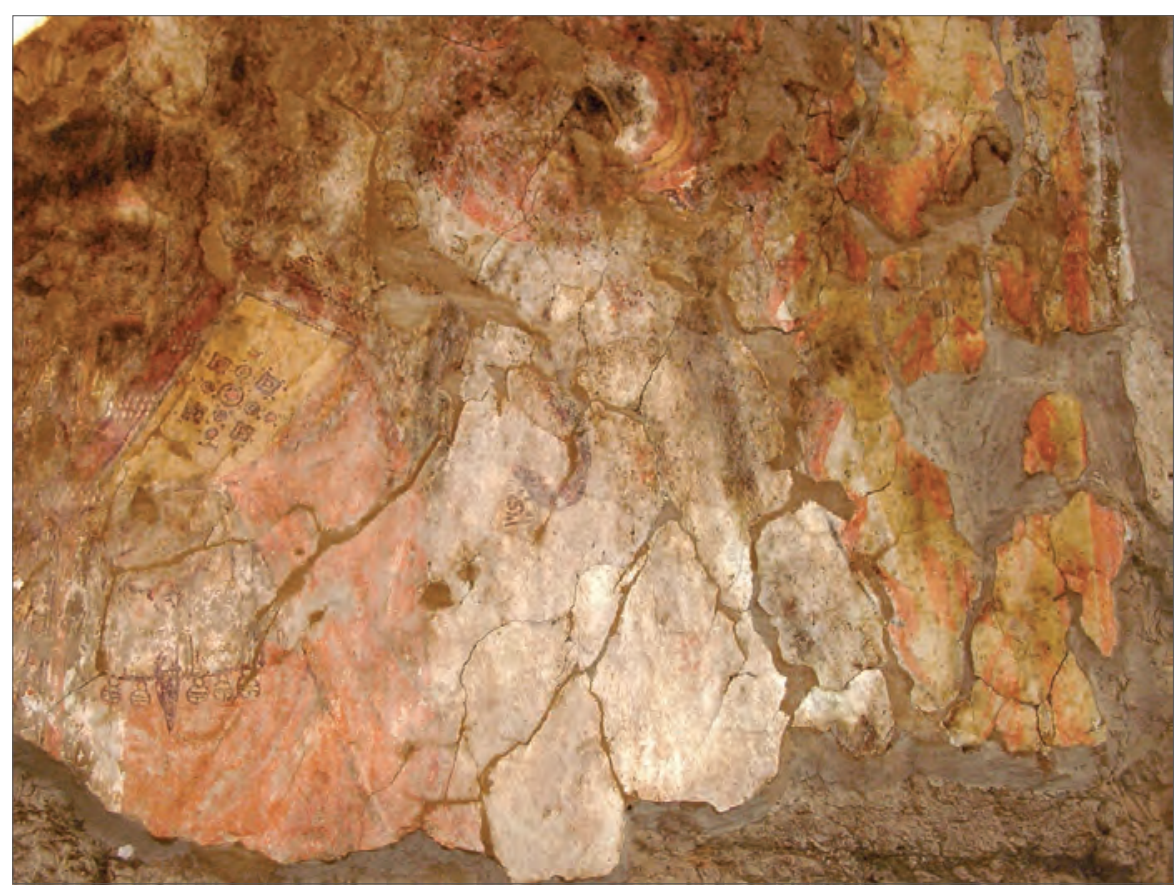

Fig. 12. Bishop protected by the Archangel Michael, Southwest Annex, room 5 (After Martens-Czarnecka 2011: Cat. 110, MMC-110-02) 
with the same combination of attributes, a staff and a pectoral cross. The omophorion identifies him as a bishop and in addition to this, the cross and staff could be the insignia of his monastic rank, possibly that of archimandrite. a rectangular piece of fabric, decorated with five pellet-bells at the hem, hangs from his lower left arm. The function or meaning of this garment or attribute remains obscure for the time being.

\subsubsection{Saints in ecclesiastical vestments}

A painting depicting a bishop, identified by Martens-Czarnecka as Epiphanius of Salamis, on the south wall of room 4 of the Southwest Annex (MartensCzarnecka 2011: Cat 101, MMC-101-01, MMC-101-03, MMC-101-04) [Fig. 13] confronts researchers with several questions. The basic vestment, as usual, is a tunic or sticharion, white with parallel purple lines that may either indicate folds or stripes. On top of this the figure wears a wide scapular, decorated with a pattern of diagonal yellow lines, forming a grid of lozenges with inscribed crosses in alternating red and yellow (see also the shoulder-

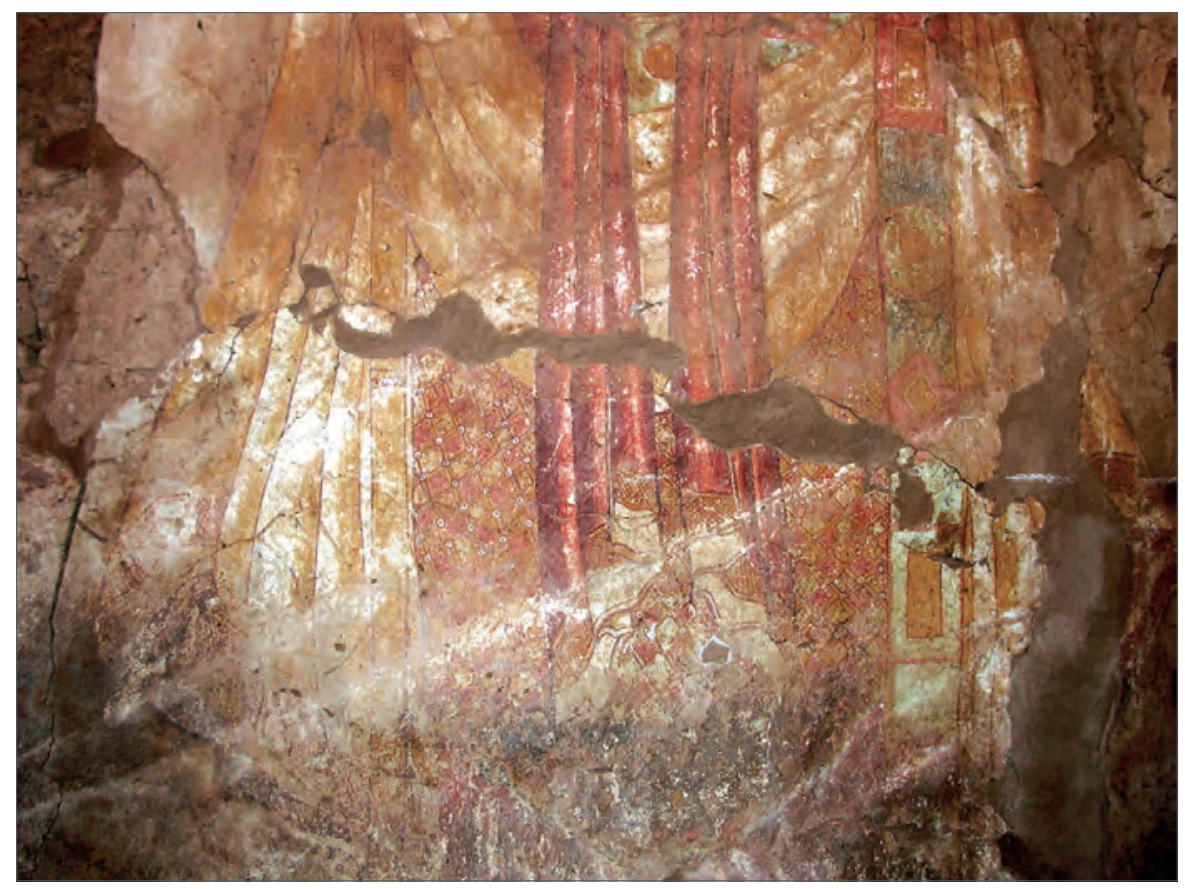

Fig. 13. Saint Epiphanius of Salamis, Southwest Annex, room 4 (After Martens-Czarnecka 2011: Cat 101, MMC-101-01, MMC-101-03, MMC-101-04) 
garment of Georgios [Martens-Czarnecka 2011: Cat 53]; see above and Fig. 3). His phelonion, creamy white with a wide decorative border decorated with a diagonal grid, shows the same curvy outlines as that in two bishop's portraits from Faras, those of Petros II(?) and Georgios (Jakobielski 1982: 138, Figs 9, 10); this model was apparently characteristic of the second half of the 11th century. Over the phelonion the bishop wears an omophorion with the usual round and rectangular (and one lozenge-shaped) ornaments painted in red and yellow on a blue background. This omophorion also resembles the ones worn by Makurian bishops depicted in the Faras cathedral. In addition to these familiar liturgical vestments, there are two more garments in this painting. Prominently hanging in front of the chest, down to knee-level, are two ends of a red shawl-like garment which shows a great similarity with the one worn by a saint in episcopal dress from Faras (Innemée 1992: 195, Pl. 12; Mierzejewska 2014: 146-147). It cannot be said how the vestment was worn around the neck and/or shoulders because the upper part of this painting from the Southwest Annex is lost, but it was most likely an omophorion worn in the archaic manner that was often depicted in this way in representations of saints (unknown holy bishop, Martens-Czarnecka 2011: Cat. 38, see above, Fig. 10]. But it would mean that what we have here is a reduplication of this episcopal attribute, a most unusual situation without parallel in other paintings known so far. But in addition to this there is a third garment worn over the phelonion. It is a narrow strip of yellow textile hanging from the left shoulder, decorated with horizontal decorative bands in red. This must be a monastic scarf of a model seen in an image of an anonymous donor (Martens-Czarnecka 2011: Cat. 2, see above, Fig. 9).

The identification of this painting as that of St Epiphanius (of Salamis) is based on fragments of fallen plaster with the inscription $\varepsilon \pi i$ ( $(\kappa о \pi о \varsigma)$

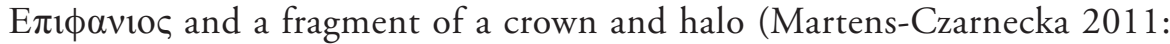
Cat. 101). Since there are no other (remains of) paintings in room 4, it is likely that this painting represented St Epiphanius, bishop of Salamis (died AD 403). He was a monk before being chosen to be the bishop of Salamis (being a monk in order to become a bishop was not yet a requirement in the 4th century) and apparently the painter wanted to express these dual qualities in the outfit depicted here. The result is, however, a curious amalgam of monastic and episcopal vestments. The omission of the epitrachelion is in keeping with the iconography of the 7 th-8th centuries, but the manner of representing the phelonion and the scapular is in line with 10th-11th century fashion. He wears two omophoria, one of an archaic model, the other following the fashion in the era in which the painting was made. 
The question that presents itself is why was this painting made and why did the painter or the person who commissioned it chose this curious combination of garments. a representation of Epiphanius from the cathedral at Faras (Innemée 1992: 192) is dressed in a rather basic monastic outfit. Epiphanius, who was far from being broad-minded in his opinions about what was right and wrong in terms of theology and who became known as the author of the Panarion, a catalogue of heresies, went down in history as a personification of orthodoxy, interestingly enough, for both Chalcedonians and anti-Chalcedonians. It is imaginable that in a monastery so closely related to the royal court, from whence more than one monk was probably recruited to become bishop of Dongola, he was considered exemplary for both monks and bishops. This is all speculative, but if Epiphanius was seen as a role model for Nubian monks and bishops, it could explain why he was represented in anachronistic costume that is a combination of episcopal and monastic garments from different periods.

\section{The Cruciform Building}

A small building that was probably erected as a commemorative monument was built on the citadel of Dongola, south of the so-called Palace of Ioannes; it was turned into a small church in the 14th century (Godlewski 2004). As part of the refurbishing an apse composition was painted and in it, at the far right of a row of apostles, a Makurian bishop, most likely a bishop of Dongola, was portrayed (Zielińska 2004: 221-222; Godlewski 2013: 77) [Fig. 14 left]. Little remains of this painting, but the remnants show a head with a red collar around the neck. Directly to the right of the head are the remains of a round ornament belonging to an omophorion, which identifies him as a bishop. He wears a headdress of the kind that can be seen in the Rivergate Church in Faras and in room 31 of the Northwest Annex (MatensCzarnecka 2011: Cat. 54, see above, Fig. 5), a hood or scarf worn tightly around the head, decorated with a cross with rounded arms on the forehead. This is the third example of this model of episcopal headdress that we know and it leads to the conclusion that it had become part of the episcopal costume from the end of the 11 th/beginning of the 12 th century. The origin must have been a monastic head cover or hood that was widely in use from at least the 9th century. It can be found for instance in a representation of Epiphanius, an illustration in MS BM Oriental 6782 (The Discourse of Apa 
Epiphanius, Bishop of Cyprus, on the Holy Virgin, a Coptic manuscript from the 10th century), which shows him in monastic dress with a hood and scarf around the shoulders (Innemée 1992: Pl. 45.1). Both hood and scarf are decorated with crosses.

In the lower church of San Clemente in Rome there is a painting that represents an Eastern monk, possibly Saint Cyril, apostle of the Slavs (828869). ${ }^{12} \mathrm{He}$ also wears a similar white hood with decorations in red on the side and a cross on the forehead. Two other examples of monastic hoods with crosses on the forehead, from the late 9th or early 10th century, were to be found in the now lost mosaics from the north tympanum of the Hagia Sophia in Constantinople, depicting the saints Methodius of Constantinople and Cyril of Alexandria (Mango 1962: Pls 61, 66-68, 74) [Fig. 14 right]. ${ }^{13}$
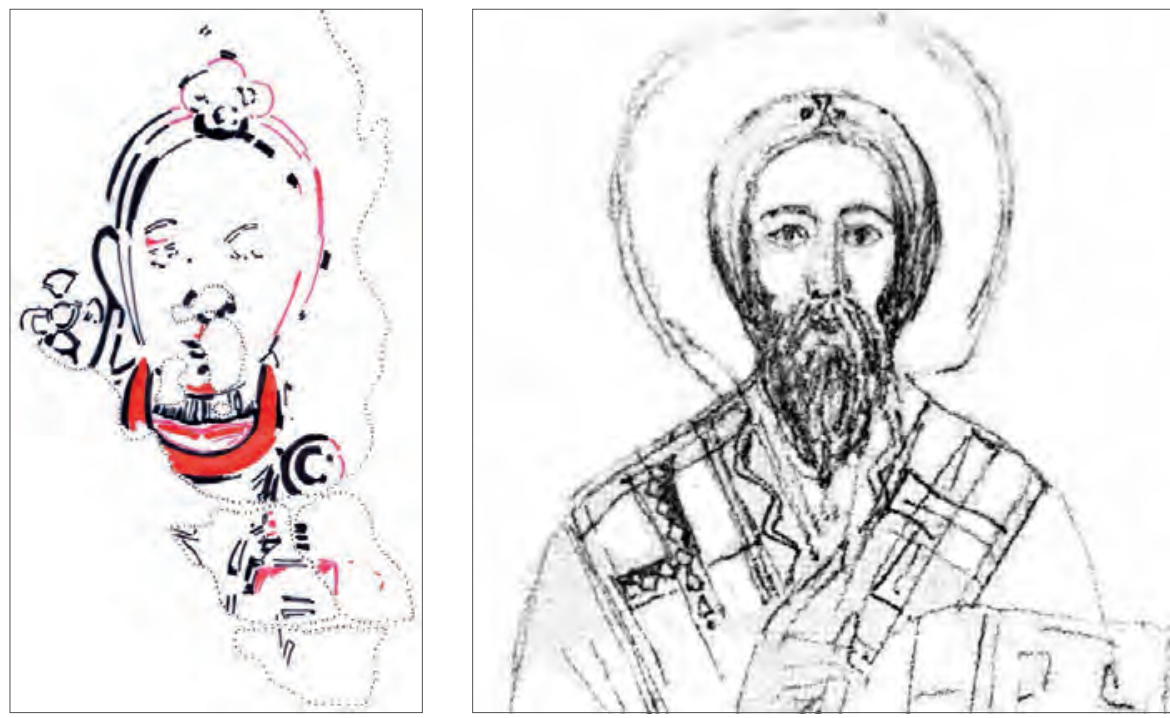

Fig. 14. Portrait of an anonymous bishop (left), apse of the Cruciform Building in Dongola; right, St Cyril of Alexandria, drawing by the Fossati brothers after a lost mosaic in Hagia Sophia (left, drawing D. Zielinska; right, after Mango 1962)

12 The painting is dated to the second half of the 9th century and the identification as a representation of St Cyril is only one of the possibilities: http://www.servizio-fotograficoroma.com/demo5/restoration/anastasis. For further discussion of this painting, see Osborne 1984: $179-182$.

13 Mango (1962: 52-53) identifies the headdress of Methodius as a bandage for his broken jaw, but this seems far-fetched, given the similarity with monastic hoods from the same period. 
In the Historia Ecclesiastica et Mystica Contemplatio (PG 98, Col. 395), attributed to Patriarch Germanos of Constantinople (from 715 to 730), the author discusses the symbolism of ecclesiastical vestments and in this context there is an allusion to the cross with which the monastic koukoullion (hood) was decorated. ${ }^{14}$ Not many monastic garments from this period have survived, but in this particular case we have confirmation that such hoods were worn in Egypt. a hood from Naqlun (8th-10th century), of white linen with red and blue decoration, resembling that of the painting in San Clemente, and slightly more pointed in model, is kept in the collection of the Louvre (Richter 2015: Fig. 128). In Syria as well as in Makuria, the white hood made its way from monastic dress into episcopal costume. In the miniatures of MS Paris, Bibl. Nat. Syr. 112 (Fol. 28r $, 32 \mathrm{v}^{\circ}, 61 \mathrm{v}^{\circ}, 67 \mathrm{r}^{\circ}, 69 \mathrm{r}^{\circ}, 180 \mathrm{v}^{\circ}$ ), we see bishops wearing a white hood with a cross on the forehead (Leroy 1964: Pls 111-113).

A third element that can be identified in the painting in the Cruciform Building is the cross to the left of the head. This can be the top of a staff, as depicted in the bishop's portrait in room 31 of the Northwest Annex (MartensCzarnecka 2011: Cat. 54, see above, Fig. 5). It means that also this person probably combined his office of bishop with high monastic rank.

\section{The Throne Hall}

A painting that has always been exposed, but which has not received much attention so far, is a mural from the so-called mosque of Old Dongola, formerly most probably the throne hall of the kings of Dongola. The mural was located on the west wall of the central room on the first floor, to the right of the entrance (Innemée 1992: 211, Pl. 37), but all that can be recognised are the contours of a head with a yellow halo, fragments of a red phelonion over which a yellow omophorion is worn, decorated with green circles surrounded by a yellow line and green squares, framed with a red line. In his left hand the figure held a book, of which traces in yellow remain. Concerning the identification, all that can be said is that it was a representation of a holy bishop. The iconographic program of this presumed throne hall still awaits a thorough analysis.

A cross on a stepped pedestal is depicted on the north wall of the Throne Hall with two figures on the left-hand side. One of them is a king, the other

14 For the cuculla the text refers to Galatians 6:14: 'May I never boast except in the cross of our Lord Jesus Christ, through which the world has been crucified to me, and I to the world.' 
a priest or a bishop. He is slightly turned towards the figure of the king, raising his left hand towards him, and holding an unidentified object. He is bareheaded, wearing a wide garment (phelonion?), decorated with a dense pattern of small spirals. Two elements observed in the lower part of the robe can be interpreted as the ends of an epitrachelion and/or a monastic scapular (Innemée and Zielińska forthcoming). Due to the poor state of preservation little more can be said about this figure.

\section{Conclusions}

What are the conclusions that can be drawn from these paintings of bishops, priests and monks in Dongola? First of all, they provide us with additional information concerning Makurian liturgical and monastic dress and the influence of the latter on the former. But such influences and developments are more than just a matter of ecclesiastical fashion and should be seen as symptomatic for the relationship between monasteries and the clergy. In the portraits of bishops of Faras the scapular appears in the first half of the 10th century, apparently to underline their monastic status. Although by the 10 th century it was still possible for a married man to become a bishop or even a patriarch (Krause 1978: 155156), in practice most of them were recruited from the monastic milieu. We do not know how these procedures went and who was responsible for the selection of the candidates, but although it was the patriarch of Alexandria who ordained the Nubian bishops, the Makurian king must have had a considerable influence on the process. This is at least the impression one gets from the description of an incident in the History of the Patriarchs, supposed to have happened under Patriarch Mikhail I (743-767). The Makurian king Abraham insisted on the dismissal of bishop Kyriakos, with whom he was at odds and wanted to have him replaced by a candidate of his own choice, a certain Ioannes. To invigorate his demand, King Abraham threatened to make his country return to idolatry (HPA I.3). Mikhail gave in and John was ordained the new bishop of Dongola. Although this may be an incident, it illustrates the rivalry over the investiture of bishops that may have occurred from time to time between the royal court in Dongola and the Patriarchate in Alexandria.

Very little is known concerning the background and career of Makurian bishops and in the case of Georgios of Dongola we have evidence that he was archipresbyteros, archistylites of the monastery of the Holy Trinity and archimandrite of the monastery of St Anthony before becoming archbishop. It is still far from 
clear whether the Monastery on Kom H was that of St Anthony or that of the Holy Trinity. The numerous references in graffiti to the Holy Trinity and their repeated occurrence in the paintings of the Northwest Annex, however, can be taken as a strong indication that the monastery was in fact dedicated to it and that the monastery of St Anthony was located elsewhere (Jakobielski 2008: 288). Whatever the case, the Monastery on Kom $\mathrm{H}$ must have been literally and figuratively within reach of the royal court and may have been the place from where not only Georgios, but more bishops of Dongola were recruited. The intertwinement of monastic ranks and the episcopal office was already visible in the portraits of bishops from Faras, but in Dongola there is further evidence of this. The paintings provide us with additional information concerning the range of monastic vestments. The portrait of a cleric in room 31 (Martens-Czarnecka 2011: Cat. 53) of the Northwest Annex is certainly not a bishop, but probably Georgios dressed as an archimandrite. Apart from the scapular, the staff with a cross at the top, the pectoral cross, the white hood or headscarf and the long, narrow scarf around the shoulders appear as attributes that can be worn by (high ranking) monks and bishops. In general, we can find a clear distinction in Makurian iconography between portraits of clerics and (devotional) representations of saints in ecclesiastical dress. An interesting exception to this rule is the figure of St Epiphanius in the Southwest Annex; the saint appears in a remarkable combination of monastic and episcopal vestments from different periods, possibly with the aim of presenting him as a role model for Makurian monks and bishops.

The fragmentary character of some of the paintings raises questions concerning the exact shape and meaning of certain garments. The vestment worn by Georgios on his right shoulder, for instance, cannot be identified so far.

Clothing, especially uniforms and official costumes, are a mirror of society and, as in other societies, the costumes of Nubian religious and worldly officials can be 'read' as a valuable source of information. The last word has not been said or written about this subject, but the paintings of Dongola provide a few tesserae in the total mosaic of Nubian culture.

\section{References}

\section{Primary sources}

Severus ibn al-Mukaffa, History of the patriarchs of the Coptic Church of Alexandria III. Agathon to Michael I (766) [=Patrologia Orientalis 5/1], transl. by B. Evetts, Paris: Firmin-Didot, 1909 


\section{SECONDARY SOURCES}

Effenberger, A. and Severin, H.-G. (1992). Das Museum für Spätantike und Byzantinische Kunst. Berlin: Die Museen

Festugière, A.J. (ed.) (1961). Historia monachorum in Aegypto [=Subsidia Hagiographica 34]. Brussels: Société des Bollandistes

Godlewski, W. (2004). Old Dongola. Kom a (Acropolis), 2003. Polish Archaeology in the Mediterranean, 15, 193-215

Godlewski, W. (2013). Dongola: Ancient Tungul. Archaeological guide [=PCMA Archaeological Guides 1]. Warsaw: PCMA UW

Griffith, F.L. (1926). Oxford excavations in Nubia. Liverpool Annals of Archaeology and Anthropology, 13, 25-93

Innemée, K.C. (1992). Ecclesiastical dress in the medieval Near East [=Studies in Textile and Costume History 1]. Leiden: E.J. Brill

Innemée, K.C. (1995). Observations on the system of Nubian church-decoration. In Actes de la VIII Conférence Internationale des Études Nubiennes: Lille 11-17 septembre 1994, I. Communications principales [=Cahiers de recherches de l'Institut de papyrologie et d'égyptologie de Lille 17/1] (pp. 279-287). Villeneuve-d'Ascq: Université Charles de Gaulle-Lille III

Innemée, K.C. and Zielińska, D. (forthcoming). The king and the cross. The iconography of a painting in the Throne Hall of Dongola. In M. Honegger (ed.), Proceedings of the 13th International Conference for Nubian Studies - Neuchâtel 2014

Jakobielski, S. (1982). Portraits of the Bishops of Faras. In J.M. Plumley (ed.), Nubian studies: Proceedings of the Symposium for Nubian Studies, Selwyn College, Cambridge, 1978 (pp. 127-142). Warminster: Aris \& Phillips

Jakobielski, S. (1994). Old Dongola 1993, Polish Archaeology in the Mediterranean, 5, 115-128

Jakobielski, S. (1997). Old Dongola 1996, Kom H, Site NW, Polish Archaeology in the Mediterranean, 8, 161-168

Jakobielski, S. (2001). Das Kloster der Heiligen Dreifaltigkeit. Bauphasen des nordwestlichen Anbaus. In S. Jakobielski and P.O. Scholz (eds), Dongola-Studien: 35 Jahre polnischer Forschungen im Zentrum des makuritischen Reiches [=Bibliotheca Nubica et Aethiopica 7] (pp. 141-168). Warsaw: ZAŚ PAN

Jakobielski, S. (2008). The Holy Trinity Monastery in Old Dongola. In W. Godlewski and A. Łajtar (eds), Between the cataracts: Proceedings of the 11th Conference for Nubian studies, Warsaw University, 27 August - 2 September 2006, I. Main papers [=PAM Supplement Series 2.1] (pp. 283-302). Warsaw: Warsaw University Press

Krause, M. (1978). Bischof Johannes III von Faras und seine beiden Nachfolger: Noch einmal zum Problem eines Konfessionswechsel in Faras. In Études nubiennes: colloque de Chantilly, 2-6 juillet 1975 [=Bibliothèque d'étude 77] (pp. 153-164). Cairo: Institut français d'archéologie orientale 
Leroy, J. (1964). Les manuscrits syriaques à peintures conservés dans les bibliothèques d'Europe et d'Orient. Contribution à l'étude de l'iconographie des Eglises de langue syriaque [=Bibliothèque archéologique et historique 77]. Paris: P. Geuthner

Leroy, J. (1974). Les manuscrits coptes et coptes-arabes illustrés [=Bibliothèque archéologique et historique 96]. Paris: P. Geuthner

Łajtar, A. (2002). Georgios, Archbishop of Dongola (†1113) and his epitaph. In T. Derda, J. Urbanik, and M. Węcowski (eds), Euergesias Charin: Studies presented to Benedetto Bravo and Ewa Wipszycka by their disciples [=Journal of Juristic Papyrology Supplement 1] (pp. 159-192). Warsaw: Raphael Taubenschlag Foundation

Mango, C.A. (1962). Materials for the study of the mosaics of St. Sophia at Istanbul [=Dumbarton Oaks Studies 8]. Washington: Dumbarton Oaks Research Library and Collection

Martens-Czarnecka, M. (1998). An attempt to define the function of selected rooms at the Monastery in Old Dongola, Gdańsk Archaeological Museum African Reports, 1, 81-83

Martens-Czarnecka, M. (2011). The wall paintings from the Monastery on Kom H in Dongola [=Nubia 3; Dongola 3; PAM Monograph Series 3]. (B.M. Gostyńska, trans.). Warsaw: Warsaw University Press

Mierzejewska, B. (2014). The Professor Kazimierz Michatowski Faras Gallery: Guidebook. Warsaw: National Museum

Monneret de Villard, U. (1957). La Nubia medioevale IV. Cairo: Institut français d'archéologie orientale

Mossakowska-Gaubert, M. (2004). Tuniques à manches courtes et sans manches dans l'habit monastique égyptien (IVe-début VII e siècle). Antiquité Tardive, 12, 153-167

Nauerth, C. (2009). Furnishing textiles in the Cairo Coptic Museum. In A. De Moor and C. Fluck (eds), Clothing the house: Furnishing textiles of the 1st millennium AD from Egypt and neighbouring countries. Proceedings of the 5 th conference of the research group "Textiles from the Nile Valley" Antwerp, 6-7 October 2007 (pp. 100-114). Tielt: Lannoo Publishers

Osborne, J. (1984). Early mediaeval wall-paintings in the lower church of San Clemente, Rome. New York: Garland

Richter, S.G. (2015). Anachoreten und Mönche. In C. Fluck, G. Helmecke, and E.R. O'Connell (eds), Ein Gott: Abrahams Erben am Nil. Juden, Christen und Muslime in Ägypten von der Antike bis zum Mittelalter (pp. 114-119). Berlin: Staatliche Museen zu Berlin, Preussischer Kulturbesitz

Ruffini, G.R. (2011). Georgios. In E.K. Akyeampong and H.L. Gates (eds), Dictionary of African biography II (pp. 453-454). Oxford: Oxford University Press

van Moorsel, P. (1997). Les peintures du monastère de Saint-Antoine près de la Mer Rouge II. Cairo: Institut français d'archéologie orientale

Veilleux, A. (1980). Pachomian Koinonia I. The life of Saint Pachomius and his disciples [=Cistercian Studies Series 45]. Kalamazoo, MI: Cistercian Publications 
Zielińska, D. (2004). Painted decoration of the Cruciform Building in Dongola. Preliminary report. Polish Archaeology in the Mediterranean, 15, 216-223

Zielińska, D. (2010). The iconographical program in Nubian churches: Progress report based on a new reconstruction project. In W. Godlewski and A. Łajtar (eds), Between the cataracts: Proceedings of the 11th Conference for Nubian studies, Warsaw University, 27 August - 2 September 2006, II.2. Session papers [=PAM Supplement Series 2.2/2] (pp. 643-651). Warsaw: Warsaw University Press 


\title{
The northern pastophorium of Nubian churches: ideology and function (on the basis of inscriptions and paintings)
}

\author{
Adam Łajtar \\ Department of Papyrology, Institute of Archaeology, University of Warsaw \\ a.f.lajtar@uw.edu.pl \\ Dobrochna Zielińska \\ Department of the Archaeology of Egypt and Nubia, \\ Institute of Archaeology, University of Warsaw \\ d.zielinska@uw.edu.pl
}

\section{KeYwords}

Christian Nubia, Oriental Christianity, church architecture, Nubian painting, wall inscriptions, Christian liturgy

\section{Abstract}

A well established program can be observed in the decoration of the northern pastophoria of Nubian churches from the 9th/10th century onwards. It consisted of a painted representation of Jesus Christ blessing with his right hand the chalice held in his left and inscriptions in Greek with prayers from the Liturgy of the Presanctified Gifts. The authors argue that this program was a Nubian creation, alluding to the function of the northern pastophorium as a place for storing oblations, keeping liturgical implements and liturgical reserve, and possibly also celebrating the Liturgy of the Presanctified Gifts.

Pastophoria (side rooms) are a recurring element in Nubian church buildings. ${ }^{1}$ They were present, from an early period on, in the adapted spaces of pagan temples converted into churches, early basilicas, big cathedrals, both with basilical and central plans, small churches mainly of central plan, and very

1 The complex issue of the origin, names and function of pastophoria in Christian church architecture will not be addressed here, as will not the routes by which they reached Nubia. For a detailed discussion, with a focus on Byzantine churches, see Babić 1969; Ćurčić 1977. 
small, late structures, where the sanctuary together with pastophoria was unified into one space. ${ }^{2}$

Lacking explicit evidence, either textual or archaeological, we are poorly informed about the exact role of the pastophoria in liturgical space in Nubia. The southern pastophorium is presumed to have filled the functions of both baptistery and diakonikon. This idea is based on the presence (especially in early churches) of baptismal fonts, and the painted decoration with the repeated occurrence of the figures of Saint John the Baptist and Saint Stephen, Deacon and Protomartyr. ${ }^{3}$ The northern pastophorium is commonly interpreted as a prothesis, a room for the preparation, during the initial part of the Eucharistic liturgy, of bread and wine that were subsequently transferred to the main altar and were consecrated during the anaphora as the body and blood of Jesus Christ. The internal arrangement of the space in question, including the altar near its east wall and the niche in the immediate vicinity of the altar, is in favor of this idea and the interpretation is further confirmed by the liturgical implements found inside the northern pastophorium, ${ }^{4}$ as well as the presence of benches and containers, connected most probably with the storing of the prosphora [Fig. 1]. ${ }^{5}$

The painted decoration of the northern pastophoria of Nubian churches seems to vary from one church to the other except for one element: the representation of Jesus Christ in half figure located on the east wall of the room, behind the altar. Two main iconographic types can be discerned: (1) Jesus blessing the chalice, and (2) Jesus appearing from the clouds holding the chalice and paten, liturgical vessels that were traditionally stored in the prothesis.

For Nubian church architecture, see Adams 1965; 2009.

3 For the fullest analysis of Nubian baptisteries, see Godlewski 1979. For painted decoration of the southern pastophorium, see Zielińska 2009.

4 Liturgical vessels were found, for example, in the northern pastophorium of the North Church at Old Dongola (Godlewski 1990: 53-54), and in the northern pastophorium of the Upper Church at Banganarti (Żurawski 2003: 249 [report from the discovery]; 2004a; 2004b [description]; 2014: 219-220, Figs 3-5). Storing liturgical paraphernalia in the northern pastophorium was not the rule, however. A chalice and paten were discovered under the main altar of the cathedral at Faras (Michałowski 1964: 196) and in the central nave of the church at Abdallah-n Irqi (van Moorsel, Jacquet, and Schneider 1975: 24, No. 27). In the South Church at Faras, a chalice was found in the southern pastophorium (Mileham 1910: 35, Pl. 19a).

5 Benches and ceramic containers were found in great number standing on the floor of the northern pastophorium of the Faras cathedral (Kubińska 1976: 12-14, Figs 9, 12-16). They also occurred in the northern pastophorium of the Church on the South Slope in Faras (Kubińska 1976: 14, note 14). Excavations in the northern pastophorium (Room 26) of the Upper Church at Banganarti brought to light numerous amphorae and mud stoppers, indicating that large quantities of wine had been stored there (Adam Łajtar's personal observation). A priest with two big jars is represented in paint on the north wall of the northern pastophorium of church B.V on the citadel of Dongola (see note 7). 
The first type, more common, will be studied in greater detail below. The second one was found only twice: in the small church at Abd el-Gadir ${ }^{6}$ and in the socalled Church of Angels at Tamit [Fig. 2] (Monneret de Villard 1935: 156, No. 13; 1957: Pl. CLX, No. 13; Baldassare 1967: 56). There is also a single representation of a blessing Jesus without liturgical vessels in the church at Wadi el-Sebua [Fig. 3] (Gauthier 1911: 113).

In addition to the representation of Jesus, the northern pastophoria of Nubian churches have the following scenes represented on their walls: Melchisedech or Aaron (probably as a prefiguration of the Christian priest) on the west wall of the northern pastophorium of the cathedral at Faras (Michałowski 1974: 154156); Jesus Christ with Archangels Michael and Gabriel protecting a Nubian Church dignitary, a priest named Theouphorou, offering two big jars to the Virgin Mary and the Child and another priest, Petr[ou], most probably shown doing the same, on the north wall of the northern pastophorium of church B.V on the citadel of Dongola; ${ }^{7}$ Saint Peter with priest Abramē on the east wall of the same church; ${ }^{8}$ a Nubian priest depicted with the Virgin Mary(?) on the south wall of Raphael's church at Tamit (Baldassare 1967: 45, Pl. 14,3); Four Apocalyptic Creatures or Cherubim, added in a later phase, one on each wall, of the northern pastophorium of the Church of Angels at Tamit. ${ }^{9}$ The small number of known representations of these subjects and their dispersed character (apart from the repeated depictions of members of the clergy) caution against suggesting a more complex iconographic program.

The northern pastophorium of the cathedral at Faras had numerous inscriptions written on its walls. The material, although published (Kubińska 1976), is in need of a greatly improved scholarly presentation. The texts look to be mostly literary or sub-literary in character (prayers, quotations from holy writings, invocations and acclamations); they belonged to the original decoration of the room, although one also finds inscriptions added later by worshippers, mainly members of the clergy. The northern pastophorium of church B.V on the citadel of Dongola has some painted inscriptions, including

6 The painting was not included in the publication of the church in Abd el-Gadir (Griffith 1928: 63-82), but was mentioned on a list of paintings in the conservation report of the Yugoslavian team that saved and transferred murals form the church (Medić 1965: 71). It is stored now in the Sudan National Museum in Khartoum (Inv. No. KH. 33123).

7 Known to the authors from autopsy, the northern pastophorium of church B.V still being under excavation at the time of writing. For church B.V generally, see Godlewski 2013: 6970; for the results of most recent research, see Godlewski 2015.

8 See the preceding note.

9 Monneret de Villard 1935: 156, Nos 11, 12, 14, 15; 1957: Pl. CLIX, No. 11 (where the figures are identified as angels, however); Godlewski 1987: 368. 


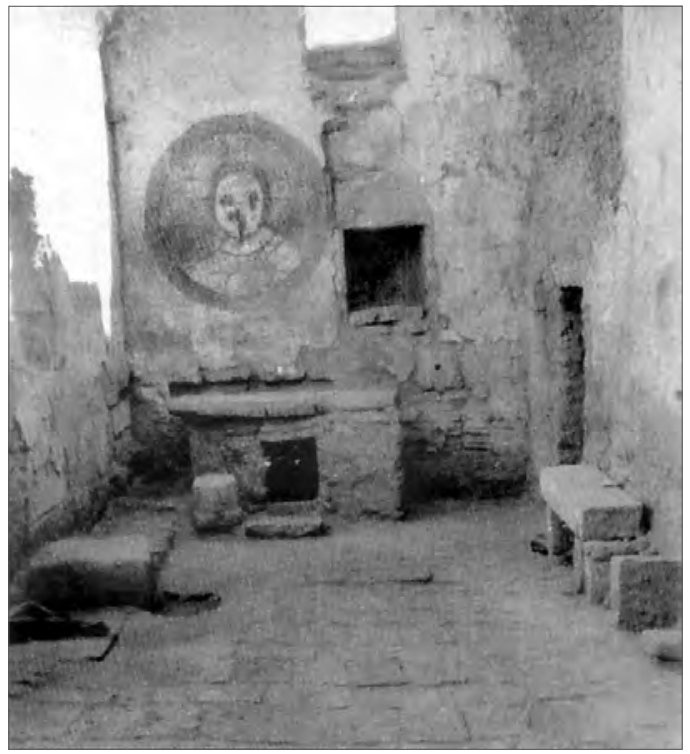

Fig. 1. Interior of the northern pastophorium of the cathedral at Faras (After Godlewski 2006: 104, Fig. 90)

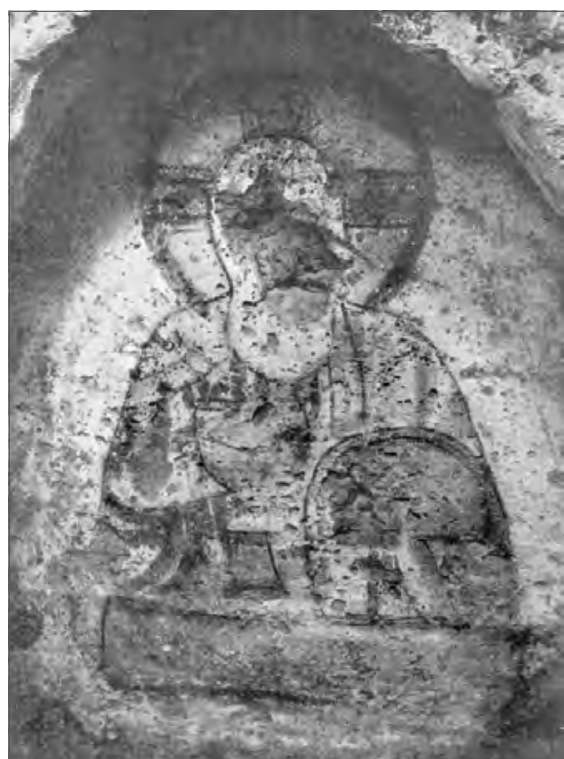

Fig. 2. Jesus Christ with liturgical vessels; niche in the east wall of the northern pastophorium of the Church of Angels in Tamit (After Monneret de Villard 1957: Pl. CLXVII)

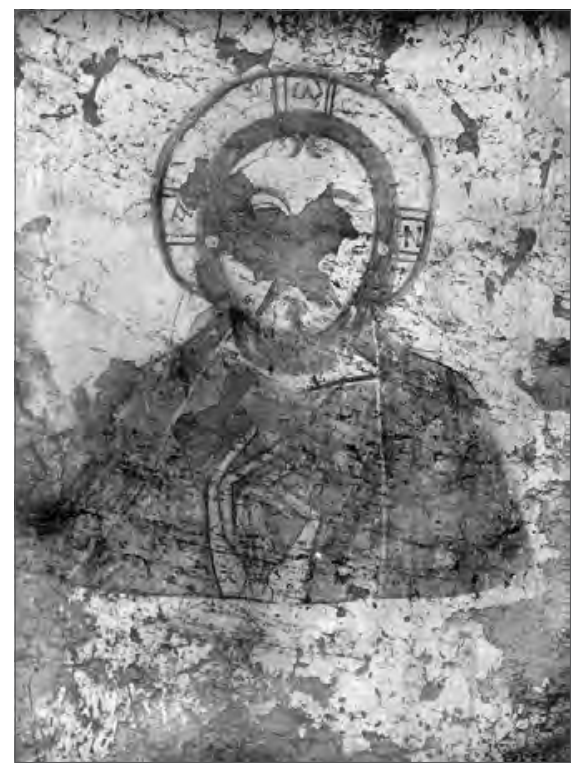

Fig. 3. Jesus Christ on the east wall of the northern pastophorium of the church in Wadi el-Sebua (After Gauthier 1911: Fig. $C X X V B)$ 
literary texts and, significantly, a list of ten or so individuals (including women) followed by a reference to an amount of wine and a day of the month (possibly a list of donors) (Eajtar 2015). A dipinto with a liturgical prayer was found in the northern pastophorium of the church at Sonqi Tino. Otherwise, this space in the Nubian churches is seldom graced with inscribed texts.

A specific decorative program, consisting of both paintings and inscriptions, can be observed in some pastophoria. An essential element of the program is a painted representation of Jesus Christ on the east wall of the room behind the altar. In churches built in the period after the 10th century, the painting could be located in a niche. Jesus, clad in a garment covered with eyes, was shown against the background of a brick wall or a firmament framed either by an oval or by the edges of the niche itself. His head, if preserved, has a cross nimbus with the acclamation of $̋ v$. He holds in his left hand a chalice that he blesses with his right hand. ${ }^{10}$

One or two inscriptions, always in Greek, written in black ink against the plaster ground of the walls, accompany the representation of Jesus Christ. They contain prayers, up to five items, arranged in a certain order. The most complete set of prayers is found in the inscriptions discovered in Room 7 of the Northwest Annex to the Monastery on Kom H in Dongola. ${ }^{11}$ The prayers as contained in these inscriptions read as follows:

I. O Lord our God, who has accepted the offering of your saints our fathers Abraham and Isaac and Jacob, just like you have accepted the offering of the righteous Abel, the gifts of Noah, the offerings of all (those who are) yours, accept the offering of your servant in order that it is multiplied according to the proclamation sixtyfold, hundredfold, to our Lord, for he is blessed.

II. O Lord Jesus Christ, Word incomprehensible and without beginning together with your immaculate Father and the Holy Spirit, you are the bread that came down out of Heaven and did aforetime make yourself a lamb without spot for the life of the world, make your face shine on this bread and on this cup which are supplied on this table in order to change them through the apostolic service and priestly chant into your immaculate body and precious blood for preservation and refreshment of souls and bodies, for he is blessed.

$\overline{10}$ Some scholars (e.g., Gołgowski 2007: 48-49) mistakenly speak of Jesus dipping a piece of bread in the chalice.

11 See below, note 15. 


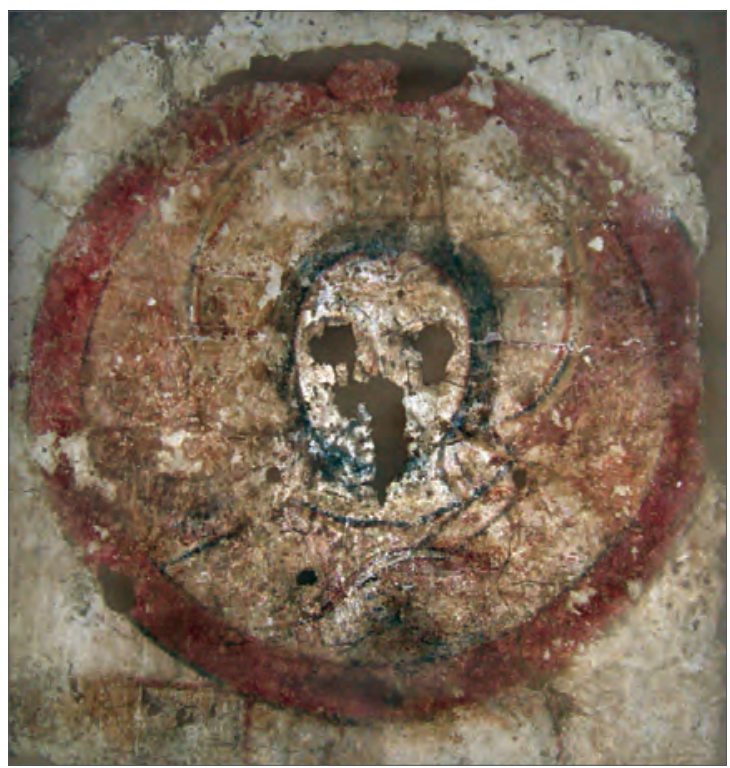

Fig. 4. Jesus Christ consecrating wine; northern pastophorium of the Petros Cathedral in Faras (KH 24311) (Photo D. Zielinska; courtesy of the Sudan National Museum in Khartoum)

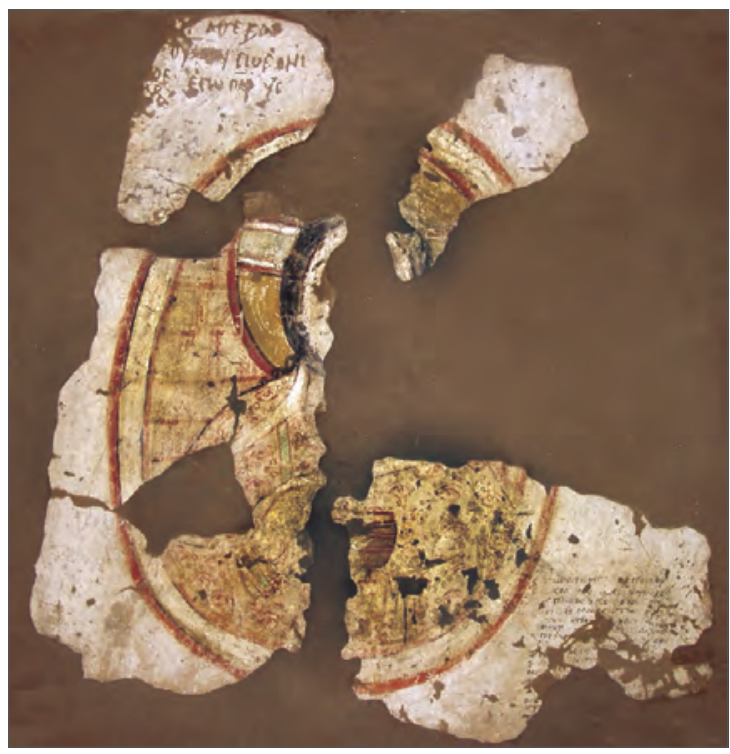

Fig. 5. Jesus Christ consecrating wine; northern pastophorium of the church in Sonqi Tino (KH 4346/D) (Photo D. Zielinska; courtesy of the Sudan National Museum in Khartoum) 
III. O Lord our God, you who are without beginning together with your immaculate Father and the Holy Spirit, you who have sprung himself for us from your immaculate side as a source of holiness, send down the power of your Holy Spirit on the mixture which is in this cup and make it change through the previously sacrificed piece, for the source of life is with you and we sing glory to you together with your immaculate Father.

IV. O Lord Jesus Christ our God, You who were present in Kana of Galilee and who blessed the wedding and made the water wine, bless this cup and offer it for the soundness of soul and body, for he is blessed.

V. What shall I give back to you, o Lord the King, from all of mine, for all those things you have given to me? I shall bring myself the chalices that are worthy in your holy place [-- ] you have made me through your holy and immaculate sacraments, but I beseech you, savior the only good one, release me from my affairs in order that with chaste heart and unashamed mouth I greet and glorify the only merciful one.

This decorative program has been attested five times so far:

(1) Northern pastophorium of the cathedral at Faras, from the period after its rebuilding by bishop Petros (second half of the 10th century) [Fig. 4]. ${ }^{12}$ The painting shows Jesus Christ in a tondo placed on the east wall, above the altar, and next to a niche, against a background imitating masonry bondwork. $\mathrm{He}$ is dressed in a robe covered with an eyes-motif. An unnaturally long finger underscores the consecration gesture. Of the chalice only the upper part was shown. The two inscriptions are located in the eastern part of the north wall of the room. One of them contains prayer I, and the other prayers II-IV.

(2) Northern pastophorium of church B.V on the citadel of Dongola. ${ }^{13}$ The painting on the east wall is very poorly preserved: a decorative plaited tondo frame and remains of a Jesus figure. One inscription was on the east wall, under the tondo, the other in the central part of the north wall. The inscription on the east wall gives the text of prayer II, that on the north wall of prayer III. The construction of church B.V can be dated to the end of the 8th century on architectural grounds (Godlewski 2013: 67). The painting of Jesus Christ and the accompanying inscriptions were thus created shortly after.

12 The northern pastophorium of the cathedral at Faras with all its equipment and decoration, including inscriptions, was presented by Kubińska (1976) and discussed by Gamber (1983: 28-30). Note that Gamber interpreted the find as connected with ordinary liturgy rather than with the Liturgy of the Presanctified Gifts. For a more accurate description of the northern pastophorium, see now Godlewski 2006: 104-106 with photos 89-93. For a photo of Jesus Christ, see Michałowski 1967: Pl. 11.

13 See note 7. To the works cited there add Zielińska 2015. 
(3) Northern pastophorium of a small church at Sonqi Tino [Fig. 5]. ${ }^{14}$ The painting, together with an accompanying inscription, was located in a niche in the east wall. The image was framed by an oval red band. It represents Jesus Christ in half figure wearing a white robe covered with an eyes-motif. The chalice, held by Jesus in His left hand, is shown in full. Horizontal stripes imitating glass decoration are visible on the chalice cup. The inscription situated to the bottom right of the oval contained only prayer III. Stylistic and epigraphic criteria suggest a date in the 10th century.

(4) Room 7 in the northern part of the Northwest Annex to the Monastery on Kom H at Dongola [Fig. 6]. ${ }^{15}$ The painting and an inscription with prayers II-V appeared in a niche in the east wall of the room. Another inscription with prayer I was found in the eastern part of the north wall. The painting is preserved only in its lower part. It shows Jesus Christ in half figure against a masonry bondwork pattern. One can see elements of Jesus's face, including eyes, and the upper part of a chalice. Room 7, together with neighboring rooms 1-6 and $8-9$, belonged originally to a tower-like structure built in the 10 th century near the northern end of the western girdle wall of the monastery. In the second half of the 11th century, it was incorporated into a commemorative complex arranged over three burial crypts and played the role of a pastophorium for the Eucharistic chapels 3 and 5 [Fig. 8]. The painting of Jesus Christ and the inscriptions are undoubtedly connected with this later stage of room use. ${ }^{16}$

(5) Room 27 in the southern part of the Northwest Annex to the Monastery on Kom $\mathrm{H}$ at Old Dongola [Fig. 7]. ${ }^{17}$ The painting and inscriptions are located

14 The dossier was never published entirely. It was briefly described in Donadoni 1970: 214; see also Vantini and Donadoni 1967: 254; Donadoni and Curto 1968; Zielińska 2012: 594. The painting was discussed in Pasi 2012: 572-573; Fig. 6. A good photo of it can be found in Martens-Czarnecka 1998: 89, Fig. 12. The inscription was mentioned in Donadoni 1975: 36, who cites, though not without mistakes, the initial invocation.

15 For a preliminary presentation of the find, see Jakobielski, Pluskota, and Zuurawski 1993: 294-295, with note 5, and 315, Fig. 6 (facsimile drawing of the painting of Jesus Christ). The painting (Cat. 23) is published in Martens-Czarnecka 2011: 52, Fig. 3; see also Jakobielski and Scholz 2001: Pl. XXII 1 (view of room 7 looking from the west) and 2 (photo showing the niche in the east wall with a representation of Jesus Christ and an inscription with prayers II-V). The inscriptions were briefly presented with English translation in Łajtar 1995: 55-61. Their final publication is being prepared by Adam Łajtar.

16 For the complex history of the northern part of the Northwest Annex to the Monastery on Kom H in Dongola, see Jakobielski 2001: passim, especially 143-144 and 164-168, and Godlewski 2013: 85-91.

17 The find was described briefly in Jakobielski 2001: 149, Fig. 9, Pl. XVII 2. The painting of Jesus Christ (Cat. 57) is published in Martens-Czarnecka 2011: 166-167, Fig. 79. A good photo of the painting and the inscription to the left of it is found in Martens-Czarnecka 1998: 87, Fig. 10. The publication of the inscriptions is being prepared by Adam Łajtar. 
The northern pastophorium of Nubian churches...

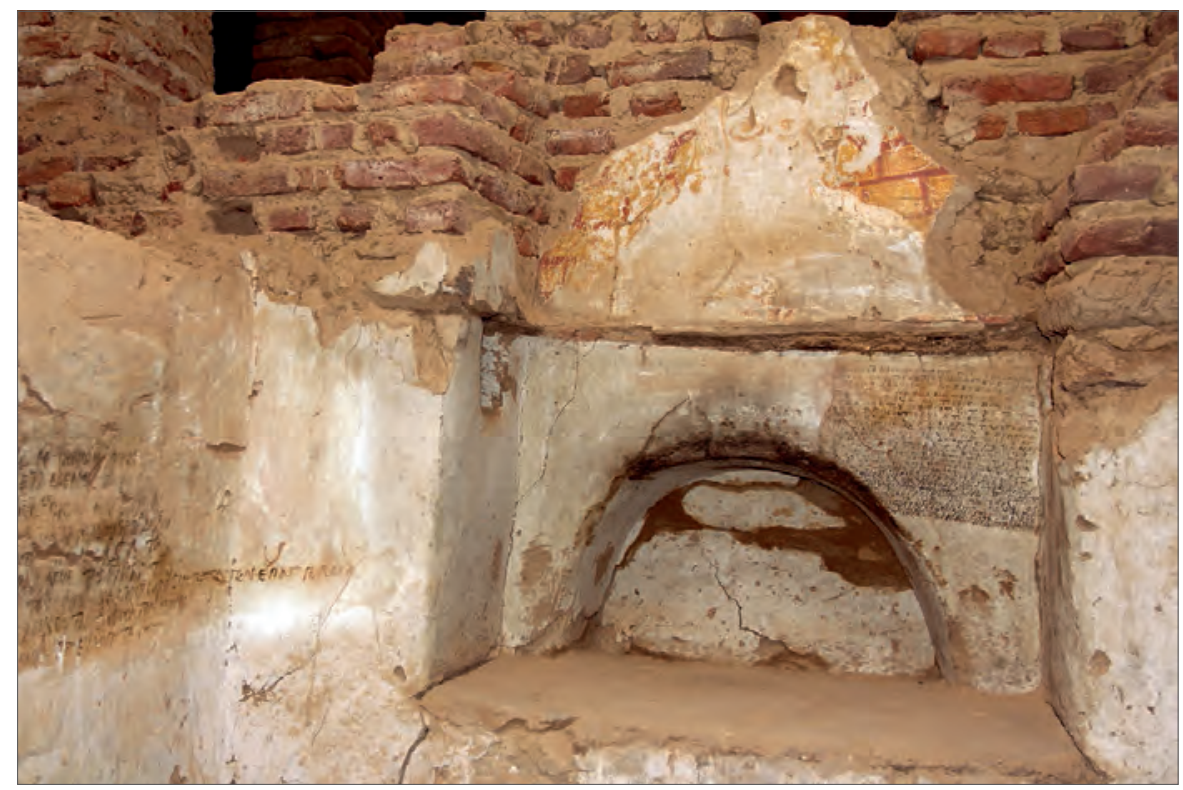

Fig. 6. Niche in the eastern room 7 of the Northwest Annex to the Monastery on Kom H in Old Dongola (Photo D. Zielinska; courtesy of the PCMA UW)

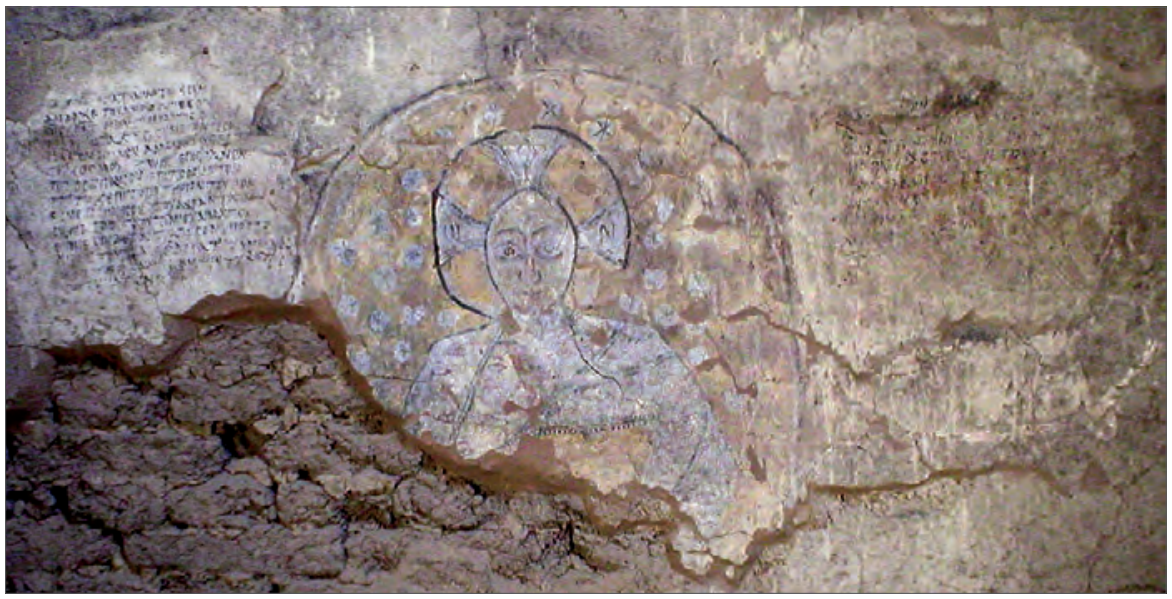

Fig. 7. Jesus Christ consecrating wine; room 27 of the Northwest Annex to the Monastery on Kom H in Old Dongola (Photo D. Zielinska; courtesy of the PCMA UW) 
on the east wall of the room, above an altar. The painting represents Jesus Christ in an oval frame, depicted in half figure, wearing a white robe covered with an eyes-motif. The background of the oval is filled with a firmament full of white stars on a yellow background. The upper part of a yellow chalice with a decorated rim is visible at the bottom of the representation. ${ }^{18}$ An inscription is placed on either side of the representation of Jesus Christ. The one on the left-hand side contains prayer II, the other prayer III. Room 27, together with the adjacent rooms $22,24,25,26,28$, was built in the 10 th century. In the mid-11th century, it was incorporated into a liturgical space (church) and served as a pastophorium for the Eucharistic chapels 29 and 31, and later also 13 [see Fig. 8]..$^{19}$ The painting of Jesus Christ and the inscriptions are connected undoubtedly with this later period of the use of this room.

Judging from laconic excavation reports, Jesus Christ consecrating the chalice might have been represented also on the east wall of the northern pastophorium of the so-called Raphael's Church in Tamit. ${ }^{20}$ The church in question is dated to the 11 th century, the painted decoration to the 11 th -12 th century (first phase) and 12th century (second phase). The painting of Jesus Christ should have belonged to the first phase (Baldassare 1967: 59). The same subject was found possibly also in a niche in the east wall of the northern pastophorium of the central church in Serra. ${ }^{21}$ The photo of the painting shows Jesus clad in a robe covered with an eyes-motif, a type of vestment characteristic of the representations discussed in this paper (Tsakos and Zielińska 2014: 125, Fig. 10). The church is dated to 11 th-12th century on formal grounds. ${ }^{22}$ Its painted decoration must have come into existence shortly after.

The prayers in the inscriptions are found also on two leaves of parchment, most probably coming from a euchologion, found on the floor of the cathedral

18 The chalice is wrongly identified as a book in the description of Cat. 57 in Martens-Czarnecka 2011, although the author rightly ranks the painting amongst those with a chalice in another place of the same work (p. 165).

19 For the history of the southern part of the Northwest Annex to the Monastery on Kom $\mathrm{H}$ in Dongola, see Jakobielski 2001: passim, especially 147-153, and Godlewski 2013: 85-91.

20 Baldassare 1967: 44. The author qualifies the painting as one of the numerous representations of Jesus Christ. The identification of the iconographic type suggested in this paper is based on the observation that Jesus is shown on a background of painted masonry bondwork. Reportedly, the painting was transferred and stored at the Coptic Museum in Cairo.

21 For the church in question, see Griffith 1927: 101, 113, Pl. LXXIX/1.

22 Bruce Williams, personal communication, mirroring the current state of research by the Oriental Institute of the University of Chicago on the final publication of the Central Church in Serra. For the previous dating, see Adams 2009: 321-323. 
at Qasr Ibrim. ${ }^{23}$ It is assumed that the euchologion could have belonged to the cathedral library robbed and dispersed during the sack of Qasr Ibrim by the troops of Shams el-Dawla in 1172/1173. Palaeographic criteria suggest that it might have been written in the $11 \mathrm{th} / 12$ th century.

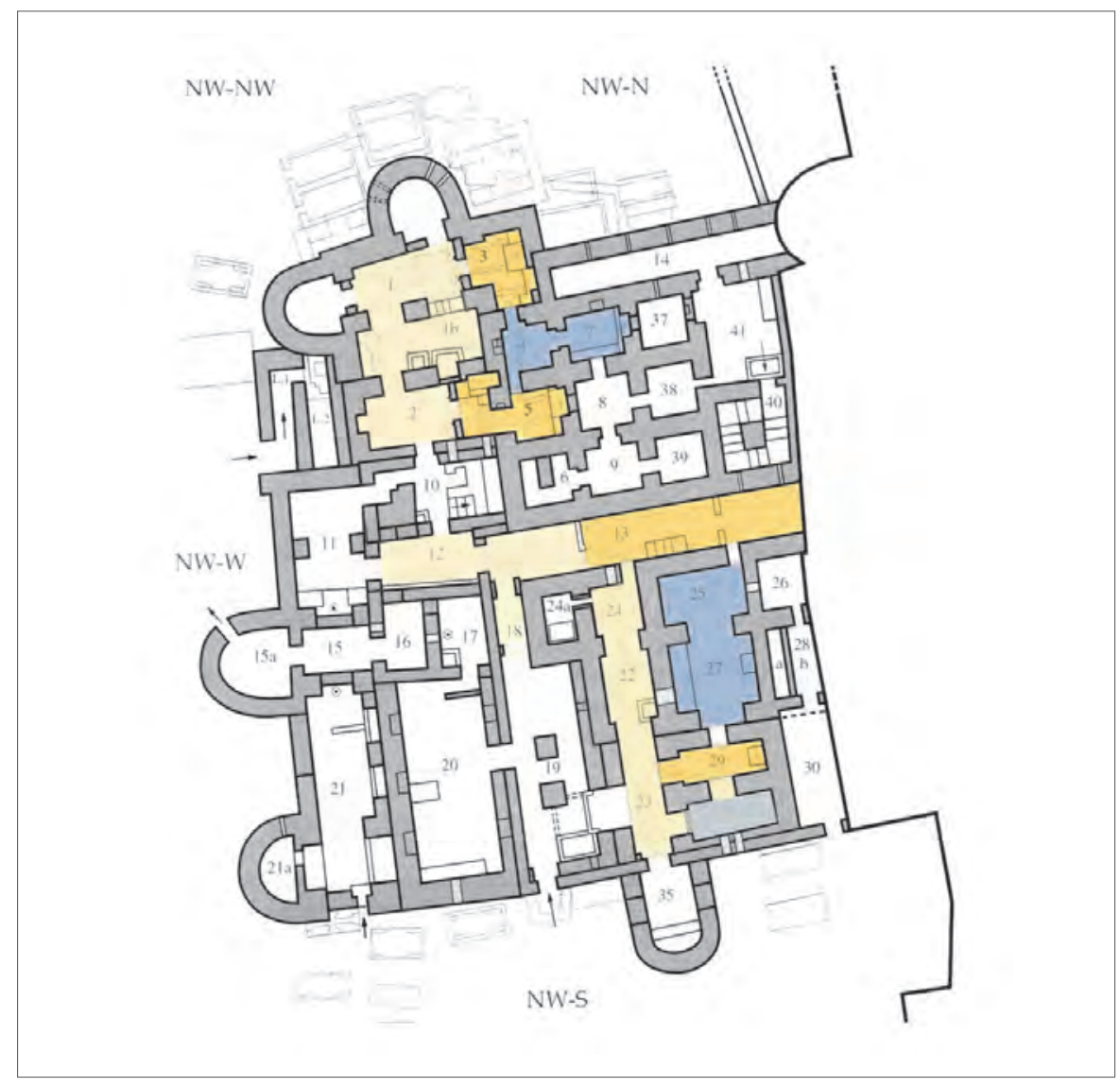

Fig. 8. Plan of the Northwest Annex to the Monastery on Kom H in Old Dongola with the function of the rooms indicated in color: sanctuaries marked in yellow, pastophoria in blue (Plan after Jakobielski and Scholz 2001: 157, Fig. 14)

23 The leaves were published separately and their texts were identified as anaphoric prayers. Leaf (1): Frend, Dragas, and Kontoyiannis 1992: 130-131, Pl. 4a, who recognised an offertory prayer resembling the offertory prayer from the Liturgy of St James. Leaf (2): Frend and Muirhaid 1976: 45-47, who identified the text as the offertory prayer of the Liturgy of St Mark. The leaves were connected and identified as containing prayers of the Nubian Liturgy of the Presanctified Gifts in Łajtar 1996. 
Representations of Jesus Christ blessing the chalice are unknown in Egypt. However, there is a similar motif of Ecclesia with the chalice, found in Chapel 17 of the monastery of St Apollo in Bawit [Fig. 9] (Clédat 1906: 76, Pl. XLV,1), and also in the church at Naqa el-Oqba, which, although situated in northern Nubia, definitely represents an Egyptian tradition. ${ }^{24}$ The iconographic type of Christ consecrating wine has no parallels in Byzantine art. The closest analogies are supplied by representations of Jesus Christ in the miniature illuminations in Syriac codices from the 11th and 13th centuries [Fig. 10] (Leroy 1964: 88, Figs 3, 4). They come as part of the scene of the Last Supper, thus being representations of Christ establishing the tradition of the Eucharistic liturgy.

The prayers accompanying Nubian representations of Jesus Christ blessing the wine are undoubtedly of liturgical character. The order of their appearance on the walls follows the order of the liturgy. Textually and theologically, the prayers have a number of analogies in various Oriental liturgies, even if none of them are attested in exactly this form elsewhere. ${ }^{25}$

Prayer I represents a text widely known in numerous variants and translations

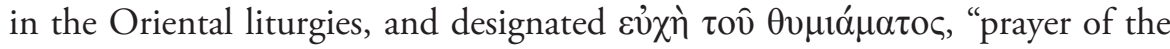
frankincense", because it frequently contains a request for acceptance of an offering of frankincense. The text apparently was of Palestinian origin and could have come into existence still in late antiquity. ${ }^{26}$ Apparently the Nubian version

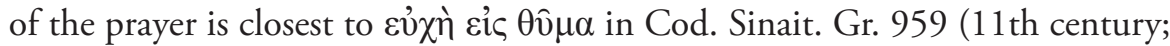
Dmitrievskij 1901: 46-47). Equally similar to the Nubian version of the prayer

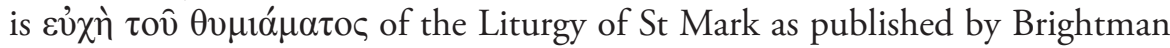
on the basis of Vat. Gr. 1970 (Brightman 1965: 129). An interesting element of the Nubian version of the prayer is that it lacks the mention of frankincense $(\theta v \mu i ́ \alpha \alpha)$, which suggests that it was used in a different context within the liturgy here discussed. It could generally be designated as a "prayer for acceptance of the offerings". Another point of interest is the place of the prayer within the

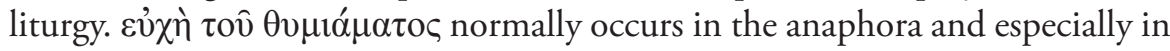
the intercession (so in the Liturgy of St Mark); here the prayer is placed at the very beginning of the liturgy, before the prothesis. One should observe further

24 Firth 1927: 235, Pl. 30b; Monneret de Villard 1935: 80; 1957: Pl. CXXXVIII (in both cases as letter "F"). St Stephen, Deacon and Protomartyr, appears near that of Ecclesia and is depicted also holding a chalice, which prompted earlier scholars to identify him wrongly as Jesus Christ; see Firth 1927: 235; Monneret de Villard 1935: 80 (in both cases as letter "D”); the new identification was suggested by G.J.M van Loon in Zielińska et al. forthcoming.

25 For an analysis of the prayers, see Brakmann 2006: 320-324.

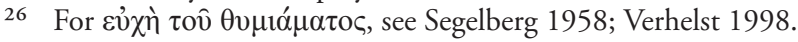


The northern pastophorium of Nubian churches...

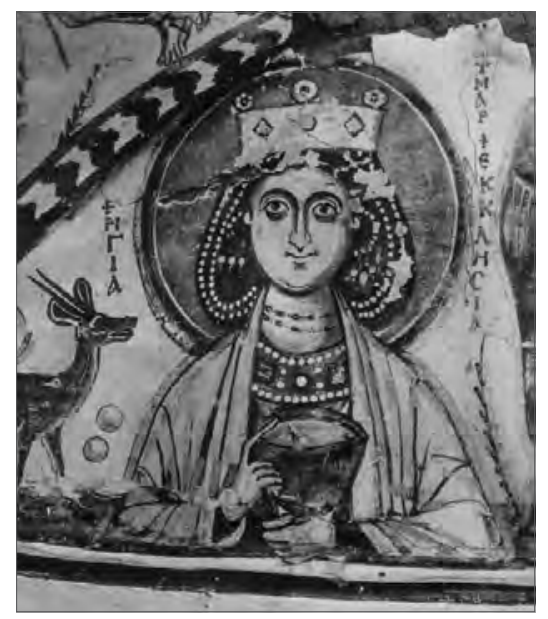

Fig. 9. Ecclesia; painting in chapel XVII of the Monastery of St Apollo in Bawit (After Clédat 1906: Pl. XLV)

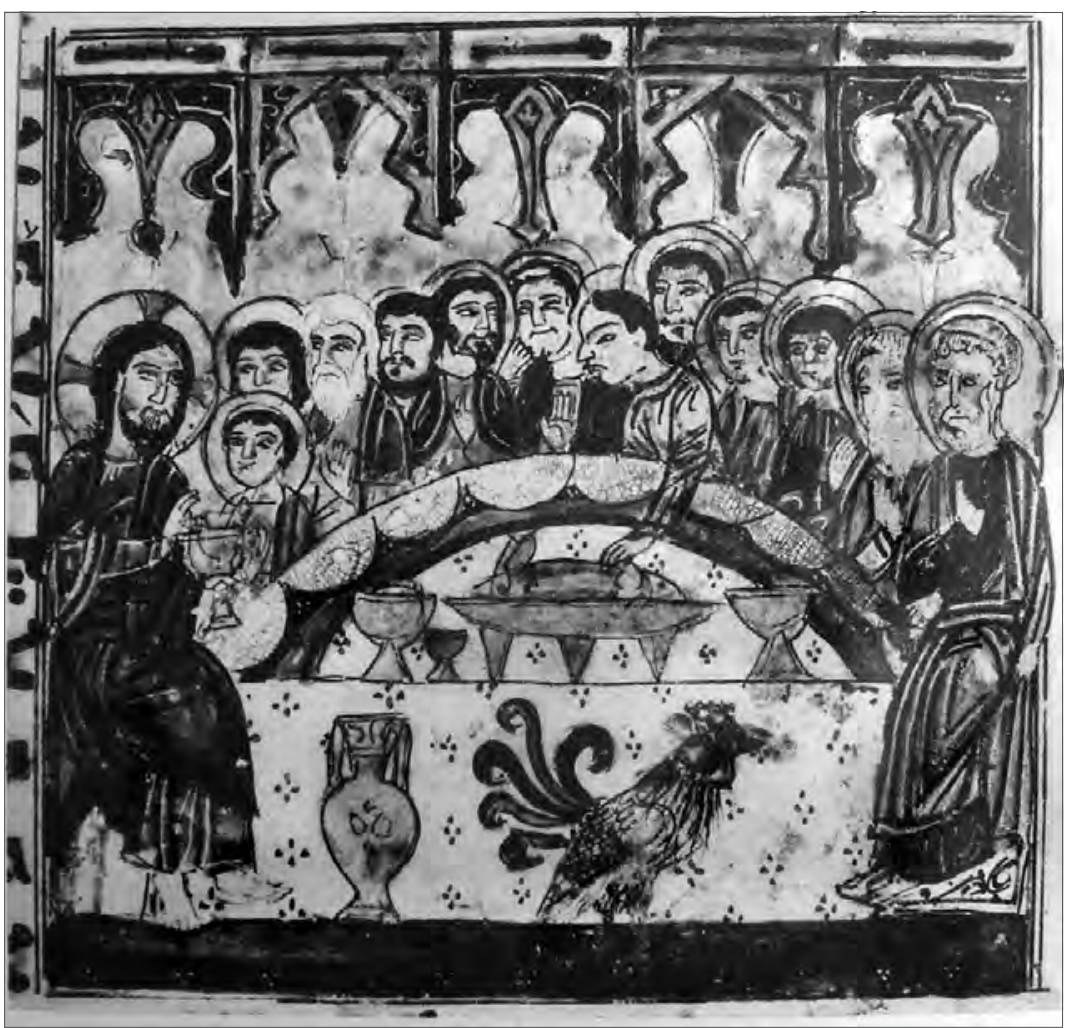

Fig. 10. Last Supper; illumination of a Syriac manuscript, Vatican Library Syr. 558, Folio 128r (After Leroy 1964: 88, Fig. 4) 
that the prayer was inscribed separately in testimonies (1) and (4). This may indicate that it had a somewhat independent status. Perhaps it could have been recited alone, e.g., over the gifts brought to the church by the believers.

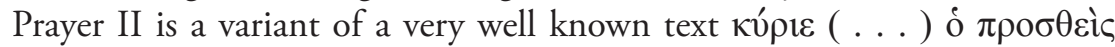

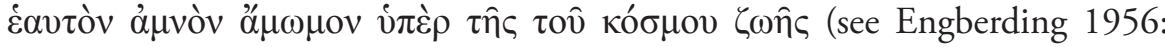
41-46). The main characteristic of this text is an explicit epiklesis over bread and wine. The text is found in various Oriental liturgies in which it always appears at the beginning of the liturgy, though the exact context may vary from one liturgy to the next. In the Alexandrian-Egyptian liturgies, e.g., in the Liturgy of St Mark ${ }^{27}$ and the liturgy of St Basil as contained in the Kacmarcik

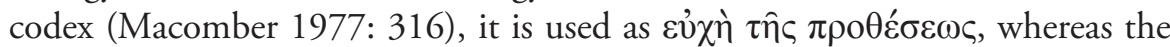
Liturgy of the Abyssinian Jacobites places the text in the enarxis (Brightman 1965: 204). The same prayer is found in the famous illustrated liturgical roll (Constantinople, 12th-13th century), once kept in the Russian Archaeological Institute in Istanbul, now in the State Public Library in Saint Petersburg, as an addition over the form of the Greek (Byzantine) Liturgy of the Presanctified Gifts. ${ }^{28}$ In the Nubian liturgy examined here, similarly as in the AlexandrianEgyptian liturgies, the prayer in question most probably played the role of $\varepsilon \hat{x} \chi \grave{\eta} \tau \hat{\uparrow} \varsigma \pi \rho \circ \theta \varepsilon \varepsilon_{\sigma \varepsilon \omega \varsigma}$. It should be noted that the version of the prayer used in Nubia must be an Egyptian composition, perhaps created on the model of or in

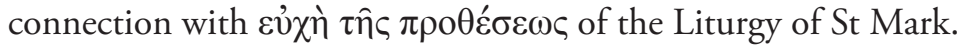

Prayer III is the actual consecration prayer in the liturgy here discussed. Among the Copts, this prayer has an analogy in the Prayer for the Consecration of the Wine from the Rite of the Filling of the Chalice (Al-Masri 1940). Outside the Nile Valley, a parallel can be found in the consecration prayer of the Syrian Liturgy of the Presanctified Gifts of St Severus (Codrington 1902: 75). Parts of this prayer, e.g., the reference to a drink from the side of Christ and to the mixture in the chalice, find a parallel in another prayer of the same Syrian Liturgy of the Presanctified Gifts of St Severus, namely in the so-called sedro (entrance) prayer (Codrington 1902: 73). Still closer to it, both in wording and in theological contents, is the prayer for the consecration of wine used in the Syrian Maronite church outside the Liturgy (Graf 1916).

27 Cuming 1990: 4. It should be noted that the text of the prayer as given by Cuming in his edition follows that of Ms. Vat. Gr. 2281. The text of the same prayer in Vat. Gr. 1970, which was the base of the edition of the St Mark liturgy in Brightman 1965, shows some variant readings.

28 Farmakovskij 1900. It should be stressed that the prayer in question does not belong to the form of the Greek (Byzantine) Liturgy of the Presanctified Gifts. It must have been copied into the roll from another source, perhaps from an Egyptian-type Presanctified. 
Prayer IV is the second prayer over the chalice. It makes an appeal to the wedding at Kana, and asks for a blessing over the chalice to ensure the soundness of the believers' souls and bodies. The text finds an exact parallel in the so-called second prayer of the nuptials over the chalice of the liturgy of the Abyssinian Jacobites (Brightman 1965: 200). Interestingly, the prayer is placed there in the prothesis, while here it occurs in the anaphora, immediately after the consecration.

Prayer V is composed in the first person singular. The "I" style and the content indicate that we are dealing with a private prayer by a priest expressing gratitude to God for the communion. Similarly worded prayers occur in various Oriental liturgies either in thanksgiving or in other places. ${ }^{29}$ Also the Roman mass has an analogous prayer of post-communion "Quid retribuam Domino". ${ }^{30}$ The closest analogy is probably yielded by the oratio super mysteria in the socalled Baumstark Alexandrian liturgy (Baumstark 1901: 28-29).

The prayers can be identified without any doubt as belonging to the textual content of a Liturgy of Presanctified Gifts. This is demonstrated most clearly

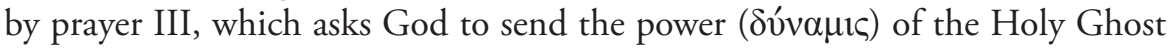
onto the mixture $(\kappa \rho \hat{\alpha} \mu \alpha)$ contained in the cup in order that it be transformed into the blood of Jesus Christ through the previously consecrated particle ( $\delta i \grave{\alpha}$ $\tau \hat{n} \varsigma \pi \rho \circ \eta \gamma(\alpha \sigma \mu \varepsilon \dot{v} \eta \varsigma \mu \varepsilon \rho i \delta \delta \varsigma)$. The designation "the previously consecrated

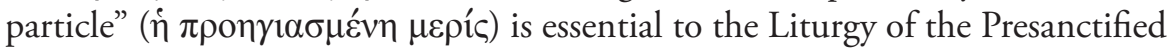
Gifts and gives it its Greek name ( $\tau \dot{\alpha} \pi \rho 0 \eta \gamma 1 \alpha \sigma \mu \varepsilon \dot{v} \alpha)$. As was shown above, the liturgy transmitted through the inscriptions in the northern pastophoria of the Nubian churches and through the parchment leaves from Qasr Ibrim has no exact parallels among known forms of the Liturgy of the Presanctified Gifts. Perhaps we are dealing with the Presanctified of St Mark, of which it is known that it once existed, but which is lost with the exception of one prayer (see Brakmann 2006: 321, note 184). The supposition is quite plausible, since on the one hand the characteristically Egyptian Liturgy of St Mark was the main type of liturgical celebration in Nubia, and on the other hand Egyptian traits are clearly observable in the prayers here discussed.

The Liturgy of the Presanctified Gifts (also called Liturgy of the Presanctified or simply Presanctified) came into existence in the Syrian region during late antiquity, more specifically in the 6th century $\mathrm{AD},{ }^{31}$ and spread quickly through

29 See for example the prayer of the Lord's Prayer in the Liturgy of St Mark (Brightman 1965: 135-136).

30 For this prayer, see Jungmann 1948: 429.

31 Generally for the Liturgy of the Presanctified, see Ziadé 1936. Specifically for the Byzantine Presanctified, see Alexopoulos 2009. For the Syrian Presanctified, see Codrington 1902; 1904; 1908; Rajji 1918-1919; Graf 1916. 
the entire Christian world including Constantinople. It was commonly used in Oriental Churches throughout the Middle Ages, even if the documentation at our disposal concerns mainly the Greek Orthodox Church and the Churches of the Syrian area, including the Jacobite Church, the Nestorian Church, the Syrian Melkite Church, and the Maronite Church. ${ }^{32}$ It was abandoned at the beginning of the modern era everywhere with the exception of the Greek Orthodox Church. The Liturgy of the Presanctified serves the purpose of distributing the Holy Communion, in the form of bread and wine, outside the regular Eucharistic liturgy. Its main feature is the consecration of the Eucharistic wine with the help of a previously consecrated piece of bread kept from the last performed regular liturgy. The chalice full of the new wine is blessed with the sign of cross with the help of the already consecrated bread (this is especially characteristic of the Syrian variant of the Liturgy) and the bread is finally dipped into the wine.

In the Greek Orthodox Church, the Liturgy of the Presanctified is essentially a cathedral rite celebrated with solemnity according to a strict form. It is used mainly on aliturgical days of the Lent (all days except for Saturdays, Sundays and the Annunciation) and on some other occasions, both regular and irregular. There is also information that it was celebrated as a private rite, too, resembling the private Presanctified of the Syrian churches. In Churches of the Syrian area, the Liturgy of the Presanctified is of distinctly double character. It is either an "official" rite celebrated in a church on firm dates and according to an established form, or a "private" one served on occasions, according to a much-abbreviated form or without an obligatory form. The "official" rite, like its Byzantine counterpart, was celebrated first of all in Lent as well as some other feasts during the liturgical year. As for the "private" Liturgy of the Presanctified, "it appears to have been used in lieu of the ordinary liturgy whenever the latter was inconvenient" (Codrington 1902: 70). A canon of the Jacobite patriarch Theodosius (died AD 896) ordered its celebration when the oblations had been brought to the church by the congregation and there was no need of mass, and even permitted a deacon to "sign the chalice" in the absence of a priest (Codrington 1902: 70; Ziadé 1936: 85). Ja'qûb of Edessa (died $\mathrm{AD} 708$ ) mentions its use by anchorites in priest's orders either in solitude or in community, and leaves it to the discretion of the celebrant to recite any or none of the prescribed prayers. The same author also permits the priest to "sign the

32 The practice of keeping the liturgical reserve is attested also among the Copts of the medieval period; see Nussbaum 1979: 25-26. The available attestations refer to Alexandria and the St Makarios Monastery in Sketis. 
chalice" with the host for the communion of the sick and those who fast until the evening (Codrington 1902: 70; 1904: 371; Graf 1916: 48; Ziadé 1936: 85).

The use of the Liturgy of the Presanctified in the Nubian Church is difficult to assess on the basis of the available evidence. The occurrence of the specific decoration connected with this liturgy in the cathedral of Faras, the "royal" church B.V in Dongola, and the "parochial" church at Sonqi Tino leads us to suppose that the liturgy under consideration was celebrated in Nubia as a regular, most probably Lenten office. This supposition is further corroborated by the Qasr Ibrim parchment leaves with the prayers from this Liturgy, which, as was suggested above, most probably come from an euchologion originally belonging to the cathedral of Qasr Ibrim. However, the dossiers from Rooms 7 and 27 of the Northwest Annex to the Monastery on Kom H at Old Dongola situate the Nubian Liturgy of the Presanctified in a less formal sphere. Room 7 was part of a burial complex of some high-ranking officials, possibly archbishops of Old Dongola, which seems to suggest that the liturgy in question could have been used in the commemoration of the dead. Room 27 served as a pastophorium for a "church" created around 1050 by Georgios, the future bishop of Dongola, possibly as his private foundation and a means of glorification of his achievements. Here, the Liturgy of the Presanctified could have been celebrated for him, his close collaborators and members of his family on the occasion of their visits to the Annex. Another occasion for the celebration of the Liturgy was probably when members of the congregation brought offerings to the Church outside the regular Eucharistic liturgy. The offerings were stored in the northern pastophorium and the donators were remunerated with communion. It should be kept in mind that the northern pastophorium of the cathedral at Faras boasted numerous ceramic containers, most probably for storing the prosphora, while a priest with two big (wine) jars is represented on the north wall of the northern pastophorium of church B.V in the citadel of Dongola.

Whatever range of use the Liturgy of the Presanctified has in the Nubian church, one can observe that paradoxically, it is the best-known type of a liturgical celebration in Christian Nubia. The importance of this specific liturgy for Nubians is further confirmed by the creation of a fixed decorative program as far as both the image and the text are concerned. The earliest attestations of this program can be dated to the turn of the 9th and the 10th century, and it may safely be assumed that it came into existence not very long before that. The textual part of the program was based on the prayers taken verbatim from the contents of the liturgy as transmitted in the euchologia and read during liturgical celebrations. The visual part made use of the known iconographical motif of Jesus blessing the chalice, probably adapted from a different context, 
but interpreted in a new manner. According to this new interpretation, Jesus is the priest who consecrates the wine with the help of his own body in order to change it into his own blood. Jesus's presence is symbolically underlined by the tondo, which sometimes frames the representation. ${ }^{33}$ This representation of Jesus may be considered an original Nubian creation, since it is to our knowledge unknown outside Nubia.

The question arises why such a decorative program was located in the northern pastophorium. Several reasons can be proposed. First, the northern pastophorium was the place where the prosphora and liturgical vessels were stored, and the physical presence of which, especially of the chalice, is very important for the Liturgy of the Presanctified. Second, the northern pastophorium in Nubian churches could have been the place for keeping the liturgical reserve: the consecrated bread, with the help of which wine was consecrated during the Liturgy of the Presanctified Gifts. Finally, it is also possible that this room was the place for celebrating the liturgy under consideration. Such a scenario can easily be imagined, especially in the case of private celebrations, when a small number of people was assembled and a solemn integument was not required. This may have been the case with accepting the prosphora brought to the Church by believers, or the commemorative ceremonies that took place in small interiors of monastic complexes. On the other hand, the regular Liturgy of the Presanctified Gifts during Lent would have taken place rather on the main altar in the naos.

\section{References}

Adams, W.Y. (1965). Architectural evolution of the Nubian Church, 500-1400 A.D. Journal of the American Research Center in Egypt, 4, 87-139

Adams, W.Y. (2009). The churches of Nobadia [=Sudan Archaeological Research Society Publications 17; British Archaeological Reports International Series 2000]. Oxford: Archaeopress

Al-Masri, I.H. (1940). The rite of the filling of the chalice. Bulletin de la Société d'archéologie copte, 6, 77-90

Alexopoulos, S. (2009). The presanctified liturgy in the Byzantine rite: A comparative analysis of its origins, evolution, and structural components [=Liturgia condenda 21]. Leuven: Peeters

33 For the symbolism of the tondo in Christian art, which goes back to the Roman imperial imago clipeata, see Grabar 1957. 
Babić, G. (1969). Les chapelles annexes des églises byzantines: fonction liturgique et programmes iconographiques [=Bibliothèque des cahiers archéologiques 3]. Paris: Klincksieck

Baldassare, I. (1967). Le pitture. In Tamit (1964). Missione archeologica in Egitto dell'Università di Roma [=Serie Archeologica 14] (pp. 39-60). Rome: Istituto di Studi del Vicino Oriente

Baumstark, A. (1901). Eine aegyptische Mess- und Taufliturgie vermutlich des 6 . Jahrhunderts. Oriens Christianus, 1, 1-45

Brakmann, H. (2006). Defunctus adhuc loquitur: Gottesdienst und Gebetsliteratur der untergegangenen Kirche in Nubien. Archiv für Liturgiewissenschaft, 48(3), 283-333

Brightman, F.E. (ed.). (1965). Liturgies, eastern and western I. Eastern liturgies (reprint of the 1896 ed.). Oxford: Clarendon Press

Clédat, J. (1906). Le monastère et la nécropole de Baouît I.2 [=Mémoires publiés par les membres de l'Institut français d'archéologie orientale 12]. Cairo: Institut français d'archéologie orientale

Codrington, H.W. (1902). The Syrian liturgies of the Presanctified. The Journal of Theological Studies, 4(13), 69-82

Codrington, H.W. (1904). The Syrian liturgies of the Presanctified II. The Journal of Theological Studies, 5(19), 369-377

Codrington, H.W. (1908). Liturgia praesanctificatorum syriaca Sancti Joannis Chrisostomi. In Chrysostomika: studi e richerche intorno a S. Giovanni Crisostomo (pp. 719-729). Rome: Pustet

Cuming, G.J. (ed.). (1990). The liturgy of St. Mark [=Orientalia Christiana analecta 234]. Rome: Pontificium Institutum Studiorum Orientalium

Ćurčić, S. (1977). Architectural significance of subsidiary chapels in Middle Byzantine churches. Journal of the Society of Architectural Historians, 36(2), 94-110

Dmitrievskij, A.A. (1901). Opisanie liturgičeskih rukopisej hranâsihssâ v bibliotekah Pravoslavnogo Vostoka II. Euhologia [Description of the liturgical manuscripts preserved in the libraries of the Orthodox East II. Euchologia]. Kiev: Universitet Sv. Vladimira [in Russian]

Donadoni, S. (1970). Les fouilles à l'église de Sonqi Tino. In E. Dinkler (ed.), Kunst und Geschichte Nubiens in christlicher Zeit: Ergebnisse und Probleme auf Grund der jüngsten Ausgrabungen (pp. 209-218). Recklinghausen: A. Bongers

Donadoni, S. (1975). Les graffiti de l'église de Sonqi Tino. In K. Michałowski (ed.), Nubia: récentes recherches. Actes du Colloque nubiologique international au Musée national de Varsovie 19-22 Juin 1972 (pp. 31-39). Warsaw: National Museum in Warsaw

Donadoni, S. and Curto, S. (1968). Le pitture murali della chiesa di Sonki nel Sudan. La Nubia cristiana [=Quaderno del Museo egizio di Torino 2]. Turin: Museo egizio

Engberding, H. (1956). Neues Licht über die Geschichte des Textes der ägyptischen Markusliturgie. Oriens Christianus, 40, 40-68 
Farmakovskij, B.W. (1900). Vizantijskij pergamennyj rukopisnyj svitok s miniatǔrami, prinadležaŝyj Russkomu Arheologičeskomu Institutu v Konstantinopole [Byzantine illuminated parchment manuscript from the Russian Archaeological Institute in Constantinople]. Izviestâ Russkogo Arheologičeskogo Instituta v Konstantinopole, 6(2), 253-360 [in Russian]

Firth, C.M. (1927). The archeological survey of Nubia. Report for 1910-1911. Cairo: Government Press

Frend, W.H.C., Dragas, G.D., and Kontoyiannis, S. (1992). Some further Greek liturgical fragments from Q'asr Ibrim. Jahrbuch für Antike und Christentum, 35, 119-134

Frend, W.H.C. and Muirhaid, I.A. (1976). The Greek manuscripts from the Cathedral of Q'asr Ibrim. Le Muséon, 89, 43-49

Gamber, K. (1983). Zur Liturgie Nubiens. Die Kathedrale von Faras und ihre Wandmalereien. Ostkirchliche Studien, 32, 21-35

Gauthier, H. (1911). L'église nubienne d'es-Sebouâ. In G. Maspero, Les temples immergés de la Nubie. Rapports relatifs à la consolidation des temples I (pp. 111-121). Cairo: Institut français d'archéologie orientale

Godlewski, W. (1979). Les baptistères nubiens [=Faras 6]. (Z. Kiss, trans.). Warsaw: Éditions scientifiques de Pologne

Godlewski, W. (1987). The Nubian Seraphim. In P.O. Scholz and R. Stempel (eds), Nubia et Oriens Christianus: Festschrift für C. Detlef G. Müller zum 60. Geburtstag [=Bibliotheca Nubica 1] (pp. 367-371). Cologne: J. Dinter

Godlewski, W. (1990). The Northern Church in Old Dongola. Archéologie du Nil moyen, 4, 37-62

Godlewski, W. (2006). Pachoras: The cathedrals of Aetios, Paulos and Petros. The architecture [=PAM Supplement Series 1]. Warsaw: Warsaw University Press

Godlewski, W. (2013). Dongola: Ancient Tungul. Archaeological guide [=PCMA Archaeological Guides 1]. Warsaw: PCMA UW

Godlewski, W. (2015). Building SWN.B.V: The Church of Raphael. In W. Godlewski and D. Dzierzbicka (eds), Dongola 2012-2014. Report on work in the Mosque Building, Citadel and Monastery on Kom H [=PCMA Excavation Series 3] (pp. 5364). Warsaw: PCMA UW

Gołgowski, T. (2007). Liturgia w Nubii i problem jej rekonstrukcji [The liturgy in Nubia and the problem with its reconstruction]. Saeculum Christianum, 14(1), 43-51 [in Polish]

Grabar, A. (1957). L'imago clipeata chrétienne. Comptes rendus de l'Académie des inscriptions et belles-lettres, 101(2), 209-213

Graf, G. (1916). Konsekration außerhalb der Messe: Ein arabisches Gebetsformular mitgeteilt und liturgiegeschichtlich erläutert. Oriens Christianus, 6, 44-48

Griffith, F.L. (1927). Oxford excavations in Nubia. Liverpool Annals of Archaeology and Anthropology, 14, 57-116

Griffith, F.L. (1928). Oxford excavations in Nubia, LVI-LXI: The church at Abd el-Qadir. Liverpool Annals of Archaeology and Anthropology, 15, 63-88 
Jakobielski, S. (2001). Das Kloster der Heiligen Dreifaltigkeit. Bauphasen des nordwestlichen Anbaus. In S. Jakobielski and P.O. Scholz (eds), Dongola-Studien: 35 Jahre polnischer Forschungen im Zentrum des makuritischen Reiches [=Bibliotheca Nubica et Aethiopica 7] (pp. 141-168). Warsaw: ZAŚ PAN

Jakobielski, S., Pluskota, K., and Żurawski, B. (1993). Polish excavations at Old Dongola, twenty-fifth season 1991/92. Kush, 16, 310-325

Jakobielski, S. and Scholz, P.O. (eds). (2001). Dongola-Studien: 35 Jahre polnischer Forschungen im Zentrum des makuritischen Reiches [=Bibliotheca Nubica et Aethiopica 7]. Warsaw: ZAŚ PAN

Jungmann, J.A. (1948). Missarum sollemnia: eine genetische Erklärung der römischen Messe II. Vienna: Herder

Kubińska, J. (1976). Prothesis de la Cathédrale de Faras. Documents et recherches. Revue des Archéologues et Historiens d'Art de Louvain, 9, 7-37

Leroy, J. (1964). Les manuscrits syriaques à peintures conservés dans les bibliothèques d'Europe et d'Orient. Contribution à l'étude de l'iconographie des Eglises de langue syriaque I-II [=Bibliothèque archéologique et historique 77]. Paris: P. Geuthner

Łajtar, A. (1995). Greek inscriptions from the monastery on Kom H in Old Dongola. In M. Starowieyski (ed.), The spirituality of ancient monasticism: Acts of the International Colloquium, held in Cracow-Tyniec, 16-19th November 1994. Specialized contributions (pp. 47-61). Tyniec: Wydawnictwo Benedyktynów

Łajtar, A. (1996). Varia Nubica III. Ein liturgisches Gebet aus Qasr Ibrim. Zeitschrift für Papyrologie und Epigraphik, 112, 140-142

Łajtar, A. (2015). Wall inscriptions in church B.V on the Citadel of Dongola: Report on work in the 2014 season (with an appendix: Inscriptions discovered in previous seasons). In W. Godlewski and D. Dzierzbicka (eds), Dongola 2012-2014. Report on work in the Mosque Building, Citadel and Monastery on Kom $H[=P C M A$ Excavation Series 3] (pp. 111-116). Warsaw: PCMA UW

Macomber, W.F. (1977). The Greek text of the Coptic Mass and of the Anaphoras of Basil and Gregory according to the Kacmarcik Codex. Orientalia Christiana Periodica, 43, 308-334

Martens-Czarnecka, M. (1998). An attempt to define the function of selected rooms at the Monastery in Old Dongola. Gdańsk Archaeological Museum African Reports, 1, 81-93

Martens-Czarnecka, M. (2011). The wall paintings from the Monastery on Kom H in Dongola [=Nubia 3; Dongola 3; PAM Monograph Series 3]. (B.M. Gostyńska, trans.). Warsaw: Warsaw University Press

Medić, M. (1965). Radovi na spomenicima [Work on monuments]. Zbornik zaštite spomenika, 16, 41-80 [in Serbian]

Michałowski, K. (1964). Polish excavations at Faras, 1962-63. Kush, 12, 195-207

Michałowski, K. (1967). Faras: die Kathedrale aus dem Wüstensand. Einsiedeln-ZürichCologne: Benziger

Michałowski, K. (1974). Faras: Wall paintings in the collection of the National Museum in Warsaw. Warsaw: Wydawnictwo Artystyczno-Graficzne 
Mileham, G.S. (1910). Churches in lower Nubia. Philadelphia: University Museum

Monneret de Villard, U. (1935). La Nubia medioevale I. Cairo: Institut français d'archéologie orientale

Monneret de Villard, U. (1957). La Nubia medioevale IV. Cairo: Institut français d'archéologie orientale

Nussbaum, O. (1979). Die Aufbewahrung der Eucharistie [=Theophaneia 29]. Bonn: Hanstein

Pasi, S. (2012). I dipinti della chiesa di Sonqi Tino in Nubia. Scienze dell'Antichità, 18, 571-595

Rajji, M. (1918-1919). Une anaphore syriaque de Sévère pour la messe des présanctifiés. Revue de l'Orient Chrétien, 21, 25-39

Segelberg, E. (1958). Euche tou Thumiamatos. Towards the history of a prayer in the Liturgy of St. James. In G.I. Konidarēs (ed.), Eucharistērion: timètikos tomos epi tè 45etêridi tès epistèmonikès draseōs kai tē 35etēridi taktikès kathēgesias (pp. 400-408). Athens: Apostolikē Diakonia (republished with emendations and additions in 1990 in: J. Bergman, J. Hjärpe, and P. Ström (eds), Gnostica, Mandaica, liturgica: opera eius ipsius selecta \& collecta septuagenario Erico Segelberg oblata (pp. 147-155). Uppsala: Almqvist \& Wiksell International

Tsakos, A. and Zielińska, D. (2014). Serre Mato. Wall paintings and inscriptions In B.B. Williams, L. Heidorn, Oriental Institute Nubian Expedition (OINE). Publication project. In G.J. Stein (ed.), The Oriental Institute 2013-2014 annual report (p. 125). Chicago: Oriental Institute of the University of Chicago

van Moorsel, P., Jacquet, J., and Schneider, H.D. (1975). The central church of Abdallah Nirqi. Leiden: Brill

Vantini, G. and Donadoni, S. (1967). Gli scavi nell diff di Sonqi Tino (Nubia Sudanese). Rendiconti della Pontificia Academia Romana di Archeologia, 40, 247-273

Verhelst, S. (1998). La seconde partie de la deuxième prière de Saint-Basile. Le Muséon, $111(1-2), 157-172$

Ziadé, I. (1936). Présanctifiés (messe des). In Dictionnaire de théologie catholique XIII.1 (pp. 77-111). Paris: Letouzey et Ané

Zielińska, D. (2009). Program ikonograficzny kościotów nubijskich. Studium lokalizacji malowidet we wnętrzu sakralnym [Iconographical program of Nubian churches. A study of wall paintings location in sacral interior] (unpubl. Ph.D. diss.). University of Warsaw [in Polish]

Zielińska, D. (2012). The painted decoration of the church at Sonqi Tino in the context of the iconographical program of Nubian churches. Scienze dell'Antichità, 18, 593-599

Zielińska, D. (2015). The painted decoration of Building SWN.B.V (Royal Church) on the Citadel: State of research. In W. Godlewski and D. Dzierzbicka (eds), Dongola 2012-2014. Report on work in the Mosque Building, Citadel and Monastery on Kom H [=PCMA Excavation Series 3] (pp. 103-110). Warsaw: PCMA UW

Zielińska, D., van Loon, G.J.M., Tsakos, A., and Obłuski, A. (forthcoming). Naqa el-Oqba - a church in the frontier zone between Nubian and Egyptian traditions 
Żurawski, B. (2003). Dongola Reach. The Southern Dongola Reach Survey Project, 2002. Polish Archaeology in the Mediterranean, 14, 237-252

Żurawski, B. (2004a). Chalice. In D.A. Welsby and J.R. Anderson (eds), Sudan: Ancient treasures. An exhibition of recent discoveries from the Sudan National Museum (p. 225). London: British Museum Press

Żurawski, B. (2004b). Paten. In D.A. Welsby and J.R. Anderson (eds), Sudan: Ancient treasures. An exhibition of recent discoveries from the Sudan National Museum (p. 225). London: British Museum Press

Żurawski, B. (2014). Kings and pilgrims: St. Raphael Church II at Banganarti, mideleventh to mid-eighteenth century [=Nubia 5]. Warsaw: Neriton 



\title{
Archangel Raphael as protector, demon tamer, guide and healer. Some aspects of the Archangel's activities in Nubian painting
}

\author{
Magdalena Łaptaś \\ Cardinal Stefan Wyszyński University, Warsaw \\ magda.laptas@gmail.com
}

KeYwords

Banganarti, Archangel Raphael, Nubian painting

\section{Abstract}

The article is devoted to the Archangel Raphael and his position in Nubian painting, taking into consideration new archaeological discoveries. The cult of the Archangel Raphael seems to be more extensive than it was thought to be before, given the examples from Banganarti and Old Dongola. His special position was a result of his multiple activities, described in the Book of Tobit and the apocryphal texts. He was a guide, healer, God's intercessor for mankind, demon tamer and so on. In Nubia, he also seemed to be a special patron and protector of kings.

Raphael is one of the three chief angels mentioned by name in the Holy Scripture. Only Michael and Gabriel occupy a similarly prominent position. Michael is the leader of the heavenly forces [Rev 12:9-7] and protector of Israel [Dan 12:1], whereas Gabriel is the highest messenger of God [Lk 1:19, 26-27].

Until recently, it was thought that Raphael took the third position in the Nubian archangelic hierarchy (Łaptaś 2003: 138; Martens-Czarnecka 2011: 197). However, new discoveries in Old Dongola and Banganarti have shown that Raphael was a highly venerated archangel, at least in the Dongolese milieu (Łajtar 2014: 169).

1 Some of the ideas presented in this article were formed while writing my doctoral thesis on archangels in Nubian painting. I would like to express my gratitude to Professor Włodzimierz Godlewski for his supervision of this thesis. 
Raphael, whose name derives from the Hebrew רָָָָאָ (God Heals), appears in the Book of Tobit. ${ }^{2} \mathrm{He}$ is sent by God to guide and protect young Tobias who is on his way from Nineveh to Media. Tobias, son of Tobit, comes from a pious Israelite family living in exile in Nineveh. When his father goes poor and blind, Tobias is sent to Media to recover the money deposed there. Looking for a guide he meets Raphael, yet the Archangel does not reveal his true identity. On his way to Media, Tobias takes a bath in the Tigris River, where he is attacked by a big fish. Raphael advises him to catch the fish and remove its entrails in order to make medicine for later use. When the two travellers arrive at the city of Ecbatana in Media, they stay at the home of Raguel, who is Tobit's kinsman. His daughter Sarah has been bewitched by the dangerous demon Asmodeus. The evil creature has already caused the death of her seven previous husbands. Nevertheless, Raphael encourages Tobias to marry Sarah, instructing him how to drive the devil out. During the wedding night, Tobias burns the heart and liver of the fish he had killed earlier. The stench of the burnt fish entrails drives Asmodeus away. He escapes to Upper Egypt, where Raphael catches and binds him. Then the archangel is sent to Rages to collect the money from Gabelus. After returning to Nineveh, Tobias uses the gall of the fish to restore Tobit's eyesight. The old man wants to offer a reward to his son's guide and protector. However, Raphael does not take any money and reveals his true identity. $\mathrm{He}$ says that he is "one of the seven angels who stand ready and enter before the glory of the Lord" [Tob 12:15]. ${ }^{3}$ He explains that he has been sent by God to protect Tobit's family. He then ascends to the Heavens.

The prominent role that Raphael played in the Book of Tobit was developed in the tradition of the Nile Valley. In the Coptic Encomium on the Archangel Raphael (BM Ms Oriental, No 7022), ${ }^{4}$ he was described as one who fulfils many functions. He was the guide who led Tobias through a foreign land and the chief cook who prepared the fish for Tobit's son. He was "a master of the bridal ceremonies", "a physician", "a commander-in-chief", "a good servant", "an unpaid minister", and so on (Budge 1915: 530-531 [Coptic text], 1038-1039 [English translation]).

The great number of epigraphic material from the Upper Church in Banganarti, as well as from Old Dongola, has not only proven these numerous activities of Archangel Raphael, but has also significantly enriched our knowledge

\footnotetext{
For the Greek edition, see Hanhart 1983.

3 All Scripture quotations are taken from The New Oxford Annotated Bible with Apocrypha: New Revised Standard Version (Coogan 2001).

4 The encomium has been attributed to St John Chrysostom; however, this authorship is rather doubtful (see Geerard 1974: 540, No. 4500).
} 
about them. As Adam Łajtar demonstrated in his recent article, Raphael was named "a ruler of saints", "a saviour", "a helper of the whole of mankind" (Eajtar 2014: Nos 12, 9, 16). In addition to these epithets, more unique ones were assigned to Raphael such as: empsychos "having life in him", amisthos "healing without payment", or archinous "chief intellect" (Eajtar 2014: 265; 2015b).

While the inscriptions allow us to define the specific role Archangel Raphael fulfilled in Nubia; nevertheless, the murals do not determine his role unambiguously. The archangels in Nubia are very often presented in a similar way, which makes it difficult to differentiate among them in practice, without the help of tituli. This is especially the case when two archangels are portrayed together, since they usually wear analogous attire. The two pairs of angels from the cathedral at Faras can be cited as examples. One pair flanked the western entrance to the cathedral ${ }^{5}$ and the other the niche in the east wall of the socalled baptistery (Michałowski 1967: 131-132, Pl. 51; Godlewski 2006: 106, Fig. 95). The first mural, exhibited now in the National Museum in Warsaw, shows Michael and Gabriel with identical hairstyles and dressed in similar tunics and loroi [Fig. 1]. The wings of the archangels are covered with eyes and the composition is antithetical. In the left hand both Michael and Gabriel hold an orb, symbol of God's reign over the world (Łaptaś 1997: 25). The attributes in their right hands are different, a trumpet in Michael's and a sword in Gabriel's. ${ }^{6}$ Identification of the archangels is clear, however, owing to the tituli.

The second mural, painted on the east wall of the baptistery of the cathedral at Faras, and dated to the last quarter of the 10th century, is now on exhibition at the National Museum in Khartoum (Michałowski 1967: 132). The archangels are rendered on the wall in a mirror composition adoring Christ, who is painted inside a niche [Fig. 2]. They are floating in the air, their heads bowed and their hands folded in a gesture of prayer. They are dressed identically in white tunics and himatia, their heads crowned and maniakia around their necks. Differentiating

5 Kazimierz Michałowski dated these murals to the 8th century. He thought that they had been painted "on both sides of the west entrance to the Cathedral, blocked up in the second half of the 9th century and turned into a recess with the painting of Madonna Eleusa" (Michałowski 1974: 95). His dating was upheld by other scholars, such as Jakobielski 1982: 152; MartensCzarnecka 1982: 174 and Godlewski 1982: 27-28. However, Bożena Mierzejewska suggested a few years ago that this dating was too early and moved it to the second half of the 9th century. Therefore, the images of the archangels would have been painted at the same time as the oldest mural of the Virgin in the niche, after the western entrance to the cathedral had been blocked (Mierzejewska 2006: 160). Nevertheless, in my opinion, both the style and iconography of the images as well as their protective function allow them to be dated to the time before the entrance to the cathedral was blocked.

6 A sword is usually Michael's attribute in view of his role as commander-in-chief. 
them is the manner in which their wings were represented. The wings of one are plain, whereas in the case of the other archangel, his wings are adorned with eyes and peacock feathers. Was this done perhaps on purpose so as to differentiate Michael from the second archangel, Gabriel?? As Michael is the leader of the heavenly forces, his position is portrayed with additional splendour.

These two examples indicate that attributes play a role more significant than attire in distinguishing particular Nubian archangels. However, another mural from the cathedral at Faras proves by contrast that robes could be indicative of status as well. It is the Nativity scene from the northern aisle of the cathedral (now in the National Museum in Khartoum), depicting the three chief archangels standing around a large figure of the Virgin Mary resting on a bed, next to the manger (Michałowski 1967: 144-145, Pls 64-65; Scholz 2001: 216, Fig. a) [Fig. 3]. Their individual functions are clearly specified (Eaptaś 2003: 140-142). Gabriel, who announced the Nativity [Mt 1:26], stands on the

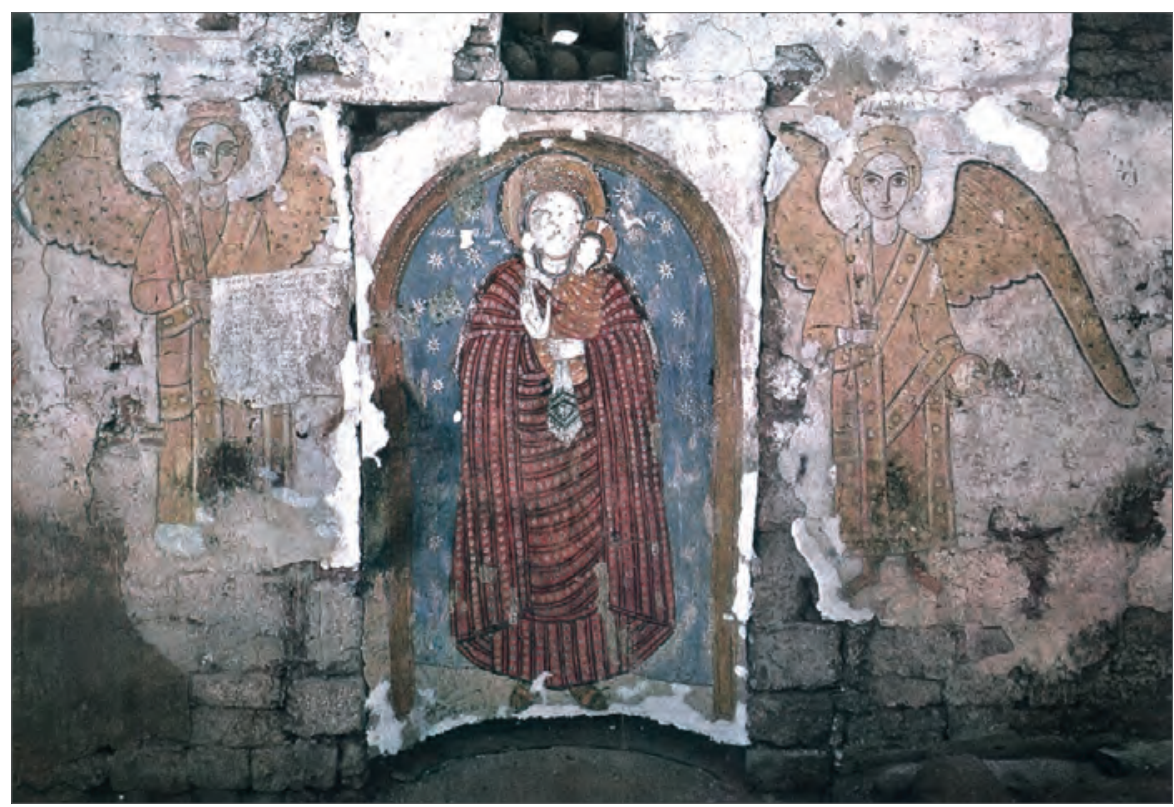

Fig. 1. The archangels Michael and Gabriel depicted on either side of the west entrance to the cathedral at Faras (After Michatowski 1967: Pls 24-25)

7 A titulus is still in place next to Michael's head, describing him as "archistrategos, loving people and good", while next to the second archangel's head only the last three letters of his name remain, allowing him to be identified as Gabriel (Michałowski 1967: 131). 
a Virgin's right, pointing toward Christ lying in the manger. As God's messenger, he is dressed in white robes and holds a scepter in his left hand. Michael, who stands on the Virgin's left, is dressed as a Byzantine emperor: in a tunic with a loros draped over it. He holds an incense burner in his right hand and a scepter in his left. Raphael, standing below Michael, carries similar attributes, but is dressed differently, in a chlamys instead of a loros, placing him slightly lower in the hierarchy than his companion. Additionally, only Michael has wings covered with eyes to distinguish him from Raphael and Gabriel, whose wings are plain [see Fig. 3]. All three archangels are wearing crowns and maniakia, the latter element being a distinction from the ordinary angels in the upper part of the composition wearing simple diadems instead. Ultimately, the archangels are identifiable by the tituli in this image.

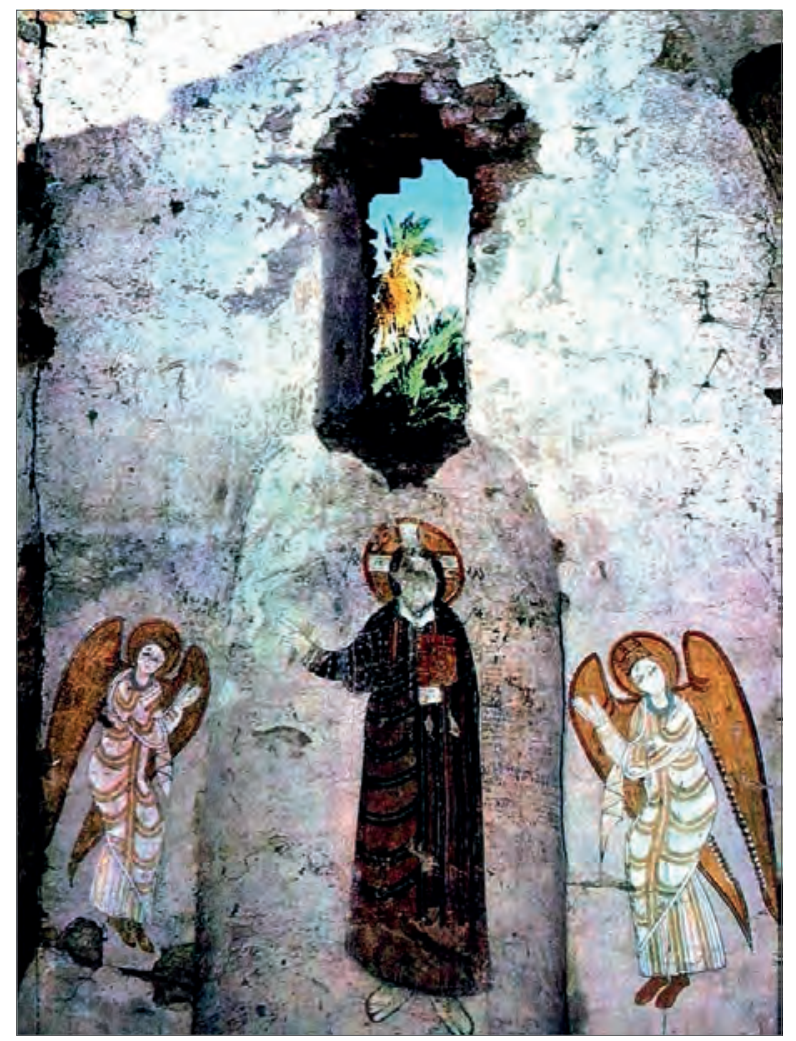

Fig. 2. Two archangels adoring Christ Emmanuel. Cathedral at Faras (Photo M. Niepokólczycki, archeological documentation of the Institute of Mediterranean and Oriental Cultures) 
These were fortunately preserved in the Faras mural, but there are many images of archangels in Nubian art lacking such inscriptions, thus making the task of identification much more difficult. Context may be of help on occasion, but is hardly definitive in enabling the identification of particular figures. It is so in the case of the murals from Banganarti. The Upper Church, built in the second half of the 11th century, was dedicated to Archangel Raphael, as proved by the available epigraphic sources (Żurawski 2014: 259; Łajtar 2014: 262). An archangel was painted in each of the seven apses, protecting a Nubian ruler. None of the figures have been preserved in full, but the surviving fragments of wings allow the figures to be identified. The large size of these figures, as well as their position, lead to the conclusion that they are not ordinary angels, but archangels. The most complete figure of an archangel comes from Chapel III [Fig. 4]. This figure is preserved up to its arms, but the head is missing. The archangel stands firmly on the ground, his feet set apart. He is much bigger than the ruler floating in front of him. The archangel's hands touch the ruler's arms in a gesture of protection. The small

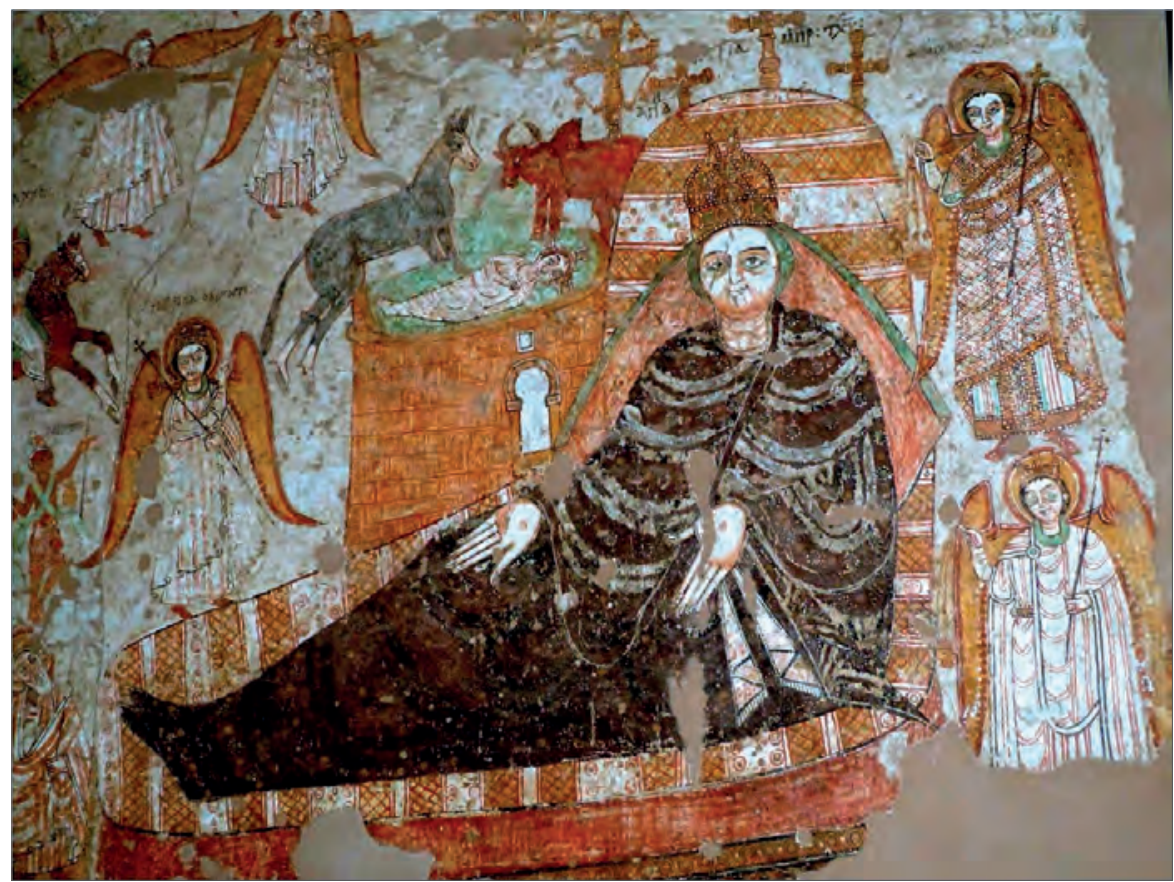

Fig. 3. The Nativity (detail); figures of the archangels Michael and Raphael at far right of the composition. Cathedral at Faras

(Photo T. Jakobielski; courtesy of the Sudan National Museum in Khartoum) 
object that the archangel holds additionally in his right hand I would interpret as a model of a church. ${ }^{8}$ The figure is depicted dressed in a white tunic with wide sleeves, fastened with a bejeweled golden belt. A purple chlamys, probably buckled on his right arm is thrown over it. This garment matches the attire of Raphael in the Faras Nativity scene. There are no peacock feathers notably on the yellowish wings. The indication is clearly Raphael, and if the object held by him is indeed a church model, he would be a protector of not only the ruler, but also of the building as a whole. The interpretation is easily justified,

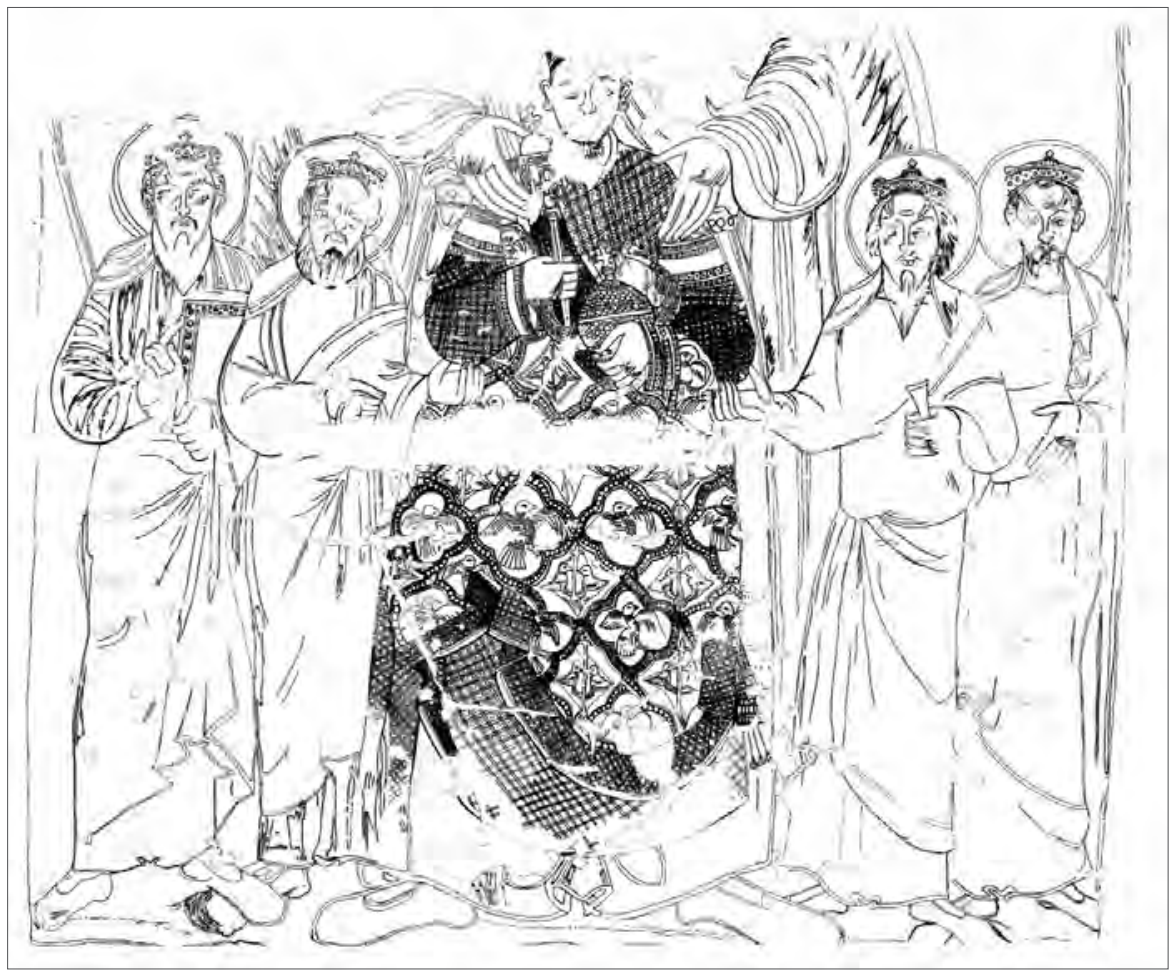

Fig. 4. Apse composition in Chapel III. Upper Church in Banganarti (Drawing W. Chmiel)

8 This small object, held by the archangel in his right hand, has initiated extensive discussion among scholars. At the 11th Conference of Nubian Studies, held in Warsaw in 2006, Bogdan Zurawski presented his identification of this object as a reliquary. However, both the author of this text as well as Bożena Mierzejewska commented that it is rather a model of a church than a reliquary. This point of view was based on the argument that it would be difficult to understand why the archangel would be giving relics to an earthly ruler. Żurawski upheld his opinion in his later publications (Żurawski 2011: 291-296; 2014a: 37; 2014b: 145). 
considering that the king painted in this chapel would have been the founder of this mural, or one of the ktetors of the church. It is supported further by the text of the Old Nubian version of In Raphaelum Archangelum. One fragment of this text (dedicated to the Caesar Honorius) brings a promise addressed to the ruler who was to build a church dedicated to the Archangel Raphael. As he was going to erect this earthly church, the Archangel would prepare a seat for him in the Heavens "amongst these who shall survive till the Resurrection, who shall not yield or change in the place of His glory, who shall not be consumed by insects or termites and shall not be destroyed forever" (Plumley and Browne 1988: 40; see also Łaptaś 2010: 677).

The identification of the archangel in Chapel III as Raphael seems very probable, but what about the archangels painted in the other chapels of the Upper Church in Banganarti? Do all of them represent the Archangel Raphael? In the Book of Tobit, Raphael appears as "one of the seven angels who stand ready and enter before the glory of the Lord" [Tob 12:15]. The Nubian tradition distinguishes seven archangels known by their names, i.e., Michael, Gabriel, Raphael, Ourouel, Iael, Anael and Zadekiel (Eajtar 2009: 115-119). The symbolism of this number plays a crucial role in the layout of the Upper Church in Banganarti, which has seven apses. ${ }^{9}$ Does it mean that the chapels were each dedicated to a different archangel or was it that Raphael was represented seven times in the seven apses? The present state of research, especially the condition of the paintings and the absence of tituli, do not afford an answer, Nevertheless, it is worth noting that the wings of the archangel in one of the chapels are highlighted by peacock feathers. According to Małgorzata Martens-Czarnecka (2011: 186), this is a detail which differentiates the Archangel Michael from other archangels in Nubian painting. This principle works in most images, though some aberrations exist. ${ }^{10}$ In Chapel V of the Upper Church in Banganarti, an archangel with peacock wings is painted twice, once on an earlier painting in the niche of the apse and a second time, repeating the earlier composition, on the dividing wall built inside the interior of the same chapel. The repeating

9 The symbolism of the number seven and its impact on the layout of the Upper Church in Banganarti has been more broadly discussed in my recent article (Łaptaś 2014: 287-292). The popularity of the number seven in ancient and medieval art resulted from an awareness of seven planets that could be seen with the naked eye (including the Sun and the Moon). I would like to express my gratitude to Paweł Żaczek for explaining certain aspects of ancient astronomy.

10 Such as the earlier discussed image of two archangels from the narthex of the cathedral at Faras, on which both Michael and Gabriel have wings adorned with eyes but not peacock feathers. 
could hardly have been a coincidence; the chapel was most probably dedicated to Michael, which is why his wings were shown differently than those of other archangels in the other chapels of the church.

Concluding, Raphael was not painted in all the chapels of the Upper Church in Banganarti. The most reliable of his images comes from Chapel III, where he was rendered with a model of a church in his hand. A similar image of the Archangel standing next to a model of a church was painted in the Church of Raphael in Tamit (Baldassare 1967: 52). The mural originally decorated the south wall of the southern aisle, but was transferred to the Coptic Museum in Cairo after the Nubian Campaign. The name of the Archangel is not preserved in full, as only the last four letters have survived (Baldassare 1967: 51). The Archangel is standing on a beast and trampling it with his feet [Fig. 5]. The beast has four legs, a twisted tail, and its body is covered with scales and fins. A bearded man is shown emerging from the creature's dragon-like maw, his hands raised in an orans gesture. Raphael has pierced the beast with a spear. In his left hand he holds a globe, with the symbol of a cross painted on it. The Archangel is dressed in a loros, underneath which he is wearing a robe, richly decorated with medallions, floral motifs and crosses. ${ }^{11} \mathrm{~A}$ small model of a church is visible next to his leg. It is a central building vaulted with a dome raised on a high tambour. The meaning of this scene is clear: the Archangel, as the patron of the church in Tamit, protects the building and its faithful from evil forces. He is also shown saving a worshipper by killing the beast that is trying to swallow the man. He is victorious in his fight against the attacking beast, killing it and freeing the pious man. Therefore, the Archangel is presented here in a double role: he is not only the patron of the church, but also a tamer of demons.

Archangel Michael was usually assigned the function of tamer of demons, in the Old Testament Apocrypha (e.g., 1 En 10:15-16), as well as in the Book of Revelation, where he fought with "the great dragon", an "ancient serpent who is called the Devil and Satan" [Rev. 12:9]. After his victory over the devil, Michael cast the devil out of heaven and sent him down to earth. On the other hand, Raphael in the Book of Tobit was also described as the tamer of the demon Asmodeus. When Asmodeus fled from Tobit's wedding room to the "remotest parts of Egypt", the Archangel followed him and bound him there [Tob. 8:3]. In Nubia, these kinds of activities attributed to Raphael must have been highly

11 Ida Baldassare compared these motifs to the attire of the eparch on the mural from Abd el-Gadir. Baldassare followed Monneret de Villard's (1967: 53) dating of this mural to the 11 th and 12th centuries. However, the dating of the Abd el-Gadir painting was later moved to the 13th century (Griffith 1928: 74 and lately Godlewski 1995: 38). 
appreciated as is evidenced not only by the graffiti from the Banganarti Church, but also by an image in the Southwest Annex of the Monastery on Kom H in Old Dongola (preserved in situ). ${ }^{12}$ Two archangels, identified by a titulus, were painted on the east wall of Room 3 (Martens-Czarnecka 2011: 197-198, Cat. 93). While Michael is riding a horse, Raphael is presented as standing next to him, bending over a monster. The mural is only partly preserved, which
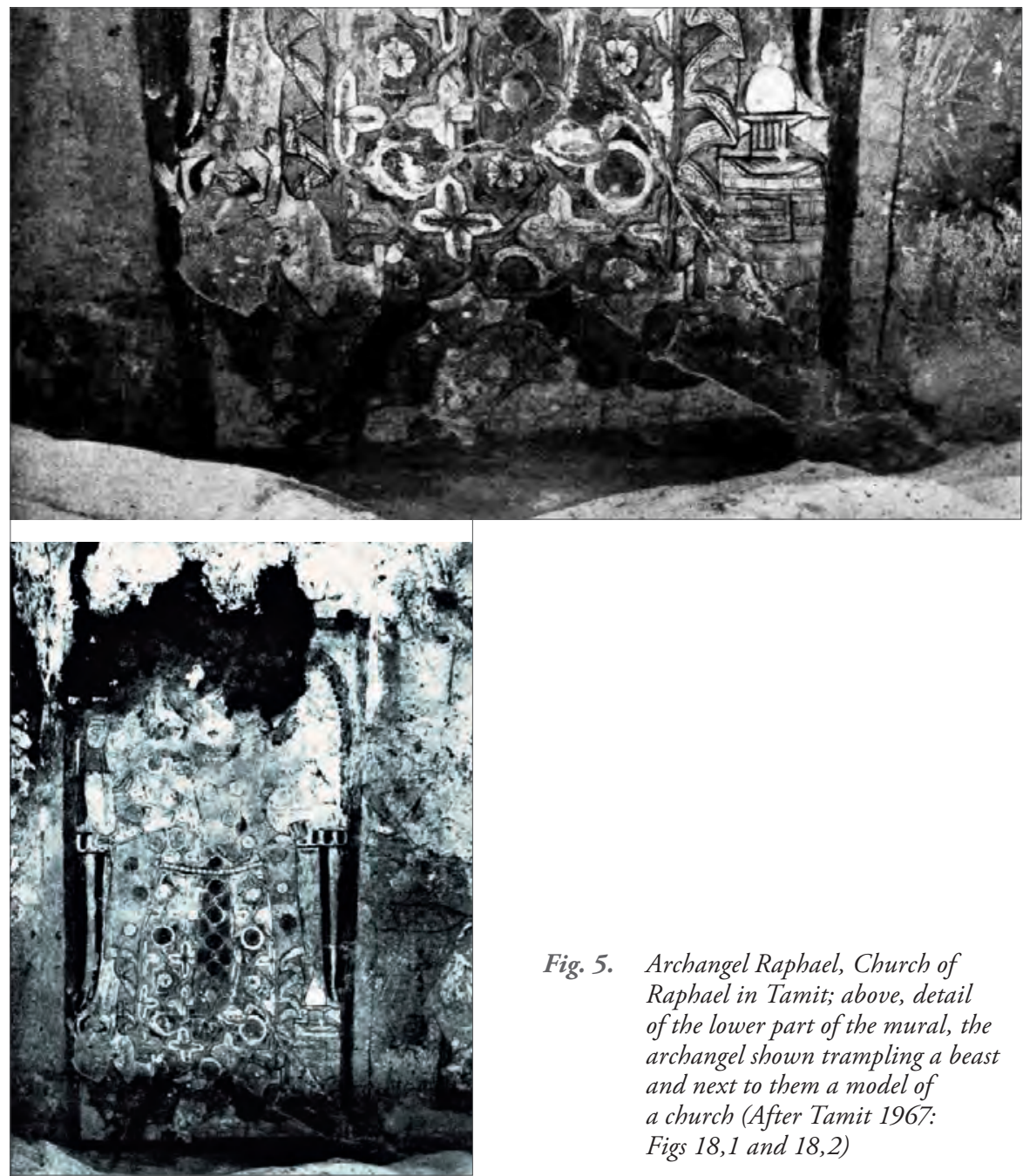

Fig. 5. Archangel Raphael, Church of Raphael in Tamit; above, detail of the lower part of the mural, the archangel shown trampling a beast and next to them a model of a church (After Tamit 1967:

Figs 18,1 and 18,2)

12 Dated to the "second part of the 12th century into the 13th century" by Małgorzata MartensCzarnecka (2011: 254, 257). 
hinders its full interpretation. Despite the absence of a greater part of Michael's figure, the Archangel can be recognized thanks to his wings, adorned with eyes. In contrast, Raphael's wings are plain, but the crown on his head is impressive [Fig. 6 . It consists of a golden rim, surrounded by rows of pearls and studded with precious stones, topped with a cross emerging from a semicircular plaque. Constantine IX Monomachos would not have been ashamed of wearing such a crown (Cormack 1985: 184, Fig. 66). This stemma is fixed firmly on Raphael's head and does not move upwards, even though the Archangel is bending his torso during his fight with the monster. It is difficult to interpret precisely what the Archangel is doing. He is grabbing the monster's muzzle with both his hands in an effort to defeat it. One of the monster's big horns is directed towards the Archangel, whereas the other one droops listlessly (Martens-Czarnecka 2011: Pl. 93). ${ }^{13}$ Perhaps Raphael is trying to break the monster's protruding horn to deprive it of its evil power?

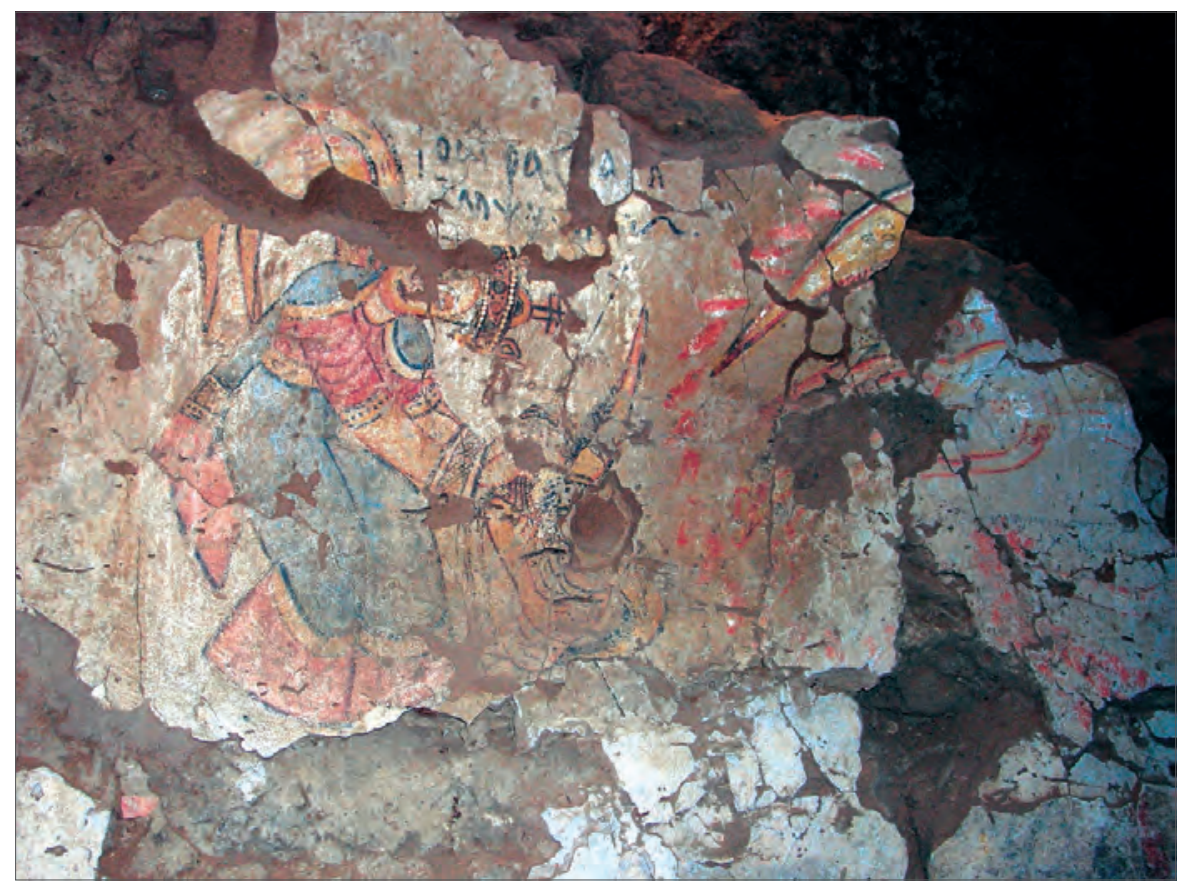

Fig. 6. Archangels Raphael and Michael. Southwest Annex of the Monastery on Kom H in Old Dongola (After Martens-Czarnecka 2011: Fig. 98)

13 Such is my reading of this scene; however, Małgorzata Martens-Czarnecka interprets this monster as a "beast with the head of a single-horned rhinoceros" (2011: 197). 
Living in constant fear of the evil forces, members of the Nile Valley society depicted demons in different forms and shapes. As Jacques van der Vliet has written with regard to the Life of St Anthony, an entire "zoo" of animals seemed to materialize in Chapter 9 to terrify the Saint. "The appearance of lions, bears, leopards, bulls, serpents, asps, scorpions and wolves, who, each in their own fashion, attack him ..." (van der Vliet 1990: 137). Asmodeus, defeated by Raphael, was one of the most powerful demons. He was mentioned in magical texts, especially in the Testament of Solomon. In this text, Asmodeus described himself as the one who destroys marriages through intrigues and conspiracies, attacks virgins and commits murders. Asked by Solomon who had thwarted his activities, he admitted that it was Raphael who had power over him (Test. Sol. 5:7-9). ${ }^{14}$ This explains why the name of the Archangel was so often written on the walls of Nubian churches and on pottery (Mierzejewska 2014: 252-253). This name could protect the faithful against demons and fulfill an apotropaic function.

Another important function of Archangel Raphael was to guard and protect the faithful in life and in death. This motif, which appears in the Book of Tobit, is wonderfully developed in the Coptic Encomium on the Archangel Raphael (BM Ms Oriental, No. 7022). In this text the archangel says, "I am Raphael the archangel, and Christ gave thee into my hand from the time when thou wast a child. And moreover, from the time when thou was born until this day I have never left thee for an hour or for half an hour, or even for the twinkling of an eye. And I will never leave thee until the day [cometh] when I shall take thee to the king the Christ" (Budge 1915: 1042). This idea seems to have been represented in art, in scenes showing an archangel standing next to various protected figures. One such example is a mural from the Abd el-Gadir Church, dated to the 13th century (Godlewski 1995: 52; Mierzejewska 2008: 41). It was originally painted in the church naos (Zielińska 2009: 199), and is now housed in the National Museum in Khartoum. The inscription with Raphael's name allows for the identification of this archangel (Monneret de Villard 1935: 217). The figure stands frontally with his feet apart and wings lowered [Fig. 7]. A trumpet in his right hand is raised above his head, whereas a globe appears in his left. He is wearing a long-sleeved tunic under a short-sleeved one and a chlamys. The grey outer tunic is embellished with two purple clavi. The head of the Archangel is adorned with a stemma decorated with two rows of pearls. A man is standing by the right wing of the Archangel. The man is raising his

14 Asmodeus was also mentioned in Coptic magical curses, e.g., Papyrus Yale 1800 (Meyer 1999: 216, No. 106). 
right hand in which he holds a branch, while in his left he has an unidentified object consisting of a rim and an elongated element hanging from it. The skin of the man is brownish unlike the Archangel's, which is white. ${ }^{15}$ The man is dressed in white robes, whereas his head is adorned with a crown or bonnet. Francis Llewellyn Griffith identified this figure as a deacon. ${ }^{16}$ The attributes held by the Archangel as well as by his protégé allow us to link this image with the text of the Revelation. There the vision of chosen people during Judgment Day is expressed. The chosen people stand "before the throne and before the Lamb, robed in white, with palm branches in their hands" [Rev 7:9]. Further in the text, seven angels holding trumpets are described. The first six angels

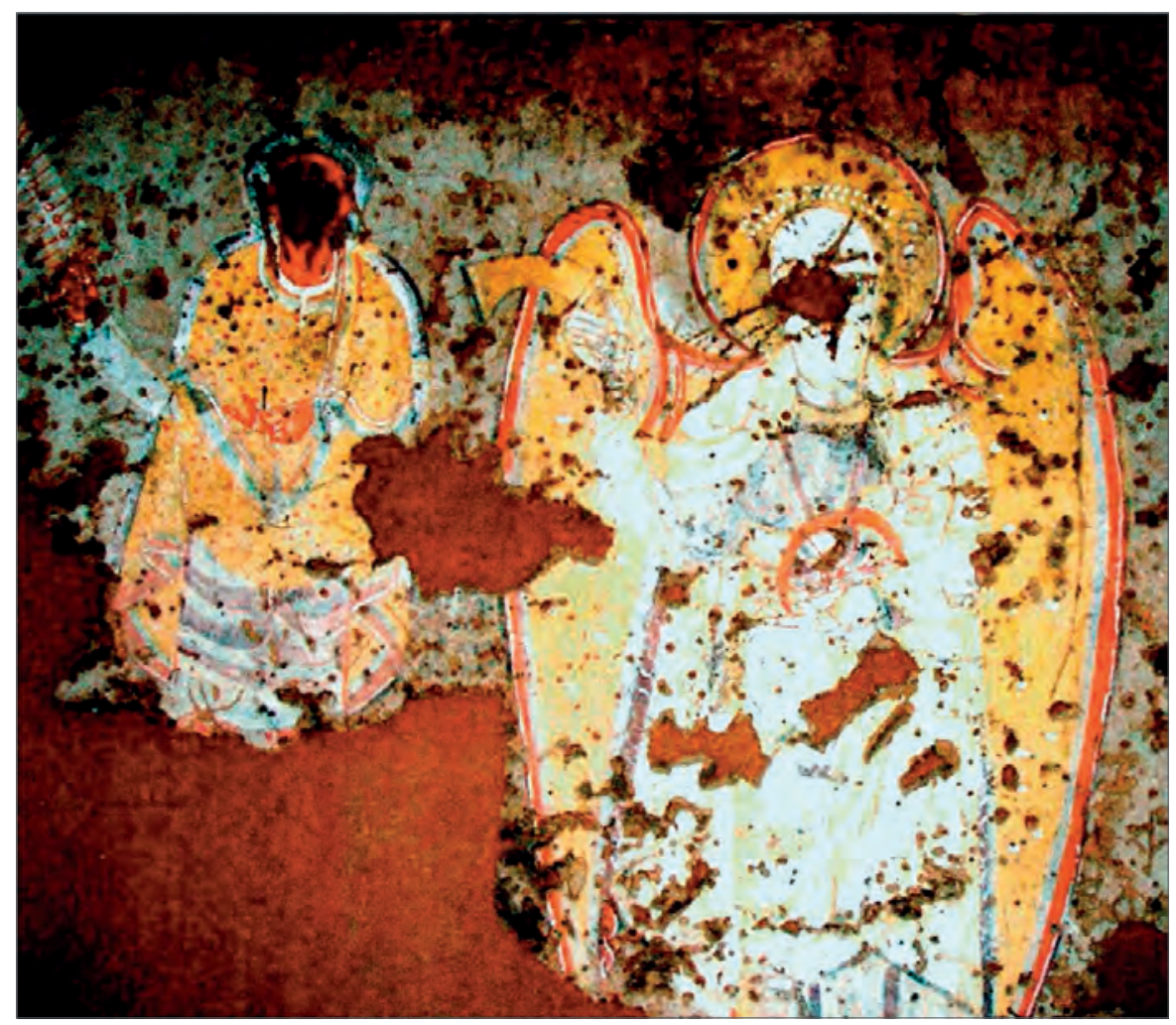

Fig. 7. Archangel Raphael and a Nubian man. Abd el-Gadir Church (Photo M. Eaptaś; courtesy of the Sudan National Museum in Khartoum)

15 Francis Llewellyn Griffith described the color of this man as reddish (1928: 74).

16 This is based on an inscription containing a request to Jesus Christ asking him to provide protection for a deacon (Griffith 1928: 74). 
successively blow their trumpets, causing disasters on Earth. When the seventh angel blows his trumpet, the "Kingdom of the Lord" is announced [Rev 11:15].

It seems that the mural from Abd el-Gadir portrays Raphael's protection in such an apocalyptic context. The trumpet that he holds is proof of such an interpretation. The Archangel leads the Nubian man to the Last Judgement. He is the protector of this man and an intercessor on his behalf to God. Therefore, this scene refers to the afterlife of the Nubian man, when after the sound of the last trumpet "the dead will be raised imperishable" [ 1 Cor 15:52]. Archangel Raphael performs here the role of a guide, leading the Nubian man to Salvation. In some graffiti from the Upper Church in Banganarti, the role of the Archangel is extended even further, he being named a "saviour" (Eajtar 2014: 265). This epithet is used to describe him probably because he saved Sarah from the demon Asmodeus. He also introduces the souls of the deceased to the Lord during the Last Judgment. As the "Chief intellect" he discerns between people's good and bad deeds. He knows not only their flesh but also their souls from inside, as is learned from the Greek inscription coming from the cathedral at Faras. This inscription (now lost) contained the request of a certain priest, Petros, asking Raphael for protection. ${ }^{17}$ It was located on the south wall of the staircase by the painting of an archangel. This painting (now lost) was already in a very poor state of preservation at the moment of its discovery. In fact, all the upper part of the figure and its wings were destroyed. ${ }^{18}$ The archangel was rendered standing to front (Martens-Czarnecka 1983: 178, Fig. 178). He was dressed in a white tunic and a purple loros. His narrow wings were lowered. The proportions of the figure (very elongated), as well as the painting style date the image to the late period of Nubian art. ${ }^{19}$ The Petros inscription was painted between the figure of the archangel and his right wing, so it is highly probable that the mural represented Raphael. This figure was painted on the second layer of plaster and covered another image of an archangel painted on the first layer. This earlier mural was removed from the wall and is now housed in the National Museum in Warsaw (Michałowski 1974: 95-101, No. 17, Pl. 17; Seipel 2002: 75-76, No. 9). It is

17 It was first partly transcribed and translated by Stefan Jakobielski (1974: 106-107, Fig. 25), then another version of this text was published and translated by Jadwiga Kubińska (1974: 172-173, No. 125, Fig. 111). Recently Adam Łajtar presented a new translation and interpretation of this text (2009: 59-63).

18 I have prepared this description of the mural on the basis of photo documentation held in the Institute of Mediterranean and Oriental Cultures of the Polish Academy of Sciences.

19 It seems that this mural can be stylistically related to the painting of St Epiphanius from the Faras Cathedral (Michałowski 1974: 247, No. 57, Pl. 57). In my opinion both murals can be dated to the second half of the 13th century AD (cf. Seipel 2002: No. 29). 
a splendid image of an archangel, dressed in imperial attire and presented as a courtier [Fig. 8]. The archangel is standing frontally, holding a sceptre in his right hand and supporting a disc with his left. He is wearing a long-sleeved white tunic with orbiculi and epimanikia and a purple loros decorated with fringes ${ }^{20}$ His hair is trimmed below the ears and elegantly curled. Around his head there is a bejeweled stemma. The wings of the archangel are adorned with peacock feathers. This detail, as well as the acclamation IC XC NIKA (Jesus Christ conquers), link this image to Archangel Michael as the archistrategos. ${ }^{21}$ On the other hand, this image had been painted underneath another one, representing Raphael. Jadwiga Kubińska identified this figure with Michael (1974: 172); however, Bożena Mierzejewska suggested a new identification

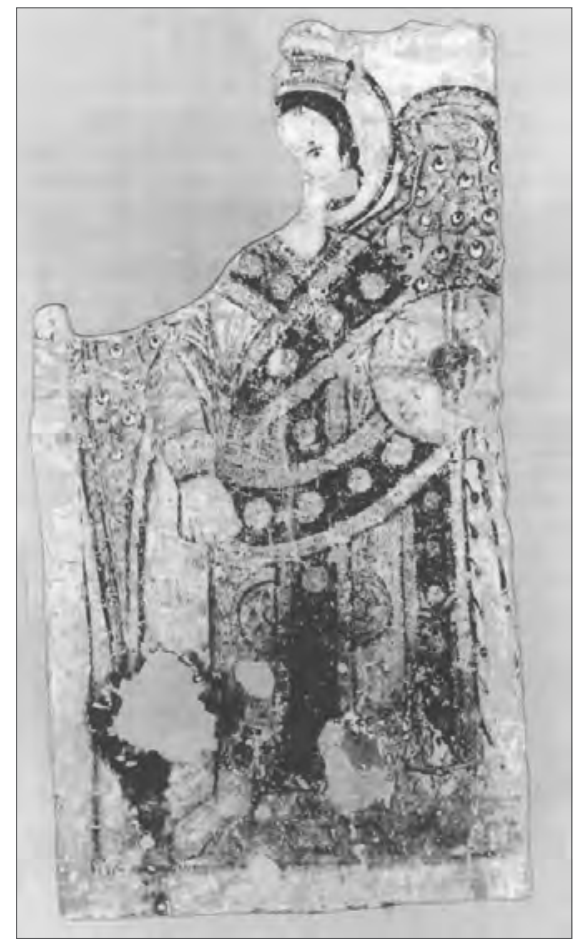

Fig. 8. Archangel Raphael(?). Cathedral at Faras (After Michatowski 1974: Pl. 17)

20 This type of loros is particularly ceremonial. On a mosaic from the Hagia Sophia Church in Constantinople, the emperor Alexander (912-913) is shown wearing a loros of this kind (Underwood and Hawkins 1961: 189-217); the same can be said of the attire of Roger II (1130-1154) as depicted in the Church of St Mary's of the Admiral in Palermo (Kitzinger 1990: 314, No. 71, Pl. XXIII, 120).

21 But a similar acclamation was scratched on the wall of the Church of Raphael in Tamit, on which the Archangel Raphael was painted (Donadoni 1967: 65). 
linking the archangel with Raphael (2014: 84). In my opinion, the identity of this figure is difficult to determine; however, the hypothesis that it is Archangel Raphael is quite interesting.

Our knowledge of Archangel Raphael in Nubia has been extended recently owing to the newly discovered murals and inscriptions from Church B.V on the Citadel of Dongola. The inscriptions accompanying the murals of three donors painted in the prothesis of this edifice inform us that all three were priests of a Church of Raphael (Eajtar 2015b). It is very probable that the Archangel Raphael was the patron of this church. One of these murals, painted on the west wall of the prothesis, shows a Nubian priest under the protection of Christ and two archangels (Zielińska 2015). The inscription makes it clear that one of the archangels was Michael, here defined as "hilaroprosopos" (with cheerful countenance), whereas the other one, Raphael, was "empsychos" (Eajtar 2015b). ${ }^{22}$ It is interesting that Michael is not accompanied here by Gabriel but by Raphael. On the other hand, the dedication of this church to Raphael justifies his high position in this scene.

Another interesting image of this archangel comes from the 11 th-century Church of Raphael in Tamit (Innemée 1992: 214) [Fig. 9]. It presents a threefigured scene of protection. The painting, originating from the west wall of the diaconicon, ${ }^{23}$ was removed from the wall and transferred to the Coptic Museum in Cairo. A brown-faced Nubian bishop was rendered in the middle of the scene, holding a book in his right hand and an encheirion in his left one. His holy protector stands to his right, slightly behind him, touching his right shoulder with the left hand, and holding a book and encheirion in the other. Behind the Nubian bishop, a huge figure of an archangel emerges. The archangel touches the bishop's right arm with his right hand, while holding a disk and a cross scepter in his left one. The Nubian bishop can be identified by his costume which consists of a white sticharion with potamoi, a red scapular and an epitrachelion. On top of this he wears a yellow phelonion, a red collar and a green omophorion. His holy patron is dressed also in bishop's garb, but his face is white and his head is topped with a splendid crown and encircled with a halo. The archangel is dressed in a long tunic with a maniakion and a loros. His hair is tied back and his head is encircled with a crown. Ida Baldassare (1967: 48)

22 The epithet $\dot{\varepsilon} \mu \psi v \chi o ́ \varsigma$ is evidenced three times altogether in the Dongolese milieu: it occurs twice in tituli accompanying the foregoing murals from room 3 of the Church B.V in Old Dongola (Eajtar 2015b) and the Southwest Annex to the Monastery on Kom H (Łajtar 2015a). The third example is an inscription from the Upper Church in Banganarti (Łajtar 2014: 265)

23 Ida Baldassare (1967: 47) designated this place as "Room Q". 
suggested that the figure of the archangel could be identified as Raphael on the grounds of the name of the Archangel, preserved in a painted graffito below the image. The interpretation seems to be justified as the Archangel was the patron of the whole church. Nonetheless, Karel Innemée (1992: 214) identified the holy bishop as John Chrysostom. Such an identification is very interesting as this Doctor of the Church was venerated in Nubia. ${ }^{24} \mathrm{He}$ was also supposed to have been the author of the Encomium on the Archangel Raphael. However, the text (quoted several times in this article) is now counted among the dubia et spuria works of John Chrysostom (Geerard 1974: 540, No. 4500), but people living in medieval Nubia did not have access to knowledge available to modern scholars. Therefore, the whole scene can be read as the protection of a Nubian bishop by the Archangel Raphael through the intercession of John Chrysostom. As a result, it depicts a typical Byzantine way of thinking based on the idea of ascending hierarchy. The Nubian bishop is under the protection of another holy bishop, who has an archangel above him, with God placed at the top of this heavenly ladder. Therefore, the mural from Tamit is a prefect representation of the idea of mediation and intercession of archangels in Nubian art.

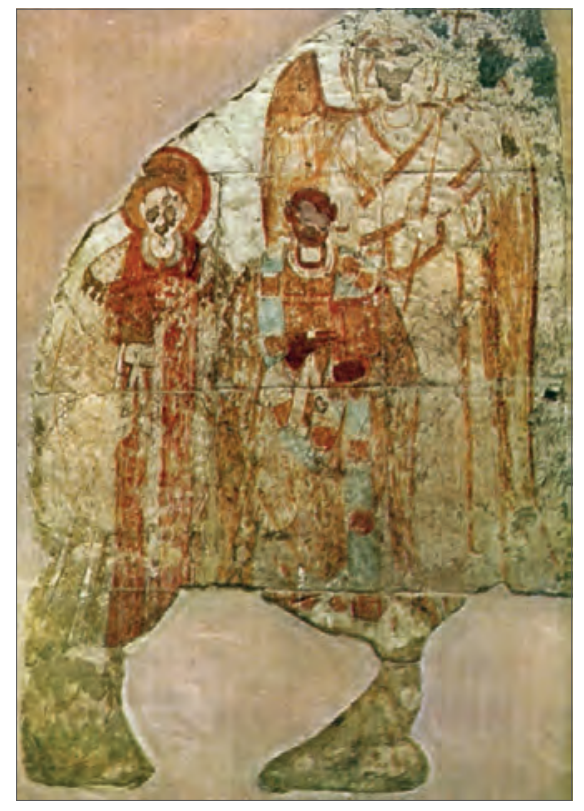

Fig. 9. Unidentified bishop under the protection of John Chrysostom and archangel Raphael(?). Church of Raphael in Tamit (After Baldassare 1967: color pl. b)

24 The image of John Chrysostomos from the cathedral at Faras proves this apparently (see Michałowski 1974: 145, Pl. 20). 
Another important aspect of Raphael's activities was connected with healing. This function was ascribed to him already in the Book of Tobit, when he instructed Tobias how to cure his father's eyes by rubbing them with fish gall. This motif was developed in some of the graffiti coming from the Upper Church in Banganarti. The invocation of a certain deacon named Nalsi is put forward as an example (Łajtar 2014: 273, Cat. No. 7). In this inscription, Raphael is mentioned as the one who was sent to Media by God "in order that the eyes of Tobit would see again" (Eajtar 2014: 271, Cat. No. 7). One of the attributes characteristic of holy healers is a bag holding their medical instruments. In Old Dongola there is a mural presenting an archangel passing such a bag to the Holy Anargyroi (Żurawski 1999: 429). ${ }^{25}$ Another figure of an archangel with a bag hanging from his right arm was painted below this scene (Martens-Czarnecka 2011: 197, Cat. No. 44, Fig. 96). ${ }^{26}$ Małgorzata Martens-Czarnecka (2011: 197) identified this archangel as Raphael. Such an interpretation is appealing, because it allows us to link the functions of the Archangel, already well proven by the available texts, with the painted images.

Summing up, the foregoing examples indicate with sufficient clarity that Archangel Raphael held a distinct position in Nubian painting, a position already defined in the Book of Tobit where he was shown to fulfill many important functions for mankind. These activities the Nubians expanded on and clearly articulated thanks to their creativity. The multiplication of Raphael's activities led to his functioning as a more characteristic and independent figure than Gabriel. While the latter acted mainly as Michael's companion, Raphael occupied a self-governing position. Raphael's towering position within the Nubian painting tradition was unique in Christian art and it confirmed the creativity of Nubian angelology.

\section{References}

\section{Abbreviations}

$1 E n=$ The Ethiopic Book of Enoch

Test. Sol. $=$ Testament of Solomon

25 Similar bags are held by the Holy Anargyroi in Room No. 13 of the Upper Church in Banganarti (Łaptaś 2004: 248).

26 The murals were painted on the wall of Room 23 of the Northwest Annex to the Monastery on Kom H (Martens-Czarnecka 2011: 197). 


\section{Primary sources}

Septuaginta VIII.5. Tobit, ed. by R. Hanhart, Göttingen: Vandenhoeck \& Ruprecht, 1983

\section{SECONDARY SOURCES}

Baldassare, I. (1967). Le pitture. In Tamit (1964). Missione archeologica in Egitto dell'Università di Roma [=Serie Archeologica 14] (pp. 39-60). Rome: Istituto di Studi del Vicino Oriente

Budge, E.A.W. (ed.). (1915). Miscellaneous Coptic texts in the dialect of Upper Egypt. London: British Museum

Coogan, M.D. (ed.). (2001). The New Oxford annotated apocrypha: New revised standard version. New York: Oxford University Press

Cormack, R. (1985). Writing in gold: Byzantine society and its icons. New York: Oxford University Press

Donadoni, S. (1967). Le iscrizioni. In Tamit (1964). Missione archeologica in Egitto dell'Università di Roma [=Serie Archeologica 14] (pp. 61-74). Rome: Istituto di Studi del Vicino Oriente

Geerard, M. (ed.). (1974). Clavis patrum Graecorum II. Ab Athanasio ad Chrysostomum. Turnhout: Brepols

Godlewski, W. (1995). The late period in Nubian art - from the middle of 13th to the end of 14th centuries. In R. Gundlach, M. Kropp, and A. Leibundgut (eds), Der Sudan in Vergangenheit und Gegenwart/Sudan past and present [=Nordostafrikanisch/ westasiatische Studien 1] (pp. 37-63). Frankfurt am Main: P. Lang

Godlewski, W. (2006). Pachoras: The cathedrals of Aetios, Paulos and Petros. The architecture [=PAM Supplement Series 1]. Warsaw: Warsaw University Press

Griffith, F.L. (1928). Oxford excavations in Nubia, LVI-LXI: The church at Abd elQadir. Liverpool Annals of Archaeology and Anthropology, 15, 63-88

Innemée, K.C. (1992). Ecclesiastical dress in the medieval Near East $[=$ Studies in Textile and Costume History 1]. Leiden: E.J. Brill

Jakobielski, S. (1982). Remarques sur la chronologie des peintures murales de Faras aux VIII et IX ${ }^{\mathrm{e}}$ siècles. Nubia Christiana, 1, 142-172

Kitzinger, E. (1991). The mosaics of St. Mary's of the Admiral in Palermo [=Dumbarton Oaks Studies 27]. Washington, D.C.: Dumbarton Oaks Research Library and Collection

Kubińska, J. (1974). Inscriptions grecques chrétiennes [=Faras 4]. Warsaw: Éditions scientifiques de Pologne

Łajtar, A. (2009). Varia Nubica XII-XIX. Journal of Juristic Papyrology, 39, 83-119

Łajtar, A. (2014). Archangel Raphael in inscriptions from the Upper Church at Banganarti. In B. Żurawski, Kings and pilgrims: St. Raphael Church II at Banganarti, mid-eleventh to mid-eighteenth century [=Nubia 5] (pp. 261-283). Warsaw: Neriton

Łajtar, A. (2015a). Wall inscriptions in the Southwest Annex to the Monastery on Kom H at Dongola: Report on work in the 2013 season. Polish Archaeology in the Mediterranean, 24/1, 344-351 
Łajtar, A. (2015b). Wall inscriptions in church B.V on the Citadel of Dongola: Report on work in the 2014 season (with an appendix: Inscriptions discovered in previous seasons). In W. Godlewski and D. Dzierzbicka (eds), Dongola 2012-2014. Report on work in the Mosque Building, Citadel and Monastery on Kom H [=PCMA Excavation Series 3] (pp. 111-116). Warsaw: PCMA UW

Łaptaś, M. (1997). A sphere, an orb or a disc? The object held by the archangels in the Faras Cathedral wall paintings. Bulletin du Musée National de Varsovie, 38(1-4), 24-42

Łaptaś, M. (2003). Representations of angelic hierarchy in a Nativity scene from Faras cathedral. Gdansk Archaeological Museum African Reports, 2, 137-143

Łaptaś, M. (2004). Banganarti 2003. The wall paintings. Polish Archaeology in the Mediterranean, 15, 244-252

Łaptaś, M. (2014). The holy protectors of the Nubian rulers and symbolism of numbers in the Upper Church in Banganarti. In B. Zurawski, Kings and pilgrims: St. Raphael Church II at Banganarti, mid-eleventh to mid-eighteenth century [=Nubia 5] (pp. 289-295). Warsaw: Neriton

Martens-Czarnecka, M. (1982). Les éléments décoratifs sur les peintures de la Cathédrale de Faras [=Faras 7]. Warsaw: Éditions Scientifiques de Pologne

Martens-Czarnecka, M. (1983). L'Archange Michel sur les peintures de Faras. Études et Travaux, 12, 171-193

Martens-Czarnecka, M. (2011). The wall paintings from the Monastery on Kom $H$ in Dongola [=Nubia 3; Dongola 3; PAM Monograph Series 3]. (B.M. Gostyńska, trans.). Warsaw: Warsaw University Press

Meyer, M. (ed.). (1999). Ancient Christian magic: Coptic texts of ritual power. Princeton, NJ: Princeton University Press

Michałowski, K. (1967). Faras: die Kathedrale aus dem Wüstensand. Einsiedeln-ZürichCologne: Benziger

Michałowski, K. (1974). Faras: Wall paintings in the collection of the National Museum in Warsaw. Warsaw: Wydawnictwo Artystyczno-Graficzne

Mierzejewska, B. (2008). Postacie fundatorów trzymających gałązki na malowidłach ściennych w Nubii [The figures of founders holding the twigs on the wall paintings in Nubia]. Ikonotheka, 21, 33-53 [in Polish]

Mierzejewska, B. (2014). Galeria Faras im. Profesora Kazimierza Michatowskiego: przewodnik [Guide to the Professor Kazimierz Michatowski Faras Gallery]. Warsaw: Muzeum Narodowe [in Polish]

Monneret de Villard, U. (1935). La Nubia medioevale I-II. Cairo: Institut français d'archéologie orientale

Plumley, J.M. and Browne, G.M. (1988). Old Nubian texts from Qașr Ibrīm I [=Texts from Excavations 9]. London: Egypt Exploration Society

Scholz, P.O. (2001). Das nubische Christentum und seine Wandmalereien. In S. Jakobielski and P.O. Scholz (eds), Dongola-Studien: 35 Jahre polnischer Forschungen im Zentrum des makuritischen Reiches [=Bibliotheca Nubica et Aethiopica 7] (pp. 177-251). Warsaw: ZAŚ PAN 
Seipel, W. (ed.). (2002). Faras: die Kathedrale aus dem Wüstensand. Vienna: Kunsthistorisches Museum

Tamit (1964). Missione archeologica in Egitto dell'Università di Roma [=Serie Archeologica 14]. (1967). Rome: Istituto di Studi del Vicino Oriente

Underwood, P.A. and Hawkins, E.J.W. (1961). The mosaics of Hagia Sophia at Istanbul: The portrait of the emperor Alexander. A report on work done by the Byzantine Institute in 1959 and 1960. Dumbarton Oaks Papers, 15, 187-217

van der Vliet, J. (1990). Demons in early Coptic monasticism. Image and reality. In H. Hondelink (ed.), Coptic art and culture (pp. 135-156). Cairo: Shouhdy Publishing House

Zielińska, D. (2009). Program ikonograficzny kościotów nubijskich. Studium lokalizacji malowidet we wnętrzu sakralnym [Iconographical program of Nubian churches. A study of wall paintings location in sacral interior] (unpubl. Ph.D. diss.). University of Warsaw [in Polish]

Zielińska, D. (2015). The painted decoration of Building SWN.B.V (Royal Church) on the Citadel: State of research. In W. Godlewski and D. Dzierzbicka (eds), Dongola 2012-2014. Report on work in the Mosque Building, Citadel and Monastery on Kom H [=PCMA Excavation Series 3] (pp. 103-110). Warsaw: PCMA UW

Żurawski, B. (1999). Faith healing, philanthropy and commemoration in Late Christian Dongola. In S. Emmel, M. Krause, S.G. Richter and S. Schaten (eds), Ägypten und Nubien in spätantiker und christlicher Zeit: Akten des 6. Internationalen Koptologenkongresses, Münster, 20.-26. Juli 1996, I. Materielle Kultur, Kunst und religiöses Leben [=Sprachen und Kulturen des christlichen Orients 6] (pp. 423-448). Wiesbaden: Reichert Verlag

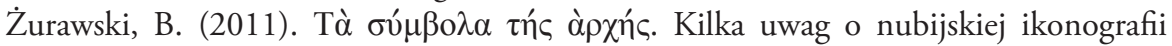
królewskiej XI-XII wieku [A few remarks on the Nubian royal iconography of the 11th-12th century]. In B. Nowak, M. Nagielski, and J. Pysiak (eds), Europejczycy, Afrykanie i inni: studia ofiarowane profesorowi Michatowi Tymowskiemu (pp. 265300). Warsaw: Wydawnictwa Uniwersytetu Warszawskiego [in Polish]

Zurawski, B. (2014a). Banganarti on the Nile: An archaeological guide. Warsaw: Artibus Mundi

Żurawski, B. (2014b). Kings and pilgrims: St. Raphael Church II at Banganarti, mideleventh to mid-eighteenth century $[=N u b i a 5]$. Warsaw: Neriton 



\title{
Nobadian and Makurian church architecture. Qasr el-Wizz, a case study
}

\author{
Artur Obłuski \\ PCMA Research Center in Cairo \\ a.obluski@uw.edu.pl
}

\section{KeYwords}

Nubia, church/sacral architecture, cathedral, Qasr el-Wizz, Faras, Dongola

\begin{abstract}
"To date the research on the church architecture in Nubia has consistently failed to differentiate, territorially and historically, between two different Nubian kingdoms" (Godlewski 2006b) and one could add the third, Alodian, kingdom to this. The author's involvement in a project to publish the Oriental Institute of the University of Chicago excavations at the Qasr el-Wizz monastery has generated this study of the early architectural history of the katholikon at Qasr el-Wizz and its development, analyzed in the context of studies on Nubian Christianity. Due to a rampant misuse of terminology referring to the functional parts of churches in Nubian studies, a review of this vocabulary was deemed essential as a background for a presentation of the late George T. Scanlon's views on the development of this particular church, followed by the present author's addenda et corrigenda, and a discussion and conclusions for the study of Christian Nubian sacral architecture.
\end{abstract}

After fifteen years of cooperation in Egypt and Sudan Włodek encouraged me to start a wider program in Nubian studies. Since I was always interested in the archaeology of religion, Christianity in particular, I decided to tackle the subject of Nubian monasticism. The topic is prospective and interesting of itself, and research is still in the initial stages. Several articles have been published regarding monasteries in Nubia: Piotr Jeute (1994), Julie Anderson (1999), Marzanna 
Romaniuk (2010) and Włodzimierz Godlewski (2013), not to mention reports on excavations at the Monastery on Kom H in Old Dongola (Jakobielski and Scholz 2001). In the course of the program I have initiated two projects: excavations at the Ghazali monastery in Wadi Abu Dom (Obłuski 2014) and publication of the Oriental Institute of the University of Chicago excavations at the Qasr el-Wizz monastery. In the following pages the early architectural history of the katholikon at Qasr el-Wizz will be presented and its development analyzed in the context of studies on Nubian Christianity. The article begins with a review of the functional parts of the Byzantine church, as well as of the vocabulary used both in the primary sources and by modern scholars in order to designate these parts. The views of the late George T. Scanlon on the development of the church at Qasr elWizz are then presented, followed by my addenda et corrigenda to his preliminary analysis. Discussion and conclusions for the study of Christian Nubian sacral architecture complete the text.

\section{Functional parts of Byzantine churches}

\section{EASTERN PART: HIERATEION, THYSIASTERION, BEMA, SANCTUARY}

The church was divided into two functional parts which appeared early in ecclesiastical legislation: the part restricted to the clergy and the other accessible to the entire congregation. The Council of Laodicea (about 368) banned everyone (except the sacred ministers) to enter the thysiasterion (Mansi, Sacr. conc. coll., II, 567 [can. 19] and 571 [can. 44]). The Council in Trullo (692) repeated this regulation and forbade access to the sanctuary for everyone save the clergy and the Emperor when making his offering (Mansi, Sacr. conc. coll., XI, 973 [can. 69]). This division was also mentioned by Procopius (about 500-about 560) in De adificiis (1.1.32). He was referring to the eastern part of the church, the hierateion, as the one "which faces the rising sun, that portion of the building in which they (=clergy $[\mathrm{AO}]$ ) perform the mysteries in worship of God". Another source on the limited access to the hierateion is the Canon of the Synod of Agatha (see below, Diakonikon). A similar division is described by Maximus the Confessor (580662) in the Mystagogy, in chapters on the symbolism of church building and by the patriarch of Constantinople Germanus (about 634-733 or 740) (Germanus, Historia ecclesiastica, Chapter 9). Except in Syria, the hierateion occupies the space directly in front of the apse. Later in Byzantium, it extended into the aisles to include areas in front of the subsidiary apses (Johnson 2005a). In research on Egyptian sacral architecture, Arabic terminology, namely haikal, is used for 
the sanctuary, replaced by khurus from the 7th century onward (Grossmann 1991). According to Peter Grossmann, the haykal initially comprised the area immediately in front of the apse; it then took the form of a rectangular chamber, a triconch or an apse, the last present only in the area of Akhmîm. In Egypt, the sanctuary was often also adorned with decorative niches.

The naos was reserved for the laity (Maximus Confessor, Mystagogia, in Patrologia Graeca XCI 668). It was separated from the hierateion by the chancel barriers. Germanos states that (Mathews 1971: 123): "There are barriers...to define the place of prayer; by which is meant [that] the people [have] access to the area outside while inside the place [is] reserved as the Holy of Holies and [is] accessible only to the priests" (Mathews' translation).

In Byzantine sources, chancel barriers appear under the following names:

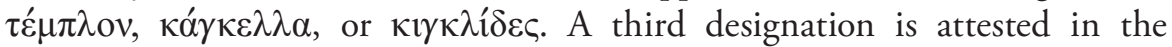
History of the Church by Theodoret of Cyrrhus (about 393-about 458/466) (Marinis 2014: 41). The screen took on the form of a low parapet; the templon developed into a taller partition about the mid-5th century and by the time of the Iconoclasm was extended to the pastophoria (Bouras 2005).

The altars stood in front of the apse, later within the main (central) apse of the Byzantine triple-apsed sanctuary (Taft and Bouras 2005). There were two kinds of altars: a monolithic "Roman-style" and the altar table supported by four small columns (Arranz 1996: 227). They were frequently adorned by ciboria. Traces of such an altar have been preserved in the Church of St John the Baptist in the Monastery of Lips in Constantinople (Macridy 1964: 266).

Some churches were also furnished with a set of benches, reserved for the clergy, that was arranged in a semicircular tier in the apse (Johnson 2005b). It has been called a synthronon ( $\sigma v 0 v \theta \rho o v o v$ ) since the 5 th century. The bishop sat on the cathedra at the top of the synthronon, flanked by the clergy (Johnson and Cutler 2005). Michael Altripp pointed out that the synthronon and episcopal throne cannot be attributed only to cathedral or episcopal churches, although they are often found in episcopal cult buildings (Altripp 2000). The same conclusion was reached by Vasileios Marinis on the basis of the existence of a synthronon in monastic katholika in Constantinople and elsewhere, e.g., in the 11th-century katholikon of Hosios Loukas in Steiris, Greece (Marinis 2014: 28, note 26). Multitier synthrona with only the top bench intended for sitting were common in the early Christian churches of Constantinople, e.g., Hagia Eirene, Hagia Euphemia, Ioannes Studios (Mathews 1971: 99). In mainland Greece they were often reduced to a double-tier structure. It seems that this reflected local church structures, as well as the number of clerics expected to sit on the synthronon on a daily basis. 


\section{Auxiliary rooms (DiAKonika, SKeUphylakia, PASTOPHORIA)}

The tripartite eastern section of the church reportedly originated in Syria (Gartkiewicz 1990: 92). It was common all over the Christian world but surprisingly not popular in Constantinople until the Middle Byzantine period. After Iconoclasm churches were built with two side apses flanking the larger sanctuary apse. Such a pattern of triple-apsed hierateion had never developed in nor reached Nubia. There are examples of remodeling of early Christian basilicas to fulfill new needs. Subsidiary rooms on both sides of the apse were added, for example, to the basilica at Geraki in Greece, to the churches of Archangel Michael at Frangokastello on Crete and the church at Dion in Macedonia, the church of the monastery of St John of Pelekete as well as the church at Sebaste in Asia Minor (Varalis 2006: 291). The north room was used for the rite of the prothesis, and was subsequently named after it. The south room, the diakonikon, was used for the storage of vestments, books and other liturgical equipment (Varalis 2006: 283). The triple-room arrangement of the eastern part of the church was widespread in Egypt (Monneret de Villard 1940: 291) and North Africa (Grabar 1967: 347, 403-416), as well as the northwestern areas of the Balkan peninsula, that is, Dalmatia and Istria (Marušić 1972: 266). It was far less popular in Asia Minor and in Europe, especially on the southern Mediterranean coastline (Krautheimer 1965: 82; MacDonald 1962: Fig. 26; Rusconi 1965: 710, Fig. 4; Testini 1972: Pl. CCXXX, Fig. 14).

The terminology and function of the auxiliary rooms in Byzantine churches is still a matter of debate due to inconsistent use of various terms in the primary sources. The words skeuophylakion and diakonikon, as well as prothesis, were used interchangeably in some Middle Byzantine texts. In the typikon of the Pantokrator monastery, they were referred to as diakonika (Marinis 2014: 35 and note 83 ). In the 12th century, all three eastern rooms were called bemata (Giros 1992: 430). The commonly used term pastophoria appears in the Old Testament where it denoted the treasury and the priests' quarters in the temple of Solomon. Pastophoria were mentioned in the 4th century in the Apostolic Constitutions (2.57.3) where they were described as a sacristy consisting of two parts located in the eastern section of the church (Taft, Loerke, and Johnson 2005). The skeuophylakion, literally "place to keep the vessels", may have also been a separate building. Its functions were transferred gradually to the side rooms of the tripartite hierateion (Marinis 2014: 31). The process was completed in Byzantium not later than the 11th century.

The term diakonikon is attested for the first time in the 4th century in the twenty-first canon of the Synod of Laodicaea and the Apostolic Constitutions (2.57.3). It designated the sacristy where sacred vessels were kept. According 
to some scholars the term diakonikon was restricted to the sacristy south of the apse (Taft, Loerke, and Johnson 2005). The most explicit example is the baptistery of the katholikon of the monastery of Moses on Mount Nebo,

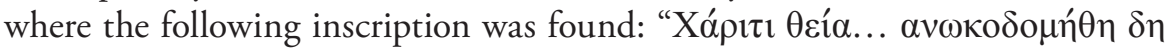

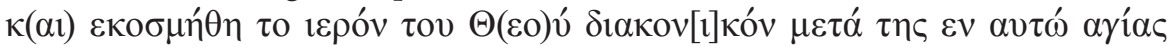

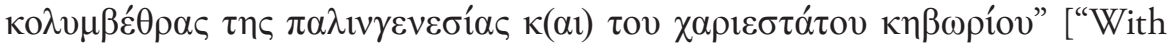
the divine grace ... the holy diakonikon of God was built and decorated with the saint font of rebirth inside it and the most graceful baldachin" (Varalis's translation)] (Varalis 2006: 289). An interesting source is the fiftyfifth canon of the Synod of Agatha (506) which prohibits non-consecrated ministers from touching the sacred vessels kept in the secretarium, the place that the Greeks call diakonikon: "quoniam non oportet insacratos ministros licentiam habere in secretarium, quod Graeci diaconicon appellant, ingredi et contingere vasa domenica" (Mansi, Sacr. conc. coll., VIII, 336; Varalis 2006: 289). In monastic contexts, the diakonikon is attested as a designation of a place for hearing (Rosenqvist 1986: 40; Thomas and Hero 2000: 1137) and for a collation meal after communion (Thomas and Hero 2000: 405).

The word prothesis ( $\pi \rho \operatorname{oo} \theta \varepsilon \sigma 1 \varsigma$, literally "offering") was used in three instances to designate: the Proskomide (Office of Oblation) itself; the table on which the preparation of the Eucharistic gifts takes place; and the chamber to the left of the apse of the church in which this table stands (Taft 2005). The office of prothesis is attested at the beginning of the 8th century in Germanos's Historia ecclesiastica (Descoeudres 1983: 91-92). The earliest known attestation of a prothesis-rite in the form of a prayer comes from the Barberini Euchologion (second half of the 8th century) (p. 57).

The existence of the prothesis in Byzantine churches can be deduced from the instructions of processions, especially the Great Entrance, because it began from the prothesis (Marinis 2014: 36). The chamber is further substantiated by the iconography from the Balkans collected by Altripp (1998), e.g., Hospitality of Abraham, the Akra Tapeinosis ("Man of Sorrows"), Christ the Anapeson.

In Nubia, however, the theme of wall paintings in the prothesis was entirely different, that is, Christ Blessing, Consecration of wine by Christ, and Christ with the Sacred Vessels (Zielińska 2009: 37). These choices show a more literary approach to the iconographic themes in this space.

\section{WESTERN PART}

In Egyptian churches, the most western row of pillars or columns had additional roof supports placed perpendicular to the axis of the building. The space between the columns or pillars and the west wall of the church is called the return aisle. 
In Byzantium, quite often there was a narthex $(v \alpha \dot{\rho} \rho \eta \eta \xi)$ located at the western end of the church. The narthex was a functionally distinct vestibule preceding the naos. From the 4th to the 6th centuries the narthex was a long large hall in which the preparation of the liturgical entrances into the naos took place. After the 9th century, the narthex was reduced in size, but the number of its functions increased and included baptism and commemoration of the dead (Ćurčić 2005).

\section{George T. Scanlon's view of the development of the Qasr el-Wizz church}

The following presentation of George T. Scanlon's interpretation of the development of the church at Qasr el-Wizz retains his vocabulary, even though the present author is opposed to the use of Arabic names for the designation of the liturgical furnishing of the church (such as higab for templon or haikal for hierateion) that were present in the Levant clearly before the Arab conquests and were referred to by the Greek terms.

\section{Early Church}

The earliest church (Scanlon 1970: 31-42) [Fig. 1 left] was a basilica $12.50 \mathrm{~m}$ long and $8.75 \mathrm{~m}$ wide. It was built of sun-dried bricks laid in mud and could be entered by two entrances: one located in the middle of the west wall and the other in the south wall in the southwestern corner of the building. The structure was vaulted. The eastern section of the church was tripartite with an apse in the middle and two side-chambers north and south of it, which could be entered directly from the apse and the aisles. There were three niches and no synthronon in the apse. There was "possibly no altar, at least no trace within the apsidal area", nor was there a passage behind the apse (Scanlon 1970: 41). There was a triumphal arch at the mouth of the apse. A carved stone ambo was located at the north side of the nave between the third and fourth pillars. There were no western rooms. The nave was $2.60 \mathrm{~m}$ wide, while the widths of the aisles were approximately 1.50 and $1.60 \mathrm{~m}$. There were two sets of enlarged pillars dividing the naos from the narthex (original Scanlon's description, although I would call this space a return aisle) and the bema. Between them and on each side of the nave there were three almost square pillars. There was no painted decoration in the church at that time.

Scanlon found it difficult to fit the church into William Adams's typology of Nubian churches: 
"In size it is barely within his dimensions for Type I.b.2 and though it has a narthex and a western entrance, it is far too small to be covered by Type I.a.3. The niching in the apse and the entrance to the sacristies might place it within category II.a, but it lacks the western rooms, the entrance in the north wall, the triumphal arch is differently placed, and, most tellingly, it is too small." Yet he placed it within Type I.b, emphasizing some differences and assigning it a date of about AD 550-750 (Scanlon 1970: 42).

\section{Enlarged Church}

According to Scanlon, the enlarged church was $22.50 \mathrm{~m}$ long (Scanlon 1970: 4252) [see Fig. 1 right]. Its width varied from $12.50 \mathrm{~m}$ across the eastern extension to $9.50 \mathrm{~m}$ across the western one. The width of the nave was $2.35 \mathrm{~m}$ and that of the aisles approximately $1.35 \mathrm{~m}$ and $1.25 \mathrm{~m}$. The following modifications were made to the church layout and structures (Scanlon 1970: 50-51):

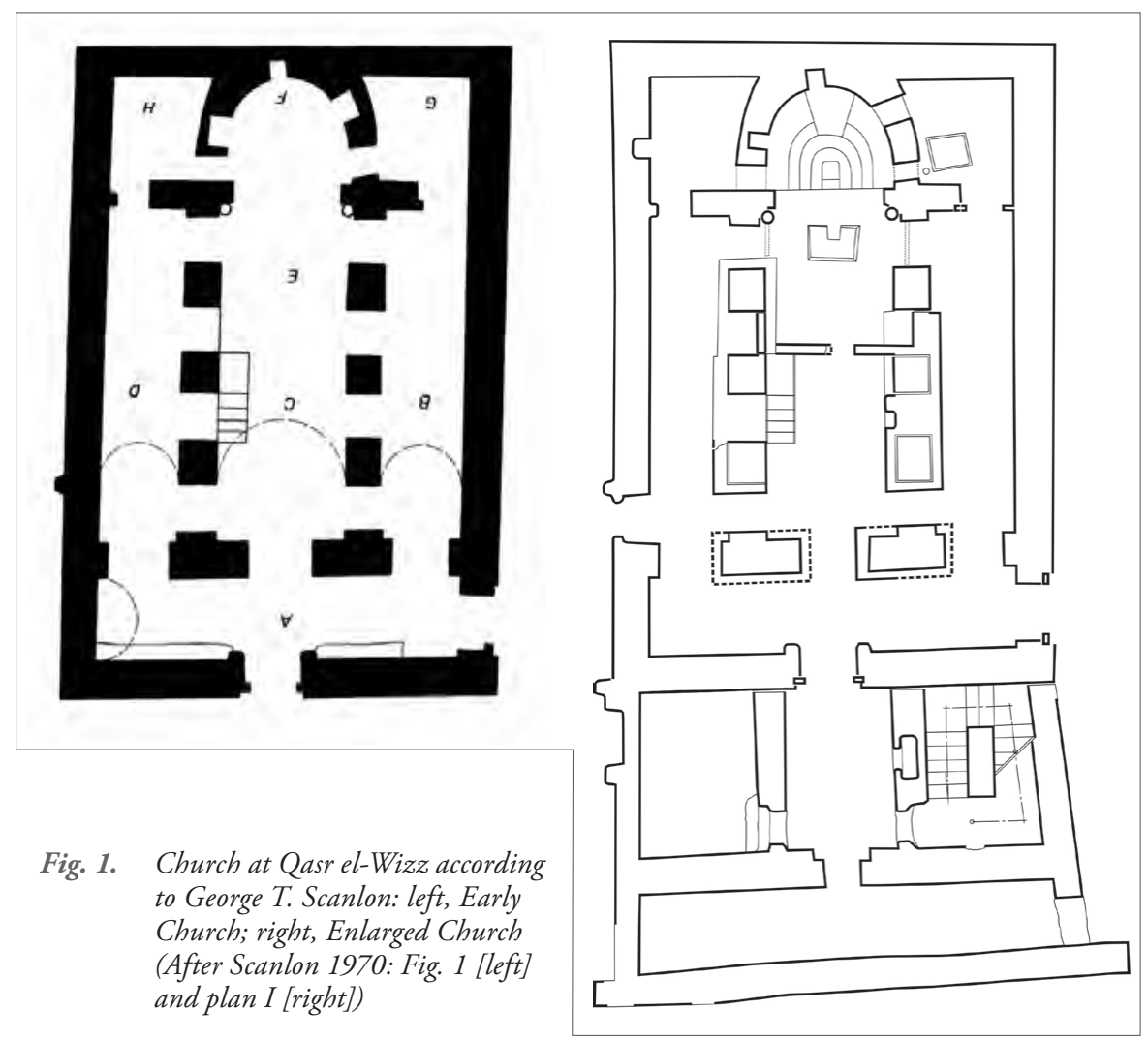


1. Vaultings were retained over the church and expanded over several new rooms (S-T-X-P-Q-K). For other rooms: Q, L and M, Scanlon suggested domes.

2. All the pillars in the church were strengthened. The central pillars were conjoined and thus turned into a wall. The westernmost pillars were made thicker as well.

3. The synthronon was inserted into the apse closing off any access from the apse to the auxiliary rooms.

4. A new altar (for evidence of the existence of an older one, see below) was raised in the haikal (hierateion) which had an enlarged space defined by the addition of a higab (templon) at approximately the western limit of the middle pillar of the earlier phase. Possibly a second triumphal arch was added on wooden piers built on the nave-side of the higab (templon).

5. Western extension: Two rooms (,,$T)$, a stairway (R), and a second narthex $(\mathrm{X})$ were added. Remains of rooms above $S$ and $T$ and the stairway point to the provision of upper galleries in the enlarged church.

6. Eastern extension: Three rooms were added, designated as $\mathrm{K}, \mathrm{L}$, and M. Room K was a burial chapel and was added to the east of the apse with an arched entrance to the north and south. It created thus an 'Eastern Passage' between sacristies G and H. Rooms L and $\mathrm{M}$ were added to the east on either side of $\mathrm{K}$ with a second 'Eastern Passage' connecting them. $\mathrm{K}$ and $\mathrm{M}$ had crypts: two in $\mathrm{K}$ reached by a single shaft and two separate crypts in $\mathrm{M}$. The eastern walls at $\mathrm{G}$ and $\mathrm{H}$ were broken to form the entrances to $\mathrm{L}$ and $\mathrm{M}$.

7. Wall paintings were added, but the carved decoration was left intact.

In Scanlon's opinion “it would seem that K, L, and M represent an enlargement of the Early Church and are architecturally consonant with the western rooms and second narthex (R, S, T, and X). With these eastern and western additions the church should have achieved its quasi-Classical Christian enlargement" (Scanlon 1970: 48). ${ }^{1}$

The eastern extension, which belongs to the Church IV phase, will not be discussed here, as it is a later development embedded in the more extensive changes of Makurian Christianity (for more information, see Obłuski forthcoming) 


\section{New interpretation of the architectural changes in the church at Qasr el-Wizz}

The main line of George T. Scanlon's hermeneutics of the development of church architecture at Qasr el-Wizz stands firm, at least as far as the distinction between the earliest building and the later additions is concerned. This picture, however, needs to be diversified chronologically. I have distinguished four phases of architectural and functional evolution of the church and designated them by successive numbers: Church I, Church II, Church III and Church IV.

\section{Church I [Fig. 3]}

In order to understand the architectural modifications of the Qasr el-Wizz katholikon, its distinctive characteristic traits need to be clarified. The first is the lack of a baptismal tank and thus a baptistery in the southeast auxiliary room. The second is the construction of floors in the earliest church. The stone tiles of the floor in the earliest church were laid in mud and then covered with a lime plaster. The location of the altar in the earliest church can be established thanks to the vast photographic documentation of the excavations made by Gordon Holler. In the following images [Fig. 2], sockets to embed the altar supports are clearly visible between the synthronon and the latest altar found by Scanlon. The location of the triumphal arch delivers further supportive evidence. Its symbolic meaning as an entrance to the "Holy of Holies" can be sustained only when it is placed between the congregation and the altar, where the Eucharistic rite takes place - not behind it.

\section{Church II [Fig. 5]}

The second phase is characterized by one important change in the eastern part of the church. A baptismal tank was sunk into the floor in the southeastern room (I-G). The floor paving was replaced with fired bricks, also laid in mud and covered with a layer of lime plaster [Fig. 4].The entrance to the apse was blocked in effect, but because direct communication between these two spaces was still important, the southern niche in the apse was enlarged to form a new entrance to the baptistery [Fig. 6 ]. This secondary entrance was subsequently also blocked before the introduction of the synthronon, since whitewashed plaster was discovered on the blocking inside the apse. 


\section{Church III [Fig. 9]}

Substantial modifications in the building in the next phase mirrored changes in the functional organization of church space. The central pillars were conjoined, forming a thick wall supporting the vaults over the aisles and nave. The construction of a staircase validated the existence of a first floor (or access to the roof). This staircase (I-R), along with two more rooms, was added at the west end of the church (Rooms I-S and I-T) and thus formed a tripartite western extension complemented by the addition of an exonarthex on the west.

The synthronon filled the entire apse. It was a five-tier bench with a central seat designed for a bishop or the highest ranking churchmen. Its construction
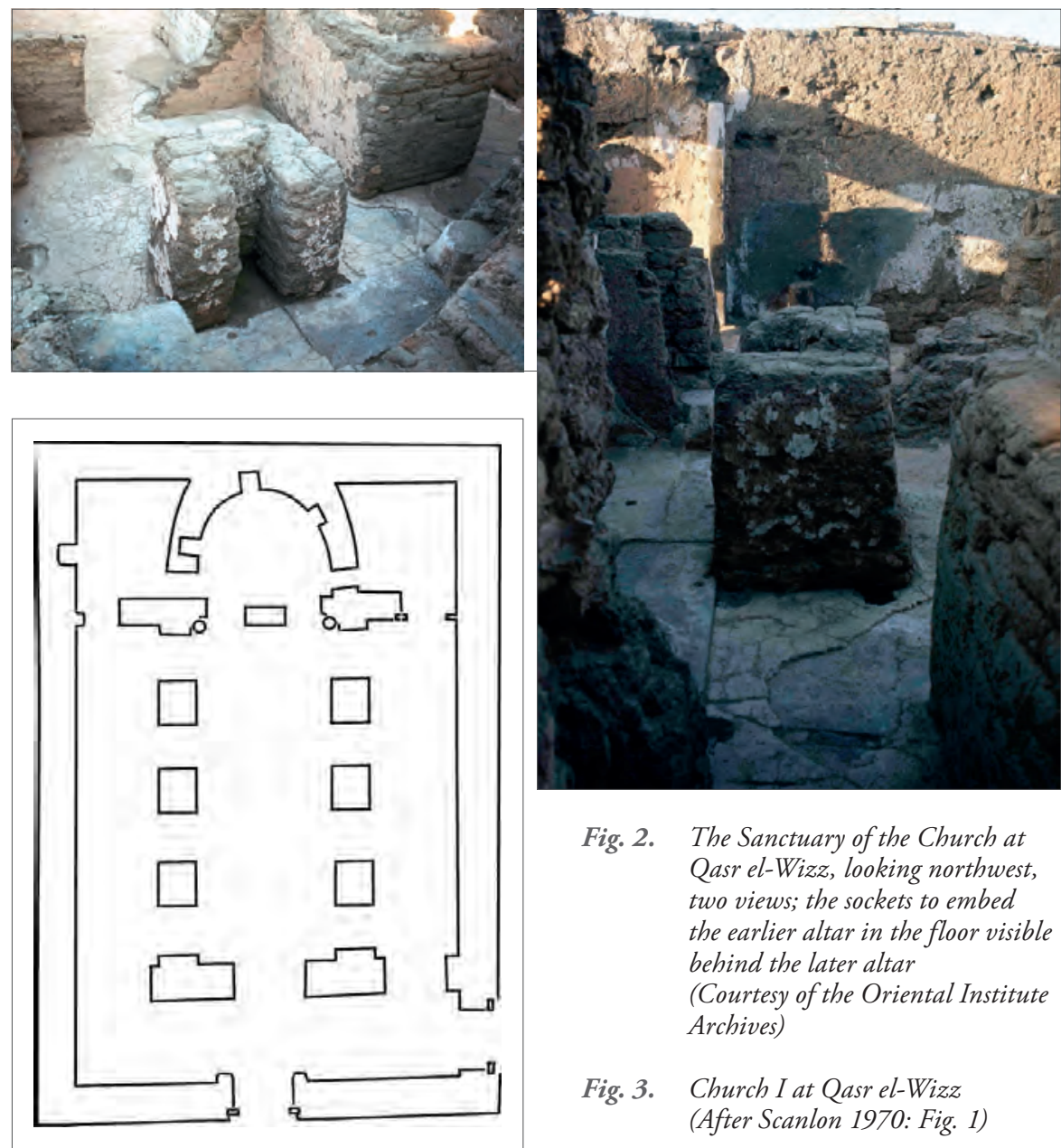

Fig. 2. The Sanctuary of the Church at Qasr el-Wizz, looking northwest, two views; the sockets to embed the earlier altar in the floor visible behind the later altar

(Courtesy of the Oriental Institute Archives)

Fig. 3. Church I at Qasr el-Wizz (After Scanlon 1970: Fig. 1) 
Nobadian and Makurian church architecture. Qasr el-Wizz, a case study

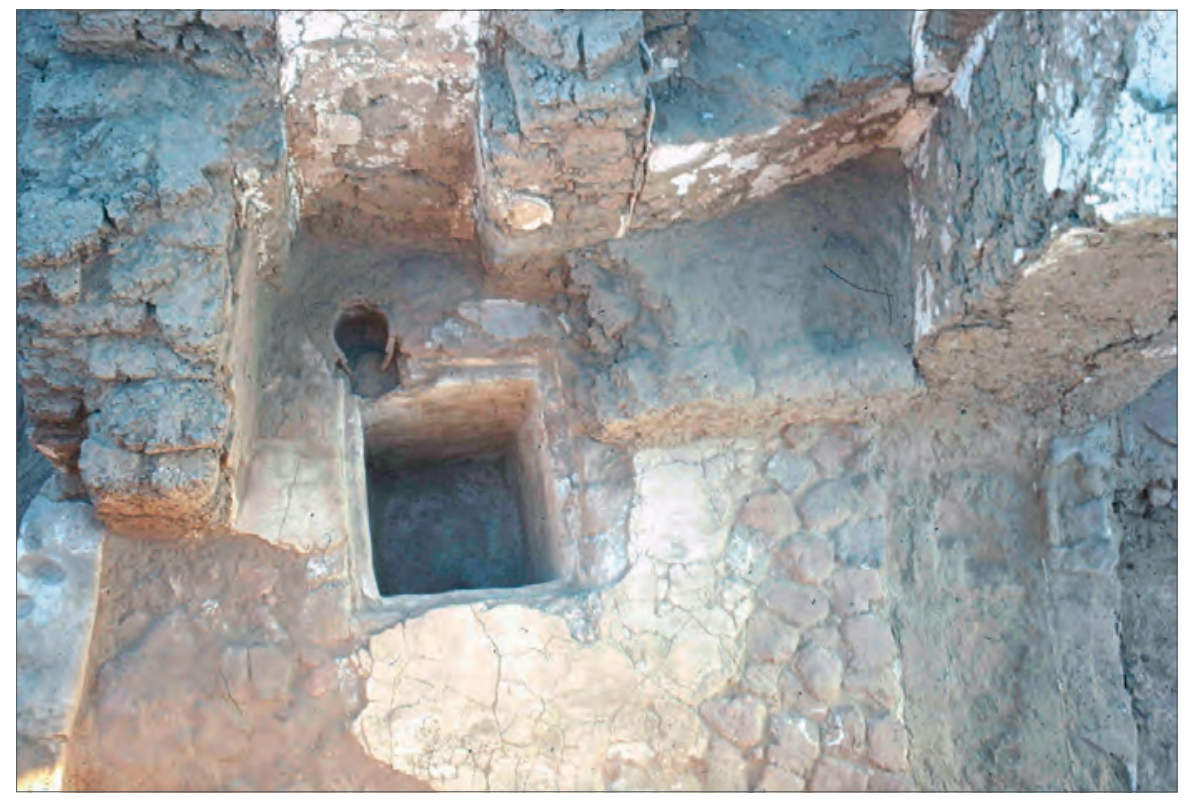

Fig. 4. Northern part of the baptistery in Church II at Qasr el-Wizz, view looking north (Courtesy of the Oriental Institute Archives)

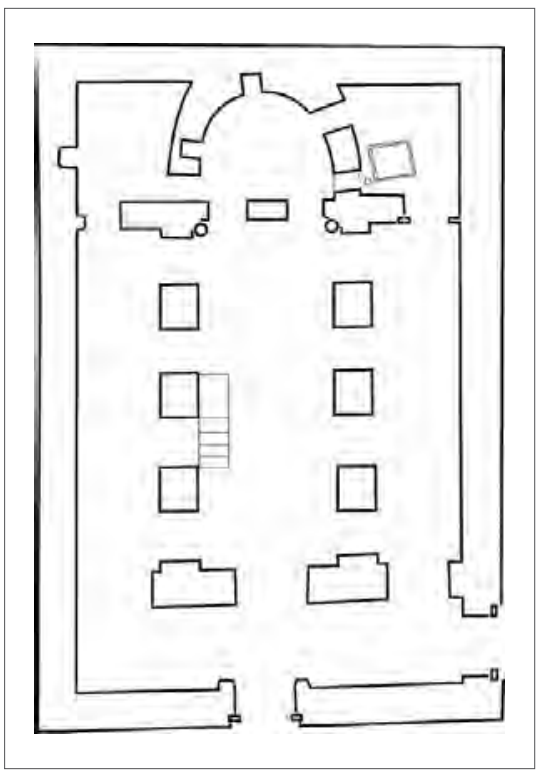

Fig. 5. Church II at Qasr el-Wizz (Drawing S. Maślak, A. Obtuski)

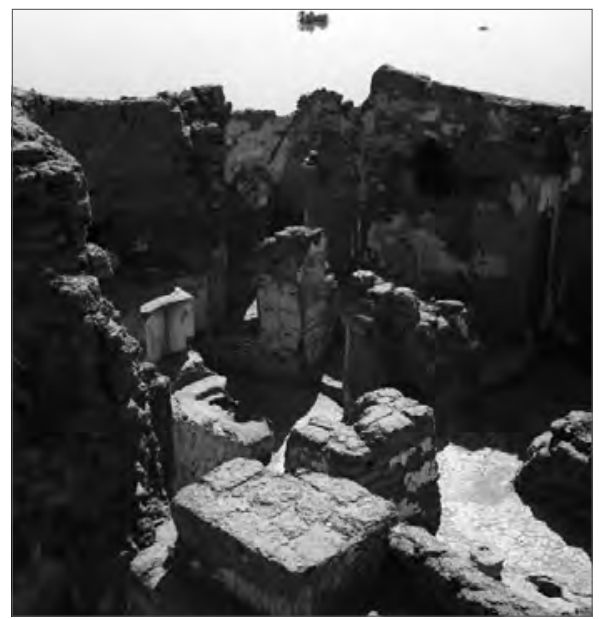

Fig. 6. Sanctuary of the Church at Qasr el-Wizz after partial removal of the synthronon, view looking southeast (Courtesy of the Oriental Institute Archives) 
caused the sealing off of both side entrances to the apse and necessitated the moving of the altar into the nave. The change of location of the altar implied changes in the symbolism of the architecture, that is, the allegory of the triumphal arch became obsolete. It was no longer a gate to the "Holy of Holies". Nevertheless the distinction between the presbytery and the rest of the church space was still an important and valid issue from the standpoint of both symbolism and architecture. A new and more substantial partition was installed: one-brick thick walls between pillars N2-N3, S2-S3 and a wall with a central entrance dividing the nave [Fig. 10] The eastern end of the north aisle was also screened off from the presbytery by a wooden screen socketed into the column of the triumphal arch [Fig. 7]. Wooden decorative elements, namely pieces of columns and capitals, were recovered in their original positions in the northeastern and southeastern corners of the reduced nave [Fig. 8]. They imply that there was wooden decoration on the templon built of sun-dried brick, at least on the side of the congregation. On the north side of the nave just next to the templon, an ambo was added.

\section{Summary}

To sum up this part, the earliest church was a three-aisled basilica with an additional return aisle at the west end of the church and a tripartite eastern section. The latter consisted of the central apse, the width of which equaled the width of the nave, and an auxiliary room on each side of the apse, accessible from both the aisles and the apse. The altar was situated inside the apse and the triumphal arch spanned the opening of the sanctuary.

The first modifications (Church II) were limited to the installation of the baptismal tank in the southeastern room (Room I-G), the blocking of the south doorway to the sanctuary, and the opening of another one east of the previous door.

The next modification (Church III) was more substantial and included reinforcing the roof supports by adding a wall between the central pillars. Second, a western extension consisting of three rooms adjoining the church on the west, and containing a staircase and the exonarthex, was added. Finally, a synthronon was built inside the apse and a new presbytery was created in the eastern section of the nave with an altar standing in front of the apse. The new "Holy of Holies" was screened from the nave by a templon made of sun-dried bricks. Its western side was decorated with wooden elements. The ambo was added next to the templon. 
Nobadian and Makurian church architecture. Qasr el-Wizz, a case study

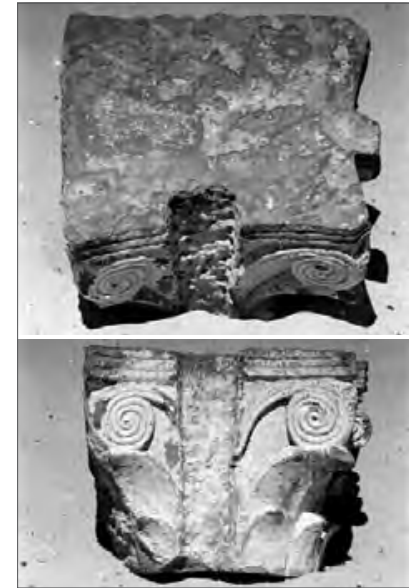

Fig. 7. Slots to mount the wooden screen into the northern column of the triumphal arch, top and side views

(Courtesy of the Oriental Institute Archives)

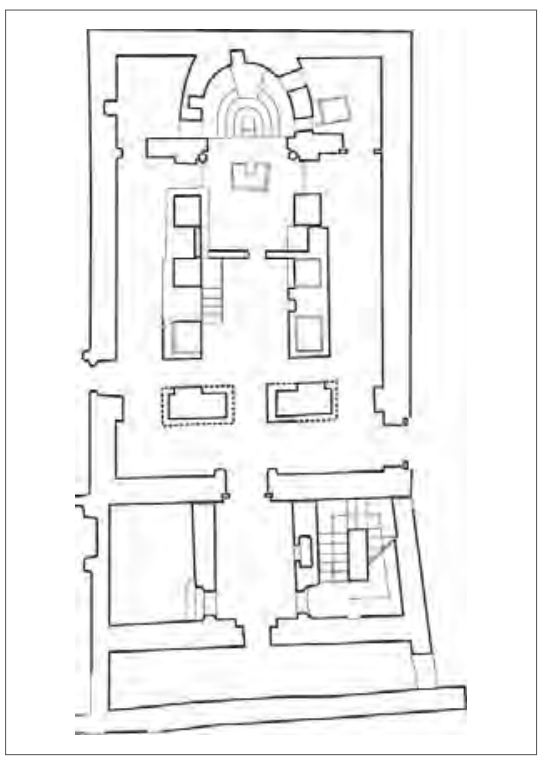

Fig. 9. Church III at Qasr el-Wizz (Drawing S. Maślak, A. Obtuski)

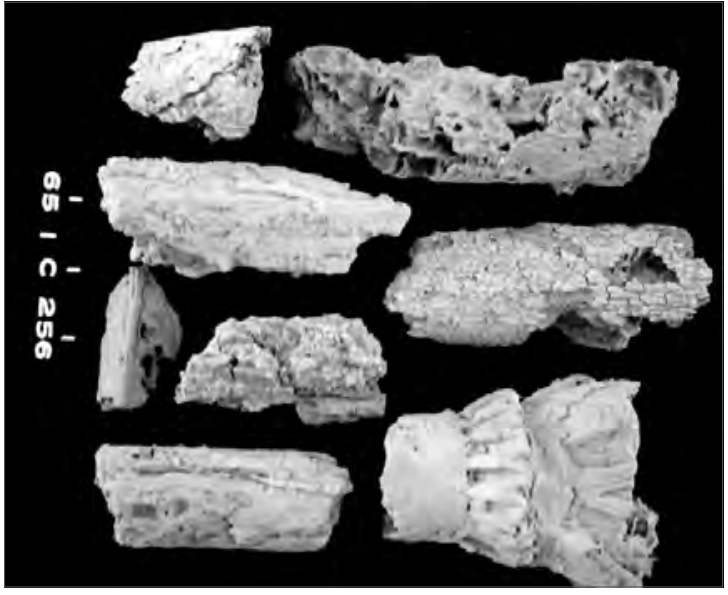

Fig. 8. Wooden decoration of the western side of the templon (Courtesy of the Oriental Institute Archives)

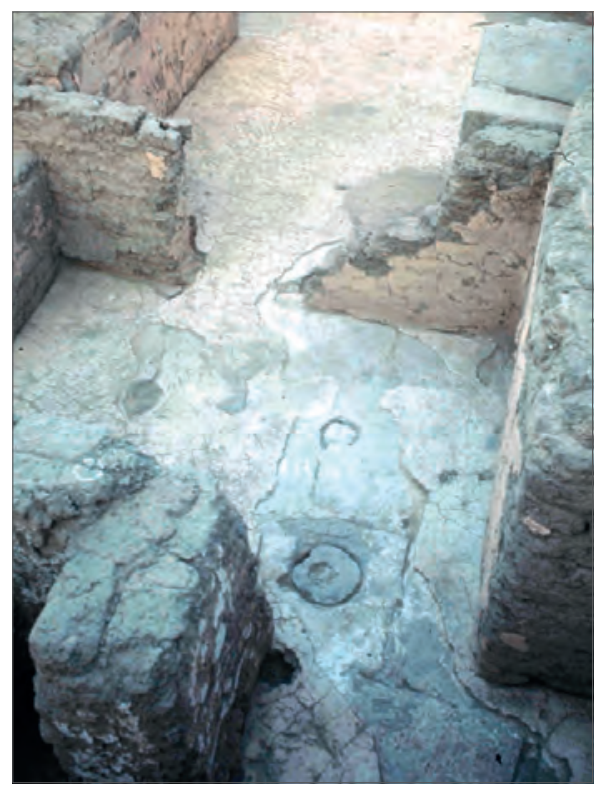

Fig. 10. Sun-dried brick templon in the western part of the sanctuary of the Church at Qasr el-Wizz, view looking southwest (Courtesy of the Oriental Institute Archives) 


\section{Analysis}

\section{Church I}

Church I at Qasr el-Wizz is almost without parallel in Nubian sacral architecture and does not fit into the existing typology proposed by William Y. Adams. It bears, however, many similarities to 5 th-7th century churches from Egypt. These similarities are manifested in a basilican division of the naos into a nave wider than the aisles; a return aisle at the west end of the church; and the presence of niches in the apse. The Egyptian churches most clearly paralleling the Qasr el-Wizz establishment include the following [Fig. 11]: church at Qal'at al-Babên (Effland 2004: 68, in terms of the return aisle and niche decoration of the apse), Lower (5th century) and Upper Churches (7th century) at Abu Fana (Grossmann 2002: 518); churches in both Shenutian monasteries near Sohag (5th century) (Grossmann 2002: Figs 150, 155, and 528,536 , in terms of the apse with three niches and entrances to auxiliary room and return aisle), church in the Courtyard of the Temple of Chnum at Latopolis (6th century) (Grossmann 2002: 460, Fig. 76); church at Deir Abu Hinnis (5th-6th century) (Grossmann 2002: 522, Fig. 141, in terms of the triple-niched apse and entrances to auxiliary rooms).

Even so, Church I at Qasr el-Wizz demonstrates some local features of building technique and materials. Pillars made of sun-dried bricks replaced the stone columns and the triumphal arch was located at the mouth of the apse, not like the first pair of pillars from the east. The nearest Nubian parallels for Church I are [see Fig. 11]:

1. Cathedral Number One at Faras (Gartkiewicz 1986: 250), because, apart from its basilican layout, which Włodzimierz Godlewski pointed out already together with other affinities between the two complexes (Godlewski 2006: 41), it has the altar located inside the apse and the triumphal arch spanning the opening of the apse;

Fig. 11. Parallels for Church I from Egypt (in rows from top left: Lower Church at Abu Fana (after Grossmann 2002: Fig. 135); church at the Shenute monastery in Sohag (after Grossmann 2002: Fig. 150); church at Qal'at al-Babên (after Effland 2004: 68); church at Deir Abu Hinnis (after Grossmann 2002: Fig. 141); Upper Church at Abu Fana (after Grossmann 2002: Fig. 136); church at Anba Bishoi monastery in Sohag (after Grossmann 2002: Fig. 155); Cathedral Number One at Faras (after Gartkiewicz 1986: Fig. 17); church in the Courtyard of the Temple of Chnum at Latopolis (after Grossmann 2002: Fig. 76); Central Church at Ikhmindi (after Deichmann and Grossmann 1988: Fig. 7); Church at Qasr Antawu (Gimei) (after Monneret de Villard 1935/I: Fig. 218); Alwan churches at Soba (after Welsby and Daniels 1991: Fig. 2); Old Church at Qasr Ibrim (after Aldsworth 2010: Fig. 68) 


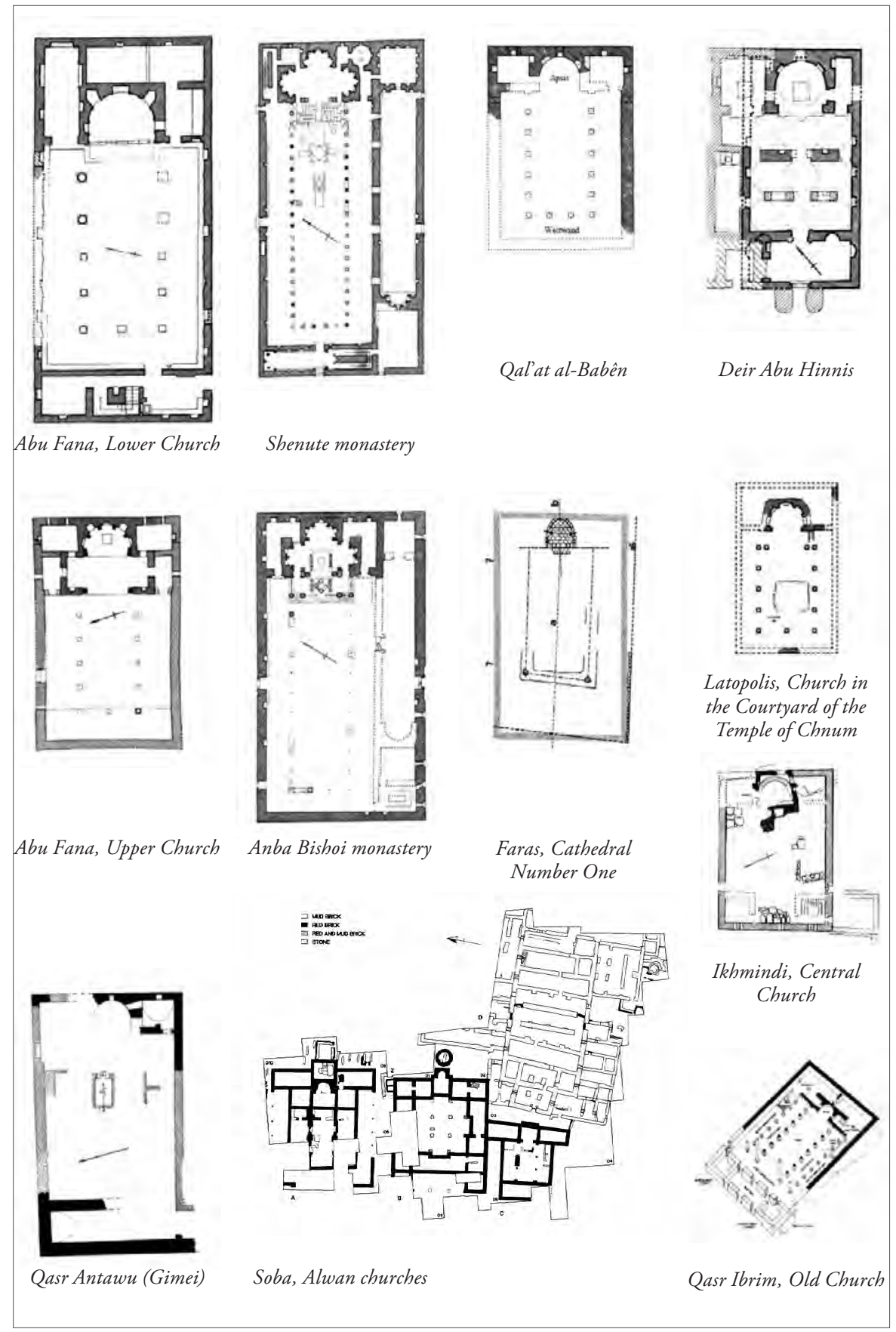


2. hypothetical Old Church at Qasr Ibrim (Aldsworth 2010: 126), because of entries to the apse and lack of tripartite western section;

3. Church at Qasr Antawu (Gimei) (Clarke 1912: 50; Monneret de Villard 1935/I: 227), in view of the entries to the apse, niches, and lack of tripartite western section;

4. Central Church at Ikhmindi (Deichmann and Grossmann 1988: 1420; Stenico 1960), because of the lack of a tripartite western section;

5. Alwan churches at Soba (Welsby and Daniels 1991), because of the lack of a tripartite western section.

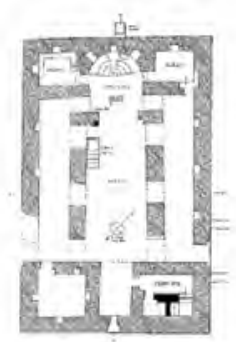

Faras, North Church

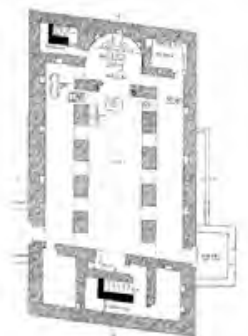

Faras, South Church

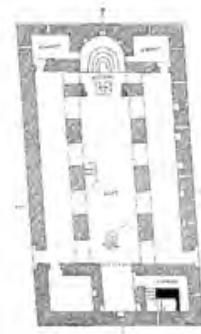

Faras, Riverside Church

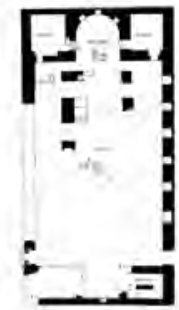

Serra, Southern Church

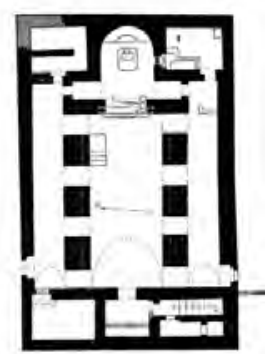

Sheikh Bedawi

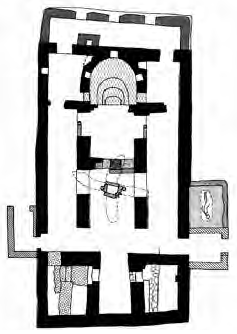

Sahaba

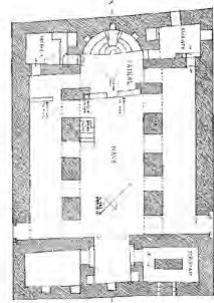

Hammam el-Farki (Serra Gharib)

Fig. 12. Parallels from Nubia for Church III (in rows from top left): North Church at Faras (after Mileham 1910: Pl. 14); South Church at Faras (after Mileham 1910: Pl. 17); Riverside Church at Faras East (Mileham's Northern Church near Adindan; after Mileham 1910: Pl. 23); Southern Church (Basilica) at Serra (after Mileham 1910: Pl. 36); church at Sheikh Bedawi (after Monneret de Villard 1935/I: Pl. 164); church at Sahaba (after Gardberg 1970: Fig. 6); Church at Hammam el-Farki (Serra Gharib) (after Mileham 1910: Pl. 8) 


\section{Church II}

In Church II, the introduction of the baptismal tank in the southeastern room was an important modification reflecting the liturgical function of the church. Its location can be regarded as typical for Makurian churches and we can find several parallels of this spatial distribution:

1. Church at Arminna West (Godlewski 1979: 63, Figs 9, 10);

2. Central Church at Ikhmindi (Godlewski 1979: 89, Fig. 41);

3. Old Church at Old Dongola (Godlewski 1979: 98, Figs 55-61);

4. Church of the Stone Pavement at Old Dongola (Godlewski 1979: 103, Figs 63-69);

5. Church at al-Ramal (Godlewski 1979: 129, Fig. 96).

Moreover, the baptismal tank at Qasr el-Wizz is cube-shaped, as in the following churches situated in the territory of Nobadia: at al-Ramal, Ikhmindi, Arminna West, the so-called Paulos Cathedral at Faras (Godlewski 1979: 67, Figs 14, 15, 17-19); Sheikh Bedawi (Godlewski 1979: 130, Fig. 97); Wadi el-Sebua (Godlewski 1979: 124, Figs 92, 93).

\section{Church III}

After the third set of modifications, the monastic church at Qasr el-Wizz became a typical Nubian church. The synthronon filled the apse, the altar stood in front of the apse, which was screened off from the congregation by a templon. The western part consisted of three rooms, of which the southwestern one contained a staircase. The nearest Nubian parallels are constituted by churches of Adams's type 2.a (2009: 73-95) [Fig. 12], e.g.:

1. Northern Church at Faras (Mileham 1910: 27-30);

2. Southern Church at Faras (Mileham 1910: 31-36);

3. Riverside Church at Faras East (Mileham's Northern Church near Adindan; Mileham 1910: 37-38);

4. Southern Church (Basilica) at Serra (Mileham 1910: 45-47);

5. Church at Sheikh Bedawi (Monneret de Villard 1935/I: 181-183);

6. Church at Sahaba (Gardberg 1970: 27-39);

7. Church at Hammam el-Farki (Serra Gharib) (Mileham 1910: 14-21).

\section{Discussion}

There are several studies on typology and chronology of Nubian church architecture. The first was presented by the American architect Geoffrey 
Mileham (1910). He was followed by Somers Clarke (1912), Ugo Monneret de Villard (1935), and William Y. Adams (1965). Przemysław M. Gartkiewicz offered an innovative outline of the development of Nubian church architecture (Gartkiewicz 1980). Last but not least, Włodzimierz Godlewski made both special studies and general overviews of these topics, most recently with a monograph on the Cathedrals at Faras (Godlewski 1990; 1998; 2006a; 2006b). My study aims to shed some additional light on specific aspects of Nubian church architecture.

The first feature of Nubian churches discussed here is the triumphal arch, an architectural element surpassing the decorative function and encompassing important symbolical meaning. It was used extensively in the Christian world, especially in the early period. The topic of triumphal arches in Nubia has been commented upon by Bartosz Wojciechowski (2010: 221-223). The churches where a triumphal arch was certainly introduced were the Northern Church in Adindan (Riverside Church at Faras East), Debeira West, the Northern and Southern Churches in Faras, the Southern Church in Serra East, Sheikh Bedawi, Qasr el-Wizz, Sahaba and Naga Abdallah. It is striking that all of them come from the territory of Nobadia. The last mentioned church was never properly studied, thus its value for the discussion is very limited or non-existent. There are also several churches where the presence of the triumphal arch is hypothetical, e.g.,

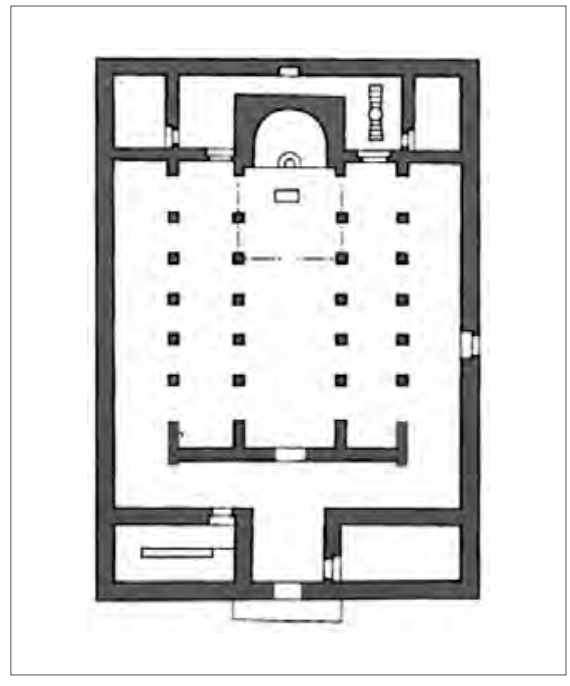

Fig. 13. Church of the Stone Pavement (EC.1) at Old Dongola (After Godlewski 2006a: Fig. 14)

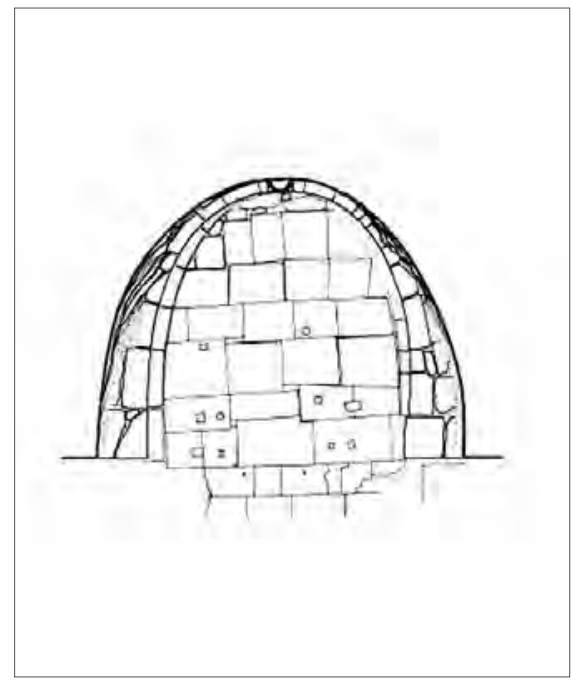

Fig. 14. Altar sockets in the apse of Cathedral Number One (After Gartkiewicz 1986: Fig. 13) 
the so-called Cathedral of Aetios in Faras and the Church of the Stone Pavement in Dongola. Triumphal arches are located either at the mouth of the apse, like in Qasr el-Wizz and Sahaba, or at the first pair of pillars west of the apse. In every case, the arch was placed between the altar and the naos, clearly marking the division between the hierateion and the naos, that is, the area restricted to the clergy and the one accessible to the laity. It proves its allegorical meaning as the gates of heaven, deeply rooted in early Christian symbolism.

The suggested presence of triumphal arches in the so-called Cathedral of Aetios at Faras and Church of the Stone Pavement in Old Dongola (Wojciechowski 2010:222) is based solely on the presence of recesses in the walls where columns may have stood. A similar situation is seen in the Friedhofskirche at Gebel Adda (Wojciechowski 2010: 224), but it will not be considered here as not only the arch itself, but also the recesses for the columns at the mouth of the apse were not preserved there. In the so-called Aetios Cathedral and in the Church of the Stone Pavement there are recesses in the walls at the mouth of the apse, but there is also a synthronon in the apse and the altar stands in front of it. Therefore, in these churches the location of the triumphal arch does not harmonize with the symbolism of the gate from earth to the heavens. In the Church of the Stone Pavement there is even a templon separating the hierateion from the naos, making the triumphal arch obsolete [Fig. 13]. Thus the possible scenarios are as follows:

1. There was no triumphal arch in these churches, which is possible albeit quite surprising, because the recesses look like they were suited for the columns of the triumphal arch, as in the Nubian churches that clearly had this element.

2. The triumphal arch belongs to earlier phases of building activity at sites which are earlier than the Church of the Stone Pavement and the so-called Cathedral of Aetios. The Church of the Stone Pavement cannot be analyzed in detail for lack of publication of this structure. Yet the plausible existence of a triumphal arch strongly implies a phase of this church when there was no synthronon in the apse. This alternative supports Gartkiewicz's suggestion of the existence of an additional church between the so-called Mud Church and Michałowski's First Cathedral at Faras (Gartkiewicz calls this building Cathedral Number One and Godlewski Church No. 2) and this church (not the so-called Aetios Cathedral) would feature the triumphal arch, as well as an altar in the apse and a ciborium.

3. The triumphal arches in the so-called Cathedral of Aetios and in the Church of the Stone Pavement are to be dated as suggested by Włodzimierz Godlewski and synthrona belong to the later phases. The dating of the synthrona in the Faras cathedrals is a long-standing matter of controversy 
(Godlewski 2006a: 39). According to Gartkiewicz, in Cathedral Number Two (Cathedral of Aetios), the apse was filled with a synthronon decorated with half columns (Gartkiewicz 1986: 252) [Fig. 14]. These half columns were allegedly mounted in sockets in the floor. Actually, there were more hollows in the floor and they were located deeper into the apse than the columns reconstructed by Gartkiewicz. The pattern formed strongly indicates use for the purpose of embedding the altar and ciborium over it. So there is the alternative that either there was an altar in the apse or a synthronon. Both could not have been housed in the apse at the same time, since the bench was built over the sockets. If the apse was filled with a synthronon, then the altar had to stand outside it and the hierateion would have been divided from the rest of the church by a triumphal arch or a templon installed in the nave. Yet none of those who studied the building itself and/or the related documentation reconstructed such a feature in their interpretations of the architecture. If we rule out the possibility that Michałowski, Gartkiewicz and Godlewski missed this evidence, we should accept that no templon existed either in Cathedral Number One or in Cathedral Number Two (Cathedral of Aetios). The location of the altar suits the presence of the triumphal arch and supports either the installation of a synthronon in Cathedral Number Two at a later date or Kazimierz Michałowski's suggestion that the synthronon made of sun-dried bricks belonged to the so-called Cathedral of Paulos and could be dated to the year 707 (Michałowski 1967: 70-71). In the first case, the troublesome question of the location of the altar and templon in the so-called Cathedral of Aetios remains open.

The presence of the triumphal arch at the mouth of the apse in the church at Qasr el-Wizz, combined with the lack of a synthronon, makes this church at least comparable to Cathedral Number One. The latter is dated by Gartkiewicz to the first quarter of the 7th century (Gartkiewicz 1986: 249) and by Godlewski before 620, since it is earlier than the so-called Cathedral of Aetios.

The next feature of the eastern part of Church I at Qasr el-Wizz discussed here is the communication between the sanctuary and the auxiliary side rooms. There are entrances to both of them in the original building. Direct communication was sustained in Church II, but in Church III both entries were blocked. Entrances to the side rooms from the sanctuary are very common in the layout of the eastern part of Nubian churches. There are numerous buildings where such an arrangement is present: 
1. Gebel Adda Basilica, Faras East (Riverside Church), Faras West North Desert Church, Debeira West (Hammam al-Farki), dated to the 7th century;

2. Sahaba, Qasr Antawu, Arminna, Ikhmindi (Central Church), dated to the Early Christian period;

3. Tamit (Basilica), Faras (Desert Church), Sunnarti Church, Sonqi West, Old Dongola Northwest Church, dated to the Classic Christian period (AD 750-1250);

4. Qasr Iko (Northeast Church), Duweishat East (Church 16-S-1), Duweishat West, Attiri, Hellet el-Bib, Mis Island, Old Dongola North Church, Us Island, Teiti, Old Dongola Tower Church, Tamit (Church of the Angels), Faras West (Citadel Church), Serra East (North and South Domed Churches, New South Church), Sonqi East (Kidinkoing Church), dated to the Late Christian/Terminal period (AD 11501500).

In ten other churches there is a passage only to the northeastern room, as in the late Church II at Qasr el-Wizz, while there is a single example of a church with an entrance only to the southeastern room, namely Sheikh Bedawi. In all but three churches (Gendal Irqi, Qasr Iko Southwest Church and Tamit's St Paul's Church), there is no passage behind the apse, which suggests that it played a similar role to the direct communication of the side rooms with the apse. Thus, the rationale behind the direct communication with the sanctuary and the passage at the back of it was to provide a route for clergy that would not be disturbed by the congregation.

The lack of passage behind the apse and the direct communication with the sanctuary indicate that the clergy had to enlarge the hierateion at the expense of the naos (namely the aisles), when it sought to preserve an undisturbed communication in the eastern part of the building. Thus, in the churches where there is neither a passage behind the apse nor entries from the sanctuary to the side rooms we should expect encroachment of the hierateion into the spaces in front of the auxiliary rooms. This implies the introduction of a templon, as is the case of the South Desert Church at Faras, Sheikh Bedawi, Tokor, as well as at Qasr el-Wizz. In all of them there was a screen put in front of the entrance from the south aisle to the southeastern room (see Mileham 1910: Pl. 17 for Faras South Desert Church; Scanlon 1970: Plan I and Pl. XXXVII, Fig. 3 for Qasr el-Wizz). The enlargement of the area screened by a templon in Byzantine churches is dated to the period after the Iconoclasm, that is, the middle of the 9th century (Bouras 2005). 
The propensity for preservation of the direct communication between the sanctuary and the northeastern room in 46 buildings is important for the determination of the function of this room. In my opinion, it demonstrates the location of the prothesis there. The sustained communication allowed entry into the sanctuary with the Eucharistic gifts directly from the prothesis without passing through the naos. Lack of communication with the southeastern room in these churches: Tokor, Faras South Desert Church, St Paul Church at Tamit, Qasr Iko South-West Church, Gendal Irqi, Qasr Ibrim Cupola Church, Central and New South Church at Serra East, Tanjur, and Ferka East also implies that this room had a limited role in the liturgy in late churches.

The third feature of the Qasr el-Wizz church to be tackled here is the tripartite western extension, which contains a staircase in the southwestern room. This feature has been considered so far as typical of Nubian architecture. In most cases, it is situated in the southwestern corner of the building. The staircases were rectangular in plan. In the middle of the room there was a newel, which supported a set of barrel-vaults on which flights of steps and landings were constructed. The entrance to the staircase may have been from the aisle or the western bay, seldom was the staircase entered from outside, as for example in the South Church at the Ghazali monastery (Obłuski 2014). In northern Nubia there seems to have been no fixed rule for the location of a staircase, but from Faras southward the staircases were nearly always at the southwest (Adams 1965: 99). There are five possibilities as to where the staircases in Nubian churches may have led: to the first floor, to the galleries over the aisles, to the gallery over the western part of the building, to the roof or to the terrace thus forming a kind of tower. In my opinion, its role may have varied in Makurian sacral architecture, but the consistency of its presence in the churches and its location in the building indicate that it played the same role in most cases. A hint for a better understanding of this is offered by Geoffrey Mileham's discovery in the church at Buhen (Church near Wadi Halfa in his terminology). He found there two strings of brass bells, which may have been used for calling the community to prayer (Mileham 1910: Pl. 38).

The function of the other two rooms at the western end of Nubian churches has not been determined yet. Adams suggested that they might have been included more for symmetry than to serve specific purposes (Adams 1965: 94). In the North Church at the Ghazali monastery benches were built against the walls of the western bay. Remains of the plaster preserved on the walls suggest that the benches may have been arranged into separate seats [Fig. 15]. This room and the corner one, in which no staircase was located, may have been diakonika used for purposes put forward by Rosenquist and Thomas in the context of 
Byzantine monastic churches (see above, section on diakonika). Very evocative is the evidence found in the church at Nag' el-Scheima. There is a staircase in the northwestern room and in the southwestern room there are three containers made of stone slabs (Bietak and Schwarz 1987: see Plan V). This space is located right next to the southern entrance to the church and opened on the southern aisle, a plausible location for offerings brought by the congregation.

There is a group of churches where the western tripartite section and staircase are absent and in this regard they are parallels for the Qasr el-Wizz Church I. These are the Faras Cathedral, Gebel Adda Friedhofskirche, Qasr Antawu, Central Church at Ikhmindi and all of the churches known from Alwa. The sole attestation in the territory of Makuria is the Church on Kom D at Old Dongola, but it seems to be more a commemorative chapel than a communal church in its initial phase of use. I exclude from the discussion several churches lacking the discussed feature, since they represent a separate development in the Late Makurian period (after 1100) when the western tripartite division was abandoned. One should note Fred Aldsworth's doubts regarding a staircase in the southwestern part of the Qasr Ibrim Cathedral. He pointed out a change in the coursing in the south wall about $4 \mathrm{~m}$ east of the south door that could indicate a rebuilding of the west end of the original building (Aldsworth 2010: 126). It seems that there may

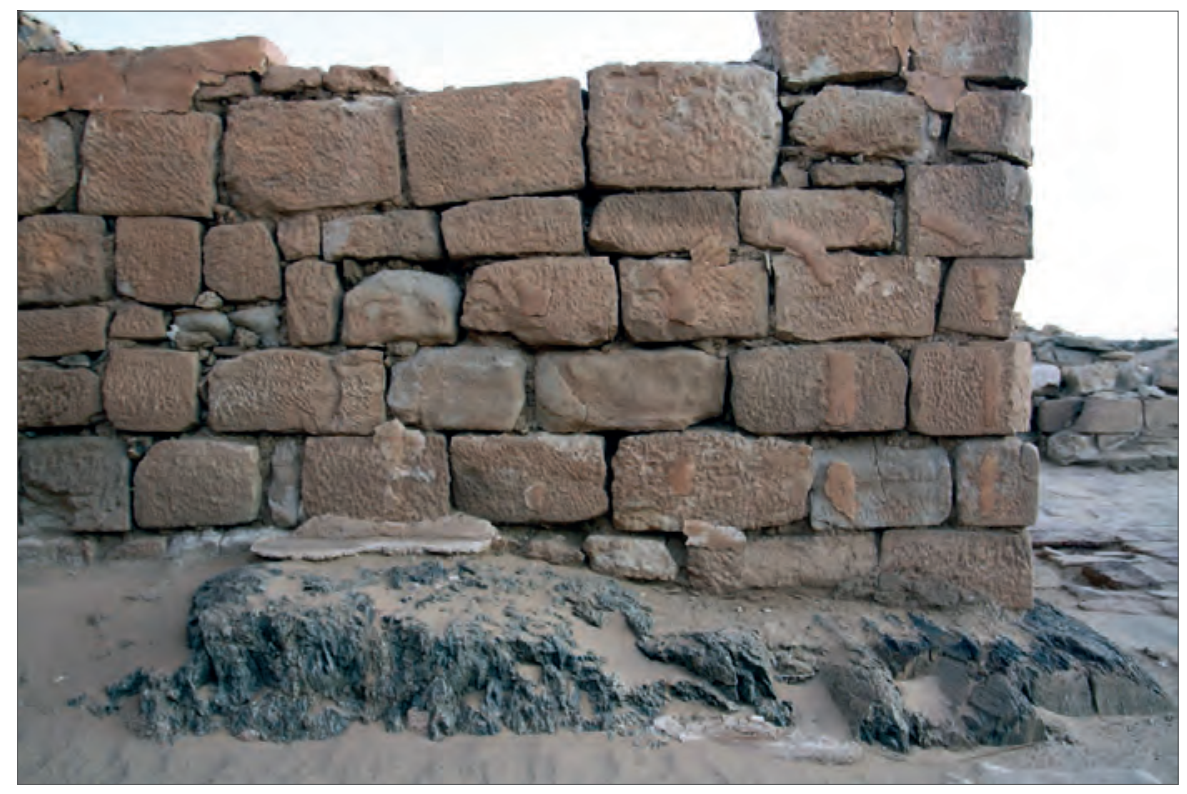

Fig. 15. Plaster in the western bay of the North Church at Ghazali in 2011 (PhotoA.Obtuski@PCMAUW) 
have been no triple-room in the western part of also the Old Church at Qasr Ibrim. All reconstructions of this building so far were based on two assumptions: the existence of a staircase in the second phase of the Qasr Ibrim Cathedral and the paradigm of the tripartite western section as an obligatory feature of Nubian churches. The Gebel Adda church is not a good comparative piece due to its uniqueness. It is the only Friedhofskirche in Nubia. The entire western tripartite section of the church was built on a different level than the rest of the church. There were also wall joints between it and the naos, yet Deichmann and Grossmann did not rule out that it could have belonged to the original building (1988: 55). Nevertheless, it is plausible that the foundation level would be the same, if the two parts were contemporary. The same authors proposed that the three western rooms believed to be a later development of the Central Church at Ikhmindi may never have happened. The location of the staircase in the room attached to the southwestern corner of the church is equally possible (Deichmann and Grossmann 1988: Fig. 7).

All of the churches without western rooms are atypical for Nubia and escape simple categorization. All of them can be dated to the 6th century. Deichmann's and Grossmann's dating of the Gebel Adda Friedhofskirche to the end of the 7th and beginning of the 8th century would fit the introduction of the western triple-room extension, as it happened at Qasr el-Wizz (1988: 56).

According to Gartkiewicz, the presence of a corner staircase points to North Africa as a source of inspiration. In churches in this area, a staircase, sometimes sticking out beyond the uniform plan of the building, was attached to the corner of the church (Gartkiewicz 1990: 93 and Fig. 43). There are also numerous examples from Egypt, where like in North Africa, the staircase very often is placed outside the regular building (Grossmann 2002: figures in parenthesis in the following list are the figure numbers from Grossmann's book): church at Leucaspis (Fig. 8); Crypt church (small basilica) at Abu Mina (Fig. 16); North Basilica at Abu Mina (Fig. 22); Church of St Barbara in Old Cairo (Fig. 34); Basilica in Palace A in Helwan (Fig. 37); church CHA84 at Narmuthis (Fig. 40); Cemetery Church at Hawwara (Fig. 49); Querhaus basilica at Hermopolis Magna (Fig. 59); Triconch Church at Dendera (Fig. 63); church at Medinet Habu (Fig. 72); East Church on Philae (Fig. 78); Southwest Church at Kellis (Dakhleh Oasis) (Fig. 85); Town church of Cosmas and Damian at Pharan (Fig. 99); Al-Adra Church at the alSuryan Monastery (Fig. 119); Lower Church at Abu Fana Monastery, Building II (Fig. 135); Southeast Church at al-Bala'iza (Fig. 148); Great Church at the Monastery of Shenute at Suhag (Fig. 150); Church in the Monastery of Bishoy at Sohag (Fig. 155); Church at the al-Kubaniya Monastery (Fig. 174); Church at Anba Harda Monastery in Aswan (Fig. 177). 
Adams assembled all the churches without western rooms into a group, which he designated as "1. Very early churches with narthex"; it included the following churches: Philae Cathedral, Qasr Ibrim Cathedral, Faras Cathedral, Sai Cathedral (not yet excavated), Gebel Adda Friedhofskirche, Philae Western Church, Sitte Gasma and Qasr el-Wizz (Adams 2009: 44-72). According to him the narthex was attested in three of these churches and was possible in the others. In Philae Cathedral and at Qasr el-Wizz there is a typical Egyptian return aisle at the west end of the church. The rest of the buildings, that is, Philae Western Church, Gebel Adda Basilica and Sitte Gasma, are basilicas without any feature at the west end that could be called a narthex. Their western parts are not even separated by any means, for instance, by an additional row of columns or pillars as at Qasr-el Wizz. This observation makes the Faras Cathedral the sole building with a narthex from the Early Nobadian period. Thus, the evidence puts a big question mark on distinguishing this group even as a hermeneutical tool for analysis of Nubian church architecture.

The issue of the division of the western part of the Nubian churches into three rooms is also of the utmost importance for the interpretation of Church III at Qasr el-Wizz, where the enlargement of the church is contemporary with the introduction of a synthronon into the apse. The synthronon caused the moving of the altar into the nave, made the triumphal arch symbolism obsolete, and rendered the insertion of a templon indispensable. It also rearranged the eastern part of the church by blocking direct communication between the apse and the side rooms. Godlewski argues that the synthronon was a "latecomer" in Nobadia (Godlewski 1990: 284). Yet he points to its presence in the so-called Cathedral of Aetios at Faras, which he dates to the first quarter of the 7th century. At Qasr el-Wizz, the church was enlarged and rearranged, and thus it lost its unique character. Yet it gained all the features present in Makurian churches from the very beginning. This "Makurization" of the church of the monastery at Qasr elWizz can be dated to the end of the 7th or to the early 8th century, on the basis of a sequence of architectural changes, as well as of the plaster stratigraphy, and the wall paintings preserved in the northwestern corner of the church, which are parallel to the paintings from the so-called Paulos Cathedral at Faras (Zielińska forthcoming).

Adams states that: "In the field of church architecture, it is probably to the merger of the two kingdoms that we must attribute the appearance, in Nobadia, of the eastern passage and the tribune-features that had been present in the Makuritan churches from the beginning. The synthrona are always present in the churches with tripartite western end. Adoption of these features did not follow immediately upon the merger of the kingdoms; cannot be securely dated in 
Nobadia until at least a century later" (Adams 2009: 436). According to him the synthronon, with one exception, appears in Nobadia in churches of Type $3 \mathrm{a}$ and Type 3c, which he dates to the period between 850 and 1250 (Adams 2009: 141).

While the introduction of the tripartite western section of the church in the territory of Nobadia became common in the 8th century and was caused by the influence of the Makuritan church, most probably after the fusion of the two kingdoms, the introduction of the synthronon should be linked to another but simultaneous process. The idea behind the insertion of a bench for the clergy into the sanctuary - regardless of the presence of a cathedra - is associated with the development of the ecclesiastical hierarchy, not with the merger of the two countries. The number of the clergy rose to more than one presbyter attributed to a church or visiting several communities. The ecclesiastical hierarchy grew, and apart from the presbyters there were other clerics, such as deacons. The evidence from Qasr el-Wizz suggests that the unification of Makuria and Nobadia and the growth of Christianity and the Church organization may have been mutually related and contemporaneous.

\section{Conclusions}

The architecture of Church I at Qasr el-Wizz supports the suggestion by Adams (2009: 437, 439), Gartkiewicz (1980: 137) and Grossmann (Grossmann and Bailey 1994: 52-53) that the early period in Nobadian church architecture was dominated by Egyptian influence.

Christian sacral architecture of Nobadia is different from its Makurian counterpart in the Nobadian period (about AD 500-700). The primary difference is the arrangement of the eastern part of the building. In Makurian churches a synthronon filled the apse, causing the location of the altar in the nave and the introduction of a templon marking the boundary of the hierateion. The presence of a triumphal arch at Church EC.1 (Church of the Stone Pavement) in Dongola is hypothetical, and if there was a triumphal arch, it would have belonged to an earlier, as yet unidentified, phase of the building. Otherwise, the synthronon must be considered later than hitherto suggested. The auxiliary rooms on both sides of the sanctuary were accessed by entrances from the aisles and they were also interconnected by a passage behind the apse. The latter was probably an influence from Palestinian architecture (Godlewski 2006b: 274275). From the beginning the southeastern room was occupied by a baptistery. 
In Nobadian churches, the eastern section was tripartite and it lacked the passage behind the apse. The lack of a synthronon allowed for direct communication between the apse and auxiliary rooms on both sides of the sanctuary. The altar of the Early Nobadian churches was situated in the apse or just in front of it. The division between the sanctuary and the naos was marked by a triumphal arch located at the mouth of the apse or at the first pair of pillars west of the apse. In the early period, this symbolic partition between hierateion and naos was sufficient and the templon was absent or not yet introduced.

The next distinctive feature is the arrangement of the western section of the church. In Makuria, even the earliest buildings were divided into three rooms at the western end and a staircase occupied one of the corner spaces. In Nobadia, this feature was absent in the earliest churches: Qasr el-Wizz, Old Church at Qasr Ibrim and perhaps also in the second phase of the Qasr Ibrim Cathedral. It is also lacking in Cathedral Number One, that is, the so-called Aetios Cathedral at Faras. The most important parallel for the chronological sequence of building phases at Qasr el-Wizz is the Central Church at Ikhmindi, which can be dated securely to the second half of the 6th century, that is, the time of the erection of the entire fortified town, in which the church occupied a central position.

Godlewski has suggested that the Makurian Church of the Stone Pavement (EC.I) at Old Dongola served as the inspiration for the rebuilding of the Old Church at Qasr Ibrim into the Cathedral, for Phase 2, and for the so-called Aetios Cathedral (Godlewski 2006b: 270). When we compare its eastern end arrangements, the similarities between the Qasr Ibrim Cathedral Phase 2 and Old Dongola are clear: both are five-aisled basilicas with a tripartite western section, a synthronon in the apse, altar in the nave, a templon dividing the nave from the sanctuary, a passage behind the apse, and the baptistery positioned in the southeastern room. The so-called Aetios Cathedral is similar only when it comes to the number of aisles. The arrangement of the western end of the church is different; there is neither the passage behind the apse nor the baptistery in the southeastern room. The existence of a synthronon in the apse is still a matter of controversy. If it was indeed present, then there should have been no altar in the apse, but if the altar was in the sanctuary, which would then extend into the nave, the triumphal arch would be obsolete. Thus, we need to accept that there were various inspirations for the so-called Aetios Cathedral and EC.I at Old Dongola. Closer to EC.I in terms of spatial planning is the Cathedral of Paulos at Faras with three rooms at the western end, a staircase in the southwestern room, synthronon in the apse, altar enclosed by a templon, and the baptistery situated in one of the multiple auxiliary eastern rooms. This makes the Old Church at Qasr Ibrim and the so-called Aetios Cathedral products of independent Nobadian developments 
in church architecture. The "Makurization" of the churches happened at a time when the Old Church at Qasr Ibrim was rebuilt and the Paulos Cathedral was erected, that is, at the beginning of the 8th century. This was also the time that the church at Qasr el-Wizz was rearranged according to a fashion coming from the new capital at Tungul (for dating of the phases of the Qasr Ibrim Cathedral, see Aldsworth 2010: 127, 136). This development is also supported by another change in the churches at Qasr Ibrim, Faras and Qasr el-Wizz: the introduction of the entrances to the church on the north and south side of the church, a feature that also belongs to the Makurian canon of sacral architecture.

\section{ACKnowledgments}

The project has been implemented with support from the Foundation for Polish Science. The initial phase of the program was also supported by the de Brzezie Lanckoronski Foundation. The excavations at Ghazali were sponsored by the Qatar-Sudan Archaeological Project and the program on Nubian monasticism is carried out under Grant 2014/13/D/HS3/03829 from the National Science Center, Poland.

\section{References}

\section{Primary sources}

Germanus, Historia ecclesiastica, transl. by D. Sheerin, Fairfax, VA: Damascene Foundation, 1984

L'Eucologio Barberini gr. 336: ff. 1-263, ed. by S. Parenti and E. Velkovska, Rome: C.L.V.-Edizioni Liturgiche, 1995

Mansi, J.D., Sacrorum conciliorum, nova, et amplissima collectio. Florence: Zalta, 17591798. Retrieved from http://www.documentacatholicaomnia.eu/01_50_16921769-_Mansi_JD.html [accessed: February 2015]

Maximus Confessor, Mystagogia. In S.P.N. Maximi Confessoris, Opera omnia [=Patrologiae Cursus Completus. Series Graeca 91], ed. by F. Combefis, Paris: J.-P. Migne, 1865

Procopius, On buildings [=Loeb Classical Library 343], transl. by H.B. Dewing, Cambridge: Harvard University Press, 1940

\section{SECONDARY SOURCES}

Adams, W.Y. (1965). Architectural evolution of the Nubian Church, 500-1400 A.D. Journal of the American Research Center in Egypt, 4, 87-139

Adams, W.Y. (2009). The churches of Nobadia I-II [=Sudan Archaeological Research Society Publications 17; British Archaeological Reports International Series 2000]. Oxford: Archaeopress 
Aldsworth, F. (2010). Qasr Ibrim: The Cathedral Church [=Excavation Memoir 97]. London: Egypt Exploration Society

Altripp, M. (1998). Die Prothesis und ihre Bildausstattung in Byzanz unter besonderer Berücksichtigung der Denkmäler Griechenlands [=Studien und Texte zur Byzantinistik 4]. Frankfurt am Main: P. Lang

Altripp, M. (2000). Beobachtungen zu Synthronoi und Kathedren in byzantinischen Kirchen Griechenlands. Bulletin de correspondance hellénique, 124(1), 377-412

Anderson, J.R. (1999). Monastic lifestyles of the Nubian Desert: Seeking the mysterious monks of Makuria. Sudan \& Nubia, 3, 71-83

Arranz, M. (ed.). (1996). L'eucologio costantinopolitano agli inizi del secolo XI: hagiasmatarion \& archieratikon (rituale \& pontificale). Con l'aggiunta del Leiturgikon (messale). Rome: Pontificia Università Gregoriana

Bietak, M. and Schwarz, M. (1987). Nag' el-Scheima: eine befestigte christliche Siedlung und andere christliche Denkmäler in Sayala - Nubien. Vienna: Österreichische Akademie der Wissenschaften

Bouras, L. (2005). Templon. In A.P. Kazhdan (ed.), The Oxford dictionary of Byzantium III (pp. 2023-2024). New York: Oxford University Press

Clarke, S. (1912). Christian antiquities in the Nile Valley. A contribution towards the study of the ancient churches. Oxford: Clarendon Press

Ćurčić, S. (2005). Narthex. In A.P. Kazhdan (ed.), The Oxford dictionary of Byzantium II (p. 1438-1439). New York: Oxford University Press

Deichmann, F.W. and Grossmann, P. (1988). Nubische Forschungen [=Archäologische Forschungen 17]. Berlin: Gebr. Mann

Descoeudres, G. (1983). Die Pastophorien im syro-byzantinischen Osten: eine Untersuchung zu architektur- und liturgiegeschichtlichen Problemen [=Schriften zur Geistesgeschichte des östlichen Europa 16]. Wiesbaden: Harrassowitz

Effland, A. (2004). Materialien zur Archäologie und Geschichte des Raumes von Edfu (unpubl. Ph.D. diss.). University of Hamburg

Gardberg, C.J. (1970). Late Nubian sites: Churches and settlements [=Scandinavian Joint Expedition to Sudanese Nubia 7]. Copenhagen: Scandinavian University Books

Gartkiewicz, P.M. (1980). New outline of the history of Nubian church architecture. Bulletin Antieke Beschaving, 55(1), 137-160

Gartkiewicz, P.M. (1986). Cathedral in Faras in the light of an architectural reanalysis. In M. Krause (ed.), Nubische Studien: Tagungsakten der 5. Internationalen Konferenz der International Society for Nubian Studies, Heidelberg, 22.-25. September 1982 (pp. 245-268). Mainz am Rhein: Philipp von Zabern

Gartkiewicz, P.M. (1990). The Cathedral in Old Dongola and its antecedents [=Nubia 1; Dongola 2]. Warsaw: Państwowe Wydawnictwo Naukowe

Giros, C. (1992). Remarques sur l'architecture monastique en Macédoine orientale. Bulletin de correspondance hellénique, 116(1), 409-443 
Godlewski, W. (1979). Les baptistères nubiens [=Faras 6]. (Z. Kiss, trans.). Warsaw: Éditions scientifiques de Pologne

Godlewski, W. (1992). The early period of Nubian art. Middle of 6th - beginning of 9th centuries. In C. Bonnet (ed.), Études nubiennes: conférence de Genève. Actes du VII Congrès international d'études nubiennes, 3-8 septembre 1990, I. Communications principales (pp. 277-305). Geneva: C. Bonnet

Godlewski, W. (1998). The role of Dongolese milieu in the Nubian church architecture. In M. Krause and S. Schaten (eds), Themelia: spätantike und koptologische Studien. Peter Grossmann zum 65. Geburtstag (pp. 127-142). Wiesbaden: Reichert Verlag

Godlewski, W. (2006a). Pachoras: The cathedrals of Aetios, Paulos and Petros. The architecture [=PAM Supplement Series 1]. Warsaw: Warsaw University Press

Godlewski, W. (2006b). The churches of Dongola, their origin and importance in the general line of development of church architecture in Makuria. In I. Caneva and A. Roccati (eds), Acta Nubica: Proceedings of the XInternational Conference of Nubian studies, Rome, 9-14 September 2002 (pp. 263-286). Rome: Istituto Poligrafico e Zecca dello Stato, Libreria dello Stato

Godlewski, W. (2013). Monastic life in Makuria. In G. Gabra and H.N. Takla (eds), Christianity and monasticism in Aswan and Nubia [=Christianity and Monasticism in Egypt 5] (pp. 157-174). Cairo: American University in Cairo Press

Grabar, A. (1967). The golden age of Justinian: From the death of Theodosius to the rise of Islam. (S. Gilbert and J. Emmons, Trans.). New York: Odyssey Press

Grossmann, P. (1991). Architectural elements of churches, sanctuary. In A.S. Atiya (ed.), The Coptic encyclopedia I (pp. 194-226). New York: Oxford University Press

Grossmann, P. (2002). Christliche Architektur in Ägypten [=Handbuch der Orientalistik 62]. Leiden: Brill

Grossmann, P. and Bailey, D.M. (1994). The South church at Hermopolis Magna (Ashmunein): A preliminary account. In K.S. Painter (ed.), Churches built in ancient times: Recent studies in early Christian archaeology [=Society of Antiquaries of London Occasional Papers 16] (pp. 49-71). London: Society of Antiquaries of London

Jakobielski, S. and Scholz, P.O. (eds). (2001). Dongola-Studien: 35 Jahre polnischer Forschungen im Zentrum des makuritischen Reiches [=Bibliotheca Nubica et Aethiopica 7]. Warsaw: ZAŚ PAN

Jeute, P. (1994). Monasteries in Nubia - An open issue. Nubica, 3(1), 59-97

Johnson, M.J. (2005a). Bema. In A.P. Kazhdan (ed.), The Oxford Dictionary of Byzantium I (p. 281). New York: Oxford University Press

Johnson, M.J. (2005b). Apse. In A.P. Kazhdan (ed.), The Oxford Dictionary of Byzantium I (p. 144). New York: Oxford University Press

Johnson, M.J. and Cutler, A. (2005). Synthronon. In A.P. Kazhdan (ed.), The Oxford dictionary of Byzantium III (p. 1996). New York: Oxford University Press

Krautheimer, R. (1965). Early Christian and Byzantine architecture. Baltimore: Penguin Books 
MacDonald, W.L. (1962). Frühchristliche und byzantinische Architektur [=Grosse Zeiten und Werke der Architektur 3]. Ravensburg: O. Maier

Macridy, T. (1964). The Monastery of Lips and the burials of the Palaeologi. Dumbarton Oaks Papers, 18, 253-277

Marinis, V. (2014). Architecture and ritual in the churches of Constantinople: Ninth to fifteenth centuries. Cambridge: Cambridge University Press

Marušić, B. (1972). Monumenti istriani dell'architettura sacrale altomedioevale con le absidi inscritte. Arheološki Vestnik, 23, 266-288

Mathews, T.F. (1971). The early churches of Constantinople: Architecture and liturgy. University Park: Pennsylvania State University Press

Michałowski, K. (1967). Faras: die Kathedrale aus dem Wüstensand. EinsiedelnZürich-Cologne: Benziger

Mileham, G.S. (1910). Churches in Lower Nubia. Philadelphia: University Museum Monneret de Villard, U. (1935). La Nubia medioevale I-II. Cairo: Institut français d'archéologie orientale

Monneret de Villard, U. (1940). La basilica cristiana in Egitto. In Atti del IV Congresso internazionale di archeologia cristiana, Città del Vaticano, 16-22 Ottobre, 1938, I [=Studi di antichità cristiana 16] (pp. 291-319). Rome: Pontificio Instituto di archeologia cristiana

Obłuski, A. (2014). Ghazali Site Presentation Project 2012-2014 preliminary results. Der Antike Sudan, 25, 197-205

Obłuski, A. (ed.). (forthcoming). Excavations at Qasr el-Wizz, George T. Scanlon, Director [= The University of Chicago Oriental Institute Nubian Expedition 15]. Chicago: The Oriental Institute

Romaniuk, M. (2010). The character of Nubian monasticism - social significance. In W. Godlewski and A. Eajtar (eds), Between the cataracts: Proceedings of the 11th Conference for Nubian studies, Warsaw University, 27 August - 2 September 2006, II.2. Session papers [=PAM Supplement Series 2.2/2] (pp. 633-641). Warsaw: Warsaw University Press

Rosenqvist, J.O. (ed.). (1986). The life of St Irene, abbess of Chrysobalanton [=Acta Universitatis Upsaliensis. Studia Byzantina Upsaliensia 1]. Stockholm: Almqvist \& Wiksell International

Rusconi, A. (1965). La basilica paleocristiana di S. Lorenzo Maggiore di Napoli. In Atti del VI congresso internazionale di archeologia cristiana: Ravenna 23-30 settembre 1962 [=Studi di antichità cristiana 26] (pp. 709-731). Città del Vaticano: Pontificio Istituto di Archeologia Cristiana

Scanlon, G.T. (1970). Excavations at Kasr el-Wizz: A preliminary report I. Journal of Egyptian Archaeology, 56, 29-57

Stenico, A. (1960). Ikhmindi: una città fortificata medievale della bassa Nubia. Milan: A. Nicola \& C.

Taft, R.F. (2005). Prothesis. In A.P. Kazhdan (ed.), The Oxford dictionary of Byzantium III (p. 1743). New York: Oxford University Press 
Taft, R.F. and Bouras, L. (2005). Altar. In A.P. Kazhdan (ed.), The Oxford dictionary of Byzantium I (p. 71). New York: Oxford University Press

Taft, R.F., Loerke, W., and Johnson, M.J. (2005). Pastophoria. In A.P. Kazhdan (ed.), The Oxford Dictionary of Byzantium III (p. 1594). New York: Oxford University Press

Testini, P. (1972). Il complesso paleocristiano di Cornus (Regione Columbaris) in Sardegna. In Actas del VIII Congreso Internacional de Arqueologia Cristiana, Barcelona, 5-11 octubre 1969 [=Studi di antichità cristiana 30] (pp. 537-561). Barcelona: Consejo Superior de Investigaciones Científicas

Thomas, J. and Hero, A.C. (eds). (2000). Byzantine monastic foundation documents: A complete translation of the surviving founders' typika and testaments. Washington, D.C.: Dumbarton Oaks Research Library and Collection. Retrieved from http:// www.doaks.org/resources/publications/doaks-online-publications/byzantinemonastic-foundation-documents [accessed: February 2015]

Varalis, Y. (2006). Prothesis and diakonikon: Searching the original concept of the subsidiary spaces of the Byzantine sanctuary. In A.M. Lidov (ed.), Hierotopy: The creation of sacred spaces in Byzantium and medieval Russia (pp. 282-298). Moscow: Indrik

Welsby, D.A. and Daniels, C. (1991). Soba: Archaeological research at a medieval capital on the Blue Nile [=British Institute in Eastern Africa Memoir 12]. London: British Institute in Eastern Africa.

Wojciechowski, B. (2010). Triumphal arches in Nubian sacral architecture. Études et Travaux, 23, 213-259

Zielińska, D. (2009). Program ikonograficzny kościotów nubijskich. Studium lokalizacji malowidet we wnętrzu sakralnym [Iconographical program of Nubian churches. A study of wall paintings location in sacral interior] (unpubl. Ph.D. diss.). University of Warsaw [in Polish]

Zielińska, D. (forthcoming). Wall paintings from the monastery. In A. Obłuski (ed.), Excavations at Qasr el-Wizz, George T. Scanlon, Director [= The University of Chicago Oriental Institute Nubian Expedition 15]. Chicago: The Oriental Institute 


\title{
When epigraphy meets art history: On St Phoibammon from Abdallah-n Irqi
}

\section{Grzegorz Ochała}

Department of Papyrology, Institute of Archaeology, University of Warsaw g.ochala@uw.edu.pl

\author{
KeYwORDS \\ Abdallah-n Irqi, St Phoibammon, wall inscriptions, Era of Diocletian, \\ stylistic dating of Nubian wall painting
}

\begin{abstract}
The article offers a new reading of one of the wall inscriptions discovered during Dutch excavations in the central church of Abdallah-n Irqi. According to the new interpretation, the text includes an annual date, a fact that is extremely important for the dating of not only the text itself, but also of the wall painting (mounted St Phoibammon) it accompanies. In more general terms, the inscription has helped to verify methods for the stylistic dating of Nubian murals.
\end{abstract}

When I came to the University of Warsaw in 1999 I had not the slightest idea of the existence of a land as fascinating as Nubia, not to mention the three Christian kingdoms that dominated the Middle Nile Valley between the 6th and 15th centuries. It was Professor Włodzimierz Godlewski who introduced me to the richness of the history and culture of the people inhabiting Nobadia, Makuria, and Alwa, and showed me how to take the first steps in this still understudied field of research. In utmost gratitude to my first teacher of Nubiology, I would like to offer this modest, but hopefully interesting contribution. 
The site of Abdallah-n Irqi ${ }^{1}$ situated on the west bank of the Nile in the Abu Simbel area (approximately $3.5 \mathrm{~km}$ to the east), was excavated in 1964 by two independent missions, Hungarian and Dutch, within the framework of the international salvage campaign prompted by the construction of the High Dam in Aswan and the subsequent emergence of Lake Nubia. The former mission unearthed the remains of a Christian-age town (so-called town A) (Castiglione and Török 1974; Barkóczi and Salomon 1974; Hajnóczi 1974; Török 1974a; 1974b), and the latter, whose main object of studies was a Meroitic settlement situated a bit farther to the west (so-called town $\mathrm{B}$ ), ${ }^{2}$ also managed to excavate a church (the so-called central church) situated in 'town A'.

The church, measuring $12 \mathrm{~m}$ by $14 \mathrm{~m}$, proved to be a very well preserved (up to $3 \mathrm{~m}$ in height) three-aisled edifice with tripartite eastern and western parts, typical of Christian Nubia [Fig. 1]. Its walls had been decorated extensively with wall paintings and inscribed with some two dozen graffiti and dipinti. ${ }^{4}$ The construction of the building was dated, with the help of architectural, stratigraphic, and ceramological studies, to the middle of the 8th century, and its abandonment to the 15th century. The date of the interior decoration of the church was established, based on a stylistic analysis already available for the wall paintings discovered by the Polish mission in a cathedral church in nearby Faras. ${ }^{5}$ In this way, two styles were distinguished at Abdallah-n Irqi: the 'violet' one (dated between about 750 and 800), represented by only a couple of murals, two of which were almost completely preserved, and the 'white'

1 The site is commonly designated as 'Abdallah Nirqi' in scientific publications, a name used for the first time by Ugo Monneret de Villard in the monumental publication of his survey of the Middle Nile Valley (Monneret de Villard 1935: 170). However, as noted by Schneider (1970: 88), its correct orthography should be Abdallah-n Irqi, as it is a Nubian genitival expression, meaning 'the land of Abdallah', where the suffix $-\mathrm{n}$ is attached to the first element, the rectum.

2 The nomenclature 'town A' and 'town B' was proposed by Harry S. Smith, who surveyed the area in 1961 (Smith 1962: 40-41 and 42-44, respectively).

3 Klaesens 1967: passim, especially 83-86; van Moorsel, Jacquet, and Schneider 1975. In fact, it was the Dutch archaeologists who arrived first at the site (beginning of 1964), but they limited their work to the church; the Hungarian mission started digging in the second half of that year.

4 For the wall paintings and their legends, see van Moorsel 1975; for the remaining inscriptions, see Schneider 1975. A part of the paintings was taken off the walls of the church and is now preserved in the Coptic Museum in Cairo and the Nubia Museum in Aswan (D. Zielińska, personal communication).

5 Michałowski 1967: 72-73, 75-81. Among publications postdating the final publication of the central church at Abdallah-n Irqi, see, e.g., Michałowski 1974: 28-41; Martens-Czarnecka 1987; Jakobielski 2002. 
one $^{6}$ (dated between about 980 and 1020), to which belong all the remaining representations (Van Moorsel 1975: 55-58). This dating, reliable as it appears, lacked firm proof, confirmation in the form of a precisely dated object, as no such date was identified in the collected epigraphic material. But is it really reliable?

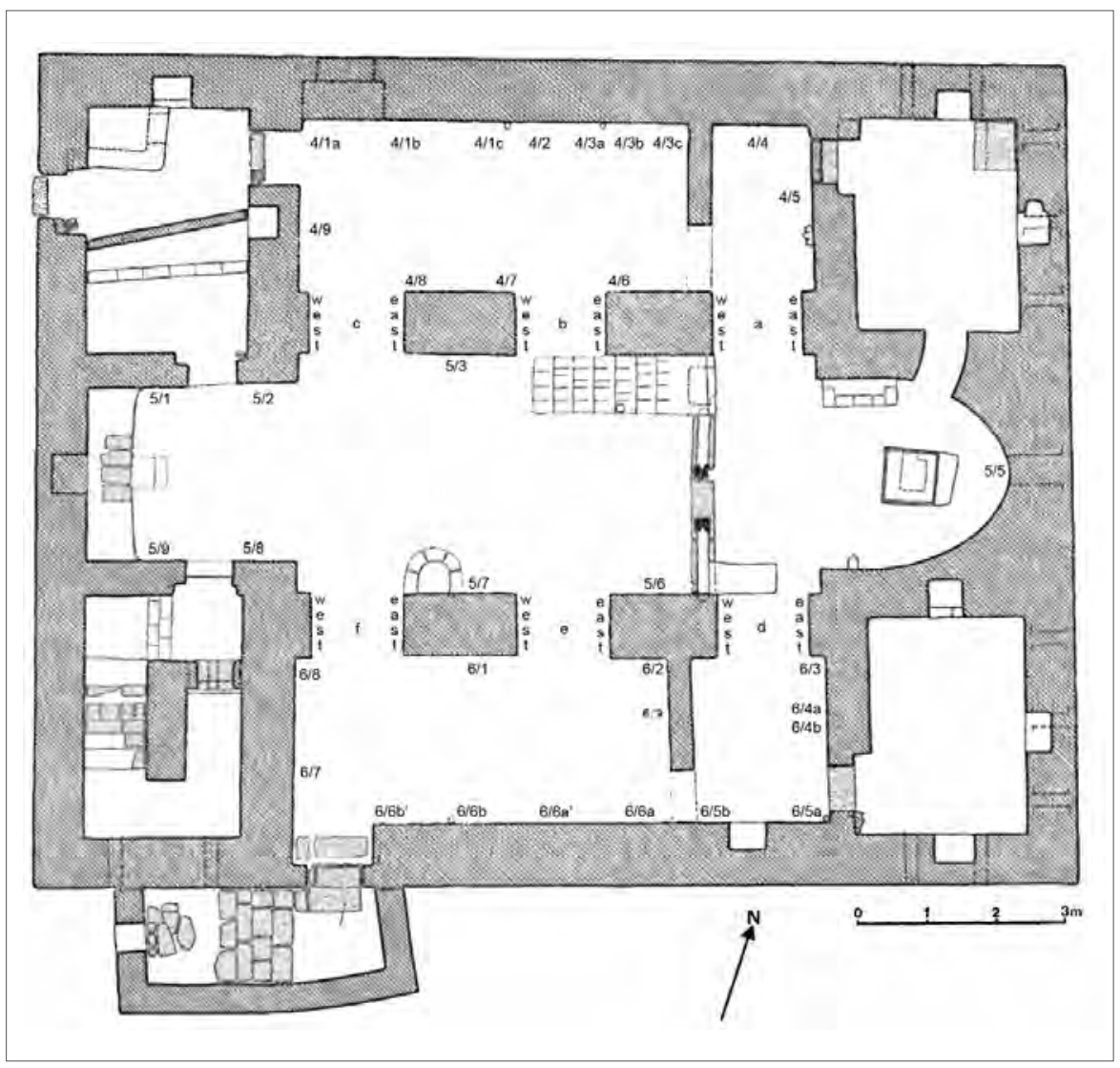

Fig. 1. Plan of the central church at Abdallah-n Irqi, with localisation of the wall paintings (After van Moorsel 1975: Fig. 1)

6 These designations as well as the whole 'color' classification of Nubian painting are now obsolete (see Łaptaś 1996). I use them here, nevertheless, to show the reasoning of the excavators. 
While conducting a thorough survey of Nubiological publications in preparation for a major update to the Database of Medieval Nubian Texts (DBMNT), ${ }^{7}$ I also reexamined the epigraphic finds from Abdallah-n Irqi. Among the wall inscriptions from the central church there is one curious graffito, labelled No. 6 in Hans Schneider's publication (Schneider 1975: 33 = DBMNT $2376=$ TM 370880), scratched near the painting of a mounted warrior saint (No. 6/6b), located on the south wall of the south aisle [see Fig. 1]. Like all the remaining texts found on the church walls, this one, too, is lacking a proper edition; the reader must rely on photographs, crude tracings, and a rather basic and superficial description by the author. According to him, graffito No. 6 "gives the name of 'Phoibammōn' and the monogram for 'presbyteros'. The epithet 'Ethiopian' most likely refers to the writer's home country" (Schneider 1975: 33). Indeed, a look at the tracing gives the following reading:

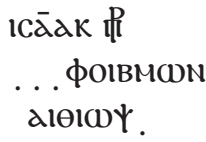

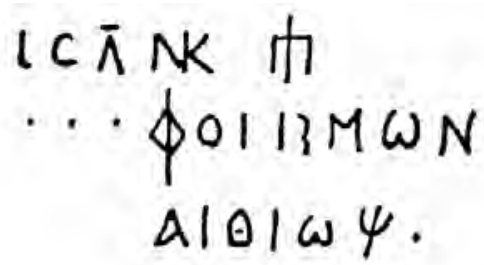

Tracing after Schneider 1975: 34

It seems to entitle the interpretation that a certain priest, Isaak (the name was apparently not identified by Schneider), an 'Ethiopian', left the inscription in commemoration and/or supplication of St Phoibammon. However, the final word is quite puzzling in terms of both its interpretation and its position within the syntax of the text.

First of all, it should be remembered that in classical antiquity the term 'Ethiopian' served to describe all the peoples inhabiting the lands beyond the First Cataract, regardless of their true ethnic classification, as applied today, and it certainly did not specifically refer to the territory of present-day Ethiopia. ${ }^{8}$ Second, if it were to be an ethnonym referring to Isaak, it should be placed right after his name or his title. In the present syntax, however, it would

7 The DBMNT has been available online at <www.dbmnt.uw.edu.pl> since 2011, including some 700 texts bearing signs of counting time in Christian Nubia (see Ochała 2011). The update launched in 2015 has made available a further 2200 texts.

8 Originally, the name designated all lands in the far south, but north of the equator; from the time of Herodotus it applied mainly to the lands south of Egypt, including Nubia, Sennar, Kordofan, and north Abyssinia ( $R E$ I, s.v. 'Aithiopia'; $O C D$, s.v. 'Ethiopia'). 
belong rather to Phoibammon, which is an obvious impossibility, if we indeed assume that the saint was meant here. Third, precious few attestations of this ethnonym are known from Nubia. One of them is the famous inscription of King Silko from the temple of Mandulis in Kalabsha, dating to not long before $\mathrm{AD} 450 .{ }^{9}$ The ruler titles himself "king of the Nobades and all the

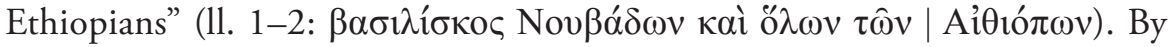
this ethnonym Silko appears to refer to a non-Nobadian population of the Dodekaschoinos, probably Meroites, who fell under his control as he pressed down the Nile from the area of the Second Cataract, where the Noba tribes are believed to have originally settled in the first centuries AD. ${ }^{10}$ The second and last attestation of the ethnonym in question comes from a Coptic deed of land sale, originating from the territory of Nobadia and dating to the 9th century (P. Lond. Copt. $449=$ DBMNT $630=$ TM 86137). In the opening protocol of this text, a certain Georgios, protoeparchos, protodomestikos, and protomeizoteros is described as if "all the Ethiopians were under him, from Tilimaura to the

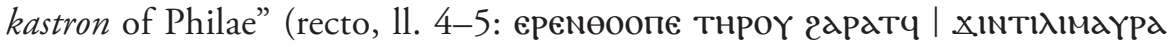

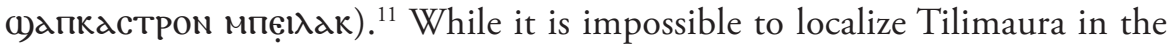
present state of research, there can be no doubt, given the mention of Philae, that the northern part of the region of Nobadia was meant. Hence, a local Nubian population must be understood under the term 'Ethiopians'. ${ }^{12}$

Taking all of the above into consideration, Schneider's interpretation of the discussed graffito seems hardly defendable. Luckily, a photograph of painting No. 6/6b, showing also the inscription, makes it possible to correct the tracing significantly. ${ }^{13}$ Moreover, another photograph, showing a large portion of the

9 Published numerous times, most recently in FHNIII, No. 317, pp. 1147-1153, where earlier literature is cited on p. 1147.

10 For the most recent analysis of the Nobades' conquest of the Dodekaschoinos, see Obłuski 2014: 22-38. See also Rilly 2008, for the origin of the Nobadians and the date of their appearance in the Middle Nile Valley.

11 To the best of my knowledge, the word өоопє has not been attested elsewhere. Its interpretation as 'Ethiopians', by no means certain, was proposed by Walter Crum, the original editor of the

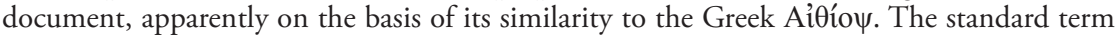
for an Ethiopian in Sahidic Coptic is e600) (Crum 1939: s.v.).

12 The Nubians naming themselves 'Ethiopians' is a fact interesting in itself, but the data at our disposal is too modest for a reasonable hypothesis to be proposed.

13 This photograph has not been published yet. I would like to thank Dobrochna Zielińska and Alexandros Tsakos, who found it in the archives of the Rijksmuseum van Oudheden in Leiden during their work on the "Corpus of Nubian wall paintings" and made it available to me for the present article. The final publication of the Dutch excavation contains a color photograph of only the right part of the inscription, but the date is clearly discernible there, too (van Moorsel, Jacquet, and Schneider 1975: Pl. 96, see also 1975: Pl. 94 and van Moorsel 1970: Fig. 43, for even more fragmentary views of the inscription). 
south wall in the south aisle (van Moorsel, Jacquet, and Schneider 1975: Pl. 92), shows that the inscription was in fact longer than suggested by the tracing, as lines 2 and 3 were severely damaged at their beginning. The text can thus be transcribed and translated as follows:

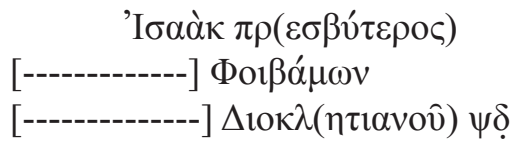

\section{1cāak R}

Isaak, priest

[---] Phoibamon

[---] Diocletian 704.

Traces of letters visible in the lacuna regrettably cannot be deciphered, but the photograph enables a significantly improved reading of the last line. Indeed, the new reading is a true revelation, eliminating a bizarre ethnonym and contributing an extremely important detail, namely, the exact annual date for the execution of the graffito. The year 704 of the Diocletianic Era lasted from 30 August 987 until 28 August 988 in the Julian calendar. ${ }^{14}$ The visit of the priest Isaak to the church should thus be dated within this period. We could imagine that the lacuna at the left contained a day, most ideally the day of the feast of St Phoibammon. A couple of wall inscriptions from Nubia attest to such a custom, ${ }^{15}$ but, regrettably, this saint is not present among them; neither is he mentioned in the preserved fragments of the Nubian liturgical calendar (Ochała 2015). Egyptian (especially Upper Egyptian) material is hardly of help, there being several different dates preserved in late antique and medieval sources for the commemoration of two different martyrs by this name (Papaconstantinou 2001: 204-214).

14 Normally, the Diocletianic year commenced on 29 August, but year 703 from Diocletian was a leap year, hence the following year started one day later, on 30 August. For an exhaustive discussion of the Era of Diocletian/the Martyrs in Nubia, see Ochała 2011: 31-82.

15 E.g., graffito of Philotheos from Tamit, dated to the feast of Archangel Raphael (Eajtar and van der Vliet 1998: 45-46 [No. 4] = DBMNT $451=$ TM 141556) and a dedicatory inscription of one Mariakouda from Faras (Altheim and Stiehl 1971: 497-499 = DBMNT $716=$ TM 102631). See Ochała 2011: 322. 
Apart from establishing the date of Isaak's visit to the central church at Abdallah-n Irqi, the new reading has serious implications of a more general nature. First of all, it needs to be observed that the graffito appears to be connected with the painting of the warrior saint (No. 6/6b), next to which it was incised. The mural is accompanied by a legend [Fig. 2] painted in two vertical lines next to the raised right arm of the figure, holding a spear (van Moorsel 1975: 122 = DBMNT 2391 = TM 370895). The inscription is incomplete, but sufficiently clear to be reconstructed.

$[\dagger o ̛$ ó

[Фо]ı $\beta \dot{\alpha} \mu \omega v$

[t] Saint

[Pho]ibammon.

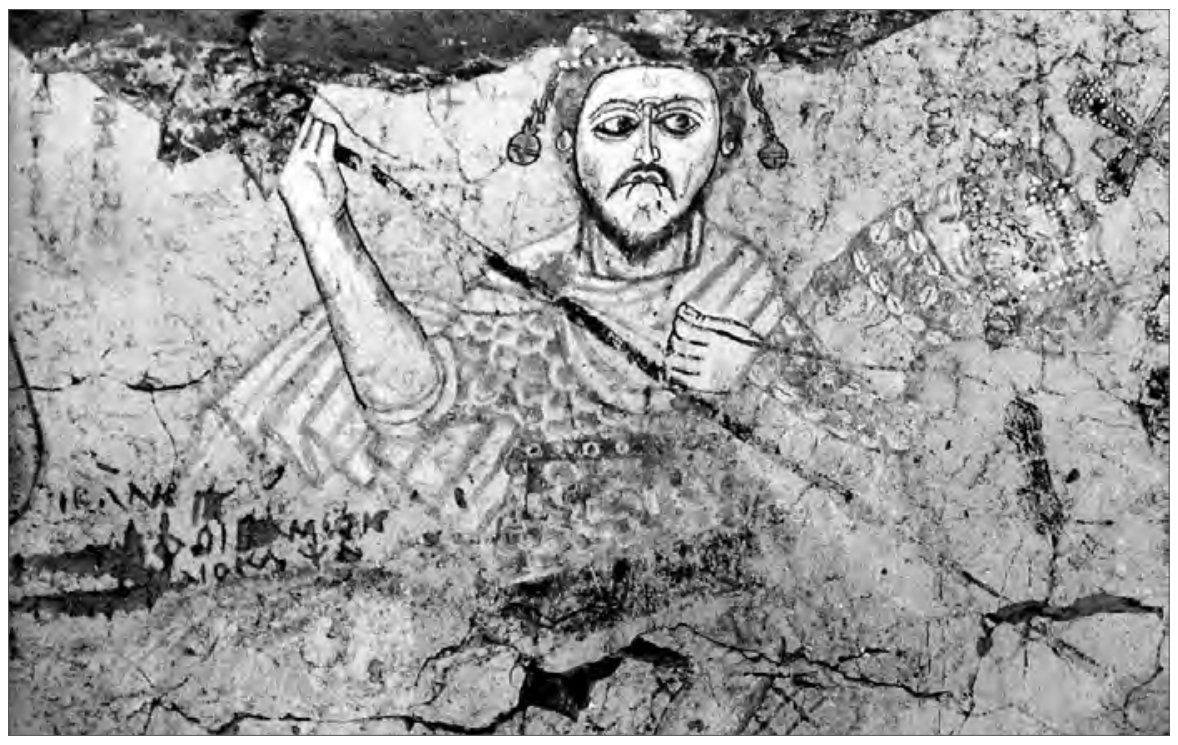

Fig. 2. Painting No. 6/6b with accompanying inscriptions

(Photo courtesy of Rijksmuseum van Oudheden in Leiden) 
Thus, despite Paul van Moorsel's doubts, ${ }^{16}$ the identification of the figure depicted in the painting as St Phoibammon is nearly certain. The identification is confirmed by Isaak's graffito, as already observed by van Moorsel, confirming at the same time its commemorative/supplicatory character and its link to the mural.

This leads us to the second observation, namely that Isaak's inscription, incised below St Phoibammon's raised right hand, between his mantle and the horse's back, appears to respect the layout of the painting. Therefore, we have reason to suppose that the text was executed when the painting had already been there for some time. The date of Isaak's visit to the church in $987 / 8$ is thus a terminus ante quem for the execution of the mural.

This is indeed an extremely rare situation for studies of Nubian wall paintings. So far, more or less precise chronological anchors have been identified only in the case of the Faras murals. ${ }^{17}$ Thanks to the data from the famous list of bishops of Pachoras, combined with exact dates provided by funerary stelae of several of those bishops and stylistic analyses of their portraits, it was possible to distinguish a few phases of decoration. Yet, strong as it appears, the thus established chronology of the Faras paintings lacks such a direct indicator as identified now in Abdallah-n Irqi, an annual date so clearly connected with a specific representation.

As mentioned above, the dating of the painted decoration of the central church at Abdallah-n Irqi was based exclusively on stylistic analysis and comparison with murals from the Faras cathedral. Now, since the church has gained its own chronological indicator, it is worthwhile to revise this dating, at least for the painting in question and those in its immediate vicinity. ${ }^{18}$ The table below shows all the murals from the south aisle belonging to the same period as the depiction of St Phoibammon, along with their dates as established by Paul van Moorsel (1975: 108-124) [Table 1; for the locations, see Fig. 1].

According to van Moorsel, two paintings in the south aisle can be dated with relative precision, Nos $6 / 1$ and $6 / 4$ b, owing to their striking similarity with the portrait of Bishop Petros I (episcopate in 974-999) from Faras (van Moorsel 1975: 109 and 112), believed to have been executed around 975 (Michałowski 1974: 172). The dating of the remaining paintings is thus dependent on this indication and oscillates around the end of the 10th century. The only exceptions are the last two murals (Nos 6/6b and 6/6b'). The former, which is our main

16 Van Moorsel 1970: 104-105, where the legend is transcribed as АГІОС...KAM $\Omega$ N and van Moorsel 1975: 60 (inventory of paintings) and 122.

17 See above, note 6.

18 As I am no art historian, I must rely on specialist opinion in this respect and my remarks must be limited to basic chronological questions. 
concern here, was dated slightly later than the rest because of a clear difference of style in comparison with other warrior saints in the south aisle (Nos 6/3, 6/5a, and 6/6a): a "lamentable" anatomy and the shape of the horse, which is "more of an attribute than a dramatis persona" (van Moorsel 1975: 122). The latter was estimated to come from the same period on the basis of the position of the horse, which is the same as in St Phoibammon's depiction (van Moorsel 1975: 123).

Table 1. Dates of wall paintings from the south aisle of the central church

\begin{tabular}{l|l|l}
\hline Inv. no. & Theme & Date \\
\hline $6 / 1$ & mounted angel with a sword & about $980-990$ \\
\hline $6 / 3$ & mounted warrior saint (St Merkurios?) & end of 10th century \\
\hline $6 / 4 \mathrm{~b}$ & Theophany & about $980-990$ \\
\hline $6 / 5 \mathrm{a}$ & mounted warrior saint & about 1000 \\
\hline $6 / 5 \mathrm{~b}$ & St John Chrysostom & about 1000 \\
\hline $6 / 6 \mathrm{a}$ & mounted warrior saint (St Theodore Stratelates) & shortly before 1000 \\
\hline $6 / 6 \mathrm{a}$ & anchorite & about 1000 \\
\hline $6 / 6 \mathrm{~b}$ & mounted warrior saint (St Phoibammon) & beginning of 11th century \\
\hline $6 / 6 \mathrm{~b}$ & mounted warrior saint (St Epimachos) & beginning of 11th century \\
\hline
\end{tabular}

In view of the new chronological evidence, the dating of the last two paintings, if they were indeed executed simultaneously, should be moved back to the period before 987/988. There is, unfortunately, no way of knowing how far back. However, on the basis of the stylistic analysis, it would seem that the two paintings cannot be earlier than the remaining murals. Thus, if the attribution of representations Nos $6 / 1$ and $6 / 4 \mathrm{~b}$ to the episcopate of Petros I is credible, we are forced to consider the whole decoration of the south aisle as a one-time undertaking, albeit carried out by a number of different masters. This must have taken place some time in the 970s-980s. The present discovery is all the more important since the second phase of decoration did not involve applying a new plaster coat on the church walls, but only adding new paintings to an already existing set.

To conclude, this minor discovery is significant not just for the history of the central church at Abdallah-n Irqi. First and foremost, it appears to validate the method of stylistic analysis formulated by Kazimierz Michałowski et consortes while working on the Faras wall paintings. After all, the new dating falls exactly within the period established on this basis by Paul van Moorsel; 
in fact, the change is merely cosmetic. Second, similarly as in the case of Faras, the discovery confirms the importance of the cooperation between epigraphists and art historians. Last but not least, the present study shows how fruitful browsing through older publications can be. In the present state of our knowledge about Christian Nubia, it is very often possible to understand earlier finds much better than their original discoverers and to reinterpret them using modern standards.

\section{ACKNOWLEDGMENTS}

I would like to thank Giovanni Ruffini for correcting my English.

\section{References}

\section{Abbreviations \\ $D B M N T$ \\ Database of Medieval Nubian Texts. (2011). Retrieved from http://www.dbmnt.uw.edu.pl/ [accessed: November 2015] \\ FHN III \\ $O C D$ Eide, T., Hägg, T., Pierce, R.H., and Török, L. (eds). (1998). Fontes historiae Nubiorum III. From the first to the sixth century $A D$. Bergen: Klassisk Institutt, Universitetet i Bergen Hornblower, S. and Spawforth, A. (eds). (1999). The Oxford classical dictionary (3rd ed.). Oxford: Oxford University Press \\ RE Wissowa, G. et al. (eds).(1894-1978). Paulys Real-encyclopädie der classischen Altertumswissenschaft, Stuttgart: Metzler \\ $T M$ Trismegistos. (2011). Retrieved from http://www.trismegistos. org/ [accessed: November 2015]}

Altheim, F. and Stiehl, R. (1971). Christentum am Roten Meer I. Berlin: de Gruyter Barkóczi, L. and Salomon, Á. (1974). Abdallah Nirqi 1964. Archaeological investigation of the settlement town "A". Acta Archaeologica Academiae Scientiarum Hungaricae, 26, 289-338

Castiglione, L. and Török, L. (1974). Abdallah Nirqi 1964. Introduction; Abbreviations; Index of the find objects according to sites. Acta Archaeologica Academiae Scientiarum Hungaricae, 26, 277-287

Crum, W.E. (1939). A Coptic dictionary. Oxford: Clarendon Press

Hajnóczi, G. (1974). Abdallah Nirqi 1964. Architectural characteristics of the settlement and buildings. Acta Archaeologica Academiae Scientiarum Hungaricae, $26,339-368$ 
Jakobielski, S. (2002). Die Chronologie der Wandmalereien in der Kathedrale von Faras. In W. Seipel (ed.), Faras: die Kathedrale aus dem Wüstensand (pp. 51-56). Vienna: Kunsthistorisches Museum

Klasens, A. (1967). Dutch archaeological mission to Nubia. The excavations at Abu Simbel North 1962-1964. In Fouilles en Nubie (1961-1963) (pp. 79-86). Cairo: Organisme général des Imprimeries gouvernementales

Łajtar, A. and van der Vliet, J. (1998). Rich ladies of Meinarti and their churches. With an appended list of sources from Christian Nubia containing the expression "having the Church of so-and-so". Journal of Juristic Papyrology, 28, 35-53

Łaptaś, M. (1996). Paintings from the Faras Cathedral. The "colour" classification method. Nubian NoteLet, 2, 1-18

Martens-Czarnecka, M. (1987). Nubian wall painting. In T. Hägg (ed.), Nubian culture: Past and present. Main papers presented at the sixth International Conference for Nubian studies in Uppsala, 11-16 August, 1986 (pp. 261-274). Stockholm: Almqvist \& Wiksell International

Michałowski, K. (1967). Faras: die Kathedrale aus dem Wüstensand. EinsiedelnZürich-Cologne: Benziger

Michałowski, K. (1974). Faras: Wall paintings in the collection of the National Museum in Warsaw. Warsaw: Wydawnictwo Artystyczno-Graficzne

Monneret de Villard, U. (1935). La Nubia medioevale I. Cairo: Institut français d'archéologie orientale

Obłuski, A. (2014). The rise of Nobadia: Social changes in northern Nubia in late Antiquity [=Journal of Juristic Papyrology Supplement 20]. (I. Zych, trans.). Warsaw: Raphael Taubenschlag Foundation

Ochała, G. (2011). Chronological systems of Christian Nubia [=Journal of Juristic Papyrology Supplement 16]. Warsaw: Raphael Taubenschlag Foundation

Ochała, G. (2015). The Nubian liturgical calendar: The evidence of the Nubian lectionaries. Le Muséon, 128(1-2), 1-48

Papaconstantinou, A. (2001). Le culte des saints en Égypte des Byzantines aux Abbasides: l'apport des inscriptions et des papyrus grecs et coptes. Paris: CNRS éditions

Rilly, C. (2008). Enemy brothers. Kinship and relationship between Meroites and Nubians (Noba). In W. Godlewski and A. Łajtar (eds), Between the cataracts: Proceedings of the 11th Conference for Nubian studies, Warsaw University, 27 August - 2 September 2006, I. Main papers [=PAM Supplement Series 2.1] (pp. 211-225). Warsaw: Warsaw University Press

Schneider, H.D. (1970). Abdallah Nirqi - Description and chronology of the central church. In E. Dinkler (ed.), Kunst und Geschichte Nubiens in christlicher Zeit: Ergebnisse und Probleme auf Grund der jüngsten Ausgrabungen (pp. 87-98). Recklinghausen: A. Bongers

Schneider, H.D. (1975). Epigraphica. In P. van Moorsel, J. Jacquet, and H.D. Schneider, The central church of Abdallah Nirqi (pp. 33-36). Leiden: Brill 
Smith, H.S. (1962). Preliminary reports of the Egypt Exploration Society's Nubian survey. Cairo

Török, L. (1974a). Abdallah Nirqi 1964. Finds with inscriptions. Acta Archaeologica Academiae Scientiarum Hungaricae, 26, 369-393

Török, L. (1974b). Abdallah Nirqi 1964. Fragments of wall-paintings. Acta Archaeologica Academiae Scientiarum Hungaricae, 26, 395-403

van Moorsel, P. (1970). Die Wandmalereien der zentralen Kirche von Abdallah Nirqi. In E. Dinkler (ed.), Kunst und Geschichte Nubiens in christlicher Zeit: Ergebnisse und Probleme auf Grund der jüngsten Ausgrabungen (pp. 103-111). Recklinghausen: A. Bongers

van Moorsel, P. (1975). The wall-paintings. In P. van Moorsel, J. Jacquet, and H.D. Schneider, The central church of Abdallah Nirqi (pp. 54-131). Leiden: Brill van Moorsel, P., Jacquet, J., and Schneider, H.D. (1975). The central church of Abdallah Nirqi. Leiden: Brill 


\title{
The pig - a mystery of medieval Makuria
}

\author{
Marta Osypińska \\ Institute of Archaeology and Ethnology, Polish Academy of Sciences, Poznań \\ archeozoo@o2.pl
}

\section{KeYwords}

medieval Nubia, pig husbandry, archaeozoology, animals in Makuria, economy

\section{Abstract}

Regular archaeozoological research at key sites from the region of Makuria has contributed significant data on animal breeding and meat consumption in this Nubian kingdom. The appearance of the domestic pig, absent earlier from sites in the Middle Nile Valley, was one of the most distinctive features of the Makurian economy. Pig has been demonstrated to be the third most important meat for consumption, likewise in historic Dongola and in Banganarti (after cattle and ovicaprids) in all phases of Nubian history, including sporadic occurrence in contexts dated to the Funj period. The article looks at the origins and importance of the pig as a species in Makurian animal economy and the tentative socio-economic implications of this unique phenomenon in Nubia.

Of the African domestic animals the domestic pig is the least known. The story of the species, its origin and the routes by which it spread in Africa continue to excite a lively controversy (Blench 2000). Notwithstanding the input of researchers in the fields of biology (DNA testing), ethnography and linguistics, contemporary archaeozoological knowledge can hardly be deemed satisfactory in this regard (Epstein 1971; Brewer, Redford, and Redford 1994; Blench 2000). In view of this, a study of the importance of breeding pigs in the 
economy of Makuria, based mainly on osteological material from Old Dongola and Banganarti, takes on added value as a means of rectifying the state of knowledge on the history and role of the domestic pig in northeastern Africa.

According to Blench (2000: 355-356), such poor recognition of the history of the domestic pig in Africa is due to several factors. First and foremost, the identification of the remains of domestic pig amongst possible remains of wild species of suidae has been fraught with difficulty. Furthermore, owing to the developed import of European pigs into all parts of Africa, related both to missionary activity and colonial agriculture reaching back to the 16th century, the pig population currently living in Africa is considerably mixed and genetically diverse (Adebambo 1982; Blench 2000). A significant reduction in the range of pig breeding due to the religious and cultural expansion of Islam has been another major factor. In several areas of Africa (like Ethiopia, for example) the importance of pig breeding is a matter barred from scientific discourse not only due to religious prohibitions, but also deeply rooted prejudices and superstitions (Mason and Maule 1960; Phillipson 1993).

\section{The origin of the domestic pig}

The domestic pig on all continents evolved from a common ancestor - the wild boar (Sus scrofa), found also in North Africa (Hecker 1982; LasotaMoskalewska, Kobryń, and Świeżyński 1987; Blench 2000; Giuffra et al. 2000; Kijas and Andersson 2001; Larson et al. 2005; 2007). In the area of the Maghreb and the Sahara, the wild boar went by the name of Sus scrofano barbarus or sahariensis (Epstein 1971: 314; Blench 2000: 355), and Sus scrofa algira (Groves 1981: 29). Wild pigs native to Africa are represented by three species: bush-pig (Patamochoerus porcus), warthog (Phacochoerus aetiopicus) and giant forest hog (Hylochoerus meinertzhageni) (Harris and White 1979). They had no part, however, in the domestication of the pig in Africa as they cannot interbreed with the pig (after Blench 2000: 355). The view currently prevailing in archaeozoology is of a polytopic domestication of pigs, that is to say, occurring independently in different periods and disjunctive areas (e.g., Larson et al. 2005; 2007; Lasota-Moskalewska 2005). Early domestication was inconsistent: it appeared and disappeared in different areas of the Euphrates and Tigris basins (e.g., Jarmo, Çayönü Tepesi, Gürcütepe). By the 6th millennium $\mathrm{BC}$ breeding domestic pig was so widespread that one can pronounce its final domestication. It was never as common as breeding small ruminants (Lasota- 
Moskalewska 2008). The ease with which wild boars are tamed and then domesticated triggered the phenomenon independently in all areas of Asia and Europe where the animals lived in their natural state (after Lasota-Moskalewska 2005). By contrast, there is no unequivocal archaeozoological data to prove that the domestication of wild boars happened also in Africa (Manlius and Gautier 1999). Remains of the domestic pig from Merimde (in the Nile delta in Egypt), from Predynastic contexts, do not necessarily testify to the process, claim some researchers (Blench 2000: 357). The issue is still without answer (Giuffra et al. 2000; Bertini and Cruz-Rivera 2014).

In general, the domestic pig in sub-Saharan Africa comprises two types: the so-called 'indigenous' pig and the imported pig, identified on the basis of DNA analysis (Blench 2000) [Fig. 1].

Researchers have hypothesized based on ethnographic data on pig breeding in Sennar and in the Sudanese-Ethiopian borderlands that the spread of pig farming in the Nile Valley occurred at least as early as in the Middle Ages, possibly even earlier (Murdock 1959; Bechhaus-Gerst 2000). Results of archaeozoological research in central Sudan failed to confirm these assumptions: rich bone assemblages from the early medieval town of Soba have not yielded any pig remains (Chaix 1998), and earlier sites likewise. The growing popularity of pork south of Aswan seems to have been begotten by Greek influences throughout the Ptolemaic and later also the Roman period. Remains of domestic pig have been registered in provincial civilizational centers of the period, such as Berenike, the seaport on the coast of the Red Sea (Osypińska 2011). In an earlier phase (3rd-2nd century BC), these animals had to be specially brought in to the port by land or sea, because unlike ruminants, they are unsuited for long treks. Pigs also spread widely along the African coast of the Mediterranean Sea. Their farming was of

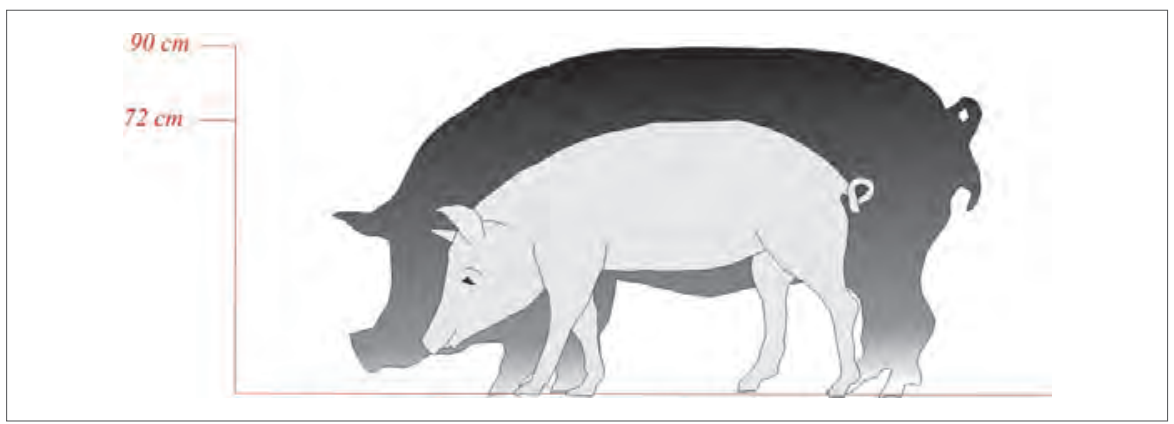

Fig. 1. Body proportions: the African "indigenous" pig (smaller), and the European modern swine (bigger)

(Data M. Osypiniska, drawing J. Sawicka) 
great importance already inprehistoric Tangier (Morocco), in Punic Carthage, and also among the Berbers, until the spread of Islam. Epstein (1971) suggested that pigs were kept by some communities of the Maghreb even in the early 20th century. Particularly important for our studies is the modern tradition, rooted in Late Antiquity, of rearing pigs by the Egyptian Copts (Hecker 1982; Bertini and Cruz-Rivera 2014). Current archaeozoological knowledge on domestic pig in sub-Saharan Africa (e.g., Sudan, Chad, Senegal) in the periods following antiquity is also modest. Pig bones have been recorded at two archaeological sites: the 9th-century site of Ndondondwane in Kwa Zulu Natal, South Africa (Voigt and von den Driesch 1984) and at the site in Nkile in Zaire, dating to the 19th century (Van Neer 2000).

Thus, the abundant osteological materials recovered in the course of excavation at Old Dongola, on the site of the palace of the Makurian rulers on the citadel and the Monastery of the Holy Trinity on Kom H, as well as at the pilgrimage center in Banganarti, offer unrivalled information on the history of pig farming in Africa.

\section{The domestic pig in Makuria}

In spite of the relatively good state of research on breeding domestic animals in Sudan in various stages of its history (thanks to the invaluable contribution of scientists like Achilles Gautier and Louis Chaix), no evidence has been turned up so far to confirm the keeping of pigs in any period other than the medieval Kingdom of Makuria [Table 1], to wit, Neolithic, broadly understood Kerma period, civilization of the Kingdoms of Kush and the post-Meroitic period. The said research in Soba, capital of the Christian Kingdom of Alodia, has yielded nothing in the archaeological record to evidence a special role of pig breeding in the economy. The suidae theme in craft ornamentation of almost every cultural unit of Central Sudan is an issue to be addressed separately (after Spaulding and Spaulding 1989: 3).

In Old Dongola, ancient Tungul, capital of the medieval Kingdom of Makuria, remains of domestic pig were noted already in contexts dated to the 6th century, the earliest years of the functioning of the city as the royal seat of the Makurian rulers (Osypińska 2004; 2013a; 2014). In fact, they accounted for the highest percentage of bones from the period of the Early Kingdom of Makuria. This applies to osteological assemblages from both the area of the royal palace in Old Dongola and from the Banganarti religious center. In Dongolan 
Table 1. Proportion of pig and ruminant remains from the Old Dongola palace and Banganarti by successive periods

\begin{tabular}{|c|c|c|}
\hline Species / Site context & Swine & $\begin{array}{l}\text { Ruminants } \\
\text { (cattle / sheep / goat) }\end{array}$ \\
\hline \multicolumn{3}{|c|}{$\begin{array}{l}\text { Early Makuria } \\
\quad \text { 6th-9th century AD }\end{array}$} \\
\hline $\begin{array}{l}\text { Old Dongola } \\
\text { (palatial building B.I) }\end{array}$ & $15.86 \%$ & $84.13 \%$ \\
\hline $\begin{array}{l}\text { Banganarti } \\
\text { (settlement) }\end{array}$ & $12.86 \%$ & $87.13 \%$ \\
\hline \multicolumn{3}{|c|}{$\begin{array}{l}\text { Classic Makuria } \\
\qquad 11 \text { th-12th century AD }\end{array}$} \\
\hline $\begin{array}{l}\text { Banganarti } \\
\text { (settlement) }\end{array}$ & $16.28 \%$ & $83.71 \%$ \\
\hline \multicolumn{3}{|l|}{$\begin{array}{l}\text { Late Makuria } \\
\qquad 13 \text { th century AD }\end{array}$} \\
\hline $\begin{array}{l}\text { Old Dongola } \\
\text { (palatial building B.I) }\end{array}$ & $3.06 \%$ & $96.93 \%$ \\
\hline \multicolumn{3}{|c|}{$\begin{array}{l}\text { Post-Makurian period } \\
\qquad 16 \text { th-17th century AD }\end{array}$} \\
\hline Old Dongola & $1.06 \%$ & $99.93 \%$ \\
\hline
\end{tabular}

deposits from the 6th-7th century, the percentage of domestic pig remains amounted to $15.86 \%$ of all identified remains (NISP=6404) [Table 1], making pork the third most commonly consumed meat of the elite, after mutton and beef (Osypińska 2014). No pig bones were recovered from sites of the earlier periods in the vicinity of Old Dongola. None were found at the Meroitic settlement site in Selib (1st-2nd century AD) (Osypińska 2000), located only a few kilometers away from Banganarti and several kilometers from Old Dongola (Osypińska in preparation), nor at the Jebel Barkal temples (1st-3rd century AD) (Osypińska 2000) and Sonyat (Tergis) temple (1st-2nd century AD) (Osypińska 2001). Neither were there any pig remains at post-Meroitic funeral sites coming from an age also dubbed Early Makuria, dated to the 5th century AD, such as El-Zuma (Osypińska 2010) and Hammur Abbasija (Osypińska 2000). It seems reasonable, therefore, to conjecture that pig rearing and pork consumption in Makuria were closely interrelated with the advent of Christianity and the formation of the state of Makuria in Nubia. Despite a roughly 4000-year-long tradition of pig rearing in 
Egypt, never had the interest in breeding of these animals spread to areas south of the Third Cataract before the Middle Ages (end of 5th-14th century AD). Extant written sources bear witness to the fact that domestic pig farming was practiced in northern Nubia, but only until the 12th century. In 1173, Turan Shah, the brother of Saladin, killed 700 pigs after the successful siege of the fortress of Ibrim (Abu al-Makarim, History of churches and monasteries, fol. 96b).

In the Classical Makuria period (10th-12th century AD), pig breeding, and thus pork consumption, were invariably common as evidenced by material excavated from the fortified settlement around the pilgrimage center of Banganarti (no osteological assemblages of such date have been recovered from Old Dongola). Pig remains in 11th-12th century contexts continued to be high, amounting to as much as roughly 17\% (NISP=3107) (Osypińska 2014).

A dramatic change occurred in the late period (13th-15th century AD). Pig bones recovered from this phase in Old Dongola account for only $3.06 \%$ of the assemblage (Osypińska 2013a; 2014). There is also a marked change compared to the earlier chronological contexts as regards the state of preservation of pig remains. There is practically no evidence of consumption to be observed from the bones, the assemblages consisting almost exclusively of whole bones and practically complete skulls [Fig. 2]. In the older materials the bones had been fragmented and the anatomical distribution bespoke of modification during the division of the carcass for consumption (Osypińska 2014).

Interestingly, pig bones were still present in the latest settlement contexts in the citadel in Dongola, namely in the 16th-17th century AD, after the fall of the Christian state. Pig remains did not exceed one per cent at the time, nonetheless the domestic pig definitely continued to live in Dongola. Importantly, the

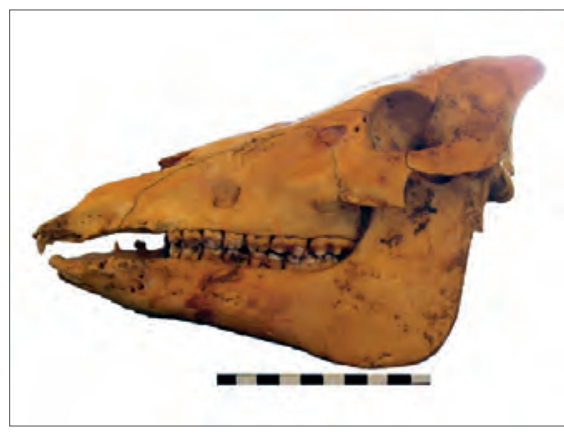

Fig. 2. Pig skull from the debris of the palace staircase in Old Dongola, 13th century AD (Photo M. Osypinska)

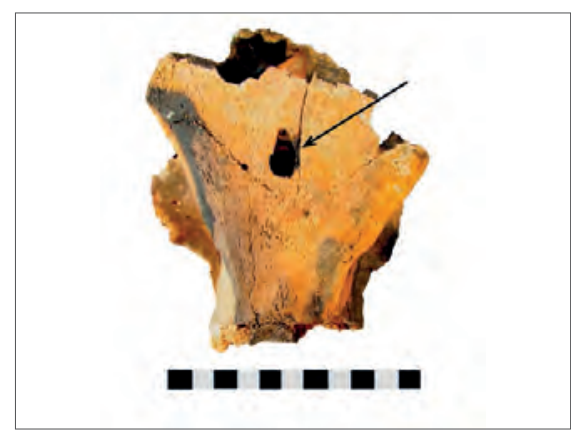

Fig. 3. Fragment of a pig's skull (os frontale) with consumption damage (traces of burning and cut hole) (Photo M. Osypinska) 
taphnomic analysis of the remains detected no post-consumer characteristics. Such a late occurrence of pigs in a community most likely professing Islam in part seems intriguing (Holt 1961; 1963; Gray 1975; Mrozek 1969; Trimingham 1949). Muslims living in multi-religious societies are known to tolerate pigs kept by non-Muslims (after Epstein 1971/II: 330), and even use pigs or pork for magical purposes. Epstein claims that although the Muslims in Nubia considered pigs to be unclean, they nevertheless believed that a small piece of pork applied in the throat of a sick horse or donkey worked therapeutically and was able to cure a sick animal. In some regions of North and East Africa, and in Zanzibar people used to keep a pig in the stable in order for the 'evil spirits' or the jinn to be removed from the horses into the body of the pig. However, the beliefs were not practiced in Nubia, mainly because horses and donkeys were not kept in stables specially designed for this purpose (after Epstein 1971/II: 331).

In the osteological material from Christian Makuria pig remains exhibited characteristics typical of post-consumer waste [Fig. 4]. This applies also to the anatomical distribution dominated by bone fragments from the parts of the carcass richest in meat (for details, see Osypińska 2014). Consumption of pork is marked by an evident preference for meat from the pig's head; a similar preference is shown by osteological materials from medieval Europe, for example. This was not the case of the ruminants. Interesting examples were recorded at Banganarti, in materials from the classical period, wherein the pig

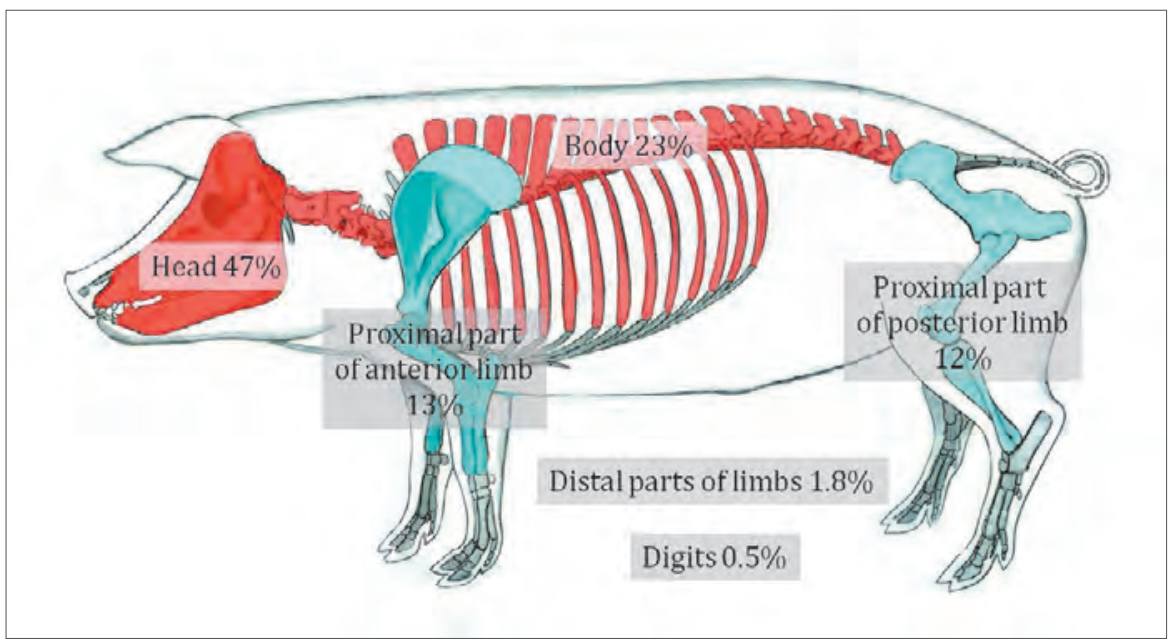

Fig. 4. Body parts of highest consumption value in Makurian society based on archaeological osteological finds (Data M. Osypinska) 
skulls were found to have holes knocked in the frontal bone, probably in order to extract the brain or grill the meat from the pig's head on a spit [Fig. 3]. In the Dongola materials, the share of the remains of the cranial skeleton was also significantly higher than in the case of ruminants. Another feature that distinguishes the consumption of pork was a relatively high interest in the meat of young animals. The share of remains of pigs killed before the age of three was the highest among all consumed species (over 7\%) particularly in bone assemblages dated to the classical period. Male individuals were selected for consumption much more often than females. These observations on the model of consumption of pork in Makuria betokens intentional breeding of these animals and planned slaughter of unnecessary individuals, yet with high nutritive value of meat, all in accordance with the rules of the economics of animal husbandry.

Data on the morphology of pigs (Osypińska 2005; 2013a; 2014) kept in Makuria, derived from archaeozoological examination, demonstrate characteristics of pigs not unlike the indigenous population known from Egyptian iconography. The animals were of fairly slight build, 60 to 77 inches tall at the withers (coefficients for calculating height at the withers from Teichert 1966/69, cited after von den Driesch and Boessneck 1974). An elongated facial portion of the skull and a rectangular lacrimal bone were typical. An analysis (after Lasota-Moskalewska, Kobryń, and Świeżyński 1987) of the proportions of the humeral block has shown that while in the early period pigs were allowed a semi-free range and were ordinarily not locked in a confined space, all the examined bones of the classical period from the Banganarti materials displayed much reduced mobility in life, which indicates that the animals were kept in small pens, where their movement was severely restricted. There is no data to suggest how the pigs were kept in later periods, that is, Late Makuria and Funj. Morphological characteristics of skulls found at Makurian sites manifest that the animals heavily burrowed in search of food (Genov 1992).

\section{Role of the Middle Nile Valley in the spread of pig to Nubia}

From the perspective of current archaeozoological research, the issue of the lack of data on the early spread of pig husbandry along the Nile, as assumed by linguists, is highly intriguing (Blench 2000: 364). Until the time of the Christian kingdoms, that is to say, for roughly four millennia, the practice of breeding pigs apparently did not gain new followers south of the Third Cataract (Chaix 2006). The reasons for such a disinclination are still unaccounted for; they could have been social, cultural, religious. In this context, it is equally important to understand the fairly sudden emergence of pig husbandry already 
at the dawn of the kingdom of Makuria. Given the lack of data, any attempts to address the issue will have to remain purely hypothetical. At present, there are two plausible explanations to be considered; whether any of them is accurate or if both operated at the same time remains indeterminate for obvious reasons. Firstly, religious and cultural determinants may have been involved, as well as an imitation of practices, including those related to consumption and economy that typified the regions which were the source of Christianity. The pig was of great importance within the circle of influence of Greek culture, as reflected in the vast popularity of pork during the Ptolemaic period in Egypt and throughout the Eastern Empire. Furthermore, pig husbandry is still practiced in present-day Egypt, albeit only by the Copts. Conceivably, Makuria showed eagerness, typical of neophytes, to take on possibly complete patterns of the 'model' civilization, in this case, Byzantine, together with elements of material culture associated with consumption-related habits. This hypothesis can further be expanded to include the imported wine and garum sauces, both luxury goods from the area of impact of Greco-Roman culture.

Another factor that may have contributed to the rapid import of the idea of breeding pigs could have been economic and sociological in nature. The pig is the most prolific species among animals. Thus, pig husbandry is able to meet a soaring demand for large quantities of meat very quickly. Unlike ruminants, pigs do not need a large space to be reared, pastures or good feeding; they can feed on organic refuse. Pigs can be grown in very confined spaces, in densely built-up areas, e.g., in towns. A distant analogy for this situation is the emergence of the Piast state in 10th-century Poland, when a sudden growth of pig farming was observed in strongholds newly established in freshly conquered tribal areas, where ruminant husbandry had traditionally dominated the economy of the Central European Lowlands (e.g., Lasota-Moskalewska 2007; Osypińska 2013b). This phenomenon was likely triggered by the necessity to provide quickly more caloric meat to feed the warriors stationed in the strongholds. Only pig breeding could have met such a sudden increase in demand for food. It is likely that in the case of Makuria and the emergence of new, large centers with large military crews, the adoption of a husbandry previously unknown in the area could have rapidly met the demand for larger quantities of meat, particularly if the conquered areas were less populated and historically keeping livestock for meat there was of marginal significance.

Whichever factors played a decisive role in the adoption of pig husbandry in Makuria, they did not occur in Alodia. Research in Soba (Chaix 1998) has not produced any bones of the domestic pig (only one bone of a warthog was found). Based on the (marginal) presence of pig breeding in Sennar and in 
the Sudanese-Ethiopian borderland, and on the presence of concepts associated with the pig in the Omotic languages, related to the Pre-Kushite languages, some linguists have suggested an ancient pedigree of pig rearing in the region of central Sudan, which resulted from the spread of this idea along the Nile Valley, and further through the Bantu peoples to equatorial, west and south Africa (after Blench 2000: 364). The lack of archaeological data for these areas is partly explained by the mistaken identification of the bones of domestic pigs as wild species. Yet, in the complete absence of domesticated or wild pigs in assemblages from Upper Nubia, this argument cannot be upheld. It is perhaps reasonable to consider routes of the spreading of the idea of breeding pigs that would be less stereotypical than from the north to the south and up the Nile Valley, taking into account only the medieval episode of the popularity of pig husbandry in Makuria. The zone of sub-Saharan Africa did not provide a suitable area for these animals to be bred, in view of the lack of appropriate environmental conditions, undisturbed access to water and mud, lack of feed much like human food, as well as low population density. Perhaps one should take into consideration that pig breeding as an idea spread into the area of Sennar from the south and west. It is reasonable to conjecture that pig farming is somehow attributable to the peoples of the Bantu family, although any considerations on its origin, dating back to pre-colonial times, remain purely hypothetical. Alternatively, a predominant impact of imports of pigs from Europe to the areas of central, west and southern Africa could provide an answer to this unsolved mystery.

\section{Conclusions}

Regardless of how the discussion on the genesis of pig husbandry in Africa will develop, considering current archaeozoological knowledge, the significant episode of the importance of pig in the economy of Makuria will undeniably remain unique in the history of Sudan. In this regard, archaeozoological research, and thus the study of the economic role of animals, the specificity of breeding and economy of medieval Makuria, constitutes an important element in reconstructing the history of livestock in Africa. Of paramount importance here is research in the territory of medieval Makuria, including its main center, the Citadel in Old Dongola. The results of archaeozoological research from Dongola, the importance of which Professor Włodzimierz Godlewski was the first to recognize, has allowed the pig to take a permanent place among the domestic animals of this remarkable region. The discovery of pig remains at Makurian sites, in several sociotopographically and 
chronologically varied contexts, has revolutionized the state of knowledge on the origin and history of domestic animals in the Nile Valley and Africa. Furthermore, this element of archaeozoological knowledge provides also new proxy data for the multidisciplinary study of the economic, cultural, environmental and sociological aspects of the emergence and functioning of Christian Makuria.

\section{References}

\section{Primary sources}

Abu al-Makarim, The churches and monasteries of Egypt and some neighbouring countries, attributed to Abû Ŝalih, the Armenian, transl. by B.T.A. Evetts, Oxford: Clarendon Press, 1895

\section{SECONDARY SOURCES}

Adebambo, O.A. (1982). Evaluation of the genetic potential of Nigerian indigenous pigs. In 2nd World Congress on Genetics Applied to Livestock Production: 4th-8th October 1982, Madrid, Spain (pp. 543-553). Madrid: Editorial Garsi

Bechhaus-Gerst, M. (2000). Linguistic evidence for the prehistory of livestock in Sudan. In R.M. Blench and K.C. MacDonald (eds), The origins and development of African livestock: Archaeology, genetics, linguistics, and ethnography (pp. 449461). London: UCL Press

Bertini, L. and Cruz-Rivera, E. (2014). The size of ancient Egyptian pigs: A biometrical analysis using molar width. Bioarchaeology of the Near East, 8, 83-107

Blench, R.M. (2000). A history of pigs in Africa. In R.M. Blench and K.C. MacDonald (eds), The origins and development of African livestock: Archaeology, genetics, linguistics, and ethnography (pp. 335-367). London: UCL Press

Brewer, D.J., Redford, D.B., and Redford, S. (1994). Domestic plants and animals: The Egyptian origins. Warminster: Aris \& Phillips

Chaix, L. (1998). The fauna. In D.A. Welsby, Soba II. Renewed excavations within the metropolis of the Kingdom of Alwa in Central Sudan [=British Institute in Eastern Africa Memoir 15] (pp. 233-255). London: British Museum Press

Epstein, H. (1971). The origin of the domestic animals of Africa I-II. New York: Africana Publishing Corporation

Genov, P. (1992). Wptyw warunków ekologicznych na zmienność czaszki dzika (Sus scrofa L.) w zachodniopótnocnej Afryce, środkowopotudniowej Europie, środkowej Azji i Dalekim Wschodzie [The impact of ecological conditions on the variability of wild boar skulls (Sus scrofa L.) in northwestern Africa, central Southern Europe, Central Asia and the Far East]. Warsaw: Uniwersytet Warszawski, Wydział Biologii [in Polish] 
Giuffra, E., Kijas, J.M.H., Amarger, V., Carlborg, Ö., Jeon, J.-T., and Andersson, L. (2000). The origin of the domestic pig: Independent domestication and subsequent introgression. Genetics, 154(4), 1785-1791

Gray, R. (ed.). (1975). The Cambridge history of Africa IV. From c. 1600 to c. 1790. Cambridge: Cambridge University Press

Groves, C.P. (1981). Ancestors for the pigs: Taxonomy and phylogeny of the genus Sus [=Technical Bulletin 3]. Canberra: Department of Prehistory, Research School of Pacific Studies, Australian National University

Harris, J.M. and White, T.D. (1979). Evolution of Plio-Pleistocene African Suidae. Transactions of the American Philosophical Society, 69(2), 1-128

Hecker, H.M. (1982). Domestication revisited: Its implications for faunal analysis. Journal of Field Archaeology, 9(2), 217-236

Holt, P.M. (1961). A modern history of the Sudan: From the Funj Sultanate to the present day. London: Weidenfeld and Nicolson

Holt, P.M. (1963). Funj origins: A critique and new evidence. The Journal of African History, 4(1), 39-55

Kijas, J.M. and Andersson, L. (2001). A phylogenetic study of the origin of the domestic pig estimated from the near-complete mtDNA genome. Journal of Molecular Evolution, 52(3), 302-308

Larson, G., Albarella, U., Dobney, K., Rowley-Conwy, P., Schibler, J., Tresset, A., Vigne, J.-D., Edwards, C., Schlumbaum, A., Dinu, A., Bălăçsescu, A., Dolman, G., Tagliacozzo, A., Manaseryan, N., Miracle, P., Wijngaarden-Bakker, L., Masseti, M., Bradley, D.G., and Cooper, A. (2007). Ancient DNA, pig domestication, and the spread of the Neolithic into Europe. Proceedings of the National Academy of Sciences, 104(39), 15276-15281

Larson, G., Dobney, K., Albarella, U., Fang, M., Matisoo-Smith, E., Robins, J., Lowden, S., Finlayson, H., Brand, T., Willerslev, E., Rowley-Conwy, P., Andersson, L., and Cooper, A. (2005). Worldwide phylogeography of wild boar reveals multiple centers of pig domestication. Science, 307(5715), 1618-1621

Lasota-Moskalewska, A., Kobryń, H., and Świeżyński, K. (1987). Changes in the size of the domestic and wild pig from the Neolithic to the Middle Ages. Acta Theriologica, 32(5), 51-81

Lasota-Moskalewska, A. (2005). Zwierzęta udomowione w dziejach ludzkości [Domesticated animals in human history]. Warsaw: Wydawnictwa Uniwersytetu Warszawskiego [in Polish]

Lasota-Moskalewska, A. (2007). Cechy metryczne w ewolucji ssaków udomowionych [Metric features in the evolution of domesticated mammals]. In M. Makohonienko, D. Makowiecki, and Z. Kurnatowska (eds), Studia interdyscyplinarne nad środowiskiem i kultura $w$ Polsce [=Środowisko, cztowiek, cywilizacja 1] (pp. 115120). Poznań: Bogucki Wydawnictwo Naukowe [in Polish]

Lasota-Moskalewska, A. (2008). Archeozoologia: ssaki [Archaeozoology: mammals]. Warsaw: Wydawnictwa Uniwersytetu Warszawskiego [in Polish] 
Manlius, N. and Gautier, A. (1999). Le sanglier en Égypte. Comptes Rendus de l'Académie Des Sciences - Series III - Sciences de La Vie, 322(7), 573-577

Mason, I.L. and Maule, J.P. (1960). The indigenous livestock of eastern and southern Africa [=Commonwealth Bureau of Animal Breeding and Genetics. Technical communication 14]. Farnham Royal: Commonwealth Agricultural Bureaux

Mrozek, A. (1969). Wybrane aspekty islamu sudańskiego. Etnografia Polska, 13(2), 133-169

Murdock, G.P. (1959). Africa: Its peoples and their culture history. New York: McGrawHill Book Co.

Osypińska, M. (2000). Animal remains from Hammur Abbasija tumuli archaeozoological analysis. Unpubl. manuscript

Osypińska, M. (2003). Faunal remains from the Southern Dongola Reach. In B. Zurawski, Survey and excavations between Old Dongola and Ez-Zuma [=Nubia 2; Southern Dongola Reach Survey 1] (pp. 490-493). Warsaw: Neriton

Osypińska, M. (2004). Animal bone remains from Old Dongola. Osteological material from Building B.I on Kom A. Polish Archaeology in the Mediterranean, 15, 224-230

Osypińska, M. (2005). Animal bones from the excavations at Ez-Zuma. Polish Archaeology in the Mediterranean, 16, 404-408

Osypińska, M. (2010). Animal bone remains from the cemetery in El-Zuma (2007 season). Polish Archaeology in the Mediterranean, 19, 488-493

Osypińska, M. (2011). Archaeozoological remains. In S.E. Sidebotham and I. Zych (eds), Berenike 2008-2009: Report on the excavations at Berenike, including a survey in the Eastern Desert [=PCMA Excavation Series 1] (pp. 67-76). Warsaw: PCMA UW

Osypińska, M. (2013a). Archaeozoological research on animal remains from excavations in Dongola (Sudan) in 2010. Polish Archaeology in the Mediterranean, 22, 229-247

Osypińska, M. (2013b). Zwierzęta w gospodarce wczesnośredniowiecznego Szczecina [Animals in the economy of early medieval Szczecin]. Poznań: Instytut Archeologii i Etnologii PAN [in Polish]

Osypińska, M. (2014). Animals in the economy of Christian Makuria. In J.R. Anderson and D.A. Welsby (eds), The Fourth Cataract and beyond: Proceedings of the 12th International Conference for Nubian Studies [=British Museum Publications on Egypt and Sudan 1] (pp. 909-916). Leuven: Peeters

Osypińska, M. (in preparation). The cattle kingdoms. Two thousands years of livestock history in Sudan between 3rd c. BC-17th c. AD

Phillipson, D.W. (1993). The antiquity of cultivation and herding in Ethiopia. In T.E. Shaw, P. Sinclair, B. Andah, and A. Okpoko (eds), The archaeology of Africa: Food, metals and towns [=One World Archaeology 20] (pp. 344-357). London: Routledge

Southey, R. (1823). The Pig. A colloquial poem. In The minor poems of Robert Southey II (pp. 97-100). London: Longmans, Hurst, Rees, Orme, and Brown 
Spaulding, J. and Spaulding, J.L. (1989). Pigs: The democratic philosophers of the medieval Sudan. Boston: African Studies Center, Boston University

Trimingham, J.S. (1949). Islam in the Sudan. London: Oxford University Press

Van Neer, W. (2000). Domestic animals from archaeological sites in Central and west-central Africa. In R.M. Blench and K.C. MacDonald (eds), The origins and development of African livestock: Archaeology, genetics, linguistics, and ethnography (pp. 163-190). London: UCL Press

Voigt, E.A. and von den Driesch, A. (1984). Preliminary report on the faunal assemblage from Ndondondwane, Natal. Southern African Humanities, 26(1), 95-104

von den Driesch, A. and Boessneck, J. (1974). Kritische Anmerkungen zur Widerristhöhenberechnung aus Längenmassen vor- und frühgeschichtlicher Tierknochen. Sängetierkundliche Mitteilungen, 22, 325-348 


\title{
Dotawo's later dynasties: a speculative history
}

\author{
Giovanni R. Ruffini \\ Fairfield University \\ gruffini@fairfield.edu
}

\section{KEYWORDS}

medieval Nubia, Dotawo, Nubian kings, Nubian dynasties, Makouria, Alwa

\begin{abstract}
This article proposes speculative reconstructions of the genealogies of the royal families of the medieval Nubian kingdom of Dotawo. It synthesizes the literary, documentary and epigraphic evidence for Nubian kings and their families in the 1100s-1300s. The result is a series of family trees intended to produce a testable model. That model proposes that despite the apparent conflict between various contenders for the throne dynastic succession was the standard operating principle in Dotawo throughout the late medieval period; that peaceful stability was normative; and that a single family dynasty may have ruled Dotawo through the entire span of these several centuries.
\end{abstract}

Nubian studies is an intensely empirical field. Its practitioners are, in the main, archaeologists on the one hand and philologists on the other. Scholars in both disciplines hold closely to the evidence at hand, the material remains on one side, the texts on the other. As an historian, and an interloper at that, I want to ask questions about Nubia that neither body of evidence can really answer. I have found few Nubiologists willing to engage in the speculation, indeed guesswork, necessary to answer some of these questions. Włodzimierz Godlewski’s articles on the history of Nobadia and Makuria are role-models to me in this regard. When I once asked him what he would present at the next Nubian studies conference, he replied, "Some new heresy, no doubt." With this spirit of adventure in mind, I am happy to dedicate this article to the heretic at hand. 
In an earlier study on the kingdom of Dotawo, I suggested that a speculative history of the late medieval royal families of Nubia was an obvious next step in research on this kingdom. ${ }^{1}$ I present such a study here, admitting in advance its necessary weaknesses. I rely on the one hand on documentary evidence studied only via photographs of imperfectly preserved and poorly understood Old Nubian letters and legal documents, and on the other hand literary evidence available to me, because of my lack of Arabic, only through a now rather old translation of even older editions of a wide range of medieval Arabic historians and geographers. ${ }^{2}$ The result is necessarily a shaky foundation, and I claim no certainty in my conclusions. I present the following genealogical conjectures only as models of what might be possible about the dynasties of Dotawo, knowing as always that they must be tested against future evidence, and that other alternatives may present themselves.

\section{Godlewski and the standard historiography}

Scholars typically take the "peak in development of Nubian culture" to be the 9th to the 11th centuries. ${ }^{3}$ That period seems to have seen the rule of a single dynasty which Godlewski has argued followed a rule of royal succession by the king's eldest son (Godlewski 2002). A major change followed, with the unification of Makuria in the north and Alodia (alternatively Alwa or Arwa) in the south. According to Godlewski's reconstruction of the merger, "the Kingdom of Dotawo was established in the 11th century as the result of a union between the ruling families of Arwa and Makuria."

Confronted with Nubia's dynastic turmoil as it appears in the Arabic evidence, Godlewski supposed that it stemmed from trouble caused by that union. He wrote, "in the 12th and 13th centuries, the Kingdom of Dotawo suffers a general weakening caused by internal conflicts between the ruling

1 Ruffini 2013: 191. Narratives of Nubian royal succession over the last thirty years typically rely on Munro-Hay 1982, but much new material from both early and late medieval Nubia has been published since.

2 Old Nubian documents: P.QI 3 and P.QI 4. Arab literary sources: Vantini 1975, for which see now the online edition at www.MedievalNubia.info. Quotations from Arab literary sources in this paper, when given solely by page number, are from Vantini 1975.

3 Godlewski 2002: 75. See Godlewski 2004 for his study of medieval Nubia's earlier centuries.

4 Quoting Godlewski 2013a: 129. See Godlewski 2008: 271. See Welsby 2002: 89 for an alternative but similar reconstruction. 
families in Dongola and Soba." However, the union between Makuria and its northern partner, Nobadia, remained strong: "the eparchs [of Nobadia] are still being designated by the successive kings of Dotawo" (Godlewski 2013a: 130).

The standard historiography has long assumed that succession to the Nubian throne in this later period was matrilineal, that it passed from the king to the king's sister's son. ${ }^{5}$ This system held in the main, although exceptions are known. (Indeed, scholars have long known that attempts to depict medieval Nubia as a matrilineal society or posit a "fixed rule of succession" face considerable limitations, Spaulding 2004: 414-415). Nubian documents provide a central character at the heart of this system. The Old Nubian legal protocols refer to a ngonnen, a title or term modern scholars translated as "Queen-Mother". This translation has never, to my knowledge, been challenged in any way, but it is not problem-free. It has its origins in Ali Osman's study of the Old Nubian documents from Qasr Ibrim, and stems from his comparison of the term ngonnen to Nobiin noono, which Osman glosses as "the great mother". ${ }^{6}$ Presumptively, this "great mother" is the woman through whom the royal succession passes, in most cases the sister of the previous king and mother of the next.

This presumption gives us considerable genealogical leverage. It allows us to construct speculative family trees for the kings of Dotawo, and test those trees against the standard historiographical models. The result will be a reconstruction - or series of reconstructions - of Nubia's later royal families in the spirit of Godlewski's reconstruction of Nubia's earlier royal family, during its so-called Golden Age. I propose to focus on four major family groups, the first long known from the Old Nubian documentary evidence from Qasr Ibrim, and the other three well known from various Arabic historians and geographers, and now at least partly confirmed by more recently published Old Nubian evidence from Qasr Ibrim.

5 Godlewski argues that a different system, succession by the eldest son, held under the preceding period, from 835 to 1080 (2002: 78), and that matrilineal succession was restored with the abdication of Solomon in 1079 (2002: 92). He later concluded that matrilineal succession was in fact restored with Solomon's rise to the throne as sister's son of his predecessor Stephanos (Godlewski 2008: 271). Here, Godlewski builds on earlier conclusions reached by Adams et al.; see the brief summary in Spaulding 2004: 414. For the social and political conditions surrounding this change in succession practice, see Godlewski 2013b: 666. See also Kronenberg and Kronenberg 1965: 256-260, explaining succession by the king's son in matrilateral terms.

6 Osman 1982: 193, although the term is absent from Khalil 1996. See Donadoni 1969 and Rostkowska 1982 for discussion of the term "mother of the king". 


\section{The family of Moses George (XII)}

We know of at least four Nubian kings from the 12th century: George, David, Moses George and Basil. ${ }^{7}$ We know George from the famous Wadi Natrun inscription, which gives us specific dates for his life, but tells us nothing about his relatives or place in the Nubian royal family (Van Gerven Oei 2011). We know Moses George from multiple sources, including an Old Nubian text from Qasr Ibrim (P.QI 3.30) in which he tells us that his mother's name is Mari (an ein mari) and that he is the nephew of King David (dad ourounalon joutil). A Greek inscription from Faras with elements of Old Nubian tells us further that Moses George is the son of Koudapis (môusês geôrgiou basi u(io)u kould/ apis), and that he is descended (eggonos) from Maranya George, who built the church at Ami; Zachari; and King David, who held the Mari church at Ami. ${ }^{8}$ Another document from Qasr Ibrim tells us that Moses George had a brother named Joel, who was the kingdom's granary-keeper (ïoel tan [i.e. Moses George's] engngal shounga einin) in 1188 (P.QI 3.35).

We know King Basil from several Old Nubian texts from Qasr Ibrim, including two dating to the end of 1199 and 1200 (P.QI 3.37-40). In one of those texts, Basil's ngonnen or queen-mother is named Mari (P.QI 3.37). In another, she is named Iêsousi-kol (P.QI 3.38). An earlier text, from the reign of King Moses George, names the ngonnen as Mari Iêsousi-kol. I have previously suggested that this similarity of names leads to an obvious conclusion: that both men, Moses George and Basil, have the same ngonnen or queen-mother, alternatively called Mari, Iêsousi-kol or Mari Iêsousi-kol (Ruffini 2012: 267).

This could mean several things, most obviously that the two men were brothers (Ruffini 2012: 267 note 9). In this scenario, perhaps they had no sister at all, or that their sister(s) had not yet produced any heir eligible or ready for the throne. Alternatively, Mari retained her position as queen-mother because Basil's mother no longer lived or was otherwise unable to serve. We may also suppose, despite Osman's initial proposal, that the title ngonnen in and of itself tells us nothing about its holder's family ties to the king. If so, Moses George's statement that Mari is an ein ("my mother") is purely coincidental. The dated texts in which Mari is queen-mother span almost half a century, from 1155 to 1199. If it is indeed the same woman in every text, she must have been well into her 60s, if not her 70s, during the reign of King Basil.

For the sequence, see Łajtar 2009: 96. Munro-Hay 1982 is obsolete, but see 115 for remarks on the legitimacy of Moses George. For Basil and Paul of Alwa, see below, p. 550.

8 Łajtar 2009: 91, but see also 97, noting that the reference to the Mari church is grammatically ambiguous and may equally refer to Moses George. 
The diagram shows both certain and speculative relations between these people. We have no information on birth and death dates for these individuals, but we can speculate. George, who was born in 1106, took the throne at the age of 27 . He may have been a member of the same generation as David's parents (marked as "Unknown" in the family tree). ${ }^{9}$ David himself, as predecessor to Moses George, could have been born in the 1120s, if he took the throne at a similar age as George did. If he came to the throne in the same way that Moses George did, he might have been his predecessor's sister's son. This is necessarily speculative.

\section{The Family of Moses George}

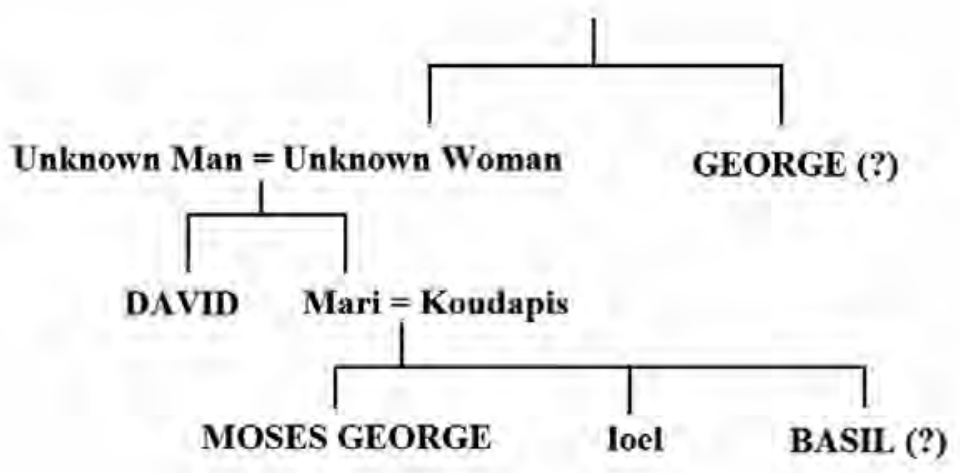

We also note in passing a puzzle posed by Moses George's claim to be descended (eggonos) from a King David. This term may not be literal: it may simply imply succession, rather than biological descent. ${ }^{10}$ However, if it is literal, and if matrilineal succession is the norm, a king's descent from another king implies deviation from that norm at some point, even if in the distant past. Alternatively, members of the royal family may occasionally have married within their own extended family. Koudapis or some other male ancestor of Moses George could himself have been descended from an earlier King David, thus giving Moses George ties to the royal family from both parents. This, too, is speculative.

\footnotetext{
9 See Godlewski 2013b: 675 for George's own mother and his ties to previous generations of the royal family.

10 I thank Grzegorz Ochała for this suggestion.
} 


\section{The family of David (I270s)}

The surviving evidence for the 1200s is considerably more complicated than that for the 1100 s, combining as it does recently published Old Nubian documentary texts with long-known Arab literary texts.

\section{Documentary evidence}

The documentary evidence from Qasr Ibrim includes two legal texts belonging to the reign of a King David. In P.QI 4.67, we read that the name of the current king of Dotawo is Geor<gi>ou Basileos Dād, or George Basil David, and that the ngonnen or queen-mother is Tislma. In P.QI 4.69, we read that the name of the current king is Dād, or simply David, and that the ngonnen is Tislma. The two kings are presumably the same, in one case the document giving a more complete throne-name than appears in the other.

\section{Literary evidence}

The literary evidence for the family of this King David is hard to untangle. ${ }^{11}$ In the following discussion, I put in bold the initial reference to each person I take to be unique and underline the two passages I take to be implicitly contradictory. Three key figures emerge from the muddle: David himself, his cousin Mashkouda (Shekanda et var.), and an uncle to both men named Mintashkil. ${ }^{12}$ Al-Mufaddal, writing about the events of $1275 / 1276$, reports that "This same year... Shekanda [Mashkouda or MSKD], son of the paternal uncle of David (ibn 'amm-Dāwìd), king of Nubia, came to the court of the Sultan to complain about David, son of his uncle" (497). In the ensuing conflict, David escaped "with his mother, his sister and the daughter of his brother. He and his son escaped" (498). Later, "David arrived with his brother and the son of his brother" (499).

Other sources explain the source of the conflict between David and Mashkouda. Ibn al-Furat writes that "The son of the sister of the Nubian king MRTSKR [Mintashkil (Vantini: "tentative reading Murtashkur")]... whom [David] had dispossessed of the kingdom and whose name was

11 See Seignobos forthcoming for the most recent attempt, ultimately tracing all of the Arabic literary sources to reliance on Ibn 'Abd al-Z̄āhir and Ibn Šaddād.

12 For Mashkouda as the indigenous Nubian name behind the various Arabic forms, see below, p. 546. The reading preserved by a copyist of Ibn Khaldun for the name of his uncle, Mintashkil, may be closer to the underlying indigenous original. Compare Mintashkil to the highly uncertain Nubian name Minteuouajar at P.QI 4.66.8. Robin Seignobos (personal communication) dissents, observing that min tashkil may be an Arabic scribal interpolation (meaning, roughly, "with diacritic marks") that tells us nothing at all about the uncle's name. 
MSKD, or, according to others, Sakanda, came (to Cairo) complaining about his cousin" David (531). Ibn Khaldun writes that "the king of the Nubians (Mintashkīl?) came... seeking help... against the son of his brother," David "because this had overpowered him and wrestled the kingdom from his hand" (558). The testimony of el-Qalqashandi repeats this picture, reporting that "there rose to power a man called M.R. Qshankuz... He had a nephew, the son of his brother, by name David, who vanquished him" (572). Vantini, thinking Mintashkil and Shekanda to be the same, took M.R. Qshankuz to be Shekanda. But the two men are distinct, and David's uncle is clearly Mintashkil, not Mashkouda. ${ }^{13}$

One slight inconsistency emerges from these reports. ${ }^{14}$ David is the son of Mintashkil's brother. He is also the son of Mashkouda's uncle. Assuming the absence of brother-sister sibling marriage, Mashkouda cannot therefore be both the son of David's paternal uncle (as al-Mufaddal reports) and the son of the sister of Mintashkil (as Ibn al-Furat reports). The source of the dispute between David and Mashkouda seems to be the fact that David has seized the throne from Mintashkil. In a system of matrilineal succession, as son of the king's brother, David would have no claim to the throne. But as a son of the king's sister, Mashkouda would. It seems easiest then to assume that Ibn al-Furat is correct, and al-Mufaddal is mistaken: Mashkouda is the son of David's maternal uncle, not his paternal uncle.

Maqrizi gives additional information about David's descendants and siblings. He reiterates what we already know, that "during this year [1275/1276], the son of the sister of the king of the Nubians, one by name Meshked, arrived at the court of Egypt, with a complaint against David king of Nubia" (680). During the resulting war, David's brother Shanqü, the king's mother, and the king's sister were all captured (680-681). Refering to events in the 1280s, "one Sa'd ad-din Sa'd, son of the daughter of David, was sent" (685) to Nubia on Egypt's behalf. In Egypt's expeditions against Semamun in the following decade, "the Sultan sent one of the sons of the sister of king David who was at Cairo, to make him king" (687). Refering to events nearly thirty years later, Maqrizi reports that the Sultan "decided to put on the throne Barshanbo the Nubian, who was the son of the sister of David king of the Nūba" (692).

13 Munro-Hay (1982: 118) appears alone among modern authors in not conflating the two men.

14 See also Seignobos forthcoming. I thank Robin Seignobos for sharing a pre-publication draft of this paper, which he presented in Neuchâtel in 2014. His conclusions about the royal family in this period precede and anticipate mine, and are similar to them in broad outline. 
Modern authors have been misled by the confusing array of spellings and vocalizations in these passages, and have typically assumed that Meshked, Mintashkil and all of the similar variants refer to a single man. It followed from this assumption that David, the apparent usurper in this scenario, is "either... his uncle or his cousin" (Łajtar forthcoming). (Maqrizi compounds the confusion by mentioning a "king of the Nubians" and "David king of Nubia" without saying that two people are meant, not one [680].) But as Ibn al-Furat seems to make clear, David is dealing with two different male relatives. Meshked, whom Adam Łajtar has argued is more properly called by the Nubian name Mashkouda (Łajtar forthcoming), is "the son of the sister of the king," David is "the son of his uncle" and at the same time the son of the brother of Mintashkil. David has at least one sister, whose son is named Barshanbo; at least one brother, who is named Shanqu; a niece through that or another brother; a son; and a grandson through his daughter named Sa'd ad-din Sa'd. The resulting family tree follows:

\section{The Family of David}

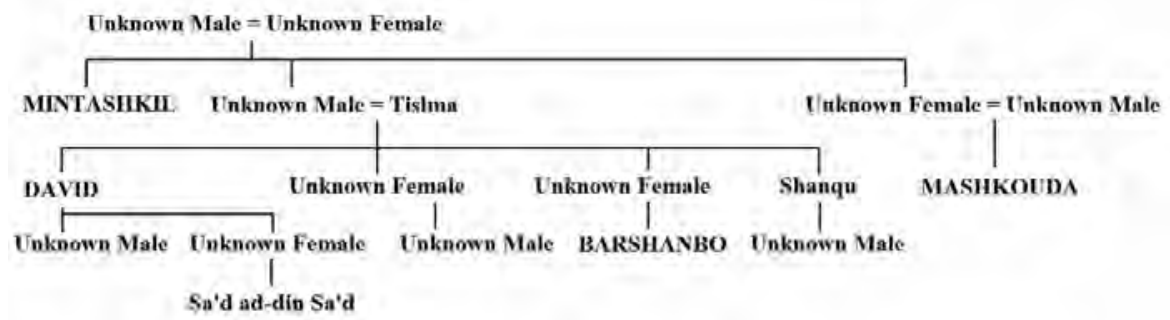

We know as little about the birth dates of these people as we do for the family of King Moses George in the previous century. But the math is revealing. As adults competing for the throne in the 1270s, David and Mashkouda were presumably born in the early 1250s, if not earlier. Indeed, David's grandson Sa'd ad-din Sa'd is an active adult in the 1280s, so David is likely to have been born in the 1240s or earlier. This likely means that the generation of his father and uncles dates to the 1220 s or earlier. The unknown parents at the top of this tree are then children of the 1200s or the 1190s, the time of Kings Basil and Moses George. 


\section{The family of Sumôn (I 28os)}

\section{Documentary evidence}

The documentary evidence from Qasr Ibrim includes three legal texts belonging to the reign of Sumôn. In P.QI 4.64, which dates to 1286, we read that Sumôn is the king of Dotawo, Ashilla the ngonnen or queen mother. In P.QI 4.65, we read that Georgiou Sumôn is the king of Dotawo, Ashilla the ngonnen or queen mother. In P.QI 4.70, we read that the king's name, while fragmentarily preserved, includes the component Simamôn, Ashila being the ngonnen or queen mother. Again, we assume that all three names refer to the same man, different scribes recording more or less full forms of the royal nomenclature.

\section{The Family of Sumôn}

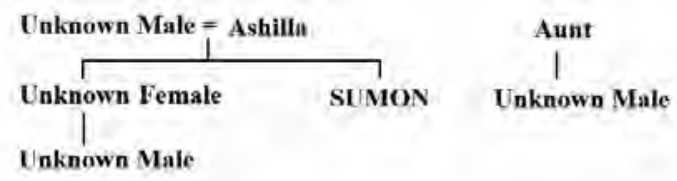

\section{Literary evidence}

Maqrizi reports the outcome of Egypt's war in 1285/1286 against the Nubian King Samāmūn, presumably the same man. The king is defeated and the Egyptian army "also seized the son of the king's aunt (ibn khālat al-malik)" (684-685). Then the emir "Izzaddin "established the son of the sister of the king in the kingdom of Nubia" and "appointed Jorais as his vicar" (685). Since we do not know whether the king's aunt is on the maternal or paternal side, we are unable to place her more precisely on this family tree.

We note in passing that the sources tell us nothing about the origin of Sumôn's rule or the nature of his claim to legitimacy. Nothing precludes a connection to David's family (see the relevant diagram above). As an adult in the 1280s, he could belong to David's generation or that of his children. He could be an unknown brother of David, or some other relative. If we assume he came to the throne through matrilineal succession, his ngonnen Ashilla could be David's sister, or the sister of one of his other male relatives, Mashkouda or Mintashkil. The possibilities are almost limitless. 


\section{The family of Kerenbes (I 3 IOS AND I 320 )}

While a Nubian king named Ayay makes a brief appearance in the sources for the early 1300s, Kerenbes, who reigned in the 1310s and 1320s, is the next Nubian king to receive extended attention in the sources. Maqrizi tells us most of what we know about him. ${ }^{15} \mathrm{He}$ writes that in 1311 , Kerenbes arrived in Cairo "bringing the fine (gawad) imposed on him, after the killing of his brother" (691). Five years later, the Sultan "decided to put on the throne Barshanbo... the son of the sister of David" (692):

When Kerenbes, king of the Nüba, was informed of this, he sent the son of his sister, Kanz ad-Dawla son of Shujäaddin Nașr (...) b. Fakhreddin Malik b. al-Kanz to enquire from the Sultan about the matter. The Sultan put Kanz ad-Dawla in jail. The army arrived at Dongola, but Kerenbes, together with his brother Abräm, fled. (692)

The obscurity of the political situation aside, the genealogical details are relatively clear, providing the picture we see in the diagram below.

\section{The Family of Kerenbes}

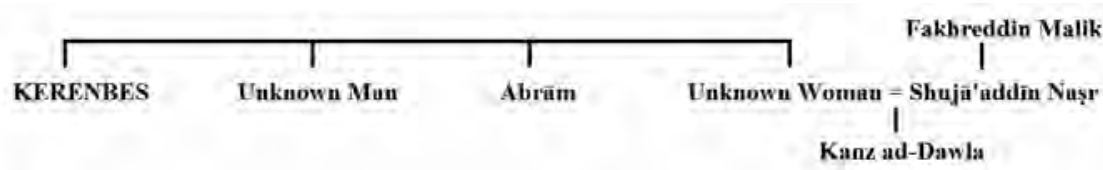

We do not know why Kerenbes should have killed his brother, but it seems a likely bet that he did so either because his brother had a better claim to the throne than he did, or because he already held it, and Kerenbes wanted to remove him. For both men to have had claims to the throne, they may both have been nephews — that is, sister's sons — of the previous king. Was Ayay, the only king we know from the previous decade, their uncle? Or was Ayay himself perhaps Kerenbes's unnamed brother? Either way, men old enough to contest the throne

15 Kerenbes also appears in the Greek Aswan inscription recorded in Griffith 1928: 134-145 as "King Kouda[npes], a king worthy of three hundred years" (rix Kouda[npes] etê triakosia basileus axios). 
as adults in the 1310s may belong to the generation of David's children or grandchildren or to the generation of Sumon's nephew (see the respective family trees above).

We should also note once again the evidence we mentioned earlier regarding the family of David: Egypt sends two of David's sister's sons against ruling Nubian kings, and David himself begins his reign with the overthrow of another ruling Nubian king. This is a curious pattern, and makes us wonder whether David and his immediate family represent an opposition faction within Nubia's larger ruling dynasty. However, given the case of Kerenbes itself, it seems just as likely that this sort of internal strife was simply endemic to the Nubian ruling family.

\section{Conclusion}

I end with two final points. The first point: the Arab historians and geographers give the impression of constant turmoil among the ruling elite of Nubia in the 13th and 14th centuries $\mathrm{AD}$, but this may create an illusion. ${ }^{16}$ The evidence they provide is lacunose, sometimes skipping half a century at a time. We have no way of knowing whether the isolated glimpses they give us reveal a single Nubian dynasty or several. The impression we have from David's family struggles in the 1270s is that of an extended family at war with itself, not that of one royal family competing against multiple others. Indeed, nothing in our evidence prevents us from supposing that all four groups belong to the same dynasty. Equally, nothing in our evidence supports such an idea. We can only observe that so many of the contests for the throne were between blood relatives. Explicit outsiders did not claim the throne. Dynastic succession of some kind was the norm. No other principle of legitimacy presents itself. (The possibility that a governing council may have guided succession, as Jay Spaulding has proposed, is not inconsistent with this observation, Spaulding 2004: 416).

16 Grzegorz Ochała suggests (personal communication) that this impression is really the consequence of a literary topos in Arabic historiography, perhaps a consequence of political justifications for Egyptian intervention in Nubian affairs. This is plausible. But it seems likely, nonetheless, that such a topos - in order to be believable to readers - had some grounding in the reality of Nubian politics. Kronenberg and Kronenberg (1965: 260) argue that this ongoing turmoil "is not a sign of instability in the Nubians, but rather of their respect for cultural values," namely, values privileging preferential matrilateral parallel cousin marriage. 
The second point: we know that in the late 1100s, King Moses George, when writing in Old Nubian, styled himself King of Dotawo, while, when writing in Greek, he claimed to be king of both Makuria and Alwa. ${ }^{17}$ We have, to my knowledge, no particularly strong evidence suggesting that anyone in Alwa disagreed with him. (His predecessor King George may be making the same claim a different way when his memorial describes him as sitting on "the throne of the two dominions" [koan trigouna thronosildo], Van Gerven Oei 2011: 253255). No kings of Alwa are attested with certainty after a David who reigned probably in the 9th/10th century (see I.Khartoum Greek 79). Two kings named Basil and Paul have crept into the scholarly literature as doubtful 12th-century kings of Alwa (Welsby 2002: 261). They appear to owe their existence only to an unpublished Arabic Fatimid-era letter to the eparch of Nobadia translated by Elizabeth Sartain (Adams 2010: 252). Little justifies the inference that they were kings only of Alwa. Indeed, the letter explicitly describes one of the kings as present in Dongola. They may have been kings of Alwa in the same way that Moses George was, not as a separate kingdom, but as part of Dotawo.

Noting, as I have above, that the Arab historians create an impression of constant turmoil in Nubia, while omitting large periods of Nubia's internal history, I wonder about the implications. Does it perhaps follow that the periods of silence in the Arab historians are periods of internal stability in Nubian history? And does it then follow that we may assume that in those periods Nubia enjoyed stable dynastic succession without any serious challenges from either inside or outside of the ruling family? We cannot be sure, but the proposal is at least plausible, if not necessarily certain.

What follows from all of this is not a conclusion, but a hypothesis to be tested against future evidence and either accepted or rejected. That hypothesis might run something like this: following Godlewski, we trace the kingdom of Dotawo from the unification of Makuria and Alwa in the 11th century; for the next four hundred years, we see no other principle of legitimacy than dynastic succession; we see no positive indication of the successful transfer of power from one family group to another; contra Godlewski, we see no particular sign that Nubia's occasional dynastic troubles directly concern the union of Makuria and Alwa; and we therefore propose that the families of Moses George, David, Sumôn and Kerenbes are representatives of a single extended family ruling over both Makuria and Alwa as a single dynasty.

17 See both P.QI 4.113, for which the address on the verso is in Greek, and the unpublished Coptic letter with Greek subscript addressed to the Patriarch of Alexandria and given in translation in Adams 1996: 228-229. 


\section{ACKNOWLEDgments}

I thank Grzegorz Ochała, Robin Seignobos and Alexandros Tsakos for their comments on an earlier draft of this paper.

\section{References}

\section{Abbreviations \\ I.Khartoum Greek Łajtar, A. (2003). Catalogue of the Greek inscriptions in the Sudan National Museum at Khartoum (I. Khartoum Greek) [=Orientalia Lovaniensia Analecta 122]. Leuven: Peeters \\ P.QI 2 \\ P.QI3 \\ P.QI 4 \\ Browne, G.M. (1989). Old Nubian texts from Qasr Ibrim II [=Texts from Excavations 10]. London: Egypt Exploration Society Browne, G.M. (1991). Old Nubian texts from Qasr Ibrim III [=Texts from Excavations 12]. London: Egypt Exploration Society Ruffini, G. (2014). The bishop, the eparch and the king: Old Nubian texts from Qasr Ibrim IV (P. QI IV) [=Journal of Juristic Papyrology Supplement 22]. Warsaw: Raphael Taubenschlag Foundation}

Adams, W.Y. (1996). Qașr Ibrîm: The late medieval period [=Excavation Memoir 59]. London: Egypt Exploration Society

Adams, W.Y. (2010). Qasr Ibrim: The earlier medieval period [=Excavation Memoir 89]. London: Egypt Exploration Society

Donadoni, S. (1969). Mētēr Basileōs. Studi Classici e Orientali, 18, 123-125

Godlewski, W. (2002). Introduction to the Golden Age of Makuria (9th-11th century). Africana Bulletin, 50, 75-98

Godlewski, W. (2004). The rise of Makuria (late 5th-8th cent.). In T. Kendall (ed.), Nubian studies, 1998: Proceedings of the ninth conference of the International Society of Nubian Studies, August 21-26, 1998, Boston, Massachusetts (pp. 52-73). Boston: Department of African-American Studies, Northeastern University

Godlewski, W. (2008). Bishops and kings. The official program of the Pachoras (Faras) Cathedrals. In W. Godlewski and A. Łajtar (eds), Between the cataracts: Proceedings of the 11th Conference for Nubian studies, Warsaw University, 27 August - 2 September 2006, I. Main papers [=PAM Supplement Series 2/1] (pp. 263-282). Warsaw: Warsaw University Press

Godlewski, W. (2013a). A short essay on the history of Nobadia from Roman to Mamluk times. In J. van der Vliet and J.L. Hagen (eds), Qasr Ibrim, between Egypt and Africa: Studies in cultural exchange (Nino Symposium, Leiden, 11-12 December 2009) [=Egyptologische uitgaven 26] (pp. 123-133). Leiden: Nederlands Instituut voor het Nabije Oosten 
Godlewski, W. (2013b). Archbishop Georgios of Dongola. Socio-political change in the kingdom of Makuria in the second half of the 11 th century. Polish Archaeology in the Mediterranean, 22, 663-677

Griffith, F.L. (1928). Christian documents from Nubia. Proceedings of the British Academy, 14, 117-146

Khalil, M. (1996). Wörterbuch der nubischen Sprache: (Fadidja/Mahas-Dialekt). Warsaw: Piotr O. Scholz

Kronenberg, A. and Kronenberg, W. (1965). Parallel cousin marriage in medieval and modern Nubia. Kush, 13, 241-260

Munro-Hay, S.C. (1982). Kings and kingdoms of ancient Nubia. Rassegna di Studi Etiopici, 29, 87-137

Łajtar, A. (2009). Varia Nubica XII-XIX. Journal of Juristic Papyrology, 39, 83-119

Łajtar, A. (forthcoming). A high-ranking visit to the commemorative complex in the northwestern annex to the monastery on Kom $\mathrm{H}$ at Dongola

Osman, A. (1982). The post-medieval Kingdom of Kokka: A means for a better understanding of the administration of the medieval Kingdom of Dongola. In J.M. Plumley (ed.), Nubian studies: Proceedings of the Symposium for Nubian Studies, Selwyn College, Cambridge, 1978 (pp. 185-197). Warminster: Aris \& Phillips

Rostkowska, B. (1982). The title and office of the King's Mother in Christian Nubia. Africana Bulletin, 31, 75-78

Ruffini, G. (2012). Medieval Nubia: A social and economic history. Oxford: Oxford University Press

Ruffini, G. (2013). Newer light on the Kingdom of Dotawo. In J. van der Vliet and J.L. Hagen (eds), Qasr Ibrim, between Egypt and Africa: Studies in cultural exchange (Nino Symposium, Leiden, 11-12 December 2009) [=Egyptologische uitgaven 26] (pp. 179-191). Leiden: Nederlands Instituut voor het Nabije Oosten

Seignobos, R. (forthcoming). Rereading the Oriental sources: Mamluk sources and the history of late Medieval Nubia. In M. Honegger (ed.), Proceedings of the 13th International Conference for Nubian Studies - Neuchâtel 2014

Spaulding, J. (2004). Medieval Nubian dynastic succession. In T. Kendall (ed.), Nubian studies, 1998: Proceedings of the ninth conference of the International Society of Nubian Studies, August 21-26, 1998, Boston, Massachusetts (pp. 413-418). Boston: Department of African-American Studies, Northeastern University

Van Gerven Oei, V.W.J. (2011). The Old Nubian memorial for King George. In A. Łajtar and J. van der Vliet (eds), Nubian voices: Studies in Christian Nubian culture [=Journal of Juristic Papyrology Supplement 15] (pp. 225-262). Warsaw: Raphael Taubenschlag Foundation

Vantini, G. (1975). Oriental sources concerning Nubia. Heidelberg: Heidelberger Akademie der Wissenschaften

Welsby, D.A. (2002). The medieval kingdoms of Nubia: Pagans, Christians and Muslims along the Middle Nile. London: British Museum Press 


\title{
La liste des conquêtes nubiennes de Baybars selon Ibn Šaddād (1217-1285)*
}

\author{
Robin Seignobos \\ robin.seignobos@orange.fr
}

\begin{abstract}
KeYwords
Egyptian-Nubian relations, toponymy, settlement history, Mamluk historiography
\end{abstract}

\begin{abstract}
Until recently, the list of Nubian towns and territories allegedly conquered by the Mamluks during Baybars's reign (1260-1277) was known only through late or corrupt versions such as the one preserved in the chronicle of al-Mufaḍual b. Abī Faḍāil (completed before 1358). Recent research by the author in the corpus of Mamluk annals and chronicles allowed the original source to be identified as Ibn Šaddād's biography of Baybars completed shortly after the sultan's death in 1277 . The present contribution provides a critical edition of this text based on the unique manuscript of this work (Edirne, Selimiye kütüphanesi, 2306) followed by a detailed commentary, which aims at identifying or locating the many place names mentioned in it. The list may also offer new insights into the settlement history of the kingdom of Makuria in the late medieval period.
\end{abstract}

Le règne du sultan mamelouk Baybars (1260-1277) a indubitablement marqué un tournant majeur dans l'histoire des relations entre les pays d'islam et le

* C'est pour moi un grand honneur d'offrir ces quelques pages au Professeur Godlewski dont les travaux ont accompagné mon initiation aux études nubiennes et demeurent aujourd'hui encore une source d'inspiration. Le choix de ce sujet n'est pas tout à fait fortuit puisque le Professeur Godlewski a souligné, à différentes occasions, l'importance de cette liste pour l'histoire du peuplement nubien durant la période chrétienne tardive. Une version préliminaire de ce travail a été présentée lors d'un séminaire organisé par Alexandros Tsakos qui s'est tenu le 26 juin 2014 à l'université de Bergen, dans le cadre du programme d'échange franconorvégien Aurora entre l'université de Bergen et l'Institut des mondes Africains (Paris). Je remercie ce dernier ainsi que Jean-Charles Ducène pour leurs relectures et suggestions de même qu'Adam Łajtar, qui a eu en outre l'obligeance de me communiquer plusieurs de ses articles avant leur publication. 
royaume chrétien de Makouria. C'est en effet sous ce souverain que prend fin la période de paix relative qui régnait entre la Nubie et l'Égypte depuis les premières tentatives de conquêtes musulmanes du VII ${ }^{\mathrm{e}}$ siècle. Même si l'incursion de Šams al-Dawla Tūrānšāh et la prise de la citadelle d'Ibrīm en 1173 avaient déjà annoncé la fin de cette longue trêve, ce n'est qu'à partir du règne de Baybars que les autorités musulmanes commencent à envisager sérieusement d'annexer le territoire nubien.

Entre 1272 et 1276, au moins deux expéditions majeures ont été lancées contre David (Dāwūd), roi de Makouria dont les agissements menaçaient directement - aux dires des chroniqueurs mamelouks — le territoire et les intérêts égyptiens. En 1272, une première expédition punitive, menée par le gouverneur de Qūṣ, 'Alā al-Dīn, fut envoyée en Nubie en représailles au sac de 'Ayd̄āb par David mais celle-ci n'a sans doute guère dépassé la deuxième cataracte. Quelques années plus tard, en réponse au pillage de la ville frontalière d'Assouan par le même roi David', une seconde expédition, de plus grande envergure, est mise sur pied en 1276. Deux émirs de haut-rang, Šams al-Dīn Aqsunqur al- Fariqānī et 'Izz al-Dīn Aybak al-Afram sont désignés pour en prendre la tête. Ils sont accompagnés par un cousin de David et prétendant au trône dont le nom apparaît dans les sources arabes sous des graphies diverses (Š.k.ndā, M.š.k.d. etc. $)^{2}$. Les deux émirs atteignent finalement Dongola et livrent bataille contre les troupes de David. Le souverain, défait, prend la fuite et se réfugie auprès du roi d'al-Abwāb qui finira néanmoins par le livrer aux autorités mameloukes. Entre temps, son cousin est couronné dans la capitale makourienne et prête serment de fidélité au sultan. Des conditions particulièrement dures sont alors imposées au nouveau roi et à ses sujets, incluant le paiement d'un tribut annuel, l'imposition de la ğizya (capitation) sans oublier l'annexion à l'Égypte des territoires compris entre la première et la deuxième cataracte. Même si ces conditions n'ont peut-être jamais été appliquées dans leur intégralité — sinon pour une période limitée — les sultans mamelouks ne cesseront plus dès lors d'intervenir dans les affaires politiques nubiennes et tenteront régulièrement de soutenir voire d'imposer des prétendants au trône qui leur soient favorables.

1 Monneret de Villard avait émis l'hypothèse que le roi David responsable de l'attaque de Aydab était distinct de celui qui avait attaqué Assouan (Monneret de Villard 1938: 212-213) mais nous sommes enclins à penser qu'il s'agit d'un seul et même souverain (voir Seignobos à paraître).

2 De toute évidence, ces noms constituent autant de tentatives de transcription du nom nubien Mashkouda (мда)коү $\Delta$ ) porté par un roi mentionné dans une inscription d'Old Dongola récemment publiée par A. Łajtar (Łajtar à paraître). 
L'objet de cette contribution n'est pas de revenir sur ces évènements, que nous avons eu l'occasion de traiter en détail ailleurs (Seignobos à paraître), mais plutôt de prolonger ces investigations en nous penchant de plus près sur un texte, déjà bien connu, énumérant les villes et territoires nubiens que le sultan Baybars aurait conquis lors de ces campagnes. Celui-ci fut porté à la connaissance du monde savant dès 1920 avec la publication de la chronique de l'auteur copte al-Mufaḍdal b. Abī al-Faḍāil, achevée en 1358 (al-Mufaḍạal 1920: 445-446). Griffith fut le premier à tirer parti de ce texte (Griffith 1927: 102-103), suivi quelques années plus tard par Monneret de Villard (Monneret de Villard 1938: 138) qui déplorait néanmoins le caractère défectueux du manuscrit unique transmettant la chronique d'al-Mufaḍdal (Paris, BnF, arabe 4525). Il est toutefois regrettable que les identifications souvent pertinentes proposées par Griffith n'aient pas toujours été reprises par le second et soient passées relativement inaperçues par la suite. Il en est de même, plus près de nous, des conjectures avancées par K.H. Priese dans un article portant essentiellement sur la toponymie antique mais tenant compte de ses prolongements dans la période médiévale (Priese 1984). Quelques années auparavant, en 1975, la publication du recueil de sources orientales du Père Vantini avait permis de faire connaître deux autres versions, plus tardives, de cette même liste : celle d'Ibn alFurāt (1334-1405) — à certains égards plus fiable que celle d'al-Mufaḍdal — et celle d'Ibn Tagrīi Birdī (1409-1470), dans laquelle seulement trois noms ont été conservés.

Nos récentes investigations dans les sources historiographiques d'époque mamelouke, nous ont permis d'identifier quatre autres témoins de ce texte qui avaient jusqu'à présent échappé à la vigilance des spécialistes, portant ainsi leur nombre à sept. Ils sont énumérés ci-après, par ordre chronologique :

- Ibn Šaddād (1217-1285), Tārīh al-malik al-Ẓāhir / Al-Raw ḍ al-zāhir fì sìrat al-Malik al-Zāhir,

- al-Yūnīnī (1242-1326), Dayl mir'āt al-zamān (al-Yūnīnī 1960: 256),

- Ibn al-Dawādārī (fl. 1309-1339), Kanz al-durar wa-ğāmi al-ġurar (Ibn al-Dawādārī 1971: 213-214),

- al-Mufaḍdal (fl. av. 1358), Nahğ al-sadīd wa-l-durr al-farīd (al-Mufaḍ̣al 1920: 445-446; Vantini 1975: 501-502),

- Ibn al-Furāt (1334-1405), Tārīh al-duwal wa-l-mulūk (Ibn al-Furāt 1939: 83 ; Vantini 1975: 538-539),

- Ibn Tag̀rī Birdī (1409-1470), Al-Nuğūm al-ẓāhira fī mulūk Miṣr wa-lQāhira (Ibn Tag̀rī Birdī 1992: 167 ; Vantini 1975: 737),

- Ibn Sibāt/Ibn Asbāṭ (m. 1520), Sidq al-ahbār / Tārīh Ibn Sibāṭ (Ibn Sibāt 1993: 448-449). 
Parmi ces témoins passés inaperçus figure la source originale dont dérivent manifestement toutes les autres versions connues du texte. Il s'agit de la biographie de Baybars composée, peu après la mort de ce dernier, par un proche du sultan connu sous le nom de 'Izz al-Dīn Ibn Šaddād (1217$1285)^{3}$. Originaire d'Alep où il exerce l'activité de secrétaire de chancellerie sous le règne du sultan ayyoubide al-Malik al-Nāṣir Yūsuf (1236-1260), Ibn Šaddād fuit l'arrivée des Mongols en 1261 et se réfugie au Caire où il jouit des faveurs de Baybars et de son successeur Qalāwūn (Sourdel 1990; Koch 1983). Proche du vizir Bahā’ al-Dīn, Ibn Šaddād bénéficiait certainement d'un accès direct aux informations liées aux affaires de l'État. Sa biographie, qu'il achève sans doute entre 1277 et 1279 (Holt 1982: 24), constitue donc une source de premier plan, œuvre d'un témoin privilégié du règne de Baybars. À cet égard, l'ouvrage d'Ibn Šaddād ne peut guère rivaliser qu'avec la biographie " officielle " composée, peu de temps auparavant, par son contemporain Ibn 'Abd al-Zāhir sous le titre Al-Rawd al-zāhir fī sìrat al-Malik $a l-Z a \bar{a} h i r^{4}$. Une très large part de ce que l'on sait du règne de Baybars se fonde en dernier lieu sur ces deux biographies dans lesquelles les chroniqueurs postérieurs ne se priveront d'ailleurs pas de puiser. Si Ibn Šaddād a peutêtre eu recours à la biographie de son prédécesseur (Holt 1982: 24), son ouvrage n'en constitue pas moins un témoignage indépendant et original qui permet dans bien des cas de compléter ou de nuancer les propos d'Ibn 'Abd al-Ẓāhir, comme nous avons déjà eu l'occasion de le montrer au sujet des affaires nubiennes (voir Seignobos à paraître).

L'ouvrage d'Ibn Šaddād nous est parvenu sous la forme d'un manuscrit unique, conservé à Edirne en Turquie (Selimiye kütüphanesi, 2306)5, mais qui ne contient toutefois que le second volume, consacré aux dernières années du règne de Baybars (1271-1277). En dépit de son indéniable intérêt historique, l'ouvrage ne fut longtemps disponible qu'à travers une traduction turque publiée en 1941 et il faudra attendre 1983 pour voir paraitre une édition en bonne et due forme réalisée par Ahmad Hutait. En raison de cette publication

3 À ne pas confondre avec son homonyme, Bahā' al-Dīn Ibn Šaddād, auteur d'une biographie de Saladin.

$4 \quad$ Il semble que ce titre ait été repris par Ibn Šaddād pour sa propre biographie puisque plusieurs auteurs postérieurs citent son ouvrage sous le même intitulé (Holt 1982: 24 ; Koch 1983: 249). Néanmoins, Ahmad Hutait a préféré reprendre pour son édition le titre " court " figurant dans le manuscrit d'Edirne à savoir Tärīh al-Malik al-Zāhhir.

5 Il existe un certain flottement concernant la côte du ms. puisque celle-ci apparaît sous le numéro 2306 dans le microfilm consulté et l'édition d'Ahmad Hutait tandis que Koch lui attribue la côte 1557. Le manuscrit est réputé autographe (Ibn Šaddād 1983: 18) mais cela reste encore à démontrer. 
tardive, la biographie d'Ibn Šaddād n'a pu être intégrée au corpus de Vantini, paru en 1975, et elle est donc restée largement ignorée des spécialistes de la Nubie. Même si son contenu était déjà en grande partie connu à travers les citations incluses dans les chroniques postérieures, il n'est pas rare que le texte en ait été abrégé, tronqué ou corrompu. Son intérêt ne tient donc pas seulement à sa relative ancienneté mais aussi à son contenu même, susceptible de fournir des informations précieuses que les auteurs plus tardifs n'auront pas préservées (voir Seignobos à paraître). Cela vaut tout particulièrement pour le texte qui nous occupe ici, composé d'une suite de noms géographiques étrangers, particulièrement sujets aux déformations induites par les copies successives.

La liste des conquêtes nubiennes figure chez Ibn Šaddād dans une section formée d'une série de chapitres visant à exalter les qualités de souverain de Baybars. Le onzième de ces chapitres est consacré à ses exploits militaires et consiste essentiellement en un catalogue des territoires conquis par le sultan au cours de son règne. Après un préambule quelque peu convenu louant le rôle joué par le souverain mamelouk dans l'expansion du domaine de l'Islam, le texte se divise en trois sous-chapitres énumèrant successivement les territoires enlevés aux Francs, aux princes musulmans (ayyoubides et ismaéliens) et enfin aux Mongols. Étrangement, c'est dans ce dernier que les territoires conquis en Nubie sont énumérés.

Tout indique qu'Ibn Šaddād est bien le compilateur original de cette liste puisque celle-ci ne se trouve pas chez Ibn 'Abd al-Ẓāhir, seul auteur antérieur auquel elle aurait pu être empruntée. Se pose alors la question délicate des sources utilisées par Ibn Šaddād. On sait que celui-ci avait accès à des documents de chancellerie susceptibles de renfermer des informations pertinentes sur la progression des opérations militaires en Nubie. Le récit qu'il livre de l'expédition nubienne de 1272 se fonde, par exemple, sur une lettre du gouverneur de Qūṣ dans laquelle sont énumérées les villes et places fortes nubiennes prises au cours de l'assaut ${ }^{6}$. Par ailleurs, la position privilégiée de l'auteur à la cour de Baybars lui permettait sans doute de s'entretenir avec les généraux et officiers militaires de retour de campagne ainsi qu'avec les agents de l'État chargés d'administrer et d'exploiter les territoires nouvellement conquis. On ne peut enfin exclure que des renseignements aient été pris directement auprès des prisonniers "politiques " nubiens capturés lors de la campagne de 1276 et détenus à la Citadelle du Caire, prisonniers parmi lesquels se trouvaient le roi David lui-même, son frère et plusieurs autres membres de sa famille.

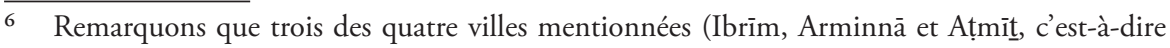
Tamit) figurent aussi dans notre liste. 
Le texte se divise explicitement en deux parties. Une première série de onze toponymes se rapporte aux territoires situés immédiatement en amont d'Assouan tandis que la seconde, comportant douze à treize noms, décrit les régions qui s'étendent plus au sud, regroupées sous la dénomination d'al'Alī ou al-'Ulā. Au sein même de ces deux subdivisions, l'énumération suit encore une logique topographique puisque celle-ci remonte normalement le cours du Nil, fait qui s'est d'ailleurs révélé d'une aide précieuse dans le travail d'identification. La plupart des entrées de notre liste prennent la forme d'un simple toponyme mais le compilateur a parfois ressenti le besoin d'ajouter quelques indications supplémentaires sur la situation ou la désignation du lieu. Notons enfin l'emploi récurrent du terme iqlìm (région, province) qui indique que certains des noms cités se rapportent plutôt à des régions ou aux chef-lieux des dites régions.

La collation des différentes versions de la liste a révélé que le texte d'Ibn Šaddād, tel qu'il nous est parvenu à travers le manuscrit d'Edirne, est celui qui offre les meilleures leçons permettant ainsi d'identifier certains toponymes devenus méconnaissables chez les auteurs postérieurs. Cette comparaison apporte également la confirmation que toutes les autres versions dérivent bien, en dernier lieu, d'Ibn Šaddād. Il semblerait qu’al-Yūnīnī comme Ibn alDawādāri y aient eu accès à travers la chronique de l'historien syrien al-Ğazarī (1260-1338), qui n’a malheureusement pas été conservée pour les années correspondant au règne de Baybars ${ }^{7}$. Le premier a néanmoins choisi d'omettre une grande partie des toponymes nubiens tandis que la formulation du second présente quelques menues différences par rapport au texte d'Ibn Šaddād sans que l'on sache si celles-ci ont été introduites par Ibn al-Dawādārī lui-même ou par l'une de ses sources ${ }^{8}$. Le texte d'al-Mufaḍalal reproduit d'ailleurs mot pour mot celui d'Ibn al-Dawādārī mais on ne peut déterminer avec certitude si le premier a copié le second ou si ces similitudes s'expliquent par le recours à une source commune (Northrup 1998: 49). Ibn al-Furāt, pour sa part, tient probablement cette liste du Nuzhat al-anām d'Ibn Duqmāq (1349-1407)

7 On dispose en revanche d'un recueil d'extraits compilés par al-Dahabī al-Ğazarī (1274-1348) pour les années 593-699. La liste des conquêtes de Baybars n'y figure pas mais on sait par ailleurs qu'al-Yūnīnī a échangé des informations avec son contemporain al-Ǧazarī et qu'il a recopié de larges portions de l'oeuvre de ce dernier (Northrup 1988: 43-44). Quant à Ibn al-Dawādārī, il semblerait qu'il ait eu accès au contenu des annales d'al-Ǧazarī par une (voire deux) sources intermédiaires (Northrup 1988: 48).

8 Alors qu’Ibn Šaddād introduit la liste par la formule : «Dieu a conquis par son intermédiaire [Baybars] le pays des Nubiens qui comprend les localités suivantes ... ", Ibn al-Dawādārī écrit simplement : «Et parmi les localités des Nubiens, déjà mentionnées plus haut : ... ». Al-Mufaụḍal reprend cette formule en omettant « déjà mentionnés plus haut ». 
qu'il cite à plusieurs reprises dans son récit des affaires nubiennes de l'année 1276. Quant à Ibn Tag̀rī Birdī et Ibn Sibāț, tous deux paraissent dépendre, directement ou indirectement, de la version d'al-Yūnīnī puisque les mêmes toponymes y sont omis, Ibn Tag̉rī Birdī en omettant même quelques-uns de plus.

Bien que l'édition d'A. Hutait soit généralement considérée comme fiable, les difficultés inhérentes à l'identification de toponymes étrangers transcrits en arabe rendent nécessaires le recours au manuscrit (Selimiye kütüphanesi, 2306, f. 229r-229v). Nous avons donc utilisé le microfilm du ms. d'Edirne conservé à la Section arabe de l'Institut de recherche et d'histoire des textes (IRHT, Paris), sous les numéros 12678 et $12679^{\circ}$. Lapparat critique indique les leçons rejetées (précédées de "ms. : )) ainsi que les variantes provenant des versions plus tardives du texte, lorsqu'il y a lieu (les toponymes omis par ces dernières ne sont pas signalés) ${ }^{10}$. À la différence de Hutait, nous avons préféré ne pas tenir compte des voyelles même si nous les évoquons parfois dans les commentaires. Dans la traduction et les commentaires, les mots précédés d'un astérisque signalent les formes corrigées ou reconstituées.

\section{Texte}

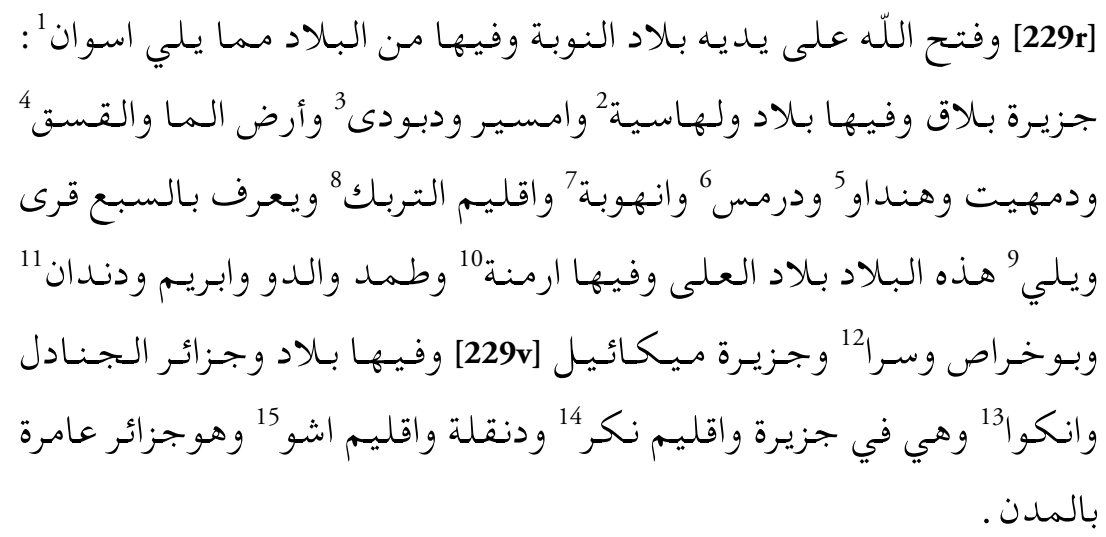

9 Qu'il nous soit d'ailleurs permis de remercier ici le personnel administratif et scientifique de la section arabe de l'IRHT pour son accueil aussi chaleureux qu'efficace.

$10 Y=$ al-Yūnīnī, Dayl mir' āt al-zamān; $D=$ Ibn al-Dawādārī, Kanz al-durar; $M=$ al-Mufaḍ̣al, Nahğ al-sadìd ; F = Ibn al-Furāt, Târìh al-duwal ; S = Ibn Sibāt, Sidq al-ahbār / Tārīh Ibn Sibät. 


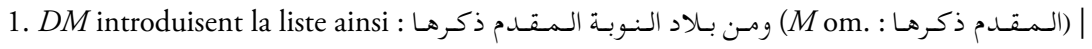

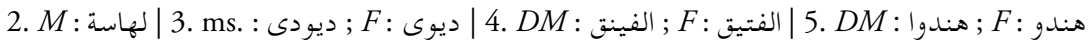

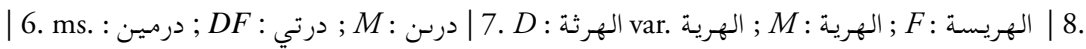

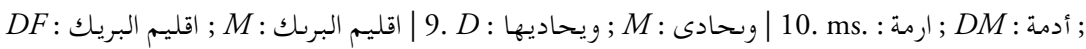

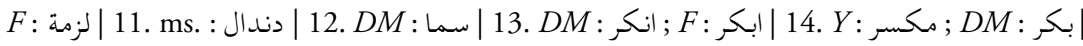

15. F : أشواء :

\section{Traduction}

Dieu a conquis par son intermédiaire ${ }^{11}$ [Baybars] le pays des Nubiens qui comprend les localités (bilād) suivantes, parmi celles qui avoisinent Assouan : l'île de Bilāq, où se trouvent des villages (bilād), L.hāsya, Amsìr, *Dabūdī, le territoire (arḍ) d'Al.mā, alQ.s.q, Dambìt, Hindāw, *Darm.s, An.hüba, la région (iqlīm) d'al-Tarbak, connue sous le nom des "sept villages" (al-sab'a qurā).

Ces localités (bilād) confinent au pays d'al-'Alì dans lequel se trouvent: *Arminna, Tamid, al-Daw, Ibrìm, *Dindān, Būharās, Sarra, l'île de Mìkàìl, où se trouvent des villages (bilād), les îles de la cataracte, Ankwā, qui se trouve sur une ile, la région (iqlīm) de N.k.r, Dunqula, et la région (iqlīm) d'Ušü qui est formée d'îles habitées pourvues de villes (mudun) ${ }^{12}$.

\section{Commentaires}

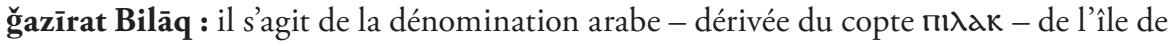
Philae, située au sud de la première cataracte. Le fait que Philae soit ici traitée comme une partie du territoire nubien et non égyptien est remarquable mais tient sans doute au statut ambigu de l'île dans le dispositif frontalier égypto-nubien (voir Seignobos 2010: 35-47 ; à paraître).

L.hāsya (lire *al-Haysa ?) : Vantini rapprochait ce nom de celui d'Ellessiya, situé non loin de Derr et Amada (Vantini 1975: 502), mais cette localisation n'est pas compatible avec l'ordre géographique selon lequel la liste est arrangée. Nous avons préféré suivre ici l'avis de Priese qui avait proposé de reconnaitre derrière cette dénomination la grande île d'elHessa située au débouché de la première cataracte, au sud de Philae (Priese 1984: 485). Celui-ci proposait même de corriger la forme L.hāsya en *al-Haysa, conjecture ingénieuse

11 Ar. : " 'alā yadayhi », litt. "par ses mains ».

12 Suit un bref rappel des conditions imposées au souverain nubien à l'issue de la grande expédition de 1276 : «Lorsqu'il les eut conquis [ces territoires] il les confia au cousin paternel (ibn 'amm) de celui [le roi] auquel ils avaient été enlevés; puis ils les partagea en deux moitiés et imposa sur la seconde moitié [un tribut] en esclaves des deux sexes, chameaux et bovins ainsi que [le versement] d'un dinar par adulte ; cela lui sera remis chaque année " (Ibn Šaddād 1983: 323). 
mais que nous n'avons pas retenue faute de parallèles dans les sources médiévales. Les traces d'un temple converti en église et la présence d'un important cimetière chrétien indiquent une occupation chrétienne substantielle mais difficile à dater (Monneret de Villard 1935/I: 16-17)

Amsīr (lire *Ibšīr, *Abšīr, *Ubšīr ?) : ce nom, qui pourrait être vocalisé de diverses manières, a été omis dans toutes les sources tardives et figure seulement dans le texte original d'Ibn Šaddād. Étant donné son emplacement dans la liste il s'agit probablement du village d'Ibshir que le voyageur danois Norden désigne sous le nom d'Ubschiir (Norden 1755/II: 212) et que l'on retrouvera chez Von Prokesch-Osten sous la forme Ebschir (Von Prokesch-Osten 1831: 43). Cette localité se trouvait sur la rive occidentale, au niveau du coude que forme le Nil au sud de la première cataracte, à environ 10 kilomètres au nord de Debod. L'absence de vestiges remarquables à Ibshir explique sans doute pourquoi l'endroit n'a guère retenu l'attention des voyageurs et des archéologues. L'équipe de l'Archaeological Survey of Nubia y a néanmoins relevé la présence de quelques tombes creusées dans la roche remontant vraisemblablement à la période chrétienne (Reisner 1908: 10) ${ }^{13}$. Si notre identification est correcte peut-être faudrait-il émender la forme Amsīr en *Ibšìr, *Abšīr ou *Ubšìr, moyennant des modifications mineures.

*Dabūdī (ms. : D.yūdī) : étant donné la place de ce toponyme dans la liste il s'agit de toute évidence de Debod, situé à une vingtaine de kilomètres en amont de Philae. C'est pourquoi nous avons choisi de lire ici ${ }^{*}$ Dabūdī, à la suite de Priese (Priese 1984: 485). Le yă' (/î̀) final représente sans doute la voyelle de liaison nubienne qui figure parfois à la fin des noms de lieux (cf. Hindawi, plus loin). On note d'ailleurs que ce même toponyme porte souvent une voyelle finale dans les translittérations des voyageurs, apparaissant sous la forme « Deboude » chez Norden (Norden 1755/II: 212, pl. CXLV) ou « Deboudy » chez Conder (Conder 1827: 271). La présence de Debod dans notre liste est néanmoins surprenante dans la mesure où le site est plutôt renommé pour son temple antique que pour ses vestiges médiévaux. Les croix et peintures chrétiennes que Von Prokesch-Osten dit avoir observées à l'intérieur du bâtiment témoignent néanmoins de la conversion de ce dernier en église (Monneret de Villard 1935/I: 20 ; Von Prokesch-Osten 1831: 82).

Le territoire (arḍ) d'Al.mā (lire *Arṭ.l.mā ?) : l'interprétation de ce nom est problématique à plusieurs égards. Il est délicat tout d'abord de déterminer si le lemme Al.mā forme un nom propre ou s'il faut le décomposer en "al-mă" " (l'eau). Si tel est le cas il faudrait alors interpréter ce toponyme comme " le territoire de l'eau » et considérer que l'expression traduit un toponyme nubien. Mais il est possible qu'Ibn Šaddād (ou ses informateurs) ait cru, à tort, reconnaître une expression arabe derrière une dénomination nubienne ${ }^{14}$. En effet, la

13 Le village est ici appelé « Bishir ».

14 On est peut-être confronté ici au même phénomène que l'on retrouvera un peu plus loin avec $a l-s a b$ ‘a qurā (" les sept villages ») qui pourrait désigner le village de Sabagura. 
localité figurant chez Ibn Šaddād sous la forme « arḍ Al.mā » est probablement identique au village (qaryā) appelé "Arț.l.mā » cité dans la biographie de l'aventurier al- 'Umarī incluse dans le K. al-Muqaffá d'al-Maqrīzī (al-Maqrīzī 1991/IV: 411) ${ }^{15}$. Si l'on en croit ce dernier, le lieu en question se trouvait à une étape (marhala) d'Assouan, soit une distance comprise entre 20 et 30 kilomètres, localisation compatible avec celle qui est suggérée par la position d'arḍ Al.mā dans notre liste. Il est délicat en revanche d'identifier ce village à un site précis de la région.

al-Q.s.q : nous n'avons pas été en mesure d'identifier ce toponyme dont plusieurs lectures sont possibles, sans tenir compte des variantes qu’offrent les textes plus tardifs (al-Fīn.q, al-F.tīq...). D'après sa position dans notre liste, cette localité devait se situer quelque part entre Debod et Dehmit.

Damhīt (ou Dimhīt) : il n'est pas difficile de reconnaître ici le nom de Dehmit, qui désigne un village nubien bien connu situé à environ 28 kilomètres au sud d'Assouan. Notons que la forme médiévale place le $/ \mathrm{h} /$ après le $/ \mathrm{m} /$ et non avant comme c'est le cas dans sa graphie moderne courante. Pour autant, il ne s'agit pas d'une simple erreur de transcription ni d'une faute de copiste puisque certains voyageurs des XVIII ${ }^{\mathrm{e}}-\mathrm{XIX} \mathrm{X}^{\mathrm{e}}$ siècles ont eux aussi choisi de placer le $/ \mathrm{h} /$ après le $/ \mathrm{m} /$, à commencer par Norden qui évoque l'endroit sous le nom de "Demhiid " (Norden 1755/II: 213). La présence de ce toponyme dans notre liste est néanmoins surprenante dans la mesure où les investigations archéologiques menées à Dehmit et dans ses environs immédiats n’ont pas révélé de traces d'une occupation chrétienne significative (Monneret de Villard 1935/I: 24 ; Curto et al. 1973).

Hindāw : il s'agit à l'évidence du village mieux connu sous le nom de Hindawi situé sur la rive droite, légèrement au sud de Dehmit. Les témoins plus tardifs de la liste ont interverti le wāw et le alif si bien que l'on y lisait plutôt « Hindwā » ou « Hindū » mais c'est certainement le manuscrit d'Edirne qui offre ici la lecture correcte. Là encore, les indices archéologiques d'une occupation médiévale à Hindawi sont rares (Monneret de Villard 1935/I: 25).

*Darm.s (ms. : D.rmīn) : nous avons choisi de corriger la leçon D.rmin que porte le ms. en *Darm.s (D.r.m.s), toponyme qui apparaît dans l'Histoire des églises et monastères d'Égypte d'Abū al-Makārim. La localité y est présentée comme la résidence d'un gouverneur et abritait aussi une église de belles dimensions dominant le Nil ainsi qu'un remarquable temple antique (Abū al-Makārim fol. 56a). L'allusion à ces vestiges est d'ailleurs l'une des raisons pour lesquelles on a pris coutume d'identifier cette localité au site de Kalabsha renommé pour son temple dédié au dieu local Mandulis. Le nom antique du site, Talmis,

15 Cette longue notice est probablement empruntée au K. ahbār al-Nūba d'al-Uswānī, rédigé sous le règne du calife-imam al-'Azīz (975-996), ce qui ferait remonter les informations qu'elle contient aux dernières décennies du $\mathrm{X}^{\mathrm{e}}$ siècle, sachant que l'épisode d'al- 'Umarī date lui-même de la seconde moitié du IX ${ }^{\mathrm{e}}$ siècle. 
se retrouverait d'ailleurs dans la forme arabe D.r.m.s qu'il faudrait alors lire " Darmis ». Les indices d'une présence chrétienne sur le site même sont relativement nombreux à commencer par le temple lui-même, reconverti en église probablement dès le VI ${ }^{\mathrm{e}}$ siècle. Monneret de Villard a même proposé d'identifier l'église mentionnée par Abū al-Makārim au temple de Beit el-Wali lui aussi transformé en sanctuaire chrétien à une époque difficile à déterminer (Monneret de Villard 1935/I: 30-35). On sait en outre que Talmis/Kalabsha était, au VIe siècle, le siège d'un exarque comme l'attestent deux stèles de fondation, l'une à Dendur (Richter 2002: 166-172) et l'autre à Ikhmindi (Deichmann et Grossmann 1988: 83-84), faisant mention d'un certain Joseph, exarque de Talmis (Tá $\lambda \mu(\varepsilon \omega \varsigma)$, талмєєс). Quant à la cité fortifiée qui s'étend près du village de Kalabsha, elle semble avoir été abandonnée avant l'an mille, mais un habitat chrétien extra-muros a pu exister et survivre au fil des transformations jusqu'au village moderne, finalement détruit par l'érection du premier barrage d'Assouan (Curto et al. 1965: 71) ${ }^{16}$.

Anhūba : la forme qu'offre ici le texte d'Ibn Šaddād differe nettement de celles transmises par Ibn al-Dawādārī (al-H.r.ța, al-H.r.yā), al-Mufạ̣̣̣al (al-H.r.yā) et Ibn al-Furāt (al-H.rīsa). En l'état, il nous est impossible de proposer une identification satisfaisante.

al-Tarbak, que l'on appelle « les sept villages " (al-sab 'a qurā) : Monneret de Villard avait déjà proposé de rapprocher l'appellation des "sept villages " (al-sab 'a qurā) du toponyme Sabagura, ville chrétienne fortifiée située sur la rive orientale, à un peu moins de 90 kilomètres au sud d'Assouan (Monneret de Villard 1935/I : 49 ; Bresciani et al. 1962). En revanche, le premier nom, apparaissant chez al-Mufaḍal sous la forme al-B.rì, n'avait pas pu être identifié. Le manuscrit d'Ibn Šaddād offre ici une ponctuation différente du même ductus - al-T.r.b.k - qui n'est pas sans rappeler un autre toponyme mystérieux apparaissant dans les textes locaux. Trois documents nubiens mentionnent en effet une localité connue sous le nom de тєрпєкк̄ (Browne 1992: 455 ; P. QIIV, 84, 1. 5; 115, r ${ }^{\circ} 1$. 1) à laquelle il est également fait référence sous forme abrégée (тєр)п/) dans quatre autres textes (P. QI III, 49, $v^{\circ} 1.6 ; 50,1.9: 94, v^{\circ} 1.2$; Plumley 1981: 7, 1. 9). Cette localité y est généralement présentée

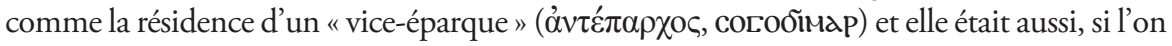
en croit une liste épiscopale copte que nous avons récemment publiée, le siège d'un évêché (*терпехl, voir Seignobos 2015: 176, 190-191). La terminaison «-il » peut être interprétée comme le marqueur du subjectif vieux-nubien $(-\lambda)$ précédé de sa voyelle de liaison $(-1-)$ ce

16 Il est possible toutefois que le nom de D.r.m.s corresponde plutôt à Darmus, village situé légèrement plus au nord, sur la rive orientale, en amont du resserrement du Nil connu sous le nom de Bab Kalabsha. Les ruines de ce village sont encore mentionnées par les voyageurs $\mathrm{du} \mathrm{XIX}^{\mathrm{e}}$ siècle mais n'étaient déjà plus visibles lors des grandes prospections archéologiques du début du XXe siècle. En revanche, l'île située vis-à-vis du village de Darmus abritait des vestiges chrétiens qui ont fait l'objet de fouilles en 1961 (Ricke 1967: 36-38). De toute évidence, le site était encore occupé peu avant les premières expéditions mameloukes comme en témoigne la découverte sur place d'un fragment de manuscrit arabe contenant une vente de terre datée de 666/1267-68 (Ricke 1967: Pl. 30). 
qui pourrait expliquer la disparition de celle-ci lors de la transcription du nom en arabe. Si ce rapprochement est fondé et si, comme l'avait supposé Monneret de Villard, "sab a qurā » renvoie bien au site de Sabagura, il faudrait alors en conclure que la résidence viceéparcale connue dans les sources locales sous le nom de Terpekk(il) n’est autre que Sabagura.

al-'Alī (al-'Alā, al-'Ulā...) : cette dénomination, de vocalisation incertaine, apparaît dans d'autres sources d'époque mamelouke, et notamment dans le serment d'allégeance que le roi nubien Mashkouda (Š.k.n.da, M.š.k.d...) aurait prêté lors de son couronnement. Si l'on croit ce texte, tel qu'il est reproduit par al-Nuwayrī - sans doute d'après Ibn 'Abd al-Zāhir -, le souverain se serait engagé à remettre au sultan les territoires (bilād) d'al-'Alī et d'al-Ǧabal (al-Nuwayrī 2004: 30, 222). Le nom d'al-Ǧabal ("la Montagne ») auquel al- 'Alī est ici associé se retrouve aussi dans le titre de "Seigneur de la Montagne " (șăhib $a l-\breve{G} a b a l)$ qui désigne, dans les sources arabes, l'éparque de Nobadia. Dans un autre passage de la biographie d'Ibn Šaddād, il est même question de "Seigneur du pays de la Montagne " (șăhib bilād al-Ğabal, Ibn Šaddād 1983: 130), preuve qu’al-Ğabal désigne bien une région ressortissant de l'autorité éparcale.

Il est communément admis, depuis Monneret de Villard, qu’al-'Alī et al-Ǧabal représentent deux subdivisions territoriales de la région connue des auteurs arabes sous le nom d'al-Marīs, correspondant à la portion de la Vallée comprise entre la $1^{\text {re }}$ et la $2^{\mathrm{e}}$ cataracte. Al- 'Alī en serait la partie la plus septentrionale et al-Ğabal la plus méridionale. C'est en tout cas ce qu'affirmait Monneret de Villard, en s'appuyant notamment sur le texte d'al-Mufaḍal dont la formulation peu claire pouvait en effet laisser penser que le nom d'al'Alī se rapportait à la première série de toponymes. Monneret de Villard pensait d'ailleurs pouvoir identifier ce territoire à l'antique Dodekaschène et avait même cru reconnaittre dans une forme dépourvue de points figurant à la fin de la première série de noms, le toponyme "Mehendi " (vieux-nubien : MW2WNAll), à savoir Ikhmindi, ville située non loin de Maharraqa qui marquait la limite méridionale de la Dodekaschène. Or, le toponyme en question ne figure pas dans le texte d'Ibn Šaddād, il s'agit en fait d'une forme qu'il convient de lire yuhạad $\bar{\imath}$ (inacc. du verbe de III forme hạa chez Ibn al-Dawādārī et al-Mufaụḍal en remplacement de yalì (même sens) employé par Ibn Šaddād. Cette erreur de lecture avait introduit une ambiguïté dans la formulation que le texte d'Ibn Šaddād permet de dissiper : la région qu'il désigne sous le nom d'al-'Alī/ al- 'Ulā se rapporte en fait à la seconde série de toponymes. Si l'on s'en tient aux propos d'Ibn Šaddād, al-'Alī/al- 'Ulā désignerait donc la région la plus méridionale des deux. Cette clarification vient quelque peu ébranler la démonstration du savant italien sans pour autant l'invalider complètement. En effet, tout indique par ailleurs que le terme " al-Ğabal » désigne bien le territoire sur lequel s'exerce l'autorité directe de l'éparque de Nobadia ou "șaḥib al-Ğabal " (" seigneur de la Montagne »), comme nous l'avons rappelé plus haut. Or, on sait que l'éparque résidait alors à Qașr Ibrīm ou Gebel Adda, voire à Meinarti, villes qui figurent toutes dans la seconde série de toponymes pourtant regroupés par Ibn Šaddād sous l'appellation d'al-'Alī. Cette contradiction est difficile à expliquer mais relève peut-être simplement d'une confusion de la part d'Ibn Šaddād. 
*Arminna (ms. : Ar.ma) : al-Mufaḍdal offrait pour ce toponyme la forme A.d.m.a dans laquelle Griffith avait proposé de reconnaître une possible corruption du nom d'Amada (Griffith 1927: 102). Néanmoins, la présence dans notre texte d'un rā' en deuxième position nous a incité à suppléer un nūn afin de restituer la forme *A.r.m.na qu'il conviendrait de vocaliser *Armina ou plutôt *Arminna, c'est-à-dire Arminna Ouest, localisé à quelque 270 kilomètres au sud de Philae ${ }^{17}$. Ce nom apparaît d'ailleurs un peu plus haut dans le récit d'Ibn Šaddād — sous la graphie Arminnā — parmi les villes prises lors de l'expédition nubienne du gouverneur de Qūṣ (Ibn Šaddād 1983: 53 ; Seignobos à paraître). Arminna figure également à plusieurs reprises dans les textes de Qaṣr Ibrīm, sous la forme a.入(i)mīne (P. QI III 32, 12; 38, App. 4; 60, 5 ; P. QI IV 77, 1; 78, 16; $\left.79, r^{\circ} 21 ; 123,2\right)$. En 1962, le complexe urbain médiéval d'Arminna Ouest a fait l'objet de fouilles partielles qui ont montré que la ville était florissante durant la période dite "classique " (850-1100) mais déclina nettement au cours de la période suivante avant d'être finalement abandonnée, peut-être au cours du XIII ${ }^{\mathrm{e}}$ siècle ou au début du siècle suivant (Weeks 1967: 6).

Ṭamid : la forme Ṭ.m.d se trouvait déjà chez al-Mufaḍal mais n’avait pas été identifiée jusqu'à présent. Le fait que ce toponyme se place dans l'énumération juste après Arminna invite à y reconnaître le site chrétien de Tamit situé sur la même rive, à une dizaine de kilomètres plus au sud (Monneret de Villard 1935/I: 146-166; Tamit... 1967). Ce nom apparaît aussi dans le récit de l'expédition de 671/1272 sous la forme Aṭmịt qu'il faudrait peut-être corriger en *Ṭāmīt (Ibn Šaddād 1983: 53 ; Seignobos à paraître). Le nom est par ailleurs bien attesté dans les textes de Qașr Ibrīm sous la forme TamiT (P QIIII 37, 33; 38, 21; P QIIV 77, 5), тамтн (I. QI 57, 8) ou тамті (P QIIV 105, 5).

al-Daw : al-Daw ou al-Dū (prononcé ad-Daw/ad-Dū) fait partie des quelques toponymes qu'il était déjà possible d'identifier d'après le texte corrompu d'al-Mufaḍdal. Bien que son identification ait fait un temps débat, il est généralement admis aujourd'hui que ce nom fait référence à la citadelle de Gebel Adda, près d'Abou Simbel. Durant la période médiévale tardive, Gebel Adda était en effet un centre urbain majeur, d'une importance comparable à Qaṣr Ibrīm (Millet 1963 ; 1964 ; 1967). Souvent mentionnée dans les sources mameloukes, al-Daw figure parmi les villes prises lors de l'expédition de 1276 (al-Nuwayrī 2004: 30, 220-221 ; Seignobos à paraître) et apparaît également dans

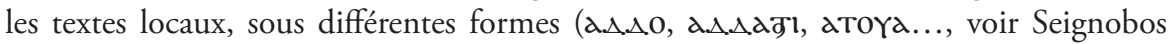
2015: 209) ${ }^{18}$.

17 Mieux connue autrefois sous le nom d'Ermenne. C'est pourquoi la vocalisation *Armanna est également possible.

18 Ochała 2010. Il convient d'ajouter à ces mentions la découverte récente, dans l'annexe sudoccidentale du monastère du Kom H à Old Dongola, d'une inscription dans laquelle il est question d'une église située à Dau, toponyme dont la graphie rappelle la forme arabe al-Daw/ al-Dū. Aucune indication ne permet de localiser l'endroit mais il est possible qu'il s'agisse de la même localité communément identifiée à Gebel Adda (Łajtar 2015b: 350, avec note 20). 
Ibrīm : il s'agit de la désignation arabe courante du site de Qașr Ibrīm, connu dans les textes locaux sous le nom de Phrim (фРім) (Ochała 2010). On note ici une entorse à la succession nord-sud que suit d'ordinaire l'énumération puisque Ibrīm est la localité la plus septentrionale de cette seconde série de toponymes et devrait donc se placer en tête de celle-ci et non après al-Daw. Le fait que les noms des deux principales places fortes de Basse Nubie soient souvent associés dans les sources mameloukes n'est peut-être pas étranger à cette bizarrerie. Un peu plus haut, Ibn Šaddād évoque lui-même « Daw et Ibrim, deux places fortes bien protégées situées non loin d'Assouan, à sept jours de celle-ci », laissant ainsi entendre que les deux villes étaient voisines (Ibn Šaddād 1983: 130). Signalons enfin qu'Ibrīm est aussi mentionnée parmi les villes prises lors de l'expédition du gouverneur de Qūṣ en 1272 (Ibn Šaddād 1983: 53 ; Seignobos à paraître).

*Dindān (ms. : D.ndāl) : la forme et la position de ce nom dans la liste invitent à reconnaître le site d'Adindan, situé sur la rive droite du Nil légèrement en aval de Faras, comme l'avait déjà proposé Griffith (Griffith 1927: 102). Le toponyme est attesté dans les documents de Qașr Ibrīm, sous la forme aTiN_daN (P. QI III 31, 11; 37, 23), et apparaît également dans d'autres sources arabes. Selon la chronique perdue d'Ibn Abī Tayyi' (1180-ca. 1228-1233), citée par Abū Šāma (1203-1268), le territoire d'Ibrīm, conquis par Šams al-Dawla Tūrānšāh, fut confié en iqtāé (concession terrienne) à l'un de ses émirs, Ibrāhīm al-Kurdī, qui se noya vers 1175 aux abords de l'« île de Dindān ${ }^{19}$ " (ğazìrat Dindān), mettant ainsi fin à l'éphémère présence ayyoubide dans la région (Abū Šāma 2002: 2, 161 ; Vantini 1975: 369). Dindān est aussi mentionnée — sous la forme légèrement corrompue " Dìdān » - dans la biographie d'al- 'Umarī incluse dans le $K$. al-Muqaffà d'al-Maqrīzī. Il y est relaté que Zakariyyā', fils du roi Qurqī (Georgios), parvint à amadouer une partie des tribus arabes soutenant al- 'Umarī en leur offrant des terres situées " en aval (düna, litt. "en dessous ») de la première cataracte du pays de Marīs (= la $2^{\mathrm{e}}$ cataracte) dans la région que l'on appelle *Dindān, à Adwā (Gebel Adda) et dans les territoires avoisinants » (al-Maqrīzī 1991/IV: 410). Enfin, c'est sans doute aussi à Adindan qu'il est fait référence lorsque Abū al-Makārim décrit le monastère d'Abū Ğaras (lire *Abūharas = Faras) situé sur la «montagne de Zìdān » (ğabal Zìdān). Comme l’a suggéré Priese (Priese 1984: 489), la forme Zidān résulte sans doute d'une faute de lecture pour *Dindān, Adindan se trouvant presque vis-à-vis de Faras, sur la rive orientale ${ }^{20}$. Ces diverses mentions nous ont incité à corriger la forme D.ndāl que porte notre liste en *Dindān, ce qui se justifie parfaitement du point de vue paléographique.

19 Lîle d'Adindān se trouvait en face du village du même nom.

20 Mileham avait proposé d'identifier le monastère en question à celui de Kasr al-Wizz, situé sur un escarpement rocheux à environ deux kilomètres en aval de Faras (Mileham 1910: 6). Il ne serait pas étonnant, en effet, que cette éminence ait reçu le nom de " ğabal Dindān "étant donné la proximité d'Adindan, située sur l'autre rive. Les fouilles de Kasr al-Wizz, menées dans les années 1960 par l'Oriental Institute de l'université de Chicago, sont en cours de publication sous la direction d'Artur Obłuski, avec la collaboration d'Alexandros Tsakos (épigraphie), Dobrochna Zielińska (peintures) et Katarzyna Danys (céramique). 
Būharāṣ : Griffith n'avait guère eu de peine à reconnaître ici la cité épiscopale de пахораc, la moderne Faras (Griffith 1925: 264 et passim), l'un des centres urbains les plus importants de basse Nubie au Moyen Âge (Ochała 2010). La ville était néanmoins sur le déclin lorsque ont été lancées les premières incursions mameloukes. Plusieurs églises des faubourgs avaient été abandonnées et la cathédrale elle-même avait alors largement disparu sous les sables, ce qui n'empêcha pas le site d'être occupé au moins jusqu'à la fin du XIV e siècle (Godlewski 1995a ; 1995b).

Sarrā (ou Sirrā) : al-Mufaḍḍal, à la suite d'Ibn al-Dawādārī, donnait pour ce toponyme la forme corrompue S.mā, que l'on pouvait éventuellement rapprocher de Semna, l'une des imposantes citadelles d'époque pharaonique gardant l'accès de la deuxième cataracte (Godlewski 1995b: 41). Griffith hésitait à y voir une corruption pour Serra (Est) qui se trouve à une dizaine de kilomètres au sud de Faras (Griffith 1927: 102). Cette conjecture est désormais confirmée par le texte d'Ibn Šaddād qui offre ici la leçon S.rā que nous proposons de lire Sarrā — si l'on suit la vocalisation du ms. - ou bien Sirrā. Il s'agit d'une ancienne forteresse pharaonique réoccupée à l'époque chrétienne tardive, période durant laquelle Serra Est semble devenir un centre urbain relativement important (Knudstad 1966: 165-172). Le nom est par ailleurs attesté dans la documentation locale sous la forme ceppe (серрем матто = Serra Est) (Griffith 1913: 4) $)^{21}$.

Île de Mikā'îl, où se trouvent des villages (bilād) : comme al-Daw il s'agit d'une localité qui apparaît de façon récurrente dans les sources d'époque mamelouke. On s'accorde à reconnaître derrière cette dénomination l'île de Meinarti (parfois orthographié Meilnarti), située immédiatement au nord de la deuxième cataracte, à une dizaine de kilomètres en amont de Wadi Halfa. Bien que ce toponyme n'apparaisse pas en tant que tel dans la documentation locale, sa forme

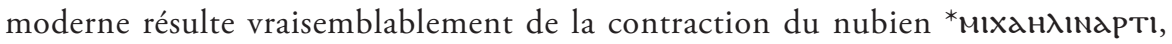
littéralement " l'île de Michel », comme l'avait déjà suggéré Griffith (Griffith 1927: 103) ${ }^{22}$. Les fouilles du Sudan Antiquities Service menées dans les années 1960 sous la direction de William Adams, ont révélé que l'île était occupée depuis la fin de l'époque méroïtique jusqu'à la période chrétienne tardive et même au-delà (Adams 2002). Lors des incursions mameloukes de la fin du XIII siècle, Meinarti

21 Ochała 2010. Les résultats des fouilles de la période chrétienne à Serra East paraitront prochainement dans le $12^{\mathrm{e}}$ volume des Oriental Institute Nubian Expedition (OINE), sous la direction de Bruce Williams et avec la collaboration de Nadejda Reshetnikova (architecture/ topographie), Alexandros Tsakos (épigraphie grecque et copte), Dobrochna Zielińska (peintures) et Robin Seignobos (épigraphie arabe).

22 Deux graffiti de l'église haute de Banganarti (XIII $-\mathrm{XIV}^{\mathrm{e}}$ s.) mentionnent un lieu connu sous

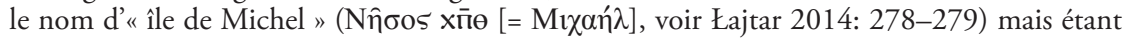
donné la popularité de l'archange en Nubie, il est impossible de savoir si ce toponyme se rapporte bien à Meinarti. 


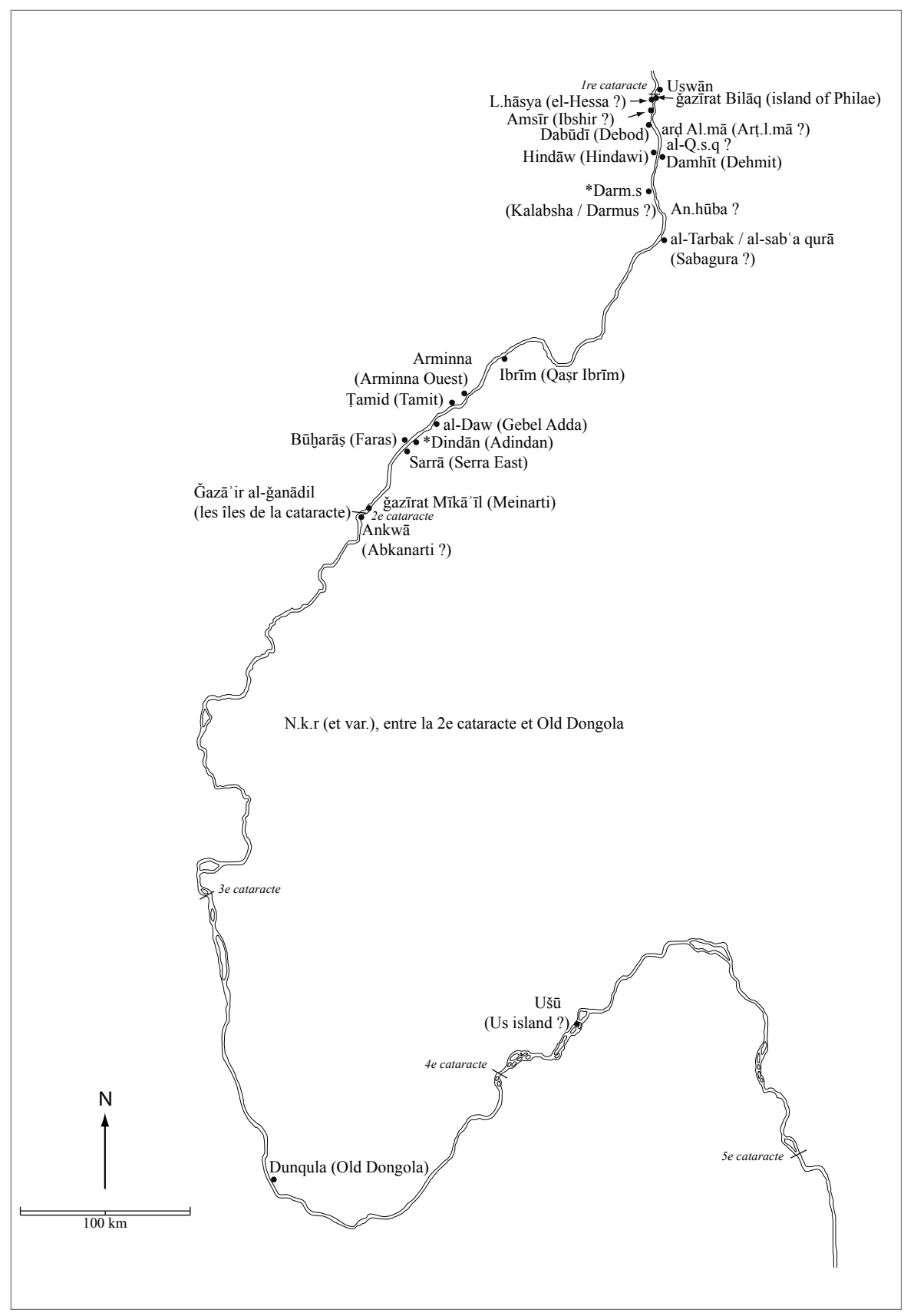

Fig. 2. Localisation des toponymes mentionnés dans la liste d'Ibn Šaddād 
a probablement servi de résidence secondaire pour l'éparque de Nobadia et a joué un rôle stratégique dans la défense du territoire nubien (Adams 2014). Meinarti est d'ailleurs prise par l'émir Aqsunqur al-Fariqānī au cours de l'expédition de 1276, ainsi que le rapportent al-Nuwayrī et d'autres chroniqueurs mamelouks (al-Nuwayrī 2004: 30, 221 ; Seignobos à paraître).

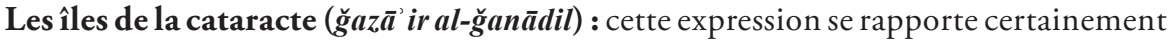
à la multitude d'îles et d'îlots de la deuxième cataracte. Al-Nuwayrī — d'après Ibn 'Abd al-Zāhir — semble d'ailleurs y faire allusion lorsqu'il indique que le gouverneur $\left(n \bar{a}^{\prime} i b\right)$ d'al-Daw a fui l'arrivée des troupes mameloukes en direction "des îles " (al-ğazāàr) (al-Nuwayrī 2004: 30, 221).

An.k.wā (lire *Abkwā ou *Abkū ?), qui se trouve sur une île : si l'on considère que notre liste continue de remonter le Nil, la localité dont il est question se situerait en amont de Meinarti. Nous proposons donc d'identifier cette localité à Abka, au sud de la deuxième cataracte, ou, plus précisément, à l'île attenante d'Abkanarti puisque Ibn Šaddād précise que cette localité se trouve sur une île. Les hauteurs de la presqu'île d'Abkanarti, à une dizaine de kilomètres en amont de Meinarti, abritait en effet un village chrétien fortifié (occupé du IX ${ }^{\mathrm{e}}$ au $\mathrm{XV}^{\mathrm{e}}$ siècle) qui fut fouillé dans les années 1960 par une équipe espagnole (Presedo Velo $1965)^{23}$. Sa présence dans notre liste se justifierait en outre par son statut de point de rupture de charge : jusqu'à une époque relativement récente c'était à Abka - ou à Gemai, légèrement plus au sud — que les cargaisons déchargées et transportées par terre en aval de la Grande cataracte rejoignaient à nouveau les embarcations. Si cette identification est correcte, la graphie An.k.wā serait à corriger en *Abkwā ou *Abkū mais cela n'a rien de certain étant donné qu'Abka est aussi connue sous le nom d'Amka ${ }^{24}$.

N.k.r : la vocalisation du texte suggère de lire ce toponyme " Nukkar » mais les lectures possibles sont nombreuses. Sa place dans la liste indique que cette localité doit être recherchée quelque part entre la deuxième cataracte et Dongola, zone trop vaste pour permettre une quelconque localisation.

23 Gardberg, qui a visité le site quelques années plus tard, a néanmoins fait remarquer que la ville s'étendait probablement bien au-delà de l'enceinte de la "ville haute " dégagée par les Espagnols : "The centre of this region in Christian times, the town of Abkanarti, was surrounded by rather large areas of flat land, covered with late potsherds, which showed that the town was once much larger than just the upper town, excavated by the Spanish expedition" (Gardberg 1970: 50-51).

24 Il serait tentant de rapprocher la dénomination An.k.wā du village de B.q.wā (var. : T.q.wā) mentionné, à la fin du $\mathrm{X}^{\mathrm{e}}$ siècle, dans le récit du voyageur fatimide al-Uswānī (al-Maqrīzī 1922: 253-254). Toutefois, si la forme du toponyme rappelle en effet celle d'An.k.wā, sa description comme point de rupture de charge pour les embarcations remontant le Nil depuis le nord évoque plutôt l'île de Meinarti, comme l'a récemment fait remarquer Adams (Adams 2014: 875). 
Table 1. Tableau synthétique des toponymes mentionnés dans la liste d'Ibn Šaddād

\begin{tabular}{|c|c|c|}
\hline Forme arabe du ms. & $\begin{array}{l}\text { Forme arabe } \\
\text { corrigée }\end{array}$ & Translittération \\
\hline جزيرة بـلاق & - & ğazīrat Bilāq \\
\hline لهاسية & - & L.hāsya (lire al-Haysa?) \\
\hline |مسير & - & Amsìr (lire Ibšìr, Abš̀ir... ?) \\
\hline ديودى & دبودى & Dabūdì \\
\hline 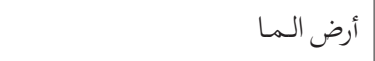 & - & $\operatorname{ard}$ Al.mā (lire Arț.l.mā ?) \\
\hline | - القستق & - & al-Q.s.q \\
\hline دمهيتت & - & Damhit (ou Dimhit) \\
\hline هـنـاو & - & Hindāw \\
\hline 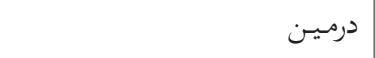 & 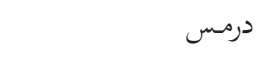 & Darm.s (Darmus, Darmis...) \\
\hline انهـوبـة & - & $A n \cdot h \bar{u} b a$ \\
\hline السـبع قرى/ اقلـيـم التربـك & - & iqlim al-Tarbak / al-sab'a qurā \\
\hline 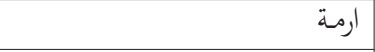 & 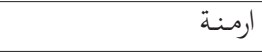 & Arminna \\
\hline طم & - & Tamid \\
\hline ل الدو & - & al-Daw (al-Dī) \\
\hline ابريـم & - & Ibrìm \\
\hline 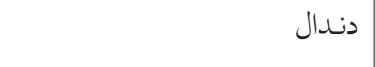 & 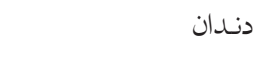 & Dindān \\
\hline 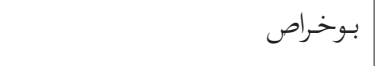 & - & Büharāạs \\
\hline سرا & - & Sarrā (ou Sirrā) \\
\hline جزيرة ميكائيل & - & ğazirat Mìkāìl \\
\hline انـكوا & - & Ankwā, Ankū (lire Abkwā, Abkū ?) \\
\hline اقليـم نـكر & - & iqlim N.k.r \\
\hline دنقـلة & - & Dunqula \\
\hline اقليـم اشو & - & iqlìm $U^{v} \bar{u}(A s ̌ \bar{u}, I s ̌ \bar{u})$ \\
\hline
\end{tabular}




\begin{tabular}{|c|c|c|}
\hline $\begin{array}{l}\text { Autres attestations arabes } \\
\text { médiévales }\end{array}$ & $\begin{array}{l}\text { Attestations dans } \\
\text { la documentation } \\
\text { locale médiévale }\end{array}$ & $\begin{array}{l}\text { Identification, } \\
\text { localisation }\end{array}$ \\
\hline nombreuses attestations & $\Pi 1 \lambda \alpha \kappa, \pi \in \lambda \lambda \alpha \kappa . .$. & île de Philae \\
\hline- & - & île d'el-Hessa? \\
\hline- & - & Ibshir? \\
\hline- & - & Debod \\
\hline Arț.l.mā (al-Uswānī) & - & $\begin{array}{l}\text { entre Debod et } \\
\text { Dehmit }\end{array}$ \\
\hline- & - & au nord de Dehmit \\
\hline- & - & Dehmit \\
\hline- & - & Hindawi \\
\hline D.r.m.s (Abū al-Makārim) & 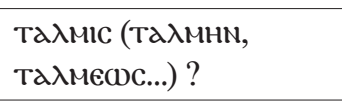 & $\begin{array}{l}\text { Kalabsha ou } \\
\text { Darmus? }\end{array}$ \\
\hline- & - & au sud de Kalabsha? \\
\hline- & 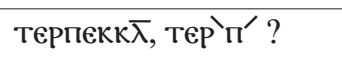 & Sabagura? \\
\hline Arminnā (Ibn Šaddād) & $d \triangle(l) M \bar{N} N \epsilon$ & Arminna \\
\hline Aṭmīt (lire Tāmīt ?, Ibn Šaddād) & TגMIт (TגMTl, ТАMTH) & Tamit \\
\hline $\begin{array}{l}\text { nombreuses attestations } \\
\text { (chroniqueurs mamelouks) }\end{array}$ & 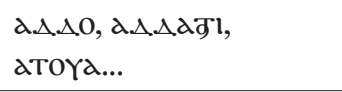 & Gebel Adda \\
\hline $\begin{array}{l}\text { nombreuses attestations (al-Uswānī, } \\
\text { Abū Šāma, listes épiscopales, } \\
\text { chroniqueurs mamelouks...) }\end{array}$ & $\phi \overline{\mathrm{PM}}, \phi Р \mathrm{PI}, \epsilon \phi Р I M . .$. & Qașr Ibrīm \\
\hline $\begin{array}{l}\text { Dindān (Abū Šāma) ; Zīdān (Abū } \\
\text { al-Makārim) ; Dīdān (al-Maqrīzī) }\end{array}$ & dTIN $\triangle d \mathrm{dN}$ & Adindan \\
\hline $\begin{array}{l}\text { plusieurs attestations sous des } \\
\text { formes proches (al-Uswānī, Abū } \\
\text { al-Makārim, listes épiscopales...) }\end{array}$ & пахорас & Faras \\
\hline- & CEPPEN (MATO) & Serra Est \\
\hline $\begin{array}{l}\text { nombreuses attestations } \\
\text { (chroniqueurs mamelouks) }\end{array}$ & - & Meinarti \\
\hline- & - & Abkanarti? \\
\hline- & - & $\begin{array}{l}\text { entre la } 2^{\mathrm{e}} \text { cataracte } \\
\text { et Old Dongola }\end{array}$ \\
\hline nombreuses attestations & 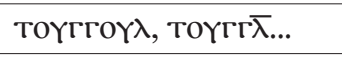 & Old Dongola \\
\hline- & - & île d'Us? \\
\hline
\end{tabular}


Dunqula : i s s'agit de la dénomination arabe la plus communément employée au Moyen Âge pour désigner la capitale du royaume de Makouria, Dongola (vieux-nubien : тоүггоү入) correspondant au site actuel d'Old Dongola.

La région d'Ušū, formée d'îles habitées pourvues de villes : étant donné sa place à la fin de la liste, la région en question devrait être recherchée en amont d'Old Dongola. C'est pourquoi nous avons choisi de vocaliser ce nom $\mathrm{Ušu}^{25}$ car la description de cette région nous paraît correspondre aux environs de l'île d'Us, sur la quatrième cataracte. Les fouilles récemment menées par l'université Humboldt à Us et dans les environs ont mis en évidence l'importance du peuplement médiéval dans cette zone (Näser 2012: 262-263 ; Näser, Billig, and Lange 2007 ; Tsakos 2007). La découverte, sur l'̂̂le voisine de Sur, d'un ensemble de documents grecs et vieux-nubiens constitue également un indice de l'importance de la région sur les plans religieux et culturel et de ses possibles liens avec le cœur du royaume de Makouria ${ }^{26}$.

\section{Conclusion}

Au terme de ce travail d'identification (synthétisé en Table 1) il n'est pas inutile de prendre un peu de recul afin de mieux apprécier ce que cette liste est susceptible de nous apprendre de l'organisation du territoire nubien au lendemain de la première invasion mamelouke. Le placement des toponymes sur une carte [voir Fig. 2] fait apparaître une répartition très inégale puisque seuls trois noms sur vingt-trois ou vingt-quatre se rapportent à des localités situées en amont de la deuxième cataracte (N.k.r., Dunqula et Ušū). Ce déséquilibre n'a rien d'étonnant dans la mesure où, d'après les chroniqueurs mamelouks, seules les régions d'al-'Alī et d'al-Ğabal auraient été annexées à l'Égypte à l'issue de l'expédition de 1276. Il est donc tout à fait logique que la liste décrive avant tout les territoires les plus septentrionaux, placés sous l'autorité directe du sultan - peu importe que celle-ci ait été reconnue dans les faits ou non. Pour autant, ce texte n'a pas vocation à livrer un état des lieux fidèle de la répartition du peuplement nubien et entend avant tout dresser un inventaire des territoires qui ont été soumis militairement à l'autorité de Baybars. C'est pourquoi la liste reflète peut-être davantage l'itinéraire des armées mameloukes que la topographie administrative nubienne. Il se peut

25 Comme le suggère d'ailleurs la vocalisation du ms.

26 La publication des parchemins grecs de l'île de Sur a fait l'objet d'une thèse de doctorat par Alexandros Tsakos, soutenue en 2013 à l'université Humboldt de Berlin et qui sera prochainement publiée. 
donc que certaines localités figurent dans la liste non pas en raison de leur importance démographique, politique ou économique, mais simplement parce que les armées mameloukes y ont livré bataille ou y ont fait halte.

Au sein de l'espace ainsi délimité, les toponymes se répartissent en deux zones correspondant aux deux régions distinguées par le texte : celle qui s'étend entre Philae et Sabagura (si cette dernière identification est correcte) et celle comprise entre Qașr Ibrīm et la seconde cataracte — région qu'Ibn Šaddād désigne, à tort peut-être, sous le nom d'al-'Alī/al-'Ulā. Presque tous les noms relevant de cette dernière sont reconnaissables et correspondent généralement à des sites médiévaux bien connus (Qașr Ibrīm, Arminna Ouest, Tamit, Gebel Adda, Faras, Adindan, Serra Est, Meinarti). Plus au nord, la situation est quelque peu différente puisqu'il est rare que les toponymes identifiables y soient clairement associés à un site d'occupation médiéval documenté par l'archéologie. Mais ce déséquilibre reflète sans doute celui des recherches archéologiques qui furent souvent moins poussées et moins systématiques dans le territoire correspondant à l'ancienne Dodekaschène qu'elles ne l'ont été plus au sud. La Basse Nubie ayant aujourd'hui disparue sous les eaux du lac Nasser, la liste d'Ibn Šaddād n'en devient que plus précieuse en livrant les noms de villes et villages nubiens alors jugés dignes de mention mais désormais inaccessibles aux investigations de terrain.

\section{Références bibliographiques}

Les papyrus sont cités conformément aux sigles de J.F. Oates et al., Checklist of Greek, Latin, Demotic and Coptic papyri, ostraca and tablets, disponible sur Internet : http://scriptorium.lib.duke.edu/papyrus/texts/clist.html.

\section{SOURCES PRIMAIRES}

Abū al-Makārim, The churches and monasteries of Egypt and some neighbouring countries, attributed to Abû Șalih, the Armenian, trad. par B.T.A. Evetts, Oxford : Clarendon Press, 1895

Abū Šāma, Kitāb al-Rawḍatayn fì aḩār al-dawlatayn al-Nüriyya wa-ăl-Șalahiyya, éd. par I. Šams ad-Dīn, Beyrouth : Dār al-Kutub al-'Ilmiyya, 2002

al-Ǧazarī, al-Muhtār min Tārīh Ibn-al-Ǧazarī, éd. par Muhammad Halīfa al-Manšadāwī, Beyrouth : Dār al-Kitāb al-'Arabī, 1988

al-Maqrīzì, Kitāb al-Mawā 'iz wa-l-i 'tibār fi dikr al-hitat wa-l-ātāar III, éd. par G. Wiet,

Le Caire : Institut français d'archéologie orientale, 1922

al-Maqrīīi, Kitāb al-Muqaffā al-kabìr I-VIII, éd. par M. al-Ya 'lāwī, Beyrouth : Dar al-gàrb al-islāmī, 1991 
al-Mufaḍdal Ibn Abi-l-Faḍāil, Histoire des sultans Mamelouks II [=Patrologia Orientalis 14/3], trad. par E. Blochet, Paris : Firmin-Didot, 1920

al-Nuwayrī, Nihāyat al-arab fí funūn al-adab I-XXXIII, éd. par M. Qumayḥah, Beyrouth : Dār al-Kutub al-'Ilmiyya, 2004

al-Yūnīnī, Dayl Mir'āt al-zamān III. Haiderabad : Maṭba'at Mağlis Dā’irat al-Ma'ārif al-'Utmāniyya, 1960

Ibn 'Abd al-Z̄āhir, al-Rawd al-zähir fì sīrat al-malik al-Z̄āhir, éd. par 'Abd al-'Azīz al-Huwayțir, Riyadh : Mu'assasat Fu'ād, 1976

Ibn al-Dawādārī, Die Chronik des Ibn ad-Dawādāri VIII. Der Bericht über die frühen Mamluken, éd. par U. Haarmann, Freiburg : Schwarz, 1971

Ibn al-Furāt, Tārīh Ibn al-Furāt / The history of Ibn al-Furät, éd. par Q. Zurayq, Beyrouth : American Press, 1939

Ibn Šaddād, Die Geschichte des Sultans Baibars, éd. par A. Hutạaiț, Wiesbaden : Steiner, 1983

Ibn Sibāt, Șidq al-aḥbār Tārīh Ibn Sibāt, éd. par 'Umar 'Abd al-Salām Tadmurī, Ṭarābulus : Ğarrūs Press, 1993

Ibn Tağrī Birdī, al-Nuğūm al-zāhira fì mulūk Miṣr wa-l-Qāhira I-XVI, éd. par M. Ḥusayn Šams al-Dīn, Beyrouth : Dār al-Kutub al-'Ilmiyya, 1992

\section{SOURCES SECONDAIRES}

Adams, W.Y. (2002). Meinarti III. The late and terminal Christian phases [=Sudan Archaeological Research Society Publications 9; British Archaeological Reports International Series 1072]. Oxford: Archaeopress

Adams, W.Y. (2014). The Eparch at Meinarti. Dans J.R. Anderson et D.A. Welsby (éds), The Fourth Cataract and beyond: Proceedings of the 12th International Conference for Nubian Studies [=British Museum Publications on Egypt and Sudan 1] (pp. 875885). Louvain : Peeters

Bresciani, E., Donadoni, S., Roveri, A.M., Stenico, A., et Torelli, M. (éds). (1962). Sabagura (1960) [=Orientis antiqui collectio 1]. Rome : Centro per le antichità e la storia dell'arte del Vicino Oriente

Browne, G.M. (1992). Griffith's Old Nubian sale. Orientalia, 61(4), 454-458

Conder, J. (1827). Egypt, Nubia, and Abyssinia I-II. Londres: Printed for James Duncan

Curto, S., Geraci, G., Maragioglio, V., et Rinaldi, C. (1973). Dehmit [=Università di Roma, Istituto di studi del Vicino Oriente. Serie archeologica 19]. Rome : Istituto di studi del Vicino Oriente, Università

Curto, S., Maragioglio, V., Rinaldi, C., et Bongrani, L. (1965). Kalabsha [=Orientis antiqui collectio 5]. Rome : Centro per le antichità e la storia dell'arte del Vicino Oriente

Deichmann, F.W. et Grossmann, P. (1988). Nubische Forschungen [=Archäologische Forschungen 17]. Berlin : Gebr. Mann

Gardberg, C.J. (1970). Late Nubian sites: Churches and settlements [=Scandinavian Joint Expedition to Sudanese Nubia 7]. Copenhague : Scandinavian University Books 
Godlewski, W. (1995a). The Bishopric of Pachoras in the 13th and 14th centuries. Dans C. Fluck, L. Langener, S.G. Richter, S. Schaten, et G. Wurst (éds), Divitiae Aegypti: koptologische und verwandte Studien zu Ehren von Martin Krause (pp. 113-118). Wiesbaden : L. Reichert

Godlewski, W. (1995b). The late period in Nubian art - from the middle of 13 th to the end of 14th centuries. Dans R. Gundlach, M. Kropp, et A. Leibundgut (éds), Der Sudan in Vergangenheit und Gegenwart/Sudan past and present [=Nordostafrikanisch/ westasiatische Studien 1] (pp. 37-63). Frankfurt am Main : P. Lang

Griffith, F.L. (éd.). (1913). The Nubian texts of the Christian period. Berlin : Verlag der Königlich Akademie der Wissenschaften

Griffith, F.L. (1925). Pakhoras-Bakharâs-Faras in geography and history. Journal of Egyptian Archaeology, 11, 259-268

Griffith, F.L. (1927). Oxford excavations in Nubia. Liverpool Annals of Archaeology and Anthropology, 14, 57-116

Holt, P.M. (1982). Three biographies of al-Zāhir Baybars. Dans D.O. Morgan (éd.), Medieval historical writing in the Christian and Islamic worlds (pp. 19-29). Londres : School of Oriental and African Studies, University of London

Knudstad, J.E. (1966). Serra East and Dorginarti: A preliminary report on the 196364 excavations of the University of Chicago Oriental Institute Sudan Expedition. Kush, 14, 165-186

Koch, Y. (1983). 'Izz al-Dīn ibn Shaddād and his biography of Baybars. Annali dell'Istituto Universitario Orientale, 43, 249-287

Łajtar, A. (2014). Archangel Raphael in inscriptions from the Upper Church at Banganarti. Dans B. Żurawski, Kings and pilgrims: St. Raphael Church II at Banganarti, mid-eleventh to mid-eighteenth century [=Nubia 5] (pp. 261-283). Varsovie : Neriton

Łajtar, A. (2015). Wall inscriptions in the Southwest Annex to the Monastery on Kom $\mathrm{H}$ at Dongola: Report on work in the 2013 season. Polish Archaeology in the Mediterranean, 24/1, 344-351

Łajtar, A. (à paraître). A high-ranking visit to the commemorative complex in the northwestern annex to the Monastery on Kom H at Dongola

Mileham, G.S. (1910). Churches in lower Nubia. Philadelphie : University Museum

Millet, N.B. (1963). Gebel Adda preliminary report for 1963. Journal of the American Research Center in Egypt, 2, 147-165

Millet, N.B. (1964). Gebel Adda Expedition preliminary report, 1963-1964. Journal of the American Research Center in Egypt, 3, 7-14

Millet, N.B. (1967). Gebel Adda preliminary report, 1965-66. Journal of the American Research Center in Egypt, 6, 53-63

Monneret de Villard, U. (1935-1957). La Nubia medioevale I-IV. Le Caire : Institut français d'archéologie orientale

Monneret de Villard, U. (1938). Storia della Nubia cristiana [=Orientalia Christiana analecta 118]. Rome : Pontificium Institutum Orientalium Studiorum 
Näser, C. (2012). The Humboldt University Nubian Expedition 2006 to the Fourth Nile Cataract: Fieldwork in the island concession. Dans H.-P. Wotzka (éd.), Proceedings of the Third International Conference on the Archaeology of the Fourth Nile Cataract, University of Cologne, 13-14 July 2006 [=Africa praehistorica 22] (pp. 257-269). Cologne : Heinrich-Barth-Institut

Näser, C., Billig, D., and Lange, M. (2007). The church US022.A at the Fourth Nile Cataract. Dans C. Näser et M. Lange (éds), Proceedings of the Second International Conference on the Archaeology of the Fourth Nile Cataract, Berlin, August 4th-6th, 2005 [=Meroitica 23] (pp. 143-158). Wiesbaden : Harrassowitz

Norden, F.L. (1755). Voyage d'Égypte et de Nubie I-II. Copenhague : Imprimerie de la Maison royale des orphelins

Northrup, L.S. (1998). From slave to sultan: The career of Al-Manșūr Qaläwün and the consolidation of Mamluk rule in Egypt and Syria (678-689 A.H./1279-1290 A.D.). Stuttgart : Franz Steiner

Ochała, G. (2010). Toponyms and ethnonyms occurring in Nubian texts. Disponible en ligne : http://www.medievalnubia.info/dev/index.php/Toponyms_and_ Ethnonyms [accédé: novembre 2015]

Plumley, J.M. (1981). A Coptic precursor of a medieval Nubian protocol. Sudan Texts Bulletin, 3, 5-8

Presedo Velo, F.J. (1965). El poblado cristiano de la isla de Abkanarti en la segunda catarata del Nilo (Sudán) [=Memorias de la Misión Arqueológica Española en Nubia 7]. Madrid : Dirección General de Relaciones Culturales

Priese, K.-H. (1984). Orte des mittleren Niltals in der überlieferung bis zum Ende des christlichen Mittelalters. Dans F. Hintze (éd.), Meroitistische Forschungen 1980: Akten der 4. Internationalen Tagung für Meroitistische Forschungen vom 24. bis 29. November 1980 in Berlin [=Meroitica 7] (pp. 484-497). Berlin : Akademie-Verlag

Reisner, G.A. (1908). The progress of the archaeological survey. The Archaeological Survey of Nubia Bulletin, 2, 3-27

Richter, S.G. (2002). Studien zur Christianisierung Nubiens [=Sprachen und Kulturen des christlichen Orients 11]. Wiesbaden : Reichert

Ricke, H. (1967). Ausgrabungen von Khor-Dehmit bis Bet el-Wali. Chicago : University of Chicago Press

Seignobos, R. (2010). La frontière entre le bilād al-islām et le bilād al-Nūba : enjeux et ambiguïtés d'une frontière immobile (VII'-XII e siècle). Afriques, 2. Disponible en ligne : http://afriques.revues.org/800 [accédé: novembre 2015]

Seignobos, R. (2015). Les évêchés nubiens : nouveaux témoignages. La source de la liste de Vansleb et deux autres textes méconnus. Dans A. Łajtar, G. Ochała, et J. van der Vliet (éds), Nubian voices II. New texts and studies on Christian Nubian culture [=Journal of Juristic Papyrology Supplement 27] (pp. 151-230). Varsovie : Raphael Taubenschlag Foundation 
Seignobos, R. (à paraître). Rereading the Oriental sources: Mamluk sources and the history of late Medieval Nubia. Dans M. Honegger (éd.), Proceedings of the 13th International Conference for Nubian Studies - Neuchâtel 2014

Sourdel, D. (1990). Ibn Shaddād. Dans B. Lewis, M.L. Ménage, C. Pellat, et J.Schacht (éds), Encyclopédie de l'Islam III (2 éd., p. 958). Leyde : E.J. Brill

Tamit (1964). Missione archeologica in Egitto dell'Università di Roma [=Serie Archeologica 14]. (1967). Rome : Istituto di Studi del Vicino Oriente

Tsakos, A. (2007). On the medieval inscriptional material from M.D.A.S.P. Dans C. Näser et M. Lange (éds), Proceedings of the Second International Conference on the Archaeology of the Fourth Nile Cataract, Berlin, August 4th-6th, 2005 [=Meroitica 23] (pp. 235-246). Wiesbaden : Harrassowitz

Vantini, G. (1975). Oriental sources concerning Nubia. Heidelberg : Heidelberger Akademie der Wissenschaften

Von Prokesch-Osten, A. (1831). Das Land zwischen den Katarakten des Nil : mit einer Karte, astronomisch bestimmt und aufgenommen im Jahre 1827. Vienne : Gerold

Weeks, K.R. (1967). The classic Christian townsite at Arminna West. New Haven, CT : Peabody Museum of Natural History of Yale University 



\title{
The 'bead-side' story of medieval and post-medieval Nubia: Tentative approach to the bead collection of the Museum of Archaeology University of Stavanger, Norway
}

Joanna Then-Obłuska

Polish Centre of Mediterranean Archaeology, University of Warsaw j.then-obluska@uw.edu.pl

\section{KeYwords}

Beads, pendants, Lower Nubia, medieval, post-medieval, modern

\begin{abstract}
The paper presents a group of beads and pendants from the collection of the Museum of Archaeology University of Stavanger, Norway, derived from excavations carried out by the Scandinavian Joint Expedition to Sudanese Nubia. The finds come from burials at Debeira, Sahaba and Abka, and a church site at Sidi Amir el-Sahaba, and cover a timespan from the Christian period through modernity. A few are currently introduced in terms of the material they were made from and most are paralleled by bead finds from other Nubian sites, but some types remain unidentified. Despite not being welldated or properly provenanced in many cases at this time, they are presented here in order to 'thread' them into the Nubian bead story from medieval and post-medieval times.
\end{abstract}

The bead collection of the Museum of Archaeology University of Stavanger, Norway, encompasses more than 230 beads and pendants coming from Lower Nubian sites ascribed to the Christian (7th-14th centuries) and Islamic periods. The finds were excavated from well-dated archaeological contexts by the Scandinavian Joint Expedition (SJE) to Sudanese Nubia and have been reported on, although not in detail or color (Säve-Söderbergh 1981: 133-134, 136, 158; Gardberg 1970: 36). The present study offers a comprehensive, even if still tentative approach to the collection, contributing a thorough analysis of the 
diverse materials and techniques applied to the production of these beads and pendants, including tracing of the provenance of individual objects, whenever possible, through macroscopic analysis of the material. The intrinsic value of this presentation lies in its contribution of well-dated and investigated material in a field were there is hardly any detailed or illustrated comparative material for the periods under discussion.

The present author's idea for bead studies grew from an understanding of the importance of this category for research on the political and economic changes in the region reflected in local fashion as represented by pieces of personal adornment and for investigation of short and long-distance trade contacts, regardless of whether direct or indirect in character. Professor Włodzimierz Godlewski endorsed the idea immediately when first approached with it by the author in 2009 and has remained an enthusiastic supporter of the project ever since.

\section{Find contexts}

The collection of beads and pendants is presented by findspot, that is, by site and context in which they were found. Objects, including some still tightly threaded on their original string or fragments of string, came from Christianperiod graves in Debeira $(178 / 1,178 / 28)$ and Sidi Amir el-Sahaba (401/60), an Islamic-age grave in Abka (168A/2) and a Christian church at Sidi Amir el-Sahaba (100/179).

Debeira site 178, graves 1 and 28 from an "X-Group, Christian and Muslim cemetery" (Säve-Söderbergh 1981: 133) yielded beads and pendants: 178/1:2, associated with an adult [Fig. 1], and 178/28:6 [Fig. 2] (SäveSöderbergh 1981: 133-134, 136). A pillar with a Coptic capital marked the surface of the latter of the two tombs. The excavators thought that the 10th to 12th century Greek and Arabic tombstones found at the site were reused there in post-Christian Muslim tombs (Säve-Söderbergh 1970: 238). According to William Y. Adams (1981: 26), the pottery he studied from site 178 dates almost exclusively to the AD 550-650 period.

Sidi Amir el-Sahaba site 401, grave 60 yielded beads and a shell pendant (401/60:1) [Fig. 3] comparable to the finds from grave 1 at Debeira site 178. The cemetery was dated broadly from A-Group to post-Meroitic times (SäveSöderbergh 1981). Grave 60 was an intact burial of a two- or three-year-old child. The skeleton was found in contracted position, wrapped in a textile shroud 
(Säve-Söderbergh 1981: 152). Some beads are still preserved on fragments of the original string. Additionally, a leather thong and knot fragments probably belonged to a cowry pendant. Thirteen beads and pendants from the same grave are currently in the collection of the Sudan National Museum (SNM [=The Sudan National Museum, Khartoum] 13794, personal observation).

Sidi Amir el-Sahaba site 100, identified as a Christian church, yielding several beads [Fig. 4] from debris lying on top of the original floor in the nave. The construction of the building was dated to much earlier than the date suggested by $90 \%$ of the pottery finds, which were assigned from after AD 1200 through the 15th century (Gardberg 1970: 36). In the published report, the beads were described as "pottery beads from different places in the filling", but the collection of the museum under this inventory number (100:179) holds many beads made of diverse materials and threaded on modern string, spanning a chronological range from medieval to modern times.

Abka site 168A, grave 2 dated to the Islamic period, probably the 16th century (Säve-Söderbergh 1981: 158), yielded beads and pendants [Figs 5-10] buried with an intact mummified body of a child, probably a young girl wrapped in a textile shroud (Säve-Söderbergh 1981: 49). The assemblage was formed of bracelets, one on the left wrist (168A/2:1) [Fig. 5] and two on the right one (168A/2:2 and 168A/2:3) [Figs 6 and 7], a necklace (168A/2:6) [Fig. 8], a triangular forehead ornament (168A/2:9) [Fig. 9], and a "neck ornament" (168A/2:10) [Fig. 10]. The "neck ornament" originally consisted of "some kind of button with five cowry shells" (non vidi), a pendant made from a brass "counter", and four beads (Säve-Söderbergh 1981: 158, Pl. 102). Most of the finds were kept on their original strings or string fragments.

\section{The collection: analysis by material}

The five different contexts were analyzed separately in terms of the material used to produce the beads and pendants. Production technique, shape, and color were taken into account whenever possible. Material was classified in the following categories: organic, inorganic (minerals and metals), and manmade (faience/glazed composition and glass). Organic materials of faunal origin were divided into aquatic (e.g., mollusk shell, coral) and terrestrial (e.g., ostrich eggshell). Bead shape was defined using Horace Beck's classification (1928). For details, including measurements, see the captions to the figures. 


\section{Context I78/r:2}

The beads from this context were made of the following materials: organic (aquatic: 3 coral, 5 mollusk shell, and terrestrial: 26 ostrich eggshell), inorganic ( 2 carnelian) and manmade ( 25 glass).

Coral. Tiny bead cut from a coral branch [Fig. 1:5], $2.7 \mathrm{~m}$ in diameter, of faded salmon color with characteristic darker lengthwise striations. Small coral beads of Corallium rubrum sp. appeared in late Roman and early Byzantine Egyptian and post-Meroitic Nubian assemblages of the 4th-6th century AD (Then-Obłuska 2015: Fig. 2:2-3). The coral bead from Debeira has a comparatively larger hole opening (1.6 $\mathrm{mm}$ in diameter). The salmoncolored beads measuring about $5.5 \mathrm{~mm}$ in diameter from the same context are made most probably also of coral [Fig. 1:20]. They are similar to large specimens known from a post-Meroitic private and royal graves in Lower Nubia (Then-Obłuska forthcoming a; forthcoming b), as well as from later Nubian contexts (e.g., Adams 2010: 298, No. 78/609, string of seven beads from a context dated to the Classic Christian II period, about AD 950-1172).

Mollusk shell. Irregular short cylinders, made of marine mollusk shell, probably a bivalve [Fig. 1:1]. Large beads from $9.6 \mathrm{~mm}$ to $14.1 \mathrm{~mm}$ in diameter and from $1.8 \mathrm{~mm}$ to $8.5 \mathrm{~mm}$ thick. They are characterized by an oval-shaped hole opening that measures up to $5.2 \mathrm{~mm}$.

Ostrich eggshell. Small, short ostrich eggshell beads, from $2.7 \mathrm{~mm}$ to $3.5 \mathrm{~mm}$ in diameter and from $1.0 \mathrm{~mm}$ to $1.6 \mathrm{~mm}$ thick [Fig. 1:3]. Discand short-cylinder ostrich eggshell beads dominated the bead assemblages on post-Meroitic Lower Nubian burial sites (Then-Obłuska 2014). Later on, they were recorded at non-burial sites in Nubia (e.g., Adams 2010: 300-301; Then-Obłuska 2013: Cat. 39, and compare below).

Carnelian. Long, slightly-faceted octagonal cylinder [Fig. 1:12] and long, tabular hexagonal bicone [Fig. 1:18] with perforations drilled from either end; composed of two parallel-sided segments. The faceted bead is similar to an example from Serra East found in late Christian Serra, about 13th century AD (OIM [=The Oriental Institute Museum, University of Chicago] E24655, personal observation).

Glass. Beads of glass represented both drawing and winding glassworking techniques.

Drawn and segmented glass. A few small blue glass beads were made by the technique of drawing and segmenting [Fig. 1:9, 17]. They measured from $3.0 \mathrm{~mm}$ to $4.0 \mathrm{~mm}$ in diameter. Beads of this kind were common finds on Lower and Upper Nubian post-Meroitic sites (Then-Obłuska forthcoming a). Still, drawn and segmented beads have been recorded at medieval sites 
in North and Northeast Africa, for example, 7th-to-12th century AD Fustat (Francis 2002b: 15, Fig. 2) and 10th and 11th century AD al-Basra, Morocco (Robertshaw et al. 2010: 357, Fig. 4, upper row, Table 1, PR number PR883FM, PR884FM).

A drawn and segmented colorless glass bead is much eroded; it could have been a metal-in-glass bead, which has preserved only the inner layer [Fig. 1:2].

Drawn, cut and rounded glass. Larger drawn glass short barrels with rounded ends, represented by semi-translucent blue beads, $6.0 \mathrm{~mm}$ in diameter [Fig. 1:10], and green beads, $5.4 \mathrm{~mm}$ in diameter [Fig. 1:11].

Many opaque orange drawn standard-to-long cylinder beads, $3.6 \mathrm{~mm}$ to $5.6 \mathrm{~mm}$, have ends that were simply cut or rounded [Fig. 1:4]. Similar specimens were found at Qustul, in an intrusive infant burial (OIM E21837, personal observation; Williams 1992: 10, 306 for beads from infant grave V 65-1; Williams 1989: 90 for the reused grave) and in a Christian burial (OIM E21575, personal observation). Others were picked up out of context in Dongola (Then-Obłuska 2013: Fig. 5:217). The type was recorded also from the Sahaba grave and the church site (see below, Figs 3:3; 4:2).

Mandrel-wound glass. A large translucent blue long-barrel bead made of wound glass measures $7.4 \mathrm{~mm}$ in diameter and $15.4 \mathrm{~mm}$ in length [Fig. 1:19]. Another bead might have been a wound gold-in-glass bead [Fig. 1:7]. It measures $6.1 \mathrm{~mm}$ in diameter, $3.7 \mathrm{~mm}$ in thickness, and has a hole diameter of $3.0 \mathrm{~mm}$. A short-barrel bead is characterized by a thick transparent glass layer and heat-rounded ends; whether the lustrous appearance of the object is due to thin gold or silver foil embedded between layers of transparent glass cannot be established at present. Combining glass beads with metal was a technique used from Hellenistic times through the Middle Ages (Spaer 2001). Wound gold-in-glass beads are part of an 11th-12th century necklace from Iran (Jenkins 1986: Cat. 77, MET [=Metropolitan Museum of Art, New York] 1973.347; Dubin 2009: Timeline, No. 500).

A wound, rough, opaque olive green short-barrel bead measures $6.2 \mathrm{~mm}$ in diameter and $5.3 \mathrm{~mm}$ in thickness [Fig. 1:15].

An outstanding opaque orange short-cylinder type bead seems to be made of wound glass [Fig. 1:8]. It measures $6.0 \mathrm{~mm}$ in diameter.

While some standard-barrel beads with an opaque blue color have an applied white central trail [Fig. 1:16], other beads were made of banded glass. The latter include a long-barrel bead with an opaque blue color and two white bands [Fig. 1:14], and a dark purple long-cylinder bead with a single white band [Fig. 1:G]. 


\section{Context 178/28:6}

The beads from this context were made of the following materials: organic (aquatic: 2 mollusk shell) and manmade (12 faience).

Mollusk shell. Two cowries, one of them identified as Monetaria moneta sp., present a removed dorsum [Fig. 2:1]. In Nubia, worked cowries were found in an early Christian context in Meinarti (Adams 2001: Pl. 10b,c,d, Object 802, Level 13, Phase 3a, about AD 660-750). Cowries on leather thongs, probably worn as bracelets, were found at Qasr Ibrim in Early and Classic Christian contexts (7th to 12th centuries AD) (Adams 2010: 187). Perforated shells of Monetaria moneta sp. were recorded at Dongola (Then-Obłuska 2013: 682, Fig. 1:190) and Abkanarti (MAN [=Museo Arqueológico Nacional, Madrid] Inv. Nos 1980/101/1073, 1074, personal observation). They are recorded in Egypt among early Islamic Fustat finds (Rodziewicz 2012: Pl. 123.4-5) and from the 13th-14th centuries AD layers at the Red Sea port site of Quseir al-Qadim (Hamilton-Dyer 2011: Fig. 20.3.2).

Faience. Twelve large faience rings have white cores and blue glaze [Fig. 2:2], traces of which can be discerned in the perforation. Large blue faience rings range from $13.8 \mathrm{~mm}$ to $18.5 \mathrm{~mm}$ in diameter, from $7.0 \mathrm{~mm}$ to $11.2 \mathrm{~mm}$ in thickness, and have hole diameters ranging from $5.6 \mathrm{~mm}$ to $8.2 \mathrm{~mm}$. The beads are consistent with a faience bead found at the Sahaba church (see below, Fig. 4:6, 22, 23), as well as with many beads from medieval sites in Nubia.

Although large faience beads were once ascribed to the medieval period in Nubia, they lack more specific dating. They were found in a broadly-dated level at Meinarti, assigned to phases 3-4, 7th-12th centuries AD (Adams 2002: 114, Object 1471, SNM 17526). The large faience beads and Monetaria moneta sp. shells were found together in many Nubian assemblages, e.g., Bab Kalabsha (OIM E42044, E42045, personal observation) and Kasanarti (SNM 17146, personal observation). At Serra East (OIM E24655, personal observation), they were found together with a faceted bead made of mosaic glass overlying a monochrome core. This type of glass bead is said to be more likely post-10th century (Lankton 2003: 77, Fig. 8.3, upper row) and the context of the Serra finds is late Christian, around the 13th century $\mathrm{AD}$ (Bruce $\mathrm{B}$. Williams, personal communication). In Dongola, large faience beads appeared in non-burial contexts dated to the 13th and 14 th centuries, and their use intensified in the post-Makuria Islamic period (Then-Obłuska 2013: 715).

\section{Context 401/60:1}

The beads from the burial are held partly in Stavanger and partly in Khartoum. The collection in the Sudan National Museum consisted of seven drawn, long-cylinder beads of opaque orange to red glass (see below, Fig. 3:3), one cowry shell (see below 
Fig. 3:1), some miscellaneous glass beads, and two long coral beads (SNM 13794, personal observation). The SJE assemblage consisted of 1 mollusk shell (organic aquatic category) and 11 beads of manmade material, 1 of faience and 10 of glass.

Mollusk shell. Unlike the cowry shell examples with removed dorsum described above (see Fig. 2:1), a smaller hole for threading was made in the dorsum of Monetaria moneta sp. [Fig. 3:1].

Faience. One tiny faience bead, measuring $2.8 \mathrm{~mm}$ in diameter [Fig. 3:2]. Small coarse faience beads are common finds in the post-Meroitic period (ThenObłuska 2014). Later on, they become rare (e.g., Adams 2010: 298-300).

Glass. Coiled glass beads appeared next to drawn ones.

Drawn and cut or broken glass. Long-cylinder drawn beads of opaque orange color [Fig. 3:3], from $2.7 \mathrm{~mm}$ to $4.3 \mathrm{~mm}$ in diameter, $5.7 \mathrm{~mm}$ to $11.0 \mathrm{~mm}$ in length, hole diameter of around $1.0 \mathrm{~mm}$. This type was already recognized in the SJE assemblage (see above, Fig. 1:4, and below, Fig. 4:2).

Drawn and rounded glass. One small short-barrel light blue glass bead [Fig. 3:5] and half of a long-cylinder aqua green bead, their ends slightly rounded [Fig. 3:4].

Coiled glass. A translucent blue double bead [Fig. 3:6] and an opaque black single-coiled bead [Fig. 3:7] are outstanding wound objects in the assemblage. They measure 4.4 to $4.6 \mathrm{~mm}$ in diameter. Coiled glass beads belong among the most recognizable Chinese bead types (e.g., Francis 2002a; Liu 2013). They have been macroscopically recognized in the Awad Collection from Fustat, Old Cairo (e.g., Francis 2002b: 24-25). A chemical compositional study has pointed to Singapore as the origin for the coiled bead found in the 14th century Red Sea port of Quseir al-Qadim in Egypt (Then-Obłuska and Dussubieux 2016). Small coiled beads in opaque light blue, white and semi-translucent dark blue have also been illustrated from an Islamic child grave in the Fourth Cataract region in Sudan (Then-Obłuska 2014: 1072-1073, Pl. 2: Cat. 243-245). Chemical composition analysis of Sahaba examples should resolve the question of their provenance (Gan 2009; Carter and Beavan 2014: 17).

\section{Context 100:179}

The materials represented by beads from this context include: organic (terrestrial: 1 wood, 2 ostrich eggshell), inorganic (1 carnelian) and manmade (8 faience and 21 glass).

Wood. A single large wooden (date palm?) disk measuring $13.3 \mathrm{~mm}$ in diameter and $1.9 \mathrm{~mm}$ in thickness [Fig. 4:1]. Similar large disks made of bone were found attached to a leather-plaited thong together with resin beads at Byzantine Qarara in Egypt (Vorderstrasse and Treptow 2015: 180, Fig. C6). 
Ostrich eggshell. Two very different ostrich-eggshell beads were recorded at Sahaba. One is a cream-colored regular disk cylinder, $7.3 \mathrm{~mm}$ in diameter. It was perforated from both ends [Fig. 4:3]. The other disk bead is slightly larger in size, $9.8 \mathrm{~mm}$ in diameter, and brownish in color [Fig. 4:21].

Carnelian. A large, long hexagonal cylinder, $12.6 \mathrm{~mm}$ wide, $9.7 \mathrm{~mm}$ thick, and $25.9 \mathrm{~mm}$ long [Fig. 4:4]. Drilled from either end, the perforation is composed of two parallel-sided segments. Long hexagonal cylinders are known from 9th-12th century Nishapur, Iran (Jenkins 1986: 30-32, Cat. 11, MET 48.101.70). From Nubia, they were recorded at medieval Soba and a stone bead production center in Cambay, India, has been suggested as their provenance (Shinnie 1961: 53, Fig. 28:22). Such large hexagonal beads were also recorded at a graveyard in Karagunduz, Eastern Anatolia. However, some of the burials in this graveyard dated from the end of the 16th century (Sevin and Sevin 2007: Fig. 17).

Faience. Two small faience beads were picked up at Sahaba: a short bicone with greenish glaze [Fig. 4:20] and an oblate with bluish glaze traces [Fig. 4:11]. Many biconical faience beads were found at the Christian site of Meinarti, level IIb (3c), dated to the Classic Christian I period, about AD 850-960 (Adams 2001: 37, Pl. 10a: Object 671, Site 6-K-3, SNM 18142, personal observation). A biconical bead was also recorded from 12th-13th century levels at Dongola (Then-Obłuska 2013: Fig. 4: Cat. 98, D.10.0 mm and Th.6.6 mm).

Two large faience rings and a few fragments were collected from church fill $[$ Fig. 4:6, 22, 23]. Some string remnants were preserved in the perforation of one of them [see Fig. 4:22]. The beads are similar in appearance to other large faience rings from Debeira and to many others from medieval Nubia (see above, Fig. 2:2).

Glass. Molded beads were represented also beside drawn and mandrelwound specimens.

Drawn and cut glass. Some opaque orange beads are sections of long drawn glass tubes. They measured from $3.2 \mathrm{~mm}$ to $5.6 \mathrm{~mm}$ in diameter, and from $4.0 \mathrm{~mm}$ to $14.5 \mathrm{~mm}$ in length, with a hole diameter of $1.0 \mathrm{~mm}$ to $1.9 \mathrm{~mm}$ [Fig. 4:2]. Many of them were found in a Debeira grave (see above, Fig. 1:4) and in a child's grave in Sahaba (see Fig. 3:3).

Drawn and rounded glass. A semi-translucent orange long drawn glass bead [Fig. 4:17] and a semi-translucent green drawn glass cylinder [Fig. 4:7] have their ends rounded and are around $4.0 \mathrm{~mm}$ in diameter.

Drawn and constricted glass. A semi-translucent blue short-barrel bead [Fig. 4:16] and translucent blue beads are made of drawn glass and are characterized by constricted ends [Fig. 4:10]. 
Mandrel-wound glass. An opaque blue glass bead has traces of glass winding that are discernible in the surface next to the hole opening [Fig. 4:12]. It measures $7.9 \mathrm{~mm}$ in diameter and $7.0 \mathrm{~mm}$ in thickness.

A single dark purple long-barrel bead [Fig. 4:18], a fragment of a blue glass melon bead [Fig. 4:24], and a blue glass fragment [Fig. 4:25] are wound. A similar fragment of a melon bead has been recorded from Christian Serra East (OIM E19806, personal observation).

A blue wound glass bead [Fig. 4:14] and a small irregular blue glass bead may belong to the same category [Fig. 4:8].

European-made wound beads found at Sahaba are an opaque white [Fig. 4:13, 15]. They have been found as far as at Mapungubwe hill and K2 in Southern Africa (Prinsloo, Tournié, and Colomban 2011: 3275, Fig. 3f). The chemical composition of the glass could verify a more precise date of production. In Europe, a transition was made from tin-rich to antimony-rich opacifiers during the 17th century, which was again replaced by arsenic in the 18th and 19th centuries (Sempowski et al. 2000).

Molded glass. A raised medial band, characteristic of Prosser molded beads, can be discerned on a green bead [Fig. 4:19]. The materials that make up the mixture ${ }^{1}$ include crushed feldspar, calcium fluoride, and silica sand. Metallic oxides (used by potters and glassmakers alike) are added to obtain the desired colors. Milk was introduced by Bapterosses as a binder to hold the powder together as it was pressed into the molds. Beads that are made by the Prosser method share several distinguishing features. Mold seams often create pronounced equatorial bands on spherical beads (van der Sleen 1973: 114; Kaspers 2014: 48).

The Nubian example could be either French or Czech, as it is practically impossible to distinguish between the two. The Prosser beads were made for a relatively long time (about 1860-1960s) and it is uncertain when exactly their bulk was made. The bead from Sahaba was created no earlier than 1870 (F. Kaspers, personal communication).

\section{Context 168A/2:1-3, 6, 9-10}

This was a rich context with different objects made up of beads and pendants, but glass beads prevailed (108) with just a smattering of other materials ( 8 organics and 3 brass).

1 Prosser beads are also called Bapterosses beads after the French entrepreneur who further improved the Prosser method for the manufacture of buttons, and began making beads in France in the 1860s. For production of Gablonz (Jablonec and Nisou) molded beads during the 19th and 20th centuries, see Neuwirth 2011: 69-83. 
Coral(?). Three semi-translucent long-cylinder beads measuring from $2.3 \mathrm{~mm}$ to $3.3 \mathrm{~mm}$ in diameter and from 26.7 to $30.2 \mathrm{~mm}$ in length [Fig. 9:2], made most likely of sections of black coral, a gorgonian or horny coral. Gorgonian (Gorgoniidae or Plexauridae) skeletons have a lengthwisestriated surface and become translucent when dried (Cooper et al. 2011: 7273, Fig. 3.3.21-22).

The material of the above-mentioned beads is similar to that forming the larger, long- [Fig. 7:1] and short-cylinder beads [Figs 7:2; 10:2]. They range from $4.6 \mathrm{~mm}$ to $5.1 \mathrm{~mm}$ in diameter. Their perforations are slightly off-center.

Glass. This extensive assemblage presents a variety of drawn beads as well as ones of mandrel-wound glass.

Drawn and cut/broken glass. Many beads were made of monochrome drawn glass that was shaped into a square tube and cut up or broken into standard and long-square cylinders. They are a transparent [Figs 5:1; 8:2] and translucent blue color [Figs 5:2; 6:1; 8:3], and measure from $3.9 \mathrm{~mm}$ to $5.3 \mathrm{~mm}$ in diameter and from $4.1 \mathrm{~mm}$ to $7.3 \mathrm{~mm}$ in length.

Drawn and rounded glass. Small, semi-translucent green short and standard cylinders $3.1 \mathrm{~mm}$ to $3.9 \mathrm{~mm}$ in diameter [Figs 8:4; 9:3] and a large opaque dark red one of $4.8 \mathrm{~mm}$ in diameter [Fig. 6:4]. Also, an opaque yellow drawn bead, $4.5 \mathrm{~mm}$ in diameter, appears to have rounded ends [Fig. 9:4].

Drawn and segmented glass. A translucent blue segmented drawn bead is an outstanding piece in terms of color and technique [Fig. 10:3].

Drawn and segmented metal-in-glass. Single- and multiple-segmented drawn metal-in-glass beads measure $3.2 \mathrm{~mm}$ to $4.2 \mathrm{~mm}$ in diameter [Figs 8:6; 9:6. Metal-in-glass beads, also known as sandwich metal-glass beads, are made from two tubes of drawn glass. An inner tube was coated with metal foil and slipped into a wider tube before the whole construction was segmented. The result was a golden or silver bead, with the thin foil protected by the outer casing of glass (Francis 2009: 93). Drawn gold-in-glass and silver-in-glass beads were known in the whole ancient world from the Hellenistic period on, and their production lasted until medieval times. The 16th century goldin-glass examples are rare finds, and they were mentioned by Peter Francis, Jr. (2009: 93, Type 115 - 3) as being one of the European beads found at a 16th-17th century burial site on St Catherines Island (Georgia, USA).

Mandrel-wound glass. Translucent green short and standard barrels, single- [Figs 6:2; 7:5] and double-segmented [Figs 7:6; 9:5], measuring from $4.7 \mathrm{~mm}$ to $5.8 \mathrm{~mm}$ in diameter. 
A semi-translucent/opaque green short-cylinder and barrel [Figs 6:3; 7:10, 11;9:8], blue [Fig. 7:8], and opaque light blue beads [Fig. 7:9] range from $4.0 \mathrm{~mm}$ to $4.6 \mathrm{~mm}$ in diameter.

Opaque yellow truncated barrels and cylinders appear as short- [Figs 7:4; 8:5; 9:7] or double-segmented beads [Fig. 7:3]. They measure between 3.3 $\mathrm{mm}$ and $5.3 \mathrm{~mm}$ in diameter. Similar beads, although larger in size, are known from Dongola, dating from the 14th-15th century AD (Then-Obłuska 2013: Fig. 6: Cat. 157, D.11.3, Th.7.8, HD.2.8-3.7).

Opaque dark red glass was wound into a long cylinder and measures $5.3 \mathrm{~mm}$ in diameter [Fig. 6:5]. It seems to be made from the same glass as the drawn one (see Fig. 6:4).

Brass. Nuremberg counting jetons, otherwise called reckoning counters, were identified as being made of brass (Säve-Söderbergh 1981: 158). They were used in calculations on a lined board similar to an abacus. Nuremberg jetons in particular are known to have been produced in very large quantities, and they were distributed widely throughout much of Europe and beyond (Barnard 1916: 65, 208). Three examples from Debeira were reused as pendants [Figs 8:1; 9:1; 10:1]. In every case, the obverse presents three French lillies (fleur-de-lis) with two annulets/pellets above, alternated with three crowns around a central rose with five petals [Figs 8:1a; 9:1a; 10:1a]. On the reverse, an imperial orb (called a Reichsapfel) in trefoil (within a double tressure of three arches and three angles) is surmounted by a cross [Figs 8:16; $9: 1 b ; 10: 1 b]$. On both sides, the decoration is bordered by Gothic letters. The legends appear to be intentionally absurd and meaningless.

According to Mitchiner (1988: 377), the rose/orb type in the anonymous series has a rose with five petals. ${ }^{2}$ They were minted in Nuremberg between 1500 and 1585. Similar pierced jetons, manufactured in the late 16th and early 17th centuries, are not infrequently found in excavations in Israel (Kool and Ariel 2002: 10, Cat. 5-7). Two Nuremberg jetons and one silver Venetian coin (all dating to the 16th century) were also found at Al-Mina, a port of Antioch (Vorderstrasse 2005: 146). The Nuremberg jetons are also known from the Amuq Plain (T. Vorderstrasse, personal communication), Rhodes (Kasdagli 1999; Wilski 1993), Corinth (Rohn, Barnes, and Sanders 2009), and last but not least from Qasr Ibrim. A catalog card for the latter is kept at the British Museum and describes objects like the 16th-century one (Vorderstrasse in preparation, and see discussion below).

2 For a rose with six petals recorded in France, see Yoon 2005: 179, Cat. 12, Pl. 29:12. 


\section{Discussion and conclusions}

The material presented here demonstrates the diverse nature of medieval and post-medieval Lower Nubian personal adornments with a wide range of objects dating up to the 19th century. While the beads from the Abka tomb can been dated to the 16th century, the finds from Debeira and Sahaba seem to be earlier. Taking into consideration parallels known from other Nubian sites, the Debeira and Sahaba finds can be dated generally to the Christian period. Moreover, Adams's estimation of the date of pottery from site 178 (1981: 26) would support the early Christian dating of finds from Debeira 178/1 and similar bead types from Sahaba 401/60 [Figs 1 and 3]. Modern beads collected at the church site [see Fig. 4] are obvious exceptions.

Some beads from Debeira and Sahaba are made using materials and techniques known from the post-Meroitic period. These are ostrich-eggshell and coral beads, small faience beads, and monochrome drawn and segmented glass beads. The new types that are introduced here are large beads cut from mollusk shell, perforated Monetaria moneta sp., a crude wound bead of opaque green glass, Chinese coiled monochrome beads, opaque orange drawn glass long cylinders, and crude faience rings.

By the 12th century, large blue faience beads were commonly found in early Islamic centers, such as Siraf or Fustat, where they were believed to possess amuletic properties and were used to protect animals and children (Then-Obłuska 2013: 715). In Debeira [see Fig. 2], faience rings were found with cowry beads in a human burial, confirming that this type of faience bead was used as a personal adornment. Taking into consideration the quantity and quality of the Nubian specimens, they were most probably locally produced.

In the child burial at Sahaba (see Fig. 3:3 and SNM 13794, personal observation) and in the Christian burial at Qustul (OIM E21575, personal observation), the orange glass beads were found strung together with long coral ones of Mediterranean Corallium sp. It is probable that long-cylinder beads of orange glass served as perfect imitations of coral, which was a fertility symbol and from antiquity it was given to children as a talisman to be worn around the neck (Torntore 2004; Ward 2008: 145-147). The 11th-century AD Persian poet and traveler Nasir-i-Khusraw mentioned coral, next to beads and combs, as a traded import in Nubia (in Vantini 1975: 233).

Orange glass and coral beads were found together with Monetaria moneta sp. shells in the Sahaba grave. While the Red Sea Cyprea annulus sp. was usually used in Nubian beadwork until the post-Meroitic period (e.g., Then-Obłuska 
forthcoming b), it was Monetaria moneta sp. that was commonly recognized from medieval and post-medieval sites in Nubia and Egypt (see above). Cowries have always been an important part of rich Nubian beadwork. A dance scene combining indigenous African and Arabic features confirms the diversity of Nubian society also in the 12 th-13th centuries $\mathrm{AD}$. This scene is preserved in a wall painting at an annex of the monastery in Dongola. Among other things, it depicts cowry beadwork in the form of a necklace and decorated masks (Martens-Czarnecka 2011: 234-236 and Cat. 109). Nevertheless, it is impossible to ascertain whether Monetaria moneta sp. specimens as found in medieval and post-medieval Nubia were of the Red Sea or Indian Ocean origin. Similarly, it remains uncertain whether large carnelian beads and small drawn and rounded glass beads are of Indian provenance. Moreover, the Chinese provenance of the coiled glass beads at Sahaba should be verified through chemical compositional analysis. Trade in some beads and bead materials could have been incorporated into networks existing in the Indian Ocean maritime trade between the Middle Eastern Islamic center and its western Indian Ocean periphery. Khutba networks played an important role in the expressions of allegiance and thinking of Muslims living under non-Muslim rule. They existed in the Indian Ocean at least from the 13th century AD into the 15th and 16th centuries and the dawn of the modern era. Various reports indicate that by the 19th century, it was the Ottoman Caliph's name that was used among Muslim communities from Sri Lanka to northern India (Lambourn 2008; 2011).

Lower Nubian beadwork from the medieval and post-medieval periods provides evidence for a lively connection with sea littorals. This can be observed in organic materials such as mollusk shells and corals. Some of them may have arrived in the Nile Valley as offshoots of overseas trade contacts. They may have formed part of an everlasting trade activity of the Eastern Desert population in the region between the Nile Valley and the Red Sea coast (Dahl and Hjort-afOrnas 2006).

At one point, Lower Nubian beadwork was influenced by the politics, trade and culture of the Ottoman Empire. The rich and consistent originallystrung beadwork found in the burial of a young girl in Abka seems to be an intentionally composed set in which the same bead and pendant types are repeated in a necklace, bracelets, neck and head adornments [see Figs 5-10]. The set of bead adornments with Nuremberg brass jetons has already been dated to the 16th century AD. If the associated beads are of a similar date, the jetons would provide the approximate dating for many drawn and wound glass bead types, including drawn and segmented metal-in-glass, that were found as originally strung and arranged. Whether all glass beads in the Abka beadwork are of European origin remains uncertain. Similarly, the identification of the 
material that the long flared cylinder beads [see Fig. 9:2] were made of cannot be confirmed. They are tentatively identified as a Red Sea coral species.

Coins are known to have been used as jewelry in late antiquity and this practice continued into modern times (Bruhn 1993). Necklaces composed of glass and faience beads, and 16th- and 17th-century Nuremberg jetons were excavated in Corinth at a 17th-century Ottoman cemetery with evidence of Christian and Muslim burial practices. The jetons were found with Christian-style child burials. ${ }^{3}$ Beads in the necklaces were white, yellow, and dark blue, and accompanied by jetons (Rohn, Barnes, and Sanders 2009: 525-526, 597, Figs 31-32). However, the so-called "neck ornament" from Abka that was composed of a brass counter and coral(?) and glass beads could be a part of a head ornament. It was found linked to a metal cupola button-like adornment set on a round fiber base to which five Monetaria moneta sp. shells were attached (Säve-Söderbergh 1981: Pl. 102:1-3). Such a central metal cupola disc with attached strings of coral beads and coins is a typical element of Ottoman bridal head ornaments. Thus, the Abka "forehead ornament" and "neck ornament" [see Figs 9, 10] may once have been parts of a headdress adornment. Judging by the results of ethnoarchaeological studies, it may have belonged to a bride (e.g., Gansell 2007: 455-456) or a girl who died before marriage.

Excavators explained the presence of jetons in Abka as related to the conquest of Nubia by Soliman the Magnificent, who installed garrisons of European origin, e.g., Bosnians and Hungarians in the Second Cataract region. An island in the neighborhood is called Magyanarti and the personal name of Magyar is still used by the Nubian population (Säve-Söderbergh 1981: 49). Presumably, the Abka specimens reached Lower Nubia through European commerce with the Ottoman Empire. ${ }^{4}$

The beads from the church at Sidi Amir el-Sahaba are a chronologicallymixed assemblage which also contains modern European objects. Europeanmade green Prosser bead [see Fig. 4:19] belongs to this group. White Prosser beads (OIM E24513, personal observation) have been recorded from Serra East in Lower Nubia. These cases provide evidence for the European bead trade

3 Burials of a 10 or 11-year-old child (grave 33), a 12 or 13-year-old pre-adolescent (burial A in grave 54), and an infant (grave 73) (Rohn, Barnes, and Sanders 2009: 525-526, 597).

4 The complicated process of circulation and fast change in requisition of beads in Northeast Africa is exemplified by the story of James Bruce, an 18th-century European explorer. $\mathrm{He}$ employed a person to buy beads at Jeddah, Arabia, to be bartered among the Tigre people on his journey to Ethiopia. Surprisingly, he faced an abrupt change in bead fashion "among the beauties of Tigré" (Tigray) from one year to the next, and all of his beads were rejected as their colors and shapes were no longer in use (in Phillips 2012: 489-490). According to Jackie Phillips (2012: 490), the rejected beads might have been given away or bartered in the countryside of Sudan or Egypt. Bruce's story would rather indicate that the beads were arriving in Northeast Africa also from an Asian direction in the 18th century. 
in Nubia into the 19th century. Furthermore, a Nissim Namer bead sample card from Sudan, presently in the Royal Ontario Museum (Accession No. 907.31.11), exhibits European beads that were used by Sheikh Abdullah about 1870. The handwritten note on the card speaks of Sheikh Abdullah being with Mahdi during this period (Billeck 2008: 50, Pls IXC, XA).

Further details and interdisciplinary studies on bead material identification and chronology should allow for more specific conclusions concerning the typology and provenance of beads from the Nubian medieval and post-medieval periods.

\section{ACKNOWLEDGMENTS}

I wish to thank Arne Johan Nærøy, director of the Museum of Archaeology University of Stavanger (MAUS), for making this study possible. My deepest gratitude goes to Åsa Dahlin Hauken (MAUS) for her assistance during my time in the museum. I appreciate the help of Dr. Ghalia Garelnabi, the Director of the Sudan National Museum (SNM) and Sarah Abdulatteef from the SNM for checking on beads from the SJE collection, presently kept in the SNM. I am especially indebted to Dr. Tasha Vorderstrasse for sharing her knowledge on Nuremberg jeton finds, to Floor Kaspers for her confirmation on Prosser beads, and to Dr. Daniella Bar-Yosef for information on mollusk shell beads. Special thanks go to Dr. Matthew Richmond for discussion on potential coral beads from Abka. Comments and improvements by two anonymous reviewers are greatly appreciated. The study is part of a broader research project focused on an interdisciplinary analysis of Nubian beads funded from National Science Centre grant UMO-2013/09/D/HS3/04508.

\section{FIGURES}

The objects illustrated in the plates are identified by their catalogue numbers. The catalogue is presented by archaeological context as found by the Scandinavian Joint Expedition to Sudanese Nubia. Bead descriptions list (in sequence): material (quantity) | technique | shape (following a classification by H. Beck [1928]) | color (according to the Munsell Bead Color Book) and degree of transparency $\mid$ measurements (given in millimeters; D. - diameter, L. - length, W. - width, Th. - thickness, H. - height, HD. - diameter of hole opening). All photos and plate design by the author. Lowercase letters mark different photo views of objects in the plates. 


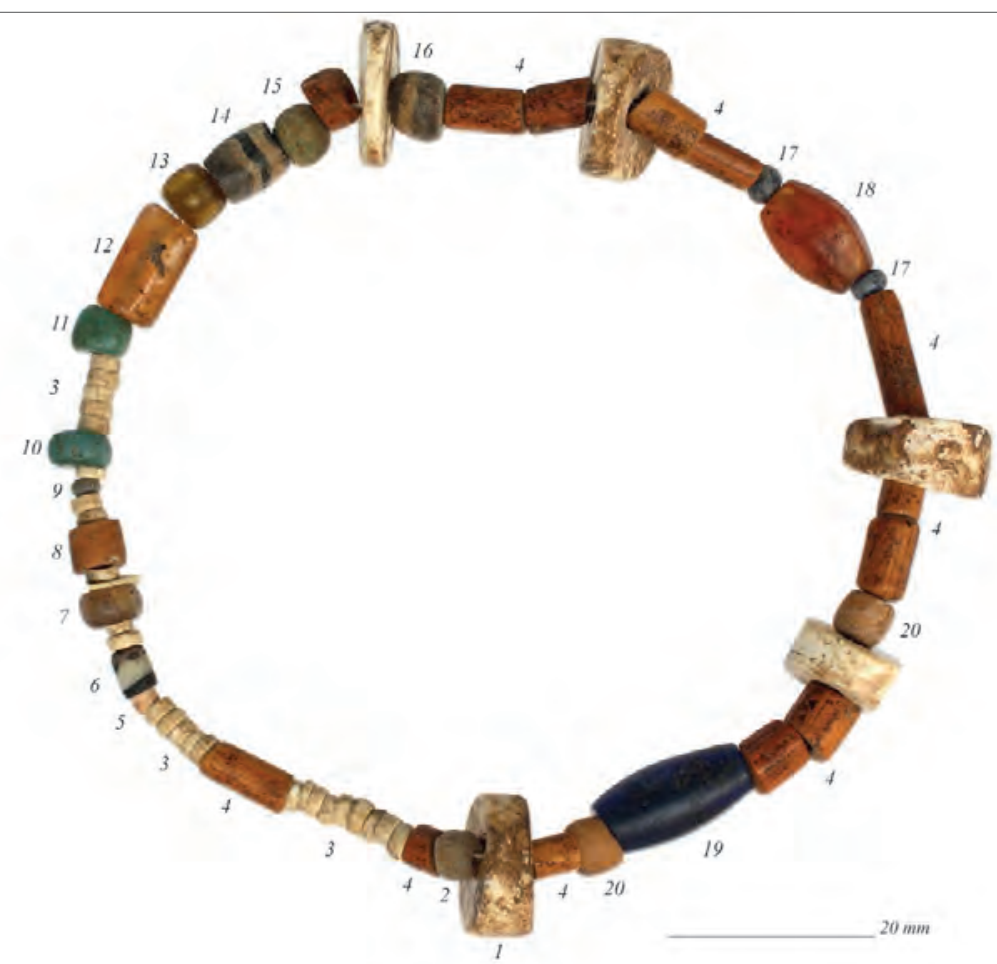

1. Mollusk shell (5) $\mid$ short cylinder|light ivory $2.5 Y 9 / 3 \mid$ D.13.8x12; 10.2x9.6; 14; 13.6; 14.1, Th.4.3-6.7; 4.9-6.7; 3.9-6.9; 2.4-8.5; 1.8-4.2, HD.2.6x5.2; 3.0x3.9; 3.2x4.7; 5.2×3.4; 5.1×3.5

2. Glass (1) $\mid$ drawn, single-segmented barrel|light lemon yellow $7.5 Y 8 / 6$, semi-translucent $\mid D .5 .5$, Th.4.5, HD. 1.5

3. Ostrich eggshell (26)| short cylinder|D.2.7-3.5, Th.1.0-1.6, HD.1.0

4. Glass (13)| standard to long cylinder $\mid$ copper $\mid 2.5 Y R$ 5/10|D.3.6-5.6, Th.4.4-14.5, HD.1.0-1.9

5. Coral (1)|short cylinder $\mid$ salmon|D.2.7, Th.2.2, HD.1.6

6. Glass (1)|wound, long cylinder|garnet $2.5 R 2 / 6$ apparent black with white band $\mid D .3 .6$, L.4.7, HD. 1.0; 1.6

7. Glass (1)|wound, short barrel|D.6.1, Th.3.7, HD.3.0

8. Glass? (1)|short cylinder|sandalwood 7.5YR 5/10|D.6.0, L.4.5

9. Glass (1)|drawn segmented, oblate|garnet 2.5R 2/6 apparent black, semi-translucent|D.2.9, Th.1.8, HD.1.2

10. Glass (1)|drawn, short barrel|medium turquoise blue $2.5 B 5 / 5$, semi-translucent $\mid$ D.6.0x5.5, Th.3.4, HD.1.4

11. Glass (1)|drawn, globular|surfgreen 5.0G 5/4, semi-translucent|D.5.4, Th.4.6, HD.1.4

12. Carnelian (1)|drilled from both ends, long octagonal cylinder|light orange-red, translucent|D.6.6x5.1, L.11.5, HD.1.2

13. Glass (1)|drawn, short barrel|amber, translucent|D.6.1, Th.5.0, HD.2.0

14. Glass (1)|barrel, black and white banded body|D.6.3, L.7.5, HD.1.2; 1.7

15. Glass (1)|wound, globular|olive 10.0Y 4/4, opaque|D.6.2, Th.5.3, HD.1.2; 2.2

16. Glass (1)|barrel, black body with white trail, opaque|D.6.6, Th.5.2, HD.2.0, 2.5

17. Glass (2)|drawn and segmented, oblate|medium blue 5.OPB 3/6, semi-translucent $\mid$ D.3.7, Th.3.0, HD.1.0

18. Carnelian (1)|drilled from both ends, hexagonal tabular bicone, terracotta 2.5YR 4/10, translucent $\mid D .8 .9 \times 6.5$, L.12.2, HD.1.3

19. Glass (1)|wound, long barrel|dark blue 7.5PB 2/5, translucent|D.7.4, L.15.4, HD.2.3; 2.5

20. Coral (2) $\mid$ standard barrel|sandalwood $7.5 Y R$ 5/10|D.5.5x5.0; 5.4, L.3.4-4.7; 4.9, HD. 1.2; 1.6 
The 'bead-side' story of medieval and post-medieval Nubia: Tentative approach...

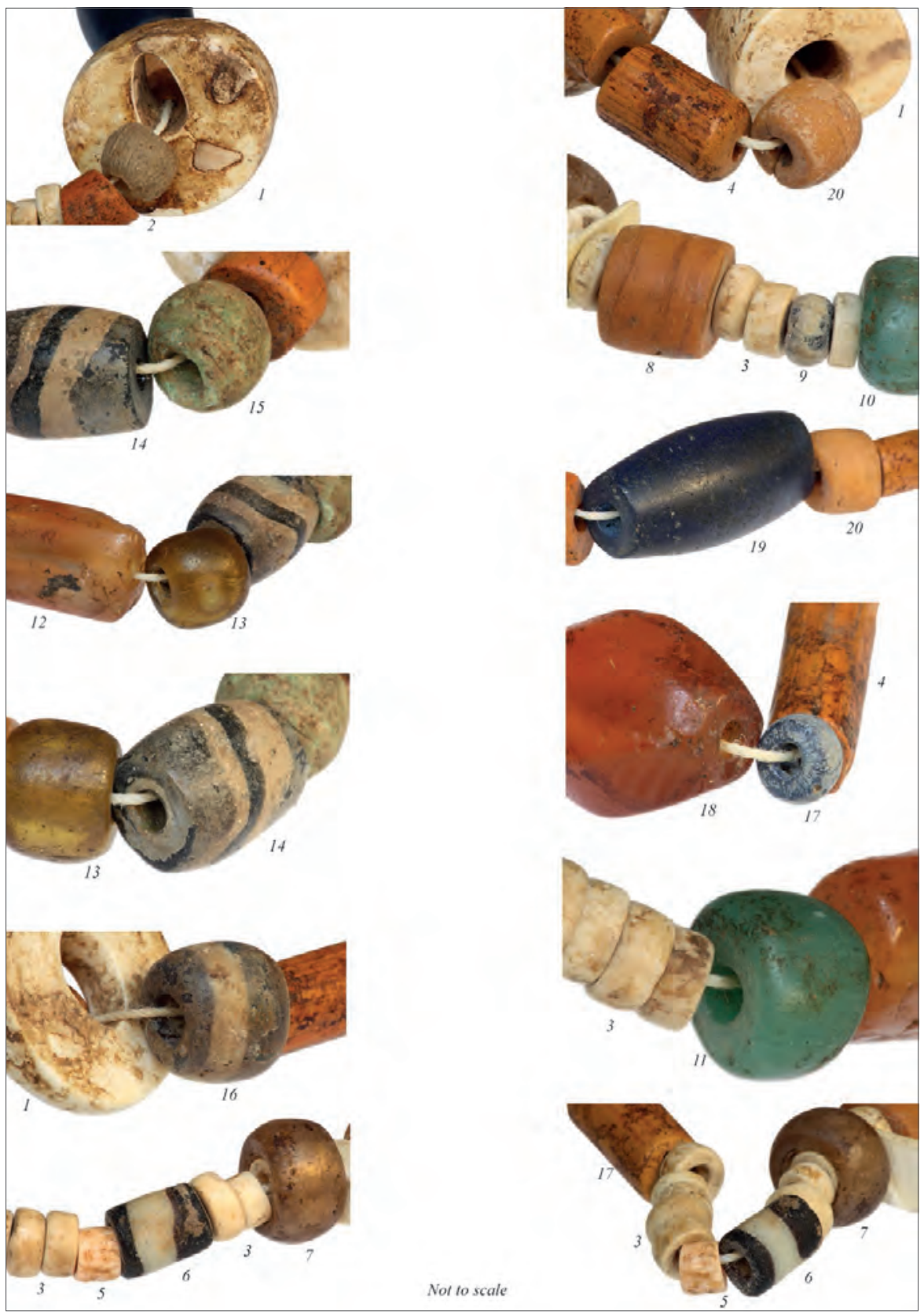

Fig. 1. Debeira, Fadrus 178/1:2; opposite page, modern stringing and arrangement (After Säve-Söderbergh 1981: 133-134) 
1. Cowry (2)|||W.14.3, Th.7, L.17.6, HD.9.7x7.7; W.14.1, Th.5.5, L.19.1, HD. $10.2 \times 14.4$

2. Faience (12)|ring |medium turquoise blue 2.5B 5/5|D.13.8-18.5, Th.7.0 11.2, HD.5.6-8.2

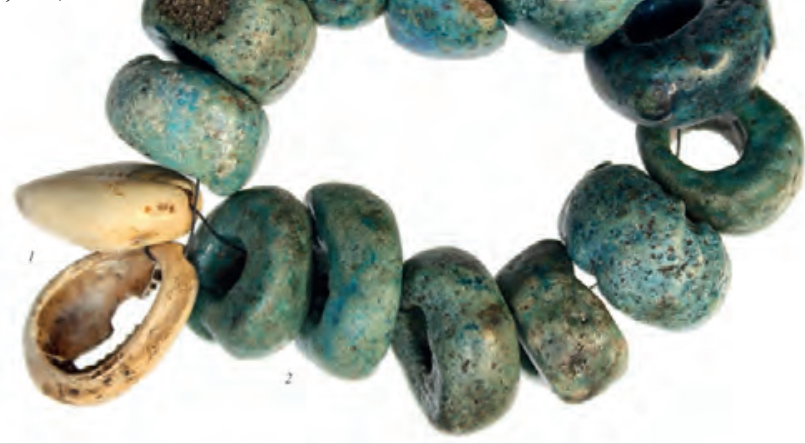

Fig. 2. Debeira, Fadrus 178/28:6; modern stringing and arrangement (After Säve-Söderbergh 1981: 134)

1. Monetaria moneta sp. (1)|body perforated|white, opaque|W.7.9, Th. 5.4, L12, HD.3.0x1.5

2. Faience (1)|short tube| light blue spruce 5.0BG 6/3|D.2.8, Th.1.6, HD.1.2

3. Glass (6)|drawn, long cylinder|russet orange 5.0YR 6/12, opaque|D.2.7-4.3, L.5.7-11.0, HD.1.1

4. Glass (1/2)|drawn, long cylinder|aqua green $7.5 B G$ 6/6, opaque|D.3.5, L.9.3, HD.1.0

5. Glass (1)|drawn, short barrel| light turquoise 10.0BG 7/4, translucent|D.4.4, L.3.4, HD.1.2

6. Glass (1)|coiled, barrel|dusk blue 5.OPB 4/8, translucent|D.4.4, L.3.5, HD1.5

7. Glass (1)|coiled, short barrel|black, opaque|D.4.6, L.2.4, HD.2.1

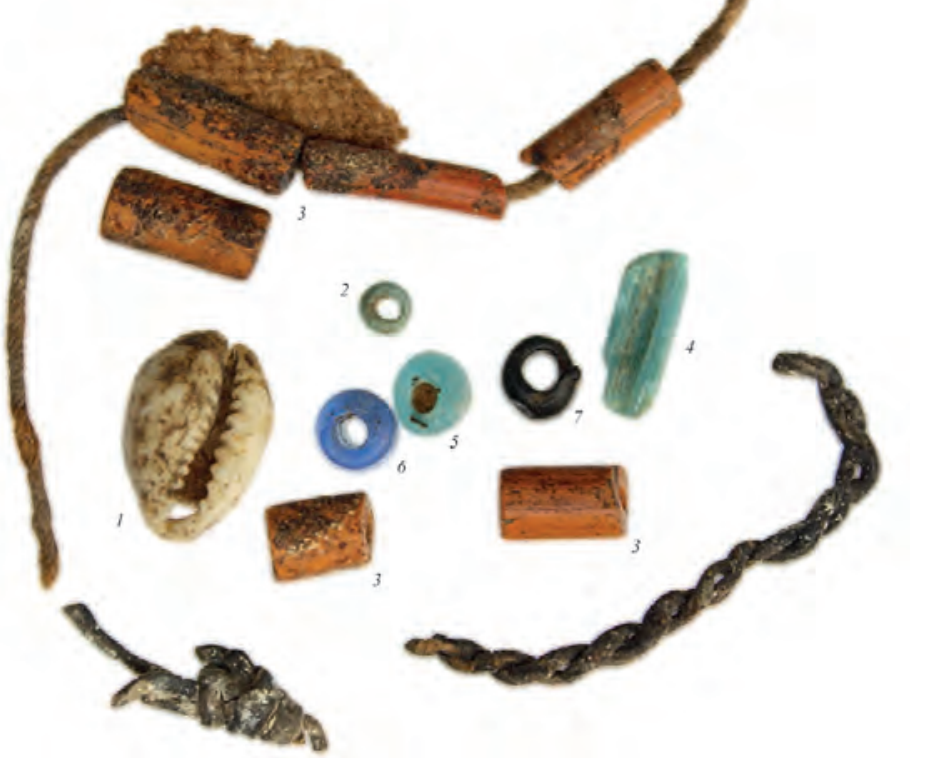


The 'bead-side' story of medieval and post-medieval Nubia: Tentative approach...

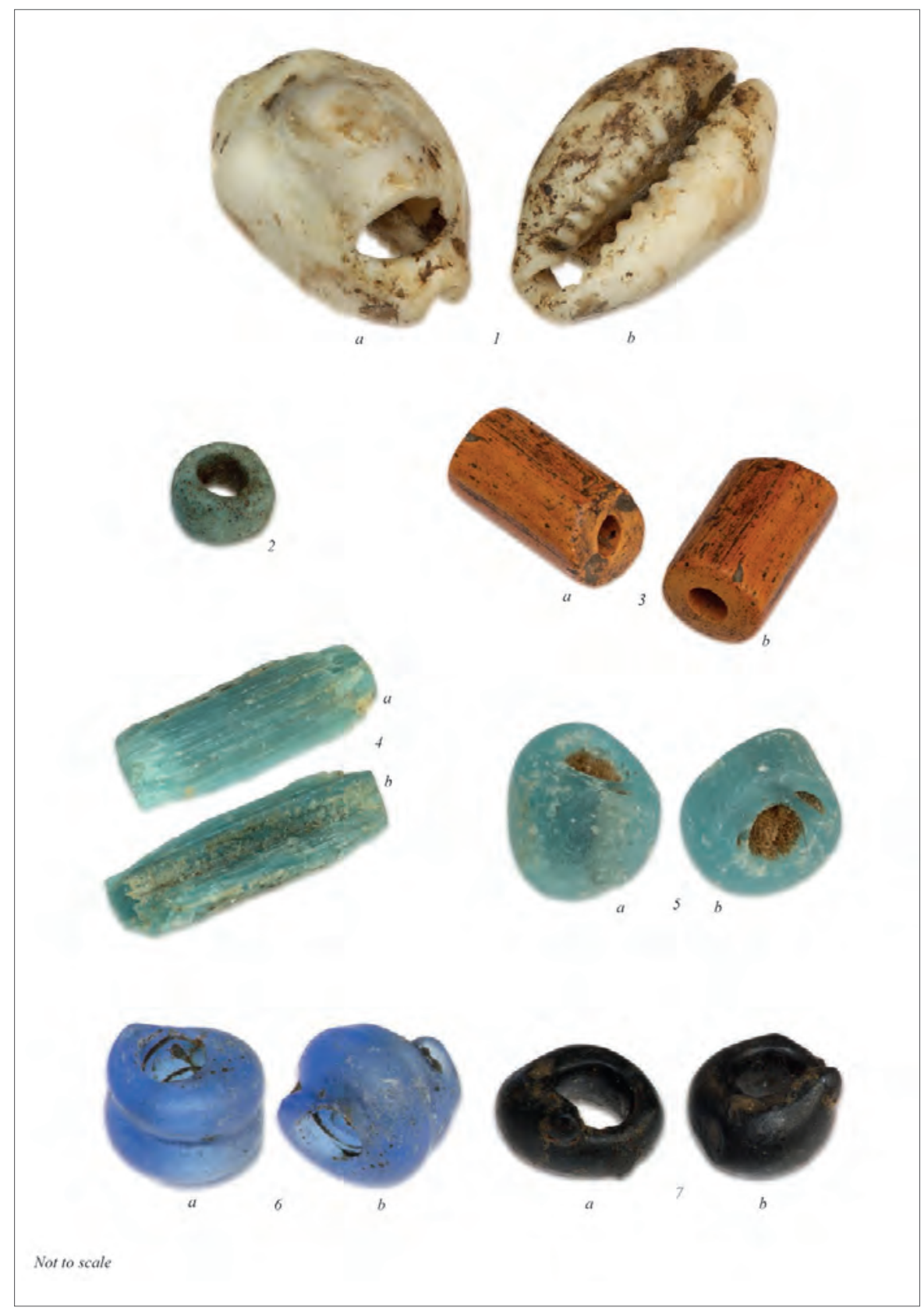

Fig. 3. Sahaba 401/60:1; some on original string and leather thong fragments (see opposite page) (After Säve-Söderbergh 1981: 152) 


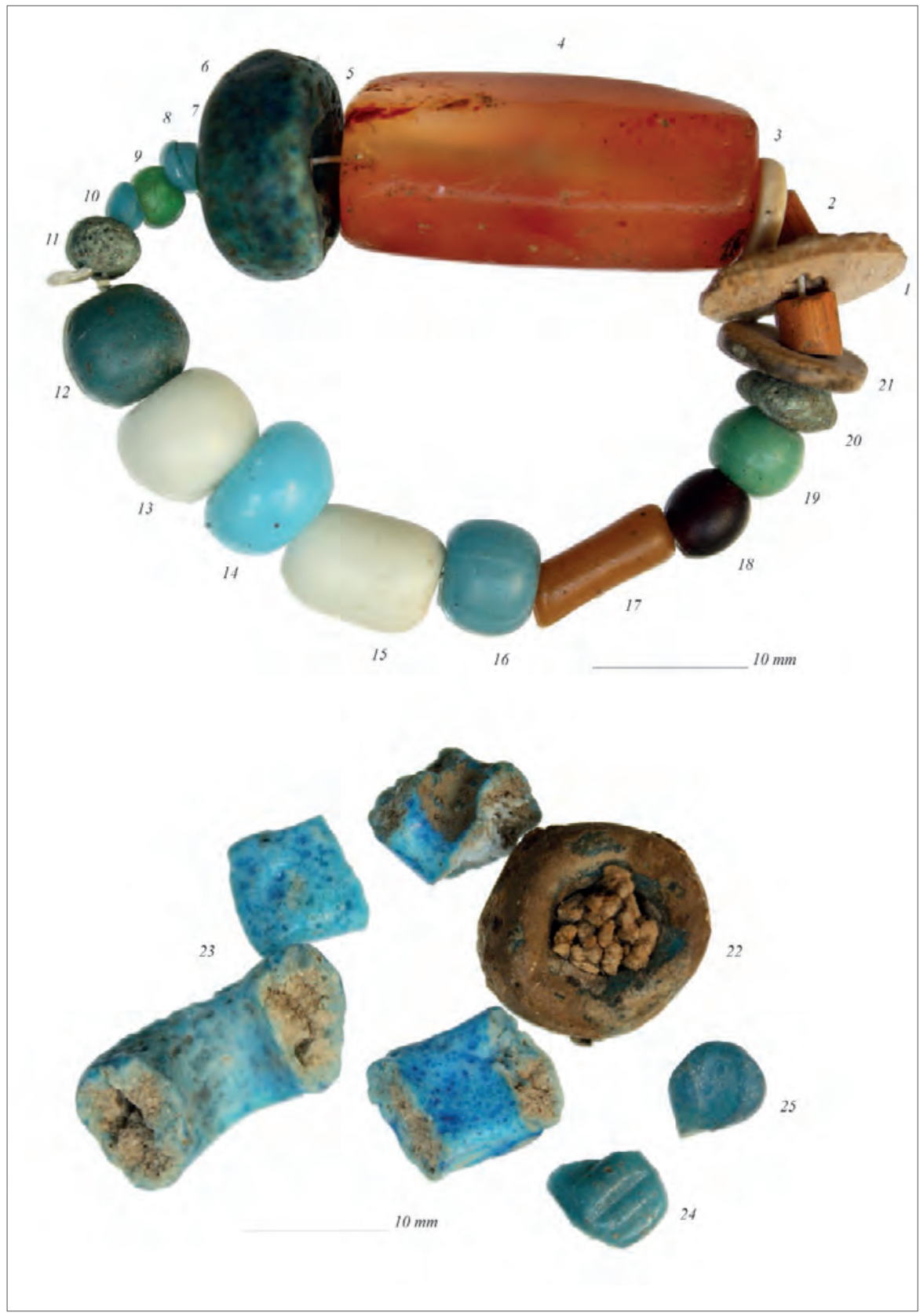

Fig. 4. Sidi Amir el-Sahaba 100/179b; opposite page, modern stringing and arrangement (After Gardberg 1970: 36) 
The 'bead-side' story of medieval and post-medieval Nubia: Tentative approach...

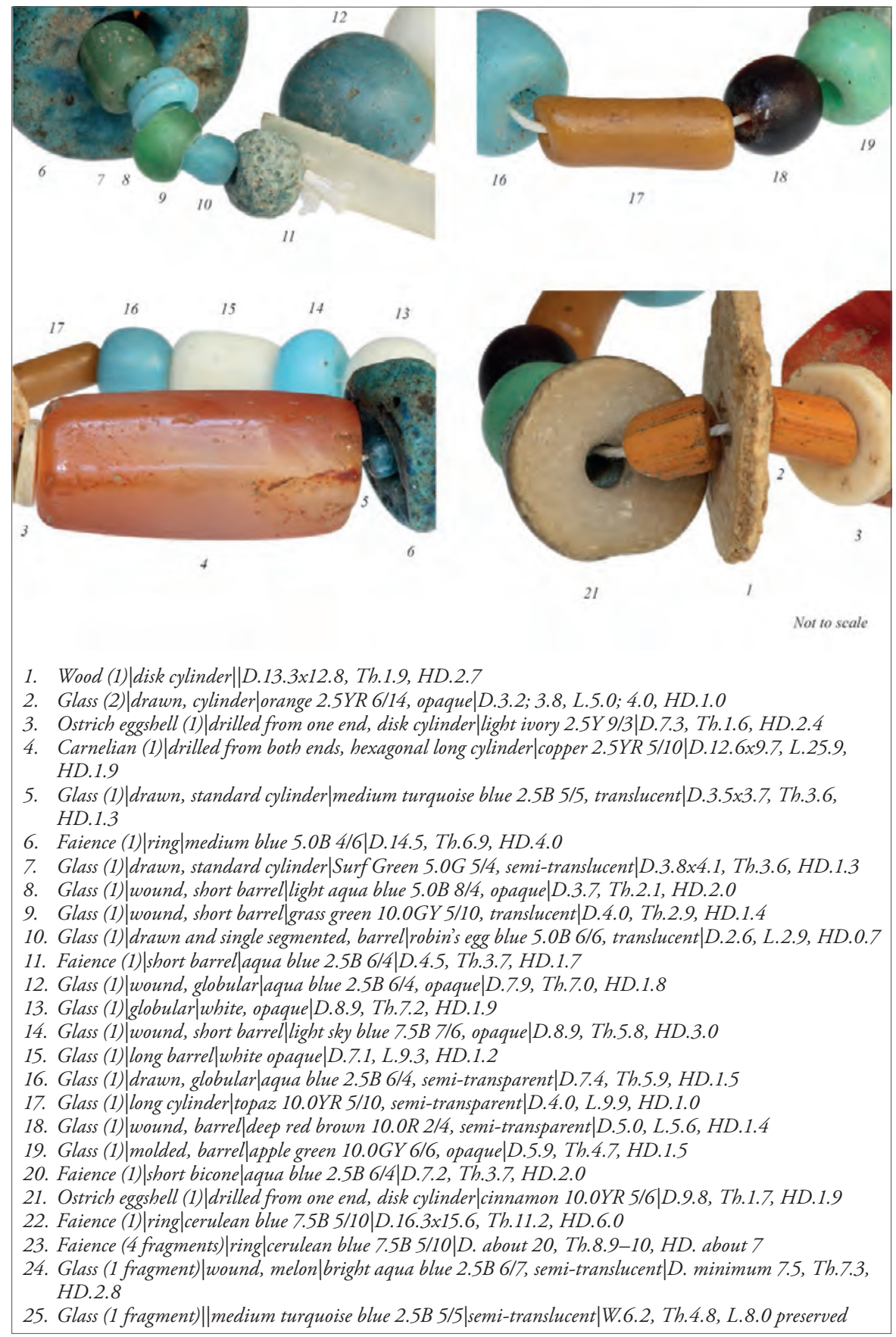


1. Glass (13)|drawn and cut, standardto-long square and rectangular cylinder|transparent $\mid$ Th.3.9-5.3, L4.1-7.3, HD. about 1.8

2. Glass (7)|drawn, broken off, standardto-long square and rectangular cylinder|dark blue 7.5PB 2/5, translucent $\mid$ Th.4.5-4.9, L.5.0-6.7, HD. 1.3

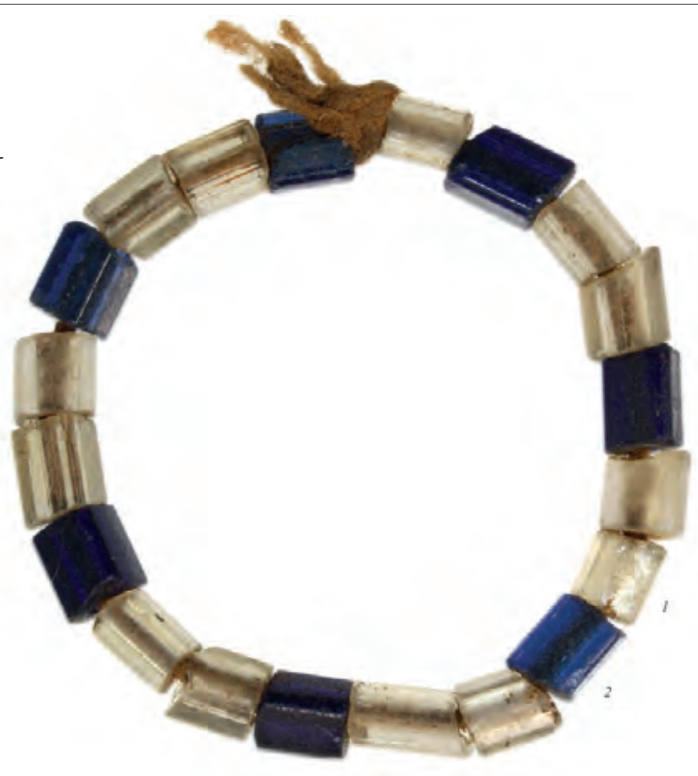

Fig. 5. Abka 168A/2:1: bracelet from left wrist; original stringing and arrangement (After Säve-Söderbergh 1981: 158)

1. Glass (8)|drawn and broken off, standard-tolong square and rectangular cylinder|dark blue $7.5 P B$ 2/5, translucent $\mid D .4 .1-4.7$, Th.4.2-6.4, HD.1.3-1.7

2. Glass (2)|wound, short barrel, slightly conical|deep grass green 10.0GY 5/8, translucent $\mid D .5 .8$; 6.1, Th.3.8; 4.7, HD.1.7

3. Glass (4)|wound, short barrel, slightly conicalldark green $2.5 G 3 / 6$, semitranslucent $\mid D .4 .4-4.6$, Th.2.5-3.1, HD.1.5-1.7

4. Glass (1)|drawn, long tube|barn red 10.0R 3/8, opaque|D.4.8, L.10.4, HD.1.5

5. Glass (1)|wound, long tube|barn red 10.0R 3/8, opaque|D.5.3, L.8.0, HD.1.9

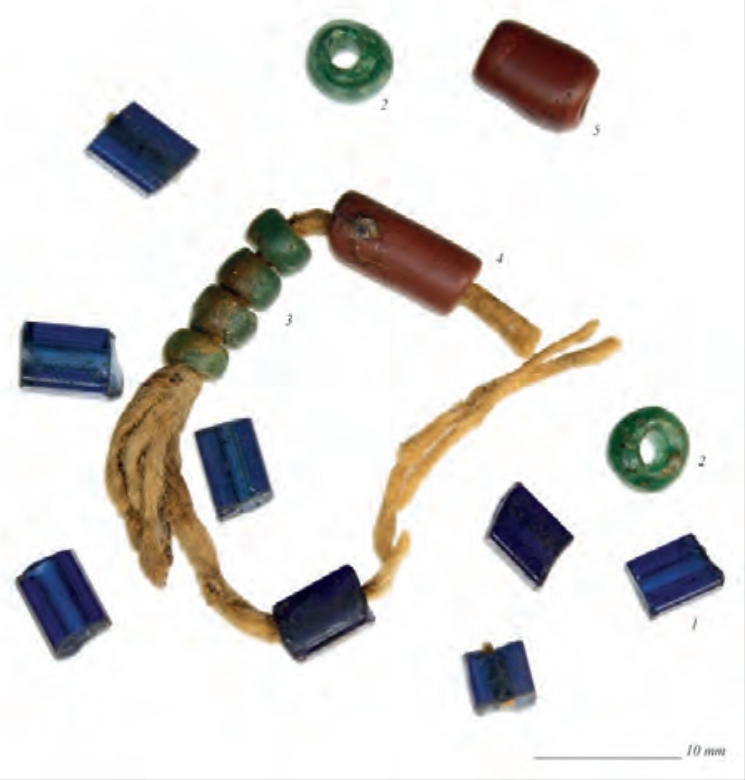


The 'bead-side' story of medieval and post-medieval Nubia: Tentative approach...

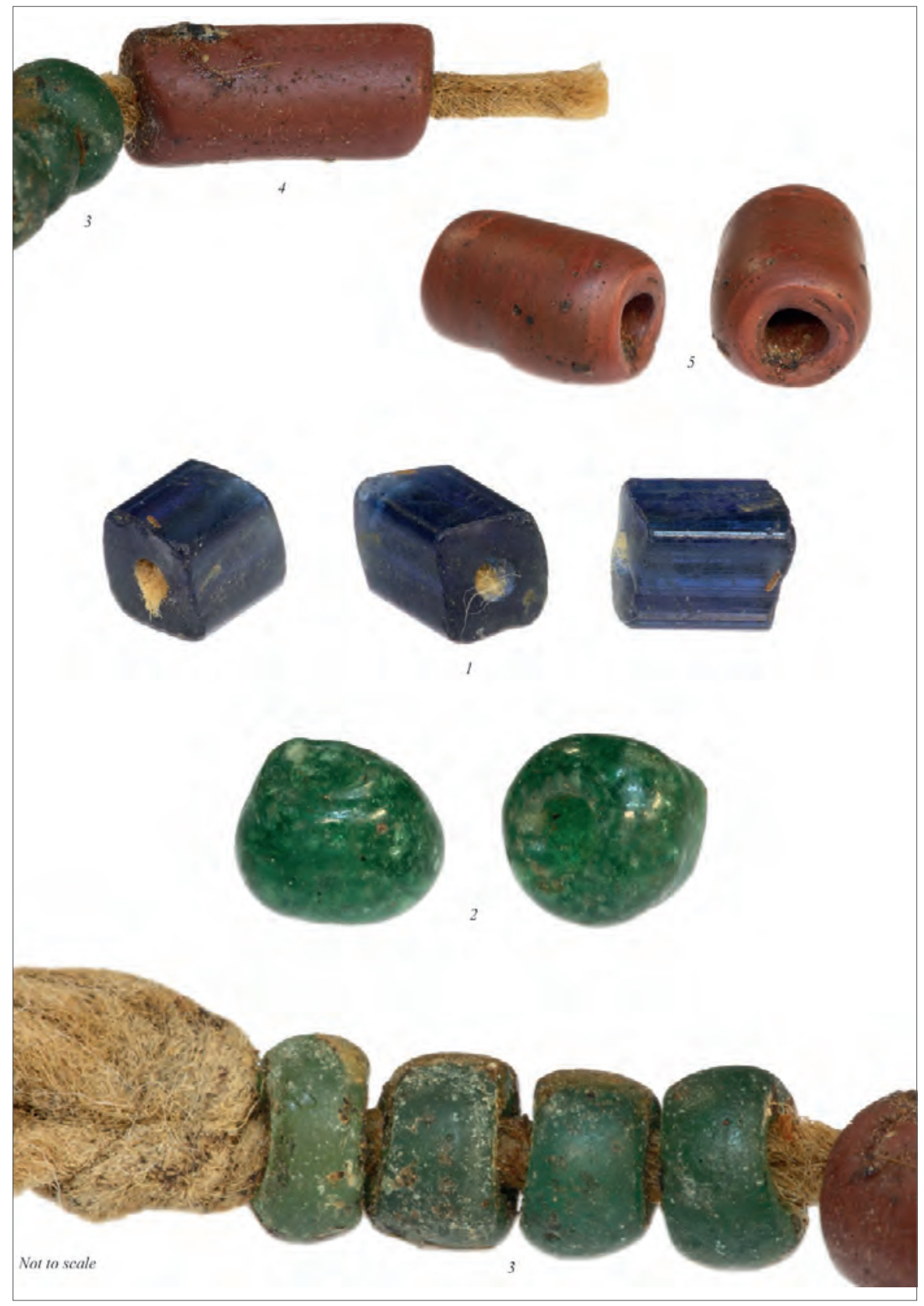

Fig. 6. Abka 168A/2:2: bracelet from right wrist; opposite page, original stringing and arrangement (After Säve-Söderbergh 1981: 158) 


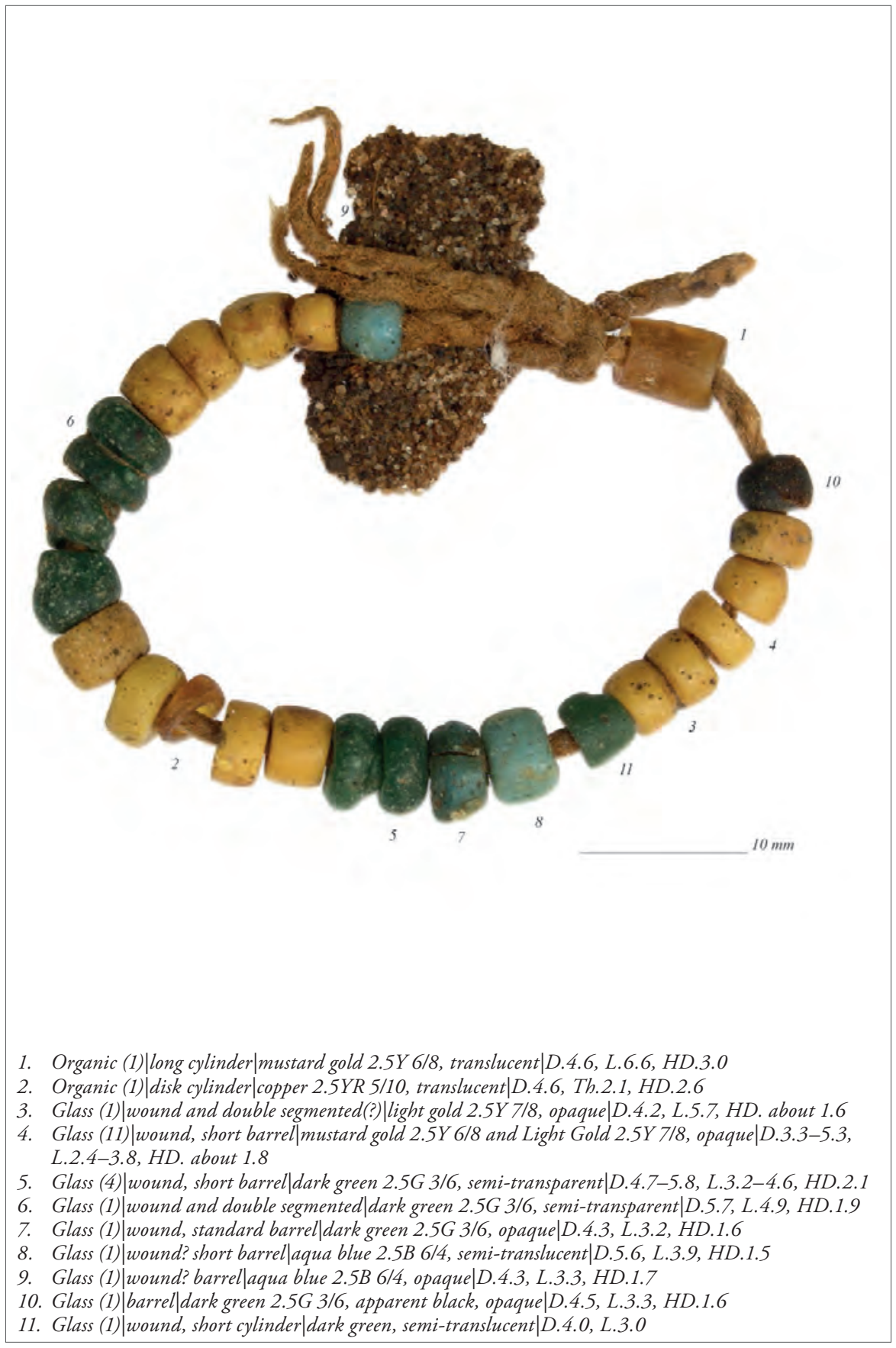


The 'bead-side' story of medieval and post-medieval Nubia: Tentative approach...

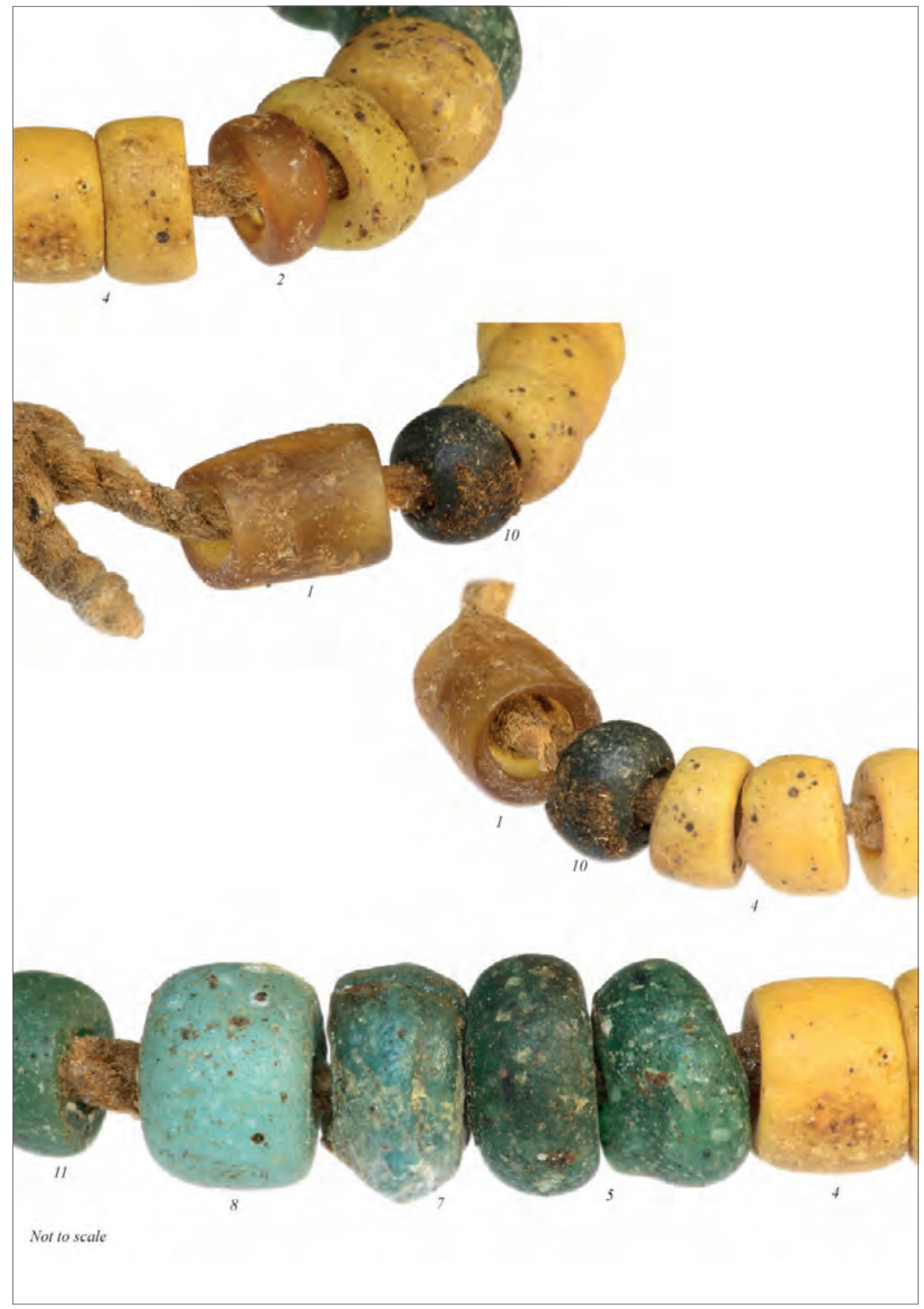

Fig. 7. Abka 168A/2:3: bracelet from right wrist; opposite page, original stringing and arrangement (After Säve-Söderbergh 1981: 158) 


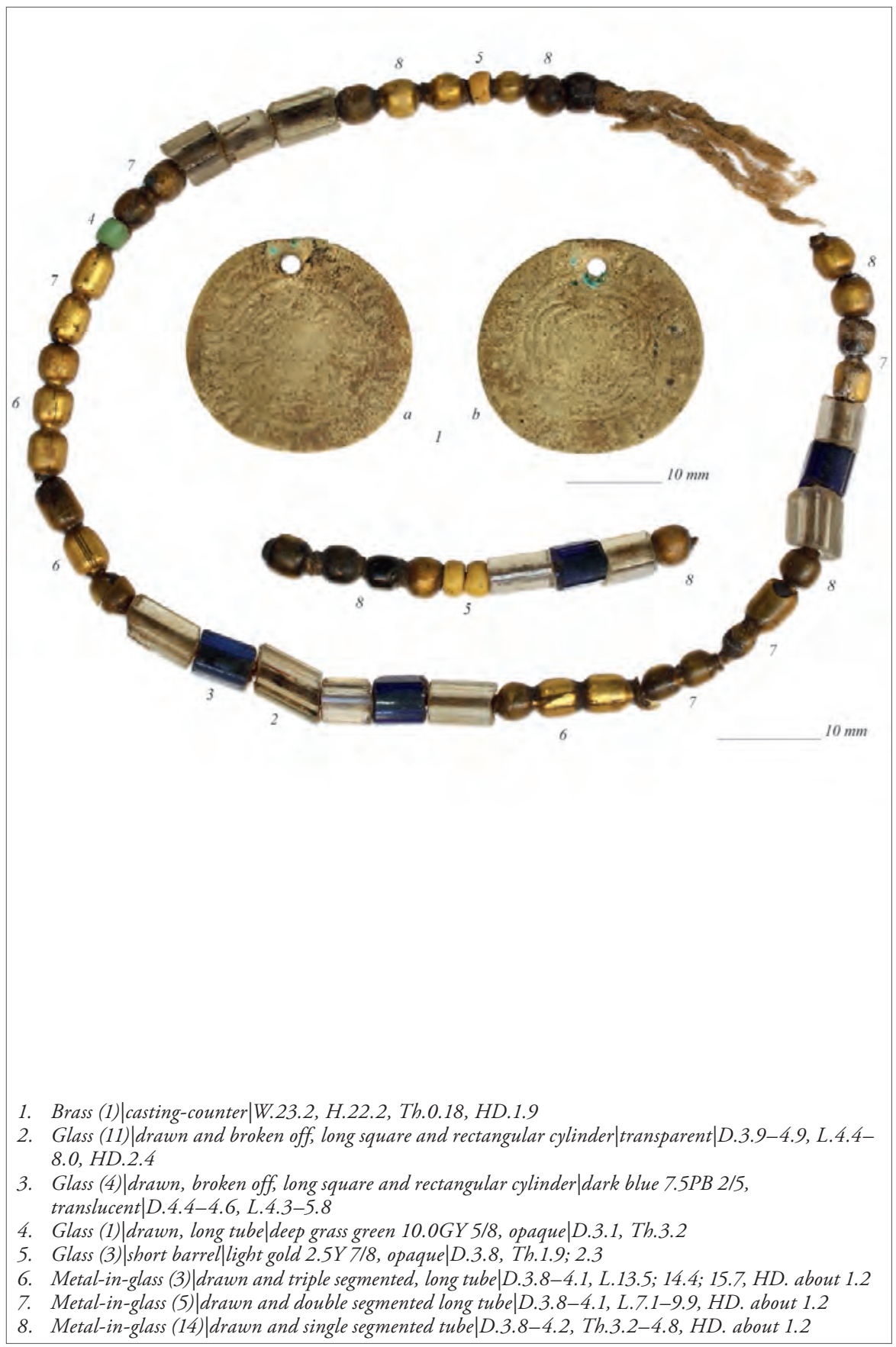


The 'bead-side' story of medieval and post-medieval Nubia: Tentative approach...

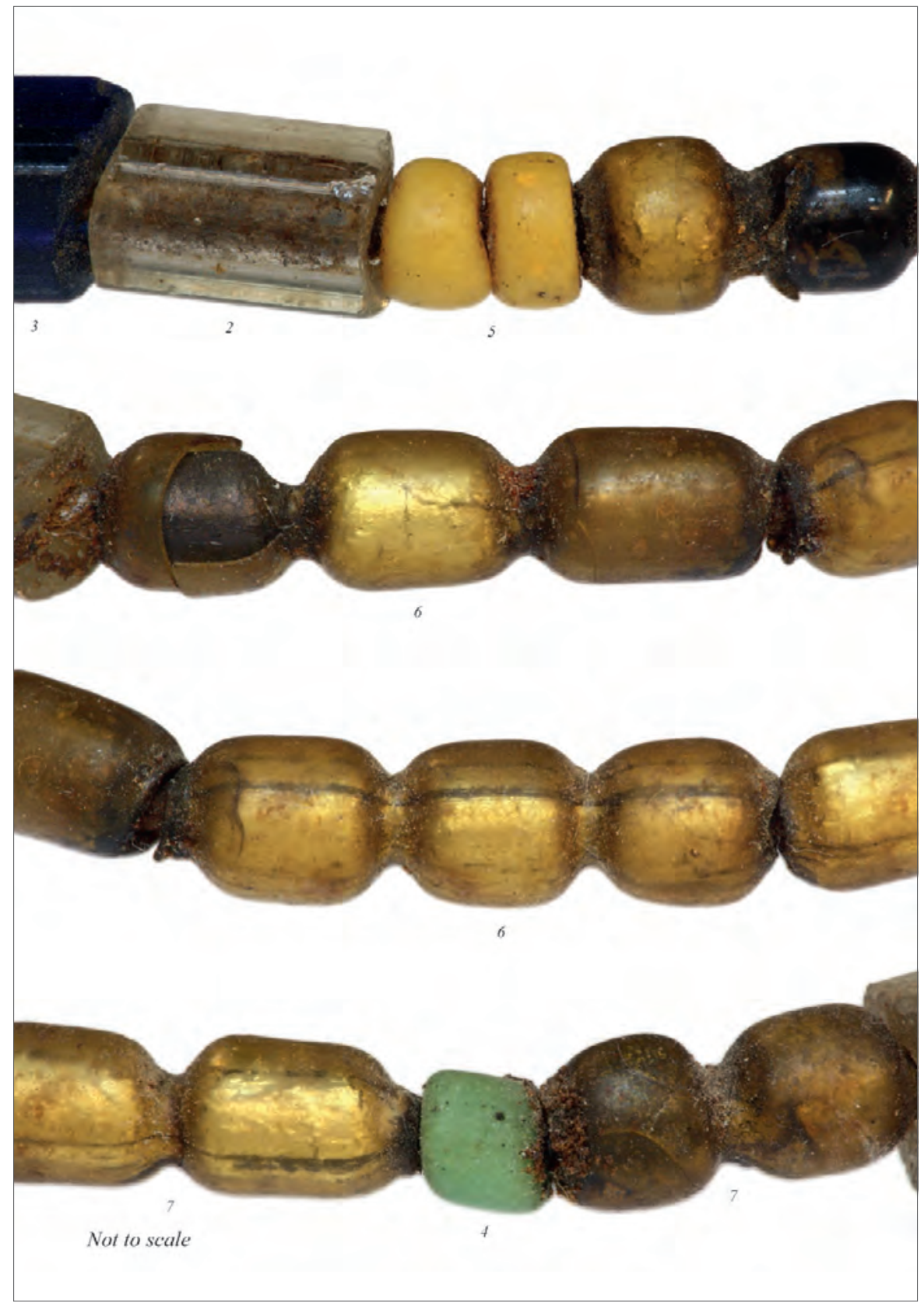

Fig. 8. Abka 168A/2:6: necklace; opposite page, original stringing and arrangement (After Säve-Söderbergh 1981: 158) 


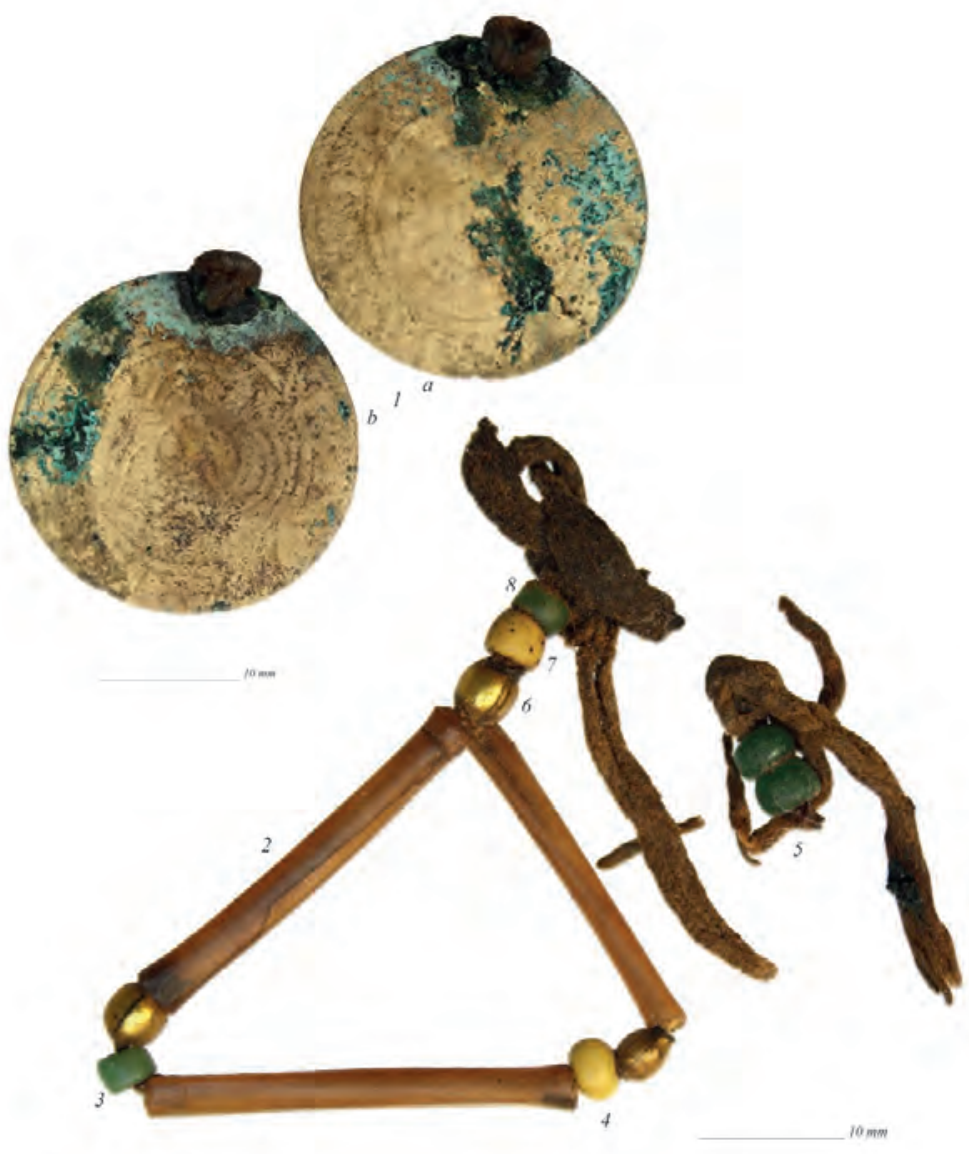

1. Brass (1)|'casting-counter'||W.24.5, H.23.3, Th.0.4

2. Coral? (3)|very long cylinder|sandalwood 7.5YR 5/10, translucent|D.2.3-3.3, L.26.7; 30.2; 28.8, HD.1.1

3. Glass (1)|drawn short barrel|deep grass green 10.0 GY $5 / 8$, semi-transparent|D.3.9, Th.2.7, HD.1.0

4. Glass (1)|drawn, oblate|light gold 2.5Y 7/8, opaque|D.4.5, Th.3.0

5. Glass (1)|wound and double segmented, barrel|dark green $2.5 G 3 / 6$, translucent $\mid D .4 .6, T h .5 .9$, HD.2.1

6. Metal-in-glass (3) |drawn $\mid$ D.3.2-4.2, Th.3.8-4.5, HD.1.4

7. Glass (1)|wound, short barrel|light gold $2.5 Y 7 / 8$, opaque|D.4.1, Th.3.2

8. Glass (1)|wound? short barrel||D.4.5, L.3.0 
The 'bead-side' story of medieval and post-medieval Nubia: Tentative approach...

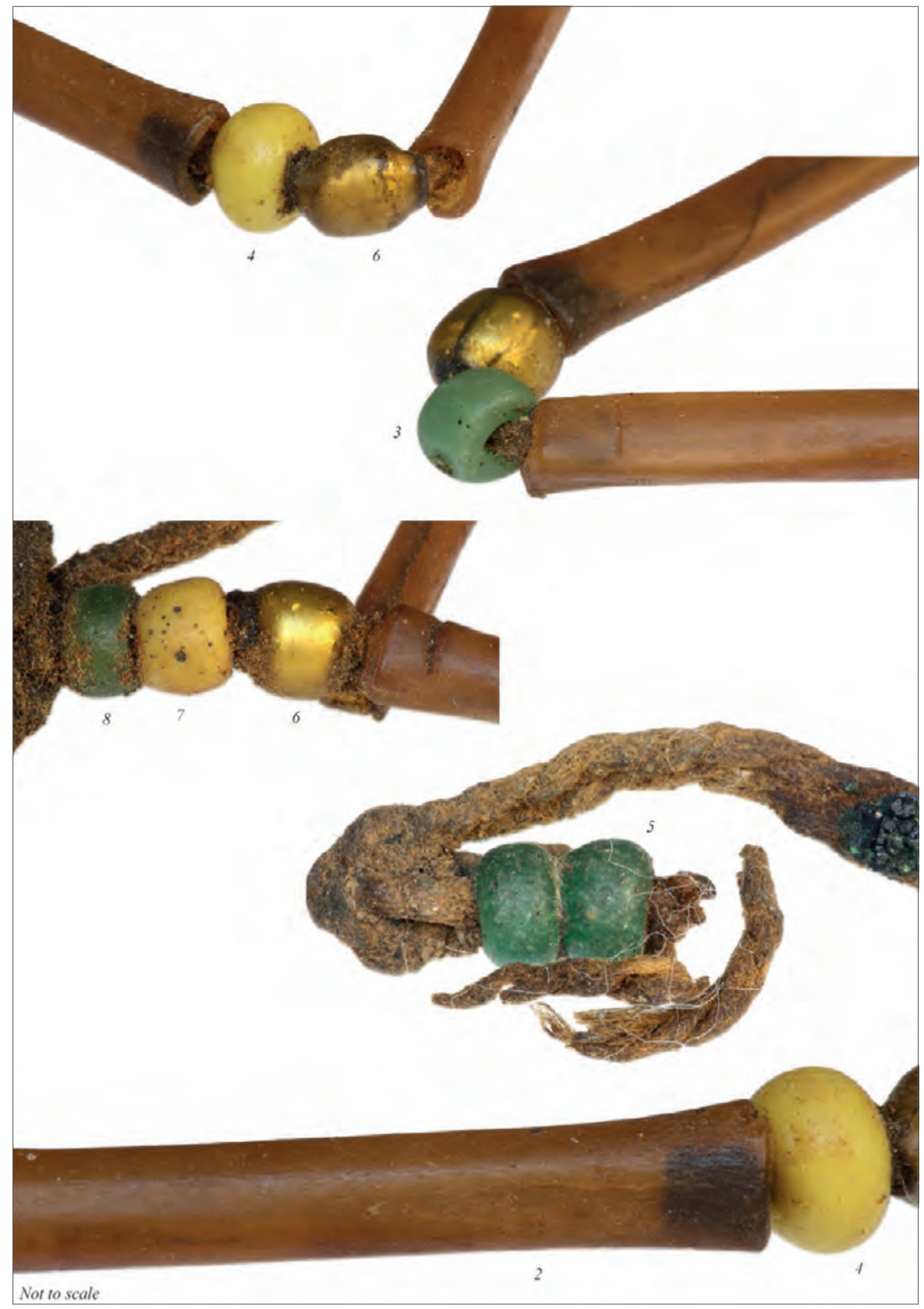

Fig. 9. Abka 168A/2:9: forehead ornament; opposite page, original stringing and arrangement (After Säve-Söderbergh 1981: 158) 


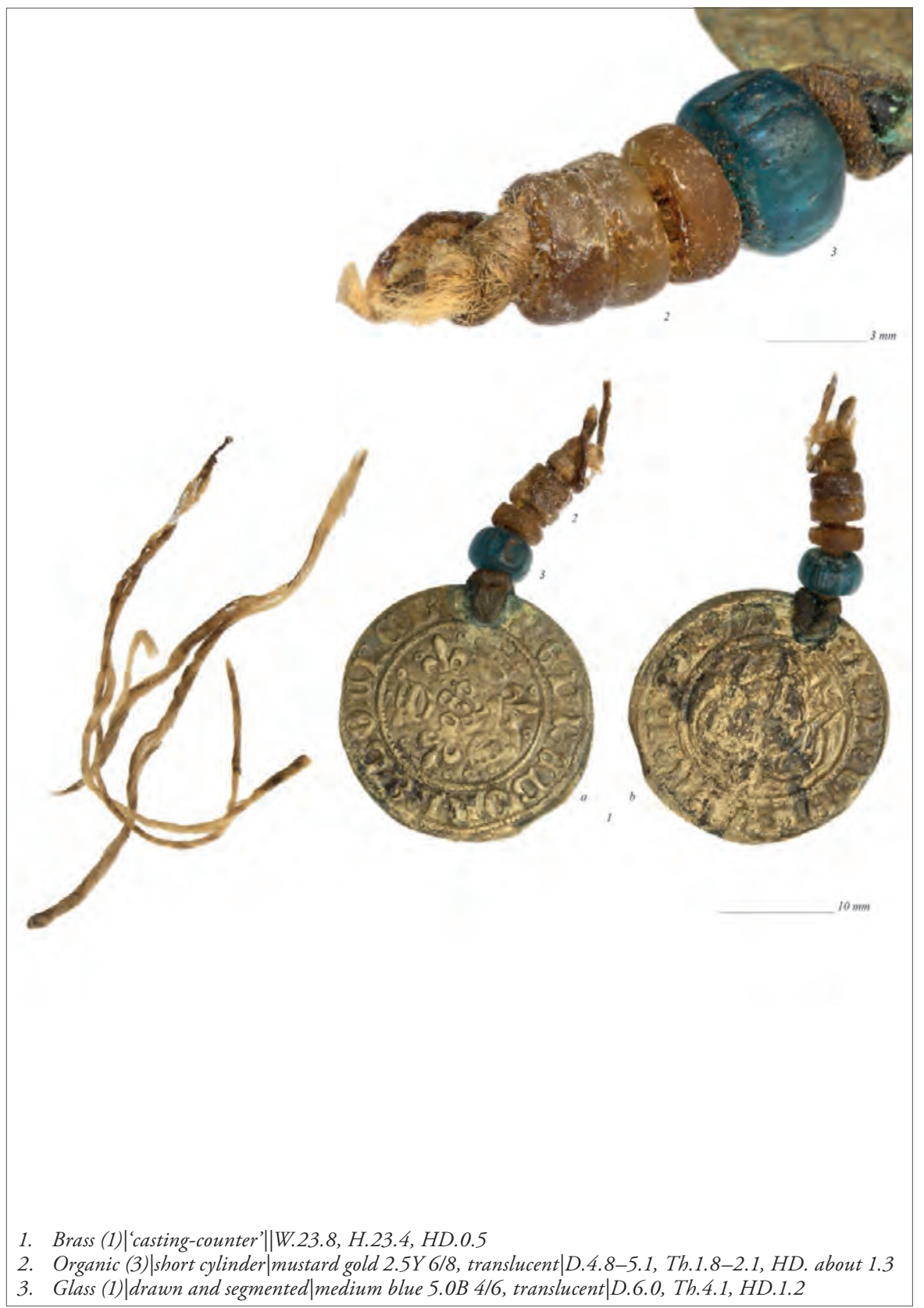

Fig. 10. Abka 168A/2:10: neck ornament; original stringing and arrangement (After Säve-Söderbergh 1981: 158) 


\section{References}

Adams, W.Y. (1981). Comments on Nubian pottery collections at Stavanger. In T. SäveSöderbergh, Late Nubian cemeteries [=Scandinavian Joint Expedition to Sudanese Nubia 6] (pp. 24-27). Copenhagen: Scandinavian University Books

Adams, W.Y. (2001). Meinarti II. The early and classic Christian phases [=British Archaeological Reports International Series 966]. Oxford: Archaeopress

Adams, W.Y. (2010). Qasr Ibrim: The earlier medieval period [=Excavation Memoir 89]. London: Egypt Exploration Society

Barnard, F.P. (1916). The casting-counter and the counting-board: A chapter in the history of numismatics and early arithmetic. Oxford: Clarendon Press

Beck, H.C. (1928). I. - Classification and nomenclature of beads and pendants. Archeologia (Second Series), 77, 1-76

Billeck, W.T. (2008). Red-on-white drawn or cornelian beads: A 19th-century temporal marker for the plains. BEADS. The Journal of the Society of Bead Researchers, 20, 49-61

Bruhn, J.-A. (1993). Coins and costume in late antiquity. Washington, D.C.: Dumbarton Oaks Research Library and Collection

Carter, A. and Beavan, N. (2014). Glass beads from jar burials of the 15th-17th centuries in the Cardamom Mountains of Cambodia. BEADS. The Journal of the Society of Bead Researchers, 26, 9-21

Cooper, E.W.T., Torntore, S.J., Leung, A.S.M., Shadbolt, T., and Dawe, C. (2011). Guide to the identification of precious and semi-precious corals: In commercial trade. Vancouver: TRAFFIC North America and WWF-Canada

Dahl, G. and Hjort-af-Ornäs, A. (2006). Precolonial Beja: A periphery at the crossroads. Nordic Journal of African Studies, 15(4), 473-498

Dubin, L.S. (2009). The history of beads: From 100,000 B.C. to the present (rev. and expanded ed.). New York: Abrams

Francis Jr., P. (2002a). Asia's maritime bead trade: 300 B.C. to the present. Honolulu: University of Hawai'i Press

Francis Jr., P. (2002b). Beads. In J.L. Bacharach (ed.), Fustat finds: Beads, coins, medical instruments, textiles, and other artifacts from the Awad collection (pp. 12-31). Cairo: American University in Cairo Press

Francis Jr., P. (2009). The glass beads of Spain. In E. Blair, L.S.A. Pendleton, and P. Francis Jr., The beads of St. Catherines Island [=Anthropological Papers of the American Museum of Natural History 89] (pp. 85-94). New York: American Museum of Natural History

Gan, F. (2009). Origin and evolution of ancient Chinese glass. In F. Gan, R.H. Brill, and S. Tian (eds), Ancient glass research along the Silk Road (pp. 1-40). New Jersey: World Scientific 
Gansell, A.R. (2007). From Mesopotamia to modern Syria: Ethnoarchaeological perspectives on female adornment during rites of passage. In J. Cheng and M.H. Feldman (eds), Ancient Near Eastern art in context: Studies in honor of Irene J. Winter by her students [=Culture and History of the Ancient Near East 26] (pp. 449-483). Leiden: Brill

Gardberg, C.J. (1970). Late Nubian sites: Churches and settlements [=Scandinavian Joint Expedition to Sudanese Nubia 7]. Copenhagen: Scandinavian University Books

Hamilton-Dyer, S. (2011). Faunal remains. In D.P.S. Peacock and L.K. Blue (eds), Myos Hormos - Quseir al-Qadim: Roman and Islamic ports on the Red Sea II. Finds from the excavations 1999-2003 [=British Archaeological Reports International Series 2286] (pp. 245-288). Oxford: Archaeopress

Jenkins, M. (1986). Islamic glass: A brief history. The Metropolitan Museum of Art Bulletin, 44(2), 1-56

Kasdagli, A.M. (1999). Logistika kai alla kermata atto ta eurēmata tēs Rodou / Nuremberg and other reckoning counters found on Rhodes. Nomismatika Khronika, 18, 129-132

Kaspers, F. (2014). Beads from Jablonec: A history in beads. Amsterdam: Marblings Publishing

Kool, R. and Ariel, D.T. (2002). Coins from the salvage excavations at Meron. 'Atiqot, 43, 109-114

Lambourn, E. (2008). India from Aden - Khutba and Muslim urban networks in late thirteenth-century India. In K.R. Hall (ed.), Secondary cities and urban networking in the Indian Ocean Realm, c. 1400-1800 (pp. 55-97). Lanham: Lexington Books

Lambourn, E. (2011). Khutba and Muslim networks in the Indian Ocean (Part II) Timurid and Ottoman engagements. In K.R. Hall (ed.), The growth of non-western cities: Primary and secondary urban networking, c. 900-1900 (pp. 133-160). Lanham, MD: Lexington Books

Lankton, J.W. (2003). A bead timeline: A resource for identification, classification and dating I. Prehistory to 1200 CE. Wahington, DC: Bead Society of Greater Washington

Liu, R.K. (2013). Chinese glass beads: export and minority. Ornament, 36(4), 38-43

Martens-Czarnecka, M. (2011). The wall paintings from the Monastery on Kom H in Dongola [=Nubia 3; Dongola 3; PAM Monograph Series 3]. (B.M. Gostyńska, trans.). Warsaw: Warsaw University Press

Mitchiner, M. (1988). Jetons, medalets \& tokens I. The medieval period and Nuremberg. London: B.A. Seaby

Neuwirth, W. (2011). Beads from Gablonz. BEADS. The Journal of the Society of Bead Researchers, 23, 3-111

Phillips, J. (2012). On the use and re-use of jewellery elements. In M.-L. Nosch and R. Laffineur (eds), Kosmos: Jewellery, adornment and textiles in the Aegean Bronze Age [=Aegaeum 33] (pp. 483-491). Leuven: Peeters

Prinsloo, L.C., Tournié, A., and Colomban, P. (2011). A Raman spectroscopic study of glass trade beads excavated at Mapungubwe hill and K2, two archaeological sites in southern Africa, raises questions about the last occupation date of the hill. Journal of Archaeological Science, 38(12), 3264-3277 
Robertshaw, P., Benco, N., Wood, M., Dussubieux, L., Melchiorre, E., and Ettahiri, A. (2010). Chemical analysis of glass beads from medieval Al-Basra (Morocco). Archaeometry, 52(3), 355-379

Rodziewicz, E. (2012). Bone carvings from Fustat - Istabl Antar: Excavations of the Institut français d'archéologie orientale in Cairo, 1985-2003 [=Fouilles de l'Institut français d'archéologie orientale 70]. Cairo: Institut français d'archéologie orientale

Rohn, A.H., Barnes, E., and Sanders, G.D.R. (2009). An early Ottoman cemetery at ancient Corinth. Hesperia, 78(4), 501-615

Säve-Söderbergh, T. (1970). Christian Nubia. The excavations carried out by the Scandinavian Joint Expedition to Sudanese Nubia. In E. Dinkler (ed.), Kunst und Geschichte Nubiens in christlicher Zeit: Ergebnisse und Probleme auf Grund der jüngsten Ausgrabungen (pp. 219-244). Recklinghausen: A. Bongers

Säve-Söderbergh, T. (1981). Late Nubian cemeteries [=Scandinavian Joint Expedition to Sudanese Nubia 6]. Copenhagen: Scandinavian University Books

Sempowski, M.L., Nohe, A.W., Moreau, J.-F., Kenyon, I., Karklins, K., Aufreiter, S., and Hancock, R.G.V. (2000). On the transition from tin-rich to antimony-rich European white soda-glass trade beads for the Senecas of northeastern North America. Journal of Radioanalytical and Nuclear Chemistry, 244(3), 559-566

Sevin, N. and Sevin, V. (2007). Eastern Anatolian beads through the ages. In J.D. Allen and V. Hector (eds), International Bead \& Beadwork Conference: 22-25 November 2007, Istanbul. Istanbul: Rezan Has Museum, Kadir Has Üniversitesi

Shinnie, P.L. (1961). Excavations at Soba. Khartoum

Spaer, M. (2001). Ancient glass in the Israel Museum: Beads and other small objects. Jerusalem: Israel Museum

Then-Obłuska, J. (2013). Medieval transcultural medium: Beads and pendants from Makurian and post-Makurian Dongola in Nubia. Preliminary assessment. Polish Archaeology in the Mediterranean, 22, 679-720

Then-Obłuska, J. (2014). The code of the hidden beads - From the Kerma to the Islamic Period according to the Fourth Cataract material from the Gdańsk Archaeological Museum Expedition excavations. In J.R. Anderson and D.A. Welsby (eds), The Fourth Cataract and beyond: Proceedings of the 12th International Conference for Nubian Studies [=British Museum Publications on Egypt and Sudan 1] (pp. 1069-1090). Leuven: Peeters

Then-Obłuska, J. (2015). Cross-cultural bead encounters at the Red Sea port site of Berenike, Egypt. Preliminary assessment (seasons 2009-2012). Polish Archaeology in the Mediterranean, 24/1, 735-778

Then-Obłuska, J. (forthcoming a). Short and long distance contacts of Late Nubia: A view through a bead hole. In Proceedings of the 13th International Conference for Nubian Studies

Then-Obłuska, J. (forthcoming b). Trade and faith in the Fourth Cataract region during the Early Makurian period: A view according to macroscopic study of the Early Makurian personal adornment remains from El-Zuma site, Nubia, Sudan (about AD 450-550). Polish Archaeology in the Mediterranean, 25/1 
Then-Obłuska, J. and Dussubieux, L. (2016). Glass bead trade in the Early Roman and Mamluk Quseir ports - A view from the Oriental Institute Museum assemblage. Archaeological Research in Asia, 6, 81-103, http://doi.org/10.1016/j. ara.2016.02.008

Torntore, S. (2004). Precious red coral: Markets and meanings. BEADS. The Journal of the Society of Bead Researchers, 16(1), 3-16

van der Sleen, W.G.N. (1973). A handbook on beads. York, PA: Liberty Cap Books

Vantini, G. (1975). Oriental sources concerning Nubia. Heidelberg: Heidelberger Akademie der Wissenschaften

Vorderstrasse, T. (2005). Al-Mina: A port of Antioch from Late Antiquity to the end of the Ottomans. Leiden: Nederlands Instituut voor het Nabije Oosten

Vorderstrasse, T. (in preparation). The Qasr Ibrim coins

Vorderstrasse, T. and Treptow, T. (eds). (2015). A cosmopolitan city: Muslims, Christians and Jews in Old Cairo [=Oriental Institute Museum Publications 38]. Chicago: Oriental Institute of the University of Chicago

Ward, G.W.R. (ed.). (2008). The Grove encyclopedia of materials and techniques in art. Oxford: Oxford University Press

Williams, B. (1989). Neolithic, A-Group, and post-A-Group remains from cemeteries W, $V, S, Q, T$, and a cave east of cemetery $K[=$ Oriental Institute Nubian Expedition 4]. Chicago: Oriental Institute of the University of Chicago

Williams, B. (1992). New Kingdom remains from cemeteries R, V, S, and W at Qustul and cemetery Kat Adindan. Chicago: Oriental Institute of the University of Chicago

Wilski, H. (1993). The Agiasos hoard. Nomismatika Khronika, 12, 45-59

Yoon, D. (2005). Counting tokens from the excavations at Psalmodi (Gard, France). American Journal of Numismatics, 16-17, 173-184 


\title{
Observations on the graves of the medieval period in the SARS concession at the Fourth Cataract
}

\author{
Derek A. Welsby \\ The British Museum \\ DWelsby@britishmuseum.org
}

\section{KeYwords}

Fourth Cataract, funerary culture, tumulus, box grave, Kushite, PostMeroitic, Christian

\begin{abstract}
Several large cemeteries of the medieval period were excavated either extensively or in their entirety by the missions of the Sudan Archaeological Research Society in its concession at the Fourth Cataract. The data collected allows an assessment of developments in funerary culture spanning from the pagan into, and throughout, the Christian period. It highlights the generally dramatic changes in burial practices between the Post-Meroitic and Christian periods alongside the similarities between some of the later Kushite and Christian graves. These changes and similarities are discussed in connection with the physical continuity of cemeteries which demonstrate a close link between Post-Meroitic and Christian burials, the former often forming a focus for the later burials and being respected by the later grave diggers.
\end{abstract}

It is with great pleasure that I contribute to this volume in tribute to the immense and continuing contribution of Wtodzimierz Godlewski to the study of the history and archaeology of medieval Nubia.

As a response to the appeal by the National Corporation for Antiquities and Museums during the 1990s the Sudan Archaeological Research Society planned to undertake an initial survey in a concession granted to it above the Fourth Nile 
Cataract in the winter of 1998. Owing to political problems between Sudan and the UK that season had to be postponed. The SARS team went into the field in the autumn of 1999 and annually from 2002 until 2007. During that time up to four groups of archaeologists were working concurrently throughout the SARS concession stretching for a distance of $40 \mathrm{~km}$ along the left bank of the Nile from Dar el-Arab to Jebel Musa and on all the islands in that reach of the river.

Amongst the nearly 2000 archaeological sites noted some of the most extensive were cemeteries of the medieval period with graves marked by tumuli in the earlier pagan phase and by box-grave monuments in the later Christian phase. ${ }^{1}$ In these cemeteries, which were both on the mainland and on islands, all aspects of most of the graves investigated conformed to the types known throughout the Middle Nile region from the First Cataract at least as far south as Soba East on the Blue Nile. Although the norms of burial especially in the Christian period are well established, in this article I shall draw attention to a number of variations from those, the significance of which is far from clear.

As at many periods in the cultural development along the Middle Nile the evidence at the Fourth Cataract is for cultural change being a gradual process from one archaeologically recognisable 'culture' to another and this was amply illustrated in the SARS concession. At a number of cemeteries where tumuli tomb monuments were visible excavation showed that these covered graves associated with what we would consider to be later Kushite, Meroitic, material along with other graves associated with the early Medieval, i.e., post-Meroitic, artifacts.

At cemetery 3-Q-33 [Fig. 1] ${ }^{2}$ graves in the eastern part were of Meroitic date,

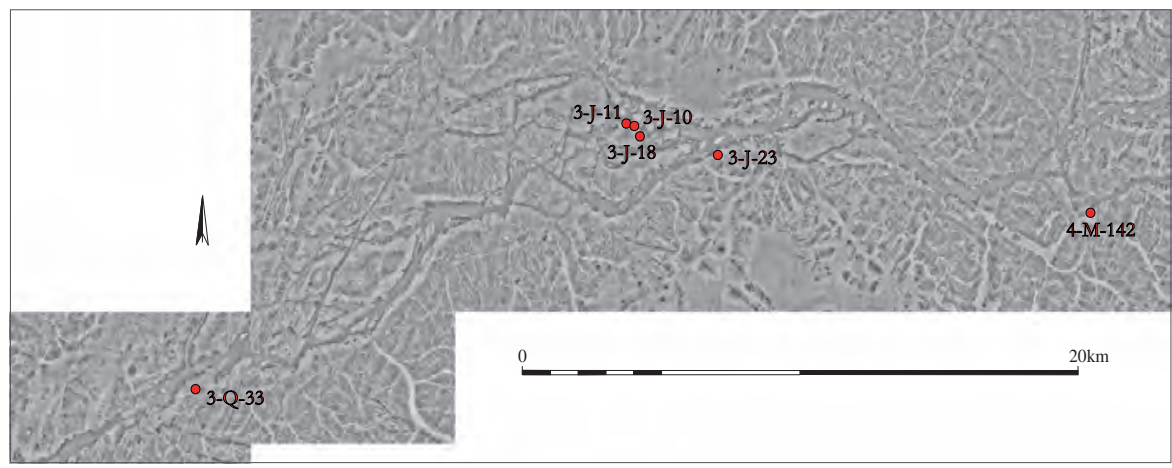

Fig. 1. Map showing the location of sites at the Fourth Cataract mentioned in the text

1 Draft reports on the cemeteries at 3-J-10, 3-J-11 and 3-J-18 by Andrew Ginns and 3-O-1 by the present author are available at http://www.sudarchrs.org.uk/fieldwork/fieldworkmerowe-dam-salvage/.

2 All the sites mentioned in the SARS concession lie within grid square NE-36-F. 
in the western part post-Meroitic (Wolf and Nowotnick 2006b: 21). Half of the former had no monuments while the rest were marked on the surface by low flat tumuli with stone kerbs, low stone rings and elongated stone settings. The grave cuts were elongated vertical-sided pits aligned north east/south west and east/west. Some had lateral niches. Only one of the graves excavated had a descendary and transverse chamber. Most graves contained an extended supine skeleton, a very few placed slightly on their sides and/or in a slightly flexed position. Usually, the head was to the west or southwest. Occasionally, the body was wrapped in a woven shroud sometimes with leather under the bones. The graves usually had side ledges on which rested stone slabs (Wolf and Nowotnick 2006b: Fig. 2).

The post-Meroitic burials were in deep circular shafts, with oval side chambers in which the deceased lay in a contracted position. The associated grave monuments were flat-topped gravel-covered circular, oval or egg-shaped mounds with stone kerbs (Wolf and Nowotnick 2006a: 23). ${ }^{3}$

Unfortunately, owing to a total inability to date precisely the graves themselves, it is impossible to ascertain whether graves with the 'older' and 'newer' objects, or following the well-established or new fashions, overlap chronologically. This is exacerbated where some of the Meroitic graves have few or no grave goods and can only be dated using radiocarbon (Wolf and Nowotnick 2006b: 21). The intermingling of graves does suggest that people from the same community and social group were being buried in these cemeteries through the period of transition of funerary traditions. This did not stop the practice of grave robbing, some of which may have occurred soon after the interment, but such a practice is prevalent at all periods in Nubian history and does not reflect a specific targeting of a group seen as alien to the current inhabitants of the area. The only factor mitigating grave robbing appears to have been the knowledge in some cases that particular graves did not contain anything worth robbing. ${ }^{4}$

The arrival of Christianity had a profound effect on the form of graves, the layout of the body and the nature of the grave monuments, as well as on the provision of objects associated with the deceased. As with the transition from the Kushite to the early medieval graves, the transition from those of the pagan citizens of the Kingdom of Makuria to those of the Christian citizens of the kingdom

3 It is clear from excavations in the cemetery at 3-O-1 that the flat or sloping tops of these tumuli are far removed from their original form which was of a high dome of a type that can still be seen at el-Zuma (see, for example, the stratigraphy of the tumulus in Welsby 2013: VII, Fig. 3O.11).

4 For a discussion of grave robbing by the same community burying the dead in the Meroitic cemetery at Abu Simbel North, see Näser 1999: 24, and elsewhere at the Fourth Cataract in Kerma period cemeteries, see Kołosowska and El-Tayeb 2005: 142. 
cannot be documented in great detail owing to chronological uncertainties. Not only does a very precise chronology elude us, but, in the frequent absence of any grave goods in the burials of those professing the Christian faith, even approximate chronological data is unavailable. Again as with the Kushite/early medieval transition, there is clear evidence for continuity of burials within some cemeteries and clear evidence for a continuing respect for the graves of pagan ancestors by those who can be assumed to be their Christian descendants.

Site 3-J-23, which lies close to the banks of the Nile a little to the east of elTereif, illustrates this clearly. Little remains of the early medieval tumuli, but their original size is clearly visible in the cemetery from the circular areas around the graves, which have not been disturbed by later Christian internments. At 3-J-23, the community continued to use the same restricted area for its cemetery and there was obviously no desire by Christians to distance themselves from the pagan heritage of the cemetery. A similar situation has been noted elsewhere; well documented examples are at Sesebi (Edwards 1994: 176) and Jebel Gaddar (Źurawski and El-Tayeb 1994: 302-303) where Christian burials cluster around post-Meroitic tumuli.

Elsewhere in the concession there is less evidence for continuity. Several post-Meroitic cemeteries were not used in the Christian period, while several Christian cemeteries do not have any obvious post-Meroitic antecedents. This may well be a reflection of changing patterns of settlement rather than a conscious abandonment of an earlier burial ground for ideological reasons. The cemetery at site 3-J-11 on Mis Island is unusual as there a medieval Christian cemetery overlies Later Kushite and Meroitic burials. There is no evidence for post-Meroitic use of the cemetery. One Kushite grave (Gr. 1208) (Ginns 2010: XXVIII) had a trapezoidal descendary aligned east/west, leading down to an oval tomb chamber with its long axis north/south. The position of the body was uncertain as it had been much disturbed. The other Kushite graves were pits of very similar form to those of the Christian burials both in this cemetery and elsewhere in the concession. They are frequently orientated with the bodies laid west/east and have ledges along the long sides of the graves roofed over with stone slabs [Fig. 2].

They were, however, accompanied by pottery vessels contained in an extension of the grave pit at its eastern end [Fig. 3]. The similarities between many of the Meroitic and Christian graves are striking, while their differences to graves of the post-Meroitic period are equally so.

At the end of the Christian period with the arrival of Islam we see a similar situation with Muslims buried in close proximity to Christians. The Muslim graves can generally be recognised from the orientation of the associated tomb monuments and by monuments of distinctive forms. Further details of Muslim 
Observations on the graves of the medieval period in the SARS concession...

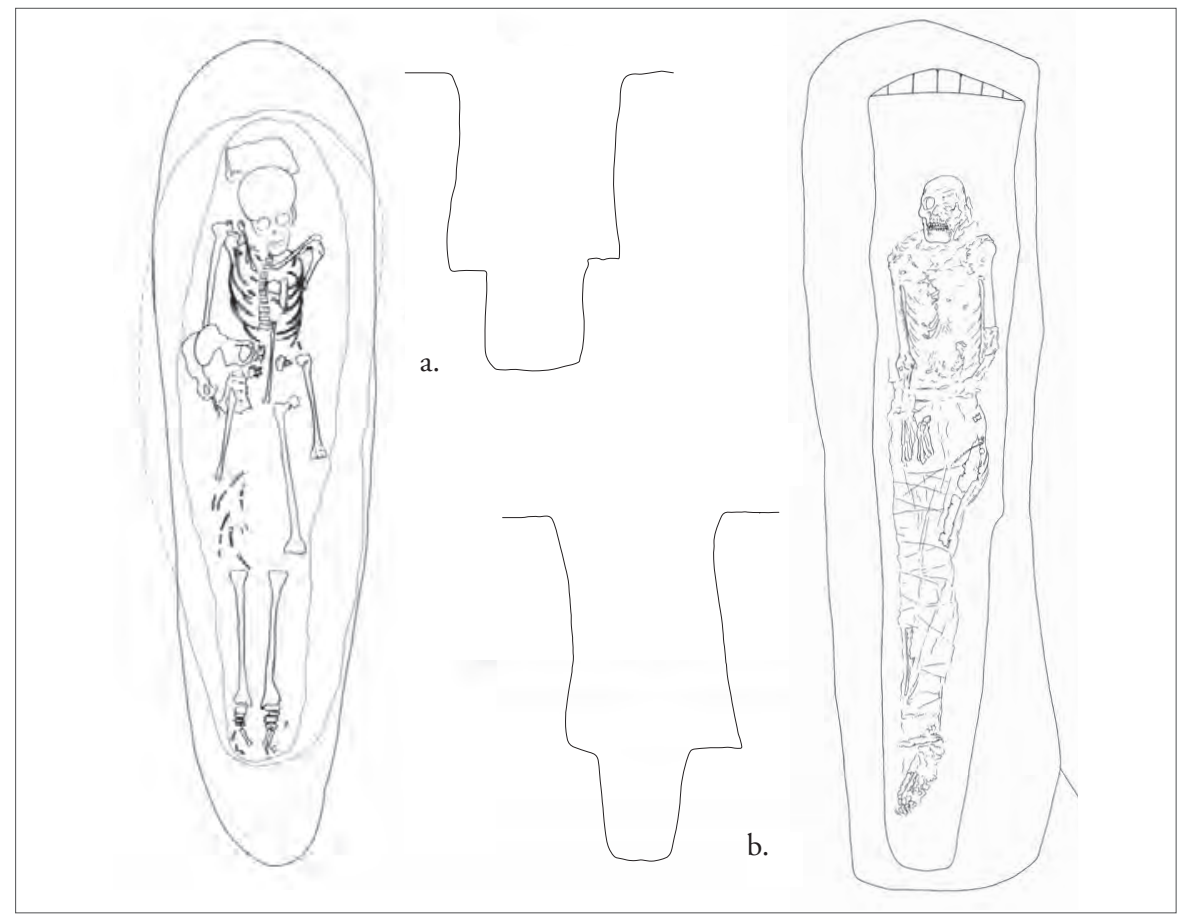

Fig. 2. Oval grave pits with side ledges: a - Meroitic grave at Cemetery 3-Q-33 (after Wolf and Nowotnick 2006b: Fig. 2); b - Christian grave at Cemetery 3-J-23, grave (B)76 (Drawing SARS AKS Archive)

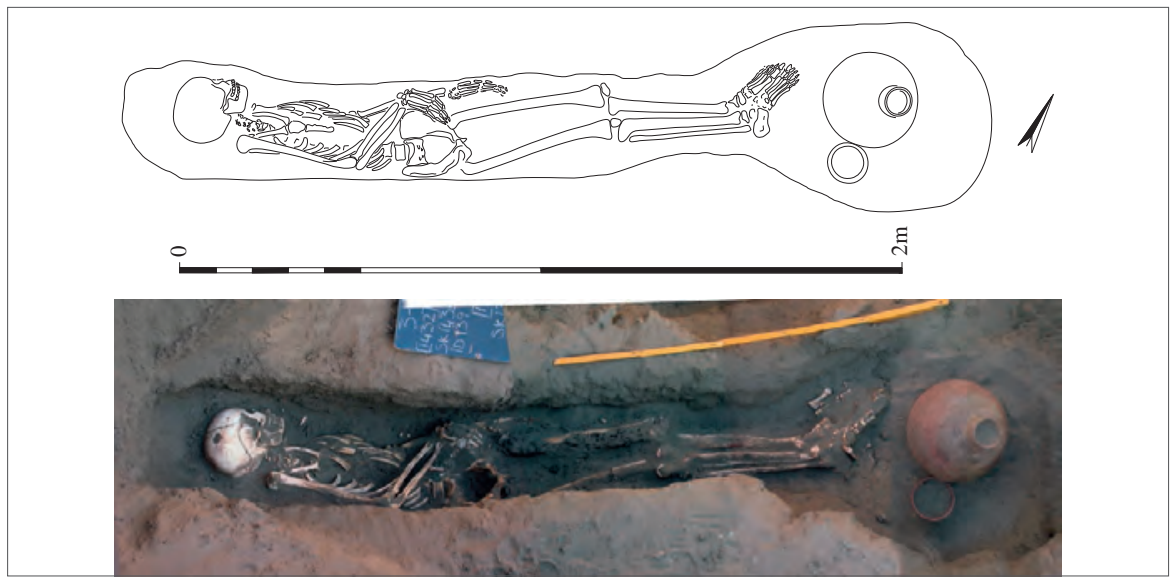

Fig. 3. Meroitic grave 1432 at cemetery 3-J-11 on Mis Island (Photo and drawing SARS AKS Archive) 
burial practices are lacking, as it is forbidden under the antiquities laws in Sudan to excavate graves of that period. Muslim tradition demands that the body be placed on its right side facing towards Mecca. Although the orientation is specifically Muslim, in northern Sudan resulting in burials aligned broadly north/south, the burial attitude is far from new. In the cemetery at site 3-J-11, for example, many Christians were placed on their sides, the right being a little more common than the left, facing in these cases north or south [see Table 2].

At least in the area of the SARS concession, the norms of burial from the later Kushite into the Medieval Christian period are clear [Table 1].

Table 1. Comparison of burial traditions across three cultural periods

\begin{tabular}{|c|c|c|c|}
\hline $\begin{array}{l}\text { Period / } \\
\text { norms }\end{array}$ & $\begin{array}{l}\text { Later Kushite / } \\
\text { Meroitic }\end{array}$ & $\begin{array}{l}\text { Early medieval / } \\
\text { post-Meroitic }\end{array}$ & $\begin{array}{l}\text { Later medieval / } \\
\text { Christian }\end{array}$ \\
\hline $\begin{array}{l}\text { Skeleton } \\
\text { orientation }\end{array}$ & $\begin{array}{l}\text { - West/east } \\
\text {-Southwest/northeast } \\
\text { - Northwest/south- } \\
\text { east }\end{array}$ & $\begin{array}{l}\text { - South/north } \\
\text { - East/west }\end{array}$ & West/east \\
\hline $\begin{array}{l}\text { Burial at- } \\
\text { titude }\end{array}$ & $\begin{array}{l}\text { - Extended supine } \\
\text { - Slightly on their side } \\
\text { and flexed a little }\end{array}$ & Crouched & Supine, extended \\
\hline $\begin{array}{l}\text { Form } \\
\text { of tomb } \\
\text { chamber }\end{array}$ & $\begin{array}{l}\text { - Long narrow grave } \\
\text { pit with vertical sides } \\
\text { - Long narrow verti- } \\
\text { cally-sided grave pit } \\
\text { with a lateral niche } \\
\text { - Sloping trapezoidal } \\
\text { descendary opening } \\
\text { onto oval chamber }\end{array}$ & $\begin{array}{l}\text { - Vertical pit with side } \\
\text { niche at the base; } \\
\text { - Circular pit with oval } \\
\text { cut, leading to beehive } \\
\text { chamber; } \\
\text { - Trapezoidal descen- } \\
\text { dary with transverse } \\
\text { oval chamber at end; } \\
\text { - U-shaped grave pit at } \\
\text { base of descendary }\end{array}$ & $\begin{array}{l}\text { Chamber: vertical } \\
\text { pit, rectangular with } \\
\text { rounded ends to elon- } \\
\text { gated oval }\end{array}$ \\
\hline $\begin{array}{l}\text { Tomb } \\
\text { monument }\end{array}$ & Low tumuli & $\begin{array}{l}\text { Tumulus, circular to } \\
\text { egg-shaped, MDASP } \\
\text { types FT05 and FT06 }\end{array}$ & $\begin{array}{l}\text { - Rectangular, from } \\
\text { pavement to prominent } \\
\text { box-shaped monument, } \\
\text { MDASP types FF01- } \\
\text { FF03 } \\
\text { - Tumulus, stone ring, } \\
\text { MDASP type FT04a }\end{array}$ \\
\hline
\end{tabular}

Of all the burial traditions those of the medieval Christian period are the most strictly adhered to, but variation does exist, as already alluded to above, and a number of instances of this were noted in the SARS concession. 


\section{Christian graves}

Orientation [Table 2]. Almost all grave pits are broadly aligned west/east although the exact orientation does vary. In a very few cases the body was placed in an east/west orientation. This is most commonly found in the case of children, but a few adults were also buried in this way. No obvious reason for this can be suggested. Unlike with individuals placed in a dorsal position where it is thought that a mistake may have been made with a wrapped body, this can hardly be the case with the orientation where the head end of the body will have obviously been much heavier than the other.

The most dramatic variation from the norm came from two burials in the church at site 3-J-18 where one grave had been inserted under and parallel to the west wall of the building from the exterior and another from the interior. Both bodies here were aligned north/south and placed on their right sides facing west. These were special cases imposed on the burial party by their desire to inter these important individuals in such a prominent sacred place. The quality of the clothing worn by one individual, which included a fine silk garment, is directly comparable to that found on an individual interred in Crypt 2 within the Monastery on Kom H at Old Dongola (Godlewski, Mahler, and Czaja-Szewczak 2012: $351 \mathrm{ff}$.).

Body position [Table 3]. Extended supine burials varied a little in the placement of the hands and feet. Hands could be by the side of the body, on the pelvis or occasionally the lower arms could be crossed. Feet were either next to each other or the lower legs were crossed. Other variations may have been more significant. Sometimes the legs were flexed at the knees. Often it appears that the feet had been drawn up to the body in line with it and only during the filling of the grave or decomposition of the bodies did the legs get pushed over, the knees often resting against the side of the grave. This position was not necessitated by the length of the grave in many cases; it was a conscious decision to place the body in that way. However, sometimes individuals who were too large to be placed in an extended position were accommodated in much smaller graves $[$ Fig. 4:A] and on other occasions very small individuals were placed in long graves clearly designed for someone else [Fig. 4:B]. 
Table 2. Body orientation

\begin{tabular}{|c|c|c|c|c|c|}
\hline \multirow[t]{2}{*}{ Site } & \multirow{2}{*}{$\begin{array}{l}\text { No. of bodies } \\
\text { observed }\end{array}$} & \multicolumn{2}{|c|}{ Adults } & \multicolumn{2}{|c|}{ Sub-adults } \\
\hline & & West/east & East/west & West/east & East/west \\
\hline $3-J-10$ & 126 & $100 \%$ & $0 \%$ & $81 \%$ & $9 \%$ \\
\hline $3-J-11$ & 259 & $100 \%$ & $0 \%$ & $100 \%$ & $0 \%$ \\
\hline $3-J-18$ & 217 & $97 \%$ & $3 \%$ & $100 \%$ & $0 \%$ \\
\hline $3-J-23$ & 175 & $99 \%$ & $1 \%$ & $97 \%$ & $3 \%$ \\
\hline 4-M-142 & 34 & $100 \%$ & $0 \%$ & $94.5 \%$ & $5.5 \%$ \\
\hline
\end{tabular}

Table 3. Body position

\begin{tabular}{|l|l|l|l|l|l|l|l|l|l|}
\hline Site & \multicolumn{2}{|c|}{$\begin{array}{l}\text { No. of } \\
\text { bodies } \\
\text { observed }\end{array}$} & \multicolumn{4}{|c|}{ Adults } & \multicolumn{4}{|c|}{ Sub-adults } \\
& Supine & Prone & Side & $\begin{array}{l}\text { Flexed } \\
\text { supine }\end{array}$ & Supine & Prone & Side & $\begin{array}{l}\text { Flexed } \\
\text { supine }\end{array}$ \\
\hline $3-\mathrm{J}-10$ & $\mathbf{1 2 3}$ & $87 \%$ & $0 \%$ & $\begin{array}{l}\mathrm{R}=12 \% \\
\mathrm{~L}=1 \%\end{array}$ & $0 \%$ & $33 \%$ & $17 \%$ & $\begin{array}{l}\mathrm{R}=31 \% \\
\mathrm{~L}=17 \%\end{array}$ & $0 \%$ \\
\hline $3-\mathrm{J}-11$ & $\mathbf{2 5 9}$ & $93 \%$ & $0 \%$ & $\begin{array}{l}\mathrm{R}=3 \% \\
\mathrm{~L}=4 \%\end{array}$ & $0 \%$ & $88 \%$ & $0.8 \%$ & $\begin{array}{l}\mathrm{R}=8 \% \\
\mathrm{~L}=4 \%\end{array}$ & $0 \%$ \\
\hline $3-\mathrm{J}-18$ & $\mathbf{2 1 7}$ & $35 \%$ & $4 \%$ & $\begin{array}{l}\mathrm{R}=32 \% \\
\mathrm{~L}=29 \%\end{array}$ & $0 \%$ & $48 \%$ & $1.4 \%$ & $\begin{array}{l}\mathrm{R}=34 \% \\
\mathrm{~L}=17 \%\end{array}$ & $0 \%$ \\
\hline $3-\mathrm{J}-23$ & $\mathbf{1 7 5}$ & $100 \%$ & $0 \%$ & $0 \%$ & $0 \%$ & $99 \%$ & $0 \%$ & $\mathrm{~L}=1 \%$ & $0 \%$ \\
\hline 4-M-142 & $\mathbf{3 1}$ & $99 \%$ & $0 \%$ & $0 \%$ & $<1 \%$ & $69 \%$ & $0 \%$ & $\mathrm{R}=<1 \%$ & $16 \%$ \\
\hline
\end{tabular}

Legend: $\mathrm{R}=$ placed on right side; $\mathrm{L}=$ placed on left side; flexed supine = torso supine, legs flexed

Some bodies were flexed and placed on their sides. This was most common with the burials of children but no bodies were tightly flexed as in post-Meroitic graves.

In other graves the upper part of the body was placed in a supine position but the legs were markedly flexed as in grave 45 at site 4-M-142 where an adult was placed on the flat base of a very large grave where it could easily have been fully extended [Fig. 4:C]. ${ }^{5}$ Another adult with the knees bent so tightly that the ankles are by the pelvis was found in cemetery $3-\mathrm{J}-11$, grave 1269 [Fig. 4:D].

5 For an almost identical arrangement elsewhere in the region see Paner, Pudło, and Borcowski 2010: 74, Fig. 14. 
Observations on graves of the medieval period in the SARS concession...

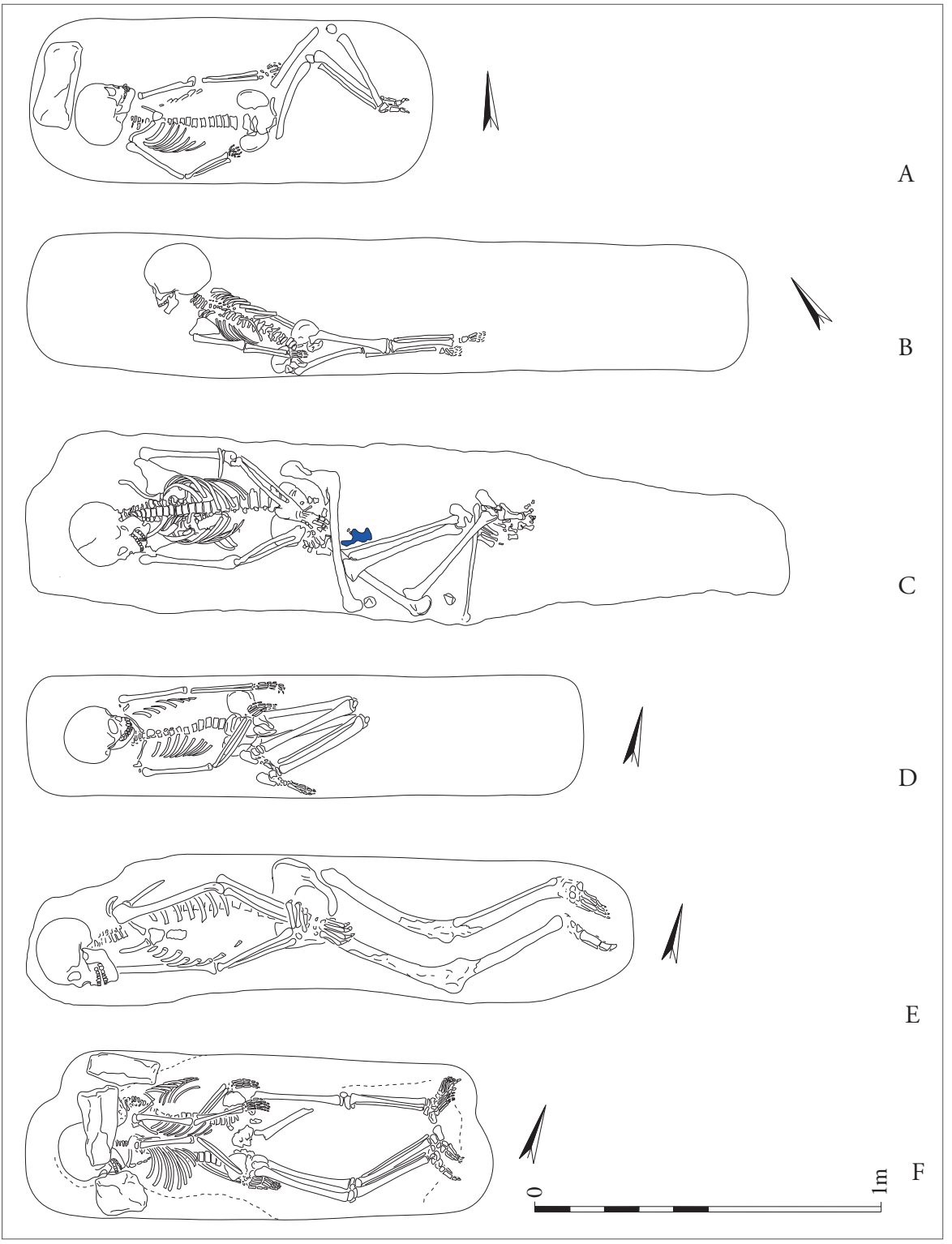

Fig. 4. Christian graves: A - 1077, small grave pit for tall individual, cemetery 3-J-10 on Mis Island; B - 1047, small individual in large grave pit, cemetery 3-J-10 on Mis Island; C-45, containing a supine flexed individual in a very large grave pit, cemetery 4-M-142; D-1269, an individual placed in a supine position but with the legs very tightly flexed, cemetery 3-J-11 on Mis Island; E-4008, an individual placed on its right side, cemetery 3-J-11 on Mis Island; F-3343 and 3398, cemetery 3-J-11 on Mis Island (scale 1:15) (Drawing SARS AKS Archive) 
As noted above, a significant number of individuals were placed on their side, both right and left and some of these have the legs flexed to some extent though never tightly so $[$ Fig. 4:E].

Virtually all graves contained a single individual. At cemetery 3-J-23 grave (P) 140 had a woman and her child whose feet still remained within the mother's pelvis. Grave 3343 in cemetery 3-J-11 appeared at first sight to have two bodies buried together but in actual fact the southern grave was later in date, with the child's body placed on its right side facing south, back to back with an earlier skeleton in grave 3398 , laid on its left side. Two of the three stones protecting the head of the earlier burial had been moved and used to form a rough protection for both skulls [Fig. 4:F].

Grave PITs. Almost all graves were long narrow pits, some having ledges along the long sides to support a covering over the body, usually of stone slabs. Where bodies were placed on their sides the graves could be even narrower so that the body was a snug fit. Only in very rare cases is the grave different. At site 3-J-23, in three graves, (B)83, (P)9 and (P)45, the body of a child was placed in a shallow side-niche dug under one of the long sides of the grave pit. The bodies in graves (B) 83 and (P) 45 were aligned east/west, in the other cases west/east.

Grave MONUMENTS. A wide range of rectangular monuments was provided and these are illustrated in the MDASP type series of monuments, types FF01FF03 (Borcowski and Welsby 2012). Occasionally the monuments were of more oval form; very rarely they are square. Very different were a few examples where a tumulus was provided, harking back to the pre-Christian tradition. At site 3-J-23 two such tumuli were excavated. The tumulus, $6.68 \mathrm{~m}$ by $6.26 \mathrm{~m}$ in size with a stone ring about $1 \mathrm{~m}$ thick, surprisingly did not cover a single burial but appears to have sealed a total of 13 graves, one of which, (B)90, had a pre-existing box-grave monument, which was incorporated into the tumulus [Fig. 5]. In the centre of the area covered by the tumulus was grave (B) 44 which may have been the principal burial. It was an unusual grave for a number of reasons. It was very shallow as it cut through the upper fills of graves (B) 111 and (B)114, but stopped before disturbing the burials contained within them [Fig. G]. It also cut the western end of grave (B) 107. Within it was the extended supine body of an adult, unusually with the head to the east. Surrounding the lower part of the body were stones against the edge of the grave. The other tumulus was a 'D'-shaped stone ring $(5.16 \mathrm{~m}$ by $5.06 \mathrm{~m})$ [Fig. 7], probably to be associated with grave $(\mathrm{P}) 39$ lying beneath its centre but it also partly sealed graves $(\mathrm{P}) 30$, $(\mathrm{P}) 38$ and $(\mathrm{P}) 40$. Grave $(\mathrm{P}) 39$ contained the body of an adult male in an extended supine position. 
Observations on graves of the medieval period in the SARS concession...

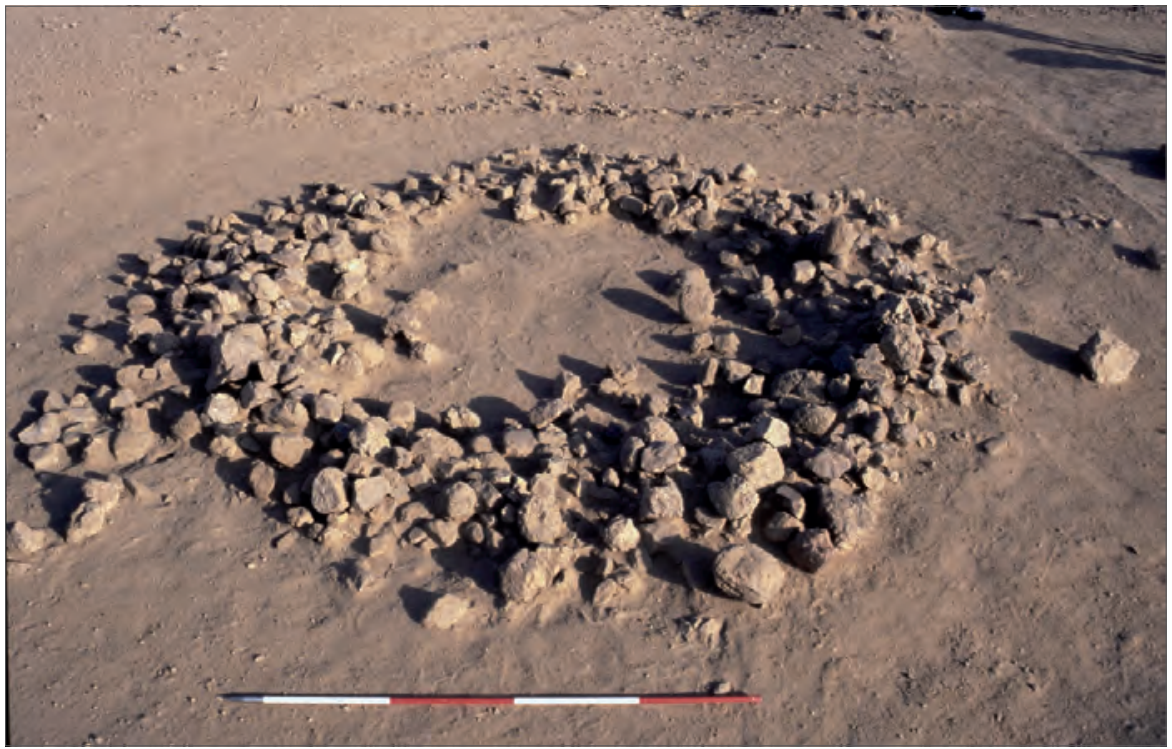

Fig. 5. Cemetery 3-J-23. Tumulus incorporating the box grave monument over grave (B)90 (Photo SARS AKS Archive)

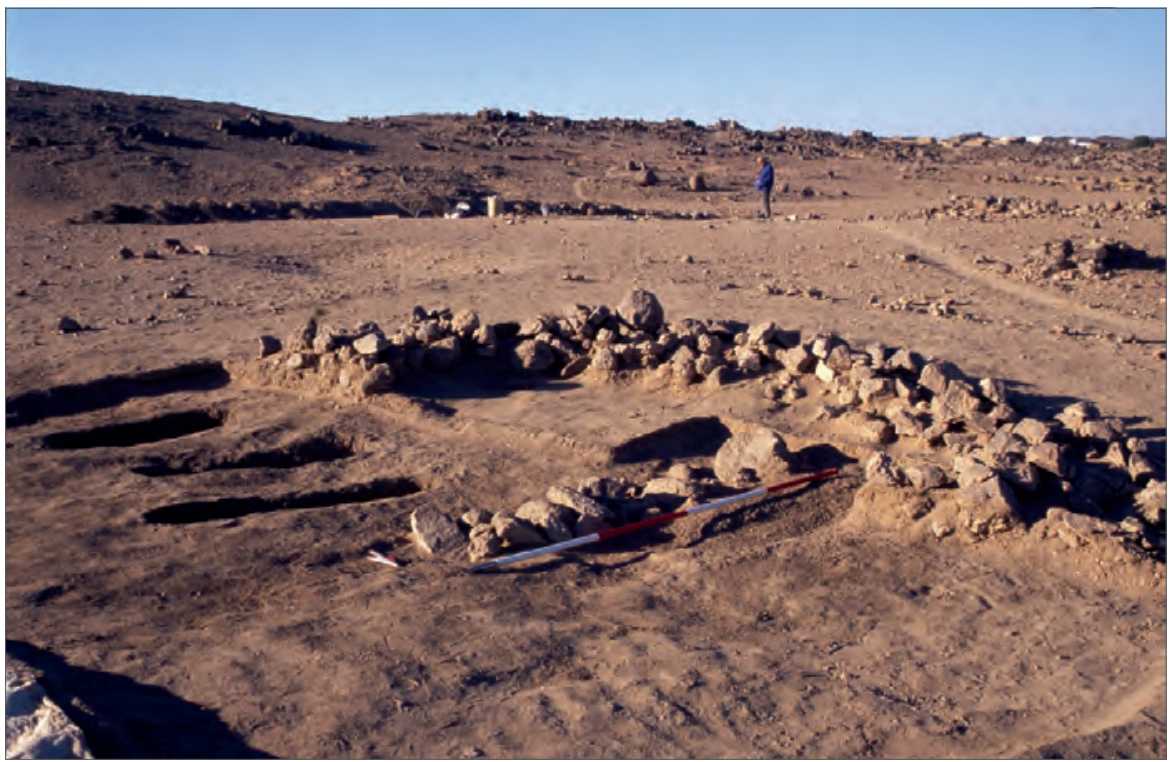

Fig. 6. Cemetery 3-J-23. Half section of the tumulus with grave (B) 44 infilled with large stones (Photo SARS AKS Archive) 
At site 3-J-11 on the nearby island of Mis, another tumulus was found amongst the box-grave monuments. Within it was a centrally placed burial (grave 1368) apparently of a Christian, containing the body of a juvenile (8-16 years old) laid in an extended position. The monument was $5.50 \mathrm{~m}$ in diameter, $0.30 \mathrm{~m}$ in height, and incorporated three pre-existing box-grave monuments into its superstructure marking graves 1165,1236 and 1286 . Whereas in some cases it may be argued that Christian tumuli were the direct successors of postMeroitic tumuli, here, as with one of the tumuli noted above at cemetery 3-J23 , it is clear that the use of box-grave monuments was well established before it was decided to mark the grave of this individual with a tumulus.

On the right bank of the river a number of small tumuli have been excavated which covered 'traditional Christian burials' radiocarbon-dated to AD 550-660 and AD 640-720 (Paner and Pudło 2010: 143).

One particular feature that links the pagan medieval tumuli and the medieval Christian box graves is the presence of a small box added on to the east side of the grave monument. Such 'lamp boxes' are a well known feature

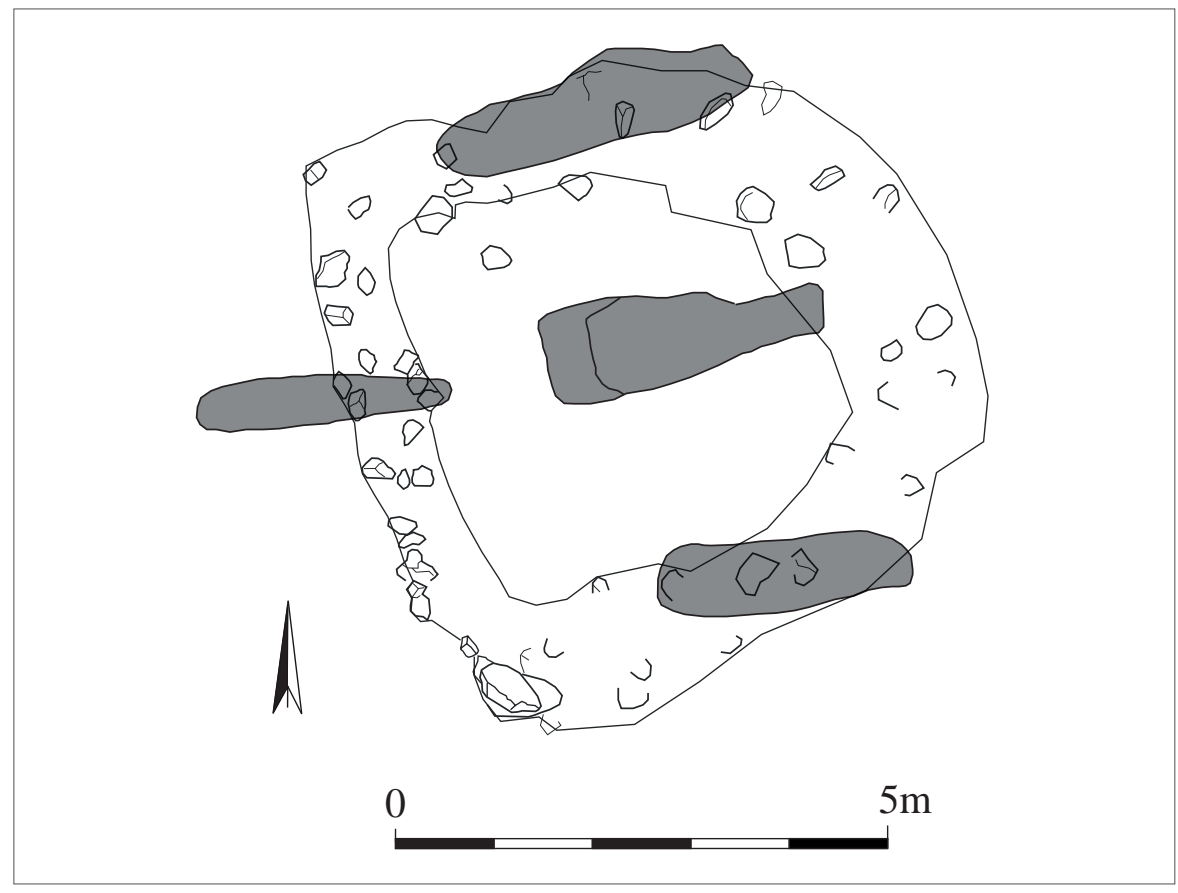

Fig. 7. Site 3-J-23. Tumulus over grave (P)39 (Drawing SARS AKS Archive) 
of Christian period box graves, but their presence on post-Meroitic tumuli has very rarely been noted. Of the two found in the SARS concession, at site 3-O-1, tumuli (10) and (18), each is on the southeast side of the tumulus [Fig. 8]. The importance of the eastern side of tomb monuments had a long tradition in the Middle Nile region. One might mention C-Group chapels appended to the east side of tumuli at Aniba (Steindorff 1935: Pl. I), chapels appended to the east side of New Kingdom pyramids at Tombos (Smith 2008: 97) and the presence of similar features attached to Kushite pyramids at many sites as at the pyramid (site 4-F-71) only a few kilometres away from el-Tereif discovered by the SARS mission (Welsby 2004). On a Christian box grave, the lamp box is often to be found at the west end as at Old Dongola (Welsby 2002: 61, Fig. 26).
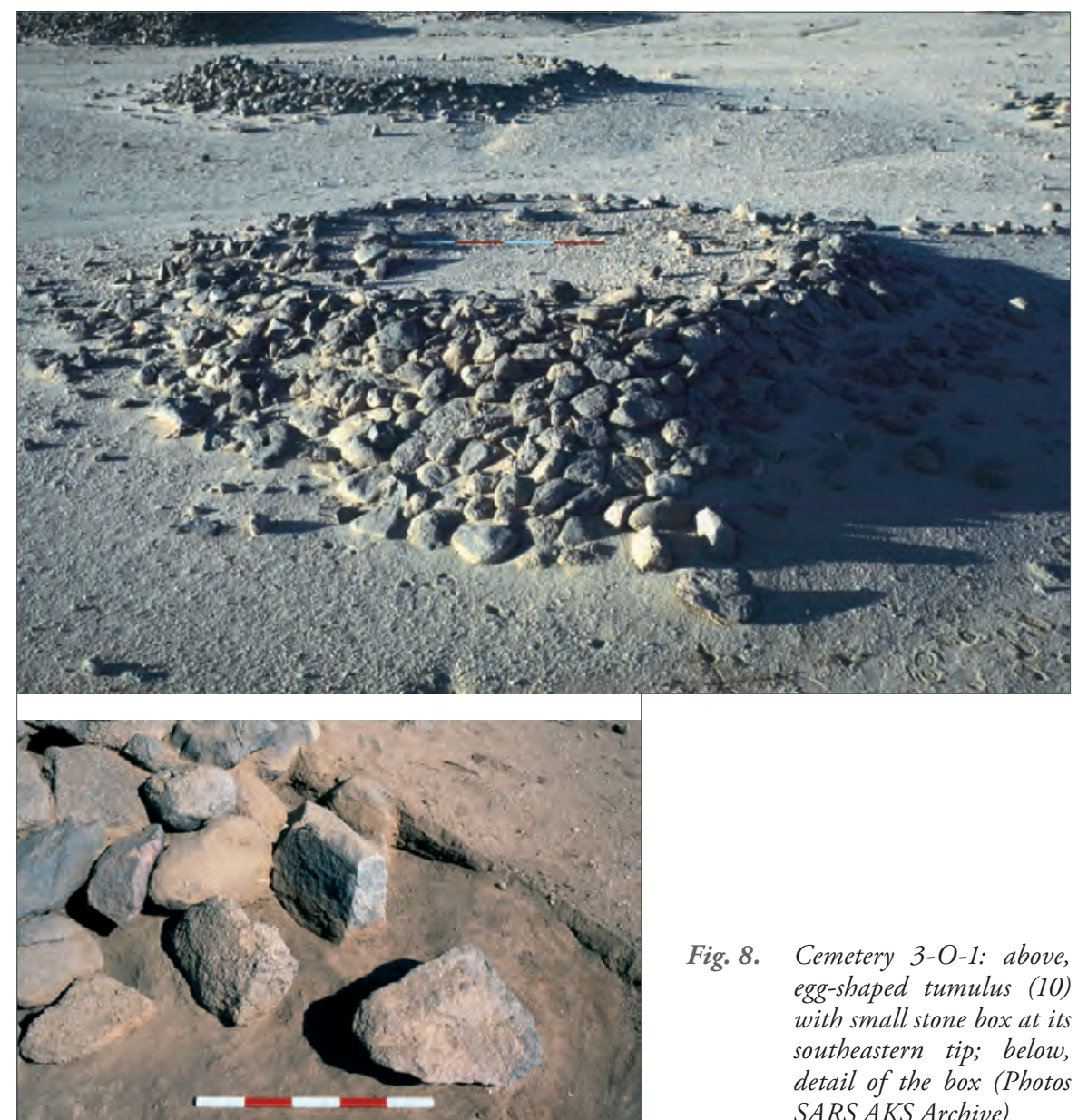

Fig. 8. Cemetery 3-O-1: above, egg-shaped tumulus (10) with small stone box at its southeastern tip; below, detail of the box (Photos SARS AKS Archive) 
Objects associated with the Deceased. The situation observed in the SARS concession can be mirrored elsewhere in the Middle Nile. Whereas in the post-Meroitic graves the provision of objects, particularly ceramic vessels, was very common this was not the case in Christian burials. ${ }^{6}$ Amongst the few objects found in Christian burials was a basket, several pendent crosses, finger rings, earrings, beads and a button. Pottery vessels placed in medieval Christian graves were extremely rare. Only one was noted in the graves excavated, in grave 1007 at cemetery $3-\mathrm{J}-10$, where a crude handmade cooking pot with lug handles and a rather thick rounded base (type 2320x), had been placed over the pelvis. The potsherds found in graves may have entered the grave fills by accident, although occasionally sherds appear to have been placed in the grave intentionally. One large potsherd had been used along with stones to 'protect' the head of an infant in grave $(\mathrm{P}) 76$ at cemetery 3-J-23, while in grave $(\mathrm{P}) 84$ there were several sherds and stones on the head of another infant.

Amongst the relatively rare graves where the preservation of organic material was good, there was a wealth of textile. Most bodies were wrapped in shrouds but some wore elaborate clothing. In grave 4149 (containing a child) at site 3-J-18, the finely woven brown shroud was decorated with cowry shells along one edge.

EMPTY GRAVES. A small number of grave pits contained no trace of a body. This is a phenomenon noted in graves of many different periods in the Middle Nile region and its significance is unclear. The examples in the SARS concession do not provide any evidence to move this discussion forward.

\section{Concluding remarks}

The most commonly used types of Christian grave monuments are highly distinctive and of a form never used at any other period of history in the Middle Nile region. However, not every grave was marked by a typical monument. The tumulus was used rarely and a little more commonly no grave monument whatsoever was employed, this being a common feature at many periods. Below ground, the norms of Christian ritual were usually adhered to, but there

6 Nor is it the case in some graves of the later Meroitic period. For example only half of 3-Q33 Meroitic burials contained grave goods - beads and pottery (Wolf and Nowotnick 2006b: 21). Even at an important urban centre such as Kawa many graves of substantial size contained bodies without grave goods.

7 Grave markers of organic materials which have since decayed may have been provided although no evidence of such markers were noted in Medieval graves. 
is a range of variability, the significance of which has yet to be ascertained. Such variability perhaps reflects local or family traditions rather than a strict adherence to the established Christian practices. Some graves of this period show a striking resemblance to a type well known in the later Meroitic period. The shape of the grave is identical, the provision of a covering of stone slabs set on ledges, and the placement of the body in a supine extended position aligned west/east. In this context, it is the post-Meroitic burials which stand out as being very different yet in many cases we can see the transition from post-Meroitic to Christian burials in the same cemetery, presumably of people from the same community, and the chronological sequence is clear. An anomalous site is 3-J11 where there are later Meroitic burials succeeded by Christian burials without the intervening post-Meroitic phase. Could the isolation of this site on Mis Island have preserved a Meroitic community observing its traditional burial practices up to the time of the arrival of Christianity? Should we see aspects of Christian funerary religion being part of the continuum of a developing local tradition with the post-Meroitic burials lying outside this local trend? Aspects of the funerary culture of the post-Meroitic period at least at the Fourth Cataract appear as a short term aberration. ${ }^{8}$

The post-excavation project relating to the sites investigated by the SARS teams is ongoing. This will hopefully allow a more definitive discussion of many of the issues alluded to in this short report. Integrating the results from the SARS concession with those from the work of other missions will be the final step in this long process.

\section{References}

Borcowski, Z. and Welsby, D.A. (2012). The Merowe Dam Archaeological Salvage Project. Provisional type series of monuments. Retrieved from https://nubianstudiessociety. files.wordpress.com/2014/02/mdasp_ts_12-2012.pdf [accessed: November 2015] Edwards, D.N. (1994). Post-Meroitic ("X-Group") and Christian burials at Sesibi, Sudanese Nubia: The excavations of 1937. Journal of Egyptian Archaeology, 80, $159-178$

Ginns, A. (2010). Medieval cemetery 3-J-11. Retrieved from http://www.sudarchrs. org.uk/wp-content/uploads/2013/09/SARS_draft_3-J-11_report.pdf [accessed: November 2015]

$8 \quad$ The similarity of Meroitic and Christian graves has been noted elsewhere on the Middle Nile, most recently discussed in Obłuski 2014: 40ff. 
Godlewski, W., Mahler, R., and Czaja-Szewczak, B. (2012). Crypts 1 and 2 in the Northwest Annex of the Monastery on Kom H in Dongola: Report on the exploration in 2009. Polish Archaeology in the Mediterranean, 21, 338-360

Kołosowska, E. and El-Tayeb, M. (2005). A cemetery site near El-Argub in the Fourth Cataract Region: Second season of test excavations. Gdanisk Archaeological Museum African Reports, 3, 131-144

Näser, C. (1999). Cemetery 214 at Abu Simbel North: Non-elite burial practices in Meroitic Lower Nubia. In D.A. Welsby (ed.), Recent research in Kushite history and archaeology: Proceedings of the 8th International Conference for Meroitic Studies [= British Museum Occasional Paper 131] (pp. 19-28). London: British Museum Press

Obłuski, A. (2014). The rise of Nobadia: Social changes in Northern Nubia in late Antiquity [=Journal of Juristic Papyrology Supplement 20]. (I. Zych, trans.). Warsaw: Raphael Taubenschlag Foundation

Paner, H. and Pudło, A. (2010). Settlements in the Fourth Cataract GAME Concession in the light of radiocarbon analysis. Gdansk Archaeological Museum African Reports, 7, 131-146

Paner, H., Pudło, A., and Borcowski, Z. (2010). Funerary customs in the GAME Fourth Cataract Concession in the light of radiocarbon analysis. In W. Godlewski and A. Łajtar (eds), Between the cataracts: Proceedings of the 11th Conference for Nubian studies, Warsaw University, 27 August - 2 September 2006, II.1. Session papers [=PAM Supplement Series 2.2/1] (pp. 61-76). Warsaw: Warsaw University Press

Smith, S.T. (2008). Tombos and the transition from the New Kingdom to the Napatan period in Upper Nubia. In W. Godlewski and A. Łajtar (eds), Between the cataracts: Proceedings of the 11th Conference for Nubian studies, Warsaw University, 27 August 2 September 2006, I. Main papers [=PAM Supplement Series 2.1] (pp. 95-115). Warsaw: Warsaw University Press

Steindorff, G. (1935). Aniba: Service des Antiquités de l'Égypte. Mission Archéologique de Nubie 1929-1934, I. Glückstadt: Augustin

Welsby, D.A. (2002). The medieval kingdoms of Nubia: Pagans, Christians and Muslims along the Middle Nile. London: British Museum Press

Welsby, D.A. (2004). The SARS Amri to Kirbekan Survey. Excavations at the pyramid, Site 4-F-71. Sudan \& Nubia, 8, 2-3

Welsby, D.A. (2013). Excavations in grid square 3-O. Retrieved from http://www. sudarchrs.org.uk/wp-content/uploads/2013/09/SARS_draft_3-O_excavations.pdf [accessed: November 2015]

Wolf, P. and Nowotnick, U. (2006a). Hamadab - A Meroitic urban settlement: Excavations 2001-2003. Archéologie du Nil moyen, 10, 257-272

Wolf, P. and Nowotnick, U. (2006b). The third season of the SARS Anglo-German expedition to the Fourth Cataract of the Nile. Sudan \& Nubia, 10, 20-31

Żurawski, B. and El-Tayeb, M. (1994). The Christian cemetery of Jebel Ghaddar North. Nubica, 3(1), 297-317 


\title{
The chronology of the eastern chapels in the Upper Church at Banganarti. Some observations on the genesis of "apse portraits" in Nubian royal iconography
}

\author{
Magdalena M. Woźniak \\ Université Paris-Sorbonne - UMR 8167 \\ magdamwozniak@gmail.com
}

\section{KeYwords}

apse portrait, Banganarti, iconography of power, royal costume

\section{Abstract}

The article deals with a specific type of Nubian royal iconography, namely, the "apse portraits". The paintings discovered in 2001 at Banganarti (Sudan) form the most numerous and complete ensemble of such portraits. The author follows the evolution of royal power through the prism of its imagery, comparing the Banganarti set with earlier royal portraits from Faras and Old Dongola. She demonstrates the progressive affirmation of the king's prerogative as the leader of the Nubian church and privileged mediator between God and his people. The examination of royal costume as well as decorative motifs leads the author to propose a more detailed chronology of the eastern chapels of the church.

The architectural uniqueness of the Banganarti complex has been repeatedly emphasized since its discovery in 2001 (Z̈urawski 2003: 241). The originality of the eastern part of the structure, divided into seven apsidal chapels, and its relationship with the equally exceptional painted decoration were recently analyzed by Magdalena Łaptaś who established an interesting correspondence between the number of chapels and the Archangels mentioned in biblical literature (Łaptaś 2014). Her demonstration highlights the intrinsic relationship of architectural and iconographic programs implemented in this unprecedented building. 
However, a study of the arrangement of the decorative program in the apses as well as of the paintings themselves demonstrates the involvement of distinct workshops and various stages in the display of such an ambitious program dedicated to the worship of the ruler. Whether the king's worship was practiced during his lifetime or after his death (Zielińska 2014: 945; Godlewski 2013: 672), an update of the royal portraits is inevitably expected and partly explains the interventions of different painters in the decades following the inauguration of the complex. But it is also tempting to see through these different compositions a progressive elaboration of the iconography of royal power, and in a broader scope, of the monarchical ideology as reflected in the specific context of the apse portraits. The validity of this interpretation can only be confirmed, if the internal chronology of these paintings is clarified and for this purpose a variety of available dating criteria will be considered in combination: the location of the murals, composition of the portraits, stylistic markers, iconographical details in the representation of the Apostles, different elements of royal costume, and, last but not least, decorative patterns on the royal clothes. The number of chapels under consideration is seven, but the number of portraits is higher than that, there being several instances of late repaints, particularly in chapels 1 and 4 . Moreover, screen walls were put up later in chapels 5 and 6 , obstructing the view of the original apses and decorating the walls with a figure of a ruler protected by an archangel. ${ }^{1}$

The location as well as the architectural ornaments (arches, columns) of the central apse highlight its primacy over other chapels and it is very likely that chapel 4 was decorated first. The stylistic markers as well as the quality of execution of the frieze of the Apostles, probably contemporary with the representation of the saints Cosmas and Damian, argue in favor of this idea. ${ }^{2}$
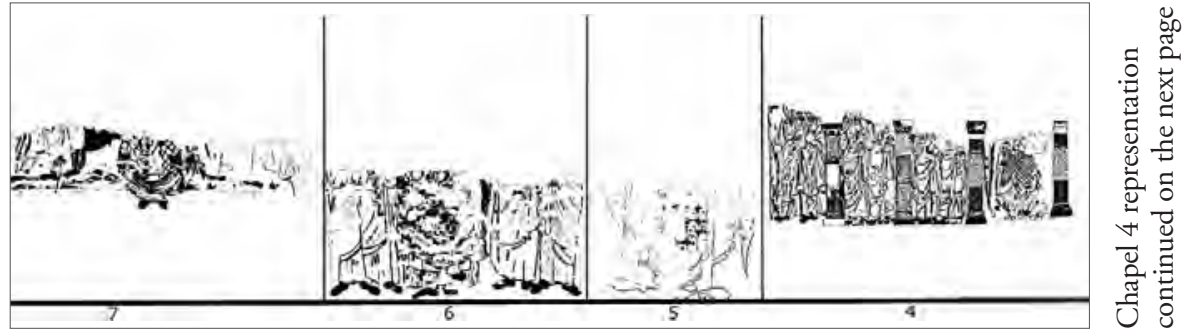

1 Figures of the Apostles can also be traced on the screen wall of chapel 6 (Żurawski 2014b: 162, Fig. 1).

2 Supported by the dating put forward in the publication of the Upper Church (Zurawski 2014b: 156 and 185). However, a 12th-century date does not fit well with the decorative pattern on the earlier layer of the painting in chapel 4 (see below). 
As far as the other chapels are concerned, it would seem logical that the next chapels to be decorated would be the ones immediately adjacent to chapel 4 . Assuming the location to the right of the main chapel might be considered more prestigious than to the left, a probable sequence would be chapels 5 and 3 , then chapels 6 and 2, and finally chapels 7 and 1 .

However, a close examination of the location of portraits in the eastern chapels [Fig. 1] shows the paintings divided into two distinct groups: the decoration in apses 1, 4 and 7 is placed at mid-height, while that in chapels 2, 3, 5 and 6 has a monumental setting with the feet of the Apostles and Archangels based on ground level. In the first group, the figures of the Apostles are smaller and (almost) all located on the apse wall (12 figures in chapel 4, eight in chapels 1 and 7). In the second group, only three or four of the Apostles appear in the apse itself, the rest of the apostolic college being distributed on the side walls of the chapel; in chapel 5, the Archangel and the king are the only occupants of the apse. Such differences in the implementation of a firmly pre-established decorative program are quite unexpected. The involvement of more than one workshop to complete the paintings of the church should be considered, but that does not explain the formal differences of the compositions in achieving the iconographic program in these chapels.

Changes are also noticeable in the compositions themselves, though they seem almost identical at first sight. For the first group, observation of these details is very limited owing to a poor state of preservation of the paintings. Nevertheless, one notes in chapels 1 and 7 the royal figure being located below the main register on which the Apostles and probably the Archangel stand (no trace of the latter figure has been preserved). In the central chapel 4, which is the main chapel, the figures all stand on the same register: the Apostles are

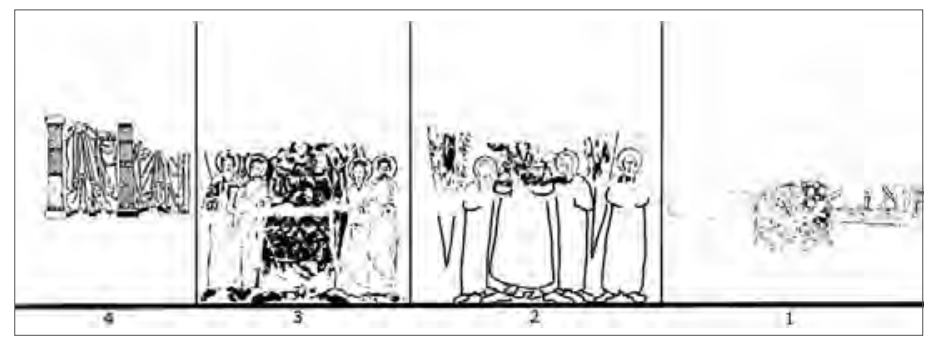

Fig. 1. The apse decoration of the seven eastern chapels in the Upper Church at Banganarti (continued from opposite page) (Tracing A. Btaszczyk, W, Chmiel, M. Eaptaś, D. Zielinska; montageldrawing M.M. Woźniak) 
distributed in pairs on either side of the central group consisting of the sovereign and the Archangel. Due to the late repaint on this part of the composition, however, the original attitude of the two protagonists cannot be determined.

Four variants and thus a different arrangement for each portrait can be observed in the second group. In chapel 2, the Archangel touches the left shoulder of the king, ${ }^{3}$ while St Peter and St Andrew (see Łaptaś 2008) place a protective hand on the arms of the sovereign (Źurawski 2014: 138, Fig. 4). In chapel 3, both hands of the Archangel are painted on the king's shoulders; in its right hand the celestial figure holds an object shaped like a building with a dome surmounted by a cross. ${ }^{4}$ The Apostles placed on either side of the king support him with their hands under his elbows (Żurawski 2014: 143, Fig. 2). ${ }^{5}$ The situation in chapels 5 and 6 is quite different: in one case, as noted above, the king is represented alone with the Archangel, the Apostles being relegated to the side walls (Żurawski 2014: 159, Fig. 5/Upper, 160-161, Figs 6, 8); in the second case, four Apostles stand with the Archangel and the king in the apse, but it seems that there is no contact between the Apostles and the sovereign (Żurawski 2014: 163, Fig. 4). Although the composition is destroyed in the upper part, the figure of Peter can be identified at the king's right, as the saint's attribute par excellence, namely the key, can be seen held in the figure's left hand, brought to the chest.

In this small group of seven paintings a surprising number of different combinations has been used to represent the same theme: the king in the company of the Archangel and the apostolic college. Yet these variants are not trivial in terms of their significance for the development of the iconography of power. For example, the internal relationship of the figures in the composition of chapel 3 strongly differs from that found in chapel 5: in chapel 3, all the tutelary figures combine to surround the king with benevolent protection, but in chapel 5 the king is shown alone in the company of the Archangel, the Apostles appearing rather as observers or maybe witnesses to the main scene (the wide purple border framing the figures of the king and the archangel in the apse emphasizes the separation between the two groups of the composition).

A minute examination of royal garments can add dating elements to our investigation of the chronology of the apse portraits. Regarding the clothes worn by the sovereign, they consist of a round-neck dress with long sleeves and of a mantle worn in a particular way, typical of the evolution of Nubian royal

3 The Archangel's right hand is not preserved, but the sleeve of his robe indicates that his hand had been raised over the king's head, probably in blessing.

4 It is interpreted as a model of a church (Eaptas 2016, in this volume) or as a reliquary (Żurawski 2008: 316).

5 Żurawski noticed an interesting parallel with Kushite iconography (Żurawski 2014a: 14) 
attire between the late 11th and mid 12th century. A part of this coat is worn on the right shoulder, while the main piece of the cloth is wrapped around the waist, covering the dress (only its lower part remains visible). Another part of the fabric is placed on the left forearm of the sovereign. ${ }^{6}$ In the lower part, the coat forms a large central panel that can be observed in chapels 3, 5, 6 and 7. In chapels 1 and 4, where portraits were repainted in the late medieval period, a tripartite edge of the mantle is observed. This feature appears perhaps as soon as the middle of the 12th century, but more probably in the 13th century. ${ }^{7}$

Among the attributes represented in these paintings, the most frequent elements are the crown and the scepter. In portraits preserved in chapels 2, 3 and 6, the king was arguably figured with two crowns: one placed on his head, the other in his left hand. ${ }^{8}$ The type of the crown worn on the head cannot be determined owing to the state of preservation of the paintings, but the one held in the hand is helmet-shaped (decorated with scales or ribbed) and surmounted by a cross; the crown from chapel 3 is enriched with a pair of horns.

The scepter appears only in chapels 2 and 3. It consists of a handle crowned at the top by a small figure of Christ. The statuette appears against the background of a cross. Christ, identified by the cruciform halo, is represented seated; he makes a gesture of blessing with his right hand.

The clothing described as well as the associated regalia form a relatively homogeneous set and confirm the execution of the royal portraits between the second half of the 11th century and the late 14th century. Indeed, the evolution of Nubian royal costume reflects a trend toward the "nubianization" of ceremonial attire (Godlewski 2008: 273). An analysis of Nubian royal portraits leads to the identification of three types of costume (Woźniak in preparation) [Fig. 2]. Until the 10th century the costume may be termed "Byzantine" for it consists of a dress, a large cloak (chlamys) as well as a crown ornamented with pendants (kamelaukion) and a short cruciform scepter. A type designated as Nubian I type appeared in the first half of the 11th century. It was marked not only by a change of royal attributes (open crown, veil worn under the crown, bow), but also by a new model of cloak, worn on the right shoulder but leaving

6 It could possibly be a long stole, which follows a similar disposition and is worn also on the coat (Woźniak in preparation).

7 This element figures also in the paintings on the screen walls from chapels 5 and 6 .

8 In chapel 2, tiny yellow fragments of the crown appear above the ruler's ears and also the cross of the crown placed in his hand has been preserved. In chapel 3, the border of the crown is preserved on the ruler's forehead, while the crown placed in his hand is completely visible. In chapel 5, the left hand of the ruler is preserved as well as the lower part of a helmet-shaped crown. 


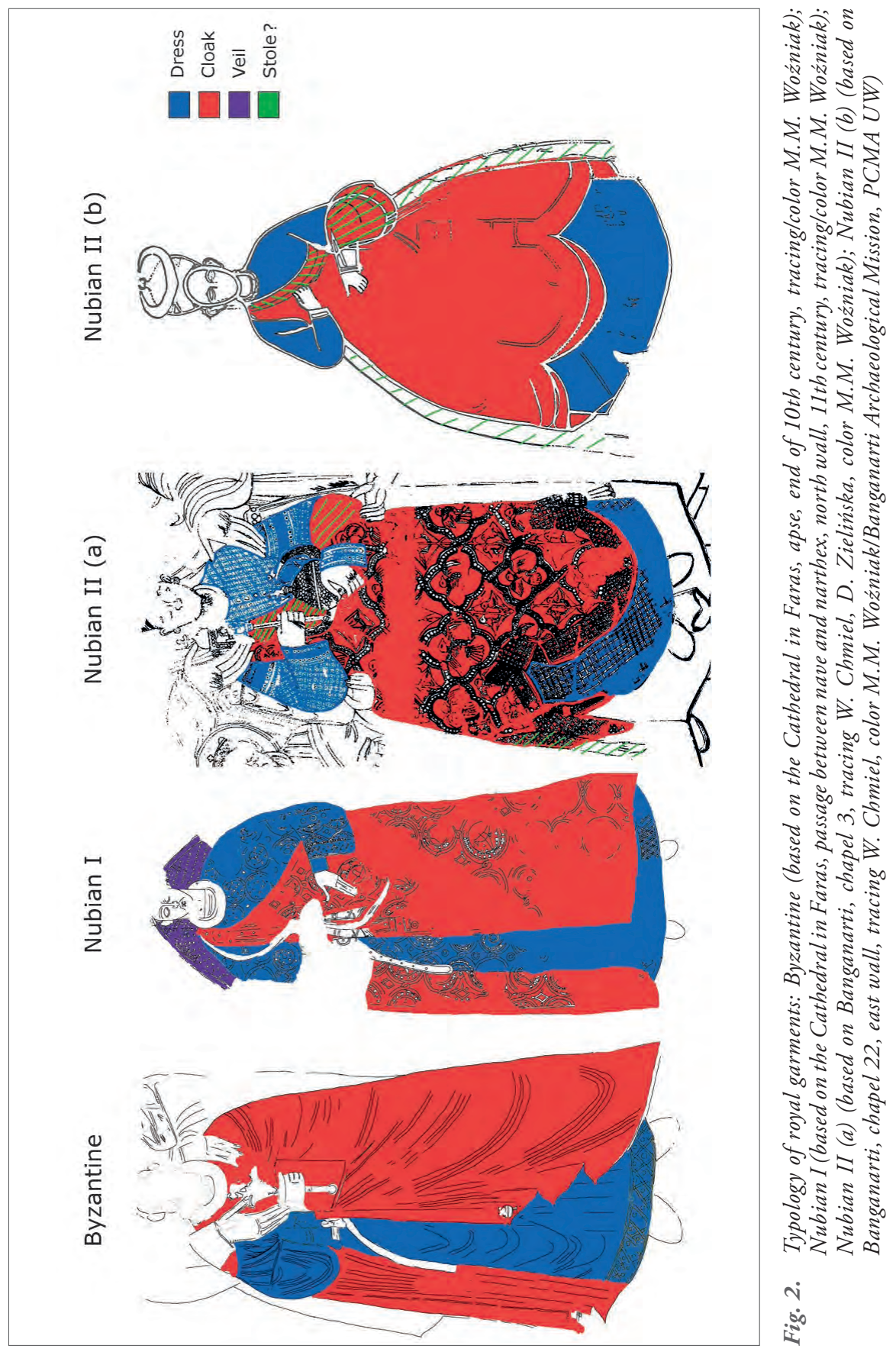


the left shoulder uncovered. A few decades later, between the mid-11th and mid-12th century, the royal costume evolved into the Nubian II type, consisting of a helmet-shaped crown topped with a cross and a new cloak, characterized with a central panel edge that covered completely the dress worn underneath. The cloak's edge was given a tripartite shape probably in the 13th century.

Consequently, the costumes represented in the Banganarti portraits belong to the Nubian II group including both variants of the cloak: the central panel (Nubian II [a]) in chapels 3, 5, 6, and 7, and the triple edge (Nubian II [b]) in the apses of chapels 1 and 4 (as well as on the screen walls of chapels 5 and 6). This analysis based on dress criteria suggests a possible ranking of apse portraits, namely those of chapels 3, 5, 6 and 7 are older than the two painted in chapels 1 and 4 .

This chronological distribution is not consistent with our precedent observations on the disposition of the decor in the apses, which had distinguished two groups: one consisting of chapels 1, 4 and 7 and the other consisting of chapels 2, 3, 5 and 6. However, this discrepancy disappears if one takes into account the fact that the portraits from chapels 1 and 4 (where the composition is located at half height) are actually late repaints. In this first group, only the portrait of the chapel 7 shows no apparent alterations.

A minute examination of paintings in chapels 1 and 4 reveals remains of the earlier layer in the form of fragmentarily preserved ornamental motifs significant for establishing the internal chronology of the chapels (Martens-Czarnecka 1982: $\mathrm{Pls}$ Ia to IIb; Woźniak in preparation). The pattern of circles and diamonds painted in shades of green, red and yellow, preserved on the first layer of chapel 4, can apparently be dated to the 10th through 11th century [Fig. 3]. Traces of robe ornaments from an earlier portrait were visible also in the central part of the mantle of the figure in chapel 1; the traces consisted of interlaced medallions; beadedpetal flowers are still preserved in the lower part of the painting [Fig. 4]. These decorative elements are typical of the 11th century. In chapel 7, the diamondshaped pattern adorned with delicate flowers and framed in a double-knotted lattice is datable to the 11th-12th centuries [Fig. 5].

A comparative analysis of textile decorations from the second group (chapels $2,3,5$ and 6 ) is more problematic. The set of patterns is easily datable to the 12 th13th centuries, but because of the popularity of some ornaments like medallions inhabited with animals [Figs $\mathbf{6 - 8}]$ it is difficult to establish a more precise chronological setting of the ornamental repertoire. On the side, one should note that the Apostles of chapel 5 were represented without crowns unlike the Apostles of chapels 2, 3 and 6 [Fig. 9], which indicates that the apostolic college of chapel 5 was painted earlier. Indeed, the crowned Apostles are a typical Nubian invention from the second half of the 12th century (Martens-Czarnecka 2011: 206). 


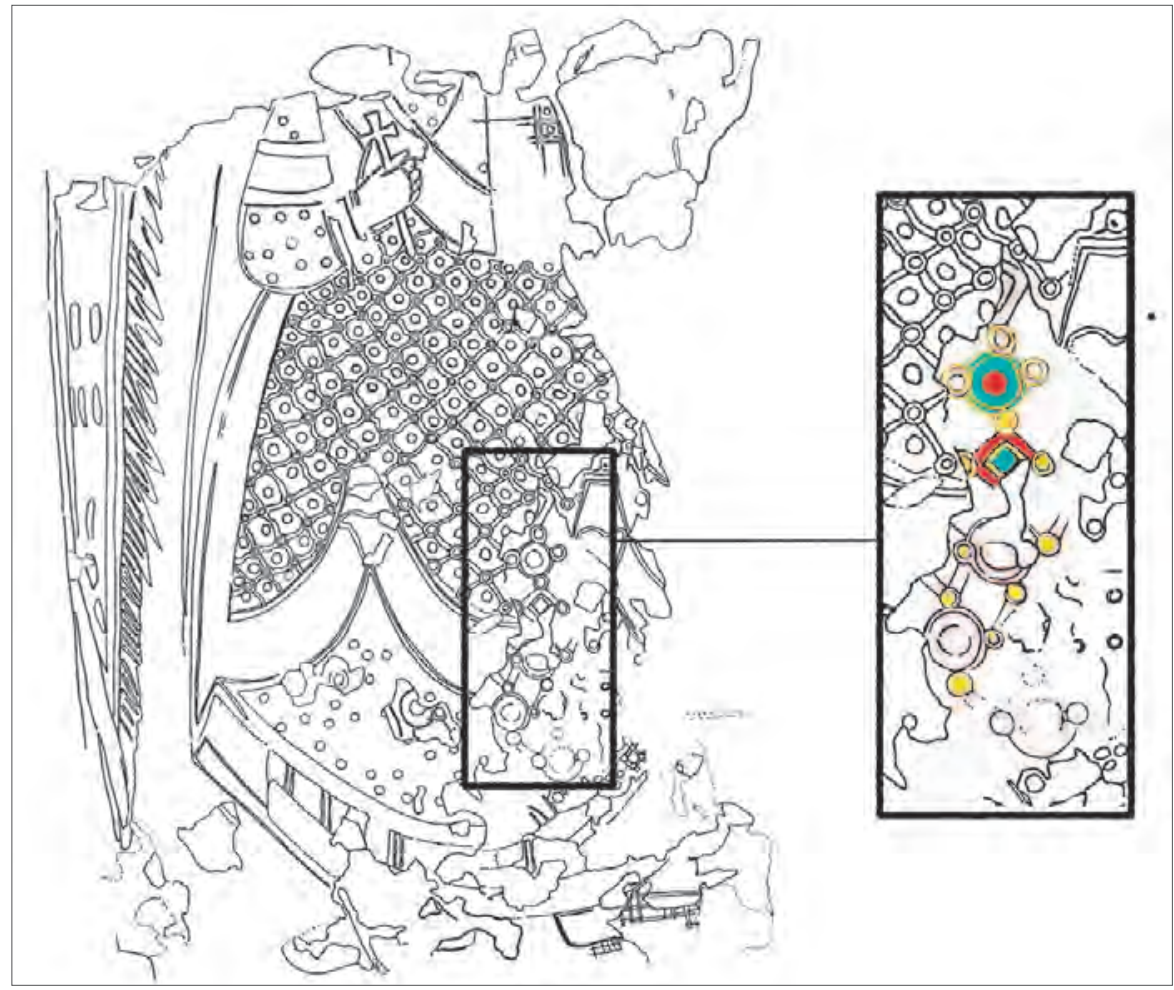

Fig. 3. Banganarti, chapel 4, decorative pattern on an earlier painting layer (Tracing D. Zielinska/Banganarti Archaeological Mission, PCMA UW, coloring based on on-site observation M.M. Woźniak)

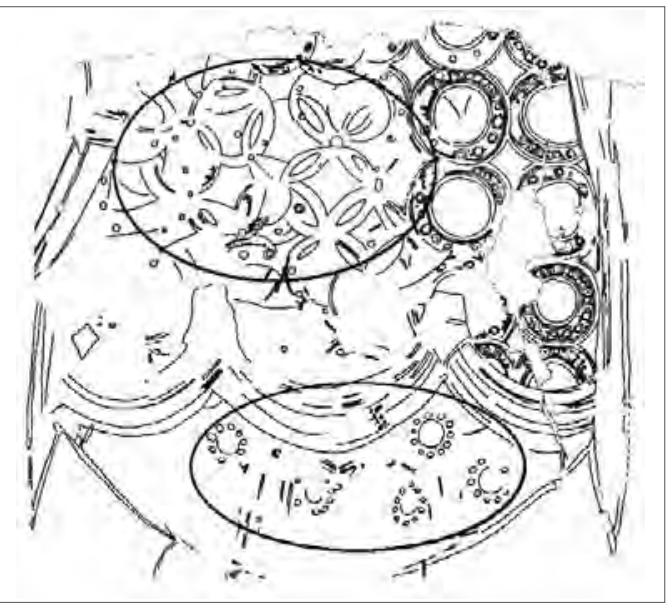

Fig. 4. Banganarti, chapel 1, decorative pattern from an earlier layer of painting (Tracing M. Eaptaśl Banganarti Archaeological Mission, PCMA UW) 
Images of the king surrounded by the Apostles and placed under the protection of a holy person were known long before the discovery of the Banganarti complex. The first example of such a composition was discovered in the early 1960s in the cathedral at Faras, a second one thirty years later in room 29 of the Northwest Annex of the Monastery on Kom H in Dongola. The portrait from Faras, dated to the end of the 10th century by current research, ${ }^{9}$ is the oldest attempt (and by far the most daring one in the decorative program of the cathedral) to place the royal figure in the most sacred area of the church, namely the apse. The apsidal decor consisted certainly of a double Theophany,

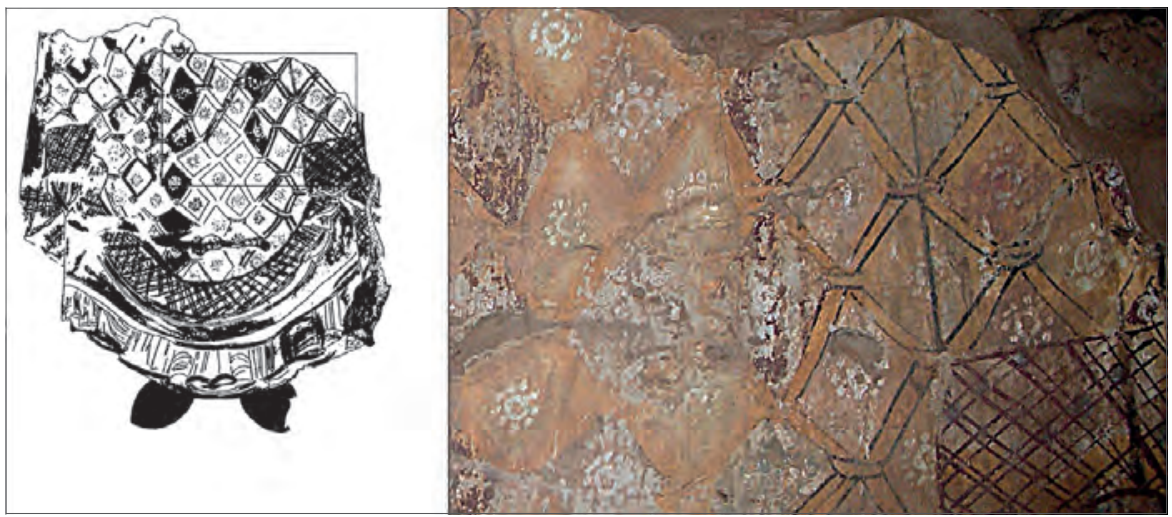

Fig. 5. Banganarti, chapel 7, pattern decoration from the king's cloak (Tracing M. Eaptas'l Banganarti Archaeological Mission, PCMA UW; photo M.M. Woźniak)

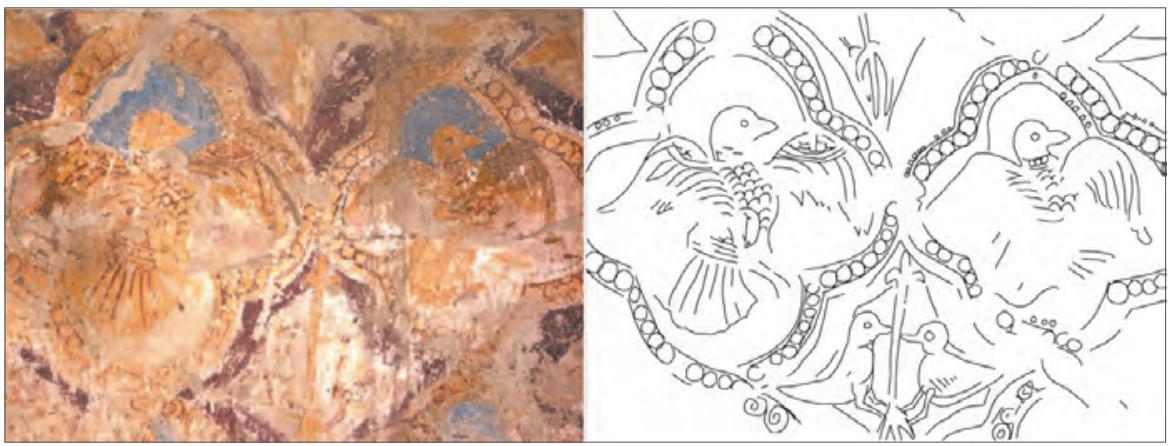

Fig. 6. Banganarti, chapel 3, ornament on a king's cloak (Photo and tracing M.M. Woźniak)

9 The apparently most ancient "apse-portrait" was recently excavated by Włodzimierz Godlewski in the "royal" church B.V on the citadel in Old Dongola (W. Godlewski, personal communication). 


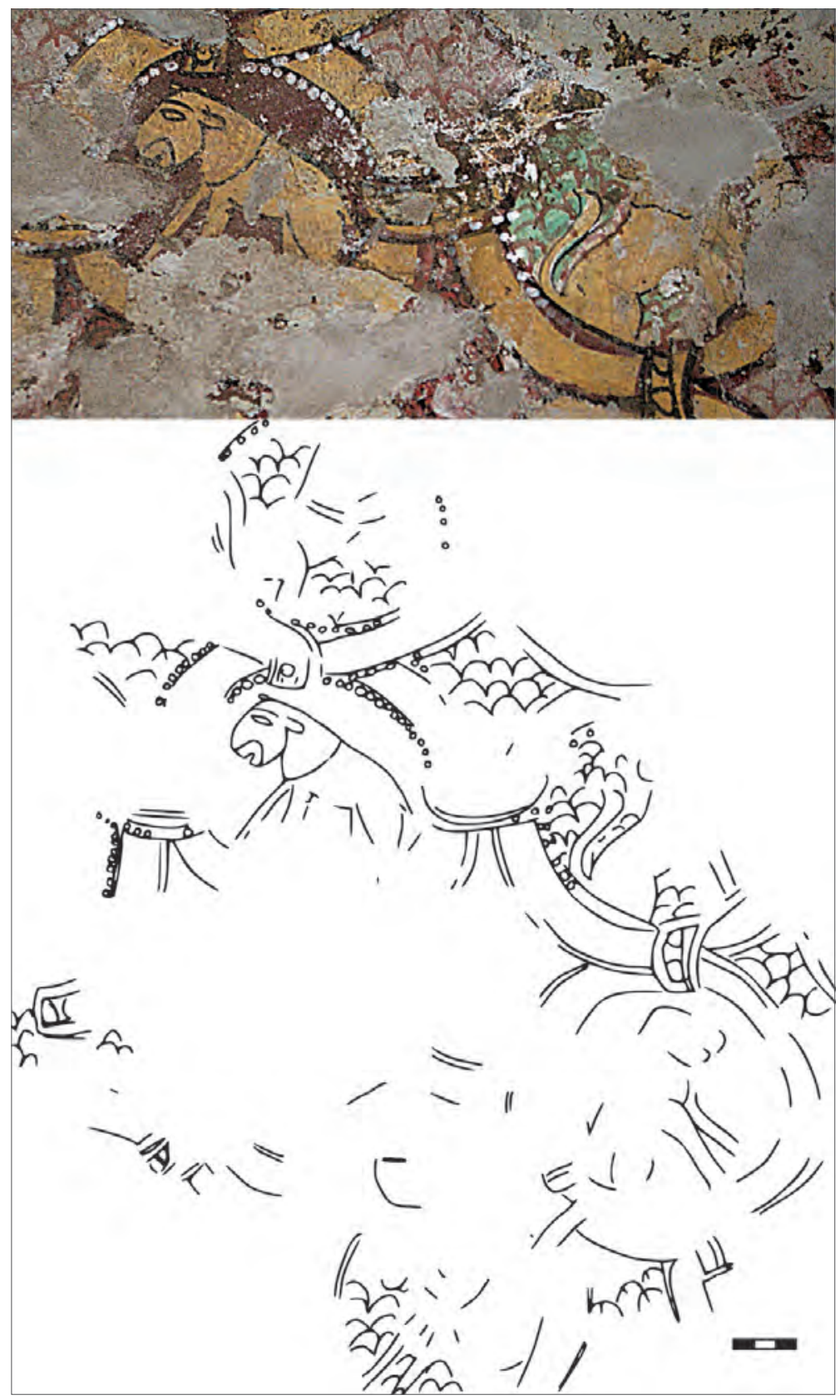

Fig. 7. Banganarti, chapel 6, decorative pattern on a king's cloak (Photo and tracing M.M. Woźniak) 
which was a current theme in Byzantine and Coptic churches (Velmans 2006: 55ff., 89). A figure of Christ in glory figured almost certainly in the upper part of the composition, while in the lower zone the Virgin and Child stood surrounded by the Apostles; the portrait of the ruler was painted partly over the representation of the Virgin and Child. The hands of the Mother of God

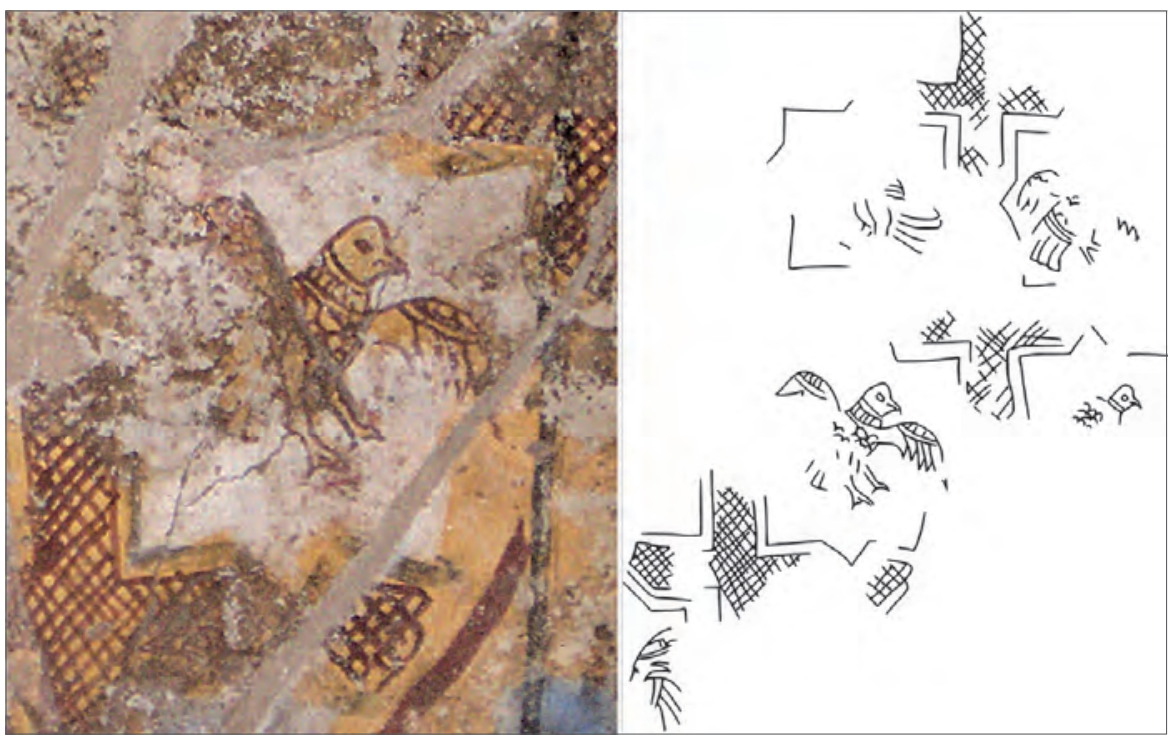

Fig. 8. Banganarti, chapel 5, decorative pattern from a king's cloak (Photo and tracing M.M. Woźniak)

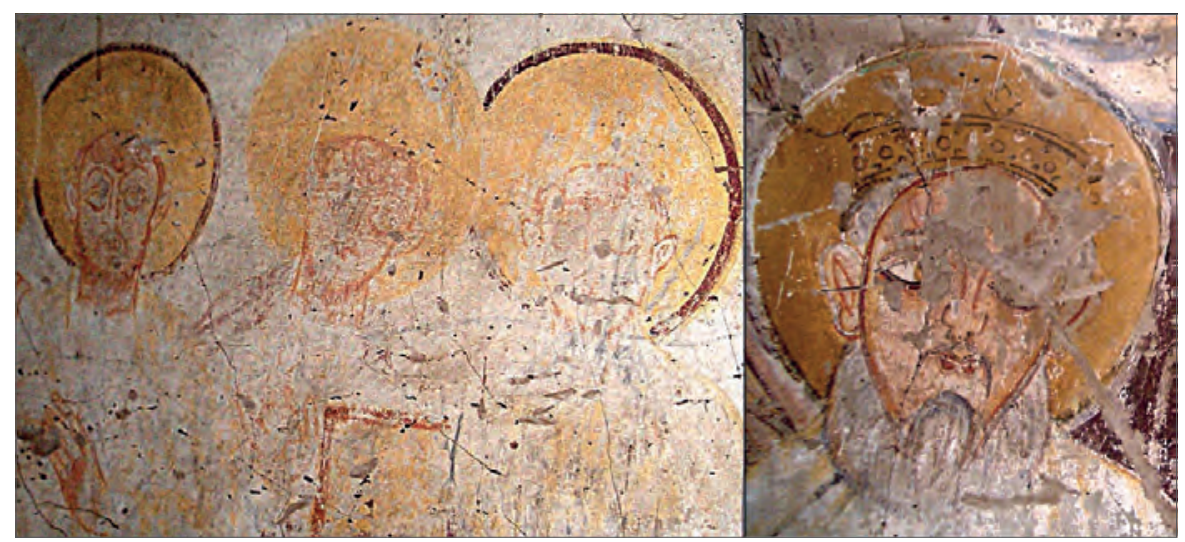

Fig. 9. Banganarti, Apostles without crowns in chapel 5 (left) and crowned St Peter in chapel 3 (right) (Photos M.M. Woźniak) 


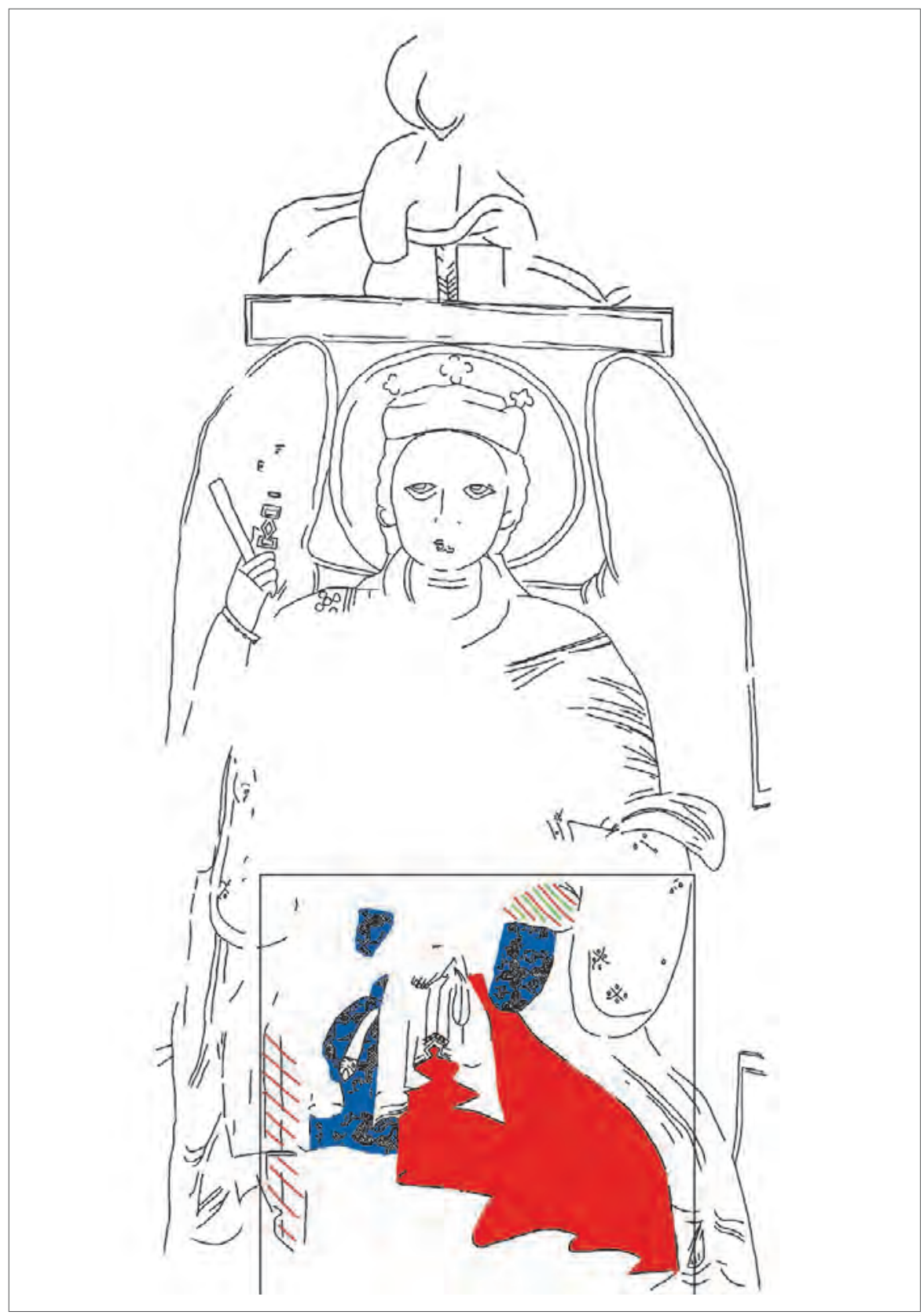

Fig. 10. Old Dongola, Northwest Annex of the Monastery on Kom H, room 29, east wall (Drawing and color M.M.Woźniak) 
were then repainted toward the shoulders of the king in a benevolent gesture of protection (Michałowski 1974: Cat. 19). It is important to note that the figure of the king is not the only addition to the apse decoration; indeed, the portrait of a bishop was located right at the end of the frieze of the Apostles. At Dongola, an analysis of the liturgical space has shown that the north wall of room 29 served as a sanctuary of the church in the adopted space of rooms $22,23,27,29$ and 31; this disposition is emphasized by the painted decoration (Zielińska 2010: 646). The composition of the painting is dominated by an immense figure of the Archangel with the Christ Pantocrator represented in bust form above it (Martens-Czarnecka 2001: 262-263, Pls XXVI-XXVII). The text of the dedication of the mural, offered by "abba Georgios, archipresbyter and archistylites" of the monastery, the future bishop of Dongola, appears in a frame between the two figures (Eajtar 2002; Godlewski 2013). In front of the Archangel, in the foreground, placed in the lower part of the composition, stands the figure of a king, recognizable by the fragments of his golden robe adorned with finely rendered octagonal medallions inhabited with birds. His cloak partly covers his dress, but both sleeves are visible indicating that the costume of the sovereign is of Nubian type I [Fig. 10]. The Apostles, divided into two groups of six figures placed on the east and west walls of the room, appear on each side of this central group formed by the Archangel and the king. The set is framed by a wide purple line, which also forms the outline of the wings of the Archangel. The painting is dated to the first half of the 11th century (see below).

A similar pattern appears at Banganarti, in chapel 5, where again the Archangel and the king occupy the apse, while the Apostles are depicted on the side walls. The resemblance is even more remarkable when looking at the king's cloak, also ornamented with octagonal medallions (this time inhabited by eagles with spread wings). Given the proximity of the two sites, one cannot ignore the deliberate reference in the Banganarti portrait to the painting of Dongola.

At Banganarti, however, there is no trace of any ecclesiastic dignitary in the apse compositions, which is a significant break from the ideological point of view with previous compositions. At Faras, the king represented under the protection of the Virgin and Child surrounded by the Apostles and placed under the figure of Christ in glory, clearly affirmed the divine origin of his power and thus the legitimacy of his reign. The offset of the royal figure compared to the register of the apostolic college guides the direction of reading along the vertical axis. But the representation of the bishop, placed at the right end of the apostolic college, on the same level as the Apostles, discreetly nuances the position of the two historical figures in the power hierarchy. The church dignitary is in fact an equal of the Apostles and surpasses the king, who is placed below the purple line on 
which stand Christ's Disciples. At Dongola, in a different but equally effective way, abba Georgios and more precisely his dedication text also occupies an intermediate position between Christ and the king. The hierarchy of authority is clearly illustrated by the composition: if the king enjoys the intercession of the great Archangel, the prior of the monastery is under the direct protection of Christ, who puts his right hand on the frame with the dedicatory inscription. Thus, even if the king is surrounded by the Apostles and protected by the powerful Archangel, all of them are placed not only under Christ's authority, but also under the authority of the prior of the monastery.

In the Banganarti sanctuary dedicated to the royal cult, it was the apse portrait model that was chosen from the extensive iconographic repertoire of representations of royal power. The sovereign was represented not only under the protection of a powerful Archangel, but also surrounded by the Apostles. In the central chapel adorned with columns, all the figures were placed on the same register. However, the king and the Archangel were still isolated from the Apostles. In chapels 1 and 7, where the decoration was located at mid-height in the apse, the king was still placed below the line on which the Apostles stand. But in chapel 5, for the first time, the feet of the monumental figures are set on ground level, all placed on the same purple line that frames the scene. In chapel 6, the Apostles join the Archangel in the apse and probably make a blessing gesture towards the king. Finally, in chapel $3,{ }^{10}$ the set is painted with a master stroke, creating an unprecedented interaction between the Disciples of Christ and his earthly representative: St Peter and St Andrew offer the king more than their blessing; they offer him solid, physical support, their hands resting on his arms. More than a mere commander obeying the Lord and entrusted with the protection of His Church that was in the bishop's authority, the ruler appearing in the middle of the apostolic college was represented as their peer, the "thirteenth" Apostle. The two saints, acting on behalf of the Twelve, seem to perform a ritual presentation of the king to Christ (Mierzejewska 2004): indeed, the ruler appears here as the head of the Nubian church. In Banganarti no member of the clergy seeks to circumscribe the extent of royal power. It is the sovereign who now appears as the privileged intermediary between the faithful and God.

In a recent contribution, Włodzimierz Godlewski offered a highly attractive interpretation of the role played by abba Georgios, Bishop of Dongola and presumably son of king Zacharias, in the development of the monarchical cult and the foundation of this exceptional sanctuary (Godlewski 2013: 671-672). It is

10 And arguably in chapel 2. 
undeniably this influential individual who commissioned the painting of room 29 in the Northwest Annex of the monastery in Old Dongola between 1060 and 1063 (Godlewski 2013: 667). The influence of this composition in the decor of Banganarti chapel 5 seems clear, however, it is important to note that the royal costume differs in the two paintings. In Old Dongola, the king wears a Nubian I type dress, while in Banganarti he is portrayed in the later Nubian II (a) type robes [Fig. 11]. ${ }^{11}$

Włodzimierz Godlewski has suggested that the change of the mode of succession to the Makurite throne started at the death of king Zacharias, whom he identifies in the portrait from Dongola (Godlewski 2013: 672). The figure represented in chapel 5 at Banganarti is dressed in a cloak made of a patterned fabric similar to that in the Dongola portrait, but the new type of royal costume suggests that the Banganarti portrait is later and would then represent one of the successors of the aforementioned king. Should one accept the idea that a portrait of Zacharias's successor occupies chapel 5 neighboring on the main chapel, then it would be reasonable to assume that at this time the apse of chapel 4 was already painted with another portrait, representing most probably the founder of the sanctuary. Also, because of the location of the scene at mid-height, one

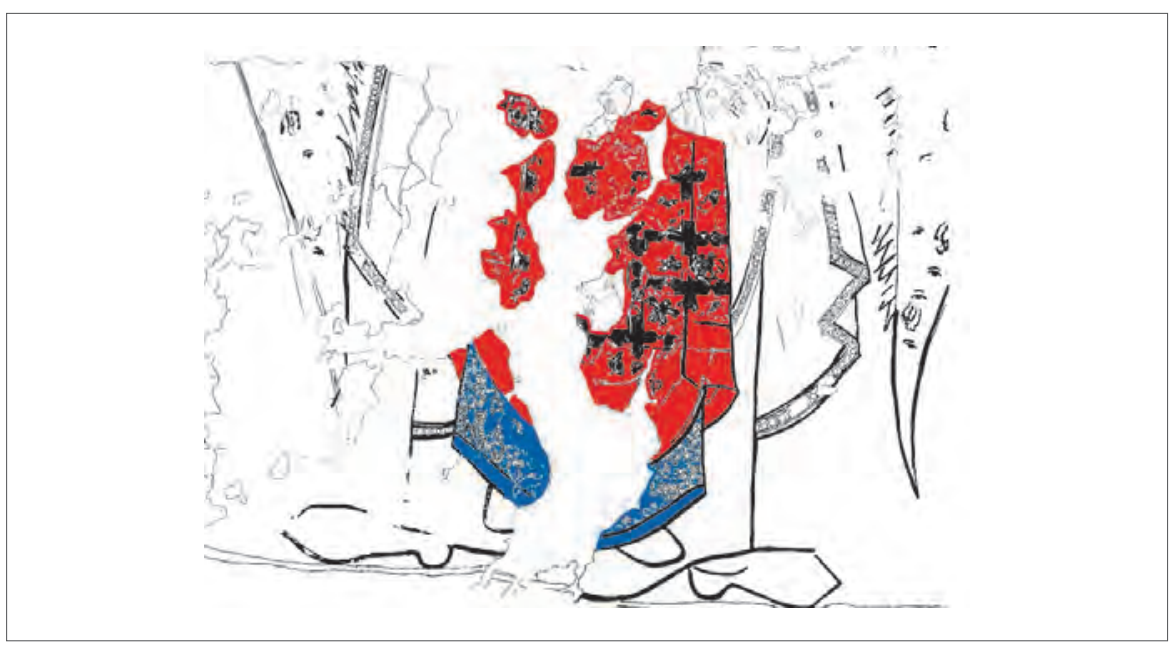

Fig. 11. Banganarti, chapel 5, painting from the apse (Tracing A. Btaszczyk/Banganarti Archaeological Mission; color M.M. Woźniak)

11 Another difference with the two paintings from Faras and Dongola is the absence of the figure of Christ above the Archangel (almost certain, given the proportions of the apses and the dimensions of the Archangels). Łaptaś' analysis is helpful to understand the location of the scenes in the decorative program of Banganarti complex: she explains that Christ was certainly painted in the central dome (Łaptaś 2014: 295). 
might consider that chapels 1 and 7 were probably decorated at this stage. An interesting clue would be the type of costume originally represented in these portraits, but this is impossible to observe because of the later repaints in both chapels 4 and 1 . However, the king figured in chapel 7, showing no apparent signs of repainting, wears a Nubian II type costume. It would be tempting to suggest that this new type of costume may have accompanied the changes in the mode of succession of the Makurite monarchy, but the limited documentation and partial state of preservation of the portraits invites the present author to remain cautious.

If the present reading of the Banganarti apse paintings is correct, the evolution of the monarchical ideology rendered in these portraits may reflect a gradual assertion of royal power in the Nubian church in the decades after the construction of the sanctuary. It allows also to propose a chronological sequence for the painting of the eastern chapels. In a broader scope, the contextualization of the iconography characteristic of the Upper Church at Banganarti demonstrates the fragile balance between temporal and secular power at the Makurite court throughout its history. The Faras and Dongola portraits illustrate previous attempts of kings to assert their supremacy at the head of the Nubian church and the clergy's efforts to curb this form of power. The apse portraits from Banganarti prove the success of the late-period Nubian rulers in occupying a privileged position as intermediaries in the relationship between the faithful and God.

\section{References}

Godlewski, W. (2008). Bishops and kings. The official program of the Pachoras (Faras) Cathedrals. In W. Godlewski and A. Łajtar (eds), Between the cataracts: Proceedings of the 11th Conference for Nubian studies, Warsaw University, 27 August-2 September 2006, I. Main papers [=PAM Supplement Series 2/1] (pp. 263-282). Warsaw: Warsaw University Press

Godlewski, W. (2013). Archbishop Georgios of Dongola. Socio-political change in the kingdom of Makuria in the second half of the 11th century. Polish Archaeology in the Mediterranean, 22, 663-677

Łajtar, A. (2002). Georgios, Archbishop of Dongola ( $† 1113)$ and his epitaph. In

T. Derda, J. Urbanik, and M. Węcowski (eds), Euergesias Charin: Studies presented to Benedetto Bravo and Ewa Wipszycka by their disciples [=Journal of Juristic Papyrology Supplement 1] (pp. 159-192). Warsaw: Raphael Taubenschlag Foundation Łaptaś, M. (2008). St Andrew the Apostle in the murals of the Upper Church in Banganarti. Etudes et Travaux, 22, 101-114 
Łaptaś, M. (2014). The holy protectors of the Nubian rulers and symbolism of numbers in the Upper Church in Banganarti. In B. Żurawski, Kings and Pilgrims: St. Raphael Church II at Banganarti, mid-eleventh to mid-eighteenth century [=Nubia 5] (pp. 289295). Warsaw: Neriton

Łaptaś, M. (2016). The Archangel Raphael as protector, demon tamer, guide and healer. Some aspects of the Archangel's activities in Nubian painting. In A. Łajtar, A. Obłuski, and I. Zych (eds), Aegyptus et Nubia Christiana. The Wtodzimierz Godlewski jubilee volume on the occasion of his 70th birthday (pp. 459-479). Warsaw: PCMA UW

Martens-Czarnecka, M. (1982). Les éléments décoratifs sur les peintures de la Cathédrale de Faras [=Faras 7]. Warsaw: Éditions Scientifiques de Pologne

Martens-Czarnecka, M. (2001). Wall paintings discovered in Old Dongola. In S. Jakobielski and P.O. Scholz (eds), Dongola-Studien: 35 Jahre polnischer Forschungen im Zentrum des makuritischen Reiches [=Bibliotheca Nubica et Aethiopica 7] (pp. 253284). Warsaw: ZAŚ PAN

Martens-Czarnecka, M. (2011). The wall paintings from the Monastery on Kom H in Dongola [=Nubia 3; Dongola 3; PAM Monograph Series 3]. (B.M. Gostyńska, trans.). Warsaw: Warsaw University Press

Michałowski, K. (1974). Faras: Wall paintings in the collection of the National Museum in Warsaw. Warsaw: Wydawnictwo Artystyczno-Graficzne

Mierzejewska, B. (2004). Parresia i moc wstawiennictwa świętych. Przedstawienia wiernych ze świętymi patronami w malarstwie nubijskim [Parrhesia and the intercession of the saints: representations of the faithful and their patron saints in Nubian painting]. Series Byzantina, 2, 109-122 [in Polish]

Velmans, T. (2006). Rayonnement de Byzance. Paris: Thalia

Woźniak, M. (in preparation). Iconographie des souverains et des dignitaires de la Nubie chrétienne: les vêtements d'apparat

Zielińska, D. (2010). The iconographical program in Nubian churches: Progress report based on a new reconstruction project. In W. Godlewski and A. Łajtar (eds), Between the cataracts: Proceedings of the 11th Conference for Nubian studies, Warsaw University, 27 August - 2 September 2006, II.2. Session papers [=PAM Supplement Series 2.2/2] (pp. 643-651). Warsaw: Warsaw University Press

Zielińska, D. (2014). The iconography of power - The power of iconography: The Nubian royal ideology and its expression in wall painting. In J.R. Anderson and D.A. Welsby (eds), The Fourth Cataract and beyond: Proceedings of the 12th International Conference for Nubian Studies [=British Museum Publications on Egypt and Sudan 1] (pp. 943950). Leuven: Peeters

Żurawski, B. (2003). Dongola Reach. The Southern Dongola Reach Survey Project, 2002. Polish Archaeology in the Mediterranean, 14, 237-252

Żurawski, B. (2008). The churches of Banganarti, 2002-2006. In W. Godlewski and A. Łajtar (eds), Between the cataracts: Proceedings of the 11th Conference for Nubian studies, Warsaw University, 27 August - 2 September 2006, I. Main papers [=PAM Supplement Series 2.1] (pp. 303-321). Warsaw: Warsaw University Press 
Żurawski, B. (2014a). Banganarti on the Nile. An archaeological guide. Warsaw: Artibus Mundi

Żurawski, B. (2014b). Kings and pilgrims: St. Raphael Church II at Banganarti, mideleventh to mid-eighteenth century [=Nubia 5]. Warsaw: Neriton 


\title{
The Banganarti Nativity: Enkolpion with scene of the Birth of Jesus from House BA/2015 in Banganarti
}

\author{
Bogdan Żurawski \\ Institute of Mediterranean and Oriental Cultures, Polish Academy of Sciences \\ bogdan.zurawski@iksio.pan.pl
}

\section{KeYwORDs}

Nativity, Christian iconography, Middle Nile, Middle Ages, pilgrimages

\begin{abstract}
The slate enkolpion engraved with the Nativity scene was found in one of the dwellings to the east of the Upper Church (Raphaelion II) in Banganarti. On the reverse, it was inscribed with the names of the three main protagonists of the scene carved on the obverse. It seems to have been used very briefly before being lost. Distinctive features include a figure of St Joseph represented as a herm and the putative Star of Bethlehem rendered as a round object hovering above the manger. The Magi and the scene of the Bathing of Jesus are missing. There is also one animal instead of two at the crib and one adoring shepherd not two (or even three). The aim was evidently to present the entire theological canon of the Nativity dogma using a minimum of iconographic elements, which is hardly surprising owing to the scarcity of space. Dating on stylistic grounds is highly speculative owing to the sketchiness of the scene, but the archaeological context seems reliable, yielding pottery from AD 1020-1172, which was a time of vigorous development of the pilgrimage movement to Banganarti.
\end{abstract}

Excavation of domestic architecture located nor theast of the Raphaelion building (Upper Church) in February 2015 brought to light an enkolpion decorated with the theme of the Nativity, crucial to the Nubian religious tradition. This led me to abandon the subject I had chosen earlier and to dedicate this very preliminary study of the newly-discovered object to the addressee of this jubilee volume. 
The enkolpion was found in trench BA.I/2015, inside one of at least six different domestic structures that were constructed before the Raphaelion church was built (that is, before the late 11th/12th century) and inhabited, mainly on the first floor during the later phases, in some cases until the 15th century or later. The trench in question was located between House E/2013 (Źurawski 2014: 68, Fig. 59, and 72, 96-97, Figs 63, 64, 67) and Building E, which is part of the so-called eastern living quarter (see Żurawski 2013: Figs 1, 3; 2014: 55-56, 58, 64, 68, 72, Figs 11-15, 44-46, 49, 53, 54). The area was heavily disturbed by digging for fertile soil. The enkolpion was found in the bottom part of the latest sand layer, 0.70 to $1.00 \mathrm{~m}$ thick, filling Room 20. This unit touched on the western limit of the trench (red dot in Fig. 2 top right). The room continued northward, away from a narrow room to the south, which may have been a latrine (hence a plausible identification of unit 20 as a cesspit). Neither potsherds nor kitchen waste were found with the enkolpion at the corresponding level.

The object (Inv. No. BA.2015/250) is made of greenish dark grey slate. It is worn with use; nevertheless, even minute details of the decoration on the obverse and the inscription on the reverse are recognizable [Fig. 1]. The remarkable state of preservation of the inscription on the back side is strong evidence attesting to relatively short usage. It was worn probably for no longer

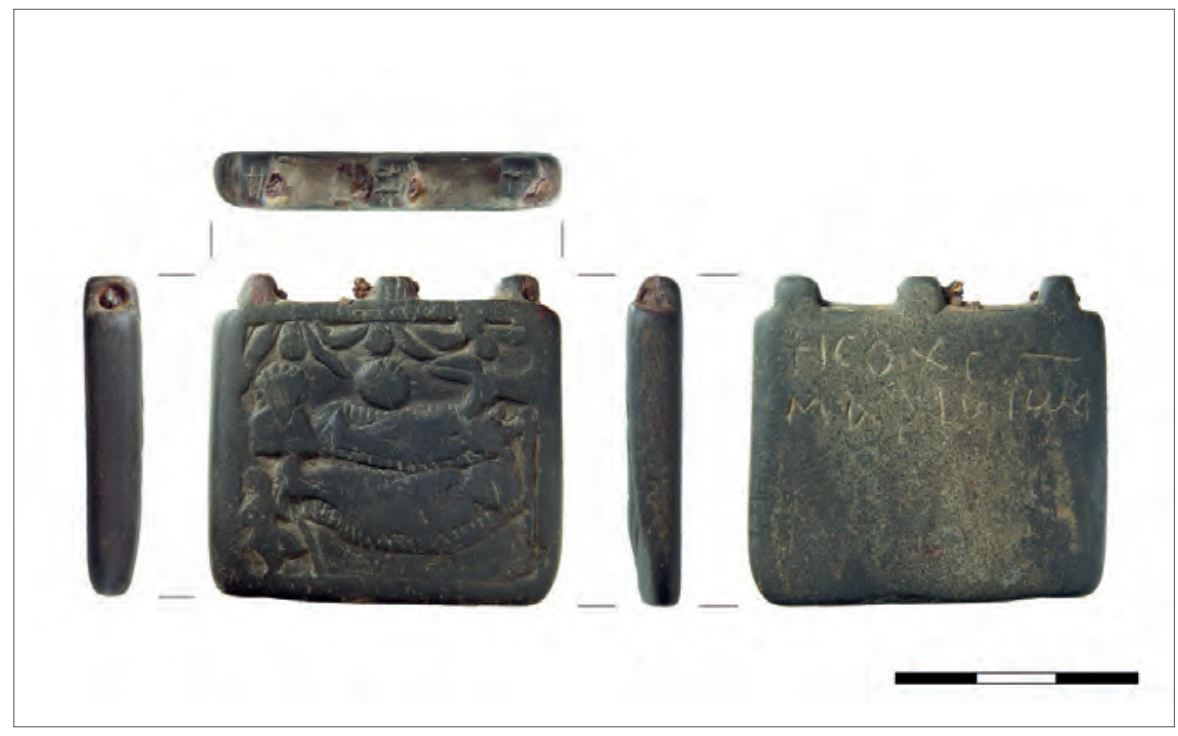

Fig. 1. Enkolpion with the Nativity scene from Banganarti (Inv. No. BA.2015/250) (Photo M. Dzik) 
than a dozen or so years; significantly, the difference in the erasure of the two faces suggests that it could have been worn mostly with the reverse side facing outward.

As all other enkolpia (Campbell and Cutler 1991: 700), it was worn around the neck (literally "on the bosom"). Remains of string could be observed in the three suspension holes pierced in the knobs projecting from the uppermost edge

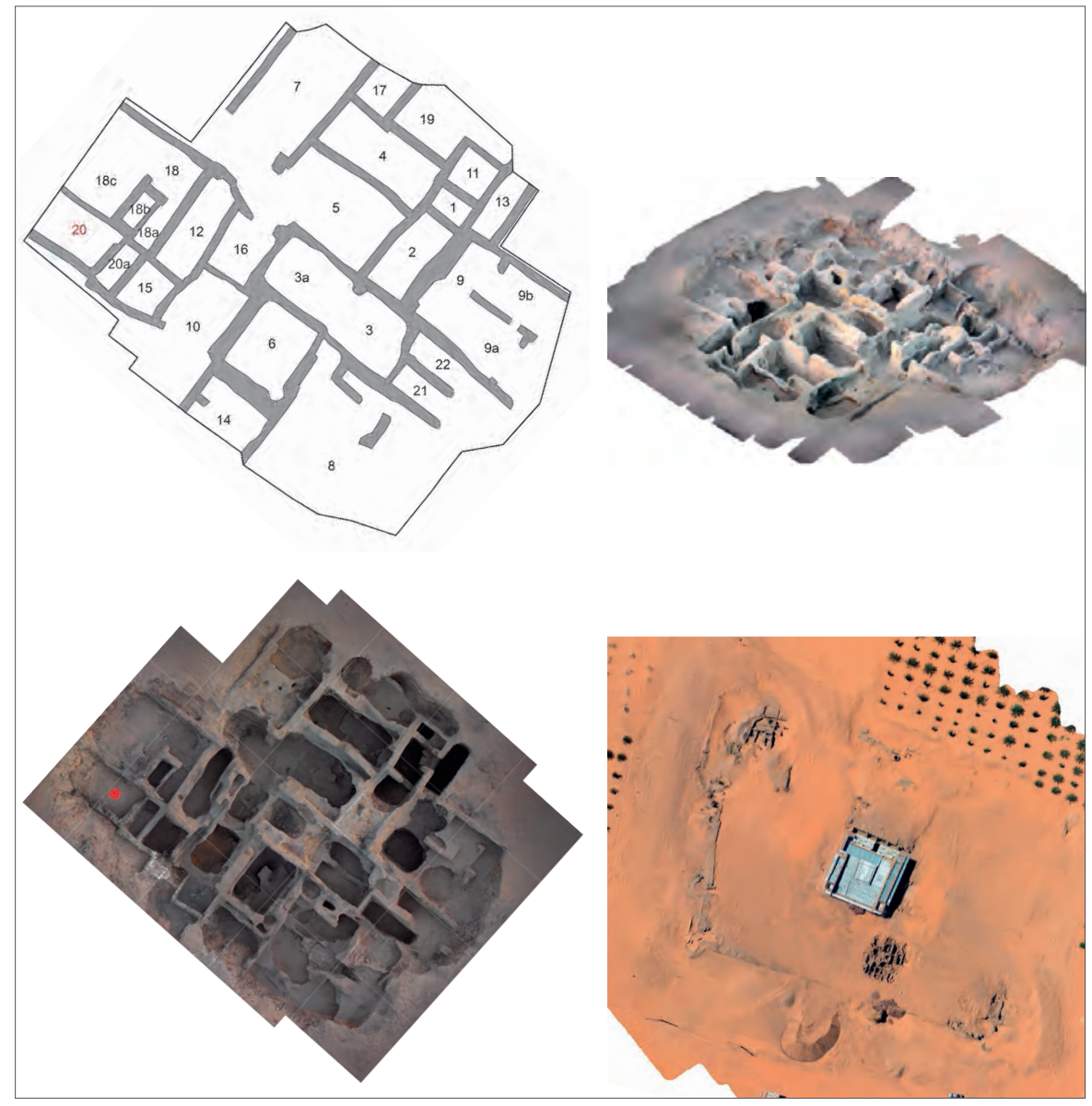

Fig. 2. Trench BA.I/2015: top left, schematic plan of the domestic architecture based on cleared tops of walls with numbering of spaces/areas; bottom left, orthophotographic vertical image of the architecture, findspot of the enkolpion marked with a dot; top right, photogrammetric $3 D$ model as seen from the north; bottom right, orthophotographic image of the Banganarti enclosure in February 2015 with the trench at the southeastern corner of the church under excavation (Kite photos and rendering B. Zurawski; drawing M. Dzik; photos and measurements M. Dzik, R. Eopaciuk; rendering M. Dzik) 
of the object (their upper sides are decorated with a simple crisscross design). An inscription was scratched into the plain smooth back side (reverse), three names listing the main characters figured on the obverse: lesus ho Christos, Maria, Joseph, preceded by a cross; the name of St Joseph of Nazareth was written in abbreviated form. The nomina sacra, like the sacred connotations of the imagery on the obverse, protected the wearer. The lower part of the reverse was left undecorated.

The composition represents the Birth of Jesus. The scene is enclosed within a plain slightly protruding rectangular band frame. The vertical (side) segments of the frame are broader than the horizontal ones. The lower part was either intentionally undercut or badly worn with use. A barely legible inscription(?), incised with a sharp tool, appears in the middle section of the upper frame. There are also traces of incised lines on the lower edge, but erased to an extent excluding their reading.

The composition within the frame is tiered horizontally. The central part of the upper tier is occupied by a round object decorated with radial incisions still clear along its upper edge. The compositional centrality of this object suggests its importance to the scene. The Star of Bethlehem seems to be the best guess one can make, all the more so as it touches the manger. ${ }^{1}$ It is not the case in the Banganarti Nativity, but it should be noted that the Star is sometimes represented by a three-pronged symbol associated with the iconography of the Trinity. ${ }^{2}$ Nevertheless, the Star is always linked more or less directly to the Child in the manger. As a rule, it hovers directly above the crib, and the rays connect it to the manger. In the Faras Nativity scene, the six-pointed Star hangs among the angels soaring around directly above the Child (Sulikowska and Mierzejewska 2014: 114, Fig. 18).

Above the Star, there are three angels, schematically represented as heads and wings only. They somewhat resemble the flying angels depicted in the

1 In the Nativity scenes, the Star of Bethlehem is usually linked with the manger, for example, by means of rays or light, tripartite lines, etc. See Millet 1916: Figs 1 (upper right), 35, 36, $38,39,41-45,51,63-65,68,69,101-104$.

2 E.g., the icon with the Birth of Christ, 15th/16th century, Novogrod School, now in the Tretyakov Gallery in Moscow (see Onasch 1961: Pls 26, 55, 357-358, 370-371). In the tripartite Carolingian ivory plaque with Nativity scenes (AD 800) from the British Museum (M\&ME 1856: 6-23, 17), the Star figures in the lowermost scene representing the Adoration by the Magi and is not present in the middle (Nativity) scene depicting the Child in the manger with the animals, Joseph and Mary (Dalton and Read 1909: 40-41, Pl. XXII.42). This suggests that the Star is associated with the Adoration to a higher extent than with the Nativity scene. Nevertheless, the absence of the Magi in the Banganarti enkolpion did not result in a similar lack of the Star. 
Faras Nativity, the latter wearing white garments that blended with the white background, leaving only the brightly colored heads and wings emphasized.

The position to the right of the Star is taken up by an ass's head, shown in left profile, springing horizontally from the border frame on the right. It is witness to the event, fulfilling the prophecy of Isaias 1:3 and Habakkuk $3: 2$. Its ears are horizontally bent forward (to the left). Characteristically enough, the carver made them look stunningly similar to the angels' wings that were depicted above. It was an intentional effort to introduce an aesthetic equilibrium to the composition.

A bust of St Joseph appears to the left of the Star. He is rendered highly schematically, his face erased (provided there ever were any facial features depicted) save for a curvilinear scratch in place of the nose. Significantly, he is shown touching the footboard of the manger. ${ }^{3}$ His position in the left part of the composition is typical, for example, of Nubian Nativity scenes. However, the rectangular form of the lower part of his figure, which is shaped like a herm, is quite unusual (see Testini 1972: 313-333). His unhaloed head is set within a ring of curled hair (it does not resemble a nimbus). The $\mathrm{v}$-shaped line reaching down to the chest suggests a long beard. This manner of representation of Joseph's figure is curious, as it alienates him stylistically from the scene, of which he is one of the three main players. His figure belongs to the middle tier, since the lower edge of his bust forms one line with the lower line of the manger. It resembles to some extent representations known from textiles, such as, for example, the clavus with the scene of the Nativity from the Musée du Louvre (No. X 4855; Del Francia 1979: Pl. XVI.7).

The Child in the manger and the manger itself are represented in top view (contrary to Joseph, who is shown full face in side view). Jesus lies on a mattress decorated with a row of short cut parallel lines (the mattress on which Mary is reclining is rendered in similar manner). ${ }^{4}$ By no means can this pattern of vertical short lines be taken for a bricked crib or, to use Weitzmann's original terminology, a "masonry altar", which became a distinctive feature of the so-called Palestinian Nativity scenes (Weitzmann 1974: 37-39). As far

3 I use the term manger as the traditional description of the place where the Baby Jesus was laid, albeit in the Banganarti Nativity the Savior rests on a mattress apparently placed on the ground.

4 This closely resembles the mattress on which Mary reclines in the ivory plaque with the Nativity scene from the Walters Art Museum (Accession No. 71.305), which is a 10thcentury Constantinopolitan creation. See also Mary's mattress in the Nativity scene on the ivory plaque from the 6th-century throne made for the Archbishop of Ravenna (Museo Arcivescovile di Ravenna). 
as the state of preservation of the surface in the central part of the enkolpion permits such a statement, the Child is wrapped in swaddling clothes. His head seen beneath the neck of the ass is surrounded by a cruciform nimbus(?). The facial features of Jesus and the roundel of the nimbus around his head are not recognizable (both are very worn).

The putative cruciform nimbus around Jesus's head touches the cross finial of a staff that stands upright parallel to the right border band forming a sort of headboard for Mary's bedstead. 5 This element could be associated with the iconographic peculiarity of Nubian Nativity scenes, namely the cross/crosses set up behind Mary's kline. Van Moorsel, Jacquet, and Schneider (1975: 92 and note 77) suspect this feature to be evidence for Nubian devotion to the cross. In the Faras Nativity, a total of four crosses jut out from behind the kline headboard (Sulikowska and Mierzejewska 2014: 113-114 and Figs 17, 18). Regardless of the validity of this argument, it must be said that the crossed(?) staff seen in the Abdallah-n Irqi Nativity, standing upright at the headboard of the Theotokos's bed, is the best and only analogy to the crossed staff represented in the Banganarti Nativity (van Moorsel, Jacquet, and Schneider 1975: 62, mural No. 4/5). ${ }^{6}$

Mary is shown lying on a mattress identical with that of Jesus and placed beneath it, in almost parallel position. Their heads are almost touching and the Child is disproportionately large compared to his Mother. In contrast to representations showing her reclining, she is shown here lying almost flat which may be a way of stressing her post-natal fatigue. Placing her on a mattress in a posture suggesting rest seems to ignore the dogma of her painless supernatural giving birth. Her big toes touch the herm of St Joseph precisely in the middle of its lower edge. Her arms appear to be folded on her womb.

The lower left corner space of the framed panel is taken up by the figure of the shepherd, who approaches the manger from the left in keeping with prevailing Nubian iconographic tradition. He is shown standing on the upper edge of the lower frame of the panel and is the best carved of all the actors in

5 Mary in the Banganarti Nativity scene rests on a mattress that "is hanging in the air" (since neither a base nor any other support can be observed). There is, however, a possibility that the thick curved stick in the hand of the shepherd, shown to the left of Mary's mattress, is in fact part of the footboard of her bedstead. If so, the crossed staff seen on the other side of the putative bed could be its headboard.

6 A vertical staff-like object seen in the el-Sebua Nativity to the right of Mary's bed could be part of a cross (Monneret de Villard 1935: Fig. 73). If so, it could serve as an even better analogy for the Banganarti cross. 
the Nativity drama. ${ }^{7}$ His arms are bent at the elbows and he holds a shepherd stick, bent in the middle, in his left(?) hand. ${ }^{8}$ His left foot is placed on his right knee (Masai pastoralists are a good example of this posture, which is, however, well known throughout the world).

The association of the shepherd figure with that of Joseph (shown immediately above) brings to mind the apocryphal story of the demon of doubt in the guise of an old shepherd who attempted to fill Joseph with doubts concerning Mary's virginity and the divine origin of Jesus.

The space beneath Mary's bedstead, where the midwives, Salome or a scene of Jesus being bathed could be expected to have been located, was left blank (although it could also be worn smooth). This is most strange as horror vacui seems to be the carver's main aesthetic observance. The empty space along the lower edge of the object is incomprehensible given the dense packing of figures above it. To some extent, this prefigures the canons of the 16th-century Council of Trent, which outlawed midwives (but also the figures of the ass and ox) as apocryphal. It is also worth noting that the absence of Salome to some extent alienates the Banganarti Nativity from the Coptic version of the Birth of Christ. ${ }^{9}$ The same argument also applies to the lack of the motif of Jesus's first bath (Kötzsche-Breitenbruch 1976: Col. 208).

\section{Commentary}

The Nativity motif was less popular in Egypt than in the other parts of the Christian ecumene, in painted and sculptured decorations in particular, being more common in the minor arts. As in textiles, the cast of characters pictured in the Banganarti Nativity was reduced to the main protagonists, who were rendered in a most schematic form (Rassart-Debergh 1991: 536; Del Francia 1979: Pls XIV.4, XVI.7). The theme of the Nativity of Jesus gained in popularity in Egypt from the 10th century onward, mainly as part of the Mariological and Christological cycle (Rassart-Debergh 1991: 534-535).

7 For the shepherds in Nativity scenes known from the Monastery on Kom H in Old Dongola and in general, see Martens-Czarnecka 2011: 138.

8 The thickness of this stick is out of proportion to its length, therefore the supposition that in reality it is not a shepherd's stick but part of Mary's bedstead, is quite plausible (see note 5 above).

9 On the relations of the version of the Nativity with Salome to Coptic art and on the origin of the Salome motif in Coptic apocryphal literature, see Smith 1917: 24-27 and Fig. 2; see also some comments on Salome and the Nativity in Crum 1905: 74-75. 
A distinctive iconographic feature of the Banganarti Nativity is the round object hovering above the manger. As either the symbol of the Messianic Star of Num 24:17 or the Star of Bethlehem of Mt 2:1-10, it is depicted quite low within the image frame (since it touches the mattress on which the Child lies), but its celestial setting is emphasized by the angels hovering around it. This constitutes a close parallel with, for example, the 6th-century Nativity scene painted on the sliding lid of a reliquary box with relic stones from the Holy Land, kept until 1905 in the treasury of the Sancta Sanctorum (see Lauer 1906: 97-99; Morey 1926: 151; Bagnoli and Klein 2011: 36, Cat. No. 13). The lack of both the Magi and the scene of the Child being bathed are other points of similarity between the two objects.

Strangely enough, the Angel hovering above Joseph's herm touches him practically head to head (as if mirrored images). Is it perhaps a visual allusion to the theme of Joseph being assured by an angel as to Mary's purity and fidelity (Mt 1:20); the scene figures in composite Nativity scenes (e.g., ivory casket in the Victoria and Albert Museum; a sarcophagus from Le Puy; mural from Antinoe, see Smith 1917: 29).

Another differentia specifica of the Banganarti Nativity is the figure of St Joseph represented as a herm. This in some ways is reminiscent of the manner of representing the "other dead" by the so-called Mumiengruppe, composed of half-figures rising from sarcophagus-like objects or a similar manner of representing the Old Testament Kings David and Solomon as half-figures in Anastasis scenes..$^{10}$ This stylistic manner is not associated with a particular period. It figures prominently in the so-called historiated reliquaries datable to the 10th century (Manafis 1990: 281; Kartsonis 1986: 109; Żurawski 2012: 258-260).

Generally, the carver of the Banganarti Nativity attempted to include the entire theological canon of the Nativity dogma using a minimum of iconographic elements. There is only one animal instead of two (the only example of this being a 17th-century Cretan icon in private hands in Lucerne, Onasch and Schnieper 2002: 104) and one shepherd not two (or even three), while the later additions to the scene, such as the bathing of Jesus, are simply omitted.

The diagnostic elements of the scene of the Birth of Jesus, present in the Palestinian version (as the bricked altar crib), are completely neglected in the Banganarti Nativity. The absence of the Magi has deprived the scene of most of its narrative character. The Star lacks its tremendous symbolism as it is placed where one would expect to see the ox's head.

10 See cloisonné enamel on a gold icon from Shemokmedi Monastery in Georgia, now in the Arts Museum at Tbilisi (Inv. No. 664), see Bank 1985: 304, Pl. 182. 


\section{Conclusions}

The enkolpion was worn most probably around the neck with the inscription facing outward. Some diagnostic elements, such as the absence of a bathing scene in the lowermost register, likens it to the Nubian model attested for the 10th and 11 th centuries (this motif is also absent from both the Faras and Abdallah-n Irqi Nativity scenes). It also shares the posture of the shepherd and the general topography of the scene (positions of Joseph, the shepherd, the angels, the Star, etc.) with the Nubianized Nativity scenes.

The scene holds a peculiar resemblance to Nubian painted representations of the Nativity; however, due to a lack of space, it imitates the (lost) original in abbreviated form. ${ }^{11}$ Since all Nubian scenes of the Birth of Jesus are known from monumental paintings, we cannot weigh the putative influence of manuscripts and the minor art iconography on the style and composition of the Banganarti Nativity.

Needless to say, the chronology and provenance of the object is also most problematic. Establishing a date on the basis of stylistic grounds is to the utmost degree imprecise, at least less precise than contextual chronology. It is the only object of its kind found so far in Banganarti (as well as in the entire Middle Nile Valley). Its peculiar iconography, which places it apart from the iconographic schemes known from Nubian mural paintings representing the Nativity, makes its provenance a real puzzle. It cannot be excluded by any means that it was the product of a local workshop producing for pilgrims visiting the Raphaelion en masse. On the other hand, it reveals some similarities with Coptic stone carvings, but it is very sketchily executed and too worn to allow more detailed consideration. The above observations additionally limit the potential dating of the object on stylistic grounds. Therefore, the only reliable attempt at fixing the time of its making is the archaeological context of the find. Knowing that it was used for a limited period of time, we can approximate the date of its carving by dating the layer in which it was found.

The eolic sand layer in which it was found yielded pottery that was dated by specialists Katarzyna Mich and Aneta Cedro mostly to a phase known from Meinarti as Classic Christian 2/Late Christian 1 and dated by Adams to 10201172 (see Adams 2001: 4, 90, Pl. 27; A. Cedro, personal communication).

11 For the list of known Nubian murals of the Nativity (prior to 1964), see van Moorsel, Jacquet, and Schneider 1975: 91; for an excellent study of the three Nativity scenes discovered in the Monastery on Kom H in Old Dongola well after 1964, see Martens-Czarnecka 2011: $135-147$. 
Consequently, it can be claimed with a narrow margin of error and high level of confidence that the object was made during the period that corresponds in Banganarti to the destruction of the so-called Lower Church (=Raphaelion I) and the first hundred years of the use of the Upper Church (Raphaelion II). In other words, it witnessed the most vigorous development of the pilgrimage movement to Banganarti. The confirmed presence of pilgrims coming to the Church of St Raphael the Archangel from sites as far away as Sai in the north and Nuri in the south (upriver) allows us to seek the provenance of the enkolpion throughout the Middle Nile Valley.

\section{References}

Adams, W.Y. (2001). Meinarti II. The early and classic Christian phases [=British Archaeological Reports International Series 966]. Oxford: Archaeopress

Bagnoli, M. and Klein, H.A. (2011). Treasures of heaven: Saints, relics and devotion in Medieval Europe. London: British Museum Press

Bank, A.V. (1985). Byzantine art in the collections of Soviet museums. Leningrad: Aurora Art Publishers

Campbell, S.D. and Cutler, A. (1991). Enkolpion. In A.P. Kazhdan (ed.), The Oxford dictionary of Byzantium I (p. 700). New York: Oxford University Press

Crum, W.E. (1905). Progress of Egyptology: Christian Egypt. In Archaeological report, 1904-1905: Comprising the work of the Egypt Exploration Fund and the progress of Egyptology during the year 1904-1905 (pp. 73-84). London: Egypt Exploration Fund

Dalton, O.M. and Read, C.H. (1909). Catalogue of the ivory carvings of the Christian era with examples of Mohammedan art and carvings in bone in the Department of British and Mediaeval Antiquities and Ethnography of the British Museum. London: British Museum

Del Francia, L. (1979). Le thème de la Nativité dans les tissus coptes, à propos d'un exemplaire inédit. In W.F. Reineke (ed.), First International Congress of Egyptology: Acts [=Schriften zur Geschichte und Kultur des alten Orients 14] (pp. 221-224). Berlin: Akademie-Verlag

Kartsonis, A.D. (1986). Anastasis: The making of an image. Princeton, NJ: Princeton University Press

Kötzsche-Breitenbruch, L. (1976). Geburt III (ikonographisch). In Reallexikon für Antike und Christentum IX (pp. 172-216). Stuttgart: Hiersemann

Lauer, P. (1906). Le Trésor du Sancta Sanctorum. Monuments et Mémoires de la Fondation Eugène Piot, 15, 7-146

Manafis, K.A. (ed.). (1990). Sinai: Treasures of the monastery of Saint Catherine. Athens: Ekdotike Athenon 
Martens-Czarnecka, M. (2011). The wall paintings from the Monastery on Kom $H$ in Dongola [=Nubia 3; Dongola 3; PAM Monograph Series 3]. (B.M. Gostyńska, trans.). Warsaw: Warsaw University Press

Millet, G. (1916). Recherches sur l'iconographie de l'évangile aux XIV ${ }^{e}, X V^{e}$ et $X V I^{e}$ siècles, d'après les monuments de Mistra, de la Macédoine et du Mont-Athos. Paris: Fontemoing et cie

Monneret de Villard, U. (1935). La Nubia medioevale I. Cairo: Institut français d'archéologie orientale

Morey, C.R. (1926). The painted panel of the Sancta Sanctorum. In W. Worringer, H. Reiners, and L. Seligmann (eds), Festschrift zum sechzigsten Geburtstag von Paul Clemen, 31. Oktober 1926 (pp. 150-167). Bonn: F. Cohen

Onasch, K. (1961). Ikonen. Gütersloh: Götersloher Verlagshaus

Onasch, K. and Schnieper, A. (2002). Ikony: fakty i legendy [Icons: Fact and legend]. (Z. Szanter, Trans.). Warsaw: Arkady [in Polish]

Rassart-Debergh, M. (1991). Nativity. In A.S. Atiya (ed.), The Coptic encyclopedia II (pp. 534-536). New York: Macmillan

Smith, E.B. (1917). The Alexandrian origin of the chair of Maximianus. American Journal of Archaeology, 21, 22-37

Sulikowska, A. and Mierzejewska, B. (2014). Exhibition Room VI. Wall paintings from Faras Cathedral. In B. Mierzejewska, The Professor Kazimierz Michatowski Faras Gallery: Guidebook (pp. 106-197). Warsaw: National Museum

Testini, P. (1972). Alle origini dell'iconografia di Giuseppe di Nazareth. Rivista di Archeologia Cristiana, 48, 271-347

van Moorsel, P., Jacquet, J., and Schneider, H.D. (1975). The central church of Abdallah Nirqi. Leiden: Brill

Weitzmann, K. (1974). "Loca Sancta" and the representational arts of Palestine. Dumbarton Oaks Papers, 28, 31-55

Zurawski, B. (2012). St. Raphael Church I at Banganarti: Mid-sixth to mid-eleventh century. An introduction to the site and the epoch [=Gdansk Archaeological Museum African Reports Monograph Series 2]. Gdańsk: Gdańsk Archaeological Museum and Heritage Protection Fund

Żurawski, B. (2013). Banganarti and Selib. Season 2010. Polish Archaeology in the Mediterranean, 22, 273-287

Żurawski, B. (2014). Kings and pilgrims: St. Raphael Church II at Banganarti, mideleventh to mid-eighteenth century [=Nubia 5]. Warsaw: Neriton 



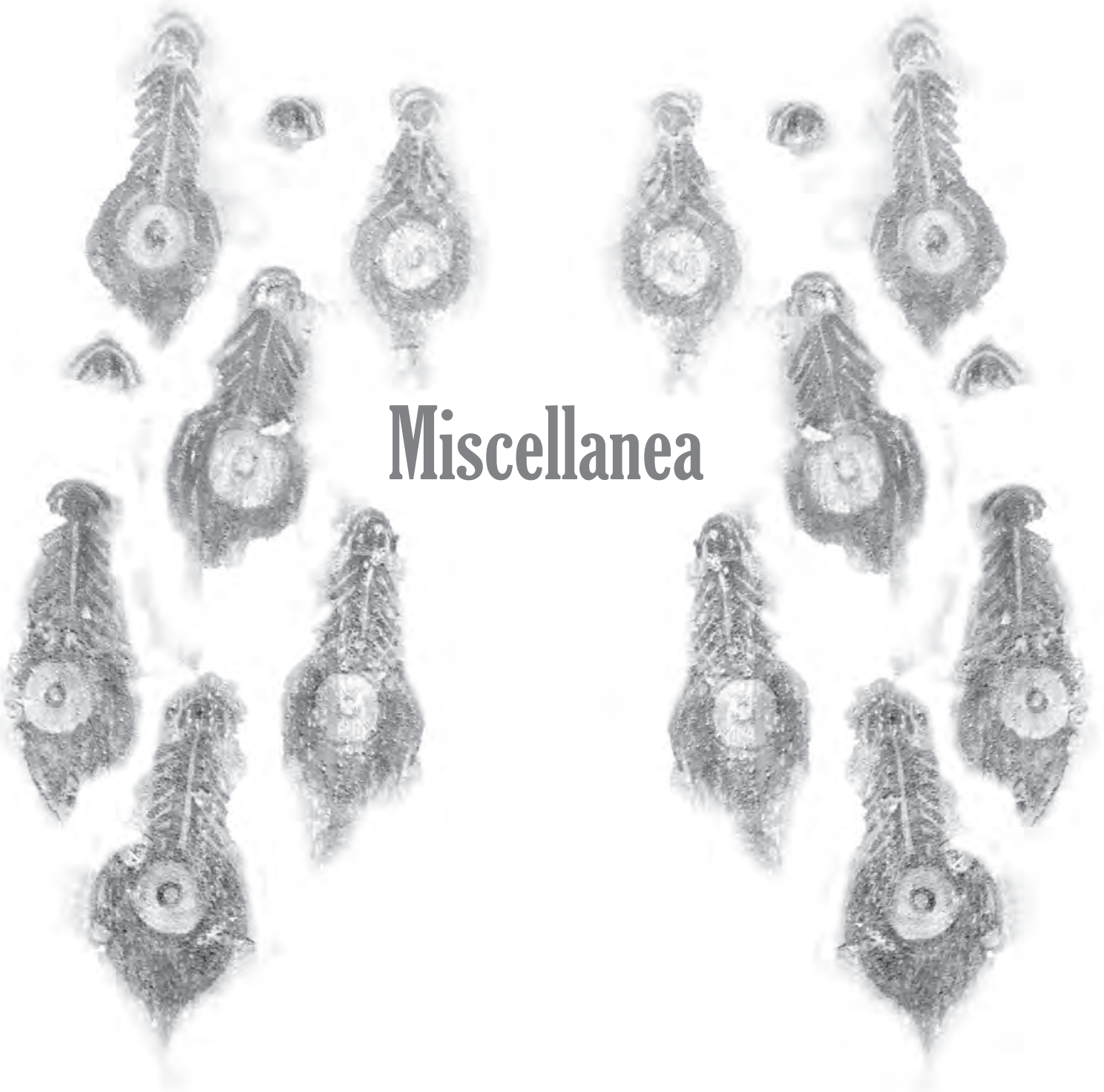





\title{
The lions of Qasr Ibrim
}

\author{
Nettie K. Adams \\ NettieKAdams@aol.com
}

\section{KeYwords}

Medieval Nubia, Qasr Ibrim, textiles

\begin{abstract}
This article describes several fragments of woolen textile that were excavated at the medieval site of Qasr Ibrim. Their outstanding feature is the depiction of numerous lion figures, shown in miniature. The pattern is organized in horizontal rows of rectangles, each enclosing a lion. In alternating rows, the lions face in opposite directions. The lions are quite clear and in many places the colors of blue and yellow are still strong and bright. These specimens were part of a large cache of discarded materials which are believed to have been ransacked from the tombs of bishops.
\end{abstract}

It is a distinct honor to be invited to contribute to the jubilee volume for Włodzimierz Godlewski. His life-long work in Christian Nubia overlaps with mine, and our similar studies make any new detail of Christian Nubia of great interest. I hope these little lions will bring the same delight that we felt on finding them.

The archaeological site of Qasr Ibrim is located in Egyptian Nubia some hundred kilometers north of the Sudanese border. Its situation on a high bluff far above the Nile and the arid climate of Nubia have combined to preserve remains to a remarkable degree.

The town site has a long and varied history. Excavations have revealed that Qasr Ibrim was continuously occupied from the Twenty-fifth Dynasty until 
the site was abandoned in modern times, in 1812. Throughout the almost 3000 years of history, the early Medieval period is one of the cultural highpoints in the long story of Qasr Ibrim. During this time the political, economic and religious life of Lower Nubia was dominated by Qasr Ibrim.

Sometime in the 8th century, a large, fine cathedral was built at Qasr Ibrim. It stood on the highest part of the city and could be seen for miles around. A cemetery for the interment of the cathedral bishops was established adjacent to the cathedral. There were thirteen tombs, some of which held multiple

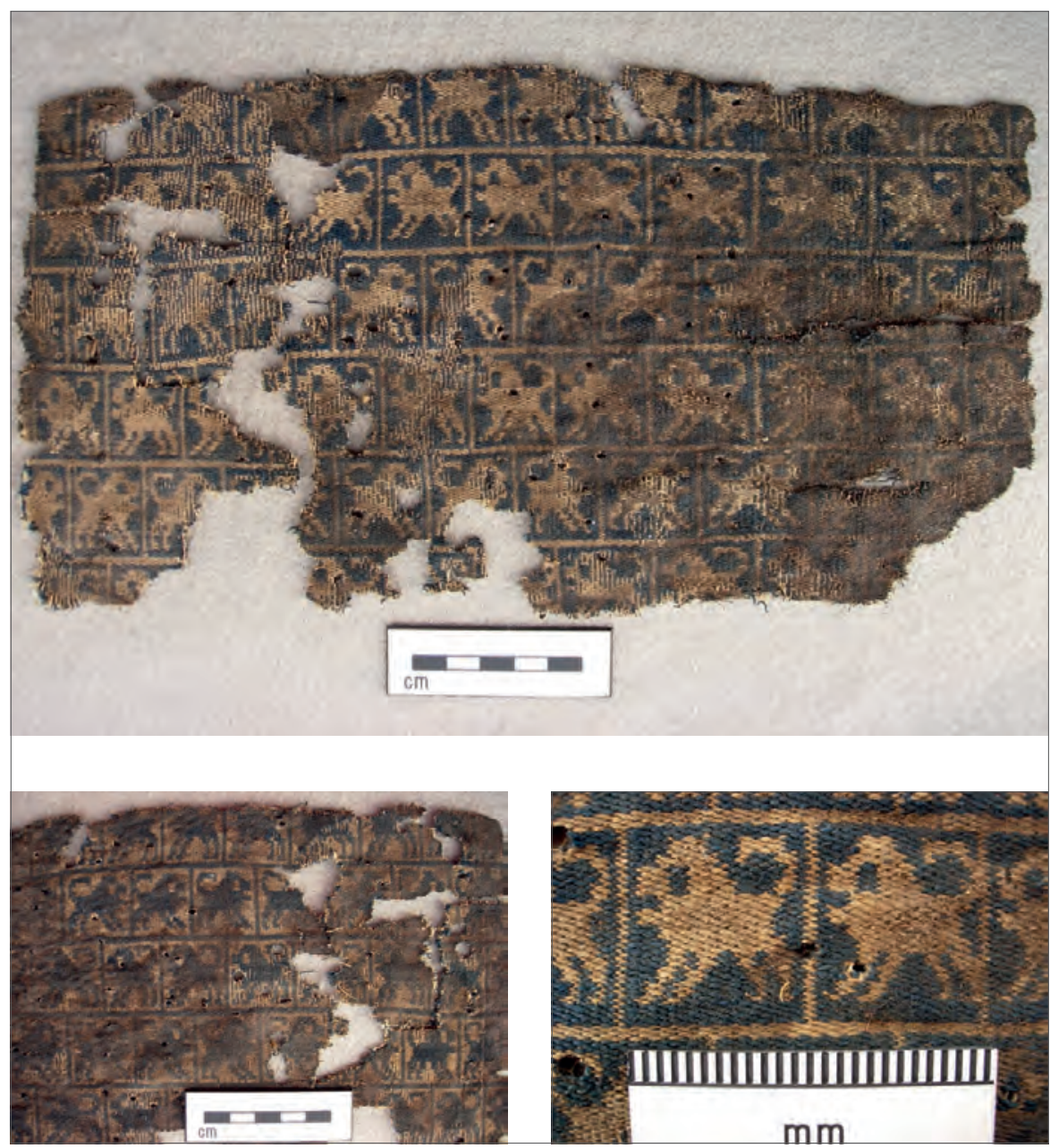

Fig. 1. Woolen cloth fragment with a repeat pattern of lion figures, two sides with reversed colors within the pattern and close-up (Photos N.K. Adams) 
burials. The bishops had been buried in ecclesiastic fashion, fully clothed in trousers, a tunic or shawl, often belts, wrapped in multiple linen shrouds, and placed on fragments of old carpets (Crowfoot 2011: 10-11).

Excavations of the tombs carried out in 1966 found that nearly all had been entered and ransacked. Bodies were disarticulated and the bones were scattered. Fragments of linen shrouds, scraps of silks and other textiles, bits of thin braided leather strips, ashy deposits, and the funerary steles of five bishops were found jumbled together. It is thought that the well-documented raid of Shams el-Dawla on Qasr Ibrim in 1172 was responsible for the destruction of the tombs and their contents (Crowfoot 2011: 8-9).

After the horrendous devastation of the city, the inhabitants gathered as many of the bones and funerary remains as could be found. They buried everything together, making no attempt to reorganize or restore any of the interments. This was the condition of what was left of the cathedral cemetery when the archaeologists began excavation.

Elisabeth Crowfoot and I, at Qasr Ibrim as specialists in textiles, analyzed and recorded all the textiles that seemed to be from the ransacked tombs. Most were fragments of linen shrouds, pieces of cloth with no distinguishing features, and tapes that had been used to bind the shrouded bodies. Occasionally, we would find scraps of silk, and there were two fragments of ecclesiastic stoles. But the most appealing were several fragments of woolen cloth depicting little lions (QI.78T/300) [Fig. 1].

The lions are quite clear and in many places the colors are still strong and bright. The pattern is organized in horizontal rows of rectangles, each rectangle containing a lion. In alternating rows, the lions face in opposite directions. Their energetic pose and wide open, roaring mouths seem to capture the essence of being a lion.

Sadly, the condition of the pieces is very poor. Areas of the fabric are degraded, and there are numerous insect holes. The woven structure is a complex one termed taqueté, or weft-faced compound weave. The weft-patterned weave has complementary wefts in two colors, blue and yellow. There are two warp systems, a main warp and a binding warp. The pattern on both sides of the fabric is the same but the colors within the pattern are reversed. Fabrics of this type require a complex loom and very skilled weavers. Our specimen was probably imported from Egypt, where specialized workshops have a long tradition of producing double-faced fabrics (Adams 2010: 162).

The straight sides and right angled corners suggest that this fabric may have had the form of a rectangle. If so, it might have been a part of a pillow under 
the head of the deceased. ${ }^{1}$ It is hoped that the lions did not disturb the eternal rest of the bishops!

\section{References}

Adams, W.Y. (2010). Qasr Ibrim: The earlier medieval period [=Excavation Memoir 89]. London: Egypt Exploration Society

Crowfoot, E. (2011). Qasr Ibrim: The textiles from the cathedral cemetery [=Excavation Memoir 96]. London: Egypt Exploration Society

1 Some lightly disturbed burials contained damask pillows under the heads of the bishops (Crowfoot 2011: 9). 


\title{
A record of offerings from the Temple of Hatshepsut in Deir el-Bahari: ostrakon DeB Inv. No. 85/75 reconsidered
}

\author{
Mirosław Barwik \\ Institute of Archaeology, University of Warsaw \\ m.barwik@uw.edu.pl
}

\begin{abstract}
KeYWORDS
ostrakon, Deir el-Bahari, Temple of Hatshepsut, offerings

Abstract

The paper presents a new rendering of the text of ostrakon Deir el-Bahari Inv. No. 85/75, originally published by the late Marek Marciniak. The context of the offerings recorded on the ostrakon is discussed and the supposed date of the festivities connected with this particular occurrence is reconsidered.
\end{abstract}

There are only two ostraka from the Temple of Hatshepsut at Deir el-Bahari that were found in well defined architectural context. One of them is ostrakon DeB Inv. No. 85/75, published already by the late Marek Marciniak shortly after its discovery by the mission from the Polish Centre of Mediterranean Archaeology University of Warsaw (Marciniak 1978: Pl. LI). ${ }^{1}$ This ostrakon was found in rubble inside a chamber formed by the relieving tent-like construction above the Bark Hall of the temple (Wysocki 1979: 209, Fig. 2; see also Wysocki 1983: Fig. 2). It was kept temporarily in the Offering Chapel of Hatshepsut, and thereafter in the storeroom of objects from the Tuthmosis III temple at Deir el-Bahari, before it was transferred recently to the newly organized Museum of Egyptian Civilization in Cairo.

1 The other one was found behind the south wall of the Bark Hall of the main sanctuary of the temple, see Wysocki 1980: 13, Figs 9-10; it will soon be published by the present author. As regards the exact provenance of ostraka found by Herbert E. Winlock in the temple area, see Hayes 1960: 29. 
Marciniak and Wysocki dated the ostrakon to the second phase in the building history of the temple (as established by Zygmunt Wysocki), when the sanctuary underwent a presumed profound rebuilding, that is, after year 11 of the reign of Tuthmosis III/Hatshepsut, according to their chronological evaluation (Wysocki 1986: 223-224 note 7; 1992: 245; see also Marciniak 1978: 170). Marciniak was of the opinion that ostrakon No. 80 from the tomb of Senenemut (TT 71) was also related to this particular phase in the building operations conducted in the Temple of Hatshepsut, namely the enlargement of the original sanctuary of the temple (Marciniak 1978: 169; see also Wysocki 1986: 223-224 note 7; ${ }^{2} 1992: 246$ ). This interpretation depends on the true meaning of the technical term $m 3[y]$.$t , translated by Hayes as$ "chamber or hall in a tomb(?), tomb chapel(?)" (Hayes 1942: 34). The term has not been attested elsewhere in the lexical material of the Tuthmoside period, but in a Late Period inscription it is presumed to designate a part of the temple. ${ }^{3}$ Marciniak's translation of the term in question as "sanctuary"

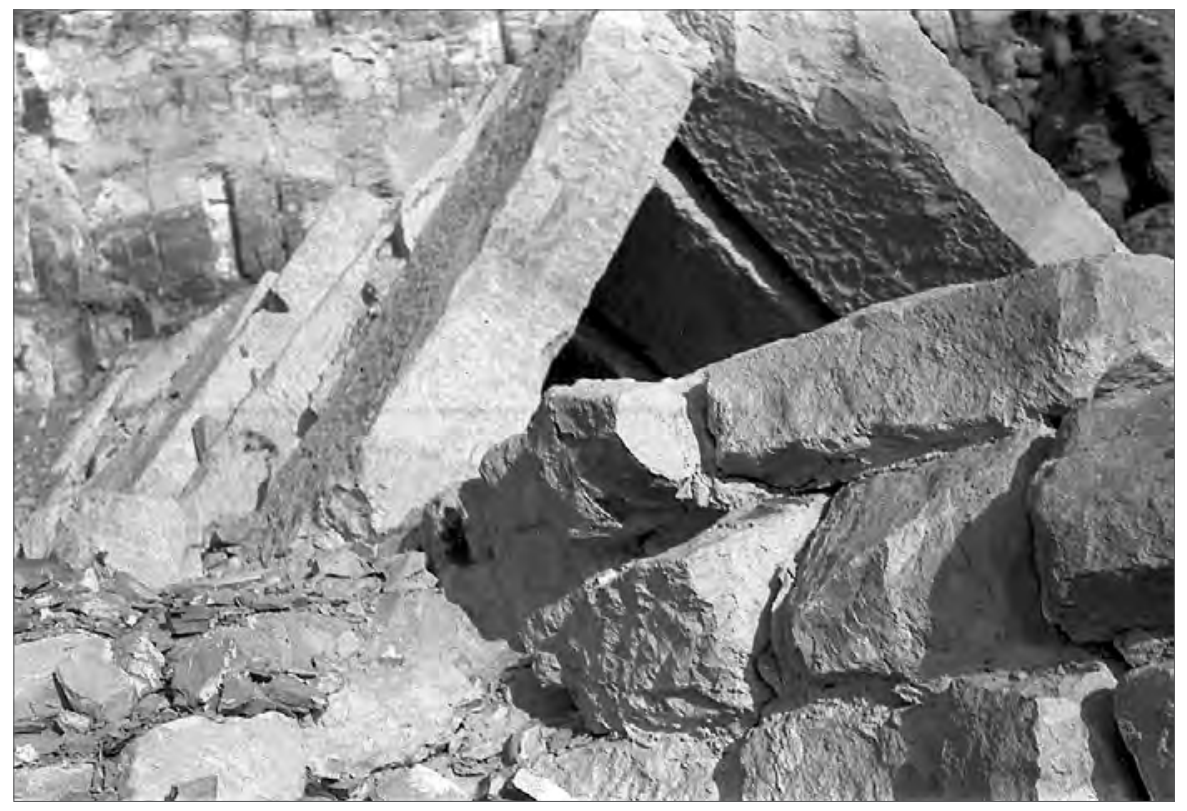

Fig. 1. Relieving structure above the Bark Hall of the Temple of Hatshepsut before undertaking restoration work (Photo (C) PCMA)

Inventory number and bibliographical data wrongly cited there.

3 See Wb. II, 12 (11); not recorded, however, in Spencer 1984. 
cannot be rejected out of hand, although his interpretation does not stand up to criticism. The ostrakon in question dealt most probably with the building activity in the tomb of Senenmut, and in consequence the technical term used in it must be related to tomb architecture.

Marciniak was certainly right that oDeB Inv. No. $85 / 75$ was thrown into the chamber above the Bark Hall at the time when the relieving structure was constructed [Fig. 1]. Thus it provides a substantial link to activity conducted in the area in the period in which the temple was still under construction. A new rendering of the text of the ostrakon seems to be necessary, mostly on account of the new readings obtained by the present author partly as a result of cleaning of the verso several years after Marciniak's publication [Fig. 2]. At the time of Marciniak's publication the verso of this limestone ostrakon had been covered with dirt, concealing part of the hieratic inscription (the last line of the verso was completely invisible). The neat hieratic signs were inked in black (signs approximately $0.8-1.2 \mathrm{~cm}$ high). The ostrakon is not complete; it is missing one of the three fragments into which it had been shattered (see Marciniak 1978: 166 note 1; Wysocki 1979: 209).

\section{Transliteration [Fig. 3]}

Recto (1) 3bd 1 3h.t sw 20 [+x snn] (2) $n$ wdn pr [hm.t-nsw?] (3) in sdm-`s $n^{`} . t$ (4) hnk.t Tnn3y (5) hnnk.t Sty[.w ds] 1 (6) [wdn.t] ḩ3r 2 (7) [t]-ḥd 2 (8) [snter $k p] d s 4$

Verso (1) [...?] 1 (2) dkr dni.t 5 (3) imy-r pr Sn-n-Mwt (4) wdn.t ḩ3r 2 (5) hnnk.t Sty.w ds 1 (6) [...] (7) dkr [dni.t ...] (8) snter kp [ds ...]

\section{Translation and commentary:}

"(Ro.1) Month 1 of the akhet season, day $20\left[+\mathrm{x}\right.$; account/list $\left.\left.{ }^{\mathrm{a}}\right)\right]$ (2) of offerings of the Domain [of the King's Wife?] ${ }^{\text {b) }}$ (3) by the servitor of the chamber (4) of beer $^{\mathrm{c})}$ Tjennay: ${ }^{\mathrm{d})}(5)$ Nubian beer, ${ }^{\mathrm{e})}$ [jar] 1 ; (6) [wdn.t-bread ${ }^{\mathrm{f})}$, sacks 2, (7) white [bread], 2; (8) [incense for fumigation] $]^{g}$, jars 4;

(Vo.1) [...] 1; (2) fruit, baskets 5; (3) the Steward Senenmut: (4) wdn.t-bread ${ }^{\text {h), }}$ sacks 2; (5) Nubian beer, jar 1; (6) [... ]'); (7) fruits, [baskets x]; (8) incense ${ }^{\mathrm{j})}$ for fumi[gation, jars $\mathrm{x}] . "$

a) Restoration after ostrakon DeB No. 9, ro.1 (Hayes 1960: Pls XI-XIA; for the meaning of the term, see Donker van Heel and Haring 2003: 106ff.)

b) Tiny traces visible below the lacuna enable one to observe here a concise record of the title of the king's wife, comparable to that of oDeB No. 14, 


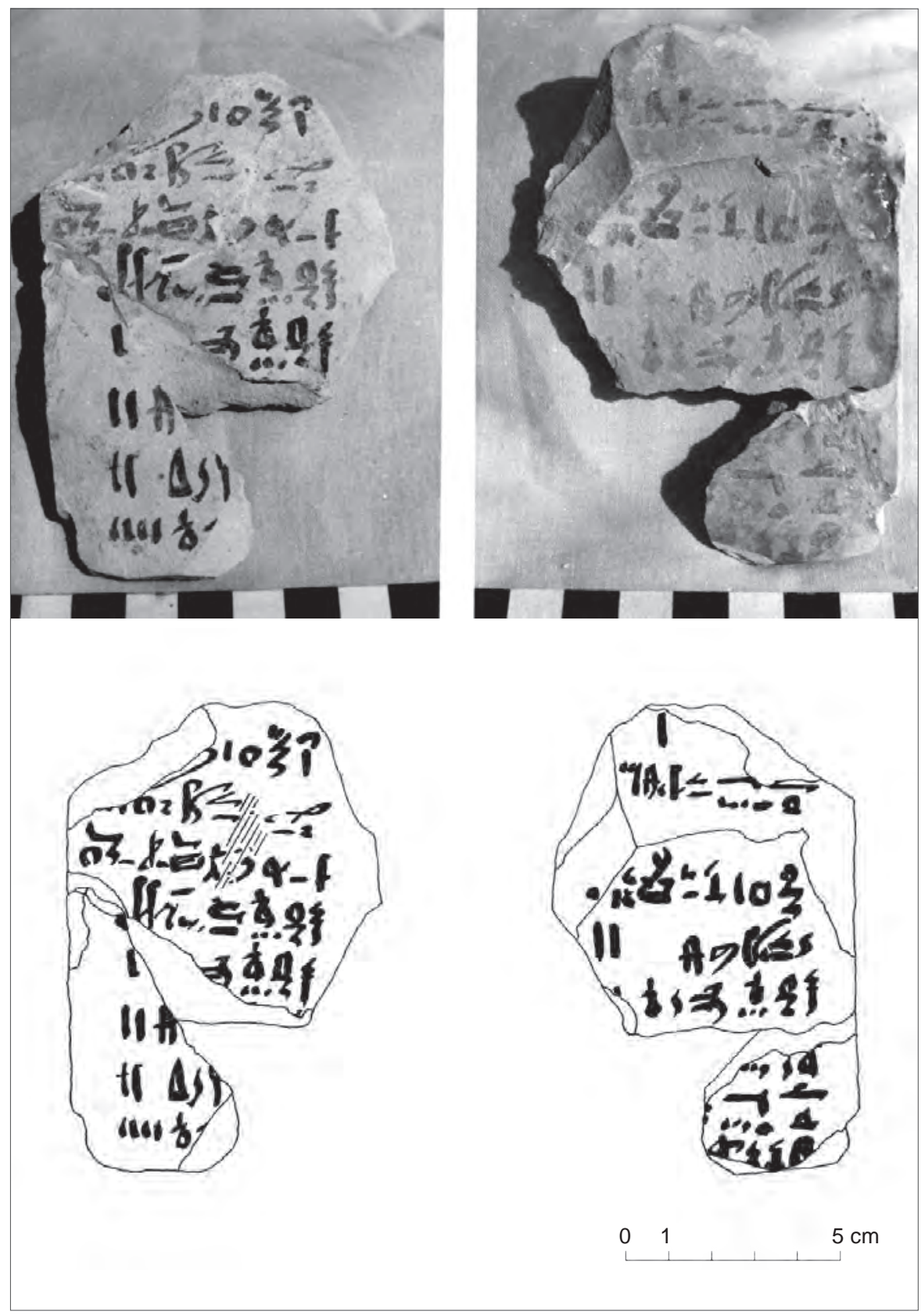

Fig. 2. Ostrakon DeB Inv. No. 85/75: top, recto and verso; bottom, facsimile of the text (Photo and drawing M. Barwik) 
ro.18 (Hayes 1960: Pl. XI = MMA photo MBC 259). ${ }^{4}$ For the "domain of the king's wife" in this period, see e.g., Helck 1961-1969/II: 211ff. A number of ostraka from Deir el-Bahari dating to the reign of Hatshepsut mention the institution in question in the context of the building operations conducted there (see Hayes 1960: Nos 2, 5, 6, and 14). The institution participated also in one way or another in the building of the Sheikh Abd el-Gurna tomb of Senenmut (TT 71), see Hayes 1942: 26, Pl. XXIII (No. 131). According to Megally (1974: 56), the king's wife mentioned in oDeB No. 2, dated to regnal year 10 (Hayes 1960: 31, Pls X-XA), was queen Ahmose (see, however, Hayes 1960: 31 note 5). ${ }^{5}$ It is worth noting that none of the sources from Deir el-Bahari, dating to the independent reign of Tuthmosis III, contain any reference to the domain of the king's
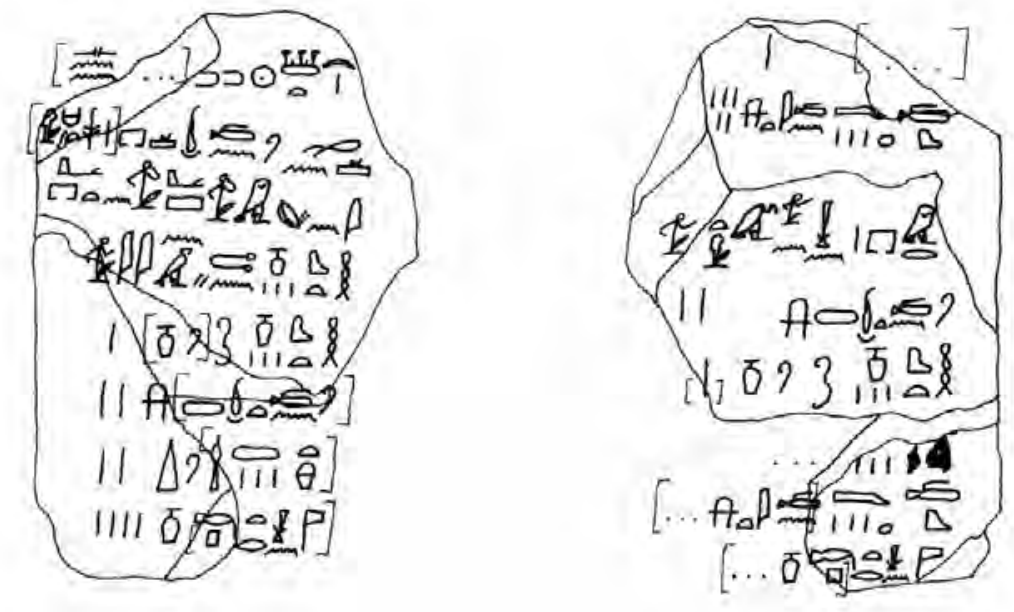

Fig. 3. Ostrakon DeB Inv. No. 85/75: transcription of the text (Drawing M. Barwik)

4 Wrongly transcribed, however, by Hayes; compare also oDeB No. 2, line 10 (Hayes 1960: Pl. IX).

5 As regards the undated ostraka DeB Nos 5, 6, and 14, it has been suggested that the title in question refers to Hatshepsut (see Hayes 1960: 33-34, 35, 42). The question cannot be resolved in the present state of research. It is worth noting, however, that in the biography of Ahmose Pennekhbet, Hatshepsut was styled quite unequivocally as hm.t-nsw wr.t $M{ }^{\top}\left(t-k{ }^{3}-\right.$ $R^{\complement} m{ }^{`}$-hrww "the great king's wife Maatkare, the justified" (Urk. IV, 34, 15); this is perhaps because the text was inscribed "at a time very close to her coronation" and reveals "an ambivalent attitude toward the new coregent" (Dorman 1988: 38); it does not necessarily mean that Ahmose's death preceded Hatshepsut's coronation, as suggested by Helck 1958: 346; for this, see also Ratié 1979: 279; Gitton 1984: 65. 
wife. It is hardly likely that the "domain of the Divine Adoratress" should be expected at the end of recto 2, because of the scarcity of space in the lacuna. In any case, the latter institution was attested also in the context of offerings of year 5 from the reign of Tuthmosis III/Hatshepsut, recorded on a writing board published by Vernus 1981: 112(j), 121 (vo.6); moreover, we are informed that the house of the Divine Adoratress had provided three servants who participated in building operations in the Asasif area in the regnal year 45 of Tuthmosis III (Römer 2008: 621, 624, Fig. 3, oDAI 56, 6; for the institution in question, see also Megally 1977: 139; Helck 19611969/I: 122-124; Gitton 1984: 95-96). Quite obviously the title of God's Wife hm.t-ntrr, equivalent to some extent with that of Divine Adoratress (see Gitton 1984: 95-96, 108ff), cannot be taken into consideration here, as it is absent from hieratic documents from Deir el-Bahari, in which they were superseded by that of the Divine Adoratress. ${ }^{6}$

c) No doubt the institution called $t 3^{\text {C }} . t \mathrm{Pr}^{-}{ }^{-} 3 \mathrm{~m}$ niw.t rs.t "the chamber of Pharaoh in the southern city", or else simply '.t hnk.t (n) Pr-? "chamber of offerings of Pharaoh", was meant here (for this institution being a department of the royal palace, see Helck 1958: 254ff; Vernus 1981: 115(ai); Kruchten 1981: 62 [B]). As regards '.t hnk.t (see Wb I, 160 [10]), it must be viewed supposedly as part of the aforementioned institution, see Helck 1958: 162, 258. According to Haring 1997: 114, 117, 195, 242 "the room of beer", responsible for provision of various items used in offering ceremonies, formed part of the temple workshop $\left(s^{r}{ }^{c}\right)$; see also Helck 1969: $197(\mathrm{k})$.

d) This must be taken as a personal name, contrary to Marciniak's supposition interpreting the word in question as a designation of a kind of beer (Marciniak 1978: 168 (d), "bière de qualité"). The name has not been attested in this particular form in the available onomastic material (compare, however, Ranke 1935: 391-392), nor among Asiatic names evidenced in New Kingdom Egypt (as documented by Schneider 1992). It cannot be excluded, however, that it is a variant writing of the foreign name Tjanuna/Tjanuny (Ranke 1935: 391 (27); Schneider 1992: 250ff), mentioned among other sources on oLeipzig 13 (Černý and Gardiner 1957: 11, Pl. XXXVI.2; see also Meyer 1982: 253-255), apparently as one of the supervisors of work done in the temple of Hatshepsut; ${ }^{7}$ significantly it is the name of the person related to the "domain of the [Divine] Adoratress" (1.2), enumerated alongside a number

\footnotetext{
For the domain of the God's Wife, see Gitton 1976: 87-88; Helck 1961-1969/I: 122-124.

For dating and attribution of the ostrakon, see Meyer 1982: 255; see also Helck 1961-1969/ I: 124 .
} 
of influential officials of the period: an unnamed chief treasurer (1. 4: most probably Nehesy may be taken into consideration here, less probably Tay, being his immediate successor who occupied the post in the later years of the reign of Hatshepsut; see Helck 1981: 39ff.), ${ }^{8}$ the mayor of This Satepihu (1. 5-6), the stewards Nebimes (1. 7), Roau (1. 7), ${ }^{9}$ and Senenmut (1. 8), but also an unnamed mayor of Nefrusy (1. 9: the name may have been written in the lacuna).

e) It is worth noting that Nubian beer is attested only in one of the published Tuthmoside ostraka from the region of Deir el-Bahari (Hayes 1960: 34, Pls XI, XIA (No. 9, ro.5); see also Helck 1975a: 791; 1961-1969/III: 460; IV: 683; for the commodity in general, see Darby, Ghalioungui, and Grivetti 1977/II: 531).

f) The restoration seems to be supported by the following entry of vo.4, where the same quantity of offering bread has been registered. Strangely enough, the same quantity of $w d n . t$-bread is recorded on ostrakon DeB No. 9 (Hayes 1960: Pls XI-XIA, ro.4); the same also concerns other commodities as recorded on both ostraka: white bread (two loaves), and Nubian beer (one jar).

g) Thus according to the selection of items as attested in two separate lists connected with two officials responsible for provision of offerings, i.e., Tjennay and Senenmut. As a matter of fact "incense for fumigation" (sntr $(n) k p)$ is seldom mentioned among the items referring to offerings (see Hayes 1960: Nos 9 and 10). Usually, it was simply "incense" (sntrr) which was burned during offering ceremonies, and listed in the offering lists. Quite obviously, the very character of the three Deir el-Bahari ostraka, relating specifically to the preparation of offerings, explains the reason for recording here incense (provided in jars or pots) destined to be burnt during a religious ceremony. It is worth noting that just four units (unspecified) of what seems to be "[incense for] fumigation" were recorded in a hieratic label written on one of the little cups symbolically used at the funeral ceremonies of king Tutankhamun (Winlock 1941: 14[I], Pl. VII). In other cases incense was provided in the form of loaves, and was measured and transported in baskets (see Vernus 1981: $113[0])$.

8 According to Meyer (1982: 255 note 2) the chief treasurer in question can be identified with Nehesy. For the sources, see also Helck 1958: 467-468; Barwik 2008: 13ff.; compare, however, Shirley 2014: 193ff., 224-225.

9 Thus according to a correction proposed already by Hayes 1960: 37 note 2. As for the steward Nebimes, he is not attested in extant sources. 
h) That is, the offering bread and not offerings in general (for the meaning of the term, see Helck 1961-1969/III: 460; Vernus 1981: 112[e]).

i) One would expect perhaps $t$ - $\underline{h} \underline{d}$ here, but it does not fit exactly the traces of signs preserved in the lower part of the line.

j) Limited space at the bottom of the verso results in the reduced height of hieratic signs and their apparent concise and clumsy writing; nonetheless there are no doubts concerning the reading.

It seems that offerings provided by two distinct institutions are reported on the ostrakon. The distinction between the two lists of offerings is clearly underlined by an empty space left before line 3 of the verso. There is no reason whatsoever to date the second list to an earlier period, as suggested once by Marciniak (1978: 166, 169). ${ }^{10}$ Of the officials mentioned here, Senenmut is the well known chief steward of the royal domains, and at the same time the steward of the domain of the temple of Amun (Dorman 1988: 170ff.; Helck 1958: 473ff.). With regard to Tjennay there is good reason to believe that it is a foreign name of irregular orthography depending on the rules of phonetic transcription presented by the syllabic writing of the period. He could have been the same person as Tjanuna of oLeipzig 13 (see above). According to Megally (1977: 141, 276; see also Luft 1977: 53), the latter must be the same person as the namesake overseer of the double granary attested in papLouvre E. 3226 (Megally 1971: Pls XXII, A vo. VII, 1; LIV B vo. X, 2; LX B vo. XVI, 6), and at the same time the owner of BD papyrus Louvre N. 3074 (Naville 1886: 98-100 (Pc); Munro 1988: 286 (No. 48)). If so, papLouvre E. 3226 would relate to the later stage of his career during the reign of Tuthmosis III. It is strange, however, that the Book of the Dead papyrus Louvre N. 3074 belonging to the "overseer of the servants of the God's Wife" (hry mrt $n$ hm.t-ntr) does not quote his presumably later and more prestigious title of the overseer of the double granary (for a discussion, see Bohleke 1991: 147148). There is no doubt, however, that the Book of the Dead papyrus can be convincingly related to the person mentioned in ostrakon Leipzig 13, and consequently to Tjennay of ostrakon DeB inv.no. 85/75. Such an assumption would be greatly strengthened providing that the domains of the God's Wife and that of the King's Wife had been related one way or another in the period under discussion (see Trigger et al. 1983: 208).

10 In fact, the title of Senenmut (imy-r pr) is clearly recognizable at the beginning of vo.3, rather than Marciniak's highly dubious reading as [3bd 1] 3h.t sw 1 (such a correction was proposed by M. Römer, personal communication). 
The role of the royal domains, and the estate of Amun, in preparation of the offerings attracts attention. The personal involvement of Senenmut with regard to providing offerings to the temple at Deir el-Bahari can be deduced from other extant sources (see below), but the most vivid account is presented by the text of the stela from the Montu temple in Karnak (Helck 1960; 1975b: 122-126). In the case of oDeB Inv. No. 85/75, the institution responsible for the preparation of offerings was probably a department of the royal palace, in this case aided by the domain of the King's Wife, being supposedly a separate institution (see Trigger et al. 1983: 208). The text of the ostrakon in question may allude to a sort of cooperation between these departments. Significantly, it was the "[inspectors/agents] of the domain of the King's Wife" ([n3 $n r w d . w]$ $n$ pr hm.t-nsw) who had effectively been involved in provision of royal landing stations or harbors (mniw.t) in the time of Tuthmosis III; so the decree of king Horemheb, referring to an earlier state of affairs (Urk. IV, 2149, 14ff.; Kruchten 1981: 96ff.).

The offerings recorded on oDeB Inv. No. 85/75 were presented on an unknown occasion on I akhet $20[+\mathrm{x}]$. It is open to question whether the date can be related to the processional feast of Osiris and offerings presented to Amun-Ra, recorded in the time of Ramesses III on I akhet 22 (Schott 1950: 83[30]). There is a handful of documents relating to offerings brought to Deir el-Bahari on other occasions. Hence we are informed that the wife of the highpriest of Amun Hapuseneb brought offerings to Deir el-Bahari on [x] peret 23 (Hayes 1960: No. 9). An undated ostrakon from Deir el-Bahari records the delivery of offerings on behalf of (or by) the scribe of the Steward Senenmut, and the Steward Roaw (Hayes 1960: No. 10). Much more lavish offerings collected by a number of officials, representing a wide spectrum of religious and administrative institutions, in year 5 (of Tuthmosis III/Hatshepsut), II peret 26, were recorded on the verso of a wooden writing board of unknown origin and present location (Vernus 1981: 89ff.). Deir el-Bahari can reasonably be inferred as the provenance of the board based on internal criteria (see Vernus 1981: 89, $112,115)$. The date of the board text falls exactly on the eve of a three-day feast of Amun, which started presumably on II peret 27, as recorded on the Red Chapel of Hatshepsut (Schott 1950: 97[103]; Vernus 1981: 115-116). Lacking any precise information on the circumstances of the offerings recorded in the aforementioned ostraka, one can only suggest the lunar date as a possible base for some of these festivities (which suggestion, however, needs a more detailed astronomical calculation of the dates). Significantly enough, the new moon feast on II peret 30 in the 24th regnal year of Tuthmosis III, coincided with the feast of Amun and temple foundation ceremonies, as evidenced by the inscription from 
the Karnak temple (von Beckerath 1982: 46[j], 47ff.). Certainly, the offerings accompanying the foundation ceremonies would be a fairly good reason for some of the festive occurrences recorded on the Deir el-Bahari ostraka and the aforementioned writing board.

As one would expect, preparations, that is, the bringing and recording of the offerings, preceded by a day the exact day of the festivities when the offerings were actually laid on the god's altars. ${ }^{11}$ The text of the writing board seems to suggest that offerings were prepared or gathered in the vicinity of the Nile canal ( $33 \mathrm{mr}$ ), i.e., most probably in the area of the Valley Temple of Hatshepsut (for the reading and meaning of this obscure location used in the text, see however Vernus 1981: 112[d], 115). It is noteworthy that during the joint reign of Tuthmosis III/Hatshepsut II, peret 27-29 fell roughly on the days when early in the morning (soon after sunrise) sunlight penetrated into the original inner sanctuary of the temple devoted to the cult of Amun-Ra, recently reconstructed with preserved blocks (Barwik 2010: 1ff.). Astronomical observations at the temple have placed this phenomenon at the beginning of February and in November according to the modern calendar. ${ }^{12}$

If the offerings listed in the text of oDeB Inv. No. 85/75 were presented to Amun, then the date of the ostrakon can be restored perhaps as I akhet 21, that is, just one day before the day of the festival celebrated at the beginning of the Twentieth Dynasty (provided that the feast in question went back to the times of Hatshepsut, which is highly doubtful in fact). According to the interpretation proposed by Marciniak, the offerings enumerated in the text of oDeB Inv. No. 85/75 were presented while the work on building the sanctuary was ongoing (Marciniak 1978: 169-170), which could shed some light on a liturgical practice of Ancient Egypt.

There is no certainty that all the items necessary for the offerings were enumerated in the two lists of oDeB Inv. No. 85/75, headed by the names of Tjennay and Senenmut. Nevertheless, the products delivered are roughly the same as those recorded on other occasions in sources originating from Deir el-Bahari (see above). ${ }^{13}$ Quite obviously, a distinction must be made between the formal enumeration of offerings presented by the king (see, for example, Helck 1961-

11 The text written on the writing board seems to suggest that offerings "were made" or rather "prepared" (iry, form of perfective passive participle) on II peret 26.

12 The calculations were done in the Temple of Hatshepsut in 2015 by Dr. Marcin Sękowski from the Institute of Geodesy and Cartography, Warsaw.

13 The absence of fowl (as well as beef and wine) is especially noteworthy. It cannot be excluded that other commodities were provided by other institutions, and consequently registered separately. 
1969/III: 349ff.), as inscribed on the temple walls, and simple scribal recordings relating to a preparation of offerings. Moreover, one can presume a differentiation of offerings depending on the actual nature of cultic performances or festive celebrations. The latter factor has not been hitherto studied satisfactorily, so one can only speculate about the purpose of the offerings concerned.

\section{References}

\section{Abbreviations}

$W b$

A. Erman, H. Grapow (eds), Wörterbuch der Aegyptischen Sprache. Berlin: Akademie-Verlag, 1926-1961

Barwik, M. (2008). Ahmose - a mayor of Thebes of the early Tuthmoside period. Göttinger Miszellen, 216, 13-16

Barwik, M. (2010). Sanctuary of the Hatshepsut temple at Deir el-Bahari. In M. Dolińska and H. Beinlich (eds), 8. Ägyptologische Tempeltagung: Interconnections between temples; Warschau, 22.-25. September 2008 (pp. 1-12). Wiesbaden: Harrassowitz

Bohleke, B. (1991). The overseers of double granaries of Upper and Lower Egypt in the Egyptian New Kingdom, 1570-1085 B.C. (unpubl. Ph.D. diss.). Yale University

Černý, J. and Gardiner, A.H. (1957). Hieratic ostraka I. Oxford: Charles Batey

Darby, W.J., Ghalioungui, P., and Grivetti, L. (1977). Food: the gift of Osiris I-II. London: Academic Press

Donker van Heel, K. and Haring, B.J.J. (2003). Writing in a workmen's village: Scribal practice in Ramesside Deir el-Medina [=Egyptologische uitgaven 16]. Leiden: Nederlands Instituut voor het Nabije Oosten

Dorman, P. (1988). The monuments of Senenmut: Problems in historical methodology. London: Kegan Paul International

Gitton, M. (1976). La résiliation d'une fonction religieuse : nouvelle interprétation de la stèle de donation d'Ahmès Néfertary. Bulletin de l'Institut français d'archéologie orientale, 76, 65-89

Gitton, M. (1984). Les divines épouses de la $18^{e}$ dynastie. Paris: Belles-Lettres

Haring, B.J.J. (1997). Divine households: Administrative and economic aspects of the New Kingdom royal memorial temples in western Thebes [=Egyptologische uitgaven 12]. Leiden: Nederlands Instituut voor het Nabije Oosten

Hayes, W.C. (1942). Ostraka and name stones from the tomb of Sen-müt (no 71) at Thebes [=Publications of the Metropolitan Museum of Art Egyptian Expedition 15]. New York: The Metropolitan Museum of Art

Hayes, W.C. (1960). A selection of Tuthmoside ostraca from Dèr el-Bahri. Journal of Egyptian Archaeology, 46, 29-52 
Helck, W. (1958). Zur Verwaltung des Mittleren und Neuen Reichs [=Probleme der Ägyptologie 3]. Leiden: E.J. Brill

Helck, W. (1960). Die Opferstiftung des Śn-mwt. Zeitschrift für Ägyptische Sprache und Altertumskunde, 85(1), 23-34

Helck, W. (1961-1969). Materialien zur Wirtschaftsgeschichte des Neuen Reiches I-VI. Mainz: Akademie der Wissenschaften und der Literatur

Helck, W. (1969). Eine Stele Sebekhoteps IV. aus Karnak. Mitteilungen des Deutschen Archäologischen Instituts Abteilung Kairo, 24, 194-200

Helck, W. (1975a). Bier. In W. Helck and E. Otto (eds), Lexikon der Ägyptologie I (pp. 789792). Wiesbaden: Harrassowitz

Helck, W. (1975b). Historisch-biographische Texte der 2. Zwischenzeit und neue Texte der 18. Dynastie. Wiesbaden: Harrassowitz

Helck, W. (1981). Die Datierung des Schatzmeisters Sennefer. Göttinger Miszellen, 43, 39-41

Kruchten, J.-M. (1981). Le décret d'Horemheb. Brussels: Éditions de l'Université de Bruxelles

Luft, U. (1977). Das Totenbuch des Ptahmose. Zeitschrift für Ägyptische Sprache und Altertumskunde, 104, 46-75

Marciniak, M. (1978). Un reçu d'offrande de Deir el-Bahari. Bulletin de l'Institut français d'archéologie orientale, 78, 165-170

Megally, M. (1971). Le papyrus hiératique comptable E. 3226 du Louvre [=Bibliothèque d'étude 53]. Cairo: Institut français d'archéologie orientale

Megally, M. (1974). À propos de l'organisation administrative des ouvriers à la XVIII dynastie. Studia Aegyptiaca, 1, 297-311

Megally, M. (1977). Recherches sur l'économie, l'administration et la comptabilité égyptiennes à la XVIII dynastie : d'après le papyrus E. 3226 du Louvre [=Bibliothèque d'étude 71]. Cairo: Institut français d'archéologie orientale du Caire

Meyer, C. (1982). Senenmut, eine prosopographische Untersuchung [=Hamburger ägyptologische Studien 2]. Hamburg: Verlag Borg

Munro, I. (1988). Untersuchungen zu den Totenbuch-Papyri der 18. Dynastie: Kriterien ihrer Datierung. London: Kegan Paul International

Naville, É.H. (1886). Das aegyptische Todtenbuch der XVIII. bis XX. Dynastie. Berlin: A. Asher $\&$ Co.

Ranke, H. (1935). Die ägyptischen Personennamen I. Verzeichnis der Namen. Glückstadt: Augustin

Ratié, S. (1979). La reine Hatchepsout: sources et problèmes [=Orientalia Monspeliensia 1]. Leiden: Brill

Römer, M. (2008). Die Ostraka DAI/Asasif 55 und 56 - Dokumente der Bauarbeiten in Deir el-Bahari und im Asasif unter Thutmosis III. In E. Engel, V. Müller, and U. Hartung (eds), Zeichen aus dem Sand: Streiflichter aus Ägyptens Geschichte zu Ehren von Günter Dreyer (pp. 613-625). Wiesbaden: Harrassowitz

Schneider, T. (1992). Asiatische Personennamen in ägyptischen Quellen des Neuen Reiches [=Orbis Biblicus et Orientalis 114]. Freiburg, Schweiz: Universitätsverlag 
Schott, S. (1950). Altägyptische Festdaten. Mainz: Verlag der Akademie der Wissenschaften und der Literatur

Shirley, J.J (2014). The Power of the Elite: The Officials of Hatshepsut's Regency and Coregency. In J.M. Galán, B.M. Bryan, and P.F. Dorman (eds), Creativity and Innovation in the Reign of Hatshepsut. Papers from the Theban Workshop 2010 [=Studies in Ancient Oriental Civilization 69] (pp. 173-245). Chicago: The Oriental Institute

Spencer, P. (1984). The Egyptian temple: A lexicographical study. London-Boston: Kegan Paul International

Trigger, B.G., Kemp, B.J., O'Connor, D., and Lloyd, A.B. (1983). Ancient Egypt: A social history. Cambridge: Cambridge University Press

Vernus, P. (1981). Omina calendériques et comptabilité d'offrandes sur une tablette hiératique de la XVIII dynastie. Revue d'Égyptologie, 33, 89-124

von Beckerath, J. (1982). Ein Wunder des Amun bei der Tempelgründung in Karnak. Mitteilungen des Deutschen Archäologischen Instituts Abteilung Kairo, 37, 40-49

Winlock, H.E. (1941). Materials used at the embalming of King Tut-'Ankh-Amün. New York: Metropolitan Museum of Art

Wysocki, Z. (1979). Deir el-Bahari 1974-1975. Études et Travaux, 11, 207-216

Wysocki, Z. (1980). Discovery, research, studies and the reconstruction of the rock platform above the upper terrace of Queen Hatshepsut temple at Deir el-Bahari. In The Temple of Queen Hatshepsut: Results of the investigations and conservation works of the PolishEgyptian Archaelogical Mission, 1972-1973 (pp. 7-43). Warsaw: State Enterprise for the Conservation of Cultural Property Information Centre

Wysocki, Z. (1983). The discoveries, research and the results of the reconstruction made at the rock platform and the protective wall over the Upper Terrace in the Temple of Queen Hatshepsut at Deir el Bahri. Mitteilungen des Deutschen Archäologischen Instituts Abteilung Kairo, 39, 243-253

Wysocki, Z. (1986). The Temple of Queen Hatshepsut at Deir el-Bahari: Its original form. Mitteilungen des Deutschen Archäologischen Instituts Abteilung Kairo, 42, 213-228

Wysocki, Z. (1992). The Temple of Queen Hatshepsut at Deir el-Bahari: The raising of the structure in view of architectural studies. Mitteilungen des Deutschen Archäologischen Instituts Abteilung Kairo, 48, 233-254 



\title{
A stray late Roman coin from the Temple of Hatshepsut at Deir el-Bahari
}

\author{
Barbara Lichocka \\ Institute of Mediterranean and Oriental Cultures, Polish Academy of Sciences, Warsaw \\ blichocka@iksio.pan.pl
}

\section{KeYwords}

Deir el-Bahari, Temple of Hatshepsut, Southern Chamber of Amun, Theodosius I, Constans, coin, ironworkers

\begin{abstract}
Examination of the east wall of the Southern Chamber of Amun on the Upper Terrace of the Temple of Hatshepsut led to the discovery of a single vota coin, possibly of Theodosius I, AD 379-383. It is not clear whether the coin was lost where it was discovered or taken there with the rest of the material found in the fill. An assemblage of six coins minted in AD 330-348 was also discovered on the Upper Terrace, but this time at the Bark Hall. Hidden or lost, the coins testify to a lateRoman interest in the Temple of Hatshepsut.
\end{abstract}

In 1984, a single late Roman coin was retrieved from the fill of the east wall of the Southern Chamber of Amun on the southern side of the Upper Terrace of the Temple of Hatshepsut. ${ }^{1}$

1 Information about the discovery of the coin during the exploration of trial pit 2/84-A, together with photographs and rubbed impressions, were provided by Zbigniew E. Szafrański, who, in 1984, was in charge of excavations of the Polish-Egyptian Archaeological and Conservation Mission in the Temple of Hatshepsut at Deir el-Bahari, and now heads the Mission. 
AE 4, $12.5 \mathrm{~mm}$, axis 7 [Fig. 1]

Obv. Pearl-diademed, draped and cuirassed bust looking right, ].VS PF AVG, dotted border.

Rev. VOT/X/MVLT/XX within a wreath, in exergue ]. $\Delta$, dotted border.

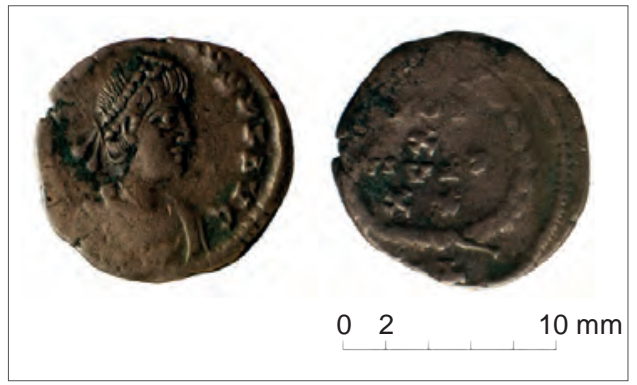

Fig. 1. Late Roman coin possibly minted in AD 379-383 (Photo Z.E. Szafrański, processing J. Iwaszczuk; courtesy PCMA)

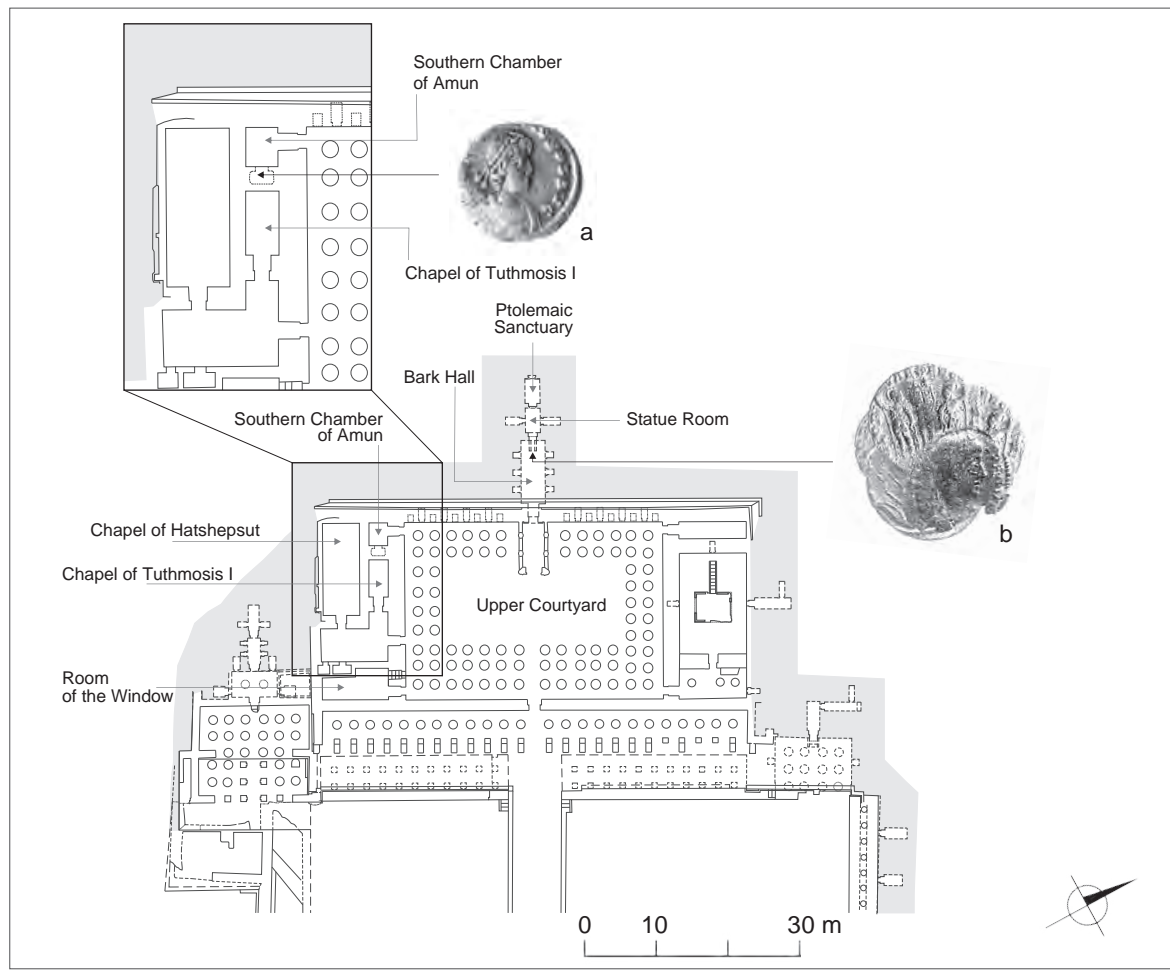

Fig. 2. Plan of the Upper Terrace of the Temple of Hatshepsut at Deir el-Bahari with indication of the place where the late Roman coins were discovered: $a$ - single stray coin; $b$-assemblage of six coins (Drawing T. Dziedzic; processing J. Iwaszczuk) 
The imperial bust is relatively large. The obliterated initial part of the obverse legend and off-centre impression of the die make it impossible to identify this specimen with certainty. The reverse die is also stamped partly off-centre. The word MVLT on the reverse is badly executed; the letters are not on the same level, the " $T$ " being significantly higher than the rest. The " $\Delta$ " terminating a mint-mark in the exergue indicates the fourth officina of a mint in the eastern part of the empire.

AE 4 smaller module (approx. 12-13 mm) VOT/X/MVLT/XX coins with a mint-mark terminating in a " $\Delta$ ", showing a draped and cuirassed imperial bust and a broken-style obverse legend, were issued in AD 379-383, regularly in the name of Theodosius, DN THEODO-SIVS PF AVG, in Heraclea (RIC IX: 196, No. 19 c), Cyzicus (RIC IX: 244, No. 21 c), Antioch (RIC IX: 289, No. 56 c) and Alexandria (RICIX: 301, No. 13 c, scarce), and later, in AD 383-388, in Antioch only (RIC IX: 292, No. 65 b).

In Antioch, in AD 378-383, VOT/X/MVLT/XX with a " $\Delta$ " terminating the mint-mark appeared on coins struck for Gratian, DN GRATIA-NVS PF AVG (RIC IX: 289, No. 56 a, scarce) and Valentinian II, VALENTINI-ANVS IVN PF AVG (RIC IX: 289, No. 56 b, common), in AD 383 and 383-388 for Arcadius, DN ARCADIVS PF AVG (RIC IX: 289, No. 56 d, scarce; RIC IX: 292, No. 65 c, common). Otherwise, in AD 383, Alexandria struck AE 4, a smaller module, VOT/X/MVLT/XX with the final mint-mark letter " $\Delta$ " and an unbroken obverse legend, DN ARCADIVS PF AVG (RIC IX: 301, No. $13 \mathrm{~d}$, rare), and in AD 383-388 a variant with a broken obverse legend, DN ARCADIVS PF AVG (RIC IX: 302, No. 19 d, scarce).

Imperial coin portraits of that period are not distinctive enough to be used for identification without an extant legend. Considering the overall composition, proportions of the image and letters, and the layout of the legend, the specimen may be attributed to Theodosius I, AD 379-383.

The coin was found in the fill of the east wall of the Southern Chamber of Amun (separating the room from the Chapel of Tuthmosis I) [Fig. 2], ${ }^{2}$ which was penetrated from the Chamber of Amun by removing some blocks from that wall. The blocks, inserted by previous explorers of the temple, covered an opening $0.90 \mathrm{~m}$ wide and $1.19 \mathrm{~m}$ high (up to the dado), $21 \mathrm{~cm}$ higher in the central part. ${ }^{3}$ A multi-layered fill, $1.80 \mathrm{~m}$ high, was explored, mainly in the central and northern parts: its surface was $1.04 \mathrm{~m}$ (width) x $1.50 \mathrm{~m}$ (depth).

\footnotetext{
For the current nomenclature of temple chambers, see Szafrański 2015: 11-14.

3 For a view of the part of the east wall of the Southern Chamber of Amun, with brick-laid opening, before exploration, Godlewski 1986: 42, Fig. 22; after exploration, Wysocki 1986: 219, Fig. 4, vertical section of the east wall of the Southern Chamber of Amun, view from the east.
} 
In his report, Zbigniew E. Szafrański suggested that "the filling of the test pit, at least in its central part, comes from the Coptic Period. Only the northern part and upper layers of the central part could have been affected in the process of installation of a modern copy of the false door into the wall of the Chapel of Tuthmosis I, which was undertaken in the modern era. The exploration of the fill showed clearly that the construction of the false door was based on the fill" (Szafrański n.d.: 4). According to Zygmunt Wysocki, the installation of the false door into the west wall of the Chapel of Tuthmosis I in antiquity not only involved damage to the western face of the chapel wall, but also disturbance of the original fill from the first construction phase of that wall. The fill was then rebuilt with fragments of blocks taken from it earlier (Wysocki 1986: 2214). He believed that the opening in the east wall of the Southern Chamber of Amun "might have been an entrance leading to a Coptic tomb located in the adjacent Chapel of Tuthmosis I" (Wysocki 1986: 218). Szafrański also supposed the existence of a passage that could have led to a Coptic burial (personal communication). Wysocki believed that the wall could have been broken through "on the occasion of looking for finds", or "to reach the back of the false door" (Wysocki 1986: 218). Izabela Uchman-Laskowska is certain that a passage existed there in the Coptic Period (Uchman-Laskowska 2010: 289). However, the plan drawn by the Polish-Egyptian Mission does not show a connection between the Southern Chamber of Amun and the Chapel of Tuthmosis I, only a type of niche appears in the east wall of the Southern Chamber of Amun [see Fig. 2]. There is no niche on Edouard Naville's plan (Naville 1906: 6, Pl. CXIX), nor in volume II of the Topographical Bibliography (Porter and Moss 1972: Pl. XXXVI [3]). The latter shows the location of the false door in the west wall of the Chapel of Tuthmosis I. The original made of red granite, with a dedication to Tuthmosis I from Hatshepsut, presently in the collection of the Louvre Museum (Porter and Moss 1972: 361 [107]), was replaced with a plaster copy by the predecessors of the Polish-Egyptian Mission (Wysocki 1986: 218). The replacement works might have removed any traces which could provide evidence of possible damage of the original façade in that spot. When Naville began his studies in 1893, he did not find the false door in situ. It was incorporated into the collection of Henry Salt, who arrived in Egypt in 1816, and was purchased for the Louvre in 1826 (Roth 2005: 156157, No. 87, C 48).

It is difficult to imagine a construction of a passage, if it was only to lead to a false door (2.69 m high; $1.51 \mathrm{~m}$ wide; $0.195 \mathrm{~m}$ deep), but it would be justified,

$\overline{4}$ In that reference, the room is called the South-west Chapel of Amon-Min (see above, note 2). 
if the false door had already been removed or the passage had followed a route to the entrance to the Chapel of Tuthmosis I next to the false door, which occupied the central part of the west wall of the Chapel. Considering that Coptic burials were found not only in the Chapel of Tuthmosis I, but also in the Chapel of Hatshepsut, located farther to the south (Szafrański 2010: 256-259; 2013: 142-143), it can be assumed that the passage was built in order to gain access to the tombs from the west. In that case, it would have been logical for the work to be undertaken from the Chapel of Tuthmosis I.

However, the wall with the false door was undisturbed, which is attested by photographs from Winlock's archive and indicated by the remains of that wall, preserved to this day (J. Iwaszczuk, personal communication).

Szafrański suggested that the material in the fill came for the most part from the Chapel of Tuthmosis I or from the Chapel of Hatshepsut located nearby, which may imply that the passage which existed there was buried, at least in part, in the Coptic Period (after the 7th century), starting from the Chapel of Tuthmosis I (Szafrański n.d.: 4-5). Szafrański observed two cases of inclination of the layers in the fill toward the east, that is, toward the west wall of the Chapel of Tuthmosis I, which, according to him, must have been destroyed and deprived of the false door. The inclination of the layers to the east seems to indicate that they had formed starting from the Southern Chamber of Amun. The fact that the opening in the east wall of the Southern Chamber of Amun is obviously much narrower than the filled niche suggests that it was not connected with a simple passage between two rooms. It remains unclear who disturbed the original structure of the wall separating the Southern Chamber of Amun from the Chapel of Tuthmosis I or why it was done.

The fill [Fig. 3] contained an abundance of pottery fragments dated to a wide span of time from the Middle Kingdom to the Roman and Coptic periods, fragments of stone blocks (including some bearing characteristic masonry marks from the Pharaonic period), mud bricks and fired bricks, fragments of textiles, fragments of handles of palm fiber baskets, doum fruit, fragments of ostraka, and a steel knife described as "Arabic" (Z.E. Szafrański, field notes and personal communication). The material was mixed, remains of the same pottery vessels (including joining pieces) were identified at different levels of the fill (Szafrański n.d.: 12).

At the bottom of the fill, near the southern edge of the opening in the east wall of the Southern Chamber of Amun, slightly below the level of the pavement, there were two completely preserved vessels [Fig. 4]; one of a round shape (12 cm high), smoke-blackened, and the other, a type of bowl ( $7 \mathrm{~cm}$ high), on top of the first one (possibly as a lid). Both were filled with debris, pieces of 
straw and ears of cereal plants. The vessels date to the Coptic period, 5th-7th century (Szafrański n.d.: 2). They may come from the times when the monastery of St Phoibamon flourished here (T. Górecki, personal communication). Not far from these artifacts, a piece of limestone was found; inscriptions in red and black ink covered three of its sides (E. Garel, in preparation).

The coin was discovered in the lowest layer of the central part of the fill. It is not clear whether it was found in situ. The state of preservation does not indicate a particularly long period of circulation, but it could have been in use for many years after being struck. It cannot be ascertained whether it was lost somewhere else and then brought to the fill with other elements,

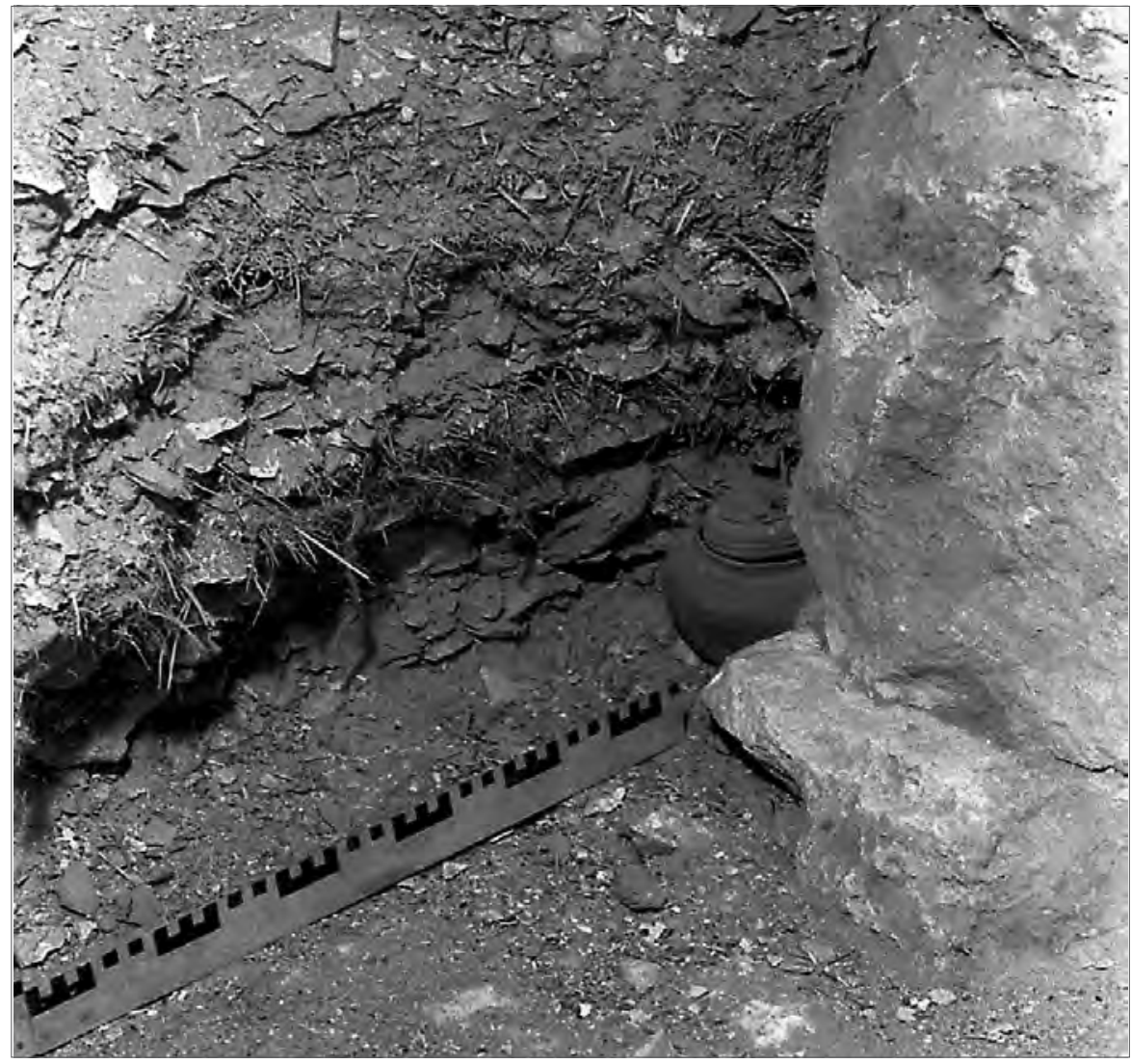

Fig. 3. Fill where the stray coin was found, view from the west, from the Southern Chamber of Amun; note the pottery vessels by the blocks of the wall on the south of the opening to the filled niche (Photo A. Stefanowicz; courtesy PCMA) 
or perhaps it was there earlier, which could indicate disturbance of the east wall of the Southern Chamber of Amun in the late Roman period. The state of preservation of the above mentioned vessels, their layout and content, suggest intentional placement. It seems that the coin would have been taken, if it had been on the pavement at the time when the vessels were inserted. Nevertheless, it is also possible that it remained unnoticed, for instance, covered with a thin layer of dirt. It could have lain very close, on the floor of the Southern Chamber of Amun, or it could have disappeared in some crack, being "swept" or moved accidentally when the vessels were deposited. The monetary system was different in the 6th-7th century. Therefore, it does not seem that a coin minted in AD 379-383 would have still been in circulation. In any case, that particular coin was lost in the temple at an unspecified time, possibly at the end of the 4th century or at the beginning of the 5 th century.

It is not the only coin from the late Roman period recorded on the Upper Terrace of the Temple of Hatshepsut. In the 1987-1988 season, an assemblage of six coins was discovered under the stairs leading from the Bark Hall to the Statue Room [see Fig. 2]. Aleksandra Krzyżanowska dated the coins to between AD 330 and AD 348 and suggested that they could have been lost by a person visiting the cemetery located over the terraces of

Fig. 4. Pottery vessels at the bottom of the fill (Photo A. Stefanowicz; courtesy PCMA)

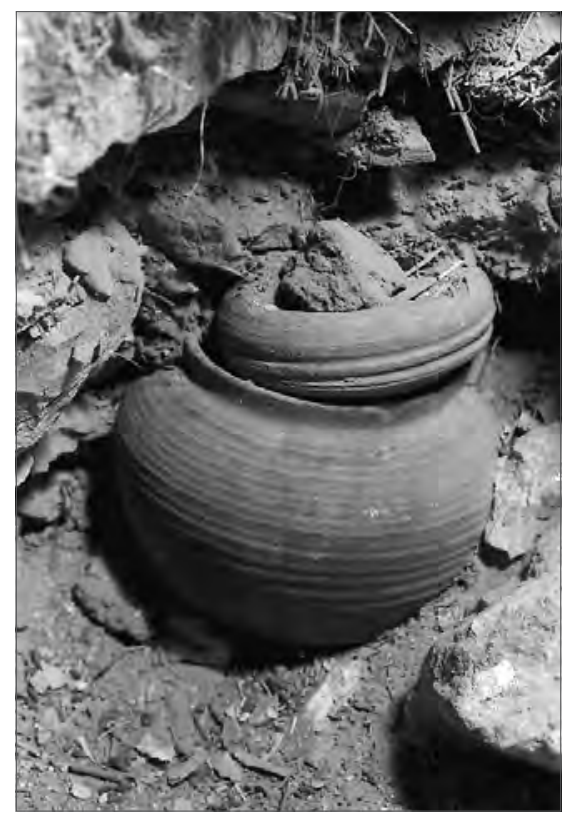


the temple (Krzyżanowska 2004: 228-2315). Adam Łajtar remarked that both the assemblage and another coin from the beginning of the 4th century AD found "within the wall separating the Court from the Room of the Window" could have been lost by a member of a corporation of ironworkers (siderourgoi) from Hermonthis, a group which had left numerous inscriptions at the Temple of Hatshepsut (Eajtar 2006: 102-1036). Franciszek Pawlicki described the circumstances in which the six coins were discovered and indicated that the owner might have been associated with the monastery of St Phoibamon or military garrison quartered in Luxor (Pawlicki 1999: 122, Fig. 2). The latter suggestion was further advocated in his monograph on Deir el-Bahari (Pawlicki 2000b: 29).

The reference to the monastery of St Phoibamon does not seem justified as the monastery was founded on the Upper Terrace of the temple much later, most likely in the 6th century AD (Godlewski 1986: 60; Łajtar 2006: 103). The stationing of Roman soldiers in Luxor could have led to a certain increase in the local circulation of coins, however the six tiny coins could have belonged to any individual who came to this area for any reason. It is impossible to confirm that the owner was someone visiting the cemetery, as Krzyżanowska believed.

In the 4th-5th century AD, the Upper and Lower Terraces of the Temple of Hatshepsut were used for burial purposes. Neither Edouard Naville nor Herbert E. Winlock documented their topography (Godlewski 1984: 115116; 1986: 19, 48-49, Fig. 26; see Strudwick 2003: 173; Riggs 2003: 190, 193).

The assemblage of six coins was discovered during conservation works, in loose debris, after removal of blocks from another structure that were inserted into the wall in the course of earlier reintegration works (Pawlicki 1999: 122). In this case, it cannot be confirmed that the coins were discovered in situ either.

The main sanctuary of the temple, dedicated to Amun-Re, was partly rebuilt and consecrated as a cult location for Amenhotep son of Hapu and Imhotep. It was also a place of oracle and healing, the fame of which could survive, as it frequently happens in such cases, for a long time (LaskowskaKusztal 1984: 107, 106-109, 121-123, 126 and personal communication;

5 In that reference the findspot of the coins was described as "under the stairs leading from the Bark Hall to the Table Hall of Amon-Re sanctuary" (see above, note 2).

6 Information regarding the place where another single allegedly late Roman coin was found is doubtful, hence the find is not discussed in this article. 
Karkowski 1983: 93-94; Godlewski 1986: 42-43; Frankfurter 1998: 157159, 205; Kákosy 1990: 175, 177; Strudwick 2003: 182; Łajtar 2006: 94, 103). It is possible that at some point in the mid-4th century AD somebody was drawn by its fame to visit it. It cannot be ascertained whether that individual entered the most sacred part of the complex, the Ptolemaic Sanctuary. Nevertheless, the person hid a few coins under the stairs in the Bark Hall or perhaps lost them nearby, and they were accidentally brought and deposited under the stairs leading to the Statue Room. ${ }^{7}$ It was definitely not a direct path to the cemetery, but it is possible that someone walking to the cemetery may have entered the famous sanctuary "on the way".

The most recent inscription of siderourgoi dates to AD 333-334 (Eajtar 2006: 95), which is not much later than ten years before the issue of the most recent specimen in the assemblage of six coins found in the Bark Hall. Elisabeth O'Connell shares Łajtar's opinion concerning the alleged owner of the coins and draws attention to cult activities performed in the 4th century $\mathrm{AD}$ in the West Bank temples. They can be seen in inscriptions related to the sacrifice of a donkey by a corporation of ironworkers in the Temple of Hatshepsut (Holmes and O'Connell 2008: 25). It was an offering of the animal of Seth, whose evil powers were neutralized in that manner, and the beneficiaries of the sacrifice, performed to re-establish cosmic law and order, were Amenhotep and Imhotep (Eajtar 2006: 97-101). A visit to the sanctuary where the cult of both divinities was performed, made by a person committed to this devotion, is very likely.

In the case of the single stray coin, which might date to AD 379-383, the suggestion that it belonged to a member of an ironworkers corporation would be rather risky as there is no evidence for their presence in the temple in the second half of the 4th century AD.

All the discussed specimens belong to common types for the periods of their minting. Their presence in the temple is natural in view of the fact that in the 4th century AD the place was not deserted, even though its role had changed with respect to its original purpose. It is rather surprising that late Roman coins found in the context of the 4th century AD Temple of Hatshepsut are so scarce. Is that due to the fact that the floor was cleaned frequently? The floor as well as the walls were most certainly subjected to repairs in antiquity (see Barwik 2002: 194-196, Fig. 3), during which any lost objects might have been found and collected. There is no mention of any coins discovered during the exploration of the cemeteries in the temple

The view of the Bark Hall and the passage to the Statue Room, Pawlicki 2000a: 161, Fig. 6. 
(Winlock n.d.; Godlewski 1986: 48, Fig. 25), whereas several dozen, including some late Roman pieces, were recovered at Deir el-Roumi (Augé and Lecuyot 1998).

Łajtar believes that in late Antiquity, the part of the temple where the Southern Chamber of Amun was situated was intensively exploited (Eajtar 2006: 261-263; and personal communication). There could have been many visitors, who could have come once or repeatedly, as was the case of the siderourgoi, who gathered there for approximately 50 years (Eajtar 2006: 95). One person arrived at the temple not earlier than the date of the issue of the most recent specimen in the assemblage of six coins, that is, a coin of Constans depicting two Victories facing one another, dated to AD 347-348 (Krzyżanowska 2004: 229; RIC VIII: 253, 78 or 81). Another person came to visit the place probably much later, not earlier than AD 379-383, and lost that very item, which was found at the bottom of the fill behind the east wall of the Southern Chamber of Amun.

\section{ACKNOWLEDGEMENTS}

I would like to express my gratitude to Zbigniew E. Szafrański for entrusting me with the task of publishing the coin, giving me access to excavation documents, and for the time he devoted to our discussions of the archaeological context in which the coin was found. I am also deeply indebted to Jadwiga Iwaszczuk for additional information concerning the topography of the Temple of Hatshepsut at Deir el-Bahari, access to the documentation, preparing the temple plan with the places of discovery of the late Roman coins, and all her suggestions. I thank Mirosław Barwik, Tomasz Górecki, Ewa Laskowska-Kusztal and Adam Łajtar for sharing additional information and their thoughts on their studies.

Translated by Barbara Majchrzak

\section{References}

\section{Abbreviations \\ RIC VIII}

RIC IX
Kent, J. (1981). The Roman imperial coinage VIII. The family of Constantine I, A.D. 337-364. London: Spink \& Son

Pearce, J.W.E. (1951). The Roman imperial coinage IX. Valentinian I- Theodosius I. London: Spink \& Son 
Augé, C. and Lecuyot, G. (1998). Deir er-Roumi: étude du matériel numismatique. Memnonia, 9, 107-119

Barwik, M. (2002). Deir el-Bahari: The Temple of Queen Hatshepsut. Season 2001. Polish Archaeology in the Mediterranean, 13, 191-200

Frankfurter, D. (1998). Religion in Roman Egypt: Assimilation and resistance. Princeton, NJ: Princeton University Press

Godlewski, W. (1984). The Late Roman necropolis in Deir el Bahari. In P. Nagel (ed.), Graeco-Coptica: Griechen und Kopten im byzantinischen Ägypten (pp. 111-119). Halle: Martin-Luther-Universität

Godlewski, W. (1986). Le monastère de St Phoibammon [=Deir el-Bahari 5]. (Z. Kiss, trans.). Warsaw: PWN - Éditions Scientifiques de Pologne

Holmes, N.M.M. and O'Connell, E.R. (2008). A parcel of Late Roman bronze coins from Thebes. The Numismatic Chronicle, 168, 405-410

Kákosy, L. (1990). Survivals of ancient Egyptian gods in Coptic and Islamic Egypt. In W. Godlewski (ed.), Coptic studies: Acts of the Third International Congress of Coptic Studies, Warsaw, 20-25 August, 1984 (pp. 175-178). Warsaw: PWN - Éditions Scientifiques de Pologne

Karkowski, J. (1983). Archaeological evidence. In J. Karkowski and J.K. Winnicki, Amenhotep, son of Hapu and Imhotep at Deir El-Bahari - some reconsiderations. Mitteilungen des Deutschen Archäologischen Instituts, Abteilung Kairo, 39, 93-101.

Krzyżanowska, A. (2004). Monety rzymskie znalezione w świątyni Hatszepsut w Deir el Bahari [Roman coins found in the Hatshepsut temple in Deir el Bahari]. In W. Kaczanowicz (ed.), Studia z dziejów antyku: pamięci Profesora Andrzeja Kunisza [=Prace naukowe Uniwersytetu Ślaskiego w Katowicach 2166] (pp. 228-231). Katowice: Wydawnictwo Uniwersytetu Śląskiego [in Polish with English summary]

Laskowska-Kusztal, E. (1984). Le sanctuaire ptolémaïque de Deir el-Bahari [=Deir el-Bahari 3]. (Z. Kiss, trans.). Warsaw: PWN - Éditions Scientifiques de Pologne

Łajtar, A. (2006). Deir el-Bahari in the Hellenistic and Roman periods: A study of an Egyptian temple based on Greek sources [=Journal of Juristic Papyrology Supplement 4]. Warsaw: Raphael Taubenschlag Foundation

Naville, E. (1906). The temple of Deir el Bahari V. The upper court and sanctuary [=Egypt Exploration Fund 27]. London: Egypt Exploration Fund

Pawlicki, F. (1999). Deir el-Bahari. The Temple of Queen Hatshepsut, 1997/1998. Polish Archaeology in the Mediterranean, 10, 119-130

Pawlicki, F. (2000a). Deir el-Bahari. The Temple of Queen Hatshepsut, 1998/99. Polish Archaeology in the Mediterranean, 11, 153-166

Pawlicki, F. (2000b). Skarby architektury starożytnego Egiptu: królewskie świątynie $w$ Deir el-Bahari [Treasures of Ancient Egyptian architecture: The royal temples at Deir el-Bahari]. Warsaw: Arkady [in Polish]

Porter, B. and Moss, R.L.B. (1972). Topographical bibliography of ancient Egyptian hieroglyphic texts, statues, reliefs and paintings II. Theban temples (2nd ed., rev. and augm.). Oxford: Clarendon Press 
Riggs, C. (2003). The Egyptian funerary tradition at Thebes in the Roman Period. In N. Strudwick and J.H. Taylor (eds), The Theban necropolis: Past, present, and future (pp. 189-201). London: British Museum Press

Roth, A.M. (2005). Hatshepsut's mortuary temple at Deir el-Bahri: Architecture as political statement. In C.H. Roehrig, R. Dreyfus, and C.A. Keller (eds), Hatshepsut, from queen to Pharaoh (pp. 147-151). New York: The Metropolitan Museum of Art

Strudwick, N. (2003). Some aspects of the archaeology of the Theban necropolis in the Ptolemaic and Roman periods. In N. Strudwick and J.H. Taylor (eds), The Theban necropolis: Past, present, and future (pp. 167-188). London: British Museum Press

Szafrański, Z.E. (n.d.). Światynia Hatszepsut. Sondaże w sezonie 1983/84. Wstępne sprawozdanie archeologiczne [The Temple of Hatshepsut. Preliminary archaeological report of the sondages made in the 1983/84 season]. Unpubl. manuscript from the Mission's archives [in Polish]

Szafrański, Z.E. (2010). Temple of Hatshepsut at Deir el-Bahari, season 2006/2007. Polish Archaeology in the Mediterranean, 19, 251-268

Szafrański, Z.E. (2013). Temple of Hatshepsut at Deir el-Bahari. Seasons 2008/2009 and 2009/2010. Polish Archaeology in the Mediterranean, 22, 131-151

Szafrański, Z.E. (ed.). (2015). Deir el-Bahari studies [=Polish Archaeology in the Mediterranean 24/2]. Warsaw: Warsaw University Press

Uchman-Laskowska, I. (2010). Conservation and restoration of wall painting in the Southern Chamber of Amun at the Hatshepsut Temple in Deir el-Bahari. Polish Archaeology in the Mediterranean, 19, 285-295

Winlock, H.E. (n.d.). Notebook. Unpubl. manuscript in the Department of Egyptian Art of the Metropolitan Museum of Art

Wysocki, Z. (1986). The Temple of Queen Hatshepsut at Deir el-Bahari: Its original form. Mitteilungen des Deutschen Archäologischen Instituts, Abteilung Kairo, 42, 213-228 


\title{
Cleopatra and kandake
}

\author{
Adam Łukaszewicz \\ Department of Papyrology, Institute of Archaeology \\ University of Warsaw \\ adlukasz@adm.uw.edu.pl
}

\section{KeYwords}

Ptolemaic Egypt, Roman history, Cleopatra VII, Meroitic Kingdom, women rulers in antiquity

\section{Abstract}

The author discusses the circumstances of Cleopatra VII taking power as the sole ruler of Egypt in 49/48 BC. The queen was forced out of Alexandria by her brother and co-regent Ptolemy XIII. When she reappeared in Egypt, it was from Palestine. The author considers the possibility that she traveled from Alexandria through the Thebaid, the Meroitic Kingdom and Arabia to Palestine, where she expected to obtain financial support necessary for recruiting mercenaries. She need not have modeled her political activity on that of the Meroitic kandake, but personal contacts between the two queens are plausible. The author suggests that a woman's head represented on the cover of a box containing a mirror, found at Faras in Nubia, may be a portrait of Cleopatra.

During the reign of Cleopatra VII (51-30 BC) Alexandria was certainly the biggest commercial center of the Mediterranean. Most luxury goods from abroad reached Alexandria via harbors of the Red Sea where they arrived either from India or from the Arab peninsula, or from the East of Africa, including the mysterious land of Punt of the ancient Egyptians and the region of Adulis and Axum which was so important in the history of Ethiopia (Bowersock 2013).

At the beginning of the reign of the last Ptolemaic queen, the international situation was extremely complex. The victory of the Parthians over the Roman 
army at the end of the reign of Ptolemy XII brought temporary relief to the weakened Alexandrian dynasty. Direct Roman exploitation of Egypt was delayed. Ptolemy XIII, the brother and co-regent of Cleopatra VII, was not yet able to elaborate a policy of his own. Next to him stood an ominous trio of tutors: the eunuch Potheinos, the army commander Achillas and Theodotos of Chios, the educator of the young king. These Alexandrian worthies took part in a vehement conflict between Ptolemy and Cleopatra, who reigned together since March of 51 BC. According to Hölbl, Cleopatra initially succeeded in expelling her brother from joint rule for a period of about 18 months (Hölbl 2001: 231). A stele in the Louvre of the 2nd of July 51 BC (year 1) (I. Fay. 205 = I. Louvre 21; Bianchi 1988: Cat. 78) can perhaps be interpreted in favour of such a hypothesis, although the dedicatory text for Queen Cleopatra, the goddess loving her father, does not mean that year 1 refers to her sole reign and not to the joint kingship.

In the autumn of $50 \mathrm{BC}$ (year 3) the king is named first and the queen is mentioned after him (BGU VIII 1730 [see BL III] $=C$. Ord. Ptol. 73). The priority of the king shows, in Hölbl's opinion, that the party of the young Ptolemy prevailed again. Two demotic documents of March $49 \mathrm{BC}$ mentioned the joint reign of "king Ptolemy and queen Cleopatra, the gods loving their father" (P. Cair. Dem. 30616a, b). Dramatic events must have occurred in the royal palace shortly after that. Year 3 of the joint reign of Ptolemy XIII and Cleopatra VII began on the 5th of September of 50 BC and ended on the 3rd of September 49 BC. During that year a new dating system was introduced. The new dating formula consisting of year 1 (of a new era) equal to year 3 (of a former era) is known from three papyri. ${ }^{1} \mathrm{Hölbl}$ assumed that Ptolemy XIII introduced dating formulas based on the count of years of his own reign (Hölbl 2001: 231). However, one of these documents mentions "queen Cleopatra and ..." (SB VI 9065.1). Although the petition directed to the "queen and ..." and mentioning the year $1=3$ apparently refers to the past, it seems also possible that the dating formula of 50/49 BC was a consequence of Cleopatra's move, maybe even of an attempted coup d'état. Year 1 could be the first year of the reign of Cleopatra, also called year 3 of the joint reign. This otherwise unknown action of Cleopatra was undoubtedly a failure, and an open war between the royal siblings followed.

In any case, the party of the young Ptolemy succeeded in expulsing the queen from Alexandria. This took place probably not earlier than in the summer of $49 \mathrm{BC}$. Cleopatra did not reappear until $48 \mathrm{BC}$.

SB VI 9065.2; VIII 9764.6-7; BGU VIII 1839.5. Nota bene, the editor of $B G U 1839.5$ suggested "year 1 also called [30]" and referred it to the last year of Ptolemy XII being the first year of his successors. "Year 1 also called [3]" is more convincing. 
The events in Egypt were undoubtedly connected with the situation in Rome. Since early 49 BC, the civil war between Caesar and Pompey introduced into Egypt's unstable foreign policy an unavoidable choice between the conflicting parties in Rome. This was probably the main reason of a controversy between Cleopatra and the body of tutors.

In the autumn of 49 BC Pompey's Roman Senate in exile at Thessalonike recognized the legitimacy of Ptolemy XIII as the sole ruler of Egypt. Like his father before him, he was proclaimed amicus et socius populi Romani. Pompey became formally the tutor of the young king of Egypt. No mention was made of Cleopatra. The decision of Pompey's senate meant that Cleopatra was left with no choice. She could only look for help from Julius Caesar, Pompey's enemy (Chauveau 2002: 18).

What happened then to the young queen of Egypt? Malalas, a late author who passed on some reliable information, mentions Cleopatra's escape from Alexandria to the Thebaid (Malalas IX 279; see Hölbl 1994: 207).

When she reappeared on the political scene in $48 \mathrm{BC}$, she was coming back to Egypt from Palestine. As a matter of fact Cleopatra had no other choice. To enrol a mercenary army, she had to reach the Near East. But what itinerary could she take to get to Palestine? The shortest route via the Delta and Pelusium, Rhinocolura (today's El-Arish) and Gaza was most probably closed. The harbors enabling a direct crossing of the Red Sea (Leukos Limen, Myos Hormos and Berenike) were probably under the control of Ptolemy's government. Passage to the Thebaid, while not entirely safe, at least opened the way to the south, which was beyond the reach of the Alexandrian government.

Travel from Egypt to Syria via the Meroitic kingdom has been hypothesized by some researchers. Egypt's southern neighbor, Nubia, was not terra incognita. Cleopatra seems to have had many reasons to choose the route upstream.

From the Egyptian point of view, the dwellers of the oros situated south of Egypt, the Blemmyes and the Nubae, were wild and dangerous tribes. In his praise of Rome, the mid-2nd century AD rhetor Aelius Aristides qualified the "peoples who live along the Red Sea" as "unfortunate". ${ }^{2}$ However, the Meroitic kingdom on the Nubian Nile was by no means a negligible place.

The sojourn of Cleopatra in Nubia is entirely hypothetical, but very probable. The road from Kush to Arabia was not very difficult. There is extensive information about contacts between these regions in later periods. The

2 Aristid., Or. 26.70. See Bowersock 2013: 54, who interprets the Greek term kakodaimonia as "wickedness". 
Ptolemaic inscription on the throne of Adulis provides evidence of contacts in the early Ptolemaic period, albeit chiefly for hunting elephants (see Bowersock 2013: 36).

We know from Strabo that Cleopatra's younger sister Arsinoe was with her on the Palestinian outskirts of Egypt (Strab., Geographia 17.1.11[C 796]; Green 1997: 730, note 135). This may imply the presence of the same company already on the earlier stage of the journey.

Finances were Cleopatra's main problem in exile. She needed money for the military operation of a prospective comeback to Egypt. In Syria, she certainly received support from the city of Askalon. We have from that period coins of Askalon with the image of Cleopatra (Walker and Higgs 2001: Cat. No. 219). She could have done what her father did in exile, promising to repay her allies and creditors after gaining a victory. The ancient world knew many bankers willing to finance influential customers who could guarantee prospective payment. Also, financial support from the Nubian rulers during Cleopatra's sojourn in their country was not unthinkable.

Whatever the case, it seems that by late $49 \mathrm{BC}$ or rather early $48 \mathrm{BC}$ Cleopatra VII was already in Palestine or on her way there. The events that followed are much clearer than Cleopatra's enigmatic itinerary. As we know, Cleopatra overcame and with the help of Julius Caesar succeeded in her struggle for the throne of Egypt. The romantic version of Cleopatra's encounter with the Roman warlord may perhaps be true as far as the strange way of smuggling the queen into the palace occupied by the Romans is concerned (Plut., Vit. Caes. 49.2). However, Caesar may not have been quite that surprised. The two had corresponded before the famous meeting in Alexandria (Cass. Dio XLII 34.36). Cleopatra and Caesar may even have met already during young Cleopatra's uncertain stay in Rome with her father a few years earlier.

From the time of Caesar's victoria Alexandrina of $47 \mathrm{BC}$, Cleopatra was the sole ruler of Egypt.

Some researchers have suggested that Cleopatra's activities as a female ruler of Egypt could have been inspired by the role of kandake in the Meroitic kingdom (Scholz 1988: 226). However, even before Cleopatra VII, there had been in Egypt ambitious queens who ruled the country. The role of Ptolemaic queens was well known in the Mediterranean world. This is confirmed by Lucan who, in the 1st century AD, used the argument of the Egyptian tradition of female rulers in the text of Cleopatra's speech intended to persuade Caesar to install her as queen of Egypt (Lucan, Pharsalia X 85-99). The application of Nubian patterns was not necessary. Nevertheless, the idea of Cleopatra's friendship with kandake Amanishakhete (41-12 BC) is not far off the mark. 
Plutarch and other authors insist on the luxury and splendor of Cleopatra's court. There is no doubt that the queen was an expert in matters of the Hellenistic tryphe. On the other hand, as an active politician and a monarch in constant trouble, she must have been very busy indeed. Her famous beauty is a myth. Plutarch first remarked on her charm rather than beauty. ${ }^{3}$

She was unlucky. Her reign was a sequence of disasters, insurmountable obstacles despite the talent and effort that the ambitious queen put into overcoming them. Involved in the intricacies of a complex and dangerous Roman policy, she was confronted with vehement conflicts of ruthless leaders commanding great professional armies. To complete Cleopatra's misfortune, Egypt's economic situation was disastrous. Pliny mentions a very bad Nile flood of the year $48 \mathrm{BC}$ (Plin., HNV 58). Famine, epidemics and increasing expenditure demanded by the Romans complete the picture. However, the fabulous wealth of Egypt was still sufficient to finance Antony's wars and to provide Octavian with a motive for conquering Cleopatra's kingdom.

Cleopatra lost her siblings in the struggle for power. She was hated by the Alexandrians who held her responsible for the arrogant Roman presence in Egypt. Her only hope were alliances with successive Roman leaders, in whom she could not really place her trust. She survived Julius Caesar and engaged in a turbulent union with Mark Antony. She strived to extend the territory under her control and to secure the future rule of her children. The maladroit military campaigns of Antony, the treason of Roman generals, intrigues of her own courtiers and the intransigent hatred of Cleopatra by some minor kings of the region led to the tragic end of the queen and her dynasty.

Under such circumstances it is easy to imagine Cleopatra treating the kandake, a queen from the remote South, as a reliable friend and ally.

Towards the end of her dramatic reign, the Egyptian queen must have considered possible ways of escape. One tempting possibility was the Meroitic kingdom from which the road to India stood open. We may assume that Cleopatra, who had quite probably visited Nubia briefly, had a detailed knowledge of geography and a perfect orientation in the realities of the Kushite kingdom.

Cleopatra's plans were not implemented. She managed to send her son Ptolemy XV Caesarion to the South. There can be no doubt that the projected itinerary was through Nubia to the sea and then to India (see Locher 2002: 75). Caesarion's tutor Rhodon either betrayed him and delivered the young king to the Romans or convinced him to surrender to Octavian who immediately had him executed. Plutarch repeats a story, which obviously belongs to Octavian's propaganda, about

3 Plut., Vit. Ant. 27.3-5. For more appreciation of Cleopatra's beauty, see Cass. Dio XLII 34.4-5. 
the Alexandrian philosopher Areios advising Octavian to kill Caesarion (Plut., Vit. Ant. 81.2). Cassius Dio gives a less complicated version. He states that the boy was captured and murdered on his way to Ethiopia (Cass. Dio LI 15.5).

These facts seem to imply good relations and mutual trust between Egypt and Meroe. It may even be possible to suggest another interpretation for the series of conflicts between the Ethiopians and Rome, which followed the Roman occupation of Egypt. The Ethiopians had avoided attacking Ptolemaic Egypt. Their invasion of Upper Egypt at the beginning of the Roman period comes as a surprise. It was allegedly an act of defence against the "injustice of the nomarchs". Certainly it was not a simple robbers' raid (Strab., Geographia XVII 53-54; Cass. Dio LIV 5.4; Plin., HN VI 29 (35). 181-182; see Łukaszewicz 2010). It is possible that Meroitic action in this situation was a consequence of an alliance of the two neighboring kingdoms dating from the late Ptolemaic period. Diodorus mentions meeting Ethiopian ambassadors during his visit to Egypt (Diod. Sic. III 11.3). Anyway, a permanent peace on the southern border of Egypt was established again by an agreement between Rome and the Meroitic kingdom (Strab., Geographia XVII 54).

Contacts between Meroe and Hellenistic Egypt are confirmed by archaeology. Richly represented among the finds from Nubian sites are imported objects and local imitations of Egyptian artefacts. A remarkable object, a cover of a box containing a mirror, came from tomb 2589 at Faras (now at the Ashmolean Museum of Arts and Archaeology in Oxford). On one side, there is an engraved image of Harpocrates on a lotus flower, surrounded by nine images of animals, real or fantastic. On the other side of the cover a raised relief shows a young woman's head in profile, simple and summary, without many details, depicted in a different, Hellenistic style (reproduced in Shinnie 1967: Fig. 116). The face seems to have been of white complexion and her hair style is of the Cleopatra type. She wears no diadem, but this is not a sufficient argument against Cleopatra VII as the prototype of the image. Relevant differences between various types of portraits of Cleopatra VII make an identification of the supposed Cleopatras difficult. However, it seems very probable that the image decorating the mirror cover of the Ashmolean was inspired by a portrait of Cleopatra VII or perhaps of her sister Arsinoe.

The presumed Cleopatra portrait may have served in this context as a symbol of beauty and body care. Cleopatra was also known as an author of treatises on cosmetics (Galen, De compositione medicamentorum secundum locos XII 403-404; see Rowlandson 1998: 41, No. 15).

In any case, the decoration of the object from Faras is not a direct copy of a known image of Cleopatra. It must have originated from an unknown 
prototype, glyptic or monetary. It may also have been a synthesis of various versions of Cleopatra's portrait on her coins (see, for example, Cadario 2013).

\section{References}

The abbreviated references to documentary sources follow J.F. Oates et al., Checklist of Greek, Latin, Demotic and Coptic papyri, ostraca and tablets, available online at http://scriptorium.lib.duke.edu/papyrus/texts/clist.html.

\section{Primary SOURCES}

Aelius Aristides, Aelii Aristidis Smyrnaei quae supersunt omnia II. Orationes XVII-LIII, ed. by B. Keil, Berlin: Weidmann, 1898

Cassius Dio, Cassii Dionis Cocceiani historiarum Romanarum quae supersunt, ed. by U.P. Boissevain, 3 vols, Berlin: Weidmann, 1895-1901

Diodorus Siculus, Diodori bibliotheca historica, ed. by K.T. Fischer (post I. Bekker and L. Dindorf) and F. Vogel, 5 vols, 3rd ed., Leipzig: Teubner, 1888-1906

Galen, De compositione medicamentorum secundum locos. In Galen, Claudii Galeni opera omnia XII-XIII, ed. by C.G. Kühn, Leipzig: Knobloch, 1826-1827

Ioannes Malalas, Ioannis Malalae chronographia, ed. by I. Thurn [=Corpus Fontium Historiae Byzantinae. Series Berolinensis 35], Berlin-New York: De Gruyter, 2000

Lucan, M. Annaei Lucani belli civilis libri decem, ed. by C. Hosius, 3rd ed., Leipzig: Teubner, 1913

Pliny the Elder, C. Plini Secundi Naturalis Historiae libri XXXVII, ed. by K. Mayhoff (post L. von Jan), 6 vols, Leipzig: Teubner, 1875-1906

Plutarch, Antonius. In Plutarch, Plutarchi vitae parallelae, ed. by K. Ziegler, vol. 3.1, 2nd ed., Leipzig: Teubner, 1971

Plutarch, Caesar. In Plutarch, Plutarchi vitae parallelae, ed. by K. Ziegler, vol. 2.2, 2nd ed., Leipzig: Teubner, 1968

Strabo, Strabonis geographica, ed. by A. Meineke, 3 vols, Leipzig: Teubner, 1877

\section{SeCONDARY SOURCES}

Bianchi, R.S. (1988). Cleopatra's Egypt: Age of the Ptolemies. Brooklyn: Brooklyn Museum

Bowersock, G.W. (2013). Throne of Adulis: Red Sea wars on the eve of Islam. OxfordNew York: Oxford University Press

Cadario, M. (2013). Il vero volto di Cleopatra. In G. Gentili (ed.), Cleopatra: Roma e l'incantesimo dell'Egitto (pp. 39-43). Milan: Skira

Chauveau, M. (2002). Cleopatra: Beyond the myth. Ithaca, NY: Cornell University Press Green, P. (1997). D'Alexandre à Actium : du partage de l'Empire au triomphe de Rome. Paris: Laffont 
Hölbl, G. (1994). Geschichte des Ptolemäerreiches: Politik, Ideologie und religiöse Kultur von Alexander dem Grossen bis zur römischen Eroberung. Darmstadt: Wissenschaftliche Buschgesellschaft

Hölbl, G. (2001). A history of the Ptolemaic empire. New York: Routledge

Locher, J. (2002). Die Anfänge der römischen Herrschaft in Nubien und der Konflikt zwischen Rom und Meroe. Ancient Society, 32, 73-134

Łukaszewicz, A. (2010). Cornelius Gallus and the beginnings of Roman policy in Nubia. In W. Godlewski and A. Łajtar (eds), Between the cataracts: Proceedings of the 11th Conference for Nubian studies, Warsaw University, 27 August-2 September 2006, II.2. Session papers [=PAM Supplement Series 2.2/2] (pp. 535-540). Warsaw: Warsaw University Press

Rowlandson, J. (ed.). (1998). Women and society in Greek and Roman Egypt: A sourcebook. Cambridge-New York: Cambridge University Press

Scholz, P.O. (1988). Frühchristliche Spuren im Lande des anēr Aithiops: historischarchäologische Betrachtungen zur Apostelgeschichte 8: 26-40 (Ph.D. diss.). University of Bonn

Shinnie, P.L. (1967). Meroe: A civilization of the Sudan [=Ancient Peoples and Places 55]. London: Thames and Hudson

Walker, S. and Higgs, P. (eds). (2001). Cleopatra of Egypt: From history to myth. Princeton, NJ: Princeton University Press 

